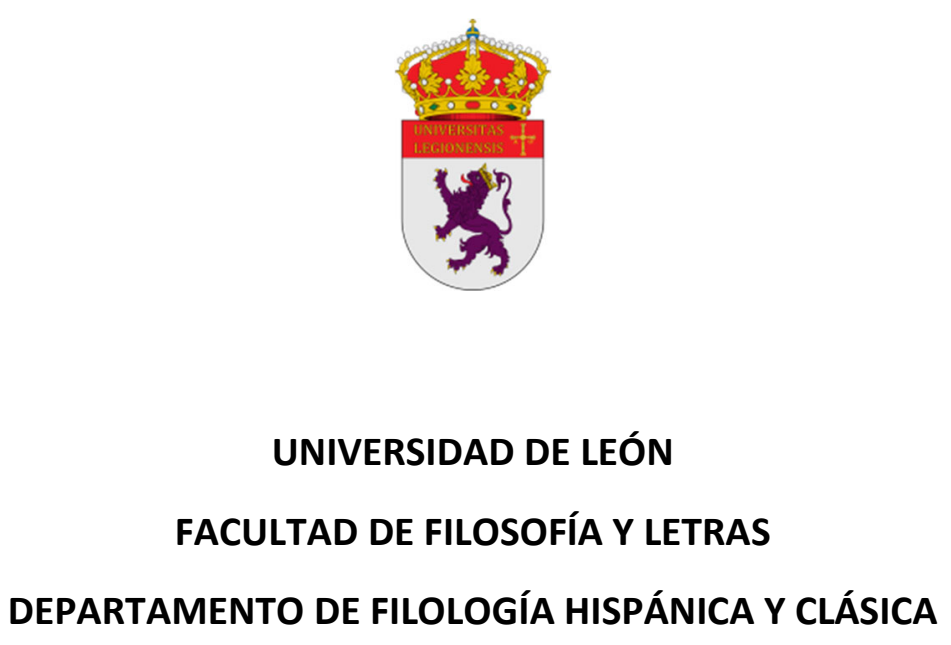

TESIS DOCTORAL

VARIACIÓN LÉXICA EN LA TIERRA DE CAMPOS EN EL SIGLO XVII

Autora: Marta Miguel Borge

Director: Dr. José Ramón Morala Rodríguez

Programa de doctorado:

MUNDO HISPÁNICO: RAÍCES, DESARROLLO Y PROYECCIÓN

León, diciembre de 2020 

[...] la vida necesita de la palabra; si bastase con vivir no se pensaría, si se piensa es porque la vida necesita de la palabra: la palabra que sea su espejo, la palabra que la aclare, la palabra que la potencie, que la eleve y que declare al par su fracaso. (María Zambrano) 



\section{RESUMEN}

La presente tesis pretende realizar el estudio del léxico en el siglo XVII en la comarca de Tierra de Campos, una zona de gran interés desde el punto de vista diatópico, pues es un área de confluencia entre las variantes históricamente leonesas y castellanas. Para ello se pretende crear un corpus documental a partir de textos notariales inéditos que se caracterizan por su riqueza léxica: inventarios, cartas de dote, almonedas, partijas, testamentos... Estos datos se han obtenido a partir de la selección de inventarios en protocolos notariales pertenecientes a los partidos judiciales de Sahagún, Valderas, Frechilla, Medina de Rioseco y Villalpando, localidades representativas de la Tierra de Campos.

Hasta hace muy poco, el periodo que ocupa nuestro estudio se caracterizaba por carecer de un corpus específico de las diferentes zonas, es decir, las referencias léxicas de las que se disponía procedían exclusivamente de obras literarias y técnicas, siempre haciendo referencia a un estadio culto y normativo de la lengua, escapándose así la variedad dialectal. Sin embargo, desde hace unos años, contamos con el Corpus Léxico de Inventarios (CorLexIn), un corpus textual que atesora documentos notariales del siglo XVII y pertenecientes a todo el ámbito hispánico. Esta herramienta va a permitir contrastar los datos obtenidos de Tierra de Campos con el resto de la Península. 



\begin{abstract}
The current thesis intends to study the lexicon of the Tierra de Campos region, an area of great interest from a diatopic point of view, as it is an area of confluence between the variants historically originated from León and Castile. In order to do so, the aim is to create a documentary corpus from unpublished notarial texts that are characterised by their lexical richness: inventories, dowry letters, documents from clearance sales, distribution of inheritances, testaments... These data have been obtained from a selection of inventories in notarial registries belonging to the judicial districts of Sahagún, Valderas, Frechilla, Medina de Rioseco and Villalpando, representative localities of Tierra de Campos.

Our study is concerned with a period of history that lacked a specific corpus for the different areas until quite recently, that is, the only lexical references available came exclusively from literary and technical works, always alluding to the standard literate language, therefore failing to acknowledge the dialectal variety. However, we have the Corpus Léxico de Inventarios or CorLexIn (Lexical Corpus of Inventories), a textual corpus that treasures notarial documents from the 17th century belonging to the whole Spanish-speaking world. This tool will allow us to compare the data obtained in Tierra de Campos with those of the rest of Spain.
\end{abstract}





\section{Quiero expresar mi agradecimiento:}

A mi director de tesis, el Dr. José Ramón Morala Rodríguez, gracias al él he podido llevar a cabo este trabajo.

Al personal de los Archivos Históricos Provinciales de Zamora, Valladolid, Palencia y León. Siempre recordaré su ayuda, colaboración y amabilidad que facilitaron mi trabajo.

A mis compañeros de la Universidad de Burgos y a mis amigos por todo su apoyo y ánimo.

A mis padres, a mi marido, a mis hijos y al resto de mi familia por su ánimo, paciencia y apoyo constantes, que han sido fundamentales en la finalización de este trabajo.

A todos ellos, 



\section{ÍNDICE}

\section{BLOQUE I: INTRODUCCIÓN}

Página

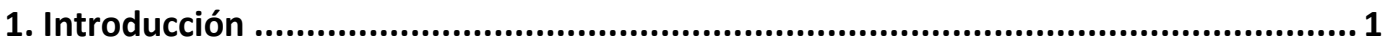

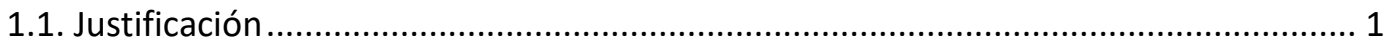

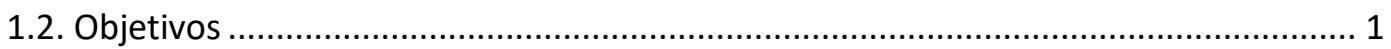

\section{BLOQUE II: ZONA DE ESTUDIO}

2. Marco geográfico y económico de la Tierra de Campos ............................................ 3

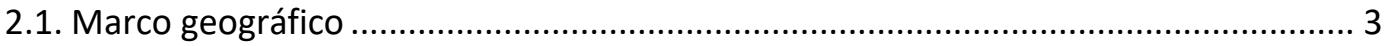

2.2. Economía y sociedad en la Tierra de Campos............................................................. 7

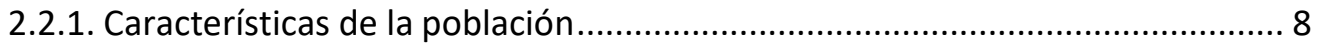

2.2.2. Economía de la Tierra de Campos ................................................................. 9

3. Marco diacrónico. Del sistema medieval al español moderno ................................. 11

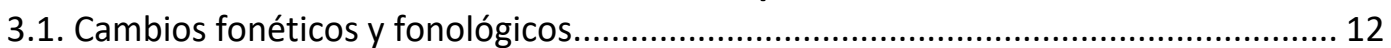

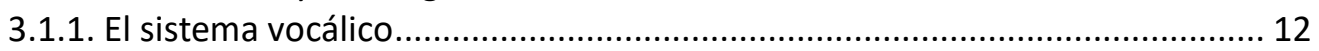

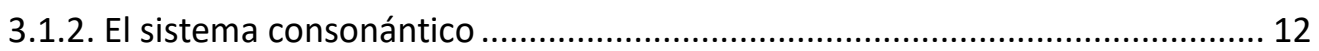

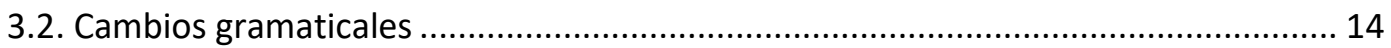

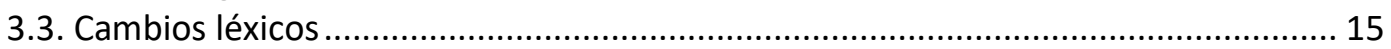

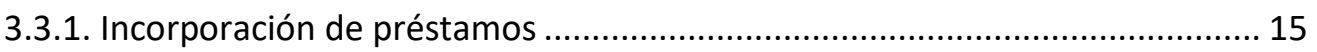

3.3.2. Formación de palabras nuevas a través de procesos internos de la propia lengua... 15

4. Marco lingüístico de la zona de estudio............................................................ 19

\section{BLOQUE III: MATERIALES Y METODOLOGÍA UTILIZADA}

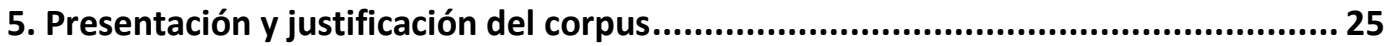

5.1. Los documentos notariales como fuente de los estudios filológicos. ....................... 25

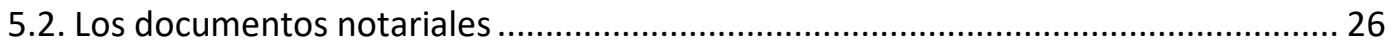

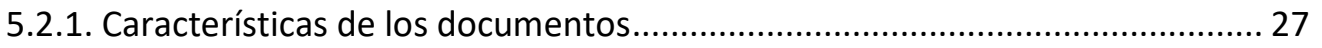

5.2.2. Dificultades de interpretación de los documentos notariales ......................... 33

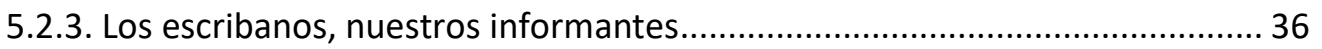

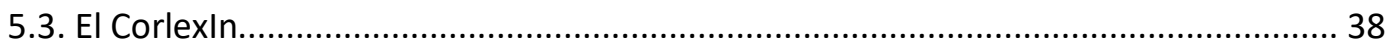

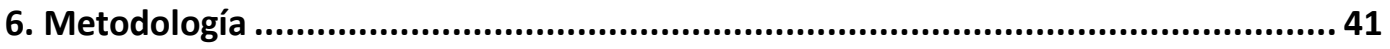

6.1. Selección del corpus de Tierra de Campos ............................................................... 41

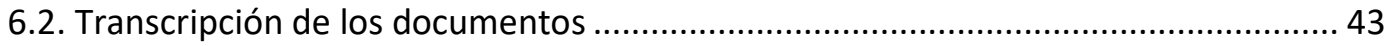

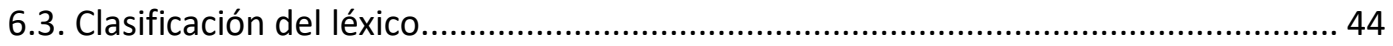

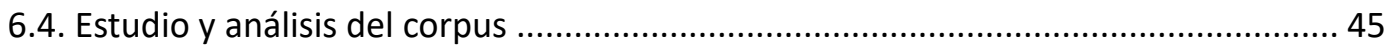

\section{BLOQUE IV: LÉXICO}

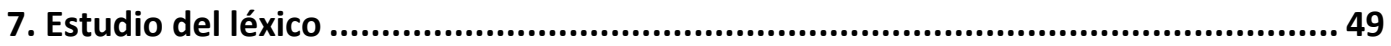

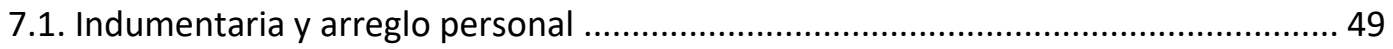

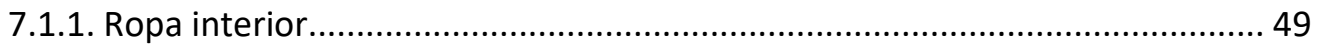

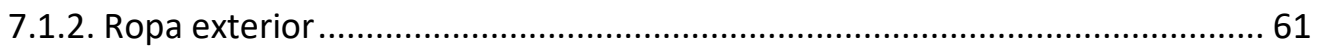

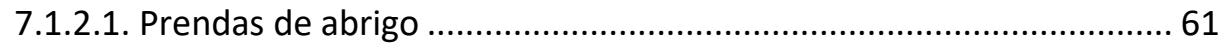

7.1.2.2. Prendas de cintura para arriba ............................................................ 71

7.1.2.3. Prendas de cintura para abajo ........................................................... 79

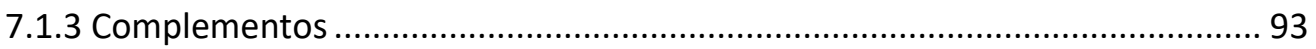

7.1.3.1 Complementos de cabeza y tocados ................................................. 93

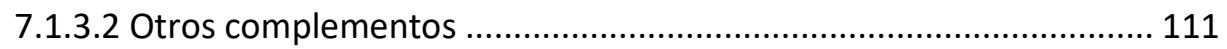

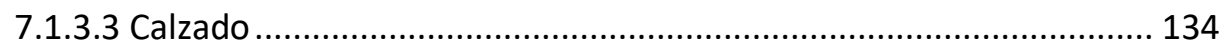

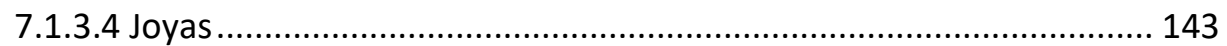




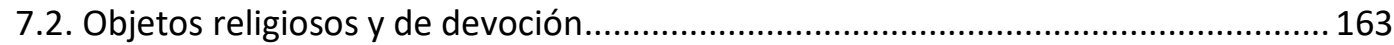

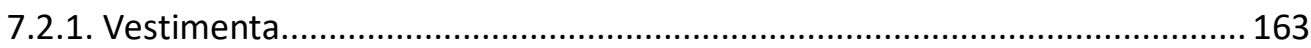

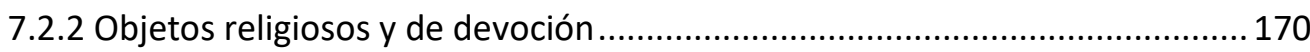

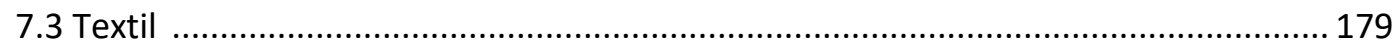

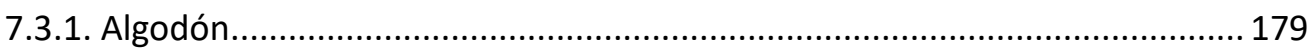

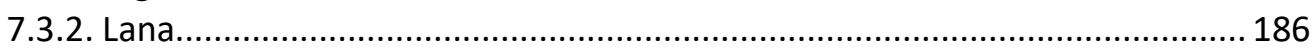

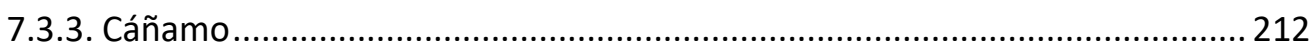

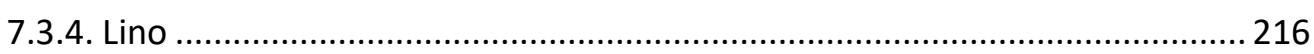

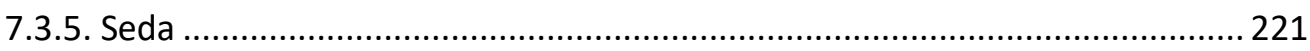

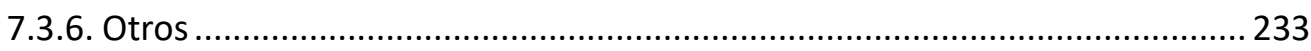

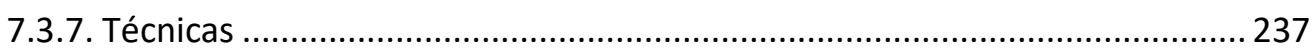

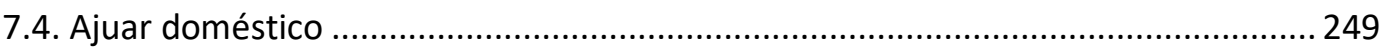

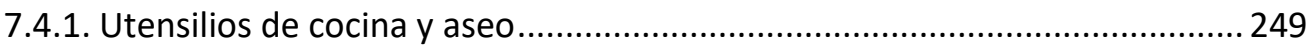

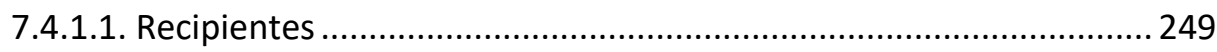

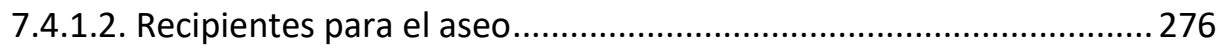

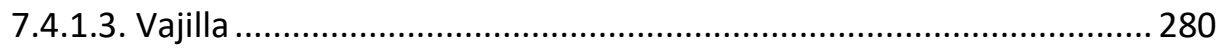

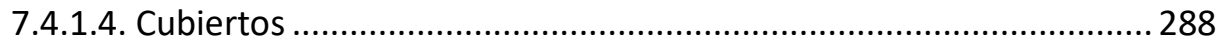

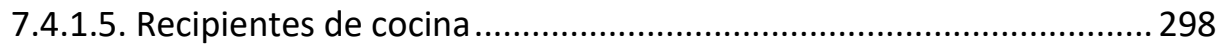

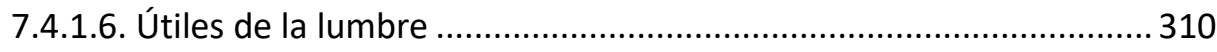

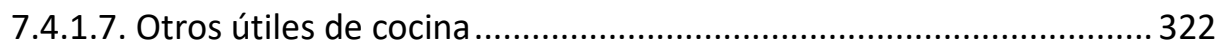

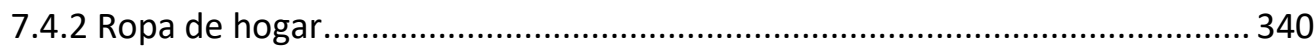

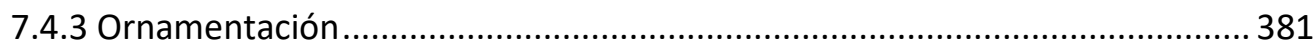

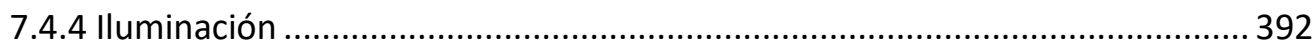

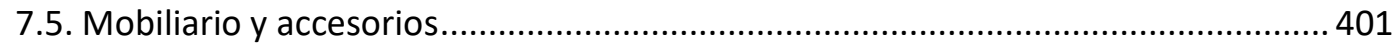

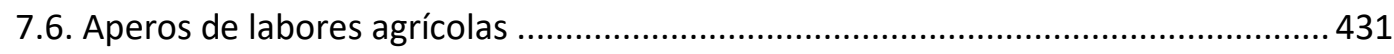

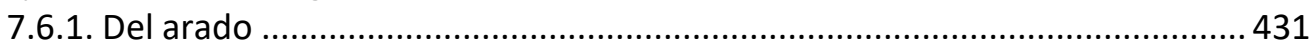

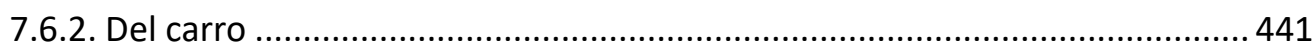

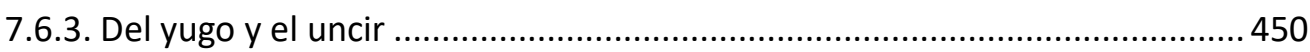

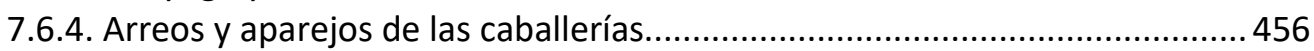

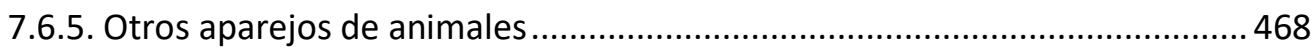

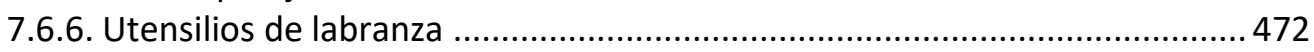

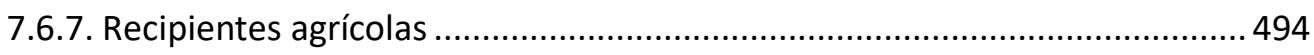

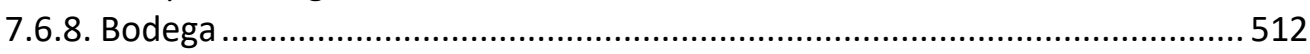

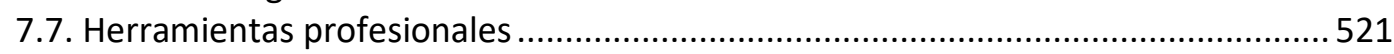

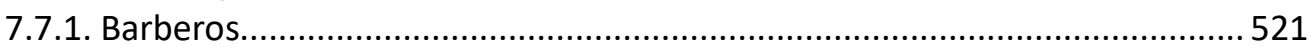

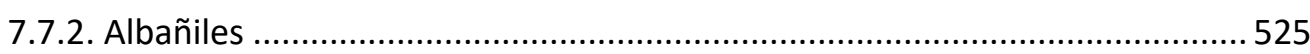

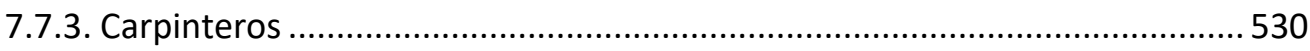

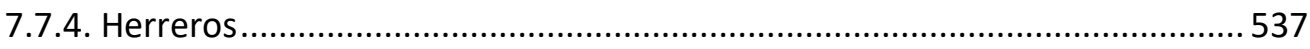

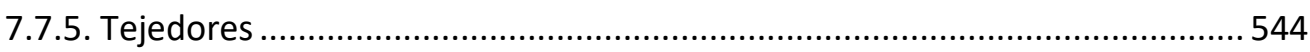

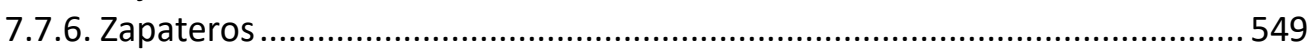


Página

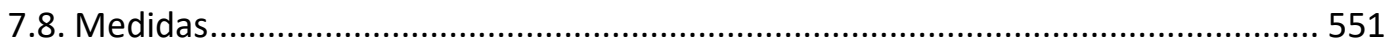

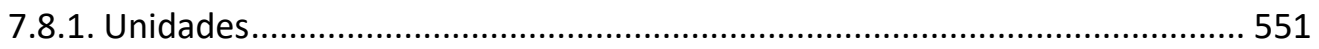

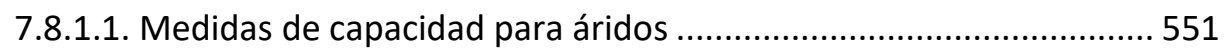

7.8.1.2. Medidas de capacidad para líquidos............................................... 557

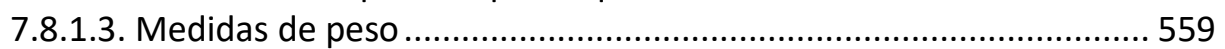

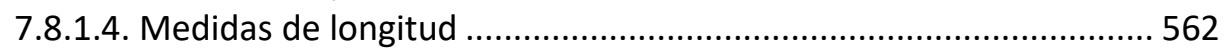

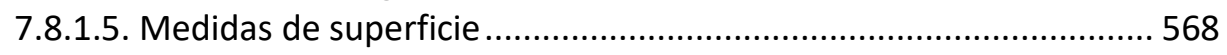

7.8.1.6. Medidas de capacidad formadas sobre partitivos ........................... 569

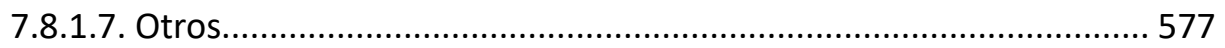

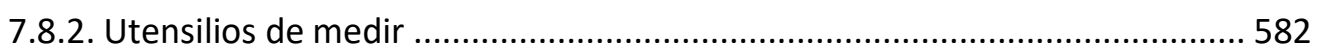

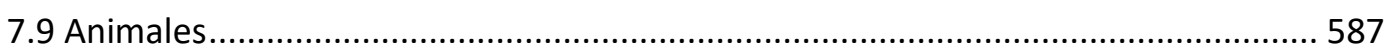

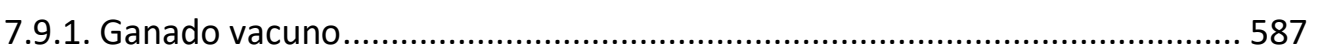

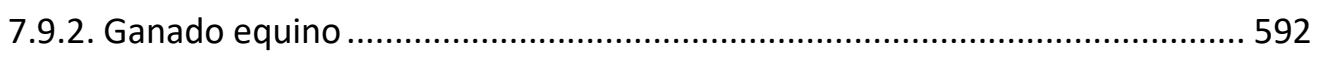

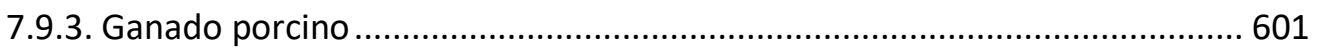

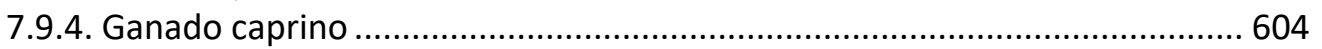

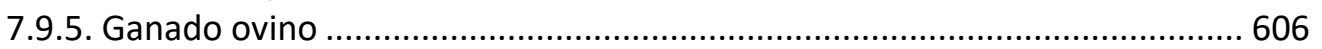

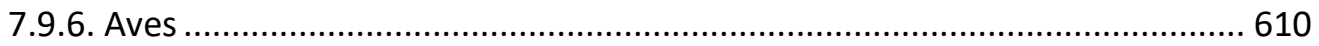

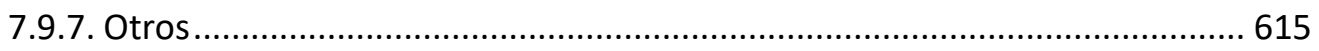

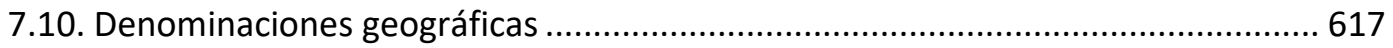

\section{BLOQUE V: CONCLUSIONES Y FUTURAS LÍNEAS DE TRABAJO}

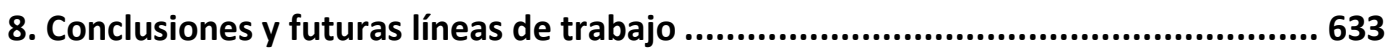

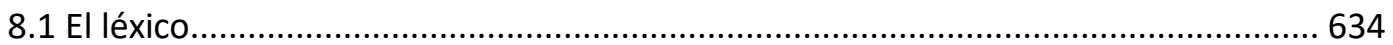

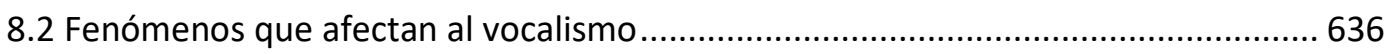

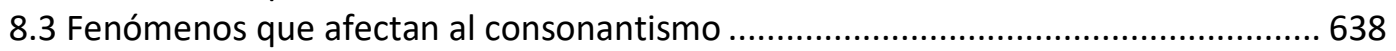

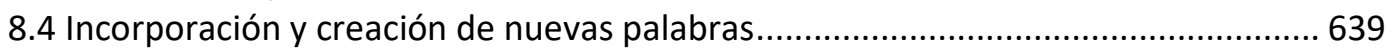

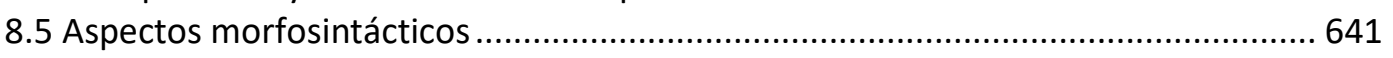

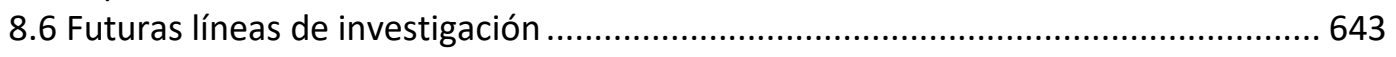

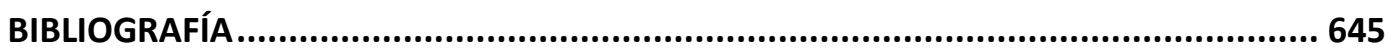

ANEXOS

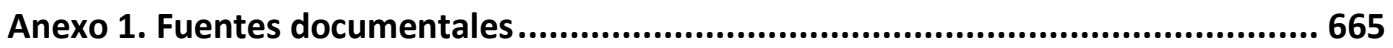

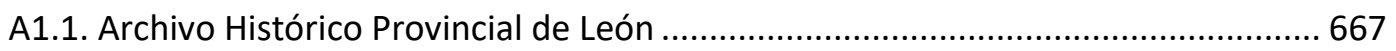

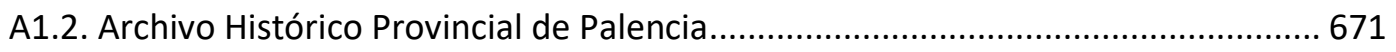

A1.3. Archivo Histórico Provincial de Valladolid .............................................................679

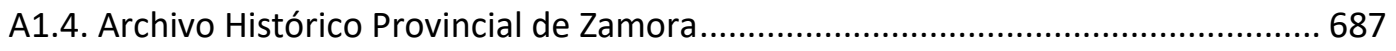

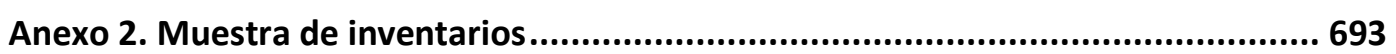

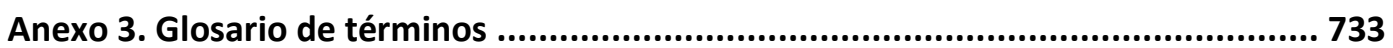





\section{ABREVIATURAS UTILIZADAS}

Muchas de las abreviaturas que aquí se utilizan se han tomado del $D E C H, D L E$ y otras obras lexicográficas:

$$
\begin{aligned}
& \text { adj. = adjetivo } \\
& \text { amb. = ambiguo } \\
& \text { amer. = americanismo } \\
& \text { ant. = antiguo } \\
& \text { antic. = anticuado } \\
& \text { ár. = árabe } \\
& \text { ast. = asturiano } \\
& \text { Ast. = Asturias } \\
& \text { átom. = atómico } \\
& \text { cast. = castellano } \\
& \text { clás. = clásico } \\
& \text { coloq. = coloquial } \\
& \text { comp. = compárese } \\
& \text { cpt. = compuesto } \\
& \text { der. o deriv. = derivado } \\
& \text { despect. = despectivo } \\
& \text { desus.=desusado } \\
& \text { dial. = dialectal } \\
& \text { disc. = discontinuo } \\
& \text { esp. = especial } \\
& \text { Ext. = Extremadura } \\
& \text { f. = femenino } \\
& \text { fr. = francés } \\
& \text { Gal. = Galicia } \\
& \text { gall. = gallego } \\
& \text { gasc. = gascón } \\
& \text { germ. = germánico } \\
& \text { gót. = gótico } \\
& \text { gr. = griego } \\
& \text { hispanolat. = medio } \\
& \text { ibér. = ibérico } \\
& \text { ibid. = ibídem } \\
& \text { íd. = ídem } \\
& \text { irl. = irlandés } \\
& \text { it. = italiano } \\
& \text { lat. = latín } \\
& \text { masculino } \\
&
\end{aligned}
$$


neerl. neerlandés

núm. = número

oc. u occ. = occitano

occid. = occidental

op. cit. = obra citada

p.ej. = por ejemplo

P.J.= Partido Judicial

pl. = plural

port. = portugués

probte. $=$ probablemente

propte. $=$ propiamente

s. v. = sub voce

Sal. = Salamanca

santand. = santanderino

sust. $=$ sustantivo

U. $\mathrm{m}$. en pl. = úsase más en plural

verb. = verbo

vg. o vulg. = vulgar

vid. $=$ véase

Zam. = Zamora

* = signo que precede a una forma hipotética en las etimologías

ALCYL = Atlas Lingüístico de Castilla y León

CORDE = Corpus Diacrónico del Español

$C D H=$ Corpus del Nuevo diccionario histórico del español

CorLexIn= Corpus Léxico de Inventarios

$D E C H=$ Diccionario Crítico Etimológico Castellano e Hispánico

$D E E H=$ Diccionario Etimológico Español e Histórico

$D H L$ = Diccionario Histórico de la Lengua Española

DHTT $=$ Diccionario Histórico de Telas y Tejidos

$D R A E=$ Diccionario de la Real Academia Española

$N D H E=$ Nuevo Diccionario Histórico del Español

NTLLE = Nuevo Tesoro Lexicográfico de la Lengua Española 




\section{INTRODUCCIÓN}

\subsection{JUSTIFICACIÓN}

La presente tesis pretende realizar el estudio del léxico en el siglo XVII en la comarca de Tierra de Campos. Es una zona de gran interés desde el punto de vista diatópico, pues es un área de confluencia entre las variantes históricamente leonesas y castellanas. Muchos de los autores identifican el romance que se habla en esta zona con el castellano. Lapesa afirma que, en el Este y Sur del antiguo Reino de León, el influjo del castellano ha desdibujado y eliminado los fenómenos más típicos del leonés (Lapesa, 2008).

El periodo del que se ocupa nuestro estudio se caracteriza por carecer de un corpus específico de las diferentes zonas. En general, las referencias léxicas proceden de obras literarias y técnicas, en las que suele figurar un estadio culto y normativo de la lengua, escapándose así la variedad dialectal. Para ello, la documentación utilizada pertenece a protocolos notariales del siglo XVII, extraídos de los Archivos Históricos Provinciales de León, Palencia, Valladolid y Zamora de donde se ha seleccionado un nutrido número de inventarios de bienes para poder aproximarnos al estudio del léxico de la vida cotidiana en Tierra de Campos en el siglo XVII.

Este estudio, contribuirá a la aportación de materiales al proyecto CorLexIn, corpus documental conformado por textos inéditos del siglo XVII, cargados de información léxica de la vida cotidiana de la época áurea, tanto de España como de América, y del que hablaremos más adelante con más detenimiento.

\subsection{OBJETIVOS}

La comarca de la Tierra de Campos es un territorio de gran interés filológico. Esto se debe a la pugna que allí ha existido entre el leonés y el castellano y que ha contribuido en gran medida a difuminar unas apariencias dialectales que nunca estuvieron demasiado claras.

Mediante esta tesis, como objetivo principal, se pretende estudiar el léxico relacionado con la vida cotidiana de la Tierra de Campos en el siglo XVII. Este tipo de léxico nos ayuda a conocer el estado de la lengua y sus rasgos representativos.

El segundo objetivo es la creación de un corpus textual con documentos extraídos de los protocolos notariales pertenecientes a diferentes localidades que forman parte de la zona de estudio en el siglo XVII. Para ello hay que seleccionar, clasificar, leer y transcribir los materiales reunidos. Así, el corpus se formará con material manuscrito e inédito procedente de inventarios, cartas de dote, partijas, almonedas, testamentos... 
Una vez seleccionadas las palabras que constituirán el cuerpo de la tesis, se procederá a la clasificación del léxico estableciendo diferentes campos semánticos.

Centrándonos en el análisis del léxico estudiaremos los rasgos específicos que tengan que ver con aspectos léxicos, semánticos o morfológicos entre otros. Por otro lado, se analizarán procesos de renovación y creación del léxico, como, por ejemplo, aquellos que provienen de la morfología derivacional, los que se toman de otras lenguas -los préstamos- o cualquier otro fenómeno significativo.

Otro de los objetivos es dar a conocer el léxico utilizado en este tipo de documentos en Tierra de Campos y contrastarlos con los datos que nos ofrece el CorLexIn.

Por último, queremos poner a disposición de la comunidad científica los materiales encontrados para que puedan servir de base para nuevos trabajos. 


\section{MARCO GEOGRÁFICO Y ECONÓMICO DE LA TIERRA DE CAMPOS}

\subsection{MARCO GEOGRÁFICO}

La zona de estudio escogida es la comarca de Tierra de Campos, también denominada con anterioridad Campos Góticos. Esta zona hacía y hace referencia a una extensa llanura situada al Norte del río Duero cuya característica más importante es ser una gran extensión de tierras de labor exentas de montañas. En el siglo XVII la conciencia de pertenencia a este espacio geográfico era patente y así aparece en algunos documentos de la época, como veremos más adelante. A pesar de esta homogeneidad geográfica, dicho territorio no cuenta con unos límites precisos; podemos decir que siempre ha existido cierta vaguedad respecto a este tema, ya que nunca ha habido una unidad institucional que la delimite (Yun, 1987: 31). De esta manera nos encontramos con un espacio geográfico muy homogéneo en cuanto a apariencia, pero muy desestructurado en cuanto a divisiones administrativas, fiscales, eclesiásticas o jurisdiccionales.

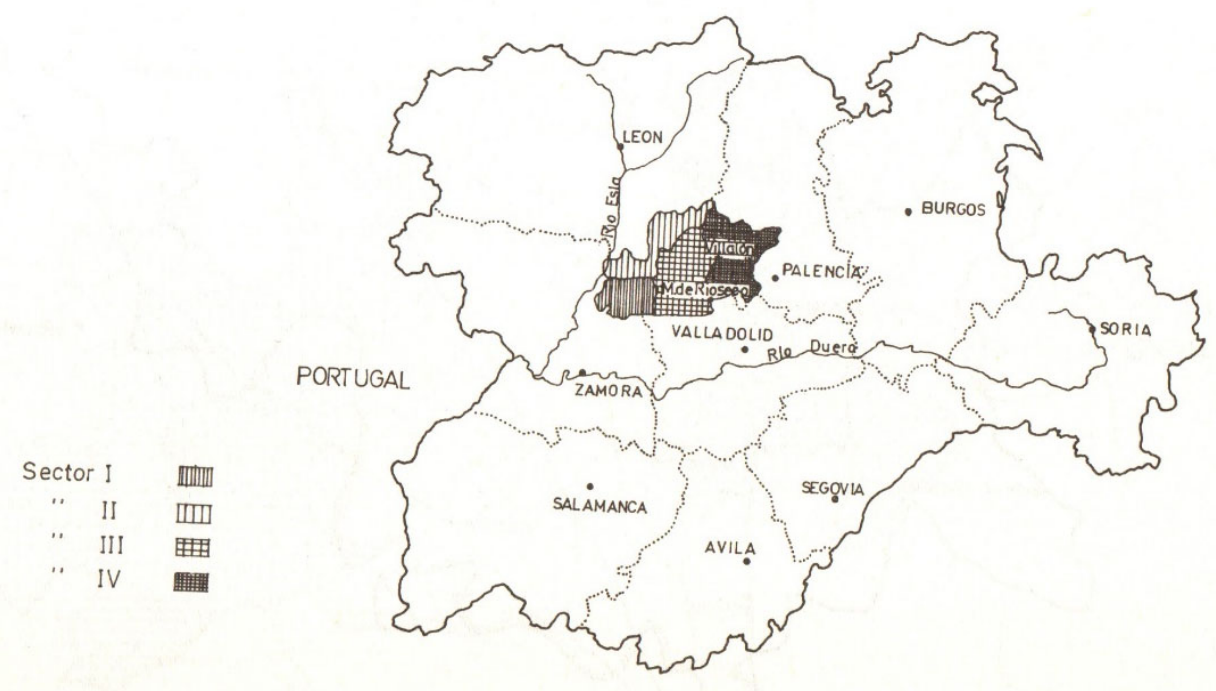

Figura 2.1. La Tierra de Campos en el espacio Castellano-Leonés (Yun, 1987).

Sánchez Albornoz opina que la denominación de Campos Góticos es anterior a la conquista musulmana y que habría sido utilizada por los pueblos que limitaban al Norte con dicha zona para designar el territorio ocupado por los visigodos; también advierte de que no harían referencia exclusivamente a esta zona, sino también a todo el territorio que les sirvió de zona de repoblación y asentamiento (Sánchez-Albornoz, 1959: 254).

Vaca Lorenzo habla de otros autores como Pérez Pujol, Menéndez Pidal o García Gallo, que también afirman que dicho topónimo alude al asentamiento de los godos en esta zona. Pero ninguno de ellos aporta ninguna prueba documental que garantice que el topónimo Campos Góticos date de la etapa visigoda (Vaca, 1992: 152). Aparece documentado en la 
Crónica de Albelda, y más tarde en las colecciones diplomáticas de la catedral de León y del monasterio de Sahagún:

Annuit namque huius serenitati regni glorie nostre ut faceremus tibi sicuti et facimus cartulam donacionis et concessionis de villa nostra propria qui est in Campos Gotorum nominata Sancti Michaelis in rivulo Sicco super villa quam dicunt Bobatella (Colección diplomática del Monasterio de Sahagún (siglos $(X-X)$, Mínguez, 1976: 20)

De Campos Góticos se pasó a la actual denominación de Tierra de Campos. Esa denominación aparece documentada en la Primera Crónica General de España del rey Alfonso $\mathrm{X}$, y en la Crónica Latina de los Reyes de Castilla que, según su editora, Cabanes Pecourt, fue redactada en los años 1224-26 (Vaca, 1992: 153).

La delimitación de la Comarca de la Tierra de Campos resulta una tarea ardua. Son muchos los autores que han tratado de establecer las fronteras de este territorio. Al margen de la dificultad que existe para delimitar cualquier área geográfica, esta zona presenta varios problemas añadidos y es que La comarca de Tierra de Campos se encuentra ubicada en el centro de una unidad geográfica mayor, Castilla y León, gran parte de cuyo territorio posee unos caracteres geográficos, económicos, demográficos e históricos similares (Vaca, 1992: 154). A todo esto hay que añadir el hecho de no haber existido nunca una unidad administrativa que abarcara y delimitara esta zona de forma precisa, como se ha comentado anteriormente.

En la Crónica General de España de Alfonso x, en pleno siglo XIII, los llamados Campos Góticos se ubican en un territorio comprendido por dos zonas que habitualmente aparecen por separado: Tierra de Campos y Toro, delimitándolos de la siguiente manera:

En 735 años de la Encarnación del mundo, Alfonso el Católico entró en Tierra de Campos, esto es Toro, la que tiene de cabo el río Esla, del otro, el Carrión, de Pisuerga, de Duero, y conquiriolo todo.

Pobló el Rey Alfonso III, en los Campos que se dice de los Godos y estos son campos de Campos de Toro, y otros lugares que estaban yermos y despoblados de los moros.

Vaca Lorenzo nos habla de otras fuentes documentales del periodo bajomedieval que intentan delimitar esta zona con mayor precisión; así, en la Crónica Latina cita dos lugares situados en el límite septentrional, Sahagún y Carrión. En la Crónica de Alfonso XI aparecen los siguientes lugares como pertenecientes a esta comarca: Becerril, Aguilar de Campos y Castroverde de Campos, así como Melgar de Abajo, Moral de la Reina, Cuenca de Campos y Abia de las Torres, localidades a las que se unían Villalón y Villalba de los Alcores. Mientras, en la Crónica de Pedro I sitúa también a Valderas en dicho territorio (Vaca, 1992: 155-157).

Habitualmente autores como Menéndez Pidal (1906) o Zamora Vicente (1974), entre otros, consideran que esta zona siempre había tenido cierta inestabilidad en cuanto a su pertenencia, al Reino de León o al Reino de Castilla. De hecho, se fijan en los límites medioevales del reino leonés que se separaba del de Castilla en un primer momento por el río Pisuerga, hasta que el Rey de Pamplona, Sancho, el Mayor, conquistó a León la actual provincia de Palencia y trasladó el límite del reino al río Cea (Menéndez Pidal, 1906: 129). 


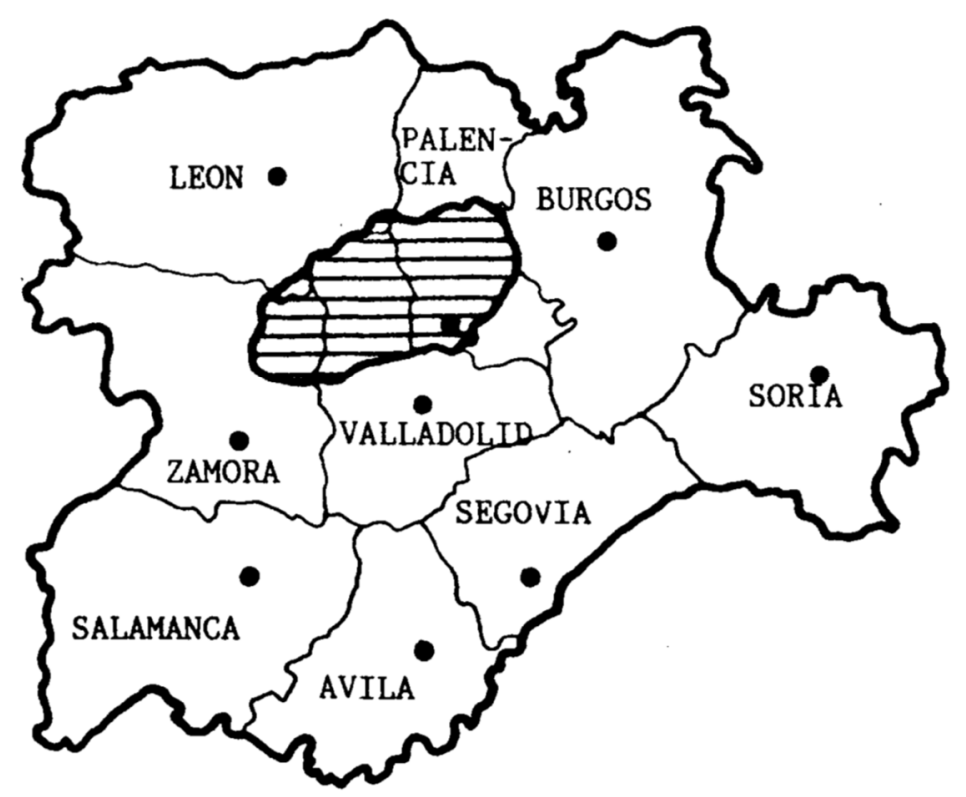

Figura 2.2. La Tierra de Campos (Vaca, 1992).

En la época de la repoblación -la documentación atestigua este hecho entre los siglos x y $\mathrm{XI}$ - esta zona fronteriza adquiere un fuerte valor estratégico entre los reinos de León y Castilla. Fernando II y Alfonso IX intentan fortalecer la frontera del Cea frente al rey de Castilla. Estos asentamientos se configuraban, por un lado, por la aparición en las zonas fronterizas de centros fortificados como el de Grajal de Campos, con una función defensiva donde se crea una serie de asentamientos de población alrededor del mismo. De otro lado, se lleva a cabo un tipo de repoblación monástica, esto es, la instauración de una serie de monasterios en diferentes puntos de Tierra de Campos reconocidos por los reyes y dotados de un territorio o coto particular donde se asentaban una serie de poblados con una densidad de población importante, entre los que destaca el monasterio de San Benito de Sahagún (Carrera de la Red, 1988: 141). La arbitrariedad de pertenencia de estos asentamientos a un reino o a otro se ve reflejada en lo ocurrido en la población de Santervás de Campos, que pertenecía en 1183 al Reino de León; pero una vez fallecido Fernando II, los castellanos se apoderan de algunos pueblos de Tierra de Campos pertenecientes al reino leonés, convirtiendo esta población en una destacada defensa castellana al final del siglo XII y primera mitad del XIII (Carrera de la Red, 1988: 214).

Esta falta de estabilidad fronteriza entre los reinos de León y Castilla provoca que en la Tierra de Campos las dependencias políticas cambiaran con cierta frecuencia (Fernández Ordóñez, 2011: 59). 
Sin embargo, al margen de esta frontera política tan oscilante entre el reino de León y el de Castilla, Morala señala otros límites que serían más estables. Se trata de las demarcaciones eclesiásticas, los obispados que se mantuvieron hasta que se instauraron los modernos límites provinciales, establecidos a mediados del siglo XX, tras el Concordato de 1954 (Morala, 2011: 104).

Así, nuestra zona de estudio presentaría unos límites que habrían pervivido desde la Alta Edad Media hasta casi nuestros días. La Tierra de Campos pertenecía casi en su totalidad al Obispado de León, de cuyos límites tenemos constancia en el Códice 13 del Archivo de la Catedral de León o también Ilamado Becerro de Presentaciones de Curatos y Beneficios. La fecha de redacción de este documento data de la segunda mitad del siglo XV, pero se advierte que este texto es un "trasumpto" copiado fielmente de un "becerro antiguo", por lo que los límites del Obispado serían válidos desde el siglo XIII (Fernández Flórez, 1984: 281). Este documento refleja cómo el Obispado se organizaba territorialmente a través de arcedianatos y arciprestazgos; en concreto, deja constancia de la división de la diócesis leonesa en cuatro arcedianatos: Valderas, Mayorga, Valdemeriel y Saldaña. La tierra de Campos discurre por el norte y oeste de la provincia de Valladolid (Villalón, Mayorga, Aguilar de Campos...), el noreste de la de Zamora, con arciprestazgos como los de Villalpando y Villafrechós, y, sobre todo, una buena parte del oeste de Palencia (Cervera, Triollo, Valdavia, Villada...).

Además, esta comarca comprendía algunas localidades que pertenecían al Obispado de Palencia. Este estaba constituido por los arcedianatos de Alcor, Carrión, Cerrato y Campos. El arcedianato de Campos se situaba al occidente de dicho obispado, formando frontera con el de León, y su ámbito territorial comprendía el curso medio del río Sequillo hasta el curso medio del Carrión, teniendo como eje central el arroyo Valdeginate y la laguna de La Nava. Administrativamente, dicho arcedianato lo conformaban seis arciprestazgos -La Cueza, Becerril, Paredes de Nava, Castromocho, Medina de Rioseco y Tordehumos- (Vaca, 1992: 158161).

La muestra recogida para el presente estudio se ha constituido a través de la selección de textos notariales de los antiguos partidos judiciales pertenecientes a la Tierra de Campos: la localidad palentina de Frechilla, Medina de Rioseco en la provincia de Valladolid, Sahagún y la localidad de Valderas de León y la localidad zamorana de Villalpando. De esta forma cubrimos el área de estudio de Norte a Sur y de Este a Oeste. 


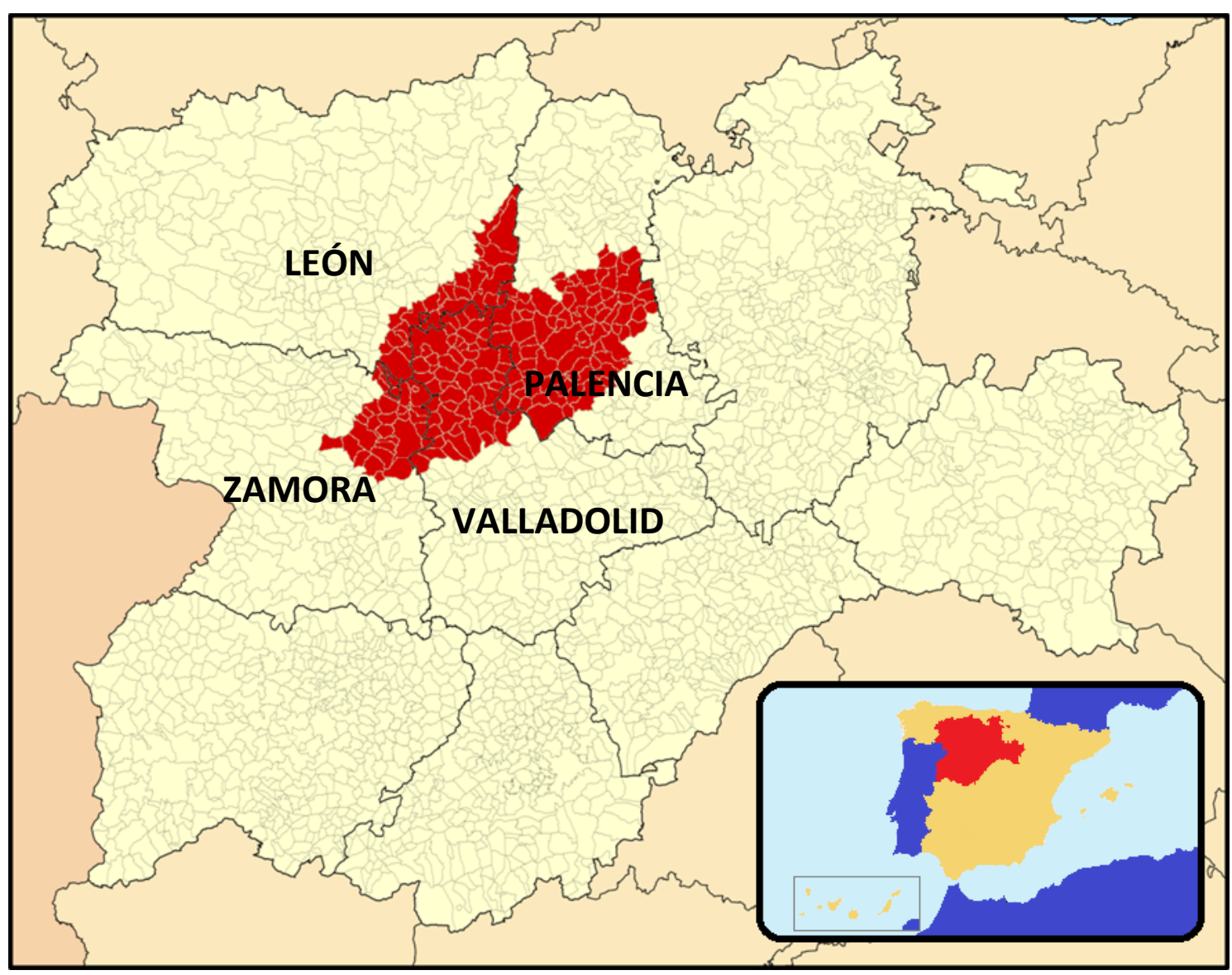

Figura 2.3. La Tierra de Campos en Castilla y León.

\subsection{ECONOMÍA Y SOCIEDAD EN LA TIERRA DE CAMPOS}

Por su fisionomía, la Tierra de Campos se convirtió en una zona privilegiada para el intercambio comercial. Las relaciones de caminos más tempranas son un testimonio claro de ello y así aparecen descritas en el libro v del Códice Calixtino donde Picaud afirma lo siguiente acerca de esta tierra:

Hec est terra plena gazis, auro et argento, palleis et equis fortissimis felix, pane, uino, carne, piscibus, lacte et melle fertilis. Lignis tamen est desolata, hominibus malis et uiciosis plena. (Lillo, 2012: 147).

La realidad es que esta comarca ejercía de bisagra entre puntos de intercambio distantes. Las relaciones comerciales de la región se mantenían en torno a rutas que atravesaban la comarca. Los centros feriales como los de Villalón, Villada, Villarramiel o Medina de Rioseco mantenían una relación muy provechosa con lugares como Santander, Asturias o La Rioja. Durante los siglos XVII y XVIII se mantuvieron estos intercambios comerciales que eran fecundos en varios sentidos, ya que no solo se limitaban al comercio de productos que regían su economía y que llevaban al trasiego de pan y vino hacia las zonas montañosas y situadas más 
al norte a cambio de ganado y pescado de la cornisa cantábrica, por ejemplo, sino que también se veía implicado el sector agrícola y ganadero, en tanto que ese comercio afectaba a productos derivados del sector primario. Esto provocó que hubiese un aumento demográfico en tanto se desarrolló desde esas fechas un fuerte trasiego de mano de obra, en particular, agosteros gallegos, asturianos y santanderinos. Todavía en el siglo XIX esta zona seguía siendo receptora de arrieros. Madoz señala lo siguiente sobre la localidad de Añaz, perteneciente a la diócesis de Santander: "[...] sus habitantes padecen de pulmonías, dolores de costado, alguna que otra afección de pecho, y calenturas tercianas, que contraen en Tierra de Campos, á donde van a trabajar en tiempo de verano" (Madoz, 1845: Tomo II, 271).

\subsubsection{Características de la población}

La Tierra de Campos resultaba interesante desde una perspectiva económica debido a las oportunidades de subsistencia que ofrecía a un gran número de repobladores. Este proceso de repoblación, como se ha señalado anteriormente, comenzó en el siglo x de una forma un tanto anárquica, con pequeños núcleos aislados. Pero en el siglo XIII comenzó una jerarquización que se iría consolidando con el tiempo y que terminó con el surgimiento de villas con renombre, centros de defensa, de administración señorial o real, de mercado y de servicios. A partir de ese momento la evolución hacia la concentración demográfica se vio notablemente impulsada (Yun, 1987: 56).

La población en esta comarca tuvo la necesidad de asentarse en las márgenes de los ríos de la región; así, el Valderaduey, el Sequillo, el Valdeginate y, al Norte, el río Cea, eran las arterias de los asentamientos más importantes. El resultado fue, en palabras de Yun Casalilla, "un poblamiento concentrado en núcleos no muy grandes, repartidos con cierta homogeneidad en un territorio sin espacios vacíos muy extensos, en el que el caminante, a las afueras de un pueblo, ya divisaba el siguiente. Aunque, como es de esperar, en todo proceso histórico que ha afectado de forma distinta a las diversas zonas de la comarca y ha estado condicionado a intereses contrapuestos, ni el equilibrio es total, ni ha faltado cierta descompensación interna de poblamiento. Las densidades de población son menores en la zona de repoblación leonesa y en las behetrías palentina" (Yun, 1987: 56-59).

A comienzos del siglo XVI, la zona terracampina se organizaba de manera jerárquica; algunas localidades eran las encargadas de gestionar la economía de la zona, así destacaban las villas de Mayorga, Villalpando, Villalón, Medina de Rioseco o Paredes de Nava. Este florecimiento de las villas iba acompañado del auge de las ferias en dichas zonas, lo que provocó un crecimiento económico y un intercambio comercial que sirvió para dar mayor auge a la zona.

A mediados del siglo XVII, La Tierra de Campos se ve inmersa en una crisis que afecta todos los sectores, económico, social y humano. A las condiciones climáticas adversas que desembocaron en malas cosechas, se sumaron el incremento de la mortalidad por la 
propagación de la peste y la subida de precios de alimentos básicos como el pan. A finales de siglo se paralizó casi por completo toda actividad económica.

[...] Sus gentes se acostumbraron a vivir al día y se familiarizaron con los peores desastres que seguidamente se sucedían [...]. [...] el pueblo empieza a decaer y los que aún resisten debido a la sucesión de los malos resultados y las pesadas cargas que padecen, se hallan descorazonados. (Informe del embajador inglés a su rey, De la Granja, 2003: 40).

En esta época cabe destacar la concentración de tierra en manos de eclesiásticos o de instituciones afines (cofradías, obras pías, memorias, instituciones de beneficencia...) que acaparaban mucha riqueza en localidades no tan importantes como los núcleos feriales. Es el caso de Sahagún, donde el monasterio de San Benito amplió su extensión, ganando en propiedades territoriales (Yun, 1987: 65-67).

\subsubsection{Economía de la Tierra de Campos}

En el siglo XVII, la zona terracampina se especializó en el cultivo del cereal -trigo y cebada principalmente-, pero también hay que señalar que en sus comienzos la actividad agrícola atravesó por un periodo de dificultades. El aumento de la presión fiscal y señorial, el encarecimiento de los productos básicos de consumo y la práctica de sistemas de cultivo abusivos provocaron una situación crítica que estuvo latente en la zona a lo largo de todo el siglo. Al incrementarse el desempleo estructural en el campo, algunos campesinos con escasa disponibilidad de tierras, ante la pérdida de la base agraria que garantizaba su reproducción se vieron obligados a buscar nuevas fuentes de ingresos, ya que el trabajo estacional no les garantizaba la subsistencia, ni resolvía la situación de subempleo. De esta forma comenzaron a adquirir importancia una serie de actividades que surgen como forma de subsistencia para los más desafortunados. Este tipo de labores tenían que ver más con trabajos de transformación y transporte. Se dio así un impulso a las ferias - destacando las de Medina de Rioseco, Villalón o Villada- y a las actividades complementarias a la agricultura. Aparecieron así núcleos especializados en la producción vitícola de orientación mercantil, en los que se hizo patente tanto la presencia de explotaciones especializadas de dimensiones considerables, como el carácter de cultivo social que adquirió el viñedo cuando se puso en práctica en régimen de monocultivo por los propietarios más desfavorecidos de la comunidad (Oliva, 2000-2001: 227228).

Por esta época, también culminó el proceso de desarrollo de la industria textil castellana. Esta actividad textil, bien de modo principal o bien de modo secundario, no era más que una actividad complementaria a otras que se desarrollaba dentro del seno doméstico (Hernández García, 2004: 129). Este desarrollo estaba íntimamente relacionado con la vinculación de los señores a la expansión de la producción de bienes en áreas rurales, haciendo florecer mercados locales de manufactura de tejidos. Existía ya en la zona un arraigado centro de producción textil que se remonta a finales del siglo XIII, que era la propia ciudad de Palencia. Pronto surgió la necesidad de extender los procesos productivos textiles en el entorno rural terracampino, fomentada por las propias condiciones vigentes en las villas que posibilitaban la 
utilización de mano de obra más barata. Así conocemos de la existencia de estas actividades en la villa de Castromocho, Becerril, Paredes de Nava o Frechilla, auténtico centro de producción textil cuyas producciones se vendían en las ferias de Medina de Rioseco y Villalón entre otros lugares. Los paños que se fabricaban en Tierra de Campos transcendían más allá de los mercados locales, así eran famosos en el Norte de Castilla, Vizcaya, Asturias, Galicia, Aranda de Duero, Oviedo o el Norte de Portugal (Oliva, 2000-2001: 229, 237, 250). Los principales centros productores eran Amusco, Frechilla y Villarramiel. La organización del trabajo era de industria dispersa, con fabricantes en sus talleres que daban trabajo a un número reducido de operarios especializados, mientras la mayoría de los trabajadores eran individuos que desarrollaban sus labores dentro de sus propias casas. Estos eran mujeres y hombres dedicados al trabajo en el campo, que se ocupaban de hilar o tejer de manera eventual, aprovechando las épocas de poca actividad agrícola (Bellido, 2006: 273). De ahí que nos encontremos inventarios en los que los aperos de labranza se mezclan con los tornos de hilar.

En cuanto al ganado, aunque se trata de una zona de extensa llanura, los pastos no abundaban entonces, ni ahora, por lo que poseían pocas cabezas de ganado. El más abundante era el ganado ovino, aunque el número de cabezas no era suficiente como para abastecer los telares de las localidades terracampinas, por lo que los fabricantes se ven obligados a buscar la materia prima lejos de los centros transformadores de la misma (Hernández García, 2004: 129). Con la crisis que imperaba en la época, el número de cabezas de ganado se vio reducido a la mitad ya en la segunda década del siglo XVII (Yun, 1987: 400).

La comarca de Tierra de Campos se convirtió así en una zona de intercambios comerciales, donde quienes vivían en zonas de montaña de León, Asturias o Cantabria se abastecían de cereales, pan, vino, telas en esta zona a cambio de madera, aperos para la labranza y demás objetos elaborados por ellos mismos. 


\section{MARCO DIACRÓNICO. DEL SISTEMA MEDIEVAL AL ESPAÑOL MODERNO}

Como hemos visto en los capítulos anteriores, el siglo XVII supone el inicio de una crisis que se manifestará en los ámbitos de la economía, la convivencia social y las relaciones internacionales. La decadencia económica española dará como resultado una disminución de la población y un debilitamiento en sectores como la agricultura, la industria y el comercio, tanto interior como exterior (Martínez Shaw, 2008: 674). Por lo tanto, va a ser un periodo de inestabilidad política y económica propiciado por la demografía, la climatología, las malas cosechas, las guerras, el hambre, las epidemias y la incapacidad de sus reyes.

Sin embargo, la producción cultural de este siglo permitirá seguir hablando de una etapa floreciente en las letras españolas. Pero antes de entrar a describir cómo era el castellano en el siglo XVII, conviene destacar los antecedentes que hicieron posible que el romance castellano pasara a primer plano de la literatura y se convirtiera en una lengua de prestigio.

Ya en el siglo XIII, con el reinado de Alfonso x, el Sabio, el castellano pasa a ser la lengua que se escribía en la corte, así como la lengua encargada de la transmisión de la cultura. Los repobladores de la reconquista llevan consigo su lengua. Este periodo abarca desde el 711 al 1492, fecha en la que se descubre América y Nebrija escribe la primera gramática en lengua romance. Al mismo tiempo que la Corona de Castilla amplía sus fronteras geográficas, extiende el uso de la lengua que se habla en la corte. Esta, en el territorio peninsular, sufre continuos traslados, de Burgos a Toledo, más tarde Valladolid y de ahí a Madrid. Así Castilla extendió su norma lingüística desde el Norte al Sur peninsular.

La aparición de la imprenta en el siglo $x \mathrm{~V}$ y la difusión de obras literarias en lengua romance contribuyeron a fijar y dar estabilidad al castellano, primero en su manifestación artística y luego hablada. La imprenta dota de mayor homogeneidad y fidelidad al original de las obras que se publican, así como contribuye a que estas se propaguen de manera más eficiente.

Ya en el siglo XVII aparece el primer diccionario monolingüe en lengua romance, el Tesoro de la Lengua castellana o española de Sebastián de Covarrubias en el año 1611. Es en esta época donde ubicamos nuestra tesis.

Por la zona de estudio escogida es conveniente recordar en qué estadio de evolución se encontraba el castellano en aquella época.

A lo largo de los siglos XVI y XVII tiene lugar una serie de transformaciones puestas en marcha en siglos anteriores, que suponen el paso del sistema medieval al sistema del castellano moderno; en este periodo se consolida el sistema fonológico del español actual (Lapesa, 2008; Ariza, 1992; Cano, 2008).

Los cambios que sufre el sistema fonológico de la lengua en los siglos XVI y XVII suponen la ruptura con la época medieval. Cuando la unidad lingüística del centro de la Península estaba 
consumada, se establece y generaliza una norma, que se presenta aún inestable, en un periodo de formación muy dinámico (Congosto, 2002: 17).

\subsection{CAMBIOS FONÉTICOS Y FONOLÓGICOS}

\subsubsection{El sistema vocálico}

Se puede decir que el sistema vocálico constituido por cinco elementos está fijado desde la Edad Media (Alarcos, 1986: 225; Morala, 2012a: 555; Cano, 2008: 825). Sin embargo, esta estabilidad vocálica es solo un espejismo, ya que la alternancia entre el uso de las vocales átonas se mantiene vivo en el periodo que nos ocupa, a pesar de haberse iniciado en siglos anteriores. Lapesa, que toma como referencia fuentes literarias para llevar a cabo este estudio, señala que este fenómeno va a ir disminuyendo a lo largo del siglo XVI (Lapesa, 2008: 91). Sin embargo, otros autores observan que esta vacilación dista mucho de haber desaparecido en el siglo XVII y son muchos los ejemplos que muestran este rasgo en documentos como los inventarios de bienes de la época (Morala, 2012a; Morala 2019a; Cano, 2008: 826). Estas alternancias se suelen dar entre /o/ y /u/ (tonel/tunel), /a/ y /e/ (lanzuelo/lenzuelo) y /e/ e /i/ (mantellina/mantillina).

\subsubsection{El sistema consonántico}

El fonema de la /f-/ latina desapareció, sustituida en un primer momento por / $\mathrm{h} /$ aspirada. Sin embargo, en Castilla, el fonema / $\mathrm{h} /$ no se aspiraba ya desde hacía mucho tiempo (Lapesa, 2008: 368). En el siglo XVII podemos ver la forma arcaizante /f-/ en distintos documentos notariales, pero, en el resto de ámbitos, este fonema inicial desapareció. La ausencia de este fonema se hace general a finales del siglo XVI. Autores como Menéndez Pidal o Lapesa afirman que la eliminación de la norma idiomática fue otra de las irradiaciones de la nueva corte madrileña, moldeada lingüísticamente sobre el hablar castellano viejo. Sin embargo, autores como Covarrubias, que en otras ocasiones había obviado la "norma toledana", dice lo siguiente: "[...] los que son pusilánimes, descuydados y de pecho flaco suelen no pronunciar la h en las dicciones aspiradas como eno por heno y umo por humo, etc.". No obstante, el área de influencia de Toledo en el centro y sur peninsular, que por aquel entonces llegaba hasta Jaén y otras zonas del oriente andaluz recién conquistado, siguió al norte en esta pérdida. Hacia el oeste (Extremadura) y el sur (Andalucía occidental y sus prolongaciones malagueñas y granadinas), en cambio, el fonema aspirado se mantuvo, uso que en esta época aún no se considera vulgar, lo cual explicaría su interferencia con el proceso de velarización (Cano, 2008: 840-841). El estudio de los inventarios de bienes en el siglo XVII, reflejan una baja presencia textual tanto del mantenimiento como de la aspiración de este fonema en la mitad norte 
peninsular. Sin embargo, en el "cuadrante sudoccidental" de la Península, la aspiración gráfica está muy bien representada (Morala y Perdiguero, 2019: 196).

En el siglo XVI, la vieja distinción entre los fonemas /b/ oclusivo con grafía "b" y /v/ fricativo escrito con grafía "u" o "v" había desaparecido, dando como resultado un único fonema /b/. Nebrija ya advierte en su gramática de la proximidad de ambos fonemas y justifica que algunos hablantes no los distingan dada la cercanía acústica de ambos sonidos; no obstante, es defensor de esta diferenciación. Covarrubias en su Tesoro de la lengua castellana o española publicado a principios del siglo XVII, aunque no habla de ello como error, sí escribe que a la "b" 'muchas vezes le damos el sonido, y aun la figura de la v'. Además, conviene tener en cuenta que en los documentos manuscritos que nos encontramos en esta época se le añade la "extrema dificultad" de distinguir la letra "b" de la "v" en los textos que utilizan la letra cursiva procesal (Cano, 2008: 829). Si bien es cierto que algunos literatos como Garcilaso o los hermanos Valdés se manifiestan a favor de la distinción de estos fonemas en sus creaciones literarias, son muchos los que a estas alturas ya no las distinguen. Esto se refleja de manera más patente en autores del Barroco donde ya no hay distinción y la confusión es protagonista de los textos (Cervantes, Quevedo, Góngora, Lope de Vega...). Lo mismo ocurre con los documentos notariales de la época donde la confusión está presente (jubón, juvón, juuón; basquiña, vasquiña, uasquiña; cribo, crivo, criuo...).

También se da la pérdida de algunos grupos consonánticos que en el habla llana se habían simplificado o transformado (duda por dubda, cobdiciar por codiciar o cobdo por codo). Se vacilaba entre formas como cien y cient, san y sant, mil o mill (Lapesa, 2008: 369).

Si hay un fenómeno fonético característico de esta época es el reajuste de las sibilantes, un proceso que se venía gestando desde hacía tiempo, pero que en el siglo XVII culmina con la consolidación de los fonemas del sistema moderno $/ \Theta /$, $/ \mathrm{s} / \mathrm{y} / \mathrm{x} /$. Estos cambios fonéticos no son homogéneos en toda la Península. Aquí solo tendremos en cuenta lo que ocurre en castellano norteño, dejando al margen la zona meridional -donde el fenómeno es más complejo- o las zonas más conservadoras por influjo de la norma toledana.

En el sistema medieval existían tres pares de sibilantes sordas y sonoras: la dental africada /ŝ/ y /ẑ/, la alveolar fricativa /s/ y /z/ y la palatal fricativa /š/ y /ž/. Estos fonemas van a sufrir una serie de procesos -ensordecimiento, fricatización, velarización e interdentalización- que desembocarán en los fonemas del castellano moderno $/ \Theta /, / \mathrm{s} / \mathrm{y} / \mathrm{x} /$. Hay que advertir que aquí los autores no se ponen de acuerdo a la hora de establecer una cronología para cada uno de los fenómenos fonéticos.

Los casos de ensordecimiento de las parejas de sibilantes son un hecho en el siglo XVI, algunos autores como Alonso o Alarcos afirman que este proceso es incluso anterior en el ámbito del leonés y el aragonés (Alonso, 1962; Alarcos, 1986). No obstante, cabe señalar que este fenómeno no se da en todas las zonas, ni en todas las clases sociales a la vez. La norma toledana es mucho más conservadora que la castellana. Mientras que en los territorios donde triunfaba la norma toledana todavía se distinguían entre sordas y sonoras, en Castilla esta distinción había desaparecido (Alarcos, 1986: 269). Lapesa considera que este 
ensordecimiento se difunde en el siglo XVI desde Castilla y Aragón, Pascual (1988) piensa que este fenómeno tuvo lugar en Castilla por influjo del leonés (en Ariza, 1992: 162).

Junto al ensordecimiento, hay un proceso de fricatización de las africadas dentales. Ariza señala que estos fenómenos alternarían dependiendo de las zonas, empezando a veces por la fricatización de los fonemas /ŝ/y /ẑ/ (Ariza, 1992: 162).

Además de la pérdida de las sonoras, algunos fonemas, como las palatales, sufrieron un cambio de articulación, las antiguas /š/ y /ž/ pasaron a tener una articulación velar, fricativa y sorda. Esta velarización tuvo lugar debido a que en el grupo de las velares existía una casilla vacía en castellano, ya que no había un fonema fricativo sordo. Por otro lado, el punto de articulación de las apicoalveolares /s, z/ estaba demasiado próximo al de la /š, ž/, lo que supuso el triunfo de dicho fenómeno (Alarcos, 1986: 272; Ariza, 1992: 166). Esta innovación no se dio en el área del leonés, en el dominio catalán, ni en zonas del aragonés pirenaico no castellanizado. En castellano dio como resultado el fonema velar sordo $/ \mathrm{x} /$.

La interdentalización es una solución para salvaguardar la distinción fonológica entre el sonido resultante de la evolución de /ŝ, ẑ/ y el de las apicoalveolares /s, z/ (Cano, 2008: 842). El fonema resultante de las fricativas dentales se acercaba mucho al punto de articulación de la apical. Por ello, en Castilla, este fonema pasa a tener una articulación interdental / $\Theta /$.

Otro fenómeno que también tienen lugar en esta época es el yeísmo -fenómeno datado desde la Edad Media-. Cano advierte que este cambio debía de ser poco visible para los gramáticos de la época, ya que no hay comentarios al respecto. En él intervienen varias causas, como el "ablandamiento" articulatorio del Siglo de Oro, el carácter aislado y escaso rendimiento funcional de la oposición con la /y/ y su proximidad fonética (Cano, 2008: 848). También es habitual en esta época el debilitamiento del consonantismo en posición implosiva -confusión entre /-r/ y /-I/, debilitación de la /-d/-.

\subsection{CAMBIOS GRAMATICALES}

En el Siglo de Oro cabe destacar una serie de cambios a nivel morfológico que determinará el español moderno. Citamos algunos de ellos señalando que, como en el apartado anterior, se iniciaron en épocas anteriores y su evolución siguió una vez terminado el siglo XVII.

En esta época la variación de género entre algunos vocablos no es la que se mantiene hoy en día; el gramático Cristóbal de Villalón (1558) recoge como dialectalismo castellano el nombre femenino de árboles -"esta peral, esta moral, esta nogal"- y en el Quijote aparecen ejemplos como "la puente", "la estambre" o "los doce tribus" (Girón, 2008: 860).

En el morfema de número, bastante homogeneizado en las gramáticas renacentistas, en otro tipo de documentos no literarios, se puede observar la vacilación de algunas terminaciones: bueyes / bueis, tapapies / tapapieses, maravedís /maravedíes. 
Mención aparte merece la morfología derivativa en esta época, proceso muy activo para la formación de palabras. Este hecho lo constatan trabajos como los de Morala (2012b, 2015a, 2017a, 2017b, 2018a) o Perdiguero (2012a) entre otros.

Para el diminutivo la alternancia de desinencias es muy variada. A las terminaciones más comunes como son -illo, -ico e -ito hay que añadir la de -uelo. Es habitual la lexicalización de estos diminutivos.

En esta época se señala en los manuales la generalización del superlativo -ísimo -por influencia del latín y también del italiano-, aunque Correas no lo considera castellano (Girón, 2008: 861). Está claro que este superlativo culto está generalizado en la literatura del siglo XVII, sin embargo, la información que transmite el análisis de la documentación notarial del CorLexIn es completamente diferente. En esta época se localizan muy pocas ocurrencias de ísimo, algunas de ellas responden a expresiones lexicalizadas referidas a títulos nobiliarios o a advocaciones religiosas (excelentísima, ilustrísima, santísima, santísimo), otras, las menos, se han localizado en algunos inventarios andaluces (Morala, 2014a: 24).

Además, se ha generalizado la preferencia por los pronombres personales compuestos nosotros y vosotros, junto con sus formas femeninas correlativas frente a las formas simples nos y os. Esto lo constata el hecho de que las gramáticas de finales del siglo XVI y XVII solo recogen las fórmulas modernas. Existe también la preferencia por la forma os frente a vos (Girón, 2008: 862).

\subsection{CAMBIOS LÉXICOS}

El siglo XVII constituye uno de los periodos más productivos en cuanto a léxico se refiere. Existen dos procesos que van a ayudar a la renovación del vocabulario español en la época áurea (Verdonk, 2008: 895). Por un lado, la incorporación de palabras procedentes de otras lenguas -préstamos-. Por otro, se creaban nuevas voces a través de mecanismos intrínsecos a la propia lengua, esto es a través de procesos de composición, derivación o parasíntesis -sobrecama, tiradero o afelpado-.

\subsubsection{Incorporación de préstamos}

La incorporación de voces procedentes de otras lenguas es un proceso que ha ocurrido en todas las épocas y el Siglo de Oro no es ajeno a este fenómeno. La adhesión de préstamos puede venir dada por palabras procedentes de lenguas muertas (latinismos y helenismos) o bien de lenguas vivas fomentadas por el contacto que existía entre las mismas (Verdonk, 2008: 895). También debemos tener en cuenta que una vez que el préstamo lingüístico se incorpora al caudal léxico puede presentar ciertas modificaciones para adaptarse a la lengua que lo recibe (Álvar Ezquerra, 1995: 16). 
La presencia de préstamos va a ser habitual en la época áurea y, por ende, en nuestro corpus terracampino.

En esta época los términos procedentes del territorio francés viven una época de esplendor que no solo se vio representado en la literatura, sino que se extendió por el vocabulario de la vida cotidiana. En este sentido debemos señalar que ocupan un lugar importante en cuanto a la denominación de algunos textiles: bayeta, burato, felpa, lamparilla, camelote, gorgorán, pero también en otros objetos más comunes como bufete, taburete, cubilete o servilleta. Otro contexto del que provienen algunos préstamos es del neerlandés. Las relaciones comerciales con Flandes se intensificaron a partir del siglo XIV, y más con el matrimonio entre Juana I de Castilla y Felipe el Hermoso. A partir de la segunda mitad del siglo XVI la presencia constante de tropas españolas en Flandes seguirá propiciando que se incorporen a nuestra lengua una serie de préstamos, muchos de ellos pertenecientes al ámbito militar (López Vallejo, 2008: 135), pero también dejaron su huella en el léxico del ámbito doméstico (Lapesa, 1985) como valón o flamenquilla.

Por otro lado, cabe señalar que el catalán sirvió muchas veces de entrada de algunos galicismos y occitanismos que, por su cercanía, en ocasiones resulta complicado especificar la procedencia del término; también sirvió de puerta a germanismos e italianismos. Sabemos que en esta época el catalán no cuenta con el apogeo que consiguió en siglos anteriores, sobre todo en el campo literario, porque su influencia está presente en la introducción de nuevas lexías (Colón, 1967: 199). Algunos de los catalanismos que forman parte de este estudio son: bombasí, cantimplora, cordellate, escabel, frazada, perol, tira o gandaya.

Con las palabras de origen portugués ocurre algo parecido a las procedentes del catalán, la semejanza entre algunos términos y el contacto tan estrecho que siempre se ha mantenido, hace que se duden de ciertos orígenes. Algunas palabras a las que designamos un origen luso son: basquiña, abanico, búcaro o bandeja.

A partir del siglo XVI las relaciones con Italia se intensifican en muchos ámbitos de la vida como el político, el comercial, el religioso y el cultural lo que provoca la incorporación de un mayor número de italianismos (Pérez Vázquez, 2007: 126 en Junquera y Morala 2019: 188). En los inventarios de bienes se puede observar qué palabras cotidianas calaron en la lengua. Algunos de los italianismos que hemos encontrado en nuestro estudio son: brocatel, coleto, escopeta, medalla, raja, sotana, vitela, catalufa o tercianela.

Los términos procedentes del territorio germano entraron en la lengua desde muy temprano a través del latín (Gómez Ferrero, 2015: 528), con lo que la evolución de las mismas sigue los patrones fonéticos del castellano. En el siglo XVII, la influencia de estas voces llega a la Península a través del tamiz del francés u otras lenguas y destacan los términos que tienen que ver con la actividad bélica. Algunos germanismos que encontramos en las relaciones de bienes de Tierra de Campos son: guadaña, guante, frasco, ganso, banda, cofia, esquila, falda, ropa o rueca.

En cuanto a los préstamos procedentes del árabe cabe destacar que son una fuente muy importante en el incremento del caudal léxico de los romances peninsulares. Su presencia está 
en diferentes parcelas de la vida desde época medieval. Lapesa reconoce que el componente árabe tuvo una gran relevancia hasta el siglo XVI, después del elemento latino (Lapesa, 1985). Sin embargo, a partir de estas fechas, a consecuencia de la pérdida del influjo político y el desprestigio del árabe, muchas de sus voces caen en desuso y son sustituidas por otros términos, muchos de ellos procedentes del latín por vía culta (Enăchescu, 2019: 188). No obstante, en el siglo áureo siguen estando presentes en la lengua de ámbito cotidiano, especialmente en el mundo rural (Maíllo 1998: 501 en Vázquez Balonga, 2015: 289). En este sentido se puede ver el aporte que proporcionan los documentos notariales $y$, en especial, aquellos que presentan relaciones de bienes, ya que en muchas ocasiones dan fe del uso de términos que apenas se documentan en otro tipo de fuentes (Morala, 2012b). En el corpus terracampino encontramos muchas de estas voces: albanega, abalorio, alcorques, albornía, alcuza, aljáfana, almofía, albornoz, alcorcí, algodón, azafate o alamar entre otros.

Respecto a los americanismos, en esta época todavía son poco visibles en los textos, por lo que el número de préstamos procedentes del territorio americano son más bien escasos: enagua, pita, chocolatera o jícara. Estos indigenismos suelen proceder del Caribe, del náhuatl y del quechua (Gómez Ferrero, 2015: 529).

Menos visibles son en los textos términos procedentes del vasco, en nuestro corpus localizamos la voz cencerro, zamarro o zurrón. Esta última palabra no está dentro del estudio léxico, pero sí presente en el corpus:

Dos zurrones, uno de cordero y otro de cabrito (Sahagún, LE-1608)

Un zurrón bueno (Castroañe, LE-1609)

A estos préstamos procedentes del contacto con otras lenguas, hay que sumar aquellos que proceden de lenguas muertas como el latín y el griego, en su gran mayoría referidos a objetos religiosos y de devoción: agnusdéi, lignum crucis, cíngulo, amicto pero también greguescos o gorgorán.

\subsubsection{Formación de palabras nuevas a través de procesos internos de la propia lengua}

La lengua también cuenta con procesos internos de naturaleza morfológica para crear nuevas palabras. Destacan entre ellos los de derivación y composición.

En la derivación se crean términos nuevos a través de la adición de afijos a palabras ya existentes (Alvar Ezquerra, 1995: 49). Se pueden observar procedimientos de prefijación, sufijación y parasíntesis, entre otros.

La prefijación consiste en anteponer un afijo a la raíz. Estos prefijos no alteran la categoría gramatical de la base a la que se adhieren. Esta característica la comparten con los sufijos apreciativos. Este proceso se puede observar en voces como sobremesa, sobredorado, sobretodo, sobreaño, trasfuego o antepuerta. 
Con respecto a la sufijación, se forman nuevas palabras posponiendo el afijo a la raíz. Estos sufijos que aparecen en posición final, en ocasiones, poseen la capacidad de cambiar la categoría gramatical, otras provocan un cambio de significado como ocurre con los diminutivos y aumentativos lexicalizados. Además de estos últimos (justillo, ropilla, zapatillas, arquetón, artesón, barreñón...) contamos con una serie de sufijos que provocan la creación de nuevas palabras y que son muy productivos en esta época (-dero/a, -ero/a, -azo/a, -ete/a, -aje...).

Hay ocasiones en las que nos encontramos la aplicación simultánea de prefijos y sufijos, a este proceso se le llama parasíntesis, un proceso frecuente en la creación, sobre todo, de adjetivos: acabellado, acanelado, achapinada...

Por su parte, en la composición participan dos o más unidades léxicas que pueden figurar de forma independiente en la lengua, algo que no es posible en los procesos de derivación (Alvar Ezquerra, 1995: 20). Algunas palabras compuestas que nos encontramos son escusabaraja, guardabajos, guardapiés, tapapiés, pasamanos, rodapiés o tentemozo. 


\section{MARCO LINGÜÍSTICO DE LA ZONA DE ESTUDIO}

La Tierra de Campos se encuentra en el área de influencia de dos romances, el leonés y el castellano. Menéndez Pidal ya advierte de lo complicado que es establecer características definitorias que marquen un límite claro entre el leonés oriental y el castellano. Considera que esta zona está lo suficientemente castellanizada como para no encontrar ningún rasgo fonético que permita constatar unos límites claros (Menéndez Pidal 1906, en Morala, 2011). Inés Fernández Ordóñez nos recuerda que las raíces históricas de las que brotó esta área se remontan a la Edad Media. Palencia y Valladolid formaron parte del Reino de León hasta bien entrado el siglo XII. Solo tras la muerte del emperador Alfonso VII en 1157, cuando hacía al menos dos siglos que estaba ocupado ese territorio, se retrotrajo la frontera al río Cea. La lengua de estas provincias coincide en no pocas soluciones con las del Reino de León porque refleja características originarias a toda la zona. Esta autora señala que a ellas debe sumarse Ávila, el occidente de Toledo y el oeste de Segovia, zonas que repetidamente vemos coincidir en los mapas lingüísticos, y que fueron repobladas en el siglo XII con abundancia de colonos procedentes de condados de Tierra de Campos (Fernández Ordóñez, 2011: 56). No obstante, es una lengua que no puede ser considerada otra cosa que castellano (Morala, 2008: 130).

La zona oriental del leonés se localiza en una amplia franja donde el proceso de castellanización ha borrado "prácticamente cualquier vestigio del antiguo romance patrimonial de la zona oriental leonesa" (Morala, 2011: 94). De hecho, tan solo perviven ejemplos en la toponimia y en palabras que no tienen un correlato en castellano, por lo que se trata de formas totalmente lexicalizadas. Sin embargo, el hecho de que algunos de estos rasgos leoneses aparezcan hacia zonas pertenecientes a la Tierra de Campos que se consideran castellanas, nos hace constatar que antiguamente esas isoglosas llegaban a esta zona.

Hay una fecha que debemos tener en cuenta en todo este proceso y es que en 1230 el Reino de León y el Reino de Castilla se unifican bajo la corona castellana de Fernando III y más tarde la de Alfonso x el Sabio. Por otro lado, la lengua romance comenzaba a sustituir al latín en la documentación escrita. Estos hechos, junto a la versatilidad de las fronteras entre reinos cuando aún eran reinos independientes, hacen que el romance de esta zona sufra muy pronto interferencias del castellano, pero también -como lengua de prestigio- que influya de alguna manera en la norma castellana.

El hecho de que en esta zona se hablara un romance diferente lo constatan algunos documentos, como ocurre en el prólogo de la obra del siglo XV, La vida de los Santos Religiosos de Gonzalo García Santa María, donde se puede leer:

Hay allende esso en la misma Castilla, como son diuersos reynos en vno ayuntados, algunas tan grosseras e ásperas lenguas como es Galizia, Uizcaya, Asturias e Tierra de Campos, que ni aquellas ni lo muy andaluz es houido por lenguaje esmerado. Ca lo vno de muy gruesso e rudo se pierde, e lo otro de muy morisco en muchos vocablos a penas entre los mismos castellanos se entiende (Pensado, 1999: 12).

Este texto advierte de la heterogeneidad entre los romances que se hablaban en la Corona de Castilla y menciona entre ellos el de la Tierra de Campos, lo que da pie a pensar que en esta 
zona se hablaba un romance que no se identificaba con el leonés, pero que tampoco se equiparaba con el castellano histórico, sino que tendría unas características lingüísticas peculiares y que pudo servir de bisagra entre el castellano y el leonés.

Una serie de trabajos realizados por Morala intentan arrojar luz sobre cómo evolucionó la lengua romance en esta zona de transición a través de la documentación notarial de diferentes épocas (Morala, 2002a, 2004a, 2008, 2009, 2011, 2015b). Para este autor, es la lengua escrita -documentación notarial- la que puede proporcionar datos de interés para el estudio lingüístico de la franja oriental del leonés a la que pertenece la comarca de Tierra de Campos -teniendo en cuenta lo que supone trabajar con textos escritos- (Morala, 2011: 100).

En la Baja Edad Media parece que el leonés tiene el prestigio suficiente en esta zona como para ser el modelo de lengua escrita. Morala localiza una donación fechada en 1292 del arcediano de Valderas escrita en una variedad romance que se puede identificar como leonés. El romance en el que se escriben este tipo de documentos -desde finales del siglo XIII y durante el siglo XIV-está cargado de rasgos leoneses (Morala, 2008: 139).

Para ilustrar brevemente el romance que afloraba en los textos medievales en esta zona, a continuación, se señalan algunos ejemplos sacados de la documentación de diferentes monasterios que se ubicaban en la Tierra de Campos -Monasterio de Sahagún, del de Vega, del de Trianos o del de San Pedro de las Dueñas- siguiendo el mismo patrón de estudio que Morala señala para documentos escritos en la zona del leonés oriental (Oteros y Sahagún) (Morala, 2015b: 33-45). En dichos textos aparecen formas marcadas como leonesas junto a las formas castellanas; esto quiere decir que el amanuense consideraba este romance como lengua culta, válida para utilizarla en sus escritos y que nos puede ilustrar algunas de las características del romance de la zona.

En cuanto a vocalismo se refiere, suele ser habitual la diptongación para las antiguas vocales latinas /ŏ/ y /ĕ/, que además del resultado que comparte con el castellano en /ue/ e /ie/, el leonés alterna las variantes [ue, ua, uo] para /ŏ/ y [ie, ia] para /ĕ/, que Morala localiza en documentos pertenecientes al Monasterio de Carrizo y a los Archivos de la Catedral de León.

Otra de las peculiaridades del vocalismo leonés es la diptongación ante yod, donde el castellano no lleva a cabo dicho proceso. Así, encontramos en documentos del Monasterio de Sahagún junto a noche, coja, ocho u hoy:

se ante fu dada la senal o fata en la nueche (Sahagún, 1239) sea pregonado que nenguno nol cueya pora labrar fata I anno (Sahagún, 1239) en era de mill e duzientos e nonaenta e vuecho annos (Sahagún, 1260) el dia de vuey adelantre sea de nuestro iuro ye de nuestro poder tolido (Sahagún, 1254)

Suelen aparecer en estos documentos casos de cierre de /-o/ en /-u/:

per cunctis suis terminis: de susu per illo Allizaze Petrinia (Sahagún, 1028) notario sobredicho, porque ffuy presente a esto de ssusu dicho (Sahagún, 1291) con ludas enno enfierno dannado, e de susu a uos (Vega, 1253) con todo so iuru e con toda súa entreguidat e con todas súas pertenencias (Vega, 1262) 
También aparece la epéntesis de la /i/:

Fernando Munniz per uim et forcia et sic eam inuenit gloriosissimus (Sahagún, 1048)

sed si dominus fecerit forcia suo uasallo (San Pedro de las Dueñas, 1198)

ene mes de dezenbrio (Trianos, 1236)

in mense decembrio. Regnante rege domno Ferdenando (Vega, 1240)

Esta es la remembrancia de las preseas que lexa Martin Paris (Sahagún, 1245)

aquello es lo que finca en remembrançia por él al mundo (Vega, 1286)

En cuanto al consonantismo, uno de los rasgos que mejor identifica al leonés es la solución /y/ para /lj/, frente a la /ž/ del castellano:

Yo, Domingo Pédrez, una cum mía muyer, dona Sancha (Vega, 1244)

e doble esta heredat en meyor logar (Trianos, 1253)

que non fezies ne migaya en esse pleito (Sahagún, 1260)

arrendamos a dona María Pérez, muyer que fue de Yuan Feneto (San Pedro de Dueñas, 1276)

çient cabos de gan[a]do entre oueias e cabras (Trianos, 1296)

También aparece en topónimos como Teyar o Grayar:

pro ingressu et regressu ad illam populationem del Teyar (Sahagún, 1231)

en quanta heredat ella ha en Bouadiella et en Teyadiello (Sahagún, 1233)

que uien de Rrequexo e ua a Grayar (Sahagún, 1266)

La palatalización de /I-/ que encontramos en ejemplos como:

Todo esto ssobredicho uos do, que ssea uuestro llibre (Trianos, 1278)

Trianos, e al conuento desse mismo llugar (Trianos, 1287)

e çient Iladriellos mas que yo mande para la eglesia (Sahagún, 1289)

el conuento des mismo llogar (San Pedro de Dueñas, 1293)

Mantenimiento del grupo consonántico latino /-mb-/ que en estos documentos se refleja principalmente en los topónimos y en la onomástica:

suo medio orto, cum palumbare suo, cum arbores, parras, palumbare, exitus (Sahagún, 1222)

alio maliolo in illa lomba de Melgarelios (Vega, 1082)

Domna Columba Stephaniz confirmat (San Pedro de Dueñas, 1131)

Pecenin sicut prendunt de riuo Grandi usque ad la carreiram de La Lomba (Trianos, 1181)

El tratamiento de $/ \mathrm{g}^{\mathrm{e}, \mathrm{i}} / \mathrm{\text {: }}$

Fecha ene mes de ienero, $\mathrm{X}$ días andados (Vega, 1291)

enno mes de genero, miércoles, XI díes por andar (Vega, 1291)

Ffecha esta esta (sic) carta ocho dias de ienero (Sahagún, 1293)

Pérdida de la palatal central / $/$ / procedente de los grupos / dj, gj y lj/ en entornos vocálicos no palatales:

Maordomo, Gundiçaluus. Alfiéreza regis (Trianos, 1229)

uos dades a nos una uina en término de Maorga (Trianos, 1235)

Gonzalo Morán, merino maor del rey (Vega, 1291)

Domingo Pelaz, alfaat, confirma (Vega, 1291)

los marabedís traerlos aquí al monesterio, o dárnoslos en Maorga (Vega, 1291) 
Morala (2015b: 37), señala además, el resultado /š/ dorsopalatal sordo para los grupos iniciales $/ \mathrm{pl}-/, / \mathrm{kl}-/$ y $/ \mathrm{fl}-/$, rasgo peculiar que se da en la zona de influencia de la ciudad de León:

Il payares xenos de paya menuda (Sahagún, 1245)

saber la uerdat, e se axaren en uerdat, que tal arfía (Vega, 1252)

En cuanto a los rasgos morfológicos, en estos textos se observa un tratamiento especial del artículo, a veces mantiene la /e-/:

tragan entrambos elas dos partes del auer moueble (Vega, 1227)

Ela terra que nos recebimos de [uos] iaz en Pozuelos (San Pedro de las Dueñas, 1235)

ela vina de los Cenizal (Trianos, 1236)

ela deuandicha ochaua de la egrisia de San Miguiel (Sahagún, 1246)

elos nuestros molinos (San Pedro de las Dueñas, 1276)

Por otro lado, el artículo aparece asimilado a las preposiciones a las que acompaña, dando lugar a formas como ena, enna, eno, conna, connos y la forma enne o ene que aparecen principalmente en la documentación oriental:

una tierra que he en término de Ualelobón, ena Uega (Vega, 1234)

auentura quesier ficar enne casa a so finamento (Vega, 1236)

conna heredat que fu de las donnas de Almaraz (Sahagún, 1246)

Estos fueron presentes quando metioron al prior segundo enne uuerto (Sahagún, 1247)

todas las pertenencias, conna eclesia e connos uassallos, con terras, con uinas (Vega, 1252)

El numeral dos presenta diferencia de género:

concedimus abbati et conuentui de Trianis habere duas uineas (Trianos, 1188)

mandamos fazer duas kartas partidas por abecedario (Sahagún, 1233)

Presencia de la preposición ata frente a fata o fasta del castellano o preferencias por las partículas se, ne, nen, sien frente a si, ni, nin o sin:

ne negligencia rerum res subscripti monasterii (San Pedro de las Dueñas, 1219)

se non los dyerdes a este plazo, perdades la heredad (San Pedro de Dueñas, 1246)

ata un anno que me delexaxen el mueble (Trianos, 1247)

non pagardes ata que los reçibades éntregamientre (Vega, 1276)

sien enpennamiento et sien otro enbargo (Vega, 1296)

Por lo que se refiere al verbo, también estos documentos presentan algunos rasgos como el apócope de /-e/ en la tercera persona:

así como suel leuar el nuestro çillerizo (San Pedro de las Dueñas, 1254)

asi commo diz esta carta (Sahagún, 1256)

seellamos ela carta que tien el abbat e el conuento (Trianos, 1294)

Martino primero que vien fasta veynte annos conplidos (Vega, 1294)

Las terminaciones etimológicas -aron o -eron se sustituyen en ocasiones por -oron en la tercera persona del plural del pretérito perfecto:

Pesquisas qui lo uioron e qui lo odioront: Don lohan el Maestro (Sahagún, 1213)

Estas son elas pesquisas que uioron e odioron [...] fiadores e recabdos (Trianos, 1241)

et los quinones que me dioron dona Marina (Vega, 1276) 
Esporádicamente también se encuentra la desinencia verbal -oren por -eron, y que Morala localiza también en inventarios notariales del siglo XVII (Morala, 2009: 11):

los otros uos ante prometioren spiritalmyentre (Sahagún, 1239)

Estos son los omnes que uioren e oyron (Sahagún, 1253)

Otro elemento que debemos tener en cuenta del leonés es la forma ye que hace referencia a partículas de diferente naturaleza: como resultado de la copulativa latina ĕt, la tercera persona del presente de indicativo del verbo sum, ěst y el referente átono de tercera persona procedente del dativo illi y con función de complemento indirecto (Morala, 2015b: 41):

do al eleyto de Trianos ye al conuento dees mismo logar ela uinna (Trianos, 1241)

Conocida cosa sea a los qe son ye an de ser (San Pedro de las Dueñas, 1246)

segundo que de suso dicho ye prometedes de dar a ellas (Vega, 1276)

E la primera tierra ye determinada (Trianos, 1282)

Como se puede observar, estos documentos ofrecen soluciones de un romance que se puede tildar de leonés y que se combinan con las formas castellanas. Muchas veces, estos dialectalismos tienen que ver con las fórmulas utilizadas en los textos escritos, por lo que hallamos escribanos que se habían formado bajo la norma de la corte leonesa y ahora tenían que adaptarse a la castellana.

Parece que el proceso de castellanización se habría completado ya en el siglo xv y tan solo quedan restos del romance en el léxico y en la toponimia. El castellano es la lengua escrita de prestigio y la utilizada para los documentos oficiales. Sin embargo, Morala pone el ejemplo de un copista que a mediados del siglo XV se ve en la obligación de copiar una serie de documentos pertenecientes a la Catedral de León y fechados un par de siglos antes. Lo que debería ser una copia se convierte en todo un alarde de adaptación a la lengua de su época (siglo XV). No tiene ningún problema en sustituir formas que en el original del siglo XIII aparecen con rasgos leoneses por palabras que le resultan más adecuadas o le parecen mejor opción-senos por sendos, enna por en la, axar por fallar o maor por mayor-. Esto es síntoma de que muchos de los rasgos leoneses habían desaparecido. Sin embargo, este copista vacila a la hora de escribir fijo, conceio o le como referente átono de tercera persona o fiyo, conceyo o ye. Por otro lado, hay una serie de características leonesas que mantiene-diptongo en el sufijo -iello en vez de -illo, las formas del verbo ser ye o yera, en vez de es o era o la utilización de las variantes femeninas dúas o súas-, lo que demuestra que aún quedaban rasgos leoneses, no en la lengua escrita -ahora la lengua de prestigio es el castellano-, pero muy probablemente sí en la lengua hablada (Morala, 2008: 144).

Así, en la Tierra de Campos principalmente encontramos un romance castellano que, en ocasiones, mantiene rasgos pertenecientes al leonés. En este último caso suele tratarse de formas lexicalizadas de la solución romance.

Para el estudio del estado del léxico de esta zona en el siglo XVII recurrimos de nuevo a los protocolos notariales para observar si aún existen vestigios de leonés o cualquier otra particularidad lingüística que se identifique como propia de esta zona. No debemos olvidar que este tipo de documentos solía ajustarse a una norma jurídica y también lingüística. El lenguaje 
utilizado por los escribanos responde a un uso de la lengua culto, ciñéndose a la norma castellana. Sin embargo, no es extraño que rasgos del habla local se trasvasen al papel por el contacto con las declaraciones que hacen personas de la zona o por algún lapsus, como le ocurrió al copista del siglo XV.

Así, los documentos notariales se convierten en una de las mejores fuentes documentales para conocer el léxico de la comarca de Tierra de Campos en el siglo XVII. 


\section{PRESENTACIÓN Y JUSTIFICACIÓN DEL CORPUS}

\subsection{LOS DOCUMENTOS NOTARIALES COMO FUENTE DE LOS ESTUDIOS FILOLÓGICOS}

Durante mucho tiempo, la historia del español basó sus estudios en textos de tipo literario. El propio Menéndez Pidal se vio condicionado en sus interpretaciones por la utilización preferente de textos literarios como fuentes de sus datos a partir del siglo XIII. EI hecho de anteponer la literatura sobre cualquier otro tipo de texto escrito no mostraba la variedad lingüística dentro de la lengua de Castilla. Este autor seguía los dictámenes de los filólogos de su tiempo, cuando la literatura y la variedad culta eran las únicas varas de medir toda la lengua (Fernández Ordóñez, 2001: 22).

Sin embargo, siempre han existido voces que han defendido el estudio de otras tipologías textuales para obtener una visión más completa de la evolución diacrónica del español. Entre esas otras tipologías, han sido los textos notariales los que han alcanzado un mayor auge en el estudio filológico, debido a diferentes motivos que se relacionan con algunas de sus características: la seguridad de su datación y su origen geográfico (Ramírez, 2005: 29; Morala 2010a: 436).

Para el estudio filológico de la lengua en época áurea se contaba principalmente con el análisis de fuentes de corte literario o técnico. Este tipo de fuentes serán referencia obligada para la configuración de grandes obras de referencia como es el Diccionario de Autoridades, primer diccionario general de la lengua española que recoge gran cantidad de voces del Siglo de Oro y que sienta las bases de la lexicografía moderna. Son las referencias a grandes obras literarias de este siglo las que sellan el uso normativo de la lengua. Sin embargo, este corpus solo ofrece una imagen parcial ya que no se contaba con estudios de la variedad diatópica de la lengua. De ahí la preocupación de los autores por buscar otras fuentes que completen el acervo lexicográfico de esta época.

Sin embargo, en los últimos años, los estudios filológicos que toman como fuente inventarios y otras relaciones de bienes tipológicamente cercanas a este tipo de textos han cobrado especial interés desde el punto de vista lingüístico y, de modo particular, desde una perspectiva léxico-semántica (Ortiz, 2013: 72). Destacan la producción de trabajos de autores como Morala, Egido, Perdiguero, Pérez Toral, Bastardín, Carriazo, Quirós o Puche entre otros muchos, que han aportado y siguen aportando datos que suponen el avance en la investigación sobre la historia del léxico español desde esta perspectiva.

Así pues, este tipo de documentos ayudan a ampliar y completar el acervo lingüístico, registrando formas que van mucho más allá de lo que podemos considerar que constituye el léxico más normalizado y académico. Por ello, son la fuente ideal para el estudio de la diversidad geográfica del léxico. La minuciosidad con la que se describen los bienes que posee una persona o comunidad-bienes muebles, inmuebles o semovientes- hace que este tipo de textos se conviertan en un tipo documental idóneo para el estudio de la vida cotidiana (Porres, 1996: 17) 


\subsection{LOS DOCUMENTOS NOTARIALES}

Los inventarios han sido empleados fundamentalmente para reconstruir los aspectos más variados de la vida cotidiana medieval y renacentista, dado que, junto a los testamentos, "presentan la imagen más íntima que tenemos de la vida y las posesiones de las gentes" (Pounds, 1999: 246). De ahí su papel protagonista en la historia de la cultura material, en el análisis del proceso evolutivo de la existencia humana y en la comprensión de determinados comportamientos en el ámbito del espacio privado (Bustillo, 2000: 582), lo que les ha convertido en una valiosa fuente para la investigación en múltiples áreas: desde los estudios sociológicos, etnográficos y económicos hasta la incursión en el mundo del arte, la arquitectura o la moda.

La documentación notarial nos permite acceder de manera indirecta a la vida cotidiana del individuo que vive en pleno siglo XVII. Son documentos con una nutrida cantidad de léxico propicia para el presente estudio. Sería, en cierto modo, como la información que hoy en día aportan los repertorios dialectales y los atlas lingüísticos a la lexicografía actual (Morala, 2012c: 200). Además, este tipo de documentos proporcionan información sobre el léxico de la vida cotidiana, un campo donde se conserva en mayor medida el léxico con marca diatópica.

Por lo tanto, entre los documentos seleccionados para el estudio del léxico en la Tierra de Campos estarían aquellos que tengan en su haber una gran cantidad de léxico, suficiente para permitirnos crear un corpus desde el que realizar nuestro análisis. Bajo esta premisa hemos seleccionado diferentes tipos de documentos: inventarios, tasaciones, partijas, almonedas, cartas de arras o de dote, testamentos o cualquier documento similar donde se enumere de forma exhaustiva los bienes que posee una persona.

Debemos recordar las palabras de Morala -sabedor de que los inventarios nos ofrecen una versión mediatizada de la lengua oral- cuando afirma que "los escribanos de las notarías serán, si se nos permite el símil, nuestros dialectólogos encuestadores, los declarantes harán las veces de informantes y los inventarios conservados en los archivos se convertirán en los cuadernos de encuestas de cada uno de los puntos que componen nuestro particular atlas lingüístico del Siglo de Oro" (Morala, 2012c: 201-202).

No obstante, hay que tener cautela a la hora de interpretar estos textos y emitir sentencias absolutas sobre la lengua que representan. Estamos ante una tipología textual redactada por gente culta que tiene conciencia de estar utilizando la lengua de prestigio a la hora de elaborar sus escritos.

Otro dato importante es el hecho de que estos documentos no son representativos de toda la sociedad: solo unos pocos privilegiados tenían acceso a los servicios de los escribanos, por lo que la representación social es limitada, ya que son pocos los que pueden pagar los servicios judiciales y esto ocurre tanto en el ámbito rural como en el urbano. 


\subsubsection{Características de los documentos}

Los inventarios presentan una estructura interna muy similar en la mayoría de los casos, algo que nos permite identificarlos visualmente entre los documentos que conforman los protocolos notariales. Estos textos utilizan una serie de fórmulas fijas que se repetirán al comienzo (protocolo) y al final (escatocolo) del documento. No obstante, suelen comenzar con un par de líneas separadas del resto del documento donde se informa del tipo de documento que se va a presentar y a quién pertenece. A continuación, localizan físicamente y datan el documento que el notario se dispone a dar fe con la fórmula siempre presente ante mí, -son varias las personas que aparecen en este acto judicial: tasadores, familiares, vecinos...- y, anterior al comienzo del recuento de bienes, solemos encontrar en la forma y manera siguiente.

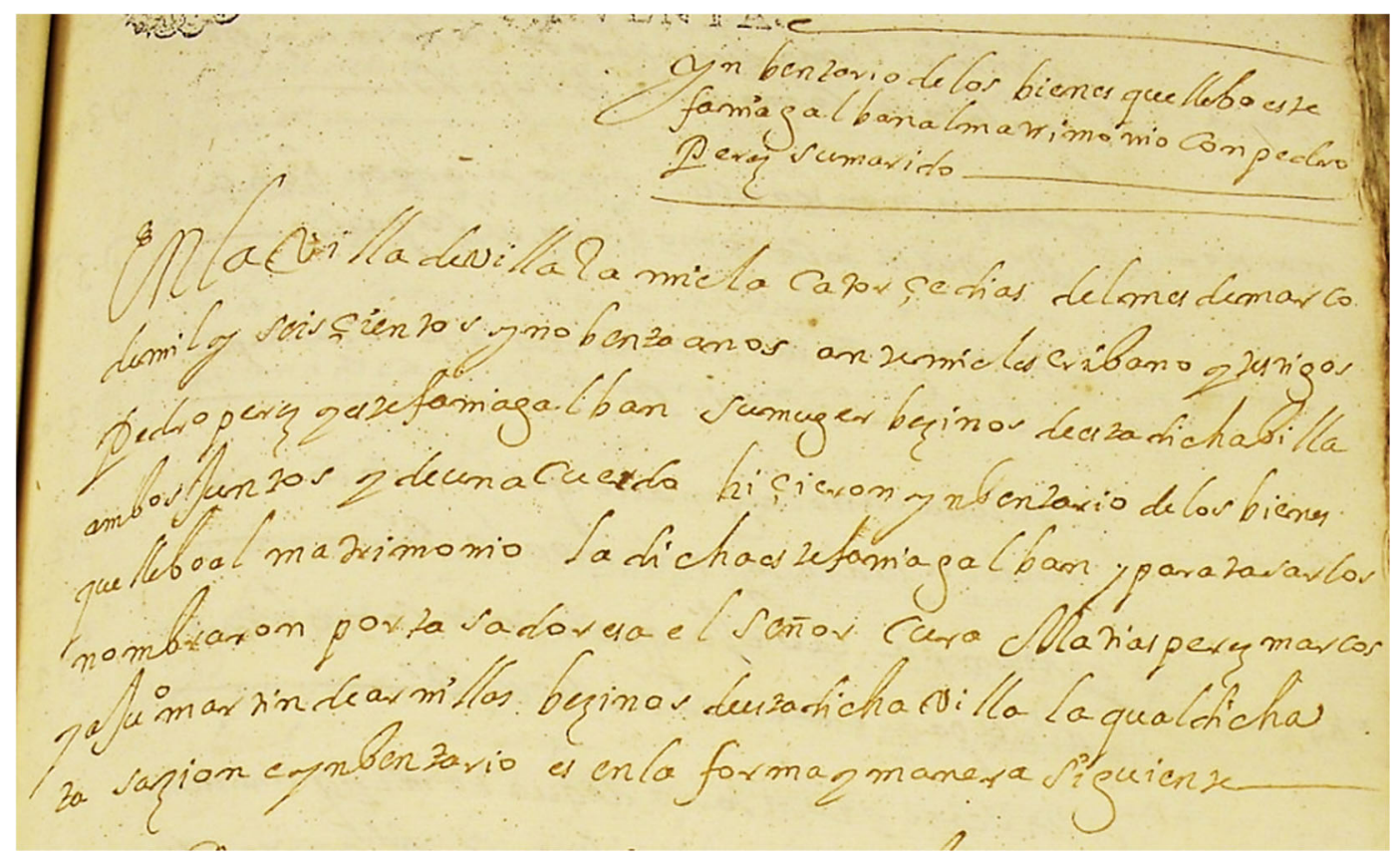

Figura 5.1 Comienzo de un protocolo (Villarramiel, Palencia, 1690; Sig. 13332).

La datación del documento a veces viene dada por el propio protocolo, ya que en el siglo XVII se implanta el papel sellado, obligatorio para toda la escrituración notarial a través de la Pragmática de Felipe IV en 1636. Este sello contribuía a dar autenticidad y validez a los documentos, aunque, en realidad, era otra forma de conseguir ingresos por parte de la corona (Gil, 1986: 41). Sin embargo, debemos tener en cuenta que no siempre coincide el sello con la fecha del inventario, por lo que hay que estar atento y comprobar la correspondencia. 


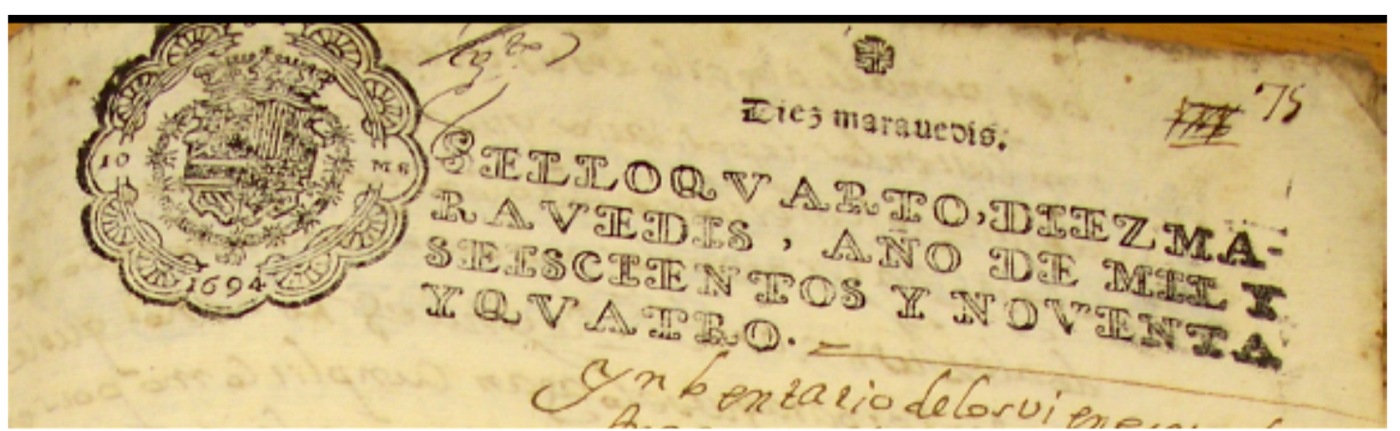

Figura 5.2. Sello obligatorio en un protocolo. (Villarramiel, Palencia, 1694; Sig. 2183).

A continuación, se describen de manera precisa todos los bienes muebles, inmuebles o semovientes -en nuestro caso solo seleccionaremos los bienes muebles o semovientes-. Estamos ante el cuerpo del documento que, desde un punto de vista visual, en ocasiones presentan una configuración diferente.

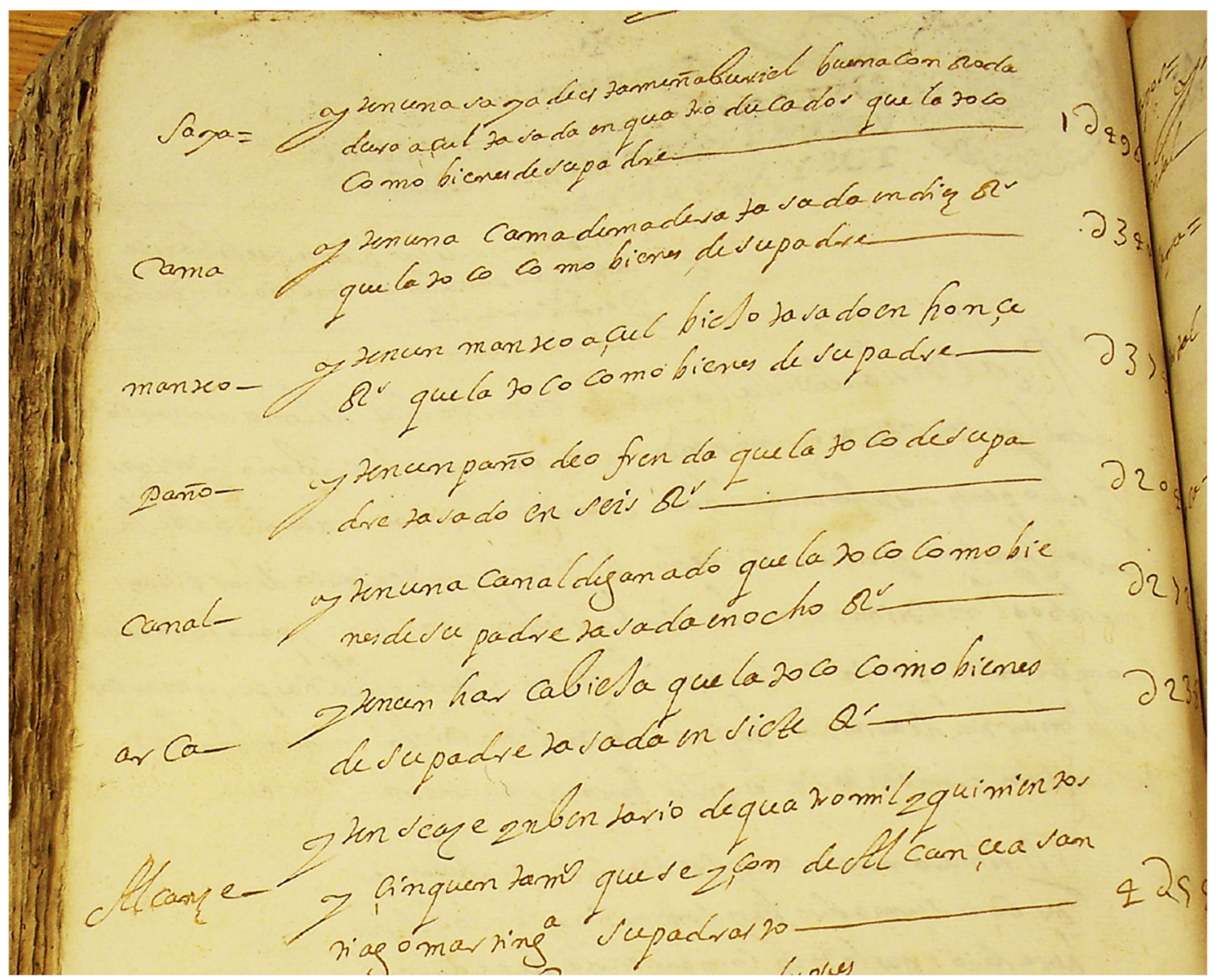

Figura 5.3. Presentación de bienes a modo de lista (Villarramiel, Palencia, 1690; Sig. 13332). 


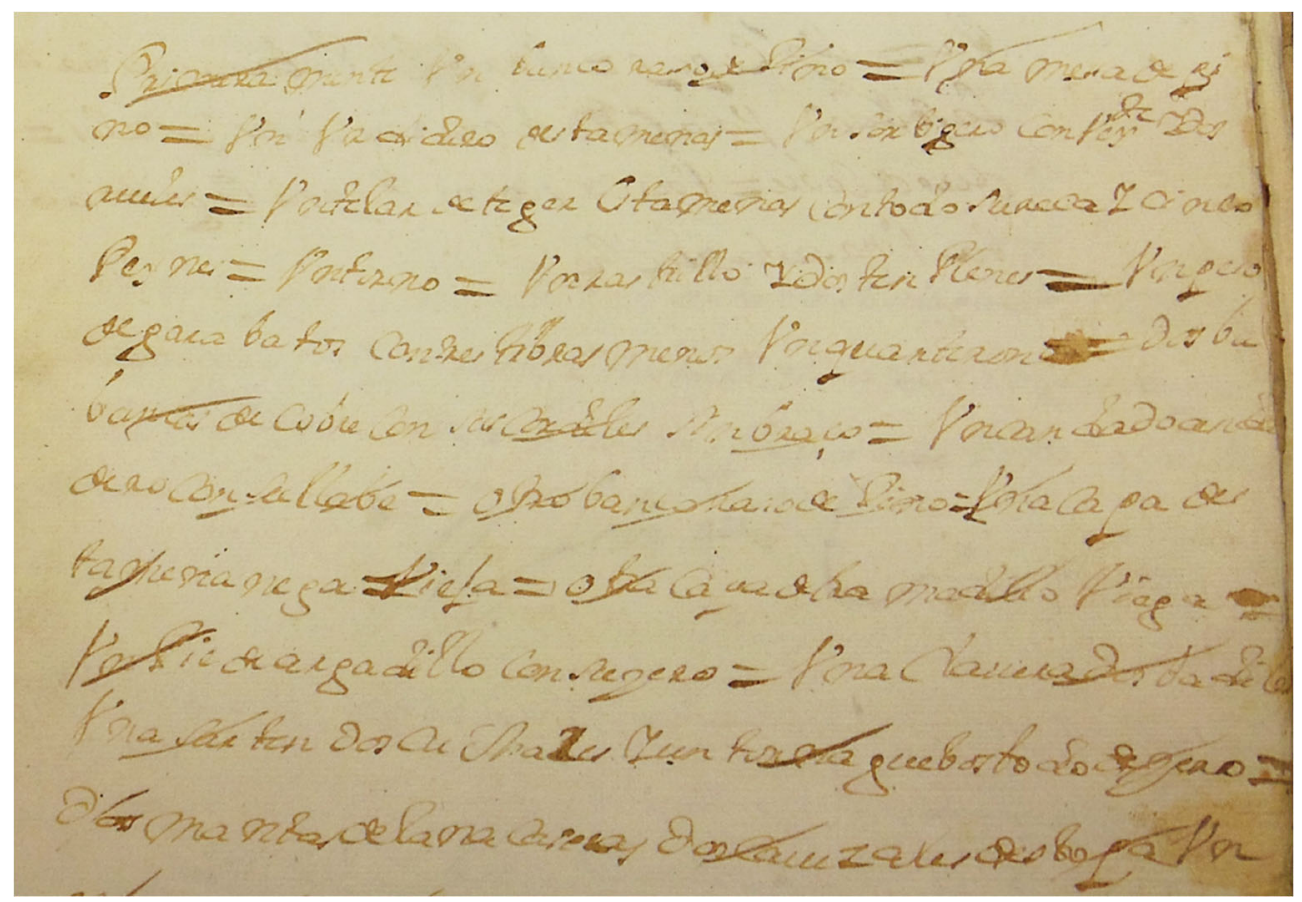

Figura 5.4. Presentación de bienes de forma continua

(Cuenca de Campos, Valladolid, 1670, Sig. 13093)

Por último, figura el escatocolo final donde se encuentra la validación -firma del escribano, de las autoridades pertinentes y de los testigos- (Quirós, 2011: 429-430).

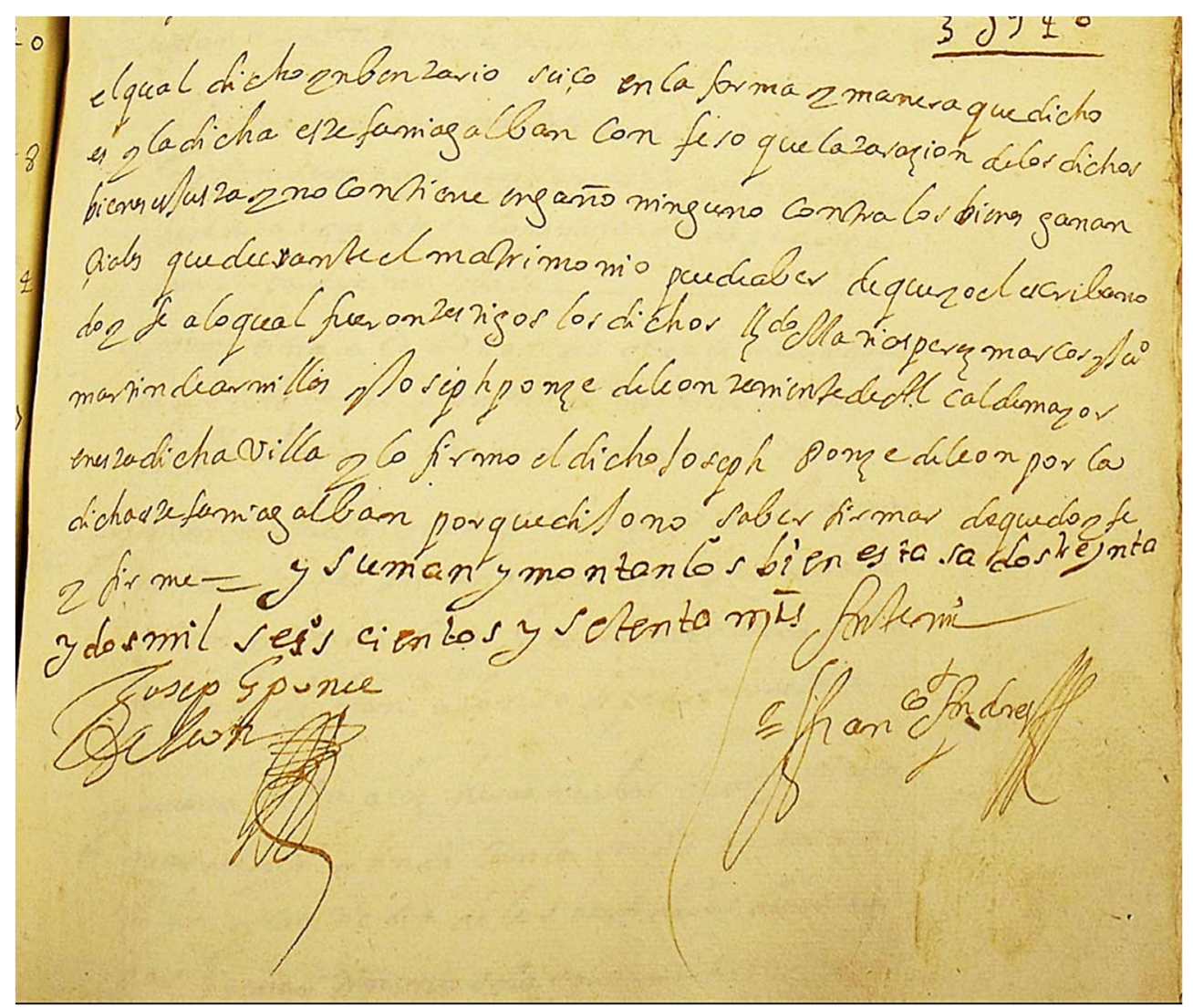

Figura 5.5. Escatocolo final en un protocolo (Villarramiel, Palencia, 1690; Sig. 13332). 
La causa que motiva la elaboración del recuento de bienes influye en la extensión del inventario que nos vamos a encontrar. No es lo mismo inventariar los bienes que alguien deja a su fallecimiento y que ha estado acumulando a lo largo de su vida, que la dote que alguien lleva a su matrimonio.

También se aprecia que la propia naturaleza del documento notarial provoca diferencias organizativas. Por ejemplo, en las almonedas los objetos no aparecen agrupados con un orden lógico, simplemente forman parte de un lote subastado, en el que los objetos que lo integran no tienen que obedecer a un bloque homogéneo, con lo que la contextualización de la palabra se hace más complicada. En cambio, los inventarios de bienes suelen presentar uniformidad a la hora de exponer los objetos que se recuentan y suelen agruparlos siguiendo un criterio lógico, lo que permite, en ocasiones, contextualizar un objeto en cuestión. Así, se van enumerando teniendo en cuenta su ubicación en la casa (una sala de la vivienda, lo que hay en un arca, la cocina, los aposentos, los objetos que se encuentran en alguna de las dependencias anejas a la casa...), también por la función que desempeñan (indumentaria, ajuar doméstico, enseres de la casa, aperos de labranza...), o por el tipo de material del que están hechos (madera, metal, piezas textiles...). Incluso hay documentos donde se indica en el margen el grupo de objetos que van a ser inventariados, tal como se indica en la figura 5.8.

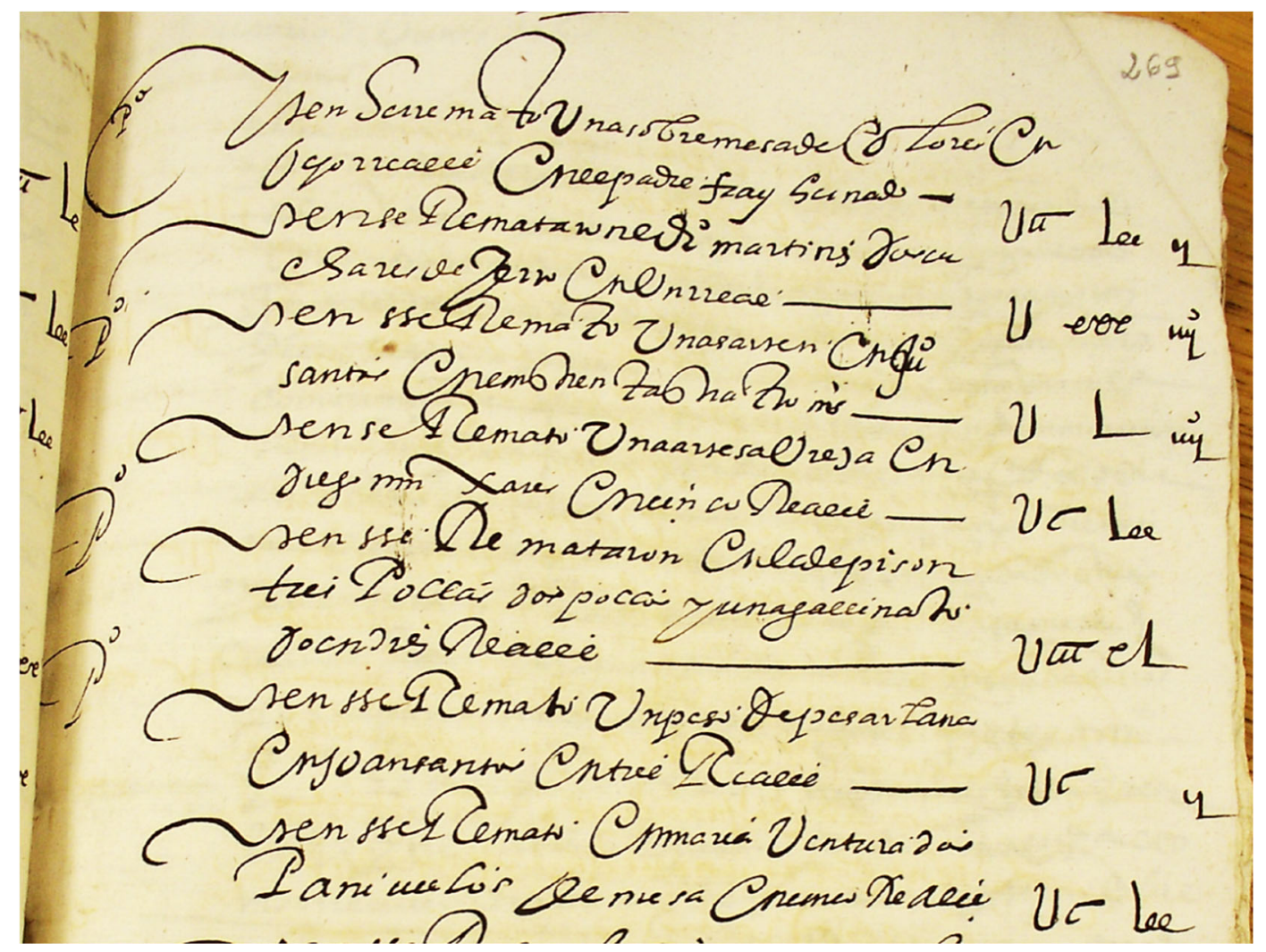

Figura 5.6. Ejemplo de Almoneda (Castromocho, Palencia, 1602; Sig. 2286). 


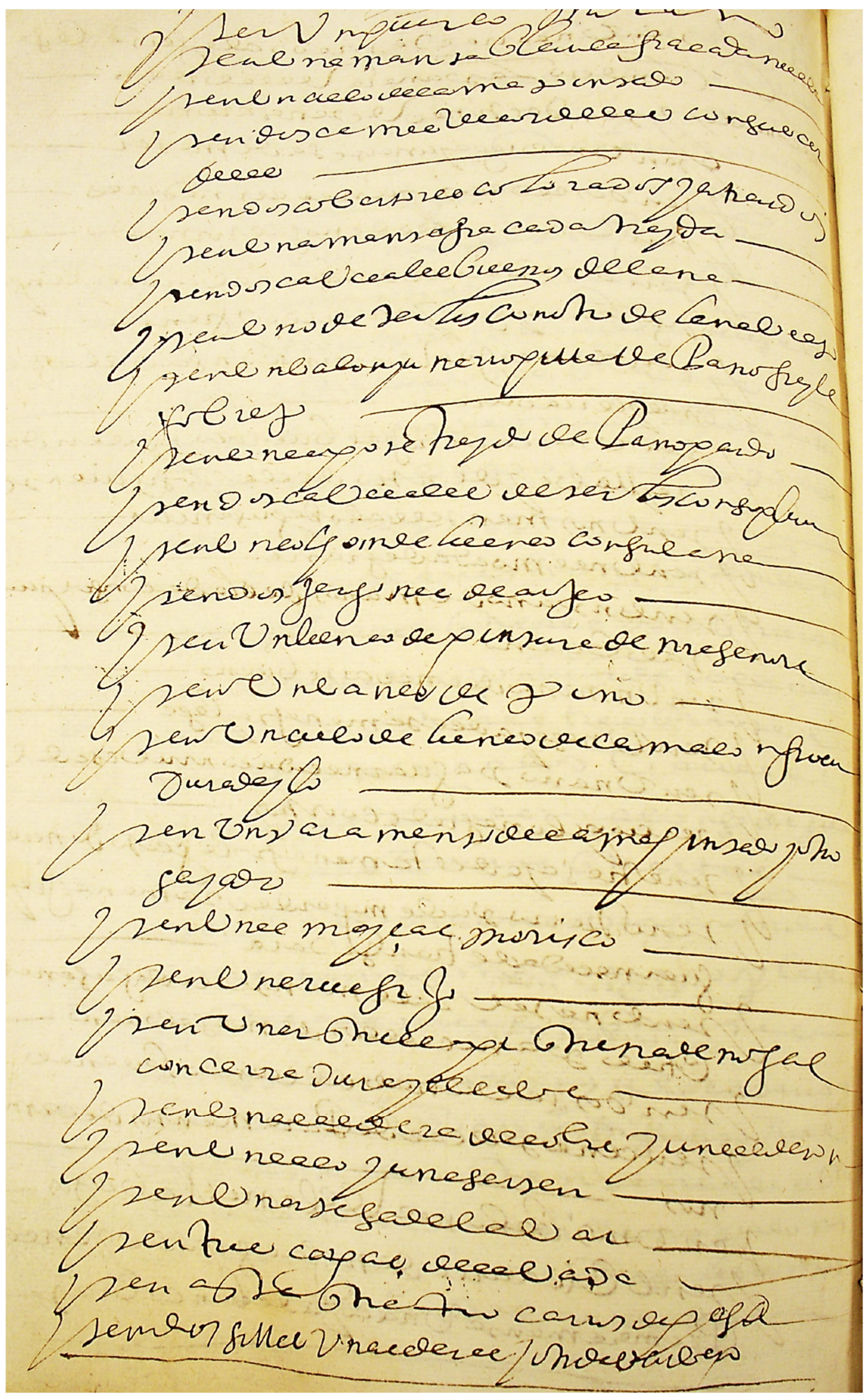

Figura 5.7. Enumeración de objetos (Castromocho, Palencia, 1602; Sig. 2286). 


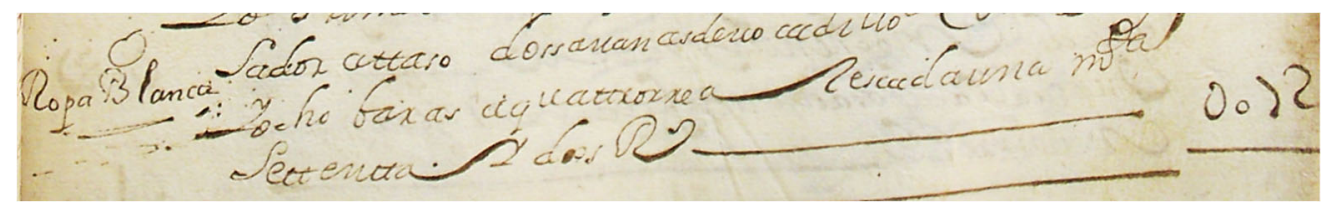

Figura 5.8. Indicación de tipo de objeto (Medina de Rioseco, Valladolid, 1685, Sig. 9151)

Morala indica que esta forma de clasificar los objetos inventariados junto con las anotaciones que el escribano hace de vez en cuando en los márgenes de dichos documentos "permite dar una interpretación en el caso de palabras desconocidas de las que no disponemos de más información que una escueta referencia en el inventario" (Morala, 2012c: 203). Así, por ejemplo, en un inventario de Villalpando (Zamora) encontramos inventariado "un bernal de plata sobredorado", en el margen el escribano corrige el término del asiento y pone en el margen bernegal; esta información es útil para el filólogo, que sabrá interpretar que la palabra bernal es tan solo un lapsus del autor del listado.

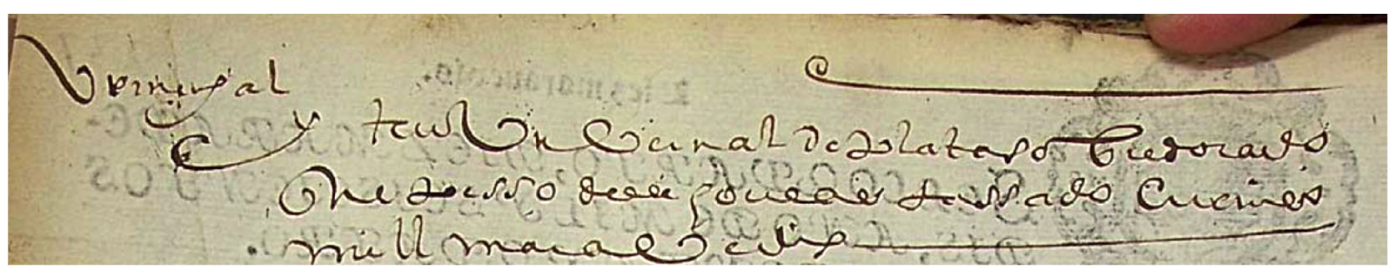

Figura 5.9. Corrección de un término (Villalpando, Zamora, 1644, Sig. 7540)

Hay ocasiones en las que el escribano se olvida por descuido o por error alguno de los objetos inventariados; la solución viene dada al margen debidamente señalada.

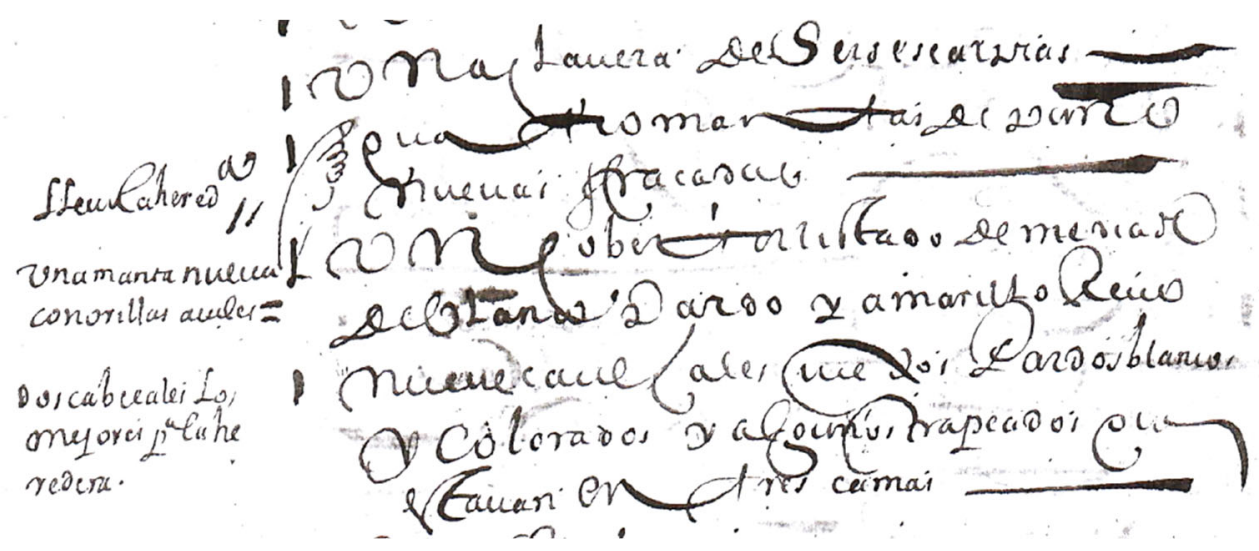

Figura 5.10. Incorporación de asientos (Frechilla, Palencia, 1631, Sig. 2500 ) 


\subsubsection{Dificultades de interpretación de los documentos notariales}

Como recuerda Morala, no siempre es fácil hacer una transcripción, dependiendo del tipo de letra utilizado y el grado de conservación del documento (Morala, 2012c: 202). En cuanto al primer punto hay que decir que estos documentos presentan dos tipos de letra bien diferentes entre ellas: la llamada procesal y la humanista. Hasta mediados del siglo XVII la inmensa mayoría de los documentos notariales están en el primer tipo de escritura que hemos señalado: procesal. La complicación de la escritura procesal viene dada por la falta de legibilidad de los trazos de la misma, dando problemas a la hora de leer e interpretar el documento. Esto, sumado al desbarajuste gráfico, del que hablaremos más tarde, hace que este tipo de textos resulten difíciles de interpretar.

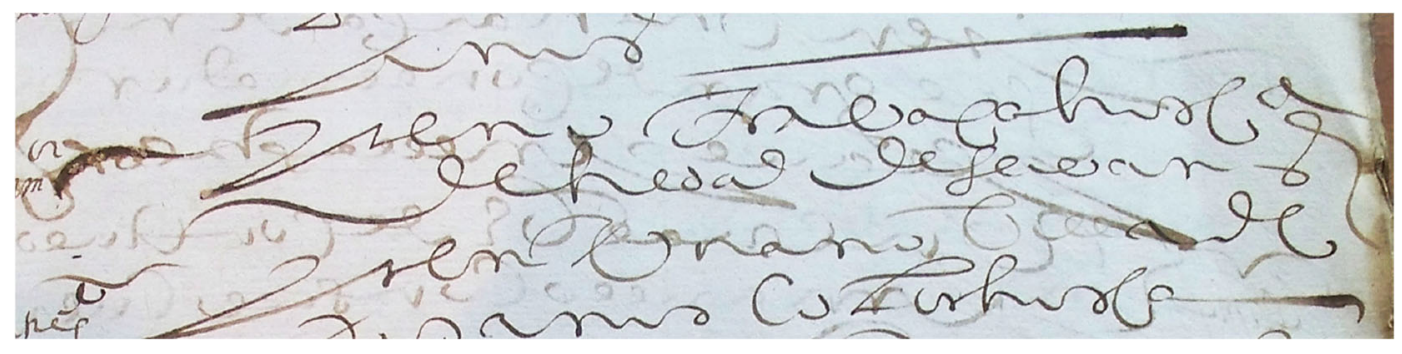

Figura 5.11. Escritura procesal (Castroañe, León, 1609, Sig. 135, f. 3r)

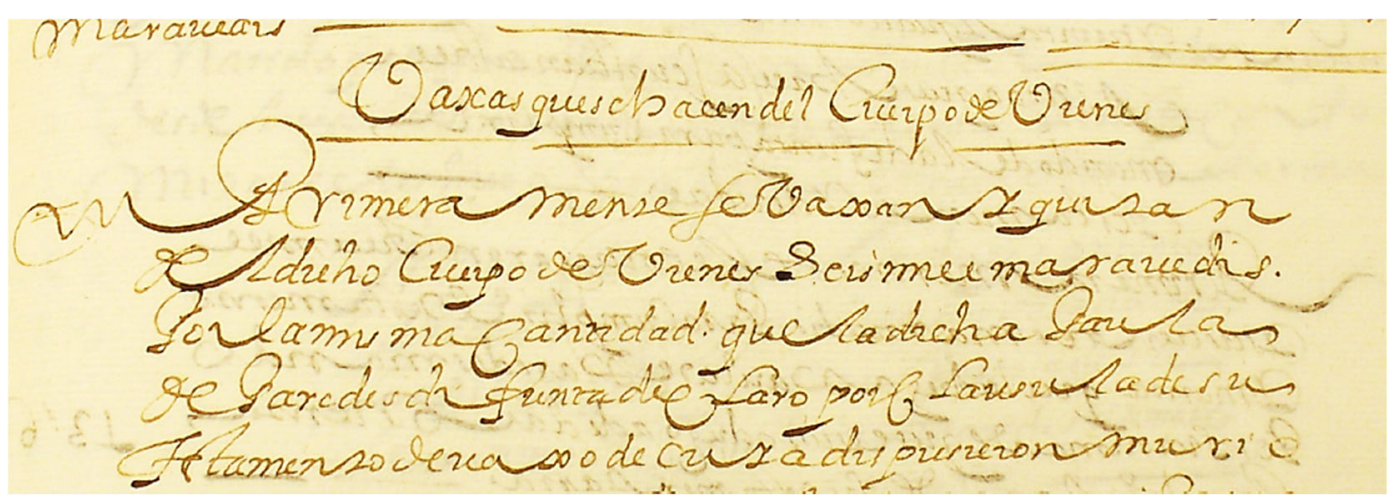

Figura 5.12. Escritura humanista (Frechilla, Palencia, 1642, Sig. 2125, f. 99r)

La escritura procesal se mantiene hasta mediados del siglo XVII; aunque hubo notarios que mejoraron su forma de escribir, otros la empeoran aún más. En la segunda mitad de siglo los notarios abandonan el uso de la procesal y se pasan definitivamente a la escritura humanista.

Otra de las dificultades añadidas es la mala conservación en la que se hallan algunos de los protocolos consultados; en ocasiones, la humedad y las polillas hacen que encontremos documentos realmente mal conservados que impiden su lectura. 


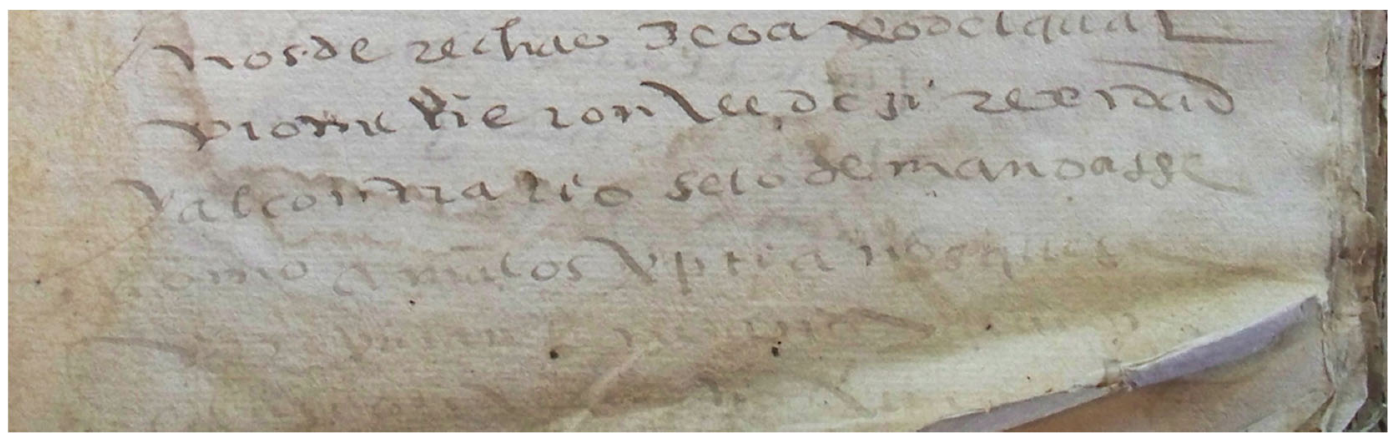

Figura 5.13. Inventario mal conservado por la humedad (Castrillo, León, 1606, Sig. 105 f. 1r)

En otras ocasiones los protocolos alcanzan un volumen tan grande que es muy difícil manipularlo, impidiendo hacer fotocopias o fotografías que abarquen todo el folio, e incluso resulta difícil leer el final de línea en el propio original.

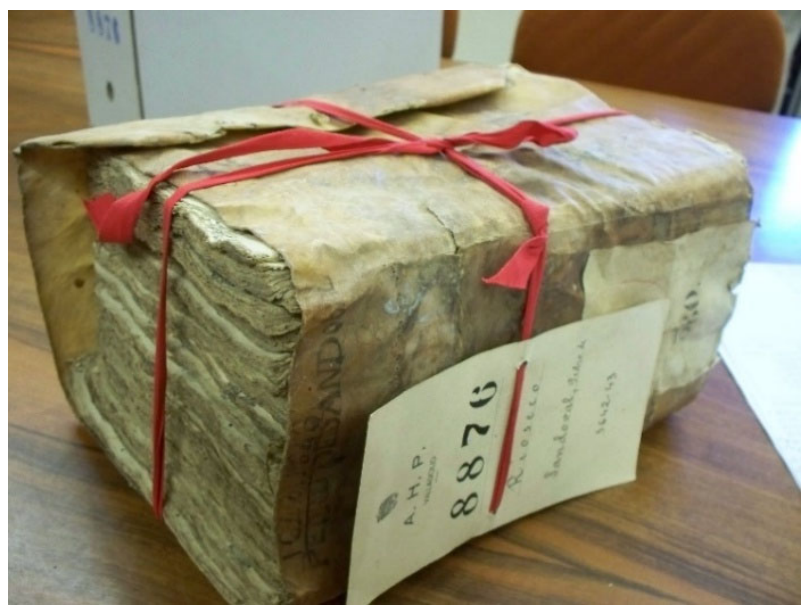

Figura 5.14. Protocolo de grandes dimensiones (Medina de Rioseco, Valladolid, 1642 Sig. 8876)

Por otro lado, los cambios en la fonología del español durante los siglos XVI y XVII no solo cambiarán el paradigma fonético medieval, sino que ese cambio también afectará a la representación gráfica de dichos fonemas. Esto va a provocar que existan textos en los que una de las características más habituales sea la diversidad gráfica que presentan.

A la hora de llevar a cabo las transcripciones de los documentos, los autores están de acuerdo en reducir al mínimo las intervenciones modernizadoras; y es que las grafías "tienen una importancia lingüístico-cultural, ya que forman parte de un bloque mayor donde están integrados los rasgos de identidad de una lengua (grafemáticos, fonéticos, gramaticales, semánticos, léxicos, semiológicos, etc.), y, por otro, pueden mostrar hechos dialectales y de lengua hablada " (Barroso y Sánchez de Bustos, 1993: 164).

Uno de los fenómenos más característicos del paso del sistema (fonológico) medieval al moderno es la evolución de las sibilantes. Estos cambios desembocarán en una igualación fonética en los sonidos $[\Theta],[s]$ y $[x]$. Sin embargo, la evolución gráfica constituye un cambio más lento, que pasa antes por un estado de confusión, de tal forma que la unificación de grafemas no se producirá hasta el siglo XVIII. 
Debemos tener en cuenta que algunos de estos cambios están activos todavía en el siglo XVII, sobre todo en la primera mitad del siglo. Esto hace que la alternancia entre las grafías "ç" y "c" / "z" y "x" / "j" y "g" puedan responder a una diferenciación fonológica muy leve pero existente, o bien a un estado de fusión de esos fonemas. Es un periodo sensible a este respecto. Así, en los textos nos vamos a encontrar diferentes soluciones.

Para la solución interdental $[\Theta]$ en los textos se van a barajar las grafías $c / c ̧ / z$ y no parece que atienda a ninguna diferencia en cuanto a pronunciación:

Una çesta blanca (Sahagún, LE-1623)

Una zesta de costillas (Autillo de Campos, PA-1653)

Yten, un escriño pequeño, una escriña y una cesta para paños (Villalpando, ZA-1654)

Para la solución apicoalveolar [s] contemplamos las grafías s/ss en los textos de manera aleatoria:

Yten una camissa del difunto vuena (Cea, LE-1621)

Dos camisas nuebas de muger cortadas por hacer (Castroañe, LE-1622)

Unas calças atacadas de raso paxiço con cuchilladas (Medina de Rioseco, VA-1644)

Un calçón y ropilla de rasso (Paredes de Nava, PA-1680)

Para la solución velar $[\mathrm{x}]$ alternan las grafías $\mathrm{x} / \mathrm{j} / \mathrm{g}$ :

Dos cántaros, dos cantarillas y tres xarros (Grajal de Campos, LE-1613)

Unas parrillas y un jarro de cobre (Castromocho, PA-1614)

Una botija y una jarra (Villalpando, ZA-1629)

Más una xarra de Talavera (Villalpando, ZA-1686)

Más seis garros para bino y quatro jarras de barro (Villalpando, ZA-1661)

Un colchón y un jergón (Boadilla de Rioseco, PA-1641)

Yten tres xergones buenos (Grajal de Campos, LE-1656)

Un gergón de estopa (Cuenca de Campos, VA-1670)

La grafía "h" se utiliza en contextos de diferente índole. Por un lado, la h en palabras procedentes de /f-/ latina y cuyo resultado, en esta época y en esta zona, vacila entre la "h" y la ausencia de la misma (hunda/unda; hosco/osco; harina/arina), incluso en resultados que presentan una /f-/.

\footnotetext{
Una unda blanca viexa con un poco de orégano (Sahagún, LE-1600)

Una hunda de lino y lana vuena (Cea, LE-1621)

Unos corporales con sus fundas de guadamazil (Villalpando, ZA-1660)

Yten, una baca osca de tiempo de seis años (Santa María del Río, LE-1617)

Yten, dos bueys uno vermexo y otro hosco (Castroañe, LE-1629)

Una harca de tener harina (Frechilla, PA-1612)

Una tina de minbres de tener arina (Cuenca de Campos, VA-1670)
}

Además, también aparecía la "h" procedente del latín como las formas procedentes de habeo (hay/ay), donde también encontramos inestabilidad gráfica.

Más una colcha de dos olandas y olgadon que hay (Villalpando, ZA-1688)

Más ay en dicha Capilla unos candeleros de peltre fino para el altar (Villalpando, ZA-1696) 
El tercer contexto en el que aparece esta grafía es delante del diptongo inicial [we-] (huevo, hueso); en algunas ocasiones este diptongo inicial se representa gráficamente como "gu", como en el caso de "güevo" y "güerto".

Un bolbedor de huebos (Frechilla, PA-1612)

Yten una paleta de bolver huevos (Cea, LE-1621)

Otro xarro pequeño deçhura de güebo (Medina de Rioseco, VA-1649)

Tres cuchares de plata dos grandes y otra de güebos (Villalpando, ZA-1676)

Parece que la aspiración de este sonido se fue perdiendo poco a poco en esta época; de hecho, Covarrubias en su Tesoro dice que 'no es letra sino señal de aspiración, que esfuerça el sonido de la letra a que se junta'. Sin embargo, cabe recordar que este autor se regía por la norma conservadora toledana.

En esta zona parece que la aspiración se perdió muy pronto y así encontramos los mismos términos escritos con y sin "h", incluso en los casos donde se conservó la /f-/ (acer / azer, hemina / emina; haya / aya; horca /orca).

A veces, la confusión es tal que aparece / $\mathrm{h}$-/donde etimológicamente no es posible; son ultracorrecciones de los propios escribanos que ya dudan de la presencia o no de esta grafía (hespejo, hesterilla, hesparragón...).

En el siglo XVII el fonema fricativo / $/$ / se iguala en su pronunciación con el fonema oclusivo /b/. Por otro lado, /u/ y /v/ se utilizaban tanto para representar la vocal como la consonante. De esta forma en los textos nos encontramos con palabras en las que alternan las tres grafías:

Una cuba de bino (Frechilla, PA-1640)

Una cuba de uino en bodega de la cassa (Villada, PA-1669)

Un tonel lleno de vino tinto (Frechilla, PA-1675)

Lo mismo que ocurre con la grafía de las "úe", ocurre con las "íe", casos donde las grafías que van a alternar tanto para la vocal como para la consonante van a ser " $y$ " e "i". Las dos grafías se utilizan para la representación de la vocal (yglesia/iglesia, buey/buei). Pero también para la representación de la consonante (haya/haia, bayeta/baieta). Además, la conjunción copulativa " $y$ " se puede localizar en estos documentos bajo las dos grafías, además de la "e".

\subsubsection{Los escribanos, nuestros informantes}

Los escribanos eran los garantes y depositarios de la fe pública desde la época medieval. En un primer momento esta labor era desempeñada por los scriptores, pertenecientes al estamento eclesiástico principalmente. Con el tiempo, esa labor se fue abriendo camino entre personas del ámbito laico de la sociedad. El rey Alfonso x el Sabio da a los escribanos la titularidad de un oficio público cuya actividad queda regulada por ley. Posteriormente, en la época de los Reyes Católicos se estipulará de forma más concreta cuáles son las funciones de dichos escribanos. Estos tenían que pasar un examen para comprobar su idoneidad profesional y moral (Bejarano, 1996: 11). Era esta una profesión que tenía mucho peso y una constante presencia en la vida cotidiana de la época, por lo que los escribanos constituyen un grupo 
profesional de gran interés por ser protagonista común y autor material de los escritos y documentos que son fuente de información para historiadores, filólogos, etnógrafos... para el conocimiento de nuestro pasado en diferentes épocas (Mendoza, 2005: 406).

Los escribanos debían poner todas sus dotes léxicas para describir con la mayor minuciosidad los objetos que se inventariaban, debían ser altamente reconocibles y su única arma eran sus palabras para describirlo y valorarlo (Morala, 2012c: 200). No obstante, Puche considera que los notarios no eran tan cultos como en un primer momento pueda pensarse, de hecho, el oficio se transmitía muchas veces de padre a hijo (Puche, 2012: 347).

Junto con los escribanos, estaba también la figura del tasador, que era quien daba el valor oportuno a los objetos que constituían el inventario. La presencia de estos tasadores aparece en ocasiones documentada en los textos que encontramos en la Tierra de Campos:

[...] presentes don Sebastián Vázquez de Quintana y Francisco Lozano tasadores (Medina de Rioseco, VA-1644)

[...] marido y muger de un acuerdo y consentimiento nombraron por tasadores de los bienes de dicho Pedro Pérez al señor cura, Mathías Pérez Marcos y Julio Martín, vecinos de esta dicha villa para que los tasen y se pongan por inventario [...] (Villarramiel, PA-1690)

Lo primero se pone por ynbentario y se tasan pa los dichos tasadores noventa libras de lana en pelo peinada [...] (Medina de Rioseco, VA-1643).

La función de tasador, en ocasiones era llevada a cabo por mujeres, ya que una parte importante del léxico que aparece en los inventarios hace referencia al ajuar femenino y a enseres utilizados principalmente por las mujeres, por lo que resultan unas informantes idóneas para poner valor y describir los objetos. Algunos de estos ejemplos también los encontramos en Tierra de Campos:

Quatro sávanas de lienzo casero nuebas tasadas por las dichas tasadoras a treinta reales cada una (Medina de Rioseco, VA-1641)

Lo primero que debemos asumir cuando trabajamos con este tipo de documentos es que nos enfrentamos a textos escritos a merced del criterio personal de cada escribano. Por regla general, para identificar y justificar el valor concedido a un determinado objeto, este hace una descripción minuciosa del mismo. En una época donde la fotografía no era un recurso factible para dejar constancia, el escribano recurre al lenguaje para afanarse en dar fe de lo que tiene delante de sus ojos. Son muchos los recursos que pone a su disposición para construir lingüísticamente una imagen del objeto y es tan rica la gama léxica con la que cuenta que bien merecerían un estudio aparte. Junto a los enseres inventariados aparece una serie de adjetivos o expresiones que dan cuenta de la calidad, el estado, la forma, el tamaño o la procedencia y que facilitan la identificación de cada uno. Son abundantes los adjetivos como nuevo, viejo, usado, demediado, delgado, grueso, bana, doblada, sencillo, ordinario, basto, fino...) o expresiones como a medio traer, de por estrenar, de la tierra, de obra entera, de media labor... 


\subsection{EL CorLexIn}

El detonante de la creación de este corpus es un proyecto de investigación coordinado (2006-2008) -Diccionario del español de los siglos de oro. Sus bases filológicas y lingüísticasen el que un equipo de investigadores de la Universidad de León liderados por Morala (Morala, Egido, Le Men) tienen como objetivo estudiar textos diatópicamente marcados procedentes de los Siglos de Oro. Enseguida se dan cuenta del valor de una serie de documentos en los cuales se refleja el léxico de la vida cotidiana de aquella época y las posibilidades de estudio que ofrece. El proyecto comienza a funcionar de manera autónoma, poniendo el foco de atención sobre este tipo de documentos. Al equipo de la Universidad de León, se suman investigadores de la Universidad de Burgos (Perdiguero) y de Oviedo (Pérez Toral).

Aunque el CorLexIn sigue incrementando los materiales de los que dispone -hay que advertir que el corpus está todavía en formación-, en estos momentos tiene incorporados en su haber 545 documentos manuscritos e inéditos que proporcionan más de 1.350 .000 palabras publicadas en el mismo. Las transcripciones de estos textos se pueden consultar gracias a la colaboración de la Fundación Rafael Lapesa para el Nuevo Diccionario Histórico del español (NDHE) en <www.frl.es>. Todos los datos relativos al proyecto (descripción, equipo, corpus, índice de voces estudiadas, publicaciones...) se pueden buscar en la siguiente página creada por Morala en 2013: <http://corlexin.unileon.es/>.

Toda esta información procede de la selección de documentos notariales pertenecientes a los archivos históricos provinciales españoles -exceptuando los de Galicia, Cataluña, Mallorca y Valencia- $y$, para la obtención de los inventarios procedentes de América, se han consultado el Archivo de Indias y archivos de algunos países de Hispanoamérica tales como Bolivia y Colombia. De América se tienen documentos de Bolivia, Chile, Colombia, El Salvador, Guatemala, México, Panamá, Perú, Puerto Rico y Venezuela.

El Corpus Léxico de Inventarios (CorLexIn) nace de la necesidad de crear una base de datos que contenga una serie documentos notariales capaces de ofrecer una visión de la lengua diferente a la proporcionada por los textos literarios o técnicos, de donde beben las grandes obras lexicográficas como Autoridades. Una de las ventajas que ofrece este tipo de documentos es el hecho de ubicar esta tipología de textos en el lugar donde se han registrado, ofreciendo una visión global de la distribución del léxico por diferentes zonas geográficas en una horquilla temporal que abarcaría desde finales del siglo XVI hasta los primeros años del siglo XVIII.

Esta herramienta resulta muy útil para el estudio de la lexicografía histórica -localizar léxico que no aparece en otro tipo de fuentes y registrar la variación diatópica de la época-. En nuestro caso, nos permite contrastar el léxico cotidiano de la Tierra de Campos con el resto de la Península en esa misma época, y también con la presencia de dicho léxico en América.

El hecho de escoger los Siglos de Oro, en especial el siglo XVII, tiene que ver con la inquietud por la obtención de información de fuentes diferentes a las literarias o técnicas. En este caso, los inventarios de bienes, que por sus características contribuyen a completar el acervo lexicográfico de aquella época. Para Morala el análisis adecuado de los datos que nos 
ofrece esta herramienta puede proporcionar una información equiparable a los modernos atlas lingüísticos, pero para el siglo XVII (Morala y Egido, 2018: 399-400).

Los datos del CorlexIn aumentan día a día con nuevas incorporaciones y aportan nuevas contribuciones a la historia de la Lexicografía de la mano de Morala, Egido, Le Men, Perdiguero, Pérez Toral, Gómez Ferrero y, más recientemente, por Junquera.

Así, el CorLexIn permite analizar diacrónicamente localismos, estudiar voces con una distribución geográfica interesante, estudiar los neologismos que se van incorporando al léxico en época áurea, registra formas no documentadas por otra vía, detecta préstamos de otras lenguas y refleja la variación diatópica, entre otros aspectos.

$\mathrm{Y}$, aunque los estudios se centran principalmente en el léxico, se puede recabar información sobre otros ámbitos, como la morfología, la sintaxis, la fonética, la ortografía, la formación de las palabras o el cotejar la documentación de diferentes corpus. 



\section{METODOLOGÍA}

En este estudio se va a trabajar a través del método comparativo, fundamental en la lingüística histórica, ya que, en palabras de Carriazo (2012: 128), "solo a partir del cotejo de las designaciones de los propios objetos pueden establecerse las homologías o divergencias lingüísticas entre los territorios, sean posteriormente clasificadas como diferencias dialectales (las más), o causadas por razones no geográficas (diastráticas o diacrónicas, fundamentalmente debidas a la acción de las modas o de la difusión de novedades, principalmente)".

Pero antes de realizar el estudio del léxico de la zona objeto de estudio, debemos constituir un corpus lo suficientemente representativo de la comarca de Tierra de Campos que permita mostrar la lengua que se usaba en los inventarios de bienes del siglo XVII.

\subsection{SELECCIÓN DEL CORPUS DE TIERRA DE CAMPOS}

Uno de los objetivos que pretende este trabajo es el de configurar un corpus textual conformado con inventarios de la Tierra de Campos que sea lo suficientemente representativo de la zona. Este tipo de corpus puede constituir una fuente de información cuyo análisis sirva para ampliar estudios de la historia de la lengua española, no solo para demostrar y ejemplificar de manera empírica aquello que ya se sabe, sino también llegar a cuestionar lo que se conoce a través de los datos obtenidos (Sánchez-Prieto, 2012: 9).

Tal como se ha indicado, todos los documentos seleccionados han sido localizados en los Archivos Históricos Provinciales de León, Palencia, Valladolid y Zamora. La muestra recogida comprende una selección de textos notariales de los antiguos partidos judiciales pertenecientes a la Tierra de Campos: Frechilla (Palencia), Medina de Rioseco (Valladolid), Sahagún (León) y Valderas (perteneciente al partido judicial de Valencia de Don Juan) y Villalpando (Zamora).

En concreto, entre los documentos consultados solo se han seleccionados documentos notariales que contenían inventarios, partijas, almonedas, cartas de dote... Además, estos documentos debían estar en un estado de conservación suficientemente bueno, que permitiera realizar su posterior transcripción. En muchos casos el papel se había degradado e impedía o dificultaba la transcripción total o parcial de texto recogido. Como norma general, solo se seleccionaron documentos que no presentaban pérdidas de texto (o sólo pérdidas puntuales y reducidas) por deterioro del papel.

Tal como puede verse en el anejo de fuentes documentales, los documentos seleccionados se distribuyen de la siguiente forma:

- 87 documentos de León,

- 208 documentos de Palencia,

- 165 documentos de Valladolid y

- 125 documentos de Zamora. 
En dicho anejo se muestra la relación de los mismos agrupada por partidos judiciales. Dentro de cada partido judicial se organizan los documentos de acuerdo al lugar en el que se encuentra la notaría, el notario, el año, la caja, la signatura y el número/s de folio/s en el que se encuentra el documento seleccionado. En algunos casos, no es posible completar toda esta información debido al deterioro de los documentos. Finalmente se señala, en la mayoría de los casos, el tipo de documento sobre el que se ha trabajado (inventario, carta de dote, almoneda etc.).

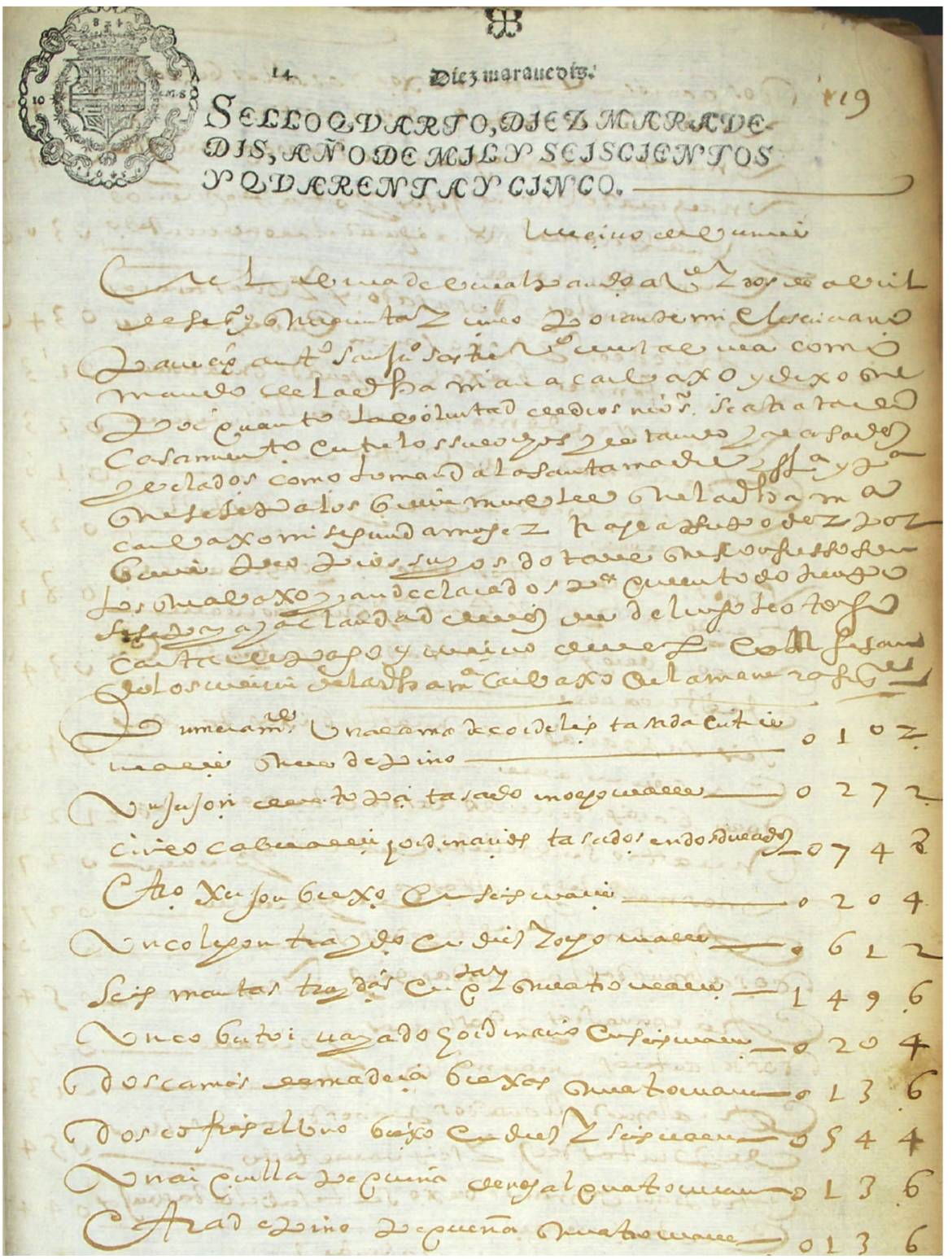

Figura 6.1 Parte inicial de un inventario (Villalpando, Zamora, 1645, Sig. 7541, f. 119). 


\subsection{TRANSCRIPCIÓN DE LOS DOCUMENTOS}

Las transcripciones de los textos que conforman nuestro corpus de estudio se ajustan a una serie de normas que se deben tener en cuenta a la hora de leer esta tesis y que se ajustan a la transcripción llevada a cabo en el CorLexIn.

Se ha intentado ser lo más fiel posible al texto original, pero para facilitar su lectura se han realizado una serie de cambios generalizados en las transcripciones. Se mantienen las grafías heredadas del sistema medieval $-x, c, z, h,-s s-\ldots-$ tal y como se usen en el texto:

- Se mantienen el uso de la "i" e "y" según el original: ylo, ynbentario, inventario, fraylega, camysón, seys...

- Se mantiene la alternancia de diferentes grafías para un mismo término como ocurre con el uso de "b", "v" o "u" o "z", "c" o "ç" según el original: honcejo, honcexo, onçexo, onzexo, cribo, crivo, crivo...

- Se mantiene el uso o la ausencia de "h" tal y como aparezca en el original: honcejo, onçexo, azada, haçada...

- Se mantiene la grafía "q" en todas las palabras que la lleven en el original: quatro, quarenta, quartillo...

- Se mantiene usos gráficos como el de " $\mathrm{n}$ " en vez de "m" en palabras como senpiterna, enpeñado, estanpa...

Para facilitar la lectura de los ejemplos en algunos casos se modernizan según el sistema actual:

- Se regulariza la separación entre palabras y la puntuación.

- Se regulariza el uso de las mayúsculas y minúsculas.

- Se siguen las reglas de acentuación modernas.

- Se regulariza el uso de la r/rr.

- La grafía -ss- solo se conserva en posición intervocálica (camissa, massera, artessa) pero en posición inicial se simplifica (ssarta $\rightarrow$ sarta)

- Se simplifican las consonantes dobles como "ff" o "tt", tanto en posición inicial como en interior de palabra (mantta $\rightarrow$ manta)

- Se regulariza el uso de la grafía ñ (estameña, basquiña, garapiña...)

- Cuando es necesario, se corrigen ciertas grafías para que no haya duda del sonido que representan como en el caso de caco $\rightarrow$ caço, lienco $\rightarrow$ lienço acada $\rightarrow$ açada... 


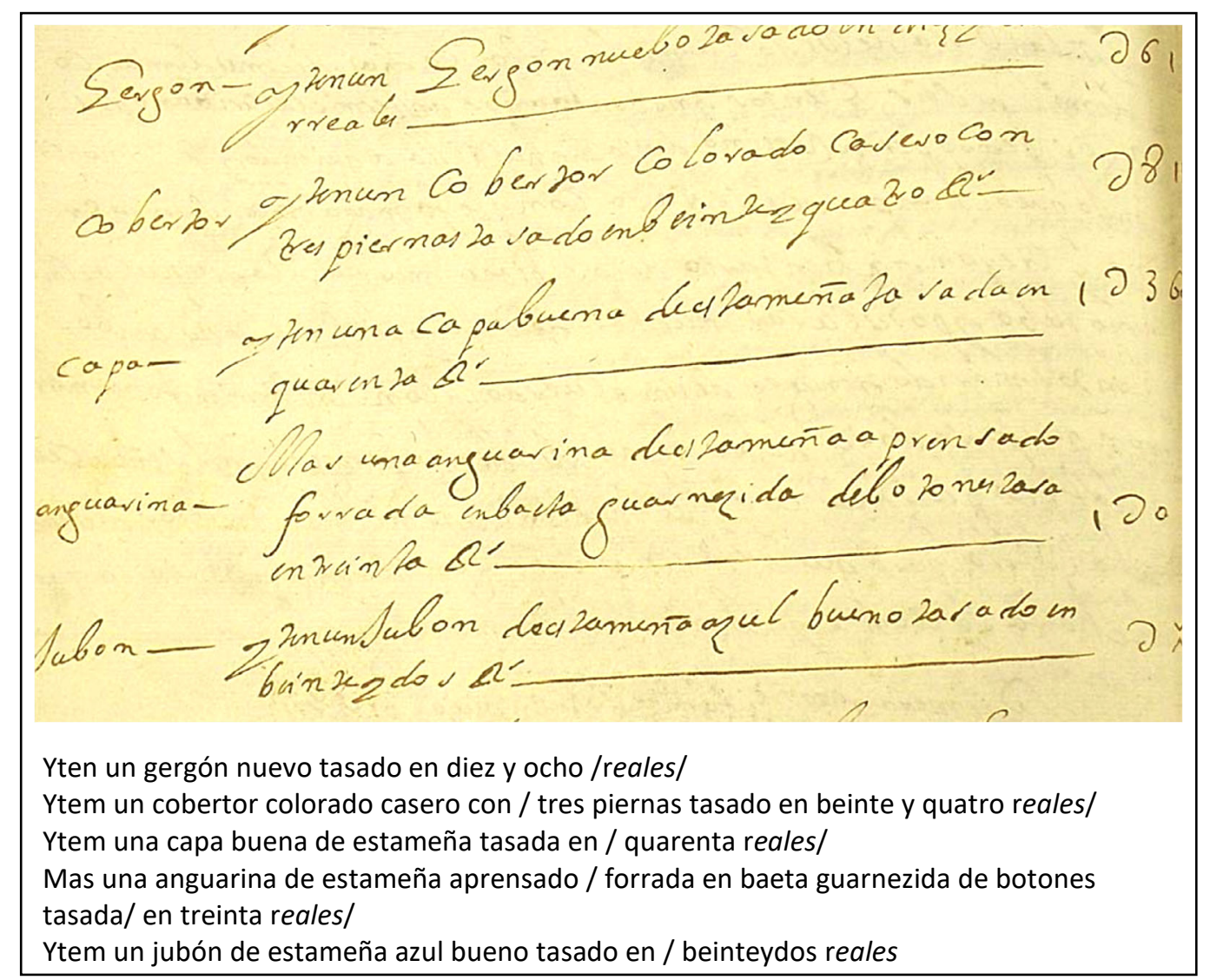

Figura 6.2. Fragmento de un inventario de bienes y su transcripción (Villarramiel, Palencia, 1690 (Sig. 13332, f. 26v.).

\subsection{CLASIFICACIÓN DEL LÉXICO}

Tras realizar la transcripción de los documentos se fueron seleccionando y organizando las distintas palabras candidatas a formar parte del corpus léxico de este trabajo.

Uno de los problemas que surgieron a la hora de realizar el estudio del léxico terracampino fue el de cómo distribuir y organizar estas voces a lo largo de la tesis. Para ello se ha tenido en cuenta a investigadores como Quirós (2011) o Carriazo (2012), que abordan la clasificación onomasiológica en sendos trabajos. Estos autores ven como una necesidad el establecer una serie de categorías donde se pueda fijar el valor de cada una de las voces seleccionadas y ponerlas en relación con otras pertenecientes a la misma familia. Para llevar a cabo este tipo de clasificaciones, a veces no es suficiente con un estudio lexicográfico (Carriazo, 2012: 129), sino que hay que identificar los referentes de dichos términos, tarea que a veces entraña alguna dificultad -como cuando contamos con un número reducido de ocurrencias de un término o no existen en los repertorios léxicos en los que nos apoyamos(Quirós, 2011: 435).

La clasificación diseñada para esta tesis se compone de once apartados en los que se estudiará el léxico referido a: indumentaria y aseo personal, objetos religiosos y de devoción, 
textil, ajuar doméstico, mobiliario, aperos agrícolas, herramientas profesionales, medidas, bienes semovientes (ganado) y denominación geográfica. A estos apartados se les añade una serie de sub-apartados.

También se establecen subdivisiones en cada uno de los apartados, dado el carácter tan amplio que tienen cada una de las categorías. Para muchos de los mismos se toman como referencia los realizados por Egido (2010) o Gómez Ferrero (2015).

Los términos que componen cada apartado se organizan alfabéticamente, salvo que sea necesario cotejarlos con otras voces, donde prima un interés filológico más que el alfabético (embarradera, trulladera, trulla, llana o plana).

\subsection{ESTUDIO Y ANÁLISIS DEL CORPUS}

Debemos tener en cuenta cómo hemos aplicado diferentes pautas de estilo para confeccionar estos documentos:

- Las voces estudiadas se transcriben en minúscula y en cursiva.

- Las acepciones de cada palabra aparecen entre comillas simples (' ').

- Los términos aparecen dentro del cuerpo de tesis en cursiva.

- Los términos que aparecen omitidos en el texto original porque se sobreentienden, se expresan en los ejemplos entre paréntesis.

- Los ejemplos extraídos del corpus que se incluyen en la microestructura aparecen entre " ", así como los que aparecen en otros corpus, por ejemplo el CorLexIn, $C D H$, CORDE... A no ser que sean demasiado extensos, en cuyo caso se pondrán con el mismo formato que los ejemplos (letra menor y a menor espacio y diferentes márgenes)

- Cuando se habla de un término en el texto del comentario aparece en cursiva, salvo que sean un ejemplo, en cuyo caso irá entre comillas (" ").

- La referencia a siglos va en versalitas.

- Las citas bibliográficas aparecen con el apellido del autor, el año de publicación cuando se trata de un libro y las páginas siempre que sea posible. En el caso de los diccionarios, se indica la sigla, s. v. y la palabra buscada en cursiva.

- Se utiliza el símbolo [...] para sustituir alguna palabra que no aparece expresada por dificultades en la lectura del original o en el caso de que el texto no sea interesante para lo que se está explicando. 
Por último, con el léxico de la vida cotidiana de Tierra de Campos del siglo XVII seleccionado se propone trabajar -desde una perspectiva o metodología comparativa- de la siguiente forma:

\section{Presentación de la palabra}

En primer lugar, se indica en mayúsculas y negrita la voz que se va a describir -entre corchetes y en minúsculas irán todas las variantes que se localizan de ese término en el corpus-. El análisis comienza con la búsqueda de la definición en el DLE; en caso de que no aparezca en ninguno de los diccionarios académicos, se recurrirá a repertorios léxicos en los que se encuentre dicha palabra (Le Men, Gordaliza, Casas...).

En un segundo paso se procederá a reflejar cómo incorporan los diccionarios tanto preacadémicos como académicos la palabra objeto de estudio, poniendo especial atención a las definiciones que muestran Covarrubias y sus coetáneos, ya que estas obras lexicográficas se incardinan en la época de estudio. Como regla general se consultarán estos datos a través de la web de la Academia en el Nuevo Tesoro Lexicográfico de la Lengua Española de la lengua española (NTLLE), donde tiene cabida una amplia selección de obras lexicográficas que atesoran el acervo léxico de nuestra lengua.

Para terminar con la presentación del término, se procederá a consultar el Diccionario Crítico Etimológico Castellano e Hispánico $(D E C H)$ de Corominas y Pascual, que, entre otras cosas, nos da información del origen de dicha palabra.

\section{Selección de ejemplos}

Una vez realizada la consulta en las obras lexicográficas y en el $D E C H$, se procede a incorporar las ocurrencias encontradas en la Tierra de Campos de la voz estudiada -si se trata de una palabra de uso general, se pondrán cuatro ejemplos de cada zona para cubrir los materiales de los que están hechos, de la función del objeto o el estado en el que se encuentra-. El término que se estudia irá señalado en cursiva y al final del ejemplo se pondrá entre paréntesis la localidad donde se ubica, la provincia y el año. Estos ejemplos irán en orden de ubicación -primero los casos de las localidades pertenecientes a León, luego las pertenecientes a Palencia, seguidas de las de Valladolid y Zamora-:

Vna mantilla de garrobillas parda, en siete reales (Sahagún, LE-1601) Un jubón de estameña de niña y unos cuerpos de garrubilla de niña (Frechilla, PA-1640) Tres reales de una pretenilla de garrubilla (Medina de Rioseco, VA-1642)

Otro ferreruelo de garrubillas a medio traer (Villalpando, ZA-1620) 


\section{Comentario}

En este apartado se refleja cómo aparece documentada la palabra desde una perspectiva diacrónica en los textos; para ello se consultan bases textuales como el Corpus Diacrónico del Español (CORDE) o el Corpus del nuevo Diccionario Histórico del español (CDH), donde se localiza la palabra sobre todo en textos de corte literario o técnico.

Para cotejar lo que ocurre en la Tierra de Campos con lo que pasa en el resto de la Península y América, consultamos el Corpus Léxico de Inventarios (CorLexIn), base textual que, como hemos visto en el capítulo anterior, es básica para los estudios sobre el léxico del Siglo de Oro.

Es importante la consulta de diferentes repertorios léxicos que pertenecen a la zona para constatar su pervivencia o no (Léxico del leonés actual (2002-2014) de J. Le Men, el Vocabulario palentino (1988) de Gordaliza, El habla de una localidad de Tierra de Campos: Villada (1989) de Casas o Una cala en el vocabulario hondo de Tierra de Campos. Paredes de Nava (1990) de M. A. Helguera y P. Nágera entre otros).

Por otro lado, será de suma importancia recabar informaciones en diferentes publicaciones científicas que permitan completar el estudio del léxico (trabajos de los miembros que configuran el CorLexIn como Morala, Egido, Le Men, Perdiguero, Pérez Toral, Junquera o Gómez Ferrero; trabajos de otros autores interesados en el léxico del Siglo de Oro o estudios léxicos de zonas limítrofes como el de Álvarez Tejedor (1989)). 



\section{ESTUDIO DEL LÉXICO}

\subsection{INDUMENTARIA Y ARREGLO PERSONAL}

El campo léxico de la vestimenta está fielmente representado en los inventarios de bienes de la época. Para identificar los diferentes atuendos, el escribano no duda en hacer detalladas descripciones que nos permiten imaginar cómo eran los trajes. Por ello, este campo conforma un caudal léxico de estimable valor que proporciona una visión fidedigna del léxico de la moda en aquella época. Otro factor que se refleja en estos textos es el carácter efímero de la moda, ya que podemos encontrar términos que se van apagando en los inventarios con el paso de los años y otros que hacen su entrada en un período determinado.

Para organizar el apartado de Indumentaria y arreglo personal se han diferenciado tres apartados: ropa interior, ropa exterior y complementos. Dentro de la ropa exterior se ha particularizado entre ropa de abrigo, prendas de cintura para arriba y prendas de cintura para abajo. Dentro del apartado de complementos se ha diferenciado entre los complementos de cabeza y tocados, otro tipo de complementos que adornaban el vestuario, calzado y joyas.

\subsubsection{Ropa interior}

\section{BRAGA [braxa]}

Sust. f. 'Calzón' (DLE, 2. ac.). Puede comprobarse que el término aparece ya en Nebrija. Covarrubias define esta prenda como 'cierto género de çarafuelles justos, que se ciñe por los lomos, y cubren las partes vergonçosas, por delante, y por detrás, y un pedaço de los muslos [...]'. En Autoridades se registra como 'voz usada en Aragón, que significa el trapo que se pone a los niños dentro de las mantillas, para que no se ensucien en ellas, que en Castilla se llama metedor' (NTLLE, s. v. braga, Nebrija, 1495; Covarrubias, 1611; Autoridades, 1726). Término procedente del lat. BRACA y este a su vez del galo (DECH, s. v. braga).

Un pedaço de bragas viexas (Tamariz de Campos, VA-1651)

Otras braxas biexas (Tamariz de Campos, VA-1651)

Esta voz aparece recogida en el $C D H$ desde el siglo XIII en el Fuero de Cáceres junto a otras prendas de vestir con la acepción dada por Covarrubias. Es un término muy presente en los textos que conforman la literatura en el siglo XVII, algo que contrasta con lo que ocurre en los inventarios que forman parte del CorLexIn, donde apenas encontramos ejemplos. En la muestra recogida se localizan dos ocurrencias pertenecientes a un mismo inventario. El contexto en el que aparecen no ofrece muchas pistas de si se ajustan a la acepción dada por Covarrubias o el DLE. El primer caso, "pedaço de bragas", se encuentra después de un escriño y antes de un dental y un banco, por lo que podemos suponer que se trataría de una especie de trapo o tela. En el segundo caso sí parece tratarse de la prenda de vestir, ya que aparece junto a un jubón. 
En esta época el término más utilizado es calzón, abundante en los inventarios de la época a lo largo de todo el territorio peninsular, insular y americano, en contraposición a braga, cuya presencia en los inventarios será más frecuente en el siglo XIX (Gómez Ferrero, 2015: 49).

La acepción que conocemos hoy en día de braga no aparece en los diccionarios académicos hasta el suplemento del DRAE de la edición de 1947, donde esta prenda añade la acepción de 'prenda interior que usan las mujeres, y que cubre desde la cintura hasta el arranque de las piernas, con aberturas para el paso de éstas' (NTLLE, s. v. braga, DRAE Suplemento, 1947).

\section{CALCETAS [calzetas, calçetas]}

Sust. f. 'Media. Prenda que cubre el pie y la pierna' (DLE). Es una palabra que aparece registrada desde Autoridades y en el resto de diccionarios académicos con esta acepción. En concreto, Autoridades indica que es 'la media de hilo que se calza en la pierna á míz de la carne, y regularmente debaxo de las de seda, estambre ò lana' (NTLLE, s. v. calceta, Autoridades, 1729). Derivado de calza, del término procedente del lat. vg. *CALCĔA, derivado del lat. CALCĔUs 'zapato' (DECH, s. v. calza).

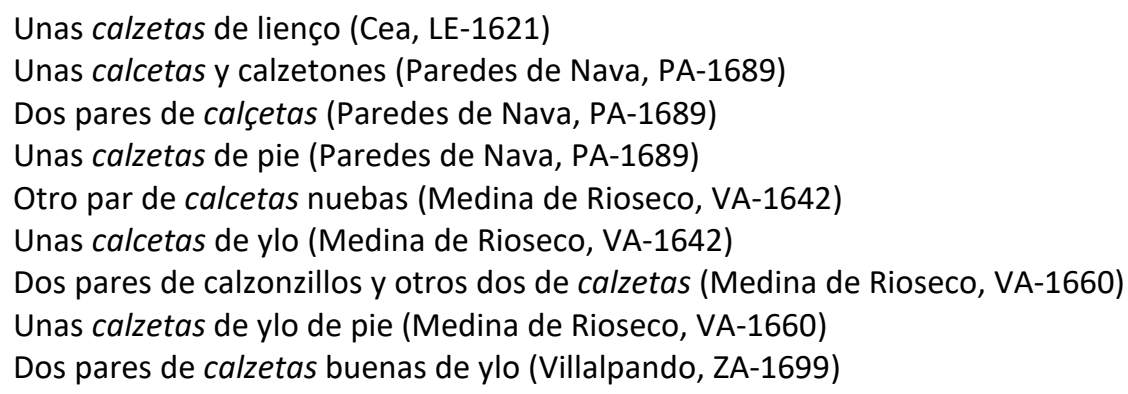

Este es un término de uso general que mantiene el significado de 'media o calcetín' y que en los documentos siempre aparece en plural. Se documenta por primera vez a mediados del siglo XVI en el CORDE y en el CDH. Su uso es generalizado en el siglo XVII, como se puede observar en el CorLexIn, donde se localizan ocurrencias a lo largo de todo el territorio peninsular y también en Canarias y América.

\section{CALCETÓN [calzetón]}

Sust. f. 'Media. Prenda que cubre el pie y la pierna' (DLE). Desde muy pronto aparece como 'media de lienzo o paño que se pone debajo de la bota, cuyo extremo suele salir afuera, algunas veces guarnecido o bordado por gala' (NTLLE, s. v. calcetón, Autoridades, 1729). Palabra derivada del término procedente del lat. vg. *CALCĔA, derivado del lat. CALCĔUS 'zapato' (DECH, s. v. calza).

Unas calcetas y calzetones (Paredes de Nava, PA-1689)

En la zona de estudio tan solo hemos encontrado un ejemplo en Paredes de Nava. Esta escasez de ocurrencias también se observa en bases de datos como el CORDE y el $C D H$, donde aparecen muy pocos ejemplos, todos ellos fechados en documentos del siglo XVII, con una acepción igual o similar a calcetas: 
'[...] Aquella noche hice provisión de esponjas y estopas, y a la mañana, quitándole a mi faraute unos grandes calcetones de paño que traía debajo de unas botas, que le pudieran servir de calzones, le metí en la una dellas todas las esponjas y estopas en lugar de escarpín y calcetón [...]' (1646 ANÓNIMO, La vida y hechos de Estebanillo González [España]).

El escaso uso de esta palabra se ve también reflejado en el CorLexIn, donde no se localiza ningún ejemplo.

\section{CALZA [calças]}

Sust. f. 'Prenda de vestir que, según los tiempos, cubría, ciñéndolos, el muslo y la pierna, o bien, en forma holgada, solo el muslo o la mayor parte de él' (DLE). Autoridades señala que esta palabra se usa más en plural y da cuatro acepciones diferentes, en la tercera advierte que se utiliza poco, ya que coincide con el significado de media (NTLLE, s. v. calza, Autoridades, 1729). Significó primeramente 'media', procedente del lat. vg. *CALCĔA, derivado del lat. CALCĔUs 'zapato' (DECH, s. v. calza).

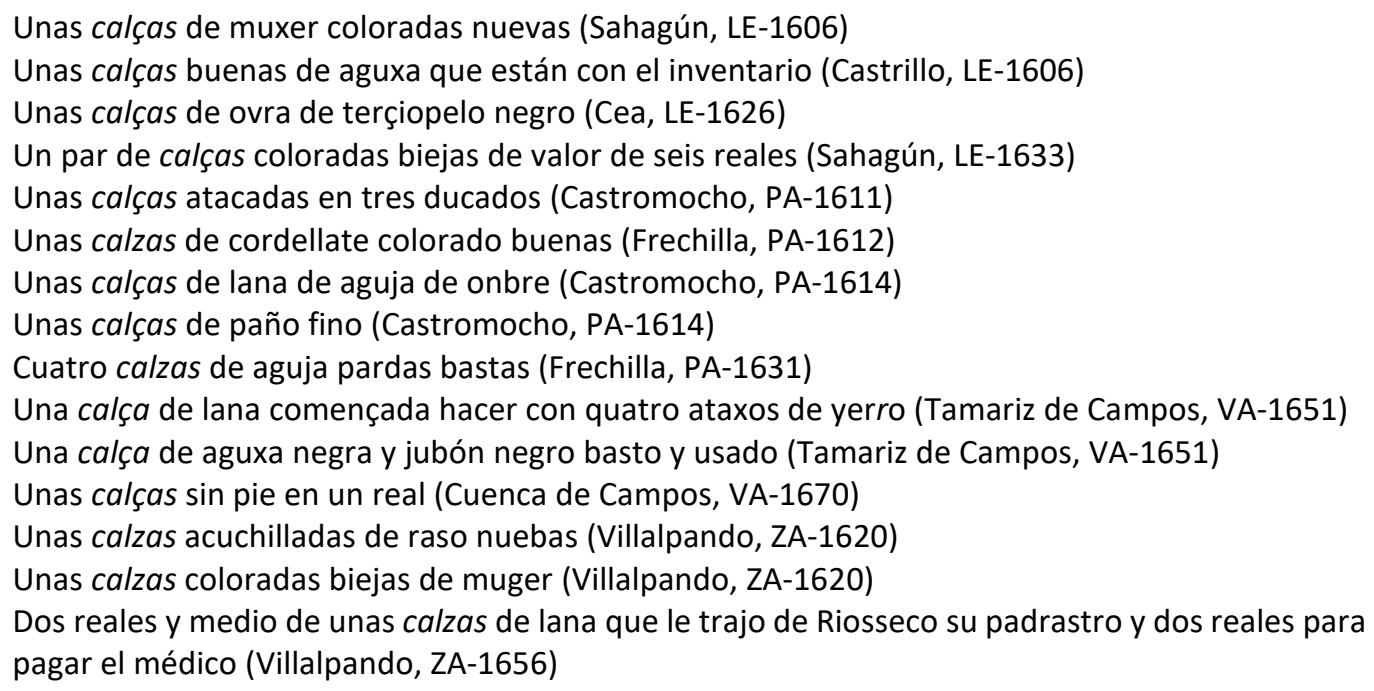

Es una palabra de uso general en esta época y, en el caso de los documentos estudiados, la forma más empleada es la de plural. En los corpus léxicos consultados, como el CORDE y el CDH, observamos que su uso era generalizado en el siglo XVII y que el término era frecuente también en América. En los ejemplos que encontramos en nuestra zona de estudio, parecen existir dos tipos de calzas, unas elaboradas con telas más ricas -como el raso, el cordellate o el paño finoy otras que el escribano especifica que son "de aguja", al parecer de lana y tejidas a mano.

El uso extendido de esta palabra también se ve reflejado en el CorLexIn, donde se localizan ocurrencias a lo largo del territorio peninsular y también en América.

\section{CALZón [calçón]}

Sust. m. 'Prenda de vestir con dos perneras, que cubre el cuerpo desde la cintura hasta una altura variable de los muslos' (DLE). A partir del diccionario académico de 1780 se define como 'parte del vestido de un hombre que cubre desde la cintura hasta la rodilla. Está dividido en dos piernas, ó cañones, y cada uno cubre su muslo. Úsase más comúnmente en plural: los hay de 
diferentes echuras' (NTLLE, s. v. calzón, DRAE, 1780). Término derivado de calza, procede del lat. vg. *CALCĔA, derivado del lat. CALCĔUs 'zapato' (DECH, s. v. calza).

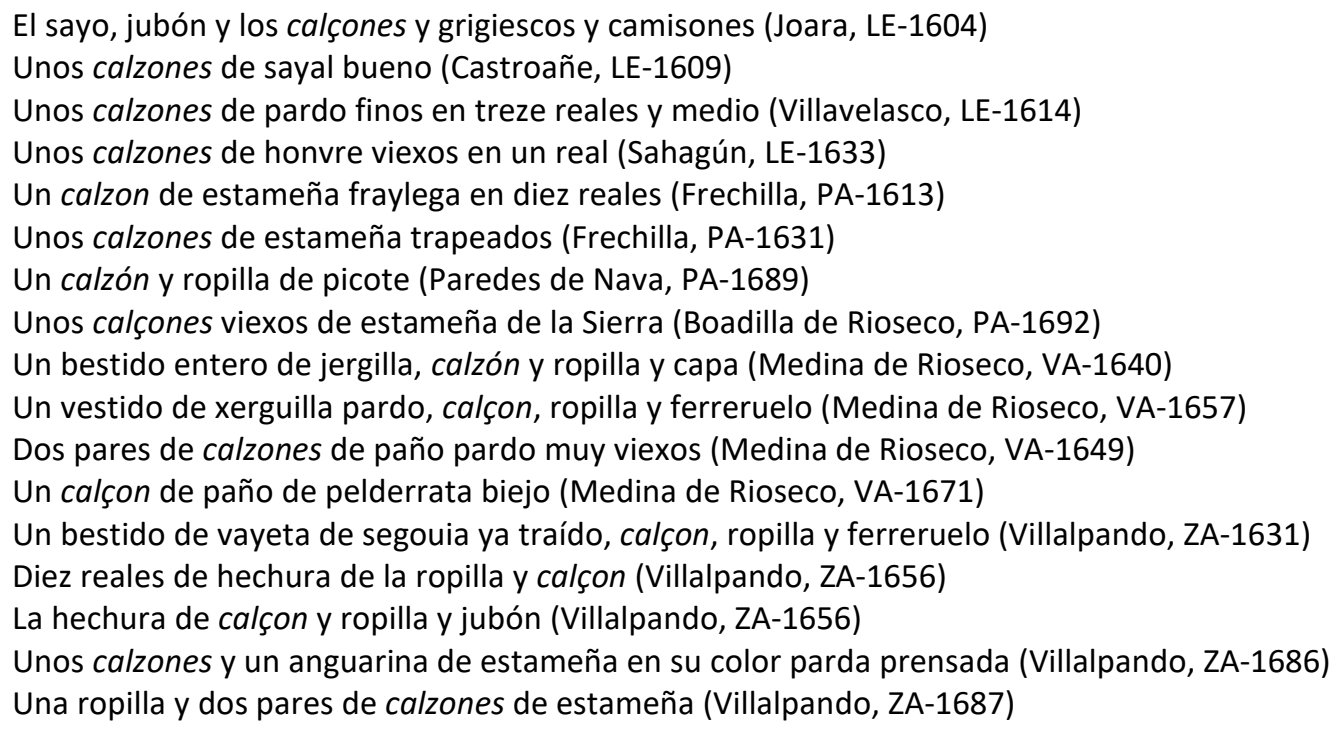

Este término aparece de forma generalizada en el siglo XVII en el CORDE, en el $C D H$ y en el CorLexIn, al igual que en los documentos estudiados. Era una prenda de vestir masculina que cubría desde la cintura hasta las rodillas. El calzón estaba confeccionado mayoritariamente por paño más bien basto (estameña, pardo, buriel...), aunque hay algún ejemplo en el que aparecen telas más ricas (bayeta de Segovia, gorguerán o tirela). Aparece en los textos, incluidos los pertenecientes a la Tierra de Campos, tanto en singular como plural y forma parte de la indumentaria masculina.

\section{CALZONCILLOS [canzonzillos]}

Sust. m. 'Prenda de la ropa interior masculina, que cubre desde la cintura hasta parte de los muslos, cuyas perneras pueden ser de longitud variable' (DLE). Deriva de calzón, y este procede de calza, del lat. vulgar *CALCĚA 'media', según se ha señalado anteriormente, derivado a su vez del lat. CALCĚUs 'zapato' (DECH, s. v. calza).

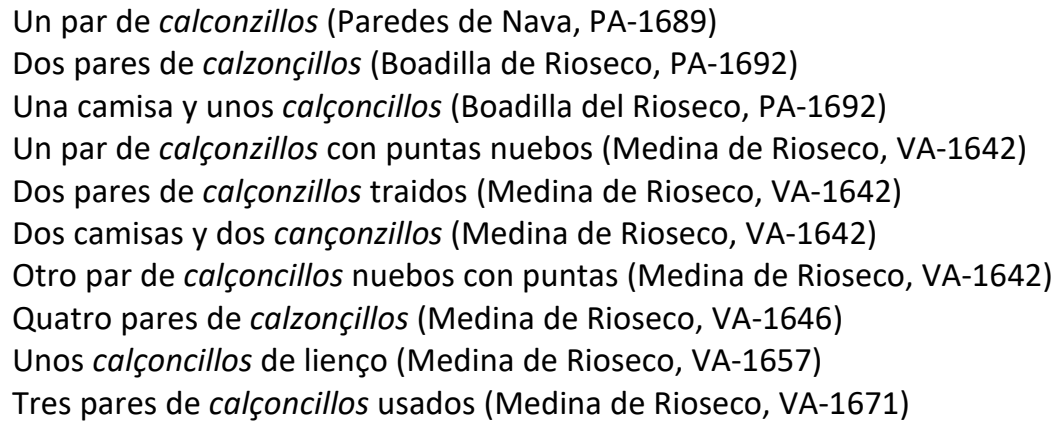

El primer ejemplo que aparece de esta palabra en el CORDE data de principios del siglo XVII y se halla en un documento fechado en 1622 con la acepción académica.

"[...]boca muy ancha, ceñida toda de puntas de oro, debaxo calçoncillo de caça con puntas de Flandes [...]" (Fernando de Monforte y Herrera, Relación de las fiestas que ha hecho el Colegio Imperial de la Compañía de Jesús[...] 1622) 
En los ejemplos registrados aparece siempre en plural. Hace referencia a la prenda interior masculina, que podía ser de lienzo o lino y que, como podemos apreciar en los ejemplos, en algunos casos llevaba adornos. Solo se localiza un caso en el que aparece la forma cançoncillos, con una / $\mathrm{n} /$ en vez de / $/$ por asimilación, aunque en el partido judicial de la Bañeza (León), zona leonesa próxima a la Tierra de Campos, este fenómeno es bastante frecuente (Gómez Ferrero, 2015: 51). Esta variante no se encuentra en el CORDE, ni en el $C D H$ o en el CorLexIn.

\section{CAMISA}

Sust. f. 'Prenda interior de tela fina y largura media, que cubre hasta más abajo de la cintura' (DLE, 2. a ac.). Esta palabra la recoge Nebrija; señala que la prenda es tanto para hombre como para mujer en la edición de 1495, pero en la de 1516 solo hace referencia a la camisa de hombre. Covarrubias la define como 'vestidura de lienço que el hombre trae debaxo de la demás ropas [...]'. Los diccionarios académicos no especifican si es de hombre o de mujer y mantienen la misma definición, con pequeñas variantes, a lo largo de las diferentes ediciones (NTLLE, s. v. camisa, Nebrija, 1495; Covarrubias, 1611). Se trata de un término derivado de camisa del lat. tardío camisia, de origen celta (DECH, s. v. camisa).

Tres camisas de muger apuñetadas usadas (Sahagún, LE-1603)

Tres camisas de muger, la una nueva y las otras de mediada (Celada, LE-1606)

Una camisa de honbre buena (Castroañe, LE-1609)

Siete camisas de onbre, las cinco vuenas y las dos viexas (Riosequillo, LE-1610)

Dos camisas de mujer usadas (Sahagún, LE-1626)

Una camisa de mujer con su caveçón y puños labrados de ruan (Castromocho, PA-1603)

Una camisa de mujer con un cuello azul labrado y faldas de estopa bieja (Frechilla, PA-1613)

Otra camisa con una tira negra labrada apreçiada en tres reales (Frechilla, PA-1614)

Una camisa de muger delgada con cauezón de seda negro (Frechilla, PA-1642)

Tres camisas nuebas de lienco con ruedos de estopa labrados todas de negro (Villada, PA-1665)

Tres camisas de muger de lienço en zinquenta reales (Medina de Rioseco, VA-1640)

Tres camisas muy biejas (Medina de Rioseco, VA-1641)

Tres camisas de ombre traídas (Medina de Rioseco, VA-1643)

Una camisa de muger nueba (Medina de Rioseco, VA-1650)

Una camisa de mujer de lienzo de Santiago (Medina de Rioseco, VA-1660)

Una camisa de mujer labrada el cabeçón de seda negra (Villalpando, ZA-1620)

Dos camisas de muger de lienço (Villalpando, ZA-1629)

Una camisa de lienco de Aroca (Villalpando, ZA-1639)

Dos camisas nuebas de muger (Villalpando, ZA-1664)

Una camisa de diziplina a medio traer (Villalpando, ZA-1685)

Este término de uso general está ampliamente documentado en el CORDE y en el CDH. En más de la mitad de las ocurrencias localizadas en el corpus de Tierra de Campos, la voz camisa hace referencia a una prenda femenina, dato que parece extrapolable a los ejemplos del CorLexIn. A pesar de que en la actualidad el término camisa sirve para designar una prenda tanto masculina como femenina, Gómez Ortín (2012) señala que en el habla popular de Murcia la camisa llegó a identificarse como prenda femenina, y el camisón como prenda masculina. En repertorios dialectales modernos se localizan zonas de León en las que esta palabra hace referencia a la prenda interior femenina (Le Men, s. v. camisa, 2004). 


\title{
CAMISÓN [camysón]
}

Sust. m. 'Camisa' (DLE, 2. a ac.). En Autoridades se señala que 'propiamente significa la camisa de hombre, por ser más alta de cuello y más larga de falda, pero se toma promiscuamente por toda camisa, que es mayor de las que traen regularmente'. La acepción de camisón como la entendemos en nuestros días aparece en el DRAE de 1947 (NTLLE, s. v. camisón, Autoridades, $1729, D R A E, 1947)$. Es un término derivado de camisa del lat. tardío camisia, de origen celta. (DECH, s. v. camisa).

\author{
Dos camisones de ombre nuevo y otra de mediado (Celada, LE-1606) \\ Otro camysón de onbre usado (Santa María del Río, LE-1607) \\ Tres camisones de onbre buenos (Cea, LE -1610) \\ Un camysón (Grajal de Campos, LE-1916) \\ Un camisón de honbre bueno (Sahagún, LE-1615) \\ Otro camisón de honbre viexo (Sahagún, LE-1615) \\ Un camisón biejo en quatro reales menos un quartillo (Villavelasco, LE-1615) \\ Un camisón vueno (Sahagún, LE-1626) \\ Cinco camisones de onvre, el uno vueno y los quatro viexos y rotos (Sahagún, LE-1626) \\ Un camisón de hombre lavrado el caueçón tasado en dos ducados (San Nicolás del Real Camino, \\ LE-1631) \\ Un camisón de honbre viejo (Villadiego, LE-1627) \\ Un camisón de lienzo delgado lavrado de vlanco nuevo (Grajal de Campos, LE-1613) \\ Un camisón de hombre labrado el caueçón (San Nicolás del Real Camino Francés, LE-1631) \\ Rematose en Santiago [...] pregonero, un camisón de çerro en ocho reales (Frechilla, PA-1615) \\ Un camisón de lienzo de onbre (Medina de Rioseco, VA-1640)
}

Como ocurre con camisa, la grafía que se prefiere es -s-, ya que solo encontramos un ejemplo con -ss-. Es una palabra también de uso general. Los ejemplos recabados en la Tierra de Campos corresponden principalmente a localidades pertenecientes a León. Llama la atención que, en la gran mayoría de los ejemplos encontrados, el camisón sea una prenda destinada a los hombres. En los inventarios de bienes pertenecientes a los moriscos que van camino de Francia se puede observar cómo se emplea el término camissa para las prendas de mujeres y niños y camissiones para los de hombre (Perdiguero, 2012a: 341). Esto mismo lo corroboran ejemplos localizados también en el $\mathrm{CDH}$ :

'[...] Otra camisa de muger, vieja, los pechos labrados de seda azul y negra. Unos çaragüeles de honbre, de lienço, labrados. Unas mangas de fustán vareteado. Otro camisón de honbre, nuevo. Otro camisón de honbre, labrado, viejo. [...]' (1562, "Secuestro de bienes", Inventarios de bienes moriscos del Reino de Granada).

Con los datos que nos aporta el CorLexIn, se puede indicar que su uso era generalizado en esta época a lo largo del territorio peninsular.

\section{CORPIÑO}

Sust. m. 'Almilla o jubón sin mangas' (DLE). Covarrubias recoge este término como 'el cuerpo de la saya de la mujer, a corpore, porque se abraça, lo que es el cuerpo, pecho y espalda [...]'. En Autoridades y en el resto de los diccionarios académicos se mantiene la definición utilizada hasta el momento (NTLLE, s. v. corpiño, Covarrubias, 1611; Autoridades, 1729). Se trata de una palabra derivada de cuerpo, del lat. CŎRPUS, -ŎRIS (DECH, s. v. cuerpo). 
Unos corpiños guarnecidos de terçiopelo (Cea, LE-1626)

Unos corpiños de raxa colorada con sus fajas de tafetán açul (Castromocho, PA-1602)

Un corpiño de una libra biejo (Castromocho, PA-1611)

Una camisa y unos çarafuelles y un corpiño biexo de paño pardo y un cuello (Frechilla, PA-1615)

Un corpiño fraylego sin mangas nuevo (Frechilla, PA-1616)

Un corpiño de paño fraylego sin mangas, es viexo (Frechilla, PA-1631)

Otra basquiña, un reboçino de gorguerán aforrado y un copiño guarneçido (Guaza de Campos, PA-1637)

Un corpiño de estameña en quatro reales (Medina de Rioseco, VA-1639)

Un corpiño de gorguerán traído (Medina de Rioseco, VA-1639)

Un corpiño de gorguerán traydo (Medina de Rioseco, VA-1649)

Dos camisas y un corpiño de lienço vuena (Medina de Rioseco, VA-1642)

Una basquiña de raso carmesí con corpiño de lo mismo (Villalpando, ZA-1620)

Unos corpiños de grana colorada con unas fajas y ribetes de terziopelo negro tasados en siete reales (Villalpando, ZA-1620)

En la zona de estudio su distribución no es equilibrada: esta voz tiene más presencia en Palencia y Valladolid que en Zamora y León, donde solo se han encontrado dos ejemplos en el primer caso y uno en el segundo. La ausencia de esta palabra ya era señalada por Gómez Ferrero en su estudio sobre el léxico de La Bañeza (Gómez Ferrero, 2015: 67). Esta voz se documenta en la Península, Canarias y América en el CorLexIn. Se trataba de una prenda femenina sin mangas que no pasaba de la cintura y que solía llevar diferentes adornos. Se confeccionaba con telas ricas como la raja, el gorgorán, el raso o la grana.

\section{CULERO}

Sust. m. 'Especie de bolsa de lienzo que se pone a los niños en la parte posterior, para su limpieza' y 'remiendo en los calzones o pantalones sobre la parte que cubre las asentaderas' (DLE, 3. - y 7.. ac.) Término derivado de culo, del lat. cūLus íd. Culero, que aparece ya en Nebrija como 'pañal'. (DECH, s. v. culo).

Dos culeros pardos (Frechilla, PA-1640)

Una cincha y una manta de culeros bueno (Fechilla PA-1675)

Quatro baras de culeros texidos con picuelos (Fechilla PA-1675)

El primer ejemplo que encontramos de este término parece coincidir con la acepción académica, ya que, aunque no especifica sus características, el contexto en el que aparece (un "tajaderuelo de niño", "unas camisillas de niños", "un babadero", "un cabeçito de niño") nos hace pensar que se trata de 'el pañal que ponen à los niños para poderlos limpiar á menudo sin desenvolverles' (NTLLE, s. v. culero, DRAE, 1780). En la provincia de Palencia comprobamos que este término hace referencia a una 'especie de braga que se ponía a los niños para absorber el pis' (Gordaliza, 1988: 80). Caballero recoge este término en un estudio del léxico de Alaejos (Valladolid), localidad próxima a la Tierra de Campos y lo define como 'ropa que se pone en las cunas a los niños para empapar los orines' (Caballero, 1999: 20).

Sin embargo, en los otros dos ejemplos hallados, el significado es diferente, pues parece tratarse de un tipo de tejido que se utilizaba para proteger las prendas del desgaste en las nalgas. En León, encontramos culero como 'parte trasera de los pantalones', 'remiendo en la parte del pantalón correspondiente a las posaderas' (Le Men, 2004 s. v. culero). Con esa misma acepción 
lo identificamos en prendas tradicionales de los gauchos en Argentina, donde esta prenda cubre parte de las caderas para impedir el desgaste de los pantalones con el lazo (Leguizamón, 1896: 262).

No es una voz de uso generalizado en la zona y tampoco en la época, ya que no se localiza ningún ejemplo de este término en los documentos del CorLexIn. Los tres casos hallados en el corpus pertenecen a Frechilla, centro de producción textil de referencia en el siglo XVII (Bellido, 2006: 273), por lo que dicha zona ofrece un léxico más amplio y rico en el campo semántico de las telas.

\section{ENAGUAS [enagüillas]}

Sust. f. 'Prenda interior femenina, similar a una falda y que se lleva debajo de esta' (DLE). En Autoridades se recoge que es un 'género de vestido hecho de lienzo blanco, à manera de guardapiés, que baxa en redondo hasta los tobillos, y se ata por la cintúra, de que usan las mugeres, y le trahen ordinariamente debaxo de los demás vestidos'. (NTLLE, s. v. enaguas, Autoridades, 1732). Del antiguo naguas, y este del taíno de Santo Domingo, donde designaban una especie de faldas de algodón que las indias llevaban hasta las rodillas; el resultado enagua es fruto de la aglutinación de la /e-/ en frases como "estaba en naguas", evitando así que pudiera entenderse "en aguas" (DECH, s. v. enagua).

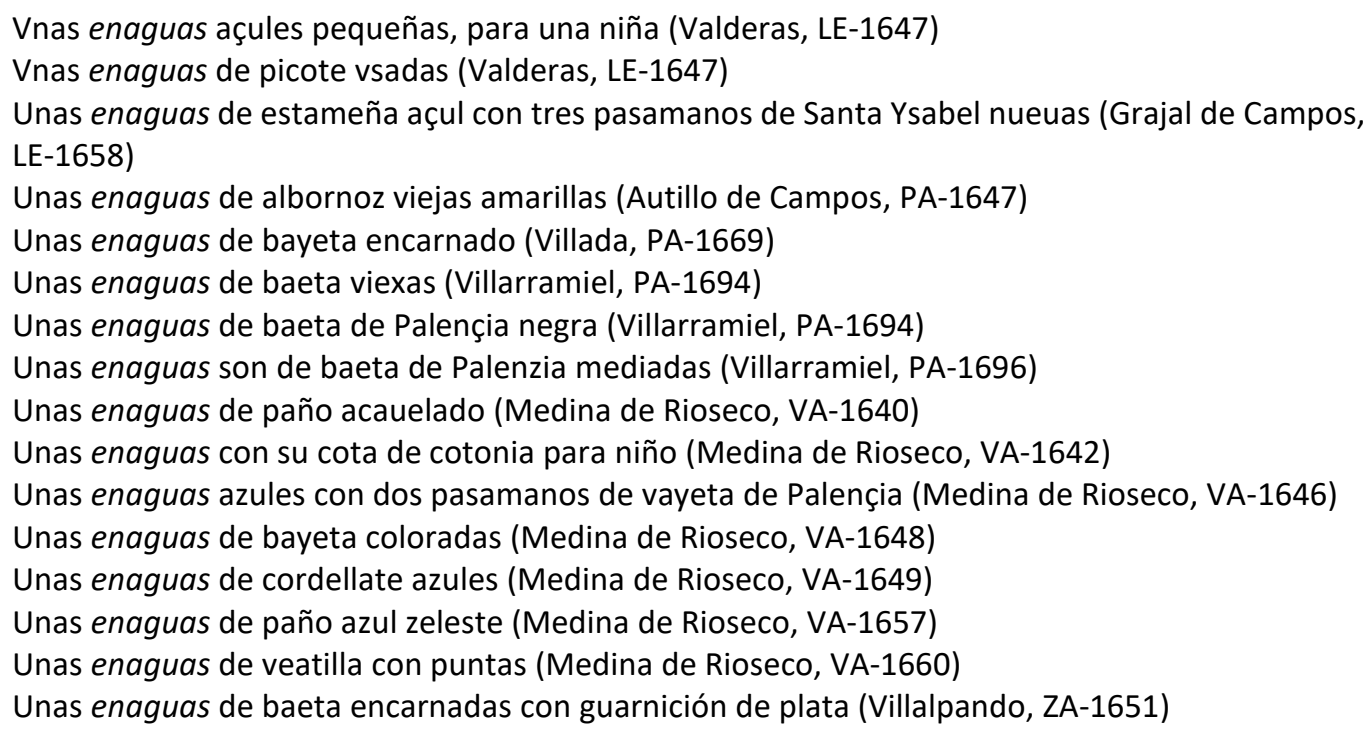

Voz ampliamente documentada en el CORDE, es de uso generalizado en el siglo XVII. Siempre aparece en plural. Este americanismo que tuvo una rápida aceptación y en esta época ya formaba parte del léxico cotidiano. Se encuentra en los documentos con la acepción que aparece en el DLE. En el CorLexIn aparece a lo largo de todo el territorio peninsular y en las islas Canarias, además de América.

Desde un punto de vista morfológico, en el corpus terracampino se documenta la forma derivada de diminutivo formado por el sufijo -illa:

Unas enagüillas y un xubonçillo de niño (Villarramiel, PA-1694) 


\section{FALDELLíN [faldillín]}

Sust. m. 'Falda corta y con vuelo que usan las campesinas sobre las enaguas' ( $D L E$, 2. a ac.). 'Ropa interior que trahen las mujeres de la cintura abaxo, y tiene la abertura por delante, $y$ viene a ser lo mismo que comunmente se llama brial o guardapiés'. (NTLLE, s. v. faldellín, Autoridades, 1732). Es un derivado del término falda que procede probablemente del franco *Falda (DECH, s. v. falda).

Un rebozino de gorgerán y faldellín azul guarnezido (Guaza de Campos, PA-1637)

Un faldellín de raja azul con ribete de terziopelo colorado y pasamanos de santa Ysabel (Autillo de Campos, PA-1647)

Un faldellín azul guarnezido de pasamanos (Autillo de Campos, PA-1649)

Un faldellín de damasco colorado usado guarnecido de pasamanos de Santa Ysabel (Autillo de Campos, PA-1653)

Un faldellín de estameña azul de garapiña con tres guarniziones negras (Paredes de Nava, PA1689)

Una vasquiña de estameña y labor aforrado en lienzo y faldillín azul de estameña de cajas (Paredes de Nava, PA-1690)

Un faldellín de paño azul con guarnicion de pasamanos (Medina de Rioseco, VA-1642)

Un faldellín guarneçido en sesseta y seis reales (Medina de Rioseco, VA-1642)

EI CDH y CORDE recogen este término pasada la segunda mitad del siglo XVI en el "Secuestro de bienes" a los moriscos del Reino de Granada:

Un faldellín vasquina de escarlata guarneçida con terciopelo morado (1562, "Secuestro de bienes", Inventarios de bienes moriscos del Reino de Granada)

Los datos que ofrece el CorLexIn sitúan esta voz sobre todo en la parte centro y sur de la Península, aunque se hallan ejemplos aislados en Bilbao y Soria. También se documenta en los textos de América.

En Tierra de Campos se localiza en las provincias de Palencia y Valladolid y comparte campo semántico con manteo, guardapiés o brial, términos que aparecen con mayor frecuencia en el corpus terracampino. Además de la forma académica, se localiza también la variante faldillín, en la que se ha producido un cambio de timbre en la vocal átona, fenómeno que se documenta de forma frecuente en esta época (Morala, 2012a: 555-556).

\section{GUARDAINFANTE}

Sust. m. 'Especie de tontillo redondo, muy hueco, hecho de alambres con cintas, que se ponían las mujeres en la cintura debajo de la basquiña' (DLE). Es una palabra compuesta, que mantiene la misma acepción desde Autoridades (NTLLE, s. v. guardainfante, Autoridades, 1734). Es una palabra compuesta.

Un guardaynfante nueuo, siete reales, con trançaderas coloradas (Villlalpando, ZA-1652)

Un guardainfante (Villalpando, ZA-1654)

Un guardainfante viexo (Villalpando, ZA-1690)

En la zona de estudio se encuentran tres ejemplos en documentos notariales de Villapando (Zamora). Aparece documentada en el CORDE durante el siglo XVII en muchos de los escritores áureos, pero también figura en un tratado de Bartolomé Jiménez Patón titulado Reforma de 
trajes. Doctrina de Fray Hernando de Talavera (1635). En él escribe que el guardainfante se hacía 'con los aros de los cedazos [...] aforrados en orillos de paño o en bayeta y que se ataban con unas cintas'; advierte que posteriormente esta prenda fue sustituida por las enaguas. Otro dato interesante es que quienes dice que le informan sobre esta prenda son cortesanos, por lo que podemos intuir que se trataba de una prenda reservada a la nobleza. La escasa documentación es también patente en el CorLexIn, donde solo aparecen dos casos, uno en Madrid y otro ya citado de Villalpando (1652).

Para Seseña estos guardainfantes constituyen el armazón interior de los trajes de la alta nobleza de la segunda mitad del siglo XVII (Seseña, 2009: 13). Esta falta de ocurrencias en los inventarios de bienes de la época junto con la presencia de dicho término en obras literarias nos hace pensar que trata de un cultismo.

\section{LIGA}

Sust. f. 'Cinta o banda de tejido normalmente elástico para sujetar las medias o los calcetines' $(D L E)$. Covarrubias lo recoge como 'la atapierna, cenogil o jarretera, que también se llama ligagába'. Autoridades también recoge esa acepción (NTLLE, s. v. liga; Covarrubias, 1611; Autoridades, 1734). Término derivado de ligar, del lat. LIGARE 'atar', por vía semiculta (DECH, s. v. liga).

\footnotetext{
Unas medias de punto buenas de lana con sus ligas de tafetán (Frechilla, PA-1631)

Unas ligas pardas (Medina de Rioseco, VA-1641)

Unas ligas pardas con puntas de plata (Medina de Rioseco, VA-1642)

Dos pares de ligas pardas sin puntas (Medina de Rioseco, VA-1642)

Dos pares de ligas con puntas de oro (Medina de Rioseco, VA-1642)

Unas ligas pardas biejas (Medina de Rioseco, VA-1642)
}

Aunque es una voz de uso común en la época y su presencia se puede documentar en distintos puntos de la Península (CorLexIn), los ejemplos documentados para este estudio se encuentran casi en su totalidad en Medina de Rioseco (Valladolid). Tal vez por casualidad, pero no hemos hallado ninguno en las localidades pertenecientes a León y Zamora. Todos los ejemplos localizados aparecen en plural y por pares y mantienen el mismo significado que nos da el $D L E$. Las ligas se confeccionaban de varios materiales y con adornos.

\section{MEDIAS}

Sust. f. 'Prenda de punto, seda, nailon, etc., que cubre el pie y la pierna hasta la rodilla o más arriba' ( $D L E)$. Covarrubias recoge este término en plural y escribe que 'absolutamente suele sinificar medias calças'. Autoridades recoge el término en singular y lo define como 'la vestidura de la pierna, desde la rodilla abaxo' (NTLLE, s. v. media / medias, Covarrubias, 1611; Autoridades, 1780). Derivado de medias calzas, del lat. MĔDǏus íd. (DECH, s. v. media).

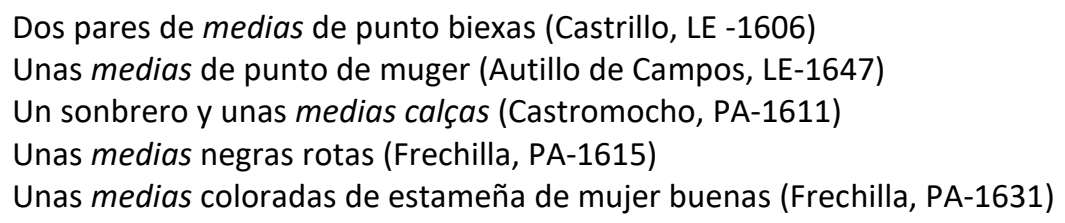


Dos pares de medias unas burieles y otras plateadas (Baquerín de Campos, PA-1658)

Unas medias negras buenas (Frechilla, PA-1675)

Unas medias de pelo encarnadas (Paredes de Nava, PA-1689)

Unas medias coloradas de Valtanás (Boadilla de Rioseco, PA-1692)

Unas medias de nacar de ylo en seis reales (Medina de Rioseco, VA-1639)

Dos pares de medias de pie blancos de ylo nuebas (Medina de Rioseco, VA-1642)

Otro par de medias de seda cavelladas traidas (Medina de Rioseco, VA-1642)

Unas medias de punto de doçe reales (Medina de Rioseco, VA-1643)

Tres pares de medias del corral (Medina de Rioseco, VA-1648)

Unas medias de punto coloradas (Medina de Rioseco, VA-1650)

Dos pares de medias de Yngalaterra (Medina de Rioseco, VA-1661)

Unas medias de lana biexas (Medina de Rioseco, VA-1671)

Unas medias de punto negras (Villalpando, ZA-1633)

Unas medias encarnadas nueuas (Villalpando, ZA-1652)

Dos pares de medias gordas de punto (Villalpando, ZA-1699)

Es una palabra de uso general en esta época; las medias formaban parte de la indumentaria del siglo XVII y eran usadas tanto por hombres como por mujeres. En los documentos analizados aparece siempre la forma del plural y en un ejemplo de la localidad palentina de Castromocho aparecen las "medias calzas" que Covarrubias identifica con este término. Suelen ser de punto, de lana o hilo pero también de seda. Los colores que presentan son variados: en los inventarios las encontramos de color blanco, negro, colorado, verde, cabellado, encarnado y plateado.

\section{PAÑAL [bañal]}

Sust. $m$. 'Sabanilla o pedazo de lienzo en que se envolvía a los niños de teta' ( $D L E, 2$. a ac.). Nebrija recoge 'pañales para criar niño' y Covarrubias define esta voz como 'Las sauanillas y lienços con que se empañan y abrigan los niños. Pañal, el cabo de la camisa que cuelga fuera de las calças; es argumento de mucho desaliño, y alos que esto acontece llamamos pañalones'. Autoridades mantiene esa acepción y la amplía indicando que 'se toma también por cualquier túnica o tela, en que está envuelta alguna cosa. En este sentido tiene poco uso' (NTLLE, s. v. pañal, Nebrija, 1516; Covarrubias, 1611; Autoridades, 1737). Término derivado de paño, del lat. PANNUS (DECH, s. v. paño).

Un zesto de minbres blanco con unos pañales viejos (Cea, LE-1621)

Un bañal biexo tasado en tres reales (Cuenca de Campos, VA-1670)

Solo hay siete ejemplos de esta palabra en el CORDE durante el siglo XVII. La escasa presencia de esta voz se aprecia también en el CorLexIn, donde aparecen ejemplos situados en Badajoz, Navarra y León. En la zona de estudio nos encontramos con dos ejemplos, uno en Cuenca de Campos (Valladolid) -anotado en el margen del inventario aparece pañal-y otro en Cea (León).

\section{POLAINAS [polaynas]}

Sust. f. 'Especie de media calza, hecha regularmente de paño o cuero, que cubre la pierna hasta la rodilla y a veces se abotona o abrocha por la parte de afuera' (DLE). En Covarrubias se define como 'medias calças de labradores sin soleras, que caen encima del çapato sobre el empeine [...]' (NTLLE, s. v. polainas, Covarrubias, 1611). Tomado del fr. ant. polaine, que designó la punta larga del calzado que estuvo a la moda de los siglos XII y XV, y también una bota provista de esta 
punta; polaine era propiamente el femenino de 'polaco', que se aplicó a una clase de piel (DECH, s. v. polainas).

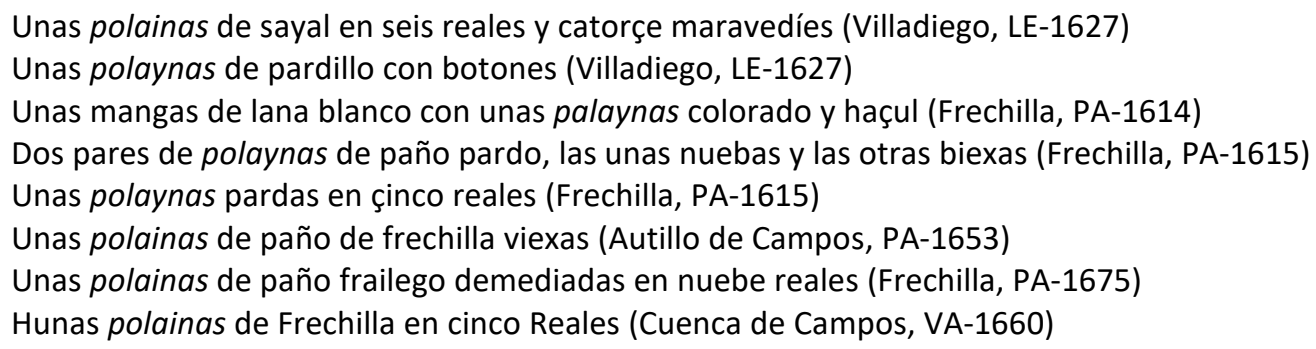

Puede verse que, en los ejemplos encontrados en los inventarios, este término solo se encuentra en plural y la acepción concuerda con la indicada en Covarrubias. Se trata más bien de un complemento de abrigo o protección, dado que las telas con las que se confeccionan son más ordinarias y carecen de adornos.

En el $C D H$ y en el CORDE se localizan numerosos casos a partir del siglo XVI, con preferencia del término en plural. Respecto al CorLexIn, los ejemplos se distribuyen en nueve provincias peninsulares, localizadas en el norte y occidente preferentemente -Cantabria, León, Burgos, Soria, Huelva-, aunque también encontramos ejemplos en Toledo, Ávila y Segovia, además de algún caso en América.

En repertorios más modernos localizamos esta palabra en León como la 'pieza de paño, abotonada a un lado, que abraza las pantorrillas desde la rodilla al pie, uniendo los calzones con los borceguíes'. También aparece en Asturias, Cantabria, Galicia o Cuenca (Le Men, 2009, s. v. polaina). En Palencia se recoge como 'especie de pantalones de lana de los pastores que sólo llegan hasta la rodilla. Sobre ellos se ponían los zahones' (Gordaliza, 1988: 181).

\section{TÚNICA}

Sust. f. 'Vestidura exterior amplia y larga', 'vestidura de lana que usan algunos religiosos debajo de los hábitos', 'vestidura sin mangas, que usaban los antiguos y les servía como de camisa' (DLE, 1. a , 3. a y 4. a ac.). En Autoridades se define este término como 'vestidura interior sin mangas que utilizaban los antiguos y les servía como camisa' (NTLLE, s. v. túnica, Autoridades, 1739). Del lat. TǓNĭCA que era el 'vestido interior de los romanos, empleado por los dos sexos' ( $D E C H$, s. v. túnica).

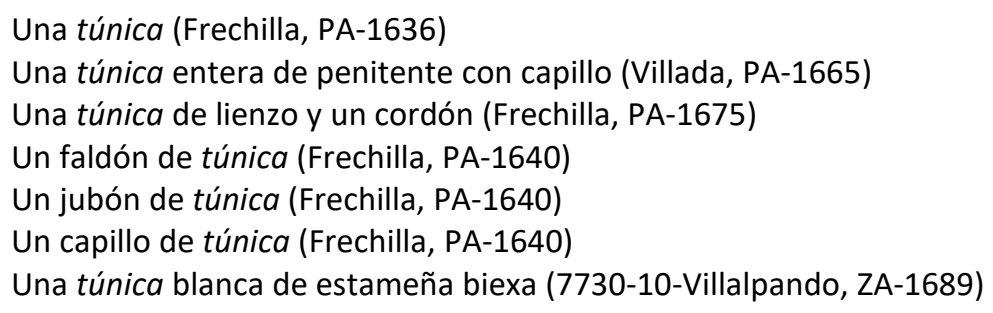

Palabra documentada en el $C D H$ a partir de la segunda mitad del siglo XIII con la acepción de 'vestimenta talar'. Sin embargo, en nuestro corpus el contexto en el que se encuentra este término no da la suficiente información para determinar el referente. Se documenta en Villada (Palencia) con el sentido religioso con el que aparece en la literatura. Sin embargo, en otros 
casos no está claro que haga referencia a este tipo de vestimenta, ya que se halla entre ropa interior o ropa de cama, lo que nos hace sospechar que podría tratarse de un vestido interior e incluso de ropa para dormir. El CorLexIn ofrece una veintena de ejemplos a lo largo de todo el territorio peninsular; en ellos se puede apreciar esta dicotomía de significados: por un lado, el vestido destinado a los oficios religiosos, pero, por otro, aparecen ejemplos en los que esta prenda se inventaría junto a la ropa de cama. Así, encontramos el siguiente ejemplo "Una túnica de lienço con su cordón, de acostarse" (Segovia, 1659), donde está clara la función de dicha prenda. Por otro lado, en la zona de estudio, concretamente en la localidad palentina de Frechilla -centro textil de la época- aparece el sintagma preposicional "de túnica"; por tanto, nos encontramos con un faldón, un jubón y un capillo "de túnica" que parecen no hacer referencia al mismo tipo de vestido que en los otros documentos sino, más bien, a un tipo de tela con la que se confeccionaban las diferentes prendas. El término también puede hacer referencia al conjunto de prendas que formaban la túnica.

\subsubsection{Ropa exterior}

\subsubsection{Prendas de abrigo}

\section{ANGUARINA [enguarina, anguarona, unguarina, ongarina]}

Sust. f. 'Gabán rústico de paño burdo y sin mangas, que se pone sobre las demás prendas para protegerse del frío y de la lluvia' (DLE). Autoridades registra este término con la forma ungarina como 'especie de casaca hueca, llamada assi por ser à la moda de los Ungaros', es a partir de su edición de 1770 cuando se añade la entrada anguarina, en los diccionarios académicos del siglo XVIII, se mantiene la entrada unguarina y se tilda de vulgar el término anguarina (NTLLE, s. v. anguarina, unguarina, Autoridades, 1739, Autoridades, 1770). Se trata de una palabra derivada de húngaro, por ser a la moda de los trajes campesinos húngaros ( $D E C H$, s. v. anguarina).

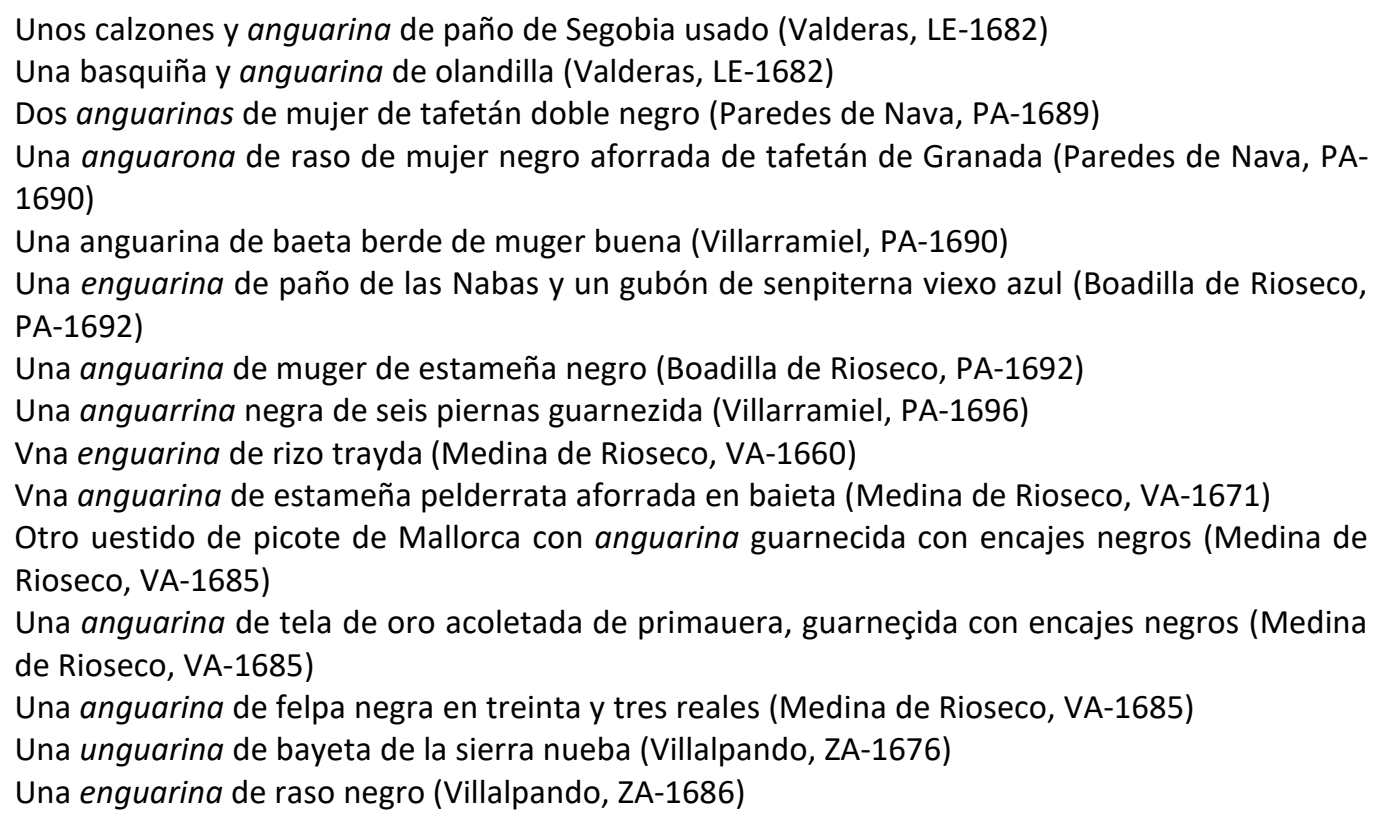


Una ongarina de vayeta de zien filos (Villalpando, ZA-1686)

Una enguarina nueua de paño de Herrera (Villalpando, ZA-1689)

Una ongarina de muxer de senpiterna ya usada (Villalpando, ZA-1690)

Una ongarina de paño de Somonte ya usada (Villalpando, ZA-1699)

Esta voz presenta diferentes variantes en la zona estudiada: anguarina, enguarina, ongarina, unguarina. La forma más frecuente es la variante anguarina, que aparece en toda la comarca de Tierra de Campos. Junto a ella figura también la forma enguarina; aquí se puede observar la vacilación entre las vocales átonas /a/ y /e/, que es bastante frecuente en esta época y en el contexto que aquí se presenta -/an-/ y /en-/-. Aparentemente, existe una indefinición en el timbre de la vocal inicial (Morala, 2012a: 559).

De la veintena de casos documentados de la forma estándar anguarina que aparecen en el CORDE, tan solo hay un caso fechado en el siglo XVII. En el caso de enguarina, aparecen dos ejemplos, en un mismo documento del siglo XVIII.

En el CorLexIn se localizan las diferentes variantes de las que hemos hablado: tres casos de anguarina documentados en Sevilla y Guadalajara -este último ya en el siglo XVIII -, un caso de enguarina en Málaga en 1699 y siete de ongarina. El resultado ungarina aparece al otro lado del Atlántico, en Potosí. En cuanto al significado de la palabra, no parece que haga referencia a una prenda tosca utilizada por labriegos, como nos dicen los diccionarios académicos; al menos en esta zona, ya que en los documentos analizados nos encontramos con una prenda confeccionada con telas ricas como el raso, tela de oro, tafetán, guarnecida con encajes negros. Lo mismo que ocurre si consultamos los ejemplos de esta prenda hallados en el CorLexIn, en los que la anguarina es de raso bordado con plata o de tafetán doble.

En el Atlas Lingüístico de Castilla y León (ALCyL; Alvar,1999) esta palabra se halla en casi todas las provincias que conforman la comunidad autónoma de Castilla y León, con la vacilación de la vocal átona inicial ( $A L C y L$, mapa 724). Le Men localiza esta voz con sus variantes en todas las comarcas leonesas (Le Men, 2002, s. v. anguarina).

\section{BALANDRÁN [malandrán]}

Sust. m. 'Vestidura talar ancha y con esclavina, que usaban algunos eclesiásticos' o 'abrigo largo y ancho' (DLE). Autoridades lo define como 'vestidúra talár ancha, que no se ciñe, y por la parte que cubre los hombros penden de ella unas como mangas perdidas largas. Hácese de paño, ú otro género de lana, y usan de ella los Colegiales y Eclesiásticos dentro de casa, para su abrigo y comodidad [...]' (NTLLE, s. v. balandrán, Autoridades, 1726). Término derivado del oc. balandran, -au, 'capote largo usado por curas y pastores' (DECH, s. v. balandrán).

Un malandrán berdosso vueno (Cea, LE-1621)

Un malandrán viexo roto (Frechilla, PA-1631)

Este término se documenta en el $C D H$ en el siglo XV en obras literarias haciendo referencia a un tipo de indumentaria con la forma normativa balandrán. Ni en este corpus, ni en el CORDE encontramos la forma malandrán que aparece en los documentos objeto de estudio. 
Hallamos un uso exiguo de esta palabra en el CorLexIn, donde localizamos un caso de la forma académica en el Burgo de Osma (Soria). En el ejemplo encontrado se inventaría como una prenda de vestir; lo que no queda tan claro es que haga referencia a un tipo de indumentaria eclesiástica como en la primera acepción del DLE.

En la Tierra de Campos la forma que aparece en los documentos es malandrán, por confusión entre las bilabiales $/ \mathrm{b}-/ \mathrm{y} / \mathrm{m}-/$. Puede que este sea un rasgo que proceda de la lengua oral. Y por el contexto en que se encuentra -entre gorgueras, sayuelos, fajaderos...-, no podemos decir que haga referencia a una vestimenta de tipo talar exclusivamente en esta época. En zonas del leonés aparece la forma malandrán con varias acepciones, entre las que se encuentra 'guardapolvos para servicios sucios, ordeñar, etc' (Le Men, 2002, s. v. balandrán).

\section{CAPA}

Sust. f. 'Prenda de vestir larga y suelta, sin mangas, abierta por delante, que se lleva sobre los hombros encima del vestido' (DLE). Aparece desde Nebrija 'vestidura común'. Covarrubias la define como 'la vestidura que se pone sobre todas las demás' (NTLLE, s. v. capa, Nebrija, 1495; Covarrubias, 1611). Término procedente del lat. tardío CAPPA 'capucho' (DECH, s. v. capa).

Una capa de contray con su pasamanillo negro (Sahagún, LE-1600)

Una capa de Londres en casa de Juan (Sahagún, LE-1601)

Una capa biexa de pardo remendada tasada en quatro reales (Sahagún, LE-1605)

Una capa de pardillo buena (Sahagún, LE-1608)

Una capa de picote buena (Villadiego, LE-1627)

Una capa parda bieja (Frechilla, PA-1638)

Una capa colorada con ribete amarillo (Frechilla, PA-1639)

Una capa parda de paño (Frechilla, PA-1640)

Huna capa de paño de Frechilla trayda (Autillo de Campos, PA-1649)

Una capa de paño pardo con riço (Villalón, VA-1638)

Una capa de bayeta de Sebilla en cinquenta reales (Medina de Rioseco, VA-1643)

Una capa de paño arenosso usado (Medina de Rioseco, VA-1657)

Una capa de estameña buena y otra capa de paño usada (Cuenca de Campos, VA-1660)

Una capa bieja negra de paño (Villalpando, ZA-1620)

Una capa de pastor ya mediada (Villalpando, ZA-1632)

Otra capa de cordellate bieja (Villalpando, ZA-1661)

Una capa de paño de Somonte (Villalpando, ZA-1690)

Es una palabra frecuente en el corpus analizado, ya que forma parte de la indumentaria masculina en esta época. Se documenta desde el siglo XII en corpus léxicos como el $C D H$. Localizada en el CorLexIn, sobre todo en la mitad norte de la Península, donde las prendas de abrigo tienen mayor presencia en los inventarios. En la Tierra de Campos observamos que la capa forma parte del atuendo diario de los hombres.

\section{CAPOTE}

Sust. $\mathrm{m}$. 'Capa de abrigo hecha con mangas y con menor vuelo que la capa común' (DLE). Aparece en Nebrija como 'vestido rústico'. Covarrubias indica que es similar a la capa y Autoridades explicita que 'solo se diferencia en la manera del cuello, que por lo común es redondo' (NTLLE, 
s. v. capote, Nebrija, 1495; Covarrubias, 1611; Autoridades 1729). Término derivado de capa, procedente del lat. tardío CAPPA 'capucho' (DECH, s. v. capa).

\author{
Un capote de pardo usado tasado en tres ducados (Sahagún, LE-1605) \\ Un capote de pardo dado y una mantilla de lana nueba (Valdavida, LE-1606) \\ Un capote pardo husado (Santa María del Río, LE-1607) \\ Un capote de pardillo nuevo (Riosequillo, LE-1610) \\ Un capote de pardo nuebo (Galleguillos, LE-1618) \\ Un capote nuebo de pardillo (Villadiego, LE-1627) \\ Un capote traydo de paño pardo (Castromocho, PA-1603) \\ Un capote fraylego biexo y roto en diez reales (Frechilla, PA-1615) \\ Un capote biexo de barragán açulado (Paredes de Nava, PA-1689) \\ Un capote de varragán aforrado de vaieta de Palençia (Boadilla de Rioseco, PA-1692) \\ Un capote cerrado de xerguilla sin guarniçion (Medina de Rioseco, VA-1642) \\ Un capote de grana colorada forrado en lama de flores campo verde (Medina de Rioseco, VA-1642) \\ Un capote cerrado de jerguilla sin guarnizion (Medina de Rioseco, VA-1642) \\ Un capote en seis reales (Cuenca de Campos, VA-1668) \\ Un capote de varragán con su forro de vaeta de la sierra (Villalpando, ZA-1686) \\ Un capote de barragán nuebo (Cotanes del Monte, ZA-1687)
}

Es voz de uso frecuente en el siglo XVII. Este término está ampliamente documentado en el CORDE a lo largo de todo el siglo. En el CorLexIn aparecen ejemplos de este vocablo sobre todo en la zona norte y centro de la Península, así como en América. Cuando en los textos se anota "capote de pardo", cabe la posibilidad de que se esté haciendo alusión a la 'capa de pastores'; y en aquellos ejemplos en los que se hace referencia a otro tipo de telas más finas, el significado probablemente sería el que ofrece el DLE (Gómez Ferrero, 2015: 59). Actualmente, en la zona noroccidental de León y de Zamora esta palabra tiene la acepción de 'capa de los pastores' (Le Men, 2004, s. v. capote).

\title{
CAPOTILLO
}

Sust. m. 'Prenda a manera de capote o capa que llegaba hasta la cintura' (DLE). Derivado de capote, y este a su vez de capa, procedente del lat. tardío CAPPA 'capucho'. (DECH s. v. capa).

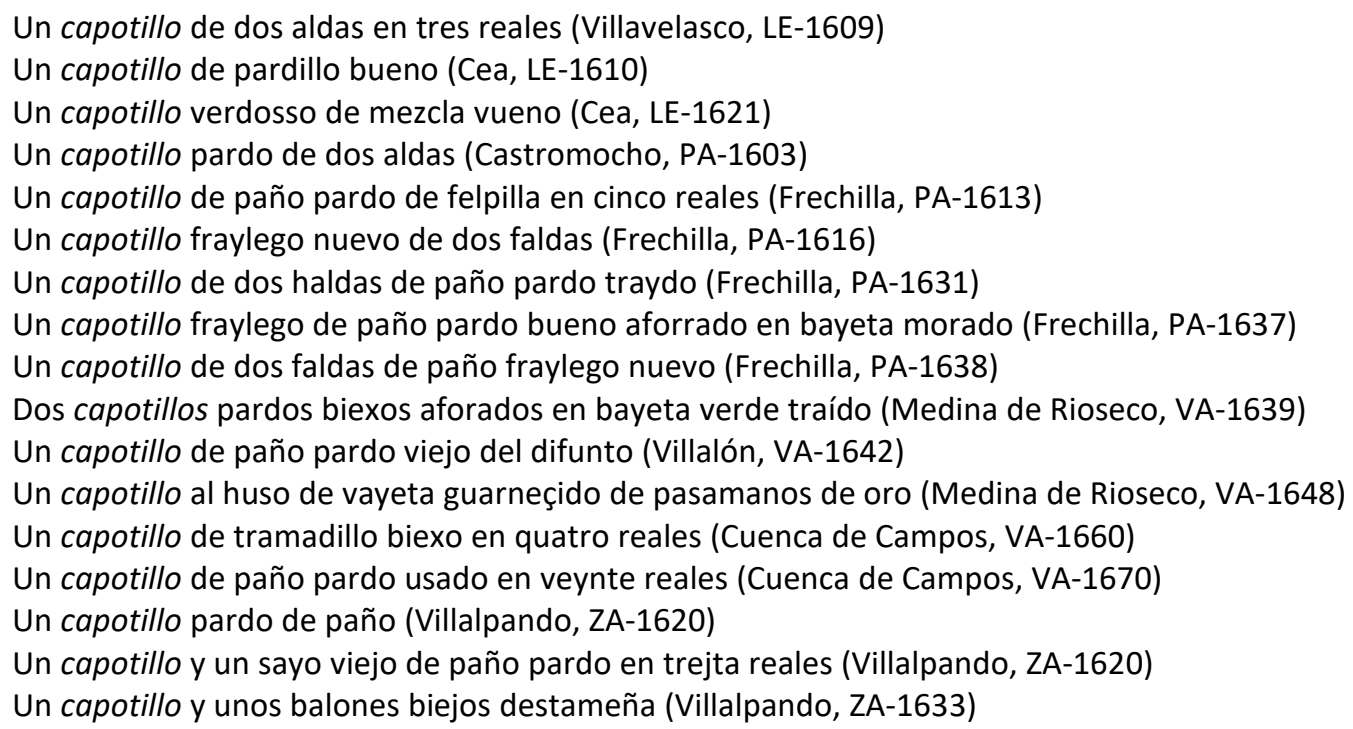


Está presente en toda la zona de estudio. Se documenta en el CORDE desde el siglo XVI y parece que su uso se intensifica en el siglo XVII. En el CorLexIn esta palabra con la acepción académica aparece documentada en la Península sin seguir un patrón de reparto claro. Además, se localizan ocurrencias también en textos de Canarias y América.

En Tierra de Campos se localiza la expresión "capotillo de dos haldas o faldas". Esta expresión es recogida desde Autoridades y la define como 'casaquilla hueca abierta por los costados hasta abaxo, de forma que viene á quedar como en dos mitades, por estar cerrada por delante, con su abertúra para meterla por la cabéza' (NTLLE, s. v. capotillo, Autoridades, 1729). EI CORDE documenta a principios de siglo "capotillo con haldas" en el inventario de los bienes que pertenecieron a Felipe II, y también en obras de corte literario hasta el siglo XVIII:

Un capotillo de dos haldas, de gorguerán, guarnecido con dos soguillas de raso y pasamanos encima, forrado en tafetán (1600, Inventarios Reales. Bienes muebles que pertenecieron a Felipe II)

Sin embargo, el CorLexIn recoge "capotillo de haldas o faldas" tan solo en inventarios de Cantabria. Aunque sabemos que la localización de este sintagma es más amplia en esta época, Perdiguero señala "un capotillo de dos aldillas y un ferreruelo" en inventario de moriscos procedentes del Reino de Granada (Perdiguero, 2012a: 339).

\section{CASACA [cassaca]}

Sust. f. 'Vestidura ceñida al cuerpo, generalmente de uniforme, con mangas que llegan hasta la muñeca, y con faldones hasta las corvas' (DLE). Aparece en Covarruvias como 'vn genero de ropilla abierta por los lados [...]' (NTLLE, s. v. casaca, Covarrubias, 1611). Se trata de una palabra procente del fr. casaque, de origen incierto (DECH, s. v. casaca).

Una cassaca y unos calzones de paño frailego (Frechilla, PA-1671)

Una cassaca de bayeta negra echo para muxer en ocho reales (Frechilla, PA-1671)

Una cassaca de bayeta de cienfilos aforrada en bayeta negro (Frechilla, PA-1671)

Una cassaca de paño pardo y unos valones (Frechilla, PA-1671)

Este término se documenta a lo largo de todo el siglo XVII en el CORDE y en el CDH con numerosos ejemplos. En Tierra de Campos encontramos cuatro ejemplos ubicados en la localidad palentina de Frechilla, que, como hemos señalado anteriormente, es uno de los centros de producción textil en esta época. En el CorLexIn se documenta en la zona meridional de la Península preferentemente -no obstante, se localizan ejemplos en Zamora y Zaragoza-, así como en algunos países de América (Bolivia y Chile). La mayoría de los ejemplos que aparecen tanto en el corpus estudiado como en el CorLexIn se fechan a finales de siglo, a excepción de los de Zaragoza, que adelanta la fecha poco antes de mediados de siglo. Gómez Ferrero (2015:63) nos indica que aparecen ejemplos de este término en el siglo XVIII en la zona de La Bañeza.

\section{COLETO}

Sust. m. 'Vestidura hecha de piel, por lo común de ante, con mangas o sin ellas, que cubre el cuerpo, ciñéndolo hasta la cintura' (DLE). Aparece en Autoridades como 'vestidura como casaca ó jubón, que se hace de piel de ante, búfalo ú de otro cuero' (NTLLE, s. v. coleto, Autoridades, 
1729). Procedente del it. antic. colleto 'vestidura de cuero que cubría pecho y espalda y se llevaba bajo la coraza', derivado de collo 'cuello' (DECH, s. v. coleto).

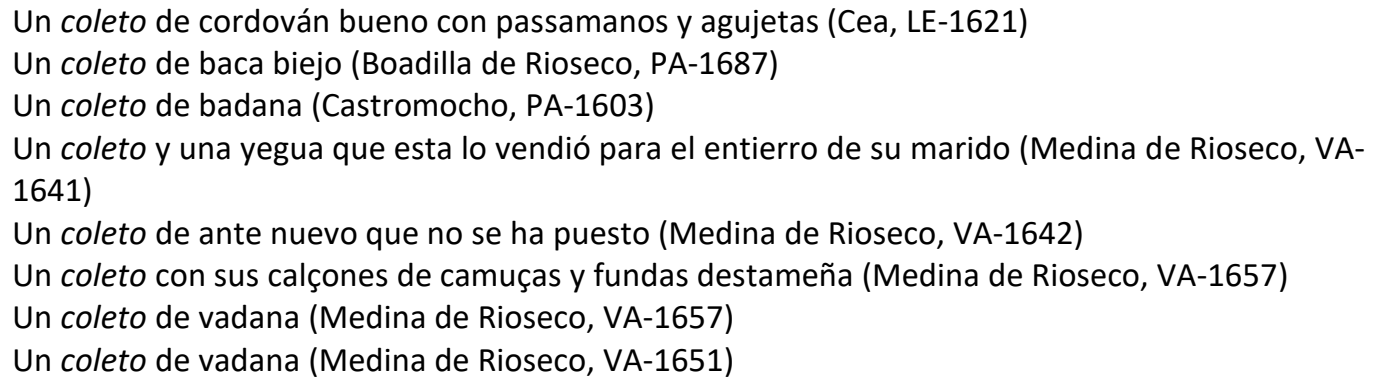

Se trata de una palabra de uso general en la época, documentada en el siglo xvi en el CORDE. Este término pasó al español como tantos términos militares del siglo XVI desde el italiano (DECH, s. v. coleto). Pronto pasaría a designar una prenda de uso cotidiano. En el CorLexIn aparece en toda la Península y también en América.

\section{ESTUFILLA [estofilla]}

Sust. f. 'Manguito pequeño hecho de pieles finas, para llevar abrigadas las manos en el invierno', 'brasero de mano' (DLE, 1. y 3. a ac.). Aparece desde Autoridades con estas mismas acepciones; en el caso de la segunda, aparece como 'un género de braserillo, à manéra de un caxoncito con su tapa agujereada, hecha de hoja de lata, de que usan las mugéres para calentarse, el qual se pone debaxo de las faldas' (NTLLE, s. v. estufilla, Autoridades, 1732). Término derivado de estufa (DECH. s. v. estufa).

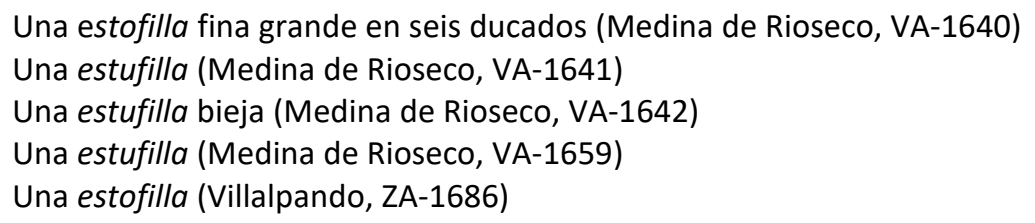

En el $C D H$ se documenta en 1604 como 'complemento de ropa para abrigar las manos'. A lo largo del siglo XVII aparece también como 'brasero pequeño'; a partir de dicho siglo, este término comienza a desaparecer de los textos. En los archivos del CorLexIn se localizan media docena de ejemplos repartidos entre Madrid y el País Vasco, manteniendo las dos acepciones que figuran en Autoridades. El corpus de la Tierra de Campos documenta unos cuantos ejemplos en las zonas de Palencia y Valladolid. Además, aparece la forma estofilla con el cambio de timbre de la vocal átona provocado por la vocal tónica /i/ (Morala, 2012a 557). En cuanto a las acepciones que la palabra presenta en esta zona, el escribano no da muchas pistas sobre lo que puede referenciar esta voz; a través de los contextos podemos decantarnos por 'prenda de vestir' cuando lo encontramos entre jubones, guardapiés, medias..., en todos los casos menos el fechado en Medina de Rioseco en 1659, donde esta voz se encuentra entre los elementos que componen la cama, y podría hacer referencia a un pequeño brasero que sirviera para calentarse. 


\section{GABÁN}

Sust. m. 'Abrigo', 'capote con mangas, y a veces con capilla, que se hacía por lo regular de paño fuerte' ( $D L E, 1$. y 2. a ac.). En Autoridades se define como 'cierto género de capote con capilla y mangas, hecho de paño gruesso y basto, de que usa ordinariamente la gente del campo para defenderse de las inclemencias del tiempo' (NTLLE, s. v. gabán, Autoridades, 1734). En el DRAE de 1852 ya no se describe como una prenda que utilicen los hombres del campo. Probablemente del ár. qabẩ 'sobretodo de hombre' ( $D E C H$, s. v. gabán).

Un gabán de pardo de Antonio de Bacea (Castromocho, PA-1611)

Este término aparece documentado en el CORDE desde el siglo XVI y su uso es generalizado en el siglo XVII. Este hecho contrasta con lo que ocurre en el CorLexIn, donde apenas aparece media docena de ocurrencias repartidas principalmente por el norte peninsular -Cantabria, Álava, Guipúzcoa-, aunque también hay algún caso en Toledo y en textos de América -Bolivia-. Esta falta de testimonios se extiende también a nuestra zona de estudio, donde tan solo encontramos un ejemplo. Por el contexto en el que se encuentra dentro del inventario, podemos decir que la acepción corresponde a la que aparece en el DLE.

\section{GABARDINA [gauardina]}

Sust. f. 'ropón con mangas ajustadas, usado por los labradores en algunas comarcas' (DLE, 4. a ac.). Es un término que aparece en los diccionarios de la academia desde Autoridades y lo equiparan a casaca y gabán. (NTLLE, s. v. gabardina, Autoridades, 1734). Se trata del resultado del cruce de gabán con tabardina, diminutivo del sinónimo tabardo (DECH, s. v. gabardina).

Una gabardina husada destameña (Santa María del Río, LE-1617)

Una gabardina fraylega y jubón biejo (Frechilla, PA-1636)

Vna gauardina de grana aforrada en espolín de seda blanco y encarnado guarnizido de medio galón de ojuela (Medina de Rioseco, VA-1642)

Vna gabardina de herbaje acaballado y blanco y broches de plata aforrado en tafetán carne de doncella en treynta reales (Medina de Rioseco, VA-1661)

Vna gabardina y unos calzones de paño traydo en beynte reales (Medina de Rioseco, VA-1661)

En el CORDE aparece documentada desde el siglo XV, en el siglo XVII tan solo aparecen dos casos que se localizan en una Carta de dote y arras de 1664. Entre los documentos consultados se atestiguan cinco casos de gabardina, casi todos ubicados en Valladolid. La acepción con la que aparecen en los protocolos no parece coincidir con la que utilizamos hoy en día. Si observamos los ejemplos de Medina de Rioseco, hay dos casos en los que gabardina tampoco parece coincidir con la acepción de los primeros diccionarios académicos, ya que las descripciones presentan telas y adornos poco propicios para el trabajo en el campo.

\section{GUARDAPOLVO}

Sust. m. 'Protección de tela, tablas u otra materia, que se pone encima de algo para preservarlo del polvo', 'sobretodo de tela ligera para preservar el traje de polvo y manchas', 'pieza de vaqueta o becerrillo, que está unida al botín de montar y cae sobre el empeine del pie' (DLE, 1.a , 2. a y 4. a ac.). La segunda acepción no la introduce la Academia hasta su edición de 1925: 
'sobretodo de tela ligera para preservar el traje de polvo y manchas, especialmente en los viajes' (NTLLE, s. v. guardapolvo, DRAE, 1925). Término compuesto de guardar, del germánico wardôn y polvo del lat. vulgar *PǓLVUS, clásico PULVIS, PULVĔRIS (DECH, s. v. guardar y polvo).

Un guardapoluo de camino viejo de bocazí (Villalpando, ZA-1633)

Encontramos un solo caso de este término en los documentos consultados. Por lo general, guardapolvos en el siglo XVII hacía referencia al trozo de lienzo que servía para cubrir los objetos y evitar así que se ensuciasen. Aparece escasamente documentado en el CORDE en esta época y la acepción que presenta coincide con la primera que da la Academia. Quizá porque se trataba de una prenda cuyo uso se generalizó en el siglo XIX y, por tanto, en fechas anteriores no era de uso común. En el CORDE la mayoría de los ejemplos pertenecen a los siglos XIX y XX. En el CorLexIn aparecen dos ocurrencias en la Península localizadas en Plasencia (Cáceres) y Vicuña (Álava) con la acepción de 'paño o tela que se utiliza para cubrir y proteger', función que queda clara en el ejemplo de Álava: "Dos baras y media de bocaçín, encarnado la mitad dello, y la otra mitad colorado, para guardapolvo de los cordones de las almáticas la mitad dello, y la otra mitad para poner a raíz de la pared para la defensa de la humedad". Se localizan otros dos ejemplos en un documento de Colombia, donde guadapolovo se referencia junto a una saya y una mantellina, que tal vez se refieran al segundo significado que da el DLE para esta palabra, con la función parecida de proteger -"vna salla colorada, de granilla, con tres galones de oro falso y guardapolbo de olandilla asul, ya traída"-. El corpus de la zona de estudio nos da información que nos hace pensar que no se trata del lienzo para preservar los objetos de la suciedad, sino que advierte que es "de camino", y además se encuentra entre objetos que tienen que ver más con las caballerías y los enseres de viajes (maletas, angarillas...), por lo que podría tratarse de una prenda para preservar del polvo del camino. Además, está confeccionada con un tipo de tela que solía usarse como forro de sayas, sayuelos o mantos.

\section{MONTERA}

Sust. f. 'Prenda para abrigo de la cabeza, que generalmente se hace de paño y tiene varias hechuras, según el uso de cada provincia' (DLE). Es un término que en un primer momento surge de las coberturas que utilizaban los hombres cuando iban de cacería, pero que luego se traslada a un uso generalizado de dicha prenda (NTLLE, s. v. montera, Covarrubias, 1611). Se trata de una voz derivada de monte (DECH, s. v. monte).

Una montera de yerbas (Paredes de Nava, PA-1689)

Una montera de escarlatín (Paredes de Nava, PA-1689)

Una montera de paño frailego aforrada tassada en treinta y seis reales (Fechilla PA-1675)

Una montera colorada (Medina de Rioseco, VA-1642)

Una montera de paño bieja (Medina de Rioseco, VA-1643)

Dos monteras (Medina de Rioseco, VA-1660)

Una montera de senpiterna encarnada aforrada en tafetán verde y guarnezida con puntas negras (Medina de Rioseco, VA-1661)

Una montera de senpiterna encarnada (Medina de Rioseco, VA-1661)

Una montera (Villalpando, ZA-1670)

Una montera de paño de hombre (Villalpando, ZA-1689)

Una montera de paño de Somonte (Villalpando, ZA-1690) 
Es un término localizado en toda la Tierra de Campos excepto la zona leonesa, quizá por coincidencia, ya que su uso está generalizado siglo XVII, si vemos la abundante documentación que muestran el CORDE, CDH y el CorLexIn.

\section{PELLIZA}

Sust. f. 'Prenda de abrigo hecha o forrada de pieles finas', 'chaqueta de abrigo con el cuello y las bocamangas reforzadas de otra tela' ( $D L E, 1$. a y 2. a ac.). Este término lo recoge por primera vez el DRAE de 1803 como 'especie de vestido hecho ó forrado de pieles' (NTLLE, s. v. pelliza, DRAE 1803). Término derivado de piel, del adjetivo latino PELLICEUS, -A, -UM 'hecho de piel' (DECH, s. v. piel).

Una pelliza de lienzo delgado nueba (Villalpando, ZA-1620)

Es el único ejemplo encontrado en el corpus de la zona de estudio. En el CORDE y en el CDH aparece en varias ocasiones en un mismo documento, el testamento de Calderón de la Barca, fechado en 1681. En dicho documento aparecen dos acepciones de dicha palabra; por un lado, la que da el DRAE, "una pelliza de pielles"; pero por otro, el contexto en el que aparece nos hace pensar que pelliza tiene más que ver con ropa de cama: "[...] rodapiés, pelliza, doselillo de cabecera, toalla listada [...]". En este caso parece coincidir con esta acepción, al aparecer junto a la cama. En el CorLexIn no encontramos datos sobre esta voz.

\section{ROQUETE}

Sust. m. 'Especie de sobrepelliz cerrada y con mangas' (DLE). Covarrubias lo define como la 'vestidura de Olanda, ò otra tela delgada de que los Obispos, y Prelados vsan sobre la sotana, debaxo del mantelete' (NTLLE, s. v. roqvete, Covarrubias, 1611). Término procedente del cat. u occitano roquet 'sobrepelliz', diminutivo de roc, también nombre de vestido. Este se tomó del fráncico *rok 'chaqueta' (DECH, s. v. roquete).

Un roquete de estameña açul (Frechilla, PA-1639)

Un roquete de lienço con mangas de ruán bueno (Frechilla, PA-1638)

Un roquete de ruán mediado de mujer (Frechilla, PA-1637)

Aparece documentado en el CORDE como vestimenta eclesiástica y también como 'Hierro de la lanza de torneo' (DLE s. v. roquete ${ }^{2}$ ). El CDH documenta este término a partir del siglo xv. Esta voz poco frecuente en los inventarios del siglo XVII. En el CorLexIn se localizan en Granada dos ejemplos que hacen referencia al vestido religioso, al igual que el localizado en Panticosa (Huesca). Sin embargo, los ejemplos localizados en Burgos parecen tener una acepción más bien referida a prenda de vestir. En el corpus estudiado aparecen tres ejemplos en Frechilla (Palencia), pero no parecen hacer referencia a vestimenta eclesiástica, ya que en uno de los casos se especifica que este tipo de prenda es de mujer. 


\section{SOBRETODO}

Sust. $m$. 'Prenda de vestir ancha, larga y con mangas, en general más ligera que el gabán, que se lleva sobre el traje ordinario' (DLE). Autoridades lo define como 'ropa ancha, y larga, como hasta media pierna, que generalmente se hace de barragan, abierta por delante, con sus mangas anchas, y sirve para abrigo, y defensa de las aguas' (NTLLE, s. v. sobretodo, Autoridades, 1739). Palabra compuesta por todo, del lat. TŌTUs 'todo entero' y la preposición sobre ( $D E C H$, s. v. todo)

Capa y sobretodo y justacón y dos pares de calzones de lo mismo usados (Villalpando, ZA-1698)

Tan solo contamos con un ejemplo en el corpus que manejamos. La primera documentación que encontramos en el CORDE haciendo referencia a la prenda de vestir es del siglo XVIII; más concretamente, en una poesía de Tomás de Iriarte en la que lo equipara a sayo. Pero es en el siglo XIX donde se encuentran más ejemplos, tanto en España como en América, donde todavía hoy se utiliza como sinónimo de abrigo.

En el CorLexIn aparece documentado este término en Córdoba, Tenerife y La Rioja, en documentos de finales del siglo XVII, como en nuestro caso. Parece que estamos ante una palabra de nueva adquisición.

\section{ZAMARRO}

Sust. m. 'Zamarra', 'prenda de vestir, rústica, hecha de piel con su lana o pelo' (DLE). En Autoridades se define como 'el vestido de pieles de cordero, que tienen el pelo suave, y corto, de que usan los regadores, y delicados para defensa del frío. Covarrubias lo distingue en esto del vestido, que llaman zamarra, aunque regularmente se usan con igual significación' (NTLLE, s. v. zamarro, Autoridades, 1739). Derivado de zamarra, del vasco zamar 'vellón del ganado lanar', el zamarro sería 'piel empleada para abrigo' ( $D E C H$, s. v. zamarra).

Un zamarro demediado en doce reales (Sahagún, LE-1601)

Un zamarro en dos ducados (Sahagún, LE-1600)

Un zamarro viexo en ocho reales (Sahagún, LE-1600)

Un zamarro biejo (Sahagún, LE-1603)

Es una palabra que se documenta en la zona leonesa de la Tierra de Campos. En el CDH este término aparece documentado a partir de finales del siglo $\mathrm{xv}$, en concreto en las Cuentas de Gonzalo Baeza, tesorero de Isabel la Católica de 1477. A partir de esta fecha se recoge como un tipo de prenda de vestir, que podía ser llevada por hombres, mujeres y niños. En el siglo XVII comienza a aparecer en la documentación de América. A partir de este siglo, los ejemplos empiezan a ser más esporádicos, hasta el punto de casi desaparecer. Sin embargo, sigue presente en textos americanos ( $C D H$, s. v. zamarro). Esto contrasta con lo que ocurre con los inventarios de bienes del siglo XVII, donde apenas hay ejemplos y los que se documentan están muy localizados en la zona de estudio (CorLexIn). Las ocurrencias recogidas en Tierra de Campos no dan mucha información, salvo el estado en el que se encuentra la prenda.

Gordaliza recoge la forma zamarra para referirse a 'chaqueta de piel de oveja usada por los pastores. Se llama también zalea. Tenía un solo agujero para la cabeza y llevaba la lana por dentro' (Gordaliza, 1988: 232). 


\subsubsection{Prendas de cintura para arriba}

\section{ALMILLA [almillica]}

Sust. f. 'Especie de jubón, con mangas o sin ellas, ajustado al cuerpo', 'Jubón cerrado, escotado y con solo medias mangas, que no llegaban al codo. Se ponía debajo de la armadura' (DLE, 1. y y 2.a ac.). Aparece en Covarrubias donde la describe como 'cierta vestidura militar corta, y cerrada, por todas partes escotada, y con solas medias mangas, que no llegan al codo'. Autoridades por su parte define esta voz como 'una espécie de jubón con mangas ajustado al cuerpo. Es trage interior, assi del uso de los hombres, como de las mugeres, y de ordinario se pone y viste en tiempo de Invierno, para reparo y defensa del frio' (NTLLE, s. v. almilla, Covarrubias, 1611; Autoridades, 1726). Forma derivada de alma, del lat. ANIMA (DECH, s. v. alma).

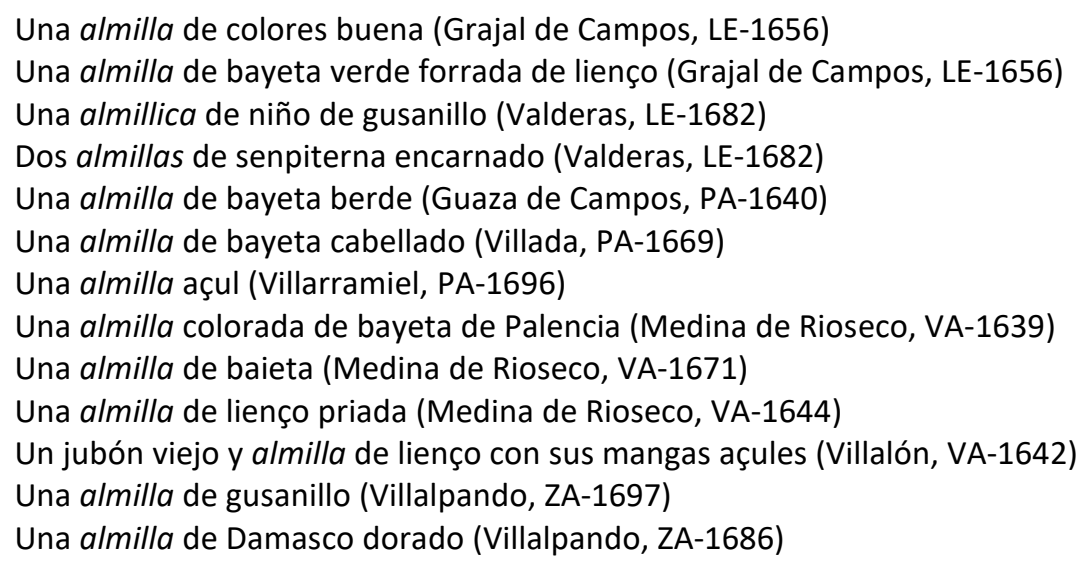

Es una palabra que aparece de forma habitual en los inventarios de la Tierra de Campos, así como en los textos del $C D H$, donde se documenta a partir del siglo xv con la misma acepción que aparece en del DLE. En la zona analizada no encontramos más variantes que el diminutivo almillica, que especifica que se trata de una prenda infantil. No es extraño encontrar en zonas próximas a la de estudio la variante armilla, que Corominas y Pascual ubican en León (DECH, s. v. almilla) y que Gómez Ferrero (2015: 62) localiza en La Bañeza en siglos posteriores. No obstante, esta variable no es exclusiva de la zona leonesa, sino que en el CorLexIn podemos observar que la variante armilla con la acepción de prenda de vestir aparece en textos de Vizcaya, Córdoba, Granada o Sevilla. En la zona de la Tierra de Campos, almilla se presenta siempre como prenda de vestir; sin embargo, Pérez Toral (2017a: 197) localiza varios documentos en Guadalajara, Cádiz y Huelva, donde este término designa un tipo de tejido, aunque por la escasez de los datos, no es posible dilucidar qué tipo de tejido es.

\section{ARMADOR}

Sust. m. 'Jubón' ( $D L E, 4$. a ac.). La primera definición lexicográfica se halla en Autoridades como 'cierta especie de jubón que se solía hacer de ante, y aforrar o cubrir por encima con tela, ó seda por gala. Parece se pudo decir porque armaba bien al talle, ó porque asentaban bien sobre él las armas, ó porque en algún momento era defensa del cuerpo' (Autoridades, 1726). Palabra derivada de armar, del lat. ARMA (DECH, s. v. arma). 
Un armador de olanda (Medina de Rioseco, VA-1642)

Dos armadores de olanda acuchillados (Medina de Rioseco, VA-1642)

Tan solo hemos encontrado dos ocurrencias en sendos inventarios de la localidad vallisoletana de Medina de Rioseco que parecen coincidir con la acepción de la Academia. En el CORDE es raro encontrar esta acepción en el siglo XVII, y los escasos ejemplos que aparecen remiten a América (Morala, 2015a: 1506). Esta situación se repite en la documentación del CorLexIn, donde la mayoría de los ejemplos que encontramos corresponden a Andalucía o al territorio americano. Parece que el uso de esta palabra fue mayor en épocas posteriores, pues la frecuencia de la misma se ve reflejada en estudios como el realizado en la zona de La Bañeza, donde esta palabra se documenta con mayor éxito en el siglo xIX (Gómez Ferrero, 2015: 63).

El término presenta el sufijo -dor; este tipo de derivados muchas veces presenta una escasa documentación y suele aparecer en zonas muy concretas, pues se trata de voces a las que apuntó la lengua pero que no siempre llegaron a consolidarse (Morala, 2015a: 1506).

\section{COTA}

Sust. f. 'Arma defensiva del cuerpo usada antiguamente, que en un principio era de cuero y guarnecida de cabezas de clavos o anillos de hierro, y más tarde, de mallas de hierro entrelazadas', 'jubón' (DLE, 1. a , 5. a ac.). Nebrija registra cota de malla en su Vocabulario. Por su parte, Covarrubias Ilama cota a 'vna cierta armadura del cuerpo, que resiste a los golpes, y punta de espada'. Autoridades añade que 'se halla también tomado por lo mismo que jubón. Es voz antiquada' (NTLLE, s. v. cota, Nebrija, 1495, Covarrubias, 1611, Autoridades, 1729). En el DECH: Cota ant. 'jubón, esp. el de cuero o de mallas llevado como arma defensiva', del fr. ant. cote íd., y éste del fráncico *kotta 'paño basto de lana' (alem. kotze, kutte) (DECH, s. v. cota I).

Una cota de malla en ocho reales (Frechilla, PA-1671)

Una cota de estameña nueba con prespunte de ylo amarillo (Villarramiel, PA-1694)

Unas enaguas con su cota de cotonia para niño (Medina de Rioseco, VA-1642)

Una cota de malla y un casco de yerro viexo (Medina de Rioseco, VA-1644)

A pesar de ser un término poco documentado, nos encontramos con dos acepciones de las que recoge el $D L E$. Por un lado, parece que se trata de una prenda de vestir que, por su descripción, podemos comparar al jubón y, por el otro, tenemos la cota de malla, término un poco arcaico dada la época de este estudio. Ambas acepciones se documentan en el siglo xV $(C D H)$. También se puede observar en el CorLexIn que los ejemplos, en gran medida, se refieren a cota de malla.

\section{CUERPOS [querpos]}

Sust. m. 'Parte del vestido, que cubre desde el cuello o los hombros hasta la cintura' (DLE, 5a ac.). 'Se llama con particularidad la parte del hombre, que comieza desde la horcaxadúra: y assi se dice le ciñeron por el cuerpo, le atravesaron el cuerpo: y en el vestido comúnmente para diferenciarlo de las mangas, calzones y otras piezas, se llama cuerpo el que cubre esta parte' (NTLLE, s. v. cuerpo, Autoridades, 1729). Término procedente del lat. CŏRPUS, -ǑRIS (DECH, s. v. cuerpo). 
Otros cuerpos colorados buenos (Celada, LE-1600)

Una saya azul con cuerpos colorados y husado (Santa María del Río, LE-1607)

Un brial verde con ruedo amarillo con sus cuerpos nueuos (Castroañe, LE-1609)

Unos cuerpos de terciopelo con guarnición de lo mismo (Grajal de Campos, LE-1656)

Dos pares de cuerpos, unos açules y otros verdes de paño (Castromocho, PA-1602)

Unos cuerpos de grana traídos guarnecidos de terciopelo negro (Frechilla, PA-1612)

Unos cuerpos de grana con guarnición de terciopelo colorado (Frechilla, PA-1642)

Unos querpos de gorguerán con pasamanos de Santa Ysabel (Autillo de Campos, PA-1653)

Unos cuerpos de gorguerán de color (Villalón, VA-1637)

Unos cuerpos de estameña en doze reales (Medina de Rioseco, VA-1643)

Unos cuerpos de gorquerán en dos ducados (Medina de Rioseco, VA-1643)

Unos cuerpos de paño (Medina de Rioseco, VA-1651)

Unos cuerpos de damasquillo (Tamariz de Campos, VA-1651)

Unos cuerpos de grana colorada catorze reales (Villalpando, ZA-1600)

Dos pares de cuerpos viejos, unos berdes y otros de paño (Villalpando, ZA-1620)

Unos cuerpos de gorgarán nuebos con su guarnición (Villalpando, ZA-1645)

Unos querpos de chillón en treinta reales (Carrizo, ZA-1646)

Dos pares de cuerpos de senpiterna encarnada con sus guarniziones (Villalpando, ZA-1685)

Es un término de uso general en toda la Península en el siglo XVII, como nos indican el CORDE y el CorlexIn. Lo mismo ocurre con la Tierra de Campos; aparece en toda su extensión, siempre en plural, y por pares cuando se trata de más de uno. Egido afirma que parece poco probable que cuerpos designara más de una prenda, ya que es poco habitual tener varias prendas con las mismas características; por ello, este plural sería un resto de la forma del neutro latino de la tercera declinación CORPUS, o bien se trata de una palabra procedente del francés corps (Egido, 2010).

\section{FERRERUELO [herreruelo]}

Sust. m. 'Capa corta con cuello y sin capilla' (DLE). Covarrubias recoge este término como 'genero de capa, con solo cuello sin capilla, y algo largo. Tomó el nombre de cierta gente de Alemania, que llaman Herreruelos, porque fueron los primeros que vsaron dellos' (NTLLE, s. v. ferrervelo, Covarrubias, 1611). Del antiguo ferrehuelo, y este del ár. vulgar feriyûl 'especie de capa o blusa', el cual procede a su vez del lat. PALLIŎLUM 'manto pequeño', diminutivo de PALLIUM 'manto, toga' (DECH, s. v. ferreruelo).

Un ferreruelo negro dado a tres ducados (Sahagún, 1600)

Un ferreruelo de contray bueno (Valdavida, LE-1606)

Un ferreruelo negro de beinteydoseno con riço de piñuela (Grajal de Campos, LE-1655)

Un ferreruelo de paño de contray negro con el rizo de terciopelo (Grajal de Campos, LE-1671)

Un ferreruelo de pardo fino (Castromocho, PA-1602)

Un ferreruelo negro traydo (Guaza de Campos, PA-1637)

Un ferreruelo de paño acanelado traydo (Autillo de Campos, PA-1653)

Un ferreruelo de baeta bueno no vuelta de terciopelo usado (Autillo de Campos, PA-1653)

Un ferreruelo de paño pardo (Villalón, VA-1638)

Un ferreruelo de paño de Cuenca pardo oscuro con cerco de rizo (Medina de Rioseco, VA-1639)

Otro ferreruelo de aguas negro (Medina de Rioseco, VA-1644)

Un ferreruelo de bayeta de Sevilla en dos ducados (Medina de Rioseco, VA-1646)

Un ferreruelo negro sin riço en cinco ducados (Villalpando, ZA-1613)

Un ferreruelo de garrubillas a medio traer (Villalpando, ZA-1620)

Un herreruelo pardo de paño traydo con cuello de fustán (Villalpando, ZA-1620)

Un herreruelo negro biejo de paño (Villalpando, ZA-1620) 
Un herreruelo de pardillo (Villalpando, ZA-1644)

Un herreruelo de paño bueno tasado en seis ducados (Carrizo, ZA-1646)

Voz de uso común en el siglo XVII en toda la Península. Es un término que está ampliamente documentado en el CORDE y en el CorLexIn. En nuestra zona existen dos variantes: ferreruelo para toda el área terracampina y herreruelo, que aparece en Zamora. En la mayoría de los casos se opta por la conservación de la /f-/. En esta época lo habitual era conservar la forma castellana con /h-/, como ocurre en los casos de Zamora; sin embargo, hay determinadas voces que optan por la conservación de la /f-/ latina (Morala, 2009: 13). Esta prenda era muy común en el siglo XVII, y también lo es en los documentos notariales de la época (Perdiguero, 2012a: 335-336).

\section{JAQUETILLA}

Sust. f. 'Chaqueta más corta que la común' (DLE). Este término lo introduce la Academia en 1817, donde remite a jaqueta. Es en el DRAE de 1843 en el que la define como 'chaqueta corta' y advierte de que es un término ya anticuado, aspecto que desaparecerá en la edición de 1884, donde la define como 'jaqueta más corta de lo común' (NTLLE, s. v. jaquetilla, DRAE 1817 y 1843). Se trata de un derivado de chaqueta tomado del francés jaquette; las voces castellanas jaco y jaqueta son también galicismos, aunque de fecha anterior (DECH, s. v. chaqueta).

Un ferreruelo y una jaquetilla de estameña biejo (Medina de Rioseco, VA-1643)

Encontramos un solo en ejemplo en la documentación objeto de estudio. Es un término que aparece de forma muy aislada también en bases de datos textuales, como ocurre con el CORDE, en el que tan solo encontramos cuatro ejemplos. Algo parecido se aprecia en el CorLexIn, donde los ejemplos se reparten por Guadalajara, Bilbao, Burgos, Cuenca y Zaragoza con las formas de jaqueta o xaqueta. Tampoco hemos encontrado ningún ejemplo en los repertorios dialectales manejados.

\section{JUBÓN [juvón, xubón, gubón]}

Sust. m. 'Vestidura que cubría desde los hombros hasta la cintura, ceñida y ajustada al cuerpo' $(D L E)$. Ya lo recoge Nebrija y Autoridades lo define como 'vestido de medio cuerpo arriba, ceñido y ajustado al cuerpo, con faldillas cortas, que se ataca por lo regular con los calzónes' (NTLLE, s. v. jubón, Nebrija, 1495; Autoridades, 1734). Derivado del antiguo aljuba o juba, que a su vez procede del árabe ŷúbba 'especie de gabán con mangas' (DECH, s. v. jubón).

Un jubón de lienzo sin mangas viejo (Castroañe, LE-1609)

Dos juvones y un sayo de cuerpo demediado (Celada, LE-1624)

Un jubón de hombre de pardo viexo (Sahagún, LE-1626)

Un jubón de paño pardo guarneszido de terciopelo demediado (Arenillas, LE-1636)

Un jubón de veynteydoseno negro (Castromocho, PA-1602)

Un jubón de raso negro bueno apreciado en mil y quinientos marauedís (Frechilla, PA-1612)

Un juuón de paño biejo con mangas destameña vieja (Frechilla, PA-1642)

Una basquiña y un gubón de rasilla (Boadilla de Rioseco, PA-1692)

Un jubón de tirela nuevo (Villalón, VA-1637)

Un xubón biexo de paño con un broche de plata sin cadenilla (Medina de Rioseco, VA-1639)

Un xubón biexo de estameña (Tamariz de Campos, VA-1651)

Un jubón de camuças sin mangas (Medina de Rioseco, VA-1671)

Un jubón de olanda en beynte reales (Villalpando, ZA-1600) 
Un jubón de carmesí de rasso con ribetes de terciopelo (Villalpando, ZA-1639)

Un jubón de estameña parda (Villalpando, ZA-1644)

Un jubón de damasco nuevo con su galón realçado (Villalpando, ZA-1652)

Un jubón de labradora con su garapiña y cuerpos de damasco berde con guarnición de oro (Villalpando, ZA-1670)

Palabra de uso general en la época, ampliamente documentada en bases de datos como el CORDE y el $C D H$. Este hecho se puede extrapolar a lo que ocurre en los inventarios de bienes: el CorLexIn documenta este término en todo el territorio peninsular, insular y americano. Lo mismo ocurre en la comarca de Tierra de Campos, donde aparece este término con la inestabilidad gráfica de la época; así, se localizan alternancias entre "b", "v" o "u" y entre "j" y "x" -esta última pareja, en ocasiones, también se confunde con "g" (Morala y Perdiguero, 2019:188-189)-. Era una prenda que servía tanto para hombres como para mujeres.

\section{JUSTILLO [xustillo]}

Sust. m. 'Prenda interior sin mangas, que se ciñe al cuerpo y no baja de la cintura' (DLE). Autoridades lo define como 'Vestido interior ajustado al cuerpo a modo de jubón, de quien se diferencia en no tener mangas' (NTLLE, s. v. justillo, Autoridades, 1734). Término derivado de justo, del lat. Jūstus 'justo, conforme a derecho' (DECH, s. v. justo).

Un justillo viejo de damasco de nagorrones açul (Grajal de Campos, LE-1658)

Un justillo de raso de flores berde (Paredes de Nava, PA-1689)

Un justillo de raso (Boadilla de Rioseco, PA-1689)

Un justillo de sempiterna azul aforrado con liezo (Paredes de Nava, PA-1689)

Un xustillo de estameña (Villarramiel, PA-1694)

Un xustillo de estameña açul con mangas mediadas (Villarramiel, PA-1696)

Un justillo de tafetán azul doble (Medina de Rioseco, VA-1640)

Un justillo de lienço biejo (Medina de Rioseco, VA-1642)

Un justillo y unas enaguas de raso de flores (Medina de Rioseco, VA-1644)

Un justillo de damasco carmesí guarneçido con ojuela de oro (Medina de Rioseco, VA-1648)

Un justillo de damasco encarnado aforrado en tafetán encarnado (Medina de Rioseco, VA-1660)

Un justillo de tela de plata encarnado (Medina de Rioseco, VA-1685)

Un justillo de senpiterna (Villalpando, ZA-1676)

Esta voz se documenta en el CORDE a finales del siglo XVI. Es un término de uso generalizado en la Península, con la acepción académica por los datos que nos proporciona el CorLexIn. Fuera de la Península, se documenta a finales del siglo XVII algún caso esporádico en América. En la comarca de Tierra de Campos parece que hay preferencia por esta voz en la zona más oriental (Palencia y Valladolid), mientras que en León y Zamora solo se halla un ejemplo. Egido afirma que los jubones, el justillo o los corpiños eran prendas de la indumentaria femenina ajustadas que se llevaban sobre la camisa (Egido, 2018: 1934).

\section{MANTELLINA [mantillina]}

Sust. f. 'Mantilla de la cabeza' (DLE). Covarrubias señala que se trata de un 'diminutivo de manto por ser corta que no cubre aun el medio cuerpo'. En Autoridades, en cambio, se equipara a 'mantilla de muger'. (NTLLE, s. v. mantellina, Covarrubias, 1611; Autoridades, 1734). Término derivado de manto, del lat. tardío MANTUM 'manto corto' (DECH, s. v. manto). 
Una mantillina flor de romero guarneçida en quarenta reales (Grajal de Campos, LE-1658)

Otra mantillina de bayeta blanca guarneçida (Grajal de Campos, LE-1658)

Otra mantellina de damasco berde aforrada con bitán dorado (Villalpando, ZA-1685)

Una mantillina nueba de bayeta blanca (Villalpando, ZA-1676)

El CORDE documenta esta palabra a lo largo de todo el siglo XVII. Tan solo contamos con cuatro ejemplos en la comarca estudiada, dos en León y dos en Zamora; además, la variante que más aparece es mantillina, con el cambio de timbre en la vocal átona, tan frecuente en esta época (Morala, 2015a). En el CorLexIn los documentos en los que aparece pertenecen a la zona centro y sur de la Península y a varios países de América.

Entre los repertorios dialectales modernos, Le Men registra mantillín o mantillina en las zonas leonesas de Murias de Paredes y Astorga como 'especie de capa, de paño más o menos basto, que usan las mujeres como abrigo y como prenda de ceremonia en los actos religiosos'o 'pañuelo para el cuello' (Le Men, 2007, s. v. mantillina).

\section{MANTO}

Sust. m. 'Especie de mantilla grande sin guarnición, que usan las señoras' $(D L E)$. Covarrubias además indica que 'antiguamente fue la cobertura, o capa delos nobles, y assi se ha quedado oy dia con el las ordenes militares [...]'. Autoridades amplía las acepciones: 'se llama asimismo una rica vestidúra de ceremonia [...]', '[...] la que trahen algunos Religiosos encima de los hábitos' o 'se suele llamar metaphoricamente todo aquello que cubre y oculta alguna cosa: como el manto de la noche'. (NTLLE, s. v. manto, Covarrubias, 1611; Autoridades, 1734). Del lat. tardío MANTUM 'manto corto', que a su vez es de origen incierto; parece haberse extraído del lat. MANTELLUM, que quizá fuese voz antigua en latín (DECH, s. v. manto).

Un manto de contray bueno (Celada, LE-1600)

Un manto negro biexo con un ribete de terciopelo (Valdavia, LE-1606)

Un manto negro reveteado de terciopelo bueno (Riosequillo, LE-1610)

Un manto de luto negro (Grajal Campos, LE-1670)

Un manto de luto viejo (Castromocho, PA-1602)

Un manto de anascote tasado en tres ducados (Mazariegos, PA-1619)

Un manto de luto en bayeta berde (Guaza de Campos, PA-1640)

Un manto de seda de Sevilla nuevo digo viejo con cintas coloradas (Autillo de Campos, PA-1653) Un manto de Toledo nueuo (Villalón, VA-1637)

Dos mantos de anascote y otro de Sevilla (Medina de Rioseco, VA-1646)

Un manto de Sevilla nuevo (Medina de Rioseco, VA-1649)

Un manto requemado viejo (Medina de Rioseco, VA-1660)

Dos mantos de soplillo tasados ambos en quinçe ducados (Villalpando, ZA-1620)

Un manto de anascote traydo (Villalpando, ZA-1620)

Un manto de gala nuevo (Villalpando, ZA-1652)

Un manto nuevo de Seuilla (Villalpando, ZA-1660)

Se trata de un término de uso general en el siglo XVII, que aparece ampliamente documentado en las bases de datos textuales como el CORDE y el CDH. Atestiguado en el CorLexIn en la Península y en sus colonias de ultramar. Esta prenda está muy presente en los inventarios de la Tierra de Campos, donde se alternan los "mantos de luto, humo o requemado" -los más abundantes- con los "mantos de gala" elaborados con diferentes telas. En cuanto a la 
forma, aparece también mantiyuelo, posiblemente para hacer referencia al tamaño de esta prenda:

Un mantiyuelo de paño negro viejo y trapeado (Frechilla, PA-1631)

\section{MONILLO}

Sust. m. p. us. 'Jubón de mujer, sin faldillas ni mangas' (DLE). Aparece en Autoridades con esta misma acepción. Este término se señala en desuso a partir del DRAE de 1984. (NTLLE, s. v. monillo, Autoridades, 1734, DRAE, 1984). Palabra derivada de mona, de origen incierto, probablemente abreviación de mamona, variante de maimón, -ona, procedente a su vez del ár. maimûn 'feliz', vulgarmente 'mono' (DECH, s. v. mona).

Cinquenta reales de unos monillos de felpa (Paredes de Nava, PA-1689)

Ocho reales de un monillo de yeruas (Paredes de Nava, PA-1689)

Este término no aparece documentado en el CORDE con la acepción de prenda de vestir hasta bien entrado el siglo xx. Los datos aportados por el CorLexIn indican que es un término localizado preferentemente en la zona meridional de la Península -Cádiz, Huelva, Sevilla, Córdova y Badajoz-. En la comarca de Tierra de Campos aparecen tan solo un par de ocurrencias en un mismo documento de la localidad palentina de Paredes de Nava. Cabe considerar que la datación de los ejemplos corresponde a finales del siglo XVII y principios del XVIII.

\section{ROPILLA}

Sust. f. 'Vestidura corta con mangas y brahones, de los cuales pendían regularmente otras mangas sueltas o perdidas, y se vestía ajustada al medio cuerpo sobre el jubón' (DLE). Autoridades comparte esa acepción y además indica que es 'la ropa pobre, ù de poca estima' (NTLLE, s. v. saya, Autoridades, 1737). Término derivado del verbo robar (DECH, s. v. robar).

Dos ropillas negras biejas del inbentario (Castrillo, LE-1606)

Una ropilla nueba del difunto y sus greguescos de pardo nuevo (Valdavia, LE-1606)

Una ropilla destameñica dada (Grajal de Campos, LE-1671)

Una ropilla de paño de Segobia vieja (Valderas, LE-1682)

Una ropilla de lila con mangas de tafetán traydo (Castromocho, PA-1611)

Una ropilla de paño pardo buena aforrada en bayeta (Frechilla, PA-1642)

Una ropilla de estameña mediada (Baquerín de Campos, PA-1658)

Un vestido negro con calzón y ropilla, ferreruelo (Villalón, PA-1637)

Dos ropillas biexas, una de paño y otra de estameña (Medina de Rioseco, VA-1639)

Ropilla y calçón de paño almendrucado nuevo (Medina de Rioseco, VA-1643)

Una ropilla de paño pardo con sus calçones usados (Tamariz de Campos, VA-1652)

Una ropilla de paño pardo algo usada (Cuenca de Campos, VA-1668)

Una ropilla, calçón de terciopelo (Villalpando, ZA-1644)

Una ropilla de paño de Ágreda diezyocheno tasada en quatro ducados (Carrizo, ZA-1646)

Un ferreruelo negro y una ropilla negra (Villalpando, ZA-1653)

Una ropilla y capa de vaeta negra (Villalpando, ZA-1686)

Una ropilla y unos calzones y un jubón ya usado (Villalpando, ZA-1689)

Es un término de uso general en el siglo XVII para designar tal prenda de vestir. Se encuentra ampliamente documentado tanto en el CORDE como en el $C D H$. Los datos que proporciona el 
CorLexIn corroboran el uso generalizado de esta voz en textos peninsulares, insulares y americanos.

\section{SAYO [saio]}

Sust. m. 'Prenda de vestir holgada y sin botones que cubría el cuerpo hasta la rodilla' (DLE). Covarrubias lo define como 'vestidura, que recoge y abriga el cuerpo, y sobre ella se pone la capa para salir fuera de casa'. Autoridades, por su parte, recoge esta palabra como la 'casaca hueca, larga, y sin botones, que regularmente suele usar la gente del campo, ù de las Aldeas' (NTLLE, s. v. sayo, Covarrubias, 1611; Autoridades, 1739). Del lat. vulgar *SAGĬA, derivado del lat. SAGUM 'especie de manto', 'casaca militar' (DECH, s. v. saya).

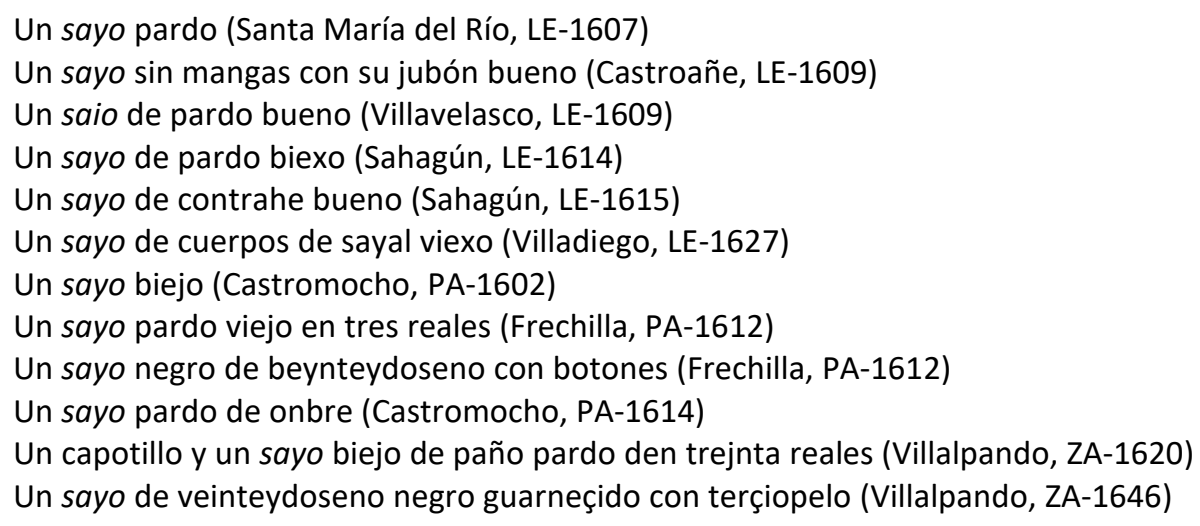

Se trata de una prenda principalmente masculina de cuerpo entero que se ponía sobre la camisa (Lasmarías, 2009: 138). Esta voz se documenta en bases de datos como el CDH y el CORDE a partir de finales del siglo XIII. El CorLexlin la localiza en el extremo noroccidental principalmente -Asturias, Vizcaya, Navarra, La Rioja, Soria, Burgos y León-, aunque también aparece algún caso aislado en Cáceres, Guadalajara y Toledo y en algunos países de América -Perú, Colombia-.

\section{SAYUELA}

Sust. f. 'Camisa de estameña que usan en algunas órdenes religiosas' (DLE, 2. ac.). Esta palabra no se recoge hasta la edición académica de 1803 con la acepción que se mantiene en el DLE (NTLLE, s. v. sayuela, DRAE, 1803). Término derivado de saya, del lat. vulgar *SAGİA, derivado del lat. SAGUM 'especie de manto', 'casaca militar' (DECH, s. v. saya).

Una sayuela vieja (Castromocho, PA-1602)

Una sayuela entera de bayeta blanca de niña (Castromocho, PA-1611)

Una sayuela de picote de niño (Castromocho, PA-1614)

Una sayuela bieja (Castromocho, PA-1614)

Es un término que se documenta en el CORDE y en el CDH a partir del siglo xv; sin embargo, dado el número de ejemplos, no debió de ser una voz de uso extenso. Esta escasez de casos se traslada al CorLexIn, donde tan solo se localizan un par de ejemplos en Durango (Vizcaya) con la variante gráfica saiuela que referencia una prenda femenina. Todos los casos de esta voz que se han documentado en la comarca de Tierra de Campos pertenecen a la localidad palentina de Castromocho. En un par de ejemplos, sayuela aparece junto al sintagma "de niña" y también "de 
niño", en este contexto estamos ante una prenda infantil, ámbito muy poco habitual en los inventarios de esta época. Así pues, en estos casos la acepción de esta palabra sería la de 'saya pequeña', como diminutivo de saya.

\section{SAYUELO}

Sust. m. 'León. Manga rajada que llevaban en su vestimenta las maragatas' (DLE). En Autoridades aparece como diminutivo de sayo y sin marca diatópica. Este término también hace referencia a una 'especie de jubon, que suelen usar las mujeres, y se hace de varias telas' (NTLLE, s. v. sayuelo, Autoridades, 1739). En el DRAE de 1869 solo aparece como diminutivo de sayo, hasta el de 1925, donde se incluye la marca dialectal de esta voz. Término derivado de saya, del lat. vulgar *SAGIA, derivado del lat. SAGUM 'especie de manto', 'casaca militar' (DECH, s. v. saya).

Un sayuelo de roxo bueno (Celada, LE-1600)

Un sayuelo de contray bueno (Santa María del Río, LE-1607)

Un sayuelo roxo guarneçido de terciopelo negro (Sahagún, LE-1608)

Un sayuelo de contray bueno (Castroañe, LE-1609)

Dos sayuelos de contray el uno ribeteado de terciopelo buenos (Riosequillo, LE-1610)

Un sayuelo de contray guarnecido bueno (Cea, LE-1610)

Un sayuelo de contrae biexo (Grajal de Campos, LE-1613)

Un sayulo de contrahe viexo (Sahagún, LE-1615)

Un sayuelo de contrai bueno (Santa María del Río, LE-1617)

Un sayuelo de contray tasado en siete reales (Celada, LE-1624)

Un sayuelo mediado (Sahagún, LE-1626)

Un sayuelo negro viejo (Castromocho, PA-1602)

Un sayuelo de veintedoseno negro bueno con pespuntes de seda (Frechilla, PA-1612)

Un sayuelo negro en treçe reales (Frechilla, PA-1612)

Un sayuelo negro biejo con aforro de fustán y de lienço y estopa (Frechilla, PA-1614)

Un sayuelo negro bueno guarneçido de terçiopelo negro (Frechilla, PA-1615)

Un sayuelo de paño de contray (Villalpando, ZA-1637)

Un sayuelo de veinteydoseno tasado en doze reales (Villalpando, ZA-1646)

Es un término que aparece sobre todo en la zona leonesa de la Tierra de Campos, aunque también se hallan ejemplos en Palencia y Zamora. No son muy abundantes los ejemplos en CORDE, aunque se distribuyen a lo largo de todo el siglo, con las dos acepciones que registra Autoridades. Es un término utilizado en tierras leonesas en esta época, ampliamente documentado en la Maragatería, Cepeda y Órbigo; junto con la camisa, el sayuelo es la prenda femenina para el busto por excelencia (Egido, 2010: 100). También se documenta en los inventarios de la época en localidades leonesas del partido judicial de la Bañeza (Gómez Ferrero, 2015: 74).

\subsubsection{Prendas de cintura para abajo}

\section{BASQUIÑA [uasquiña, vasquiña]}

Sust. f. 'Saya que usaban las mujeres sobre la ropa para salir a la calle' (DLE). Aparece en los diccionarios preacadémicos y Autoridades lo define como 'ropa, ó saya que trahen las mugéres desde la cintura al suelo, con sus pliegues, que hechos en la parte superior forman la cintúra, y por la parte inferior tiene mucho vuelo. Pónese encima de los guardapiés y demás ropa, y 
algunas tienen por detrás falda que arrastra' (NTLLE, s. v. basquiña, Autoridades, 1726). Término procedente del port. anticuado vasquinha, diminutivo del gentilicio vasco (DECH, s. v. basquiña). Una basquiña y saya de flor de lino guarneçida de terciopelo morado (Sahagún, LE-1602) Una basquiña de raso amarillo (Cea, LE-1626)

Una vasquiña de estameña plateada aforrada de olandilla morada (Grajal de Campos, LE-1656) Una basquiña y anguarina de olandilla (Valderas, LE-1682)

Una basquiña de estameña de las fiestas tasada en beinte reales (Mazariegos, PA-1619) Una basquiña de estameña buriel con ruedo acanelado (Villarramiel, PA-1694)

Otra basquiña de raxa aceitunada (Autillo de Campos, PA-1649)

Una basquiña de estameña buriel con ruedo gordellate pardo (Autillo de Campos, PA-1653)

Una vasquiña de estameña con riuetes de tercio pelo negro (Villalón, VA-1637)

Una basquiña de estameña en quatro ducados (Medina de Rioseco, VA-1643)

Una basquiña y jubón destameña françisca estopa (Medina de Rioseco, VA-1657)

Una uasquiña de chamelote negra (Medina de Rioseco, VA-1685)

Una basquiña de paño almendrucado aforrada a delantera en boatí azul y con zinco pasamanos de seda negra (Villalpando, ZA-1620)

Una basquiña de raxa parda con olandilla (Villalpando, ZA-1637)

Una basquiña de chamalote de aguas (Villalpando, ZA-1644)

Otra basquiña con cuchillos con su jubón (Villalpando, ZA-1676)

Hay que aclarar que, aunque el término lo recoge el diccionario de Autoridades en 1726, Covarrubias ya menciona dicha palabra dentro de la definición de falda (Alameda Molina: 2013). Covarrubias indicaba '[...] Faldillas, y faldetas, y faldellin, la mantilla larga que las mugeres traen sobre la camisa, que sobrepone la vna falda sobre la otra, siendo abiertas, a diferencia de las vasquiñas y sayas, que son cerradas, y las entran por la cabeça. [...]'. Es una voz muy habitual en la documentación del CORDE. Aparece a lo largo de toda la comarca de Tierra de Campos en el siglo XVII. El CorLexIn muestra un uso generalizado de esta palabra a lo largo de todo el territorio peninsular, insular y algún punto de América -México-.

\section{BRIAL [vrial]}

Sust. m. 'Vestido de seda o tela rica que usaban las mujeres' (DLE). Recogido por Nebrija como 'vestido de mujer', 'túnica'. Covarrubias señala que se trata de 'vestidura antigua española, de que vsauan las Reynas y grandes señoras, a modo de mongil'. Autoridades indica que es un 'Género de vestido ò trage, de que usan las mugéres, que se ciñe y ata por la cintúra, y baxa en redondo hasta los pies, cubriendo todo el medio cuerpo: por cuya razón se llama también Guardapiés, ò Tapapiés, y de ordinario se hace de telas finas: como son rasos, brocados de seda, oro, ò plata'. En una segunda acepción también indica que 'es el faldón de seda, de tela, ò brocado, que trahian antiguamente los hombres de armas desde la cintúra, hasta por encíma de las rodillas, de que oy usan los que se llaman armados, que por otro nombre se dice Toneléte'. (NTLLE, s. v. brial, Nebrija, 1495; Covarrubias, 1611; Autoridades 1726). Término del occ. ant. blial, de origen incierto, como el fr. ant. bliaut, quizá germánico (DECH, s. v. brial).

Un brial bueno (Celada, LE-1600)

Un brial verde con ruedo amarillo con sus cuerpos nueuos (Castroañe, LE-1609)

Un brial azul ruedo amarillo bueno (Cea, LE-1610)

Otro brial de contray bueno (Cea, LE-1610)

Un vrial leonado bueno con ruedo amarillo (Sahagún, LE-1615)

Un vrial verde demediado tasado en diez y ocho reales (Celada, LE-1624) 
Un brial de contray, ruedo amarillo bueno (Sahagún, LE-1608)

Un brial de contrai negro con ruedo amarillo bueno (Sahagún, LE-1600)

Un brial berde con ruedo amarillo casi nuevo (Sahagún, LE-1605)

Un brial de grana con rodadura verde apreciado en ochenta y ocho reales (Frechilla, PA-1612)

Un brial azul de veinteydoseno bueno, rodadura amarilla (Frechilla, PA-1613)

Un brial berde con rodadura açul (Frechilla, PA-1639)

Una saya, brial de paño açul con rodapié amarillo (Guaza de Campos, PA-1639)

Un brial de paño azul (Boadilla de Rioseco, PA-1641)

Un brial colorado (Castromocho, PA-1602)

Un brial colorado con rueda (Cuenca de Campos, VA-1660)

Este término se documenta en el CORDE desde el siglo XII; parece que en el siglo XVII era una palabra que estaba cayendo en cierto desuso, ya que el número de ejemplos es bastante inferior a siglos anteriores. Los datos que nos aporta el CorLexIn ponen de manifiesto que para esta prenda de vestir existían alternativas más exitosas como basquiña, saya o pollera. No hay un patrón de reparto geográfico claro, aunque sí una preferencia por el término en localidades del Norte de la Península -Vizcaya, La Rioja, Burgos, Palencia, Ávila-. En la comarca de Tierra de Campos el uso de esta palabra está generalizado, sobre todo en las localidades más norteñas pertenecientes a los partidos judiciales de León y Palencia.

\section{FALDA}

Sust. f. 'Prenda de vestir o parte del vestido de mujer que cae desde la cintura' (DLE). Este término lo recoge Covarrubias como 'lo que cuelga del vestido que no se pega al cuerpo' (NTLLE, s. v. falda, Covarrubias, 1611). Procedente del germánico *falda 'pliegue' (DECH, s. v. falda).

Dos camisas de muger nuebas, por hazer, con sus faldas (Sahagún, LE-1601)

Una camisa labrada de negro nueba, cuerpo y mangas de ruan y faldas de estopa (Sahagún, LE1608)

Otra camisa de muger traída con sus faldas de estopa y labrada de lana negra (Frechilla, PA-1612)

Una camisa de ruan, faldas de lienço çerro con lauor negra de lana (Frechilla, PA-1613)

Una camissa de mujer con sus faldas de estopa y un cuerpo de ruan (Frechilla, PA-1613)

Una camissa de mujer con unas faldas de estopa rotos (Fechilla PA-1613)

Otra (camisa) de lienço delgado labrada buena, faldas de cerro (Guaza de Campos, PA-1637)

Corominas y Pascual señalan que el predominio de la forma con /f-/ no se puede explicar por cultismo o arcaísmo: ha de ser debido a cierto resabio extranjero que el vocablo conservaría desde sus orígenes. (DECH, s. v. falda). Es una palabra muy documentada en el CORDE. El CorLexIn muestra la preferencia por esta voz en el sur de la Península, aunque aparecen casos aislados en el norte como en Asturias, Cantabria, Huesca y León. También localiza algún ejemplo aislado en los documentos americanos -Colombia-. Las ocurrencias halladas en Tierra de Campos aparecen con la acepción de 'complemento que lleva la camisa'. Formalmente aparece el diminutivo faldillas en los dos únicos ejemplos localizados en la zona vallisoletana:

Dos juvones, uno de vayeta de Segobia bueno y el otro destameña vuriel con faldillas redondas traydas (Medina de Rioseco, VA-1645)

Unos cuerpos de paño pardo y faldillas de estameña guarneçidos de pasamanos de seda (Medina de Rioseco, VA-1649)

En zonas de León como Riaño, La Vecilla y Astorga, este término designa la 'prenda interior femenina, enagua, combinación' (Le Men, 2005, s. v. falda). 


\section{FALDÓN}

Sust. m. 'Falda suelta al aire, que pende de alguna ropa' (DLE). Ya desde Autoridades se recoge con esa misma acepción (NTLLE, s. v. faldon, Autoridades, 1732).

Término derivado de falda del germánico *falda 'pliegue' (DECH, s. v. falda).

Un faldón de tela de plata y terziopelo negro (Sahagún, LE-1603)

Un faldón de armar de terciopelo (Riosequillo, LE-1610)

Un faldón de terçiopelo guarnecido de amarillo (Cea, LE-1610)

Un faldón de túnica (Frechilla, PA-1640)

Un faldón y un medio lenzuelo (Medina de Rioseco, VA-1642)

Dos faldones de armar en quatro reales (Medina de Rioseco, VA-1644)

Este término se documenta a finales del siglo XIV como 'parte de la armadura'. Como prenda de vestir aparece a finales del siglo XV y muchos de los ejemplos documentados en el siglo XVII lo hacen como parte de la vestimenta talar $(C D H)$. En los inventarios de la época de estudio, este término aparece en muchas ocasiones como parte o complemento de una prenda de vestir; así, nos encontramos "Una almilla blanca, con faldones" (Baza, Granada-1662), o "unos faldones de damasco para un jubón" (Mora, Toledo-1637). Sin embargo, en Tierra de Campos ese significado no está tan claro, pues parece que, además de adornar prendas, como sucede en el ejemplo de Frechilla "un faldón de túnica", también formaría parte del adorno de la ropa blanca y así nos encontramos faldones entre ceñidores de cama, telas o pañuelos. Además, aparecen dos faldones de armar que por el contexto parecen no hacer referencia al ámbito textil. Le Men (2005, s. v. faldón) localiza este término en Zamora como 'mantillas de los niños pequeños' y en algunas zonas de León como La Bañeza aparece con el significado de 'tejido fino con forma de falda con que se cubría a los bebés, el día del bautizo, desde debajo de los brazos hasta los pies', acepción que no encontramos en los documentos analizados.

\section{GREGÜESCOS [grigüescos, greguiescos, gregescos, grigescos]}

Sust. m. pl. 'Calzones muy anchos que se usaron en los siglos XVI y XVII' (DLE). Autoridades lo recoge como sinónimo de calzones y en el diccionario de la edición académica de 1803 ya aparece como una palabra antigua. (NTLLE, s. v. greguescos, Autoridades, 1734; DRAE, 1803). Es un término derivado de griego que hace referencia a aquellos calzones muy anchos que se usaban antiguamente ( $D E C H$, s. v. griego).

Unos gregüescos de hombre morados en dos ducados (Sahagún, LE-1600) El sayo, jubón y los calçones y grigiescos y camisones dos ducados (Joara, LE-1604) Una ropilla nueva del difunto y sus gregüescos de pardo nuevo (Valdavida, LE-1606) Unos greguiescos de contray nuebos apreçiados en cinco ducados (Sahagún, LE-1608)

Unos greguiescos pardos nuevos apreçiados en quarenta reales (Sahagún, LE- 1608)

Unos gregüescos de veyntedoseno pardo aforrados apreziados en tres ducados (Grajal de Campos, LE-1613).

Unos gregescos guarnecidos de paño pardo en treinta y quatro reales (San Nicolás del Camino Francés, LE-1631)

Unos grigüescos biejos en dos reales (Frechilla, PA-1605)

Unos greguiescos de terciopelo fino en treinta reales (Castromocho, PA-1611)

Unos gregüesco de contray apreçiados en beynte reales (Frechilla, PA-1612)

Unos grigüescos de gordellate pardo (Frechilla, PA-1636) 
Unos grigüescos de cordellate pardo en quatro reales (Frechilla, PA-1636)

Esta palabra aparece en poblaciones de León y Palencia con diferentes variantes gráficas. Además de la palabra normativa gregüescos-documentada en el CORDE desde el siglo XVI con esta acepción-, otra de las variantes que aparecen es grigüescos, ejemplo en el que se puede contemplar la alternancia que existe entre las vocales átonas en esta época, en especial los transvases entre las vocales palatales (Morala, 2012a: 555-556). En el CorLexIn figuran algunos casos esporádicos en Puentedura (Burgos), en Villacelama (León), en Carbajales del Alba (Zamora) y en Zaragoza. Con la variante grigescos se localizan en Zamora y Zaragoza. El origen extranjero de esta palabra hace que abunden las variantes gráficas en los textos.

\section{GUARDABAJOS [guardavajos]}

No aparece ni en el $D L E$, ni en ningún diccionario académico anterior.

Otros dos pares de enaguas y guardavajos y capotillo al huso de bayeta guarneçido de pasamanos de oro (Medina de Rioseco, VA-1648)

Esta palabra se documenta a partir de la segunda mitad del siglo XVII en el $C D H$, aunque tan solo aparecen siete ejemplos repartidos en un inventario de bienes y una carta de dote; ambos documentos pertenecen al Archivo Provincial de Toledo. En el CorLexIn tan solo localizamos un ejemplo en Baza (Gr-1662):

Vn guardabajos de chamelote, açul çeleste, con tres guarniciones de oro, nuebo, en çiento y treinta reales

La misma escasez de ejemplos también se da en la zona de Tierra de Campos, donde localizamos una sola ocurrencia de este término. Por el contexto en el que se localiza, parece tratarse de una prenda femenina, ya que está junto a basquiña, pollera, escapulario... Parece que se prefería más el término guardapiés o tapapiés para hacer referencia a este tipo de prenda.

\section{GUARDAPIÉS [guardapié, guardapiesses]}

Sust. m. El DLE nos remite al término brial, 'vestido de seda o tela rica que usaban las mujeres' (DLE). Autoridades también remite a brial (NTLLE, s. v. guardapies, Autoridades 1726). Término compuesto de guardar, del germánico wardôn y pie, del lat. PĒS, PĔDIS (DECH, s. v. guardar y pie).

Un guardapiés encarnado de senpiterna tasado en seis ducados (Grajal de Campos, LE-1658)

Un guardapiés llano de bayeta en veynte y seis reales (Grajal de Campos, LE-1658)

Un guardapié de estameña açul bordado (Valderas, LE-1682)

Un guardapié de rasillas azules con tres garapiñas (Valderas, LE-1682)

Un guardapiés de bajeta berde con la rodadura de baeta morada (Frechilla, PA-1671)

Un guardapiés de bayeta de Palencia colorado con dos guarniciones (Boadilla de Rioseco, PA1689)

Un guardapiés de chamelo berde con tres guarniziones de esterilla de oro (Paredes de Nava, PA1689)

Un guardapiés de cordellate açul (Paredes de Nava, PA-1690)

Un guardapiés de estameña açul aprensado con cinco garrapiñas negro (Paredes de Nava, PA1690) 
Un guardapiés con dos pasamanos y una enaguas destameña colorada (Medina de Rioseco, VA1651)

Un guardapiés de jerguilla encarnada con dos garapiñas y frajón de plata (Medina de Rioseco, VA-1659)

Un guardapiés de chamelote azul aforrado en tafetán dorado con dos franjas de plata (Medina de Rioseco, VA-1660)

Dos guardapiesses, el uno de senpiterna encarnada con una franja de plata, y el otro también de senpiterna azul con dos franjicas de plata y dos guarniciones negras (Medina de Rioseco, VA1661)

Unas enaguas digo guardapié de bayeta encarnado con tres guarniciones de garapiña de color (Villalpando, ZA-1660)

Más dos guardapiés, uno de estameña fina açul celeste con tres guarniciones de garapiña y otro de vaeta pajiça con tres guarniciones de garapiña (Villalpando, ZA-1670)

Un guardapiés de trama encarnada con un franjón de plata (Villalpando, ZA-1686)

Un guardapié de estameña verde con guarniziones (Villalpando, ZA-1697)

Parece que el término comienza a estar vigente en la literatura a partir de este siglo XVII $(C D H)$. La literatura se decanta más por su variable en plural guardapiés, los ejemplos en singular son escasos y localizados en siglos posteriores. En el CorLexIn aparece documentada en distintas zonas de la Península y en los archivos abunda la variante en plural guardapiés, aunque también se encuentran casos de guardapié. Se documenta a lo largo de la Tierra de Campos y se presenta tanto en singular como en plural. Cabe destacar que la variante guardapié aparece en las provincias de Zamora y León junto a la forma en plural, mientras que en Palencia y Valladolid solo aparece la variante guardapiés para el singular y guardapiesses para el plural. Parece que la lengua se decantó por la forma guardapiés para hacer alusión a esta prenda de vestir femenina, frente a tapapiés y guardabajos. En la zona zamorana de la Tierra de Campos se documenta un ejemplo que parece hacer referencia a algún tipo de objeto que nada tiene que ver con prendas de vestir: se trata de "Un guardapiés moldeado arrimado al frontal" que se localiza en un inventario de Villalpando fechado en 1696 y que se encuentra junto al mobiliario de iglesia (mesa de altar, tarima, frontal).

\section{TAPAPIÉS}

Sust. m. desus. 'brial' (DLE). No aparece en los diccionarios preacadémicos y se recoge por primera vez en el DRAE de 1780 en el que equipara el término con brial. Se trata de una palabra compuesta por tapa procedente del lat. TAPA, probablemente del gót. *tappa y por pie, del lat. PES, PĚDIS (DECH, s. v. tapa y pie).

Un tapapiés de brocato (Paredes de Nava, PA-1689)

Un tapapiés de sempiterna (Paredes de Nava, PA-1689)

Dos tapapiés, el uno de senpiterna azul zeleste con zinco guarniciones de color nuebos, más otro berde de bayeta llano (Villalpando, ZA-1676)

Un tapapiés de estameña azul labrado viexo (Villalpando, ZA-1690)

Otro tapapiés viexo y otro de vayeta acavellada (Villalpando, ZA-1690)

Es una voz muy poco documentada en el CORDE y en el $C D H$; tan solo aparece un caso documentado en el siglo XVII, en una obra de Juan de Zabaleta fechada en 1660, donde aparece "unos tapapiés que chispean oro". Sin embargo, no sucede lo mismo en los protocolos notariales del siglo XVII: el CorLexIn documenta esta palabra sobre todo en la zona sur de la Península 
-Huelva, Sevilla, Cádiz, Córdoba y Jaén-, aunque también hay algún caso aislado en La Rioja y Zamora. Tierra de Campos documenta esta voz siempre en su forma en plural.

\section{LOBA}

Sust. f. 'sotana', 'vestidura talar, abrochada a veces de arriba abajo, que usan los eclesiásticos y los legos que sirven en las funciones de iglesia. Fue empleada también por los estudiantes de las universidades' (DLE). Aparece en el suplemento al Tesoro que Covarrubias hace con esta acepción, y Autoridades lo registra como un 'cierto género de vestidúra talar, que hoy usan los Eclesiásticos y estudiantes' (NTLLE, s. v. loba, Covarrubias Suplemento, 1611 y Autoridades 1734). Se trata de una palabra procedente del lat. LǓPUS ( $D E C H$, s. v. Iobo)

Una loba de una saya aforada en tafetán de Granada (Paredes de Nava, PA-1690)

Una loba de paño de Segovia andada (Paredes de Nava, PA-1690)

Una loba vieja de bayeta de çien filos (Boadilla de Rioseco, PA-1687)

Una loba de senpiterna en ocho reales (Medina de Rioseco, VA-1646)

Una loba de seda biexa, rota y añadida y un çiñidor de seda viexa (Medina de Rioseco, VA-1671)

Una loba de bayeta de Segovia vieja (Villalón, VA-1642)

Un manteo y loba de bayeta de zien filos ya usado (Cotanes del Monte, ZA-1687)

Otra loba de tafetán doble ya usada (Cotanes del Monte, ZA-1687)

Es una prenda que aparece documentada en Tierra de Campos junto con otras prendas de abrigo como capas, manteos, capotes y anguarinas. En el CORDE aparecen ejemplos de esta prenda en la Crónica del Emperador Carlos V, en 1550. Como ocurre con muchos de los términos relacionados con la moda, la loba aparece de forma aislada en documentos del siglo XVII; así lo vemos en el CorLexIn, donde se documentan casos aislados de esta palabra con esta misma acepción-Badajoz, Madrid y León-.

\section{LUTO}

Sust. m. 'Vestido negro que se usa por la muerte de alguien' (DLE, 2. ac.). Aparece en Nebrija 'luto vestidura', y en Autoridades como 'el vestido negro, que se ponen los immediatos parientes de los difuntos, ó las personas de su obligación, en señal de dolor y tristeza. En lo antiguo era trage singulár; oy está reducido al mismo que ordinariamente se trahe, sin mas diferencia que ser negro, y omitirse algunos adornos. Y también se llaman assi los paños o bayetas negras que se ponen en la casa del difunto o en la Iglesia donde se entierra' (NTLLE, s. v. luto, Nebrija, 1495; Autoridades 1734). Término procedente del lat. LUCTUS, derivado de LUGERE 'Ilorar, lamentarse' (DECH, s. v. luto)

Un luto de lanilla mui traído (Medina de Rioseco, VA-1648)

Un luto de lana y ferreruelo (Medina de Rioseco, VA-1649)

Un luto de bayeta de Sevilla, capa y sotanilla (Villalón, VA-1637)

Un luto, capa y sotana (Villalpando, ZA-1644)

En los inventarios de esta época se prefiere añadir el sintagma "de luto" a la prenda en cuestión; así nos encontramos tanto en el CorLexIn como en corpus terracampino mantos, basquiñas, sayas, bestidos, mangas, tocas, capas o chapines "de luto". Sin embargo, como ocurre con otras palabras, se da el fenómeno de metonimia, en el que luto pasa a designar las prendas 
de vestir que sirven para representar el duelo. A pesar de su exiguo uso, el CorLexIn documenta este término con la acepción mencionada en la Península -Jaén, Sevilla y Navarra-y en América -Panamá-. En Tierra de Campos son más numerosos los casos con la expresión de luto al lado de la prenda en cuestión, aunque localiza ocurrencias de luto en localidades de Valladolid y Zamora.

\section{MANTEO [mantheo]}

Sust. m. 'Ropa de bayeta o paño que llevaban las mujeres, de la cintura abajo, ajustada y solapada por delante' (DLE, 2. a ac.). Desde Autoridades al DRAE de 1791, esta voz aparece como 'cierta ropa interior, de bayeta ó paño, que tahen las mugeres de la cintura abazo, ajustada y solapada por delante' (NTLLE, s. v. manteo, Autoridades 1734; DRAE, 1791). Término derivado de manto, del lat. tardío MANTUM 'manto corto', que a su vez es de origen incierto; parece haberse extraído del lat. MANTELLUM, que quizá fuese voz antigua en latín (DECH, s. v. manto).

Un manteo de frayliego casi nueuo de valor de diez y seis reales (Sahagún, LE-1633)

Un manteo de frailengo en diez e seis reales (Sahagún, LE-1633)

Un manteo de bayeta berde (Grajal de Campos, LE-1656)

Otro manteo de bayeta negro de Palençia (Grajal de Campos, LE-1656)

Un mantheo de paño de Frechilla viexo (Autillo de Campos, PA-1653)

Un manteo requemado (Paredes de Nava, PA-1689)

Un manteo de sacerdote de bayeta de Segovia (Paredes de Nava, PA-1690)

Un manteo de cordellate basto nuevo (Villarramiel, PA-1694)

Un manteo azul de paño guarneçido (Villalón, VA-1637)

Un mantheo colorado de paño (Medina de Rioseco, VA-1640)

Un manteo azul nuevo con ribete verde (Medina de Rioseco, VA-1642)

Un manteo y loba de çienfilos (Medina de Rioseco, VA-1671)

Un mantheo de raja de Florençia guarneçido (Villalpando, ZA-1631)

Un manteo de paño açul (7537-05-Villalpando, ZA-1637)

Un manteo de vuelta de raja guarnecido con siete guarniciones y con su riuete gayado con con guarnición de Sancta Ysabel color azul (Villalpando, ZA-1652)

Un manteo de raja azul con ocho guarniciones de Santa Ysauel y su ribetón por bajo (Villalpando, ZA-1660)

Es una palabra cuyo uso es general en el siglo XVII; así lo muestran los corpus léxicos consultados. En la zona de estudio alterna la grafía manteo con mantheo, con preferencia de la primera.

\section{MONJIL [monxil]}

Sust. m. 'Traje de lana que usaban por luto las mujeres' ( $D L E$, 4. a ac.). La Academia no incorpora este término hasta su edición de 1843, en la que lo define como 'el hábito ó túnica de la monja. Traje de lana que usa la mujer que trae luto' (NTLLE, s. v. monjil, DRAE, 1843). Palabra derivada de monje, tomado de oc. ant. monge íd. que procede del lat. vulgar MONĭcus ( $D E C H$, s. v. monje).

Un monxil de paño razonable (Sahagún, LE-1603)

Un monxil tres ducados (Sahagún, LE-1605)

Un monjil biejo de estameña negra (Castromocho, PA-1614)

Un monxil de paño negro biexo (Medina de Rioseco, VA-1643)

Un monjil de bayeta de zienfilos con mangas de pelo de camello (Medina de Rioseco, VA-1661) 
Los ejemplos aquí expuestos son los únicos que se han encontrado en los textos del área de estudio. Sin embargo, este tipo de prenda se documenta ampliamente durante el siglo XVII en el CORDE. Este hecho contrasta con lo que sucede en el CorLexIn, donde solo aparece documentado en un ejemplo de Madrid de 1649: "vn monjil de bayeta, aforrada la delantera en tafetán".

\section{POLLERA}

Sust. f. 'Falda que las mujeres se ponían sobre el guardainfante y encima de la cual se asentaba la basquiña o la saya' (DLE, 8. a ac.). En Autoridades aparece con este significado en su tercera acepción y la completa con 'Dixose assi por la semejanza que tiene con el cesto en que se crían los pollos'. No es hasta el diccionario de 1925, donde se señala esta voz como término utilizado en Argentina ('Argent. falda externa del vestido femenino') y en la edición de 1936 se indica que se trata de un americanismo (NTLLE, s. v. pollera, Autoridades, 1937; DRAE, 1925 y 1936). Es un término derivado de pollo, del lat. PǓLLUS ( $D E C H$, s. v. pollo).

La echura de un xubón y pollera catorce reales (Medina de Rioseco, VA-1640)

Una pollera de cordellate cavellado en veinte y quatro reales (Medina de Rioseco, VA-1644)

Una pollera verde con nuebe guarniziones (Medina de Rioseco, VA-1646)

Una pollera de damasco de lana con galón de plata de puntas (Medina de Rioseco, VA-1648)

Una pollera de paño azul nueba con ocho guarniziones y ribetón (Medina de Rioseco, VA-1649)

Una pollera de paño açul nueba (Medina de Rioseco, VA-1650)

Una pollera de raxa berde con sus guarniciones de garrapiña negra (Medina de Rioseco, VA-1657)

Otra pollera de chamelote encarnado con una franja de oro ancha aforrada en tafetán encarnado

(Medina de Rioseco, VA-1660)

Una pollera de paño colorado con diez y ocho guarniciones (Villalpando, ZA-1639)

Más vna pollera de bayeta encarnada con guarnición de plata (Villalpando, ZA-1652)

Otra pollera de estameña encarnada con tres guarniciones de plata y fratiqueras con la misma guarnición (Villalpando, ZA-1652)

Una pollera de bayeta encarnada con guarnición de plata (Villalpando, ZA-1654)

Una pollera de estameña encarnada con tres guarniciones de plata y fraltiqueras de la misma guarnición (Villalpando, ZA-1654)

La primera documentación que encontramos con el significado que aparece en los documentos consultados en el CORDE y en $C D H$ datan del siglo XVII; anteriormente, los diccionarios recogían esta voz como 'jaula de pollos'. Si a esto le sumamos los datos encontrados en numerosas entradas del CorLexIn, podemos concluir que se trata de una voz de uso general en la Península y América en el siglo XVII con el significado de 'falda'.

\section{ROPA}

Sust. f. 'Prenda de vestir' (DLE). Covarrubias advierte que esta voz cuenta con varias significaciones: 'vulgarmente llamamos ropa las alajas de la casa, de seda, paño, lienço, tapizes, colgaduras [...]. Ropa, la vestidura suelta, que traemos sobre la que está ceñida y justa al cuerpo, ropa de por casa la que el señor se pone quando le quitan la capa' (NTLLE, s. v. ropa, Covarrubias, 1611). Término derivado del verbo robar, con el sentido primitivo de 'despojos, botín' y luego 'mercancías, ropa' (DECH, s. v. robar).

Una ropa de cotonia blanca, biexa en seys reales (Sahagún, LE-1600) 
Una ropa de bayeta negra tasada en tres ducados (Sahagún, LE-1602)

Una ropa de chamelote aforrada en pellejos (Cea, LE-1621)

Una ropa de raxa de mujer verde (Cea, LE-1626)

Tres ropas, una de tafetán, otra de tramoya (Grajal de Campos, LE-1658)

Una ropa de bayeta vieja (Castromocho, PA-1602)

Una ropa de lila con su pasamano negro (Castromocho, PA-1611)

Una ropa de tafetán aterciopelado mediada (Autillo de Campos, PA-1653)

Una ropa de bayeta de Segobia con su manga ancha (Villalón, VA-1637)

Una ropa capona de damasco muy traída (Medina de Rioseco, VA-1640)

Dos ropas de bayeta de Palençia vuenas (Medina de Rioseco, VA-1648)

Un vestido de picote azul y negro, ropa y basquiña (Medina de Rioseco, VA-1649)

Una ropa y basquiña de tafetán pisado con su guarnición de terciopelo (Villalpando, ZA-1601)

Una ropa de gurbión de Italia acauellado con sus pasamanos de Calabria aforrada de tafetán verde (Villalpando, ZA-1631)

Una ropa de terciotpelo negro con pasamanos y bueltas de tafetán negro (Villalpando, ZA-1644)

Una ropa de damasco biexa (Villalpando, ZA-1651)

El término ropa en esta época se presenta en muchas ocasiones como una prenda de vestir que conformaba parte del vestido cotidiano y de la que Covarrubias da buena cuenta en su Tesoro; así, nos encontramos con ropas de terciopelo, sempiterna, bayeta, tafetán y un largo etcétera de tejidos y adornos. También cuenta con la acepción genérica para referirse a la vestimenta en general, por lo que en el corpus analizado nos encontramos ejemplos con este uso: "un cozino para lavar la ropa" (Frechilla, PA-1675), "una arca messa de tener ropa" o "una cesta de colar ropa" (Boadilla de Rioseco, PA-1692). En otras ocasiones aparece en los inventarios para dar mayor claridad a la forma de clasificar los enseres que se inventarían, y así aparecen en los márgenes de los mismos títulos como "Ropa blanca" en inventarios de Medina de Rioseco y "Ropa de cama" en los de Paredes de Nava, para hacer referencia al ajuar textil que acompañaba al dormitorio en general. Además, aparece otro compuesto sintagmático estudiado por Pérez Toral (2015a: 147-161) que es cama de ropa. En el caso de la Tierra de Campos encontramos un ejemplo en Sahagún: "una cama de ropa con quatro cauezales y dos mantas y un repostero", y en Villalpando aparece un documento que lleva el nombre de "entrega de cama de ropa". Pérez Toral (2015a: 147-161) después de hacer un exhaustivo estudio de la presencia de este sintagma en la documentación, tanto literaria como notarial, concluye que existen ejemplos en los que cama de ropa no solo hace mención a la ropa que compone una cama, sino que, observando otros ejemplos, incluiría también el mobiliario que la configura.

\section{SAYA [saia, saja]}

Sust. f. 'falda' (DLE). Nebrija incorpora este término a su Vocabulario y en Autoridades la saya es 'ropa exterior con pliegues por la parte de arriba, que visten las mugeres, y baxa desde la cintura á los pies' (NTLLE, s. v. saya, Nebrija, 1516; Autoridades, 1739). Del lat. vulgar *SAGĬA, derivado del lat. SAGUM 'especie de manto', 'casaca militar' (DECH, s. v. saya).

Una saya leonada uieja, ruedo amarillo (Sahagún, LE-1601)

Una saya azul con cuerpos colorados y husado (Santa María del Río, LE-1607)

Una saja de color azul (Carvajal, LE-1609)

Una saja verde con sus querpos buena (Santa María del Río, LE-1617)

Otra saia verde biexa (Santa María del Río, LE-1617)

Una saya de luto negra viexa (Grajal de Campos, LE-1670) 
Una saya colorada con un ruedo açul (Castromocho, PA-1602)

Una saya de palmilla açul con rodadura amarilla buena (Frechilla, PA-1612)

Una saya de estameña pardo con ruedo amarillo (Frechilla, PA-1642)

Una saja de raxa llana, rodapié de lo mesmo (Guaza de Campos, PA-1637)

Una saya de estameña con su ribete de terziopelo (Medina de Rioseco, VA-1640)

Una saya de raja traída (Villalón, VA-1637)

Una saya de estameña parda buena con olandilla morada (Medina de Rioseco, VA-1644)

Un saya y jubón de estameña vuriel parda (Medina de Rioseco, VA-1657)

Una saya de mezcla berde, veinte y quatro reales (Villalpando, ZA-1600)

Una saya de papal tasada en beynti ocho reales (Villalpando, ZA-1613)

Una saya de picote vieja fraylenga (Villalpando, ZA-1620)

Otra saya meidada açul en veinte y dos reales (Carrizo, ZA-1646)

Término de uso común en el siglo XVII. En el CORDE y en el CDH esta prenda ya aparece en el Becerro gótico de Cardeña, "[...] solidos de argento, et una saya vermelia de habi valente.", en el año 994. Se trata de una prenda básica del vestuario femenino de esta época, una falda que cubría desde la cintura y que se caracterizaba por llevar una serie de pliegues y por no llegar a cubrir los pies del todo (Lasmarías, 2009: 135). Hasta mediados del siglo XVII la saya se impone en los inventarios y junto a los cuerpos y las almillas configura el vestido femenino, pero a partir de esta fecha será la basquiña la que se imponga en la documentación. Los ejemplos que nos encontramos en la Tierra de Campos se reparten a lo largo del territorio analizado y, en la mayoría de los casos, datados en la primera mitad del siglo. Además, estas sayas solían llevar rodadura o ruedo. Observando la documentación del CorLexIn se corrobora que era una palabra de uso generalizado en España y América.

\section{VALÓN [balón]}

Sust. m. 'zaragüelles o greguescos al uso de los valones, que los introdujeron en España' (DLE, 4. a ac.). Covarrubias registra la palabra con "b" y con la acepción que mantiene hoy en día la Academia, además indica que los 'balones' introducen también en España las 'balonas'. Sin embargo, no es hasta la edición académica de 1884 donde introducen la acepción en plural como la prenda de vestir que reconocía Covarrubias (NTLLE, s. v. valón, Covarrubias, 1611; DRAE, 1884)' Especie de gregüescos o calzón corto', el valón fue introducido en España por los cortesanos procedentes de Valonia que acompañaron a Carlos $\mathrm{V}(D E C H$, s. v. valones).

Un valón verdoso vueno con pasamanos (Cea, LE-1621)

unos balones de beynte y doseno pardo con sus molinillos (Arenillas, LE-1636)

Otro uestido de estameña delgado negro nueuo, capa, jubón, ropilla y valones (Grajal de Campos, LE-1656)

Un balón y una ropilla de pano fraylego biejo (Castromocho, PA-1603)

Un balon de terciopelo de genoba nuebo (Castromocho, PA-1610)

Un valón y una ropilla de estameña (Frechilla, PA-1631)

Unos balones de paño y gordellate fraylego (Frechilla, PA-1675)

Unos balones de cordellate buenos (Paredes de Nava, PA-1689)

Otro bestido de paño aceytunado, capa, ropilla y valón traydo (Villlalón, VA-1637)

Un bestido de terziopelo balón y ropilla y mangas (Medina de Rioseco, VA-1640)

Unos valones de estameña de diez y siete reales y medio (Cuenca de Campos, VA-1660)

Unos balones pardos (Cuenca de Campos, VA-1668)

Una ropilla y un balón de paño (Villalpando, ZA-1633)

Un capotillo y unos balones biejos de estameña (Villalpando, ZA-1633)

Unos valones de estameña fina con pasamanos berdes (Carrizo, ZA-1646) 
Dos pares de valones (Villalpando, ZA-1689)

Es un término generalizado en los inventarios de la comarca de Tierra de Campos en el siglo XVII. Sin embargo, en el CORDE solo aparecen siete ejemplos con esta acepción. Los casos que presenta el CorLexIn, aunque no son numerosos, están repartidos por toda la geografía peninsular e incluso aparecen ejemplos en América. Se trataba de una especie de calzones que recibían ese nombre por ser una prenda importada por el pueblo valón y que tuvo su mayor auge en este siglo ( $D E C H$, s. v. valones). En esta época aparece junto a calzón, con el mismo significado, en algunos inventarios terracampinos, con la palabra calçones en el margen, cuando en el cuerpo del inventario aparece balones (Cuenca de Campos, VA-1668). Este hecho nos hace pensar que al escribano no le gusta mucho el término valón, ya sea porque lo considera un extranjerismo ajeno, un vulgarismo o por cualquier otra razón. A veces, incluso, no es el mismo escribano el que escribe la relación de bienes y el que anota en el margen. Esto explica la escasez de ejemplos en el CORDE, que refleja un registro más literario que nuestros inventarios.

\section{VAQUERO [baquero]}

Sust. m. 'Dicho de un tipo de tela de algodón: Resistente y, generalmente, de color azul, semejante a la usada en la ropa de los vaqueros del lejano Oeste' (DLE, 2.a ac.). El término aparece recogido en Nebrija y Autoridades la describe en su segunda acepción como 'lo que es proprio de los Pastores de vacas. Aplícase regularmente al sayo, ù vestidura de faldas largas, por ser parecido à los que los Pastores usan: y entonces suele usarse como substantivo'. En diccionarios no académicos como el de Terreros y Pando nos remite directamente a sayo (NTLLE, s. v. vaquero, Nebrija, 1495, Autoridades, 1739 , Terreros y Pando, 1788). Término derivado de vaca, del lat. vacca íd. (DECH, s. v. vaca).

Un baquero de garrobillas de niño en doze reales (Sahagún, LE-1602) Un baquero de niño (Frechilla, PA-1640)

Tan solo se han encontrado estos dos ejemplos en los documentos recogidos en la zona de la Tierra de Campos, y los dos casos se refieren a una prenda de vestir infantil. El término aparece en la literatura con acepciones y naturaleza diferentes. Se documenta como adjetivo en una obra fechada en 1582 al lado de las prendas de vestir "sayo pardo vaquero". En otras ocasiones, lo encontramos como sustantivo y con la acepción de 'prenda de vestir': así, en una obra fechada en 1598 Lope de Vega escribe "[...] con un vaquero de palmilla verde" $(C D H)$.

En el CorLexIn aparecen ejemplos tanto en la Península como en Canarias y América. A pesar de no ser muy frecuente en los inventarios, se extiende por un ámbito geográfico bastante extenso, ya que encontramos esta voz en inventarios de La Rioja, Albacete, Murcia, Almería y Madrid. Las acepciones con las que se localiza tienen que ver mayoritariamente con las prendas de vestir -dejando al margen el significado de pastor, que también aparece en los documentos que conforman el CorLexIn-. Morala apunta que, si nos fijamos en el contexto en el que aparece, podemos intuir que estamos ante una prenda de uso femenino, y del mismo modo deduce que se trata de una prenda exterior (Morala, 2012d: 430). Sin embargo, en el corpus de la Tierra de Campos, la prenda a la que hace referencia este término es a una vestimenta infantil. Egido localiza este término en el léxico del ámbito colonial, y advierte que esta prenda se convirtió en 
el vestido infantil por excelencia (Egido, 2018: 1939). En los ejemplos del CorLexIn encontramos varios vaqueros de niños, en Madrid "vn baquero de niña de tafetán azul [...]" y en Potosí (Bolivia) "una saya y vaquero de terciopelo morado, fondo en raso para niña" y a estos ejemplos podríamos añadir, con cierta cautela, un tercer ejemplo del que se hace eco Morala, "tres baquerillos de vn Niño Jesús" localizado en México y que se acercaría a la acepción vista en este corpus.

\section{VESTIDO [bestido, uestido]}

Sust. $m$. 'Prenda o conjunto de prendas exteriores con que se cubre el cuerpo', 'traje enterizo de la mujer' ( $D L E, 1$. - y 2. a ac.). Registrado por Nebrija y Covarrubias, en Autoridades aparecen las dos acepciones que mantiene el DLE actualmente (NTLLE, s. v. vestido, Nebrija, 1495, Covarrubias, 1611, Autoridades, 1739). Del lat. VESTITTUS, -ŪS (DECH, s. v. vestido).

Un vestido negro de hombre, capa, ropilla de bayeta de Palençia y calzones y mangas de damasco de lavor acuchillado. (Grajal de Campos, LE-1658)

Otro uestido de estameña delgado negro, nueuo, capa, jubón, ropilla y valones (Grajal de Campos, LE-1656)

Otro bestido de luto, manteo y sotanilla de bayeta de çienfilos nuevo (Grajal de Campos, LE-1656) Un vestido extraordinario (Villarramiel, PA-1696)

Un bestido entero de mujer de gurguiran o damasco, jubón, basquiña y ropa (Guaza de Campos, PA-1637)

Otro bestido de estameña fina, basquiña y jubón guarneçido y picado (Guaza de Campos, PA1637)

Un bestido de estameña de mezcla haçul y pardo que se compone de ropila, calçón y capa (Paredes de Nava, PA-1690)

Todos los vestidos festivales que el dicho Llorente García mandó a Francisca Gracía su hija en su testamento (Fechilla PA-1616)

Un bestido de estameña buriel, basquiña, jubón y escapulario (Medina de Rioseco, VA-1640)

Un bestido a la francesa de alamares de oro (Medina de Rioseco, VA-1642)

Un bestido de tafetán doble (Medina de Rioseco, VA-1657)

Un vestido destameña plateada nuevo aforrado en fustán y guarnezido con galón realzado (Medina de Rioseco, VA-1649)

Un vestido negro con calzón y ropilla, ferreruelo y mangas de tirela traída (Villalón, VA-1637)

Un vestido de estameña plateado (Villalpando, ZA-1644)

Un bestido de paño pardo digo de color arenosso con jubón y manga de senpiterna con sus çapatos y medias y valona y sombrero (Villalpando, ZA-1647)

Un bestido de estameña pardo aprensado, jubón y basquiña (Villalpando, ZA-1660)

Un bestido de erbaje con todo aparejo y su manto (Villalpando, ZA-1670)

Es un término de uso general en el siglo XVII, por lo que encontramos una gran cantidad de ejemplos en comarca de la Tierra de Campos. Aparece en los documentos con los dos significados que señala el DLE: por un lado, como un traje de una pieza; por otro, como un término colectivo, refiriéndose al conjunto de prendas exteriores que cubren el cuerpo. En los corpus textuales como el CORDE y el $C D H$, aparece documentada esta voz desde el siglo XII. Nos encontramos ante una palabra de uso generalizado en esta época a lo largo de toda la Península y América. 


\section{ZARAGÜELLES [çarafueles, çarafuelles, zarafueles, zarafuelles]}

Sust. m. pl. coloq. 'Calzones muy anchos, largos y mal hechos' (DLE). Autoridades lo registra como 'especie de calzones, que se usaban antiguamente, anchos, y follados en pliegues, por lo que parece natural la etimología, que le dán algunos, que cita Covarr. Y dicen ser voz compuesta de la voz Hebrea Zara, que vale esparcir, y de la voz Fuelle, como quien dice Zarafuelles, y otros dicen viene del Vascuence Zaragollac' (NTLLE, s. v. zaragüelles, Autoridades, 1739). Término tomado del ár. sarāwîl, plural sirwâl 'pantalón muy ancho', 'calzoncillos' (DECH, s. v. zaragüelles).

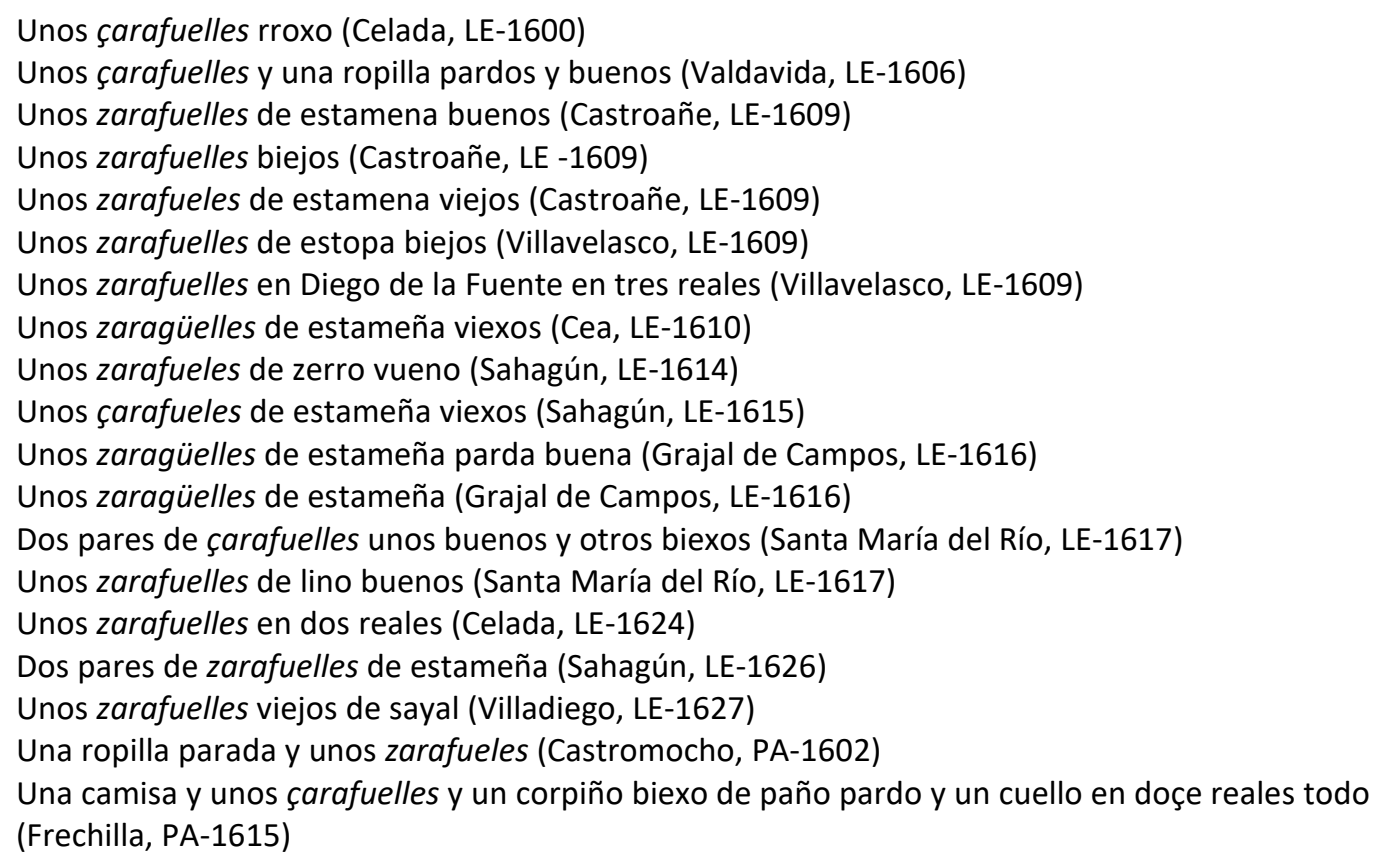

En el CORDE solo encontramos siete ejemplos de zaragüelles en tres documentos diferentes, dos de ellos de finales del siglo XVI y uno de principios del siglo XX. Esta voz aparece con marca diatópica en el DRAE de 1843 donde aparece como 'especie de calzones anchos y follados en pliegues que se usaban antiguamente, y ahora usan las gentes del campo de Valencia y Murcia' (NTLLE, s. v. zaragüelles, DRAE 1843). En la zona leonesa de la Comarca de la Tierra de Campos, aparecen las variantes zarafuelles y zaragüelles, con mayor presencia de la primera. De los ejemplos que se documentan en el CorLexIn, aparecen las dos variantes, zarafuelles y zaragüelles, el primero documentado en León y Burgos y el segundo en Guadalajara y Jaén; además, Vivancos (2013: 138), en su estudio sobre el léxico en la Tierra de Vera (Almería), también documenta esta segunda variante. 


\subsubsection{Complementos}

\subsubsection{Complementos de cabeza y tocados}

\section{ALBANEGA [aluanega]}

Sust. f. 'Especie de cofia o red para recoger el pelo o para cubrir la cabeza' (DLE). Término recogido por Covarrubias como 'cierta red en forma redonda, que las mugeres vsan traer en la cabeça con que recogen el cabello', pero Autoridades en 1726 ya registra esta voz como anticuada (NTLLE, s. v. albanega, Covarrubias, 1611; Autoridades, 1726). Término procedente del ár. banîqa 'pieza triangular que se agrega a una prenda de vestir para ensancharla', 'cofia', 'gorro de mujer' (DECH, s. v. albanega).

Una aluanega lavrada (Sahagún, LE-1615)

Una albanega cofia con pinos de oro en dos reales (Fechilla PA-1614)

Una albanega de seda negra con pinos de seda negro en un real (Fechilla PA-1614)

Una albanega labrada con seda negra en un real (Fechilla PA-1614)

Una albanega de pinos de seda negro (Fechilla PA-1616)

Albanega se documenta en el CORDE a partir del siglo XIV, pues Corominas y Pascual localizan esta voz en un inventario aragonés de 1330 (DECH. s. v. albanega). Sin embargo, la falta de testimonios de esta palabra con el significado de cofia hace pensar que pronto entró en desuso.

Aunque se trata de una palabra cuyo resultado parece ser el normativo, figura de forma muy aislada en los inventarios de la época. En el CorLexIn apenas hay ocurrencias de esta voz: se localiza una en Revilla del Campo (Burgos) y Morala encuentra otra en Aguilafuente (Segovia) (Morala, 2012e: 81). En Tierra de Campos, el mayor número de ejemplos se concentra en la localidad palentina de Frechilla, centro textil por excelencia en aquella época, por lo que es habitual encontrar voces pertenecientes al mundo de la moda y de los tejidos que no localizamos en otros lugares de esta comarca.

En la actualidad, esta prenda es aún recordada en localidades como Astorga (Le Men, 2002, s. v. albanega).

\section{BABADERO [babadero, bauador]}

Sust. m. 'babero', 'prenda que se pone a los niños sobre el pecho' (DLE). Aparece en Autoridades como un término ya en desuso, 'es lo mismo que babador que es como hoy se dice' (NTLLE, s. v. babadero, Autoridades, 1770). Término procedente del lat. vulgar *BABA, voz expresiva creada por el lenguaje infantil con la repetición de la sílaba /ba/, para expresar el babeo, mezclado con balbuceo, de los niños pequeños (DECH. s. v. baba).

Un babadero (Frechilla, PA-1640)

Un babador de niño con randas de ilo blanco en cinco reales (Frechilla, PA-1613)

Una valona pequeña conpuntas y un babadero de niño que tiene puntas (Frechilla, PA-1631)

Un bauador en nuebe reales (Medina de Rioseco, VA-1639)

Dos bavaderos con puntas en veinte y quatro reales (Medina de Rioseco, VA-1640) 
Aparece tan solo en tres documentos en el CORDE, uno perteneciente al siglo XVI y dos del XVII, con la misma acepción que aparece en el DLE. En zona terracampina aparecen ejemplos aislados, tanto de babadero como de babador, ya que no se trata de una prenda de vestir como tal, sino de un babero que solían utilizar sobre todo los niños; así se especifica en los ejemplos que encontramos, en los que suele aparecer junto al sintagma "de niño". Formalmente, hay que señalar la vacilación entre las formas babador y babadero en los textos sin que exista una diferencia semántica entre las mismas, alternancia muy común en esta época (Morala, 2012b: 337). En el CorLexIn aparece documentada solamente la forma babador en Albacete y Alicante.

BABADOR [bauador] (vid. babadero)

\section{PECHERO (babero)}

Sust. m. 'babero (prenda que se coloca a los niños)' (DLE, s. v. pechero ${ }^{1}$ ). El término se registra en Nebrija, y Autoridades lo define como 'el lienzo ù paño que se suele poner a los niños en el pecho, para que no se ensucien ni manchen'. Esta definición se mantiene hasta la edición de 1822, donde se remite a la entrada babador, y a partir de la edición de 1970, esta voz remite a babero (NTLLE, s. v. pechero, Nebrija, 1495; Autoridades, 1737, DRAE, 1822, DRAE, 1970). Término derivado de pecho, del lat. PĔCTUS, -ŎRIS (DECH, s. v. pecho).

Un pechero de ruan guarnezido con prentas (Autillo de Campos, PA-1653)

Un pechero de olanda (Medina de Rioseco, VA-1639)

Un pechero de una bara de nabal (Medina de Rioseco, VA-1660)

No aparece en bases de datos como el CORDE o el $C D H$ con la acepción que aquí se presenta. Pechero parece compartir campo semántico con babador y babadero, un complemento textil destinado a los niños para evitar que se ensucien, por lo que no es de extrañar la ausencia de testimonios en los documentos (CorLexIn). En la comarca de Tierra de Campos se localizan tres casos de este término y, por el contexto en el que aparecen, su significado no se ajusta a la definición dada por la Academia. En estos casos, pechero se encuentra inventariado junto a sábanas, tablas de manteles, servilletas..., por lo que nos hace sospechar que el significado con el que aquí aparece tiene que ver con un complemento del ajuar de la casa. Más concretamente, dentro del campo semántico de la ropa blanca. Sin embargo, por la falta de datos no podemos a aventurarnos a dar un significado concreto.

\section{BEBEDERO [vivedero]}

Sust. m. pl. 'Piezas o pedazos largos de tela que se ponen en los extremos del vestido, como en las delanteras y bocamangas, por la parte de adentro, para reforzarlos' (DLE, 8. a ac.). En Autoridades se indica esa misma acepción (NTLLE, s. v. bebedero, Autoridades, 1726). Término derivado de beber, procedente del lat. B̆̈вӗRE (DECH, s. v. beber)

Un jubón negro de muger con bebederos colorados en las mangas (Sahagún, LE-1600) Un sayuelo de grana bueno con ribete de terciopelo negro y bebederos verdes (Sahagún, LE-1600) Un jubón de olanda de muger con sus bebederos morados bueno en dos ducados (Sahagún, 1600) Un sayuelo negro con vivederos colorados (4152-01-Sahagún, LE-1608) 
Un sayuelo negro de contray guarnecido de terciopelo con bebederos de tafetán colorado apreciado en quarenta reales (Fechilla PA-1612)

Se trata de una voz que aparece siempre en plural y se corresponde con la 8.a acepción que da el DLE para este término. La variante que aparece con mayor frecuencia es la normativa, bebederos, pero también nos encontramos con vivederos, donde la vocal átona ha sufrido un cambio de timbre. No es un adorno muy frecuente en esta época; de hecho, nos encontramos con casos aislados en el CorLexIn, donde aparece esta voz, además de en la zona de estudio, en Guadalajara, Alicante Cuenca y Cantabria. Se presenta en singular en documentos de Álava y Cantabria haciendo referencia al 'pico saliente que en el borde tienen algunas vasijas y que sirve para beber' (DLE, 4. a ac.).

\section{BONETE [vonete]}

Sust. m. 'Especie de gorra, comúnmente de cuatro picos, usada por los eclesiásticos y seminaristas, y antiguamente por los colegiales y graduados', 'dulcera de vidrio ancha de boca y estrecha de suelo' (DLE, 1. - y 3. a ac.). Término recogido por Nebrija como 'cobertura para la cabeza. En Autoridades aparece como 'todo abrígo que se ponen en la cabéza, aunque no sea con picos [...]'; también aparece como última entrada del término 'cierto género de vaso de vidro, ancho de boca, y angosto de suelo, en que de ordinario se guardan y echan las conservas de dulce, y por lo común se venden en ellos en las confiterías' (NTLLE, s. v. bonete, Nebrija, 1495; Autoridades, 1726). Término procedente del cat. bonet, diminutivo del lat. ABONNIS íd. (DECH, s. v. bonete).

Un vonete y una cesta carretera, una garrafa quebrada todo viexo (Villalón, VA-1642)

Quatro docenas de vonetes colorados de Toledo (Medina de Rioseco, VA-1645)

Es un término polisémico. En la zona de estudio lo encontramos con dos acepciones diferentes: por un lado, sería una especie de tocado principalmente masculino; por otro, también hace referencia al utilizado por los eclesiásticos. Se trata de una prenda hecha de ricas telas, utilizada por personas de prestigio, pertenecientes a las clases pudientes (Bernis Madrazo, 1979: 24). Con esta acepción el término se encuentra ampliamente documentado en bases de datos como el CORDE o el $C D H$ a partir del siglo XV. Esta frecuencia contrasta con lo que nos encontramos en el CorLexIn, donde los ejemplos se reparten entre la Península y América, en la mayor parte de las ocasiones con la acepción de 'tocado o sombrero': así nos encontramos casos en Huesca, Soria, León, Cuenca y Badajoz, además de en Bolivia y Venezuela.

Por otro lado, en Tierra de Campos encontramos otro ejemplo con la acepción de 'recipiente' dado el contexto, ya que aparece anotado junto a garrafa y cesta carratera. En inventarios de la época también es escasa su presencia, ya que solo encontramos un ejemplo en América: "un platillo de barro de la China y un bonete de vidro"; en estos casos puede hacer referencia a la 3.a acepción recogida por el DLE. 


\section{CABECITO [cabeçito]}

No aparece en el $D L E$, ni en ninguno de los diccionarios académicos ni en ninguna obra lexicográfica consultada. Tal vez sea una forma de designar el capillo.

Un cabeçito de niño (Frechilla, PA-1640)

Tan solo encontramos un ejemplo de esta voz en la zona de estudio. Por el contexto podemos decir que estamos ante una prenda infantil que posiblemente sirviera para tapar y proteger la cabeza del niño.

\section{CABEZóN [caueçón, caveçón, cauezón, cabeçón]}

Sust. m. 'En algunas prendas de vestir tradicionales, tira de tela que rodea el cuello' ( $D L E$, 8. ac.). Este término lo recoge Nebrija como 'cabeçón de camisa'. Covarrubias registra la palabra como 'el cuello del vestido, y de la camisa, en especial los que vsan los labradores que traen escotados los cuellos de los sayos a lo antiguo' y Autoridades introduce una definición más específica de esta prenda: 'cierta lista ò tira de lienzo, que rodea el cuello, y se prende con unos botones, à la qual está afianzada la camísa, que para que pueda estrecharse el tamaño del cabezón se le hacen unos pliegues ò rayados, que se cosen à él: el qual suele ser labrado de hilo, y en algunas partes de seda' (NTLLE, s. v. cabezón, Nebrija, 1495; Covarrubias, 1611; Autoridades, 1729). Aumentativo del término cabeza, del lat. CAPITIUM (DECH, s. v. cabezón).

Otro camisón como el dicho, falta el cauezón (Sahagún, LE-1608) Un camisón de hombre labrado el caueçón (San Nicolás del Real Camino, LE-1631) Una camisa de mujer con su caveçón y puños labrados de ruan (Castromocho, PA-1603) Dos sillas ordinarias y un taburete y una valona y un caveçón (Castromocho, PA-1611) Una camissa de muger delgada con cauezón de seda negro (Frechilla, PA-1642) Una camisa de mujer labrada el cabeçón de seda negra en çinco reales (Villalpando, ZA-1620)

Junto a cuello, valona o gorguera hace referencia a un complemento utilizado en las camisas y camisones, además de otras vestimentas. Este término se documenta en el $C D H$ desde el siglo XIII con esta acepción, aunque su auge en la documentación se experimenta en el siglo XVI. En el siglo XVII este término aparece también en documentos americanos con la acepción que aquí ocupa. Sin embargo, a partir de mediados de este mismo siglo, esta voz parece caer en desuso con el significado de complemento. Esto se ve reflejado en los inventarios de bienes del siglo XVII en los que, si se observan los resultados obtenidos del CorLexIn, el uso de esta voz es menor que otros términos como cuello, valona o gorguera, pues se localizan ocurrencias aisladas en Teruel y León. A estas ocurrencias hay que sumarles las encontradas por Perdiguero en el Archivo General de Simancas, en inventarios de bienes de los moriscos granadinos que residían en Palencia fechados en 1610 -"quatro camisas de muger con cabeçones negros raídos" (AGS, Est. 243)- (Perdiguero, 2012a: 341).

En Tierra de Campos aparecen ejemplos de esta palabra en algunos de los inventarios estudiados; no es tan frecuente como cuello, valona o gorguera, pero sí tiene una representación importante. 
Repertorios actuales como el de Gordaliza (1988: 52) registran este término con acepciones diferentes a la aquí estudiada. Le Men en su estudio sobre el leonés documenta la acepción de 'cuello alto y labrado de la camisa del hombre' en La Bañeza y de 'escote ancho de camisa' en el ámbito rural castellano leonés, entre otras acepciones para este término (Le Men, 2004: 16).

\section{CAPERUZA}

Sust. f. 'Bonete que remata en punta inclinada hacia atrás' (DLE). Autoridades lo describe como 'Cobertura de la cabeza, ó bonéte, que remata en punta inclinada hacia atrás' (NTLLE, s. v. caperuza, Autoridades, 1729). Término derivado de capa, con el sufijo-uza (DECH, s. v. capa).

Una caperuza de contray tassada en dos reales y medio (Celada, LE-1624)

Tan solo encontramos un ejemplo en los textos analizados. Está documentada en el CORDE desde el siglo XV y es abundante en textos del XVI. Sin embargo, en el XVII esta voz debió de entrar en retroceso porque en el CorLexIn tan solo aparece un ejemplo en Toledo "vna caperuça prieta, trayda en medio real".

\section{CAPILLO}

Sust. m. 'Gorro de lienzo que se pone a los niños de pecho', 'capucha y mantilla del traje popular de algunas zonas' (DLE, 1. y 2. ac.). En el Tesoro de Covarrubias aparece como 'Las labradoras de Tierra de Campos usan unos capillos, que le sirven de sombreros y mantellinas, y las señoras de aquella tierra, los traen por bizarría de sedas, de telas, y de bordados' (NTLLE, s. v. capillo, Covarrubias, 1611). Término procedente del lat. *CAPPELLUS, diminutivo de CAPPA 'capa' (DECH, s. v. capa).

Un capillo bueno (Calzada, LE-1601)

Camisas y capillos y cofias de muxer que parecieren en mi casa buenas o malas como se allaren (Sahagún, LE-1606)

Un capillo de estopa (Sahagún, LE-1608)

Un capillo de niño de olanda deshilado de red (Frechilla, PA-1613)

Un capillo de túnica (Frechilla, PA-1640)

Un capillo de penitente en quatro reales (Cuenca de Campos, VA-1666)

Un capillo de toca pajiço con puntas blancas (Villalpando, ZA-1652)

Una camisa de deziplina con su capillo (Villalobos, ZA-1654)

Un capillo de seda con puntas finas y dos camisas nuevas (Villalpando, ZA-1670)

Un capillo de espumilla (Villalpando, ZA-1690)

Encontramos ejemplos en toda la zona de estudio con diferentes acepciones al igual que en el CorLexIn. Por un lado, encontramos capillo con la primera acepción que da el DLE, como 'gorro para cubrir la cabeza a los niños'. Con esta acepción se documenta en un inventario de Badajoz (1683) "un capillo de una niña".

El capillo referencia una parte de la vestimenta talar que también aparece en textos de Ávila, Madrid y Granada. 
En Tierra de Campos, capillo aparece mayoritariamente con el significado que le da Covarrubias a este vocablo. El CorLexIn-además de en la propia Tierra de Campos-lo documenta en zonas leonesas próximas a la zona de estudio y en La Rioja.

En León y en otras zonas de Castilla y León o de Asturias, este término se utiliza con otros significados que no aparecen recogidos en el DLE. Así, se llama capillo a la 'piel de oveja que los pastores se ponen cuando llueve', 'vaina que encierra el grano de trigo' (con este último significado se utilizaba el vocablo en Astorga). También se conocía por capillo a la 'caperuza que se ponía a la rueca para que no se saliera el lino en el hilado' (Le Men, 2004, s. v. capillo). En otros estudios dialectales como el de Gordaliza aparece este término como 'mantilla que usaban las mujeres de Tierra de Campos, de seda, a veces bordada con delizadeza' (Gordaliza, 1988: 59), acepción que parece coincidir con la que encontramos en el corpus recogido.

\section{CARIÑANA [cariñaña]}

Sust. f. 'Toca femenina del siglo XVII ajustada al rostro, como las que usan las religiosas' (DEL). Stevens registra este término y Autoridades lo define como 'espécie de toca que trahían las mugéres ajustada al rostro, al modo que la de las Religiosas' (NTLLE. s. v. cariñana, Stevens, 1706; Autoridades, 1729). Esta voz obedece al nombre de la Princesa de Carignan, que la introdujo en España ( $D E C H$, s. v. cariñana).

Una valona de mujer cariñana con guarnición negra bordada con lentejuelas (Grajal de Campos, LE-1658)

Vna cariñaña blanca con sus puntas blancas, y otra de tela amarilla con guarniçión negra y blanca en quatro ducados (Villalpando, ZA-1652)

Una cariñana con sus juntas blancas y otra de tela amarilla con su guarnición negra y blanca (Villalpando, ZA-1654)

Este término es exclusivo del siglo XVII, en la documentación que conforma el $C D H$ y el CORDE solo aparecen ocurrencias de esta época y con el sintagma 'valona cariñana' y del que Juan de Zabaleta en 1654 escribe 'que es como una muceta, con más labores que si fuera labrada en China. Ésta se prende toda alrededor'. En el CorLexIn no llegan a la media docena los ejemplos de esta voz que se reparten entre algunas localidades de Ciudad Real, donde aparece el sintagma 'valona cariñana', y Villalpando (Zamora) donde aparece el término cariñana como sustantivo, referenciado, este último, en los ejemplos anteriores. Formalmente aparece también cariñaña.

\section{COFIA}

Sust. f. 'Red de seda o hilo, que se ajusta a la cabeza con una cinta pasada por su jareta, que usaban los hombres y las mujeres para recoger el pelo'. 'Gorra que usaban las mujeres para abrigar y adornar la cabeza, hecha de encajes, blondas, cintas, etc' (DLE, 2. a y 3.a ac.). Aparece en Nebrija y Covarrubias que define esta prenda como 'cierta cobertura de la cabeça hecha de red, dentro de la qual las mugeres recogen el cabello'. Sin embargo, en Autoridades no solo se trata de una prenda femenina, sino que 'se sirven los hombres y mugeres para recoger el cabello' (NTLLE, s. v. cofia, Nebrija, 1495; Covarrubias, 1611). Del lat. tardío COFIA íd., de origen incierto, acaso germánico (DECH, s. v. cofia). 
Dos cofias la una labrada de oro y otra de seda buena (Valdavia, LE-1606)

Una cofia sobredorada buena (Santa María del Río, LE-1617)

Una cofia negra tasada en tres reales (Celada, LE-1624)

Una cofia de ruan labrada de negro en seis reales (Sahagún, LE-1633)

Una cofia con puntas de oro vordada (Grajal de Campos, LE-1670)

Una cofia de pinos de oro apreciada en seis reales (Frechilla, PA-1612)

Una cofia de oro biexa (Frechilla, PA-1615)

Una cofia de oro guarnezida (Frechilla, PA-1631)

Una cofia de lienço biexa (Villalón, VA-1642)

Un desaliño, una cofia y un tocado (Medina de Rioseco, VA-1644)

Una cofia y un garbín con puntas en seis reales (Medina de Rioseco, VA-1644)

Una cofia de tafetán colorado guarneçida (Medina de Rioseco, VA-1649)

Una cofia de oro y grana (Villalpando, ZA-1600)

Una cofia de oro y grana de randa de aguja (Villalpando, ZA-1600)

Una cofia de beatilla con una randa de oro (Villalpando, ZA-1620)

Una cofia de beatilla nueba (Villalobos, ZA-1654)

Se trata de una voz cuyo uso está generalizado en el siglo XVII en Tierra de Campos. Se documenta a principios del siglo XII en el Cantar de Mío Cid, y aparecen ocurrencias abundantes del término en el CORDE y en el $C D H$. En el CorLexIn aparece una serie de ejemplos repartidos por la zona central y noroccidental de la Península. Esta voz no tiene la misma presencia que otras prendas destinadas al mismo fin como puede ser el tocado, cuyo número de casos encontrados es mayor. Se trata de una especie de gorro o tocado que servía para recoger el cabello y que se utilizaba como un elemento más de la indumentaria. Con el tiempo este término se hizo más exclusivo para designar parte del uniforme de las doncellas o criadas.

\section{CUBRIDOR}

Sust. m. Este término no aparece en el $D L E$, pero sí en diccionarios preacadémicos como el de Sobrino, que lo define como adjetivo 'el que cubre' (NTLLE, s. v. cubridor, Sobrino, 1705). Se trata de una palabra derivada del verbo cubrir, del lat. COOPERIRE (DECH, s. v. cubrir).

Un cubridor con sus puntas (Valderas, LE-1682)

Una mantilla de bautizar con cubridor de caza con punta y encaje blanco (Medina de Rioseco, VA1647)

Un cubridor de niño de caça acanbrayado con tres baras y media de puntas de monta finas (Medina de Rioseco, VA-1685)

En la zona de Tierra de Campos encontramos algún ejemplo de este término en León y Valladolid. En el CORDE no aparece ningún caso en el siglo XVII, y con la acepción con la que aparece en los textos estudiados, no se documenta hasta el XX. Tampoco encontramos ejemplos en el CorLexIn, por lo que parece que se trata de una prenda poco utilizada en la época. Como suele ocurrir con la vestimenta infantil, no hay demasiados testimonios en los textos. En el caso de los inventarios de Medina de Rioseco (Valladolid), está claro que quienes usaban el cubridor eran los niños; además, en uno de ellos se dice que lo utilizaban para bautizar. En el caso de Valderas (León), aunque no se especifica directamente, este término se encuentra junto a otros donde sí se indica quién lo usa: encontramos "una almillica de niño" o "una camisica de una niña". 


\section{CUELLO}

Sust. m. 'Parte de algunas prendas de vestir que rodea o cubre el cuello' o 'alzacuello' ('tira del cuello en el traje eclesiástico' ( $D L E$, 3. - y 4. a ac.). Término procedente del lat. cŏLLUM ( $D E C H, \mathrm{~s}$. v. cuello).

Otra camisa de muger de manga ancha randada labrado de negro el cuello y puños (Sahagún, LE1600)

Un cuello nuevo de olanda apreçiado en ocho reales (Fechilla PA-1614)

Dos cuellos de bofetán el uno nuevo y el otro biexo (Fechilla PA-1615)

Cuatro cuellos viexos rotos (Fechilla PA-1637)

Otro ferreruelo de bayeta nuevo con cuello de pico (Medina de Rioseco, VA-1644)

Un ferreruelo de paño de quenca pardo oscuro con cuello de riço (Medina de Rioseco, VA-1649)

Más un ferreruelo destameña con el cuello de terciopelo y un poco de la tierra morada (Cuenca de Campos, VA-1666)

Dos cuellos biejos de hombre de ruan (Villalpando, ZA-1620)

Un herreruelo pardo de paño traydo con cuello de fustán (Villalpando, ZA-1620)

Un ferreruelo de paño muy fino aferrado el cuello enbayetado (Villalpando, ZA-1661)

Se trata de un complemento de la indumentaria que comparte significado con la valona y la gorguera. Aun así, hallamos bastantes ejemplos en la zona terracampina. En el CDH encontramos este término con esta acepción en una obra fechada en 1568 y en varios inventarios a finales de siglo. Por otro lado, en el CorLexIn hay unos cuantos ejemplos de esta acepción tanto en la Península como en América; en muchos casos, cuello aparece junto a otros complementos de la camisa como los puños y las mangas, al igual que ocurre en los textos de la zona objeto de estudio.

\section{GANDAYA [gandaia]}

Sust. f. 'Redecilla del pelo' (DLE, s. v. gandaya ${ }^{2}$ ). En diccionarios no académicos como el de Núñez de Taboada aparece con la acepción 'especie de cofia'. Lo recoge con esta acepción el DRAE de 1832 con la forma gandayas (NTLLE, s. v. gandaya, Núñez de Taboada, 1825, DRAE, 1832). Se trata de un término procedente del cat. gandalla, probablemente porque los bandoleros catalanes de los siglos XVI y XVII llevaban el cabello recogido con gandalla (DECH, s. v. gandaya).

Quatro pieças de gandaias de colores (Medina de Rioseco, VA-1645)

Tan solo encontramos un ejemplo en el corpus de la Tierra de Campos en un inventario perteneciente a una tienda de ropa, lo que explica que aparezcan en él ciertos términos específicos del mundo de los ropajes y tejidos. En el $C D H$ aparecen ejemplos de esta voz a partir de la segunda mitad del siglo XVI y siempre en sentido figurado en obras literarias. Tampoco es muy frecuente en los inventarios del siglo XVII; en el CorLexIn aparecen dos casos en Córdoba ("unas senaguas de gandaya" y "un tapapiés de gandaya") y el que aparece en nuestra zona de estudio. En estos tres casos parece claro que no se trata de una prenda de cubrir la cabeza, sino de un tipo de tejido con el que se elaboraban otras prendas. 


\section{GARVÍN}

Sust. m. 'Cofia hecha de red, que usaron las mujeres como adorno' (DLE). En Autoridades esta palabra aparece escrita con la grafía $b$, hasta la edición del DRAE de 1869, donde esta voz remite a la grafía con $v$ (NTLLE, s. v. garvín y garbín, Autoridades, 1734; DRAE, 1869). Se trata de una palabra de origen desconocido ( $D E C H$, s. v. garvín).

Una cofia y un garbín con sus puntas en seis reales (Medina de Rioseco, VA-1644)

Seis garbines con sus puntas (Villalpando, ZA-1645)

Encontramos escasos ejemplos en la documentación terracampina. En el CORDE aparece documentado de forma exigua durante los siglos XVI y XVII. En el CDH esta voz muestra un uso mayoritario en el siglo siglo XVI; a partir del siglo XVII deja de utilizarse en los textos y aparece esporádicamente en compendios de moda u obras literarias y lingüísticas, siempre por vía culta. Por el contexto en el que se encuentran localizados estos ejemplos, parece que se ajusta a la definición que da el diccionario académico.

\section{GOLILLA}

Sust. f. 'Adorno hecho de cartón forrado de tafetán u otra tela negra, que circundaba el cuello, y sobre el cual se ponía una valona de gasa u otra tela blanca engomada o almidonada, usado antiguamente por los ministros togados y demás curiales' (DLE). Esta voz se registra en el Diccionario de Henríquez en 1679 (como 'ornamentum colli contentum') y en el de Stevens en 1706. Más adelante la recoge Autoridades con la acepción que tenemos hoy en día y señalando que 'es moda introducida de cien años à esta parte, con poca diferencia, para el uso de los hombres, y oy solo la conservan los Ministros Togados, Abogados y Alguaciles, y alguna gente particular' (NTLLE, s. v. golilla, Henríquez, 1679; Stevens, 1706; Autoridades, 1734). Voz derivada de gola, del lat. GŬLA 'garganta' (DECH, s. v. gola).

Una golilla con dos valonas de cañamaço finas en nuebe reales (Frechilla, PA-1671)

Este complemento formaba parte del vestido masculino y servía de soporte a la valona. EI término convive con otros como cuello, gorguera y cabezón, todos ellos muy próximos. En Tierra de Campos tan solo se localiza una ocurrencia de esta voz en Frechilla junto a valona, algo común en la época, ya que de los casos que aparecen en los inventarios que conforman el CorLexIn, aparece de manera frecuente "golillas con sus valonas". Esta voz se reparte a lo largo de la Península sin un patrón geográfico claro y resulta de uso general.

\section{GORGUERA}

Sust. f. 'Adorno del cuello, hecho de lienzo plegado y alechugado' (DLE). Este término ya se recogía en Autoridades con esa acepción (NTLLE, s. v. gorguera, Autoridades, 1734). Término derivado del lat. vulgar GŬRGA (DECH, s. v. gorguera)

Una gorguera en dos reales (Frechilla, PA-1612)

Una gorguera de red blanca apreciada en un real (Frechilla, PA-1613)

Una gorguera colchada con sus puntas (Castromocho, PA-1602)

Dos gorgueras (Castromocho, PA-1602) 
Una gorguera de red colchada (2286-08-Castromocho, PA-1603)

Tres gorgueras de ruan (Castromocho, PA-1611)

Una gorguera guarnezida de oro (Frechilla, PA-1631)

Otra gorguera de lienzo (Frechilla, PA-1631)

Una gorguera de terliz labrada (Cuenca de Campos, VA-1660)

Se trata de una palabra documentada en la zona palentina de la Tierra de Campos. La gorguera fue un complemento que tuvo mucho auge en los siglos XVI y XVII: aparece muy documentada dicha voz en el CORDE durante este periodo, aunque a partir de mediados de siglo parece entrar en retroceso. En el CorLexIn se localizan los ejemplos mayoritariamente en la zona noroccidental de la Península, con algún ejemplo aislado en Toledo y Albacete. Este término también llega a América -Panamá y Bolivia-.

Por el contexto en el que se encuentra este vocablo en los documentos analizados, parece que se ajusta a la definición académica, ya que aparece referenciado junto a sayas y cuerpos.

\section{GRIÑóN}

Sust. m. 'Toca que se ponían en la cabeza las beatas y las monjas, y les rodeaba el rostro' (DLE). Autoridades comparte esa acepción y la completa indicando que 'se prende alrededor del pecho'. (NTLLE, s. v. griñón, Autoridades, 1734). Se trata de una voz derivada de greña, emparentada con el radical céltico grěnn- 'pelo en la cara' (DECH, s. v. greña).

Otros dos griñones biexos en dos reales (Sahagún, LE-1600)

Una libra de griñones en diez reales (Sahagún, LE-1602)

Otra toca de griñón buena (Castroañe, LE-1622)

Una camisa delgada y dos tocados, un griñón (Guaza de Campos, PA-1639)

Una gorguera con su valona y un griñón (Castromocho, PA-1603)

Unos griñones y un volante de seda (Castromocho, PA-1603)

Dos griñones de lino y una toca de seda (Villalpando, ZA-1620)

Dos griñones de los anchos buenos en diez reales (Villalpando, ZA-1629)

Este término aparece documentado en el CORDE a partir del siglo XIII; sin embargo, pronto desaparece de la documentación, figurando de forma esporádica en algún tratado sobre el traje. Esta falta de testimonios se extiende a los inventarios de bienes. Tan solo se localizan dos casos de esta palabra en el CorLexIn, en Cuenca y Ávila; en Cuenca aparece "una toca de griñón", donde esta voz parece estar referenciando un tipo de tejido o una técnica textil que también localizamos en Castroañe, localidad leonesa de la Tierra de Campos. El resto de los ejemplos del corpus terracampino se reparten entre la zona de León, Palencia y Zamora. Se trata de una especie de toca que rodea el rostro, la cual no debía ser exclusiva de beatas y de monjas, como señala el DLE, sino también de moriscas (Perdiguero, 2012a: 337).

\section{MANTILLA}

Sust. f. 'Prenda de seda, blonda, lana u otro tejido, adornado a veces con tul o encaje, que usan las mujeres para cubrirse la cabeza y los hombros en fiestas o actos solemnes'. 'Prenda de lana u otra tela para abrigar y envolver a los niños por encima de los pañales' (DLE, 1. a y 2. a ac.). Covarrubias registra el término en plural: 'los paños en que se embueluen los niños desde que 
nacen hasta que se sueltan a andar, que se las acortan'. En Autoridades, mantilla aparece en singular, y se define como 'la cobertúra de bayeta, grana ú otra tela, con que las mugeres se cubren y abrigan: la cual desciende desde la cabeza hasta más abaxo de la cintura' (NTLLE, s. v. mantilla, Covarrubias, 1611; Autoridades, 1734). Se trata de una voz derivada de manto, del lat. tardío MANTUM 'manto corto', que a su vez es de origen incierto; parece haberse extraído del lat. MANTELLUM, que quizá fuese voz antigua en latín (DECH, s. v. manto).

Dos mantillas de ceñir, una nueva y otra mediada (Celada, LE-1600)

Tres mantillas de tocar nuevas (Sahagún, 1608)

Una mantilla verde de cubrir (Sahagún, LE-1615)

Quatro mantillas de ceñir buenas tasadas en quarenta reales (Sahagún, LE-1626)

Una mantilla de paño pardo de cubrir tasada en quatro ducados (Grajal de Campos, LE-1670)

Una mantilla de veinteydoseno azul apreciada en trescientos marauedís (Frechilla, PA-1612)

Una mantilla blanca de grana (Castromocho, PA-1614)

Una mantilla de media grana buena (Autillo de Campos, PA-1649)

Un jubón biejo y una mantilla de estameña (Boadilla de Rioseco, PA-1690)

Una mantilla y una capa de paño pardo (Villalón, VA-1637)

Una mantilla de bautiçar con curbridor (Medina de Rioseco, VA-1647)

Una mantilla de çerro de perpetuán con su guarnición de oro (Tamariz de Campos, VA-1652)

Una mantilla de estameña nueba en diez reales (Cuenca de Campos, VA-1666)

Una mantilla de palmilla (Villalpando, ZA-1600)

Una mantilla de grana colorada en tres ducados (Villalpando, ZA-1613)

Una mantilla azul (Villalpando, ZA-1614)

Una mantilla de estameña bieja tasada en quatro reales (Carrizo, ZA-1646)

Esta prenda es una las vestimentas femeninas más documentadas en nuestra zona de estudio. Las mantillas estaban confeccionadas en una gran variedad de tejidos, desde los más finos, si eran de fiesta, hasta los de menor calidad (Egido, 2010: 107). Esta voz se encuentra documentada extensamente en el CORDE. En la zona leonesa de la Tierra de Campos, se pueden distinguir varios tipos de mantillas: "de cubrir", "de ceñir" y "de tocar"; puede que esta diferenciación viniera dada por el tamaño y la función de la mantilla. Aparece también este término con la segunda acepción, como prenda destinada a los niños pequeños; de hecho, aparece como una prenda utilizada para bautizar a los niños.

Pero, junto a estas mantillas para cubrirse, registramos otro tipo de mantillas que no parecen ser la misma prenda, ya que al parecer su cometido es otro bien distinto. No se trata de una prenda de vestir, sino más bien de una prenda doméstica que servía para cubrir el producto que estuviera en una artesa, para evitar que quedara en contacto con el aire:

Una mantilla de artessa de lana blanca (Grajal de Campos, 1613)

Una mantilla de artesa buena (Sahagún, LE-1608)

Una mantilla de artesa de lino y lana de dos baras (Grajal de Campos, LE-1656)

Esta acepción aparece en la zona más occidental de la Tierra de Campos; en otros lugares se utiliza sábana o manta "de artesa". 


\section{MOÑo}

Sust. m. 'Rodete que se hace con el cabello para tenerlo recogido o por adorno'. 'Lazo de cintas' ( $D L E, 1$. y Y 2.a ac). Autoridades lo define como 'el nudo ó lazo que hacen del cabello, para tenerle recogido. En las mugéres es especie de tocado o peinado [...]' (NTLLE, s. v. moño, Autoridades, 1734). Se trata de un término procedente posiblemente de una raíz prerromana MŪNN- 'bulto, protuberancia', que parece ser variante de la sinónima BŪNN-, cuyos representantes se hallan en todos los romances ibéricos y gálicos, y reaparecen en vasco y aun en los idiomas neocélticos (DECH, s. v. moño).

Un moño rizado con sus aderezos y lazos (Medina de Rioseco, VA-1660)

Tan solo hemos encontrado un ejemplo en los documentos analizados. Por el contexto sabemos que puede tratarse de una especie de tocado que iba adornado. En el CorLexIn aparece un único ejemplo en Tenerife ("un moño") entre valonas y capotillos.

En repertorios más modernos, como el de Le Men, se registra moño en el noreste de León como 'fibras textiles de lino o de cáñamo fino e igual después de maceradas y rastrilladas' (García Lomas, 1949: 208 en Le Men, 2007, s. v. moño).

\section{PAÑUELO}

Sust. $m$. 'Pedazo de tela pequeño, generalmente cuadrado, que sirve para limpiarse la nariz o el sudor y para otras cosas' y 'trozo de tela, por lo general cuadrado y mayor que el de bolsillo, usado para abrigarse o como accesorio en la indumentaria femenina y masculina' ( $D L E, 1$. y 2. a ac.). En Autoridades se registra como 'pedazo de lienzo, seda ó algodón, que sirve para limpiarse las narices, el sudor y para otros usos' (NTLLE, s. v. pañuelo, Autoridades, 1737). Se trata de un término derivado de paño, del lat. PANNUS 'pedazo de paño', 'trapo', 'harapo' (DECH, s. v. pañuelo).

Dos pañuelos de red (Frechilla, PA-1640)

Un pañuelo de ruan biexo (Autillo de Campos, PA-1653)

Un pañuelo de ruan biexo (Autillo de Campos, PA-1653)

Un pañuelo de çerro con unos cordoncillos en real y medio (Fechilla PA-1614)

Un pañuelo con puntas (Medina de Rioseco, VA-1642)

Un pañuelo pequeño con puntas (Medina de Rioseco, VA-1642)

Quatro pañuelos y tres pares de manguillas de Canbray y caza (Medina de Rioseco, VA-1661)

Un pañuelo de Cambray de vara con sus encajes (Villalpando, ZA-1686)

Un pañuelo de caza (Villalpando, ZA-1697)

Aparece documentado en toda la zona de Tierra de Campos excepto en la zona leonesa. En este caso, los ejemplos que aparecen de pañuelo hacen referencia a la segunda acepción que da el $D L E$, es decir, a un tipo de prenda femenina muy común en la época. Para la primera acepción, en esta época aparecen en los inventarios pañizuelo de narices para la zona leonesa y lienzos de narices, repartidos por Valladolid y Zamora:

Un pañizuelo de narizes (Sahagún, LE-1603)

Otro lienzo de narizes (Sahagún, LE-1603)

Un pañizuelo de narizes guarneszido (Grajal de Campos, LE-1613)

Dos panizuelos de narizes buenos (Santa María del Río, LE-1617) 
Tres panizuelos de narizes (Galleguillos, LE-1618)

Dos pañizuelos de narizes (Cea, LE-1621)

Dos lienços de nariçes con quadros y puntas (Medina de Rioseco, VA-1640)

Un lienço de narices (Medina de Rioseco, VA-1642)

Un lienço de narices con una escobilla (Medina de Rioseco, VA-1642)

Seis lienços de narizes dos de canbray y el otro de olanda (Medina de Rioseco, VA-1648)

Un lienzo de narizes blanco de bocadillo bueno (Villalpando, ZA-1699)

\section{PAPAHÍGO [papaygo]}

Sust. m. 'Especie de montera que puede cubrir toda la cabeza hasta el cuello, salvo los ojos y la nariz, y que se usa para defenderse del frío' (DLE). Nebrija lo recoge en su Vocabulario y Covarrubias lo define como 'vna como mascarilla que cubre el rostro, de que vsan los que van camino para defensa del aire, y del frio', definición que mantiene Autoridades (NTLLE, s. v. papahígo, Nebrija, 1495, Covarrubias, 1611, Autoridades, 1737). Término compuesto con el sentido de 'gorro de paño que cubre el cuello y parte de la cara' (DECH, s. v. papahígo).

Otro jubón de hombre de deziplina y papaygo de lienzo (Grajal de Campos, LE-1670)

Tan solo hemos encontrado un ejemplo en los documentos estudiados. Esta palabra aparece documentada en la segunda mitad del siglo XV, y a partir del siglo XVII comienza a ser una palabra en desuso $(C D H)$. Se trataba de un complemento que protegía al viajero de las inclemencias del tiempo. Para algunos autores, el papahigo era un complemento que utilizaban los hombres para protegerse del viento y del frío, que tan solo dejaba un hueco para los ojos (Lasmarías, 2007: 223-224).

\section{REBOCIÑO [rebociño, revoziño, rebocillo, reboceño]}

Sust. m. 'Mantilla o toca corta usada por las mujeres para rebozarse', 'toca de lienzo blanco, comúnmente muy sutil, ceñida a la cabeza y al rostro de las mujeres, que unas veces caía sobre el cuello y los hombros y otras sobre el cuello y el pecho' (DLE). Esta palabra la registra Covarrubias como 'vna mantellina corta, de las damas con que se reboçan al reboçarse, cubrirse el rostro' (NTLLE, s. v. rebociño, Covarrubias, 1611). Es un término derivado de bozo, de origen incierto, quizá de un *BŬCCIU, derivado romance antiguo del lat. BUCCA; pero es posible que este derivado se extrajera del verbo embozar, que entonces vendría de *IMBUCCIARE (DECH, s. v. bozo).

Vn reboçiño de gorguerán açul y paxiço con passamanos de plata y oro que pareçe falso, aforrado de tafetán dorado (Valderas, LE-1647)

Dos reboçiños de bayeta negro de Segovia (Grajal de Campos, LE-1656)

Un rebociño pardo (Castromocho, PA-1602)

Otra basquiña, un rebociño de gorguerán aforrado y un corpiño guarneçido (Guaza de Campos, PA-1637)

Un rebociño de tirela aforrado en tafetán berde (Frechilla, PA-1640)

Un revoziño de baeta biexo (Autillo de Campos, PA-1653)

Un rebociño con galones (Villarramiel, PA-1690)

Un rebociño de paño negro (21Villarramiel, PA-1696)

Un revoziño de tafetán aterziopelado aforrado (Medina de Rioseco, VA-1642)

Un rebociño de bayeta bueno en veinte reales (Medina de Rioseco, VA-1643) 
Un rebocillo de bayeta de Palencia (Medina de Rioseco, VA-1643)

Un rebociño de bayeta acauellada (Medina de Rioseco, VA-1649)

Un reboceño de bayeta de Segovia de la buena con galón de seda y su tafetán negro en setenta reales (Cuenca de Campos, VA-1666)

Un reuoçiño de escarlata con una guarnición de plata (Medina de Rioseco, VA-1685)

Un rebociño de terciopelo con flanjón (Villalpando, ZA-1644)

Un rebociño pardo en tres ducados y medio (Villalpando, ZA-1646)

Se trata de una prenda muy parecida a la mantilla y que aparece documentada a lo largo de toda la Tierra de Campos. En los escasos ejemplos que aparecen en el CORDE, esta voz aparece como sinónimo de mantellina en alguno de los documentos. Los textos en los que se localiza esta voz son en su mayoría del siglo XVII.

El CorLexIn documenta esta voz en el Norte de la Península mayoritariamente, aunque también aparecen ejemplos en Madrid y Toledo; sin embargo, no aparece ningún ejemplo en la zona meridional. Egido también localiza esta prenda en la comarca de los Argüellos, en la montaña central de León (Egido, 2010: 106).

En repertorios dialectales más modernos, en zonas del leonés esta prenda designa un tipo de capa de mujer (Le Men, 2012, s. v. rebociño).

\section{SERENERO}

Sust. m. 'Toca que usan las mujeres en algunas regiones como defensa contra la humedad de la noche' (DLE). Aparece en Autoridades como 'la cubierta de la cabeza que sirve para la defensa del sereno' sin marca diatópica (NTLLE, s. v. serenero, Autoridades, 1739). Se trata de un término derivado de sereno, del lat. SERĒNUS (DECH, s. v. sereno).

Un serenero de tafetán en verde, con puntas de plata (Grajal de Campos, LE-1658)

Un serenero de tafetán de color en nuebe reales (Medina de Rioseco, VA-1640)

Un serenero de tafetán tornasolado con puntas (Medina de Rioseco, VA-1642)

Tan solo aparecen tres ejemplos en los inventarios analizados. Esta falta de ocurrencias se extiende al CORDE, pues todas las que documenta pertenecen al siglo XVII y con la acepción académica. Lo mismo se aprecia en los datos que nos aporta el CorLexIn: tan solo encontramos tres ejemplos dispersos por la Península -Madrid, Córdoba y Almería-. A estos hay que añadir el localizado por Perdiguero en Segovia: "Vn serenero de tafetán de nácar" (Perdiguero, 2012b: 388). En la mayoría de las ocurrencias localizadas, este complemento está confeccionado con tafetán.

\section{SOBARBIO [sobaruios]}

Este término no aparece recogido en el $D L E$, ni en ninguno de los diccionarios académicos, ni tampoco encontramos información en el DECH.

Seis sobarbios, los tres labrados e los otros tres llanos nueuos (Calzada, LE-1601)

Tres sobaruios delgados buenos (Sahagún, LE-1608)

Otro sobarbio de lienzo delgado bueno (Grajal de Campos, LE-1613)

Dos sobarbios biexos (Grajal de Campos, LE-1616)

Quatro sobarbios en diez e seis reales (Sahagún, LE-1633) 
Quatro sobarbios de valor cada uno a quatro reales (Sahagún, LE-1633)

En la comarca de Tierra de Campos se localiza esta voz en la zona perteneciente a León y con la forma con epéntesis de la /i/ sobarbio, con la misma forma que la localiza Egido en inventarios leoneses de Astorga con el significado de 'toca que llegaba hasta la sobarba ocultando el cuello' (Egido, 2010: 98; 2014: 78-79). En el CorLexIn aparece documentado en la localidad leonesa de Santas Martas. En el Fichero General de la Academia aparece una cédula donde se localiza la voz sobarbo en el Vocabulario Medieval de Cejador donde se puede leer "sobarbo, de sobarba, cosa de debajo de la barba. [...]- Sobarbos y velos".

\section{SOMBRERO [sonbrero]}

Sust. $\mathrm{m}$. 'Prenda de vestir que sirve para cubrir la cabeza y consta de copa y ala' (DLE). Término derivado de sombra, del lat. ŬMBRA ( $D E C H$, s. v. sombra).

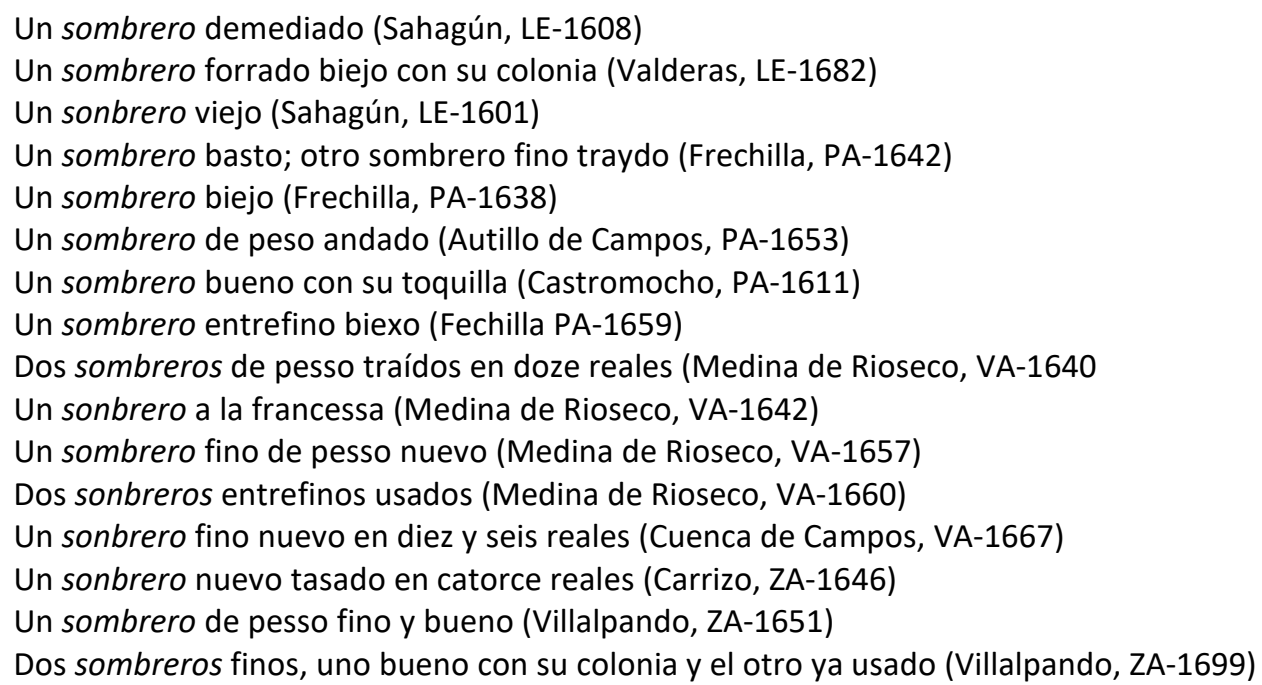

Es una palabra de uso general en el siglo XVII en toda la Península. En Tierra de Campos abundan los sombreros finos, entrefinos, de peso o a la francesa.

\section{TOCA}

Sust. f. 'Prenda de tela con que se cubría la cabeza', 'tela, especie de beatilla, de que ordinariamente se hacen las tocas' ( $D L E, 1$. $\underline{\text { a }}$ y $3 . \underline{a}$ ac.). Esta palabra aparece registrada en Nebrija, Covarrubias y Autoridades con esa acepción. (NTLLE, s. v. toca, Nebrija, 1495; Covarrubias, 1611; Autoridades, 1739). Este término procedente de la forma primitiva TAUCA, aunque tampoco se descarta la posibilidad de que esta a su vez proceda del persa tāq 'velo, pañuelo, chal', transmitido en fecha temprana por el árabe (DECH, s. v. toca).

Quatro tocas de mujer la una nueva y otras de mediada (Celada, LE-1600)

Una toca de ruan buena (Santa María del Río, LE-1617)

Tres tocas de zerro en doze reales (Castroañe, LE-1622)

Una toca de ruan nueva (San Nicolás, LE-1631)

Tres tocas de reina, las dos llanas y la otra con puntas (Villarramiel, PA-1696)

Una toca de seda roja (Autillo de Campos, PA-1653)

Una toca con su encaje (Paredes de Nava, PA-1689) 
Unas tocas de Reyna andadas (Villada, PA-1665)

Una toca de veatilla (Medina de Rioseco, VA-1642)

Una toca capona con puntas alrededor de espumilla (Medina de Rioseco, VA-1649)

Una toca de Reyna con puntas de umo negras (Medina de Rioseco, VA-1660)

Huna toca de lino delgada (Cuenca de Campos, VA-1660)

Tres tocas de mujer buenas (Villalpando, ZA-1660)

Dos griñones de lino y una toca de seda tasadas en siete reales (Villalpando, ZA-1620)

Es un término de uso general ya desde antiguo en toda la Península, según se refleja en el CORDE, y esa presencia es igual de abundante en el siglo XVII, como se puede ver en los datos que ofrece el CorLexIn. En los inventarios de Tierra de Campos se registra un tipo de toca, llamada de reina, que era una toca de seda para ocasiones especiales. Además de como complemento que llevaban las mujeres en la cabeza, toca aparece también en los inventarios como un tipo de tela parecido a la beatilla con la que se elaboraban las tocas; este significado ya se registra en Autoridades.

Una cofia de toca de seda con una guarnizión de puntas buenas (Grajal de Campos, LE-1658)

Un capillo de toca con puntas en quatro reales (Frechilla, PA-1675)

Un capillo de toca Pajico con puntas blancas (Villalpando, ZA-1652)

\section{TOCADO}

Sust. m. 'Prenda con que se cubre la cabeza'. 'Peinado y adorno de la cabeza, en las mujeres'. 'Juego de cintas de color, encajes y otros adornos, para tocarse una mujer' (DLE). Aparece registrada esta voz en el Tesoro de Covarrubias, que la define como 'el ornamento de la cabeça de la muger, y dize más que toca' (NTLLE, s. v. tocado, Covarrubias, 1611). Se trata de una voz derivada de toca (DECH, s. v. toca).

Otro tocado que llaman tocón de Valençia en ocho reales (Sahagún, LE-1600)

Doce tocados los tres delgados y los nueve bastos todos vuenos (Riosequillo, LE-1610)

Seis tocados de muxer (Sahagún, LE-1615)

Tres tocados de mujer en ocho reales (Sahagún, LE-1617)

Siete tocados tasados en tres reales (Celada, LE-1624)

Siete tocados nuevos de valor de ocho reales cada uno (Sahagún, LE-1633)

Tres tocados de las fiestas (Arenillas, LE-1636)

Tres tocados hordinaros y una delgada (Grajal de Campos, LE-1671)

Tres tocados (Castromocho, PA-1602)

Otro tocado recio de puntas (Frechilla, PA-1612)

Onçe tocados buenos delgados de espumilla, algondón y beatillas apreçiados en ochenta reales (Frechilla, PA-1612)

Quatro tocados de coritos (Frechilla, PA-1639)

Un tocado de algodón (Frechilla, PA-1642)

Un tocado aneho andadao (Villada, PA-1665)

Dos tocados de beatilla (Villalpando, ZA-1620)

Dos tocados biexos (Villalpando, ZA-1629)

Palabra de uso general en la época de estudio, tanto en la Tierra de Campos como en el resto de la Península. En los textos analizados parece ser sinónimo de toca; sin embargo, aparecen las dos entradas en los diccionarios, y hay inventarios en los que se hallan toca y tocado en el mismo documento, una al lado de la otra. 


\section{TOQUILLA}

Sust. f. 'Adorno de gasa, cinta, etc., que se ponía alrededor de la copa del sombrero' (DLE, 3.a ac.). En Autoridades, esta voz aparece como sinónimo de toca; Terreros y Pando la registran como un tipo de lino muy claro, y en el DRAE de 1803 se añade el significado de 'cierto adorno de gasa, cinta ú otra cosa que se ponía al rededor de la copa del sombrero' (NTLLE, s. v. toquilla, Autoridades, 1739, Terreros y Pando, 1788 y DRAE, 1803). Es un término derivado de toca, de una base TAUCA, muy antigua en tierras hispánicas, aunque no puede descartarse la posibilidad de que esta a su vez proceda del persa tāq 'velo, pañuelo, chal', trasmitido en fecha temprana por el árabe (DECH, s. v. toca).

Un sonbrero con su toquilla viexo (Cea, LE-1610)

Un sombrero bueno con su toquilla (Castromocho, PA-1611)

Un sombrero bueno con su toquilla apreçiado en diez reales (Fechilla PA-1614)

Un sonbrero fino aforrado de tafetán sin toquilla (Frechilla, PA-1631)

Término poco documentado en el área de estudio, que siempre aparece en el mismo contexto y con la misma acepción. En este caso, toquilla hace referencia a una especie de cinta que llevaban como adorno los sombreros, compartiendo este campo semántico con la colonia. Se documenta en el siglo XVII con esta acepción en documentos del CORDE. Y en el CorLexIn se localiza con esta acepción en inventarios de Toledo; también se recoge este vocablo en otras zonas como Cantabria, Albacete o Segovia, pero con otras acepciones.

\section{VALONA [balona]}

Sust. f. 'cuello grande y vuelto sobre la espalda, hombros y pecho, que se usó especialmente en los siglos XVI y XVII' (DLE, 5. a ac.). Autoridades lo registra como 'adorno, que se ponía al cuello, por lo regular unido al cabezón de la camisa, el qual consistía en una tira angosta de lienzo fino, que caía sobre la espalda, y hombros y por la parte de adelante era larga hasta la mitad del pecho' (NTLLE, s. v. valona, Autoridades, 1739) '[...] introducido en España por los cortesanos procedentes de Valonia que acompañaban a Carlos $V$ [...]. "[...] porque estos mesmos traen unos cuellos de camisas, estendidos y caídos sobre los ombros, llamaron en España balonas las que han empeçado a usar a este modo"' (DECH, s. v. valones).

\footnotetext{
Una valona de mujer cariñana con guarnizión negra bordada con lentejuelas (Grajal de Campos, LE-1658) Una balona con sus puntas (Valderas, LE-1682)

Una gorguera con su balona y un griñón (Castromocho, PA-1603)

Una balona pequeña con puntas y un babadero de niño que tiene puntas (Frechilla, PA-1631)

Una balonçilla como la de arriba (Frechilla, PA-1631)

Una balona (Frechilla, PA-1637)

Una balona nueba (Autillo de Campos, PA-1653)

Una balona de canutos (Paredes de Nava, PA-1689)

Dos balonas de caza (Medina de Rioseco, VA-1939)

Dos valonas de puntas que llaman desaliños en doze reales (Medina de Rioseco, VA-1640)

Una camisa nueba de olanda con balona (Medina de Rioseco, VA-1642)

Otra balona de puntas de umo vlancas (Medina de Rioseco, VA-1660)

Otra balona de puntas de umo negras de dos carreras (Medina de Rioseco, VA-1660)

Una valona de plata y azul con lazos de lo mismo (Medina de Rioseco, VA-1660)
} 
Un bestido de paño pardo digo de color arenoso con jubón y manga de senpiterna con sus çapatos y medias y balona y sombrero (Villalpando, ZA-1647)

Una tabla de balonas (Villalpando, ZA-1666)

Se trata de una prenda muy común en el siglo XVII, según lo demuestra el nutrido número de concordancias que presentan corpus como el CORDE, donde la máxima cantidad de ejemplos se localizan en dicho siglo. Se trata de un tipo de cuello introducido en España por los valones y que complementaba la indumentaria de la época. Por lo que se puede observar en los ejemplos, las valonas solían ir adornadas con puntas, lazos o plumas. Con los datos que nos aporta el CorLexIn se puede apuntar que estamos ante una prenda de uso generalizado en el siglo XVII por toda la Península y también en América.

\section{VELO [belo]}

Sust. m. 'Cortina o tela que cubre algo'. 'Prenda del traje femenino de calle, hecha de tul, gasa u otra tela delgada de seda o algodón, y con la cual solían cubrirse las mujeres la cabeza, el cuello y a veces el rostro' (DLE, 1. Y 2. a ac.). Ya Nebrija diferencia tres tipos de velo, el sagrado que llevaban las religiosas, el velo del templo y el velo o toca de mujer. Covarrubias además indica que es 'el que lleva la novia quando se casa'. Autoridades registra esta voz como 'la cortina o tela delgada que cubre alguna cosa'. 'usase para ocultar lo que no se quier, que esté comúnmente à la vista por respeto, ù veneracion' (NTLLE, s. v. velo, Nebrija, 1495; Covarrubias, 1611; Autoridades, 1739). Término procedente de VĒLUM 'velo', 'tela, cortina' (DECH, s. v. velo).

Quatro velos, los dos nueuos y dos mediados (Calzada, LE-1601)

Un belo de luto (Sahagún, LE-1601)

Un velo delgado de zinco baras bueno (Sahagún, LE-1608)

Otro belo delgado de zinco baras bueno (Sahagún, LE-1608)

Seis belos de belillo de altar de Nuestra Señora (Medina de Rioseco, VA-1651)

Una echura de un Santo Cristo de bulto con su belo y su cajón (Villalpando, ZA-1688)

Es una palabra de uso general en el siglo XVII. En la zona de estudio lo encontramos con dos acepciones diferentes: por un lado, hace referencia al velo que llevan las mujeres y que está documentado en la zona leonesa; y por otro, hace referencia a la cortina que cubría los altares o los santos, que es el tipo de velo que encontramos documentado en Valladolid y Zamora.

\section{VOLANTE}

Sust. m. 'Guarnición rizada, plegada o fruncida con que se adornan prendas de vestir o de tapicería' ( $D L E, 4$. a ac.). En el DRAE de 1780 aparece este término como 'un género de adorno pendiente, que usan las mugeres para la cabeza, hecho de tela delicada' (NTLLE, s. v. volante, $D R A E, 1780)$. Se trata de una voz derivada de volar, del lat. VŏLARE íd (DECH, s. v. volar).

Unos griñones y un volante de seda (Castromocho, PA-1603)

Es una voz poco documentada en la zona de estudio. Por el contexto en el que aparece, se puede intuir que tiene que ver con los complementos que las mujeres llevaban en esa época en la cabeza. En el CORDE aparece documentado en obras de autores áureos y en otro tipo de documentos como cartas de dote, con la misma acepción con la que aparece en el ejemplo 
encontrado en Tierra de Campos. No obstante, se trata de un vocablo poco utilizado en general en los inventarios de esta época, ya que en el CorLexIn solo aparecen ejemplos en tres localidades de Huesca, Teruel y Tenerife.

\subsubsection{Otros complementos}

\section{ABALORIO}

Sust. m. 'Objeto de adorno vistoso y generalmente de poco valor', 'cuenta o pieza taladrada que se ensarta con otras o se cose sobre ciertas prendas como adorno', 'conjunto de cuentas agujereadas, con las cuales, ensartándolas, se hacen adornos y labores' (DLE, 1.르, 3. y 4.a). Aparece registrado en Autoridades como 'cierto género de cuentas de vidro de varios colores, de que se hacen rosarios, collares, lámparas, y otras cosas' (NTLLE, s. v. abalorio, Autoridades, 1726). Término procedente del ár. billáurri 'cristalino' (DECH, s. v. abalorio).

Unas juntas de abalorio de manto (Medina de Rioseco, VA-1639)

Dos relicarios pequeños con cercos de abalorio (Medina de Rioseco, VA-1651)

Este término se documenta en el CORDE a partir del siglo XVI, tanto en singular como plural y con la acepción de 'adorno', generalmente de poco valor. El número de ejemplos encontrados en la literatura contrasta con los datos que ofrece el CorLexIn, donde localizamos dos ejemplos en la Península -Guipúzcoa y Cuenca- y otros dos en América -México y Guatemala-, siempre en singular. Podríamos decir que abalorio tiene un significado genérico que nos sirve para identificar cualquier tipo de adorno, bien sea en los complementos textiles, bien en joyas, sin mucho valor. En Tierra de Campos el uso de este término en los inventarios es exiguo: tan solo aparecen dos ejemplos, ambos en singular como en el CorLexIn, con la acepción de 'adorno'.

Entre los repertorios dialectales actuales, Le Men señala su presencia en el Bierzo y Astorga (Le Men, 2002, s. v. abalorio).

\section{ABANICO}

Sust. m. 'Instrumento para hacer o hacerse aire' (DLE). Aparece registrado en Autoridades como 'diminutivo de abano. Instrumento, que regularmente se hace de cabritilla, ú de papél pegádo á unas varillas mui delgadas de madéra, concha, ó marfil, las quales se unen por un extremo con un clavillo remachado por ambas partes, y hecho un pliegue del papél ó cabritilla en cada varilla, se abre y cierra facilmente, y sirve para hacerse aire. También se suele hacer de concha, talco, y de otras materias'. (NTLLE, s. v. abanico, Autoridades, 1726). Como ya anunciaba Autoridades, se trata de un diminutivo de abano derivado de abanar 'abanicar' del port. y gall. abanar 'aventar, cribar', 'agitar', 'abanicar', y este derivado del lat. vANNUs 'criba' (DECH, s. v. abanar).

Las pieças de vn juego de damas y vn abanico de tafetán berde y negro (Valderas, LE-1647)

Vn abanico de ala de mosca y vnos guantes biexos (Valderas, LE-1647)

Unos abanicos (Paredes de Nava, PA-1689) 
Quatro abanicos de tarco con barillas de marfil y uno de plumas de rasso. (Medina de Rioseco, VA-1660)

Otro abanico de plumas azul y blanco viejo (Medina de Rioseco, VA-1660)

Un abanico de tarcos y barillas de marfil (Medina de Rioseco, VA-1661)

El CORDE ofrece una colección de ejemplos de esta voz desde finales del siglo XVI. Este elevado número de ocurrencias contrasta con los datos que proporcionan los inventarios de bienes, donde el número de casos es inferior. Los datos que aporta el CorlexIn no presentan un patrón claro de reparto geográfico en la Península. Esta voz también aparece en los documentos de América. No es una voz frecuente en los inventarios de la Tierra de Campos, ya que se trata de un elemento muy relacionado con el lujo y el estatus social.

\section{AGUJETAS [aguxeta, auxeta, agugeta]}

Sust. f. 'Correa o cinta con un herrete en cada punta, que servía para sujetar algunas prendas de vestir' (DLE). En Autoridades encontramos que servía 'para atacar los calzónes, jubónes y otras cosas' y que, además de ser de cuero, podían hacerse 'de seda, colónia, hilo, ó lana para el mismo uso' (NTLLE, s. v. agujeta, Autoridades, 1726). Término derivado de aguja, del lat. vulgar ACUCǓLA, diminutivo de ACUs 'aguja' (DECH, s. v. aguja).

\footnotetext{
Aguxetas coloradas finas y de yladillo, una gruesa (Mazariegos, PA-1619)

Un coleto de cordován bueno con passamanos y agujetas (Cea, LE-1621)

Ocho aguxetas de seda (Medina de Rioseco, VA-1642)

Una gruesa de agujetas (Medina de Rioseco, VA-1644)

Auxetas de seda de Ytalia (Medina de Rioseco, VA-1644)

Treinta y quatro gruesas de agugetas de morte coloradas y moradas (Medina de Rioseco, VA-1645)

Dos gruesas y tres docenas de agujetas colaradas de morte (Medina de Rioseco, VA-1645)

De agujetas, volsas, mangas, carzas, beatillas, colonias, rosarico, corchetes y otras cosas de merzería y joería duçientos reales (Medina de Rioseco, VA-1646)
}

Es un término que se documenta sobre todo en la zona vallisoletana de la Tierra de Campos. Se recoge en el CORDE desde el siglo XV, con un incremento importante de casos en el siglo XVI. Sin embargo, parece que su uso en el siglo XVII es menor y la palabra entra en cierto retroceso. Así lo refleja el CorLexIn, en el que se documentan cinco casos ubicados en nuestra zona de estudio y en Teruel. Acerca de la forma cabe señalar que aparece la variante académica salvo en un caso en el que hemos encontrado auxetas, donde se observa la síncopa de la consonante intervocálica, fenómeno ocasional en este tipo de textos notariales (Morala y Egido, 2010: 433). Tal vez este término se vio sustituido por el término cordón; sin embargo, en América el término agujeta con la acepción académica sigue vigente hoy en día.

\section{ALAMAR}

Sust. m. 'Presilla y botón, u ojal sobrepuesto, que se cose, por lo común, a la orilla del vestido o capa, y sirve para abotonarse o meramente para gala y adorno, o para ambos fines' o 'cairel

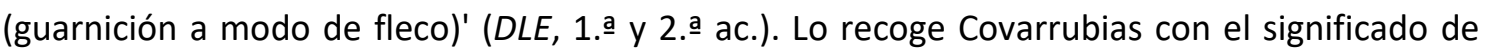
'boton de macho y hembra hecho de trenças de seda, o de oro' (NTLLE, s. v. alamar, Covarrubias, 1611). Se trata de una palabra de origen incierto, quizá del ár. 'amâra 'sedal de pescador', 'guarnición de traje' (DECH, s. v. alamar). 
Una ropa de paño negro veintydosseno nueva con dos alamares (Frechilla, PA-1638)

Una cama de paño berde con alamares de seda berde (Medina de Rioseco, VA-1640)

Un bestido a la francesa de alamares de oro (Medina de Rioseco, VA-1642)

Una cuja de cama de nogal dorada con cortinas, couertor y cielo de damasco carmesí y goteras de terciopelo y flocadura y alamares de oro (Medina de Rioseco, VA-1647)

Cubierta de paño azul con tres pasamanos y alamares (Villalpando, ZA-1633)

La madera de una cama de campo con cinco cortinas, su çielo y cobertor, digo que son seis las cortinas y todo de paño verde, con sus alamares y flocadura de seda verde (Valderas, LE-1647)

En Tierra de Campos, este término aparece con el significado de 'adorno para la indumentaria y la ropa del hogar', tal y como vemos en los ejemplos encontrados en el corpus de estudio. Aparece referenciado siempre en plural. En el CORDE se encuentran ejemplos a partir de mediados del siglo XVI, en plural también. Los casos en singular son más escasos, aunque sí que aparecen. Este corpus nos indica que a partir del siglo XVII esta palabra entra en retroceso. En el CorLexIn aparece documentada esta forma tanto en la Península como en América, con el significado de 'adorno'. Sin embargo, aparece otra acepción para la palabra alamar: se trata de una variante de la voz alfamar, 'manta', donde se ha perdido la /f-/ precedida de la partícula al-, y es habitual la convivencia de las dos soluciones (Morala, 2012e: 93-94). Hasta el momento se han localizado ejemplos de esta variante con este significado en Guadalajara y Segovia. También aparece un ejemplo de alamar con el significado de 'joya' o 'botón', en un inventario de Vitoria de 1638: "Yten, un alamar de plata que pessó dos onzas y media".

\section{ALFORZA [alforça]}

Sust. f. 'Pliegue o doblez que se hace en ciertas prendas como adorno o para acortarlas y poderlas alargar cuando sea necesario' (DLE). Aparece ya en el Vocabulario de Nebrija 'alforza de vestido'. Covarrubias recoge el término alhorza como 'la dobladura que se toma en la saya por la parte de abaxo'. Autoridades la define como 'aquella porción que se recoge á las basquiñas y guardapieses de las mugéres por lo alto, para que no arrastren, y puedan soltarla quando quieran' (NTLLE, s. v. alforza, Nebrija, 1495; Covarrubias, 1611, Autoridades, 1726). Término derivado del ár. húzza íd., de hazz 'cortar, hacer un corte (en algo)' (DECH, s. v. alforza).

\footnotetext{
Una saya colorada ya trayda con dos alforças y ruedo amarillo (Fechilla PA-1612) Una saya parda con un alforça y con un ruedo açul biejo (Fechilla PA-1613) Una saya parda con dos alforças (Frechilla, PA-1613)

Otra mantilla haçul de paño haçul claro con tres budeçillos y una alforça (Frechilla, PA-1616)

Un delantal de estameña freylego llano con una alforça mediado (Frechilla, PA-1631)
}

Este arabismo aparece escasamente documentado en el CORDE. EI CDH recoge esta palabra a finales del siglo XV, en el Vocabulario de Nebrija, y figura, sobre todo, en textos de corte literario en los que alforza se utiliza con un significado figurativo. A partir del siglo XVII, esta voz entra en retroceso en la Península hasta llegar a desaparecer de los textos. Sin embargo, el término alforza se conserva en algunos documentos americanos.

Es un término poco común en la documentación notarial. En el CorLexin no encontramos ninguna ocurrencia de este término, tampoco de la variante castellana alhorza. 
La forma alforza se documenta en algunos inventarios pertenecientes a la localidad palentina de Frechilla, localidad en la que solemos encontrar disparidad de términos referidos a la indumentaria y a las telas, por lo que seguramente estemos ante un tecnicismo textil. La alforza era una especie de dobladillo que se hacía en las sayas para adornar, pero también para subir el largo excesivo de las mismas.

\section{ANTEOJO [antojos]}

Sust. m. pl. 'anteojo binocular' ( $D L E$, 2. a ac.). Aparece en Nebrija la forma antojos equiparada con espejuelos y Covarrubias los define como 'los espejuelos que se ponen delante de la vista, y para alargarla a los que la tienen corta, inuención admirable, y de gran prouecho para los viejos, y los cortos de vista, y para no cansarla leyendo o escriuiendo [...]' (NTLLE, s. v. antojo, Nebrija, 1495; Covarrubias, 1611). Término derivado de ojo, del lat. ŏcŭLUS (DECH, s. v. ojo).

Una caxa con unos antojos (Villalpando, ZA-1689)

Se localiza un único ejemplo en el corpus estudiado con la acepción académica. Sin embargo, hallamos este término muy documentado a lo largo del siglo XVII según los datos que nos ofrece el $\mathrm{CDH}$; hecho que contrasta con la información que nos ofrece el CorLexIn, donde tan solo aparecen cuatro casos en la Península -en Solanilla (León) y Madrid con la variante antojos, y un caso en Huelva con la forma culta anteojos-. Además, registra ocurrencias en documentos de Canarias y América, donde, en proporción, es más frecuente en los inventarios:

Una caxa con tres pares de antojos (Bolivia, 1609)

Tres pares de antojos, los dos con cerco de plata y los unos de acero (Bolivia, 1677)

Quatro antojos (Chile, 1681)

Vn señidor y unos antojos (Panamá, 1681)

Siete docenas de antojos (Bogotá, 1691)

Cabe afirmar que la palabra antojos, siempre en plural, aparece registrada en los diccionarios preacadémicos y en Autoridades. Sin embargo, a partir de la edición de 1770, antojo nos remite al vocablo en singular. De esta forma comienza a adquirir más fuerza el uso de esta lexía, pero ya pasado el siglo XVII, como se puede observar en algunos estudios dialectales como el que hace Gómez Ferrero sobre La Bañeza, donde encuentra muestras de esta variable en el siglo XIX (Gómez Ferrero, 2015: 94).

\section{BANDA [vanda, bandilla]}

Sust. f. 'Cinta ancha de colores determinados que se lleva atravesada desde un hombro al costado opuesto, como distintivo de rangos, honores o dignidades', 'faja (tira de tela o de tejido que rodea la cintura)' (DLE, 1. y y 2. a ac.). La primera acepción que da Autoridades a este término es el de 'adorno de que comunmente usan los oficiales militares, de diferentes espécies, hechúras y colores [...]'. En la edición de 1770 del diccionario, este significado ya aparece como anticuado. Es en la edición académica de 1925 donde se le asigna el significado de 'faja o lista'. En la edición no académica de Terreros y Pando esta palabra se define en primera instancia como 'pieza larga y angosta de ésta, ó la otra tela' y también como 'adorno que se ponían las mujeres'. (NTLLE, s. v. banda, Autoridades, 1726, 1770, DRAE, 1925 y Terreros y Pando, 1786). 
Término derivado del fr. ant. bende, bande 'faja, cinta, venda', y este del fráncico bĭnda (DECH, s. v. banda I).

Vna bandilla de cañutillos de bidrio blancos y negros (Valderas, LE-1647)

Un cofrecito vordado de paja forrado en tafetán amarillo y en él una encomienda de San Joan de azauache y más una muerte y unos panezitos de azavache y una vanda, de canuticos noguerado con su rossa (Grajal de Campos, LE-1658)

Otro regalillo de lienzo delgado con una banda blanca viexo en dos reales (Frechilla, PA-1671)

Otra halmoada de lienzo con banda blanca en siete reales (Frechilla, PA-1675)

Más una banda de tafetán negro (Medina de Rioseco, VA-1640)

Una vanda de tafetán doble con puntas de plata (Medina de Rioseco, VA-1642)

Una banda de oro angostas con ciento y sesenta y tres piezas esmaltada de blanco (Medina de Rioseco, VA-1647)

Una vanda de tafetán colorado (Medina de Rioseco, VA-1651)

Es un término que se encuentra documentado en bases de datos como el CDH o el CORDE desde el siglo XII con diferentes acepciones. También está presente en los documentos que alberga el CorLexIn de la Península y América -en textos canarios también aparece este término, pero no con la acepción principal de complemento o adorno de la vestimenta-. En Tierra de Campos aparece esta voz con la forma académica y dos acepciones principalmente: la de complemento que forma parte del ornamento del traje (suelen estar elaboradas con ricas telas y adornadas con puntas, randas, pasamanos, canutillos, flecos...), y la que hace referencia al adorno de la ropa blanca como almohadas, toallas o regalillos.

\section{BORDÓN}

Sust. $m$. 'Bastón o palo más alto que la estatura de un hombre, con una punta de hierro y en el medio de la cabeza unos botones que lo adornan' (DLE). Aparece en Nebrija como sinónimo de báculo. Covarrubias lo define como 'el baculo en que se sustenta el que camina a pie, y le sirue de cauallo, aunque bastardo' y en el suplemento añade que 'la ley veynte, titulo quatro, partida primera, llama palo codal al bordon de que usa el peregrino' (NTLLE, s. v. bordón, Covarrubias, 1611). Parece tratarse de un término derivado de bohordo, que a su vez procede de bohordar, y su significado sería 'bastón, especialmente el de peregrino' (DECH, s. v. bordón).

Una lança y un bordón de caminantes (Castrillo, LE-1606)

EI CORDE ofrece un abundante abanico de ocurrencias en los textos del XVII, mientras que en el CorLexIn los casos que aparecen son más bien escasos; bordón se halla en un inventario de Albalá, provincia de Cáceres, con una acepción que no incluye la Academia y que referencia la 'vara para llevar los bueyes' -"dos aperos de coyuntas con sus soueos y bordones"-. Se localiza otro caso de bordón en un inventario de Huesca -Panticosa- con la acepción académica, con una función más ceremonial: un "bordón de la Cruz" junto a "dos astas de las banderas". En el caso encontrado en Tierra de Campos, el significado que presenta es el de 'especie de bastón para ayudar al caminante', como refería Covarrubias. 


\section{BOTÓN [votones]}

Sust. m. 'Pieza pequeña de metal, hueso, nácar u otra materia, forrada de tela o sin forrar; que se pone en los vestidos para que entrando en el ojal, los abroche y asegure' (DLE). Término recogido ya en el Vocabulario de Nebrija y que Covarrubias define como 'el globulo, o clauete, con que abrochamos sayos, jubones, y las demás ropas, quecomunmente es redondo, y dixose asi, por la semejança que tieen al voton de la vid, quando brota [...]' (NTLLE, s. v. botón, Nebrija, 1495; Covarrubias, 1611). Término procedente del francés antiguo boton (hoy bouton) (DECH, s. v. botón).

Unas polaynas de pardillo con botones de bidrio (Villadiego, LE-1627)

Vna basquiña y jubón de estameña negra, nueba, con su galón de fleco y botones de bidrio (Valderas, LE-1647)

Una basquiña y juvón de damasco pardo de lauor de nogarrones y un jubón con votones de bidrio y faldilla corta (Grajal de Campos, LE-1658)

Dos corales y ámbar y rosarios bastos y botones de bidrio (Mazariegos, PA-1619)

Una sotanilla nueva de paño negro beinteydoseno con botones (Frechilla, PA-1638)

Quatro docenas de botones de seda negro (Autillo de Campos, PA-1653)

Un ferreruelo de estameña pardo con botones plateados (Frechilla, PA-1675)

Otros uotones de uoema (Bohemia) (Paredes de Nava, PA-1689)

Dos sortijas y un botón de plata (Villarramiel, PA-1696)

Quarenta y ocho botones de oro que pesaron dos onças (Medina de Rioseco, VA-1641)

Doçe almoadas de lienço delgado llanas con sus botones (Medina de Rioseco, VA-1646)

Ducientas y quarenta y cinco gruesas de botones de cerdas (Medina de Rioseco, VA-1645)

Dozena y media de votones de plata (Villalpando, ZA-1620)

Un ferreruelo y sotanilla de bayeta de Palençia bueno con botones de seda (Villalpando, ZA-1629)

Un jubón de estameña parda con pasamanos y botones (Villalpando, ZA-1632)

Una gruesa de botones (Villalpando, ZA-1670)

Es un término de uso general en el siglo XVII, documentado desde antes del siglo XVI en el CORDE. El CorLexIn ofrece un número muy nutrido de ejemplos en la Península, Canarias y América. Esta abundancia de ejemplos en la documentación se hace patente en la zona de estudio donde aparece con dos acepciones principalmente, la de objeto que sirve para abrocharse la indumentaria, y como un tipo de adorno y que se inventaría junto a diferentes joyas.

\section{CARTERA}

Sust. f. 'Objeto rectangular hecho de piel u otro material, plegado por su mitad, con divisiones internas, que se lleva en el bolsillo y sirve para contener documentos, tarjetas, billetes de banco, etc.' (DLE). Tan solo Sobrino recoge este término antes que Autoridades (NTLLE, s. v. cartera, Sobrino, 1705; Autoridades, 1729). Término derivado de carta, del latín charta 'papel', y este del griego xáptns 'papiro, papel' (DECH, s. v. carta).

Otra tabla con sus pies a donde están un escriptorio y una cartera (Grajal de Campos, LE-1658) Yten, dos reales de una cartera de ambar (Paredes de Nava, PA-1689)

Este término es poco frecuente en la documentación del siglo XVII en el CORDE, donde aparece una decena de ejemplos, tres de los cuales pertenecen a un inventario de bienes de 1655: 
[...] una cartera y una cajita de plata aobada / una cartera de ambar con un peinecillo de plata / una cartera bordada con lentejuelas, otra de ambar bordada con arrequiles [...] (Inventario de los bienes de don Martín Martínez, 1655)

En este inventario aparece una cartera como un tipo de bolsa para meter artículos de aseo ("un peinecillo de plata"). El resto de ejemplos hacen referencia a cierto complemento elaborado en ricos materiales. Desde una perspectiva diacrónica, estamos ante una palabra cuyo uso será mayor en siglos posteriores.

Esta falta de testimonios se trasvasa al CorLexIn, donde tan solo se localiza un par de ejemplos en Almería con dos acepciones diferentes; una de ellas se equipara con el término papelera, una especie de contendor de papeles y documentos, y la otra hace referencia a una bolsa confeccionada con "diferentes telas", más relacionada con el complemento del que hablábamos anteriormente.

Los ejemplos encontrados en la Tierra de Campos también presentan estos dos significados: en el ejemplo localizado en Grajal de Campos estamos ante un auxiliar semejante a un cajón donde se guardan documentos, mientras que en el caso de Paredes de Nava, estaríamos ante un complemento fabricado con ricos materiales, en este caso ámbar, lo que hace pensar en un objeto delicado, con cierto valor.

\section{CEÑIDOR [zeñidor, ciñidor, çiñidor, zeñidero, ziñidero]}

Sust. m. 'Faja, cinta, correa o cordel con que se ciñe el cuerpo por la cintura' (DLE, s. v. ceñidor, ceñidero). Aparecen tanto ceñidor como ceñidero en Autoridades, en la edición de 1729; mientras que se marca ceñidero como una voz anticuada con la acepción de 'cinta, cordón, ú otra matéria, con que se ajusta el cuerpo por la cintura', ceñidor se presenta como un término en uso que hace referencia al 'texido de seda negra, de poco más o menos dos varas y media de largo, ò fabricado en forma de red, con un botón gruesso en cada uno de los dos cabos: y por remates unos pendientes retorcidos. Úsanle los clérigos, estudiantes y otras personas, que andan vestidos de hábitos largos, para ceñirse la sotana abierta'. En la edición de 1780, ceñidero aparace como voz anticuada y remite al lema ceñidor 'especie de faxa con que se ciñe el cuerpo por la cintura' (NTLLE, s. v. ceñidor/ceñidero, Autoridades, 1729, DRAE, 1780). Término derivado de ceñir, del lat. CIINGĚRE (DECH, s. v. ceñir).

Dos çeñidores de cama (Cea, LE-1610)

Unos cuerpos de paño azul y un çiñidero con guarnición de plata falso (Grajal de Campos, LE1670)

Un zeñidero de muxer de plata falsa (Grajal de Campos, LE-1671)

Un ziñidero de muger viejo (Grajal de Campos, LE-1671)

Un ceñidor de seda negra apreciado en dos reales (Frechilla, PA-1613)

Un zeñidero de lino labrado de azul (Frechilla, PA-1631)

Un ciñidor y unas çapatillas nuebas (Guaza de Campos, PA-1640)

Un ciñidor de seda nuevo (Medina de Rioseco, VA-1643)

Una loba de seda biexa, rota y añadida y un çiñidor de seda viexo (Medina de Rioseco, VA-1671) 
Tanto ceñidor como ceñidero aparecen en los documentos analizados de la Tierra de Campos. En casi todos los ejemplos localizados, este término tiene el significado que aparece en el $D L E$, 'faja'. Sin embargo, nos encontramos con un ejemplo en Cea en el que esta palabra no hace referencia a un complemento de la indumentaria, sino que parece ser más bien un complemento de la casa, en concreto del ajuar de la cama.

Ambas formas aparecen documentadas en las Cuentas de Gonzalo de Baeza, tesorero de Isabel la Católica, fechado entre los años 1477 y 1491 (CDH, s. v. ceñidor/ceñidero). Es un término que no aparece con mucha frecuencia en la Península; encontramos la voz ceñidor -y ciñidor- documentada en el CorLexIn en las localidades meridionales de Cádiz y Sevilla. Sin embargo, no hay ningún ejemplo de ceñidero en dicho corpus, por lo que se intuye que existía una preferencia por la forma ceñidor. En esta época es muy común la vacilación entre las formas derivadas en -dor y -dero, hasta el punto que todavía hoy no está clara la diferencia semántica entre los mismos. Morala señala que la forma ceñidero aparece en documentos pertenecientes a la frontera del leonés oriental (Morala, 2012b: 337, 346), hecho que se ve reflejado en los ejemplos encontrados en Tierra de Campos. Formalmente, también encontramos en los textos analizados las variantes ciñidor y ziñidero con cierre de la vocal átona.

\section{CINTURA}

Sust. f. 'Cinta o pretina con que las damas solían apretar la cintura para hacerla más delgada' (DLE, 3. a ac.). En Autoridades aparece como 'cinta ó pretinilla, de que suelen usar las damas, ajustada con una hebilla, para hacer mas airoso el talle' y en la edición del DRAE de 1780 ya consideran el vocablo en desuso (NTLLE, s. v. cintura, Autoridades, 1729, DRAE, 1780). Término derivado de cinta, del lat. CǏNCTA (DECH, s. v. cinta).

Una cintura de camafeos y asientos de perlas con beinte y dos pieças (Medina de Rioseco, VA1647)

En corpus como el $C D H$ aparece recogido con este significado desde el siglo $\mathrm{XV}$, en un documento de Pero López de Ayala, fechado en 1402. Aunque este término aparece en obras literarias de autores como Cervantes o Tirso de Molina, figura también en inventarios de bienes pertenecientes a personajes nobles como Ana de Austria o d.a María de Dávalos. Cabe destacar que a lo largo del siglo XVI encontramos ejemplos de cintura como parte de la indumentaria que servía para ajustar el talle y también como un rico ornamento que formaba parte de las joyas.

En el CorLexIn se documenta este término en textos americanos donde se equipara cintura a joya de gran valor:

Una zintura de camafeos, con ueinte y zinco pieças (Potosí, Bolivia, 1609)

Una zintura de muger de oro (Santiago de los Caballeros, Sacatepéquez, Guatemala (1623)

Con ese significado de 'joya' lo documentamos en el único ejemplo registrado en Tierra de Campos. 


\section{COLONIA}

Sust. f. 'Cinta de seda, lisa, de dos dedos de ancha, poco más o menos' (DLE, 2.a ac.). Aparece en Autoridades como 'cierto género de cinta de tres dedos o más de ancho. Suelense hacer lisas o labradas, y de un solo color, o de vários. Pudo llamarse assí por haver venido las primeras cintas de esta calidad de la Ciudad de Colónia' (Autoridades, 1729). Se trata de una palabra derivada de colono del lat. colōnUs 'labriego' (DECH, s. v. colono).

Vna pieçilla de cristal con vna ymaxen de Nuestra Señora con vn niño en los braços pendiente de media bara de colonia negra (Valderas, LE-1647).

Zinco colonias coloradas y azules (Grajal de Campos, LE-1671)

Un sombrero forrado biejo con su colonia (Valderas, LE-1682)

Ciento y noventa varas de colonias negras de Toledo en tres pieças (Medina de Rioseco, VA1645).

Esta voz presenta dos significados en las ocurrencias documentadas. Colonia hace referencia a la 'cinta' que adornaba diferentes ropas y complementos -sombreros, zapatos, mantos- o a la ropa de cama:

Doçe almuadas con su galón de seda y colonias (Medina de Rioseco, VA-1685)

Unos chapines medianos con sus colonias encarnadas (Villalpando, ZA-1652)

Dos sombreros finos uno Bueno con su colonia y el otro ya usado (Villalapando, ZA-1699)

Estas cintas también se contabilizaban en bruto para venderlas, solían ser principalmente de seda, y recibían el nombre de la ciudad alemana de Colonia, donde se fabricaba:

Quinientas y quince varas de colonias de colores en pedaços (Medina de Rioseco, VA-1645).

Doze piezas de colonias de diferentes colores (Medina de Rioseco, VA-1660)

Más ocho baras de colonias negras (Villalpando, ZA-1670)

Estas acepciones se documentan en los textos que conforman el $C D H$ y el CORDE desde finales del siglo XVI y durante el siglo XVII, tanto en textos literarios como en inventarios de bienes, en textos peninsulares y también americanos (CorLexIn). Sin embargo, la vigencia de estas significaciones se amplía en el tiempo y se documentan en inventarios del siglo XIX localizados en La Bañeza como un 'tejido de seda' -"chalecos de colonia"- (Gómez Ferrero, 2015: 97).

\section{CORDÓN}

Sust. m. 'Cuerda, por lo común redonda, de seda, lino, lana u otra materia filiforme', 'cuerda con que se ciñen el hábito los religiosos de algunas órdenes'(DLE, 1. a y 2.a ac.). Presente en los diccionarios desde Nebrija, Covarrubias lo define como 'cuerda: ciñense con estos los religiosos de San Francisco, y algunos otros: y las cintas de seda, que se labran redondas, se llaman cordones à forma' (NTLLE, s. v. cordón, Nebrija, 1595, Covarrubias, 1611), definiciones que se mantienen hasta nuestros días. Término derivado de cuerda, procedente del lat. CHŎRDA (DECH, s. v. cuerda).

Una bolsilla de raso y blanco con la guarniçion y cordones encarnados (Valderas, LE-1647)

Vna bolsa de seda de colores con sus cordones de oro y seda (Valderas, LE-1647)

Una túnica de lienzo y un cordón todo bueno (Frechilla, PA-1675)

Unos cordones de oro que pessan dos doblones de ocho (Paredes de Nava, PA-1690) 
Un cordón de ylo de plata (Medina de Rioseco, VA-1642)

Un cordonçillo de seda de lienço morada (Medina de Rioseco, VA-1642)

Una gruesa de cordones (Medina de Rioseco, VA-1644)

Dos pañuelos de olanda para los sacerdotes con sus cordones para colgar en la cinta (Medina de Rioseco, VA-1644)

Sesenta y una varas de cordones de cañamaço (Medina de Rioseco, VA-1645)

Un cordón con puntas de umo negras (Medina de Rioseco, VA-1660)

Un cordón con su bolsa (Villalpando, ZA-1629)

Una gola y un manipulo con su cordón (Villalpando, ZA-1660)

Es una palabra de uso general, aparece documentada en la Tierra de Campos con las acepciones que le da la Academia. Junto a la forma cordón, encontramos el término cordoncillo que, además de ser el diminutivo de cordón, también hace referencia a 'aquella labor, que en algúnos texidos hace la trama, sin formar dibuxo algúno, y que solo muestra algúna aspereza: como en el rizo, en la tercianela, carro de oro y otros' (Autoridades, 1729); encontramos ejemplos en distintos puntos de la comarca de Tierra de Campos:

Una colcha de cordonçillo nueba grande (Grajal de Campos, LE-1656)

Unos manteles demediados de cordonçillos (Frechilla, PA-1639)

Otra manta blanca de cordonzillo trayda (Autillo de Campos, PA-1648)

Otra manta de cordoncillo buena (Paredes de Nava, PA-1690)

\section{DELANTAL [debantal, avantal]}

Sust. m. 'Prenda, con peto o sin él, que atada a la cintura se usa para proteger la ropa en tareas domésticas o profesionales' (DLE). No aparece recogido hasta Autoridades donde se le equipara al término avantal; en Terreros y Pando ya se identifica con devantal y a partir de la edición académica de 1869 se registra con una definición propia: 'pedazo de tela de que usan las mujeres para cubrir la delantera de la falda, atándolo por la cintura. Se usa también por adorno', 'mandil' (NTLLE, s. v. delantal Autoridades, 1732, Terreros y Pando, 1786, DRAE, 1869). Palabra derivada de delante, del arcaico denante, procedente del lat. İNANTE 'delante, enfrente' (DECH, s. v. delante).

Un delantal de estameña fraylega viejo con listillas azules (Frechilla, PA-1612)

Un delantal de cordellate fraylego viejo (Frechilla, PA-1612)

Un delantal de estameña fraylega bueno en quatro reales (Frechilla, PA-1613)

Un delantal de estameña açul (Frechilla, PA-1639)

Un delantal de estameña (Frechilla, PA-1640)

Un delantal de cordellate nuevo llano (Frechilla, PA-1631)

Otro delantal en dos reales (Fechilla PA-1615)

Un delantal de estameña parado con tres galones de seda negro (Frechilla, PA-1675)

Con la acepción de complemento del vestir -bien para preservar la ropa o bien como adorno- se documenta en el CORDE a partir del siglo XVI, aunque no aparece con tanta frecuencia como otras variantes -avantal, debantal-. Es a partir del siglo XIX cuando esta voz comienza a ser habitual en los textos.

Aunque la forma delantal es la académica, en esta época era la menos frecuente en los textos. Así, en el CorLexIn aparecen media docena de ejemplos repartidos por puntos dispersos de la Península -Atienza (Guadalajara), Cádiz, Mahamud (Burgos), Orihuela (Alicante) y Valle de Guriezo (Cantabria)-. Todos los ejemplos que se documentan en nuestro corpus pertenecen a 
la localidad palentina de Frechilla. En algunos ejemplos, delantal aparece como sinónimo de mantilla, no la que se utiliza para cubrir la cabeza, sino la que va atada a la cintura. Se inventarían entre mantillas los siguientes casos:

Una mantilla delantal fraylego de esta uilla con una alforça (Frechilla, PA-1631)

Una mantilla de estameña fraylega con pasamanos de seda negro / Mas otro delantal de estameña (Frechilla, PA-1631)

Además de la forma académica delantal, tanto en Tierra de Campos como en el CorLexIn aparece la variante avantal:

Dos abantales de lienzo en doze reales (Sahagún, LE-1600)

Un avantal (Castromocho, PA-1602)

Un abantal de estameña açulado en quatro reales y medio (Fechilla PA-1613)

Un abantal de gordellate basto (Fechilla PA-1613)

Un abantal de estameña pardo (Paredes de Nava, PA-1689)

Un abental de estameña tasado en siete reales (Villarramiel, PA-1690)

Un avantal de estameña buriel (Medina de Rioseco, VA-1657)

Dos avantales destameña (Medina de Rioseco, VA-1642)

Un avantal de estameña buriel (Medina de Rioseco, VA-1648)

Un avantal de raja azul con dos guarniciones (Medina de Rioseco, VA-1651)

Un abantal de beatilla (Medina de Rioseco, VA-1660)

Un abental de estameña, no está enpeñado (Medina de Rioseco, VA-1641)

Un abental de estameña en cinco reales (Medina de Rioseco, VA-1643)

Un abental diez reales (Medina de Rioseco, VA-1643)

Un avental de estameña más usado (Medina de Rioseco, VA-1657)

Un auental buriel de dos anchos, otro abental destameña usado (Medina de Rioseco, VA-1657)

Avantal se define en Autoridades como 'paño de seda, lana, algodon, ó lino, de que usan las mugéres por adorno ó limpieza, trahiéndoles atado a la cintúra sobre la basquiña ó brial. Su tamaño es de diferentes manéras, unos cortos, y otros largos. También usan dél los hombres que tratan en algunos oficios mechánicos, para resguardo y limpieza: como son Cocineros, Pasteleros, Zapateros y otros, mientras están exerciendo sus oficios'. Sin embargo, en la siguiente edición del diccionario, este término aparece como una palabra en desuso y remite a la voz devantal. En la edición de 1933 del Diccionario Histórico de la Academia, aparece la entrada abental como voz antigua de delantal. (NTLLE, s. v. avantal, Autoridades, 1726, 1770, Diccionario Histórico, 1933).

Corominas y Pascual (2012) afirman que avantal se usaba de manera corriente hasta el siglo XVII, e identifican abantal como forma empleada en Castilla frente a delantar 'delantal', empleada en Andalucía ( $D E C H$, s. v. delante). Por su parte, Morala indica que es una voz perfectamente viva en la primera mitad del siglo XVII en Burgos (Morala, 2009: 19). En el CorLexIn aparece media docena de ejemplos repartidos por Cuenca, Toledo, La Solana (Ciudad Real), Nava del Rey (Valladolid) y Sahagún (León). En la zona terracampina este término se localiza sobre todo en el área perteneciente a Valladolid. Formalmente, aparecen dos variantes -avantal y avental- debido al cambio de timbre en la vocal átona, frecuente en esta época. Esta voz comparte significado con otros términos como debantal y delantal, así como mandil.

El significado más frecuente de avantal es el académico; sin embargo, en el corpus terracampino aparece en contextos en los que el significado podría ser otro. En Medina de 
Rioseco se inventaría "un abantal de beatilla" junto a toallas, sábanas, almohadas, servilletas..., lo que nos hace sospechar que aquí no figura con el significado que le da la Academia, sino que estaríamos ante un tipo de textil que formaría parte de la ropa blanca.

Además de las formas delantal y avantal, el corpus terracampino documenta debantal. Covarrubias define esta palabra como 'el mandil que se ponen las mugeres delante para hazer hazienda, y no ensuciar las sayas'; no obstante, en Autoridades este término se registra como voz en desuso, menos utilizada que avantal o delantal (NTLLE, s. v. debantal, Covarrubias, 1611, Autoridades, 1732).

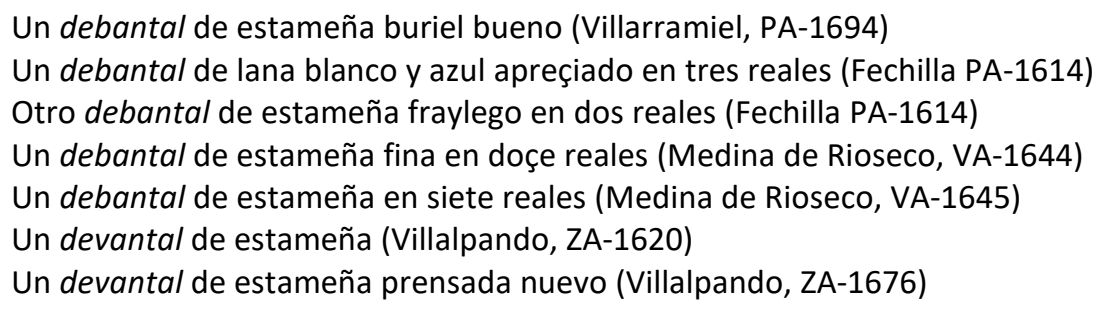

El término aparece en los documentos analizados de la zona terracampina. Apenas se recogen ejemplos de esta variante en el CORDE o el $C D H$; tan solo se registran dos casos en obras literarias. Este hecho contrasta con los datos que ofrece el CorLexln, ya que su uso es más frecuente, por lo que se puede deducir que es de uso general en castellano.

\section{MANDIL}

Sust. m. 'Prenda de vestir que, atada a la cintura, usan las mujeres para cubrir la delantera de la falda y, por analogía, el que usan algunos artesanos, los criados, los camareros y los niños' (DLE). Covarrubias da a este término la misma definición que a debantal 'el levantal que las mugeres de seruicio se ponen delante, por no ensuciar las sayas' (NTLLE, s. v. mandil, Covarrubias, 1611). De la misma etimología que mantel, del lat. MANTÉLE 'toalla', pero llegado probablemente por conducto del árabe (DECH, s. v. mantel).

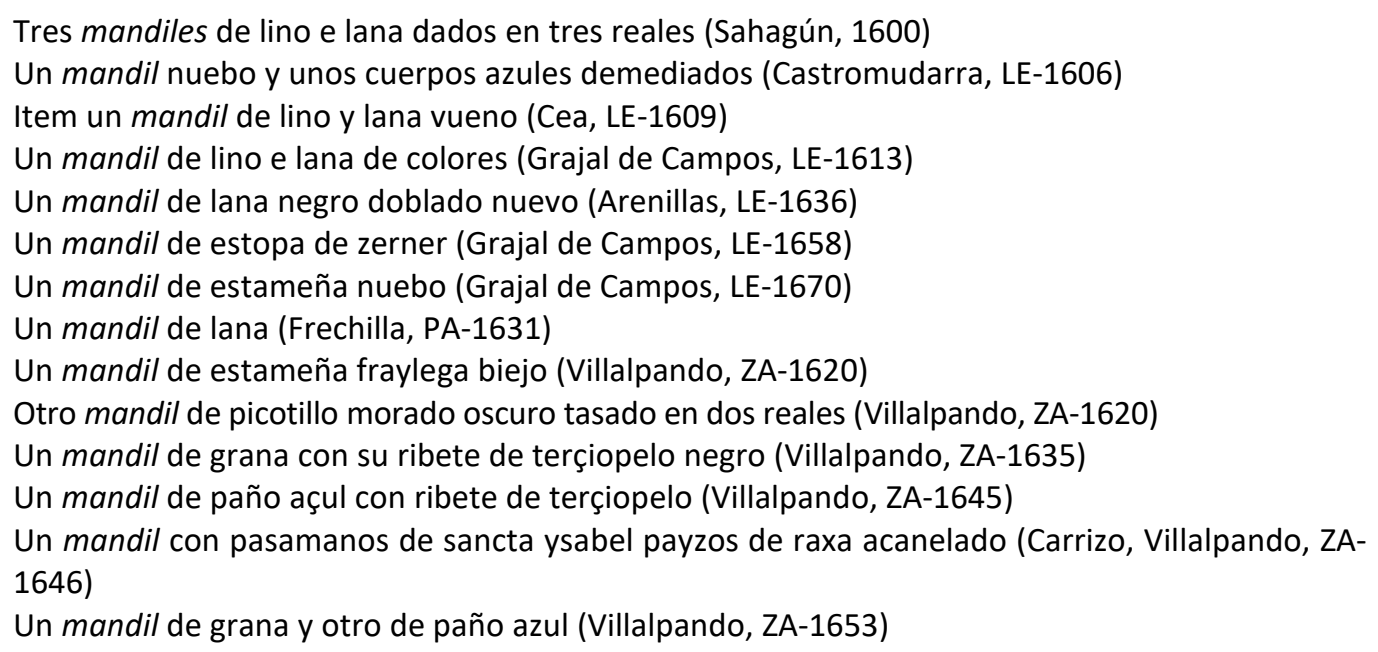

Mandil aparece en el corpus terracampino como sinónimo de delantal en la mayoría de los casos. Existe una preferencia por este término en las zonas más occidentales de la Tierra de Campos -León y Zamora-, mientras que en las localidades pertenecientes a Palencia y Valladolid 
el término más usual son las variantes de delantal (Miguel Borge, 2018: 88). Se documenta en corpus académicos como el CORDE desde el siglo XII hasta nuestros días. Cabe la posibilidad de que exista una diferencia de calidad o de ornato o de forma de manufacturarse.

En ocasiones mandil aparece junto a un sintagma preposicional que especifica la función que tendría esta prenda. Por ejemplo, documentamos un "mandil de ceñir" donde se equipararía al término mantilla, como prenda regional que se utilizaba de cintura para abajo:

Un mandil de çeñir de lino y lana tasado en dos reales (San Nicolás del Real Camino, LE-1631)

También se documenta un "mandil de zerner" que tendría el valor de cernedero, 'el delantal que se pone para delante la que cierne por no enharinar el vestido' (Covarrubias, 1611):

Un mandil de estopa de zerner (Grajal de Campos, LE-1658)

Esta especificidad la encontramos también en otros inventarios de la Península; por ejemplo, encontramos en Cuenca, Teruel o Alicante, un "mandil de horno" y en Cuenca también se localiza un "mandil de coçer" (CorLexIn).

\section{FAJA [faxa]}

Sust. f. 'Tira de tela o tejido con que se rodea el cuerpo por la cintura, dándole una o varias vueltas', 'prenda interior elástica que ciñe la cintura o la cintura y las caderas' (DLE, 1. y 3 . a ac.). Se trata de una voz que recoge Nebrija y que Covarrubias define como 'una cinta ancha, la qual sirue de muchos ministerios: con ella atan los niños despues de embueltos en las mantillas. [...] Faxa, cerca de las mugeres, es vna faldilla, a rayz de la camisa, y esta a prieta con vna angosta que llaman faxero, y tambien faxa. Las guarniciones que echan a los vestidos llaman faxas. Los antiguos usauan, en lugar de calças, vnas faxas que se rodeauan a las piernas [...]' (NTLLE, s. v. faxa, Covarrubias, 1611). Término procedente del lat. FASCĩA 'venda', 'faja', 'sostén del pecho', derivado de FASCIS 'haz'; de procedencia dialectal o tomado de otro romance ibérico (DECH, s. v. fajar).

Una faxa negra de baeta (Grajal de Campos, LE-1613)

Un manto de anescote nuevo con su faxa de tafetán (Castromocho, PA-1602)

Unos cuerpos de paño berde con fajas de terçiopelo berde (Frechilla, PA-1638)

Una faja açul (Frechilla, PA-1640)

Una faxa de cordellate (Medina de Rioseco, VA-1642)

Unos corpiños de grana colorada con fajas y ribetes de terziopelo negro tasados en siete reales (Villalpando, ZA-1620)

Una faxa de paño de Segouia (Villalpando, ZA-1689)

Es una palabra de uso común en esta época. Documentada en bases de datos como el CORDE y el $C D H$ desde el siglo XIII. En la zona de estudio aparece con dos acepciones diferentes. Por un lado, como prenda que permitía fijar y afianzar las ropas, pero también como adorno de las mismas, según vemos en ejemplos de Villalpando (Zamora): "unos corpiños de grana colorada con fajas y ribetes de terziopelo [...]", o de Frechilla (Palencia): "unos cuerpos de paño berde con fajas de terçiopelo berde". En Autoridades ya no se hace mención de 'las guarniciones que echan a los vestidos' de las que hablaba Covarrubias. 


\section{FAJADERO [faxadero, fajaderillo, fajaderuelo]}

No aparece en el $D L E$, ni en el resto de diccionarios académicos.

Un faxadero fraylego roto (Frechilla, PA-1616)

Un fajadero de fraylego (Frechilla, PA-1631)

Un fajadero de paño fraylego (Frechilla, PA-1637)

Un fajadero de niña de paño açul demediado (Frechilla, PA-1640)

Un fajaderillo morado de niño (Frechilla, PA-1640)

Un fajaderuelo morado de niño (Frechilla, PA-1640)

No hay referencias de esta palabra en el CORDE, ni en el $C D H$, ni en otras bases de datos. Tampoco se localiza en los documentos que configuran el CorLexIn. Todos los ejemplos de los que se disponen correspondientes a la Tierra de Campos pertenecen a inventarios ubicados en la localidad palentina de Frechilla. Dato significativo, por ser núcleo de trabajos textiles preindustriales en el siglo XVII (Bellido Blanco, 2006: 273). Por tanto, podríamos estar ante un tecnicismo textil para designar una especie de 'faja' elaborada con un tipo de tela concreto $y$ que vemos en los tres primeros ejemplos por un lado. Sin embargo, en los siguientes ejemplos recuerda a una de las acepciones que Covarrubias daba a faja, como un tipo de cinta ancha 'con que atan los niños despues de embueltos en las mantillas', ya que algunas de las ocurrencias localizadas especifican este uso infantil. Formalmente, la palabra presenta el sufijo de verbal procedente del latín -dero, que alterna con -dor en esta época, hasta el punto de que todavía hoy no está clara la diferencia semántica entre los mismos (Morala, 2012b: 337). A pesar de ser un término poco documentado, presenta las formas diminutivas fajaderillo y fajaderuelo para referirse al uso infantil del mismo.

\section{FAJERO}

Sust. m. 'Faja de punto que se pone a los niños de teta' (DLE). Autoridades recoge este término que Covarrubias incluye dentro de la definición de faja y señala marca diatópica de Castilla la Vieja (NTLLE, s. v. faxero, Autoridades, 1732). Término del lat. FASČ̃ 'venda', 'faja', 'sostén del pecho', derivado de FASCIS 'haz'; de procedencia dialectal o tomado de otro romance ibérico (DECH, s. v. fajar)

Un fajero de lana (Valderas, LE-1682)

Otro fajero de ilo (Valderas, LE-1682)

Un alba y un fajero (Castromocho, PA-1611)

Aparece un solo ejemplo en el CORDE, pero con un significado diferente al encontrado en los inventarios del corpus objeto de estudio y fechado en 1400 :

A un faxero, por portar el dicho retable a Santa Maria, 16 dineros (Gastos de la Catedral de Pamplona)

El recuento también es escaso en el $C D H$, donde los ejemplos no llegan a media docena y, excepto un documento fechado en 1540 -"[...] a tratarme en los brazos, pañales y mantillas y fajeros $[\ldots] "-$-, el resto pertenecen a obras literarias de finales del siglo XX. 
También son escasos los ejemplos en el CorLexIn: aparece un caso en La Alberca (Salamanca) donde tampoco se especifica qué tipo de prenda es y a quién está destinado -habitualmente en los inventarios se suele señalar si se trata de ropa de niño-:

Un fajero blanco de grana / un fajero de corona (La Alberca, SA-1600)

En Tierra de Campos los ejemplos localizados no aclaran inequívocamente a qué tipo de prenda se refieren y si coinciden con la acepción académica. Solo el ejemplo que se localiza en Castromocho aparece junto a un alba, indumentaria talar de los sacerdotes, y que, por tanto, podríamos equiparar al cíngulo que utilizan los sacerdotes para ceñirse el alba al cuerpo. En el resto de ocurrencias no sabemos más que el tejido con el que se confeccionan, por lo que no podemos equipararlo con seguridad a la acepción académica. Mientras en fajadero sí se señala que se trata de una prenda para niños, en el caso de fajero no se especifica.

En la actualidad, aparece en León como 'faja de niño de pañales' en la Vecilla, Valencia de don Juan, Astorga o Murias de Paredes. Además, también se localiza en Zamora, en Toro, en Andalucía como 'ombliguero' y Aragón como 'vestidura de los niños que van en pañales'(Le Men, 2005, s. v. fajero).

\section{JIRÓN [jerón]}

Sust. $\mathrm{m}$. 'Faja que se echaba en el ruedo del sayo o de la saya' (DLE, 4. ac.). En diccionarios no académicos como el de Terreros y Pando, jirón se registra como 'el ruedo del vestido'. Esta voz aparece por primera vez en el DRAE de 1843 con varias acepciones: una, 'la faja que se echa en el ruedo del sayo y la saya', otras son 'pedazo desgarrado del vestido o de otra ropa' y 'parte ò porcion pequeña de algun todo' entre otras (NTLLE, s. v. jirón, Terreros y Pando, 1787; DRAE, 1843). Término procedente del fránc. *gario (DECH, s. v. jirón).

Un jerón de esparto (Frechilla, PA-1613)

Un jirón de lienzo (Villalpando, ZA-1620)

Un jerón de estopa bueno (Villalpando, ZA-1620)

Tan solo encontramos estos tres ejemplos en la Tierra de Campos; de los tres casos, el último parece ser un lapsus del propio escribano: si bien la transcripción se corresponde con el documento, el contexto es significativo, ya que se halla entre una cama con sus sábanas, cabezales, mantas o cobertores, por lo que posiblemente el escribano se olvidaría de la /g/ y realmente se trate de un jergón. En el otro ejemplo de Villalpando, jirón parece hacer referencia a un trozo de lienzo, más cuando a continuación se pone en el inventario "otro pedazo de lienzo", como sinónimo de la voz anterior. Y en el ejemplo de Palencia aparece la variante jerón -de nuevo el cambio de timbre de las vocales átonas señalado por autores como Pascual (2009: 188) o Morala (2012a, 555-556) - y que parece hacer referencia a un 'trozo o pedazo' de esparto, sin más. 


\title{
GUANTES
}

Sust. m. 'Prenda para cubrir la mano, que se hace, por lo común, de piel, tela o tejido de punto, y tiene una funda para cada dedo' (DLE). Término registrado por Nebrija y que mantiene la misma definición desde Autoridades. Voz procedente del germánico, probablemente del fránc. *want (DECH, s. v. guante).

\author{
Vn abanico de ala de mosca y vnos guantes biexos (Valderas, LE-1647) \\ Vnos guantes odinarios de muxer (Valderas, LE-1647) \\ Unos guantes de hombre (Valderas, LE-1682) \\ Unos guantes bordados (Paredes de Nava, PA-1689) \\ Otros guantes leonados (Paredes de Nava, PA-1689) \\ Unos guantes biexos (Baquerín de Campos, PA-1658) \\ $\mathrm{Vn}$ atado de guantes thasado en ocho reales (Medina de Rioseco, VA-1645) \\ Dos pares de guantes de jazmín con lazos azules y alistados (Medina de Rioseco, VA-1660) \\ Siete pares de guantes, todos bordados y los zinco pespuntados con seda de colores (Medina de \\ Rioseco, VA-1661)
}

Término de uso general que en los textos de la comarca terracampina siempre aparece en plural y haciendo referencia al complemento del vestir que se ocupaba de cubrir las manos y cuya función no era solo de abrigo, sino más bien de adorno, a juzgar por las telas y los aderezos empleados para su confección. Se documenta un nutrido número de ejemplos a partir del siglo xIV en el $C D H$. En el CorLexIn también localizamos varias ocurrencias que se distribuyen por Península, las islas Canarias y algún caso en América; no se trata de una presencia tan abundante como ocurre con otros complementos como pueden ser las mangas.

\section{LENTEJUELA}

Sust. f. 'Plancha, pequeña y redonda, de metal u otro material brillante, que se cose en los vestidos como adorno' (DLE). Autoridades lo registra como lantejuela 'cierta pieza de metál chata, y del tamaño y hechura de la lenteja comun, y con un agujerito en medio. Hacianse antiguamente varias labóres con estas lantejuélas, cosiendolas sobre los vestidos y otras ropas', además de señalar que se trataba de un adorno antiguo. El DRAE de 1817 introduce el lema lentejuela, aunque sigue remitiendo a la voz lantejuela. Es en la edición de 1843 cuando aparece la entrada lentejuela con la misma definición que encontramos hoy en día (NTLLE, s. v. lentejuela, Autoridades, 1734, DRAE, 1817, DRAE, 1843). Se trata de un término derivado de lenteja, del lat. LENTǏCǓLA íd., diminutivo del sinónimo LĔNS, -TIS (DECH, s. v. lenteja).

Una valona de mujer cariñana con guarnición negra bordada con lentejuelas (Grajal de Campos, LE-1658)

Dos láminas de papel en sus marcos adobados con sus lentejuelas y ylos de oro (Villalpando, ZA1696)

En bases de datos como el CORDE o el $C D H$ aparecen tanto la forma lentejuelas como lantejuelas, también en singular, con dicha acepción a partir del siglo XVII. En textos anteriores el significado con el que se documenta este término es de 'un tipo de lenteja o altramuz'. Encontramos dos ejemplos en el corpus estudiado: un caso en Grajal de Campos (León) y otro en Villalpando (Zamora), en plural y con la forma lentejuela, los dos con la acepción académica. 


\section{MANGAS [manguillas, manguitas]}

Sust. f. 'Parte del vestido en que se mete el brazo' (DLE). Recogido por Nebrija y Covarrubias que define esta palabra como 'la parte de la vestidura, que cubre los braços' y que más tarde mantiene Autoridades (NTLLE, s. v. manga, Nebrija, 1495, Covarrubias, 1611, Autoridades, 1734). Voz procedente del lat. MANǐCA íd., derivado de MANUS 'mano' (DECH, s. v. manga).

Unas mangas de la niña nuevas de lana (Sahagún, LE-1608)

Unas mangas de lino biexas (Santa María del Río, LE-1617)

Unas mangas de lana de colores nuebas de mujer en tres reales (San Nicolás, LE-1631)

Un par de mangas de aguja biejas de valor de tres reales (Sahagún, LE-1633)

Quatro pares de mangas de lana de aguxa de color finas (Mazariegos, PA-1619)

Unas mangas de raso negro de ombre andadas (Paredes de Nava, PA-1690)

Unas mangas de camuza (Medina de Rioseco, VA-1642)

Unas mangas de piñuelas (Medina de Rioseco, VA-1649)

Unas mangas de chamelote sacadas bocados sobreazul traydas (Medina de Rioseco, VA-1660)

Unas mangas de sarga usada (Villalón, VA-1642)

Un jubón de filipechín con mangas de gorgerán (Carrizo, Villalpando, ZA-1646)

Se trata de un complemento de la indumentaria que se añadía a aquellas prendas que carecían de las mismas (Egido, 2010). Se combinaban con diferentes materiales y colores y se sujetaban a los cuerpos, las sayas o el jubón con agujetas. Este término se documenta a partir del siglo XII en el $C D H$. El término mangas como complemento textil es habitual en los inventarios de bienes que conforman el CorLexIn y que se localizan en la Península y sus colonias de ultramar. En Tierra de Campos aparece con la forma y la acepción académicas.

En esta zona se localiza también la forma diminutiva de esta voz, manguillas, muy habitual en los textos a partir del siglo XVI y durante principios del siglo XVII $(C D H)$ :

Unas manguillas de tafetán amusco (Valderas, LE-1682)

Unas manguillas de nabal blancas (Paredes de Nava, PA-1689)

Unas manguillas de tafetán biejas (Castromocho, PA-1611)

Unas manguillas de canbray (Medina de Rioseco, VA-1660)

El CorLexIn nos ofrece una serie de ejemplos de esta voz ubicados mayoritariamente en la zona meridional de la Península -Córdoba, Almería, Huelva, Badajoz-, aunque también localiza casos en Teruel y en América-Bolivia y Chile-. En los casos del sur peninsular se hace referencia a un tipo de mangas confeccionadas principalmente con lienzo, aunque hay un caso de "manguillas de seda" a las que el escribano añade "del tiempo antiguo", lo que haría pensar que las manguillas elaboradas con telas más ricas ya estaban en desuso. Sin embargo, tanto los ejemplos de Teruel como los de América y los de la zona de estudio presentan unas manguillas, confeccionadas con tejidos de seda, como un complemento de cierto valor. Hoy en día, el término manguilla se conserva en Chile para designar la 'manga superpuesta para preservar la ropa' (DLE).

Otro diminutivo que aparece es manguitas, cuya presencia es bastante menor que la del anterior $y$, en el caso que encontramos en nuestra zona, referencia una vestimenta infantil.

Dos pares de manguitas de niño de ylo fino (Medina de Rioseco, VA-1660) 


\section{MANGUITO [mangito]}

Sust. m. 'Manga sobrepuesta para preservar la ropa'. 'Rollo o bolsa, con aberturas en ambos lados, comúnmente de piel fina y peluda, y algodonado por dentro, que usaban las señoras para llevar abrigadas las manos', 'media manga de punto que usaban las mujeres ajustada desde el codo a la muñeca' (DLE). Lo recoge Autoridades como 'cierto género de manga abierta por ambos lados, hecha de martas ú otras pieles adobadas; que sirve para traher abrigadas las manos en el invierno, metiendolas cada una por su lado' y también 'la media manga ajustada al brazo, que llega desde el codo á la muñeca' (NTLLE, s. v. manguito, Autoridades, 1734). Término derivado de manga, y esta a su vez del lat. MANǐca íd., derivado de MANUS 'mano' (DECH, s. v. manguito).

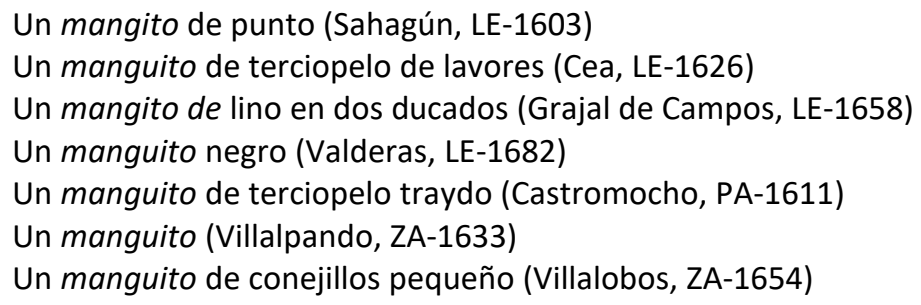

Es un complemento que usaban tanto hombres como mujeres para protegerse del frío, aunque en algunas ocasiones por la cantidad de adornos que lleva y el tejido del que está elaborado parece ser más un elemento de adorno y boato. Se documenta en el $C D H$ a finales del siglo $x V y$, aunque con menos frecuencia, continúa presente en los textos con esta acepción hasta el siglo XIX. En el CorLexIn aparecen siete ejemplos de esta palabra en la Península -repartidos sin un patrón claro- y Canarias. Se documentan "un manguito de martas finas" o "tres manguitos blancos de corderillos", pero también los hay de cotonía o de terciopelo, lo que nos hace suponer que este tipo de complemento también era indicador del estatus social que ocupaba quien lo poseía.

\section{PESTAÑA}

Sust. f. 'Adorno estrecho que se pone al canto de las telas o vestidos, de fleco, encaje o cosa semejante, que sobresale algo' (DLE, 2.a ac.). Este significado está presente en la tercera acepción de Autoridades 'por semejanza llaman qualquier adorno angosto, que ponen al canto de las telas ù vestidos, de flueco, encaxe ù cosa semejante, que sobresale algo' (NTLLE, s. v. pestaña, Autoridades, 1737). Es una voz de origen incierto, seguramente prerromano (DECH, s. v. pestaña).

Unos cuerpos negros demediados con pestañas de oro (Frechilla, PA-1640)

Una vasquiña destameña nueba con pestañas (Medina de Rioseco, VA-1651)

Con este mismo significado la encontramos en bases textuales como el $C D H$ a partir del siglo XV, en la Crónica de los Reyes Católicos, donde aparecen "ribetes y pestañas de seda en las ropas". Las escasas ocurrencias que ofrece el CorLexIn se reparten entre la Península -Madrid y Sevilla- y América, con tan solo un caso en México. Este uso exiguo de la palabra se traslada a la Tierra de Campos, donde solo se localizan dos ocurrencias en dos localidades destacadas de 
la manufactura textil, Frechilla y Medina de Rioseco. En cuanto al significado, todos los ejemplos encontrados, tanto los hallados en el CorLexIn como los de la zona terracampina referencian un tipo de adorno o complemento de la indumentaria femenina, ya que se encuentra en basquiñas, cuerpos, coletillos o ropas de mujer.

\section{PRETINA [petrina, pretinilla, petrenilla, petrinilla]}

Sust. f. 'Correa de cinta con hebilla o broche para sujetar en la cintura ciertas prendas de ropa', 'parte de los calzones, briales, basquiñas y otras ropas, que se ciñe y ajusta a la cintura' (DLE, 1. y 3.a ac.). Lo registra Autoridades con estas mismas acepciones (NTLLE, s. v. pretina, Autoridades, 1737). Este término procedente del lat. PECTORĪNA, que da como resultado petrina y que por metátesis pasa a la forma pretina ( $D E C H$, s. v. pecho).

Una pretina en un real (Frechilla, PA-1613)

Una petrina (Frechilla, PA-1631)

Un rosario y una petrina (Baquerín de Campos, PA-1658)

Unas pretinillas de estameña buriel en diez y seis reales reales (Medina de Rioseco, VA-1641)

Tres reales de una pretenilla de garrubilla (Medina de Rioseco, VA-1642)

Una pretinila de grana guarnecida de Santa Ysavel (Cuenca de Campos, VA-1666)

Una pretina viexa (Villalón, VA-1642)

Una petrenilla de senpiterna nueba azul guarnecida de pasamanos de Santa Ysabel (Cuenca de Campos, VA-1668)

Una pretinilla de piñuela negra y açul celeste guarnecida con tres guarniciones fino (Villalpando, ZA-1652)

Este término presenta dos variantes en los textos, la normativa pretina con metátesis y petrina, esta última se conserva todavía hoy en el área del asturleonés (Le Men, 2009, s. v. petrina). El contexto en el que aparece no da muchas pistas para dilucidar su significado exacto; en ninguno de los casos sabemos de qué material está confeccionado. Las consultas en el CorLexIn nos muestran pretinas comunes en Teruel y comunes, finas y entrefinas en Tudela (Navarra), que, por estar al lado de ropa, suponemos que se trataba de un complemento más. También encontramos en documentos de Cantabria y Salamanca con la variante petrina con esta misma acepción. Sin embargo, existe otra serie de ejemplos en los que el significado de esta voz es diferente y que aparece también en documentos de la Península, además de todos los que se localizan en América. Se trataría de un elemento que forma parte del campo semántico de las armas, pues en los casos encontrados aparece junto a tiras y tiros de espadas, dagas y machetes. En la zona de estudio también encontramos un ejemplo en Medina de Rioseco, donde localizamos "una pistola con pretina".

El diminutivo pretinilla, que también presenta la forma petrenilla, siempre aparece junto al tipo de tejido con que está elaborada (estameña, garrubilla, sempiterna, piñuela o perpiñán). Autoridades define este diminutivo como 'cierto género de adorno que trahen las mugeres ceñido à la cintúra: y es una cinta, galón ù otra cosa assegurado por delante con una hebilla: y à veces solía estar guarnecido de piedras preciosas' (NTLLE, s. v. pretinilla, Autoridades, 1737). 


\section{PUÑO}

Sust. m. 'Parte de la manga de la camisa y de otras prendas de vestir, que rodea la muñeca' o 'adorno de encaje o tela fina, que se pone en la bocamanga' (DLE, 3. y y 4 . a ac.). Estas acepciones se mantienen desde Autoridades (NTLLE, s. v. puño, Autoridades, 1737). Término procedente del lat. PǓGNUS (DECH, s. v. puño).

Unos puños de hombre (Cea, LE-1610)

Unos puños de camisa (Grajal de Campos, LE-1616)

Unos puños e unas mangas de muger en seys reales (4148-08-Sahagún, 1600)

Una camisa con las randas de ruan y su cabezón y puños labrados (Castromocho, PA-1602)

Una camisa de mujer con su caveçón y puños labrados de ruan (Castromocho, PA-1603)

Corominas y Pascual (2012) señalan que es una palabra de uso general en todas las épocas y común a todos los romances y documentan esta acepción de complemento del vestir en el Cantar de Mio Cid (DECH, s. v. puño). En los documentos, cuando corresponde a esta acepción siempre aparece en plural, ya que los puños, al igual que las mangas, van por pares. En Tierra de Campos aparece el término con este significado y referenciado junto a camisa, mangas y cabezones. No es un complemento muy usado a juzgar por las veces que aparece en los documentos, pero está extendido por diferentes puntos de la Península. En otros lugares aparece en singular y con la acepción de 'puño de bastón' o 'puño de daga': así encontramos un ejemplo en Almería ("vna guarniçión de daga con su puño o pomo") y en Canarias, donde no encontramos ningún ejemplo del complemento del vestir, y donde además aparece "tierra de puño" o "media fanega de puño". En América ocurre algo parecido: el mayor número de ejemplos hace referencia al 'puño de la espada', aunque también aparecen en México casos de "puños de muger" junto a un cuello.

\section{REGALILLO [regalico]}

Esta voz aparece en el DLE como 'manguito de las señoras para llevar abrigadas las manos' y así se documenta en algunos textos de la época. Covarrubias también lo identifica con el 'manguito en que las damas traen metidas las manos, aforrado en martas, ó en otras pieles' (Covarrubias, 1611 , s. v. regalo). Sin embargo, la acepción que encontramos en nuestro corpus no parece tener relación con el complemento para abrigar las manos. Se trata de una voz derivada del verbo regalar 'agasajar', de posible origen germánico (DECH, s. v. regalillo).

Dos regalillos de lienzo fino con los bordes de seda negro en catorce reales (Frechilla, PA-1671) Otro regalillo de lienzo delgado con una banda blanca viexo en dos reales (Frechilla, PA-1671) Un regalillo en un real (Medina de Rioseco, VA-1642)

Un regalillo (Villalpando, ZA-1601)

Otros dos regalillos labrados con seda amarilla y negra, otro regalillo labrado de amarillo (Villalpando, ZA-1644)

Se trata de un vocablo escasamente documentado en los textos analizados. Si consultamos bases léxicas como el $C D H$, tan solo aparece en un documento de Quevedo de finales del siglo XVI con la acepción académica: "El regalillo de martas que pide con tantas veras". El resto de ejemplos que aparecen en la documentación se localizan como diminutivo de la palabra regalo y se ubican en textos americanos en su mayoría $(C D H)$. Sin embargo, en el CORDE existen más 
documentos donde aparecen ejemplos de esta palabra con el significado académico de 'manguito' -"[...] los guantes, manoplas; el regalillo, espada; el abanico[...]" , "[...] este cuello, esta gargantilla de perlas, este regalillo y este abanillo [...], "que mehe de arañas el rostro / con martas de un regalillo", "con un sombrero que salía sobre la capa, una roseta, guantes y regalillo negro, con bota justa y chinela [...]"-, datados todos ellos entre finales del siglo XVI y principios del XVII. Sin embargo, esta palabra aparece con el significado de 'almohada', en dos casos, uno en un documento de Fray Juan de los Ángeles ("con la izquierda me sirve de regalillo ò almohada para mi cabeza") que equipara esta voz con almohada; y otro de San Juan Bautista de la Concepción en el que escribe ("iQué presto se le pegó el regalillo y las sábanas de la cama [...]"), ambos casos de principios de siglo XVII. En los protocolos notariales que conforman el CorLexIn se localizan apenas un par de ejemplos, el primero en Guadalajara, que hace referencia a 'parte de los complementos de mujer' y que podría coincidir con la acepción académica, y el segundo en la población leonesa de Villacelama, donde aparece "una almoada fundada, un regalillo fundado" de 1638. Los ejemplos hallados en Tierra de Campos están entre almohadas, servilletas, paños o fruteros, siempre con ajuar doméstico, no con los complementos de la vestimenta, por lo que posiblemente la acepción coincidiría con la de los ejemplos encontrados en el CORDE y sería una especie de almohadilla pequeña, ricamente adornada.

Además de la forma regalillo, documentamos regalico, que no aparece en los diccionarios académicos ni en las bases de datos como el CORDE o el $C D H$ con la acepción que encontramos en la zona de estudio. Así encontramos los siguientes ejemplos en la Tierra de Campos:

Una almoada con su regalico labrado de amarillo en nueve reales (Sahagún, LE-1605)

Una almoada y un regalico de olanda viexa con guarniçión de ylo açixado (Medina de Rioseco, VA-1644)

Dos almuadas de ruan con su regalicos labradas de pinos negros (Villalpando, ZA-1620)

Una almuada y un regalico de olanda labrado de amarillo (Villalpando, ZA-1639)

Un regalico de olanda (Villalpando, ZA-1688)

Podemos afirmar que se trata de una voz documentada especialmente en la Tierra de Campos como un tipo de almohada. Puede que la acepción académica no esté muy presente en la documentación por tratarse de un complemento que implicaba cierto lujo y poder adquisitivo.

\section{TRANZADERAS [trançadera]}

Sust. f. 'Lazo que se forma trenzando una cuerda o cinta' (DLE). Se registra en la edición de Autoridades de 1737 con la misma acepción que conservamos hoy día. Término derivado de tranzar (DECH, s. v. tranzar).

Dos libras de trançaderas de belduque he ylo açul y de caparrosa con cerdones (Mazariegos de Campos, PA-1619)

Unas trançaderas moradas (Baquerín de Campos, PA-1658)

Nobenta y quatro pieças de trançaderas pineras, moradas y de color (Medina de Rioseco, VA1645)

Nueue doçenas y tres pieças de tranzaderas de belduque blancas (Medina de Rioseco, VA-1645) Treinta y siete pieças de trançaderas, piñeruelas y chorrillos (Medina de Rioseco, VA-1645)

Vn guardaynfante nueuo, siete reales, con trançaderas coloradas (Villalpando, ZA-1652)

Mil ciento y treinta y ocho marauedis de fustán, botones, seda, bayeta de aforro, trancaderas, bayeta para mangas aforro dellas y hechura de todo el dicho bestido (Villalpando, ZA-1656) 
La voz tranzadera referencia un tipo de lazo trenzado que servía de adorno y complemento a las vestiduras. En los escasos ejemplos que aparecen en el CORDE, esta voz se corresponde con la acepción de 'especie de rienda que forma parte de los arreos del caballo'. En el CDH apenas aparecen media docena de ejemplos que no sobrepasan el siglo XVII y que representan un significado diferente: en una obra de Juan Pedro de Aguado, este escribe "[...] se recogen el cabello con vnas anchas trançaderas de algodon, y lo juntan todo al colodrillo"; este ejemplo nos puede dar pistas de uno de los usos este adorno, tal vez para recoger el pelo por la espalda.

El CorLexIn muestra un escaso número de ocurrencias, repartidas mayoritariamente en la Tierra de Campos, aunque documenta esta voz también en Guadalajara. Además, habría que añadir las localizadas por Morala (2018a: 89) en Cáceres, Cantabria, Huesca, Guipuzcoa y Navarra. En la Tierra de Campos, donde se encuentra un mayor número de referencias, la acepción con la que aparece es de 'adorno o complemento'. En algunos documentos aparece la variante trenzadera recogida por Autoridades como sinónimo de tranzadera y como aragonesismo cuando hace referencia a la 'cinta de hilo'. Esto ya ha sido señalado por Enguita y Arnal, que mencionan la presencia de esta voz en los protocolos aragoneses también del siglo XVII (Enguita y Arnal, 1994: 58). No se localiza en estudios dialectales actuales. Se trata de una voz que estuvo presente en los documentos notariales desde finales del siglo xv y que en el siglo XVII entró en retroceso. Debemos puntualizar que los ejemplos pertenecientes a la localidad vallisoletana de Medida del Rioseco pertenecen a un inventario de una tienda de ropa.

\section{VUELTA [uuelta, buelta] (Vid. Joyas)}

Sust. f. 'adorno que se sobrepone al puño de las camisas, camisolas, etc.', 'tela sobrepuesta en la extremidad de las mangas u otras partes de ciertas prendas de vestir' o 'embozo (parte de la capa)' (DLE, 14. a , 15. a y 16. ac.). En Autoridades aparece también con varios significados entre los que se encuentra 'el adorno, que se sobrepone al puño de las camisas, que es una tira plegada, y ancha de lienzo delgado, ò encaxes', o también 'se toma por la labor, que se dá à la tierra, ò heredad: y assi se dice: Esta tierra está de una vuelta, está de dos vueltas' (NTLLE, s. v. vuelta, Autoridades, 1739). Término derivado de volver, del lat. VŏLVĔRE (DECH, s. v. volver).

Otro sayuelo de raso liso aforrado de bocazí con buelta de tericiopelo (Sahagún, LE-1600) Otro ferreruelo de estameña bueriel bueno con vuelta de terciopelo usado (Autillo de Campos, PA-1647)

Un ferreruelo de paño negro veinteydoseno con vueltas de terciopelo (Frechilla, PA-1637)

Un ferreruelo de paño pardo de esta dicha villa bueno guarnecido con buelta de terciopelo negro (Frechilla, PA-1631)

Un ferreruelo de paño fraylego con buelta de paño negro (Frechilla, PA-1637)

Una capa de paño pardo casero con buelta de terçiopelo (Guaza de Campos, PA-1640)

Una camissa valona nueba con bueltas y con puntas grandes de olanda (Medina de Rioseco, VA1642)

Una ropa de bayeta de Seuilla con tres ribetes con bueltas de tafetán (Villalpando, ZA-1632)

Una ropa de terciopelo negro con pasamanos y bueltas de tafetán negro (Villalpando, ZA-1644)

En estas ocurrencias recogidas de la Tierra de Campos, la acepción con la que aparece la voz vuelta es la académica, como el 'adorno' o como 'parte de la capa'. Sin embargo, esta palabra es 
polisémica y en los documentos analizados aparece con otras acepciones que no se recogen en los diccionarios académicos; por ejemplo, con el significado de 'collar' o 'hilo del collar':

Yten, un sartal de coral hueso de tres uueltas (Sahagún, LE-1600)

Item, un sartal de corales de dos vueltas con una sarta de christal (Riosequillo, LE-1610)

Yten, unas vueltas de coral (Sahagún, LE-1615)

Más una gargantilla de siete bueltas de alxófar (Grajal de Campos, LE-1658)

Dos bueltas de corales con dos alconçies de plata (Frechilla, PA-1616)

Zinco vueltas de corales que pesan (Medina de Rioseco, VA-1660)

Una gargantilla de perlas de quatro vueltas y manillas de lo mismo (Medina de Rioseco, VA-1660)

Un cabestrillo de aljófar de quatro bueltas (Villalpando, ZA-1631)

Egido señala que en algunos casos estos collares se nombran por el número de vueltas que lo componen (Egido, 2010: 114). Cotera localiza ejemplos en Zamora donde "una vuelta conlleva dos o más hiladas de cuentas que, hacia las puntas, tórnase un único hilo" (Cotera, 1999: 234 en Gómez Ferrero, 2015: 106). Esta acepción también la localiza Gómez Ferrero en La Bañeza en los siglos XVII y XVIII.

Aunque con menos frecuencia, aparece también este término para designar las 'ristras de embutido'.

Ocho bueltas de longanizas (Frechilla, PA-1638)

En vocabularios dialectales como el de Gordaliza aparece esta voz como el 'chorizo hecho sin atados intermedios' (Gordaliza, 1988: 229).

Vuelta también se localiza en los textos terracampinos como un elemento relacionado con los aperos para uncir los bueyes al carro o a la carreta, ya que se encuentra entre trasgas, bentriles o cabezadas. Esta acepción no se documenta en el DLE.

Más dos vueltas, dos bentriles, tres cabezadas con sus cadenas (Villalpando, ZA-1661) 


\subsubsection{Calzado}

\section{ABARCAS [albarcas]}

Sust. f. 'Calzado de cuero crudo que cubre solo la planta de los pies, con reborde en torno, y se asegura con cuerdas o correas sobre el empeine y el tobillo. Se hace también de caucho' y también con marca geográfica de Cantabria y Palencia como 'zueco' (DLE). Aparece en Nebrija. Covarrubias lo define como 'vn genero de calçado rustico de que vsan los que viuen en tierras y lugares asperos. Son en dos maneras, vnos de palo, que por tener forma de varcas, le dixeron avarcas: $y$ otras de cueros de vaca crudos que con vnos cordeles se los atan a los pies [...]'. En la edición de 1770 de Autoridades se puede leer 'hoy se usan con este nombre en algunas partes de Castilla la Vieja y Montañas, aunque á las de palo llaman comunmente almadreñas' (NTLLE, s. v. abarca, Nebrija, 1495; Cobarrubias, 1611, Autoridades, 1770). De origen desconocido, seguramente prerromano (DECH, s. v. abarca).

Un par de albarcas (Cea, LE-1610)

Dos albarcas (Cea, LE-1610)

Unas abarcas herradas (Fechilla PA-1613)

En Tierra de Campos se documentan dos variantes: abarcas y albarcas. La forma albarca la recoge Autoridades con el mismo significado que abarca, advirtiendo que en algunas provincias se dice así 'entre la gente rústica' (NTLLE, s. v. albarca, Autoridades, 1726). El CORDE ofrece un número importante de ejemplos de la variante abarcas en todo el siglo XVI; algo que contrasta con el término albarcas, que para este siglo muestra solo un caso.

Abarcas con el primer significado que da la academia se localiza en Ávila, Soria y Guadalajara en el CorLexIn -en estos ejemplos abarca aparece junto a tiras de pellexo, túrdigas o calzaderas para atarlas al pie-. Aunque todo indica que es un uso norteño el que presenta esta palabra, con tan pocos datos, no podemos aventurarnos a trazar una marca geográfica para el término. Del término albarca no encontramos ninguna ocurrencia en el CorLexIn. En la localidad palentina de Otero de Guardo se registra un taladro que serviría para la fabricación de este tipo de calzado.

El corpus terracampino ofrece un par de ejemplos de albarcas en la localidad leonesa de Cea, mientras que en Frechilla la variante que aparece es abarcas. El contexto no nos da muchos datos para saber ante qué acepción estamos.

En repertorios más modernos localizamos en la zona del Bierzo, Riaño, Sahagún o La Bañeza albarcas, mientras que Astorga o la Cepeda Baja comparten ambas formas (Le Men, 2002). Le Men cita el estudio El habla de Villacidayo de José Millán Urdiales, según el cual es un tipo de 'calzado que traen algunos que vienen de tierra de Campos y los meriteros [...]' (Urdiales, 1966: 217 en Le Men, 2002). En Gordaliza aparecen las dos variantes de este término y se refieren al 'calzado de madera, de una sola pieza que se apoya en tres tacos y que suele ir decorado con hendiduras o relieves en color. Se suele identificar también con madreña, y en algunos sitios suelen dar este nombre a un tipo de calzado que usaban los pastores' (Gordaliza, 1988: 17). En la localidad terracampina de Villada es habitual el uso de la variante albarcas (Casas, 1989: 540). 


\section{ALCORQUES}

Sust. m. 'Chanclo con suela de corcho' (DLE). Autoridades los define como 'chapín, ú otro calzádo, que tenga la suela de corcho' (NTLLE, s. v. alcorque, Autoridades, 1726). Procede del árabe magrebí qúrq, y éste del lat. africano CORTEX, -̌̃cIs, 'corteza', 'corcho' ( $D E C H$, s. v. alcorque).

Dos pares de alcorques, unos biexos y otros buenos (Celada, LE-1600)

Unos botines y unos alcorques tasados en doçe reales (Sahagún, LE-1605)

Alcorque aparece en las Serranillas del Marqués de Santillana hacia la primera mitad del siglo XV, aunque bajo el tamiz poético de este autor, hace referencia a un tipo de zapatos:

¡Sant Jullán en buen estrena! /Pellote negro vestía / e lienços blancos tocava, / a fuer del Andaluzía, /e de alcorques se calçava (Serranillas, Marqués de Santillana, 1429-1440)

Sin embargo, a partir del siglo XVII los casos de esta palabra en los textos se reducen considerablemente (CORDE, s. v. alcorques). Parece ser que en este siglo la palabra entró en retroceso hasta desaparecer y por eso en el CorLexIn no encontramos ejemplo alguno.

En Tierra de Campos se localizan un par de ocurrencias en Celada y Sahagún con la forma y acepción académicas.

Tampoco hemos encontrado información de este término en repertorios dialectales actuales.

\section{BORCEGUÍs [borçeguíhes, borzeguíes]}

Sust. m. 'Calzado que llegaba hasta más arriba del tobillo, abierto por delante y que se ajustaba por medio de correas o cordones' (DLE). En Autoridades aparece como 'especie de calzádo ú botín con soletilla de cuero, sobre que se ponen los zapatos ó chinelas' (NTLLE, s. v. borceguí, Autoridades, 1726). De origen desconocido (DECH, s. v. borceguí).

Tres pares de borçeguíhes biexos del inbentario (Castrillo, LE-1606)

Unos borzeguies nuevos de badana (Frechilla, PA-1631)

Un juvón viejo de camuza y tres borceguíes (Frechilla, PA-1638)

Unos çapatos de cordouan traydos y unos borceguíes de vaca (Fechilla PA-1659)

El término borceguíes designa un tipo de calzado, una especie de botas confeccionadas con cuero o badana. Se documenta desde el siglo xv en el $C D H$. Anteriormente, en el año 1351, Corominas y Pascual localizan este término en las Cortes de Valladolid, con las formas borzeguía y borzeguina (DECH, s. v. borceguí). En el CorLexIn aparecen ejemplos distribuidos por diversos puntos de la Península y también hay ejemplos en América. Es un término que suele aparecer en plural, como ocurre con otras prendas que van por pares. En Tierra de Campos siempre aparece la forma académica borceguíes con alternancias de las grafías típicas en los documentos de esta época. Sin embargo, Morala localiza algunos ejemplos donde se añade a esta voz el "engañoso sufijo en -il", así tenemos "tres pares de borçeguiles de cordobán" en Cañedo (Cantabria) o "vnos vorceguiles" en la localidad zamorana de Vezdemarbán, muy próxima a la Tierra de Campos (Morala, 2017b: 279). 


\section{BOTAS}

Sust. f. 'Calzado generalmente de cuero, que resguarda el pie y parte de la pierna' (DLE). Término recogido en el Vocabulario de Nebrija en 1495, así como por Covarrubias, que lo describe como 'el calçado de cuero que coge toda la pierna hasta la rodilla, y difiere del borceguí por ser más justa que el, y tener suela de vacas' (NTLLE, s. v. bota, Nebrija, 1495; Covarrubias, 1611). Palabra común con los demás romances de Francia y de la península ibérica, de origen incierto. Es probable que el término se tomara del galorrománico o del catalán, pero en realidad no se sabe cuál es el origen. Suele relacionarse con el francés pied bot, teniendo en cuenta que el francés botte designaba primitivamente un calzado grosero, forrado para proteger del frío, pero no está suficientemente atestiguado ( $D E C H$, s. v. bota).

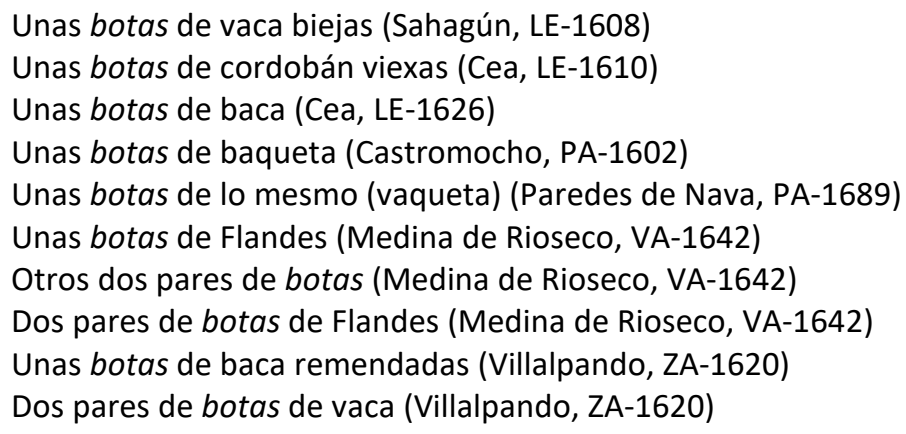

Esta palabra comparte campo semántico con otros términos referidos al calzado, como pueden ser los borceguíes o los escarpines. En el CORDE se encuentra ampliamente documentado desde el siglo XIII.

En el CorLexIn apenas aparece una decena de ocurrencias de este término con la acepción relativa a calzado. Los testimonios que aparecen en la Península se reparten entre Cuenca, La Rioja y Zaragoza. En el sur entra en colisión con bota con el significado de 'recipiente para el vino'. En los ejemplos localizados en Cuenca y La Rioja aparecen como ajuar de camino, esto es, adecuadas para viajar, ya que se referencian junto a las espuelas o directamente el escribano especifica el término con el sintagma "de camino". En la documentación americana y canaria también se localiza esta voz con la acepción de 'calzado'. Parece que el uso de este término se generalizó en siglos posteriores.

La presencia del término es frecuente en la Tierra de Campos; cuando aparece en los textos se especifica si son botas "de vaca", "de vaqueta" o "de Flandes".

\section{BOTINES [votines]}

Sust. m. 'Calzado de cuero, paño o lienzo, que cubre la parte superior del pie y parte de la pierna, a la cual se ajusta con botones, hebillas o correas', 'calzado antiguo de cuero que cubría todo el pie y parte de la pierna' (DLE, 1. y 2 . a ac.). Aparece en el Tesoro de Covarrubias donde dice que 'a diferencia de bota, que es calçado de hombre, se dixo botin el de la muger, y botinillo el corto'. Autoridades ya no lo presenta como calzado exclusivo de la mujer, sino que dice que lo usaban, como si fuera un término ya en desuso con esta acepción (NTLLE, s. v. botín, Covarrubias, 1611; Autoridades, 1726). Término derivado de bota (DECH, s. v. bota). 
Unos botines y alcorques tasados en doçe reales (Sahagún, LE-1605)

Unos botines bueno todo (Sahagún, LE-1608)

Unas chinelas y botines tasados en quatro reales (Celada, LE-1624)

Unos votines nueuos de valor de quatro reales (Sahagún, LE-1633)

Unos botines nuebos en quatro reales (Sahagún, LE-1633)

Unos botines colorados de cordobán ya traydos en dos reales (Fechilla PA-1613)

El CDH documenta botines con la acepción de calzado entre mediados del siglo xv y principios del XVI en una obra literaria:

Estas botas llevareys, / perdoná que son ruynes, / por escusar los botines / moriscos que alla hazeys (Cancionero de obras de burlas provocantes a risa, anónimo, 1445-1519)

Los testimonios de esta voz se irán incrementando en siglos posteriores, en especial durante el siglo XIX y XX, según se puede observar en el CORDE.

En el CorLexIn no se documentan ejemplos de esta voz, lo que contrasta con las ocurrencias que aparecen en la documentación terracampina. En este caso parece coincidir botín con un calzado que usaban preferentemente las mujeres, ya que, en casi todos los casos, coinciden en inventarios pertenecientes a distintas mujeres, ajustándose así con la definición que Covarrubias da de esta palabra.

Las nuevas incorporaciones léxicas que hace la lengua no se producen de la noche a la mañana, sino que requieren de un tiempo para afianzarse. Posiblemente esto sea lo que pasa en la documentación con botín. En estudios como el que hace Gómez Ferrero sobre La Bañeza los datos que recupera de esta palabra pertenecen a los siglos XVIII y XIX (Gómez Ferrero, 2015: 107).

\section{CHAPINES}

Sust. m. 'Chanclo de corcho, forrado de cordobán, muy usado en algún tiempo por las mujeres' $(D L E)$. Nebrija ya lo recoge como calzado de mujer y Covarrubias lo describe como 'calçado de las mugeres, con tres, o quatro corchos'. En Autoridades aparece como 'calzádo propio de las mugéres sobrepuesto al zapáto, para levantar el cuerpo del suelo: y por esto el assiento es de corcho, de quatro dedos, ó más de alto, en que se assegúra al pié con unas corregüelas ó cordónes. La, suela es redonda, en que se distingue de las chinelas' (NTLLE, s. v. chapín, Nebrija, 1495, Covarrubias, 1611; Autoridades, 1729). Término derivado de una onomatopeya chap-, imitativa del ruido que hacía la que andaba en chapines (DECH, s. v. chapín).

Unos chapines balençianos (Sahagún, 1600)

Unos chapines (Cea, LE-1626)

Unos chapines nuebos negros (Valderas, LE-1647)

Unos chapines sin uiras dorados nueuos (Grajal de Campos, LE-1658)

Unos chapines viejos (Castromocho, PA-1602)

Unos chapines (Castromocho, PA-1611)

Unos çhapines nuebos (Medina de Rioseco, VA-1641)

Unos chapines con sus zintas (Medina de Rioseco, VA-1642)

Unos chapines con sus viras de plata y otras viras viexas (Medina de Rioseco, VA-1644)

Dos pares de chapines plateados (Medina de Rioseco, VA-1646)

Tres pares de chapines con biras de plata pequeñas (Medina de Rioseco, VA-1647)

Un par de chapines (Medina de Rioseco, VA-1651) 
Unos chapines medianos con sus colonias encarnadas (Villalpando, ZA-1652)

Palabra muy documentada en el CORDE, se localiza mayoritariamente en la primera mitad del siglo XVII y a partir de entonces comienza a entrar en desuso: ya en el siglo XVIII casi no aparecen casos de este término.

En el CorLexIn observamos que hay un mayor número de ejemplos hacia las zonas centro y sur de la Península, aunque también aparecen casos en Guipúzcoa, León o Valladolid e incluso en América.

En la zona de estudio aparece siempre en plural. Aunque es una palabra de uso generalizado en la época, en el área de estudio aparecen más casos en la zona vallisoletana de la Tierra de Campos.

En repertorios dialectales modernos, esta palabra se documenta en zonas de León y Palencia con una acepción diferente a la académica; en León sería una especie de 'calcetines o calzado ligero' (Le Men, 2004, s. v. chapín), en Palencia es una 'especie de calcetín o zapatilla de sayal, hecha para andar por casa' o 'especie de calzado hecho de sayal, hasta media caña, abierto por delante, con costura a medio pie, desde los dedos del talón. Es propio de pastores ' (Gordaliza, 1988: 83).

\section{CHINELAS [chiñelas]}

Sust. f. 'Calzado a modo de zapato, sin talón, de suela ligera, y que por lo común solo se usa dentro de casa', 'especie de chapín que usaban las mujeres sobre el calzado en tiempo de lodos' (DLE). Aparece en Nebrija como 'calzado'. Covarrubias lo define como 'vn genero de calçado, de dos, o tres suelas, sin talon, que con facilidad se entra, y se saca el pie del, y traese de ordinario con borcegui, y assi le vsan los señores que andan en cauallos a la gineta [...]. En Autoridades se afirma que este calzado 'usase para andar en casa por lo ligéro y acomodado, y para tener calientes los pies', y en el DRAE de 1780 se especifica quiénes son los usuariarios de este zapato 'Los hombres solo le usan dentro de casa: las mugeres dentro y fuera' (NTLLE, s. v. chinela, Nebrija, 1495; Covarrubias, 1611; Autoridades, 1729; DRAE, 1780). Término procedente de cianella, variante dialectal del it. pianella, diminutivo de piano 'plano, llano' (lat. PLANUS). Se explica este nombre porque las chinelas se distinguían de los chapines y demás calzado por su falta de tacón (DECH, s. v. chinela).

\footnotetext{
Unas chinelas con zerco negro (Sahagún, LE-1608)

Unas chinelas y botines tasados en quatro reales (Celada, LE-1624)

Unas chinelas traydas de valor de tres reales (Sahagún, LE-1633)

Unas chinelas de mujer en tres reales (Sahagún, LE-1633)

Unas chiñelas negras con sus zapatillas nuebas (Grajal de Campos, LE-1671)

Unas chinelas (Castromocho, PA-1602)

Unas chinelas nuebas negras (Frechilla, PA-1638)

Unas chinelas negras (Frechilla, PA-1639)

Un calçado, chinelas y çapatillas doçe reales (Medina de Rioseco, VA-1644)

Unas chinelas con tres çapatillas, ocho reales (Medina de Rioseco, VA-1646)

Unas chinelas y zapatllas nuebas (Medina de Rioseco, VA-1642)

Unas chinelas, zapatillas y unos zapatos (Medina de Rioseco, VA-1644)

Unas chinelas y zapatillas (Villalpando, ZA-1637)
} 
Unas chinelas açules y çapatillas blancas picadas con sus listones (Villalpando, ZA-1652)

Unas chinelas achapinadas con listones azules (Villalpando, ZA-1652)

Otras chinelas achapinadas con listones azules (Villalpando, ZA-1654)

Dos pares de chinelas, çapatos y medias (Villalpando, ZA-1660)

Esta voz y la de zapato son las que más aparecen en la zona de estudio para referirse al calzado.

Término documentado en el CORDE y en el $C D H$ entre mediados del siglo xV y principios del XVI según la documentación de estas bases de datos. A partir del siglo XVIII comienza a ser menos frecuente en los textos.

Pese a ser una voz poco frecuente en los inventarios, el CorLexIn muestra un ámbito geográfico de uso bastante extenso: encontramos ocurrencias en Navarra, Oviedo, Valladolid, León, Zamora o Zaragoza en la parte septentrional, y Teruel, Murcia o Sevilla más al sur. Se documenta incluso un ejemplo en América -México-.

En Tierra de Campos esta voz es frecuente en los textos, que suele aparecer junto a zapatillas; al tratarse de un tipo de calzado muy ligero, con una suela muy fina, solían llevarse con las zapatillas. Formalmente, aparece la variante chiñelas, con palatalización de la /n/, tal vez por efecto del vocal palatal o puede ser, sin más, una falsa grafía.

\section{ESCARPINES}

Sust. m. 'Zapato de una sola suela y de una sola costura', 'calzado interior de estambre u otra materia, para abrigo del pie, y que se coloca encima de la media o del calcetín' ( $D L E$, 1 . a y 2 . ac.). Nebrija recoge esta voz. Covarrubias la define de la siguiente manera: 'vale la funda de lienço que ponemos sobre el pie debaxo de la calça, como la camisa debaxo del jubón' (NTLLE, s. v. escarpín, Covarrubias, 1611). Procedente del italiano scarpino, diminutivo de scarpa 'zapato' (DECH, s. v. escarpín).

Dos pares de escarpines (Valderas, LE-1682)

Cuatro pares de escarpines, dos de lienço y dos de lana (Medina de Rioseco, VA-1642)

Quatro pares de escarpines, dos de olanda y dos de lienço (Medina de Rioseco, VA-1642)

Aparece documentado en plural desde el siglo XV en el CORDE, ambas formas, singular y plural, no son abundantes en dicho corpus.

En el CorLexIn se documenta este término en la Península y América. Los escasos ejemplos peninsulares se concentran en el Norte -Cantabria, Guipúzcoa, Soria-y un caso en Madrid. Esta falta de testimonios se puede extrapolar a la Tierra de Campos, donde localizamos tres ejemplos repartidos entre la localidad leonesa de Valderas y Medina de Rioseco (Valladolid).

En estudios más recientes se localiza este término en la zona del leonés donde conviven dos variantes, carpín y escarpín, y a las acepciones académicas hay que añadir la de 'calcetín que cubría la parte baja del pie' (Le Men, 2004, s. v. carpín). Por su parte, Gordaliza afirma que 'eran los escarpines una especie de zapatillas de sayal o lana con las que se andaba por casa. Para salir se ponían las albarcas encima [...]' (Gordaliza, 1988: 99). 


\section{MADREÑAS}

Sust. f. 'almadreña', 'zueco', 'zapato de madera de una pieza' (DLE, s. v. madreña y zueco). En Autoridades aparece la entrada almadreña 'especie de calzado de madera, hueco, y de una pieza, de que usan en las Montañas de León y Castilla. Llámanlo tambien madreña'. Mantiene la marca diatópica hasta el DRAE de 1884 donde remite a la primera acepción de zueco (NTLLE, s. v. almadreña, Autoridades, 1732; DRAE 1884). Esta palabra procede del antiguo madrueña, y este de *maderueña, derivado de madera (DECH, s. v. almadreña).

Dos pares de madreñas para salir de casa en tiempo de barros (Villalpando, ZA-1696)

El primer ejemplo que documenta el $C D H$ pertenece a una obra de Jovellanos fechada en 1790:

[...] fábrica de madreñas en que trabajan casi todos los vecinos para llevarlas a León. Se hacen de álamo; primero las desbastan y dan la primera forma en bruto; luego socavan los huecos para el pie; luego las acaban y pulen. ("Diario de 1790" Diario (Cuadernos I a V), Jovellanos)

El resto de testimonios de esta voz pertenecen al siglo XX. La voz almadreña se documenta en esta base de datos en los siglos XIX y XX.

En los documentos que conforman el CorLexIn no se localiza ningún ejemplo de esta voz. Puede ser porque el uso de este tipo de calzado es muy específico y típico del norte de la Península. La poca frecuencia de esta voz se traslada también al corpus terracampino, donde solo se localiza una ocurrencia. En este caso el propio inventario nos da la información suficiente para saber que coincide con la acepción que da el DLE y también la función que tiene "para salir de casa en tiempo de barros".

Este término está recogido en toda la zona leonesa desde el Bierzo hasta Valderas pasando por Astorga y Valencia de Don Juan con la primera acepción académica. También aparece en Asturias (Le Men, 2007, s. v. madreña). En Palencia se recoge el término como 'calzado de madera también llamado almadreñas y abarcas. También se dice en bable' (Gordaliza, 1988: 142).

\section{ZAPATILLA [çapatillas]}

Sust. f. 'Zapato ligero y de suela muy delgada', 'zapato de comodidad o abrigo para estar en casa' (DLE, 1. Y Y 2.a ac.). En Autoridades se define como 'el zapato de una suela mui delgado, curioso, y ligero, especialmente el de las mugeres [...]' (NTLLE, s. v. zapatilla, Autoridades, 1739). Término derivado de zapato, de origen incierto (DECH, s. v. zapato)

\footnotetext{
Unas chiñelas negras con sus zapatillas nuebas (Grajal de Campos, LE-1671)

Unas chinelas y çapatillas y unos çapatos pequeños (Castromocho, PA-1611)

Unas çapatillas de cordouán negras nuebas de una suela para muger (Frechilla, PA-1631)

Un çiñidor y una çapatillas nuebas (Guaza de Campos, PA-1640)

Un par de chinelas coloradas con una zapatilla en quatro reales (Frechilla, PA-1675)

Unas chinelas y zapatillas nuebas (Medina de Rioseco, VA-1642)

Unas chinelas, zapatillas y unos zapatos (Median de Rioseco, VA-1644)

Unas chinelas y zapatillas nuebas (Medina de Rioseco, VA-1648)

Unas çapatillas nuebas (Medina de Rioseco, VA-1650)
} 
Unas chinelas y zapatillas en quatorce reales (Medina de Rioseco, VA-1657)

Unas chinelas y zapatillas (Villalpando, ZA-1637)

Un calçado con medias y çapatillas (Villalpando, ZA-1647)

Unas chinelas açules y çapatillas blancas picadas con sus listones (Villalpando, ZA-1652)

Unas chinelas azules y zapatillas blancas picadas (Villalpando, ZA-1654)

Es un término que se documenta desde el siglo $\mathrm{xVI}$ en el $C D H$ y el CORDE, más concretamente en la obra de Francisco Delicado, La lozana andaluza publicada en 1528 "iQué pie para galochas y zapatilla zeyena!".

El término zapatilla en el siglo XVII no era tan habitual como hoy nos parece; en dicha época era una voz con poca frecuencia en los textos, apenas llegan a media docena las ocurrencias localizadas en el CorLexIn. Más de la mitad pertenecen a localidades terracampinas-Medina de Rioseco y Villalpando- o zonas próximas como Carrión de los Condes. El resto de ejemplos pertenecen a Teruel y Ciudad Real. Las zapatillas eran un zapato ligero con suela muy fina.

\section{ZAPATO [çapato]}

Sust. m. 'Calzado que no pasa del tobillo, con la parte inferior de suela y lo demás de piel, fieltro, paño u otro tejido, más o menos escotado por el empeine' (DLE). Autoridades advierte que este tipo de calzado es el que 'más frecuentemente se estila' (NTLLE, s. v. zapato, Autoridades, 1739). De origen incierto (DECH, s. v. zapato).

Unos çapatos de los tres pares que tengo yo tengo de baqueta en mi casa (Sahagún, LE-1606) Unos calçones de pardo buenos y unos çapatos (Valdavia, LE-1606)

Unos zapatos (Santa María del Río, LE-1617)

Unos çapatos de vaca casi nueuos de medio ducado de valor (Sahagún, LE-1633)

Unos zapatos de baca en medio ducado (Sahagún, LE-1633)

Unos çapatos de baca viexos (Frechilla, PA-1631)

Tres pares de zapatos de cordován (Frechilla, PA-1631)

Unos çapatos de cordobán de siete puntos (Frechilla, PA-1639)

Unos zapatos de cordobán viexos (Autillo de Campos, PA-1653)

Onze pares de zapatos medianos con sus ormas (Villada, PA-1669)

Unos çapatos de baqueta que dexó la difunta mediada (Villarramiel, PA-1696)

Un par de çapatos de cordobán en nueve reales (Medina de Rioseco, VA-1640)

Dos pares de zapatos biexos (Medina de Rioseco, VA-1639)

Dos pares de çapatos viexos (Medina de Rioseco, VA-1649)

Unos zapatos nuebos de cordouán en ocho reales (Medina de Rioseco, VA-1646)

Zinco pares de zapatos de cordobán pequeños y grandes (Medina de Rioseco, VA-1649)

Unos çapatos de baca tasado en ocho reales (Cuenca de Campos, VA-1668)

Dos pares de çapatos nuebos (Villalpando, ZA-1645)

Unos çapatos nueuos (Villalpando, ZA-1656)

Dos pares de chinelas, çapatos y medias (Villalpando, ZA-1660)

Unos zapatos de cordobán (Villapando, ZA-1670)

Unos zapatos de baqueta ya ussados (Villalpando, ZA-1690)

Es una palabra de uso general en el siglo XVII que se mantiene hasta nuestros días. El CorLexIn documenta esta palabra en la Península y América. 


\section{ZUECOS [çueco]}

Sust. m. 'Zapato de madera de una pieza', 'zapato de cuero con suela de corcho o de madera' (DLE, 1. y y 2. ac.). A finales del siglo xv lo recoge Nebrija en su Vocabulario y Autoridades registra esta palabra como 'el zapato enteramente de palo, que oy se usa en varias Provincias de España entre la gente pobre' (NTLLE s. v. çueco, zueco, Nebrija, 1495; Autoridades, 1739). Del latín sŏccus 'especie de pantufla empleada por las mujeres y los comediantes' ( $D E C H$, s. v. zueco).

Unos çuecos (Villalpando, ZA-1637)

Unos çuecos nuebos en nuebe reales (Carrizo, ZA-1646)

Unos çuecos de cordouán nuebos (Villalobos, ZA-1654)

De los documentos analizados en Tierra de Campos, encontramos alguna referencia a zuecos en inventarios de Zamora.

En los textos del $C D H$, localizamos este término a partir de la segunda mitad del siglo XIII, en obras de Alfonso X, en las que se habla de "çuecos de mugieres". Por otro lado, Francés de Zúñiga escribe lo siguiente en una obra de 1525: "anden en ynvierno en çuecos de palos y verano jueguen a la chueca". Cervantes utiliza este término de manera figurada cuando en la segunda parte de El Quijote aparece "que si de zuecos la sacáis a chapines [...]", entendiendo zuecos como el calzado que representa al pobre; lo mismo ocurre con las obras de teatro, donde "los coturnos y chapines altos vsauan los trágicos en las personas trágicas y graues; las mulillas y çuecos, en los cómicos y ciudadanos" (1596).

Este término es poco frecuente en los documentos que conforman el CorLexin; los testimonios se hallan repartidos entre Segovia, Zamora y León, todas ellas localidades de la meseta norte. Estos documentos poseen un denominador común: todos los inventarios pertenecen a mujeres, algo que coincide también en la Tierra de Campos. En ninguno de los ejemplos localizados en la Península aparece esta voz con la primera acepción del $D L E$, sino que el zueco parece ser un tipo de calzado destinado a cubrir el pie femenino y que estaba hecho de algún tipo de cuero. Sin embargo, en los textos de la época también se encuentran el zueco destinado a cubrir el pie en época de barros, así como las abarcas y las madreñas (CDH).

Formalmente, nos encontramos con la solución castellana para la /ŏ/ tónica procedente del latín. 


\subsubsection{Joyas}

\section{AHOGADERO [aogadero]}

Sust. $\mathrm{m}$. 'ahogador, especie de collar' ( $D L E, 4$. a ac.). Recogido en Autoridades con este significado y refiriendo el poco uso del término: 'se halla tambien usado por gargantilla, ò collár, adorno de que usaban las mugeres trahiendolo al cuello. Es voz poco usada' (NTLLE, s. v. ahogadero, Autoridades, 1726). Término derivado del verbo ahogar, del lat. OFFŌCARE 'sofocar, ahogar' (DECH, s. v. ahogar).

Dos aogaderos de aljófar y panecicos de açauache y seis rosas de oro con aljófar (Medina de Rioseco, VA-1647)

Un aogadero de perlas que valdrá sesenta reales (Villalpando, ZA-1620)

No es una voz muy frecuente en el corpus. Como ya se advierte en Autoridades, se trata de una palabra 'poco usada'. Aun así, encontramos algunos ejemplos documentados no solo en la Tierra de Campos.

El CDH y el CORDE localizan este término en una memoria de bienes en 1617: "una almenara de perlas con su aogadero, en quarenta y quatro reales". Este escaso uso se refleja en corpus como el CorLexIn, donde aparecen "dos ahogaderos de aljófar y quentas de oro, en veynte pesos" (Ciudad de México, 1622) y "un ahogadero de perlas y granates pequeño" (Guatemala, 1623); también se documenta algún ejemplo más en los registros de bienes de moriscos granadinos fechados en 1610, como señala Perdiguero ("Más un aogadero de oro con diez y siete peiças grandes y chequitas"), localizados en el Archivo General de Simancas (Perdiguero, 2012a: 338).

Formalmente, podemos observar que se trata de una palabra derivada, formada por sufijo - dero, aunque en este caso también alternaba con la variante activa ahogador, introducida en el DRAE con esta misma acepción en la edición de 1770 . A pesar de ser una palabra no muy habitual en los inventarios, sí que existía esta alternancia entre las dos variantes ahogadero y ahogador, por interferencias que se daban entre los dos sufijos deverbales y que es frecuente en esta época (Morala, 2012b: 337-338). Se documenta un par de ejemplos de ahogador en el CorLexIn en Salamanca y en Chile.

En la Tierra de Campos solamente encontramos formas con la variable pasiva -dero, pero en la documentación de la época podemos encontrar diferentes ocurrencias de la forma ahogador, como "Un ahogador de aljófar con una ymajen de Nuestra Señora de oro" (Ciudad Rodrigo, SA-1611), "Un aogador de perlas pequeñas y corales" (Santiago de Chile, 1681) (CorLexIn, s. v. ahogador). Ambas formas no solo aparecen en la Península, sino que también presentan esa alternancia en tierras americanas. Es más, mientras que en España la edición de Autoridades de 1726 considera la palabra en desuso, en América aparece con plena vigencia (Egido, 2016b: 120-121) 


\section{ALCORCí [alcorcil, alconçil, arcoçil arcorcil, alcoçí, arcorciles, harcoçí]}

Sust. m. El DLE recoge el lema alcorcí como 'especie de joyel'. Autoridades también registra el término alcorcí como 'joyel, ù otro adorno de muger y la tilda de 'voz anticuada'. (NTLLE, s. v. alcorci, Autoridades, 1726). Se trata de un arabismo proveniente del hisp. ár. Alkursí 'soporte, silla' (DLE, s. v. alcorcí).

Doçe alconçiles y un tablero de plata sobredorado (Sahagún, LE-1600)

Un sartal de coral con diez alconçiles de plata y su tablero de lo mismo y sobredorado (Valdavida, LE-1606)

Un sartal de corales con ciento y ocho corales pequeños y uno grande y diez alcorçiles de plata sobredorado en cinquenta reales (Fechilla PA-1612)

Un sartal de corales con çinco arcoçiles de plata apreçiado en diez reales (Fechilla PA-1614)

Un sartal de corales con çinco o seis arcorçies de plata (Frechilla, PA-1614)

Dos bueltas de corales con dos alcoçies de plata y unas sartas de ambar y otros de christal (Fechilla PA-1616)

Tres bueltas con diez harcoçies de plata (Frechilla, PA-1616)

Un sartal de corales con seis arcoçiles y una mano de plata (Frechilla, PA-1675)

Un sartal de corales con seis arcorciles y una mano de plata (Frechilla, PA-1675)

El término presenta bastantes variantes gráficas, y así aparece reflejado en los inventarios de la Tierra de Campos. Esta voz muestra una vacilación de las líquidas /l/ y / r/ en posición implosiva: así, nos encontramos con alconciles y arcorciles, fenómeno fonético que en esta época manifiesta cierta vitalidad en la zona centro meridional del leonés (Morala, 2009: 12). También existe este cambio fonético entre la nasal / $\mathrm{n} /$ y la líquida / $\mathrm{r} /$ : aparecen alconçiles y alcorçiles y, en otras ocasiones, desaparece -alcoçiles-. Debido a esta variabilidad gráfica, ha sido complicado encontrar ejemplos en el CORDE. En los textos del CorLexIn aparecen las formas alcorcillos y alconcillos en Zamora y alcorziles en Villacabiel (León). Como señala Egido (2010: 110-111), existen artículos y estudios donde sí aparece este término: estudios sobre el traje tradicional maragato o estudios sobre La Bañeza como el de Gómez Ferrero, donde aparece esta voz como 'piezas de filigrana de plata, en forma alargada, que son parte de los collares y que suelen alternar con otras piezas esféricas llamadas avellanas' (Casado, 1991: 501 en Gómez Ferrero, 2015: 112). Morala localiza repertorios dialectales más modernos como el de Aliste (Zamora) elaborado por Hernández, donde alcorcil es el 'adorno femenino que remata los collares a los lados' (Hernández, 2001: 1048 en Morala, 2017b: 278).

\section{ALMENDRILLAS}

Sust. f. pl. desus. 'Pendientes con diamantes de forma de almendra, que usaban las mujeres' (DLE, 4. a ac.). El término almendrilla no se recoge hasta el Diccionario Histórico de 1933; anteriormente, aparece en diccionarios no académicos como Terreros y Pando o Domínguez, registrado en plural y con la misma acepción que recoge el DLE (NTLLE, s. v. almendrilla, Terreros y Pando, 1786; Domínguez, 1853; Diccionario Histórico, 1933). Este término viene dado por su analogía formal con la almendra, tiene su origen en la forma latina AMYGDĂLA (DECH, s. v. almendra).

Unas almendrillas sobredoradas (Celada, LE-1600)

Dos almendrillas con sus junquillos de plata sobredorados (Sahagún, LE-1600) 
Otras tres almendrillas de plata viexo (Sahagún, LE-1600)

Dos pares de almendrillas de plata las unas grandes sovredoradas y las otras vuenas tanvién (Riosequillo, LE-1610).

Otra almendrilla suelta grande de plata (Riosequillo, LE-1610)

Dos sortixas de plata y unas almendrillas en diez reales (San Nicolás del Real Camino, LE-1631)

Unas almendrillas de oro con zinco perlas cada una (Villalpando, ZA-1620)

Una hechura de un Christo de oro con tres perlas y unas almendrillas de oro con sus barillas y tres anillos con sus piedras (Villalpando, ZA-1632)

Se trata de un término que suele aparecer en plural en los inventarios de la Tierra de Campos. En el CORDE aparecen tan solo ocho casos, de los que únicamente uno hace referencia a parte de unos pendientes en un documento de 1625: "a la Reyna nuestra señora siruió con unas arracadas con unos manojos de perillas de diamantes, o de almendrillas que valen de doze mil escudos arriua". No se han hallado ejemplos de este término en los textos que conforman el CorLexIn.

\section{ANILLO}

Sust. m. 'Aro de metal u otra materia que se lleva, principalmente por adorno, en los dedos de la mano' (DLE, 2. a ac.). Lo recoge Nebrija en su Vocabulario y Covarrubias lo define con la expresión 'se toma por qualquier círculo pequeño, especialmente el que se trae en el dedo'; en Autoridades se equipara con el término sortija, presente también en este corpus (NTLLE, s. v. anillo, Nebrija, 1495, Covarrubias, 1611, Autoridades, 1726). Término procedente del lat. ANĚLLUS 'anillo pequeño' diminutivo de ANǓLUs 'anillo' (DECH, s. v. anillo).

Dos anillos de oro, uno con piedra berde y otro con piedra colorada (Sahagún, LE-1600)

Dos anillos de oro en dos ducados (Sahagún, LE-1602)

Dos anillos de oro, el uno con siete piedras y el otro con quatro (Valderas, LE-1682)

Un anillo de oro con nuebe piedras (Guaza de Campos, PA-1640)

Vn anillo de oro esmaltado (Autillo de Campos, PA-1654)

Dos anillos de oro (Paredes de Nava, PA-1689)

Un anillo de oro con su piedra açul (Tamariz de Campos, VA-1652)

Quatro anillos de oro de çintilla y, uno con una piedra, (Villalpando, ZA-1620)

Un anillo de oro con un zafiro que valdrá çinquenta ducados (Villalpando, ZA-1620)

Tres anillos de oro con piedras (Villalpando, ZA-1639)

Quatro anillos de oro (Villalpando, ZA-1644)

Tres anillos de oro (Villalpando, ZA-1650)

Cuatro anillos de oro, los tres de una piedra y el otro con nueue piedras (Villalpando, ZA-1652)

Se trata de una palabra de uso general y que en esta época convive con otro término, el de sortija, con mayor presencia en los textos. Esta voz aparece documentada en el CDH desde el siglo XIII, con la acepción que aquí se estudia. En el CorLexIn aparece tanto en la Península como en América, aunque en este siglo hay preferencia por el término sortija.

\section{APRETADOR}

Sust. m. desus. 'Cintillo o banda que servía a las mujeres para recogerse el pelo y ceñirse la frente' (DLE, 6. a ac.). Covarrubias en su Tesoro define apretador como 'ornamento de mugeres' y como término derivado de apretary entre los distintos significados que recoge Autoridades de apretador aparece 'cinta ò banda ricamente aderezada y labrada, que servía antiguamente de 
ornamento à las mugéres para recoger el pelo y ceñirse la frente', señalando que se trata de una palabra que ya no se usa (NTLLE, s. v. apretar, apretador, Covarrubias, 1611, Autoridades, 1726). Término derivado del verbo apretar, de *apetrar y éste del lat. tardío APPĔCT-RARE 'estrechar contra el pecho', derivado de PĔCTUS, PĔCT-ORIS 'pecho' (DECH, s. v. apretar).

Vn apretador de bidrio con su rascamoño y flor de piedras blancas y berdes (Valderas, LE-1647) $\mathrm{Vn}$ apretador de oro, esmaltado de roxo y verde, tiene catorze piezas pequeñas y una rosa grande en medio y todas con piedras blancas (Valderas, LE-1647).

Más un apretador de oro (Villalpando, ZA-1635)

Yten una gargantilla y apretrador de oro con una cruz (Villalpando, ZA-1644)

Este término aparece en los inventarios como una especie de adorno que llevaban las mujeres en la época. Aunque el término apretador se documenta en el $C D H$ desde el siglo XV, no se corresponde con el significado que aparece en los inventarios. Es en un documento de 1553 en el que aflora esta voz como 'adorno femenino' ("[...] será tiempo en que les quitará Dios sus joyeles, sortixas, zarzillos, collares, medallas, axorcas y apretadores de cabeça [...]"), donde aparece como complemento femenino para la cabeza. En el CorLexIn aparecen unos cuantos ejemplos de este término, tanto en la Península como en América, casi todos con la acepción que aparece en el corpus estudiado. Llama la atención un ejemplo en un documento de 1668 localizado en Santiago de Chile, en el que aparece "camisa y apretador", con el sentido de 'cinto'. Formalmente, estamos ante una palabra formada por el sufijo deverbal-dor, que en este caso mantiene su sentido activo a pesar de ser un objeto, fenómeno muy común en esta época (Morala, 2012b: 337-338).

\section{ARILLO}

Sust. m. 'arete' que es 'arillo de metal, casi siempre precioso, que como adorno llevan algunas mujeres atravesado en el lóbulo de cada una de las orejas' (DLE, s. v. arillo, arete). Este término lo recoge Covarrubias como 'diminutivo de aros, son las sortijuelas que se ponen en las orejas de que cuelgan los cercillos'; Autoridades mantiene esta acepción: 'el aro que se ponen las mugéres en las oréjas de que penden los zarcillos' (NTLLE, s. v. arillo, Covarrubias, 1611, Autoridades, 1726). Término derivado de aro, palabra peculiar del portugués y el castellano, de origen incierto $(D E C H$, s. v. aro)

Unas encomiendas con sus arillos de oro (Castromocho, PA-1611)

Dos arillos de plata para las orexas en real y medio (Frechilla, PA-1671)

Unos arillos de oro (Paredes de Nava, PA-1695)

La variante en plural arillos se documenta en los inventarios de bienes moriscos del Reino de Granada en 1549 en el $C D H$ :

[...] dos çarçillos de las orejas y dos arillos de plata, ocho reales ("Carta de dote y arras", Inventario de bienes moriscos del Reino de Granada, 1549).

En el corpus estudiado, los ejemplos que se han encontrado aparecen en plural; no es extraño, ya que en algunos diccionarios preacadémicos como el de Stevens (1706) se registra esta entrada en plural y se identifica con la locución inglesa ear-rings. En la edición de 1770 de Autoridades también registra esta entrada en plural con la acepción de 'pendientes' (NTLLE, s. v. arillos, Autoridades, 1770). 
En el CorLexIn aparecen media docena de ejemplos en la Península repartidos por localidades meridionales pertenecientes a las provincias de Sevilla, Córdoba y Málaga. Un poco más hacia el Norte se documentan ejemplos en Toledo y Guadalajara. En las provincias andaluzas arillo aparece como un objeto de adorno independiente: "unos arillos de oro", "unos arillos guarneçidos de perlas", mientras que en las otras dos localidades, los arillos aparecen siempre al lado de las arracadas, un adorno que se suele ir también en la oreja ("Dos arracadas con sus arillos de oro"). Las ocurrencias de Tierra de Campos aparecen con estas dos acepciones: en ocasiones figuran como joyas independientes, mientras que en el ejemplo de Castromocho los arillos de oro forman parte de unas encomiendas.

En el corpus objeto de estudio aparece esta voz en singular con menor frecuencia y con otra acepción:

Un arillo de hacer quesso (Autillo de Campos, PA-1653)

En este contexto, arillo hace referencia al aro que se utiliza para hacer el queso. Con esta acepción no lo encontramos en los documentos del CorLexIn.

\section{ARRACADA [arrecadas]}

Sust. f. 'Arete con adorno colgante' (DLE). Lo registra la edición de 1770 de Autoridades como 'qualquiera de los dos pendientes que se ponen las mugeres en las orejas, por gala y adorno', hasta la edición de 1884, donde aparece la definición que se conserva hoy en día (NTLLE, s. v. arracada, Autoridades, 1770, DRAE, 1884). Se trata de un vocablo procedente del hispanoár. *qarrat. (DECH, s. v. arracada).

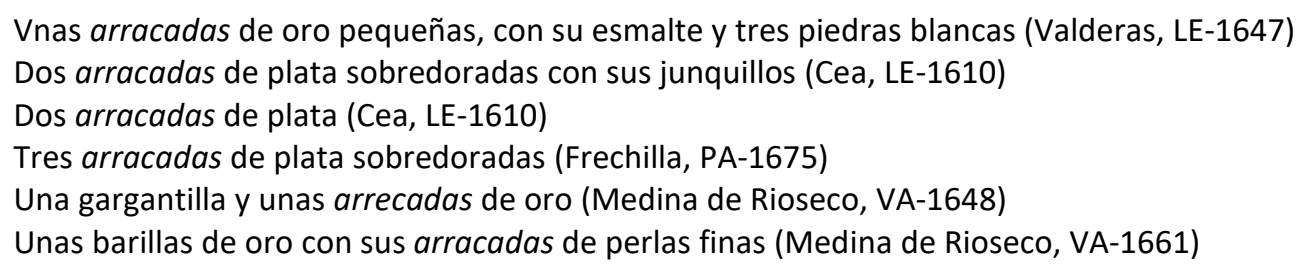

Como ocurre con los arillos o las almendrillas, este término aparece en plural en los inventarios consultados. Se documenta en el $C D H$ en varios textos del siglo $x \mathrm{~V}$, fundamentalmente en plural. También aparecen ejemplos en el CorLexIn en diferentes puntos de la Península. Frente a la forma arracada, aparece la variante arrecada, término que presenta una disimilación de la vocal átona, ya documentada por Morala (2012a: 559). Esta variante, aunque no es muy frecuente en los textos, aparece documentada en el CORDE en un documento de Alfonso de Palencia datado en 1490; también aparecen algunos ejemplos en el CorLexIn, en inventarios de Atienza (Guadalajara) y Solanilla (León). La forma arrecada es también documentada en otros estudios léxicos como el de La Bañeza (Gómez Ferrero, 2015: 112). En la actualidad esta palabra en las dos variantes ha quedado relegada a Asturias, León y Murcia (Le Men 2002, s. v. arracada). 


\section{AVELLANA [abellana]}

Sust. f. 'Fruto del avellano' (DLE). Se trata de una palabra procedente del lat. AVELLANA NUX 'nuez de Abella' (DECH, s. v. avellana).

Dos anegas de avellana (Medina de Rioseco, VA-1646)

Encontramos avellana con el significado académico en los inventarios estudiados. Desde el punto de vista diacrónico, aparece en textos desde el siglo XIII $(C D H)$ y también se documenta algún caso en el CorLexın -"vna poca almendra, avellana" (Cádiz, 1665) -. Es una palabra de uso general en la época.

Avellanas se localizan en los inventarios de Tierra de Campos con otro significado que no aparece en ninguno de los diccionarios académicos. Esta voz haría referencia a 'piezas de filigrana de plata, en forma esférica, que son parte de los collares, junto a los alargados alconciles' (Casado 1991: 502).

Una abellana de açogue descepar a los niños de plata (Paredes de Nava, PA-1690)

Cuatro anus deys de plata y una avellana tanvien de plata (Medina de Rioseco, VA-1641)

Una abellana de plata y una piedra de xristal guarnecida de plata (Cuenca de Campos, VA-1667) Unas abellanas de plata (Quintanilla del Monte, ZA-1689)

En las ocurrencias anteriores el significado es el de 'pieza de plata', llamado de esta manera por el parecido de este objeto con el fruto seco. Estamos ante una metáfora formal, fenómeno muy empleado en la creación de palabras. Avellana como 'joya' aparece por primera vez en una carta de dote y arras de 1664 -"una abellana de plata, diez y siete reales"- (CORDE, s. v. avellana). En el corpus estudiado, se encuentran ejemplos anteriores, en Medina de Rioseco que localiza esta acepción en el año 1641, y en el CorLexIn se adelanta hasta 1631, en un documento conquense.

\section{BROCHE}

Sust. m. 'Conjunto de dos piezas, por lo común de metal, una de las cuales engancha o encaja en la otra', 'alfiler' 'joya más o menos preciosa, semejante al alfiler común, o en forma de broche, que se usa para sujetar exteriormente alguna prenda del traje, o por adorno' (DLE, s. v. broche, 1. y 2. a ac.). Aparece en Autoridades con una definición mucho más extensa y explicativa: 'un género de instrumento en forma de alamár, que consta de dos piezas iguales, que la una en su extrémo tiene un agujéro largo y angosto como el ojál, à la qual llaman hembra, y la otra también en el un extrémo un gancho capaz de entrar en el expressado agujéro, a quien llaman macho. Hácense de plata, oro ù otro metál, y algunas veces guarnecidos de piedras preciosas. Su uso es para ligar, ò abrochar alguna cosa: como casáca, coléto, capote...' (NTLLE, s. v. broche, Autoridades, 1726). Término derivado de brocha en su acepción de 'joya', del fr. broche f. íd., y éste del mismo origen que el cat. broca, probablemente de origen céltico (DECH, s. v. brocha ॥).

Un xubón biexo de paño con un broche de plata sin cadenilla (Medina de Rioseco, VA-1639) Un broche y una sortixa y un agnus dey pequeño de plata todo (Medina de Rioseco, VA-1646) Vna gabardina de herbaje acaballado y blanco y broches de plata aforrado en tafetán carne de donzella en treynta reales (Medina de Rioseco, VA-1661) 
Documentado en el CORDE y el $C D H$ desde el año 1542 con la acepción que aquí nos ocupa en un texto literario -"[...] le ponen una cadena de oro y en medio un broche lleno de piedras preciosas"-. Antes de que finalice el siglo $\mathrm{XVI}$, aparecen ejemplos localizados en textos americanos. La frecuencia de esta voz en estos corpus contrasta con los testimonios que nos ofrece el CorLexIn, donde documentamos una docena de casos entre la Península, Canarias y América. Estos ejemplos se concentran principalmente en la zona meridional en el territorio peninsular -Huelva, Jaén, Almería y Alicante-, con casos también en Toledo.

Este uso exiguo de broche se extiende a la zona terracampina, donde se localizan tres ejemplos en la localidad vallisoletana de Medina de Rioseco. Aun así, estamos ante una palabra de uso general. Junto a camafeos y cabestrillos, los broches son las joyas más comunes de España y América (Egido, 2018: 1941).

\section{CABESTRILLO}

Sust. m. 'Cadena delgada de oro, plata o aljófar, que se llevaba al cuello por adorno' (DLE, 2.a ac.). Aunque Covarrubias hace mención a este término como 'adorno, joya', la edición de 1729 de Autoridades especifica más este significado: 'era también una joyíta ò cadeníta que trahían las mugéres colgada del hombro, hecha de oro, plata, seda, aljófar, etc.' (NTLLE, s. v. cabestrillo, Covarrubias, 1611, Autoridades, 1729). Término derivado de cabestro, del lat. CAPǏSTRUM íd. (DECH, s. v. cabestro).

Un cabestrillo de aljófar de quatro bueltas (Villalapando, ZA-1631)

Una cadena de oro, cabestrillo de dos bueltas (Villalpando, ZA-1644)

Documentada en el CORDE a partir del año 1542 con el significado de 'adorno para el cuello', es frecuente en los documentos de los siglos XVI y XVII; aparte de estas fechas, no encontramos ejemplos con este significado ( $C D H$, s. v. cabestrillo).

Como ocurre con broche, el CorLexIn ofrece un número reducido de ocurrencias que en la Península se concentran en la zona centro oriental -Toledo, Cuenca y Teruel-, además de un caso aislado en Guipúzcoa. Sin embargo, la escasez de datos no nos permite trazar un uso geográfico de la palabra. Así mismo, esta palabra se localiza en inventarios de América -México-. Esta situación se repite en Tierra de Campos, donde tan solo se localizan un par de ejemplos.

\section{CASCABELERO}

Sust. m. 'sonajero', 'juguete con sonajas o cascabeles que sirve para entretener a los bebés' $(D L E)$. Este término se recoge en el diccionario no académico de Terreros y Pando como 'instrumento, ó juguete que la dán á los niños para que se entretengan; y le llaman asi porque suele tener algunos cascabeles añadidos á otros juguetes, como un chupadór de cristal, coral, o marfil'. Casi un siglo después, la Academia recoge este término como adjetivo, en la edición del $D R A E$ de 1869, pero no con la acepción que encontramos en los textos estudiados. Será en la edición del DRAE de 1925 donde se recupera la acepción como sustantivo y se equipara con 'sonajero' (NTLLE, s. v. cascabelero, Terreros y Pando, 1786; DRAE, 1869; DRAE, 1925). Término 
derivado de cascabel, del oc. cascavel íd., diminutivo del lat. vulgar CASCABUS, ( $D E C H$, s. v. cascabel).

Un cascabelero de plata con una jarrica de plata y una campanilla de plata (Medina de Rioseco, VA-1660)

Es un término recogido de forma tardía por los diccionarios. Su presencia en bases léxicas como el CORDE o el $C D H$ es más bien escasa y tardía: la primera documentación que señalan es de finales del siglo XVIII. La restricción de este término se traslada a los inventarios del siglo XVII, del cual el CorLexIn no ofrece ningún resultado. El único ejemplo que se documenta en la Tierra de Campos pertenece a la localidad vallisoletana de Medina de Rioseco. Este término aparece referenciado junto a una "jarrica" y una "campanilla" de plata. En un estudio sobre platería madrileña de esta época, localizamos "un cascabelero con quatro cascabeles y un silbatillo y tres cadenillas" (1683) que parece tener el significado académico (Puerta, 1994: 185). Estos dos ejemplos comparten el estar inventariados junto a objetos que formalmente son diminutivos, algo muy común cuando se registran prendas u objetos infantiles y que suelen ser escasos en los inventarios de bienes.

\section{CINTILLO [centillo]}

Sust. m. 'Sortija pequeña de oro o plata, guarnecida de piedras preciosas' o 'cordoncillo de seda, labrado con flores a trechos y otras labores hechas de la misma materia, que se usaba en los sombreros para ceñir la copa. Se hacían también de cerdas, plata, oro y pedrería' ( $D L E, 1$. a y 2 . a ac.). Covarrubias recoge el término como 'el que se pone en el sombrero en el lugar de toquilla, con algunas pieças de oro'; es en Autoridades donde se añade que 'se suele llamar tambien la sortija pequeña, guarnecida de diamantes, ù otras piedras, que se trahe en el dedo' (NTLLE, s. v. cintillo, Covarrubias, 1611, Autoridades, 1729). Término derivado de cinto del lat. CĩNCTUS, -ŪS, 'acción de ceñir', 'cinturón', 'cintura' (DECH, s. v. cinto).

Un centillo con piedras (al margen pone zintillo) (Paredes de Nava, PA-1689)

Otro centillo con piedras de boema (Paredes de Nava, PA-1689)

Cintillo se documenta en el CORDE desde principios del siglo XVII, con la acepción de 'sortija' o 'anillo', también aparece la variante centillo en el CDH en un documento de 1638:

Lleuauale la falda el Conde de Talora su sobrino, hijo Primogenito de los Marqueses de Fuentes, con vestido bordado de plata, y oro sobre azul, con vanda rica, y centillo de estimacion de diamantes de buen fondo. (Relación de Bautismo de la Infanta, Anónimo, 1638)

El CorLexIn solo nos ofrece ejemplos de cintillo repartidos mayoritariamente por la zona centro meridional de la Península, y un caso aislado en Guipúzcoa. También localiza ocurrencias en textos americanos -México, Bolivia y Guatemala-.

En Tierra de Campos se localiza la variante centillo únicamente, con la disimilación de la vocal átona: la vacilación entre las vocales palatales /e, i/ está muy extendida en esta época. Algunas de estas variaciones se localizan en áreas muy concretas (Morala, 2016a: 378). Aunque lo habitual es que este tipo de vacilaciones no conlleven una marca diatópica, solo localizamos centillo en documentos terracampinos. Cabe destacar que, con un número escaso de 
ocurrencias, como es el caso, y con el CorLexin aún en desarrollo, somos conscientes de que esta afirmación puede variar. De los casos recabados en el corpus -todos localizados en la localidad palentina de Paredes de Nava-, en el primer ejemplo, "un centillo con piedras", el escribano rectifica y escribe en el margen zintillo, por lo que, aunque era un fenómeno común, no estaba muy aceptado.

\section{CORAL}

Sust. m. pl. 'Sartas de cuentas de coral, de que usan las mujeres por adorno' (DLE, 3.a ac.). Se trata de una voz recogida por Nebrija y Covarrubias y en Autoridades le dotan de un poder curativo y protector '[...] es muy útil para muchas enfermedades, y dél se hacen muchas cosas curiosas, como son, rosarios, sortijas, escritórios [...]. El coral tiene la virtud contra los truenos è los relámpagos, è rayos, è cotra piedra, è contra toda tempestad' (NTLLE, s. v. coral, Nebrija, 1495; Covarrubias, 1611; Autoridades, 1729). Se trata de un término procedente del lat. CORALLIUM o CORALLUM, y este del griego korállion (DECH, s. v. coral).

Unos dixes de niños que tienen una corneta de plata y unos corales y otras cosas tasados en cinco ducados (Sahagún, LE-1602)

Un sartal de corales y otras quentas y con una cruz de plata (Santa María del Río, LE-1607)

Un coral grande (Cea-LE-1610)

Un coral grande (Riosequillo, LE-1610)

Un coral pequeño engastonado en plata (Riosequillo, LE-1610)

Un sartal de corales menudo con sus alcorçiles de plata (Guaza de Campos, PA-1637)

Un coral y un christal con el estremo de plata (Frechilla, PA-1675)

Un coral guarnecido en plata (Castromocho, PA-1614)

Otra gargantilla de feligrana de plata con corales pequeños (Medina de Rioseco, VA-1660)

Una gargantilla de perlas y corales finos (Medina de Rioseco, VA-1661)

Tres agnus deyes de plata y dos anillos de horo y siete sortijas de plata y cuatro bueltas de corales (Villalpando, ZA-1653)

Se trata de un término muy común en los inventarios de la Tierra de Campos, ya que era un tipo de adorno básico en aquella época al que se le atribuían características sanadoras y de protección (Egido, 2010: 116). Es una voz presente en los corpus léxicos desde el siglo XIII. Y en el siglo XVII es frecuente encontrarlo en los inventarios de bienes a lo largo de toda la Península y América.

\section{CORNALINA [cornelina]}

Sust. f. 'Ágata de color sangre o rojiza' (DLE). No se recoge en el DRAE hasta la edición de 1869 como sinónimo de ágata (NTLLE, s. v. cornalina, DRAE, 1869). Es un término procedente del fr. cornaline (DECH, s. v. cuerno).

Una gargantilla de piezas de feligrana de plata con cornalinas (Medina de Rioseco, VA-1660)

Una cornalina y una sarta de leche (Cuenca de Campos, VA-1670)

Una cornalina pequeña engastonada en plata, una sarta de leche (Cuenca de Campos, VA-1670)

Unas mantillas con catorce cornelinas guarneçidas de oro (Medina de Rioseco, VA-1647) 
Desde una perspectiva diacrónica, este término se documenta a partir del siglo XVIII en bases de datos como el CORDE y el $C D H$, aunque no debió de ser una palabra de uso extendido, dada la escasez de ejemplos, todos ellos procedentes de documentos literarios.

El CorLexIn no ofrece ejemplos de este término, por lo que se trata de un objeto poco habitual en los inventarios de bienes al menos en esta época. Sin embargo, en Tierra de Campos localizamos varias ocurrencias en localidades vallisoletanas. La cornalina aparece en los textos como un tipo gema de color rojo y en los inventarios de Medina de Rioseco aparece como un tipo de joya u ornamento para vestimentas, mientras que en los de Cuenca de Campos esta piedra figura referenciada junto a "sartas de leche". Casado localiza en inventarios del siglo XVIII y XIX las "piedras de leche" como un amuleto que las mujeres se colgaban cerca del pecho para facilitar la lactancia. También documenta la "cornalina" con una función de protección o sanación contra los flujos de sangre (Casado, 1996: 244-245).

Cornelina se presenta en este corpus como un término de nueva adquisición, que se data en un documento terracampino fechado en 1647, adelantando la fecha dada por el $D E C H$ (1872) y las fechas que se barajan en el CORDE y el $C D H$.

Formalmente se documenta la variante cornelina con cambio de timbre de la vocal átona, fenómeno muy frecuente en esta época.

\section{DESALIÑO}

Sust. m. pl. 'Adorno que usaban las mujeres, a modo de arracadas o pendientes, guarnecido de piedras preciosas, que llegaba desde las orejas hasta el pecho' (DLE, 3. a ac.). Esta acepción del término se conserva desde Autoridades. (NTLLE, s. v. desaliños, Autoridades, 1732). Término derivado de línea, tomado del lat. LĪNĚA 'hilo de lino', 'cordel', 'línea', 'rasgo' derivado de LĨNUM 'lino' (DECH, s. v. línea).

\footnotetext{
Dos valonas de puntas que llaman desaliños en doze reales (Medina de Rioseco, VA-1640) Un desaliño en çinco reales (Medina de Rioseco, VA-1644)

Un desaliño con sus puntas en doce reales (Medina de Rioseco, VA-1646)

Un desaliño con sus puntas en doce reales (Medina de Rioseco, VA-1646)

Dos desaliños buenos con sus puntas (Medina de Rioseco, VA-1642)

Un desaliño, una cofia y un tocado (Medina de Rioseco, VA-1644)

Un desaliño con cofia (Medina de Rioseco, VA-1649)
}

Desaliño aparece mayoritariamente con la primera y segunda acepción que nos da el DRAE: 'desaseo, descompostura, desatavío, falta de aliño' o 'negligencia, omisión, descuido'; en bases como el CORDE y el CDH desde finales del siglo XV. Con el significado de 'adorno' se documenta en una monografía dedicada al traje fechada a finales del siglo XIX (CDH, s. v. desaliño):

[...] de las tembladeras, bronjas, desaliños, gregorillos, etc., y otras alhajas de gran valor (Josep Puiggarí i Llobet, Monografía histórica e iconografía del traje, 1886)

El CorLexIn no presenta ningún ejemplo de esta voz en los inventarios. Las pocas ocurrencias que encontramos de este término como 'adorno' en la documentación coetánea, siempre aparece en plural; por ejemplo, en una carta de pago y recibo de dote fechada en 1691 se puede leer "unos desaliños de alxofar y oro que se componen de un alcaperron avavxo y tres piezas 
copetes encima" (Barrio Moya, 1999: 337). Por su parte, Arbeteta señala que los desaliños eran grandes pendientes que conjugaban elementos textiles y metálicos y que se pusieron de moda a finales del siglo XVII (Arbeteta, 1998: 17). De ahí su escasez en los textos revisados.

Los datos que nos ofrece el corpus terracampino no presentan ninguno de los significados académicos, aunque en este caso el contexto va a servirnos de ayuda para aclararlo. Salimos de dudas con el primer ejemplo que aparece en el corpus, donde el escribano identifica las "valona de puntas" con un "desaliñ̃o". También aparece referenciada junto a cofias y tocados, lo que situaría esta prenda junto a los complementos de la indumentaria. Se documenta un puñado de ocurrencias en la localidad vallisoletana de Medina de Rioseco, que, como hemos indicado en otras ocasiones, presenta un léxico más extenso y técnico en el ámbito textil.

\section{DIADEMA}

Sust. f. 'Joya femenina, en forma de media corona abierta por detrás, que se coloca en la cabeza', 'adorno o aderezo femenino en forma de aro abierto, que sujeta el pelo hacia atrás' o 'aureola' (círculo en la cabeza de las imágenes sagradas) (DLE, 1. , 2. y 5. a ac.). Covarrubias habla de esta palabra en pasado y señala en su Tesoro que 'era una faxa, que se ataua por la frente, insignia particular de los Reyes, al principio fue sin ninguna curiosidad, y después la fueron adornando con oro y piedras preciosas [...]. En las figuras de los Santos para diferenciarlos en los retablos y pinturas, de los que no lo son, les ponen sobre la cabeça encaxada por la mitad della vna forma de Luna llena, que comúnmente llamamos diadema [...]. También pienso que vino a ser la diadema ornamento de cabeça de algunas mugeres, como lo fue la mitra [...]' (NTLLE, s. v. diadema, Covarrubias, 1611). Se trata de una voz tomada del lat. DIADĒMA (DECH, s. v. diadema).

Una diadema de plata (Medina de Rioseco, VA-1640)

Una lamina de San Cayetano que esta detrás de la diadema de Nuestra Señora con su marco de pino (Villalpando, ZA-1696)

Desde el punto de vista diacrónico, esta voz se documenta a partir de finales del siglo XIII en el CORDE y el $C D H$. La frecuencia con la que aparece en la literatura contrasta con la escasez de ejemplos en el CorLexIn, donde solo se localizan un par de casos en un documento chileno.

Tampoco es habitual esta voz en los documentos que conforman el corpus terracampino. El significado con el que aparece en la zona tiene más que ver con el ámbito litúrgico que con el de 'joya femenina': los dos ejemplos que aparecen se encuentran entre imágenes de santos, "un niño Jesús de bulto" o "un Santo Cristo". Este hecho coincide con los ejemplos documentados en Chile, donde forma parte de la indumentaria de Santa Teresa de Jesús en el primer caso, y en el otro forma parte de la "hechura de una Virgen". En esta época este es el significado más común con el que encotramos diadema, como ya advierte Covarrubias en su Tesoro. Egido afirma que en los siglos XVI y XVII no era común su uso como adorno personal femenino (Egido, 2016b: 107). 


\section{DIJE [dixe, dix]}

Sust. m. 'Adorno de los que se ponían a los niños al cuello o pendientes de la cintura' o 'joya, relicario o alhaja pequeña con que se suelen adornar las mujeres e incluso los hombres' (DLE, 1. - y 2. ac.). Covarrubias registra esta palabra en su Tesoro con la forma dix o dixes en plural y lo define como '[...] las menudencias que cuelgan a los niños ordinariamente al cuello para acallarlos, y alegrarlos [...]', Autoridades añade la forma dixe, mantine la definición de Covarrubias y añade para la forma dixes 'por extensión se suelen llamar así las joyas y otros aliños de que usan las mugeres, y tal vez los hombres [...]'. En estos casos, con grafía "x"; con la grafía "j" lo introduce la Academia en la edición de 1832 (NTLLE, s. v. dije, Covarrubias, 1611; Autoridades, 1732, DRAE, 1832). Quizá vino de la idea de 'friolera, menudencia' y esta de la de 'cuentecillo, patraña, enredo, bravata', formado con dije, pretérito del verbo decir ( $D E C H$, s. v. dije).

Unos dixes de niños que tienen una corneta de plata y unos corales y otras cosas tasados en cinco ducados (Sahagún, LE-1602)

Una gargantilla de corales con un dixe de plata (Medina de Rioseco, VA-1644)

Un dix pendiente de unos listones que tiene las piezas siguentes: una cruz de santo Torivio con los extremos de plata, dos sortixas de plata, una pieza de plata sobredorada pequeña, otra pieza muy pequeña, una cruz y una imagen de Christo crucificado todo de plata, tres arracadas de plata sobredorada que tienen dos bidrieras y en una está san Antonio, otra pieza con el cerco de plata sobredorado y un coral y un christal, el estremo de plata y una sarta berde tassado en ciento y diez reales todo (Frechilla, PA-1675)

Este término se encuentra documentado desde el siglo XVI tanto en España como en América, siempre en plural y con dos acepciones principalmente: como 'adornos que servían a los niños para entretenerse' o como 'adornos de poco valor que utilizaban tanto hombres como mujeres' (CDH, s. v. dije).

En el CorLexIn se localizan unos pocos ejemplos repartidos entre la Península -Badajoz y Guipúzcoa-y América-Bolivia-.

En Tierra de Campos localizamos una forma en plural que hace referencia al conjunto de colgantes con los que se entretenían los niños, y dos formas en singular con dos variantes: dixe para un colgante de una gargantilla y dix, para hacer referencia a un conjunto de joyas, litúrgicas en su gran mayoría.

\section{GARGANTILLA}

Sust. f. 'Adorno femenino que rodea el cuello' (DLE, 2.a ac.). Lo recoge Autoridades como 'el adorno que trahen las mugéres en la garganta, que suele ser de piedras preciosas: como diamantes, rubíes, esmeralda, ù perlas, corales, azabáche [...] (NTLLE, s. v. gargantilla, Autoridades, 1729). Término derivado la misma raíz onomatopéyica de gargajo (DECH, s. v. gargajo).

Vna gargantilla de açabache, pendiente en medio de ella vna pieçicita mui pequeña que dixo ser de oro (Valderas, LE-1647)

Una gargantilla de siete bueltas de alxófar que pesa un doblón de a ocho y un escudo que açen çiento y cuarenta y quatro reales de plata. (Frechilla, PA-1616) 
Una gargantilla de oro con alzofar en ziento y beinte reales (Medina de Rioseco, VA-1640) Una gargantilla y un rosario digo dos de azauache y perlas de Veneçia (Medina de Rioseco, VA1642)

Una gargantilla de perlas tasada en duçientos y cinquenta reales (Medina de Rioseco, VA-1646) Una gargantilla de aljófar con estremos de oro (Medina de Rioseco, VA-1648)

Una gargantilla de perlas de oro con lazo de lo mismo y joya (Medina de Rioseco, VA-1660) Una gargantilla y apretador de oro con una cruz (Villalpando, ZA-1644)

Término documentado en el $C D H$ desde el siglo XV y en el siglo XVI ya se observan ocurrencias en documentos de América. El CorLexIn ofrece nutridos ejemplos de esta voz tanto en España como en sus colonias de ultramar. En esta época el uso del término está generalizado.

\section{INSIGNIA [ynssinia, ynsinia]}

Sust. f. 'Señal, distintivo, o divisa honorífica', 'emblema distintivo de una institución, asociación, o marca comercial, que se usa prendido en la ropa como muestra de vinculación o simpatía' (DLE, 1. y 2.a ac.). Nebrija recoge esta palabra en 1516 y Covarrubias la define como 'la señal que vno lleua para ser diferenciado delos demas, como en las cofradias [...] Insignias el ornato y aparato que lleuan los magistrados, y otras personas para ir señaladas y conocidas, por que nadie inore sus dignidades y oficios, y sean respetados' (NTLLE, s. v. insignia, Nebrija, 1516, Covarrubias, 1611). Término derivado de seña que procede del lat. ŠGNA, plural de šGNUM 'señal, marca', 'insignia, bandera' (DECH, s. v. seña).

Una ynssinia pequeña de oro de familia en zinquenta y siete reales (Medina de Rioseco, VA-1640) La ynsinia de la encomienda de Santo Oficio esmaltada de cristal (Medina de Rioseco, VA-1649) Una cruz con la ynsinia de la passion (Medina de Rioseco, VA-1657)

Dos quadros grandes de pintura con sus marcos que son dos ángeles con ynsinias de la passión en las manos (Villalpando, ZA-1696)

La forma culta insignia que mantenemos hoy en día en el DLE aparecía también en bases de datos como el $C D H$ y el CORDE, mientras que en los inventarios de bienes del siglo XVII este término prefiere la forma ynsinia o ynssinia, tal como se puede observar en los textos que conforman el CorLexIn y los documentos terracampinos estudiados.

\section{JOYEL [joel]}

Sust. m. 'Joya pequeña' (DLE). Autoridades lo define como 'joya pequeña, que à veces no tiene piedras' (NTLLE, s. v. joyel, Autoridades, 1734). Palabra procedente del francés antiguo joie, derivado regresivo de joyel, que a su vez procede del lat. vulgar *jocale íd. (DECH, s. v. joya).

Dos bueltas de corales y un joyel (Sahagún, LE-1601)

Un joel de un cauallo marino con la echura (Medina de Rioseco, VA-1648)

Un joyel de plata veinte reales (Villalpando, ZA-1634)

Un joel de plata nuebe reales (Carrizo, ZA-1646)

Se trata de un término documentado desde el siglo XV en el CORDE. Esta voz hacía referencia a un tipo de joya de pequeño tamaño que se lucía en el pecho, aunque en el siglo XVI solía referirse a una joya de mucho valor, como ocurría con el Joyel Rico de los Austrias (Aranda, 2000: 234). Encontramos documentada esta palabra en diferentes zonas de la Península con la acepción que aparece en la academia -"joyelito de ébano", "joyel pequeño"-; los materiales con 
los que están elaborados no son de un valor extraordinario (CorLexIn). Lo mismo ocurre con los ejemplos encontrados en la comarca de la Tierra de Campos. Formalmente hallamos dos variantes: el término joyel que es el que registra la Academia, y la forma Joel, que presenta una elipsis de la yod intervocálica y que aparece tanto en la zona de estudio como en La Alberca (Salamanca).

\section{JUNQUILLO}

Sust. m. El DLE no registra la acepción con la que aparece en el corpus terracampino, identifica este término con 'planta de jardinería, especie de narciso de flores amarillas muy olorosas, cuyo tallo es liso y parecido al junco', 'Arq. Moldura redonda y más delgada que el bocel' (DLE). Aparece recogido en la edición Autoridades con este mismo significado (NTLLE, s. v. junquillo, Autoridades, 1734). Término derivado de junco, procedente del lat. JŭNCUs íd. (DECH, s. v. junco).

Dos almendrillas con sus junquillos de plata sobredorados (Sahagún, LE-1600)

Dos arracadas de plata sobredoradas con sus junquillos (Cea, LE-1610)

Dos junquillos de plata grandes (Riosequillo, LE-1610)

Por el contexto en el que se encuentra en los inventarios del corpus estudiado y por los materiales de los que está hecho, parece que se trata de un elemento que forma parte de algunas joyas como las almendrillas o las arracadas, o que conforman un tipo de joya por sí mismo, como podemos suponer en el ejemplo localizado en Riosequillo. Con esta acepción encontramos un ejemplo en documentos de La Orotava en Tenerife (CorLexIn), el resto de significados tienen que ver con la planta o lo que se hace con ella.

En repertorios dialectales actuales encontramos junquines en Valporquero (León) con la acepción de 'pendientes' y juncos como 'primeros pendientes que se ponen a las niñas' (Fernández González, 1959: 291 en Le Men, s. v. junco); ambas acepciones pueden ser las que más se acerquen a los junquillos encontrados en Tierra de Campos.

\section{MANILLA}

Sust. f. 'ajorca' 'especie de argolla de oro, plata u otro metal, usada por las mujeres para adornar las muñecas, brazos o gargantas de los pies' o 'manija', 'palanca pequeña para accionar el pestillo de puertas y ventanas, que sirve también de tirador' ( $D L E, 1$. a y 4 . a ac.). Covarrubias recoge el término en su Tesoro en plural y lo define como 'las axorcas, que las mugeres traen en los braços', Autoridades por su parte registra este término en singular con la acepción de 'adorno para la muñeca' (NTLLE, s. v. manilla, Covarrubias, 1611, Autoridades, 1734). Voz derivada de mano, procedente del lat. MANUS, ŪS, probablemente tomado del cat. manilla ( $D E C H$, s. v. mano).

Quatro manillas de plata (Sahagún, LE-1600)

Otra arca de nogal grande con su çerradura sin llave ni manilla (Valderas, LE-1659)

Dos manillas de cristal guarnecidas de oro (Castromocho, PA-1611)

Unas manillas de azabache en diez y seis reales (Frechilla, PA-1671

Unas manillas de oro y perlas con quinze piezas (Medina de Rioseco, VA-1640)

Unas manillas con catorce cornelinas guarneçidas de oro (Medina de Rioseco, VA-1647)

Otra gargantilla de perlas de quatro vueltas y manillas de lo mismo (Medina de Rioseco, VA-1660)

Unas manillas de aljófar que pessan dos onças y media (Medina de Rioseco, VA-1685) 
Encontramos esta palabra documentada en la Tierra de Campos con dos significados diferentes que coinciden con los dados por la Academia en su primera y cuarta acepción. Por una parte, manilla como parte de las joyas que servían para adorno personal y que solían estar fabricadas con metales preciosos. Documentado desde el siglo $x \mathrm{~V}$ en bases de datos como el $C D H$, con el significado de 'alhaja'. Se localiza en los inventarios de la época, sobre todo en el centro peninsular (Madrid, Valladolid y Toledo) y en América (CorLexIn). Algunos autores aseguran que estas manillas se utilizaban por parejas y que hacían referencia a hilos de perlas o aljófares (Aranda, 2000: 240, Andueza, 2009: 377). En los ejemplos localizados en la zona de estudio con este significado siempre aparecen en plural, no se especifica que sean pares, pero sí más de una.

Por otra parte, con la acepción de 'manija' también aparece en los documentos analizados. Sin embargo, este significado no se registra hasta el DRAE de 1984. El CorLexIn ofrece un solo caso de este significado en la zona palentina de Herrera de Valdecañas. Sin embargo, en Tierra de Campos esta acepción figura en distintos documentos; puede deducirse que su uso era más habitual en esta zona:

Un candado vueno sin llave ni manilla (Cea, LE-1621)

Una manilla de la dicha zerradura (Cea, LE-1621)

Un candado con su manilla y llave que esta en la panera (Cea, LE-1621)

Tres candados con sus manillas y llaues (Grajal de Campos, LE-1656)

Un candado andadero con su llave y manilla tasado en seys Reales (Cuenca de Campos, VA-1670)

\section{MEDALLA}

Sust. f. 'Pieza de metal batida o acuñada, comúnmente redonda, con alguna figura, inscripción, símbolo o emblema' (DLE). Covarrubias la define como 'la efigie de Emperador, Rey, Príncipe, o persona notable, que aya merecido quedar su figura, y nombre, estampado en metal. Estas medallas son de oro, plata, y cobre [...], en Autoridades también lo definen como 'pieza de metal en que se vé la efigie de algún Santo o Santa, o se representa algún misterio de nuestra Sagrada Religión, que suele bendecir el Sumo Pontifice, y conceder indulgencias a quien las trahe' (NTLLE, s. v. medalla, Covarrubias, 1611 , Autoridades, 1734). Se trata de un término procedente del italiano medaglia (DECH, s. v. medalla).

Un rosario de coral engaçado de plata con los pater noster de lo mismo con un santo christo de plata sobredorado y dos medallas de plata pequeñas (Paredes de Nava, PA-1690)

Una medalla de la Verónica (Paredes de Nava, PA-1689)

Una caxica, dos medallas de peltre y dos de candelero (Villalpando, ZA-1689)

Es un término documentado a finales del siglo xV, principios del xVI en el $C D H$. También se documenta en textos del siglo XVII en la Península y América (CorLexIn). En la zona de estudio aparece con otros objetos de devoción como rosarios, pater noster..., o representando alguna virgen, o en este caso a la Verónica. El uso más frecuente era el de objeto de devoción; en las relaciones de bienes se inventaría junto a rosarios, agnus dey, cruces, estampas, imágenes, etc.; así ocurre tanto en el corpus estudiado como en el CorLexIn. Aunque hay que destacar que no era ese un uso exclusivo, ya que hay otras zonas donde las medallas sirven de complemento y adorno a otros objetos como sombreros o cintillos, o ir grabadas en fuentes. 


\section{PENDIENTE}

Sust. m. 'Joya que se lleva colgando' (DLE). 'Significa tambien un adorno, que colgado de un arillo se ponen las mugeres en las orejas. Usase regularmente en plural' (NTLLE, s. v. pendiente, Autoridades, 1737). Se trata de un término derivado de pender, del lat. PĔNDĒRE (DECH, s. v. pender).

Gargantilla de perlas con treynta y tres pendientes engastada en oro (Medina de Rioseco, VA1647)

A pesar de ser una palabra de uso general, en los documentos estudiados tan solo hemos localizado un ejemplo en el que parece coincidir su significado más con la definición dada por el $D L E$ que con la de Autoridades; es decir, parece que en este caso se trata de joyas que cuelgan, más que de las alhajas que las mujeres se ponen en las orejas.

Esta voz se documenta como sustantivo y con la acepción que aparece en Tierra de Campos en el año 1600 en Pragmáticas relativas a indumentaria española del siglo XVII (CDH, s. v. pendiente).

Si consultamos el CorLexIn, nos encontramos con ejemplos de este vocablo con la acepción con la que aparece en nuestro corpus. En la mayoría de los casos se localizan en la zona meridional de la Península -Almería (1659), Andújar (Jaén, 1665), Baza (Granada, 1662), Córdoba (1683), Málaga (1671)-. Puede ser que en otras zonas de la Península se usara otro tipo de palabras para designar los objetos colgantes de las joyas, como pueden ser cuentas o sartas. Además, dentro de la zona de estudio se barajaban diferentes términos para hacer referencia a los adornos que las mujeres se ponían en sus orejas: zarcillos, arillos, almendrillas, calabazas, arracadas... El término pendiente como joya que se pone para adornar las orejas podemos encontrarlo a principios del siglo XVIII en localidades como Málaga -"unos pendientes de oro"y se pueden encontrar ejemplos con dicha acepción en documentos del siglo XIX en la zona de La Bañeza (Gómez Ferrero, 2015: 119).

\section{PERENDENGUE}

Sust. m. 'pendiente (arete)', 'adorno femenino de poco valor', en plural 'adornos, atavíos' (DLE, 1. , 2. y y . ac.). En Autoridades se define como 'adorno que se ponen las mugeres pendiente de la punta de las oréjas. Son de diferentes hechuras y materias: como oro, plata, azabache, crystal, y enriquecidos de piedras preciosas. Llamanse tambien pendientes' (NTLLE, s. v. perendengue, Autoridades, 1737). Se trata de un término popular y afectivo, de formación incierta, resultante de la metátesis de penderengue, derivado de pender, $(D E C H$, s. v. perendengue).

Unos perendengues de oro de cinco piedras verdes (Paredes de Nava, PA-1689)

Unos perendengues (Paredes de Nava, PA-1689)

Unos perendengues de oro que pessarán dos doblones y sin esmaltados (Paredes de Nava, PA-1690) Unos perendengues de filigrana de oro guarneçidos con aljófar gruesso (Medina de Rioseco, VA-1685)

El término se registra a partir de 1675 en el $C D H$ y en el CORDE con un significado distinto al de 'joya' o 'alhaja', aunque Corominas y Pascual (2012) localizan este vocablo un año antes en 
una obra del Padre Noydens, donde aparece como 'un género de listones ensartados en los vestidos franceses' ( $D E C H$, s. v. perendengue). En el CorLexIn hay escasos ejemplos del término; se documentan en La Rioja y Toledo a finales del siglo XVII. Se trata de una palabra que está comenzando a usarse, dada la escasez en la documentación. En Tierra de Campos esta voz hace referencia a un tipo de adorno de cierto valor, ya que los ejemplos que nos encontramos estaban fabricados con metales preciosos como el oro. En estudios dialectales como el de Le Men esta voz se presenta referenciando los colgantes de cualquier tipo o a adornos que cuelgan en los vestidos, no solo los pendientes (Le Men, 2009, s. v. perendengue).

\section{SARTA [sartilla]}

Sust. f. 'Serie de cosas metidas por orden en un hilo, en una cuerda, etc.' (DLE). Covarrubias lo recoge como 'collar, o gargantilla de pieças ensartadas, y enhiladas vnas con otras, o hilo de perlas, o pieças de oro o plata pendientes del cuello' (NTLLE, s. v. sarta, Covarrubias, 1611). Término derivado del lat. vulgar SARTA 'guirnalda, corona' (DECH, s. v. sarta).

Una buelta de corales con tres sartas de plata e un anus dey pequeño e una sarta de perlas (Sahagún, LE-1601)

Una sarta grande de leche (Fechilla PA-1612)

Un sartal con quarenta y seis sartas de coral y diez y siete de cristal (Frechilla, PA-1639)

Veinteyocho sartas de cristal (Frechilla, PA-1642)

Una sarta de leche con los estremos de plata en nuebe reales (Frechilla, PA-1671)

Diez y nueve corales pequeños y una sarta y un cuchillo de plata muy pequeño tassado todo en tres reales (Frechilla, PA-1675)

Diez y siete sartas de christal en seis reales (Frechilla, PA-1675)

Una sarta de plata que pesso quarenta y tres honças (Medina de Rioseco, VA-1640)

Una canalina [margen cornalina] y una sarta de leche (Cuenca de Campos, VA-1670)

Una sarta de quentas de ambar que baldrían seis reales (Villalpando, ZA-1620)

Estamos ante un término de uso general. Documentado en los textos desde el siglo XIII (CORDE). Presente en los inventarios de bienes del siglo XVII, según los datos registrados en el CorLexIn, donde además de ocurrencias en la Península, se localizan también en textos de Canarias y de América. Sarta se presenta como conjunto de cuentas que forman un todo, cuyo significado equivaldría al de 'sartal' como enel ejemplo de Villalpando -"una sarta de quentas de ambar"-. Sin embargo, sarta también referencia cada una de las cuentas que componen un conjunto mayor, como ocurre en ejemplos como el de Frechilla -"un sartal con quarenta y seis sartas de coral y diez y siete de cristal"-.

Tanto en los documentos estudiados como los inventarios que recoge el CorLexIn aparece el diminutivo sartilla, haciendo referencia a un adorno bien más pequeño:

Una sartilla de azabache (Grajal de Campos, LE-1613)

Un sartal de corales con unas sartillas de plata y dos cruzetillas de plata y un agnus de plata pequeño (Grajal de Campos, LE-1613) 


\section{SARTAL [sartalejo]}

Sartal lo define el DLE como sust. $\mathrm{m}$. 'sarta (serie de cosas metidas en un hilo)' (DLE). La palabra sartal aparece en Nebrija como 'sartal de cuentas', y desde Autoridades se equipara con el término sarta (NTLLE, s. v. sartal, Nebrija, 1495; Autoridades, 1739). Término derivado de sarta (DECH, s. v. sarta).

Un sartal en dos ducados (Sahagún, LE-1602)

Un sartal de coral con diez alconçiles de plata y su tablero de lo mismo y sobredorado (Valdavida, LE-1606)

Un sartal de corales y otras quentas y con una cruz de plata (Santa María del Río, LE-1607)

Un sartal de corales con unas sartillas de plata y dos cruzetillas de plata y un agnus de plata pequeño (Grajal de Campos, LE-1613)

Un sartal de corales con diez arcoçiles y su tavlero de plata (Villacalabuey, LE-1639)

Unos sartales de corales con dos anus dei de plata que pesaron quatro onzas y media (Grajal de Campos, LE-1671)

Un sartal de corales gruesos de ocho onças apreciado en quarenta y quatro reales (Frechilla, PA1613)

Un sartal con quarenta y seis sartas de coral y diez y siete de cristal (Frechilla, PA-1639)

Un relicario de plata con sus bidrieras y un sartal de corales finos (Villada, PA-1665)

Sartal se localiza en los documentos que configuran el $C D H$ a mediados del siglo XIII y a partir del siglo XVI esta voz también se documenta en textos americanos, aunque desde el siglo XVII este término parece entrar en retroceso y los ejemplos se reducen en la documentación. Las ocurrencias de esta voz en el CorLexIn son menores que las de sarta y, a pesar de que en la mayoría de los ejemplos parece coincidir con la acepción de sartal, en Tierra de Campos encontramos ejemplos como "un sartal con quarenta y seis sartas de coral y diez y siete de cristal", entre otros, donde sarta parece ser un componente del sartal. Además, este término se reparte por las localidades leonesas y palentinas dentro de la zona de estudio.

En los documentos de Tierra de Campos también aparece el término sartalejo:

Un sartalejo pequeño para dolor de muelas en çinco reales (Frechilla, PA-1675)

Registrado por el DRAE de 1803 como diminutivo de sartal; anteriormente, Oudin lo recoge como 'vn petit cordon' (NTLLE, s. v. sartalejo, Oudin, 1607; DRAE, 1803). Sin embargo, en el ejemplo localizado en el corpus de Tierra de Campos parece tener una acepción diferente: posiblemente se trate de un objeto medicinal, utilizado para calmar el dolor de muelas. Cabría la posibilidad de estar ante un diminutivo lexicalizado que referencia algo diferente a un 'sartal pequeño'.

\section{SORTIJA [sortixa]}

Sust. f. 'Anillo, especialmente el que se lleva por adorno en los dedos de la mano' (DLE). Aparece en el Tesoro de Covarrubias y Autoridades lo define como 'anillo pequeño de oro, plata, ú otro metal, que se trahe en los dedos para adornode ellos, ó memoria de alguna cosa' (NTLLE, s. v. sortija, Autoridades, 1739). Se trata de una voz derivada de suerte, procedente del lat. SORTICULA 'boleta u objeto para echar las suertes', derivado de SORS, SŎRTIS (DECH, s. v. suerte). 
Unas sortixas de prata (Celada, LE-1600)

Dos sortixas de plata vuena (Riosequillo, LE-1610)

Dos sortixas de plata y unas almendrillas (San Nicolás del Real Camino, LE-1631)

Ocho sortixas de oro con sus piedras (Grajal de Campos, LE-1658)

Una sortija de oro con su piedra (Castromocho, PA-1611)

Una sortixa de oro flor de lis con cinco piedras (Paredes de Nava, PA-1689)

Dos sortixas de oro, la una con una piedra berde y otra con echura de San Antonio (Paredes de Nava, PA-1690)

Dos sortijas y un botón de plata (Villarramiel, PA-1696)

Dos sortixas de oro en çiento y veinte reales (Medina de Rioseco, VA-1640)

Una sortixa de oro con un rubí (Medina de Rioseco, VA-1647)

Quatro sortixas engarzadas en una que llaman recuerdos (Medina de Rioseco, VA-1649)

Una sortija de oro con diez y siete diamantes pequeños (Medina de Rioseco, VA-1660)

Una sortija de una piedra morada (Villalpando, ZA-1631)

Çinco sortixas de plata (Villalpando, ZA-1645)

Tres agnus deyes de plata y dos anillos de horo y siete sortijas de plata y cuatro bueltas de corales (Villalpando, ZA-1653)

Un anus de plata sobredorado dos sortijas de oro (Villalpando, ZA-1664)

El CDH documenta esta voz a partir del siglo XIII, con la acepción académica. Es un adorno que se llevaba en el dedo y en la mayoría de las ocasiones va adornado con piedras preciosas como diamantes y rubíes, o más indefinidas como las piedras verdes, moradas o cristales. Es una palabra presente en los inventarios de bienes del siglo XVII (CorLexIn) y en la Tierra de Campos. Como singularidad, cabe indicar que en Medina de Rioseco aparece un conjunto de sortijas engarzadas, un total de cuatro, al que el escribano llama "recuerdo".

\section{ZARCILLO [çarçillo]}

Sust. m. 'Pendiente, arete' (DLE). Este término lo recoge Covarrubias y Autoridades lo define como 'el arillo por lo comun de oro, ú plata, que pende de un agujero, hecho en la parte inferior de la la oreja. Sirve para el adorno de las mugeres, y alguna vez suelen llevarle los hombres, y en especial los negros, y esclavos por algun fin. Su uso comun es llevar dos, por lo que siempre se nombra en plural, y se toman también por lo mismo que pendientes' (NTLLE, s. v. zarcillo, Covarrubias, 1611; Autoridades, 1739). Voz procedente del lat. CĬRCĚLLUS 'circulito', diminutivo de $\operatorname{CIRCUS}(D E C H$, s. v. zarcillo).

Unos çarçillos de plata sobredorado en cinco reales (Frechilla, PA-1612)

Un crucifijo de plata y unos zarcillos apreciados en ocho reales (Frechilla, PA-1613

Unos zarcillos pequeños de plata apreciados en dos reales (Frechilla, PA-1613)

Otro pedazuelo de corales con zarzillos de plata (Frechilla, PA-1631)

Tres çarçillos (Frechilla, PA-1640)

Unos zarçillos de oro en ocho ducados (Medina de Rioseco, VA-1640)

Unos zarzillos de oro y una gargantilla de perlas (Medina de Rioseco, VA-1651)

Unos zarzillos de oro y perlas (Medina de Rioseco, VA-1660)

En corpus textuales como el $C D H$ aparece esta voz -con la forma çarcillos- a principios del siglo XV con la acepción académica de 'pendiente' o 'arete'. A mediados del siglo XVI comienza a documentarse en América. Dentro de la Península, esta voz se documenta sobre todo en localidades meridionales con la acepción que aquí se estudia. En el Centro y Norte de la Península se localizan un par de casos en La Rioja y Cantabria pero con la acepción de 'herramienta de labrador'. Parece que en el siglo XVII esta voz estaba totalmente aceptada en 
América: son muchas las ocurrencias localizadas en diferentes países americanos -México, Guatemala, Bolivia, Perú, Venezuela-, llegando a superar el número de los ejemplos encontrados en la Península. Sin embargo, esta voz con el significado de 'joya o adorno' está presente en los protocolos notariales de la Tierra de Campos junto a perendengues, arracadas o pendientes. 


\subsection{OBJETOS RELIGIOSOS Y DE DEVOCIÓN}

La presencia de objetos relacionados con la devoción y la religiosidad en el ámbito doméstico fue una constante en esta época. Esto hace que, además de los que se localizan en iglesias y casas parroquiales, algunos de ellos aparecerán en viviendas particulares. En ellas estos elementos tendrán diversas funciones: además de utilizarse en las prácticas de devoción, pueden aparecer como ornamentos y decoración e incluso por el afán de coleccionar estos objetos.

\subsubsection{Vestimenta}

\section{ALBA [alva, alua]}

Sust. f. 'Vestidura o túnica de lienzo blanco que los sacerdotes, diáconos y subdiáconos se ponen sobre el hábito y el amito para celebrar los oficios divinos' ( $D L E, 4$. a ac.). Con este significado recogen el término Covarrubias y Autoridades en su edición de 1726. (NTLLE, s. v. alba Covarrubias, 1611; Autoridades, 1726) Derivado de albo, del lat. ALBUS (DECH, s. v. alba).

Dos alvas de vofetán (Cea, LE-1621)

Unas alvas buenas de ruan (Cea, LE-1621)

Un alba y un fajero (Castromocho, PA-1611)

Ocho albas de zinco de lienço y las tres de roán con puntas (Medina de Rioseco, VA-1651)

Una alua de olanda con sus puntas tasada en treinta reales (Medina de Rioseco, VA-1644)

Un admito, una casulla y una alba, una gola y un manipulo con su cordón (Villalpando, ZA-1660) Una alba nueba con sus encaxes, zíngulo y amito (Villalpando, ZA-1696)

Diacrónicamente, se documenta desde el siglo xIII en el CORDE y en el $C D H$. Su uso es generalizado en el siglo XVII, como puede observarse en el CorLexIn, donde se localizan ocurrencias a lo largo de todo el territorio peninsular y también en Canarias y América. En Tierra de Campos, esta palabra de uso general se recoge como prenda de vestir utilizada por los sacerdotes y otras autoridades de la iglesia. Ágreda indica que era una especie de túnica blanca que llegaba casi hasta los pies, con mangas estrechas y largas (Ágreda, 2011: 114).

\section{ALMÁTICA}

Sust. f. desus. 'dalmática', 'vestidura litúrgica cristiana que se pone encima del alba, cubre el cuerpo por delante y por detrás, y lleva para tapar los brazos una especie de mangas anchas y abiertas' (DLE, s. v. dalmática, 4. a ac.). Esta voz aparece registrada con la forma dalmática en Covarrubias, que la define como 'vna de las vestiduras Ecclesiasticas, de que particularmente vsan los Diaconos, con los faldones y las mangas anchas y largas, forman vna Cruz para sinificar, que el que vistiere la Dalmatica, ha de estar crucificado al mundo [...]'. Con la forma almática figura en Autoridades de 1770 (NTLLE, s. v. dalmática y almática, Covarrubias, 1611; Autoridades, 1770). El término dalmática proviene del lat. tardío DALMATICA VESTIS íd., propiamente 'túnica de los dálmatas' (DECH, s. v. dalmática). 
Un terno blanco nuevo, tres casullas y dos almáticas con todo recado (Medina de Rioseco, VA1651)

El término almática se documenta en el CORDE a partir del siglo XIII, en una obra de Gonzalo de Berceo:

[...] / vistié una almática más blanca que la toca (Vida de Santo Domingo de Silos, Berceo, 1236)

A pesar de esta localización tan temprana, el término almática no es muy frecuente en los textos que conforman el CORDE y $C D H$, y un número importante de ejemplos se documentan en el siglo XVII. Estas bases textuales ofrecen un mayor número de la variante dalmática.

El CorLexIn ofrece un par de ocurrencias de la voz almática procedentes de inventarios de iglesias y capillas ubicados en el Norte de la Península -Huesca y Álava-. La escasa frecuencia de esta voz se refleja también en el corpus estudiado de la Tierra de Campos, donde solo se localiza un ejemplo en la localidad vallisoletana de Medina de Rioseco.

La forma dalmática no se localiza ni en el CorLexIn ni en el corpus de Tierra de Campos.

\section{AMITO [admito, amicto]}

Sust. m. 'Lienzo fino, cuadrado y con una cruz en medio, que el preste, el diácono y el subdiácono se ponen sobre la espalda y los hombros para celebrar algunos oficios divinos' (DLE). Lo recoge Autoridades como 'una de las vestiduras de que usa el Sacerdóte para celebrar y decir Missa. Es un lienzo fino regularmente de una vara en quatro, con dos cintas largas de vara y média cada una, pegadas ó puestas en las dos puntas de la parte superior, el qual se pone al principio sobre la cabeza, y después se baxa y pone al cuello, y con las cintas que se cruzan por médio del cuerpo se afianza y assegúra' (NTLLE, s. v. amito, Autoridades, 1726). Tomado del lat. AMICTUS, -ŪS, 'envoltura, lo que cubre', 'vestido', derivado de AMICIRE 'envolver' (DECH, s. v. amito).

Tres amictos de olanda tassados en nueve reales (Medina de Rioseco, VA-1644)

Çinco cáliçes con sus patenas, amitos y tafetanes de color y el uno no tiene amito ni tafetán, los quatro blancos y el otro sobredorado (Medina de Rioseco, VA-1651)

Doze amitos para los cálizes (Medina de Rioseco, VA-1651)

Un admito, una casulla y una alba, una gola y un manipulo con su cordón (Villalpando, ZA-1660) Una alba nueba con sus encaxes zíngulo y amito (Villalpando, ZA-1696)

Es un término documentado en los textos desde el siglo XIII con la acepción académica y a partir del siglo XVII en los documentos de América $(C D H)$. Su presencia en los inventarios que conforman el CorLexIn es más bien escasa. Sin embargo, este hecho no es significativo, ya que estamos ante una palabra que referencia un campo léxico muy concreto y, como ocurre en otros casos, no aparece como objeto cotidiano inventariable. En Tierra de Campos se localizan media docena de ocurrencias de esta voz con tres variantes morfológicas: por un lado, la más frecuente es la variante académica amito, pero en un inventario de Villalpando aparece la forma admito, que parece más bien una ultracorrección del propio escribano; este fenómeno se localiza también en un inventario de Vicuña (Álava, 1640) donde aparecen "doce admitos". La tercera y última forma que aparece en estos inventarios es amictos, que, en este caso, el escribano recurre al uso culto de la palabra usada en el ámbito eclesiástico. 


\section{CASULLA}

Sust. f. 'vestidura que se pone el sacerdote sobre las demás para celebrar la misa, consistente en una pieza alargada, con una abertura en el centro para pasar la cabeza' (DLE). Autoridades da una definición más completa del término: 'la última vestidura que se pone el Sacerdote sobre todas las otras, con que se adorna y viste para celebrar el Santo Sacrificio de la Missa. Antiguamente eran cerradas hasta abajo con una abertúra para sacar la cabeza; pero por ser mui embarazosas se fueron acomodando al uso que oy tienen, que es en forma de un capotillo, partído en dos mitades, y abierto por los lados hasta abaxo, con una abertúra redonda en medio, para entrar por ella la cabeza. En las dos caídas de atrás y adelante se le suele poner una cenefa, que llega hasta abaxo, ancha y en médio de ellas, que es regularmente de distinta tela. Háciendose de damasco, raso, o tela mui rica y de diversos colores, según las festividades de la Iglésia' (NTLLE, s. v. casulla, Autoridades, 1729). Se trata de una voz proveniente del bajo lat. CASUBLA 'vestidura eclesiástica provista de capucho', derivado de CASA 'choza' (DECH, s. v. casulla).

Una casulla, estola y manipulo de dos tafetanes dobles que açe dos vraços carmesí y morado con su pasamano de horo tassado en çien Reales (Medina de Rioseco, VA-1644)

Siete casullas de difetentes telas y colores, las seis a medio traer y la una bieja (Medina de Rioseco, VA-1651)

Una casulla para decir missas un lado de chamelote encarnado y el otro de tafetán doble blanco con su manipulo y estola de la misma tela y sus corporales (Medina de Rioseco, VA-1685)

Un admito, una casulla y una alba (Villalpando, ZA-1660)

Una casulla de damasco carmesí con su galón de oro (Villalpando, ZA-1696)

La casulla representa el vestuario más reconocible del sacerdote. Está confeccionada con tejidos de gran calidad y ornamentada con bordados, galones, pasamanos, etc. Según la información que nos ofrece el CorLexIn, este término en el siglo XVII se localiza tanto en la Península como en América y Canarias. Es una voz presente en el corpus estudiado de Tierra de Campos con las formas y acepciones académicas. En el CDH o el CORDE ya aparece documentada desde el siglo XIII.

\section{CILICIO [siliçio]}

Sust. m. 'Faja de cerdas o de cadenillas de hierro con puntas, ceñida al cuerpo junto a la carne, que para mortificación usan algunas personas' o 'saco o vestidura áspera que se usaba antiguamente para la penitencia' (DLE). Nebrija y Covarrubias hacen referencia a un tipo de vestimenta grosera que utilizaban los penitentes (NTLLE, s. v. cilicio, Nebrija, 1495, Covarrubias, 1611). Término procedente del lat. CĭĽC̆um 'pieza de paño fabricado con piel de cabra', 'vestidura áspera, cilicio' (DECH, s. v. cilicio).

Un siliçio (Medina de Rioseco, VA-1642)

Tan solo encontramos un caso en la Tierra de Campos con la variante silicio. Aparece al lado de unas balonas y unos escarpines, es decir, referenciado junto al campo semántico relacionado con la vestimenta. Tanto cilicio como silicio se encuentran documentados en bases de datos como el CORDE y el $C D H$, normalmente con la segunda acepción académica a partir del siglo XIII. Esta voz apenas se documenta en los inventarios de la época: de las ocurrencias halladas en el 
CorLexIn, la documentada en Ciudad Real coincide con la del corpus terracampino, pues aparece un silicio entre obillos de hilo, donde el contexto no es del todo claro. Sin embargo, aparecen otros dos ejemplos -Ciudad Rodrigo (Salamanca) y Cieza (Murcia)- en los cuales este término parece hacer referencia a un tipo de tejido para elaborar jubones y basquiñas: "una basquiña y jubón de silicia" y "vna basquiña de siliçio negro". Con esta misma acepción aparece en algunos documentos que se hallan en el $C D H$; nos encontramos con "paños de cilicio" desde el siglo XIII.

\section{CÍNGULO [zíngulo, çíngulo]}

Sust. m. 'Cordón o cinta de seda o de lino, con una borla en cada extremo, que sirve para ceñirse el sacerdote el alba' (DLE). Autoridades recoge esta voz con la acepción que se mantiene hasta nuestros días, además especifica que medía 'tres varas de largo' y que además de estar confeccionados con seda 'los hai tambien de hilo, y de lana para diferentes usos' (NTLLE, s. v. cíngulo, Autoridades, 1729). Término procedente del lat. CǏNGŬLUM 'cinturón' (DECH, s. v. cíngulo).

Dos zíngulos de ylo blanco texidos (Medina de Rioseco, VA-1644)

Quinze cíngulos, los treze de ylo y los dos de seda (Medina de Rioseco, VA-1651)

Un çíngulo (Medina de Rioseco, VA-1685)

Dos cíngulos (Villalpando, ZA-1646)

Una alba nueba con sus encaxes zíngulo y amito (Villalpando, ZA-1696)

En este caso, estamos ante un cultismo propio del léxico eclesiástico. Desde una perspectiva diacrónica, esta voz se documenta a partir del siglo XIII en los documentos que conforman el $\mathrm{CDH}$.

El CorLexIn ofrece media docena de casos repartidos por la Península, Canarias y América. En el corpus terracampino se localiza siempre la solución académica con las alternancias gráficas propias de la época para representar el fonema interdental fricativo sordo $/ \theta /$. Estamos ante un cultismo propio del léxico eclesiástico.

\section{ESTOLA}

Sust. f. 'ornamento sagrado que consiste en una banda de tela de dos metros aproximadamente de largo y unos siete centímetros de ancho, con tres cruces, una en el medio y otra en cada extremo, los cuales se ensanchan gradualmente hasta medir en los bordes doce centímetros' $(D L E)$. Covarrubias, entre otras acepciones, referencia este término como 'vna de las vestiduras Sacerdotales de la Iglesia Católica, que al principio deuia ser larga, hasta los pies; y era vestidura religiosa monachal, pero despues que se vsó de la alba, se mudó la estola en collar, por otro nombre se llama orarium [...]'. Autoridades también la recoge indicando las longitudes y anchuras en varas y dedos: 'tres varas de largo y quatro dedos de ancho' (NTLLE, s. v. estola, Covarrubias, 1611; Autoridades, 1732). Se trata de una palabra tomada del lat. STǑLA 'vestido largo' (DECH, s. v. estola).

Una casulla, estola y manipulo de dos tafetanes dobles que açe dos vraços carmesí y morado con su pasamano de horo tassado en çien Reales (Medina de Rioseco, VA-1644) 
Una casulla para decir missas un lado de chamelote encarnado y el otro de tafetán doble blanco con su manipulo y estola de la misma tela y sus corporales (Medina de Rioseco, VA-1685)

Esta voz se documenta en el $C D H$ desde el siglo XIII con la forma stola en una obra de Berceo, aunque la forma más común en los textos es estola.

Tanto en las ocurrencias del CorLexIn como las de la Tierra de Campos presenta la forma y el significado académicos. La estola designa el lienzo que rodeaba el cuello de las personas distinguidas (Ágreda, 2011: 116), en este caso, el de los sacerdotes.

\section{GOLA}

Sust. f. 'pieza de la armadura antigua que protegía la garganta' o 'adorno del cuello hecho de lienzo plegado y alechugado, o de tul y encajes' (DLE, 3. ․ y 4 . a ac.). Covarrubias recoge este vocablo como 'la armadura de el cuello, que se pone sobre el peto, y espaldar'. Por su parte, Autoridades también hace referencia a la 'armadúra del cuello postíza, que usan algunos eclesiásticos' (NTLLE, s. v. gola, Covarrubias, 1611, Autoridades, 1734). Término procedente del lat. GŬLA 'garganta' ( $D E C H$, s. v. gola).

Una gola y un manípulo con su cordón (Villalpando, ZA-1660)

Un admito, una casulla y una alba, una gola y un manípulo con su cordón (Villalpando, ZA-1660)

En Tierra de Campos esta voz se documenta con diferentes significados. En los ejemplos que se recogen en la localidad zamorana de Villalpando la palabra gola figura entre diferentes complementos del traje litúrgico, por lo que designaría algún tipo de alzacuellos que junto con el amito, la casulla, el manípulo o el alba conformaban la vestimenta del sacerdote. Sin embargo, en el ejemplo recogido en Medina de Rioseco el significado es diferente:

Un arnés de armar gravado de horo con celada, morrión, gola, vraçetes, pecto de espaldar, escarceles y una rodela del mismo arnés forrada en terçiopelo morada con taalí de lo mismo tasado todo en trescientos reales (Medina de Rioseco, VA-1644)

En este caso, hace referencia a una parte de la armadura que estaba destinada a proteger la garganta. Se referencia al lado de otros términos que designan diferentes partes de la armadura como el arnés, el morrión, el peto de espaldar o la rodela. Con este significado se localiza un ejemplo en Almería en el CorLexIn.

\section{PELLIZ}

No aparece ni en el DLE, ni en los diccionarios preacadémicos. Sust. f. 'Sobrepelliz' (NTTLE s. v. pelliz, Pagés, 1925).

Una pelliz de olanda viexa (Cea, LE-1621)

Una pelliz de olanda con pespuntes y randas (Villalón, VA-1642)

Una pelliz de olandilla con tres puntas y randas vieja (Villalón, VA-1642)

Una pelliz (Villalpando, ZA-1666)

Una pelliz ya viexa (Cotanes del Monte, ZA-1687)

En el CORDE tan solo aparecen dos ejemplos de pelliz en textos de Modesto Lafuente -periodista, historiador y escritor del siglo XIX, natural de Palencia-, en los que esta voz se presenta con una acepción similar o igual que la de sobrepelliz. En el Fichero General también se 
localizan dos casos de este término en sendas obras de Emilia Pardo Bazán con esta misma acepción. Las ocurrencias que aparecen en el CorLexIn están ubicadas en León y, en la mayoría de los casos, a esta prenda siempre la acompañaba una fundilla, un fardelillo o un taleguillo donde iba metida. En los textos analizados de Tierra de Campos, aparece junto a paños de manos, manteles, almohadas, almillas, servilletas, toallas, lobas o camisas y no junto a otras prendas o complementos eclesiásticos. Se localiza también en Tierra de Campos la variante con /a-/ epentética:

Una apelliz de olandilla con tres puntas y randas bieja (Villalón, VA-1642)

Por los datos que obtenemos de las diferentes fuentes de información, podríamos considerarlo un occidentalismo.

\section{SOBREPELLIZ}

Sust. f. 'Vestidura blanca de lienzo fino, con mangas perdidas o muy anchas, que llevan sobre la sotana los eclesiásticos, y aun los legos que sirven en las funciones de la iglesia, y que llega desde el hombro hasta la cintura poco más o menos' (DLE). Término derivado de sobrepelliça, depués alterado en la sobrepelliz por contaminación de alguna otra palabra, y esta a su vez de piel, del lat. PĔLIS (DECH, s. v. piel).

Una sobrepelliz viexa (Frechilla, PA-1638)

Dos sobrepellizes, la una nueba y la otra mediada (Autillo de Campos, PA-1654)

Una sobrepelliz nueva en ochenta reales (Medina de Rioseco, VA-1645) junto a toalla

Siete amitos y dos sobrepellices, una vuena y otra bieja (Medina de Rioseco, VA-1651)

Sobrepelliz es un término más frecuente en los textos que pelliz para referenciar la vestidura que llevaban los clérigos al administrar sus sacramentos. Aparece en la documentación que conforma el $C D H$, donde además se documenta como un tipo de hábito de coro -"los mozos de coro que tiene necesidad de ropas y sobrepellices" en Documentos sobre música en la catedral de Sigüenza, fechado entre 1600 y 1713-. Al tratarse de un término especializado, su presencia en los inventarios no es tan frecuente como la de otras vestiduras de uso general, así el CorLexIn presenta ocurrencias en distintos puntos de la Península -Palencia, Soria, Huesca, Guadalajara o Sevilla-.

\section{SOTANA [sotanilla]}

Sust. f. 'Vestidura talar, abrochada a veces de arriba abajo, que usan los eclesiásticos y los legos que sirven en las funciones de iglesia. Fue empleada también por los estudiantes de las universidades' (DLE). Covarrubias la define como 'ropa de Clerigo, larga que llega a cubrir el touillo, y se ciñe' (NTLLE, s. v. sotana, Covarrubias, 1611). Término procedente del it. sottana 'sotana de cura' derivado de la preposión so 'debajo de', del lat. sŭB (DECH, s. v. so).

Una sotana negra viexa (Cea, LE-1621)

Dos pares de sotanas en nueve reales (Medina de Rioseco, VA-1642)

Una sotana con un manteo nuebos (Villalpando, ZA-1620)

Un luto, capa y sotana (Villalpando, ZA-1644) 
Esta voz es de uso general para designar una de las vestiduras de la indumentaria eclesiástica documentada en textos de la Península y América. En general, cuando se habla de la vestimenta talar en un inventario, esta suele venir acompañada del resto de ropas y complementos acordes a la misma. Sin embargo, encontramos casos en los que esta prenda aparece en textos donde no hay referencias a ningún tipo de indumentaria y complementos litúrgicos. En otras ocasiones, se localiza en inventarios de matrimonios o donde los objetos que se inventarían pertenecen a mujeres. Por todo ello, aunque el significado académico esté presente en algunos de los inventarios analizados, otras veces se duda de si puede estar haciendo referencia a un tipo de indumentaria seglar.

\section{SOTANILLA}

Diminutivo de sotana, sust. f. 'Traje que en algunas ciudades usaban los colegiales. Era de bayeta negra, ajustado al cuerpo, y de la cintura abajo como un tonelete que bajaba poco más de la rodilla' (DLE). Además de como 'sotana mas corta que las regulares', Autoridades registra sotanilla como 'trage privativo de los Colegiales [...]. Componese de la vestidúra, que propiamente se llama sotanilla, que se reduce à una capa al modo que las de golilla; pero es todo de bayeta negra, sombrero forrado de tafetán, y pretina [...]' (NTLLE, s. v. sotanilla, Autoridades, 1739).

Una sotanilla negra viexa (Cea, LE-1621)

Manteo y sotanilla de vayeta de çienfilos nuevo (Grajal de Campos, LE-1656)

Una sotanilla nueva de paño negro beinteydoseno con botones (Frechilla, PA-1638)

Un luto de vayeta de Sevilla, capa y sotanilla (Villalón, VA-1637)

Un ferreruelo y sotanilla de bayeta de Palençia bueno con botones de seda (Villalpando, ZA-1629)

Una sotanilla de bayeta de Segobia (Villalpando, ZA-1660)

Por el contexto en el que aparecen las ocurrencias en Tierra de Campos, se puede afirmar que estamos ante un tipo de vestimenta confeccionada principalmente en bayeta negra y que podría corresponder con la definición que da Autoridades para esta palabra.

Se encuentran ejemplos de esta voz en textos literarios y en inventarios de bienes desde finales del siglo XVI. Pero, atendiendo a la información que nos dan los documentos que conforman el $C D H$, la pervivencia de esta no va más allá del siglo XVII, salvo en obras de corte literario o técnico. Las ocurrencias localizadas en el CorLexIn hacen referencia tanto a la vestimenta talar como al traje secular - muchos de los inventarios pertenecen a mujeres-. Se reparte a lo largo de toda la Península, las Islas Canarias y América. Además, con estos ejemplos se amplían los tejidos con los que era confeccionada esta ropa: aparte de la bayeta o el paño, también aparecen sotanillas elaboradas con gorgorán, perpetuán, chamelote, tabí, damasco o tafetán.

\section{TERNO}

Sust. m. 'vestuario exterior del terno eclesiástico, el cual consta de casulla y capa pluvial para el oficiante y de dalmáticas para sus dos ministros' (DLE, 4. a ac.). En Autoridades se indica que 'Privativamente se toma por el vestuario uniforme de los tres, que celebran una Missa mayór, o 
asisten en esta forma à alguna función Eclesiástica'. Aunque advierte que 'se toma también por qualquier vestido, particularmente rico, ò especial'. Palabra procedente del lat. TĚRNUs 'triple' (DECH, s. v. terno)

Un terno blanco nuevo, tres casullas y dos almáticas (Medina de Rioseco, VA-1651)

En Tierra de Campos tan solo se recoge un ejemplo de esta voz dado lo específico del término, algo que se extrapola a los inventarios del siglo XVII, pues en el CorLexIn solo se localiza un caso en Panticosa (Huesca) en 1688.

\subsubsection{Objetos religiosos y de devoción}

\section{AGNUSDÉl [anus dey, anus deys, agnus dey, agnus dei, anusdej, anusdei]}

Sust. m. 'objeto de devoción consistente en una lámina de cera impresa con alguna imagen, bendecido y consagrado por el papa', 'relicario que especialmente las mujeres Ilevaban al cuello' (DLE, 2. y y 3. ac.). Lo recoge Autoridades como 'unos pedazos de cera blanca, amasados por el Papa, con polvos de reliquias de Santos, à quien sirven para esto algunos Cardenales y Prelados [...] (NTLLE, s. v. agnusdéi, Autoridades, 1726). Término procedente del lat. AGNUS DEI 'Cordero de Dios' (DECH, s. v. agnusdéi).

\footnotetext{
Dos anus deys pequeños de plata se tasó la plata en doze reales (Sahagún, 1600)

Una buelta de corales con tres sartas de plata e un anus dey pequeño e una sarta de perlas (Sahagún, LE-1601)

Un anudey de plata guarneçido en dos ducados (Grajal de Campos, LE-1658)

Unas reliquias con un anusdei (Grajal de Campos, LE-1671)

Un anus dey de cristal guarnecido de oro (Castromocho, PA-1611)

Un agnus dey de plata con dos sartas de leche en tres reales (Frechilla, PA-1613)

Un agnus dei de plata sobredorado con vidrieras (Guaza de Campos, PA-1637)

Dos agnus, el uno de madera sobredorado y el otro labrado (Autillo de Campos, PA-1653)

Un anusdey de plata sobredorado con un listón encarnado (Villalón, VA-1638)

Un anus dey de oro en ziento y treinta y seis reales (Medina de Rioseco, VA-1640)

Un anus dey con zerco de plata sobredorado (Medina de Rioseco, VA-1651)

Un anusdey de plata en ocho reales (Villalpando, ZA-1635)

Un anus dey de plata sobredorado en doce reales con su listón (Villalpando, ZA-1639)

Un anus dey de plata grande (Villalpando, ZA-1645)

Un agnus dey de Nuestra Señora de plata sobredorada (Villalpando, ZA-1652)

Un anusdej de plata sobredorado con lynum Cruçis bidriera de cristal y unas reliquias y Santa Ysauel (Villalpando, ZA-1660)
}

Esta joya de iconografía religiosa se encuentra inventariada en los textos de la Península, Canarias y América, tal como puede verse en el CORDE, $C D H$ y CorLexIn. Lo que más llama la atención es su diversidad gráfica, común en la época, pero que en este caso presenta muchas variaciones. Este objeto suntuario era muy frecuente entre las mujeres devotas de la época, de ahí la frecuencia con la que aparecen en los documentos del siglo XVII. En los inventarios de las comarcas leonesas, suelen ser de plata o sobredorados y por regla general colgaban entre las cuentas del collar, aunque también podían ponerse solos (Casado, 1991: 500 en Egido, 2010: 109). 


\section{BÁCULO [váculo]}

Sust. m. 'palo o cayado que se usa para sostenerse', 'báculo pastoral' (DLE, 1. a y 2. a ac.). Covarrubias lo define como 'el palo, el bordón, el cayado, con que se afirma el flaco de pies, viejo, enfermo, o temulento [...]. El baculo pastoral, insignia de los Obispos, no carece de misterio, por quanto imita al del pastor, que apacienta las ovejas [...]' (NTLLE, s. v. báculo, Covarrubias, 1611). Término tomado del lat. BACULUM íd. (DECH, s. v. báculo).

Un báculo herrado vueno (Cea, LE-1621)

Un báculo con un estoque dentro (Castromocho, PA-1611)

Una guarnición de un váculo de plata (Villalpando, ZA-1620)

EI CDH registra esta palabra desde finales del siglo XIV en la Gran crónica de Alfonso XI con la acepción de 'báculo pastoral' -"[...] e todos los obispos estauan rreuestidos, e sus baculos en las manos e sus mitras en las cabeças, e estaban asentados en sus façistolios [...]"-. El báculo también podía servir como portante de espadas y estoques, y con esta acepción lo encontramos en dos de los ejemplos de la Tierra de Campos y en alguno localizado en el CorLexIn: "vn báculo con su espada" (Burgo de Osma, Soria 1612) o "vn uáculo con un estoque, diez reales" en Navahermosa (Toledo 1638).

Entre los repertorios modernos, Gordaliza recoge esta palabra en Palencia como 'palo con el que se revuelve por ejemplo la mezcla de la grasa para hacer jabón casero' (Gordaliza, 1988: 40). En el corpus terracampino estudiado no aparece esta acepción.

\section{CÁLIZ}

Sust. m. 'Vaso sagrado de oro o plata que sirve en la misa para echar el vino que se ha de consagrar' (DLE). Vocablo registrado por Covarrubias. Se trata de un término procedente del lat. CALIX, -İCIS, 'copa' (DECH, s. v. cáliz).

Un cáliz y patena de plata sobredorado en su caxa de madera aforrada con su fundilla de olanda (Medina de Rioseco, VA-1644)

Cinco cáliçes con sus patenas, amitos y tafetanes de color y el uno no tiene amito, ni tafetan, los quatro vlancos y el otro sobredorado (Medina de Rioseco, VA-1651)

Un cáliz con su patena del oratorio (Medina de Rioseco, VA-1685)

Un cáliz de plata con su patena (Villalpando, ZA-1660)

Un cáliz con su patena todo de plata (Villalpando, ZA-1686)

Un cáliz sobredorado labrado el pie con su patena sobredorada (Villalpando, ZA-1696)

Es un término de uso general en los inventarios de bienes de párrocos, diáconos, iglesias y en todos aquellos que tienen relación con el ámbito eclesiástico. Se documenta con la forma académica desde el siglo XIII, según fuentes como el $C D H$ o el CORDE. Se localiza en inventarios de bienes de la Península y América.

\section{CORPORAL}

Sust. m. Rel. 'lienzo que se extiende en el altar, encima del ara, para poner sobre él la hostia y el cáliz. U. m. en pl. ( $D L E, 2$. a ac.). Covarrubias en su Tesoro dice que 'aunque sinifica las cosas que pertenecen al cuerpo; està restringido a sinificar los lienços que se ponen en el altar [...]' (NTLLE, 
s. v. corporal, Covarrubias, 1611). Término derivado del lat. CŎRPUS, -PŎRIS, íd. (DECH, s. v. cuerpo).

Dos volsas de corporales, la una de dos tafetanes morado y verde con galones de oro y la otra de terçiopelo negro y blanco (Medina de Rioseco, VA-1644)

Quatro bolsas de corporales (Medina de Rioseco, VA-1651)

Una casulla para decir missas un lado de chamelote encarnado y el otro de tafetán doble blanco con su manipulo y estola de la misma tela y sus corporales (Medina de Rioseco, VA-1685)

Un cáliz de plata con su patena, dos purificadores, unos corporales con sus fundas de guadamazil (Villalpando, ZA-1644)

Unos corporales con sus fundas de guadamazil (Villalpando, ZA-1660)

Lo mismo que ocurre con el término cáliz, corporal aparece en los textos desde el siglo XIII en la obra de Gonzalo de Berceo con la acepción que aquí se encuentra ( $C D H)$. Es una voz de uso habitual en los inventarios de bienes relacionados con la iglesia.

\section{CRUCIFIJO [cruçifijo, crucifixo, cruzifixo]}

Sust. m. 'Efigie o imagen de Cristo crucificado' (DLE). Esta voz se recoge con la forma crucifixo desde Nebrija hasta la edición académica de 1817, donde se recoge la forma que mantenemos hasta la actualidad crucifijo (NTLLE, s. v. crucifixo, crucifijo, Nebrija 1495, DRAE, 1817). Se trata de un término tomado del lat. CRUCIFIGĔRE (DECH, s. v. cruz).

Cinco tablas de figuras y un cruzifixo (Sahagún, LE-1602)

Un crucifijo (Castromocho, PA-1603)

La hechura de un crucifijo de plomo en un real (Frechilla, PA-1613)

Un crucifijo de plata y unos zarcillos apreciados en ocho rreales (Frechilla, PA-1613)

Un crucifijo de papel en un marco (Castromocho, PA-1614)

Un crucifixo en su caja (Villada, PA-1669)

Una cruz pequeña con un crucifixo de bulto (Villarramiel, PA-1696)

Un crucifixo en paramento de red (Villalón, VA-1637)

Se le volvió a entregar el rossario de coral con cruçifijo y estremos de oro contenidos en una carta de dote tasado en treynta ducados (Villalpando, ZA-1620)

El crucifijo es uno de esos objetos de devoción que se van a localizar en las viviendas de esta época. Es un término de uso general que se encuentra en documentos de España y en el resto de las colonias de ultramar. En Tierra de Campos aparece con la forma y acepción académica y lo podemos encontrar elaborado de materiales tan diversos como la plata, el plomo, la madera o el papel.

\section{CRUZ [cruzeticas, cruziticas]}

Sust. f. 'Figura formada por dos líneas que se atraviesan o cortan perpendicularmente', 'insignia y señal de cristiano, en memoria de haber padecido en ella Jesucristo' (DLE, 1. a y 4. a ac.). Término procedente del lat. CRUZ, CRŬCIS (DECH, s. v. cruz).

Una cruz con un cruçificado en pintura (Valderas, LE-1682)

Una cruz con su peana del ogar (Boadilla de Rioseco, PA-1687)

Dos cruces de carauaca (Paredes de Nava, PA-1689)

Una cruz ynbultada de ébano (Paredes de Nava, PA-1690)

Una cruzitica y dos estampas (Villalón, VA-1637)

Una cruz de oro en tresçientos y sesenta y quatro reales (Medina de Rioseco, VA-1640) 
Tres cruzeticas de plata (Medina de Rioseco, VA-1642)

Una cruz de ébano de reliquias quebrada un braço (Medina de Rioseco, VA-1651)

Una cruz de concha de tortuga pequeña (Medina de Rioseco, VA-1660)

Una cruz de oro y christal y diez perlas pequeñas con un listón nacarado (Villalpando, ZA-1620)

Una cruz de oro con reliquias con ymaxen de Nuestra Señora de la Conceción (Villalpando, ZA1644)

Una cruz de ébano (Villalpando, ZA-1666)

Una cruz de Caravaca pequeña de plata (Villalpando, ZA-1690)

Desde el punto de vista diacrónico este término se documenta desde muy temprano; el $C D H$ ofrece ejemplos del mismo desde el siglo XII.

Es un término de uso general en todas las épocas. El CorLexIn ofrece un nutrido número de ejemplos de este término en la documentación notarial. Esta frecuencia se hace extensible a Tierra de Campos, donde se localizan cruces confeccionadas de diversos materiales como oro, plata, cristal o concha de tortuga, y con diversas morfologías -con una peana para el hogar, cruces de caravaca, inbultadas-. Formalmente aparece el diminutivo cruzetica que alterna en los textos con la vacilación de las vocales átonas (cruzitica).

\section{ENCOMIENDA [encomenda]}

Sust. f. 'Cruz bordada o sobrepuesta que llevan los caballeros de las órdenes militares en la capa o vestido' ( $D L E, 6$. a ac.). Término recogido desde Nebrija, pero con la acepción indicada del $D L E$ y que encontramos en los documentos de la Tierra de Campos no se registra hasta el DRAE de 1791 (NTLLE, s. v. encomienda, Nebrija, 1495, DRAE, 1791). Término derivado del lat. MANDARE 'encargar, dar una misión', 'cofiar (algo), encomendar' (DECH, s. v. mandar).

Un cofrezico vordado de paja forrado en tafetan amarillo y en él una encomienda de San Joan de azauache (Grajal de Campos, LE-1658)

Unas encomiendas con sus arillos de oro (Castromocho, PA-1611)

Trescientos y cinquenta reales que estan debiendo de las entradas, encomiendas, escotes y derechos de la comfradia de la Beracruz (Frechilla, PA-1678)

La encomenda de oro esmaltada y un rosario (Medina de Rioseco, VA-1642)

La ynsinia de la encomienda de Santo Oficio esmaltada en cristal (Medina de Rioseco, VA-1649)

El término encomienda aparece en los textos del CORDE y el $C D H$ con la acepción académica que hace referencia al verbo o al término legal. Algo muy parecido ocurre en el CorLexIn, donde encontramos dos casos en la Península en los cuales el término encomienda hace referencia a un tipo de objeto más suntuoso y que servía de ornamento además de identificación de una determinada orden militar o eclesiástica. Además de esta acepción, en Tierra de Campos nos encontramos con que este elemento no es un simple símbolo, sino que, además, es un objeto de lujo, posiblemente un tipo determinado de cruz que aparece junto a arillos o rosarios, y que está confeccionado con materiales como el azabache, el oro y el cristal. Por otro lado, nos encontramos con un ejemplo en Villalpando donde parece hacer referencia a un tipo de colcha o de tejido que nada o poco tiene que ver con las acepciones localizadas en los textos de la Península o América: 
Vna colcha de bolilla nueua de encomiendas, de tres piernas (Villalpando, ZA-1652)

Formalmente, en Tierra de Campos suele ser fiel a la variante académica, aunque encontramos algún caso de elipsis de la vocal palatal del diptongo (encomenda).

\section{ESCAPULARIO}

Sust. m. 'Tira o pedazo de tela con una abertura por donde se mete la cabeza, que cuelga sobre el pecho y la espalda y sirve de distintivo a varias órdenes religiosas', 'objeto devoto formado por dos pedazos pequeños de tela unidos con dos cintas largas para echarlo al cuello' (DLE, 1. a y 2. a ac.). Lo recoge Autoridades como una especie de 'estola mui ancha, que pende por delante y por detrás, y enmedio tiene una abertúra en redondo capáz para que por ella pueda entrar la cabéza; y desta forma són los escapularios que visten muchos Religiosos [...]' (NTLLE, s. v. escapulario, Autoridades, 1732). Se trata de un término tomado del lat. SCAPULARIA, neutro plural del adjetivo SCAPULARIS 'que cuelga sobre los hombros' (DECH, s. v. escapulario).

Un escapulario de la Santa y más trinidad (Villalpando, ZA-1629)

Como ocurre con otras palabras de este ámbito, escapulario se documenta de forma temprana en los textos; el $C D H$ y el CORDE ofrecen ejemplos de esta voz desde el siglo XIII.

Tan solo hemos encontrado una ocurrencia en la localidad zamorana de Villalpando con el significado religioso. Esta escasez de ejemplos se observa de igual manera en el CorLexIn, donde encontramos un "escapulario de Nazareno" en Huelva (1608) y otro de la orden del Carmen en Chile. El resto de los ejemplos nos hacen dudar de este sentido exclusivamente religioso. Algo parecido ocurre en Tierra de Campos, donde localizamos los siguientes ejemplos:

Un jubón y escapulario de estameña de Françia noguerada (Valderas, 1647)

Un escapulario de tafetán azul (Grajal de Campos, LE-1658)

Un bestido de picotillo de seda que es saya, jubón y escapulario (Medina de Rioseco, VA-1640)

Un bestido de muger basquiña, jubón y escapulario de picote de seda (Medina de Rioseco, VA1642)

Otro bestido de raso pardo, basquiña jubón y escapulario forrado en tafetán doble (Medina de Rioseco, VA-1645)

Una saya y un escapulario destameña (Medina de Rioseco, VA-1648)

Otro bestido de senpiterna leonado oscuro jubón, basquiña y escapulario (Medina de Rioseco, VA-1661)

Aquí escapulario designa un complemento que forma parte del vestido, confeccionado con tafetán o estameña. El número de ejemplos es mayor con esta acepción, algo que ocurre igualmente en el CorLexIn, donde se hallan ocurrencias en diferentes puntos de la Península, con preferencia de la zona meridional. También se documentan ejemplos en América con esta acepción. 


\section{ESTAMPA [estanpa, estanpica]}

Sust. f. 'Reproducción de un dibujo, pintura, fotografía, etc., trasladada al papel o a otra materia por medio del tórculo o prensa, desde la lámina de metal o madera en que está grabada, o desde la piedra litográfica en que está dibujada' (DLE). Término derivado del verbo estampar, y este de origen germánico, probablemente del fr. estamper, antiguamente 'machacar', 'aplastar', y este del fráncico *stampôn (DECH, s. v. estampar).

Tres estanpas de papel (Cea, LE-1621)

Otra estanpa de la echura de Cristo Nuestro Señor con la cruz a cuestas, pareçe ser de papelón (Valderas, LE-1647)

Una estampa de la pintura de Santa Catalina (Grajal de Campos, LE-1670)

Dos estampas pequeñas de Nuestra Señora y de la Madalena (Frechilla, PA-1638)

Una estampa de papel (Frechilla, PA-1639)

Una estampa de la Resurreçion en su tabla (Guaza de Campos, PA-1640)

Vna estanpica con la pintura de Nuestra Señora y su Hixo (Autillo de Campos, PA-1654)

Quatro estanpas de papel con su marco (Villada, PA-1669)

Una estampa sin marco pintura de San Telmo (Paredes de Nava, PA-1690)

Ocho láminas y estanpas pequeñas (Medina de Rioseco, VA-1643)

Un rosario con dos cruces y dos estampas (Villalpando, ZA-1638)

Una estampa de Nuestra Señora de las Angustias (Villalpando, ZA-1639)

Una estampa de la Concepción (Villalpando, ZA-1653)

Una estanpa de San Antonio (Villalpando, ZA-1666)

Dos estampas de diferentes pinturas en bastidor (Villalpando, ZA-1688)

Documentado en los textos literarios y protocolarios de la época de estudio, este tipo de objetos solían estar confeccionadas en papel o papelones y representaba motivos religiosos fundamentalmente.

Es una voz habitual en los inventarios de bienes de la Tierra de Campos. Se mantiene con la forma y el significado académico. Formalmente también encontramos el diminutivo del término estanpica en Autillo de Campos que parece hacer referencia al tamaño de la estampa.

\section{FACISTOL [fafistol]}

Sust. m. 'Atril grande en que se ponen el libro o libros para cantar en la iglesia y que, en el caso del que sirve para el coro, suele tener cuatro caras que permiten colocar varios volúmenes' $(D L E)$. Covarrubias recoge el término facistor y la edición de Autoridades de 1732 le distingue del atril común 'en tener un pié alto, en proporcion que puesto en el suelo pueda servir al que ha de cantar en pié' (NTLLE, s. v. fascitor, facistol, Covarrubias, 1611, Autoridades 1732). Término tomado del oc. ant. faldestol 'facistelo', 'facistol' (DECH, s. v. facistol).

Seis fafistoles pequeños bordados y de diferentes telas para debajo del misal del altar (Medina de Rioseco, VA-1651)

El único ejemplo que encontramos en la Tierra de Campos no se corresponde con la acepción que nos dan los diccionarios académicos para este término. En el $C D H$ encontramos "paño de facistol" en diversos documentos del siglo XVII, haciendo referencia en esta ocasión al paño que cubría este atril. En Tierra de Campos puede que estemos ante un fenómeno de metonimia, ya que -claramente y según el contexto-se trata de un paño o mantelillo que servía 
para proteger el facistol. Formalmente, la ocurrencia localizada presenta una asimilación de la $/ \mathrm{f} /$.

\section{HIJUELA [yxuela]}

Sust. f. 'Pedazo de lienzo circular que cubre la hostia sobre la patena hasta el momento del ofertorio', 'documento donde se reseñan los bienes que tocan en una partición a cada uno de los partícipes en el caudal que dejó un difunto' (DLE, 4. a y 8. a ac.). Autoridades incide sobre esas acepciones indicando que 'se llama asimismo la cubierta de lienzo que se pone encima del caliz, para preservarle de que no caiga dentro de él cosa alguna, durante el sacrificio de la missa' y también 'se llama el instrumento que se dá à cada uno de los herederos del difunto, por donde consta los bienes y alhajas que les toca en la partición' (NTLLE, s. v. hijuela, Autoridades 1734). Se trata de una palabra derivada de hijo, procedente del lat. FīLIUS íd. (DECH, s. v. hijo)

Mill çiento y sesenta y siete maravedis que cobró de la dicha María de Vernal su hermana por los mismos que se la adjudiçaron en su hijuela para obrar de la susso dicha por llevarlos de más en la suya (Medina de Rioseco, VA-1642)

Una binaxera de bidrio y dos yxuelas de olanda con sus puntillas para cubrirlas (Medina de Rioseco, VA-1644)

En el $C D H$ se encuentra documentada desde finales del siglo XV con la acepción de 'documento legal'. No es hasta bien entrado el siglo XVI cuando encontramos la acepción de 'paño':

[...] vn par de hijuelas e corporales para el caliz todo guarnesçido de brocado ("Escritura de erección de una iglesia e institución de una capellanía en Trujillo" 1537)

En la Tierra de Campos aparecen un par de ejemplos que corresponden con las dos acepciones académicas en documentos pertenecientes a una misma localidad, Medina de Rioseco.

En repertorios más modernos, Gordaliza recoge la forma hijuela para referirse al 'documento de partición de una herencia o una compra' Gordaliza, 1988: 124).

\section{LÍGNUM CRUCIS [lynum Cruçis]}

Loc. lat. m. 'Reliquia de la cruz de Cristo' (DLE). Este término lo registra el DRAE de 1803 con la forma lignumcrucis, y a partir de la edición de 1852 aparece con la forma lignum crucis (NTLLE, s. v. lignumcrucis, lignum crucis, $D R A E, 1803, D R A E, 1852$ ). Se trata de una expresión latina que significa 'leño de la cruz' (DECH, s. v. leña).

Un anusdej de plata sobredorado con lynum Cruçis bidriera de cristal y unas reliquias y Santa Ysauel (Villalpando, ZA-1660)

Un lígnum Cruçis con otras reliquias alrededor y su bidriera, encajado en una cajica de ojadelata (Villalpando, ZA-1689)

La expresión Lignum Crucis 'madera de la Cruz' hace referenia a una de las reliquias más importantes del mundo cristiano. En el $C D H$ se encuentra documentada esta expresión latina desde principios del siglo XVI. 
En el CorLexIn localizamos un ejemplo en Guipúzcoa. Este uso exiguo se da también en Tierra de Campos, donde tan solo encontramos dos ocurrencias. El hecho de encontrar pocos datos posiblemente tenga que ver con la naturaleza del objeto.

\section{MISAL}

Sust. m. 'Adj. Se dice del libro en que se contiene el orden y modo de celebrar la misa' (DLE). Lo recoge Covarrubias en su Tesoro con la misma acepción que se conserva hasta nuestros días (NTLLE, s. v. misal, Covarrubias, 1611). Término derivado de misa, tomado del lat. tardío MĭsSA (DECH, s. v. misa).

Un libro misal en quarenta y quatro reales (Medina de Rioseco, VA-1644)

Seis fafistoles pequeños bordados y de diferentes telas para debajo del misal del altar (Medina de Rioseco, VA-1651)

Un misal nuevo con su atril (Villalpando, ZA-1696)

A pesar de que la Academia recoge este término como adjetivo, desde muy pronto se recoge como sustantivo en los textos que conforman el $\mathrm{CDH}$ :

Mando elos briuiarios e los salterios a la capiella, e mando que compren I buen missal e vna bona vestimienta. («Testamento», Documentos de la catedral de León, 1250).

En los datos que ofrece el CorLexin se puede observar que este término siempre se documenta como sustantivo. Es voz de uso general que se documenta de Norte a Sur de la Península y en textos americanos y canarios.

A diferencia de lo que ocurre en el CorLexIn, en Tierra de Campos sí se localiza esta voz como adjetivo, tal y como señala el diccionario académico "libro misal". Aunque el uso preferente sigue siendo como sustantivo.

\section{PURIFICADOR}

Sust. m. 'Paño de lino, con el cual se enjuga y purifica el cáliz' (DLE, 2. ac.). Autoridades define este término como 'un paño de lino, de cosa de una tercia en quadro, con el qual se enxuga y purifica el Caliz, depués de que el Sacerdote ha consumido, la segunda purificación en la Missa' (NTLLE, s. v. purificador, Autoridades, 1737). Se trata de un término compuesto procedente del lat. PŪRUS (DECH, s. v. puro).

Quatro purificadores de cáliz de olanda tasadas en quatro reales (Medina de Rioseco, VA-1644) Un cáliz de plata con su patena, dos purificadores, unos corporales con sus fundas de guada mazil (Villalpando, ZA-1644)

Diacrónicamente, la palabra se documenta con esta acepción en el $C D H$ desde finales del siglo XVI:

hizo hazer un caliz de plata muy bueno, por mi órden, y este y unos corporales de holanda muy rica y su hijuela de lo mismo, todo guarnecido de franjas ricas, y su palio y purificador y cobertor de caliz de lienço, (Memorias de Garibay, Esteban de Garibay, 1594). 
El CorLexIn documenta dos casos en la Península -Álava y Madrid-y uno en un documento boliviano, donde este término se localiza en inventarios pertenecientes a iglesias o a personas de alto rango que recibían los servicios sacerdotales en casa.

A partir del siglo XVII, purificador con el significado de 'lienzo' deja de aparecer en la documentación y ya son pocos los ejemplos que se localizan en el siglo XVIII. 


\subsection{TEXTIL}

España fue durante muchos años destacada productora de materias primas como la lana, el lino, el algodón o la seda, lo que propició que también existiese una importante industria textil. La Tierra de Campos albergaba en esta época importantes centros de producción textil como Amusco, Autillo de Campos, Frechilla, o Medina de Rioseco. Allí se elaboraban estameñas, cordellates, paños, bayetas, etc. A lo producido en la zona de estudio había que añadir los tejidos que venían de fuera con los que se confeccionaba las diferentes prendas personales y del hogar. Los inventarios de bienes atesoran un nutrido número de palabras que designan tejidos de algodón, de seda, de lana y de lino, entre otros.

\subsubsection{Algodón}

\section{ALGODÓN}

Sust. $\mathrm{m}$. 'hilado o tejido hecho de borra de algodón' (DLE, 5. a ac.). Aparece ya en Nebrija y Covarrubias, este último lo define como planta muy común que 'se coge y se hila, de que fazen telas, algunas rasas y otras vellonas' (NTLLE, s. v. algodón, Covarrubias, 1611). Procedente del ár. qutn íd., vulgarmente qotón (DECH, s. v. algodón).

Otros [tocados] de algodón nueuo en seys reales (Sahagún, LE-1600)

Otro algodón nueuo, en seys reales (Sahagún, LE-1601)

Vna madexica de algodón blanco (Valderas, LE-1647)

Una colcha grande buena de algodón (Grajal, LE-1658)

Dos tocas de muger de algodón (Castromocho, PA-1602)

Un tocado de algodón mediado en quatro reales (Frechilla, PA-1613)

Tres tocados, dos delgados y uno de algodón apreciados en doçe reales (Frechilla, PA-1613)

Otra beatilla de algodón bieja en un real (Fechilla PA-1614)

Dos colchas la una de algodón y la otra de gusanillo (Paredes de Nava, PA-1690)

Una colcha de algodón vuena (Boadilla de Rioseco, PA-1692)

Una colcha de algodón colchada (Medina de Rioseco, VA-1646)

Una colcha de dos olandas con algodón (Villalpando, ZA-1686)

Una colcha de dos olandas y algodón con puntas (Villalpando, ZA-1688)

Una colcha de algodón con sus fluecos (Villalpando, ZA-1689)

Es un término muy extendido en el siglo XVII, que se encuentra ampliamente documentado en el CORDE y en el $C D H$ desde el siglo XIII. Son igualmente abundantes los ejemplos que aparecen en el CorLexIn, tanto en la Península y Canarias como en América.

\section{BOFETÁN [vofetán]}

Sust. $\mathrm{m}$. 'Tela de algodón delgada y tiesa' (DLE). El término y la definición se registran en el Tesoro de Covarrubias y en Autoridades donde dicen tomar el nombre del sonido que hace la tela al desdoblarla. En la edición académica de 1899, aparece este término como procedente del persa báfeta (NTLLE, s. v. bofetán, Covarrubias, 1611; Autoridades, 1726; DRAE, 1899). También puede derivar del fr. bouffette que significa 'reunión de hilos de lana o seda, formando una especie de ramillete o vellón' (DHTT, s. v. bofetán). 
Dos alvas de vofetán (Cea, LE-1621)

Una toca de bofetán tassada en ocho reales (Castroañe, LE-1622)

Un cuello de bofetán en siete reales (Frechilla, PA-1615)

Dos toallas con cadeneta de bofetán en setenta reales (Medina de Rioseco, VA-1640)

Esta palabra hace referencia a una 'tela antigua de algodón cruda, sin blanquear y delgada, rígida y tiesa, fabricada en las Indias Orientales, muy extendida hasta principios del siglo XIX' (DHTT, s. v. bofetán). El Fichero General de la Academia localiza este término en una carta de dote de Granada en el año 1597 "quarenta e seis barras de lienço bofetán a quatro rreales". Los testimonios que nos ofrecen bases de datos como el CORDE o el CDH se limitan a unos pocos ejemplos localizados en el siglo XVII. Y, aunque aparecen ejemplos de este tipo de tela, tanto en la Península como en América las ocurrencias que muestra el CorLexIn no son muy frecuentes, tal como ocurre con otro tipo de tejidos. Los ejemplos se reparten por diferentes puntos geográficos de la Península -Cádiz, Jaén, Ciudad Real, Madrid, Toledo, Burgos y Navarra-. En la Tierra de Campos tampoco tiene excesivo éxito esta palabra, se prefieren otras telas de algodón. Este tejido se utilizaba principalmente para confeccionar el ajuar de la casa como cortinas, sábanas, pabellones, toallas, y complementos de la indumentaria como pañuelos, albas, tocas, cuellos y mangas.

\section{BOMBASÍ [bonbasí, vonvasí, uonvasí]}

Sust. m. 'fustán (tela gruesa de algodón)' (DLE). Este término aparece registrado en Autoridades como 'tela de vários colóres tosca y hecha de algodón y lana, que paréce está como engomada' (NTLLE, s. v. bombasí, Autoridades, 1726). Vocablo procedente del cat. bombasí y éste a su vez de una forma it. *bombagino, y derivado de bambagia o bombage, 'algodón', que a su vez pertenece a la familia del lat. вомBYX 'gusano de seda', 'seda' (DECH, s. v. bombasí).

Un jubón de bonbasí plateado con mangas de terciopelo (Medina de Rioseco, VA-1657)

Siete varas de vonvasí en cinco pedaços (Medina de Rioseco, VA-1645)

Quatro varas y media de uonvasí listado (Medina de Rioseco, VA-1645)

El CORDE documenta esta voz en dos textos, uno a principios del siglo XVII, en una obra de Góngora, donde utiliza este término en sentido figurado ("labios frescos como bombasi"), y en una obra de Núñez de Pineda y Bascuña, titulada El cautiverio feliz, donde aparecen varias enunciaciones en las que se encuentran bombasíes entre otras telas. En el CorLexIn hay ejemplos de esta palabra repartidos por diferentes puntos de la Península -localidades de Navarra, Valladolid, Toledo, Albacete, Cáceres o Huelva-. Según nos indica Pérez Toral (2017b: 96-97) el DECH propone un primer testimonio de bombasí en 1640, pero revisando el CorLexIn y Morala (2012f: 300-301) encontramos ejemplos que documentan este término con anterioridad a la fecha propuesta como primera documentación por el $D E C H$ :

Ytten, hubón uiexo de bonbasí (Veracruz. México, 1634).

Vn jubón de hombre de bonbasí en diez reales (Mora, Toledo, 1637).

Un jubón de bombasí (Vitoria, 1639). 
De los tres ejemplos encontrados en Tierra de Campos, dos de ellos pertenecen a un inventario donde se detallan las "mercaderías" pertenecientes a una tienda de tejidos de Medina de Rioseco.

Se trata de una innovación léxica, una voz importada e incorporada al castellano y que en el siglo XVII estaría implantada en gran parte de la Península (Morala, 2012f: 300). Sin embargo, parece comprobarse que el consumo de esta tela se fue extinguiendo y fue reemplazada por otros tipos de tejidos como los cutíes (DHTT, s. v. bombasi).

\section{CAZA [caça]}

Sust. f. 'Lienzo muy delgado semejante a la gasa, usado antiguamente' (DLE). Lo recoge Autoridades como 'lienzo mui delgádo, que se texe de algodón, sutilmente hilado, y esta se llama Caza ordinaria, á diferencia de la caza cambrayada [...]' (NTLLE, s. v. caza, Autoridades, 1729). Se trata de un término que probablemente proceda del ár. qazz 'seda', 'borra de seda', 'gasa', de origen persa y que entró por vía comercial ( $D E C H$, s. v. caza).

Una pieça de caza (Villada, PA-1669)

Un par de manguillas de caza biexas en seis reales (Frechilla, PA-1671)

Un par de mangas de caza para muxer en catorce reales (Frechilla, PA-1671)

Dos balonas de caza (Medina de Rioseco, VA-1639)

Una mantilla de bautiçar con cubridor de caza con punta y encaje blanco (Medina de Rioseco, VA-1647)

Otra toalla de caça thasada en ocho reales (Medina de Rioseco, VA-1647)

Dos tuallas de caza con puntas (Medina de Rioseco, VA-1660)

Quatro pañuelos y tres pares de manguillas de canbray y caza (Medina de Rioseco, VA-1661)

Un cubridor de niño de caça acanbrayado con tres baras y media de puntas de mota finas (Medina de Rioseco, VA-1685)

Otra toalla de caça labrada de oro y seda (Villalando, 1650)

Un pañuelo de caza (Villalpando, ZA-1697)

Este término se documenta en la Tierra de Campos con la acepción de 'lienzo muy delgado de algodón, semejante a la gasa, usado antiguamente', utilizado principalmente para la confección de toallas, pañuelos, balonas, cubridores y mangas. También la encontramos como tela en pieza. El término caza con la acepción de 'tejido' aparece a lo largo de toda la Península.

\section{COTONÍA}

Sust. f. 'Tela blanca de algodón labrada comúnmente de cordoncillo' (DLE). Aparece en Covarrubias como 'cierta tela hecha de hilo de algodon' (NTLLE, s. v. cotonía, Covarrubias, 1611). Quizá procedente del derivado árabe qutnîya, quizá tomado del cat. cotonia $(D E C H, \mathrm{~s}$. v. algodón).

Quatro baras de cotonía abarillado nuebo (Sahagún, LE-1600)

Una ropa de cotonía blanca biexa en seys reales (Sahagún, LE-1600)

Unas mangas de muger de cotonía en un real (Sahagún, LE-1605)

Una colcha de cotonía con un paño de red en seys ducados (Sahagún, LE-1605)

Unos cuerpos de cotonía (Castromocho, PA-1611)

Una bara de cotonía (Castromocho, PA-1611)

Yten un jubón de cotonía tasado en diez reales, es de escusa para fiestas (Mazariegos, PA-1619) 
Una colcha blanca de cotonía con sus fluecos (Guaza de Campos, PA-1637)

Un bestido a la francessa con alamares de oro calçon ropilla y jubón blanco de cotonía y una valona de puntas grandes (Medina de Rioseco, VA-1642)

Seis pieças de cotonías labradas angostas ordinarias a cinquenta y siete reales cada pieça (Medina de Rioseco, VA-1645)

Una colcha blanca de cotonía con su flueco (Medina de Rioseco, VA-1649)

Una colcha de cotonía vordada con puntas (Medina de Rioseco, VA-1660)

Dos almillas de cotonía blanca y negra (Medina de Rioseco, VA-1661)

Otros (cuerpos) de cotonia (Villalpando, ZA-1645)

Esta voz referencia un tipo de tela hecha de algodón utilizada para la confección de prendas de vestir, ropa de la casa o como tejido en pieza. En bases de datos como el $C D H$ se documenta a partir del siglo XV, especialmente en textos dedicados a la industria textil:

Otrosy, que qualquier persona que troxiere aquí a la dicha çibdad a vender fustanes o cortinas o cotonías (Ordenanzas o condiciones para el arrendamiento de la renta corredurías, 1421)

A pesar de que la documentación señalada pertenece al siglo $\mathrm{XV}$, se ve claramente una preferencia por este término en el siglo XVII, como puede observarse consultando tanto el $C D H$, como el CORDE. Así lo atestigua también el CorLexIn, donde se localizan ejemplos ubicados geográficamente a lo largo de toda la Península -también en Canarias y América, aunque en menor medida-.

Como advierte Pérez Toral, esta palabra es de uso mayoritario en el siglo XVII, pero entra rápidamente en retroceso y los casos que se pueden encontrar en los siglos posteriores se reducen (Pérez Toral, 2017a: 210).

\section{ENCAJE [encaxe]}

Sust. m. 'Tejido de mallas, lazadas o calados, con flores, figuras u otras labores, que se hace con bolillos, aguja de coser o de gancho, etc., o bien a máquina' (DLE). Término recogido por Covarrubias como 'cierta labor de randas que las mugeres entremeten en sus gorgeras y pieças labradas' (NTLLE, s. v. encaje, Covarrubias, 1611). Es una voz derivada de caja, probablemente del cat. caixa u occitano caissa, procedentes del lat. CAPSA (DECH, s. v. caja).

Dos pares de encajes anchos (Paredes de Nava, PA-1689)

Una toca con su encaje (Paredes de Nava, PA-1689)

Un paño de lienzo fino de lorençana con encaxe y puntas (Cuenca de Campos, VA-1606)

Un encaje de puntas para un manto (Medina de Rioseco, VA-1648)

Un bestido de tafetán doble negro guarneçido con encajes blancos (Medina de Rioseco, VA-1685)

Un manto de seuilla con su encaje grande y bueno (Villalpando, ZA-1637)

Un pañuelo de Contray de vara con sus encajes (Villalpando, ZA-1686)

Unos manteles que cubren el altar con sus encaxes (Villalpando, ZA-1689)

Es un tejido ligero, delgado, formado por cierta labor de randas o mallas, lazadas o calados, que forman flores, figuras $u$ otras labores, que se hace a mano con bolillos como blonda, aguja de coser o de gancho o a máquina, y que emplea hilo de seda, algodón, lino, oro o plata, torcidos y trenzados (DHTT, s. v. encaje). Es un término de uso común en Tierra de Campos en la época. Esta acepción se documenta a finales del siglo XVI y podemos encontrarla en los Romances de Luis de Góngora ("estas moçuelas que sirben / de hacer encanjes y randas") publicados entre los años 1580 y 1627 (CDH, s. v. encaje). A pesar de ser una palabra de reciente adquisición, este 
término estaba presente a lo largo de todo el territorio peninsular, no así en América, donde hasta la fecha encontramos un solo ejemplo en Santiago de Chile a finales de siglo: "Yten doze piezas de encaxes y una comenzada" (CorLexIn, s. v. encaje).

\section{FELPA}

Sust. f. 'Tejido de seda, algodón, etc., que tiene tejido por el haz' (DLE). Covarrubias recoge este término como 'quasi filelpa, a filis, porque es una cierta tela de seda, toda de cabos de hilos' (NTLLE, s. v. felpa, Covarrubias, 1611). Voz común con el portugués, catalán e italiano felpa, íd., oc. feupo, fr. ant. y dial. feupe 'harapo', de origen incierto; en castellano es probable que sea de procedencia galorrománica (DECH, s. v. felpa).

Unos monillos de felpa (Paredes de Nava, PA-1695)

Un corte de felpa y otro de picote para dos juvones (Medina de Rioseco, VA-1646)

Un estrado de terçiopelo y damasco carmesí con doçe almuadas con su galón de seda y colonias que tiene diez y seis baras de felpa y diez y seis de damasco y catorce de anexo (Medina de Rioseco, VA-1685)

Una anguarina de felpa negra (Medina de Rioseco, VA-1685)

Un boçino de terciopelo con flanjas de oro forrado con felpa (Villalpando, ZA-1644)

Este tipo de tela se fabricaba en España y se exportaba al extranjero. Además de servir para confeccionar ropa, se destinaba a cubrir sillerías, muebles de lujo, calzado y otros objetos (DHTT, s. v. felpa). El CORDE documenta esta palabra en el año 1543 en un texto donde relata el recibimiento que se hizo en Salamanca a María de Portugal. En el CorLexIn aparece documentada tanto en la Península como en América. En Tierra de Campos se recoge con el significado y forma académicos.

\section{FUSTÁN}

Sust. m. 'Tela gruesa de algodón, con pelo por una de sus caras' (DLE). Voz recogida ya por Nebrija, en Autoridades se registra como 'cierta tela de algodón, que sirve regularmente para forrar vestidos', esta definición se mantiene hasta el DRAE de 1825, donde se define este término como 'tela de algodón'. (NTLLE, s. v. fustán, Nebrija, 1495; Autoridades, 1732, DRAE, 1825). Palabra común a las varias lenguas romances y al árabe hispánico y moderno, de origen incierto; quizá alteración del árabe fustâ 'tienda de campaña hecha de algodón' (DECH, s. v. fustán).

Media quarta de fustán en beinte i quatro maravedíes (Villavelasco, LE-1609)

Una saya colorada con ruedo de fustán colorado (Frechilla, PA-1615)

Un manto biexo de beynteydoseno con bebederos de fustán (Frechilla, PA-1615)

Un manto traydo con Rodadura de fustán (Frechilla, PA-1642)

Un jubón de mujer de gorguerán azulado viejo forrado en fustán roto (Autillo de Campos, PA-1648)

Un vestido destameña plateada nuevo aforrado en fustán y guarnezido con galón realzado (Medina de Rioseco, VA-1649)

Un herreruelo pardo de paño traydo con cuello de fustán (Villalpando, ZA-1620)

Una vara de fustán nuebo (Villalpando, ZA-1637)

Mil ciento y treinta y ocho marauedis de fustán, botones, seda, bayeta de aforro, trancaderas, bayeta para mangas, aforro dellas y hechura de todo el dicho bestido (Villalpando, ZA-1656) 
Es un término de uso general en la zona de estudio. Del siglo XVII al XIX se trataba de una tela de algodón gruesa y tupida que solía utilizarse para forrar vestidos, colchones, almohadas, etc. (DHTT, s. v. fustán). Al parecer, en la primera mitad del siglo XVII también era habitual utilizar telas como el fustán para confeccionar los jubones (Lasmarías, 2009: 139). Término documentado desde el siglo xIII en el $C D H$.

Los ejemplos de esta voz que nos encontramos en el CorLexIn están ubicados en la zona Centro y Norte de la Península -Huesca, Guipúzcoa, Navarra, Valladolid y Teruel-, donde designa un tipo de tejido utilizado principalmente para la confección de forro. Con esta forma y significado se documenta igualmente en la Tierra de Campos.

Sin embargo, en el CorLexIn se localizan un par de ejemplos en Huelva que no parecen hacer referencia a un tipo de tejido, sino más bien a algún tipo de prenda que puede coincidir con la segunda acepción del $D L E$, 'enagua, combinación', con marca geográfica de algunos países de Hispanoamérica:

Un fustán de crea, en quatro reales ( $\mathrm{H}-1634)$

Un fustán de cotonía, en quince reales (H-1634)

Pérez Toral localiza esta voz en el CDH en el siglo XIII -Fuero de Cáceres (c1234-1275) donde aparece referenciada junto a saya, camisas y bragas y afirma que algunos autores como Alfau de Solalinde (1969: 107) relacionan este uso de fustán como vestimenta con la voz francesa futaine (Pérez Toral, 2017b: 101).

\section{NAVAL [nabal, naual]}

Sust. m. desus. 'morlés' 'tela de lino, no muy fina, fabricada en Morlés, ciudad de la región de Bretaña, en Francia' (DLE, 3. a ac.). Nebrija recoge la acepción de 'lienzo', pero ni Covarrubias, ni Autoridades registran esta definición. Es en el DRAE de 1925 cuando aparece como un sustantivo en desuso referido a un tipo de tejido 'morlés' (NTLLE, s. v. naval, Nebrija, 1495; DRAE, 1925). Término derivado de nave, del lat. NAVIS 'barco, nave' (DECH, s. v. nave).

\footnotetext{
Otra toca de nabal tasada en seis reales (Castroañe, LE-1622)

Unas manguillas de nabal blancas (Paredes de Nava, PA-1689)

Dos varas y tres quartas de naual (Medina de Rioseco, VA-1645)

Un paño de manos de naual con sus puntas (Medina de Rioseco, VA-1645)

Zinco almuadas de naval nuebas (Medina de Rioseco, VA-1660)

Un pechero de una bara de nabal (Medina de Rioseco, VA-1660)
}

Se trata de una tela de algodón, medianamente gruesa y tiesa, que servía para forros. Era uno de los tejidos que más se importaba en Cataluña en el siglo XVII, según las Tarifas de la Bolla catalana. El naval cordellado era el que se tejía formando un cordel (DHTT, s. v. naval). Este término aparece documentado en el CORDE a finales del siglo XV en las Cuentas de Gonzalo de Baeza, Tesorero de Isabel la Católica, con la acepción que manejamos en nuestro corpus de 'tela de algodón'. Los datos que nos aporta el CorLexIn referencian un tipo de tela que se utilizaba principalmente para la confección de complementos como cofias, mangas o paños de cabeza, incluso camisas de mujer, así como ropa del hogar, sobre todo almohadas, aunque también se referencia junto a toallas, paños, lenzuelos o peinadores. Sin embargo, no hemos encontrado 
ningún ejemplo en el que esta tela se utilizase como forro, según advertía el $D H T T$. En Tierra de Campos este tejido también se utiliza para elaborar este tipo de prendas -toca, manguillas o pechero- y también almohadas y paños de manos. En cuanto a la distribución geográfica de la palabra, no presenta un patrón claro y se extiende de Norte a Sur y de Este a Oeste.

\section{TELA}

Sust. f. 'Obra hecha de muchos hilos, que, entrecruzados alternativa y regularmente en toda su longitud, forman como una lámina. Se usa especialmente hablando de la obra tejida en el telar' $(D L E)$. Término recogido desde Nebrija, en Autoridades la define como 'qualquier obra texida de lana, seda, lino, y otras materias' (NTLLE, s. v. tela, Autoridades, 1739). Voz procedente del lat. TĒLA (DECH, s. v. palma).

Un faldón de tela de plata y terziopelo negro (Sahagún, LE-1603)

Dos pares de cuerpos de tela nuebos y un jubón de tela tasado (Sahagún, LE-1605)

Dos jubones de una misma tela de piñuela, el uno antiguo y el otro de uso nuevo viejos (Grajal de Campos, LE-1658)

Un jubón de media tela de plata (Paredes de Nava, PA-1695)

Unas medias de tela (Paredes de Nava, PA-1695)

Un relicario en tela (Paredes de Nava, PA-1695)

Un bestido desparragón de seda noguerado, calçón y ropilla forrado en tafetán plateado con un jubón de tela pardo y plateado con guantes y pretinas (Medina de Rioseco, VA-1642)

Un jubón de tela de oro camuzado (Medina de Rioseco, VA-1642)

Un jubón de tela verde y plata con passamanos de plata (Medina de Rioseco, VA-1642)

Otro jubón de tela de corte de Sebilla tres ducados (Villalpando, ZA-1635)

Una cariñana con sus juntas blancas y otra de tela amarilla con su guarnición negra y blanca (Villalpando, ZA-1654)

Tres almoadas de tela de Rey (Villalpando, ZA-1688)

Es un término de uso común en la Tierra de Campos y en el resto de la Península y América, según podemos observar en el CorLexIn. Se trata de la 'estructura hecha con hilos entrelazados, que tiene una longitud y una anchura considerable, y un grueso muy pequeño, especialmente la realizada con hilo o cáñamo; preferentemente se hace con ligamento de tafetán del cual es sinónimo tela'. En catalán, se utiliza como sinónimo de lienzo y también se utiliza para designar la ropa fina de cáñamo, algodón o lino (DHTT, s. v. tela). Durante los siglos XVI y XVII esta voz se utilizaba también para designar un tejido particular muy costoso, que servía para confeccionar prendas de calidad y para adornarlas (Bernis, 2001 citada en el DHTT).

\section{TERLIZ}

Sust. m. 'Tela fuerte de lino o algodón, por lo común de rayas o cuadros, y tejida con tres lizos' (DLE). Lo recogen Nebrija y Covarrubias. Autoridades mantiene la misma acepción hasta la actualidad (NTLLE, s. v. terliz, Nebrija, 1495, Covarrubias, 1611, Autoridades, 1739). Término procedente del lat. TRILIX, -İCIS 'de tres lizos', 'tela labrada con tres lizos' (DECH, s. v. terliz).

Un cabezal de terliz dado tasado en beinte riales (Grajal de Campos, LE-1670)

Un cauezal de terliz biejo (Valderas, LE-1682)

Un cabeçal de terliz pequeño (Frechilla, PA-1615)

Tres baras de terliz (Paredes de Nava, PA-1695) 
Dos cauezales de terliz con su pluma (Medina de Rioseco, VA-1651)

Un cabezal biexo de terliz (Cuenca de Campos, VA-1668)

Tres cauecales de terliz con su pluma (Villalpando, ZA-1630

Tres cabezales de terliz (Villalpando, ZA-1631)

Esta palabra hace referencia a un tipo de tejido que se utilizaba principalmente para forros de entretelas, telas de colchón, cabezales y fundas (DHTT, s. v. terliz). Aparece documentada en el CORDE a partir del siglo XIII en el Libro de Alexandre y presenta cierta vitalidad hasta el siglo XVII. A partir de esta fecha, el término cae en desuso. Este término aparece a lo largo de la Península con el significado de 'tejido para confeccionar delanteras, fundas, cabezales y colchones'. Tan solo aparece un caso en Jaén en el cual el término terliz sufre el fenómeno de la metonimia: la materia de la que está hecho un objeto pasa a ser la que lo designa.

Una cama de damasco açul con su çielo, cortinas, rodapies, terliz y dos cortinas de puerta (Jaén, 1650)

Sin embargo, este cambio es más habitual en la Tierra de Campos, donde existe una serie de ejemplos con el significado de 'cabezal', ya que en el resto de los casos el terliz siempre está destinado a la confección de dicho objeto:

Dos terlizes con su pluma buenos (Sahagún, LE-1601)

Tres terlizes con sus underos llenos de pluma buenos (Sahagún, LE-1600)

Tres terlices buenos en treinta y seys reales (Sahagún, LE-1600)

Dos terlizes demediados en doce reales (Sahagún, LE-1600)

\subsubsection{Lana}

\section{ALBORNOZ}

Sust. m. 'Tela hecha con estambre muy torcido y fuerte, a manera de cordoncillo', 'especie de capa o capote con capucha' (DLE, 2. - y 3. a ac.). Covarrubias lo define como 'capuz cerrado de camino con su capilla, de cierta tela que escupe de si el agua que se le cae encima sin calar adentro: y deste genero de capa, o cobertura usan mucho los Moros', sin embargo en Autoridades se da por primer significado 'especie de tela de lana, que se labraba sin teñir, texiendo la hilaza de su estambre mui torcida y fuerte à manera de cordoncillo, de la qual usaban los Moros pára capótes con capilla, o capiróte para defensa de las nieves, aguas, y malos temporales. [...]' (NTLLE, s. v. albornoz, Covarrubias, 1611, Autoridades, 1726). Término procedente del ár. burnûs (DECH, s. v. albornoz).

Unas enaguas de albornoz viejas amarillas (Autillo de Campos, PA-1647)

Un albornoz plateado (Villada, PA-1669)

Tres pieças de albornozes, pardo, negro y plateado (Medina de Rioseco, VA-1645)

Vna terçia de albornoz negro en tres reales (Medina de Rioseco, VA-1645)

Una colgadura vieja de cama encarnada de albornoz (Medina de Rioseco, VA-1660)

El DHTT describe este tejido como 'una tela de lana, que se labraba sin teñir, y que tenía la hilaza de la urdimbre, trama o ambas, de estambre muy torcida y fuerte a manera de cordoncillo, de la cual usaban los moros para capotes con capilla, o capirote para defensa de las nieves, aguas 
y malos temporales. En el siglo XVIII se usó también esta tela -con el mismo nombre-, aunque algo adulterada o viciada en la calidad, si bien la tela que servía para capotes y sobretodos se llamaba comúnmente barragán. En el siglo XIX se llamaba albornoz la 'pieza de abrigo para individuos de ambos sexos, que se hacía de cualquier tela' (DHTT, s. v. albornoz).

Este término se documenta con la acepción de 'tipo de tela de lana' desde el siglo XIII y un siglo más tarde también se encuentra con el significado de 'tipo de vestimenta' ( $C D H)$. En los documentos que conforman el CorLexIn se localizan poco más de media docena de ejemplos de esta voz, tanto en la Península como en Canarias, y la mayor parte de estas ocurrencias se refieren al tipo de tejido; tan solo hay una pequeña referencia en Bercial de Zapardiel, provincia de Ávila, donde aparece "un aforro de baieta de un albornoz". Este desequilibrio entre las diferentes acepciones también se aprecia en Tierra de Campos, donde los pocos ejemplos que aparecen se refieren a un tipo de tejido que servía para confeccionar ropas (corpiños, enaguas, ferreruelos...) y complementos de la casa como colgaduras. Tan solo nos encontramos el ejemplo en Villada donde se localiza "un albornoz plateado". Albornoz como tejido figura también en inventarios de bienes leoneses (Egido, 2015: 79).

\section{ANASCOTE [anescote, aniscote]}

Sust. m. 'Tela delgada de lana, asargada por ambos lados, que usan para sus hábitos varias órdenes religiosas. También la emplean para sus vestidos las mujeres del pueblo en algunas provincias de España' y como segunda acepción, pero ya en desuso, 'tela de seda, parecida a la sarga' (DLE). Autoridades lo recoge como una 'espécie de tela, ò texido que se fabrica de lana, de que se hacen mantos y otras cosas'. En la edición académica de 1869 aparece la definición que conservamos hoy en día, y señala el origen escocés de la tela. En cambio, en 1884 señala que viene del francés anascot y en 1970 precisa que viene del antiguo francés anascot y éste de la ciudad de Francia Hondschoote. Finalmente, en 1992 corrige indicando que viene del nombre de la ciudad flamenca de 'Hondschoote, a través del antiguo francés anascot' (NTLLE, s. v. anascote, Autoridades, 1726; DRAE, 1869, 1884, 1970 y 1992). Se trata de un término que proviene del fr. antic. anascot (hoy anacoste) íd., y este del nombre de la ciudad de Hondschoote (Francia, depto. Nord) (DECH, s. v. anascote).

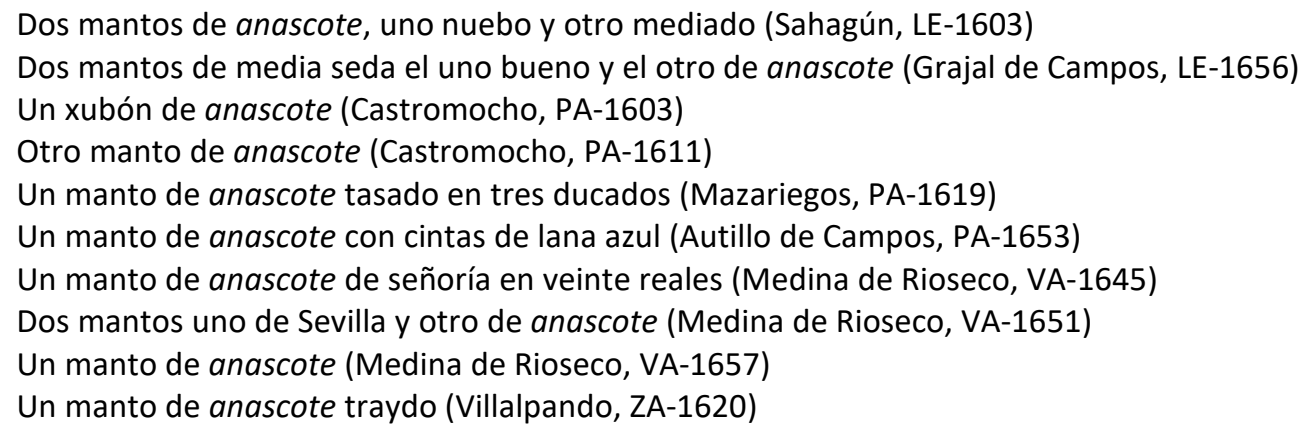

Este término aparece documentado en 1563 en Bilbao, en una relación de precios de las mercaderías que venían de fuera del Reino, lo que constata su origen foráneo. Este término estaba presente en los textos del siglo XVII, pero a partir de esta fecha comienza a perder vitalidad $(C D H)$. En esta época existen lugares en Europa en los que la producción textil alcanza 
gran relevancia, lo que hace que algunos tejidos tomen el nombre del lugar donde se producen. A veces, la adaptación formal al castellano hace que ese topónimo no sea del todo reconocible; es lo que ocurre con anascote, procedente de Hondschoote (Morala, 2014b: 259).

En el siglo XVII este término es de uso general en toda la Península (CorLexIn, s. v. anascote). En Tierra de Campos, además de la forma académica anascote, también se localizan anescote y aniscote, con cambio de timbre en la vocal átona /a/, que al ir trabada con /s/ es más susceptible de cambiar a /e/ y también a /i/, por lo que se observa en las ocurrencias señaladas (Morala, 2012a: 559):

Un manto de anescote nuevo con su faxa de tafetán (Castromocho, PA-1602)

Un manto de aniscote (Boadilla de Rioseco, PA-1692)

Este fenómeno también se advierte en los documentos del CorLexIn: aunque en menor medida, aparecen casos en zonas del Norte de la Península -anescote en documentos de Bilbao y Palencia y aniscote en textos de Guipúzcoa y Santo Domingo de la Calzada, este último localizado por Morala (Morala, 2010b: 389)-.

Pérez Toral afirma que este vocablo se documenta desde el primer tercio del siglo XVI con el significado de 'tejido de lana', que se expande a lo largo de toda la Península durante la centuria siguiente y que entra en retroceso en siglos posteriores (Pérez Toral, 2017c: 159).

\section{AÑINOS}

Sust. m. pl. 'lana de corderos'. (DLE, 3. a ac.). Nebrija recoge 'añino lana de çordero' y Covarrubias registra añino como 'el vellon del cordero de vn año, vellus agninum'. Autoridades recoge esta palabra en plural (NTLLE, s. v. añino, añinos, Nebrija, 1495; Covarrubias, 1611; Autoridades, 1726). Palabra procedente del lat. AGNĪNUS 'propio del cordero', derivado de agnus 'cordero' (DECH, s. v. añino).

Dos cestos con hasta diez libras de añinos (Frechilla, PA-1612)

Quatro arrobas y diez y nuebe libras de añinos (Frechilla, PA-1638)

Todo jénero de lana y añinos y estambres y orillas (Frechilla, PA-1639)

Diez libras de añinos negros (Frechilla, PA-1639)

Dos arrobas de añinos vlancos (Medina de Rioseco, VA-1660)

Encontramos esta voz documentada siempre en plural en la Tierra de Campos como 'lana de corderos' y en zonas con industria textil como Frechilla (Palencia) y Medina de Rioseco (Valladolid).

Diacrónicamente, los ejemplos que nos ofrecen bases de datos como el $C D H$ y el CORDE sitúan la palabra añinos a partir de finales del siglo XV en las Ordenanzas de Ávila equiparándola a la "lana castellana":

"[...] de cada arroua de lana castellana o añinos tress blancas [...]" (Ordenanzas de Ávila, 1485)

El resto de los casos documentados se localizan en textos del XVI siempre en crónicas, cédulas y ordenanzas de textiles. A partir de este momento las ocurrencias son esporádicas, siempre con la misma acepción. 
Con los testimonios que nos aporta el CorLexIn, vemos que se trata de una palabra presente en la Meseta Norte, sobre todo. Además, todas las ocurrencias hacen referencia a esta acepción. No encontramos ningún ejemplo que referencie al cordero de un año.

En repertorios léxicos más actuales, como el Vocabulario Palentino, comprobamos que esta voz aparece como 'desperdicios de la lana que no hacen vellón' y en general 'cordero de un año', aunque advierte que 'a este cordero se le llama también añojo en la Tierra de Campos' (Gordaliza, 1988: 30).

\section{BARRAGÁN [varragán]}

Sust. m. 'Tela de lana impenetrable al agua' (DLE). Aparece en Autoridades como 'género de tela hilada sutilmente, $\mathrm{y}$ hecha de lana de diferentes colores: su ancho poco menos de vara' (NTLLE, s. v. barragán, Autoridades, 1726). Para Corominas y Pascual puede ser un término que proceda del árabe barrakân íd. (DECH, s. v. barragán).

Un capote biexo de barragán açulado (Paredes de Nava, PA-1689)

Un capote de varragán con su forro de vaeta de la sierra (Villalpando, ZA-1686)

Un capote de barragán nuebo (Cotanes del Monte, ZA-1687)

Tan solo se han encontrado tres ejemplos en el corpus de Tierra de Campos y todos ellos ligados a la palabra capote. Pérez Tóral lleva a cabo un estudio diacrónico de esta palabra. A través de la consulta de diferentes bases de datos y autores, la documenta a partir del siglo XIII con el significado de 'tejido' y confirma la escasa frecuencia con la que aparece este término en la documentación (Pérez Toral, 2017c: 160). El DHTT -hablando de albornoz-afirma que "en el siglo XVIII se usó también esta tela [albornoz], con el mismo nombre, si bien algo adulterada o viciada en la calidad, aunque la tela que servía para capotes y sobretodos se llamaba comúnmente, barragán" (DHTT, s. v. albornoz). De ahí que el campo léxico de este término estuviera limitado a capotes y sobretodos, lo que haría menos frecuente su presencia en los textos. Los pocos ejemplos que se localizan en el CorLexIn se reparten en puntos muy distantes de la Península, a saber: Lumbreras (La Rioja), Puebla de Peñarubia (Málaga) y otro caso en Garachico (Tenerife), siempre con la acepción aquí estudiada junto a ropas de abrigo -capote, capotón y sobretodo-. Se trataba de un tipo de tela empleada para confeccionar ropa externa y proteger de las inclemencias del tiempo, por ser más gruesa.

\section{BAYETA [vayeta, uayeta, baieta, vaieta, baeta, vaeta]}

Sust. f. 'Tela de lana, floja y poco tupida' (DLE). Covarrubias la registra como 'vna especie de paño floxo, y de poco pelo, del cual usamos en Castilla, para aforros, y para luto: vinieron las primeras de Inglaterra' y Autoridades mantiene la definición, pero no hace mención a ningún rasgo diatópico (NTLLE, s. v. vayeta, bayeta, Covarrubias, 1611; Autoridades, 1726). Probablemente del francés antiguo baiette que parece ser diminutivo de bai 'pardo' (DECH, s. v. bayeta).

Una toca baeta y nueba (Valdavida, LE-1606)

Una faxa negra de baeta (Grajal de Campos, LE-1613)

Una ropa de vaeta negra (Cea, LE-1626) 
Un manteo de bayeta berde (Grajal de Campos, LE-1656)

Dos reboçiños de vayeta negro de Segouia (Grajal de Campos, LE-1656)

Otro guardapies de bayeta encarnada con esterilla de oro (Grajal de Campos, LE-1658)

Una mantilla de bayeta blanca (Valderas, LE-1682)

Una saya blanca de vayeta (Castromocho, PA-1612)

Un angurina de estameña nueba forrada en baeta colorado (Villarramiel, PA-1690)

Un revozino de baeta biexo (Autillo de Campos, PA-1652)

Una capa de estameña vuriel con forro de baieta (Villada, PA-1668)

Una cortina de baieta colorada (Boadilla de Rioseco, PA-1687)

Una anguarina de baeta berde de muger buena (Villarramiel, PA-1690)

Una capa de vaieta negro de la sierra (Boadilla de Rioseco, PA-1692)

Ocho varas de vaeta negro de Palencia (Paredes de Nava, PA-1695)

Otra almilla de baieta (Medina de Rioseco, VA-1645)

Vara y media de baieta mora de Burgos (Medina de Rioseco, VA-1645)

Dos ropas de bayeta de Palençia vuenas (Medina de Rioseco, VA-1648)

Una cortina de bayeta colorada con su barilla de yerro y presillas (Medina de Rioseco, VA-1671)

Treinta y quatro baras de uayeta verde de Palençia tassadas a cinco reales cada una para unas cortinas de las uentanas de la sala (Medina de Rioseco, VA-1685)

Unas enaguas de baeta encarnadas (Villalpando, ZA-1651)

Una pollera de bayeta encarnada con guarnicion de plata (Villalpando, ZA-1652)

Nueue reales de tres baras de bayeta de la tierra a tres reales (Villalpando, ZA-1656)

Un capote de varragán con su forro de vaeta de la sierra (Villalpando, ZA-1686)

Esta voz, con la acepción de 'tejido de lana', se documenta en diferentes inventarios de mediados del siglo XVI (CDH, s. v. bayeta). En la zona de estudio aparecen dos variantes: por un lado, encontramos la forma académica con las variantes gráficas documentadas en este periodo bayeta, vayeta, baieta o vaieta, formas muy extendidas por toda la Península, tal y como se puede consultar en el CorLexIn. Por otro lado, en Tierra de Campos aparece la forma baeta o vaeta. Esta variante también la documenta, aunque de manera escasa, el CORDE: de los seis casos que aparecen, uno está localizado en una novela pastoril del autor vallisoletano Gabriel García del Corral en 1629, y el resto de los ejemplos pertenecen a obras literarias de dos autores cántabros (José María de Pereda de finales del siglo XIX y Hermilio Alcalde del Río de principios del xx). En el CorLexIn también aparece documentada la forma baeta en textos localizados en Cantabria y León fundamentalmente. Aunque también se atestiguan casos en Valladolid, Málaga y Tenerife en este corpus (Pérez Toral, 2017a: 200). Formalmente, estamos ante la elisión de /$\mathrm{y}$-/ en contacto con vocal palatal, fenómeno característico de la zona leonesa, aunque no es desconocido para el castellano (Morala, 2010b: 408, nota 14).

\section{BLANQUETA}

Sust. f. 'Tejido basto de lana, que se usaba antiguamente' (DLE, 2. a ac.). La edición de Autoridades de 1770 es la encargada de recoger este término; ya la marca como voz antigua y la define como 'texido basto de lana' (NTLLE, s. v. blanqueta, Autoridades, 1770). Se trata de una palabra derivada del término blanco, del germ. blank 'brillante', 'blanco' (DECH, s. v. blanco).

Una manta de blanqueta colorada en doçe reales (Medina de Rioseco, VA-1645)

Una cama de blanqueta colorada con dos mantas y una sobrecama colorada (Villalpando, ZA1601)

Otra saya bieja de blanqueta verde (Villalpando, ZA-1620)

Más quatro mantas de blanqueta nuebas (Villalpando, ZA-1620) 
Una sobrecama de blanqueta azul con fluecos pajiços y amarillos (Villalpando, ZA-1632)

Esta palabra referencia un tejido basto que se utilizaba para la confección de ropa de cama como mantas, cobertores o cabezales, aunque, como recuerda Pérez Toral, y a la vista de lo que nos ofrecen las ocurrencias localizadas en el CorLexIn, este tejido también se utilizaba para prendas de vestir como sayas, capas, delantales... (Pérez Toral, 2017a: 202). Egido también documenta en la época de estudio almillas y sayas confeccionadas con este tejido en inventarios leoneses (Egido, 2015: 79).

EI CORDE y el CDH recogen esta voz a partir del siglo XIII, más concretamente desde 1268 , en el Ordenamiento de posturas en el Ayuntamiento de Jerez, donde se habla de precios de diferentes tejidos, adelantando así la primera documentación que propone el $D E C H$-en el Cancionero de Baena (1445)- señalado ya por Martínez Meléndez (Martínez Meléndez 1989: 38-39 en Pérez Toral, 2017a: 202).

El uso de este tejido parece desvanecerse a partir del siglo XVII, aunque se encuentran algunos ejemplos hasta el siglo XIX.

En la Tierra de Campos también se localizan casos de blanqueta para hacer mantas, ropa de cama o sobrecamas, pero también para confeccionar ropa como sayas. Morfológicamente, solo aparece la forma académica blanqueta, pues no aparece la variable branqueta que sí está presente en esta época en algunos inventarios zamoranos y leoneses. Pérez Toral localiza en el CorLexIn un ejemplo en Figueruela de Arriba (Zamora): "Yten una manta de branqueta en diez y ocho reales" (Pérez Toral, 2017a: 203) y Morala, en Valdesogo de Arriba (León) "una saia de vranqueta" (Morala, 2009: 12).

\section{BURATO [VURATO, uurato]}

Sust. m. 'Tejido de lana y seda que servía para alivio de lutos en verano y para manteos' (DLE). Autoridades presenta dos significados para esta palabra: 'cierto género de texido delgado de lana, cuyo tacto es áspero, que ordinariamente sirve para alivio de lutos en tiempo de Veráno, y para capas y manteos en el mismo tiempo' y 'el que se hace de seda a semejanza del de la lana, el qual también es algo áspero al tacto por el cordoncillo con que está texido' (NTLLE, s. v. burato, Autoridades, 1726). Esta definición se mantiene en los diccionarios académicos. Se trata de una voz derivada de buriel, del francés antiguo burel, buriau, de origen desconocido, quizá emparentado con el adjetivo romance *būrius (DECH, s. v. buriel).

Un manto de burato nuebo en siete ducados (Sahagún, LE-1602)

Un manto biejo de burato (Castromocho, PA-1611)

Un manto de burato bueno (Castromocho, PA-1611)

Un manto de vurato (Castromocho, PA-1611)

Seis varas y tres quartas de uurato negro de Valladolid (Medina de Rioseco, VA-1644)

Seis pieças de buratos de Milán (Medina de Rioseco, VA-1645)

El burato era un tejido delgado de lana peinada, de tacto áspero, que originariamente servía para alivio de lutos en verano y para capas y manteos en el mismo tiempo. De él antiguamente se hacían mujeres mantos, tan transparentes que descubrían todo lo que cubrían (DHTT, s. v. burato). Se documenta en el CORDE y en el $C D H$ en un documento notarial fechado en 1568 . En 
el CorLexIn aparecen una serie de ejemplos distribuidos por diferentes puntos geográficos de la Península y también en América. Figura en la zona de estudio como un tejido para confeccionar mantos principalmente y también como tela en pieza. Pérez Toral no encuentra documentación que certifique la presencia de esta voz antes del siglo xVI y, como ocurre con la denominación de otros tejidos, parece que burato tuvo su punto álgido de uso en el siglo XVII (Pérez Toral, 2017c 163-164).

\section{CAMELOTE [chamelote, chamalote]}

Sust. $\mathrm{m}$. 'Tejido fuerte e impermeable generalmente de lana' (DLE). Este término lo recoge Covarrubias en su Tesoro y dice de él lo siguiente: 'comúnmente dicho chamelote, es la tela de la lana del Camello: despide el agua que no la cala y vno se llama chamelote raso, y otro con aguas' Sin embargo, Autoridades, aunque mantiene la definición de Covarrubias, registra una entrada para 'chamelote de aguas', que sería 'tela de seda, prensada con tal arte, que sale su lustre ondeando el color, y formando una figura, como la que usan los Pintores para expresar ondas, por lo qual se llama de aguas' (NTLLE, s. v. chamelote, Covarrubias; 1611, Autoridades, 1729). Término procedente del francés antiguo camelot, forma dialectal de chamelot y este probablemente del francés antiguo chamel 'camello' porque el camelote se hacía con pelo de camello (DECH, s. v. camelote).

Una ropa de chamelote aforrada en pellejos (Cea, LE-1621)

Vasquiña y ropa de chamelote de agua picado bueno guarnezida la ropa con guarniçión de hesparragón (Grajal de Campos, LE-1658)

Unas ballenas de chamelote guarneçidas con esterilla de plata (Grajal de Campos, LE-1658)

Un bestido de mujer de chamelote negro que se conpone de baquiña y anguarina (Paredes de Nava, PA-1689)

Quatro varas y media de chamelote de aguas (Medina de Rioseco, VA-1645)

Otra pollera de chamelote encarnado con una franja de oro ancha aforrada en olandilla azul (Medina de Rioseco, VA-1660)

Quatro ropas, la una de piñuela, la otra de rizo y la otra de chamelote (Medina de Rioseco, VA1661)

Una uasquiña de chamelote negra (Medina de Rioseco, VA-1685)

Una basquiña de chamalote de aguas (Villalpando, ZA-1644)

Los ejemplos que encontramos en la zona de estudio siempre presentan la forma chamelote para designar el tejido con el que se confeccionan determinadas vestimentas como ropas, vestidos o polleras, entre otras. También se documenta el chamelote de aguas del que Covarrubias daba cuenta.

El término chamelote aparece documentado en el CORDE y en el $C D H$ en un documento del siglo XV:

Que lo cubriese de paños blancos de chamelote (El baladro del sabio Merlín con sus profecías, 1400-1498).

La forma chamelote está extendida por todo el territorio peninsular y por sus colonias de ultramar -Canarias, Bolivia, Colombia, Chile, Guatemala, México o Perú- en el siglo XVII (CorLexIn, s. v. chamelote). 
De la variante camelote no hay constancia ni en la comarca de Tierra de Campos, ni en los documentos que conforman el CorLexIn. Sin embargo, aunque de forma tardía, el CORDE documenta un ejemplo con la forma camelote a partir del siglo XVIII:

En verano la casaca era de camelote ceniciento (Vida de Carlos III, de Conde de Fernán Núñez, c1790)

\section{CATALUFA}

Sust. f. 'Tejido de lana tupido y afelpado, con variedad de dibujos y colores, del cual se hacen alfombras', y como acepción en desuso 'tafetán doble labrado' (DLE). Covarrubias lo recoge como 'çierta tela de seda labrada con diversas colores que podemos llamar tafetán labrado', y Autoridades define este término como 'cierta especie de alfombra, con varias labores y flores, que sirve unas veces para poner en el suelo y que sea de abrigo: y también para colgar en las parédes por adorno, y que sirva juntamente de repáro contra el frío', sin embargo en la edición del DRAE de 1780 ya aparece solo como 'tafetán doble labrado' (NTLLE, s. v. catalufa, Covarrubias, 1611; Autoridades, 1729; DRAE, 1780). Término que procede del it. antic. cataluffa 'cierto paño fabricado en Venecia' ( $D E C H$, s. v. catalufa).

Unas catalufas (Paredes de Nava, PA-1695)

Çiento y çinquenta y una varas y media de catalufas de lana (Medina de Rioseco, VA-1644)

Es un tejido no muy común en los inventarios de este estudio. Se documenta en el CORDE a partir de principios del siglo XVII y su aparición en los textos es mayoritaria en este siglo; parece ser un término que cayó rápidamente en desuso.

En el CorLexin hallamos varios ejemplos de esta palabra repartidos por la Península. Perdiguero registra esta voz en un inventario segoviano -"sobremesa de catalufa, una colcha de catalufa para la cama, un rodapies de cama de catalufa"- (Perdiguero 2015a: 1574-1575). Pérez Toral, además de Segovia, añade un listado de lugares en los que está presente -Cádiz, Huelva, Almería, Granada, Sevilla, Teruel, Cáceres, Cuenca, Toledo, Burgos, Huesca y Navarra- (Pérez Toral, 2017a: 206). Además, se confirma su localización en textos de Málaga y Lanzarote. Aparece este término como un tipo de tejido que se utiliza para confeccionar diferentes vestimentas como cuerpos, corpiños, enaguas, faldellines, pero también como tejido de ropa de casa, como colchas, paños, sobremesas, carpetas o frontales. En Tierra de Campos, tan solo encontramos dos ejemplos, uno de ellos localizado en Medina de Rioseco en un inventario sobre las mercaderías de una tienda que se dedicaba al comercio de tejidos, donde la acepción que aparece es la de 'tela de lana'. Sin embargo, el otro caso, ubicado en Paredes de Nava, no parece hacer referencia a la tela en sí, sino más bien a un objeto perteneciente al ajuar de la casa que se inventaría junto a cortinas y camas. En este caso catalufa podría referirse a la acepción que le da Autoridades como un tipo de alfombra.

\section{CHILLÓN}

Sust. m. 'Tejido de lana, bayetón' (DHTT. s. v. chillón). No se registra en ningún diccionario académico con la acepción que aparece en el corpus de estudio, 'tejido de lana'. Sin embargo, 
en el diccionario de Misheu aparece 'paño chillón' como 'a kind of cloth' (NTLLE, s. v. chillón, Misheu, 1617).

Unos cuerpos de chillón colorado con sus ribetes de terziopelo (Sahagún, LE-1605)

Vnos cuerpos de chillón colorados (Sahagún, LE-1608)

Una terçia de chillón colorado tassado en siete reales (Castroañe, LE-1622)

Una saya de chillón colorada con ruedo amarillo demediada (Grajal de Campos, LE-1655)

Otra saya de paño de chillón colorado con ruedo amarillo dada (Grajal de Campos, LE-1670)

Una saya colorada de paño chillón más que demediada con ruedo amarillo (Frechilla, PA-1614)

Una basquiña de chillón mediada (Autillo de Campos, PA-1651)

Aunque esta acepción de la palabra no aparece en los diccionarios académicos, en la zona de estudio hay los suficientes ejemplos como para decir que era una palabra de uso común. El CORDE o el $C D H$ documentan esta acepción en un único ejemplo del siglo XVı y que referencia el tejido que aparece en los inventarios:

Mandamos que la vara del paño chillón se venda a sesenta maravedís (Epistolas familiares de Fray Antonio de Guevara (1521 y 1543))

Los ejemplos que presenta con esta acepción el CorLexIn pertenecen a la Tierra de Campos leonesa (Sahagún) y a la localidad zamorana de Carbajales del Alba, lugar próximo a la zona que nos ocupa. Podemos decir que estamos ante un occidentalismo léxico. En Tierra de Campos esta lexía hace referencia a un tipo de paño, por lo general de color rojo, que se utilizaba para confeccionar sayas, basquiñas, o cuerpos.

Además, el término chillón aparece también en el corpus como adjetivo; se localizan ejemplos de "carro chillón", un tipo de carro que llevaba el eje unido a unas ruedas macizas, lo que hacía que el carro emitiese un ruido a la par que se movía:

Un carro chillón con su yugo y sobeo (Cuenca de Campos, VA-1668)

\section{CORDELLATE}

Sust. m. 'Tejido basto de lana cuya trama forma cordoncillo' (DLE). Covarrubias lo recoge como 'cierta especie de paño delgado, como estameña, dicho assi por vn cordoncillo que haze la trama', (NTLLE, s. v. cordellate, Covarrubias, 1611). Es una palabra derivada de cordel, y esta a su vez de cuerda, del lat. CHǓRDA 'soga, cordel' (DECH, s. v. cuerda).

Media bara de cordellate blanco tasado en tres reales (Castroañe, LE-1622)

Unas enaguas de cordellate (Grajal de Campos, LE-1658)

Unas calças de cordellate (Castromocho, PA-1602)

Un delantal de cordellate fraylego viejo (Frechilla, PA-1612)

Dos baras de cordellate açul (Baquerín de Campos, PA-1659)

Unos balones de cordellate buenos (Paredes de Nava, PA-1689)

Un jubón de cordellate con mangas destameña (Medina de Rioseco, VA-1661)

Otra saya de estameña más usada buena con rodadura de cordellate açul en tres ducados (Cuenca de Campos, VA-1666)

Una sobrecama de cordellate berde (Villalpando, ZA-1632)

Un cobertor de cordellate verde (Villalpando, ZA-1639)

Otra capa de cordellate bieja (Villalpando, ZA-1661) 
Término que se encuentra en los inventarios de la zona de estudio de manera habitual. Referencia un tipo de 'paño delgado como la estameña o tejido basto de lana, que tenía el hilo de la trama más grueso que el de la urdimbre, de manera que al tejer la tela forma cordoncillo' (DHTT, s. v. cordellate). Se documenta en el CORDE en el año 1462 en un documento titulado Arancel de precios y salarios de Cuenca. Desde el siglo XVII aparentemente la palabra entra en retroceso, ya que a partir del siglo XVIII los ejemplos son bastante escasos en la documentación, hecho que también señala Pérez Toral (2017c: 166). Este tipo de tejido se empleaba para confeccionar enaguas, calzas, capas, balones, sayas, así como ajuar doméstico como sobrecamas, cobertores o paños, tal como queda reflejado en el CorLexIn.

\section{DAMASCO [adamascado]}

Sust. m. 'Tela fuerte de seda o lana y con dibujos formados con el tejido' (DLE). Autoridades lo registra como 'tela de seda entre tafetán y raso, labrado siempre con dibuxo. Haile doble y simple, y de distintos colóres. Es tela noble, y la usan las Señoras, y Caballeros para vestidos y colgaduras' (NTLLE, s. v. damasco, Autoridades, 1732). Del nombre de la ciudad de Damasco, gran centro de intercambio comercial entre el Occidente y el Oriente, región desde donde se importaron estos productos ( $D E C H$, s. v. damasco).

Un calzón y ropilla de hombre, de damasco, viexo (Valderas, LE-1647)

Unos cuerpos de damasco negro con guarnición de plata falsa (Grajal de Campos, LE-1657)

Una colgadura de media cama de damasco açul con su cielo y cenefas (Grajal de Campos, LE1658)

Una vasquiña con sus cuerpos de damasco pardo (Castromocho, LE-1611)

Un faldellín de damasco colorado ussado guarnecido con passamanos de Santa Ysauel (Autillo de Campos, PA-1648)

Unas mangas de damasco colorado mediado (Autillo de Campos, PA-1649)

Unos cuerpos de damasco azul con riuete de terziopelo berde y galón de oro (Villada, PA-1669)

Un jubón de damasco negro nuebo en zien reales (Medina de Rioseco, VA-1640)

Sesenta baras de damasco blanco de Toledo (Medina de Rioseco, VA-1645)

Una pollera de damasco de lana con galón de plata de puntas (Medina de Rioseco, VA-1648)

Zinco almoadas de terciopelo y damasco carmesí (Medina de Rioseco, VA-1649)

Un guardapiés encarnado de damasco aforrado en lo mismo (Media de Rioseco, VA-1660)

Unos cuerpos de damasco berde (Villalpando, ZA-1620)

Un bestido, ropa, basquiña y jubón de damasco negro (Villalpando, ZA-1644)

Un jubón de labradora con su garapiña y cuerpos de damasco berde con guarnición de oro (Villalpando, ZA-1670)

El damasco es un 'tipo de tela de alta calidad con una sola urdimbre y una sola trama, formadas por hilos del mismo grosor, color y calidad, y con dibujo entretejido' (DHTT, s. v. damasco). Este término es de uso general desde finales de la etapa medieval (Morala, 2010b: 395) y su presencia en los inventarios de esta época es constante tanto en la Península como en América (CorLexIn). Esta tela aparece en los inventarios de bienes de Tierra de Campos como la materia prima para confeccionar vestimentas y ropa del hogar.

En la documentación analizada figura el diminutivo lexicalizado damasquillo que se analizará a continuación y además el adjetivo derivado adamascado para identificar 'telas parecidas al damasco' (DLE): 
Otra colcha blanca de lienzo adamascado con sus puntas, vsada (Valderas, 1647)

Diez tablas de manteles nuebas de gusanillo y adamascado (Medina de Rioseco, VA-1645)

Quarenta y ocho serbilletas adamascadas (Medina de Rioseco, VA-1645)

Dos dozenas y media de cintas de Santa Ysauel adamascadas (Medina de Rioseco, VA-1645)

Lo recoge Autoridades como 'el texido, ù otra cosa que está hecho en forma de damasco, ó lo paréce' (NTLLE, s. v. adamascado, Autoridades, 1726). Se documenta en el CDH a partir de finales del siglo XVI, pero su presencia es escasa en estos siglos; el número de ejemplos asciende en el siglo xx $(C D H)$. A pesar de las ocurrencias aisladas que se localizan en los inventarios de bienes del siglo XVII, los ejemplos se documentan tanto en la Península como en América con la acepción académica. Este adjetivo designa el tejido que intenta imitar el damasco y que se suele utilizar para confeccionar manteles y servilletas (CorLexIn). En nuestro corpus aparecen varios casos, en su mayoría ubicados en la zona vallisoletana de la Tierra de Campos, y el último de ellos pertenece al inventario de una tienda de ropa.

Morfológicamente, estamos ante un adjetivo denominal de formación parasintética, con un valor de 'semejante a'.

\section{DAMASQUILLO}

Sust. m. 'Tejido de lana o seda parecido al damasco en la labor, pero con menos cuerpo' (DLE). Este término no lo registra la Academia hasta su edición de 1791. Se trata de una voz derivada de Damasco 'cierta clase de tela', del nombre de la ciudad de Damasco (DECH, s. v. damasco).

Un jubón de damasquillo de lana açul y dorado (Valderas, LE-1647)

Unas enaguas de damasquillo de lana tasadas (Medina de Rioseco, VA-1640)

Trece piecas de damasquillos anchos de Flandes (Medina de Rioseco, VA-1645)

Un jubón de damasquillo de lana con botonadura de bidrio (Medina de Rioseco, VA-1648)

Otras dos cortinas de damasquillo de seda paxiza y blanco (Medina de Rioseco, VA-1651)

Unos cuerpos de damasquillo açul (Tamariz de Campos, VA-1652)

Otro jubón y dos pares de mangas, el jubón de damasquillo de lana (Medina de Rioseco, VA-1657) Un jubón de damasquillo de color en diez y seys reales (Cuenca de Campos, VA-1668)

Es un tejido muy parecido al damasco, pero con menor consistencia (DHTT, s. v. damasquillo). Aparece documentado en el CORDE y el $C D H$ en un inventario de bienes fechado en 1612, haciendo referencia a este tipo de tejido:

Una casulla de damasquillo de colores, con su çanefa colorada (Bienes inventariados en poder de doña Esperanza de Mendoza, a1612)

Este término presenta apenas una docena de ocurrencias fechadas entre el siglo XVII y la primera mitad del XVIII en estas bases de datos. La gran mayoría de los ejemplos se localizan en inventarios de bienes de España y América. La falta de testimonios en el CORDE y el CDH contrasta con la frecuencia en que aparece este término en los inventarios de bienes del siglo XVII, donde presenta ocurrencias en la Península, Islas Canarias y América (CorLexIn). Esta presencia se hace extensible a la Tierra de Campos, donde encontramos esta voz con la forma y significado académicos. Este uso frecuente del término se localiza también en inventarios leoneses del siglo XVII. Egido recoge muestras de este tipo de tejido en la zona del Órbigo, utilizado principalmente para la confección de prendas de vestir -"cuerpos de damasquillo"(Egido, 2015: 80, 88). También se localizan ocurrencias en La Bañeza en este siglo -"diez y nuebe 
pieças de damasquillos finos" o "un xubón de damasquillo de lanas de colores"- (Gómez Ferrero, 2015: 454, 573). Es un tejido muy utilizado en la época para la confección de prendas de vestir -jubones, guardapiés, corpiños, cuerpos, basquiñas-, ropa de cama -cortinas, cojines, cobertores, doseles- $y$ también se encuentra inventariada como tela en pieza.

El damasquillo es uno de esos tejidos que nos muestra el intercambio de mercancías con otros países en esta la época. Así, nos encontramos damasquillos de China, India, Inglaterra (Morala, 2014b: 252-254) y también de Italia -"otra colcha de damasquillo de Ytalia" (Vergara, San Sebastián, 1632)-.

\section{ESCARLATA}

Sust. f. 'Tela de color escarlata' ( $D L E, 3$. a ac.). Covarrubias recoge esta palabra con la acepción de color, pero también como seda, o paño con la que se vestían los grandes príncipes. Autoridades lo describe como un tipo de 'paño y texido de lana, teñido de color fino carmesí, no tan subido como el púrpura ò grana [...]. En la Edición del DRAE de 1791, además de un tipo de tejido, recupera la acepción de color, significado que poco a poco irá ganando terreno al de 'tejido'. En la edición académica de 1899, la primera acepción que se recoge es la de 'color carmesí fino, menos subido que el de la grana' (NTLLE, s. v. escarlata, Covarrubias, 1611, Autoridades, 1732, DRAE, 1791, DRAE, 1899). Es un término procedente del lat. TEXTUM SIGILLATUM 'paño sellado o marcado' (DECH, s. v. escarlata).

Un reuoçino de escarlata con una guarniçion de plata (Medina de Rioseco, VA-1685)

Este término se documenta en el CORDE con la acepción de 'tejido' en el siglo XIII, en una carta de venta fechada en 1223 donde aparece "destos morabedis somos bien pagados, \& de la robra con este manto de escarlata que nos dades".

Es un término que se encuentra de forma esporádica en los inventarios de bienes que configuran el CorLexIn: tan solo aparecen ejemplos en puntos geográficos distantes y sin un patrón claro en la Península -Sevilla, Córdoba, La Rioja, Talavera o Navarra-. Además, se encuentra algún ejemplo en documentos americanos -Bolivia y Perú-. El uso exiguo que se hace de esta voz se extrapola igualmente a la Tierra de Campos, en la que solo se localiza un caso. Pérez Toral destaca que estaríamos ante una tela "noble y selecta" y que solía ir ornamentada con hilo de plata, tal y como muestran los ejemplos registrados en el CorLexIn (Pérez Toral, 2017a: 214) y como también se puede observar en la ocurrencia localizada en Tierra de Campos.

\section{ESCARLATÍN}

Sust. m. 'Tela, especie de escarlata, de color más bajo y menos fino' con marca de término desusado (DLE). Esta definición se mantiene desde la edición de Autoridades de 1732 (NTLLE, s. v. escarlatin, Autoridades, 1732). Se trata de un término derivado de escarlata, procedente del árabe hispánico iškirlâta (DECH, s. v. escarlata).

Una montera de escarlatín (Paredes de Nava, PA-1695) 
Lo mismo que ocurre con escarlata, en la zona de estudio tan solo encontramos un ejemplo. Esta escasez de ocurrencias se corrobora también en el $C D H$ y el CORDE, donde la primera documentación data de 1565 -"vna saboyana de escarlatín"- y no se documenta ningún ejemplo más allá del siglo XVII. Sin embargo, estudios léxicos sobre la zona de La Bañeza en León revelan que este tejido aparece documentado en inventarios del siglo XVIII y XIX (Gómez Ferrero, 2015: 342). En los inventarios del siglo XVII, el término se documenta en distintas localidades de la Península -Cádiz, Huelva, Badajoz, Toledo y Guipúzcoa-(CorLexIn).

\section{ESTAMEÑA}

Sust. f. 'Tejido de lana, sencillo y ordinario, que tiene la urdimbre y la trama de estambre' (DLE). Lo recoge Nebrija en su Vocabulario como 'TEXTUM fLAMINEUM'. Pero no será hasta Autoridades donde se le dé el significado que se mantiene en los diccionarios actuales (NTLLE, s. v. estameña, Nebrija, 1495, Autoridades, 1732). Término derivado de estambre, del lat. STAMEN -ĨNIS 'urdimbre' (DECH, s. v. estambre).

Una mantilla de estameña (Valdavida, LE-1606)

Unos zaragüelles de estameña parda buena (Grajal de Campos, LE-1616)

Dos pares de zarafuelles de honbre de estameña (Sahagún, LE-1633)

Un mantheo de estameña dado (Grajal de Campos, LE-1670)

Un jubón de estameña nuevo (Frechilla, PA-1615)

Unos calzones de estameña biexos (Autillo de Campos, PA-1653)

Un cobertor de estameña açul con sus flecos (Paredes de Nava, PA-1689)

Una vasquiña de estameña de mezcla de la niña (Boadilla de Rioseco, PA-1692)

Un corpiño de estameña en quatro reales (Medina de Rioseco, VA-1639)

Una saia de estameña color buriel con su ribete de terciopelo negro (Tamariz de Campos, VA1652)

Unos valones de estameña de diez y siete reales y medio (Cuenca de Campos, VA-1660)

Vna anguarina de estameña pelderrata aforrada en baieta (Medina de Rioseco, VA-1671)

Una basquiña de estameña y jubón de lo mismo (Villalpando, ZA-1647)

Una colgadura de cama de estameña azul aprensada (Cotanes del Monte, ZA-1687)

Una manta de estameña escarmenada (Villalpando, ZA-1688)

Una túnica blanca de estameña biexa (Villalpando, ZA-1689)

La estameña es un antiguo tejido de lana, asargado, sencillo y ordinario, que se fabricaba en España para la confección tanto de ropajes como de ropa del hogar (DHTT, s. v. estameña). Pérez Toral reúne una serie de voces expertas que confirman la aparición de este término en la documentación desde el siglo XIII hasta la actualidad (Pérez Toral, 2017c: 170).

\section{ESTAMEÑICA}

Sust. f. Esta lexía referencia claramente un tipo de tejido. No se registra en ninguno de los diccionarios académicos y no académicos que conforman el NTLLE.

Un jubón de estameñica delgada (Grajal de Campos, LE-1657)

Un jubón de estameñica nuebo (Grajal de Campos, LE-1670)

Un mandil de estameñica nuebo (Grajal de Campos, LE-1671)

Una saya de estameñica azul con ruedo colorado (Grajal de Campos, LE-1671) 
En Tierra de Campos localizamos esta palabra únicamente en la localidad leonesa de Grajal de Campos. Por el contexto en el que se presenta, parece referenciar un tipo de tejido que servía para confeccionar prendas de vestir como jubones, sayas o mandiles. El hecho de que en el primer ejemplo se caracterice esta tela como "delgada" hace suponer que estamos ante un textil fino, más delicado que la estameña.

Morala localiza otro ejemplo de estameñica en un inventario de Gradefes, en la provincia de León a finales del siglo XVII (Morala, 2015c: 324, nota 23). Aparentemente, los únicos testimonios recogidos de esta voz en este siglo pertenecen a tierras leonesas bastante próximas; sin embargo, en estudios fechados en época posterior, localizamos este término en Asturias. Fernández Pérez, en un estudio posterior que hace sobre la sociedad familiar de Navia (Asturias) entre los años 1775 y 1984, en el capítulo titulado l'axuar de las novias vaqueiras, según las escrituras matrimoniales, recoge el siguiente ejemplo: "vestíu de boda d'estameñica" (Fernández Pérez, 1991: 121), algo que confirmaría que esta tela era de un valor mayor que la estameña, utilizada para confeccionar ropa de ceremonia como en este caso.

En un estudio más moderno sobre el traje regional asturiano se define la estameñica como un tipo de estameña muy conocida para la confección de este (Fernande Gutierri, 2007: 244, 272).

\section{FILIPICHÍN [felipichín]}

Sust. m. 'Tejido de lana estampado' (DLE). Autoridades lo define como 'especie de texido de lana, à modo de chamelotón, que tiene unas labores hechas con prensa' (NTLLE, s. v. filipichín, Autoridades, 1732). Palabra de origen desconocido (DECH, s. v. filipichín).

Veinte y nueue baras y media de filipichín angosto (Medina de Rioseco, VA-1645)

Dos baras y media de filipichín açul angosto (Medina de Rioseco, VA-1645)

Dos tercias de philipichín noguerado ancho (Medina de Rioseco, VA-1645)

El filipichín es un tejido que vendían los gremios de Madrid (DHTT, s. v. filipichín). Aparece documentado en la zona de estudio en inventarios de mercaderías en la localidad vallisoletana de Medina de Rioseco, donde resulta más fácil encontrar este tipo de léxico referido a tejidos de la época.

El DECH documenta por primera vez esta palabra en el año 1680 en una Pragmática citada en Autoridades; sin embargo, los ejemplos que ofrece la zona de estudio o el CorLexIn adelantan esta fecha a 1631:

Un juuón de felipichín, otro de estameña fina (Villalpando, ZA-1631)

Una saya de felipichín morado, colchada, bale çiento y beinte reales (Cuenca, 1631)

Junto a la forma filipichín -localizada en el CorLexIn en Huelva, Guadalajara, Toledo, Valladolid y Soria- aparece la variante felipichín en un inventario de Villalpando, localidad zamorana de Tierra de Campos. También se documenta esta variante en los inventarios de bienes del siglo XVII-Cuenca, Palencia, Huelva, Toledo y Soria-. 
Pérez Toral confirma que esta variante - con disimilación vocálica- es minoritaria en los textos y que el término de origen sería filipichín y no felipichín, ya que es el recogido en el DECH, en los diccionarios académicos y en bases de datos como el CORDE y el CDH (Pérez Toral, 2017c: 174). Sin embargo, Morala afirma que existe un proceso de asimilación según el cual voces no patrimoniales con la secuencia /e-i/ se resuelve en / $\mathrm{i}-\mathrm{i} /$, lo mismo que ocurre con alemanisco y alimanisco (Morala, 2012a: 561).

Aunque esta voz se encuentra recogida en los diccionarios académicos, si se consulta el $C D H$, el término no aparece documentado hasta llegado el siglo XIX, en una obra poética de 1828 de Manuel Bretón de los Herreros donde aparecen "colchas de filipichín".

\section{FRISA}

Sust. f. 'Tela ordinaria de lana, que sirve para forros y vestidos de las aldeanas' (DLE). Autoridades registra este término como 'tela de lana à modo de bayéta, aunque más corpulenta, que sirve para aforros y para otros usos'. A partir de la edición académica de 1925 se añade una nueva acepción de este término de corte dialectal 'especie de manta de lana fuerte que usan las maragatas para cubrirse la cabeza y que les cuelga hasta más abajo de la cintura' (NTLLE, s. v. frisa, Autoridades, 1732, DRAE, 1925). Seguramente, proveniente del bajo lat. tela frisia 'tela de Flandes', así llamada porque se importaba en barcos frisones ( $D E C H$, s. v. frisa).

Una antepuerta de frisa colorada con flueco de seda y su varilla de yerro en quatro reales (Medina de Rioseco, VA-1644)

Es una 'tela ordinaria de lana, que sirve para forros y vestidos de las aldeanas' y puede que su nombre le viniese dado por su procedencia, Frisia, región de la baja Alemania donde se tejían estas telas ( $D H T T, 2004: 88$ ). Se localiza un único ejemplo en un inventario de Medina de Rioseco (Valladolid). El uso exiguo de este término se traslada a los documentos que configuran el CorLexIn, donde no llega a una docena de ocurrencias repartidas por la parte del occidente peninsular principalmente -Badajoz, Cáceres y León-, aunque también aparecen algunos ejemplos en el Norte -Álava-y Centro -Madrid-. Los ejemplos encontrados en el CorLexIn y el de la zona de estudio referencian un tipo de tejido que se utiliza principalmente para confeccionar cortinas, mantas de cama o antepuertas. Sin embargo, en el ejemplo localizado en Villacabiel, provincia de León, este tejido se utiliza para prendas de vestir, como en este caso unos valones. Lo mismo ocurre también en la zona leonesa de La Bañeza, donde es muy frecuente que esta palabra aparezca referenciada en los inventarios junto a jubones, valones, ropillas, manteos, mantillas, calzones, etc., llegando incluso a inventariar, por ejemplo, "una frisa de cubrir", aparentemente una especie de manto que utilizaban las mujeres para cubrirse (Gómez Ferrero, 2015: 343-344). Con esta acepción Egido localiza el término en la Maragatería (Astorga, León) "más una frisa nueba" (Egido, 2015: 90). 


\section{GAMUZA [camuza, camuça]}

Sust. f. 'Tejido o paño de lana, de tacto y aspecto semejantes a los de la piel de la gamuza' (DLE, 3. a ac.). Covarrubias lo registra en su Tesoro como 'especie de cabra montés [...] y de sus pieles adobadas se hazen calças y jubones'. El Diccionario de Autoridades nos remite al término camuza 'piel delgada, que adobándola sirve para jubónes, calzónes y otros usos. Comúnmente se llama Gamúza [...]'. El DRAE de 1984 incluye la acepción de 'tejido que tiene cualidades semejantes a la piel de gamuza', y que generalmente se emplea para hacer limpieza (NTLLE, s. v. gamuza, Covarrubias, 1611, Autoridades, 1734, DRAE, 1984). María Moliner en la edición de 1983 habla de 'tela de lana que tiene un tacto y aspecto semejantes a los de la piel de gamuza' (Moliner, s. v. gamuza, 3. a ac.). Se trata de una voz procedente del lat. tardío CAMOX, -ōcls íd., de origen alpino prerromano (DECH, s. v. gamuza).

Un juvón de camuza estofado y un coleto (Frechilla, PA-1638)

Unos calzones de paño pardo aforrados en camuza (Frechilla, PA-1638)

Otro par de guantes de gamuza (Paredes de Nava, PA-1695)

Unas mangas de gamuza (Medina de Rioseco, VA-1642)

Un coleto con sus calçones de camuças y fundas destameña (Medina de Rioseco, VA-1657)

Aunque en el DHTT se registra este término como 'tela de lana o paño que tiene un tacto y aspectos semejantes a los de la piel de antílope', también afirma que se aplicaba a la piel delgada y adobada de diferentes animales como el rebeco, carnero, cordero, etc., y que se empleaba para jubones, calzones... (DHTT, s. v. gamuza). Aparece documentada en la zona de estudio con dos variantes: gamuza y camuza.

El término gamuza se documenta a finales del siglo XVI en obras de Góngora, Quevedo o Lope de Vega como 'piel para confeccionar calzas, bigoteras o jubones'. Por otro lado, en un inventario de bienes reales fechado en 1600 aparecen "una gamuza muy grande" y "cinco gamuzas moradas, leonadas y blancas" junto a cordobanes, becerros y cueros, lo que hace pensar que, en esta época, gamuza se refería más a un tipo de piel adaptada para elaborar determinadas piezas de ropa que a un tejido de lana.

En el CorLexIn figuran media docena de ejemplos de gamuza repartidos por Almería, Sevilla, Guadalajara Ávila, Zaragoza y también en Colombia. En todos los ejemplos se trata de un tejido o piel con el que se elaboran jubones, coletos o armadores. Sin embargo, en la Tierra de Campos, la forma gamuza se inventaría junto a mangas y guantes, es decir, para confeccionar complementos. Para la elaboración de jubones utiliza el término camuza.

Camuza se documenta a partir del siglo XVII y es menos frecuente en los textos. Los datos que nos aporta el CorLexIn localizan esta voz en Soria, Cáceres, Teruel y Ávila. Los ejemplos de Cáceres y Ávila se identifican con los de gamuza. Mientras en el documento de Soria aparecen "dos camuzas finas" dentro de un cajoncillo, aquí la acepción parece ser otra, pero el contexto no es lo suficientemente claro para saber de qué se trata. Algo de luz arrojan las ocurrencias localizadas en Teruel: en este inventario aparecen "media dozena de camuças", "doze doçenas de bolssas pequeñas de camuça" y "una doçena de faltriqueras de camuça", por lo que se trataría de un tejido para elaborar bolsas o la misma bolsa. De hecho, de esta misma época Rojo 
Vega localiza un inventario de Valladolid fechado en 1626 "docena y media de camuças $^{1}$ amarillas para fratiqueras". Y con esta acepción la encontramos también en Tierra de Campos:

Quince docenas y dos camuças de Toledo pardas y amarillas (Medina de Rioseco, VA-1645)

Diez camuças escodadas amarillas (Medina de Rioseco, VA-1645)

\section{GRANA}

Sust. f. 'Paño fino usado para trajes de fiesta' (DLE, s. v. grana², 5. a ac.). Aparece en Autoridades como 'paño muy fino de color purpúreo, llamado assi por teñirse con el polvo de ciertos gusanillos, que se crían dentro del fruto de la coscója, llamado Grana' (NTLLE, s. v. grana, Autoridades, 1734). Término derivado de la palabra grano, del lat. GRANUM id. (DECH, s. v. grano).

Un pedaço de grana colorada (Sahagún, LE-1600)

Una saya de Perpiñán colorada y unos cuerpos de grana buenos (Sahagún, LE-1600)

Unos cuerpos de grana demediados (Arenillas, LE-1636)

Unas medias de muger de media grana tasada en nuebe reales (Grajal de Campos, LE-1670)

Unos cuerpos guarnecidos de grana colorados (Castromocho, PA-1611)

Una mantilla de grana con ribetes berdes (Frechilla, PA-1640)

Dos mantillas de media grana blancas (Frechilla, PA-1640)

Vnos cuerpos de grana, en seis reales. (Boadilla de Rioseco, PA-1650)

Una cortina de grana que está enpeñada (Medina de Rioseco, VA-1641)

Una saya de grana guarneçida con ribetes de terciopelo colorado en doze ducados (Cuenca de Campos, VA-1658)

Una saya de media grana (Cuenca de Campos, VA-1666)

Otro jubón de grana biexo con mangas de baieta negra (Medina de Rioseco, VA-1671)

Una mantilla de grana colorada en tres ducados (Villalpando, ZA-1613)

Un mandil de grana en tres ducados (Villalpando, ZA-1634)

Una vasquiña de grana nueba con guarnicion de terciopelo berde forrada en olandilla (Villalpando, ZA-1639)

Una mantilla blanca de media grana (Villalpando, ZA-1644)

Este es un término de uso general. En bases textuales como del CORDE o el CDH se documenta desde muy temprano. Es frecuente en los inventarios que conforman el CorLexIn y en el corpus terracampino.

Figura también en la documentación estudiada media grana, 'los paños blancos refinados fabricados en Toledo se conocían con este nombre [grana], mientras que los medio blancos se llamaban media grana, siendo en el siglo XV paños veinticuatrenos' (Larruga, en DHTT, s. v. grana).

\section{HERBAJE [heruaje]}

Sust. m. desus. 'Tela de lana, parda, gruesa, áspera e impermeable, usada principalmente por la gente de mar' ( $D L E, 4$.a ac.). Autoridades recoge el término herbax como 'cierta especie de texido de lana, que se usaba en lo antiguo, algo áspero, y que regularmente hacía aguas, y tenia alguna

\footnotetext{
${ }^{1}$ Rojo Vega, Anastasio: Inventario de una tienda de guanteria: Maria Luisa Pelayo, 1626. Consultado en https://investigadoresrb.patrimonionacional.es/node/6708
} 
mezcla de hierba, de donde tomó el nombre' (NTLLE, s. v. herbax, Autoridades, 1734). Término recogido por la edición de 1832 del DRAE como 'tela áspera semejante al camelote, usada antiguamente en España' (NTLLE, s. v. herbaje, DRAE, 1832). Derivado de hierba, del lat. HĚRBA íd. (DECH, s. v. hierba).

Una gabardina de herbaje acaballado y blanco y broches de plata aforrado en tafetán carne de donzella (Medina de Rioseco, VA-1661)

Otra vasquiña de heruaje usada (Villalpando, ZA-1686)

Una enguarina de heruaje nueua (Villalpando, ZA-1686)

Herbaje se documenta en el $C D H$ y en el CORDE a finales del siglo XVI y se equipara este tejido al de sayal:

El vestido y traje que será bien traigan estas mujeres en reclusión. En la cual casa las podrían vestir de jerga, o herbaje, que es sayal delgado [...] (Cristóbal Pérez de Herrera, Amparo de pobres, 1598)

Sin embargo, esta presencia en los textos es efímera, pues en la primera mitad del siglo XVII comienza a desaparecer.

Tampoco es una palabra frecuente en los inventarios de la época; tan solo se localiza un ejemplo en el CorLexIn en la localidad riojana de Lumbreras, donde se inventaría este tejido en pieza: "vna vara de erbaxe ordinario" (1688). En el corpus terracampino solo se localizan tres casos de este término, repartidos entre Medina de Rioseco y Villalpando. Este textil se referencia junto a gabardina, vasquiña o enguarina.

Rojo Vega también localiza este término en inventarios de Valladolid de la época; por ejemplo, aparece:

Una basquina de herbaje ${ }^{2}$ encarnada guarnecida de tela / otros cuerpos de herbaje / dos almoadas de herbaje con su suelo de cuero (Inventario de doña Isabel de Luna, viuda de don Álvaro de Luna, Valladolid, 1591)

Un bestido de herbaje ${ }^{3}$ nuebo que tengo que llaman lanparilla (Testamento de doña Águeda de Bustamante de la Vega Arce y Peñaranda, mujer de Domingo Marcos Pérez, Valladolid, 1674)

En este último ejemplo parece equipararse el herbaje a otro tejido, la lamparilla, lo que no se corresponde con el tipo de tela que registra el diccionario académico, ya que la lamparilla es un tejido fino y ligero.

\section{JERGA [gerga, xerga]}

Sust. f. 'Tela gruesa y tosca' ( $D L E$, s. v. jerga ${ }^{1}$ ). Término recogido por Nebrija, que lo equipara a sayal; Covarrubias se hace eco del lebrijense y lo define como 'tela gruessa, como de sayal', definición que perdurará en el tiempo. En la edición del DRAE de 1817 aparece el lema con "j"

\footnotetext{
${ }^{2}$ Rojo Vega, Anastasio: Inventario de doña Isabel de Luna, viuda de don Álvaro de Luna, Valladolid, 1591. Consultado en https://investigadoresrb.patrimonionacional.es/node/8095

${ }^{3}$ Rojo Vega, Anastasio: Testamento de doña Águeda de Bustamante de la Vega Arce y Peñaranda, mujer de Domingo Marcos Pérez, Valladolid, 1674. Consultado en https://investigadoresrb.patrimonionacional.es/node/8095
} 
en vez con "x" (NTLLE, s. v. xerga, jerga, Nebrija, 1495, Covarrubias, 1611, DRAE, 1817). De origen incierto (DECH, s. v. jerga).

\author{
Una manta nueva en jerga (Castromocho, PA-1611) \\ Una manta fraçada en jerga nueba (Castromocho, PA-1614) \\ Un ramo y dos piernas en jerga pardo (Frechilla, PA-1616) \\ Un paño buriel en xerga (Frechilla, PA-1631) \\ Un paño fraylego ordinario en gerga (Frechilla, PA-1674) \\ Un costal xerga con çinco medios de trigo (Medina de Rioseco, VA-1641) \\ Dos costales de jerga nuebos (Medina de Rioseco, VA-1661) \\ Dos costales de gerga buenos (Cuenca de Campos, VA-1668) \\ Una quilma de jerga vieja remendada (Villalpando, ZA-1620)
}

La palabra jerga no indica una tela particular, sino solamente la forma de tejido, cualquiera que fuera la fibra empleada (sea seda, lana, hilo o algodón), por lo que era susceptible de infinidad de combinaciones ( $D H T T$, s. v. jerga). En los ejemplos que barajamos en el corpus, la jerga se referencia junto a costales, mantas o paños ordinarios, por lo que el tejido debía de ser bastante tosco. Los datos que nos ofrece el CorLexIn sitúa el uso de esta palabra en diferentes puntos de la Península, sin que se pueda dibujar un patrón de uso, pues hay ejemplos en Ávila, Segovia, Soria, Cáceres, Badajoz, Cádiz, Guadalajara, Cuenca o Toledo. Este tipo de tejido también se documenta en inventarios americanos. En todas las ocurrencias, este textil se utilizaba para confeccionar costales, sacas, arpilleras o mantas.

\title{
JERGUILLA [gerguilla, xerguilla]
}

Sust. f. 'Tela delgada de seda o lana, o mezcla de una y otra, que se parece en el tejido a la jerga' (DLE). En Autoridades aparece como 'tela delgada de seda, ò lana, o mezcla de una y otra, que se parece en el texido a la xerga' (NTLLE, s. v. jerguilla, xerguilla, Autoridades, 1739). Término derivado de jerga ${ }^{1}(D E C H$, s. v. jerguilla).

Un capote cerrado de jerguilla sin guarnizión (Medina de Rioseco, VA-1642)

Colgaduras de jerguilla açul y vlanco y pajiças con çinco piezas (Villalón, VA-1637)

Un capote cerrado de xerguilla sin guarniçión (Medina de Rioseco, VA-1642)

Un manteo de xerguilla xaquelada guarnecida con passamanos en treynta reales (Medina de Rioseco, VA-1644)

Media vara de jerguilla axaquelada de Toledo en dos reales (Medina de Rioseco, VA-1645)

Gerguilla plateada de Toledo (Medina de Rioseco, VA-1647)

Un uestido de gerguilla parda, calçon, ropilla y ferreruelo nueuo (Medina de Rioseco, VA-1657)

Una colgadura para la misma cama de jerguilla çielo cortinas y couertor y delantera de color encarnada con un galonçillo de plata falssa (Medina de Rioseco, VA-1685)

La jerguilla es una tela delgada de lana o seda, o mezcla de ambas que se parecía en el tejido a la jerga (DHTT, s. v. jerguilla). El CORDE documenta esta voz a finales del siglo XVI, y es en el siglo XVI donde más casos se registran. Con este tejido se confeccionaban manteos, capotes, vestiduras, pero también colgaduras.

\section{LAMPARILLA [lanparilla]}

Sust. f. 'Tejido de lana delgado y ligero del que se solían hacer vestidos y capas de verano' (DRAE, s. v. lamparilla ${ }^{2}$ ). Autoridades lo recoge también como 'texido de lana delgado y poco fino, que 
se tiñe de diferentes colores, y sirve para vestidos y capas de verano' entre otras definiciones (NTLLE, s. v. lamparilla, Autoridades, 1734). Término derivado del fra. nompareille, íd. fabricado en Flandes ( $D E C H$, s. v. lámpara).

Una basquiña de lanparilla (Villalpando, ZA-1686)

Una vasquiña de lamparilla negra ya usada a más de medio traer (Villalpando, ZA-1690)

Es un tipo de 'tejido de lana delgado y poco fino, que se teñía de diferentes colores, con flores o listado, que servía para vestidos y capas para verano' (DHTT, s. v. lamparilla). El CORDE documenta casi media docena de ejemplos de esta palabra con la acepción de tejido. La primera documentación que figura en este corpus data de finales del siglo XVII:

Es su voluntad se le den a Mariana Alonso su criada vna basquiña nueba de lanparilla que tiene y un manto traydo y un guardapies de chameleton encarnado (Codicilo al testamento de Luisa de Urbina Pimentel, 1684)

Los ejemplos localizados en el CorLexIn también se fechan a finales de este siglo, aunque adelantan la primera aparición un año respecto a la fecha dada por el $D E C H$. Se localizan ocurrencias de lamparilla en Cádiz y Sevilla en inventarios fechados en 1679. Casi todos los casos que recoge el CorLexIn pertenecen a textos documentados en provincias andaluzas -Cádiz, Huelva, Málaga y Sevilla-. No obstante, este término figura en la documentación notarial de Badajoz y La Rioja.

La Tierra de Campos presenta una escasa nómina de casos, tan solo un par de ocurrencias en documentos procedentes de Villalpando (Zamora), fechadas también a finales de siglo. De los ejemplos localizados se deduce que este tejido se usaba para la confección de basquiñas, vestidos, calzones y casacas.

La lamparilla se comparó con otras telas. Autoridades definía rasilla como 'tela de lana, delgada y parecida a la lamparilla' y que se mantine en la edición académica actual (Pérez Toral, 2017b: 104). Tambien se la cotejó con lanilla en diferentes ediciones del diccionario académico hasta la de 1884 (Perdiguero, 2014: 149).

El término lamparilla se registra en obras lexicográficas desde Autoridades hasta la edición actual del diccionario académico. Este hecho contrasta con el recuento de casos en el CORDE, y con los ejemplos documentados por el CorLexIn, donde el uso de esta palabra es poco frecuente. Parece que este término comienza a documentarse a finales del siglo XVII y que no sobrevivió el paso del tiempo.

\section{LANA}

Sust f. 'Pelo de las ovejas y de otros animales, que se hila y sirve para tejer', 'tejido de lana' (DLE, 1. - y 3. ac.). Aparece en los diccionarios desde Nebrija. Término procedente del lat. LANA (DECH, s. v. (ana).

Tres cabeçales usados los dos de lino y lana y otro de lana (Valdavida, LE-1606)

Una unda viexa con un poco de lana (Sahagún, LE-1608)

Una almoada labrada de colorado con lana (Grajal de Campos, LE-1616)

Zinquenta vellones de lana negros y blancos (Grajal de Campos, LE-1616)

Dos mantas de lana la una viexa y la otra dada (San Pedro de Valderaduey, LE-.1626) 
Dos cavecales buenos de lana (Castromocho, PA-1603)

Un colchon bueno con su lana (Guaza de Campos, PA-1637)

Zinquenta y zinco libras de lana en jugo trama y menudos (Autillo de Campos, PA-1656)

Una antepuerta de lana (Autillo de Campos, PA-1656)

Tres arrobas y media de lana en jugo (Villarramiel, PA-1690)

Tres vellones de lana vlanca (Villalón, VA-1638)

Un luto de lana y ferreruelo y otro ferreruelo del muchacho (Medina de Rioseco, VA-1649)

Un cobertor berde nuebo de lana (Tamariz de Campos, VA-1652)

Dos colchones con su lana de lienzo (Medina de Rioseco, VA-1660)

Unas alforjas de lana viexas en quatro Reales (Cuenca de Campos, VA-1666)

Dos poyales nuebos de lana blanca y colorado (Villalpando, ZA-1632)

Una almoada de lienzo con su lana (Villalpando, ZA-1660)

Un cabezal de lino y lana abarillado (Villalpando, ZA-1661)

Un bufete pequeño con una carpeta de lana (Villalpando, ZA-1686)

Una azafate con unas puntas de lana angosta (Villalpando, ZA-1689)

Se trata de un término muy utilizado y común en los documentos. Aparece como tejido para confeccionar ropas, pero también como materia natural que servía para rellenar fundas o colchones. Esta palabra se encuentra documentada desde el siglo XIII en el $C D H$.

\section{LANILLA}

Sust. f. 'Tejido de poca consistencia hecho con lana fina' (DLE, 2.a ac.). Covarrubias lo recoge en su Tesoro como 'vna cierta tela texida de lana, de la qual se hazen vestidos de Verano'. Autoridades advierte de que se trata de un tejido 'más delgado que la lamparilla' y que también se utiliza para confeccionar hábitos (NTLLE, s. v. lanilla, Covarrubias, 1611; Autoridades, 1734). Voz derivada de lana, del lat. LANA (DECH, s. v. lana).

Una pieça de cuatro varas y media de lanilla de colores buena (Grajal de Campos, LE-1656)

Unos balones de lanilla biejos (Castromocho, PA-1603)

Dos cortinas de lienço o lanilla colorado (Frechilla, PA-1640)

Un jubón de lanilla con mangas de lana (Frechilla, PA-1640)

Vara y quarta de lanilla negra ancha (Medina de Rioseco, VA-1645)

Un luto de lanilla mui traido (Medina de Rioseco, VA-1648)

Es un tejido fino destinado a confeccionar tanto prendas de vestir como ropa del hogar. También se la localiza en los inventarios como tejido en pieza. Se documenta con esta acepción en los Estatutos de la muy insigne Universidad de Salamanca fechados en 1594: "no traiga vestido de raja, seda, ni de chamelote, lanilla, burato, media seda". Sin embargo, las referencias a este tipo de tejido son más bien escasas en el siglo XVII, según corpus académicos como el CORDE y el $C D H$. Por otro lado, el $D H T T$ considera esta tela como una novedad textil del siglo xIX.

Todo esto contrasta con lo encontrado en el CorLexIn y en la zona de estudio, donde este término está presente en un número considerable de inventarios desde comienzos del siglo XVII. Esta voz se documenta en el CorLexIn en diferentes puntos de la Península, siendo más habitual encontrarla en los inventarios de zonas más meridionales como Murcia, Sevilla, Granada o Huelva.

Perdiguero señala la comparación que se hacía con otro tejido muy similar, la lamparilla. A priori, la única divergencia existente entre ambos tejidos era el grosor de la propia tela. No obstante, advierte que otra posible diferencia entre ambos textiles pudo ser el color de ambos, 
la lanilla empleada en prendas oscuras y la lamparilla para ropas de color (Perdiguero, 2014: 149). El CorLexIn recoge varios ejemplos donde lanilla referencia un tejido de color negro para la confección de diferentes prendas de vestir:

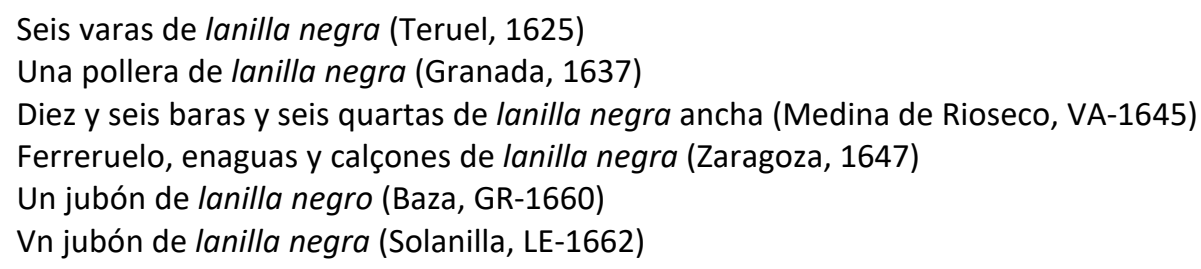

Sin embargo, en los ejemplos localizados en Tierra de Campos, frente a los ejemplos que designan un tejido de color negro, aparece "una pieça de cuatro varas y media de lanilla de colores" y "dos cortinas de lienço o lanilla colorado", por lo que el color no sería lo que diferenciaría a esta tela, al menos en la zona terracampina.

\section{LILA}

Sust. f. 'Tela de lana de varios colores' (DLE, s. v. lila $)$. Rosal registra en 1611 esta palabra como 'suerte de tela, como telilla'. Autoridades profundiza más en su definición: 'cierto género de texido ò tela de lana, de varios colores, de que se usa para vestidos y otras cosas. Llamóse assi por haber tenido su origen en Lila, ciudad de Flandes', el resto de las acepciones del término se añadirán posteriormente en otras ediciones del diccionario académico (NTLLE, s. v. lila, Rosal, 1611; Autoridades, 1734). Término procedente del fr. Lille, ciudad de Flandes donde se fabricaba esta tela (DECH, s. v. lila).

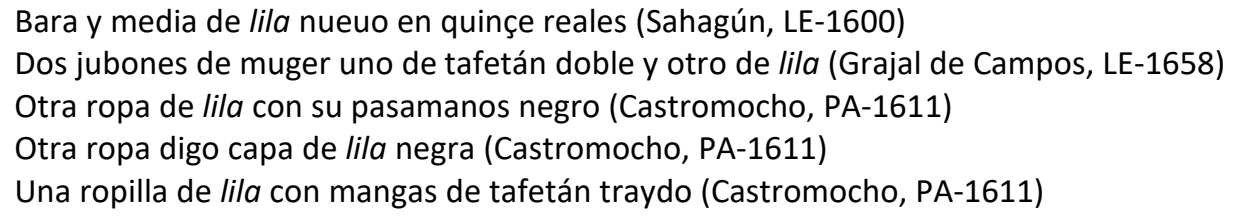

Este término referencia un tipo de tejido de lana de varios colores que se utilizaba para confeccionar vestidos. En corpus académicos como el CORDE y el $C D H$ hay un número escaso de ejemplos con la acepción textil del término. En el $C D H$, por ejemplo, contamos con cuatro casos solamente, tres pertenecientes al siglo xVI, localizados en un documento sobre el precio de las mercaderías de Bilbao ("paño de lila", "sarga de lila" y "sarga de ras y de lila") en el año 1563; y otro fechado a finales del siglo XIX, en una monografía escrita por Josep Puiggari i Llobet dedicada a la historia del traje y publicada en 1886.

Sin embargo, aparecen una serie de ejemplos de esta palabra con el significado de 'tela' en el CorLexIn, donde se documenta como tela en pieza y como tejido del que se fabrican prendas como enaguas, ongarinas, calzones y basquiñas, entre otras. Al igual que en otros casos, se trata de un epónimo, algo frecuente en mercancías que reciben el nombre de la ciudad donde se fabrican y que habitualmente sufren un proceso léxico por el que dejan de funcionar como nombres propios y pasan a actuar como nombres comunes. En el caso de lila, se trata de un término que no se identifica bien con su topónimo y que aparece en los textos con el proceso léxico ya consolidado (Morala, 2014b: 261). 


\section{PALMILLA}

Sust. f. 'Cierto género de paño, que particularmente se labraba en Cuenca' (DLE). Covarrubias define este término como 'vna suerte de paño, que particularmente se labra en Cuenca: y la que es de color açul, se estima en mas: y pienso que se dijo palmilla, quasi palomilla, por tirar al color de la paloma; sin embargo, de que hay palmillas verdes, o pudo ser que al principio se le pusiese en la orilla tejida una palma por señal'. Autoridades mantiene esa acepción concretando que 'por ser su color quasi como el de la Paloma zurita' (NTLLE, s. v. palmilla, Covarrubias, 1611; Autoridades, 1737). Palabra derivada de palma, del lat. PALMA (DECH, s. v. palma).

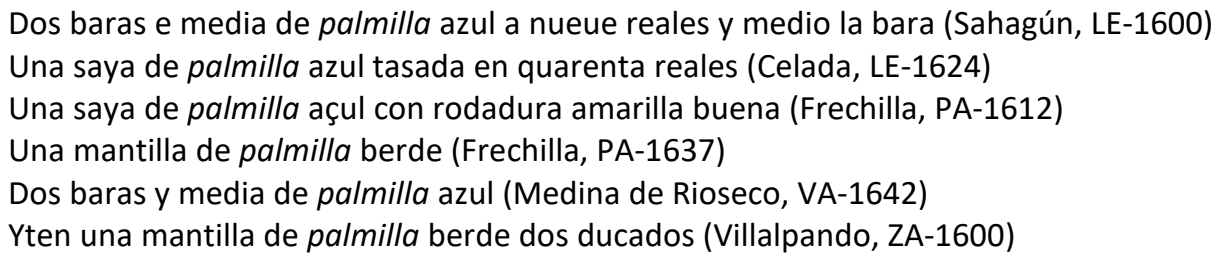

Este término aparece documentado en el CORDE y el CDH desde el siglo xV y la mayoría de los ejemplos que aparecen pertenecen al siglo XVII. Esta voz hace referencia a un tipo de paño ordinario hecho con los hilos de lana que sobraban al peinarla, fabricado en Cuenca e imitado en otros lugares (DHTT, s. v. palmilla). A parece en el corpus estudiado como tela en pieza y como tejido para confeccionar ropa tales como sayas o mantillas, preferentemente hechas con palmilla azul que, según Covarrubias, eran de mejor calidad. Sin embargo, en el CorLexIn, además de ser un tejido para confeccionar prendas de vestir, también aparece como tela utilizada para la elaboración de colgaduras de cama, rodapiés o cobertores (Pérez Toral, 2017a: 215).

\section{PAÑO}

Sust. $m$. 'Tela de lana muy tupida y con pelo tanto más corto cuanto más fino es el tejido' (DLE). Presente en los diccionarios desde Nebrija, aparece en Autoridades como 'la tela de lana de varias estofas, que sirve para vestirse y otros usos. Segun su calidad, fuertes o fábrica, toma varios nombres' (NTLLE, s. v. paño, Autoridades, 1737). Del lat. PANNUs 'pedazo de paño', 'trapo, harapo' (DECH, s. v. paño).

Zinco paños de tocar (Sahagún, LE-1601)

Una mantilla de paño pardo de cubrir buena (Sahagún, LE-1606)

Dos pedaços de paño hazul que está en la dha mi casa (Sahagún, LE-1606)

Siete beatillas nuebas y dos almoadas y dos paños de manos (Carvajal, LE-1609)

Un paño de manos de zerlas labrado de seda colorada (Castroañe, LE-1622)

Una saya frailega de paño ya traída (Castromocho, PA-1602)

Un cobertor de paño colorado (Guaza de Campos, PA-1639)

Una capa de paño pardo casero con buelta de terçiopelo (Guaza de Campos, PA-1640)

Un manteo de paño azul mediado (Autillo de Campos, PA-1649)

Un paño blanco de ofrendar (Villarramiel, PA-1696)

Un capotillo de paño pardo biejo del difunto (Villalón, VA-1642)

Unas enaguas de paño açul en çinco ducados (Medina de Rioseco, VA-1645)

Un monxil negro de paño traído (Medina de Rioseco, VA-1645)

Un Reboçino de paño negro guarnecido con un ribete de tercio (Tamariz de Campos, VA-1652) 
Un paño de lienzo casero con desylados y puntas en doze reales (Cuenca de Campos, VA-1666) Dos baras de paño berde bueno (Villalpando, ZA-1601)

Un paño de manos de lienzo bueno con sus puntas alrededor y grande (Villalpando, ZA-1661)

Un paño de manos de cenefas (Villalpando, ZA-1670)

Una mantellina de paño negro dezyocheno (Villalpando, ZA-1685)

Otra colgadura de cama de paño verde (Villalpando, ZA-1686)

Es un término de uso muy frecuente en los inventarios de la época. En esta zona aparece con dos acepciones diferentes: por un lado, hace referencia a un tipo de tela con el que se elaboran vestidos y ropa de la casa y, por otro, designa cierta ropa del hogar con diferentes funciones dentro de la casa. Así, encontramos paño de manos, paño de ofrecer o paño de tocar, este último como un tipo de pañuelo que se ponía en la cabeza y que estaría dentro de los complementos para mujeres. Esta voz se documenta en el CDH en el Mío Cid en 1140 "[...] tanta pórpola e tanto xamed e tanto paño preciado".

\section{PELO DE CAMELLO}

M. 'Tejido hecho con pelo de este animal o imitado con el pelote del macho cabrío' (DLE). Aparece registrado en el DRAE de 1780 indicando 'tela hecha del pelo mas ordinario del camello' (NTLLE, s. v. pelo de camello, DRAE, 1780).

Un jubón de tela de pelo de camello con unas mangas de tafetán negro (Frechilla, PAUna basquiña de pelo de camello como morada (Paredes de Nava, PA-1689)

Un jubón de pelo de camello (Boadilla de Rioseco, PA-1690)

Un bestido de pelo de camello (Paredes de Nava, PA-1695)

Treçe pieças de pelo de camello blanco (Medina de Rioseco, VA-1645)

Un jubón de pelo de camello (Medina de Rioseco, VA-1651)

Un monjil de bayeta de zienfilos con mangas de pelo de camello (Medina de Rioseco, VA-1661)

Una vasquiña de pelo de camello nueua (Villalpando, ZA-1686)

Se trataba de una tela de pelo largo fabricado con el pelaje más profundo de la piel de camello, que es el más fino y suave y tiene propiedades termales (DHTT, s. v. pelo de camello). En el CORDE aparece documentado en una obra de Fray José Sigüenza fechada en 1605. También figuran ejemplos de este tipo de tela en el CorLexIn en distintos puntos de la Península. En América encontramos de esta palabra en documentos de principios del siglo XVIII. Este tipo de tejido aparece documentado en los inventarios de la Tierra de Campos a partir de mediados del siglo XVII.

\section{RAJA [raxa]}

Sust. f. 'Especie de paño grueso y de baja estofa, usado antiguamente' (DLE, s. v. raja ${ }^{2}$. Este término lo recoge Covarrubias en su Tesoro como 'cierto genero de carisea, ò paño prensado'. Autoridades habla de una 'especie de paño gruesso antiguo de baxa estofa', definición que se mantiene hasta la edición actual (NTLLE, s. v. raja, Covarrubias, 1611, Autoridades, 1737). Término procedente del it. rascia íd., de origen incierto ( $D E C H$, s. v. raja).

Otros cuerpos de raxa parda con sus pasamanos (Sahagún, LE-1600)

Otra saya de raxa biexa (Sahagún, LE-1605)

Otro jubón de raja azaytunado con trenzillas de seda azul (Grajal de Campos, LE-1670)

Una ropilla de raja negra ussada (Autillo de Campos, PA-1647) 
Otra basquiña de raxa açul mediada (Autillo de Campos, PA-1651)

Una basquiña de raja berde claro con delantera açul (Autillo de Campos, PA-1653)

Una vasquiña de raja color de piel de rata (Medina de Rioseco, VA-1646)

Una basquiña de raja verde (Medina de Rioseco, VA-1648)

Unas enaguas de raja zeleste con ribetón y honze guarniziones y sus flores de lis (Medina de Rioseco, VA-1649)

Un avantal de raja azul con dos guarniziones (Medina de Rioseco, VA-1651)

Un mandil de raxa berde garnecido con terciopelo negro (Villalpando, ZA-1613)

Una basquina de raja almendrucada nueba con rodadura de lo mismo (Villalpando, ZA-1620)

Un mantheo de raja de Florençia guarneçido (Villalpando, ZA-1631)

Un mandil de raja guarnecido de pasamanos (Villalpando, ZA-1635)

Frente a la definición académica, el $D E C H$ señala que este término designaba un paño de seda o similar, altamente cotizado en el siglo XVII. Posiblemente este tejido importado de Italia fue perdiendo calidad con el paso del tiempo y este deterioro repercutió en el producto final, llegando a ser una tela de baja calidad (Congosto, 2002: 166).

Desde el punto de vista diacrónico se certifica su uso a partir del siglo XVI, así se refleja en los textos que configuran el $C D H$ :

Sedas valen en buen preçio porque está çerca de Calabria [...]. Paño hai bueno y no muy caro, prinçipalmente rraja (1557-1558, Anónimo, Viaje a Turquía)

A partir de este momento esta voz figura en las relaciones de precios de mercadurias, en pragmáticas y también en inventarios de bienes. A partir de 1568 también en documentos americanos:

Un capote de raxa de mezcla aforrado en pellejos negros (Donación de Juan Francisco Locadelo en favor de Doña Andrea de Cervantes, 1568, República Dominicana)

Una ropilla de raja negra (Memoral presentado por Ana de Alva, heredera de un boticario, 1576, Perú)

En las bases textuales académicas también se localiza un tipo de raja más apreciada, la raja de Florencia: 'especie de raja muy fina y cara que venía de Italia' $(D L E)$ y que aparece en las bases académicas desde 1580 (CDH y CORDE).

A partir de mediados del siglo XVII raja con la acepción de tejido entra en un claro retroceso, parece que su uso mayoritario fue en los siglos XVI y XVII, para luego entrar en desuso.

De los datos aportados por el CorLexIn se puede extraer que esta palabra designaba un tipo de tejido que se utilizaba para confeccionar todo tipo de vestimentas (basquiñas, polleras, sayas, enaguas, manteros, capas, ferreruelos, faldellines...), y, aunque en menor medida, también se utilizaba para la elaboración de prendas del ajuar doméstico (cortinas, camas, cobertores, paños, colgaduras...). En el CorLexIn también se encuentra como tela en pieza. En los documentos terracampinos tan solo la encontramos como tejido para confeccionar deferentes ropas (mandiles, delantales, cuerpos, sayas, basquiñas, jubones...).

Es famosa en esta época por su calidad la raja de Florencia, presente en inventarios de algunas localidades de la Península -"Vn paño de cama de raxa berde de Florençia, con su fleque berde y dorado, en doçientos reales" (Totana, Mu-1659)- y en América -"un bohemio, ropilla y calças de raxa, de Florencia, guarnecido" (Potosí, Bolivia, 1609)-. También localizamos ejemplos de esta rica tela en documentos de Tierra de Campos. 


\section{SARGA}

Sust. f. 'Tela cuyo tejido forma unas líneas diagonales' (DLE, s. v. sarga ${ }^{1}$ ). Aparece en Autoridades como 'tela de seda que hace cordoncillo, con alguna mas seda que el tafetan doble' y también como 'una tela de lana algo más fina que la sempiterna, la qual sirve regularmente para forro' (NTLLE, s. v. sarga, Autoridades, 1739). Término procedente del lat. SARǏCA (DECH, s. v. sarga).

Unas mangas de sarga husadas (Villalón, VA-1642)

Otra loba de sarga viexa rota (Villalón, VA-1642)

Vna bara menos vna ochaua de sarga negra (Medina de Rioseco, VA-1645)

Cinquenta y cinco varas y media de sargas de color y negras en nueue pedaços (Medina de Rioseco, VA-1645)

El CORDE y el CDH documentan este término en la segunda mitad del siglo XIII. Este tipo de tela de lana se fabricaba en la Península desde la Edad Media. Las referencias a este tejido son escasas en los inventarios de la Tierra de Campos, en comparación con otras telas. Algo que contrasta con lo que aparece en el CorLexIn, donde este término está ampliamente documentado. En Tierra de Campos encontramos sarga con la acepción de tejido para confeccionar ropa y también como tela en pieza. Sin embargo, en inventarios de la época aparece este término con otra acepción, y es que la sarga era utilizada como elemento decorativo en los hogares del siglo XVII. Así nos encontramos sargas pintadas que se utilizaban para decorar diferentes partes de la casa.

\section{SEMPITERNA [senpiterna]}

Sust. f. 'Tela de lana, basta y muy tupida, que se usaba para vestidos' (DLE, 4. ac.). El DRAE de 1822 registra esta voz como 'tejido de lana apretado de bastante cuerpo, de que usan regularmente las mugeres pobres para vestirse', acepción que ha llegado a la actualidad, con la salvedad de haber eliminado esa marca diastrática. (NTLLE, s. v. sempiterna, DRAE, 1822) Término derivado de siempre, sempiterno, tomado del lat. SEMPITTĔRNUS ( $D E C H$, s. v. siempre).

Otra pollera de senpiterna encarnada con una esterilla de oro (Grajal de Campos, LE-1658)

Unos cuerpos de sempiterna con terziopelo labrado nuebos (Grajal de Campos, LE-1670)

Dos almillas de sempiterna encarnado (Valderas, LE-1682)

Un jubón de sempiterna azul con sus mangas de senpiterna negra dado (Villada, PA-1668)

Un par de mangas de sempiterna azul para muxer en veinte y dos reales (Frechilla, PA-1671)

Un tapapies de sempiterna (Paredes de Nava, PA-1695)

Una petrenilla de senpiterna nueba azul guarnecida de pasamanos de santa Ysabel (Cuenca de Campos, VA-1668)

Un jubón de senpiterna berde con mangas de senpiterna negra (Medina de Rioseco, VA-1671)

Un bestido de paño pardo digo de color arenosso con jubón y manga de senpiterna con sus çapatos y medias y balona y sombrero (Villalpando, ZA-1647)

Una ongadina de muxer de senpiterna ya usada (Villalpando, ZA-1690)

Se trata de un tejido muy popular en el siglo XVIII. Lo usaban las mujeres pobres para vestirse ( $D H T T$, s. v. sempiterna). En las bases textuales académicas ( $C D H$ y CORDE) no figura más de una decena de ocurrencias de este término. EI CORDE documenta esta lexía en una tasación fechada en 1658:

Un guardabaxos de senpiterna con punttas negras, çinquenta y quatro rreales (Tasación de madera y otros bienes del inventario de Juan de Arce, 1658) 
Sin embargo, los datos que ofrece el CorLexin permiten adelantar la fecha de documentación a 1637 (Pérez Toral, 2017c: 179). Además, con un mayor número de casos que los localizados en las bases académicas. Los ejemplos que aparecen en este corpus, aunque sin patrón claro, se concentran preferentemente en la zona meridional de la Península -Huelva, Granada, Cádiz, Córdoba, Murcia, Sevilla, Málaga-, aunque también hay ejemplos en la documentación de América y Canarias. En el área de estudio aparece con bastante frecuencia en los inventarios, como tejido para confeccionar polleras, cuerpos, almillas, jubones, mangas, tapapiés o mangas, entre otras prendas.

\subsubsection{Cáñamo}

\section{ARPILLERA}

Sust. f. 'Tejido por lo común de estopa muy basta, con que se cubren determinadas cosas para protegerlas del polvo y del agua' (DLE). En el Tesoro de Covarrubias aparece registrada como harpillera con el significado de 'funda con que se embuelue la pieça de paño, o seda, por ser como delecho, y pedaço de otro paño basto', Autoridades sigue manteniendo la grafía con / $\mathrm{h} / \mathrm{y}$ manteniendo el significado de tejido que se utiliza a modo de funda para proteger diferentes enseres del polvo y el agua (NTLLE, s. v. harpillera, Covarrubias, 1611; Autoridades, 1734). Palabra de origen incierto parece ser catalanismo o galicismo antiguo (DECH, s. v. arpillera), aunque Martínez Meléndez considera que estamos ante un préstamo del francés serpillière (Martínez Meléndez, 1989: 418-420).

Un gergón de arpilleras biejo (Boadilla de Rioseco, PA-1690)

Un pedaço de arpillera biexo (Medina de Rioseco, VA-1641)

Un jergón biexo de arpilleras (Villalón, VA-1642)

Seis arpilleras, digo, onçe a dos reales cada vna (Medina de Rioseco, VA-1645)

Un gergón de arpilleras en ocho Reales (Cuenca de Campos, VA-1666)

Corominas y Pascual localizan como primera documentación sarpillera en un inventario zaragozano de 1497. Sin embargo, tanto el CDH como el CORDE adelanta en los textos su aparición, en el $C D H$, en las Ordenanzas de Navarra de 1250 aparece "cuerda arpillera" y en 1445 en Las Coplas de la panadera. En la documentación lo encontramos tanto con $h$ como sin ella, pero figura de manera más común $\sin h$. Ni en el CorLexIn, ni en los documentos de la zona de estudio encontramos este término con $h$. Suele aparecer en los inventarios junto a sacas, talegas o seras y su presencia mayoritaria es en la documentación del siglo xx ( $C D H)$.

El CorLexIn presenta una veintena de casos repartida en un ámbito geográfico extenso y sin patrón de reparto claro recogidos en la documentación peninsular -Vitoria, Navarra, Palencia, Valladolid, Madrid, Toledo, Huelva- y americana -Bolivia, Chile, Venezuela y México-. La arpillera formaba parte de esos tejidos más bastos que formaban parte de los cargamentos para las américas, como un tejido utilizado para proteger y salvaguardar mercancías y objetos (Congosto, 2002: 148). En Tierra de Campos localizamos casi media docenta de ocurrencias del 
término arpillera con dos posibles acepciones, bien como un tipo de tejido basto utilizado para confeccionar jergones; $y$ como harapo o trapo que sirve para preservar los objetos y enseres.

\section{BROCATEL}

Sust. m. 'Tejido de cáñamo y seda, a modo de damasco, que se emplea en muebles y colgaduras' $(D L E)$. Lo registra Autoridades como 'cierto género de texido de hierba ò cáñamo y seda, à modo de brocáto, ò damasco, de que se suelen hazer colgadúras para el adorno de las Iglesias, salas, camas y otras cosas' (NTLLE, s. v. brocatel, Autoridades, 1726). Se trata de un término derivado de brocado, del cat. brocatell y éste del it. broccatello (DECH, s. v. brocado).

Quatro baras y tercia de brocatel de dos canxes (Medina de Rioseco, VA-1645)

Otro frontal de damasco acul con frontaleras de brocatel (Medina de Rioseco, VA-1651)

Otras dos cortinas de brocatel blanco y azul con zenefa (Medina de Rioseco, VA-1651)

El altar de Nuestra Señor de brocatel gamuçado con zenefas de brocatel mas escuro (Medina de Rioseco, VA-1651)

EI CORDE documenta esta voz a finales del siglo XVI en una obra fechada en 1570 de Juan de Mal Lara, donde aparece "una ropa de brocatel". Sin embargo, en el $C D H$ aparece el término brocatelo casi medio siglo antes. Dicha palabra aparece como sinónimo de brocatel en el DRAE de 1936.

El CorLexIn ofrece una veintena de casos repartidos entre la Península y América, haciendo referencia a un tipo de tejido que se utilizaba para la confección del ajuar de la casa como colgaduras, cojines, doseles, frontales, cortinas o almohadas. Los exiguos ejemplos que presenta la Tierra de Campos se ubican en la localidad terracampina de Medina de Rioseco y figuran con el significado académico.

\section{CAÑAMAZO [cañamaço]}

Sust. $\mathrm{m}$. 'Tela de tejido ralo bordada con seda o lana de colores' ( $D L E$, 4. a ac.). Término recogido por Nebrija. En el Tesoro de Covarrubias aparece como 'vna tela basta sobre la qual se labran con sedas de colores, pieças de matizes para sobremesas, sillas, taburetes, etc'. Autoridades también lo define como 'tela tosca, a modo de beatilla por lo clara, que se hace del hilo del cáñamo' (NTLLE, s. v. cañamazo, Nebrija, 1495, Covarrubias, 1611, Autoridades, 1729). Término procedente del lat. vg. CANNĂBUM, lat. CANNĂBIS (DECH, s. v. cáñamo)

Una golilla con dos valonas de cañamazo finas (Frechilla, PA-1671)

Una echura de un cruçifixo en un dosel de cañamazo vordado de seda y con puntas de plata (Medina de Rioseco, VA-1644)

Sesenta y una varas de cordones de cañamaço (Medina de Rioseco, VA-1645)

Más cinco docenas de valonas de cañamaço ordinarias (Medina de Rioseco, VA-1645)

Es un tipo de tela que se documenta en bases de datos textuales como el $C D H$ y el CORDE desde mediados del siglo XV. El CorLexIn presenta una veintena de casos repartidos a lo largo de la Península y América. Los usos que se le daban a este tejido eran diversos; lo mismo servía para confeccionar mangas o valonas, que doseles de cama, así como para forrar bufetes. Los 
escasos ejemplos localizados en el corpus terracampino obedecen a la forma y significado académicos.

La derivación que presenta este término viene dada por el sufijo -azo, estudiado por Morala en voces como estopazo o trigazo entre otras y documentado en inventarios de bienes del siglo XVII, donde el significado que aporta -azo tiene que ver con la exageración, dando un sentido de aumentativo o despectivo (Morala, 2017a: 157).

\section{CÁÑAMO}

Sust. m. 'Filamento textil del cáñamo'. 'Lienzo de cáñamo' (DLE, 2.a y 3.a ac.). Esta palabra está presente en el Vocabulario de Nebrija, y Covarrubias lo define como 'planta conocida y muy vtil para la vida humana, porque del cañamo se hace el cordel y las obras que constan del, como cinchas, xaquinas, alpargates, cordones de frayles, guindaletas, maromas, y telas de lienço basto; de donde se hizieron las primeras camisas, o cañamisas' (NTLLE, s. v. cáñamo, Nebrija, 1495, Covarrubias, 1611). Término procedente del lat. vg. CANNĂBUM, lat. CANNĂBIS (DECH, s. v. cáñamo).

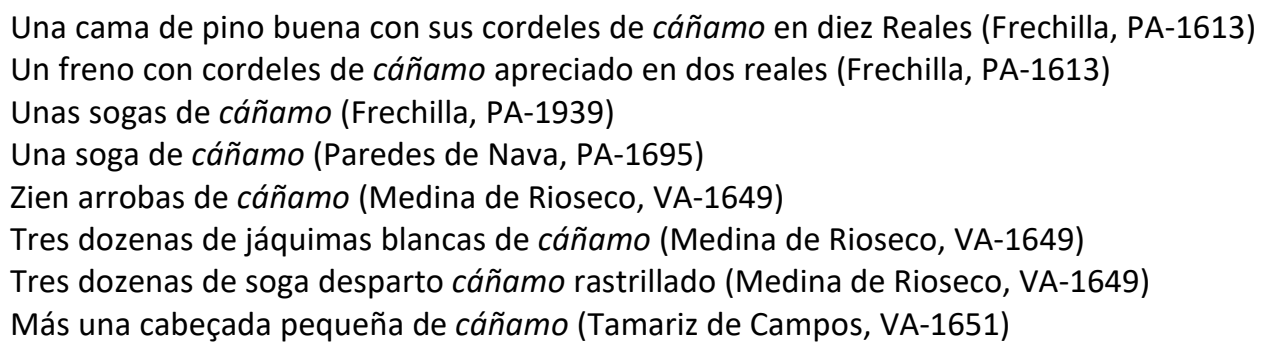

La palabra aparece documentada en la Tierra de Campos como un tipo de textil para fabricar sogas, cordeles, jáquimas o cabezadas. En bases textuales como el $C D H$ y el CORDE esta voz figura en los textos a partir del Fuero de Madrid fechado entre los años 1141 y 1235.

El CorLexIn recoge abundantes ocurrencias a lo largo y ancho de la Península, que contrasta con los dos únicos casos recogidos en documentos americanos -Bolivia y Chile-.

\section{ESTOPA}

Sust. f. 'Parte basta o gruesa del lino o del cáñamo, que queda en el rastrillo cuando se peina y rastrilla'. 'Tela gruesa que se teje y fabrica con la hilaza de la estopa' ( $D L E, 1$. ․ y 3 . a ac.). Lo recoge Nebrija, Covarrubias y Autoridades con la primera acepción 'lo gruesso y basto del lino [...]'; es en la edición de 1780 del DRAE cuando aparece estopa como 'la tela gruesa, que se texe y fabrica con la hilaza de la estopa' (NTLLE, s. v. estopa, Nebrija, 1945, Covarrubias, 1611, Autoridades, $1732, D R A E, 1780)$. Se trata de un término derivado del lat. STŬPPA ( $D E C H$, s. v. estopa).

Item, un lençuelo de estopa que tiene dos piernas (Sahagún, LE-1606)

Más se le entrego una bara de estopa nueba en real y medio (Castroañe, LE-1615)

Yten, dos sávanas, una de estopa y otra de estopilla (Cea, LE-1626)

Un jergón destopa (Valderas, LE-1652)

Una sábana casera de lino y estopa (Mazariegos, PA-1619)

Estopa para un gergon (Boadilla de Rioseco, PA-1658) 
Tres camisas nuebas de lienço con ruedos de estopa labrados todas de negro (Villada, PA-1665) Quatro colchones de estopa grandes (Paredes de Nava, PA-1690)

Tres cabezales de estopa biejos (Villalón, VA-1642)

Dos talegas de estopa en quatro reales (Medina de Rioseco, VA-1645)

Zinco sáuanas de estopa nueuas (Medina de Rioseco, VA-1648)

Un xergon destopa bueno (Cuenca de Campos, VA-1667)

Una sábana masadera de estopa de dos piernas en ocho rreales (Villalpando, ZA-1600)

Yten, un jergon de estopa nuevo y una delantera de cama de red nueba (Villalpando, ZA-1620)

Vn coladero biexo de estopa (Villalobos, ZA-1654)

Una quilma de estopa (Villalpando, ZA-1698)

Término documentado en bases de datos como el $C D H$ y el CORDE desde el siglo XIII y en el CorLexIn en toda la Península. Se trata de una palabra que aparece asiduamente en los inventarios de la Tierra de Campos y que hace referencia a un tipo de tejido muy común en esta época.

\section{ESTOPILLA}

Sust. f. 'Parte más fina que la estopa, que queda en el rastrillo al pasar por él por segunda vez el lino o el cáñamo'. 'Tela que se ha fabricado con el hilado de estopilla' (DLE, 1. a y 3. a ac.). Autoridades añade la acepción de 'lienzo ò tela mui sutil y delgada como el cambray, pero mui rala y clara, y semejante en lo transparente a la gassa' (NTLLE, s. v. estopilla, Autoridades, 1732). Se trata del diminutivo de estopa, voz procedente del lat. STŬPPA (DECH, s. v. estopa).

Un lenzuelo de estopilla de seis baras bueno (Sahagún, LE-1601)

Una sauana de estopilla vuena (Sahagún, LE-1614)

Tassaron otros manteles de estopilla en tres reales y medio (Sahagún, LE-1617)

Diez madejas de estopa y estopilla curadas de a dos libras cada una (Cea, LE-1621)

Seis baras de serbilletas de estopilla en pieza (Grajal de Campos, LE-1658)

Una ropilla de estopilla (Cuenca de Campos, VA-1660)

Siete sáuanas de estopilla casera (Medina de Rioseco, VA-1685)

Tres sáuanas, de lienço las dos y una de estopilla traídas y hordinarias (Villalpando, ZA-1652)

Dos coladeros nuebos de estopilla (Villalpando, ZA-1660)

Una delantera de cama de estopilla con su flocadura (Villalpando, ZA-1661)

Onze libras destopa y estopilla ylado (Villalpando, ZA-1688)

Es una voz derivada de estopa que se documenta en un libro de cetrería pasado el ecuador del siglo XVI-1565- en el CDH. Según el DHTT este tipo de tejido presenta diferentes acepciones: 'parte más fina de la estopa, que queda en el rastrillo al pasar por él por segunda vez el lino o el cáñamo', 'tela que se fabrica con ese hilado', 'lienzo o tela muy delgada, como el cambray, pero muy rala y clara, semejante en lo transparente a la gasa', 'tela ordinaria de algodón' (DHTT, s. v. estopilla).

Los datos que nos ofrecen el CDH y el CORDE no pasan de la veintena de ocurrencias de esta palabra, su presencia es más bien escasa, aunque aparecen casos tanto en documentos peninsulares como americanos, estos últimos ya en el siglo XIX. Desde una perspectiva diatópica, el CorLexIn atestigua poco más de una docena de casos, repartidos en dos zonas peninsulares principalmente, por un lado la franja occidental con preferencia por las provincias andaluzas -Huelva, Sevilla, Córdoba y Zamora- y por otro figura en provincias más norteñas como Zaragoza, Navarra o Álava. Parece que se trataba de un textil utilizado principalmente para 
confeccionar parte del ajuar doméstico -sábanas, manteles, serbilletas, toallas...-, aunque también se utilizaba para algunas prendas de vestir como enaguas, valonas o ropilla. Por otro lado, tanto la estopa como la estopilla eran tejidos con un valor inferior a otras telas y en ocasiones se utilizaban para el ajuar de los criados, así en los inventarios de Vitoria (Álava) figura: "diez y seis sáuanas, para los criados, de estopa y estopilla" o "quatro manteles de los criados de granillo, destopa y estopilla", aunque también había estopilla con más valor como la de Cambray. En Tierra de Campos este tipo de tejido es habitual en los inventarios de bienes y, como ocurre en los documentos del resto de la Península, se utilizaba principalmente para la confección de lenzuelos, coladores, delanteras de cama...

\subsubsection{Lino}

\section{BEATILLA [veatilla, ueatilla]}

Sust. 'Especie de lienzo delgado y ralo' (DLE). Covarrubias recoge esta voz como 'cierta tela de lino de que se hazen tocas, deuio ser inuencion aquel genero de hilado, y tela de algunas beatas, o porque las vsan ellas, y las mugeres recoletas que no se engalanan' (NTLLE, s. v. beatilla, Covarrubias, 1611). Se trata de un término derivado de beato 'feliz', del lat. BEATUS (DECH, s. v. beato).

Dos tocas de muxer, vna espumilla y otra de beatilla (Valderas, LE-1647)

Dos tocados de beatilla (Castromocho, PA-1602)

Onçe tocados buenos delgados de espumilla algodón y beatilla (Frechilla, PA-1612)

Cinco cortinas de ueatilla (Paredes de Nava, PA-1681)

Una toca de veatilla (Medina de Rioseco, VA-1644)

Un zielo de cama de beatilla (Medina de Rioseco, VA-1651)

Una pieça de veatilla con doçe baras (Medina de Rioseco, VA-1657)

Unas enaguas de veatilla con puntas (Medina de Rioseco, VA-1660)

Un abantal de beatilla (Medina de Rioseco, VA-1660)

Una delantera de ueatilla (Medina de Rioseco, VA-1685)

Una cofia de beatilla nueba (Villalobos, ZA-1654)

Dos tocas de yerbas de veatilla una amarilla y otra blanca (Villapando, ZA-1690)

Se denomina así a una 'tela de lino, delgada, clara y rala, con la que se hacían las tocas transparentes, a modo de velo o mantilla' (DHTT, s. v. beatilla). Corominas y Pascual documentan este término a finales del siglo XV (DECH, s. v. beatilla). El CDH apenas presenta casos de esta palabra, tan solo figura con el significado de tejido en La pícara Justina fechada en 1605 y en una obra de José Francisco de Isla de 1758, mediados del siglo XVIII. El CORDE ofrece poco más de media docena de ejemplos fechados entre los siglos XVI y XVIII, aunque el mayor número de ocurrencias se encuentran en el XVII. Esta falta de testimonio en las bases de datos académicas contrasta con lo que observamos en Tierra de Campos, donde se localiza un número considerable de casos donde esta lexía aparece con el significado académico de tejido. Con esta tela se confeccionaban tocas, enaguas o delantales y también ropa de cama (delanteras, cielos o cortinas). Lo mismo ocurre en el CorLexIn que presenta una distribución diatópica de carácter general, y además amplía la nómina de prendas que se confeccionaban con esta tela (camisas, 
gorguerillas, rebozos, peinadores o pellices, pero también sábanas, toallas, camas, cubiertas, cobertores, paramentos o manteles de altar).

Formalmente, en la Tierra de Campos siempre se documenta la forma académica beatilla. Sin embargo, Egido localiza la forma biatilla para referenciar este tejido en la zona de Maragatería, Cepeda y Órbigo (Egido, 2010). Esta variante también figura en un inventario de la localidad riojana de Briones (CorLexIn, s. v. biatilla). La solución con cierre de la /e/átona en /i/ no es muy frecuente en los textos, posiblemente por resultar vulgar para los notarios, aunque estuviera presente en la lengua oral (Morala y Egido, 2010: 427).

Además de como tejido, beatilla aparece como sustantivo referenciando a la toca elaborada con dicho tejido y en un mismo documento podemos tener ejemplos donde se referencia a la vez el tejido y el tipo de toca:

Dos tocados de beatilla / una cofia de beatilla con una randa de oro / otra beatilla (Villalpando, ZA-1620)

En el corpus terracampino figura una nutrida nómina de ocurrencias con esta acepción:

Dos beatillas nueuas en dos ducados (Sahagún, 1600)

Quatro beatillas en doce reales (Castromudarra, LE-1606)

Otra beatilla delgado en ocho reales (Castromudarra, LE-1606)

Siete beatillas nuevas y dos almoadas y dos paños de manos (Carvajal, LE-1609)

Tres beatillas buenas (Sahagún, LE-1614)

Dos veatillas dadas sin tasar (Sahagún, LE-1626)

Una beatilla de lienzo nueba (Grajal de Campos, LE-1613)

Una beatilla fina nueua de Obiedo (Frechilla, PA-1612)

Una beatilla de Obiedo fina y otras dos más vastas (Frechilla, PA-1642)

Dos beatillas (Villarramiel, PA-1694)

Una veatilla fina en doze reales (Medina de Rioseco, VA-1643)

Una beatilla y una tabla de manteles de gusanillo (Villalpando, ZA-1614)

Una beatilla buena (Villalpando, ZA-1639)

Los datos ofrecidos por el CorLexIn ofrecen ejemplos de esta voz con el significado de 'toca' en documentos pertenecientes a localidades norteñas como Oñate (Guipúzcoa) o Tafalla (Navarra).

Con un carácter más singular, esta palabra también funciona en los textos como adjetivo, sin nexos preposicionales:

Tres tocados beatillas buenos (Frechilla, PA-1615)

Tres tocados los dos beatillas y uno de algodón (Frechilla, PA-1615)

Esta naturaleza adjetival es señalada por Pérez Toral en alguno de los documentos que configuran el CorLexIn -"lienço beatilla" (Tolosa, SS-1633), "tocado beatilla" (Ventosa de la Cuesta-VA-1610) o "toca beatilla" (Nava del Rey, VA-1648)- (Pérez Toral, 2017c: 162).

\section{BOCACí [bocazí, bocaçil, vocaçí]}

Sust. m. 'Tela de hilo que podía ser de distintos colores, más gorda y basta que la holandilla' (DLE). Covarrubias lo define como 'tela falsa de lienço teñido de diuersas colores y bruñido'. La definición de Autoridades es más específica: 'tela de lino de varios colores, especialmente negro, 
encarnado, o verde, que paréce está engomado por lo tiesso. Es más gordo y basto que la holandilla' (NTLLE, s. v. bocací, Covarrubias, 1611, Autoridades, 1726). Se trata de una voz oriental llegada a través del árabe (DECH, s. v. bocací).

\section{Otro sayuelo de raso liso forrado en bocazí (Sahagún, LE-1600)}

Otro manto biejo con bebederos de bocaçil apreçiado en doçe reales (Frechilla, PA-1614)

Un sayuelo negro de cruz con ribetes de terçiopelo aforrado en bocaçil colorado (Frechilla, PA1616)

Una saya fraylega de paño con rodadura de bocaçí (Frechilla, PA-1639)

Siete varas y tres quartas de vocaçí de plata, pajiço, verde y negro (Medina de Rioseco, VA-1645)

Un guardapoluo de camino viejo de bocazí (Villalpando, ZA-1633)

El DHTT da tres acepciones para este tejido: 'tela falsa de lienzo, teñido de diversos colores y bruñido', 'tela de lino blanca o de varios colores, especialmente negro, encarnado o verde, engomada, alisada y lustrada' y 'tela de hilo gruesa y ordinaria'.

Desde una perspectiva diacrónica, este término aparece documentado en el $C D H$ en el inventario de bienes de Diego López Ayala fechado en 1441, donde figuran "unas sayas verdes aforradas de bocacín prieto". Casi todos los ejemplos que aparecen tanto en el $C D H$ como en el CORDE pertenecen al siglo XVII, por lo que cabe señalar que esta palabra era de uso habitual en la época.

Figuran diversas ocurrencias en el CorLexIn -sobre todo en la parte Norte de la Península, aunque también se constatan ejemplos en México y Chile-. El significado con el que aparece en estos documentos es el de forro para vestimentas, cofres y cajas principalmente. Pérez Toral considera que se trataba de una tela secundaria (Pérez Toral, 2017a: 203). Además, formalmente, se encuentra la forma bocacín en algunos puntos de la Península como Álava. En Tierra de Campos figura la forma bocacil en inventarios de la localidad palentina de Frechilla y en documentos redactados por el mismo notario: Francisco Ejado. Esta variante presenta una terminación engañosa de arabismo, tal y como pasa en el término arconcil (Morala, 2017b: 277). No se localiza ni en las obras lexicográficas académicas, ni en las bases de datos. Sin embargo, el Fichero General ofrece un caso de bocacil en un libro de 1924, concretamente en España nervio a nervio de Eugenio Noel, pero con una acepción muy diferente a la de tejido, en este caso hace referencia a un apero agrícola "no suenan los cinchos, no rechina el bocacil, no cruje el tendal".

\section{LIENZO [lienço]}

Sust. m. 'Tela que se fabrica de lino, cáñamo o algodón', 'pintura que está sobre lienzo' (DLE). Registrada por Nebrija y Covarrubias como 'tela hecha y texida de lino' (NTLLE, s. v. lienzo, Nebrija, 1495; Covarrubias, 1611). Voz procedente del lat. LǏNTĚUM 'tela de lino', 'lienzo' (DECH, s. v. lienzo).

Un jubón de lienzo de hombre mediado (Sahagún, LE-1603)

Una almoada de lienço llana buena (Cea, LE-1621)

Una colcha de botonzillos, y dos almuadas de lienzo (Valderas, LE-1670)

Seis baras de lienzo en pieza (Villemar, PA-1608)

Una halmohada de lienzo llano con una randilla de ylo blanco (Frechilla, PA-1638)

Unos manteles de lienço vasto viejos (Autillo de Campos, PA-1648) 
Un peynador de lienzo de Aroca con sus puntas (Paredes de Nava, PA-1689)

Ocho almuadas de lienço (Paredes de Nava, PA-1695)

Una tualla de lienzo delgada (Medina de Rioseco, VA-1660)

Una almoada de lienzo llana con desilados (Cuenca de Campos, VA-1668)

Dos sábanas de lienço buenas (Villalpando, ZA-1631)

Dos camisas nueuas de lienço casero (Villalpando, ZA-1633)

Otra pieça de lienço casero de diez uaras y media (Villalobos, ZA-1654)

Seis sáuanas de lienzo cassero (Villalpando, ZA-1696)

Es un término de uso general. Se localiza con tres acepciones diferentes: podemos encontrar esta palabra como un tipo de tejido con el que se confeccionaba el ajuar de la casa y también diferentes prendas de vestir, también como tejido en pieza y como soporte para pintar:

Una pintura en un lienço sin marco (Grajal de Campos, LE-1671)

Un lienço de Nuestra Señora de las Angustias pintado (Villalón, VA-1637)

Un lienço de Nuestra Señora del Rosario con marco dorado y negro (Medina de Rioseco, VA-1649)

LINO

Sust. m. 'Materia textil que se saca del tallo de la planta del lino', 'tela hecha de lino' (DLE, 2. a y 3. a ac.). Covarrubias indica que la planta 'dela qual después de seca la arrancan, y la echan a remojar, y cozer en pocas, y buelta a secar, se macea, y espadilla: y qedando en hebras se purifica del todo enel rastrillo, y lo que desecha de si se llama estopa. Hilase y texen de lino telas de lienço para camisas, sauanas, y ropa blanca, y es para otros muchos servicios'. Autoridades mantiene esa acepción (NTLLE, s. v. lienzo, Nebrija, 1495; Covarrubias, 1611; Autoridades, 1734). Voz procedente del lat. LĩNUM ( $D E C H$, s. v. lino).

Dos mantas de lino y lana nuebas (Joara, LE-1604)

Yten, tres cabeçales usados los dos de lino y lana y otro de lana (Valdavida, LE-1606)

Más se le entrego una manta de lino y lana tassada en ocho reales (Castroañe, LE-1622)

Item, un mandil de çeñir de lino y lana (San Nicolás del Real Camino, LE-1631)

Dos libras de lino en manadas (Valderas, LE-1682)

Una sabana casera de lino y estopa (Mazariegos de Campos, PA-1619)

Dos lençuelos de lana y lino de masar (Frechilla, PA-1640)

Una madexa de lino y otra de estopa (Boadilla de Rioseco, PA-1692)

Tres manadas de lino (Paredes de Nava, PA-1695)

Veinte madexas de lino y sedilla (Medina de Rioseco, VA-1644)

Una toca de lino delgada (Cuenca de Campos, VA-1660)

Item dos griñones de lino y una toca de seda (Villalpando, VA-1620)

Un cabezal de lino y lana abarillado (Villalpando, ZA-1661)

Dos libras y media de lino ylado (Villalpando, ZA-1688)

Al igual que otros términos textiles genéricos (estopa, lana, lienzo, seda), lino está presente en aquellos inventarios en los que se recogen diferentes telas, ropa de hogar y prendas de vestir. Se trata de una voz común documentada en todas las bases de datos consultadas ( $C D H, C O R D E$ y CorLexIn).

\section{MITÁN}

Sust. m. 'Holandilla', 'lienzo para forros de vestidos' (DLE, s. v. holandilla). Lo recoge Autoridades como término utilizado en La Rioja. En la edición académica de 1803 desaparece la marca 
diatópica y lo tilda de término anticuado (NTLLE, s. v. mitán, Autoridades, 1734, DRAE, 1803). Es probable que la palabra mitán sea lo mismo que el cat. mitant 'medio', por lo que el mitán riojano sería una 'media holanda', comp. holandilla. (DECH, s. v. mitán, holanda).

Un jubón de damasco de lana para hombre guarnecido con passamanos de santa Ysavel y mangas de estameña negro forradas en mitán morado (Frechilla, PA-1675)

En Tierra de Campos figura una sola ocurrencia de este término que mantiene el significado académico. Es una voz poco documentada en corpus académicos como el CORDE y el CDH, donde se registra en un documento literario de 1611 con el significado que aquí estudiamos:

"No eran más que unas muestras angostas de terciopelo o brocado en el cuello y bocamangas de un jubón, y lo demás era de lienzo o de mitán" (Enremés de los mirones, Anónimo, 1611-1617).

Lo mismo ocurre cuando consultamos el CorLexIn, pues los únicos ejemplos que nos encontramos de esta acepción se hallan en documentos de La Rioja, lo que corroboraría el carácter diatópico de esta voz. En la Tierra de Campos aparece en mayor medida el término holandilla.

\section{SOMONTE}

Adj. 'Basto, burdo, áspero, al natural y sin pulimento' (DLE). En Autoridades añade además para ejemplificar la definición 'como Paño de Somonte' (NTLLE, s. v. somonte, Autoridades, 1739). Término derivado de monte ( $D E C H$, s. v. monte).

Una capa de paño de somonte (Villalpando, ZA-1690)

Una capa de paño de somonte buena (Villalpando, ZA-1698)

Una ongarina de paño de somonte ya usada (Villalpando, ZA-1699)

Se trata de un tipo de tejido que era bastante basto. Esta palabra aparece documentada en tres inventarios en la zona terracampina zamorana. Este término siempre se presenta como "paño de somonte" en los documentos analizados.

Desde una perspectiva diacrónica, el $C D H$ documenta esta lexía en una obra poética fechada en 1551:

Salga con su gruesa lana / la de Somonte a la hora (Cristóbal de Castrillejo, Poesías, 1551)

En este ejemplo referencia la denominación de origen del tejido, esta vez de lana. Los siguientes ejemplos que aparecen con el significado de tipo de textil son bastante posteriores, en los siglos XVIII y XIX.

En el CorLexIn aparecen ejemplos con la variante sumonte mayoritariamente en la zona centro peninsular-Ciudad Real, Cuenca y Guadalajara-, aunque también hay un ejemplo de este tejido en Jaén, todos ellos haciendo referencia a un tipo de estameña. Egido encuentra documentación en la que aparece este término en inventarios leoneses del siglo XVII, donde parece utilizada en la confección de sayuelos, mantillas o capas de somonte (Egido, 2015: 80, $88,90)$. Igualmente, en Tierra de Campos se emplea para confeccionar ropa exterior (capas y ongarina). 


\subsubsection{Seda}

\section{ANAFAYA [anafaia]}

Sust. f. desus. 'Tela que se hacía de algodón o de seda' (DLE). Covarrubias define este término como 'vna cierta tela que texen de algodón', registrándola con la variante gráfica anafalla. Autoridades advierte de estar ante una palabra en desuso y la define como 'cierta espécie de tela, ó texido que antiguamente se hacía de algodón, y modernamente se hace de seda' (NTLLE s. v. anafalla, anafaya, Covarrubias, 1611; Autoridades, 1726). Es un término que aparentemente toma su nombre del árabe Alnafaya, 'despojo que queda después de escoger lo mejor' (DHTT, s. v. anafaya).

Diez y siete baras y media de anafaia plateada y negra de lana y seda (Medina de Rioseco, VA1645)

Un vestido de anafaya acabellado (Medina de Rioseco, VA-1645)

En los documentos analizados de la zona de estudio nos encontramos con escasos ejemplos de este término. Esta falta de testimonios se observa también en el CORDE y el CDH donde la nómina de casos recogidos pertenece exclusivamente al siglo XVII, repartidos entre obras literarias e inventarios de bienes. La falta de testimonios también se da en el CorLexIn donde se localiza una docena de ocurrencias repartidas sin un patrón claro -Córdoba, Jaén, Alicante, Ciudad Real, Madrid, Medina de Rioseco, Zaragoza, Navarra y Huesca-. Perdiguero señala que este textil se utilizó para la elaboración de manteos, lobas, mangas y ferreruelos (Perdiguero, 2014: 148). Pérez Toral amplía la nómina de prendas confeccionadas con este tipo de tejido: jubones, polleras, vestidos, basquiñas, calzones o mucetas (Pérez Toral, 2017b: 93).

A pesar de la falta de testimonios, en Tierra de Campos encontramos la variante anafaia. Esta forma es mucho menos frecuente en la documentación, tanto en las bases textuales como en el CorLexIn. Esta dicotomía entre las grafías /i/ y la /y/ para representar la palatal central suele ser habitual en esta época (Pérez Toral, 2017b: 94).

\section{BROCADO [brocato]}

Sust. m. 'Tela de seda entretejida con oro o plata, de modo que el metal forme en la cara superior flores o dibujos briscados' o 'Tejido fuerte, todo de seda, con dibujos de distinto color que el fondo' (DLE, 3. y 4.a ac.). Brocado aparece en los diccionarios desde Nebrija. Autoridades lo define como 'tela texida con seda, oro, ò plata, ò con uno y otro [...]. Llámase tambien Brocato [...]' (NTLLE, s. v. brocado, Autoridades, 1726). Corominas y Pascual advierten que se trata de un término que entra por el cat. brocat, que parece provenir del it. broccato íd., derivado de broca, probablemente de origen céltico ( $D E C H$, s. v. brocado).

Una basquiña de brocato (Paredes de Nava, PA-1695) 
El término brocado se encuentra ampliamente documentado en los corpus académicos -el CORDE y el $C D H$-, donde esta palabra aparece en textos fechados desde mediados del siglo XIII, y con especial presencia en los siglos XV, XVI y XVII. Algo que contrasta llamativamente con la falta de testimonios en documentos notariales del siglo XVII, por ejemplo, en el CorLexIn se localiza un único ejemplo:

Un jubón de muger, de brocado ya traído (San Cristóbal, Táchira. Venezuela, 1609)

De forma espóradica suele aparecer algún otro ejemplo en documentos de esta naturaleza como es el caso de un inventario fechado en 1590 localizado en la documentación de Mascaraque (Toledo), donde figura "una bolsa de brocado amarillo y plateado con sus cerraderas de seda morada» (Vázquez Balonga 2015: 166 en Juquera y Morala, 2019: 211, nota 21).

En Tierra de Campos no figura ningún ejemplo de brocado, la única ocurrencia localizada corresponde a la variante brocato, y perteneciente a la documentación de Paredes de Nava. Esta variante presenta un uso más restrictivo en el CORDE y el $C D H$, documentado a partir del siglo $\mathrm{XV}$, tan solo presenta cuatro de casos en el siglo XVII. El CorlexIn, por su parte, ofrece un par de ejemplos en toda la Península: en Toledo, en un inventario de 1679 (" vna hongarina de vrocato de oro") y en Guipúzcoa ("una ara, dos frontales, el uno de damasco blanco, con su çenefa de brocato encarnado, de oro y plata, y el otro de tafetán bordado").

\section{BROCALETE}

Este término no aparece recogido en ninguno de los diccionarios académicos.

Un frontal de brocalete amarillo, morado y blanco con sus frontanelas de lo mesmo (Villalpando, ZA-1633)

No encontramos información del término brocalete en ninguna de las obras lexicográficas del NTLLE. Tampoco existen testimonios de esta voz en bases académicas como el CORDE o el $C D H$. Los únicos rastros de este término nos vienen dados por la documentación notarial, entre aquellos que configuran el CorLexIn aparece una única ocurrencia localizada en el Burgo de Osma (Soria), en un inventario efectuado a la muerte del bachiller Juan de Peñaranda: en él se halla "vna bolsa de corporales de brocalete [...]" (1612). Anteriormente, en el inventario que se hace de la Catedral de Mondoñedo, encargado por el obispo de Ferrol en 1579, figura el siguiente ejemplo: "otro terno de Damasco negro de defuntos con los faldones verdes y la çanefa de la casulla de brocalete [...]" (Villaamil y Castro, 1907: 8). Por otro lado, en el año 1721 se hace un estudio para saber en qué estado se encontraba la industria de la seda en Valencia, y entre los tejidos que se producían se encontraban los brocaletes (Liarte, 2010: 14).

El término brocalete hacía referenciaba un tipo de tela de seda utilizada sobre todo en el ámbito litúrgico y que nunca llegó a ser registrada en diccionarios. 


\section{ESPARRAGÓN [hesparragón]}

Sust. m. 'Tejido de seda que forma un cordoncillo más doble y fuerte que el de la tercianela' $(D L E)$. Se registra por primera vez en la edición del DRAE de 1791. Anteriormente había sido registrado por el diccionario de Terreros y Pando como 'especie de tela de lana' (NTLLE, s. v. esparragón, Terreros y Pando, 1787; DRAE, 1791). Palabra derivada de espárrago (DECH, s. v. espárrago).

Una vasquiña y ropa de chamelote de agua picado bueno guarnezida la ropa con guarniçión de hesparragón (Grajal de Campos, LE-1658)

Un bestido de esparragón de seda noguerado (Medina de Rioseco, VA-1642)

Un jubón de esparragón de lana berde (Medina de Rioseco, VA-1643)

Seis varas y media de esparragón liso en quatro pedaços, pardo y negro (Medina de Rioseco, VA1645)

Tres varas y media de esparragón negro y pardo en dos pedaços (Medina de Rioseco, VA-1645)

Este término, además del significado recogido por el $D L E$, también hace referencia a un tipo de tejido antiguo que podía ser de lana, barragán ordinario o paño de baja calidad que se fabricaba en Inglaterra (DHTT, s. v. esparragón). Esparragón es uno de esos términos que los diccionarios académicos recogen desde antiguo y, sin embargo, bases de datos acádemicas como el CORDE o el CDH no presentan ninguna ocurrencia de dicha voz (Morala, 2010a: 442).

Por su parte el CorLexIn presenta más de una docena de ocurrencias, y a pesar de que no es muy frecuente, su uso se extiende por un ámbito geográfico muy amplio (de Norte a Sur de la Península -desde Bilbao a Granada-, en Canarias -Gran Canaria- y América -Bolivia-). En el corpus terracampino se localizan cinco ocurrencias de este término, la gran mayoría localizadas en Medina de Rioseco. Los datos ofrecidos por el corpus analizado adelantan un año la fecha que da el CorLexIn (el ejemplo de Medina de Rioseco de 1642, frente al de Bolivia de 1643).

Cabe destacar que el CorLexIn documenta la variante con aféresis parragón localizada en documentos andaluces (Pérez Toral, 2017c: 168).

Hay constancia de esta voz en el Fichero General donde aparece un ejemplo fechado en 1782 perteneciente a un Arancel de Aduanas editado en 1782:

[...] esparragones de lana hasta dos tercias de ancho, cada vara, treinta y cuatro mrvs

\section{ESPOLÍN}

Sust. m. 'Tela de seda con flores esparcidas, como las del brocado de oro o de seda' (DLE, s. v. espolín $n^{2}$, 2. a ac.), significado que se mantiene desde la edición de Autoridades de 1732. Se trata de una palabra tomada del fr. e(s)poulin u occitano espoulin 'canilla de tejedor', diminutivo del occitano antiguo espol íd. y este del gótico *spôla (DECH, s. v. espolín).

Una gavardina de grana aforrada en espolín de seda blanco y encarnado guarnezido de medio galon (Medina de Rioseco, VA-1642)

Çiento y çinquenta y dos varas de espolines de todas colores (Medina deRioseco, VA-1644)

Diez y ocho baras y media de gorguerán de Toledo y espolín de lauores grandes en dos pedaços (Medina de Rioseco, VA-1645) 
Las ocurrencias localizadas en el corpus terracampino advierten un uso escaso del término, todos ellos extraídos de la documentación perteneciente a Medina de Rioseco, localidad donde existía una industria textil y era un importante centro comercial de la época. Se trata de un tipo de tela de seda que tomó su nombre de la lanzadera llamada espolín (DHTT, s. v. espolín), esta pequeña lanzadera permitía confeccionar dibujos en el tejido de seda sin necesidad de pasarlo por toda la trama lo que aportaba mayor ligereza a la tela.

El CORDE y el CDH documentan esta voz desde el año 1615, aunque el ejemplo aparece en sentido figurado, en una poesía de Antonio Hurtado de Mendoza. Es entre los años 1625 y 1627 en la obra Noticias de Madrid cuando aparece este término con la acepción de tejido. Aún así, los ejemplos aportados por estas bases textuales son más bien escasos y, en su mayoría, concetrados en el siglo XVII. Esta falta de testimonios se puede extrapolar al CorLexIn, donde figuran una docena de asientos que en palabras de Pérez Toral "ofrecen un eje vertical peninsular de Norte a Sur: desde Cantabria a Cádiz; lo que quizá permita considerar un uso difundido y extendido en el espacio, aunque esté poco documentado" (Pérez Toral, 2017b: 99). A pesar de ser un término poco frecuente en los textos, se utiliza en un ámbito geográfico amplio, incluido en América -México:

Yten, vn bestido d[e] espolín de oro fino con susbordaduras (Ciudad de México, México, 1623)

\section{ESPUMILLA}

Sust. f. 'Tejido muy ligero y delicado, semejante al crespón' (DLE). Autoridades lo recoge como 'cierto género de lienzo delgado, no mui tupido, llamado assi por lodelicado y ralo' (NTLLE, s. v. espumilla, Autoridades, 1732). Se trata de una voz derivada de espuma, del lat. SPŪMA (DECH, s. v. espuma).

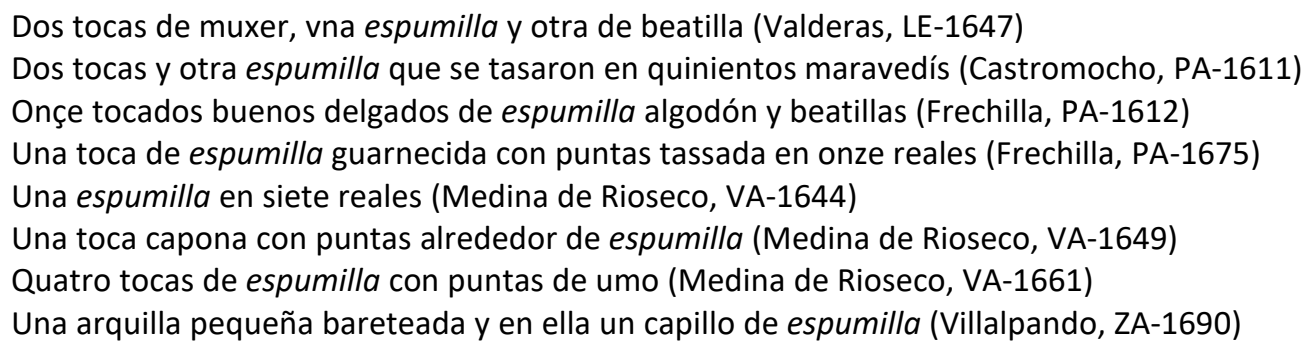

Este término aparece con dos acepciones en el corpus estudiado: por un lado, como un tipo de tejido de seda o de lienzo para confeccionar distintas ropas, y por otro aparece con el significado de 'toca'. Figuera en el CORDE y en CDH con la acepción de 'toca' en un inventario de 1580: "una toca de lino delgada, otra espumilla y otro parís"; como 'tejido' se encuentra en 1585 en una obra de Fray Juan González de Mendoza, donde aparece "tocas de seda, buratos, espumilla". Tanto en la zona de estudio como en el CorLexIn, este tipo de tejido se utilizaba en la confección de prendas para cubrir la cabeza, algo que también ocurre en la zona de la Bañeza en León (Gómez Ferrero, 2015: 358). 


\section{GORGORÁN [gorguerán, gorgerán]}

Sust. m. 'Tela de seda con cordoncillo, sin otra labor por lo común, aunque también lo había listado y realzado' (DLE). Esta es la definición que se mantiene desde Autoridades (NTLLE, s. v. gorgorán, Autoridades, 1734). Se trata de un término compuesto tomado del ing. grogoram, y éste del fr. ant. grosgrain íd. 'grano grueso' ( $D E C H$, s. v. gorgorán).

Un rebozino de gorgerán y faldellín azul gaurnezido (Guaza de Campos, PA-1637)

Un reboçiño de gorguerán negro aforrado en baye(ta) (Guaza de Campos, PA-1640)

Un jubón de gorguerán negro gaurneçido con molinillos negros (Guaza de Campos, PA-1640)

Unos querpos de gorguerán azulado mediados guarnecidos con passamanos de oro falsso (Autillo de Campos, PA-1648)

Unos querpos de gorguerán con pasamanos de santa Ysauel (Autillo de Campos, PA-1653)

Unos cuerpos de gorguerán de color (Villalón, VA-1637)

Un calzón de gorguerán (Medina de Rioseco, VA-1642)

Un jubón de gorgerán berde y pajizo (Medina de Rioseco, VA-1643)

Un jubón de gorguerán usado (Cuenca de Campos, VA-1668)

Un juvón de gorguerán con sus pasamanos (Villalpando, ZA-1632)

Un jubón de gorguerán traydo (Villalpando, ZA-1633)

Una bara de gorguerán en diez y seis reales (Villalpando, ZA-1635)

Un jubón de filipechín con mangas de gorgerán negro (Carrizo, ZA-1646)

Bara y media de gorguerán y passamanos y seda (Villalpando, ZA-1647)

En Tierra de Campos aparecen dos variantes del término académico gorgorán: por un lado, la forma más abundante en los textos del corpus estudiado es gorguerán; por otro y en menor medida, se documenta gorgerán. Esta diversidad gráfica y fonética es más acentuada en el resto de los inventarios hispanos de esta época; además de las localizadas en Tierra de Campos, aparecen la forma académica gorgorán y otras como gorgarán, gorbalán o gorbarán -esta última localizada en inventarios de México (CorLexIn)- y un ejemplo en Cádiz (Bastardín, 2012: 48). Es un término documentado desde finales del siglo XVI, aunque el grueso de ocurrencias data del siglo XVII. "Debido al origen extranjero era fácil que proliferasen variantes fonéticas y ortográficas como las documentadas" (Pérez Toral, 2017c: 175).

\section{GURBIÓN}

Sust. m 'Tela de seda de torcido o cordoncillo' o 'especie de torzal grueso usado por los bordadores en las guarniciones y bordados' (DLE). Recoge este término Autoridades con las mismas acepciones que conservamos hoy en día e indica que 'trahe esta voz Covarr. en su Thesoro, y dice se llamó Gurbión quasi Curbión, porque se va torciendo y encorvando' (NTLLE, s. v. gurbión, Autoridades, 1734). Término derivado de gubia, del lat. tardío GǓLBIA, de origen céltico (DECH, s. v. gubia).

Un bestido de gurbión de seda guarnecido de canutillo que es basquiña, jubón y ropa (Medina de Rioseco, VA-1646)

Una ropa gurbión de Italia acauellado con dos pasamanos de Calabria aforrada en tafetán berde (Villalpando, ZA-1631)

Otra basquiña de gurbión pardo y negro con diez y seis pasamanos pajiço (Villalpando, ZA-1631)

Casi todas las ocurrencias recogidas en el $C D H$ y el CORDE pertenecen casi exclusivamente a la primera mitad siglo XVII. Los testimonios que nos aporta del CORDE corresponden todos ellos 
documentos notariales (cartas de dote, cartas de pago e inventarios de bienes). Por su parte, el CDH documenta esta voz como tejido a partir de 1600 en las Pragmáticas relativas a indumentaria española del siglo XVII donde figura como 'cierta especie de torzal grueso, de seda, usado por los bordadores en las guarniciones y bordados'.

En el CorLexin se recogen algunos ejemplos dispersos por la Península -en localidades de Burgos, Toledo, Sevilla, Valladolid y Zamora-, y también en México y Colombia. Egido localiza este término en un inventario de bienes fechado en 1704 en Bolivia: "otra pollera de gurbión nueba con encaje de Cusco" (Egido, 2018: 1937). De ese mismo año es el inventario de Catalina de Cabrera -viuda del capitán de la ciudad de Córdoba Francisco Suárez de Cabrera (Argentina, 1704)-, donde figura "una pollera de gurbión de la China con tres vueltas de bandas de oro y plata" (Bonialian, 2014: 655), puede que la locución "de la China" haga referencia a su procedencia.

\section{HUMO [umo, vmo]}

Sust. $\mathrm{m}$. 'Cierta tela de seda negra mui delgada y rala de que se hacían mantos y toquillas para el sombrero en señal de luto' (Autoridades, s. v. humo 3.a ac.). Esta acepción se mantiene hasta el diccionario académico de 1791, a partir de la edición de 1803 desaparece humo con el significado de 'tejido'. Palabra derivada del lat. Fūmus íd. (DECH, s. v. humo).

Un manto de Sevilla bueno, de los que llaman de humo (Valderas, LE-1647)

Siete varas y media de manto de vmo (Medina de Rioseco, VA-1645)

Una bara y tres quartas de puntas de umo (Medina de Rioseco, VA-1660)

Otro manto de umo con encaje de umo nuevo (Medina de Rioseco, VA-1660)

Dos balonas con puntas blancas de umo y puntas negras a la parte de arriba (Medina de Rioseco, VA-1661)

Quatro tocas de espumilla con puntas de umo (Medina de Rioseco, VA-1661)

Un tafetán encarnado con puntas de umo negras (Medina de Rioseco, VA-1661)

El término humo referencia una 'tela de seda negra muy delgada, rala y transparente, con la que se hacían mantos y toquillas para el sombrero en señal de luto' (DHTT, s. v. humo). El término humo con la acepción de 'tejido' aparece documentado en el $C D H$ en textos del siglo $X V I I$, en un primer momento utilizado de forma figurativa en obras de diferentes autores como Tirso de Molina, Luis Quiñones de Benavente, Lope de Vega, Baltasar Gracián o Calderón de la Barca. El primer documento en que aparece en esta base de datos de forma referencial es en el Inventario de bienes del doctor Martín Martínez, fechado en 1655, donde aparecen "beinte y nueve puntas grandes de umo negras"; el siguiente inventario, de 1663, es más fructífero y aparece "una rropa de rraso con puntas de umo / un manto de umo / una toquilla de manto de umo para sombrero / dos balonas de muger, una de puntas de umo".

El CorLexIn documenta esta voz en la Península y hay una marcada preferencia por la zona meridional; así nos encontramos con ejemplos en Jaén, Córdoba, Sevilla, Huelva o Almería, aunque también se documenta en Madrid, Palencia y Cantabria. En Tierra de Campos aparece sobre todo en la zona de Medina de Rioseco, algo que no es de extrañar, ya que era uno de los centros textiles de la época. 
Este tejido no se ha localizado en textos de América, salvo en una referencia que hace al mismo Sor Juana Inés de la Cruz en una de sus obras fechada en 1676: "¿quién usará de humo manto?".

\section{PICOTE}

Sust. m. 'Tela áspera y basta de pelo de cabra', 'Cierta tela de seda muy lustrosa con la que se hacían vestidos' (DLE, 1. a y 2. a ac.). Lo recoge Nebrija como 'sayal' y Covarrubias lo recoge como 'una tela basta de pelos de cabra'. Autoridades añade que también se llama picote a 'cierta tela de seda muy lustrosa' (NTLLE, s. v. picote, Nebrija, 1495, Covarrubias, 1611, Autoridades, 1737). Probablemente derivado de picar porque es tan áspera que pica al tocarla (DECH, s. v. picote).

Una capa de picote husada (Santa María del Río, LE-1617)

Una capa de picote viexa en siete reales (San Pedro de Valderaduey, LE-1626)

Una capa de picote buena (Villadiego, LE-1627)

Vnas enaguas de picote vsadas (Valderas, LE-1647)

Una uasquiña de picote de seda con una guarda de raso forrada en olandilla (Grajal de Campos, LE-1658)

Unos querpos de picote de seda (Castromocho, PA-1611)

Una sayuela de picote de niño (Castromocho, PA-1611)

Un calçon y rropilla de picote (Paredes de Nava, PA-1695)

Un bestido de picote, jubón, basquiña aforradas en olandilla (Medina de Rioseco, VA-1640)

Doçe varas de picote de lana y seda (Medina de Rioseco, VA-1644)

Otro bestido de picote de seda que es juvón (Medina de Rioseco, VA-1648)

Una capa de picote viexa (Tamariz de Campos, VA-1651)

Un corte de picote de seda para haçer unos corpiños (Medina de Rioseco, VA-1651)

Una saya de picote vieja fraylenga (Villalpando, ZA-1620)

Una sayica bieja de picote y un mandil de estameña fraylengo biejo (Villalpando, ZA-1620)

Vn juvón de picote (Villalobos, ZA-1654)

Dos baras de picote para un jubón (Villalpando, ZA-1656)

Se llamaba picote a la 'tela áspera, basta y ordinaria fabricada con pelo de cabra o paño de lana grosero, que ya se fabricaba en los siglos XIII y XIV, pero en el siglo XVII comenzó a fabricarse una tela de seda utilizada para confeccionar vestidos. En este mismo siglo también existía una mezcla de lana y seda, fabricada en Lille y en Flandes para exportación a España con este mismo nombre' (DHTT, s. v. picote).

La primera documentación que propone el DECH se localiza en el Glosario y diccionario geográfico de voces sacadas de los documentos del Monasterio de Sahagún, obra publicada por Vignau en 1214. Esta voz figura en documentos desde el siglo XIII también en el CORDE y en el $\mathrm{CDH}$ con un amplio abanico de testimonios hasta el siglo XVIII, a partir de este momento parece que el término entra en retroceso (Perdiguero, 2014: 151).

El término picote resulta abundante en los documentos notariales del siglo XVII como bien refleja el CorLexIn que cuenta con una amplia nómina de casos a lo largo de la Península y América. A partir del análisis de este corpus se puede establecer que estamos ante un tejido elaborado con diferentes materias primas (lana, lana y lino, lana y lienzo, de seda, de mediad seda), se utilizada para confeccionar vestidos y, en menor medida, ropa de la casa como cortinas 
y colgaduras; y eran famosos los picotes de Valladolid, Mallorca, Córdoba, Francia o Flandes (Pérez Toral, 2017b: 102).

En Tierra de Campos era un término habitual en los inventarios de bienes. Aparece como tejido para confeccionar capas, jubones, sayas, enaguas, calzones y cuerpos, que -en el caso de esta zona- podían ser picotes de seda o de seda y lana.

\section{PIÑUELA}

Sust. f. 'Tela o estofa de seda' (DLE). Esta definición se mantiene desde la edición de 1737 de Autoridades, donde se añade que el término piñuela le venía dado 'porque tiene unas como piñas pequeñas labradas en ella' (NTLLE, s. v. piñuela, Autoridades, 1737). Se trata de un término derivado de piña, del lat. PĪNĔA (DECH, s. v. pino).

\footnotetext{
Un ferreruelo negro de beinteydoseno con riço de piñuela (Grajal de Campos, LE-1655)

Dos jubones de una misma tela de piñuela, el uno antiguo y el otro de uso nuevo, viejos (Grajal de Campos, LE-1658)

Una ropa de piñuela (Paredes de Nava, PA-1695)

Un xubón de piñuela de seda de muger en quarenta y dos reales (Medina de Rioseco, VA-1640)

Treçe varas y tres quartas de piñuela plateada y negra, a beinte y quatro reales bara (Medina de Rioseco, VA-1645)

Un jubón de piñuela negro guarnecido con guarnicion de oro con dos guarniciones (Tamariz de Campos, VA-1652)

Un vestido de piñuela negro jubón vasquiña y ropa aforrado en tafetán negro (Medina de Rioseco, VA-1660)

Quatro ropas, la una de piñuela, la otra de rizo y la otra de chamelote (Medina de Rioseco, VA1661)

Una petrinilla de piñuela negra y açul celeste guarnecida con tres guarniciones de oro fino (Villalpando, ZA-1652)

Unos cuerpos de piñuelas negros (Villalpando, ZA-1697)
}

Según el DHTT era un 'tipo de seda que tejían los indígenas de Filipinas con la fibra de la hoja de la piña americana. Se le dio este nombre porque tenía una especie de pequeñas piñas labradas en ella'. (DHTT, s. v. piñuela). Con la acepción de 'tejido' solo se documenta en el siglo XVII en una carta de dote fechada en 1613 en el $C D H$ y siempre en documentos notariales como inventarios o cartas de dote. Lo mismo ocurre con el CORDE, lo que indica que es un término que se utiliza en esta época y que poco a poco entraría en desuso. En el CorLexIn se localiza en diferentes puntos de la Península y Canarias, y se observa que este tipo de tejido se empleaba para confeccionar basquiñas, cuerpos, rebozos, calzones, xubones, taalíes o hábitos, además de complementos como pretinas, todos ellos en diferentes colores (Pérez Toral, 2017b: 103). En la Tierra de Campos es un término habitual en los inventarios estudiados.

\section{SOPLILLO}

Sust. $\mathrm{m}$. 'Especie de tela de seda muy ligera' (DLE, 3.a ac.). Autoridades recoge manto de soplillo como 'un género de manto, que hacían antiguamente de tafetan mui feble, que se clareaba mucho, y trahian las mugeres por gala'. La acepción que hacer referencia a una tela de seda ligera se recoge a partir del DRAE de 1884 (NTLLE, s. v. soplillo, Autoridades, 1739; DRAE, 1884). Término derivado de soplar y este del lat. SŬFFLARE (DECH, s. v. soplar). 
Dos mantos de soplillo tasados ambos en quinçe ducados (Villalpando, ZA-1620)

EI DLE registra la locución "manto de soplillo" en referencia al 'manto de tafetán muy fino y transparente que llevaban las mujeres'. Con esta acepción lo encontramos en el único ejemplo que se localiza en el corpus de la Tierra de Campos. De la decena de ocurrencias localizadas en el CorLexIn, tan solo una hace referencia a la confección de otra prenda: "unas ligas negras de tafetán de suplillo" (Plasencia, Cáceres, 1629). En los corpus académicos como el CDH y el CORDE aparecen ejemplos de 'manto de soplillo' hasta mediados del siglo XVII, lo que hace sospechar que este tipo de prenda entró en desuso en épocas posteriores.

\section{TABÍ}

Sust. m. 'Tela antigua de seda, con labores ondeadas y que forman aguas' (DLE). Autoridades ya señala este término como anticuado, haciendo referencia a 'cierto género de tela, como el tafetán gruesso prensado, cuyas labores sobresalían, haciendo aguas y ondas' (NTLLE, s. v. tabí, Autoridades, 1739). Término derivado del del it. tabì y éste del ár. 'attābî íd., así llamado por fabricarse en Al-`Attābîya, suburbio de Bagdad (DECH s. v. tabí).

Unos cuerpos de tabí con quatro molinillos de oro (Frechilla, PA-1640)

Esta tela referencia 'tafetán de seda, prensado, que se usaba antiguamente, cuyas labores sobresalían formando aguas y ondas como el moaré y que se fabricaba en las ciudades italianas de Florencia, Venecia, Nápoles, Luca y Verona' o 'géneros ligeros de seda o de seda y algodón elaborados según una técnica originaria de Bagdá' (DHTT, s. v. tabí).

El término casi no tiene presencia en los documentos de Tierra de Campos: se ha localizado un único ejemplo en Frechilla. Esta escasez de ocurrencias también se da a otras bases de datos, donde no parece una voz muy frecuente. En el CorLexIn, los ejemplos van del norte -Huesca y Guipúzcoa- al sur -Cádiz y Sevilla-, pasando por Teruel, en la Península. En América se localizan otros tantos ejemplos de este tejido -Ciudad de México, Potosí y La Plata (Bolivia), Guatemala y Choconta (Colombia) -.

Pérez Toral también indica que se trata de una voz poco usual en los inventarios notariales del siglo XVII (Pérez Toral, 2017c: 179).

Desde un punto de vista diacrónico, este término se documenta a partir del siglo XVII en el $C D H$ y el CORDE, más concretamente desde 1600 en Inventarios Reales: Bienes muebles que pertenecieron a Felipe II ("capa con sus capilla y pectoral, cuerpos y cenefas de tabí blanco de oro"). Sin embargo, a mediados de este mismo siglo, este término parece caer en desuso.

Por todos los datos analizados, esta voz parece presentar una restricción diacrónica al siglo XVII. La procedencia italiana del término, además de por el $D E C H$ y autores como Terlingen, viene refrendado por la propia documentación, en concreto hay un ejemplo localizado por Juquera y Morala en el CDH que pone de manifiesto dicho origen (Junquera-Morala, 2019: 210):

Una seda, que los italianos llaman tabi, que casi imita nuestro gorgoran (Pablo de Céspedes Discurso de la comparación de la antigua y moderna pintura y escultura (otros fragmentos), 1604) 


\section{TAFETÁN}

Sust. m. 'Tela delgada de seda, muy tupida' (DLE). Covarrubias recoge esta palabra con el mismo significado que le da hoy la Academia (NTLLE, s. v. tafetán, Covarrubias, 1611). Del persa tāftah 'paño de seda', 'vestido de hilo' (DECH, s. v. tafetán).

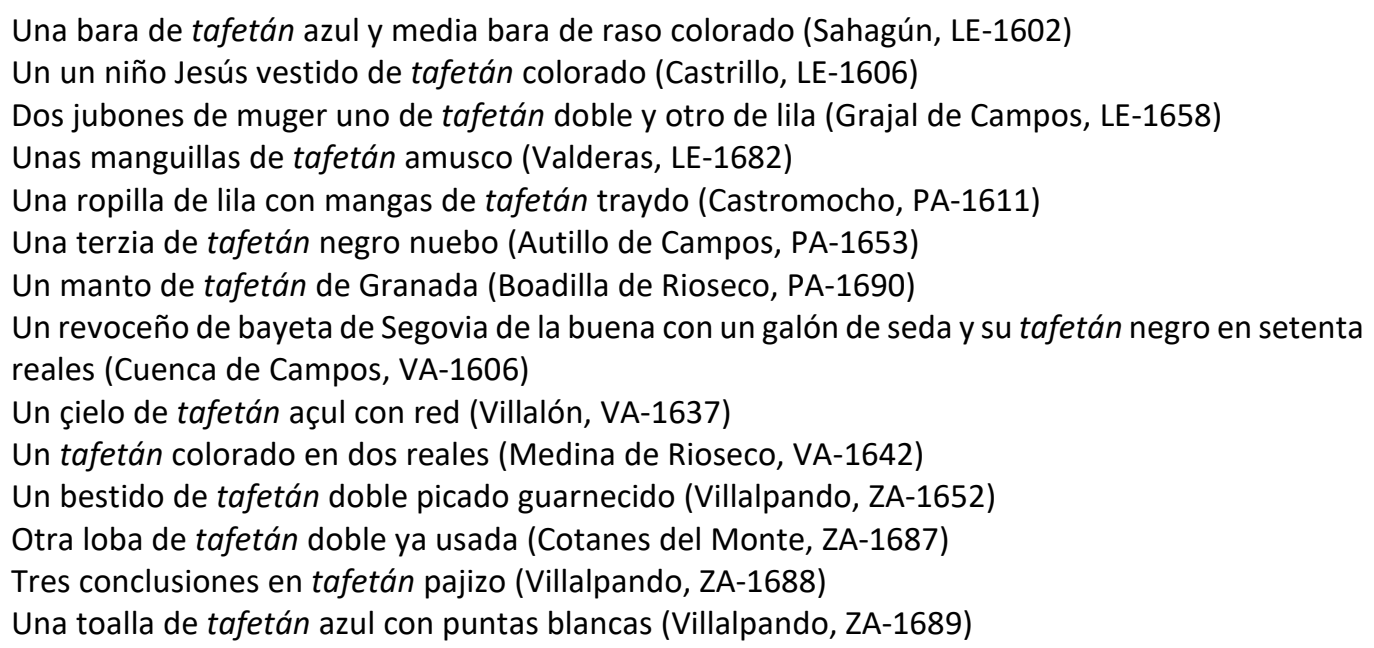

Aunque el $D E C H$ propone su origen persa, también afirma que al castellano debió de llegar por vía del comercio mediterráneo, a través del italiano o el catalán (Junquera y Morala, 2019: 213).

Es un término muy extendido en los documentos analizados. Es un tipo de tejido de colores que se utiliza para la confección del ajuar de la casa (cortinas, colchas, toallas...), de ropajes (mantos, lobas, mangas, jubones, medias...) y forros. En los inventarios también lo encontramos en pieza. Además, tafetán aparece con otra acepción, como paño que servía para cubrir o tapar:

Una cruz de desilado y un tafetán amarillo (Frechilla, PA-1639)

Un atril para él [misal] y un tafetán carmessí para cubrirle tasada en seis reales (Medina de Rioseco, VA-1644)

Cinco cáliçes con sus patenas amitos y tafetanes de color (Medina de Rioseco, VA-1651)

Desde un punto de vista diacrónico, este término se documenta en el $C D H$ desde finales del siglo XV, en las Cuentas de Gonzalo de Baeza fechado en 1477, aunque el DECH adelanta su documentación a 1348, en los Fueros aragoneses.

Esta voz se localiza a lo largo y ancho de la Península y también en Canarias y América, tal y como se puede observar consultando el CorLexIn. Lo mismo ocurre en la Tierra de Campos, donde se localiza un número importante de ocurrencias de este término con las acepciones que se han indicado anteriormente.

\section{TERCIANELA}

Sust. f. 'Gro de cordoncillo muy grueso' (DLE). La primera definición lexicográfica se encuentra en la edición de 1739 de Autoridades como 'tela de seda semejante al tafetan; pero mas doble, y lustrosa' (NTLLE, s. v. tercianela, Autoridades, 1739). Es una voz derivada procedente del it. terzanella id. (DECH, s. v. tres). 
Un bestido de terzianela de seda, calzón y ropilla y mangas xustas (Medina de Rioseco, VA-1640)

Este término se halla poco documentado en la Tierra de Campos, pues se localiza un único ejemplo. Esta escasez de ocurrencias también se observa en los textos que conforman el CorLexIn, donde los casos no llegan a media docena en documentos de Ávila (1650) y Zaragoza (1647).

Diacrónicamente, aparece la forma tercenel en el $C D H$ a finales del siglo $\mathrm{xV}$, aunque no la encontramos con la variante académica tercianela hasta 1655 en el Inventario de bienes del doctor don Martín Martínez: "un bestido, calçón y jubón de tercianela [...]". Los ejemplos del CorLexIn adelantan la fecha unos años y el encontrado en Medina de Rioseco la adelanta hasta 1640.

Dado el carácter restrictivo de esta lexía al siglo XVII y la falta de ocurrencias fuera de la documentación notarial, Junquera y Morala sugieren que "son préstamos que no sobrepasaron el ámbito técnico de los comerciantes de telas" (Junquera y Morala, 2019: 214).

\section{TERCIOPELO [terçiopelo, terziopelo]}

Sust. m. 'Tela de seda velluda y tupida, formada por dos urdimbres y una trama, o la de aspecto muy semejante' (DLE). Lo recoge Nebrija y Covarrubias define este término como 'tela de seda muy vsada, y según el nombre ha de ser de tres pelos, pero ay lo de dos, y de pelo y medio'. Autoridades indica que 'Tela de seda velluda, que, porque regularmente se hace de tres pelos, se llamó assi' (NTLLE, s. v. terciopelo, Nebrija, 1495; Covarrubias, 1611; Autoridades, 1739). Es un término compuesto, según Nebrija de SERICUM GAUSAPICUM (DECH, s. v. tres).

\footnotetext{
Un sayuelo y cuerpos de contray guarnescido de terziopelo buenos (Sahagún, LE-1601) Un manto negro biexo con un ribete de terciopelo (Valdavida, LE-1606) Unos corpiños guarnecidos de terçiopelo (Cea, LE-1626) Unos cuerpos de damasco berde con flanxas de terziopelo (Grajal de Campos, LE-1668) Un manto de contrai con su rebete de terciopelo (Castromocho, PA-1602) Una capa de paño pardo casero con buelta de terçiopelo (Guaza de Campos, PA-1640) Unos querpos de grana guarnezidos con terziopelo labrado (Autillo de Campos, PA-1642) Unos cuerpos de damasco azul con riuete de terziopelo berde y galón de oro (Villada, PA-1669) Un bestido de terziopelo balon y ropilla y mangas (Medina de Rioseco, VA-1640) Dos almoadas de terciopelo carmesí traydas con los ondones de damasco (Medina de Rioseco, VA-1640)

Una maleta y cojín de terçiopelo berde biejos (Medina de Rioseco, VA-1642)

Una saya berde, con sus ribetes de terciopelo berde (Tamariz de Campos, VA-1652) Una ropa y basquiña de tafetan pisado con su guarnición de terciopelo (Villapando, ZA-1601) Un ferreruelo de paño pardo bueno con su cuello de terziopelo rojo (Villalpando, ZA-1620) Un sayo de veinteydoseno negro guarneçido con terçiopelo Liso de dos pelos tasado en cinquenta reales (Carrizo, ZA-1646)
}

Este tipo de tejido es muy habitual en los textos. El término se recoge en el CORDE y en el $C D H$ desde mediados del siglo xv en obras literarias y en las Cuentas de Gonzalo de Baeza (1477). Es un textil común en los inventarios de bienes del siglo estudiado y su uso se extiende hasta hoy. Al tratarse de una palabra compuesta, en ocasiones encontramos los dos lexemas separados: 
Otro ferreruelo de baeta bueno con vuelta de tercio pelo usado (Autillo se Campos, PA-1647) Un manto de paño negro fino con rribete de tercio pelo negro (Frechilla, PA-1675)

Una basquiña de estameña acul prensada aforrada en olandilla del mismo color y con su ribete de terzio pelo verde (Villalpando, ZA-1661)

\section{TIRELA [tirrela]}

Sust. f. 'Tela listada' (DLE). Término recogido en la edición de Autoridades de 1739 con la misma acepción que conservamos en la actualidad (NTLLE, s. v. tirela, Autoridades, 1739). Se trata de una palabra derivada del verbo tirar, de origen incierto (DECH, s. v. tirar).

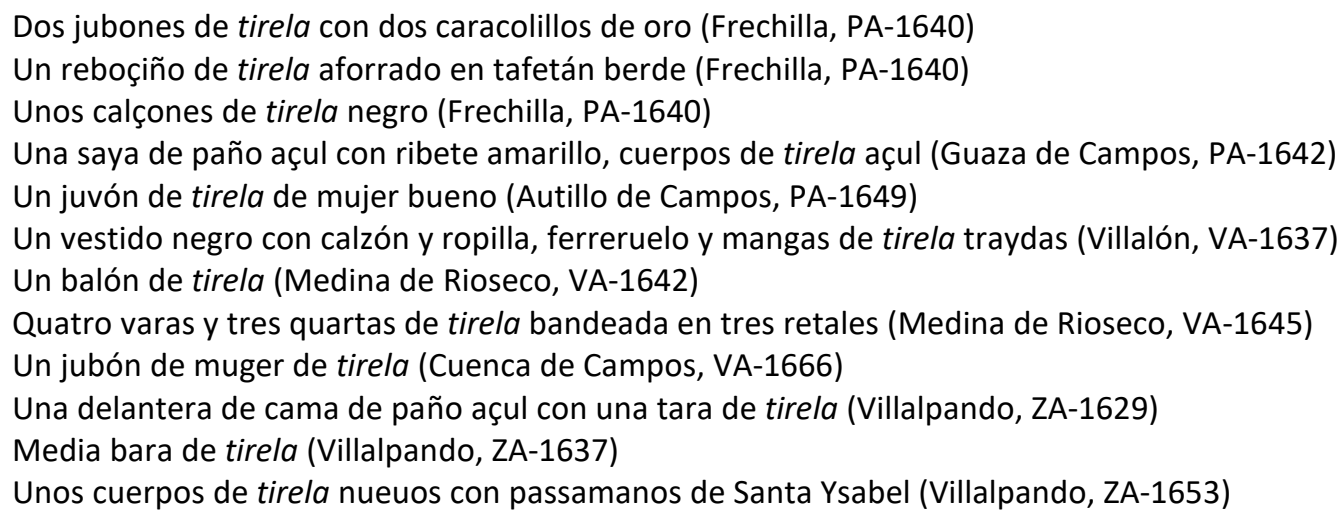

Pérez Toral afirma que este término deriva del término tira, por simular listas o tiras (Pérez Toral, 2017c: 181). El DHTT define esta tela como 'tejido mencionado en la documentación de Tarifas de la Bolla catalana en la segunda mitad del siglo XVII entre los de seda como tirela de terciopelo o tirela de vellut. Tela listada' ( $D H T T$, s. v. tirela). El término se documenta exclusivamente en el siglo XVII en bases léxicas como el $C D H$.

En el CorLexIn se localizan ejemplos de esta voz por diferentes puntos de la Península, aunque, como ocurre con los casos del $C D H$, pocos se fechan después de la primera mitad de siglo. A pesar de que este término parece entrar en desuso muy pronto, también se localizan ejemplos en América "vn jubón de tirela negra ya traydo" (Neiva, Huila, Colombia, 1638).

En Tierra de Campos la forma que encontramos principalmente es tirela, aunque en un inventario de telas, procedente de Medina de Rioseco, encontramos tirrela:

Veinte baras de tirrela negra vandeada, thasada a treinta reales vara (Medina de Rioseco, VA1645)

Morala (2015d: 167) y Bastardín (2012: 51) localizan en inventarios gaditanos la forma tirelón, variante que no se localiza en Tierra de Campos. 


\subsubsection{Otros}

\section{DUBLIÓN}

Este término no se registra en ningún diccionario académico, ni en ningún otro repertorio no académico.

Veinte y seis varas y media de dublión negro angosto (Medina de Rioseco, Va-1645)

Dos varas de dublión negro en dos pedaços (Medina de Rioseco, Va-1645)

Vna bara menos ochaua de dublión negro angosto (Medina de Rioseco, Va-1645)

Bases de datos como el CORDE o el CDH tampoco nos ofrecen información sobre este término. Sin embargo, aunque son pocas ocurrencias, se localizan algunos ejemplos en el CorLexIn en dos inventarios, uno de Tudela (Navarra, 1641) y otro de la localidad terracampina de Medina de Rioseco (Valladolid, 1645). Por el contexto se sabe que es un tejido que se mide en varas y que, preferentemente, es de color negro. Hay que recordar que en el caso vallisoletano se trata de un inventario de bienes de una tienda de ropa, por eso Pérez Toral considera que estamos ante un tecnicismo del comercio textil muy delimitado en su uso, pero que puede ser considerado como "un apunte casi diastrático de interés". Esta autora encuentra la posibilidad de que dublión sea un derivado del numeral doble, con cierre de la vocal inicial por la inflexión de la yod, y lo relaciona con doblete como tejido que el $D H T T$ registra en la segunda mitad del siglo XVII y que provenía de Italia (Pérez Toral, 2017a: 212). Esta voz es registrada en el Fichero general de la RAE como 'tela de lana parecido al damasco', pero sin indicar su procedencia o cronología (tan solo como un apunte).

\section{ESTERILLA [hesterilla]}

Sust. f. 'Galón o trencilla de hilo de oro o plata, ordinariamente muy estrecha', 'tejido de paja' ( $D L E, 1$. y 3. a ac.). Se registra en la edición de Autoridades de 1732 como diminutivo de estera (NTLLE, s. v. esterilla, Autoridades 1732). Palabra derivada de estera, del lat. STORĔA íd., probablemente pasando por *estuera (DECH, s. v. estera).

Una pollera de damasco negro con una hesterilla (Grajal de Campos, LE-1658)

Este término se documenta en el $C D H$ y en el CORDE desde el siglo XVI con la acepción 'estera pequeña para poner en el suelo'. Esterilla con la acepción de 'galón' se localiza en 1635 en el $C D H$ con sentido figurativo y años más tarde en un inventario de bienes:

Pidiome antes de ayer una esterilla, / que es pasamano ancho de caballo (Jerónimo Cáncer y Velasco, Carta escrita a un amigo suyo, 1635)

Un guardabaxos de chamelote de seda encarnadino con tres esterillas (Inventario de los bienes de don José Apestegui, ministril (1580-1664))

El CorLexIn ofrece ocurrencias con las dos acepciones. El significado de 'hilo de oro o plata que se usaba para la decoración del vestir' se localiza en dos ejemplos repartidos entre Madrid y Cantabria, mientras que con la acepción de 'estera pequeña' aparece en localidades meridionales -Cáceres, Huelva y Cádiz-. Sin embargo, es muy aventurado determinar una preferencia geográfica con tan escaso número de ejemplos. En Tierra de Campos esterilla solo aparece con la acepción de 'adorno' en un ejemplo de la localidad de Grajal de Campos. 


\section{GARROBILLA [garrubilla]}

Sust. f. 'Astillas o pedazos de algarrobo que se usan, con otros ingredientes, para curtir los cueros y darles un color como leonado' (DLE). La acepción con la que garrobilla aparece en los textos de Tierra de Campos no la registra el DLE. Este significado tampoco se localiza en el resto de diccionarios académicos. Sin embargo, el diccionario preacadémico de Vittori registra esta palabra como una especie de 'sarga' (NTLLE, s. v. garrobilla, Vittori, 1609). Término derivado de algarroba (DECH, s. v. algarroba).

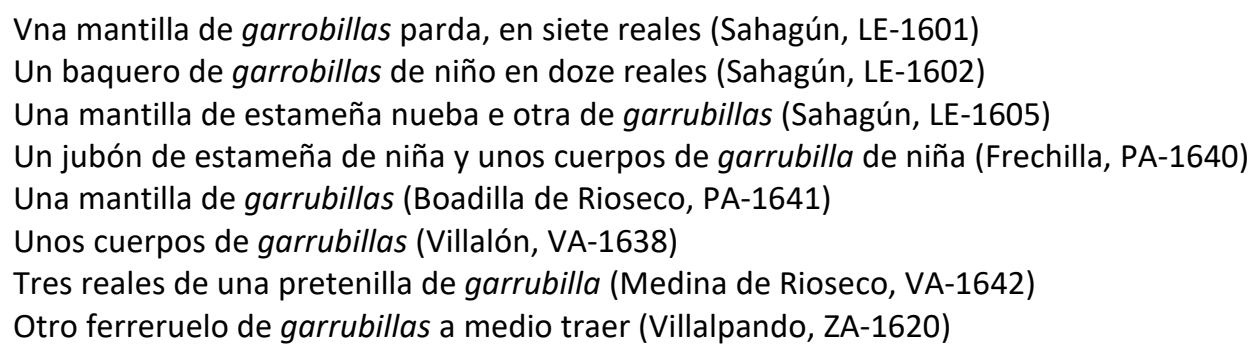

Con la acepción de un 'tipo de tela' se registra en el CORDE en un documento fechado en 1791 al describir el "vestido exterior de los colegiales":

El vestido exterior o de ceremonia que deberán llevar los colegiales [...] ha de ser manto de paño pardo, llamado de garrobillas, beca de paño fino morado sobre grana de la fábrica de Ávila y bonete de bayeta [...] (Constituciones del colegio de Nuestra Señora de los Ángeles de la Universidad de Salamanca, 1791).

Esta es la única referencia que encontramos en esta base de datos.

Sin embargo, el CorLexIn muestra algún ejemplo más de este término, todos ubicados en la zona leonesa de la Tierra de Campos:

Vn capotillo de garrovillas viexo (Villamuñío, LE-1633)

Vn ferreruelo nuevo de garrouillas caseras (Villamuñío, LE-1633)

Vnos calçones nuevos de garrouillas caseras (Villamuñío, LE-1633)

Por su lado, Perdiguero encuentra este término en el Archivo General de Simancas en documentos fechados en 1610 que dan cuenta del registro de bienes de moriscos granadinos que residían en Palencia -"cuerpos de garrubilla" o "debantal de garrubilla" (AGS, Est. 243)(Perdiguero, 2012a: 340).

Rojo Vega localiza esta voz en varios inventarios de Valladolid tales como:

Una capa manchega de garrubilla almendrucada (Inventario de Pedro de Miranda Bejarano, músico de la reina, Valladolid, 1608).

Otro baquero de garrubilla listada açul y berde con pasamanos paxiços (1631 Testamento e inventario de Beatriz de Santander alquiladora de vestidos de farsa Valladolid, 1631) ${ }^{4}$.

Morala advierte que podríamos estar ante una denominación geográfica, que podría referirse a la población de Garrovillas, en Cáceres (Morala, 2014a: 23). En el diccionario de

\footnotetext{
${ }^{4}$ Rojo Vega, Anastasio: Testamento e inventario de Beatriz de Santander alquiladora de vestidos de farsa, Valladolid, 1631. Consultado en: https://investigadoresrb.patrimonionacional.es/node/6867
} 
Madoz se indica que, en el siglo XIX, había una veintena de tejedores de paños y lienzos comunes en dicha población.

En Tierra de Campos aparece la variante formal garrubilla, que parece ser la más aceptada en los documentos, en detrimento de la forma académica.

\section{LAMA}

Sust. f. 'Tela de oro o plata en que los hilos de estos metales forman el tejido y brillan por su haz sin pasar al envés' ( $D L E$, s. v. lama ${ }^{2}$, 2. a ac.). Autoridades señala que esta tela se llama de manera más habitual restaño; da a entender que el término lama ya está en desuso (NTLLE, s. v. lama, Autoridades, 1734). Es un término que procede el fr. lame (DECH, s. v. lama ${ }^{2}$ ).

Un capote de grana colorada forrado en lama de flores campo berde (Medina de Rioseco, VA1642)

Veinte baras y media de lama lisa de Siuilla en tres pedaços (Medina de Rioseco, VA-1645)

Treinta y tres baras de lama parda de Toledo lisa (Medina de Rioseco, VA-1645)

EI CDH registra esta voz en documentos de finales del siglo XVI, en concreto en un Inventario y tasación de los bienes de Sebastián Hernández fechado en 1585, donde se lee "yten, un çillo de lama de lienço blanco". A partir de esta fecha son muchos los textos donde aparece lama con la acepción de tejido. Es una tela rica que se equiparaba con el terciopelo, el tabí o el damasco y que servía para confeccionar sayas, mantos, basquiñas, vestidos, vaqueros y jubones, además de forros. Casi todos los ejemplos de esta base de datos pertenecen a la Península, aunque también se localizan casos en colonias americanas como México, Guatemala o Ecuador. El uso de este término se extiende durante todo el siglo XVII y parte del XVIII. Es una voz de uso frecuente en esta época: el CorLexIn ofrece ocurrencias en la Península, Canarias y América, donde este tejido se utilizaba para la confección de ropa como jubones, justillos, vestidos, polleras y también complementos como mangas o golillas. En los ejemplos de América este tejido servía para la elaboración de casacas y armadores. Asimismo, se utilizaba como forro. En algunos inventarios se registran lamas de Nápoles, Milán o Francia, aunque también había manufactura nacional, como se puede ver en los ejemplos de la Tierra de Campos, donde este tipo de tejido no es muy habitual y solo se documenta en Medina de Rioseco en un inventario de una tienda de ropa.

\section{PAPAL}

Se trata de un término que no es recogido por ningún diccionario con la acepción que encontramos en Tierra de Campos, donde hace referencia a un tejido de lana.

Una saya de papal tasada en beynti ocho reales (Villalpando, ZA-1613)

Aparece en el CORDE y en el CDH en un documento titulado Arancel de precios y salarios de Cuenca, datado en 1462; ahí aparece "un panno papal fyno, quinse maravedís".

No figura en la documentación notarial de la época, salvo en un inventario de finales del siglo XVI fechado en Valladolid y localizado por Rojo Vega: 
Una saya de papal / yten un pedaço de paño papal que tendrá bara y quarta; (Inventario de un curtidor y agujetero: Juan Delgado, VA-1576) ${ }^{5}$.

Es un término muy poco frecuente en los textos en general. Era una tela o paño que se utilizaba para la confección de sayas.

\section{PITA}

Sust. f. 'Hilo que se hace de las hojas de pita' (DLE, s. v. pita' ${ }^{1}$, 2.a ac). Covarrubias recoge este término como 'yerua de Indias, de la qual hazen vn hilo muy delicado para guarniciones, como aca se saca el hilo del cañamo, y del lino'. También se recoge en Autoridades donde se indica que 'Planta que vino de Indias, algo semejante a la higuera de tuna. Arroja del tronco unas hojas largas y gruessas, que rematan en una punta muy aguda y dura, y dentro de ellas se cria una especie de hierba, de la cual seca se hace el hilo que llaman de pita' (NTLLE, s. v. pita, Covarrubias, 1611; Autoridades 1737). Es una voz de origen incierto; si es de origen americano, es más probable que proceda de las Antillas que de Méjico o Perú (DECH, s. v. pita).

Otra toalla de manteles de gusanillo delgada labrada con bordados y puntas de ylo de pita (Medina de Rioseco, VA-1640)

Dos almoadas de ruan labradas de ylo de pita (Medina de Rioseco, VA-1642)

Un frutero de ylo de pita (Villalpando, ZA-1632)

Una toalla de olanda con randa de cadeneta, ylo de pita, punta y encaje (Villalpando, ZA-1644)

Un frutero de ylo de pita muy bueno (Villalpando, ZA-1652)

Una toalla de Cambray con puntas de ylo de pita (Villalpando, ZA-1688)

Con esta acepción aparece en la documentación del $C D H$ y del CORDE desde el siglo XVI en la obra de Bartolomé de las Casas:

'[...]Casas Ilenas de cabuya y henequem y de pita, que ya dejimos ser especie de lino y de cáñamo; desto mucha en pelo y en cerro y de hilada torcida, e infinitas sogas y cabestros dello hechos [...]' (Fray Bartolomé de las Casas, Apologética historia sumaria, 1527-1550).

Es un americanismo que en esta época ya forma parte del léxico cotidiano. La pita era un 'tejido elaborado con la fibra de diferentes plantas, como yuca, ananas, agave o pita. En el siglo xvı llegaban a Sevilla camisas hechas con pita, según las tarifas de precios' (DHTT, s. v. pita). Es una voz de uso frecuente en los inventarios de bienes. Los datos que nos ofrece el CorLexIn señalan una preferencia de uso en las provincias andaluzas, aunque existen ocurrencias en otros puntos del territorio peninsular, insular $y$, por supuesto, americano.

\section{TRAMOYA [tramoia]}

Aunque la palabra se recoge en los diccionarios académicos, no figura con el significado de tejido. Palabra de origen incierto ( $D E C H$, s. v. tramoya). Covarrubias en la segunda parte de su Tesoro (vol. 3), al final de la entrada de la palabra traje, habla de las nuevas modas para las 'donzellas, que se dexan facilmente lleuar por la nouedad'. En el listado de nuevas prendas se

\footnotetext{
${ }^{5}$ Rojo Vega, Anastasio: Inventario de un curtidor y agujetero: Juan Delgado, Valladolid, 1576. Consultado en: https://investigadoresrb.patrimonionacional.es/node/5758
} 
encuentran los 'mantos de humo, las puntas de tramoya, por ser inuención nueua, y los guardainfantes' (Covarrubias, 1673).

Tres ropas una de tafetán, otra de tramoya y otra de senpiterna negras (Grajal de Campos, LE1658)

Quarenta y quatro varas de tramoia negra de Toledo (Medina de Rioseco, VA-1645)

El $C D H$ y el CORDE atestiguan un único ejemplo con este significado en el siglo XVII, en una obra de Quevedo:

'... entre busca y entre doña, / quier esgrima la chinela, / quier navegue la carroza, / la reto de dueña a dueña / y en vestidos de tramoya, / ruedos, barba de ballena, / manto de humo y de gloria...' (Francisco de Quevedo y Villegas, Jácaras, 1610-1645).

Esta falta de testimonios se traslada también a los documentos que conforman el CorLexIn; tan solo se localizan tres ocurrencias repartidas por Méntrida (Toledo) -"dos mantos de tramoya"-, Villacarrillo (Jaén) -"vna almilla de tramoya"-, y otro ejemplo donde el tejido aparece en una enumeración de textiles en pieza en la localidad terracampina de Medina de Rioseco (Valladolid). Cabe destacar que tampoco hemos encontrado ejemplos de esta voz con el significado académico. En Tierra de Campos es también un término poco frecuente y siempre aparece con la acepción de un tipo de tejido.

\subsubsection{Técnicas}

\section{AFELPADA [felpada]}

Adj. 'Parecido a la felpa por tener vello o pelusilla' (DLE). Este adjetivo lo registra Autoridades como 'lo que está hecho ò texído en forma de felpa larga: esto es lleno por una parte de cabos de hilo, o seda suelta: como las medias, guantes, y alfombras, que se llaman afelpádos por estar en esta forma: y también se llaman assi por la misma razón los ruedos de esparto: que todo sirve para mayór abrígo y defensa del frío. Es voz compuesta de la partícula $A$, y del nombre felpa' (NTLLE, s. v. afelpado, Autoridades, 1726). Se trata de un término derivado del verbo afelpar, y este a su vez de la palabra 'de felpa' (DECH, s. v. felpa).

Quarenta y siete barasde cotonías blancas felpadas (Medina de Rioseco, VA-1645) Una colcha de cotoncillos afelpada (Medina de Rioseco, VA-1685)

Una alfombra del estrado grande afelpada (Medina de Rioseco, VA-1685)

Esta lexía formada por derivación presenta una alternancia entre formas con y sin prefijo (afelpado y felpado) que documenta también Laguna en inventarios del siglo XVIII en Burgos (Laguna, 2017: 226-227). En el corpus estudiado también nos encontramos con el adjetivo afelpada of felpada, aunque en menor medida que felpa. En el CorLexIn este adjetivo, en sus dos variantes, no es muy frecuente, se observa la preferencia por el uso del término felpa.

EI CORDE y el CDH documentan el término afelpado en un sentido figurado en una obra de Francisco de Quevedo publicada entre los años 1626 y 1628. Son muy pocas las ocurrencias en las que aparece este adjetivo modificando un tejido. Las formas felpado o felpada restringe su 
uso documentos del siglo XVII principalmente, parece que en épocas posteriores su uso decae de manera considerable (CORDE, s. v. afelpado/-a, felpado/-a).

\section{AMANTELADO}

Esta voz no se recoge en ninguno de los diccionarios académicos. Del francés antiguo mantel, manto se tomó el castellano mantel como término heráldico, de donde mantelado (DECH, s. v. manto).

Una colcha amantelada con sus puntas tasada en seis ducados (Medina de Rioseco, VA-1644)

Es un 'tejido, algunas veces de algodón, mencionado en las telas vallisoletanas de 1780$1850^{\prime}$ (DHTT, s. v. amantelado). Tampoco se halla presencia de esta voz en corpus textuales como el CORDE o el $C D H$, lo que explicaría en cierta medida la falta de referencias académicas. A pesar de ser una voz poco documentada, el CorLexIn recoge varios ejemplos en inventarios de la zona meridional de la Península -Jaén, Córdoba y Murcia-, siempre referenciada junto a toalla. En Tierra de Campos se documenta junto a colcha.

Formalmente estamos ante un adjetivo denominal que presenta una estructura trimembre, proceso derivativo que era frecuente en esta época y de los que apenas existe información en los diccionarios académicos o en los corpus académicos (Laguna, 2017: 225, 227).

\section{BOCADILLO [uocadillo]}

Sust. $m$. 'Tela delgada colgada entre el visillo y la cortina' y 'en pasamanería, cinta muy estrecha' (DLE, 5 a y 6 . a ac.). Autoridades lo recoge como 'especie de lienzo delgado mui conocido, de que se hacen cortínas para los balcónes por adentro. Es entre los lienzos finos la espécie mas ínfima' (NTLLE, s. v. bocadillo, Autoridades 1726). Término derivado de boca, porcedente del fr. bocadille (DECH, s. v. boca).

Dos toallas de bocadillo con sus puntas ordinarias (Paredes de Nava, PA-1690) Dos paños de manos de bocadillo el uno con randas y el otro llano (Paredes de Nava, PA-1690) Dos sauanas de uocadillo (Medina de Rioseco, VA-1685) Un lienzo de narizes blanco de bocadillo bueno (Villalpando, ZA-1699)

El CORDE y el CDH documentan la expresión "a bocadillos" en plural a partir del siglo xv, en el Cancionero de Baena. Probablemente en este tipo de expresiones a/de bocadillos no referenciaría una tela, sino más bien la disposición externa de la tela, con una especie de aberturas a modo de cuchilladas (Pérez Toral, 2017b: 95). Estos corpus no recogen el término bocadillo como textil hasta el siglo XVIII.

La forma en singular se localiza en el CorLexIn sobre todo en provincias andaluzas y Canarias; en este último caso se recoge con la segunda acepción que da la Academia a esta voz: 'cinta muy estrecha'. De la forma en plural solo aparecen dos ejemplos distribuidos entre Cáceres y Ávila; en ambos casos se referencia una "colcha de bocadillos". En la zona terracampina aparece siempre el término en singular con la acepción de tejido para confeccionar toallas, sábanas y paños de manos. 


\section{BROCADILLO}

Sust. m. 'Tela de seda y oro, de inferior calidad y más ligera que el brocado' (DLE). Rosal registra esta voz dentro del lema de brocado, como derivado de esta palabra como 'brocado falso, como brocatello o brocadillo'. Autoridades registra la misma acepción que se conserva hoy en día (NTLLE, s. v. brocadillo, Rosal, 1611; Autoridades 1770). Palabra derivada de brocado (DECH, s. v. brocado).

Hasta una bara de brocadillo de Portugal que esta comenzado a cortar (Frechilla, PA-1671)

Adolfo Castro, en el Gran diccionario de la lengua española (1852-1855), registra el término brocadillo también como un tejido 'de algodón ó seda ligera, formada á imitación del brocado: los hay de seda y todo de lana', avanza también que el más apreciado era el que se fabricaba en Venecia (Fichero General, cédula 28).

El CDH solo ofrece un par de concordancias para el término brocadillo, en ambos casos con la acepción de 'tejido'. El primer ejemplo se documenta en una obra literaria del siglo XVI:

[...] do han sido más los indios señalados, / la ropa de algodón ligera y vana, / las diferentes mezclas de brocados, / y brocadillos de oro, y seda, y plata, / y el rico chamelote, y la escarlata.' (Luis de Barahona, Las lágrimas de Angélica, 1586)

El segundo ejemplo coincide con el único que figura en el CORDE para esta voz y que aparece a finales del siglo XIX en una obra sobre el traje:

El perpunte cada vez más menguado, de raso, brocadillo o terciopelo entre gentilhombres, rebosaba en volumen de hombreras, con la novedad de rasgar sus mangas por la parte de debajo (Josep Puiggarí i Llobet, Monografía histórica e iconografía del traje, 1886).

El CorLexIn no ofrece ningún ejemplo de esta lexía. Esta escasez de datos se trasvasa a Tierra de Campos, donde hallamos un solo ejemplo, en la localidad palentina de Frechilla de este textil en pieza y con procedencia geográfica, en este caso el brocadillo es de Portugal.

\section{CAPARROSA}

Sust. f. 'Nombre común a varios sulfatos nativos de cobre, hierro o cinc' (DLE). Es un término que aparece registrado en Nebrija y Covarrubias. Covarrubias indica que era una 'piedra, congelada de vn agua verde, que se distila de los mineros del cobre: $y$ trae consigo la calidad, la fuerça, y la flor del dicho metal'. Autoridades recoge esa acepción y la completa con: 'comun y vulgarmente se llama Flor del cobre, y hai diferentes espécies y de diversos colóres: blanca, verde y azúl'. (NTLLE, s. v. caparrosa, Nebrija, 1495; Covarrubias, 1611 y Autoridades, 1729). Palabra de origen incierto, probablemente del árabe *qubrûsi 'vitriolo de Chipre', por la fama del cobre en esta isla ( $D E C H$, s. v. caparrosa).

Un paño de manos labrado de caparrosa bueno (Grajal de Campos, LE-1655)

Ocho almuadas de çerro buenas blanco y labradas de caparrosa (Grajal de Campos, LE-1656)

Un paño de ofrenda labrado de caparrosa (Grajal de Campos, LE-1670)

Dos libras de trançaderas de belduque he ylo açul y de caparrosa (Mazariegos, PA-1619)

Dos almuadas labradas de ylo de caparrosa nuevas (Medina de Rioseco, VA-1646)

Una almuada de lienzo delgado labrada de azul y caparrossa (Villalobos, ZA-1654)

Dos almuadas labradas con ylo y labores de caparrosa dorado (Villalpando, ZA-1688) 
Una toalla de lienzo grande labrada con ylo azul y caparrosa (Villalpando, ZA-1689)

Este término se documenta desde el siglo $x v$ en el $C D H$, donde se localizan ejemplos relativos al mineral y en tratados de medicina.

En el CorLexIn esta palabra se halla en una zona geográfica muy localizada, en la Meseta Norte-Ávila, Burgos, León, Palencia, Valladolid y Zamora-, a la que hay que sumar dos ejemplos en Cantabria. El corpus terracampino ofrece unos cuantos ejemplos de este término haciendo referencia a un tipo de hilo para bordar o al color probablemente verde; así tenemos paños "labrados de caparrosa", pero también una "almuada de lienzo delgado labrada de azul y caparrosa". Esta dicotomía de significados se extiende al resto de la Península.

En localidades como Nava del Rey en Valladolid y Zárabes en Soria aparece la variante caparrosado.

\section{CONFITILLO}

Este término no aparece recogido en ninguna de las obras lexicográficas que conforman el NTLLE.

Otra colcha de confitillos en quatro ducados (Grajal de Campos, LE-1658)

Quatro almoadas de lienzo de Aroca las dos con confitillos y las otras dos por azer (Medina de Rioseco, VA-1640)

Una colcha de confitillos en tres ducados (Medina de Rioseco, VA-1643)

Tres colchas de confitillo hordinarias (Medina de Rioseco, VA-1645)

Son escasas las referencias a esta voz en el $C D H$ y en el CORDE, que ofrecen tan solo un par de ejemplos, uno del siglo XVII y otro de finales del siglo XVIII en Ecuador:

[...] Una colcha nueva de confitillo en sesenta y seis rreales [...] «Carta de dote entre Pedro de Cardenas Zapata y María Hernández», 1616)

[...] de paños, y otras telas de lana y algodón. Estas últimas, son unas de lienzos ordinarios, y otras de tela llamadas macanas, unas lisas, y adamascadas otras; unas de mota menuda, llamadas confitillo, y otras de felpa, todas muy estimadas, que hacen considerable comercio...' (Juan de Velasco, Historia del reino de Quito en la América Meridional, 1789).

En el Fichero General de la Academia se localiza esta voz en el Diccionario General de americanismos de Francisco J. Santamaría, donde se dice lo siguiente sobre esta palabra: 'en Cuba, paño negro de superior calidad que presenta en el revés las motillas que convencen de su excelencia' (cédula n.․ 3).

El CorLexIn ofrece una nómina un poco más extensa de este término repartido en la zona Centro y Occidente de la Península -Zamora, Valladolid, Ávila, Segovia, Madrid, Toledo y Guadalajara-. Esta técnica se utilizaba para la confección de ropa de cama como almohadas, colchas o delanteras. Las ocurrencias localizadas en el corpus terracampino aparecen en ese mismo contexto de uso.

\section{CUAJADILLO [quajadillo]}

Sust. m. 'Labor espesa y menuda que se hace en los tejidos de seda' (DLE). Lo registra Autoridades como 'especie de labór, que se echa en los texidos de seda, compuesta de flores 
menúdas, y de modo que descubran poco el campo' (NTLLE, s. v. cuajadillo, Autoridades, 1729). Término derivado de cuajo, 'sustancia cuajada', 'sustancia que sirve para cuajar', del lat. COAGŬLUM, íd., derivado de AGĚRE 'empujar, hacer mover', con el prefijo co- 'juntamente' (DECH, s. v. cuajo).

Dos varas de quaxadillo negro a treinta y seis reales la vara (Medina de Rioseco, VA-1644)

Esta voz ofrece una nómina muy escasa de ejemplos en la documentación académica. Encontramos un caso en el Fichero General de la Academia con el título Prematica sedas y fechado en 1593:

cada bara de los dichos terciopelados de labor, q se hizieren labrados de gorbioncillo, o quajadillo, [...], aya de pesar cinco onzas y quarta (Fichero General, cédula n.ㅇ 2)

En el CorLexIn tampoco se documentan ejemplos de esta voz: los términos más cercanos aparecen en la localidad toledana de Navahermosa, donde se puede leer "una tira de red [...] por quaxar, de estopa" y "una red nueva quaxada".

La única ocurrencia de esta voz en Tierra de Campos se localiza en el inventario de una tienda de productos textiles de Medina de Rioseco. Posiblemente se trate de un tecnicismo textil que haga referencia a la disposición externa de la tela.

\section{FLECO [flueco]}

Sust. m. 'Adorno compuesto de una serie de hilos o cordoncillos colgantes de una tira de tela o de pasamanería' y 'borde deshilachado por el uso en una tela vieja' (DLE). En Nebrija se recoge como flueco; también Autoridades lo equipara a flueco y lo define como 'cierto género de passamano texido, con los hilos cortados por un lado, que se hace de hilo, lana, seda ù otra cosa, y sirve de guarnición en los vestidos ù otras ropas, pegándole à las orillas. Hacense con mas ò menos labores, conforme al gusto de cada uno, y suelen llamarle de campanilla, de redecilla, \&c.' (NTLLE, s. v. flueco, Nebrija, 1495; Autoridades, 1732). Del anticuado flueco, descendiente semiculto del lat. FLǑcCU (DECH, s. v. fleco).

Vna basquiña y jubón de estameña negra, nueba, con su galón de fleco y botones de bidrio (Valderas, LE-1647)

Una colcha de gusanillo con fluecos en ocho ducados (Grajal de Campos, LE-1658)

Un çielo de cama de lienço con sus fluecos a los lados (Castromocho, PA-1602)

Una colcha blanca de cotonia con sus fluecos (Guaza de Campos, PA-1637)

Una delantera de cama con sus flecos (Guaza de Campos, PA-1637)

Una delantera de red con flecos (Guaza de Campos, PA-1639)

Una delantera de cama de red buena con fluecos (Guaza de Campos, PA-1640)

Una cercadura de cama tres paramentos y el çielo con sus fluecos (Guaza de Campos, PA-1640)

Unos cuerpos de grana usado con fluecos de seda negro (Villada, PA-1669)

Tres cortinas y un cielo de cerraxón con sus flecos de lo mesmo (Paredes de Nava, PA-1689)

Una colgadura de cordellate hacul de cama con sus flecos de lana amarillos y colorados (Paredes de Nava, PA-1689)

Seis baras de flecos bastos blancos de ylo (Paredes de Nava, PA-1690)

Otras tres baras de fluecos de lana amarillos y encarnados (Paredes de Nava, PA-1690)

Una colcha de votonçillos con sus flecos (Boadilla de Rioseco, PA-1692)

Un cobertor azul todo con sus fluecos pajiços (Villalón, VA-1637)

Una colcha de manteles con su flueco blanca (Medina de Rioseco, VA-1641) 
Unos flecos destopa en diez reales (Medina de Rioseco, VA-1642)

Una colcha blanca de cotonia con su flueco (Medina de Rioseco, VA-1649)

Otra colcha de manteles de gusanillo con fleco (Medina de Rioseco, VA-1645)

Una colcha gorda de gusanillo con flueco corto (Medina de Rioseco, VA-1657)

Un pauellón de paño azul con sus fluecos de seda nuevo (Villalón, ZA-1631)

Una sobrecama de blanqueta azul con fluecos pajiços y amarillos (Villalpando, ZA-1632)

Tres sillas buenas con sus fluecos (Villalpando, ZA-1656)

Un cobertor de estamiña açul con sus fluecos (Villalpando, ZA-1689)

En Tierra de Campos se localizan tanto la forma normativa fleco como flueco, esta última coincidente con la forma patrimonial y originaria del castellano. En el CorLexIn también se documentan las dos formas, con y sin reducción del diptongo, que es la variante más frecuente. Morala señala que se puede localizar la forma fleco desde el siglo XV en el CORDE, aunque de forma minoritaria (Morala, 2010a: 439). La forma diptongada parece ser más frecuente en esta época, a pesar de que fleco empieza a tener mayor peso en el léxico y acabará imponiéndose.

\section{FLOCADURA [flecadura]}

Sust. f. 'Guarnición hecha de flecos' (DLE). Nebrija recoge este término en su vocabulario. Autoridades lo define como 'la guarnicion y adorno de flueco, que se pone en las camas, coches y otras cosas, para su mayór lucimiento' (NTLLE, s. v. flocadura, Nebrija, 1495; Autoridades, 1732). Término derivado de fleco ( $D E C H$, s. v. flocadura).

Dos sobrecamas la vna leonada de labores de manteles y la otra de estameña açul de dos piernas con flocadura de lana colorada (Valderas, LE-1647)

Un cielo de lienço de cama con flocadura de ylo (Castromocho, PA-1603)

Un cobertor de paño açul con su flocadura (Castromocho, PA-1611)

Unas cercaduras de cama con unas listas negras por el medio con flocaduras de hilo amarillo y blanco (Frechilla, PA-1614)

Un paramento azul con flocadura (Frechilla, PA-1675)

Una cama de campo de nogal de Salamanca con las cortinas y zielo de paño berde y flocadura de seda berde muy trayda (Medina de Rioseco, VA-1640)

Una colçha grande buena de botonçillos atorillada y labrada con su flocadura (Medina de Rioseco, VA-1647)

Una colcha grande nueba con su randa y flocadura (Medina de Rioseco, VA-1648)

Otro couertor de paño açul con flocadura de seda dorado (Medina de Rioseco, VA-1657)

Una colcha de borlilla buena nueba con su flocadura (Quintanilla del Monte, ZA-1639)

Una colcha de borlilla buena y nueba con su flocadura alrededor (Villalpando, ZA-1661)

El CORDE localiza este término en la primera mitad del siglo XV en el Cancionero de Baena. El CorLexIn presenta varias ocurrencias de este término en distintos puntos de la Península, sin un patrón claro de reparto. En el corpus terracampino se recoge con la acepción que da Autoridades.

En la zona de estudio también se documenta la variante flecadura, mucho menos frecuente en los textos y reducido su uso a casi exclusivamente el siglo XVII. Los diccionarios académicos no recogen este término hasta época actual, en la edición académica de 1992. Anteriormente solo aparece en la edición de 1917 del diccionario de Alemany y Bolufer como americanismo (Pérez Toral, 2017d: 54).

Dos colchas blancas con su flecadura, la vna es amarilla y blanca (Valderas, LE-1647)

Un cobertor de paño berde con flecadura tasado en seis ducados (Medina de Rioseco, VA-1641) 
Una colcha de lienço de gussanillo con flecadura (Medina de Rioseco, VA-1642)

Una balona de puntas de Umo con flecadura dorada con vueltas de lo mismo y lazos (Medina de Rioseco, VA-1660)

\section{FRISADO}

Sust. $\mathrm{m}$. 'Tejido de seda cuyo pelo se frisaba formando borlillas' (DLE). Como sustantivo y con la acepción de tela de seda, aparece registrado en el DRAE de 1791 (NTLLE, s. v. frisado, DRAE, 1791). Término derivado de la palabra frisa, 'tela ordinaria de lana', probablemente del b. lat. tela frisia 'tela de Flandes importada por barcos frisones' (DECH, s. v. frisa).

Otra ropa de tafetan frisado con pasamanos (Castromocho, PA-1611)

La saya de raja y larropa de bayeta frisada (Castromocho, PA-1611)

En las Cuentas de Gonzalo de Baeza, Tesorero de Isabel la Católica se localiza a finales del siglo XV, entre otros ejemplos "Onze varas de paño negro frisado, para lobas e sayos e capirotes para traer luto por la ynfante doña Beatris de Portogal [...]" (CDH, s. v. frisado). Sin embargo, a partir de la primera mitad del siglo XVII, este térmico comienza a reducir el número de concordancias en el $\mathrm{CDH}$.

El recuento de ocurrencias que ofrece el CorLexIn de esta voz es muy reducido. Del término frisada aparece un único ejemplo en Madrid: "vn corte de vestido de baieta de Segouia frisada negra".

Esta escasez de ejemplos se refleja también en la Tierra de Campos, donde localizamos un par de ocurrencias pertenecientes a un mismo inventario de la localidad palentina de Castromocho.

\section{GARAPIÑA}

Sust. f. 'Galón adornado en uno de sus bordes con ondas de realce' o 'tejido especial en galones y encajes' (DLE, 2. a y 3. a ac.). Autoridades recoge tres acepciones de las cuales solo una está relacionada con los tejidos: 'analogicamente significa un género de texido especial, en encaxes y galones: dicho assi por la semejanza à la garapiña de los liquóres' (NTLLE, s. v. garapiña; Autoridades, 1734). Término derivado de garapiñar, procedente de un lat. vulgar *carpiniare, derivado de CARPĔRE (DECH, s. v. garapiñar).

Un guardapié de rasillas azules con tres garapiñas (Valderas, LE-1682)

Un jubón de paño berde guarnecido con un galón de garapiña negro (Frechilla, PA-1675)

Un faldellín de estameña azul de garapiña con tres guarniziones negras (Paredes de Nava, PA-1689)

Un guarda pies de estameña açul apreensado con cinco garapiñas negro (Paredes de Nava, PA1690)

Una pollera de raxa berde con dos guarniciones de garapiña negra (Medina de Rioseco, VA-1657) Un guardapiés encarnado con su garapiña (Medina de Rioseco, VA-1657)

Un guardapiés de jerguilla encarnada con dos garapiñas y franjón de plata (Medina de Rioseco, VA-1659)

Un vestido de anafaya acabellado jubón y vasquiña aforrado en tafetán negro y con unas puntas de garapiña negras (Medina de Rioseco, VA-1660)

Un guardapié de bayeta encarnado con tres guarniçiones de garapiña de color (Villalpando, ZA1660) 
Un jubón de labradora con su garapiña y cuerpos de damasco berde con guarnición de oro (Villalpando, ZA-1670)

Dos tapapiés el uno de senpiterna azul zeleste con zinco guarniçiones de garapiña negra ancha (Villalpando, ZA-1676)

Un Justillo de sempiterna verde con guarnizión de garapiñas (Villalpando, ZA-1697)

El $C D H$ documenta una veintena de casos de este término desde el siglo XVII, pero no con la acepción que presenta en el corpus objeto de estudio.

En el CorLexIn no encontramos ejemplos de esta voz, algo que contrasta con la zona terracampina, donde se presenta ampliamente documentado con el significado de ornamento para jubones, justillos, polleras, guardapiés y otras prendas. En la misma época, Egido localiza un ejemplo en Llamas de la Ribera, en la zona leonesa del Órbigo con la misma acepción que aparece en el área de estudio (Egido, 2010: 106):

Mas dos coberturas, la una de veinteydoseno negro ya usada guarnecida de tergiopelo negro y la otra de baeta blanca guarnecida de garapina negra (Llamas de la Ribera, LE-1668),

Por su parte, Gómez Ferrero atestigua un par de ejemplos fechados un siglo después en la zona de La Bañeza (Gómez Ferrero, 2015: 367):

Un guardapiés de estameña azul con garapiñas (La Bañeza, LE-1714)

Una mantilla redonda negra con su garapiña (Miñambres, LE-1729)

Aunque los diccionarios académicos no señalan marca dialectal para esta palabra, parece que con el significado textil se utiliza en un área muy concreta.

\section{GUSANILLO [husanillo]}

Sust. m. 'Cierto género de labor menuda que se hace en los tejidos de lienzo y otras telas' (DLE). En Autoridades 'se llama también cierto género de labor que se hace en los texidos de lienzos y otras telas' (NTLLE, s. v. gusanillo; Autoridades, 1734). Bartolomé y Junquera (2018: 128) localizan la deficinión que hace el Diccionario de Uso del Español para este término, donde aclara un poco más el tipo de labor que era: 'se aplica a distintos objetos que están formados por un hilo,alambre o algo parecido arrollado en *espiral; por ejemplo, a cierta labor debordado, al hilo de oro o plata empleado también para labores, o al cable for-mado por una espiral de alambre que se emplea para colgar *visillos' (DUE, s. v. gusanillo). Palabra derivada de gusano, de etimología incierta, quizá prerromano (DECH, s. v. gusano).

Dos tablas de tobajas de gusanillo buenas (Valdavida, LE-1606)

Un panizuelo de mesa de gusanillo (Santa María del Río, LE-1607)

Una servilleta de gusanillo (Cea, LE-1621)

Dos pañiçuelos de gusanillo de mesa (San Nicolás del Real Camino, LE-1631)

Unas tobajas de gusanillo (Grajal de Campos, LE-1670)

Un paño de manos de gusanillo con puntas (Grajal de Campos, LE-1671)

Ocho baras de serbilletas nuevas de gusanillo (Castromocho, PA-1611)

Unos manteles de bara y media de gusanillo (Baquerín de Campos, PA-1659)

Una tabla de manteles de gusanillo (Villada, PA-1665)

Unos manteles de gusanillo (Boadilla de Rioseco, PA-1692)

Una tabla de manteles de gusanillo (Villalón, VA-1637)

Dos toallas, la una de olanda con puntas y otra de gusanillo guarnezida (Medina de Rioseco, VA1648) 
Doçe serbilletas nuebas de alimanisco y gusanillo (Tamariz de Campos, VA-1652)

Diez servilletas de gusanillo (Cuenca de Campos, VA-1666)

Unos manteles de gusanillo de tres baras de ancho (Villalpando, ZA-1644)

Cuatro servilletas de gusanillo nueuas en pieca (Villalpando, ZA-1652)

Tres serbilletas de gusanillo usadas (Villalpando, ZA-1660)

EI CORDE documenta veintidós ocurrencias de este término con la acepción con la que aquí aparece, de los que casi una veintena están fechados entre finales del siglo xvı y la primera mitad del siglo XVII, luego entra en claro retroceso. Cabe señalar, además, que estos ejemplos pertenecen a documentación notarial (cartas de dote, inventarios de bienes, particiones de bienes...) y apenas presenta casos en los textos literarios y técnicos.

Por su parte, el $C D H$ registra una escasa nómina de ejemplos con el significado que aquí nos ocupa, tres en total, el primero en una obra de la segunda mitad del siglo XVIII:

Cáñamo hilo / para tejer mantillas / de gusanillo [...] («Las colegialas de moda. Tonadilla a cinco», Tonadillas teatrales, 1774).

El CorLexIn atestigua un centenar de casos de este término con el significado textil y queda ampliamente documentado a lo largo y ancho de la Península, con preferencia de la Meseta Norte, donde se registra un abanico de ocurrencias ligeramente mayor. Lo mismo ocurre en Tierra de Campos, donde este término es de uso frecuente.

En la localidad leonesa de Grajal de Campos se localiza la variante usanillo con elipsis de la $/ g-/$.

\section{NUDILLO [nodillos]}

Sust. m. 'Cada uno de los puntos que forman la costura de las medias, los cuales se hacen dando una vuelta a la hebra del derecho y otra en sentido contrario, con lo cual queda al revés la carrera' (DLE, 2. a ac.). Autoridades recoge nudillos e indica que 'llaman las que hacen medias los puntos que forman la cartera o costura en ellas, los quales se hacen dando una vuelta à la hebra al derecho, y otra al revés, con lo que queda del revés la carrera' (NTLLE, s. v. nudillo; Autoridades, 1734). Término derivado de nudo (DECH, s. v. nudo).

Una colcha de nudillos de tres piernas (Frechilla, PA-1671)

Una colcha de las de Galicia de nudillos nueba (Frechilla, PA-1675)

Una colcha blanca con sus nodillos vuena (Medina de Rioseco, VA-1644)

Aunque el $C D H$ ofrece un amplio abanico de concordancias, solo encontramos dos que tengan un significado textil: una en el siglo XVI y la otra en 1645, en un documento procedente de Puerto Rico en el que aparecen "unos jubones de nudillo".

Tampoco el CorLexIn ofrece muchas ocurrencias de esta voz, tan solo un ejemplo en la localidad soriana de Burgo de Osma, donde figura "vna colcha de lino de nudillos con puntas". En Tierra de Campos aparece también esta voz referenciada junto a colchas, aunque su uso no es frecuente, tan solo se localizan tres ejemplos en localidades de gran tradición textil (Frechilla y Medina de Rioseco). Formalmente, se documenta en plural y alterna la variante nodillos, como resultado de la vacilación del timbre de la vocal átona. 


\section{PASAMANOS [passamanos]}

Sust. m. 'Género de galón o trencilla, cordones, borlas, flecos y demás adornos de oro, plata, seda, algodón o lana, que se hace y sirve para guarnecer y adornar los vestidos y otras cosas' $\left(D L E\right.$, s. v. pasamano ${ }^{1}$ ). Covarrubias lo recoge como passamano e indica que 'tambien se llama la guarnición del vestido por echarse en el borde'. Autoridades recoge passamano como 'un género de galón ò trencilla de oro, plata, seda ò lana, que se hace y sirve para guarnecer y adornar los vestidos y otras cosas, por el borde ò canto' (NTLLE, s. v. passamano, Covarrubias, 1611 y Autoridades, 1737). Palabra compuesta por el verbo pasar y mano, con el significado de 'especie de galón' tomado del francés passement (DECH, s. v. paso).

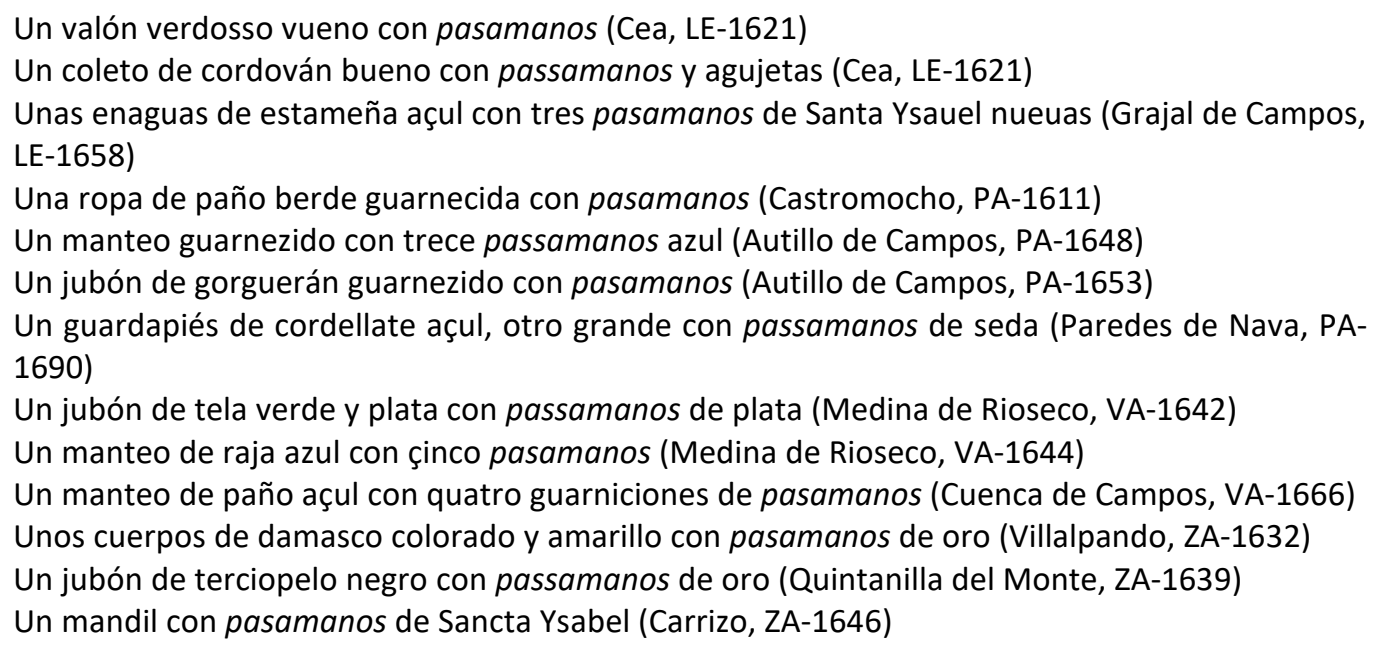

Desde un punto de vista diacrónico tanto el CORDE como el CDH documentan esta voz desde el siglo XVI con la acepción mencionada y presenta un número importante de ocurrencias, sobre todo en el siglo XVII.

El CorlexIn aporta un nutrido número de ejemplos con una distribución diatópica de carácter general que se hace extensiva a la Tierra de Campos.

\section{RANDA [randada]}

Sust. f. 'Guarnición de encaje con que se adornan los vestidos, la ropa blanca y otras cosas' (DRAE). Recogido por Nebrija, Covarrubias y Autoridades. Covarrubias indica que es 'cierta labor que se haze o con el aguja, o con los bolillos, o en telar'. Autoridades indica que es un 'adorno que se suele poner en vestidos y ropas: y es una especie de encaxe, labrado con aguja ò texido, el qual es mas gruesso, y los nudos mas apretados que los que se hacen con palillos' (NTLLE, s. v. raso, Nebrija, 1495, Covarrubias, 1611, Autoridades, 1737). De origen incierto, probablemente del céltico randa. Al parecer pasó de la lengua de Oc a través del catalán al castellano y de ahí al portugués ( $D E C H$, s. v. randa).

Tres almoadas con randas blancas buenas (Valdavida, LE-1606) Una sábana de zerro con sus randas de tres piernas nueba (Sahagún, LE-1608) Una sábana con randas azules biexa (Galleguillos, LE-1618)

Otra sabana husada de randas açules (Grajal de Campos, LE-1656)

Una sábana de tres piernas con dos randas buenas (Autillo de Campos, PA-1653) 
Una sábana de lienço griego con su randa (Baquerín de Campos, PA-1659)

Una cortina de lienzo de aroca con sus randas (Paredes de Nava, PA-1689)

Un paño de ofrendar blanco con puntas y randas (Boadilla de Rioseco, PA-1692)

Dos sávanas de lienço con randa nuevas (Medina de Rioseco, VA-1649)

Una sábana de lienço de tres piernas buena con sus randas blancas (Tamariz de Campos, VA1652)

Una sávana de lienzo vueno con randas y rodeada de puntas (Cuenca de Campos, VA-1666)

Un paño de manos con randas en quadro y puntas alrededor (Medina de Rioseco, VA-1671)

Otra almuada de randa amarilla y blanca (Villalpando, ZA-1613)

Unas randas de ylo azul y blanco (Villalpando, ZA-1620)

Una almoada labrada de ylo açul y amarillo con su randa (Villalpando, ZA-1629)

'El origen de la palabra se encuentra en el sajón rand (borde) y designaba los calados hechos a la aguja con que antiguamente se unían las piezas de una tela. En España se empezó a llamar encaje cuando la randa se hizo independiente de la tela y se tenía que encajar en ella una vez terminada'; así pasó a llamarse encaje (DHTT, s. v. randa). Con esta acepción se documenta desde el siglo XV en el CDH. Lo mismo que ocurre con el término pasamanos, randa era de uso general en la época. En Tierra de Campos esta guarnición se utilizaba sobre todo con el ajuar doméstico -almoadas, paños de manos, cortinas...-.

En el corpus terracampino figura el adjetivo randada, que hace referencia a un 'adorno con randas' $(D L E)$ :

Otra sauana randada de azul de lienzo asturiano (Sahagún, LE-1600)

Otra camisa de muger de manga ancha randada labrado de negro (Sahagún, LE-1600)

Una almoada de rexa randada (Galleguillos, LE-1618)

Este adjetivo es recogido por la Academia a partir de su edición de 1803 con el valor de 'lo que está adornado con randas' (NTLLE, s. v. randado, DRAE, 1803). El CDH ofrece una escasa nómina de casos, la mayoría pertenecientes al siglo XVII, aunque también lo recoge en el siglo XV. Su uso no es muy frecuente en el CorLexIn; la mayoría de las ocurrencias se reparten por la parte sur occidental de la Península -Cádiz, Huelva, Badajoz y Cáceres-, aunque también se encuentran casos un poco más al Norte-Ávila-y Cantabria.

\section{TORILLO [atorillado]}

Este término no aparece recogido en ninguna de las obras lexicográficas que conforman el NTLLE.

Tres tablas de manteles de torillos (Calzada, LE-1601)

Dos tablas de manteles de torillos, unos de mediados y otros buenos (Sahagún, LE-1608)

Dos pares de manteles de torillos viexos (Cea, LE-1610)

Unos manteles de torillos (Grajal de Campos, LE-1616)

Una tabla de manteles de torillos (San Pedro de Valderaduey, LE-1626)

Dos baras de manteles de torillos en dos reales (Frechilla, PA-1613)

Unos manteles hordinarios de torillos (Guaza de Campos, PA-1639)

Unos manteles de torillos (Frechilla, PA-1640)

Unos manteles de torillos (Boadilla de Rioseco, PA-1641)

Una colcha de torillos mosqueada buena (Villalón, VA-1642)

Unos manteles de torillos en ocho reales (Cuenca de Campos, VA-1660)

Unos manteles de lienzo de torillos de ocho varas en ocho reales (Cuenca de Campos, VA-1666)

Otros manteles de torillos (Villalpando, ZA-1613) 
Probablemente estamos ante un tipo de labor parecida al gusanillo o el cuajadillo que se utilizaba principalmente en mantelerías. Es una voz habitual en la Tierra de Campos. El CorLexIn presenta un nutrido número de ejemplos en León, Valladolid, Palencia y Ávila, con preferencia de uso en León. También aparecen ocurrencias en localidades de Guadalajara, Toledo y Málaga.

En Tierra de Campos encontramos el adjetivo atorillado referenciado junto a colchas y manteles:

Una colcha grande buena de botoncillos atorillada y labrada con su flocadura (Medina de Rioseco, VA-1647)

Dos pares de manteles atorillados nuevos (Boadilla de Rioseco, PA-1658)

Formalmente estamos ante un adjetivo denominal que presenta prefijo y sufijo en su formación y como se señalaba para el caso de afelpado y amantelado la información que ofrecen las obras lexicográficas es más bien escasa (Laguna, 2017: 225,227). 


\subsection{AJUAR DOMÉSTICO}

\subsubsection{Utensilios de cocina y aseo}

\subsubsection{Recipientes}

\section{ACEITERA [açeytera, azeitera, azeytera)}

Sust. f. 'recipiente que se usa para guardar el aceite, especialmente el comestible' (DLE, 5. a ac.) En la edición anterior del DLE aparecía como sinónimo de 'alcuza' (DRAE, 2001). Figura en Nebrija como 'azeitera vaso'. Autoridades registra esta voz todavía con la grafía azeitera y la define como 'vaso de barro, ú hoja de lata de diferentes hechúras y tamáños, de boca angosta, en que se pone y echa el azéite para los usos de cada dia, que por otro nombre se llama Alcúza' (NTLLE, s. v. azeitera, Nebrija, 1495; Autoridades, 1726). En el DRAE de 1817 ya se registra con la grafía de aceitera que hoy conocemos y hace referencia a 'vasija en que se tiene el aceite para el uso diario' (NTLLE, s. v. aceitera, Autoridades, 1726, DRAE, 1817). Es un término procedente del ár. zéit (DECH, s. v. aceite).

Un candil y dos azeyteras llenas de olio y zeyte (Riosequillo, LE-1610)

Una azeitera de oxa de lata (Cea, LE-1621)

Una aceitera de Talavera buena (Cea, LE-1621)

Ocho fuentes y ocho platos y dos saleros y una azeytera y vinagrera de Talabera fina (Medina de Rioseco, VA-1659)

Una azeytera de oja de lata (Villalobos, ZA-1654)

Una aceitera de bero (Villalobos, ZA-1654)

Dos jarricas pequeñas de Talauera fina, açeytera y binagrera de lo mesmo (Villalpando, ZA-1689)

Un salero de Talabera y otro de metal y dos azeyteras de Talabera (Villalpando, ZA-1696)

Esta voz presenta un uso muy exiguo en la documentación que aporta el $C D H$. Documentada a partir del siglo xV, dos siglos más tarde el recuento de casos no llega a la media docena. Esta falta de testimonios se traslada al CorLexIn donde figura un número reducido de ocurrencias, concentradas en su mayoría en la mitad Norte de la Península. En el corpus terracampino, los ejemplos se concentran en la zona más occidental -en localidades leonesas y zamoranas-. En la mayoría de los casos hace referencia a la vasija que se utiliza para contener el aceite. Por regla general, la aceitera aparece al lado de utensilios de cocina.

\section{ALBORNÍA [alvornia]}

Sust. f. 'Vasija grande de barro vidriado, de forma de taza' (DLE). Aparece en el Tesoro de Covarrubias y la define como una 'escudilla tosca y grande de barro [...]'. Autoridades la recoge como una 'vasija de barro vidriado grande y redonda en forma de taza ò escudilla. Llamase también Aljofáina, ò Ajofáina, Zafa, y Algébena. Es voz Arabe de la palabra Albernía como algunos quieren, que significa cosa de barro [...]' En el Diccionario Histórico de 1933 se añade la variante alburnía. (NTLLE, s. v. albornía, Covarrubias, 1611; Autoridades, 1726; Diccionario 
Histórico, 1933). Es un término procedente del árabe burniya (DECH, s. v. albornía). Se documenta por primera vez bajo la forma albornía en 1617.

Nuebe platos, una jarra y una alvornía y un salero bañado bueno (Medina de Rioseco, VA-1644) Dos fuentes de Talabera pintadas, la una fina y otra basta y dos albornías de Talabera fina (Villalpando, ZA-1661)

No debió de ser un término de uso extenso dado el número reducido de casos que aparecen en el $C D H$, donde encontramos una docena de ejemplos fechados entre finales del siglo XVI y comienzos del XVII con la variante albornía. En el CorLexIn no se han localizado casos de esta voz. Y en Tierra de Campos solo se contabilizan un par de ejemplos, que se verían incrementados por el localizado por Morala en San Mamés de Campos, donde se registra la variante albarnía. La forma terracampina está escasamente documentada y se registra en un vocabulario del siglo XIV (Morala, 2012e: 85).

En repertorios dialectales actuales como el Tesoro léxico de las hablas riojanas se recoge con el significado de 'palangana' (Pastor, 2004: 49).

\section{ALCUZA}

Sust. f. 'Vasija de barro, de hojalata o de otros materiales, generalmente de forma cónica, en que se guarda el aceite para diversos usos' (DLE). Aparece desde Nebrija. Autoridades la define como 'la vasija en que se tiene el azéite para el gasto ordinario, que regularmente es de barro, latón, ú hoja de lata, pero puede ser de otros metales. Es estrecha en la boca, y vá ensanchando hasta su suelo' (NTLLE, s. v. alcuza, Autoridades 1726). Término procedente del ár. marroquí y egipcio kûza 'jarrito' (DECH, s. v. alcuza).

Un alcuça de oja de lata (Fechilla PA-1613)

Tan solo hemos encontrado este ejemplo en el corpus estudiado. Aparece documentada en el CORDE desde el siglo XIII. Es una palabra que está más presente en el sur de la Península; así, en el CorLexIn nos encontramos con ejemplos en Córdoba, Sevilla, Jaén o Almería. Hay varios casos en Cuenca. En el área leonesa de La Bañeza, Gómez Ferrero localiza un caso aislado de esta voz, lo que hace pensar que no era muy habitual en la zona (Gómez Ferrero, 2015: 123).

En vocabularios dialectales más modernos, Gordaliza recoge esta voz como 'pequeño recipiente para aceite, que solía ser de hojalata para uso en la cocina' (Gordaliza, 1988: 25). El ejemplo recogido en nuestro corpus está ubicado en la zona palentina, lugar donde no se encontró ningún caso de aceitera.

\section{ALÁFANA [alxáfana]}

Sust. f. 'Jofaina' (DLE), advierte de que esta palabra ya está en desuso. En Autoridades ya aparece como voz anticuada y con la misma acepción (NTLLE, s. v. aljáfana, Autoridades, 1770). Se trata de una palabra que procede del diminutivo árabe de ğáfana o ğáfna 'escudilla grande, fuente honda' (DECH, s. v. aljáfana). 
Una aljáfana de Talavera fina (Medina de Rioseco, VA-1640)

Una fuente quebrada y una aljáfana pintada (Medina de Rioseco, VA-1649)

Dos doçenas de platos y escudillas y quatro fuentes y una alxáfana de Talavera fina (Medina de Rioseco, VA-1644)

Seis escudillas finas, una aljáfana y un salero (Villalpando, ZA-1688)

Una dozena de platos de los finos, la metad, una aljáfana y un salero (Villalpando, ZA-1688)

Una aljáfana grande de Talabera fina y dos pequeñas (Villalpando, ZA-1696)

Desde una perspectiva diacrónica, el CORDE y el $C D H$ documentan este término en una obra fechada en 1529 donde figuran varios ejemplos de esta palabra bajo la acepción de 'plato hondo'. Esta voz pasó al castellano con las formas aljáfana, aljébana y aljébena, esta última con marca diatópica de Murcia (DECH, s. v. aljáfana). Los inventarios terracampinos presentan la variante normativa con la inestabilidad gráfica propia de la época (aljáfana, alxáfana).

\section{ALMOFÍA}

Sust. f. 'Jofaina' (DLE). Covarrubias la define como 'escudilla grande tendida y no honda' (NTLLE, s. v. almofía, Covarrubias, 1611). Término procedente del ár. español y magr. múhfiya (DECH, s. v. almofía).

Una almofía de barro grande (Fechilla PA-1675)

Una almofía de las finas de Talabera (Fechilla PA-1675)

Doce platos de Talabera fina y ocho escudillas y una almofía pequeña (Frechilla, PA-1675)

Otros platos pequeños y siete escudillas y una almofía de mediobaño de barro blanco y una jarra blanca de Talabera y otros tres platos de Talabera pequeños usados (Villalpando, ZA-1620)

Tres fuentes de Talauera grandes, dos almofías de lo mismo (Villalpando, ZA-1686)

En Tierra de Campos se localizan unos cuantos ejemplos de esta voz siempre inventariada junto a recipientes domésticos. Pese a que esta voz no es muy frecuente en el CorLexIn, presenta una distribución geográfica que apunta al centro occidental de la Península -Ávila, León, Cáceres y Badajoz-; Morala refuerza esta localización indicando que "al menos durante el siglo XVII, la palabra gozaba de un apreciable arraigo popular que, como puede verse por la localización de los casos reunidos, se daba principalmente en el área centro occidental de la península" (Morala 2012e: 85).

\section{AZAFATE [açafate, açafatico]}

Sust. m. 'Canastillo, bandeja o fuente con borde de poca altura, tejidos de mimbres o hechos de paja, oro, plata, latón, loza u otras materias' (DLE). La forma açafate es recogida por Covarrubias en su Tesoro como 'vn genero de canastillo estendido, de que vsan las damas, para que las criadas les traygan los tocados, lienços o camisas' y en Autoridades se ofrece mayor número de matices en la definición 'canastillo llano texido de mimbres, levantados en la circunferencia en forma de enrejado quatro dedos de la misma labor. También se hacen de paja, oro y charol en la misma forma y hechura referida' (NTLLE, s. v. azafate, Covarrubias, 1611; Autoridades, 1726). Término procedente del ár. sáfat (DECH, s. v. azafate). 
Un azafate de minbres blancas (Grajal de Campos, LE-1671)

Dos azafates pequeños tasados en dos reales (Grajal de Campos, LE-1670)

Un azafate bordado (Medina de Rioseco, VA-1660)

Un açafate de plata pequeño (Medina de Rioseco, VA-1685)

Un açafatico de paxa (Villalobos, ZA-1654)

Un azafate con unas puntas de lana angosta (Villalpando, ZA-1689)

Un azafate y en él un dechado labrado con seda (Villalpando, ZA-1689)

Un azafate de pajas (Villalpando, ZA-1689)

Esta palabra es de uso generalizado en el siglo XVII. Son múltiples los ejemplos que nos encontramos en el CORDE y en el CDH a partir de este siglo. El CorLexIn presenta una distribución extensa de este término, recoge ocurrencias en la zona meridional de la Península -Córdoba, Málaga o Sevilla-, en puntos dispersos del Norte -Zamora y Cantabria-, además de en documentos procedentes de Canarias y América.

En Tierra de Campos hallamos diferentes ocurrencias de esta voz, y, dado el contexto en el que está, parece que se ajusta a la definición académica. No todos los azafates que aparecen tienen el mismo valor, ni la misma función. Estaban los azafates más sobrios, elaborados con pajas o mimbres que solían hacer las veces de costurero, como se puede observar en los ejemplos localizados en la localidad zamorana de Villalpando. Frente a estos, hay un tipo de azafate que tenía un carácter más suntuoso, elaborados con plata, oro y ricos ornamentos cuya función era más parecida a la de una bandeja. También se documenta el diminutivo del término açafatico, con caracter apreciativo otorgado por el sufijo -ico.

Este término se mantiene en estudios dialectales más modernos, está presente en repertorios palentinos como 'pequeño cestito para guardar cosas de costura' (Gordaliza, 1988: 38). Además de en León, se recoge en zonas de Extremadura, Navarra, o Cantabria (Le Men, 2002, s. v. azafate).

\section{BALDE}

Sust. $m$. 'Recipiente de forma y tamaño parecidos a los del cubo' (DLE, balde ${ }^{1}$, 2. a ac.). Autoridades lo recoge como 'lo mismo que cubo, ò herráda para sacar agua de los pozos'; además, señala que se trata de un término utilizado generalmente en las 'Andalucías y otras partes'. (NTLLE, s. v. balde, Autoridades, 1726). Voz de origen incierto (DECH, s. v. balde ॥).

Un barreño y un medio balde (Castromocho, PA-1614)

Un tonel de balde biejo (Autillo de Campos, PA-1649)

El CDH documenta un inventario de bienes perteneciente a la Colección Diplomática de Santa Catalina del Monte Corbán (Cantabria) fechado en 1463: "más ocho toneles e tres pipas e tres roldanas e seys tinas e dos moyales e ocho baldes". Con la acepción de recipiente se recogen dos ocurrencias en el corpus terracampino. En el primer asiento figura un medio balde, que nos recuerda a otras expresiones sintagmáticas de estos inventarios: media fuente, media fanega, media cántara... y que posiblemente tenga que ver con el concepto de medida-recipiente frecuentes en los inventarios de este siglo. En el segundo caso se puede leer tonel de balde, tal vez en esta ocasión esté haciendo referencia a la forma del recipiente. En ambos casos el 
contexto no es lo suficientemente explícito como para saber exactamente ante qué tipo de objeto estamos. Perdiguero localiza en el estudio que hace Uriarte Ayo (2009), en el que transcribe una serie de inventarios pertenecientes a la herrería vizcaína de El Pobal, entre ellos uno fechado en 1844 en el que aparece: "un balde de madera con sus cellos de hierro", donde la acepción que recoge se acerca al de recipiente para contener vino por la morfología del mismo (Perdiguero, 2017: 172) y que recuerda en cierta manera al ejemplo de Autillo de Campos.

En repertorios dialectales más modernos se mantiene este término, Gordaliza registra la palabra como 'recipiente metálico para el agua, más grande que la herrada' (Gordaliza, 1988: 41). También figura como 'recipiente de cinc de tamaño regular, usado para lavar la ropa, la vajilla en el fregadero' en zonas de León (Le Men, 2002, s. v. balde).

\section{BARQUILLO}

No hay entrada para la acepción de barquillo como recipiente en el DLE; debemos ir al lema barco para encontrar esta voz como 'recipiente hecho de madera o de calabaza ahuecada que se usa para contener líquidos' (DLE, s. v. barco, 3.a ac.), acepción que se localiza en El Salvador y Honduras. Sin embargo, se trata de una voz muy habitual en los inventarios en el siglo XVII. Palabra derivada del término barca, del lat. BARCA, quizá de origen hispánico ( $D E C H$, s. v. barca).

Un barquillo de plata (Grajal de Campos, LE-1656)

Un barquillo de Talabera (Frechilla, PA-1639)

Dos barquillos de plata medianos con sus pies (Paredes de Nava, PA-1690)

Un barquillo de plata que pessó cinquenta y tres reales (Medina de Rioseco, VA-1642)

Quatro cucharas y un barquillo de plata (Medina de Rioseco, VA-1649)

Un barquillo y una cucharica de plata (Medina de Rioseco, VA-1660)

Quatro platos y un salero y un barquillo (Villalpando, ZA-1639)

Un barquillo y cuatro cuchares todo de plata (Villalpando, ZA-1650)

Un barquillo de plata blanco grande (Villalpando, ZA-1656)

Un barquillo de plata (Villalpando, ZA-1661)

Quinze onzas de plata en esta manera, en un salero mediano y un barquillo, zinco cucharas grandes y una pequeña, dos serbidores (Villalpando, ZA-1688)

Con el significado de 'recipiente para contener líquidos' lo recoge el CORDE a partir de finales del siglo XVI -en una obra de Juan de Pineda fechada en 1589-, y con un mayor número de ocurrencias en el XVII; en el inventario de los bienes de Felipe II (1600) figuran unos cuantos barquillos de plata, de cristal, de ébano o guarnecidos con botón de oro, cuya descripción refleja que estamos ante un objeto de cierto lujo. El CorLexIn muestra una distribución diatópica de carácter general. El corpus terracampino atestigua casi una docena de casos de esta voz, un número significativo si tenemos en cuenta que estamos ante un objeto de cierto valor. De forma general, estos recipientes eran frecuentemente de plata, muchas veces de plata maciza y repujada que solía llevar la fecha y el punzón del platero. No obstante, figuran algunos casos de barquillos de barro o de Talavera. 


\section{BARREÑO [barreña, varreño, uarreño]}

Sust. m. y f. 'Vasija de barro, metal, plástico, etc., de bastante capacidad, generalmente más ancha por la boca que por la base $(D L E)$. El diccionario de Autoridades lo registra como 'vaso de barro tosco que sirve para echar en él cosas líquidas y para otros usos, como fregar, sangrar [...]' (NTLLE, s. v. barreño, Autoridades, 1770). Término derivado de barro de origen prerromano (DECH, s. v. barro).

Un barreño de oregeras (Cea, LE-1610)

Un varreño (Cea, LE-1621)

Dos barreños nuebos (Castromocho, PA-1614)

Un barreño y un medio balde (Castromocho, PA-1614)

Una barreña vidriada grande (Paredes de Nava, PA-1689)

Un barreño grande de orejones (Villalpando, ZA-1661)

La forma masculina barreño está presente en los documentos de la Tierra de Campos con mayor frecuencia que la forma femenina. Barreño figura en los textos a partir del siglo XVı en el $C D H$. Hace referencia a un recipiente de tamaño considerable, por lo general más ancho por la boca que por la base, fabricado con diferentes materiales y que se utilizaba para diferentes menesteres. Formalmente estamos ante una palabra derivada con el sufijo de origen latino eño, este sufijo se empleaba para derivar adjetivos a partir de sustantivos (Morala, 2017a: 141), en este caso el adjetivo se ha sustantivado.

En cuanto a la forma femenina barreña el DLE nos remite al lema barreño, aunque probablemente no sean sinónimos. Aparece en el Vocabulario de Nebrija procedente del latín 'cimbium fictile'. Covarrubias recoge esta forma como 'vaso grossero de tierra, de que suelen vsar los pastores, y gente del campo, en que comen sopas, o leche'. Autoridades de nuevo lo equipara con barreño y lo tilda de voz antigua (NTLLE, s. v. barreña, Nebrija, 1495; Covarrubias, 1611, Autoridades, 1726). Desde una perspectiva diacrónica, este término se documenta en el CORDE y en el $C D H$ a finales del siglo $\mathrm{xV}$, en obras de Juan del Encina donde referencia un recipiente para contener leche. Sin embargo, su presencia en los textos es escasa y siempre en obras literarias o técnicas. Los pocos ejemplos que aparecen de barreña en el CorLexIn lo hacen junto a escudillas, orzas, fuentes o tenedores que forman parte de los utensilios de cocina. En el único caso que encontramos en Tierra de Campos, no está tan claro que se refiera al 'recipiente donde se tomaban las sopas'; el contexto en el que aparece no aclara su significado, ya que el inventario en este caso no presenta un orden por campos semánticos. En la zona de Valdería (León) se suele localizar en los textos junto a platos o escudillas (Gómez Ferrero, 2015: 126).

En trabajos lexicográficos más recientes se localiza en zonas de León y Zamora como una vasija más pequeña que el barreño y destinada a contener comida principalmente (Le Men, 2002. s. v. barreño, ña). Gordaliza recoge el término masculino barreño como 'vasija grande de barro que sirve para usos varios como fregar, hacer matanzas e incluso bañarse en él. Si es todavía mayor se llama barreñón' (Gordaliza, 1988: 42). 


\section{BARREÑóN [varreñón, uarreñón]}

Este término no aparece registrado en el DLE. Covarrubias menciona esta palabra cuando presenta la definición de barreña '[...] Tomò el nombre de su materia que es barro, y de allí barreñon. [...]'. Sí que aparece registrado en Autoridades y en algunas ediciones del DRAE como aumentativo de barreño 'barreño grande' (NTLLE, s. v. barreña, Covarrubias, 1611; s. v. barreñón, Autoridades, 1770). Sust. m. 'Vasija de barro tosco, de mayor tamaño que el barreño con o sin asas', 'barreño pequeño' (Le Men, 2000, s. v. barreñón). Término derivado de barreño.

Un barreñón (Castroañe, LE-1609)

Dos barreñones grandes en dos reales (Frechilla, PA-1612)

Un barreñón grande (Frechilla, PA-1631)

Un barreñón (Frechilla, PA-1639)

Un varreñón de cobre en treinta y seis reales (Medina de Rioseco, VA-1640)

Dos barreñones vidriados (Medina de Rioseco, VA-1660)

Dos barreñones buenos en tres reales (Cuenca de Campos, VA-1660)

Lo puesto a la marxen [escudilla y un plato y un barreñón] (Cuenca de Campos, VA-1668)

Un barreñón grande de perihuela y un tajador y un mortero con media mano (Villalpando, ZA1620)

Un barreñón y una olla grande otra mas pequeña (Villalpando, ZA-1629)

Vn uarreñón verde (Villalobos, ZA-1654)

Un barreñón grande de orejones (Villalpando, ZA-1661)

Una herrada y un barreñón (Villalpando, ZA-1661)

Un barreñón de pez con su melas (Villalpando, ZA-1686)

Tres varreñones vañados de verde (Villalpando, ZA-1686)

Un uarreñón de periguela con una mela de ganado (Villalpando, ZA-1688)

Dos barreñones grandes de perihuela (Villalpando, ZA-1689)

Este término se documenta a partir de la primera mitad del siglo xv en el $C D H$, donde figura con diferentes acepciones; entre ellas, la de 'barreña o plato tosco donde se tomaba la comida', también como 'recipiente de uso doméstico' y en algunas ocasiones, se equipara con lebrillo. Cabe destacar que el uso mayoritario de esta palabra se da en el siglo XVII, figurando en obras técnicas y literarias, pero también en inventarios. En Tierra de Campos es un término frecuente en los inventarios de bienes, donde aparece entre enseres de cocina. Hay una clara preferencia de este término frente a barreño o barreña. Es posible que barreñón originalmente hiciera referencia a un barreño grande; sin embargo, con el tiempo termina lexicalizado y designando un tipo de recipiente en concreto, de ahí que nos encontremos este término modificado por el adjetivo grande. Los datos que ofrece el CorLexIn presentan una preferencia de uso en la Meseta Norte de la Península -Ávila, Soria, Zamora-, aunque aparece algún ejemplo un poco más al sur -Toledo-.

En estudios actuales esta voz se mantiene en zonas de León como Murias de Paredes, Sahagún, La Bañeza o Astorga. También se localiza en Salamanca, Palencia, Segovia, Álava o Galicia (Le Men, 2001, s. v. barreñón). 


\section{BARRIL [varril]}

Sust. m. 'Recipiente generalmente cilíndrico, de madera o de metal, que sirve para conservar, tratar y transportar diferentes líquidos y géneros', 'vaso de barro, de gran vientre y cuello estrecho, en que ordinariamente tienen los segadores y gente del campo el agua para beber' (DLE, 1. a y 2.a ac.). Nebrija lo identifica como recipiente para contener vino. Covarrubias equipara esta voz con 'vaso de tierra de gran vientre, y cuello angosto, en que ordinariamente tienen los segadores, y gente del campo el agua de beuer, [...] también llaman barriles los toneletes pequeños, en que se lleuan las azeytunas, y los pescados en escabeche, otros en que se tienen vino' (NTLLE, s. v. barril, Nebrija, 1495; Covarrubias, 1611). Este término está emparentado con barrica, barriga. Barriga es la forma genuinamente esp. de barrica, tomado del gasc. barrique, procedente de una base *barríca, cuyo origen se desconoce, de la cual procede asimismo barril (DECH, s. v. barriga, barrica).

Tres varriles zesteños, dos grandes y uno pequeño (Sahagún, LE-1608)

Un barril grande acarralado (Valderas, LE-1682)

Un barril de paxar (Medina de Rioseco, VA-1639)

Dos barriles de ostras (Medina de Rioseco, VA-1647)

Un cántaro y un barril (Villalpando, ZA-1632)

Este término lo documenta el $C D H$ a finales del siglo XIII en la General Estoria de Alfonso X (1270). Está muy presente en la documentación del CDH y el CORDE. No es una palabra tan frecuente en los documentos notariales, su presencia es menor si observamos los datos que nos ofrece el CorLexIn. Lo mismo nos ocurre en la zona de estudio, aunque se trata de una voz presente en los documentos, su uso no es tan extendido. Parece que la acepción con la que figura en los textos es la que nos ofrece el DLE: se utiliza para diferentes fines (contener líquidos u otro género de mercancías como ostras) y también está hecho con diferentes materiales. Aparecen en un inventario de Sahagún (León) unos varriles zesteños, en referencia a aquel barril que estaba forrado de mimbre o hecho de esta materia e impermeabilizado interiormente (Morala, 2017a: 144); tenemos también barriles de paxar y acarralados, estos últimos seguramente por su semejanza a las carrales (NTLLE, s. v. acarralado, Domínguez Suplemente, 1853).

\section{BERNEGAL [bernagal]}

Sust. f. 'Taza para beber, ancha de boca y de forma ondeada' (DLE). Covarrubias lo recoge como 'vaso tendido para beuer agua, es nombre que particularmente se usa en Toledo', en Autoridades se elimina la marca diatópica y se define como 'vaso tendido y no alto para beber agua ò vino. Hácense de várias figúras, por lo regulár son de plata' (NTLLE, s. v. bernegal, Covarrubias, 1611; Autoridades, 1726). Se trata de un término probablemente derivado del it. antic. vernicare 'barnizar', del mismo origen que barniz, y este a su vez del lat. VERONIX, -İCIS (DECH, s. v. bernegal, barniz). 
Un bernegal de plata dorado, otro bernegal de plata blanca balaustreado (Medina de Rioseco, VA-1640)

Un bernal [al margen pone bernegal] de plata sobredorado (Villalpando, ZA-1644)

Un bernagal de plata que pessará noventa y dos reales (Villalpando, ZA-1654)

Otra arca de castaño con su zerradura y llabe y dentro de ella un bernegal de plata (Villalpando, ZA-1660)

Un bernegal de plata (Villalpando, ZA-1666)

En la documentación los casos de bernagal son escasos. EI CDH lo recoge en la traducción y glosas de la Eneida de Enrique de Villena en 1442, donde es descrito como 'un vaso de madera en que beben los marineros'. En documentos posteriores encontramos bernegales de plata y otros de cerámica o barro. Pasado el siglo XVII, los ejemplos de este término no son frecuentes. En Autoridades se dice que 'aunque los primeros que se formaron fueron terrizos, yá comunmente por Bernegál se entiende el fabricado de plata ù oro' (NTLLE, s. v. bernegal, Autoridades, 1726).

El CorLexIn muestra una distribución diatópica de carácter general en la Península, además figuran ocurrencias en Canarias y América; estamos ante un término frecuente en la documentación de la época. Esta voz se presenta casi siempre haciendo referencia a un recipiente de plata u otros materiales valiosos.

En la documentación de la Tierra de Campos hemos localizado "bernegales de plata", junto a saleros, cucharas o vasos. También encontramos la variante bernagal con la alternancia de las vocales átonas /a/ y /e/, fenómeno muy común en esta época (Morala (2012a: 558, Perdiguero, 2016: 138). La variante bernagal es muy poco frecuente en los textos que conforman el $C D H$ y el CORDE, donde tan solo encontramos una ocurrencia en un documento del siglo XVII.

Parece ser que los bernegales formaron parte del ajuar doméstico español durante el siglo XVII. Su uso se extendió a América donde se siguieron fabricando a lo largo del siglo XVIII, mientras que en España las costumbres impuestas por los borbones frenaron su uso (Esteras Martín, 2004: 148-149).

BONETE [vonete] (Vid. Complementos de cabeza y tocados)

\section{BOTIJA [botixa, votija, votixa, botixilla]}

Sust. f. 'Vasija de barro mediana, redonda y de cuello corto y estrecho' (DLE). Covarrubias lo define como 'vaso de tierra ventrudo, con la boca y cuello angosto'. Autoridades, por su parte, lo define como 'bota de barro pequéña, ò cubeta de madéra, en que se suelen llevar los liquóres en los navíos' (NTLLE, s. v. botija, Covarrubias, 1611; Autoridades, 1726) Se trata de un término procedente del lat. tardío BŬTTİCŬLA, diminutivo de BUTTIS 'tonel' (DECH, s. v. botija).

Una botixilla de azeyte sin ella (Valdavida, LE-1606)

Dos botixas de aceyte (Sahagún, LE-1605)

Dos cántaros y una botija (Castroañe, LE-1637)

Dos botijas de olio pequeñas (Castroañe, LE-1637)

Una pozeta de madera y una botixa grande de aceyte (Castromocho, PA-1602)

Ocho botijas y un serbiçio en ochenta y quatro marauedís (Frechilla, PA-1613)

Quatro botijas de tener bino (Frechilla, PA-1639) 
Una botija de tener aceite (Frechilla, PA-1639)

Tres botijas de a tres açumbres (Frechilla, PA-1639)

Una botija de tener aceyte (Villalón, VA-1637)

Una botija de barro para aceyte (Villalón, VA-1637)

Otra olla y una botija (Villalpando, ZA-1629)

Una votixa de aceyte buena (Villalpando, ZA-1644)

Una botija de aceite de oja de lata (Villalpando, ZA-1661)

Una botija grande bidriada (Quintanilla del Monte, ZA-1689)

Se documenta a mediados del siglo XIV y aparece de forma regular en el $C D H$. Por el contexto en el que aparece en los documentos notariales de Tierra de Campos, podemos señalar que las botijas podían estar hechas de varios materiales (de barro, que en ocasiones estaba vidriado, o de hojalata) y que servían para llevar diferentes líquidos como aceite y vino. Los datos que nos ofrece el CorLexIn presentan un uso geográfico amplio en la Península, así como en Canarias y América.

Para Gordaliza, una botija es un 'recipiente de cerámica de una sola boca y también de una sola asa para agua o vino. Se usaban para llevar al campo los segadores y solían estar esmaltados de un solo color (verde o blanco marfil) y forrados de esparto las más de las veces' (Gordaliza, 1988: 47).

\section{BOTIJÓN [botixón]}

Sust. m. Término que recoge Autoridades como 'la botija grande con mucha barriga, y angosta de cuello, la qual se hace de barro' (Autoridades, 1726). Término derivado de botija, y este a su vez del lat. tardío BŬTTĩCǔLA diminutivo de BUTTIS 'tonel' (DECH, s. v. botija).

Un botijón (Frechilla, PA-1639)

Un botixón quebrado (Autillo de Campos, PA-1653)

Cinco botixas y tres botixones (Fechilla PA-1675)

Un botixón bidriado (Villalpando, ZA-1689)

El contexto en el que se presenta en la documentación terracampina confirma el significado que le otorga Autoridades, una especie de vasija que se enumera junto a otros recipientes domésticos. El recorrido que presenta esta palabra en el $C D H$ con el significado de 'recipiente doméstico' es breve, se documenta a partir del siglo XVI y a mediados del siglo XVII entra en retroceso y comienza a desaparecer de la documentación. Sin embargo, el CorLexIn documenta esta voz en diferentes puntos de la Península con este significado y de los que se puede extraer que se utilizaba sobre todo para contener aceite, aunque también agua.

\section{BÚCARO}

Sust. m. 'Vasija hecha con búcaro, principalmente para usarla como jarra para servir agua' (DLE, 2. a ac.). Covarrubias lo define como 'género de vaso, de cierta tierra colorada que traen de Portugal, y porque en la forma era ventriculoso y hinchado le llamaron búccaro o bucca, que vale el carrillo hinchado [...], Autoridades habla de un 'vaso de barro fino, y oloroso, en que se echa el agua para beber, y cobra un sabór agradable y fragante. Los hai de diferentes hechuras y tamaños. Vienen de las Indias, y son mui estimados y preciosos' En la siguiente edición (1770) 
afirma que también se traen de Portugal. El DRAE de 1817 'se da este nombre à tres especies de arcilla, que se encuentran en varias partes de América, y que despiden, especialmente mojadas, un olor agradable [...]' (NTLLE, s. v. búcaro, Covarrubias, 1611; Autoridades 1726, 1770; DRAE, 1817). Se trata de una voz que procede del dialecto mozárabe, y este del lat. PŌcúLUM 'copa'; es posible que el castellano lo tomara del portugués ( $D E C H$, s. v. búcaro).

Un búcaro de barro fino (Villalpando, ZA-1689)

El CDH y el CORDE documentan la voz púcaro en una obra fechada en 1569 -"No ay cosa que más dessee ni en más se tenga que un púcaro de agua fría"-.

Los casos que ofrece el CorLexIn se localizan en el sur de la Península, Canarias y en América -Chile- donde aparece la variante púcaro. El ejemplo localizado en Tierra de Campos se halla junto a un azafate de paja, que servía para llevar el búcaro de un lugar a otro y además se puntualiza que se trata de barro fino, dotándolo así de mayor valor. Seseña indica que este término se utilizaba en la Península para hacer referencia a una especie de vasija de barro o de cristal pensada para poner flores (Seseña, 2009: 9).

\section{CALABAZA [calavaza, calauacita]}

Sust. f. Aparece en el $D L E$ como término sinónimo de calabacino 'calabaza seca y hueca, para tener vino u otro líquido' ( $D L E, 3$. a ac.). Nebrija lo registra con la grafía calabaça, al igual que Covarrubias. Autoridades recoge esta voz en su quinto lema como 'botija que se hace de cierta espécie de calabaza, de la qual sacan la carne y pepítas, y seca sirve para llevar vino' (NTLLE, s. v. calabaza, Nebrija, 1495; Covarrubias, 1611; Autoridades, 1729). Se trata de un vocablo de origen prerrománico, probablemente ibérico, cuya base es *calapaccia (DECH, s. v. calabaza).

Una calavaza de vino (Cea, LE-1621)

De los textos analizados de Tierra de Campos, tan solo encontramos un ejemplo de este término usado como 'recipiente para contener líquidos' en la localidad leonesa de Cea; en este caso estaba destinado a contener vino. Con esta acepción aparece en los documentos desde el siglo XIII $(C D H)$. Se trata de una voz que está poco presente en los inventarios de la época: se reduce a un par de ejemplos en Murcia y Toledo como contenedor de líquidos. En Ciudad Real aparece este vocablo con la acepción de 'pimentero' (CorLexIn, s. v. calabaza).

Los otros dos ejemplos que aparecen en Tierra de Campos tienen que ver con algún tipo de joya u objeto decorativo de cierto valor:

En el dicho [barquillo] una calauacita con brocal de plata (Medina de Rioseco, VA-1642)

Una calabaza engazada en oro (Mediana de Rioseco, VA-1661)

Terreros y Pando (1786) habla de calabaza como 'nombre que le dan los lapidarios a las perlas de figura chata a modo de almendra', y con esta acepción aparece en inventarios de Sevilla (1640), donde encontramos "quarenta perlas gordas y calauaças y una gargantilla" y "unos sarsillos de oro con sus calabazas de perlas" (CorLexIn). El diminutivo calabacillas se recoge desde Autoridades: "se llaman tambien por semejanza las perillas de perlas ú de vidro que se ponen en las oréjas las mugéres" (NTLLE, s. v. calabacillas, Autoridades, 1729). En la zona 
de estudio aparece el diminutivo en singular como adorno de un barquillo; la variante calabacita se documenta en el CorLexIn en un inventario de Córdoba con la acepción de 'joya'.

\section{CANTIMPLORA [cantinplora]}

Sust. f. desus. 'Recipiente de metal, semejante a la garrafa, que sirve para enfriar el agua' (DLE, 4. a ac.). Covarrubias define este término como 'vna garrafa de cobre con el cuello muy largo para enfriar en ella el agua, o el vino, metiendola, y enterrandola en la nieue, o meneandola dentro de un cubo con la dicha nieue, cosa muy conocida y muy vsada en España, y en todas partes [...]'; Autoridades añade que, además, pueden ser de plata o estaño (NTLLE, s. v. cantimplora, Covarrubias, 1611; Autoridades, 1729). Término tomado del cat. ant. cantiplora (hoy cantimplora), y este compuesto de canta i plora 'canta y llora', por el ruido que hace la cantimplora al gotear (DECH. s. v. cantimplora).

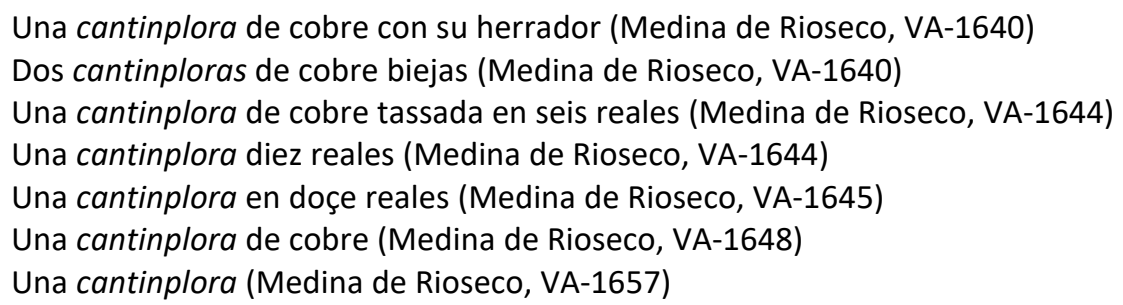

Respecto a la distribución diatópica de este término, el CORDE y el CDH registran su presencia en los textos a finales del siglo XVI en obras literarias y con un sentido figurado. Con la acepción académica está ampliamente documentado en el siglo XVII donde aparece en varias relaciones de bienes. El CorLexIn ofrece poco más de una veintena de ocurrencias distribuidas a lo largo del territorio peninsular. También atestigua algún ejemplo en América -México-. En Tierra de Campos esta voz se concentra en inventarios pertenecientes a protocolos de Medina de Rioseco y en todos los casos este término referencia 'un tipo de vasija que se empleaba en el Siglo de Oro para enfriar el agua' ( $D E C H$, s. v. cantimplora). Estos recipientes eran en su mayoría de cobre.

\section{CARACOL}

Sust. m. 'Concha de caracol' (DLE, 2. a ac.). No se registra en el $D L E$ ni en ningún diccionario académico con la acepción que encontramos en los textos analizados. Es una voz común a los tres romances hispánicos y a la lengua de Oc, de origen incierto, puede que sea un antiguo préstamo catalán u occitano (DECH, s. v. caracol).

Un caracol grande para agua uendita (Villalpando, ZA-1633)

Tan solo se ha localizado un ejemplo de este término en los documentos analizados, perteneciente a un inventario de bienes de una fortaleza perteneciente al Condestable de Castilla, por lo que puede tratarse de un objeto lo suficientemente exclusivo como para que solo estuviera en las manos de unos pocos. Por el contexto, se puede deducir que se trataba de una especie de concha para contener el agua bendita, que muy probablemente se encontrase en el 
oratario particular que poseía dicha fortaleza. El carácter singular de este término se extiende al CorLexIn donde se documentan un par de ejemplos localizados en Santander y Sevilla.

\section{CHOCOLATERA}

Sust. f. 'Vasija en que se sirve el chocolate' (DLE, 4. ac ac.). Autoridades registra chocolatera o chocolatero como 'el jarro de plata, cobre, azófar, ù barro, en que se hace chocolate, el qual es alto, y más ancho del medio que de los extremos' (NTLLE, s. v. chocolatera, Autoridades, 1729). Término derivado de chocolate, palabra de origen azteca, pero de formación incierta (DECH, s. v. chocolate).

Una chocolatera (Paredes de Nava, PA-1689)

Dos chocolateras de cobre (Medina de Rioseco, VA-1685)

Una chocolatera con su molinillo y dos xícaras de Talabera (Villalpando, ZA-1696)

En el $C D H$ se ha encontrado un solo ejemplo de este término en el siglo que nos ocupa, perteneciente al inventario de bienes de un doctor:

Tres chocolateras de plata (Inventario de los bienes del doctor Martín Martínez, 1655)

El corpus terracampino presenta tres ejemplos de la voz chocolatera repartidos por diferentes localidades y en ocasiones inventariadas junto al molinillo y las jícaras donde se tomaba el chocolate. En el CorLexIn figura la forma en masculino chocolatero en las provincias andaluzas y Canarias. La variante masculina chocolatero presenta una preferencia de uso en Andalucía ( $D L E$, 3. a ac.), al que habría que sumar el de Canarias, mientras que la forma en femenino se prefiere en el resto de las regiones penisulares. Es un término de nueva adquisición -derivado de chocolate, procedente de América-que se irá consolidando en siglos posteriores.

\section{COCO}

Sust. m. 'Vaso o recipiente elaborado con el endocarpio de I coco', 'cada una de las cuentas procedentes de las Indias, de color oscuro, con unos agujeritos, utilizadas para hacer rosarios' (DLE, 4. y y 6. ac.). El DRAE de 1780 lo registra como 'el vaso, xícara, ú otra vasija hecha de cáscara de coco' (NTLLE, s. v. coco, DRAE, 1780). Se trata de una voz de creación expresiva, posiblemente, paralela pero no descendiente del gr. кóккоৎ 'grano, pepita' (DECH, s.v. coco I).

Un coco de tener vino (Villalón, VA-1637)

El término coco está presente en la documentación desde el siglo XIII, en la General Estoria (CORDE), aunque no con la acepción con la que aparece en los textos de Tierra de Campos. Con el significado de 'recipiente' el CORDE ofrece un par de ejemplos fechados en el siglo XVII:

Un coco grande a modo de barco con pie de bronçe dorado y listas de lo mismo (Inventario de bienes de Jorge de Santa María racionero de la Santa Iglesia de Toledo, 1617)

Un coco guarnecido de oro (Discurso sobre el nacimiento y bautismo de la princesa Margarita de Austria, 1623)

El CorLexIn ofrece una escasa nómina de ejemplos con este significado, aunque representa un ámbito geográfico muy amplio; así, localiza varias ocurrencias en la Península -Cantabria, Madrid, Granada y Almería-, otra en Canarias y también en América, y por el contexto nos hace 
pensar que estamos ante un tipo de recipiente. Este uso exiguo se extiende a la Tierra de Campos, donde solo encontramos un ejemplo con esta acepción de recipiente, en este caso, de contener vino. En la mayoría de los casos, se hace referencia a un tipo de vaso guarnecido de plata que nos recuerda a los bernegales y los barquillos que hemos analizado anteriormente. Los asientos localizados en Santander, Madrid y la de Tierra de Campos dan información sobre el continente del recipiente, "con un poco de bálsamo", "para chocolate" o "de tener vino", este útimo caso es el recogido en Tierra de Campos.

Además, en la zona terracampina encontramos esta voz con la 6. a acepción que da el DLE, como cuentas para hacer rosarios.

Un rosario de coco de quentas gruessas negras (Valderas, LE-1647)

Un rosario de coco fino guarneçido de plata (Medina de Rioseco, VA-1648)

El CorLexIn ofrece media docena de casos repartidos en el centro oriental -Cuenca y Guadalajara- y el norte -Vizcaya, Guipúzcoa y Santander- de la Península.

\section{COLODRA / 0}

Sust. f. 'Vasija de madera en forma de barreño que usan los pastores para ordeñar las cabras, ovejas y vacas' o 'recipiente de madera, como una herrada, en que se tiene el vino que se ha de ir midiendo y vendiendo al por menor' (DLE, 1. a y 2. a ac.). Covarrubias lo define como 'cierto género de barreñón hondo, en que suelen ordeñar las cabras, ouejas y vacas', en Autoridades, además registran este término como una voz usada en Castilla la Vieja para designar 'un vaso mui grande de madéra, hecho á modo de una herrada, en el qual tienen prevenido el vino que se ha de ir midiendo, para venderle por menór' (NTLLE, s. v. colodra, Covarrubias, 1611, Autoridades, 1729). Palabra de origen incierto, posiblemente prerromano de raíz indoeuropea. La voz colodro es derivado de colodra y probablemente con el mismo sentido (DECH, s. v. colodra).

Dos taxaderos, e una colodra y un plato de madera en tres reales (Sahagún, LE-1601)

Una colodra biexa con su tapador (Sahagún, LE-1608)

Un hembudo y un colodro de madera (Frechilla, PA-1612)

Un colodro de madera en un Real (Frechilla, PA-1613)

Es un término poco frecuente en la documentación; el $C D H$ y el CORDE registran la forma colodra en el Fuero de Cáceres datado en 1234 con la acepción de recipiente: "una colodra de uino". Sin embargo, el uso de esta voz no debió de ser muy extenso, ya que su presencia en la documentación académica es esporádica. Tampoco hay ejemplos con los que cotejar los datos en el CorLexIn, donde solo se localizan un par de ejemplos pertenecientes a Tierra de Campos y una ocurrencia en Zaragoza en la que el término colodra funciona como adjetivo: "una salvilla con una taça colodra". Perdiguero localiza colodra con la acepción de 'funda para guadar las piedras de afilar', recogida por la Academia como propia de Palencia y Cantabria, y que este autor encuentra en documentos notariales de León y Burgos (Perdiguero, 2013: 238).

En cuanto a su variante masculina, colodro, el DLE da la definición de 'especie de calzado de madera'; sin embargo, en los ejemplos que se han encontrado en los protocolos notariales terracampinos la acepción es otra, ya que aparecen en singular y rodeados de tinaquillos, 
tinacos, cubas, carrales..., términos todos ellos que hacen referencia a tipos de recipientes para transportar, casi siempre, vino.

\section{COPA}

Sust. f. 'Vaso con pie para beber' (DLE). Término registrado desde Nebrija, Autoridades lo define como 'vaso capáz para beber, que se hace de vidro, crystal, plata, oro y de otros diferentes materiáles, cuya hechúra es semejante à la de un caliz; menos que es mas angosto por abaxo, y con su pie' (NTLLE, s. v. copa, Nebrija, 1495, Autoridades, 1729). Palabra procedente del lat. vg. CŬPPA íd. (DECH, s. v. copa).

Una dozena de copas de taberna (Medina de Rioseco, VA-1660)

A pesar de la escasa nómina de casos en Tierra de Campos, estamos ante un término de uso general. En bases de datos como el CORDE y el $C D H$ presentan un nutrido número de concordancias desde el siglo XIII a la actualidad.

El CorLexIn ofrece un abanico importante de ocurrencias que se reparten por un extenso ámbito geográfico penínsular, insular y americano. Estas copas eran de nácar, vidrio, cobre, plata... En Tierra de Campos aparecen "copas de taberna", pero el contexto no ofrece la información suficiente como saber qué tipo de copa se está inventariando. En la Pragmática de Felipe IV, sobre Precios y salarios en Jaén en 1627, la sección de "Bidrios que se venden en Jaén [...]" aparecen las copas de taberna como "Bidrios de Cuenca" (Rodríguez Molina et al., 1986: 436).

\section{CUBILETE [qubilete, gubilete]}

Sust. m. 'recipiente de cobre u hojalata, redondo o abarquillado y más ancho por la boca que por el suelo, que usan como molde los cocineros y pasteleros para varios usos de sus oficios' (DLE). Esta voz la recoge Percival en 1591 como goblet 'copa' (NTLLE, s. v. cubilete, Percival, 1591). Término procedente del francés gobelet 'vaso de beber, sin pie y sin asa' ( $D E C H, \mathrm{~s}$. v. cubilete).

Un qubilete, dos coberteras, una pequeña y otra grande (Grajal de Campos, LE-1658)

Tres ollas grandes, dos cazuelas, otras tres ollas medianas, un gubilete de cobre (Boadilla de Rioseco, PA-1692)

Cuatro cubiletes de cobre (Medina de Rioseco, VA-1640)

Dos cubiletes y una cobertera de cobre (Medina de Rioseco, VA-1643)

Quatro cubiletes de cobre (Medina de Rioseco, VA-1647)

Un cubilete de cobre (Medina de Rioseco, VA-1660)

Una tartera y un cubilete de cobre (Medina de Rioseco, VA-1671)

Un cubilete (Villalpando, ZA-1689)

Aparece en los documentos de la Tierra de Campos con diferentes variantes: la normativa cubilete o qubilete, pero también gubilete. Esta forma la registra la Academia en su edición de 1803 con la marca de voz antigua y en la de 1884 figura como sinónimo de cubilete (NTLLE, s. v. gubilete, DRAE, 1803, DRAE, 1884). 
Desde una perspectiva diacrónica, este término se documenta en el $C D H$ a finales del siglo XV en una obra de Juan del Enzina, utilizado en sentido alegórico. Un siglo más tarde figura en una obra de Juan de Pineda en la cual el significado de esta voz queda más claro:

[...] y yo no matara la sed con dos cubiletes de los del señor Maestro y matéla con poco más de la mitad del bernegal, que no pasa de tres cuartillos (Juan de Pineda, Diálogos familiares de la agricultura cristiana, 1589)

Los datos que ofrece el CorLexIn presentan una preferencia de uso en el área centromeridional de la Península -Toledo, Cuenca, Almería, Jaén, Huelva, Málaga y Sevilla-, además de atestiguar su presencia en América. En Tierra de Campos esta voz es frecuente en los textos para designar un recipiente, que se suele inventariar junto a los cacharros de cocina -ollas, cazuelas, coberteras, asadores...-. Los ejemplos que aparecen en la zona terracampina suelen ser de cobre, aunque en localidades de la Península y América se recogen "cubiletes de plata", dotando al objeto de mayor valor.

\section{ESCUSABARAJA [escusabaraxa]}

Sust. f. 'Cesta de mimbre con tapa' (DLE). Covarrubias recoge la voz escusabarajas en plural y la define como 'cesta grande de sirge o mimbres blancas, con una asa por lo alto y una cubierta, de manera que se puede echar un candadito, para que vaya seguro lo que lleva dentro; y por ir cerrada excusa pesadumbres y cuestiones si falta o no falta algo de lo que iba dentro'. Autoridades la registra con $x$ y en singular excusabaraja (NTLLE, s. v. escusabaraja/ excusabaraja, Covarrubias, 1611). Término compuesto de esconder y baraja 'riña' (DECH, s. v. esconder y baraja).

Una escusabaraja de madera enbutida de marfil con su çerradura y sin llaue (Villalpando, ZA-1689)

Una escusabaraxa grande blanca (Villalpando, ZA-1696)

En general es una palabra poco frecuente en los textos. Aunque Covarrubias la registra en su Tesoro y el DLE la mantiene sin marca diatópica y sin señalar su desuso, son pocos los ejemplos que se localizan en la documentación en general. EI DECH localiza un ejemplo en plural en la Pícara Justina de 1605 y en el $C D H$ aparece algún caso en textos literarios, como el de 1629 en una obra de Tirso de Molina o el de El sí de las niñas de Leandro de Moratín en 1805 con acepciones muy cercanas a la de azafate.

Esta falta de testimonios se traslada al CorLexIn donde tan solo se localiza un ejemplo en La Solana (Ciudad Real). En Tierra de Campos se localizan un par de ejemplos en la localidad zamorana de Villalpando a finales del siglo XVII. Gómez Ferrero también localiza otro par de ocurrencias datadas en La Bañeza en el siglo XIX.

\section{FIAMBRERA}

Sust. f. 'Recipiente con tapa bien ajustada, que sirve para guardar comida o llevarla fuera de casa' o 'cestón o caja para llevar la provisión de alimentos fríos' (DLE, 1. a y 2. a ac.). Para Covarrubias se trata de 'un género de cestones, que suelen lleuar los señores de camino con cosas fiambres, para poder comer y beuer, quando, y donde quisieren'. Covarrubias lo registra 
en plural; Autoridades recoge la entrada en singular y esta acepción se mantiene hasta la actualidad (NTLLE, Covarrubias, 1611, Autoridades, 1732). Término derivado de frío, del lat. FRĪGĬDUS (DECH, s. v. frío).

Una fiambrera de ojadelata (Villalpando, ZA-1633)

Tan solo se ha localizado un ejemplo de esta voz en los documentos analizados de Tierra de Campos. Desde el punto de vista diacrónico, el $C D H$ presenta un uso esporádico de la palabra durante el siglo XVI, que es cuando lo registra por primera vez. Poco a poco, la presencia de esta voz se va incrementado en los textos, pero no es hasta el siglo XIX cuando su documentación se hace más frecuente.

Los datos que nos ofrece el CorLexIn dan a entender que no era de uso frecuente en la época, ya que no se han localizado ocurrencias. Tan solo encontramos un caso en la zona de estudio donde referencia un tipo de recipiente de hojalata. El contexto no da mucha información sobre este objeto, ya que aparece inventariado junto a una balanza, una romana o un reloj, pero podemos sospechar que se trata de un artículo novedoso o de cierto valor si atendemos a la propiedad del inventario, el Condestable de Castilla, Bernardino Fernández de Velasco y Tovar.

En estudios más recientes como el Vocabulario de Frómista aparece como 'cacerola', ordinariamente cilíndrica y con tapa bien ajustada, que sirve para llevar la comida fuera de casa (Renedo, 2007: 35).

\section{GARAPIÑERA}

Sust. f. 'Vasija que sirve para garapiñar o congelar los líquidos metiéndola ordinariamente en un cubo de corcho, más alto y ancho que ella, y rodeándola de nieve y hielo, con sal' (DLE). Esta voz ya aparece registrada en Autoridades como 'vaso de cobre, estaño u otro metal, mui ancho de vientre, con su cuello y tapa, que sirve para helar y garapiñar los liquóres y bebidas' (NTLLE, s. v. garapiñera, Autoridades, 1734). Se trata de una palabra derivada de garapiñar, procedente de un lat. vulgar *carpiniare, derivado de CARPĔRE (DECH, s. v. garapiñar).

Zinco cántaros y una media cántara, tres garapiñeras, dos tarteras y dos couerteras, todo de cobre que pessa el cobre sessenta y seis libras (Medina de Rioseco, VA-1685)

Localizamos un único ejemplo en el corpus analizado, hecho que no resulta extraño si cotejamos las búsquedas en otros corpus. No es frecuente en las relaciones de bienes, el CorLexIn no nos da noticia alguna sobre este término. Localizamos una ocurrencia en Madrid: "garapiñera de plata guarnecida la corchera de plata con un cucharón con cabo hueco y dientes de plata" en un inventario perteneciente a los marqueses de Castel Rodrigo y fechado en 1681 (Puerta Rosell, 1994: 185). Desde un punto de vista diacrónico, la voz garapiñera presenta una nómina reducida de ejemplos en los textos que conforman el $C D H$, donde se documenta desde mediados del siglo XVIII (1743) hasta finales del siglo XIX con la acepción que le da la Academia.

El ejemplo que localizamos en Tierra de Campos se inventaría junto a cántaros, tarteras o coberteras, en definitiva, entre los enseres de la cocina, pero no resulta seguro afirmar que comparta la acepción académica. Cabe destacar que los ejemplos que encontramos están datados a finales del siglo XVII, lo que puede indicar que se trata de una voz de nueva adquisición. 


\section{GARRAFA}

Sust. f. 'Vasija esférica, que remata en un cuello largo y estrecho y sirve para enfriar las bebidas, rodeándolas de hielo' (DLE). Covarrubias lo registra como 'vaso conocido de vidrio ventricoso y de cuello largo, y angosto'; en Autoridades a este tipo de vaso se le da la función de 'enfriar liquores y bebidas' (NTLLE, s. v. garrafa, Covarrubias, 1611, Autoridades, 1734). Se trata de una palabra de origen incierto (DECH, s. v. garrafa).

Dos garrafas de cobre estañadas, la una maior y la otra menor (Paredes de Nava, PA-1690)

Un vonete y una cesta carretera, una garrafa quebrada todo viexo (Villalón, VA-1642)

Una garrafa de bidrio con su corchera (Medina de Rioseco, VA-1660)

Como indican Junquera y Morala, este término se recoge de forma tardía en los textos que conforman el CORDE y el $C D H$, concretamente a partir de 1528, en La lozana andaluza de Francisco Delicado (Junquera y Morala, 2019: 205).

El CorLexIn ofrece unas cuantas ocurrencias repartidas sobre todo por el Centro y Norte de la Península; también atestigua su presencia en Canarias, aunque no en América. En Tierra de Campos encontramos tres ocurrencias de este término con la acepción que da el DLE. Esta voz referencia un tipo de vasija que podía ser de vidrio o cobre y además solía ir acompañada de una corchera, 'cubeta hecha de corcho empegado o de madera, en que se pone la garrafa con nieve o hielo para enfriar la bebida' (DLE, 3. a ac.).

\section{JARRA [xarra, garra, jarrica]}

Sust. f. 'Vasija de barro, porcelana, loza, cristal, etc., con cuello y boca anchos y una o dos asas' (DLE). Covarrubias lo registra como 'vaso ventrudo con dos asas' y Autoridades lo define como 'vaso formado con vientre y cuello, y dos assas, en que se distingue del jarro' (NTLLE, s. v. jarra, Covarrubias, 1611, Autoridades 1634). Este término procede del árabe ýárra, id. (DECH, s. v. jarra).

Dos xarras de Talabera real e medio (Sahagún, 1600)

Una xarra blanca de Talavera quebrada (Sahagún, LE-1608)

Dos jarras de Talabera, la una quebrada (Grajal de Campos, LE-1613)

Una jarra de Talavera pintada grande (Cea, LE-1621)

Una jarra de Talabera y un platillo y otra jarrica y una escudilla (Grajal de Campos, LE-1658)

Una jarra de Talavera buena (Castromocho, PA-1611)

Dos escriños, una jarra de Talabera y un bruñidor (Frechilla, PA-1640)

Una jarra de Talabera buena (Autillo de Campos, PA-1653)

Una jarra de Talabera (Boadilla de Rioseco, PA-1689)

Una jarra de plata sobredorada con su tapador (Medina de Rioseco, VA-1649)

Dos fuentes grandes, tres medias fuentes, diez platos y una jarra de Talabera fina (Medina de Rioseco, VA-1651)

Una jarra grande de agua y un caço (Medina de Rioseco, VA-1657)

Una jarra y una aguamanil de bidrio tassado en dos reales (Cuenca de Campos, VA-1666)

Una fuente, un salero, una garra, dos platas y una escudilla tasados en ocho reales (Cuenca de Campos, VA-1670)

Una xarra de Talabera (Villalpando, ZA-1637)

Dos jarras de Talabera la una fina y la otra basta (Villalpando, ZA-1661)

Dos jarras de Talauera (Villalpando, ZA-1676)

Una xarra de Talavera (Villalpando, ZA-1686) 
Se trata de una palabra frecuente y de uso general en los documentos. Figura en el $\mathrm{CDH}$ a partir del siglo XIII. El uso de este término está generalizado en la Península y en América (CorLexIn). En los protocolos de Tierra de Campos aparecen tres variantes: jarra, xarra y garra, en los dos primeros casos es normal representar el sonido de la velar $/ x /$ con ambas grafías en esta época. En el caso de garra se trata de un trasvase gráfico, dado que la grafía /g/ en los contextos con las vocales /e/, /i/ tienen el mismo sonido que la / $\mathrm{x} /$, lo que provoca que algunas veces ocurra este tipo de cambio (Morala, 2014c: 288, nota 9). En el corpus analizado aparecen dos ejemplos con objetos destinados al aseo personal: es el caso de Cuenca de Campos (Palencia), donde jarra aparece junto a un aguamanil. Le Men señala para jarro una acepción que no recoge el $D L E$ y que estaría próxima a esta última función que encontramos para jarra en los documentos; esta definición es la de 'jofaina de metal que contiene el agua de lavarse las personas en la alcoba' (Le Men, 2007, s. v. jarro).

\section{JARRO [xarro, garro]}

Sust. m. 'Vasija de barro, loza, vidrio o metal, a manera de jarra y con solo un asa' (DLE). Este término lo recoge Nebrija en su Vocabulario. Autoridades lo define como 'vaso como la jarra, con una assa sola, y regularmente con pico, por donde se echa el liquór' (NTLL, s. v. jarro, Nebrija, 1495, Autoridades, 1734). Palabra derivada de jarra (DECH, s. v. jarra).

Un xarico berde (Castrillo, LE-1606)

Dos xarros uno berde y otro blanco buenos (Valdavida, LE-1606)

Dos xarros de barro (Cea, LE-1610)

Dos cántaros, dos cantarillas y tres xarros (Grajal de Campos, LE-1613)

Seis platos y seis escudillas y dos garros y dos botixas de aceyte (Sahagún, LE-1605)

Zinco garros viejos (Sahagún, LE-1608)

Dos jarros (Frechilla, PA-1640)

Dos jarros de teja (Frechilla, PA-1639)

Un jarro de cobre pequeño en ocho reales (Frechilla, PA-1675)

Un jarro bidriado grande (Frechilla, PA-1675)

Un jarro de plata que pessa veinte y quatro onças (Paredes de Nava, PA-1689)

Un jarro de plata sobredorada (Medina de Rioseco, VA-1640)

Otro xarro pequeño deçhura de guebo con las guarniçiones doradas (Medina de Rioseco, VA1649)

Un jarro de plata blanco con listas doradas (Villalpando, ZA-1650)

Un jarro de plata blanco (Villalpando, ZA-1656)

Seis garros para bino y quatro jarras de barro (Villalpando, ZA-1661)

Esta voz se halla con frecuencia en los documentos analizados y en el resto de textos de la época (CorLexIn). Se documenta a partir del siglo xV en el $C D H$. Como ocurre con la palabra jarra, están presentes las tres variantes en los textos jarro, xarro y garro, donde existe el trasvase gráfico en el último caso. Al contrario que la jarra, que en la mayor parte de los ejemplos está fabricada con cerámica fina, más en concreto, la procedente de Talavera, el jarro presenta varios materiales en su elaboración, por lo que encontramos jarros de teja, de barro, de cerámica fina, de vidrio, de cobre o de plata. 


\section{JíCARA [xícara]}

Sust. f. 'Vasija pequeña, generalmente de loza, que suele emplearse para tomar chocolate' (DLE). En Autoridades se señala que es 'voz americana, que vale coco, ò vaso, de que se hace dél' (NTLLE, s. v. jícara, Autoridades, 1739). Probablemente tomado del náhuatl sikálli 'vasija de calabaza, vasija de ombligo', cpt. de šíkilli, 'ombligo' y kalli, 'receptáculo' (DECH, s. v. jícara).

Dos jícaras de porzelana (Medina de Rioseco, VA-1660)

Una xícara de Talavera con su cubierta en dos reales (Cuenca de Campos, VA-1668)

Una chocolatera con su molinillo y dos xicaras de Talabera (Villalpando, ZA-1696)

Es un americanismo señalado en Autoridades y escasamente representado en los documentos del siglo XVII. En dicha época el término no está totalmente consolidado y hay pocos ejemplos en la documentación. El CDH localiza esta voz a partir de 1568 y muchos de los documentos analizados provienen del continente americano. En los inventarios de la época (CorLexIn) se localizan dos ejemplos, uno en La Rioja y otro en Madrid. Las tres ocurrencias localizadas en Tierra de Campos parecen mantener el significado académino por el contexto en que se hallan. En el ejemplo de Villalpando se inventaría junto a una chocolatera y el molinillo.

En estudios dialectales más modernos, Gordaliza registra este término como 'jarrita pequeña con asa, usada para vino o también para chocolate' y señala que también es común encontrar la variante jíquera (Gordaliza, 1988: 131).

\section{PIPOTE}

Sust. m. 'Pipa pequeña que sirve para encerrar y transportar licores, pescados y otras cosas' $(D L E)$, definición presente desde Autoridades. Término derivado de pipa, y este a su vez del lat. vulgar *PĪPA 'flautilla', derivado de PİPARE 'piar' (DECH, s. v. pipa).

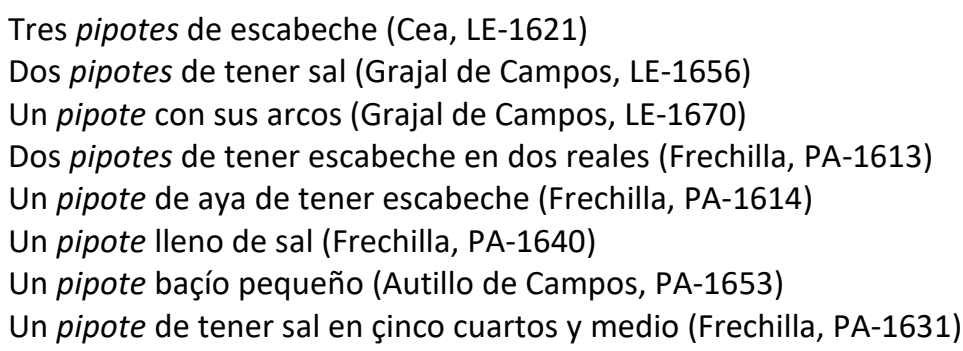

El $C D H$ documenta este término a partir del siglo XVI, en un documento de Fray Hernando de Talavera fechado en 1500, donde aparece con la acepción académica:

Que los pescados de escabeche que tuviere sea en sus pipotes o en barreñones o olla vidriado (Fray Hernándo de Talavera, Instrucción para el régimen interior de su palacio, 1500)

Sin embargo, hay una escasa nómina de ejemplos y la mayoría son del siglo XVII. El CorLexIn presenta dos ocurrencias localizadas en el sur de la Península -Córdoba y Málaga-. Estos datos contrastan con lo encontrado en la zona de estudio, pues en Tierra de Campos aparecen diferentes casos de la palabra haciendo referencia a una especie de barril pequeño donde se conservaba el escabeche y que, en otras ocasiones, contenía sal. En estudios dialectales más recientes esta palabra sigue apareciendo con la acepción que tiene en la época de estudio. Gordaliza lo recoge como un 'barril o tonel pequeño: "un pipote de chicharros"' (Gordaliza, 1988: 
179). Y Le Men, en su estudio sobre el léxico leonés, también localiza esta palabra en Tierra de Campos como 'barril o tonel pequeño que se usaba, generalmente, para guardar y transportar el pescado en escabeche' (Le Men, 2009, s. v. pipote).

\section{POMO}

Sust. m. 'Frasco o vaso pequeño de vidrio, cristal, porcelana o metal, que sirve para contener y conservar los licores y confecciones olorosas' (DLE, 3. a ac.). Se mantiene la acepción dada por Autoridades que como información adicional dice que tiene 'hechura de una manzana' (NTLLE, s. v. pomo, Autoridades, 1737). Término tomado del lat. PŌMUM 'fruto comestible de árbol' (DECH, s. v. pomo).

Un pomo de plata dorado en treinta reales (Medina de Rioseco, VA-1646)

Un pomo de plata sobredorado (Medina de Rioseco, VA-1651)

Un pomo de plata dorado (Villalpando, ZA-1631)

Es un término poco frecuente en los documentos de Tierra de Campos. Por el contexto en el que se halla esta palabra, debía de tratarse de un recipiente refinado, de cierto valor, donde se guardaban perfumes. EI CDH localiza el término con esta acepción a principios del siglo XV en un Tratado de la epidemia y pestilencia, fechado en 1410.

Los datos que nos ofrece el CorLexIn sitúa el uso de esta voz sobre todo en puntos de la mitad Norte de la Península: León, Guipúzcoa y Zaragoza. En cuanto a la función que cumple este recipiente no está muy clara en los ejemplos que nos facilita el corpus terracampino, donde referencia el material del que está hecho, en este caso plata. Algunos inventarios nos pueden dar ciertas pistas del significado, en un inventario zaragozano se localiza "un pomo de plata para tener agua de olor" y "un pomito de plata para tauaco o agua de olor" (Zaragoza, 1647) que coincide con la definición que da la Academia para este término. Esta escasa nómina de casos puede deberse a que estamos ante un objeto de cierto valor y con una función meramente decorativa.

\section{REDOMA}

Sust. f. 'Vasija de vidrio ancha en su fondo que va estrechándose hacia la boca' (DLE). Este vocablo aparece desde Nebrija. Covarrubias dice que 'destos vasos usan los boticarios para sus aguas y jaraues'. Autoridades no mantine este uso del que habla Covarrubias y mantiene la definición académica que mantenemos en la actualidad para este término (NTLLE, s. v. redoma, Nebrija, 1495, Covarrubias, 1611 y Autoridades, 1737). Se trata de una voz patrimonial del cast. y el port., documentada en la Península desde el siglo x y de origen incierto, quizá del árabe (DECH, s. v. redoma).

Dos redomas de vidrio una grande y otra pequeña (Castrillo, LE-1606)

Dos zestillas viexas pequeñas y una vasera con una redoma (Sahagún, LE-1608)

Un vasso y una redoma de vidrio vueno (Riosequillo, LE-1610)

Dos redomas de bidrio (Castroañe, LE-1637)

Tres bídrios y un plato y una redoma pequeña (Fechilla PA-1675)

Una redoma de bidrio grande (Villalpando, ZA-1689)

Una redoma de vídrio doble (Villalpando, ZA-1696) 
EI CORDE documenta la voz redoma en textos medievales, "et IIII. cugares de plata. Et Ia redoma erag" en el Inventario de las alhajas y ornamentos de la iglesia de Covarrubias, fechado en el año 1112. El resto de datos facilitados por el CORDE y el $C D H$ reflejan un uso mayoritario de esta voz en los siglos XVI y XVII.

Los datos que ofrece el CorLexIn sitúan esta voz en distintos puntos de la Península, en casi todos los casos con la acepción académica, como una 'vasija de vidrio para contener líquidos'. En los ejemplos que aparecen en Tierra de Campos no tenemos la información suficiente para saber exactamente el contenido y función de esta vasija, tan solo se hace mención del material con el que están hechas: vidrio.

\section{SERVIDOR [seruidor, serbidor]}

Sust. m. El DLE en su 6. a acepción lo equipara a 'orinal'. Recogido por Nebrija en su Vocabulario como 'bacín' y En Autoridades equipara este término también con 'servicio' (NTLLE, s. v. servidor, Nebrija, 1495, Autoridades, 1739). Se trata de una palabra derivada de siervo, del lat. SĔRVuS 'esclavo' (DECH, s. v. siervo).

Un seruidor (Frechilla, PA-1639)

Un serbidor y quatro esqudillas y un plato (Fechilla PA-1675)

Se localizan solamente dos ejemplos en los documentos analizados y, aparentemente, ninguno coincide con la acepción académica. Por el contexto en el que aparecen estos dos casos podría hacer referencia al menaje de cocina. En el CorLexIn este término también está escasamente documentado; el ejemplo que aparece en Jaén puede coincidir con el uso que se da de este objeto en Tierra de Campos, ya que figura junto a una olla y una orza, mientras que en la zona de Guipúzcoa y Navarra se registra junto a parrillas, asadores o moricos. Ni los ejemplos localizados en la zona de estudio ni los del resto de la Península señalan de qué material está hecho. Formalmente, estamos ante un término derivado que presenta el sufijo dor con valor instrumental y base verbal. Morala localiza en un inventario de Jaráiz de la Vera (Cáceres) el término servidera con un significado parejo al de servidor, por lo que estaríamos ante la alternancia de los sufijos derivativos -dor /-dera (Morala, 2012b: 344).

\section{TARRO}

Sust. m. 'Recipiente de vidrio o porcelana, generalmente cilíndrico y más alto que ancho' (DLE). Presente desde Nebrija con varias acepciones. Covarrubias lo define como 'vaso de tierra ancho'; Autoridades añade 'alto, y ancho de boca, y vidriado, el qual suele servir para conservas' (NTLLE, s. v. tarro, Nebrija, 1495, Covarrubias, 1611, Autoridades, 1739). Se trata de una voz peculiar del cast. y el port., de origen incierto $(D E C H$, s. v. tarro).

Un tarro de traer vino (Sahagún, LE-1600)

El CDH registra este término a partir del siglo XIV en el documento Privilegio Fernando IV Santa Clara (1309), donde figura junto a artesas y colodras. Sin embargo, no se atestigua un uso más regularizado hasta el siglo xIx. El único ejemplo localizado en la Tierra de Campos referencia un tipo de envase para "traer vino", acepción próxima a la localizada en el CorLexIn en 
Guadalajara, donde no se especifica la función, pero se inventaría junto a "pellexos de tener vino".

\section{TAZA [taça]}

Sust. f. 'Vasija pequeña, por lo común de loza o de metal y con asa, empleada generalmente para tomar líquidos' ( $D L E)$. Autoridades registra el término como 'vaso, que sirve para beber, y otros usos: son de diversas figuras, como anchas, y extendidas, de campanilla, y otras' (NTLLE, s. v. taza, Autoridades, 1739). Del árabe tássa 'escudilla', 'tazón', 'caldero' (DECH, s. v. taza).

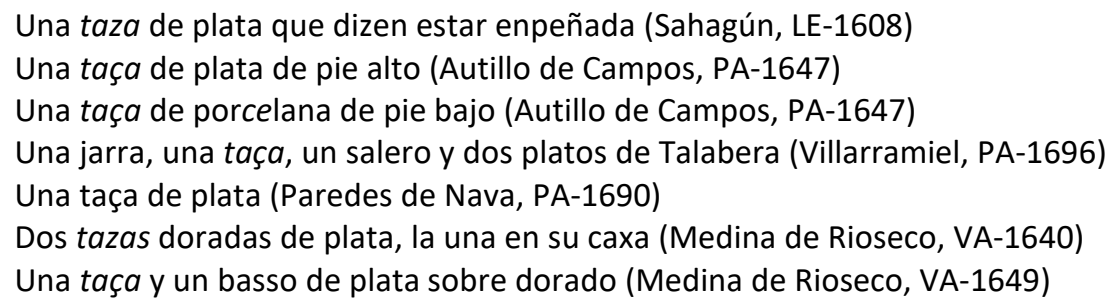

Palabra de uso general que referencia un recipiente pequeño para contener líquidos y que podía estar hecho de diferentes materiales (porcelana, plata, alabastro o barro). El CDH documenta esta voz desde el siglo XIII con la acepción que da la Academia. Es un término frecuente en los documenos de la época en la Península y también en América (CorLexIn).

\section{TEMBLADERA [tenbladera, tenvladera, tenpladera]}

Sust. f. 'Vasija ancha de forma redonda, hecha de una capa muy delgada de plata, oro o vidrio, con asas a los lados y un pequeño asiento' (DLE). Autoridades define esta palabra como 'vaso ancho de plata, oro, ù vidrio, de figura redonda, con dos assas à los lados, y un pequeño asiento. Las hai de muchos tamaños, por hacerse regularmente de una hoja mui delgada, que parece que tiembla, por lo que se le dió este nombre' (NTLLE, s. v. tembladera, Autoridades, 1739). Término derivado de temblar ( $D E C H$, s. v. temblar).

Una tenpladera de plata que pesa nuebe reales de a ocho (Grajal de Campos, LE-1658)

Quatro bassos, una xarra, una tembladera, doce cuchares y dos tenedores, salero, açucarero y pimentero (Paredes de Nava, PA-1690)

Una tenbladera y un salero de plata (Medina de Rioseco, VA-1640)

Una tenbladera blanca lissa (Medina de Rioseco, VA-1649)

Una tembladera y ocho cuchares todo de plata (Medina de Rioseco, VA-1644)

Una binaxera tenbladera un basso un braserillo de mano y una salba de plata (Medina de Rioseco, VA-1647)

Una salbilla, quatro tenbladeras pequeñas (Medina de Rioseco, VA-1660)

Una tembladera mediana de plata (Medina de Rioseco, VA-1660)

Una tembladera de plata (Villalpando, ZA-1644)

Una tenvladera de plata pequeña (Villalobos, ZA-1654)

Una tenbladera de plata y dos varquillos que pesarán diez y seis onzas poco más o menos (Cotanes del Monte, ZA-1687)

Desde el punto de vista diacrónico esta voz se documenta a finales del siglo XVI; primero aparece tímidamente en la Península y América, pero poco a poco y, sobre todo, a partir del 
siglo XVII se observa una preferencia de uso en los textos americanos, hasta tal punto, que en el siglo XX casi todas las concordancias pertenecen a documentos americanos.

El CorLexIn ofrece un nutrido número de ocurrencias peninsulares y americanas. En cuanto a la acepción de la palabra, suele ser la que da el DLE: un tipo de vasija recubierta de plata que frecuentemente se inventaría junto a salbillas, cucharas de plata, bernegales, platos, vasos... El corpus terracampino atestigua una docena de ejemplos de esta voz. El inventario perteneciente a la localidad de Grajal de Campos registra la variante templadera, para referenciar el mismo objeto. Las obras lexicográficas académicas recogen este término a partir del DRAE de 1803, pero con una acepción diferente a la que aquí aparece. Sin embargo, la foma con /p/ referenciando un tipo de recipiente aparece en el testamento de Pedro Calderón de la Barca fechado en 1681: "una templadera pequeña" (CORDE y CDH, s. v. templadera).

Por otro lado, en el corpus figura "binaxera tenbladera" donde encontramos el término como un adjetivo, posiblemente para especificar cómo estaba fabricado el objeto.

\section{TERRAZA [terraça]}

Sust. f. 'Jarra vidriada, de dos asas' (DLE, 5. a ac.). Covarrubias recoge esta voz como 'cierta forma de jarra de dos assas vedriada, que los pintores suelen poner en las tablas de la Anunciación, con vnos ramos de azucenas dentro' (NTLLE, s. v. terraza, Covarrubias, 1611).

Una terraça de barro en tres quartos (Sahagún, LE-1633)

Se trata de un término poco documentado con la acepción con la que aparece en el ejemplo localizado en Tierra de Campos, pues apenas hay testimonios en las bases de datos académicas. EI CDH documenta de forma tardía esta voz en una obra de Gonzalo Correas fechada en 1627, donde apunta que se trata de 'ollas y vasixas de barro'. La forma terrazo se documenta con anterioridad, en una obra fechada en 1250 de Abraham de Toledo: "métanlas en un terrazo que aya la boca ancha", aunque este significado tampoco resistió el paso del tiempo y en el siglo XVI entra en retroceso y se documenta de forma esporádica.

El CorLexIn solo recoge el término terrazo, pero no con la acepción de 'vasija', sino como 'terreno' en un inventario de Vitoria (Álava). Del término femenino terraza encontramos documentación en el Fichero General; en la cédula n.o 2 figura un ejemplo extraído de la General Estoria de Alfonso x (1275): "Leuaron con el ofreçer tres becerros, e tres moyos de farina e una terraza de vino". Más recientemente, se localiza este término en la cédula n.o 26 referida a estudio que hace González Ollé sobre el habla de la Bureba (Burgos), donde localiza terraza como 'vasija de barro similar a la tinaja, de vientre ancho y cuello estrecho'. Y el ALEANR (Atlas Lingüistico y Etnográfico de Aragón, Navarra y La Rioja) sitúa en Navarra el término terraza como sinónimo de 'orza ${ }^{11}$ (Fichero General, cédula n.o 9). Acepciones que parecen coincidentes con la encontrada en Tierra de Campos. 


\section{TINA}

Sust. f. 'tinaja (vasija grande de barro)', 'vasija de madera, de forma de media cuba' o 'vasija grande, de forma de caldera, que sirve para el tinte de telas y para otros usos' ( $D L E, 1$. ,, 2 . y y 3 . ac.). Nebrija recoge este término coincidiendo con la tercera acepción del DLE. Covarrubias también habla de un recipiente para teñir telas. Autoridades lo registra como sinónimo de tinaja que tiene poco uso y también como 'el vaso grande en forma de caldera, de diferentes materias, que sirve para teñir, y otros usos'. (NTLLE, s. v. tina, Nebrija, 1495; Covarrubias, 1611 y Autoridades, 1739). Término procedente del lat. TīnA 'especie de botella de vino, de cuello largo, con tapadera' (DECH, s. v. tina).

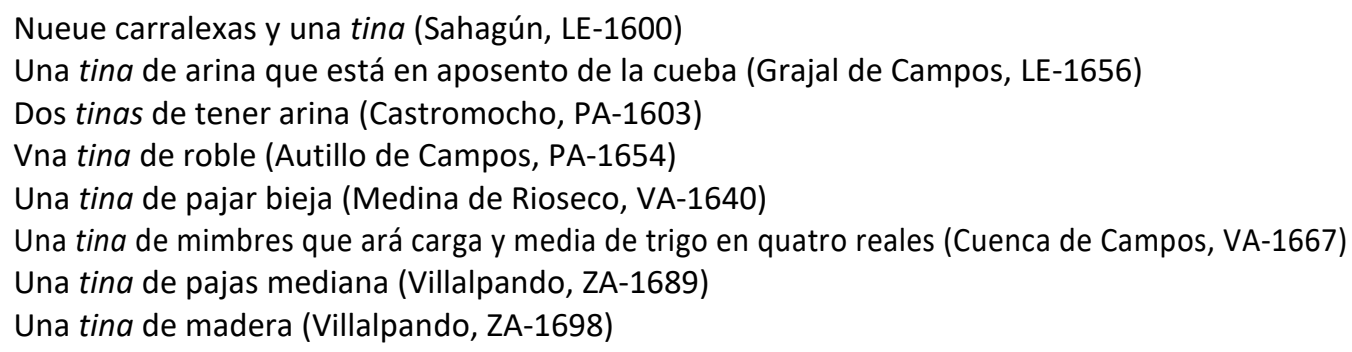

EI CDH registra esta palabra en el primer cuarto del siglo XIII, en Liber Regum donde aparece una "tina plena de olio". EL CorLexIn ofrece ejemplos de esta voz en la zona occidental y central de la Península principalmente, sin que haya una preferencia geográfica clara. En Tierra de Campos aparece este término refiriéndose a un tipo de recipiente para contener diferentes productos y que podía estar hecho de diferentes materiales (madera, paja o mimbres).

En estudios más recientes, Gordaliza define tina como 'recipiente de madera usado en las bodegas. También se llama a veces tinaco (Gordaliza, 1988: 212). Álvarez Tejedor señala que tina es la voz utilizada en Salamanca y se trata de un recipiente para guardar harina (Álvarez Tejedor, 1989: 120).

\section{TINACO [tinaquillo]}

Sust. m. 'Tina pequeña de madera' (DLE). Lo recoge el Diccionario Académico de 1803 como 'especie de tina, en algunas partes de madera' (NTLLE, s. v. tinaco, DRAE, 1803). Se trata de una voz derivada de tina, procedente del lat. TĩNA 'especie de botella de vino, de cuello largo, con tapadera' (DECH, s. v. tina).

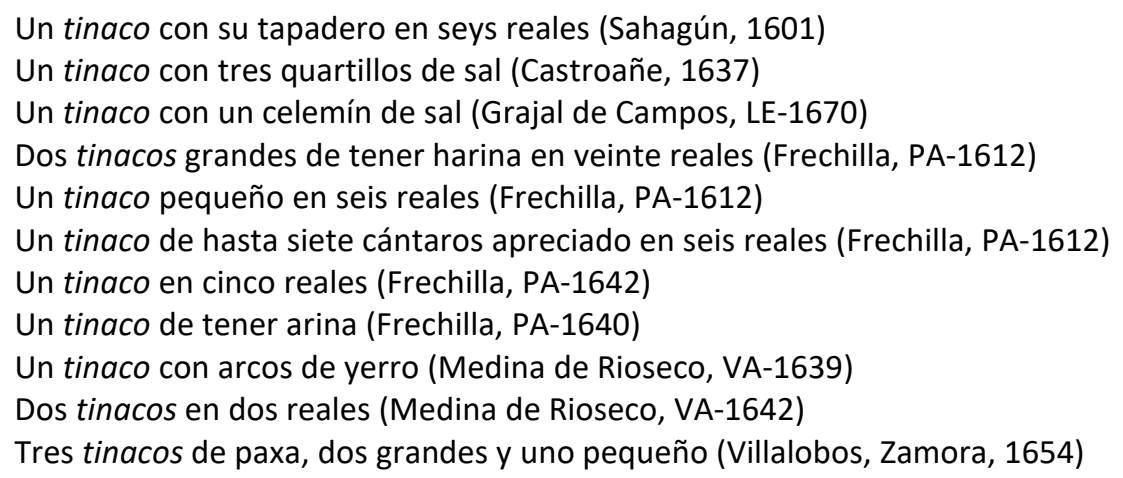


Son pocas las concordancias que presentan de esta voz el CORDE y el CDH, pero las suficientes como para establecer en qué momento aparece en los textos. El $C D H$ registra esta voz en el siglo XIV: "saluando los cubos e los tinacos [...]" en el Ordenamiento sobre racioneros de San Martín de Luquin y San Salvador de Urbiola, fechado en 1339.

Los datos aportados por el CorLexIn reflejan una distribución geográfica de esta palabra que englobaría la Tierra de Campos, localidades palentinas pertenecientes a las comarcas de BoedoOjeda y Valdavia, además de Vizcaya; localidades a las que habría que añadir un par de casos localizados en documentos notariales cántabros por parte de Bartolomé y Junquera. Tal localización no resulta novedosa, ya que una de las escasas concordancias que ofrecen tanto el CORDE como el CDH pertenece a una Sentencia de la Documentación medieval de la villa de Laredo (Bartolomé-Junquera, 2018: 116):

[...] que bertieron a Pero Peres de Gardaga el moço dos tinacos de vino que le echaron a la mar apreçiados en çiento e quarenta maravedís (Documentación medieval de la villa de Laredo, 1409)

En la Tierra de Campos el uso de esta voz es frecuente, según se observa en los textos analizados. Formalmente es una palabra derivada de tina; la mayoría de las palabras que derivan del sufijo -aco son de creación bastante reciente, lo que hace dudar del posible origen antiguo (DECH, s. v. sobaco; Pharies, 2002: 36-38 en Morala, 2017a: 155-156). Por regla general, en el corpus aparece como un recipiente, de madera en la mayoría de los casos, para contener sal y harina, principalmente. Para otro tipo de menesteres, el escribano opta por la forma diminutiva del término:

Un tinaquillo de tener escaueche (Frechilla, PA-1612)

Un tinaquillo de carral en dos reales (Frechilla, PA-1613)

Un tinaquillo que es el que tiene la cal (Frechilla, PA-1639)

Además de como recipiente, tinaco aparece en un documento zamorano con el significado de 'bañera':

Un tinaco de tomar vaños con su asiento que vale quatro ducados (Villalpando, ZA-1696)

\section{TINAJA [tinaxa]}

Sust. f. 'Vasija grande de barro cocido, y a veces vidriado, mucho más ancha por el medio que por el fondo y por la boca, y que encajada en un pie o aro, o empotrada en el suelo, sirve ordinariamente para guardar agua, aceite u otros líquidos' (DLE). Nebrija recoge este significado en su Vocabulario. Covarrubias la define como 'vaso de barro capacissimo' (NTLLE, s. v. tinaja, Nebrija, 1495; Covarrubias, 1611). Término procedente del lat. TīNA 'especie de botella de vino, de cuello largo, con tapadera' ( $D E C H$, s. v. tinaja).

Una tinaxa bedriada en quatro reales con su tapadero (Sahagún, LE-1600)

Una tinaxa grande (Sahagún, LE-1603)

Una tinaja zamorana pequeña (Valderas, LE-1682)

Una tinaxa de teja (Autillo de Campos, PA-1649)

Una tinaja para aceite en doze reales (Frechilla, PA-1675)

Trece tinaxas de Talauera (Paredes de Nava, PA-1689)

Una tinaxa grande y dos escriñas de tener arina (Boadilla de Rioseco, PA-1692)

Una tinaja de tener agua (Villalón, VA-1637) 
Una tinaja de cobre que pesa zinquenta y tres libras (Medina de Rioseco, VA-1640)

Una tinaxa de Cantalapiedra vacía (Medina de Rioseco, VA-1641)

Una tinaxa de esquina paral agua (Medina de Rioseco, VA-1641)

Una tinaja con su tapador y un cántaro (Medina de Rioseco, VA-1641)

Una tinaxa de barro con su tapadero (Medina de Rioseco, VA-1649)

Seis carralones, dos tinajas y media, unos cuebanos (Villalpando, ZA-1640)

Una tinaja grande con su tapa de madera (Villalpando, ZA-1689)

Dos tinaxas de uarro colorado (Villalpando, ZA-1696)

Una tinaja de perigüela mediana (Quintanilla del Monte, ZA-1698)

Este término se encuentra ampliamente documentado en bases textuales como el $C D H$ y el CORDE desde finales del siglo XIII. El CorLexIn atestigua, además de la forma etimológica tinaja, la variante tenaja en amplias zonas de la Península, con cierta preferencia en la zona oriental (Morala 2016a: 381). El corpus terracampino ofrece solo la forma tinaja. Es una voz de uso general. Habitualmente, el escribano especifica el material con el que están fabricadas las tinajas (vidrio, barro, cobre, zamorana, de Cantalapiedra, de Talavera). Frecuentemente, estas tinajas se inventariaban junto al tapador, tapadero o tapa que salvaguardaban el producto de ser derramado, así como algún utensilio para servir el líquido que portaban; en el caso de los documentos analizados se servían de un cazo:

Una tinaxa y un caço de sacar agua (Medina de Rioseco, VA-1648)

Una tinaja de barro con su cazico de cobre (Medina de Rioseco, VA-1660)

En los documentos terracampinos figura el término tinaja como un modificador sustantivo, que posiblemente haga referencia a la morfología del objeto:

Una olla tinaja de puchero (Frechilla, PA-1640)

En estudios más modernos, como el realizado para la zona Este de la provincia de Zamora, Álvarez Tejedor localiza este término como 'las vasijas de barro cocido, "de teja", con una capacidad muy reducida, 12 cántaros como máximo, y que solían estar destinadas para guardar vinagre'. En esta zona aparece también la forma tenaja, además de conocer unos recipientes de barro, más pequeños que las tinajas, denominados tenajillas o tenajón. (Álvarez Tejedor, 1989: 195-196).

\section{VASO [basso, baso, basito]}

Sust. m. 'Recipiente de metal, vidrio u otra materia, por lo común de forma cilíndrica, que sirve para beber' (DLE). Término recogido por Nebrija en su Vocabulario. Covarrubias escribe: 'llamamos al de la colmena. Vaso, donde se haze la calera. Vaso, la capacidad de la naue, y de otro qualquier vagel, y vaso mas comunmente que todos, en el que beuemos'. Para Autoridades se trata de 'qualquier pieza cóncaba de varias materias, como plata, oro, vidrio, etc. dispuesta para recoger, y contener en sí alguna cosa, especialmente líquida' (NTLLE, s. v. vaso, Nebrija, 1495, Covarrubias, 1611, Autoridades, 1739). Voz procedente del lat. VAS, -IS 'vasija', vulgarmente VASUM (DECH, s. v. vaso).

Un basito de plata (Valderas, LE-1682)

Un baso de bidrio (Autillo de Campos, PA-1653)

Un basso de bidrio angosto largo (Fechilla PA-1675)

Una taça y un basso de plata sobredorado (Medina de Rioseco, VA-1647) 
Un barquillo digo vaso de plata (Medina de Rioseco, VA-1648)

Un basso pieza de agua labrado y grauado por dentro con una asa sola (Medina de Rioseco, VA1649)

Un baso de vidrio y un jarro vidriado tasado en real y medio (Cuenca de Campos, VA-1670)

Se trata de un término de uso general, aunque en el siglo XVII no tiene la misma presencia que hoy en día. El CDH documenta esta palabra a partir de finales del siglo XII y principios del XIII. Esta palabra presenta una distribución diatópica general; el CorLexIn ofrece un nutrido número de ocurrencias en el territorio peninsular, insular y americano. En Tierra de Campos los vasos eran piezas que formaban parte de la vajilla. El hecho de que aparezcan otros términos con un significado próximo al de vaso hace que la aparición de este en los textos sea menor.

\subsubsection{Recipientes para el aseo}

\section{AGUAMANIL}

Sust. $\mathrm{m}$. 'jarro con pico para echar agua en la palangana o pila donde se lavan las manos, y para dar aguamanos' o 'palangana o pila destinada para lavarse las manos' ( $D L E, 1$. y 2. ac.). Término recogido por Nebrija. Autoridades lo define como 'vaso ò jarro de plata, ù otro metal, ó materia, que tiene el cuerpo ancho y el cuello angosto, con su asa, y en la boca un pico, para que el agua salga poco à poco. Sirve para dar aguamanos' (NTLLE, s. v. aguamanil, Nebrija, 1495, Autoridades, 1726). Se trata de un término compuesto procedente del lat. tardío AQUAMANILE (DECH, s. v. aguamanil).

Una calderica pequeña y una aguamanil de cobre muy traydos (Medina de Rioseco, VA-1640) Una jarra y una aguamanil de bidrio tassado en dos reales (Cuenca de Campos, VA-1660)

Desde una perspectiva diacrónica, aunque registrado desde es el siglo XIII, aguamanil tuvo un uso mayoritario en los siglos XVI y XVII, para luego decrecer considerablemente. Alfonso de Palencia en su Universal vocabulario en latín y en romance fechado en 1490 escribe lo siguiente: 'es vaso para dar agua a manos, tiene una boca angosta por donde corre el agua. Llamamos le aguamanil' (CORDE). Los datos encontrados en el CORDE constrastan con la poca representación que tiene esta voz en las relaciones de bienes. Los datos recabados en el corpus terracampino muestran un par de ejemplos inventariados junto a recipientes domésticos y elaborados con cobre y bidrio.

\section{BACíA [bazía, vazía]}

Sust. f. 'Vasija (pieza para líquidos o alimentos)' o 'vasija cóncava, por lo común con la escotadura semicircular en el borde, usada por los barberos para remojar la barba' (DLE). Nebrija recoge el término como sinónimo de bacín. Para Covarrubias la bacía era el 'vaso grande, hondo y tendido en que se suelen lauar otros vasos, y derramar sobre el agua'. En Autoridades lo encontramos como 'vaso grande de metal hondo y redondo, que sirve para echar cosas líquidas ò condensadas, y para otros usos'; también es 'la que usan los barbéros para bañar la barba quando aféitan à alguno' (NTLLE, s. v. bacía, Nebrija, 1495; Covarrubias, 1611; Autoridades, 
1726). Voz emparentada con bacín y con varias palabras del latín tardío; quizá proceda del francés anticuado bassie que parece ser forma dialectal correspondiente a un lat. vulgar * bacceata, derivado de BACCEA (DECH, s. v. bacía).

Dos baçías de Talabera (Valderas, LE-1682)

Un brasero de caxa con bazía de cobre (Medina de Rioseco, VA-1640)

Tres vaçinicas de açófar viexas y una vacía (Medina de Rioseco, VA-1644)

Una baçía de açofar, beinte y quatro reales (Medina de Rioseco, VA-1645)

Una bacía de cobre estañada con asas de yerro (Medina de Rioseco, VA-1648)

Un calentador de azófar, la cubierta y la bacía de cobre (Medina de Rioseco, VA-1649)

Un brassero de caja con la baçía (Medina de Rioseco, VA-1649)

Una bazía (Villalpando, ZA-1601)

Una vazía de Talavera de hazer la varva pintada (Cotanes del Monte, ZA-1687)

La naturaleza polisémica de este término se refleja en la documentación que nos ofrece el $C D H$. Bacía se documenta en un inventario de bienes fechado en 1325 donde figuran dos significados distintos: recipiente para amasar y especie de balde donde se podía lavar la ropa. En siglos posteriores la bacía referencia el cuenco que usaban los barberos para mojar la barba y también como parte del brasero donde se colocaban las brasas. Esta voz se documenta con mayor frecuencia en el siglo XVII.

El CorLexIn ofrece una distribución geográfica de carácter general en la Península, Canarias y América. El carácter polisémico también se refleja en las ocurrencias de los inventarios que conforman este corpus. En la Tierra de Campos este término es de uso general y designa diferenes objetos, aunque el más frecuente es el de 'vasija'. Algunas de las ocurrencias localizadas en Medina de Rioseco referencian el recipiente que forma parte de los braseros o los calentadores, esto es, el depósito donde se recogían las brasas. En el último ejemplo el significado es el de utensilio usado por los barberos para remojar la barba. Dependiendo de cuál fuera su función, las bacías podían ser de açófar, de cobre o de Talavera.

En repertorios dialectales leoneses figura como sinónimo de 'vajilla' (Le Men, 2002, s. v. bacía).

\section{BACINA [vacinica]}

Sust. f. El DLE lo contempla como una palabra en desuso y lo equipara al término bacín. Autoridades lo recoge como sinónimo de bacía (NTLLE, s. v. bacina, Autoridades, 1726). Término derivado de bacín, del lat. tardío BACCHINON, de origen desconocido (DECH, s. v. bacina).

Una bacina açofarado (Villalón, VA-1637)

Tres vaçinicas de açófar viexas y una vacía (Medina de Rioseco, VA-1644)

Una vacinica de latón y un plato grande de lo mismo (Medina de Rioseco, VA-1651)

El término bacina aparece documentado a partir de finales del siglo XV y no hay muchos ejemplos después del siglo XVI. Los testimonios de esta palabra son escasos tanto en el $C D H$ como en el CORDE. En los protocolos notariales del siglo XVII tampoco aparecen muchos ejemplos, tan solo un caso en Vitoria (Álava) en el CorLexIn. Esta escasez de resultados se traslada a Tierra de Campos, donde encontramos un solo ejemplo del término bacina que se 
encuentra referenciada entre los "aderezos" de la cocina -assadores, cazos, tornaguebos-, lo que nos hace pensar que se trata de un recipiente para cocinar y no para el aseo.

Sin embargo, en nuestro corpus figura también el diminutivo bacinica. En Autoridades aparece como 'diminutivo de bacía. La que es pequeña, y sirve para el mismo uso, y de que frequentemente se valen las mugéres para sus menestéres corporales' (NTLLE, s. v. bacinica, Autoridades, 1726). El CORDE y el $C D H$ ofrecen un número reducido de casos de esta palabra durante los siglos XVI y XVII en los documentos peninsulares, después la palabra pasa a América donde su presencia es mayoritaria, sobre todo en el siglo XX. Esta falta de testimonios peninsulares se refleja en el CorLexIn, donde muchos de los ejemplos registrados proceden del continente americano. En laTierra de Campos aparecen dos ejemplos en Medina de Rioseco (Valladolid). En el primero parece hacer referencia a un recipiente que se utilizaba en el menaje de cocina, ya que se halla junto a cazuelas y cantimploras; en el segundo, el significado es diferente por el contexto en el que aparece, en la puerta de una iglesia y referenciado junto a un aguamanil.

\section{BAÑADO}

Sust. m. 'orinal' (DLE). Terreros y Pando registran esta palabra con marca dialectal y afirma que 'en Castilla, lo mismo que bacín', en el Suplemento del diccionario académico de 1803 registra esta voz y dice que 'en algunas partes lo mismo que bacín ò sillico' (NTLLE, s. v. bañado, Terreros y Pando, 1786 y Academia Suplemento, 1803). Término derivado de baño, del lat. BALNĚUM (DECH, s. v. baño).

Un bañado (Medina de Rioseco, VA-1639)

Tres docenas de vañado fino a ocho reales (Medina de Rioseco, VA-1640)

Hay pocos testimonios de esta voz en los documentos, en la mayoría de las ocasiones aparece como adjetivo. El CorLexIn no facilita ningún ejemplo de este término como sustantivo. En Tierra de Campos encontramos dos casos: el primero de ellos podría corresponder con la acepción de 'bacín', pero en el segundo caso surgen dudas en cuanto al número de objetos inventariados (tres docenas); en este caso podría estar haciendo referencia a piezas de loza que solían ser de mayor calidad que los llamados barros y que representaban parte del ajuar doméstico de la casa. Habitualmente, en el corpus terracampino es más común el término como adjetivo:

Otra ollica de bañado blanco un real (Sahagún, LE-1601)

Nuebe platos bañados y pintados (Medina de Rioseco, VA-1639)

Treze platos bañados, nuebe escudillas vañadas (Medina de Rioseco, VA-1642)

Un salero bañado bueno (Medina de Rioseco, VA-1644)

Tres varreñones vañados de verde (Villalpando, ZA-1686)

En estos ejemplos podría estar haciendo referencia a un tipo de técnica cerámica a través de la cual se aplicaba una ligera capa de engobe al barro, lo que le proporcionaba una capa lisa que permitía pintar la pieza. Al consultar el CorLexIn, nos encontramos con un número muy reducido de casos de este adjetivo localizado en esta zona (Sahagún) y la localidad vallisoletana de Ventosa de la Cuesta, próxima a la zona de estudio. 
Volviendo a la acepción de bañado como 'orinal' cabe destacar que, en la zona de La Bañeza, ya en el siglo XIX, aparece una "silla de serbicio con su bañado" (Quintanilla de Somoza, LE-1831) (Gómez Ferrero, 2015: 205).

Entre los repertorios dialectales modernos, se registra la forma bañado en zonas de Palencia donde se da este nombre al 'orinal de metal o cerámica vitrificados que suele usar por la noche' (Gordaliza, 1988: 41). En la zona de Paredes de Nava, localidad perteneciente a la zona de estudio, se registra el término bañao, con pérdida de la /d/ intervocálica, y que hace referencia a un orinal pintado de esmalte blanco, aunque se puntualiza que esta acepción no se considera usual en Tierra de Campos (Helguera y Nágera, 1990: 535).

Le Men localiza este término con varias acepciones: 'orinal', 'pila de fregar' o como 'artesa que sirve para pelar el cerdo'; también recoge la forma bañal en la zona de El Bierzo, Asturias y Santander (Le Men, 2002, s. v. bañado).

\section{ORINAL}

Sust. m. 'Recipiente de vidrio, loza, barro u otros materiales para recoger los excrementos humanos' (DLE). Es un término recogido por Nebrija. Autoridades lo define como 'vaso de vidro, barro ù metal, hecho para recoger la orina, que regularmente es alto y ceñido por cerca de la boca' (NTLLE, s. v. orinal, Nebrija, 1495, Autoridades, 1737). Término derivado de orina, del lat. ÜRITNA (DECH, s. v. orina).

Una zestilla de tener orinal (Cea, LE-1621)

Un frasco doble y un bidrio grande y orinal de bridio (Villalpando, ZA-1676)

Son los únicos ejemplos que aparecen en los documentos analizados; en uno, referenciando directamente el objeto -"orinal de bidrio"-, y en el otro, inventariando una cestilla que actuaba a modo de protección. El CDH lo recoge a partir del siglo xIV y se halla sobre todo en tratados de medicina con la acepción académica. Por su parte, el CorLexIn presenta una escasa nómina de ocurrencias, con una preferencia de uso en la mitad Norte de la Península -Guipúzcoa, Navarra, Soria, Palencia y Ávila-, a excepción de un caso en Cáceres y otro en América-Chile-.

\section{PALANGANA [palancana]}

Sust. f. 'Jofaina' (DLE). La primera definición lexicográfica se halla en Autoridades donde define esta palabra como 'vaso ò vasija de diferentes hechuras, lo mas común es ser prolongada y profunda, con un borde al rededór de quatro dedos de ancho, en el qual, á ambos lados, tiene una muesca ò cortadura en media luna, en la qual entra el pescuezo para bañar el Barbero la barba. Sirve también para lavarse las manos y otros usos. Hacense de plata, azófar, estaño u barro' (NTLLE, s. v. palangana, Autoridades, 1737). Voz común a las tres lenguas romances hispánicas, de origen incierto, quizá de un lat. hispánico *palangana, nombre de las artesillas o bateas empleadas por los buscadores de oro, derivado del ibérico palaga 'pepita de oro'. Etimología dudosa por la fecha tardía en que aparece el vocablo castellano ( $D E C H$, s. v. palangana). 
Siete reales y medio de una palancana (Paredes de Nava, PA-1689)

Una palangana de peltre de haçer la barua (Medina de Rioseco, VA-1685)

Desde una perspectiva diacrónica, tanto el CORDE como el CDH localizan esta palabra a partir de la segunda mitad del siglo XVII, aunque el uso mayoritario aparece en el siglo XX. Los datos que nos ofrece el CorLexIn sitúan una preferencia de uso en América y un uso más esporádico en la Península. En la zona de estudio aparecen dos variantes: palangana, recogida en Autoridades y palancana, variante que recoge Terreros y Pando como 'vaso en que comunmente se lavan las manos'. El DRAE de 1803 añade este lema como 'lo mismo que palangana' (NTLLE, s. v. palancana, Terreros y Pando, 1788, DRAE, 1803).

En los vocabularios dialectales leoneses actuales se prefiere la variante palancana, que también se documenta en localidades de Asturias, Cantabria, Burgos, Soria, La Rioja, Aragón, Zamora, Salamanca, Cuenca y Guadalajara (Le Men, 2009, s. v. palangana). Gordaliza confirma el uso de esta variante en Palencia (Gordaliza, 1988: 166).

\subsubsection{Vajilla}

\section{AZUCARERO [açucarero]}

Sust. m. 'Recipiente para servir el azúcar en la mesa' ( $D L E, 4$. a ac.). Autoridades lo define como 'vaso para tener azúcar en la mesa, para servirse de ella en las viandas. Son várias sus hechúras; si bien por lo regular es en figúra de cañúto, ò torrecilla, con su tapadéra llena de agujéros, para que salga el azúcar que está hecho polvo, como lo está la pimienta en el pimentéro' (NTLLE, s. v. azucarero, Autoridades, 1726). Término derivado de azúcar, del ár. súkkar (DECH, s. v. azúcar).

Un açucarero de plata (Paredes de Nava, PA-1689)

Un salero, azucarero y pimentero de plata blanca (Medina de Rioseco, VA-1640)

Un azucarero de plata y un pimentero de plata (Medina de Rioseco, VA-1640)

Açucarero y pimentero con sus tapadores de la misma manera, dorado y estriado y un tapador del salero en forma de torrecilla con pimentero en el mismo (Medina de Rioseco, VA-1649)

Un salero, un azucarero y pimentero de plata (Medina de Rioseco, VA-1660)

Un açucarero de plata sobredorado con labores (Villalpando, ZA-1650)

Esta voz se documenta relativamente tarde en los documentos: el primer ejemplo que aparece en el $C D H$ está fechado en el año 1580, a finales del siglo xVI, y casi exclusivamente en inventarios de bienes en los ejemplos del siglo XVII. Este término también se documenta en Canarias y América. Suele aparecer en los textos junto al salero y el pimentero, pues son piezas que se tasan en conjunto y que se utilizan para el servicio de mesa.

\section{BANDEJA [vandeja]}

Sust. f. 'Pieza de metal, o de otra materia plana o algo cóncava, para servir, presentar o depositar cosas' (DLE). Autoridades la define como 'pieza hecha regularmente de plata, mas tendida y larga que ancha, y de ordinario algo cóncava, con un lábio ò cenéfa al rededor de dos dedos de ancho con poca diferéncia. Hacense de varias hechúras y labores, y también de diferentes tamaños 
conforme al gusto de cada uno. Sirve para sacar en ella qualquier genero de cosas menúdas y sueltas: como dulces secos, bizcochos, pañuelos, guantes y otras espécies de no mucho peso y volumen (NTTLE, s. v. bandeja, Autoridades, 1726). Término procedente del port. bandeja (DECH, s. v. bandeja).

Una vandeja vieja de colores (Grajal de Campos, LE-1658)

Quatro reales de una bandeja de la China (Paredes de Nava, PA-1689)

Seis reales de una bandeja de la China (Paredes de Nava, PA-1689)

Bandeja se registra en el CORDE y el $C D H$ desde mediados del siglo XVI, aunque su uso mayoritario se da a partir del siglo XIX. Respecto al siglo XVII, son pocos los testimonios que localiza el CorLexIn, media docena de ocurrencias, repartidas por un ámbito geográfico amplio y sin un patrón claro de reparto -Península, Canarias y América-. Este uso exiguo de la palabra se traslada a la Tierra de Campos. El contexto en el que aparece no da suficientes pistas sobre su función. Sin embargo, es interesante el sintagma preposicional con el que aparecen estos ejemplos: "de colores", "de la China". En este último caso referencian objetos de procedencia extranjera, y tal vez, de introducción reciente en la lengua. También se encuentran ejemplos de este sintagma en las ocurrencias que localizamos en el CorLexIn y en los textos que conforman el $C D H$ y le $C O R D E$, junto con el sintagma "de la India". En el siglo XVII se importaban bandejas de la India (DECH, s. v. bandeja).

\section{ESCUDILLA [escodilla, escodillón]}

Sust. f. 'Vasija ancha y de forma de una media esfera, que se usa comúnmente para servir en ella la sopa y el caldo' (DLE). Recogida por Nebrija. Autoridades la define como 'Vaso redondo y cóncavo, que comunmente se usa para servir en ella el caldo y las sopas' (NTLLE, s. v. escudilla, Nebrija, 1495, Autoridades, 1732). Voz procedente del lat. SCUTELLA (DECH, s. v. escudilla).

Dos escodillas en dos reales (Sahagún, 1600)

Quatro escodillas de barro (Sahagún, LE-1608)

Un escodillón de madera con celemín y medio de sal (Villacalabuey, LE-1614)

Una jarra de Talabera y un platillo y otra jarrica y una escudilla (Grajal de Campos, LE-1658)

Una fuente entrefina y una escudilla fina (Valderas, LE-1682)

De platos de Talauera jarros y jarras y escudilla seis reales (Frechilla, PA-1613)

Quatro escodillas i tres platos de Talabera (Frechilla, PA-1639)

Doce platos de Talabera fina y ocho escudillas y una almofa pequeña (Frechilla, PA-1675)

Una docena de platos y escudillas de Talabera (Boadilla de Rioseco, PA-1689)

Duze platos vañados, pintados y blancos, nueve escudillas bañadas (Medina de Rioseco, VA-1641)

Doze platos, dos jarras y tres escodillas de Talavera fina (Medina de Rioseco, VA-1644)

Una dozena de platos y escudillas, ollas y jarros (Medina de Rioseco, VA-1645)

Quatro platos y seis escudillas bastos (Medina de Rioseco, VA-1652)

Dos saleros de Talabera, quatro escudillas finas y diez y seis platos (Medina de Rioseco, VA-1657)

Ocho escudillas de Talauera (Villalpando, ZA-1676)

Seis escudillas finas una aljáfana y un salero (Villalpando, ZA-1688)

Ocho escudillas de Talauera fina (Villalpando, ZA-1698)

Es una voz de uso general en esta época. La forma escudilla se documenta desde el siglo XIII en las bases textuales académicas (CORDE y $C D H$ ). Formalmente estamos ante un diminutivo 
lexicalizado, ya que en estos casos el sufijo -illa no presenta un significado de pequeñez (Perdiguero, 2015a: 1569).

Figura también la forma escodilla, pero de manera menos frecuente y durante un periodo más reducido de tiempo: del siglo XV a principios del siglo XVII. Se trata de una palabra de uso habitual, presente en todo el territorio peninsular y en algunos puntos de América.

En cuanto a la zona de estudio, la forma más abundante es la variante normativa escudilla. Sin embargo, en algunos documentos aparece la forma escodilla en la que se observa un cambio de timbre en la vocal átona / $\mathrm{U}$, fenómeno generalizado en el siglo XVII, señalado por varios autores. En este caso, la inestabilidad en el timbre viene dada por el hecho de que la vocal tónica sea una /i/ (Morala, 2009: 557).

\section{ESCUDILLERO}

Sust. m. Ál. 'vasar, estante para colocar la vajilla' (DRAE, 1927). Se recoge de forma muy tardía, solo en algunas ediciones académicas con este significado y con marcación geográfica de Álava (NTLLE, s. v. escudillero, DRAE, 1927; DRAE, 1950; DRAE, 1984 y DRAE, 1929).

Un escudillero con dozena y media de platos y escudillas (Cea, LE-1621)

Existen muy pocas referencias a este término en los textos. Este uso escaso en Tierra de Campos, donde solo encontramos un ejemplo, se repite cuando consultamos el CorLexIn que atestigua un caso en Vitoria (Álava): "un escudillero de platos, de pino". A pesar de la escasez de datos documentales, el contexto de estos ejemplos nos hace suponer que estamos ante un estante o armario donde se colocaban las escudillas y platos. Formalmente, presenta el sufijo derivativo -ero de nominal.

\section{FLAMENQUILLA}

Sust. f. 'Plato mediano, de forma redonda u oblonga, mayor que el trinchero y menor que la fuente' (DLE). Autoridades recoge este término con la misma acepción que en la actualidad y añade 'que se usa en las mesas para servir alguna fruta ó manjár delicado: como azeitúnas, huevos moles, etc. Pudo llamarse así por venir de Flandes la invencion' (NTLLE, s. v. flamenquilla, Autoridades, 1732). Se trata de una voz derivada de flamenco, del neerl. flaming 'natural de Flandes' (DECH, s. v. flamenco).

Dos flamenquillas que pesaron nuebe marcos (Medina de Rioseco, VA-1647)

Desde el punto de vista diacrónico, el $C D H$ y el CORDE documentan este término en el siglo XVII en una obra de Lope de Vega (1606), utilizado de forma figurativa, pero de la que se intuye el significado de plato o fuente. Con esta acepción solo se localiza en otras dos obras del mismo corte, una en el mismo siglo y otra en el XVIII. Esta escasa nómina de casos se reduce aún más cuando consultamos el CorLexIn, donde no figura ninguna ocurrencia del término. Su origen está en el gentilicio flamenco que hacía referencia a los habitantes de Flandes. Este término está presente en los diccionarios desde Autoridades, lo que contrasta con su escasa presencia en los textos (CORDE, CDH, CorLexIn). Tal vez el carácter foráneo de la palabra fuese el motivo por el 
que no pervivió en el tiempo y no se consolidó de manera general en el castellano. El diminutivo flamenquilla ha perdido la significación primaria afectiva o aminorativa inherente al diminutivo -illa, adquiriendo un nuevo valor léxico; estamos ante una forma lexicalizada.

\section{PIMENTERO}

Sust. m. 'Vasija en que se pone la pimienta molida, para servirse de ella en la mesa' (DLE, 2.a ac.). Lo recoge Covarrubias en su Tesoro como 'vaso donde se echa la pimienta'. Autoridades hace una descripción más detallada del término 'vaso largo y angosto à modo de un cañuto, con su tapa hecha en figura de una torrecilla, llena de agujéros, que sirve para poner en élla pimienta sobre la mesa, y servirse de ella en las viandas que la necesitan' (NTLLE, s. v. pimentero, Covarrubias, 1611, Autoridades, 1737). Se trata de una voz derivada de pimienta, del lat. PĬGMĔNTA, plural de PIGMENTUM 'colorante, color de pintura', que ya en latín tenía el sentido de 'droga, ingrediente' y más tarde 'condimento' ( $D E C H$, s. v. pimienta).

Un salero, azucarero y pimentero de plata blanca (Medina de Rioseco, VA-1640)

Un azucarero de plata y un pimentero de plata (Medina de Rioseco, VA-1640)

Azucarero y pimentero, zinco bassos (Medina de Rioseco, VA-1644)

Açucarero y pimentero con sus tapadores de la misma manera, dorado y estriado y un tapador del salero en forma de torrecilla con pimentero en el mismo (Medina de Rioseco, VA-1649)

Dos candeleros de plata, dos salvillas, un açucarero, pimentero y salero (Medina de Rioseco, VA1661)

Un salero y pimentero de plata sobredorado (Villalpando, ZA-1650)

El $C D H$ y el CORDE documentan esta palabra con el significado que aquí nos ocupa, a partir de finales del siglo XV. Desde una perspectiva diatópica, el CorLexIn nos ofrece una veintena de casos repartidos por la Península, con una preferencia de uso en el Norte de la Península -Guipúcoa, Álava, Vizcaya, Cantabria, León y La Rioja-. En Tierra de Campos se documenta esta voz sobre todo por la zona vallisoletana. Esta lexía referencia un artículo de mesa que, como ocurre con el azucarero y el salero, a veces tenía un marcado carácter suntuario, estaba hecho de plata y solía ir provisto de tapador y cierre.

\section{PLATO [platillo]}

Sust.m. 'Recipiente bajo y redondo, con una concavidad en medio y borde comúnmente plano alrededor, empleado en las mesas para servir los alimentos y comer en él y para otros usos' $(D L E)$. Recogido por Nebrija y Covarrubias. Autoridades lo define como 'vasija baxa y redonda, con una concavidad en medio, y un borde ò alero al rededor. Hácese de diversos tamaños y materias: como plata, oro, peltre, barro, porcelana y madera. Usase dél en las mesas para servir viandas, comer en él, y para otros usos' (NTLLE, s. v. plato, Nebrija, 1495, Covarrubias, 1611, Autoridades, 1737). Término procedente del lat. vulgar *PLATTUS 'plano', 'chato, aplastado' (DECH, s. v. plato).

Zinco platos de Talabera (Sahagún, LE-1600)

Un plato de madera en tres reales (Sahagún, LE-1601)

Zinco platos de peltre y un salero y una escudilla todo en seys reales (Sahagún, LE-1605)

Una doçena de platos de Talabera y otra de porcelanas (Grajal de Campos, LE-1658)

Una jarra de Talabera y un platillo y otra jarrica y una escudilla (Grajal de Campos, LE-1658) 
Un platillo de peltre (Castromocho, PA-1614)

Ocho platos de Talabera tasados en quatro reales (Mazariegos, PA-1619)

Dos platos de Talauera fina pintados apreciados en quatro reales (Frechilla, PA-1612)

Un plato de peltre en dos reales y medio (Frechilla, PA-1613)

Un plato de peltre grande con una mella (Frechilla, PA-1640)

Seis platillos, otros platillos chinos (Paredes de Nava, PA-1683)

Beinte y quatro platillos tres jarros (Medina de Rioseco, VA-1647)

Nuebe platos de plata trincheos (Medina de Rioseco, VA-1649)

Un plato de Talavera labrado de açul (Tamariz de Campos, VA-1652)

Un plato de Málaga en dos reales (Cuenca de Campos, VA-1666)

Un plato de peltre mediano, más catorce platos de barro bastos, más diez platos de Talabera finos (Villalpando, ZA-1661)

Es un término muy común de uso general en el servicio de mesa. Se documenta en el $C D H$ a partir del siglo XIV con la acepción académica. Presenta una distribución diatópica de carácter general -Península, Canarias y América-. Es una pieza que forma parte del servicio de vajilla. Aparecen diferentes modelos en los documentos, hechos de distintos materiales (peltre, plata, madera, cerámica...) y de diferentes tamaños. Entre todos ellos, figura el plato gallinero que, por lo que encontramos en los inventarios, se trataría de un plato grande, mayor que la flamenquilla y que el trinchero, por cuyo nombre podemos deducir que servía para poner las aves antes de servirlas al trinchero:

Dos platos de plata grandes, que llaman gallineros (Medina de Rioseco, VA-1640)

Un plato gallinero de plata con una endedura en el borde (Medina de Rioseco, VA-1649)

Dos platos gallineros (Villalpando, ZA-1688)

Este adjetivo no figura en la documentación del CORDE y del $C D H$. Sin embargo, los datos que nos ofrece el CorLexIn muestran tres ocurrencias del mismo, dos en la Península y una en América. Aunque la escasez de ejemplos no permite establecer fehacientemente su distribución geográfica, cabe decir que los dos casos peninsulares se sitúan en la meseta norte: en Nava del Rey -provincia de Valladolid-y en la localidad abulense de Piedrahita. Es reseñable el ejemplo localizado en Purificación (Colombia) "un platonsito gallinero y la olleta con su tapa", donde el término platonsito ${ }^{6}$, a pesar del diminutivo, refiere un tamaño grande, por lo que estaríamos ante la misma acepción que aparece en la Península. El hecho de localizar este término en documentos americanos puede señalar un uso más extenso del que aparentemente muestran los documentos. Formalmente es un adjetivo formado por derivación con el sufijo -ero.

\section{SALERO}

Sust. m. 'Recipiente en que se sirve la sal en la mesa' (DLE). Lo recoge Nebrija en su Vocabulario. Covarrubias lo define como 'vaso o pieça en que se echa la sal' (NTLLE, s. v. salero, Nebrija, 1495, Covarrubias, 1611). Se trata de un término derivado de sal, del lat. SAL, SALIS (DECH, s. v. sal).

Tres platos de barro y un salero de peltre (Grajal de Campos, LE-1613)

\footnotetext{
${ }^{6}$ El término platón se utiliza en varios países hispanoamericanos, entre ellos Colombia, con la acepción de 'recipiente de gran tamaño y de diversos usos según las comarcas: jofaina, cazuela, fuente, etc.' (DLE, s. v. platón).
} 
Dos saleros de varro (Sahagún, LE-1614)

Una vinagrera y un salero de Talavera (Cea, LE-1621)

Un salero de Talabera (Grajal de Campos, LE-1670)

Un salero de açófar (Castromocho, PA-1602)

Dos asadores y un salero de madera en dos reales (Frechilla, PA-1615)

Un salero de Talabera (Autillo de Campos, PA-1653)

Doce cuchares y dos tenedores, salero, acucarero y pimentero (Paredes de Nava, PA-1690)

Un salero de verdugado, mendoçino, dorado y estriado (Medina de Rioseco, VA-1649)

Un salero de Talavera en un real (Medina de Rioseco, VA-1643)

Un salero bañado bueno (Medina de Rioseco, VA-1644)

Una cobertera y un salero de yerro y un salero de latón (Medina de Rioseco, VA-1644)

Un salero de plata sobredorado con su cubierta (Villalpando, ZA-1656)

Un salero de Talabera fino (Villalpando, ZA-1661)

Un salero de Talabera y otro de metal y dos azeyteras de Talabera (Villalpando, ZA-1696)

Término documentado en el $C D H$ y el CORDE desde el siglo XIII. Presenta una distribución diatópica de carácter general tanto en la Península como en Canarias y América (CorLexIn). Estamos ante una palabra de uso general en todas las épocas. La muestra de ejemplos recogida en Tierra de Campos presenta un objeto que se confecciona con diferentes materiales: los hay de barro, madera, hierro, azófar, peltre o latón, pero también de Talavera, bañados, de plata o sobredorados, lo que repercute en el valor del objeto.

\section{SALVILLA [salbilla, saluilla, salba]}

Sust. f. 'Bandeja para diversos usos, a veces con una o varias encajaduras donde se colocan copas, tazas u otros recipientes' (DLE). Autoridades lo define como 'pieza de plata, ò estaño, vidrio, ò barro, de figura redonda, con un pie hueco sentado en la parte de abaxo, en la qual se sirve la bebida en vasos, barros' (NTLLE, s. v. salvilla, Autoridades, 1739). Término derivado del lat. SALVUS 'sano', 'salvo' (DECH, s. v. salvo).

\footnotetext{
Una saluilla de peltre (Paredes de Nava, PA-1683)

Una salbilla de plata (Medina de Rioseco, VA-1640)

Dos salvillas, un açucarero, pimentero y salero (Medina de Rioseco, VA-1644)

Una salbilla aobada y un varquillo (Medina de Rioseco, VA-1648)

Una salvilla de cobre en ocho reales (Medina de Rioseco, VA-1649)

Dos salvillas una mayor que otra con sus rayas a modo de escalericas en los pies (Medina de Rioseco, VA-1649)

Una saluilla con su basso de plata sobredorada (Medina de Rioseco, VA-1657)

Una saluilla de plata mediana (Villalpando, ZA-1656)
}

De la información que nos ofrecen el $C D H$ y el CORDE se deprende que el uso mayoritario de esta palabra se dio en el siglo XVII, para luego entrar en retroceso a partir del siglo XVIII. Desde una perspectiva diatópica, este término se extiende por un amplio ámbito geográfico (CorLexIn), lo que indica que es un término común en la época.

En los documentos terracampinos, además del término salvilla y el término servilla que analizaremos a continuación, figura la voz genérica salva, menos utilizada en los textos. Nebrija, Covarrubias y Autoridades registran esta voz como sinónimo de salvilla 'que es como más comúnmente se dice' (NTLLE, s. v. salva, Autoridades, 1739).

Un braserillo de mano y una salba de plata (Medina de Rioseco, VA-1647)

Quatro trincheros, pieças de agua y salbas (Medina de Rioseco, VA-1647) 
Esta falta de testimonios que se da en Tierra de Campos es algo habitual en los inventarios de la época. El CorLexIn tan solo recoge dos ocurrencias, ambas en localidades pertenecientes a Guipúzcoa -"vna salba con sus tixeras de plata" y "vna salba dorada"-. En esta época salva ya está en desuso.

\section{SERVILLA [seruilla, serbilla]}

Sust. f. 'salvilla' (DLE). Hasta el DRAE de 1992 no se incluye este significado (NTLLE, s. v. salvilla, $D R A E, 1992)$. Término derivado de siervo, del lat. SĔRVUs 'esclavo' (DECH, s. v. siervo).

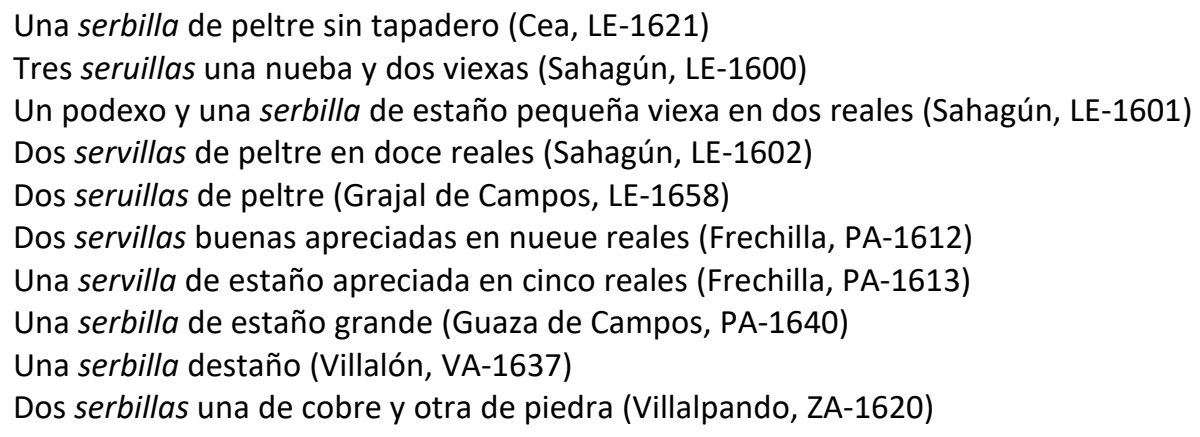

La primera documentación que aparece en el $C D H$ de este término está fechada en el siglo XIV y se refiere a servilla con la acepción que encontramos en Tierra de Campos, "en vasos e en copas e servillas, e en escodilleras e en tajaderos e en todas las otras baxillas [...]". A partir de la primera mitad de este siglo, esta palabra entra en claro retroceso.

Respecto a la distribución diatópica en el siglo XVII, el CorLexIn registra una escasa nómina de casos, repartidas sobre todo en la mitad norte peninsular, entre Cantabria, Vizcaya, León, Segovia y Salamanca.

Por su parte, el corpus terracampino muestra una nómina de casos ligeramente mayor. Frente a la preferencia en los textos vallisoletanos por la variante salvilla, los textos terracampinos procedentes de protocolos leoneses presentan un mayor uso del término servilla. Y esta preferencia se puede observar con la acepción con la que aquí aparece, hasta dos siglos más tarde en documentos notariales de La Bañeza, localidad leonesa y relativamente próxima a la zona de estudio (Gómez Ferrero, 2015: 149, 432).

\section{TRINCHERO [trincheo]}

Sust. m. 'Plato trinchero (plato que sirve para trinchar en él los alimentos)' (DLE, 2. a ac.). Autoridades registra la entrada trincheo ó trinchero para hacer referencia al 'plato pequeño, que sirve, para trinchar la comida, ò para servir las piezas yá trinchadas' (NTLLE, s. v. trinchero, Autoridades, 1739). La forma trincheo figura en el DLE como un término en desuso. En la edición del DRAE de 1803, las dos palabras dejan de estar en la misma entrada y marca esta como antigua (NTLLE, s. v. trincheo, DRAE, 1803). Término derivado de tranzar 'cortar, tronchar', probablemente del céltico *trencō 'yo corto, yo termino', en un primer momento deriva en trincheo (DECH, s. v. tranzar). 
Quatro trincheros, pieças de agua y salbas (Medina de Rioseco, VA-1647)

Nuebe platos de plata trincheos (Medina de Rioseco, VA-1649)

En los archivos analizados figura cada una de las variantes que presenta esta voz, aunque con una escasa nómina de casos. Trinchero no es muy frecuente en la documentación. El CDH recoge esta voz a comienzos del siglo XVII $\mathrm{y}$, aunque figuran algunos ejemplos en siglos posteriores, cabe destacar que, a finales del siglo XIX, esta palabra experimenta un cambio semántico y comienza a aparecer en los documentos como parte del mobiliario de la casa, como una especie de aparador.

El CorLexIn presenta un solo caso de trinchero localizado en Madrid, donde aparece como adjetivo "vn platillo pequeño de plata, trinchero". Esta escasez de datos se traslada a la Tierra de Campos donde tan solo se documenta un ejemplo de esta variante, junto a objetos propios del servicio de mesa.

Por su parte, La forma trincheo solo aparece documentada en los textos del siglo XVII según los datos aportados por el $C D H$ y el CORDE. No hay ejemplos en el CorLexIn de esta voz, y en el corpus terracampino tan solo se halla una ocurrencia de la voz trincheo como adjetivo y con caída de la líquida en posición intervocálica.

\section{VINAGRERA [binagrera]}

Sust. f. 'Vasija destinada a contener vinagre para el uso diario' (DLE, 2.a ac.). Aparece en el Vocabulario de Nebrija como 'vaso para el vinagre', Autoridades lo define como 'la vasija, ù ampolleta, en que se sirve el vinagre à las mesas, y comidas' (NTLLE, s. v. vinagrera, Nebrija, 1495, Autoridades, 1739). Es un término derivado de vino, del lat. vĩNUM (DECH, s. v. vino).

Una vinagrera y un salero de Talavera (Cea, LE-1621)

La vinagrera y el salero de peltre (Cea, LE-1621)

Dos saleros y una azeytera y vinagrera de Talabera fina (Medina de Rioseco, VA-1659)

Dos jarricas pequeñas de Talauera fina, açeytera y binagrera de lo mesmo (Villalpando, ZA1689)

Desde una perspectiva diacrónica, vinagrera se documenta por primera vez en el $C D H$ en el Vocabulario de Nebrija, fechado 1495. Tanto del CDH como el CORDE presentan un número exiguo de casos hasta el siglo Xx, que es cuando esta voz presenta un uso más extendido. Esta escasez de ejemplos también se observa en los documentos notariales de la época. El CorLexIn ofrece un escueto número de ocurrencias en el centro peninsular -Toledo, Madrid y Ávila-. En proporción, los datos que nos ofrecen los textos terracampinos son más numerosos, presentes en documentos notariales leoneses, vallisoletanos y zamoranos de la Tierra de Campos, siempre como recipiente para el vinagre y junto a recipientes como saleros y aceiteras.

\section{VINAJERA [VINAXERA, BINAXERA]}

Sust. f. 'Cada uno de los dos jarros pequeños con que se sirven en la misa el vino y el agua' (DLE). Este término lo recoge Terreros y Pando como 'vaso pequeño en que se lleva el vino y agua para el servicio de la Misa'. No es hasta la edición de 1832 cuando la Academia añade el término como 'jarrillo de oro, plata, vidrio ú otras materias para servir el vino cuando se dicen misas; $y$ 
en este ministerio se llama también así el que sirve para el agua' (NTLLE, s. v. vinajera, Terreros y Pando, 1788, DRAE, 1832). Término derivado de vino, del lat. VĨNUM (DECH, s. v. vino).

Una vinaxera de vidrio y dos yxuelas de olanda con sus puntillas para cubrirlas (Medina de Rioseco, VA-1644)

Una binaxera, tenbladera, un basso, un braserillo de mano y una salba de plata (Medina de Rioseco, VA-1647)

Otra arquilla pequeña y dentro dos pares de vinajeras de plata y dos platos de plata (Medina de Rioseco, VA-1651)

Un platillo con dos vinajeras (Medina de Rioseco, VA-1685)

Esta voz es más común en los textos que el de vinagrera. El $C D H$ la documenta desde siglo XIII. Sin embargo, la Academia no la incorpora hasta la edición de 1832. Es una pieza que solía estar en el oratorio de las casas señoriales y hace referencia a cada uno de los jarrillos que se usaban en la misa para el vino y el agua. Muchas veces se utiliza en plural en los textos para referirse a todo el conjunto (los jarros del agua y el vino, la bandeja que los sostiene e incluso los paños que los tapan). El CorLexIn presenta una distribución de carácter general de esta palabra. El corpus terracampino ofrece ejemplos en los que esta palabra atiende más al servicio de mesa que a la pieza de oratorio. El significado mayoritario es el que referencia las piezas usadas en la liturgia.

\subsubsection{Cubiertos}

\section{CACETA [caçeta, cazeta]}

Sust. f. 'Cazo de mango corto y fondo con agujeros que usan los boticarios a modo de colador' $(D L E)$. Autoridades le da el mismo significado 'un cacito de azófar, con su mango hecho en forma de flor de lis, todo de una pieza con su borde llano y ancho, en la qual hacen los Boticários las mezclas, y desatan, o deslien los ingredientes. Háilas cerradas y abiertas, esto es que lo esphérico del cazo está todo lleno de agujeros' (NTLLE, s. v. caceta, Autoridades, 1729). Es un término derivado de cazo, del cat. casseta (DECH, s. v. cazo).

Vna sartén nueba y una caçeta de la olla biexa (Valderas, LE-1647)

Una cazeta de la olla (Villalpando, ZA-1689)

Una cazeta de la olla (Villalpando, ZA-1690)

En el CORDE y el CDH figura un solo ejemplo de esta voz en el siglo XVII, localizado en el Inventario y tasación de la botica del doctor Apolinario Velázquez, fechado en 1624. El resto de las ocurrencias pertenecen exclusivamente al siglo xx. Esta falta de testimonios en los textos del siglo XVII se puede extrapolar a la documentación notarial, donde, consultado el CorLexIn, caceta figura en un inventario de Valderas, localidad leonesa perteneciente a la comarca de Tierra de Campos. En el corpus estudiado aparecen ejemplos de esta palabra en la zona más occidental de Tierra de Campos y con una acepción diferente al que da Autoridades. En esta zona no se trata de un instrumento utilizado por médicos o boticarios, sino que formaría parte de los enseres domésticos, una especie de cazo pequeño que servía para sacar líquido de los recipientes. Por otro lado, dada la localización del término, se trataría de un occidentalismo. "Es 
un término usual en todo el noroeste hispánico, incluyendo el gallego, y también Asturias, León o Zamora" (Morala, 2017c: 371).

En algunos estudios léxicos como el de Le Men se localiza esta palabra como 'cacillo, cazo pequeño que por lo general sirve para sacar líquido del recipiente que lo contiene' y aclara que el área de la presencia de esta voz parece limitada al noroeste peninsular con esta acepción: así se documenta en León, Asturias como 'cazo para repartir la sopa' o en Zamora como sinónimo de espumadera (Le Men, 2004, s. v. caceta).

\section{CUCHARA [cuchar, quchar, cucharita]}

Sust. f. 'Utensilio que se compone de una parte cóncava prolongada en un mango, y que sirve, especialmente, para llevar a la boca cosas líquidas, blandas o menudas' (DLE). Nebrija registra el lema cuchara. Sin embargo, Covarrubias y Autoridades introducen como lema tanto cuchar como cuchara. Término procedente del antiguo y dialectal cuchar, femenino y este del lat. COCHLEAR, -ĀRIS (DECH, s. v. cuchara).

Ocho cuchares e un salero todo un real (Sahagún, 1600)

Quatro cuchares y un rallo (Grajal, LE-1613)

Una cuchar de plata en catorce reales (Grajal, LE-1658)

Dos cuchares y un rallo de yerro (Grajal, LE-1670)

Una cuchara de olla y una cobertera (Valderas, LE-1682)

Un caco y una sarten y su cuchar de yerro (Castromocho, PA-1606)

Una cuchar de requesones de açófar (Frechilla, PA-1639)

Dos cuchares de hierro y un assador (Villada, PA-1668)

Dos cucharas de nácar, la una el mango quebrado (Paredes de Nava, PA-168?)

Otra cuchar de plata pequeña de guebos (Medina de Rioseco, VA-1640)

Unas tréuedes de yerro y una cuchar de yerro (Medina de Rioseco, VA-1639)

Tres cucharas de yerro, las dos nuebas y una vieja en tres reales (Cuenca de Campos, VA-1666)

Una cobertera y una cuchar (Medina de Rioseco, VA-1671)

Dos asadores, una cuchar de la olla y un caço (Villalpando, ZA-1631)

Ocho cucharas de plata (Villalpando, ZA-1644)

Tres cuchares de plata, dos grandes y otra de guebos (Villalpando, ZA-1676)

Una cuchara de metal (Villalpando, ZA-1696)

Esta voz presenta dos variantes para el singular -cuchar y cuchara- y dos para el plural -cucharas y cuchares-. Todas estas alternativas gráficas se documentan a partir del siglo XIII en el $C D H$ y en el CORDE. Los datos que ofrece el CorLexIn apuntan a un uso generalizado de este término.

En Tierra de Campos localizamos cuchara en la localidad terracampina de Villarramiel (Palencia), donde encontramos lo siguiente:

Media carga de cal, una cuchara de yerro, dos colleras (Villarramiel, PA-1691)

Aquí, cuchara se encuentra en un contexto diferente y no junto a los utensilios de cocina por lo que estamos ante un significado diferente al visto hasta el momento. Perdiguero localiza un caso similar en un documento burgalés de este mismo siglo donde cuchar se inventaría en el mismo asiento que torno, lo que le hace pensar que no se trata del cubierto para comer, pero sí sugiere que puede referenciar "el recipiente para medir el cereal" (Perdiguero, 2015a: 1573). 
Además de las variantes anteriormente señaladas, nos encontramos con el diminutivo cucharita, con el valor apreciativo de este sufijo:

Una cucharita de plata de niños (Valderas, LE-1682)

\section{CUCHARÓN}

Sust. $\mathrm{m}$. 'Cazo con mango, o cuchara grande, que sirve para repartir ciertos alimentos en la mesa y para ciertos usos culinarios' (DLE). Autoridades señala que es el aumentativo de cuchar y lo define como 'la cuchar grande, que lo mas común es hacerla de madera: y sirve para revolver los guisados, conservas y otras cosas, y sacarlos de las ollas ò peroles en que se hacen' (NTTLE, s. v. cucharón, Autoridades, 1729). Término derivado de cuchara, del antiguo y dialectal cuchar y este del lat. COCHLEAR, -ĀRIS (DECH, s. v. cuchara).

Tres cuchares y un cucharón todo de yerro (Grajal de Campos, LE-1671)

Una cuchar y un cucharón de yerro tasado en dos reales (Grajal de Campos, LE-1670)

Tres cuchares la una dorada y otro cucharón más pastoril (Medina de Rioseco, VA-1649)

Tanto el CORDE como el $C D H$ recogen este término a finales del siglo XV, en el Cancionero de Juan del Encina. Desde el punto de vista diatópico, el CorLexIn ofrece una escueta lista de ocurrencias que utiliza un ámbito geográfico extenso -se documenta en textos peninsulares, insulares y americanos-. Esta situación se repite en el corpus terracampino, donde tan solo se recogen tres ejemplos de cucharón, siempre referenciado junto a cucharas. A pesar de estos datos, es un término de uso general.

\section{CUCHILLA}

Sust. f. 'Instrumento compuesto de una hoja muy ancha de hierro acerado, de un solo corte, con su mango para manejarlo', 'instrumento de hierro acerado, que se usa en diversas partes para cortar' u 'hoja de cualquier arma blanca de corte. (DLE, 1. a, 3. - y 4. ac.). Autoridades recoge este término como 'instrumento de hierro acerado, de una tercia de largo y seis dedos de ancho, con corte por un lado, y una manija de madera para asirle, que sirve en las carnicerías y cocinas para cortar la carne, y picarla' Término procedente del lat. cǓLTĔLLUS 'cuchillito', diminutivo de CULTER 'cuchillo' (DECH, s. v. cuchillo).

Un podexo de yerro y una cuchilla de picar carne y una podadera (Grajal de Campos, LE-1656)

Una cuchilla grande de picar sebo (Villada, PA-1669)

Una cuchilla de yerro (Paredes de Nava, PA-1689)

Un puchero y tres cuchillas bastas (Boadilla de Rioseco, PA-1690)

Una cuchilla y un acha de partir leña y un azadón (Medina de Rioseco, VA-1640)

Dos cuchares, dos tornaguevos y una cuchilla de yerro (Medina de Rioseco, VA-1645)

Una cuchilla y un taxo (Medina de Rioseco, VA-1671)

Una cuchilla de yerro (Villalpando, ZA-1664)

Una cuchilla de picar carne (Villalpando, ZA-1689)

El $C D H$ recoge este término desde época medieval. Los datos que proporciona el CorLexIn presentan una voz polisémica que se reparte por distintos puntos de la Península y América. En la zona de estudio aparece con la primera acepción que da el DLE en casi todos los ejemplos; tan 
solo hay un caso -donde aparece junto a cuchares y tornaguevos- en el que esta palabra podría aparecer como instrumento de cocina.

\section{CUCHILLO [cochillo]}

Sust. m. 'Instrumento para cortar formado por una hoja de metal de un corte solo y con mango' (DLE). Resgistrado por Nebrija en la edición de 1516 de su Vocabulario (NTLLE, s. v. cuchillo, Nebrija, 1546). Término procedente del lat. cǔLtĚLLUS 'cuchillito', diminutivo de CULTER 'cuchillo' (DECH, s. v. cuchillo).

Un cochillo de monte con su vaina (Cea, LE-1621)

Quatro cuchillos nuebos en ocho reales (Grajal de Campos, LE-1658)

Un cuchillo (Grajal de Campos, LE-1658)

Una escudilla y un plato y un cochillo (Grajal de Campos, LE-1658)

Un cuchillo de cortar varro en el telar de yerro (Grajal de Campos, LE-1671)

Un cuchillo con su bayna (Frechilla, PA-1631)

Un cuchillo de raer (Villada, PA-1669)

Un cuchillo (Boadilla de Rioseco, PA-1687)

Dos cuchillos de laurar (Villalón, VA-1637)

Una caja con honçe cuchillos (Medina de Rioseco, VA-1642)

Un cochillo de rallar en un real (Medina de Rioseco, VA-1661)

Un cuchillo largo viexo en dos reales (Cuenca de Campos, VA-1670)

Un cuchillo de partir carne grande (Villalpando, ZA-1661)

Dos cuchillos de mesa (Villalpando, ZA-1696)

Un cuchillo de monte con su vaina (Villalpando, ZA-1696)

Desde una perspectiva diacrónica, la forma cuchillo figura en la documentación que conforma el $C D H$ desde el siglo XIII. Los datos que nos proporciona el CorLexIn presentan un ámbito geográfico de uso amplio. En la zona de estudio aparece la variante cochillo, variante arcaica que es habitual en la época ( $D E C H$, s. v. cuchillo). Se trata de una palabra polisémica ${ }^{7}$ y en los inventarios de Tierra de Campos suele venir especificada su función; así nos encontramos con cuchillo "de monte", "de partir", "de mesa", "de rallar", "de laurar", "de raer", "de cortar varro".

\section{ESPUMADERA}

Sust. f. 'Paleta ligeramente cóncava y con agujeros con que se espuma el caldo o cualquier otro líquido para purificarlo, o se saca de la sartén lo que se fríe en ella' (DLE). Autoridades la define como 'especie de cuchàra grande, redonda, llena de agujéros, con que se saca la espuma y se

\footnotetext{
7 En la localidad zamorana de Villalpando figura una acepción para esta voz que no se encuentra en el diccionario académico: Otra basquiña con cuchillos con su jubón (Villalpando, ZA-1676)

En este asiento, referencia un tipo de técnica textil de moda en aquella época, aunque en esta época es más habitual encontrar el adjetivo acuchillado o acuchillada para hacer referencia a dicha técnica; así encontramos "unas calzas acuchilladas de raso" (Villalpando) o "un jubón de tafetán doble acuchillado" (Medina de Rioseco). Egido documenta esta palabra entre prendas femeninas y con este significado en textos notariales de Astorga datados en 1696 (Egido, 2010).
} 
separa del caldo ú liquór, para purificarle de las heces' (NTLLE, s. v. espumadera, Autoridades, 1732). Término derivado de espuma, del lat. SPŪMA (DECH, s. v. espuma).

Unas trébedes y una espumadera de la olla de yerro biejas (Medina de Rioseco, VA-1640)

Un cazo y una espumadera de azófar (Medina de Rioseco, VA-1641)

Una espumadera de açófar tasado en diez y seis reales (Medina de Rioseco, VA-1644)

Dos cuchares de yerro, una espumadera, dos bolbederas (Medina de Rioseco, VA-1646)

Una espumadera de cobre, tres asadores y dos pares de parrillas (Medina de Rioseco, VA-1647)

Una espumadera de cobre (Medina de Rioseco, VA-1660)

Cinço cucharas de yerro y una espumadera de latón (Cuenca de Campos, VA-1666)

Una espumadera de açofar (Medina de Rioseco, VA-1685)

El CDH documenta esta voz a partir del Libro de guisados de Ruperto de Nola fechado en 1529. Aunque los primeros ejemplos son del siglo XVI, el uso mayoritario de esta voz se dará a partir del siglo XIX. El corpus terracampino presenta un nutrido número de ocurrencias, todas ellas localizadas en las localidades vallisoletanas. En cuanto a la morfología del término, proviene del sufijo deverbal -dera.

\section{FORQUETA}

Sust. f. ant. 'Tenedor' (DLE). Los repertorios lexicográficos recogen esta voz en las ediciones no académicas de Oudin (1607), Vittori (1609), Minsheu (1617), Braidenbach (1670), Stevens (1706) y Bluteau (1721), todas obras entre principios del siglo XVII y principios del XVIII. Sin embargo, en las ediciones académicas se registra de forma tardía, pues no será hasta la edición de 1791 cuando se recoja como una palabra antigua y dando como posibles definiciones: 'lo mismo que tenedor para comer' o 'lo mismo que horca por instrumento de labranza' (NTLLE, s. v. forqueta, $D R A E$, 1791). Palabra derivada de horca, del lat. FŬRCA 'horca de labrador' (DECH, s. v. horca).

Tres cuchares, la una dorada y otro cucharón más pastoril y una forqueta (Medina de Rioseco, VA-1649)

Forqueta figura de manera esporádica y tardía en la documentación del CDH y el CORDE. La primera constancia de esta voz aparece en la obra de Alonso de Contreras Discurso de mi vida, fechada entre 1630 y 1633. En dicha obra se puede leer una "forqueta de desarbolar", donde parece hacerse referencia a una herramienta de podar, lejos del 'tenedor' que tenemos en Tierra de Campos. Es el único ejemplo perteneciente al siglo XVII; el resto de ejemplos (7) se fechan en épocas más tardías -siglo XIX y XX-. Uno de los documentos pertenece a una novela del escritor leonés Julio Llamazares, donde se hace referencia al topónimo "Forqueta de Arintero"; aquí el término forqueta señala la característica forma de "u" de la montaña.

Los datos que nos ofrecen los corpus del castellano establecen que el término forqueta se introdujo de forma tardía en la lengua -bien entrado el siglo XVII-, y no resistió el paso del tiempo. La variante castellana horqueta es más frecuente.

No encontramos ni forqueta ni horqueta en el CorLexIn. De hecho, tan solo se documenta un único caso de forqueta en el corpus terracampino. Por el contexto en el que aparece, su significado se corresponde con el dado por la Academia. 
Sin embargo, Morala localiza los términos forcheta y forchina, con la misma acepción que forqueta, en la localidad terracampina de Valderas (Morala, 2009: 12):

Quatro forchetas de plata... cuatro forchinas y doçe cuchares (Valderas, LE-1647)

La palabra forchina la registra Covarrubias en su Tesoro como 'vna horquilla de plata con dos, tres, y quatro dientes, en forma de paletilla con que se lleua el manjar desde el plato a la boca, sin tocarle con la mano, y se siruen della como de cuchar, saluo que para las cosas liquidas no es vtil', Autoridades añade que es una 'voz italiana que yá no tiene uso, y se pronuncia la ch como k' (NTLLE, s. v. forchina, Covarrubias, 1611; Autoridades, 1732). En el CORDE y en el CDH figura un único caso de este término en una certificación de la partición de bienes perteneciente a la documentación notarial de Toledo y fechada en 1625 -"una forchina de plata, en siete rreales"-. El CorLexIn documenta dos ocurrencias de esta voz, en la localidad riojana de Alfaro (1642) -"siete cucharas y una forchina"- y en la soriana de Burgo de Osma (1612) -"ocho cuchares y una forchina de plata"-.

En estudios léxicos más recientes como el de Le Men aparecen forqueta en algunas zonas de León como Ancares, Laciana, Omaña, Valdesamario, Palacios del Sil o La Vecilla, pero con un significado diferente al que encontramos en los textos del siglo XVII en Tierra de Campos. Al parecer, la variante horqueta es más frecuente en localidades como Sahagún, Valencia de Don Juan o La Bañeza (Le Men, 2005, s. v. forqueta).

\section{NAVAJA [nabaxa, nauaxa]}

Sust. f. 'Cuchillo cuya hoja puede doblarse sobre el mango para que el filo quede guardado entre las dos cachas o en una hendidura a propósito' (DLE). Nebrija recoge 'navaja de barvero' y 'navaja de javalí'. Covarrubias registra el término como 'instrumento de barbero conocido para raer el pelo' (NTLLE, s. v. navaja, Nebrija, 1495, Covarrubias, 1611). Voz procedente del lat. NOVACǓLA, alterado vulgarmente en navacula (DECH, s. v. navaja).

Una caja de barbería con seis nabajas, dos tigeras, un espejo, una piedra de afilar y un peine (Valderas, LE-1682)

Una nabaxa (Baquerín de Campos, PA-1658)

Una nauaxa corba fina para limpiar árboles que bale diez reales (Villalpando, ZA-1696)

Es un término documentado a partir el siglo XIII en el $C D H$ y con bastantes ejemplos en la literatura. Esta frecuencia en la documentación contrasta con el uso exiguo que se halla de este término en el CorLexIn, donde se registran dos casos en Alcalá la Real (Jaén) con la acepción de 'navaja de barbero'. Esta situación es equiparable a lo que sucede en la comarca de Tierra de Campos, donde se contabilizan tres ejemplos. Los significados con los que figuran estas ocurrencias son como 'instrumento para cortar la barba' y también como una 'herramienta agrícola' que servía para podar o 'limpiar los árboles'.

\section{RALLADERA [arralladera]}

La palabra ralladera no está registrada en el DLE. Aparece en diccionarios no académicos: Terreros y Pando (1788), en el suplemento de Domínguez (1853-1869) y en Zerolo (1895) como 
sinónimo de rallo (NTLLE, s. v. ralladera). Posiblemente tenga el mismo origen etimológico que rallo.

Dos ralladeras (Medina de Rioseco, VA-1641)

Dos cazos pequeños y dos asadores pequeños y un rallo y una ralladera (Villalpando, ZA-1614)

Una bienda piñera y ralladera (Villalpando, ZA-1637)

Una radallera (en el margen ralladera) de artessa (Villalpando, ZA-1644)

Una hartessa de massar, y unas barillas y dos piñeras tassado todo, con la brega y su breguil, en cinquenta reales, todo concoladera, y arralladera, digo todo en cinco ducados (Villalpando, ZA1652)

Es una voz escasamente documentada en el $C D H$ y en el CORDE. Ambas bases de datos comparten dos únicos ejemplos, uno fechado en 1514 en una obra de Lucas Fernández titulada Comedia en la que se puede leer "y assadores y caldera, / y gamella y ralladera". Y el mismo texto figura en otra obra del siglo XIX. En los protocolos notariales del siglo XVII que conforman el CorLexIn figura este término en la franja occidental de la Península (Zamora, Badajoz). Morala localiza algunos casos más en localidades leonesas como Astorga, Riego de la Vega (Morala 2018a: 82) o en la localidad cacereña de Serrejón un siglo más tarde, en 1734 (Morala, 2012d: 432), aunque también aparece un par de ejemplos en Toledo.

El corpus terracampino documenta las formas ralladera y arralladera, esta con epéntesis de la $a$ y menos frecuente en los textos. La mayoría de estas ocurrencias pertenecen a la Tierra de Campos zamorana. En los inventarios analizados, en algunas ocasiones, figura junto a rallo, lo que nos hace pensar que se trata de una palabra que designa algún objeto diferente. El término rallador no aparece en el corpus estudiado y tan solo localizamos un ejemplo en el CorLexIn.

Formalmente, esta palabra presenta el sufijo deverbal -dera, forma que deriva adjetivos y sustantivos procedentes de verbos y que, entre otros significados, tiene los de nombrar lugar o instrumento.

En estudios dialectales más actuales, esta voz se localiza en zonas del leonés junto a la forma arralladera como 'espátula para rallar los residuos que la masa de pan deja en la masera' (Le Men, 2002, s. v. ralladera).

\section{RALLO}

Sust. m. 'Rallador (utensilio de cocina)' o 'chapa con agujeros como los del rallo, que sirve para distintos usos' (DLE, 1. y 2.a ac.). Aparece en Nebrija y también en Covarrubias quien lo define como 'instrumento coquinario, con que se rae el queso'. Autoridades lo recoge como 'instrumento bien conocido, que se reduce à una plancha de hierro, por lo regular con un poco de cavidad, en la qual estan abiertos y como sembrados unos agujerillos ásperos, con los quales se desmenuza el pan, queso y otras cosas estregandolas contra él: y por extensión se llama assí qualquiera otra plancha con los mismos agujeros que sirve á otros usos' (NTLLE, s. v. rallo, Nebrija, 1495, Covarrubias, 1611, Autoridades, 1737). Término procedente del lat. RALLum 'ralllador', derivado de RADERE 'raer' (DECH, s. v. rallo).

Tres cuchares y unas tixeras de despabilar y dos paletasy un rallo (Sahagún, LE-1601)

Un rallo y una quchar y una paleta buenas (Valdavida, LE-1606)

Un rallo y una cobertera de hierro grande (Arenillas, LE-1636) 
Dos cuchares y un rallo de yerro (Grajal de Campos, LE-1670)

Una sarten y un rallo en dos reales (Frechilla, PA-1613)

Un rallo (Boadilla de Rioseco, PA-1641)

Un caço aljofarado pequeño y un rallo de yerro (Tamariz de Campos, VA-1652)

Un rallo de ojadelata (Medina de Rioseco, VA-1659)

Una cobertera y un rallo en dos reales (Cuenca de Campos, VA-1666)

Un rallo de yerro grande en dos reales (Cuenca de Campos, VA-1666)

Dos cazos pequeños y dos asadores pequeños y un rallo y una ralladera (Villalpando, ZA-1614)

Un rallo y un rastrillo (Villalpando, ZA-1688)

Un rallo de yerro (Villalpando, ZA-1696)

Aparece extensamente documentada en el CDH y CORDE en el siglo XVII, y a partir de este siglo comienza a entrar en retroceso y su aparición en los textos se hace más esporádica. Es una palabra muy común en los inventarios de la época, como se puede observar en el CorLexın, donde aparecen ejemplos a lo largo de la Península, Canarias y América -Panamá-.

En Tierra de Campos, esta voz figura con la acepción académica en muchos de los inventarios de bienes estudiados. Estamos ante una palabra de uso general en el siglo XVII. Sin embargo, a partir de este momento cae en desuso, posiblemente por la incursión del término rallador, que se documenta en el $C D H$ a partir del siglo xv y que muestra un incremento de uso de dicha palabra a partir del siglo XIX. Esto se puede observar en algunos estudios léxicos como el de La Bañeza, donde aparece la voz rallador en los inventarios del siglo XIX (Gómez Ferrero, 2015: 164). En la zona de estudio no aparece ningún ejemplo de rallador.

En estudios dialectales de la zona más modernos no se recoge el término rallo.

\section{TENEDOR}

Sust. m. 'Instrumento de mesa en forma de horca, con dos o más púas y que sirve para comer alimentos sólidos' ( $D L E, 2$. a ac.). Casas registra este término en su Vocabulario equiparándolo al toscano furcina, furchetto. La primera obra lexicográfica en castellano que la recoge es Autoridades, donde se registra como 'instrumento de tres, quatro, ò mas dientes con su hastil, que sirve para prender con aseo la comida, y ayudar a la cuchara, ò trinchete. Hácese de diversas materias: como plata, oro, etc.' (NTLLE, s. v. tenedor, Casas, 1570; Autoridades, 1739). Término derivado de tener, del lat. TĚNĒRE 'tener asido u ocupado', 'mantener', 'retener' (DECH, s. v. tener).

Una tembladera, doce cuchares y dos tenedores (Paredes de Nava, PA-1690)

Cinco cuchares de plata y un tenedor (Paredes de Nava, PA-1689)

Ocho cucharas y un tenedor de plata (Medina de Rioseco, VA-1640)

Una saluilla con dos cuchares y un tenedor (Medina de Rioseco, VA-1685)

Con el significado de pieza de cubertería lo registra también Oudin en 1607 como 'una forqueta de plata para coger y servir las viandas', por lo que parece que era más un utensilio común a todos para servir la comida, que un cubierto individual (NTLLE, s. v. tenedor, Oudin, 1607). El $C D H$ documenta este término con esta acepción a finales del siglo XV, en las Cuentas de Gonzalo de Baeza, en el año 1477. Se trata de un término de uso común en la Península y América (CorLexIn). 
No obstante, hay que mencionar que es menos frecuente en los inventarios de la época que cuchara o cuchillo. Aunque en el siglo XVII ya parece estar incorporado en el servicio de mesa, su menor frecuencia en los inventarios puede deberse a que todavía en esta época existía la costumbre de tomar con los dedos los alimentos que no eran líquidos.

\section{TORNAHUEVOS [tornahuebos, torna huebos, tornahuebo, tornagüebos, tornagüevos]}

Es un término compuesto que no aparece ni en el $D E L$, ni en ninguna de las obras lexicográficas que constituyen el NTLLE. Por lo que se deduce de los ejemplos encontrados en el corpus terracampino, es un cubierto cuya función principal era la de sacar los huevos de la sartén, aunque posiblemente no fuera exclusiva.

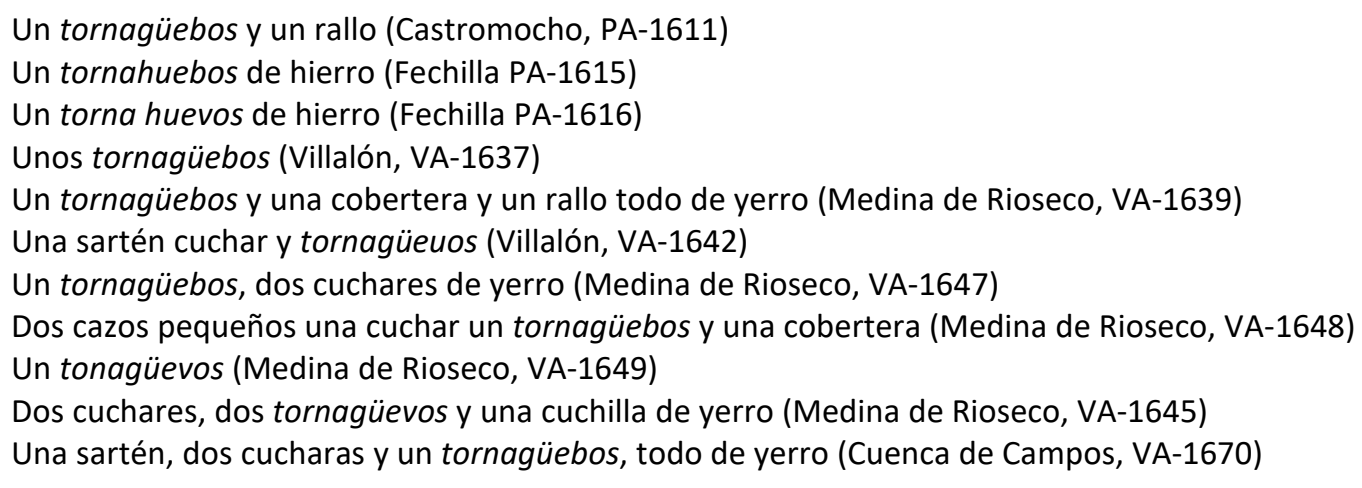

Existe una falta de testimonios en los documentos que conforman los corpus del castellano; tanto en el $C D H$ como en el CORDE no encontramos ejemplos de esta palabra compuesta.

Aunque de manera aislada, encontramos un par de casos en documentación del siglo XVI. Por un lado, encontramos esta voz en el inventario de bienes de Don Diego López de Ayala, realizado en Talavera en el año 1514: "un torna huevos" entre los enseres enumerados en la cocina. Por otro lado, Rojo Vega ${ }^{8}$ localiza el inventario de bienes de don Gaspar de Vallejo Aldrete en Valladolid, fechado unos años más tarde, en 1575, donde figura: "un tornaguevos de yerro".

Desde una perspectiva diatópica, los datos que nos ofrece el CorLexIn son escasos, aunque localiza tres ejemplos:

Un asador, una cuchar y un tornagüeuos de yerro (Medina de Rioseco, VA-1643)

Vn rallo y dos cuchares de yerro y un tornagüeuos (Carrión de los Condes, PA-1652)

Vna cuchar de yerro y un tornagüebos (Autillo de Campos, PA-1654)

Todas las ocurrencias pertenecen o están muy próximas a la zona de estudio, lo que hace suponer que estamos ante un localismo. Dentro de la documentación notarial de esta base de datos encontramos otras soluciones para referenciar este objeto $u$ otro muy parecido, como, por ejemplo, "paleta de volver güebos" en Santas Martas (LE-1625) o de manera muy ocasional,

\footnotetext{
${ }^{8}$ Rojo Vega, Anastasio: Inventario de don Gaspar de Vallejo Alderete, del Consejo de Castilla, 1575. Consultado en https://investigadoresrb.patrimonionacional.es/node/6068
} 
dada la peculiaridad de la palabra estrellador como el caso localizado en Tafalla: "vn estrellador de güebos con quatro ojos, andado" (NA-1641). El corpus terracampino muestra un mayor número de asientos de esta voz, aunque también alberga otras posibilidades sintagmáticas como:

Una paletilla de volber güebos (Cea, LE-1610)

Una paleta de rebolber güebos (Santa María del Río, LE-1617)

Una paleta de bolber güebos (Cea, LE-1621)

Una paletica de bolber güebos (Grajal de Campos, LE-1655)

Una volvedera de güebos (Villalpando, ZA-1635)

\section{VOLVEDOR / VOLVEDERA [boluedor, bolbedera, rebolbedera]}

El DLE define volvedera como 'instrumento de madera para dar vuelta a la mies' y señala que es una forma coloquial de la zona rural de Segovia y Zamora. Por otro lado, volvedor, -ora se registra como un adjetivo utilizado en Colombia y Argentina con una acepción diferente a la que encontramos en nuestro corpus. Se registran los dos términos en época bastante reciente, en el DRAE de 1925 y con marca diatópica de Segovia para volvedera (NTLLE, s. v. vovedor, volvedera, DRAE, 1925). Probablemente ambos términos procedentes de volver, del lat. VǑLVĔRE (DECH, s. v. volver).

\section{Un boluedor (Sahagún, LE-1608)}

Dos asadores de yerro, un rallo y un boluedor de uebos (Castromocho, PA-1603)

Un volvedor de huevos, diez y ocho maravedís (Fechilla PA-1612)

Dos cuchares de yerro, una es espumadera, dos bolbederas (Medina de Rioseco, VA-1646)

Un asador, rallo, una volvedera, cuchar y cobertera (Medina de Rioseco, VA-1646)

Un brasero de mano, una bolbedera, un asador, unas parrillas (Medina de Rioseco, VA-1651)

Dos asadores, una cuchar de la olla y una volvedera de güebos (Villalpando, ZA-1635)

Una rebolbedera (Villalpando, ZA-1689)

Estas formas apenas se documentan en corpus textuales como el CORDE y el $C D H$, que solo recogen la forma volvedera en un texto dedicado a la cocina de Emilia Pardo Bazán de 1913, donde se equipara al término espumadera.

En los inventarios del siglo XVII aparacen ambas formas -volvedor y volvedera-. De volvedor aparecen dos ejemplos localizados, uno en Ciudad Real, donde su significado no está del todo claro, pero que podría coincidir con el que ofrece el DEL para volvedera (Morala, 2012b: 348). La otra ocurrencia se localiza en Sahagún (León), localidad perteneciente a la zona de Tierra de Campos, cuyo significado estaría más próximo al de útiles de cocina.

La forma volvedera presenta una mayor frecuencia en los archivos que conforman el CorLexIn; registra media docena de casos repartidos entre La Rioja, León, Ávila, Cáceres y Toledo, ampliando así el territorio marcado por la academia para esta palabra. Morala también documenta esta voz en Soria y Zamora (Morala, 2012b: 348-349).

Las formas volvedor y volvedera figuran en el corpus estudiado y, por el contexto en el que aparecen, presentan un mismo significado asociado con los enseres domésticos; en este caso puede tratarse de una especie de cuchara grande que servía para remover o dar vueltas a la comida. Además, también aparece la forma rebolbedera en un inventario de Villalpando 
(Zamora), variante que también documenta Morala en alguno de los archivos localizados en Soria, León y Zamora (Morala, 2012b: 348-349).

Formalmente esta palabra presenta el sufijo deverbal -dera, forma derivada que forma adjetivos y sustantivos procedentes de verbos y que, entre otros significados, tiene los de nombrar lugar o instrumento.

Gordaliza en su estudio actual del léxico palentino registra el término revolvedera, pero con un significado distinto al que encontramos en los documentos de Tierra de Campos del siglo XVII (Gordaliza, 1988: 195).

\subsubsection{Recipientes de cocina}

\section{CALDERA [calderica]}

Sust. f. 'Recipiente de metal, grande, abombado en la base, que sirve comúnmente para poner a calentar o cocer algo dentro de él' (DLE). Término registrado por Nebrija. Covarrubias lo define como 'vaso grande coquinario, donde se calentaua el agua, y se cozian las carnes [...]', Por su parte Autoridades advierte del carácter polisémico de la palabra '[...] sirve según el oficio à que se destina, y su figúra es correspondiente al fin para que la dedican' (NTLLE, s. v. caldera, Nebrija, 1495, Covarrubias, 1611; Autoridades, 1729). Es un término derivado del lat. CALDARIA, íd. derivado de CALDUS, variante de CALIDUS (DECH, s. v. caldo).

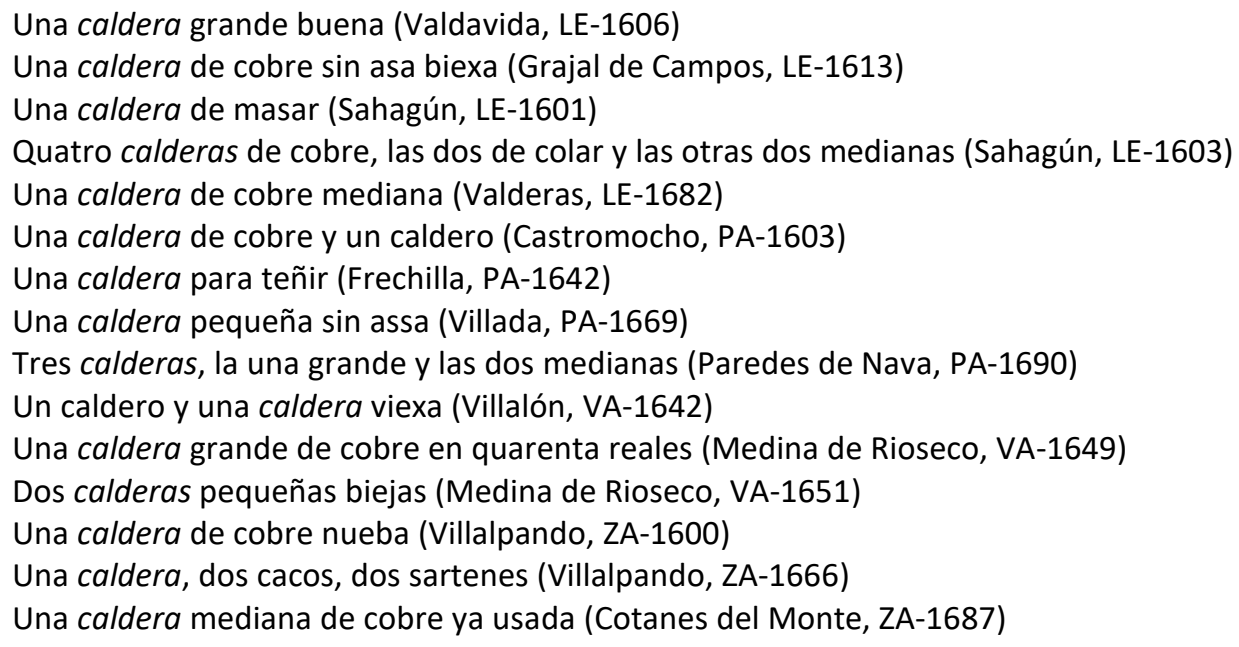

Desde una perspectiva diacrónica, el CORDE presenta ocurrencias de esta palabra en documentos notariales desde el siglo xI:

[..] Juna caldera con suos lares, duas azatas [...] (Cesión real de la heredad de Juan de Lardero y posterior donación a San Millán, Cartulario de San Millán, fechado entre 1040-1059).

El $C D H$, por su parte, aporta datos de esta palabra casi un par de siglos más tarde, también en textos de corte notarial:

[...] carro, artesas, caldera, ferrada [...] (Carta de inventario de la Colección diplomática del Monastaerio de Carrizo, fechado entre 1218 y 1300). 
Es una palabra que en el siglo XIII ya estaba totalmente consolidada en la lengua y su uso, generalizado.

El CorLexIn ofrece una distribución diatópica de carácter general de este término en toda la Península y Canarias. Aunque de una manera más restrictiva, este término también figura en documentos americanos donde se registra algún caso en México y El Salvador. En Tierra de Campos es muy frecuente encontrar esta palabra en los inventarios de bienes en los que se especifica de qué estaba hecha y para qué se utilizaba. En el copus terracampino figuran calderas "de masar", "de colar", "para teñir"..., y en su gran mayoría, de cobre.

En los textos estudiados también aparece el diminutivo calderica, término que de manera frecuente aparece modificado por el adjetivo calificativo "pequeño", lo que resultaría redundante junto al diminutivo:

Otra calderica de cobre pequeña tasada en quatro reales (Sahagún, LE-1605)

Otra calderica pequeña (Sahagún, LE-1608)

Una calderica pequeña viexa (Villacalabuey, LE-1614)

Dos caldericas una más pequeña que la otra (Grajal de Campos, LE-1616)

Otra calderica más pequeña buena (Galleguillos, LE-1618)

Una calderica pequeña (Villalón, VA-1638)

Una calderica pequeña y una aguamanil de cobre muy traydos (Medina de Rioseco, VA-1640)

Una calderica pequeña (Medina de Rioseco, VA-1657)

Una calderica muy pequeña y otra caldera mediana (Medina de Rioseco, VA-1660)

Otra calderica pequeña en quatro reales (Villalpando, ZA-1600)

Perdiguero señala que esta presencia del adjetivo pequeño puede reflejar la lexicalización del diminutivo (Perdiguero, 2015a: 1568). Sin embargo, en Tierra de Campos, dado el contexto en el que aparece este término, el diminutivo terminado en -ica simplemente aporta un significado apreciativo referenciando una caldera de menor tamaño.

\section{CALDERILLA}

Sust. dim. f. 'Caldera pequeña para llevar el agua bendita' (DLE). Autoridades recoge esta voz como 'la caldéra pequeña, que sirve para sacar agua de las tinájas y otros usos manuales. Y por semejanza se llama assi la que se hace de plata, cobre, etc. y se mete en una cestica para traher lumbre con que calentarse las manos las señoras. Y en las que se hacen la plata con una asa grande se suele meter un barro para tener la lumbre' (NTLLE, s. v. calderilla, Autoridades, 1729). Término derivado de caldo, del antiguo adjetivo caldo 'caliente' y éste del lat. CALǏDus íd. (DECH, s. v. caldo).

Una calderilla mediada (Sahagún, LE-1615)

Una calderilla pequeña buena (Sahagún, LE-1623)

Una calderilla de agua bendita (Frechilla, PA-1640)

Una calderilla (Frechilla, PA-1640)

Una calderilla pequeña (Villarramiel, PA-1690)

Una calderilla de açofar de mano (Boadilla de Rioseco, PA-1692)

Una calderilla con su badil y cadenilla de plata çercada (Medina de Rioseco, VA-1648)

Quatrozientos y zinquenta reales en dinero de calderilla (Medina de Rioseco, VA-1661)

Una calderilla de plata laurada (Villalpando, ZA-1651)

Una calderilla de lumbre (Villalpando, ZA-1666)

Una calderilla de lumbre de cobre (Villalpando, ZA-1689) 
Una estufa con su calderilla con que se calienta la cama (Villalpando, ZA-1696)

La localización de este término en el $C D H$ es tardía, figura en los textos a partir de la primera mitad del siglo XVI con la acepción de 'caldera pequeña', 'recipiente que sirve para sacar agua del pozo' e 'instrumento para calentarse'. Esta naturaleza polisémica se refleja también en los documentos notariales del siglo XVII, donde se la puede encontrar también como 'recipiente para llevar agua bendita' o como 'dinero o monedas de poco valor'; este último significado documentado en un texto fechado en 1654. Esta naturaleza polisémica se observa también en los textos terracampinos.

\section{CAZO [caço, caçito, cacico, cazico]}

Sust. m. 'Recipiente de cocina, de metal, porcelana, etc., generalmente más ancho por la boca que por el fondo, pero a veces cilíndrico, con mango y, por lo general, un pico para verter' (DLE). Nebrija y Covarrubias registran el término con la grafía ç, este último dice que 'es vaso de metal, de que usan los cozineros, conserueros, boticarios, es hondo, con vn astil de hierro, y el es de alambre, o cobre'. En Autoridades mantiene la acepción que le da Covarrubias y además añade que en algunas partes designa a 'la cuchára de hierro ò cobre, con que se saca el agua de las tinájas' (NTLLE, s. v. cazo, Nebrija, 1495, Covarrubias, 1611, Autoridades, 1729). Término de origen incierto: hay dificultades para partir del árabe o aceptar un origen griego $(D E C H$, s. v. cazo).

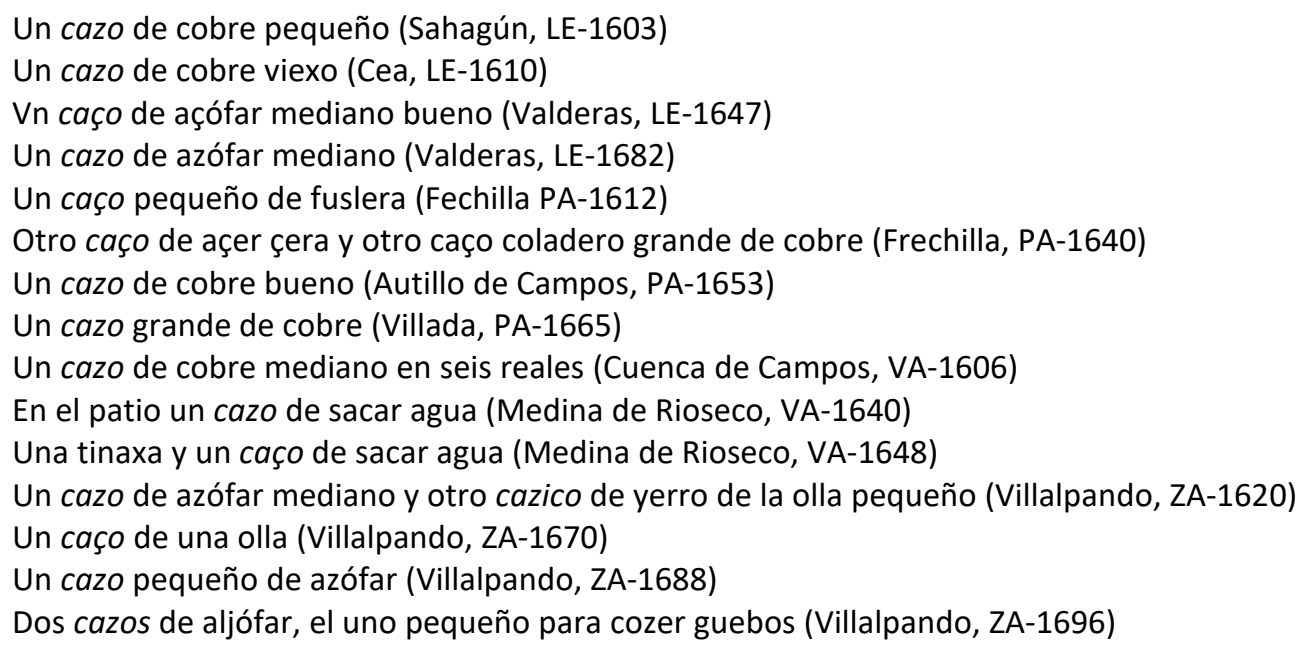

Bases de datos como el $C D H$ y el CORDE documentan esta palabra a partir del siglo XIV, en la Gran Crónica de Alfonso XI, fechada en 1348 y donde aparece "un caço de la olla". El CorLexIn presenta una distribución diatópica de carácter general en la Península; sin embargo, en sus textos no figuran ocurrencias de este término en Canarias y América. Podemos decir que estamos ante una palabra de uso generalizado en el siglo XVII en la Península, incluida la Tierra de Campos donde este término presenta las mismas acepciones que da Autoridades.

Desde un punto de vista formal, encotramos las formas derivadas del diminutivo: cacito y cacico. El primero presenta un uso más restringido -tan solo figuran dos ocurrencias en los textos analizados-, mientras que la variante acabada en -ico prensenta un mayor número de casos. 
Vn caçito de açófar pequeño y vna fuente de Talabera hordinaria (Valderas, LE-1647)

Dos caçitos pequeños y unas trévedes (Medina de Rioseco, VA-1643)

Otros dos cazicos pequeños, en tres reales (Sahagún, LE-1601)

Dos caçicos pequeños el un de azófar y el otro de cobre husados (Grajal de Campos, LE-1655)

Un caçico acofarado a modo de cuchar (Cuenca de Campos, VA-1666)

Un caçico de cobre como cuchar en real y medio (Cuenca de Campos, VA-1670)

Un candil y un caçico de la olla (Villalpando, ZA-1600)

Una sartén y un caçico de coçer agua (Villalpando, ZA-1632)

Lo mismo ocurre en los documentos que configuran el CorLexIn donde cacico registra una ligera ventaja frente al uso de cacito. El diminutivo que presenta un uso más restrictivo es cacillo.

\section{CAZOLETA [caçoleta, caçueletas]}

Sust. f. 'Pieza redonda de acero, que se fija en el medio de la parte exterior del broquel para cubrir su empuñadura', 'pieza de hierro u otro metal, que se pone debajo del puño de la espada y del sable, y sirve para resguardo de la mano' (DLE, 1. a y 2.a ac.). Covarrubias recoge las voces caçoleta y caçolexa como diminutivos de caçuela (NTLLE, s. v. caço, Covarrubias, 1611). Término derivado de cazo (DECH, s. v. cazo).

Un vrasero con su caja y caçoleta (Grajal de Campos, LE-1658)

Dos caçueletas de cobre pequeñas (Medina de Rioseco, VA-1657)

Es un término de naturaleza polisémica que se localiza en la documentación de forma tardía. La primera constancia que tenemos de este término en el $C D H$ es en un tratado sobre el cuidado de las mujeres datado en 1525 con la acepción de 'contenedor de perfume': "cazoleta de olor para perfumar", "cazoleta de perfume". Con este significado figura casi un siglo más tarde en el CORDE, en la Relación y memoria de las joyas de Ana de Austria (1615).

En este mismo siglo aparece como 'cazuela o recipiente pequeño para contener alimentos' acepción no encontrada en el diccionario académico: "[...] encima unas cazoletas pequeñas llenas de aves cortadas, con cierto caldo amarillo [...]", en la obra Historia general y natural de las Indias fechada en 1535. Otro de los significados hallados en estos documentos es de 'parte de las armas de fuego'. Es un término poco frecuente en las relaciones de bienes (CorLexIn). Lo mismo ocurre con el corpus terracampino donde tan solo figuran dos casos y con dos variantes y significados aparentemente distintos también. La ocurrencia que aparece en Grajal de Campos referencia un utensilio que formaba parte de un brasero, similar al que aparece en el inventario de Felipe II: "una cazoleta de plata toda lisa, con dos aldabas y en el medio un escudo de las armas reales, que sirve con el brasero [...]" (CDH, s. v. cazoleta). El ejemplo de Medina de Rioseco presenta la forma diptongada caçueleta y se presenta entre el ajuar doméstico (bancos, cazos, escabeles...).

\section{CAZUELA [caçuela, cazuelica]}

Sust. f. 'Vasija, por lo común redonda y de barro, más ancha que honda que sirve para guisar y otros usos' (DLE). Autoridades da como definición de cazuela 'vaso de barro redondo, mas ancho que hondo, de diferentes tamáños, que sirve para guisar, o para assar los manjares, y entonces suelen ser baxas y prolongadas, como las que usan en las Pastelerías y Figones' (NTLLE, s. v. 
cazuela, Autoridades, 1729). Término derivado de cazo, voz común a los romances ibéricos con la lengua de oc. y el it., de origen incierto ( $D E C H$, s. v. cazo).

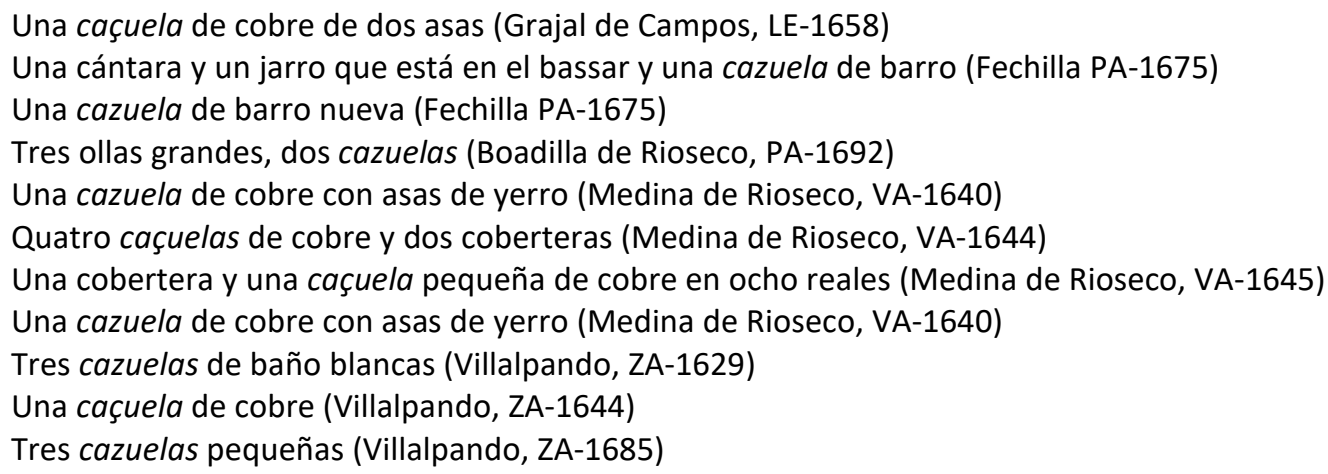

El CDH y el CORDE comienzan a documentar esta voz a finales del siglo XIV, adelantando unos años la fecha de la primera documentación que le da el $D E C H$ (1438). Desde un punto de vista diatópico y restringiendo la búsqueda al siglo XVII, el CorLexIn presenta más de una veintena de casos repartidos por todo el ámbito peninsular. Si bien presenta un uso extendido, sí que es cierto que el número de ocurrencias es menor que el de otros términos como olla, perol, caldera... Su uso será más frecuente en siglos posteriores: Gómez Ferrero encuentra más casos de este término en los siglos XVIII y XIX que en el siglo XVII, en su estudio sobre el léxico de La Bañeza (Gómez Ferrero, 2015: 144).

Desde un punto de vista formal, el corpus terracampino analizado ofrece un único ejemplo de diminutivo terminado en -ica:

Una cazuelica de cobre pequeña (Medina de Rioseco, VA-1649)

El uso del diminutivo resulta escaso a lo largo del siglo XVII, coincidiendo con corpus más generales como el CORDE.

\section{CAZUELO [caçuelo]}

Esta voz la encontramos recogida en el diccionario Histórico (1936) como un término propio de Soria y Aragón, localizado en la Tasa de Mercados de Zaragoza de 1646 (Diccionario Histórico, 1936). Con naturaleza sustantiva la encontramos en otras obras lexicográficas, no académicas como la de Castro y Rossi de 1852, donde se señala que 'en algunas partes se llama así a la cazuela honda y de culo estrecho'. También figura con marca diatópica, como ocurre en el Suplemento de Domínguez (1853): 'cazuela particular que se fabrica en Aragon, honda y estrecha en el asiento'. Término derivado de cazo.

Un caçuelo de açófar (Frechilla, PA-1639)

Como ocurre con otros derivados de cazo, esta voz se documenta en los textos a partir del siglo XVI, aunque no debió de ser una palabra de uso extenso, ya que el número de ocurrencias es significativamente escaso.

Esta escasez de ocurrencias en los corpus académicos coincide con la representación del término en el CorLexIn, donde tan solo figura un ejemplo en Cabra (Córdoba): 
Vna sartén pequeño y un cazuelo de cobre (Cabra, Córdoba, 1664)

Del mismo modo, en el corpus terracampino localizamos un único caso de este término. Este uso escaso de la palabra nos hace pensar que no tuvo mucha presencia como sustantivo en el acervo léxico del castellano del siglo XVII.

Sin embargo, esta falta de testimonios contrasta con la presencia de cazuelo en estudios léxicos más modernos y la información que nos ofrecen los atlas lingüísticos, done se registra el término cazuelo como 'recipiente de cocina'. El Fichero General registra algunas cédulas que referencian la presencia de este término en el ALEANR (Atlas Lingüístico y Etnográfico de Aragón, Navarra y la Rioja) como 'vasija en la que se desnata' (lám. 734) o también como 'instrumento con que se raspa la piel del cerdo' (lám. 761, mapa 665) (Fichero General, cédulas 3 y 7). En el ALEICan (Atlas lingüístico y etnográfico de las Islas Canarias) figura como sinónimo de 'puchero' (lám. 600, mapa 588) (Fichero General, cédula 8). Sin embargo, al consultar el DHECan, no se ha encontrado este lema.

Esta palabra se localiza en zonas leonesas como Murias de Paredes, La Vecilla, León, Valencia de Don Juan, Astorga y Sahagún, en esta última zona como 'pozuelo en el que se comían las sopas' Canarias (Le Men, 2004, s. v. cazuelo). Se registra en Palencia como 'cierto cacharro pequeño de barro, usado para guisar' (Gordaliza, 1988: 65). Además, se localiza en Asturias, Navarra, Aragón, Andalucía o Canarias (Le Men, 2004, s. v. cazuelo).

\section{COBERTERA [couertera, covertera]}

Sust. f. 'Pieza llana de metal o de barro, de forma generalmente circular, y con un asa o botón en medio, que sirve para tapar las ollas o para otros usos' $(D L E)$. Covarrubias define esta voz como 'cierta forma de plato llano, de hierro, cobre, o tierra, con que se cubre la olla [...]' (NTLLE, s. v. cobertera, Covarrubias, 1611). Se trata de un término derivado del verbo cubrir, del lat. COOPERIRE (DECH, s. v. cubrir).

Una cobertera de yerro (Cea, LE-1610)

Un rallo y una cobertera de hierro grande (Arenillas, LE-1636)

Una cobertera de olla, bieja, de yerro (Castroañe, LE-1637)

Un qubilete, dos coberteras, una pequeña y otra grande (Grajal de Campos, LE-1658)

Tres coberteras de yerro grandes (Grajal de Campos, LE-1656)

Una cuchar y dos coberteras de yerro tasado todo en un real (Grajal de Campos, LE-1663)

Una cuchara de olla y una cobertera (Valderas, LE-1682)

Dos coberteras, una de yerro y otra de teja (Frechilla, PA-1639

Una couertera de ierro (Paredes de Nava, PA-1689)

Una cobertera de hierro (Fechilla PA-1675)

Una cobertera de yerro (Medina de Rioseco, VA-1639)

Una cobertera de acófar (Medina de Rioseco, VA-1644)

Una covertera de cobre (Medina de Rioseco, VA-1660)

Una cobertera de yerro (Villalpando, ZA-1666)

Una cobertera de yerro de olla (Villalpando, ZA-1690)

Tres couerteras de yerro (Villalpando, ZA-1696)

Este término se documenta desde de la segunda mitad del siglo XIII en el $C D H$ con la acepción académica. En la zona de estudio aparece como la 'tapadera de cualquier recipiente de cocina', coincidente con la mayoría de los ejemplos que aparecen en el CorLexIn. En estudios léxicos más 
actuales como el de Gordaliza, figura como 'cualquier tapadera para cazuela o puchero de barro. Suele tener un pitorro en el centro' (Gordaliza, 1988: 69). Le Men afirma que en la parte oriental de León y Zamora se utiliza con la acepción que encontramos en Tierra de Campos (Le Men, 2004, s. v. cobertera).

\section{OLLA [holla, ollica, ollón, ollilla]}

Sust. f. 'Vasija redonda de barro o metal, que comúnmente forma barriga, con cuello y boca anchos y con una o dos asas, la cual sirve para cocer alimentos, calentar agua, etc.' (DLE). Covarrubias define este término como 'vn vaso de cozina, en que se queze principalmente carne, y todas las demas cosas. Por la figura metonimia se toma olla por los que esta dentro della [...]' (NTLLE, s. v. olla, Covarrubias, 1611). Voz procendente del lat. ōLLA (DECH, s. v. olla).

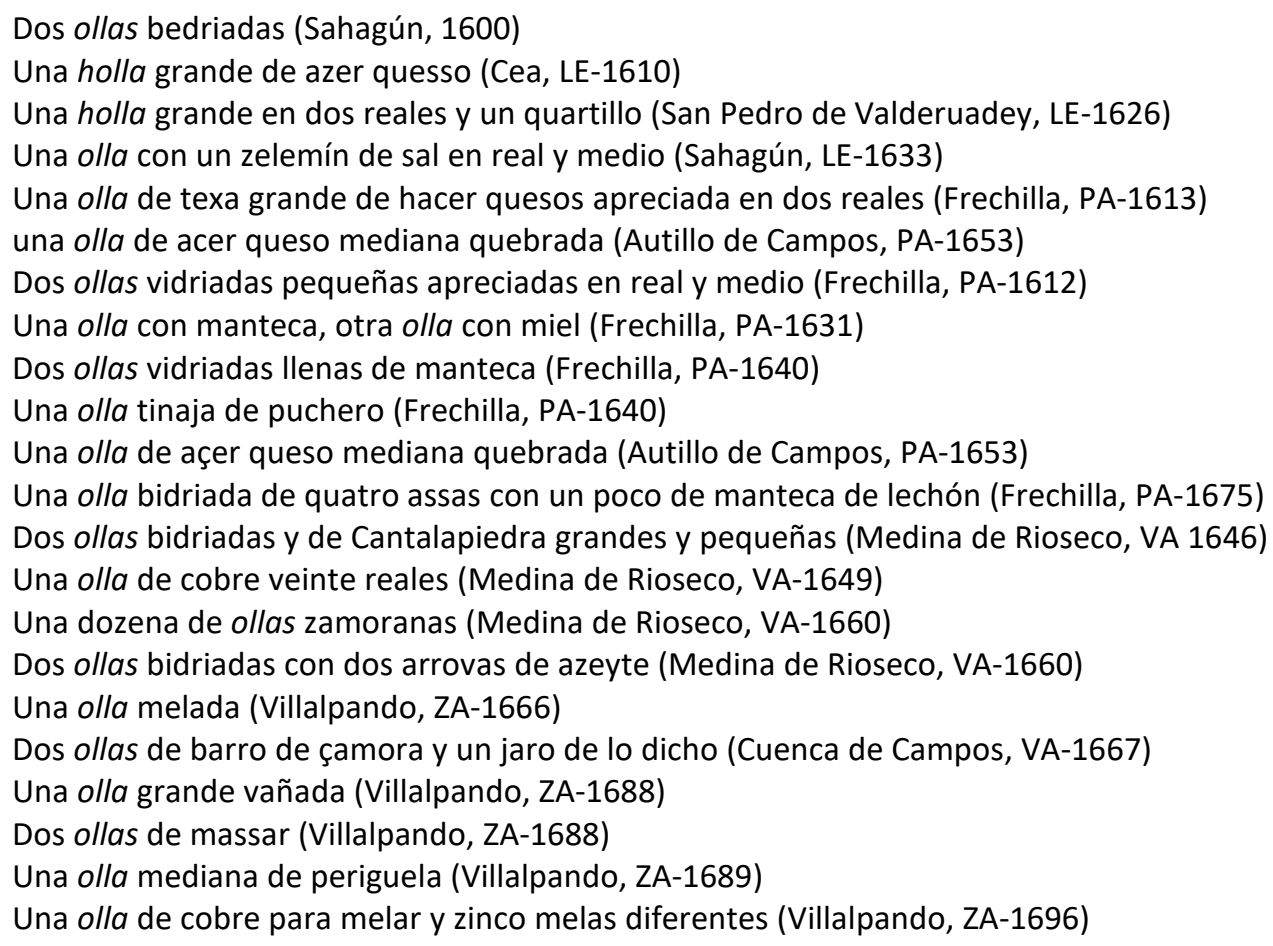

Es un término muy frecuente en los inventarios de bienes del siglo XVII y muestra una distribución diatópica de carácter general en la Península (CorLexIn). Desde una perspectiva diacrónica esta voz aparece en documentos del CORDE a partir del siglo XII y en el $C D H$ desde un siglo más tarde. En Tierra de Campos es habitual encontrar este término junto a los enseres de la cocina: con distintos usos, encontramos 'ollas para vender vino', 'ollas para hacer queso', 'ollas de masar' y 'ollas de melar', o que contienen manteca, sal, miel, vino o aceite; se suele especificar de qué material están hechas de barro (de Zamora, de Cantalapiedra, de Pereruela), de teja, vidriadas, o de cobre, entre otros.

Desde un punto de vista formal figuran diferentes variantes formadas por derivación:

Otra ollica de bañado blanco un real (Sahagún, 1600)

Una olla de bender bino y un ollón (Valderas, LE-1682)

Una ollilla berde (Frechilla, PA-1640)

Dos ollillas de sacar vino (Frechilla, PA-1631) 
Una ollilla de texa llena (Frechilla, PA-1675)

Aparece el término en diminutivo con la terminación -illa, aunque también hay un ejemplo en -ica que registra Autoridades con el mismo significado 'la olla pequeña' (NTLLE, s. v. ollica, ollica, Autoridades, 1737). Figura también el término ollón, aumentativo que no se registra en ningún diccionario académico hasta la edición actual que aparece como 'olla grande' (DLE), Pagés lo incluye en los lemas de su diccionario con el término que hoy reconoce la Academia (NTLLE, s. v. ollón, Pagés, 1925).

\section{PEROL}

Sust. m. 'Vasija de metal, de forma semejante a media esfera, que sirve para cocer diferentes cosas' (DLE). Covarrubias lo define como 'vn genero de vaso de metal abierto, que se pone sobre el fuego y se adereçan en el todos los generos de conseruas que se hazen en açucar y miel [...]' (NTLLE, s. v. perol, Covarrubias, 1611). Término procedente del cat. perol, diminutivo del catalán dialectal pér, que procede del galo * parion (DECH, s. v. perol).

Un perol de cobre mediano (Paredes de Nava, PA-1690)
Un perol de açofar (Paredes de Nava, PA-1689)
Un perol de azófar muy biejo (Medina de Rioseco, VA-1640)
Un perol de açófar pequeño (Medina de Rioseco, VA-1648)
Un perol de cobre pequeño (Medina de Rioseco, VA-1660)
Un perol de açofar pequeño con asas (Medina de Rioseco, VA-1671)
Una caldera de cobre y un perol de lo propio (Villalpando, ZA-1667)
Un perol de açófar mediano (Villalpando, ZA-1686)
Un perol de azófar ya ussado (Villalpando, ZA-1688)

Esta voz aparece documentada a finales del siglo XIV en un libro de cocina fechado en 1385 en el que se equipara el término con diferentes útiles de cocina como olla. Este interés por cotejarlo con otros objetos sigue en los textos del siglo XVII en los cuales se compara con cazuela, cazo, caldero, caldera o barreñón $(C D H)$. Es un préstamo procedente del catalán. En los archivos del CorLexIn aparece localizado en diferentes zonas de la Península entre los enseres de cocina, al igual que en la Tierra de Campos, donde se documenta de la misma manera, entre los utensilios de cocina y con una frecuencia menor que otros términos como olla, cazuela o cazo.

\section{PUCHERA}

Sust. f. coloq. 'olla (comida preparada con carne, tocino, legumbres y hortalizas)'. Para Autoridades, puchera, es lo mismo que olla (NTLLE, s. v. puchera, Autoridades, 1737). Término derivado de puches, del lat. PǓLTES, plural de PULS, -TIS (DECH, s. v. puches).

Dos cántaros biexos y dos ollas y dos pucheros y una pucherica (Celada, LE-1600)

Una puchera vidriada que tiene tres quartillos de miel tasada en ocho reales (Fechilla PA-1675)

Una puchera vidriada que tiene tres quartillos de miel (Frechilla, PA-1675)

El CORDE y el CDH documentan esta voz a partir del siglo XIII, pero a partir del siglo XVII se reduce el número de concordancias registradas, la palabra entra en un claro retroceso. 
En cuanto a la distribución diatópica del término, Morala localiza en documentos asturianos del siglo XVII esta voz con la acepción de 'medida de capacidad fraccionaria', y que coincide con un cuarto de azumbre (Morala, 2016b: 572).

Lo mismo ocurre en Tierra de Campos, donde tan solo figuran tres ocurrencias; dos de ellas presentan el mismo ejemplo en dos documentos de Frechilla (Palencia). El tercer caso presenta la forma de diminutivo pucherica y aparece junto a puchero en el mismo asiento. La acepción con la que aparecen en los inventarios terracampinos no coincide con la acepción que da el DLE, ni con la encontrada por Morala en los documentos asturianos, pues se trata más bien de una especie de vasija para guardar alimentos líquidos, en este caso, la miel. Con una acepción muy parecida, se documenta puchera en inventarios de la zona de La Bañeza, aunque ya en el siglo XIX (Gómez Ferrero, 2015: 148).

En zonas de León Le Men localiza en vocabularios dialectales esta voz como 'puchero pequeño', en La Bañeza como 'especie de tinaja o recipiente de barro o cerámica cocida, a modo de ánfora, con dos asas y barriga abultada y boca ancha, que sirve para meter alimentos en conserva, como pimientos en vinagre, pepinos, etc.' (Rivas, 1996: 190 en Le Men, 2009); en Zamora también se localiza este término como 'olla, vasija redonda, más alta que ancha, panzuda y con dos asas' (Borrego, 1981: 170 en Le Men, 2009).

En los inventarios estudiados figura el término derivado pucherica, probablemente con el valor apreciativo del diminutivo. En estudios más recientes, Gordaliza recoge la voz pucherilla en Palencia como 'pequeño puchero de barro usado para hacer sopas a fuego lento' (Gordaliza, 1988: 184).

\section{PUCHERO}

Sust. m. 'Vasija de barro o de otros materiales, con asiento pequeño, panza abultada, cuello ancho, una sola asa junto a la boca, y, por extensión, otros tipos de vasija' (DLE). Es una voz recogida por Nebrija; Autoridades la define como 'vasija de barro vedriado ù por vedriar, más pequeño que la olla, y que sirve para los mismos usos que ella' (NTLLE, s. v. puchero, Nebrija, 1495, Autoridades, 1737). Término derivado de puches, del lat. PǓLTES, plural de PULS, -TIS (DECH, s. v. puches).

Dos cántaros biexos y dos ollas y dos pucheros (Celada, LE-1600)
Una olla y un puchero (Valdavida, LE-1606)
Dos ollas y un puchero pequeño (Santa María del Río, LE-1617)
Tres ollas y tres pucheros de barro (Grajal de Campos, LE-1671)
Un puchero grande y un terrero (Frechilla, PA-1639)
Unos pucheros (Villarramiel, PA-1694)
Un puchero y tres cuchillas bastas (Boadilla de Rioseco, PA-1690)
Dos pucheros y un jarro pequeño (Tamariz de Campos, VA-1651)

Diacrónicamente, tanto el CORDE como el $C D H$ documentan esta palabra desde el siglo XIII en documenos peninsulares, y de forma más restringida en textos americanos desde el siglo XVI. Respecto a su uso en el siglo XVII, el CorLexIn no registra más de una veintena de casos repartidos por el centro y norte de la Península principalmente. Este uso, menos frecuente que el de otros términos como cazuela, olla o cazo, también se observa en el corpus terracampino, donde figura 
junto a utensilios de cocina y en muchos asientos junto a olla. En ocasiones, este término aparece formando parte de un sintagma preposicional que especifica el término al que acompaña:

Una olla de puchero a lo grande (Frechilla, PA-1631)

Una olla tinaja de puchero (Frechilla, PA-1640)

En este contexto parece posible que puchero haga referencia al 'alimento diario y regular' ( $D L E$, s. v. puchero, 4. a ac.); es decir, el escribano inventaría una olla en la que se hace la comida. Con esta acepción de 'comida o guiso' también figura en los documentos del castellano que conforman el $\mathrm{CDH}$ donde podemos encontrar ejemplos como:

[...] el primer día comí mi puchero sin sal (De los oficios más comunes, de Juan García Gómez, 1607).

Desde un punto de vista más formal, encontramos el derivado diminutivo acabado en -ico junto con el adjetivo chiquito, algo que parece redundante, pero en este caso el morfema derivativo conlleva un significado directamente relacionado con el objeto:

Dos ollas medianas y dos puchericos chiquitos (Sahagún, LE-1606)

En repertorios léxicos actuales aparece por diferentes zonas del leonés con esta acepción; así, en la zona de estudio se localiza como 'vasija de barro utilizada para poner el cocido a la lumbre' (García Caballero, 1992: 84 en Le Men, 2009).

\section{SARTÉN}

Sust. f. 'Recipiente de cocina, generalmente de metal, de forma circular, poco hondo y con mango largo, que sirve para freír' (DLE). Se trata de un término recogido por Nebrija y Covarrubias. Esta voz procede del lat. SARTĀGO, -AGINNIS (DECH, s. v. sartén).

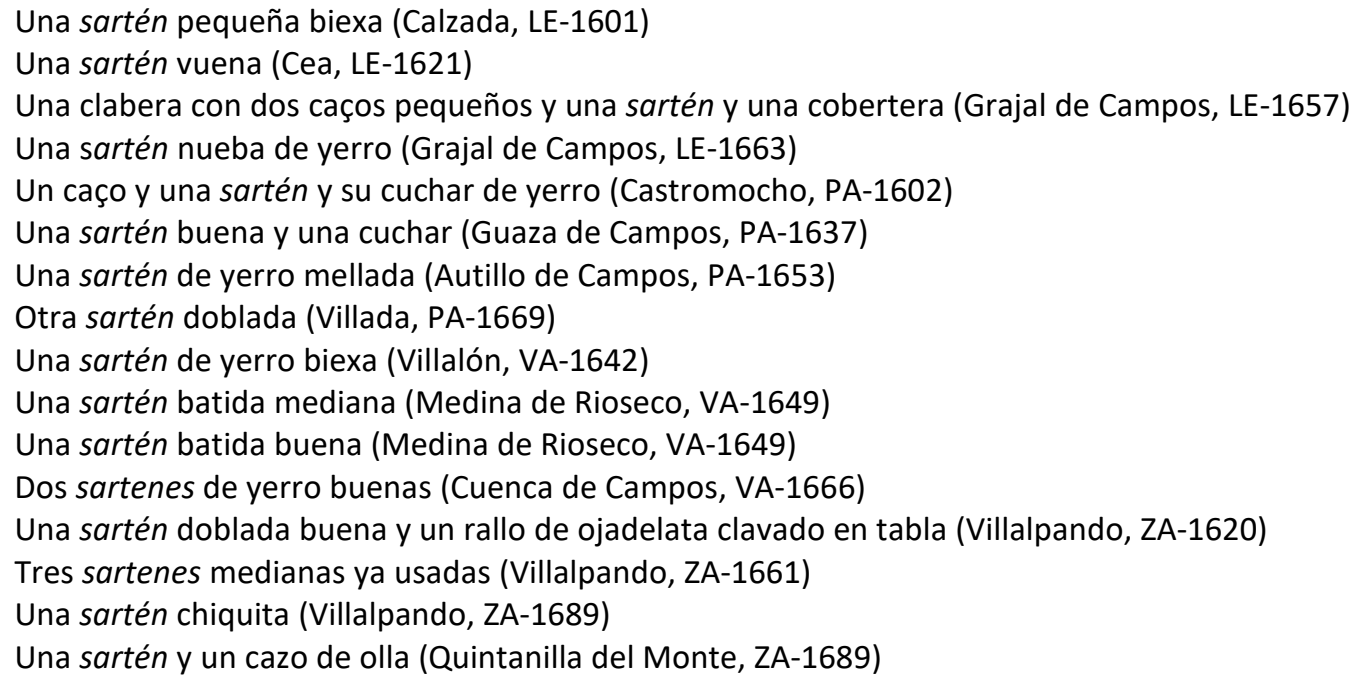

Desde una perspectiva diacrónica, este término figura en la documentación del castellano desde el siglo XIII, desde 1240 en el CDH (Libro de Apolonio) y desde 1275 en el CORDE (General Estoria de Alfonso $\mathrm{x}$ ). Adoptando una perspectiva diatópica, el CorLexIn presenta una distribución del término de carácter general. Del mismo modo, encontramos un gran abanico de casos en los textos terracampinos, casi siempre entre los enseres de cocina. Algunas veces, 
aparece modificado por el adjetivo doblada, tal para referirse a una sartén que fuera más gruesa que las demás. Doblada suele aparecer también en el corpus referenciando un tipo de manta más gruesa, habitualmente frente a vana (Morala, 2014c: 286).

El diminutivo de esta voz presenta un uso más retringido en los textos, frente a la forma acabada en -illa, de mayor frecuencia en el CorLexIn. En Tierra de Campos las dos únicas ocurrencias presentan el morfema derivativo -ica:

Dos sartenicas en dos reales (Sahagún, LE-1601)

Una sartenica pequeña en dos reales (Cuenca de Campos, VA-1666)

\section{TAPADERA / TAPADERO}

El DLE recoge tapadera como 'pieza que se ajusta a la boca de alguna cavidad para cubrirla, como en los pucheros, tinajas, pozos, etc.'; también aparece tapadero como 'instrumento con que se tapa un agujero o la boca ancha de algo' (DLE, s. v. tapadera, tapadero). Autoridades registra estos dos términos con acepciones muy similares. Término derivado de tapa, probablemente del gót. *tappa. (DECH, s. v. tapa).

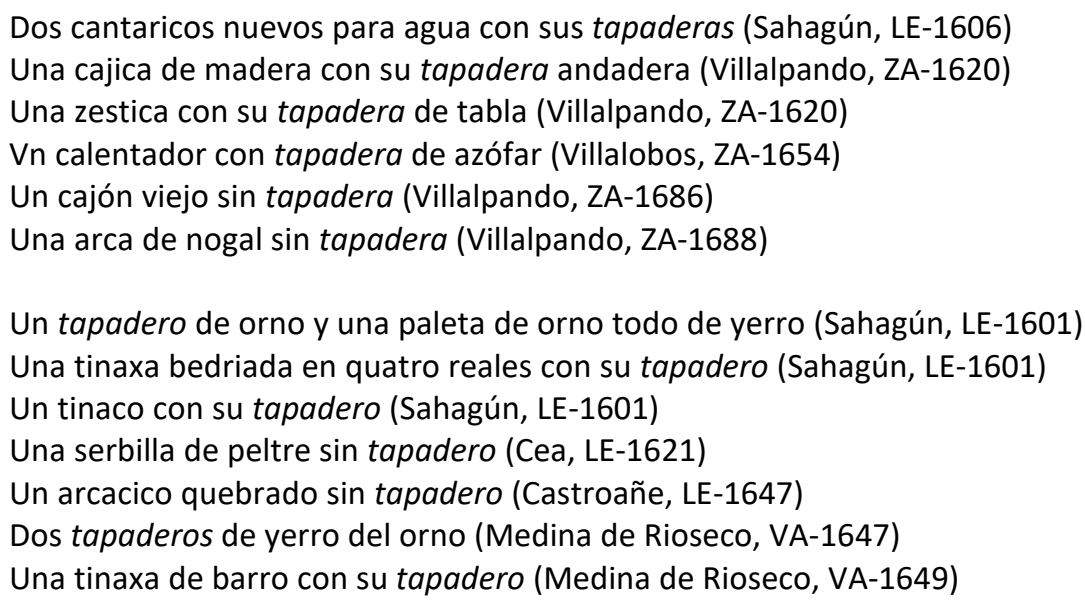

Estamos ante una forma derivada a través del sufijo deverbal -dero,-dera, muy productivo en esta época y que interfiere con el sufijo -dor. En el corpus analizado encontramos la forma femenina tapadera y la masculina tapadero.

Tapadera se documenta en el $C D H$ en el Vocabulario de Nebrija, a finales del siglo XV, y en la primera mitad del XVI ya hay testimonios en la documentación americana. Sin embargo, la forma del masculino tapadero figura siglos antes en la documentación (siglo XIII), pero solo sobrevive hasta mediados del siglo XVII; a partir de este siglo no se encuentran apenas casos.

Existe una preferencia por estos términos en la franja occidental de la Península, hecho que ha señalado Morala (Morala, 2012b: 340)

En el CorLexIn la forma del femenino tapadera se utiliza en un ámbito geográfico amplio (Ávila, Palencia, Badajoz, Cádiz, Albacete, Cáceres, pero también en Canarias y en algunos textos de América), mientras que el término tapadero concentra su uso en la zona leonesa de la zona estudiada, salvo un caso aislado en Cádiz. 


\section{TAPADOR}

Sust. m. 'tapadera' (pieza) (DLE, 3.a ac.). Esta voz la recoge Autoridades como 'un género de tapa, o tapadera, que regularmente encaxa en la boca, ò abertura de lo que se quiere tapar' (NTLLE, s. v. tapador, Autoridades, 1739). Término derivado de tapa, probablemente del gót.

*tappa.

Una colodra biexa con su tapador (Sahagún, LE-1608)

Una caja con su tapador (Cea, LE-1621)

Una serbilla pequeña destaño sin tapador (Ferchilla, PA-1612)

Una servilla de estaño con su tapador (Frechilla, PA-1614)

Una arca de pino quebarda sin tapador (Frechilla, PA-1615)

Un espexo demediado de los grandes con su tapador (Frechilla, PA-1631)

Una pala y un tapador de yerro de horno (Medina de Rioseco, VA-1640)

Una tinaja con su tapador y un cántaro (Medina de Rioseco, VA-1641)

Una tinaja de varro con su tapador y un cántaro (Medina de Rioseco, VA-1642)

Un espexo demediado de los grandes con su tapador (Frechilla, PA-1631)

Una pala y un tapador de yerro de horno (Medina de Rioseco, VA-1640)

Una tinaja con su tapador y un cántaro (Medina de Rioseco, VA-1641)

Una tinaja de varro con su tapador y un cántaro (Medina de Rioseco, VA-1642)

Una jarra de plata sobredorada con su tapador (Medina de Rioseco, VA-1649)

Dos cántaros grandes con sus tapadores (Villalpando, ZA-1629)

Tapador es un derivado deverbal que comparte significado con tapadera, tapadero, y, por supuesto, con la forma genérica tapa. Desde una perspectiva diacrónica, si bien se documentan testimonios de esta palabra desde el siglo XV, esta voz no ha resistido el paso del tiempo y las ocurrencias no van más allá del siglo XVII en el CDH y CORDE.

La consulta al CorLexIn proporciona casi cincuenta ejemplos repartidos por la zona centro oriental de la Península, salvo algún caso aislado en León (Morala, 2012b: 340).

En la Tierra de Campos tapador figura sobre todo en documentos vallisoletanos y palentinos, frente a las zonas más occidentales que prefieren los términos tapadera y tapadero.

\section{TARTERA}

Sust. f. 'Recipiente cerrado herméticamente, que sirve para llevar los guisos fuera de casa o conservarlos en el frigorífico' o 'tortera' (DLE). Autoridades registra el término y nos remite a la entrada tortera 'vaso, instrumento de cocina, en que cuecen, forman las tortadas, que regularmente es de cobre, y suelen servirse de ella para otros usos' (NTLLE, s. v. tartera, Autoridades, 1739). Término derivado de tarta.

Una tartera y un rallo y dos pares de parrillas (Grajal de Campos, LE-1658)

Una tartera de cobre (Medina de Rioseco, VA-1644)

Una tartera grande de cobre (Medina de Rioseco, VA-1643)

Dos tarteras de cobre con sus couerteras (Medina de Rioseco, VA-1648)

Dos tarteras y dos cubiletes de cobre (Medina de Rioseco, VA-1685)

El término tartera se registra de forma tardía en las bases de datos académicas. Tanto el CORDE como el CDH registran esta voz en 1600, en el inventario de bienes muebles de Felipe II, y en 1611 en el Suplemento al Tesoro de la lengua castellana de Covarrubias, en una de sus 
disertaciones. Sin embargo, esta presencia en la documentación es un mero espejismo, ya que no aparecen más ocurrencias hasta bien entrado el siglo XIX en obras de corte técnico (como tratados de cocina) o literario. Aunque esta tendencia se puede observar en algunos estudios como el de La Bañeza, donde los casos que se localizan están datados en en su mayoría en dicho siglo (Gómez Ferrero, 2015: 150). Sin embargo, la presencia en los documentos notariales es mayor. En el corpus terracampino se presentan unos cuantos ejemplos que se inventarían junto a cucharas, coberteras, asadores, cantimploras o cubiletes, lo que sitúa este objeto como un enser de cocina que en muchas ocasiones llevaba cobertera o tapa. El CorLexIn documenta esta voz en la mitad norte peninsular.

\section{TORTERA}

Sust. f. 'Caja o cesta para guardar tortas' (DEL, 3. ac.). Aunque Covarrubias recoge el término, el significado es diferente al encontrado en los textos. Autoridades registra el término con el significado de 'vaso, instrumento de cocina, en que cuecen, forman las tortadas, que regularmente es de cobre, y suelen servirse de ella para otros usos'. Término derivado de torta, del lat. tardío TŌRTA (DECH, s. v. torta).

Una tortera (Villalpando, ZA-1620)

Tortera se documenta en el $C D H$ en épocas relativamente recientes; no hay ejemplos en la documentación hasta el siglo XVII y es bastante escasa. Aunque la forma tortera se documenta a finales del siglo XV, esta voz no llega a consolidarse en la lengua. La mayor parte de los ejemplos están fechados en el siglo XX.

En los inventarios del siglo XVII aparece tanto tortera como tartera, si bien la localización es diferente para cada una de las formas: mientras que tartera se halla en documentos del norte de la Península (Álava, Guipúzcoa, La Rioja y Madrid), tortera se localiza en zonas meridionales (Badajoz, Cuenca o Murcia).

\subsubsection{6. Útiles de la lumbre}

\section{ASADOR [assador]}

Sust. m. 'Varilla puntiaguda en que se clava y se pone al fuego lo que se quiera asar' ( $D L E$, 2.a ac.). Covarrubias registra este término como 'el hierro largo en que se espeta la carne para asarla' (NTLLE, s. v. asador, Covarrubias, 1495). Término derivado de asar del lat. ASSARE íd., derivado de ASSUS, -A, -UM, 'asado' (DECH, s. v. asar).

Quatro asadores y un rallo y una cuchar (Sahagún, LE-1600)

Dos asaderos uno mejor que otro (Castroañe, LE-1609)

Una cuchar y un asador (San Nicolás del Real Camino, LE-1631)

Tres asadores de yerro (Grajal de Campos, LE-1658)

Dos candiles y un asador (Guaza de Campos, PA-1640)

Un candelero y un asador (Villada, PA-1665)

Un assador de hierro (Frechilla, PA-1675) 
Un assador de yerro (Paredes de Nava, PA-1690)

Una cuchar, un tornaguebos y un assador (Medina de Rioseco, VA-1640)

Dos cucharas y dos asadores de yerro (Tamariz de Campos, VA-1652)

Dos sartenes y dos asadores de yerro (Medina de Rioseco, VA-1661)

Dos assadores de yerro (Cuenca de Campos, VA-1666)

Dos asadores, una cuchar de la olla y un caço (Villalpando, ZA-1631)

Dos asadores i unas tenazas (Villalpando, ZA-1637)

Tres assadores pequeños (Villalpando, ZA-1688)

Es un término registrado con frecuencia en los inventarios de la Tierra de Campos y este hecho se hace extensible al resto de los inventarios de la Península. Los datos proporcionados por el $C D H$ y el CORDE sitúan las primeras documentaciones de esta voz a principios del siglo xvi. El primero localiza esta palabra en un inventario fechado en 1402, y el CORDE lo hace años más tarde en una obra de corte literario (1424). Este objeto era muy habitual en los enseres de las cocinas y así lo demuestra el alto número de ejemplos que aparecen en el CorLexIn a lo largo de la Península; no así en América, donde tan solo se localizan dos ejemplos en Chile. Dentro de nuestro corpus se localiza un ejemplo en Castroañe (León) con la variante asadero, con el mismo significado con el que encontramos la forma asador si nos remitimos al contexto en el que se ubica, dentro de los enseres de cocina. Esta variante ha sido localizada por Morala en algunos inventarios procedentes de las provincias de Ávila y Cáceres (Morala, 2012b: 338-339).

\section{BADIL [vadil]}

Sust. $\mathrm{m}$. 'Paleta de hierro o de otro metal, para mover y recoger la lumbre en las chimeneas y braseros' (DLE). Lo registran en sus obras tanto Nebrija como Covarrubias; este último lo define como 'la pala de hierro con que cogemos la lumbre, quando de la chimenea quermos echar brasa en los braseros, o en otra parte' (NTLLE, s. v. badil, Nebrija, 1495, Covarrubias, 1611). Se trata de un término procedente del lat. vulg. *BATīLE, clás. BATILLUM (DECH, s. v. badil).

Tres vadiles e una sartén (Sahagún, LE-1600)

Dos badiles buenos (Calzada, LE-1601)

Tres badiles grandes (Sahagún, LE-1608)

Dos badiles de yerro y una paleta (Santa María del Río, LE-1617)

Un badil en un real (Celada, LE-1624)

Una clabera con dos badiles y el vno de tres dientes (Castroañe, LE-16379

Dos badiles en un real (Mazariegos, PA-1619)

Un candil y un badil (Guaza de Campos, PA-1637)

Un badil y una cuchar de hierro y una caldera pequeña de cobre (Guaza de Campos, PA-1639)

Un badil de yerro (Paredes de Nava, PA-1690)

Un badil (Castromocho, PA-1602)

Dos vadiles (Villalón, VA-1637)

Una calderilla con su badil y cadenilla de plata çercada (Medina de Rioseco, VA-1648)

Desde una perspectiva diacrónica, el $C D H$ localiza esta voz a partir de la segunda mitad del siglo XII en documentos oficiales -1252 en el Fuero de Ledesma-e inventarios de bienes -1268 , Carta de inventario del Monasterio de Carrizo (León)-. Su presencia en los textos comienza a reducirse a partir de finales del siglo XVI. Badil se encuentra documentado en el siglo XVII a lo largo de la geografía española como se puede observar en el CorLexIn, lo que incluye la Tierra de Campos. 
En estudios más recientes como el de Gordaliza encontramos esta palabra como 'barra de hierro para remover las cenizas' (Gordaliza, 1988: 40) y Le Men localiza este término en gran parte del dominio leonés (Le Men, 2002, s. v. badil).

\section{BRASERO [BRASSERO, VRASERO)}

Sust. m. 'Recipiente de metal, ancho y hondo, ordinariamente circular, con borde, en el cual se echan o se hacen brasas para calentarse' (DLE). Recogida por Nebrija y Covarrubias, Autoridades define esta palabra como 'bacía ò vaso redondo de metál, plata, cobre, azófar, etc. que se pone sobre una caxa de madéra, ù de otra cosa, que sirve como de pie ò basa, y en él se pone y tiene lumbre para calentarse. Hacense tambien de barro, para el uso de la gente pobre: y de una y de otra espécie se hacen de várias hechúras y manéras' (NTLLE, s. v. brasero, Nebrija, 1495, Covarrubias, 1611, Autoridades, 1726). Palabra derivada de brasa, de origen incierto, latino o prerromano (DECH, s. v. brasa).

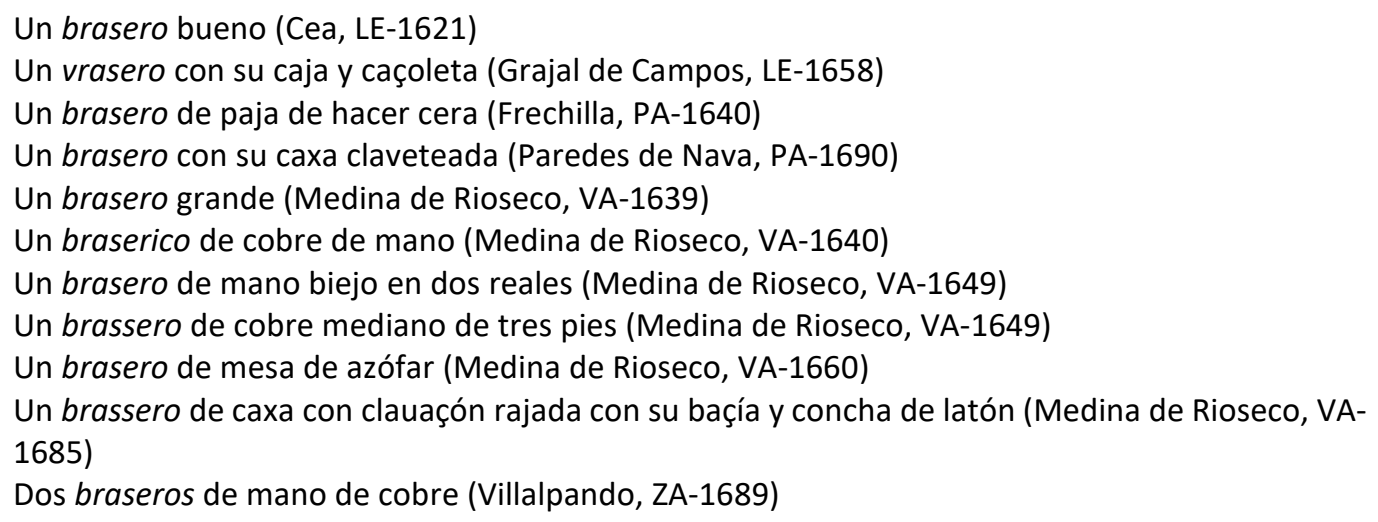

Es un término de uso cotidiano que aparece con frecuencia en los inventarios de Tierra de Campos y en el resto de documentación. El brasero tenía la función de calentar estancias, mediante cierta cantidad de brasas. Su forma podía variar, así como el material con el que estaba fabricado.

El CDH localiza este término como adjetivo en el siglo XIV (1325) "un cutiello brasero" y como sustantivo a partir del siglo Xv (1400). Los datos que nos ofrece el CorLexIn presentan una amplia nómina de casos en la Península, Canarias y América. En la zona de estudio aparecen diferentes tipos, los hay que los forman diferentes componentes como puede ser la caja, caçoleta o la bacía, y con diferentes funciones: de mano, de mesa, de paja para hacer cera, etc.

El término brasero compartía campo semántico con calentador y estufa.

\section{CALENTADOR}

Sust. m. 'Recipiente con brasas, agua o corriente eléctrica, que sirve para calentar la cama, biberones, etc.' (DLE, 2. a ac.). En el Vocabulario de Nebrija aparece como 'calentador para cama', y Autoridades lo describe como 'vaso redondo de azófar o otro metal, que se cubre con una tapa movible, la qual está agujerada por encima, para comunicar el calor de la lumbre que tiene dentro, y por un hastil de hierro o palo, de largo de una vara, se mete entre las sábanas para 
calentar la cama' (NTLLE, s. v. calentador, Nebrija, 1495, Autoridades, 1729). Es una voz derivada de caliente, del lat. CALENS, -ĚNTIS (DECH, s. v. caliente).

Un calentador (Sahagún, LE-1606)

Un calentador (Grajal de Campos, LE-1658)

Un calentador de cobre (Castromocho, PA-1611)

Un calentador de cobre (Paredes de Nava, PA-1690)

Un calentador de cobre y el tapador de azófar (Medina de Rioseco, VA-1640)

Un calentador de açófar treinta reales (Medina de Rioseco, VA-1649)

Un calentador de açófar tasado en diez y seis reales (Medina de Rioseco, VA-1644)

Un calentador bueno (Villalpando, ZA-1620)

Un calentador de cobre con tapa de azófar (Villalpando, ZA-1686)

Un calentador (Villalpando, ZA-1688)

El CDH localiza este término a finales del siglo Xv (1477) como un objeto que sirve para calentar la cama, aunque en siglos posteriores este significado se amplía y así aparecen calentadores de manos o para hervir agua. El CorLexIn registra un número de ocurrencias menor que brasero y presenta una preferencia por este término en la mitad norte de la Península, aunque también aparecen casos en algunas provincias andaluzas como Sevilla, Granada y Cádiz, pero en menor proporción. En la zona de Tierra de Campos comparte campo semántico con brasero, de ahí que su presencia en el corpus estudiado sea ligeramente menor.

\section{CARBONERA}

Sust. f. 'Lugar donde se guarda carbón' ( $D L E$, 5. a ac.). Covarrubias recoge el término como 'el lugar donde se haze, y donde se guarda, y la que lo vende', esta acepción también está presente desde el diccionario de Autoridades (NTLLE, s. v. carbonera, Covarrubias, 1611, Autoridades, 1729). Palabra derivada del término carbón, del lat. CARBO, -ōNIS, íd. (DECH, s. v. carbón).

Dos carboneras de puchero (Frechilla, PA-1640)

Una potra para peynar y una carbonera (Frechilla, PA-1659)

Una carbonera de yerro (Medina de Rioseco, VA-1647)

Los casos localizados de este término en Tierra de Campos no coinciden con la acepción dada por Covarrubias y los diccionarios académicos, pues no hacen referencia a un lugar donde se almacena carbón, sino que parece ser un objeto de uso cotidiano, dado que se inventaría junto a tapaderos de yerro, azadones, cardas, palas de hierro, escriños, bruñidores o poçaletas, entre otros. El término se localiza en el siglo XIII en un documento de lindes de pastos anónimo en el CORDE, haciendo referencia a un lugar ("en una foya carbonera en el sendero antiguo"). La restricción diacrónica al siglo XVII en la documentación del $C D H$ muestra una escasa nómina de casos que coinciden con la acepción dada por el DLE. En el CorLexIn aparece un ejemplo en Huesca que concuerda con la acepción académica. En la zona de La Bañeza se localizan en esta misma época zien carvoneras de barro, caso cuya acepción tampoco coincide con la dada por el $D L E$, pero que podría estar más cercana al significado que tiene en los inventarios terracampinos (Gómez Ferrero, 2015: 130). Aparentemente, se trata de un recipiente similar a un brasero. 


\section{CAZA}

La acepción que presenta aquí la voz caza no aparece dentro de las acepciones que da el DLE a este término. Tal vez sea una variable de la palabra cazo, que formaba parte del ajuar de cocina.

Unas tijeras y una caza pequeña (Villalpando, ZA-1629)

En Tierra de Campos se localiza un ejemplo recogido en Villalpando en 1629; aparece junto a unas tijeras y hace referencia a un objeto que se utilizaba en las cocinas. En este caso el término caza no designa el tejido estudiado anteriormente, sino que parece ser un objeto que tiene más que ver con enseres de la cocina. Caza figura en otras localidades de la Península -Hellín (Albacete) y Bielsa y Monzón en Huesca- con una acepción tiene que ver de algún modo con el fuego (CorLexIn).

\section{ESCALFADOR}

Sust. m. 'Jarro de estaño, cobre u otro metal, hecho a manera de chocolatera, con su tapa agujereada como un rallo, y en el cual calentaban y tenían los barberos el agua para afeitar' (DLE, 2. a ac.). Autoridades registra este término por primera vez con esta acepción (NTLLE, s. v. escalfador, Autoridades, 1732). Se trata de un término derivado de calfar, procedente del lat. vulgar calfare, lat. CALEFACĔRE íd., compuesto de CALĒRE 'estar caliente' y FACĔRE 'hacer' (DECH, s. v. escalfar).

Un escalfador de cobre (Valderas, LE-1682)

Este es el único caso que encontramos de esta palabra en la Tierra de Campos. Esta escasez de datos también es extrapolable a lo que ocurre en el $C D H$ y en el CorLexIn. Se documenta en las Cuentas de Gonzalo Baeza, tesorero de Isabel la Católica fechado en 1477, donde aparece "vn caldero e dos escalfadores de cobre, para cozer agua". La mayoría de los documentos están fechados en el siglo XVII en inventarios donde esta voz aparece junto a calderos, jabones, tijeras o bacías, lo que apunta al significado que mantiene Autoridades $(C D H)$. Se trata de un término poco utilizado; en el CorLexIn localizamos dos ejemplos en toda la Península en las provincias de Huesca y Guipúzcoa (en ambos casos parece tratarse del recipiente o jarro utilizado para calentar el agua), a los que hay que añadir otro ejemplo localizado por Morala en Nava del Rey, provincia de Valladolid, en 1648 (Morala, 2015a: 1513). Sin embargo, en la zona de estudio no está tan claro este significado, no contamos con datos suficientes para adjudicarle el valor que le da el $D L E$ y, por el contexto en el que aparece, pudiera ser más un enser de cocina, ya que aparece junto a unos morillos. En la zona de La Bañeza figura un caso similar en el siglo XVIII, y que podría hacer referencia a 'braserillo de hierro u otro metal, con tres pies, que se ponía sobre la mesa para calentar la comida' registrado en la 3. a acepción del DLE (Gómez Ferrero, 2015: 156). Se trata de un término escasamente documentado. Ágreda localiza este término en inventarios aragoneses del siglo XV y XVI cuya función era calentar la cama (Agreda, 2017: 25). 


\section{ESCALFETA}

Sust. f. 'Brasero manual' (DLE). La primera vez que se registra esta palabra es en Rosal como 'braserillo', y aparece en el Suplemento del DRAE de 1803 como 'pieza de hierro ó de latón' (NTLLE, s. v. escaldeta, Rosal, 1611, Suplemento DRAE, 1803). Término procedente del cat. escalfeta, derivado del verbo escalfar ( $D E C H$, s. v. escalfar).

Una escalfeta de yerro (Medina de Rioseco, VA-1640)

Tan solo encontramos un ejemplo en Medina de Rioseco, en la zona vallisoletana de Tierra de Campos. La escasez de ejemplos se hace patente en la documentación cuando consultamos el $C D H$, en el que solo localizamos un ejemplo ya en el siglo xx y con la acepción de 'calentador de cama'. Lo mismo ocurre con la consulta a los archivos del CorLexIn, figura un caso en Teruel, bastante significativo: "una escalfeta de azófar para la mesa" (Teruel, 1677); en este caso podría ser 'una pieza de metal, de la hechura de los trincheros, con una especie de cordones alrededor, que la hacen parecer seis trincheros juntos; y llena de agua cociendo, se pone á cada convidado en la mesa, para que mantenga caliente la vianda, ó plato que come [...]' (NTLLE, s. v. escalfeta, Terreros y Pando, 1787). En el ejemplo de Medina de Rioseco no se da tanta información sobre el significado del término, aunque el contexto es más esclarecedor, ya que se encuentra entre enseres de la lumbre: braseros, morillos y paletas. En este caso, como en el anterior, se trata de una palabra muy poco presente en los inventarios de la época.

\section{ESTUFA}

Sust. f. 'Aparato destinado a calentar un recinto por electricidad o combustión de madera, gas, etc.' (DLE). El término aparece recogido por Nebrija, pero no con la acepción que aparece en los documentos analizados, y lo mismo ocurre con Autoridades. Se trata de un término derivado del verbo estufar 'calderar un aposento cerrado', y este probablemente de un verbo del lat. vulgar *EXTŪPHARE 'caldear con vapores'.

Una estufa con su calderilla con que se calienta la cama (Villalpando, ZA-1696)

El CDH localiza este término a partir de finales del siglo XIV con la acepción que dan Nebrija o Autoridades de 'especie de baño o azufrador'. Los datos que nos proporcionan tanto esta base textual como el CORDE muestran una mayor frecuencia del término a partir del siglo XIX.

El CorLexIn no registra el uso del término estufa en los inventarios que lo conforman; sí aparece una ocurrencia de la forma derivada estufilla con una acepción muy cercana a la que estamos estudiando: "vna estufilla de plata para el oratorio" en Oñate (Guipúzcoa, 1617). El corpus de Tierra de Campos presenta un único ejemplo en Villalpando, en el que presumiblemente se trataba de una especie de brasero que servía para calentar la cama. Puede deducirse que había una preferencia por el uso de calentador.

No se localiza con esta acepción en estudios dialectales como los de Gordaliza o Le Men; el primero registra este término como 'habitación donde está la gloria'. Se trata de un comedor o sala de estar que se calienta subterráneamente por la gloria, por contraposición a la trébede que es donde suele estar la cocina' (Gordaliza, 1988: 107). 
ESTUFILLA (Vid. 7.1.2.1. Prendas de abrigo)

\section{FUELLE}

Sust. m. 'Instrumento para recoger aire y lanzarlo con una dirección determinada, que esencialmente se reduce a una caja con tapa y fondo de madera, costados de piel flexible, una válvula por donde entra el aire y un cañón por donde sale cuando, plegándose los costados, se reduce el volumen del aparato' (DLE). Autoridades recoge que de este instrumento 'se sirven ordinariamente los herreros y otros artífices para avivar el fuego de la fragua' (NTLLE, s. v. fuelle, Autoridades, 1732). Término procedente del lat. FŏLls 'fuelle para el fuego', 'odre hinchado', 'bolsa de cuero' (DECH, s. v. fuelle).

Dos sufrideros y dos todillos, un grande y un pequeño y unos fuelles con sus cañones y un tablón (Fechilla, PA-1614)

Un fuelle pequeño de mano de herrero (Villalpando, ZA-1633)

Unos fuelles de mano (Villalpando, ZA-1689)

Este término se localiza en los textos a partir de la segunda mitad del siglo XIII (1256), según se puede ver en el $C D H$. Sin embargo, no está tan presente en los inventarios de los protocolos notariales de la Península en el siglo XVII; esto puede deberse no tanto a la escasez de este objeto, sino a que se trata de una herramienta profesional, típica de los herreros y que no solía estar en las casas. En Tierra de Campos encontramos ejemplos que clarifican esta circunstancia: en uno se hace referencia a herramientas profesionales entre las que se encuentra el "fuelle", y en otro se especifica que se trata de un "fuelle de herrero".

\section{LLAR [llares]}

Sust. f. 'Cadena de hierro, pendiente en el cañón de la chimenea, con un garabato en el extremo inferior para colgar la caldera, y a poca distancia otro para subirla o bajarla'. Se usa más en plural $\left(D L E\right.$, s. v. $\left.\| l a r^{2}\right)$. Covarrubias registra esta palabra en plural con la misma acepción que se mantiene hoy en día. La entrada de este término se mantiene en plural hasta el DRAE de 1884, donde comienza a registrarse con acepciones diferentes: la forma llar, como masculino singular 'fogón' y con marca dialectal en Asturias y Santander, y el femenino plural /lares, con la acepción que ya le daba Covarrubias. Y no es hasta el DRAE de 1959 cuando aparecen dos entradas diferenciadas para estas dos palabras. (NTLLE, s. v. llar, llares, Covarrubias, 1611, Autoridades, 1734, DRAE, 1884, DRAE, 1954). Palabra procedente del lat. LAR 'cada uno de los dioses familiares', 'hogar' (DECH, s. v. llar).

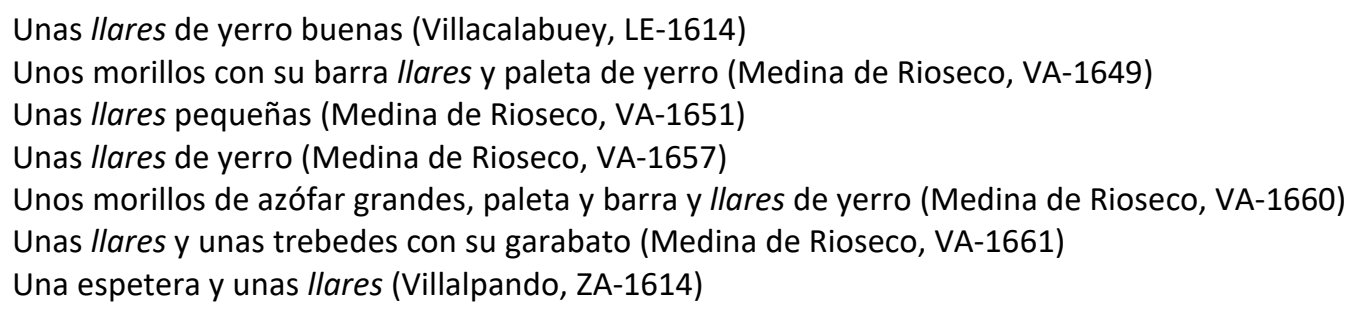

Es un término poco frecuente en bases de datos como el CORDE, donde aparecen algunos ejemplos de esta palabra desde finales del siglo XIII. Se trata de una voz habitual en los 
inventarios de bienes procedentes de Cantabria, País Vasco, Burgos, La Rioja y Segovia, aunque también aparece en Palencia, Valladolid, Ávila o Soria. Si bien, con menos frecuencia, se localizan ejemplos hacia el Sur de la Península; este hecho ya ha sido señalado por Morala, que ha estudiado en profundidad esta palabra con los datos aportados en el CorLexIn, y que rebate alguna de las teorías que señalan este término como un occidentalismo. Con estos datos, Morala parece demostrar la teoría de Pidal, según la cual la expansión del castellano en forma de cuña invertida parece estar reflejada en el mapa que conforma esta palabra, ya que la solución llares es más abundante en el entorno de Cantabria, Burgos y Palencia (Morala, 2018b: 222).

En estudios léxicos más actuales se localiza esta palabra como 'cadena de hierro que cuelga del techo en las cocinas de humo o de la parte superior de la hornacha en la trébede y que sirve para sostener la caldera y cocinar. Se dice normalmente en femenino y plural: las Ilares. En otros sitios se llama abregancias y pregancias'. (Gordaliza, 1988: 140).

\section{MORILLO}

Sust. m. 'Cada uno de los caballetes de hierro que se ponen en el hogar para sujetar la leña' $(D L E)$. Covarrubias registra esta palabra en plural y la define como 'los caualletes de hierro que se ponen en el hogar para sustentar la leña' (NTLLE, s. v. morillos, Covarrubias, 1611). Este término procede del lat. MAURUS 'moro', por las cabezas humanas con que suelen adornarse, tiznadas por el fuego ( $D E C H$, s. v. moro).

Un morillo, unas tenazas y una paleta todo de yerro en seys reales (Sahagún, 1600)

Dos morillos en dos ducados (Sahagún, LE-1602)

Dos morillos de yerro grandes (Grajal de Campos, LE-1658)

Dos morillos de yerro y unas tenaças, una paleta y unas parrillas (Grajal de Campos, LE-1656)

Un morillo de hierro en tres reales (Frechilla, PA-1612)

Un morillo de Hierro (Villada, PA-1669)

Unos morillos pequeños y tenazas todo de yerro (Medina de Rioseco, VA-1639)

Unos morillos de azófar con su barra (Medina de Rioseco, VA-1644)

Un aparexo de ogar con sus tenaça, paleta y morillos de yerro (Medina de Rioseco, VA-1657)

Unos morillos de azófar grandes, paleta y barra y llares de yerro (Medina de Rioseco, VA-1660)

Unos morillos de yerro usados con su paleta y tenazas (Medina de Rioseco, VA-1661)

Unos morillos de bronce grandes, con su varra, paleta y tenacas de yerro con los remates de bronçe (Medina de Rioseco, VA-1685)

Unos morillos de la lumbre y unas tenazas (Villalpando, ZA-1620)

Unos morillos de yerro y las caueças de latón (Villalpando, ZA-1633)

Unos morillos de yerro (Villalpando, ZA-1643)

Unos morillos altos (Villalpando, ZA-1666)

El CORDE registra esta palabra, con la acepción que aquí nos ocupa, en un par de inventarios de bienes fechados a finales del siglo XVI, en 1580. En el CDH se documenta a partir de 1585 . El uso mayoritario de esta voz se da en el siglo XVII, para luego entrar en un claro retroceso.

El CorLexIn ofrece una distribución de carácter general en el ámbito geográfico peninsular. Estamos ante un diminutivo lexicalizado que suele presentar el morfema derivativo -illo en la mayoría de los documentos.

Es un término de uso frecuente en Tierra de Campos y que suele figurar como parte de lo que, en algunos documentos, aparece como 'aparejo de hogar', constituido por las tenazas, la 
paleta y los llares junto con el término que nos ocupa. Los morillos solían ser de hierro, azófar e incluso de bronce. Además, solían ir decorados: en el corpus terracampino se referencian las cabezas que formaban parte del morillo y que cumplían también una función ornamental. Perdiguero encuentra en el Valle del Mena (Burgos) "unos morillos perrillos", tal vez por llevar la figura de un perro (Perdiguero, 2012c:1559), en Tierra de Campos los morillos pueden llevar las "caueças de latón" (Villalpando).

En estudios dialectales más modernos, Le Men localiza esta palabra en Tierra de Campos, con el significado de 'soporte metálico para contener los troncos de leña en el fogón de la cocina' (González Prieto, 1986: 147 en Le Men, 2007, s. v. morillo).

\section{PALETA [paletilla, paletica]}

Sust. f. 'Instrumento de hierro o acero inoxidable compuesto por un platillo redondo con agujeros y un astil largo, que se emplea en la cocina, principalmente para sacar los fritos de la sartén', 'badil u otro instrumento semejante con que se remueve la lumbre' o 'utensilio de palastro, de forma triangular y mango de madera que usan los albañiles para manejar la mezcla o mortero' (DLE, 3. , 4. a y 5 . a ac.). Término derivado de pala, del lat. PALA (DECH, s. v. pala).

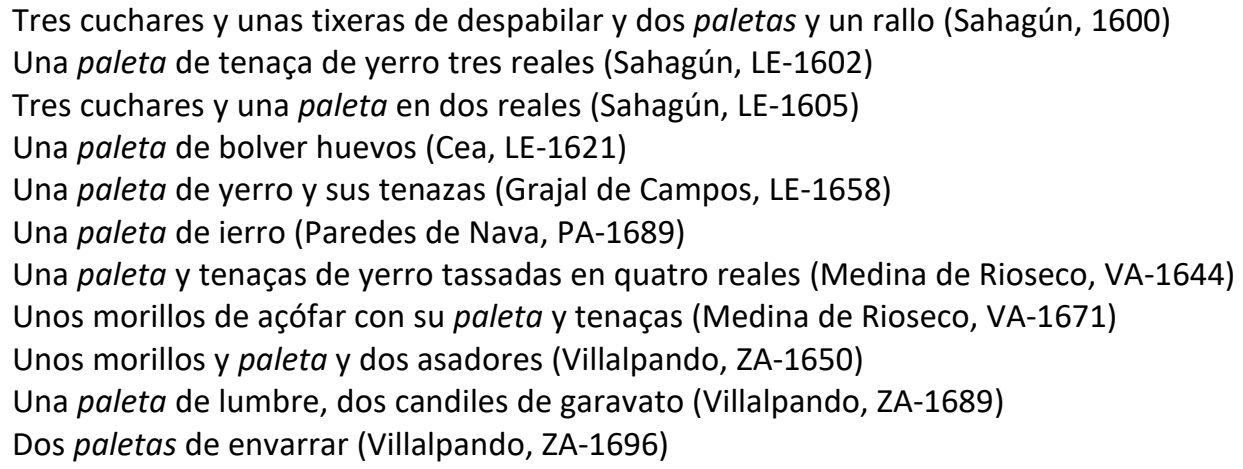

Es un término de naturaleza polisémica de uso frecuente en los documentos analizados. Entre los objetos que referencia está el de 'badil para remover el brasero', presente en los ejemplos encontrados, sobre todo en Zamora, donde recogemos "una paleta de la lumbre" o se presenta inventariado junto a morillos. Parece comprobado que en la zona zamorana de la Tierra de Campos hay preferencia por esta voz, frente a badil, voz de la que no encontramos ningún ejemplo en dicha provincia. También figura junto a los enseres de la cocina; así localizamos "una paleta de bolver huevos". Otro significado con el que figura en la documentación es la de herramienta de albañil en casos como "dos paletas de envarrar". Se trata, pues, de un término polisémico muy presente en Tierra de Campos y en el resto de la Península (CorLexIn). También aparece el diminutivo de esta voz tanto en -illa en toda la zona terracampina e -ica en la zona perteneciente a León, con la acepción de 'utensilio de cocina' en la mayoría de los casos:

Una sarten e un caço e una paletica (Sahagún, LE-1605)

Una paletilla de yerro (Valdavida, LE-1606)

Una paletilla de volber guebos (Cea, LE-1610)

Un martillo de yerro y dos taladros y una paletilla de yerro (Sahagún, LE-1610)

Un rallo y una paletica de volver guebos y una cobertera de yerro (Grajal de Campos, LE-1655) 
Tres paletillas y una cuchar y una tartera y un rallo y dos pares de parrillas (Grajal de Campos, LE1658)

Dos cuchares de yerro, unas parrillas y una paletilla del tornagueuos (Medina de Rioseco, VA1659)

Unas tenazas y paletilla de coxer lumbre de yerro (Villalpando, ZA-1689)

Esta palabra se documenta en León con distintas acepciones (Le Men, 2009, s. v. paleta).

\section{PARRILLA}

Sust. f. 'Utensilio de hierro en forma de rejilla para poner al fuego lo que se ha de asar o tostar' $(D L E)$. Este término lo registra Nebrija en su Vocabulario. Covarrubias lo define como 'instrumento de cocina, sobre el qual se asan las carnes, y los pescados, y otras cosas' (NTLLE, s. v. parrilla, Covarrubias, 1611). Probablemente, del gótico *parra, -ans, 'cercado, enrejado'. Es probable que el sentido inicial de parra fuese 'glorieta', 'emparrado', 'enrejado' de ahí parrilla 'rejilla' (DECH, s. v. parra).

Dos morillos de yerro y unas tenaças una paleta y unas parrillas (Grajal de Campos, LE-1656)

Un rallo y dos pares de parrillas (Grajal de Campos, LE-1658)

Unas parrillas con su pie (Castromocho, PA-1603)

Dos parrillas y una trebede de yerro (Castromocho, PA-1611)

Unas parrillas de yerro redondas (Autillo de Campos, PA-1653)

Unas parrillas con tres barretas de hierro en dos reales (Frechilla, PA-1675)

Unas parrillas viexas (Boadilla de Rioseco, PA-1692)

Unas parrillas de yerro pequeñas (Medina de Rioseco, VA-1643)

Dos caços de cobre, dos assadores, tres sartenes, unas parrillas de yerro, dos candeleros (Medina de Rioseco, VA-1647)

Unas parrillas de yerro (Medina de Rioseco, VA-1661)

Unas parrillas de asar sardinas (Villalpando, ZA-1685)

Unas parrillas grandes (Villalpando, ZA-1688)

Estamos ante un diminutivo lexicalizado de uso frecuente que se documenta en las bases textuales del español desde finales del siglo XIII.

Desde un punto de vista diatópico, el CorLexIn nos ofrece un número importante de ocurrencias que se reparten por toda la geografía peninsular. En la mayoría de los casos, esta voz figura con la acepción que aquí se analiza.

Es una palabra frecuente en los inventarios de la Tierra de Campos y que aparece con la acepción académica.

\section{TENAZAS [tenaças]}

Sust. f. 'Instrumento de metal, compuesto de dos brazos trabados por un clavillo o eje que permite abrirlos y volverlos a cerrar, que se usa para sujetar fuertemente una cosa, o arrancarla o cortarla' o 'instrumento de metal, compuesto de dos brazos paralelos enlazados en uno de sus extremos por un muelle semicircular y que por el otro tienen forma propia para coger la leña o el carbón de las chimeneas u otras cosas' (DLE, 1. a y 2.a ac.). Nebrija recoge este término en plural. Covarrubias registra tenaças como 'el instrumento para tratar la lumbre, y lo que tenemos en ella sin quemarnos' y '[...] también vsan los carpinteros de las tenaças para arrancar 
clauos' (NTLLE, s. v. tenazas, Nebrija, 1495; Covarrubias, 1611). Es un término derivado de tener, del lat. TĚNĒRE 'tener asido' y procedente de la alteración (a causa del género) de un más antiguo tenazes (DECH, s. v. tener).

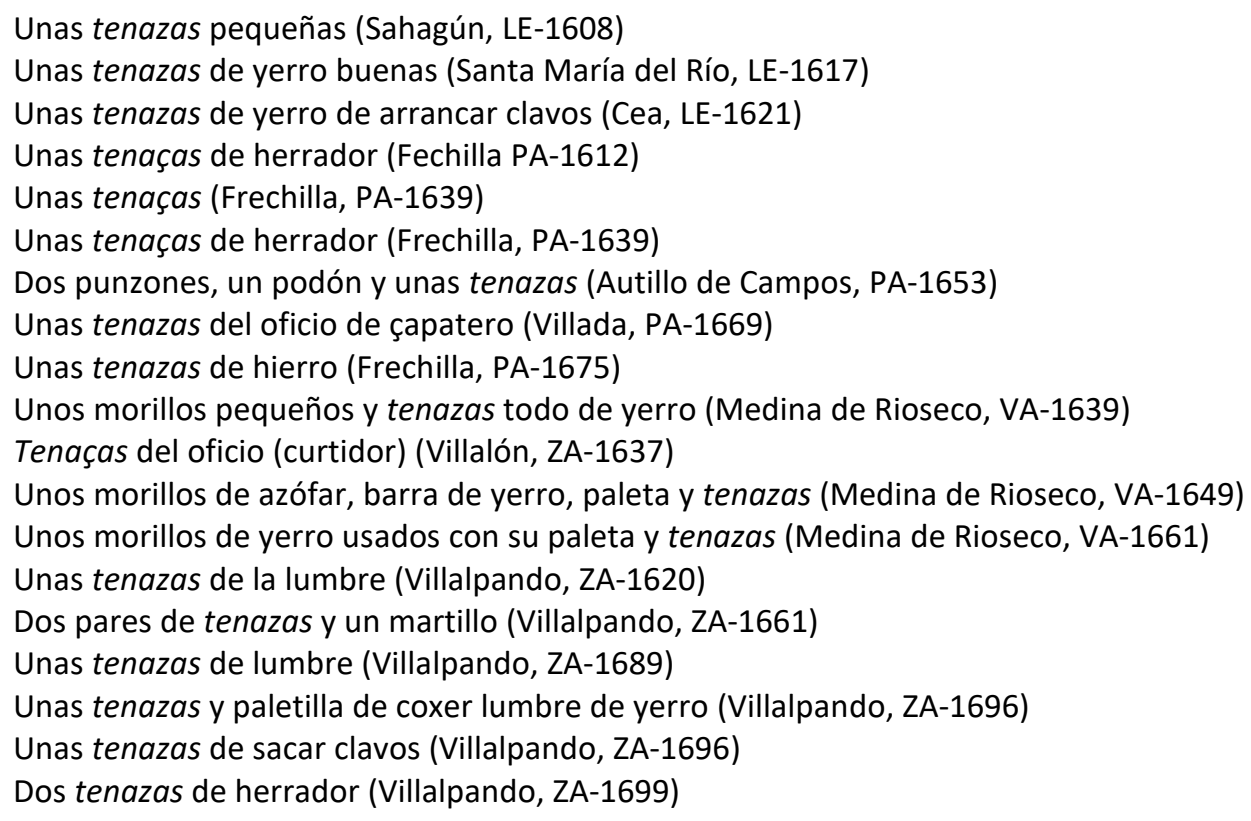

Este término se registra en la documentación que conforman el $C D H$ y el CORDE desde el siglo XIII. Los datos que nos ofrece el CorLexIn muestran una distribución diatópica de carácter general en la Península y también alguna ocurrencia en documentos americanos -Bolivia y Panamá-, aunque de manera más restringida. En el siglo XVII era una voz de uso general.

En el corpus analizado figura como un utensilio más de la lumbre y también como una herramienta especializada de diferentes oficios (herrador, curtidor y zapatero, entre otros). El término tenazas se ve especificado por una serie de sintagmas que justifican de alguna manera su valor económico y distinguen a qué tipo de tenaza se está refiriendo el escribano (Morala, 2019b:399-400).

Formado por derivación aparece el diminutivo de este término, con preferencia del morfema derivativo -illa, aunque con una escasa nómina de casos:

Unas tenazillas de calzar y un sacabocados (Medina de Rioseco, VA-1639)

Unas tenazillas de yerro pequeñas (Villalón, VA-1642)

Unas tenaçicas de yerro (Villalón, VA-1642)

Los dos asientos pertenecientes a documentos de Villalón corresponden a un inventario y a su almoneda, realizada a posteriori. En el inventario figura como diminutivo tenazillas, mientras que a la hora de realizar la almoneda se convierte en tenaçicas. Puede que haya sido un descuido del propio escribano.

\section{TRASFUEGO}

El DLE lo señala como un término propio de La Rioja y nos remite al término trashoguero que define como 'losa o plancha que está detrás del hogar o en la pared de la chimenea, para su 
resguardo' (DLE, s. v. trashoguero, 2. a ac.). No aparece en ningún diccionario académico hasta la edición de 1925, donde se registra con la marca diatópica (NTLLE, s. v. trasfuego, DRAE, 1925).

Un trasfuego de barras de yerro que toma todo el ancho de la chiminea (Villalpando, ZA-1633)

Trasfuego no se registra en las bases académicas como el CORDE y el CDH. Los ejemplos que encontramos en el CorLexIn se localizan en inventarios de La Rioja -coincidiendo con la notación diatópica que le otorga el $D L E-$, pero también en inventarios de Álava. El único ejemplo que se localiza en Tierra de Campos pertenece a un inventario de bienes perteneciente a la fortaleza que el Condestable de Castilla poseía en Villalpando y que, por aquel entonces, era Bernardino Fernández de Velasco y Tovar. Posiblemente este término esté presente en dicho inventario como reflejo del refinamiento privado de su dueño, dado que en este caso el objeto que se inventaría es una plancha de yerro que solía ponerse en la chimenea como protección, y que solía ir decorada con dibujos. La forma más común de tener calor en las casas terracampinas era la gloria.

Sin embargo, no encontramos ningún ejemplo de la forma castellana trashoguero, ni en la zona de estudio, ni en el CorLexIn. En bases de datos académicas como el CDH encontramos un ejemplo datado en 1549 en un libro de refranes: "Tal queda la casa de la dueña, ido el escudero, como el fuego sin trashoguero".

\section{TRÉBEDES [trévedes, tréuedes]}

Sust. f. 'Aro o triángulo con tres pies, que sirve para poner al fuego sartenes, peroles, etc.' (DLE, 2. a ac.). Covarrubias recoge esta palabra en plural, trévedes, y la define como 'un cerco de hierro con tres pies que se pone en el fuego, y sobre ellas caldera y ollas. Dixose treuedes, quasi trepedes, por los tres pies que tienen [...]', Autoridades también registra el término, ya con la grafía académica trébedes y con la misma definición que da Covarrubias. El término en singular lo recoge el DRAE de 1899 para designar 'parte de una habitación, levantada del suelo y calentada à modo de hipocausto', muy común en la zona de estudio, pero que no se ha encontrado ningún caso en los documentos analizados; para designar el utensilio que aquí se estudia, se sigue manteniendo en plural (NTLLE, s. v. trébedes, Covarrubias, 1611; Autoridades, 1739, DRAE, 1899). Término procedente del lat. TRIYPĚDES, plural del adjetivo TRIPES,-EDIS, 'de tres pies', compuesto de TRES y PES, PEDIS 'pie' (DECH, s. v. trébedes).

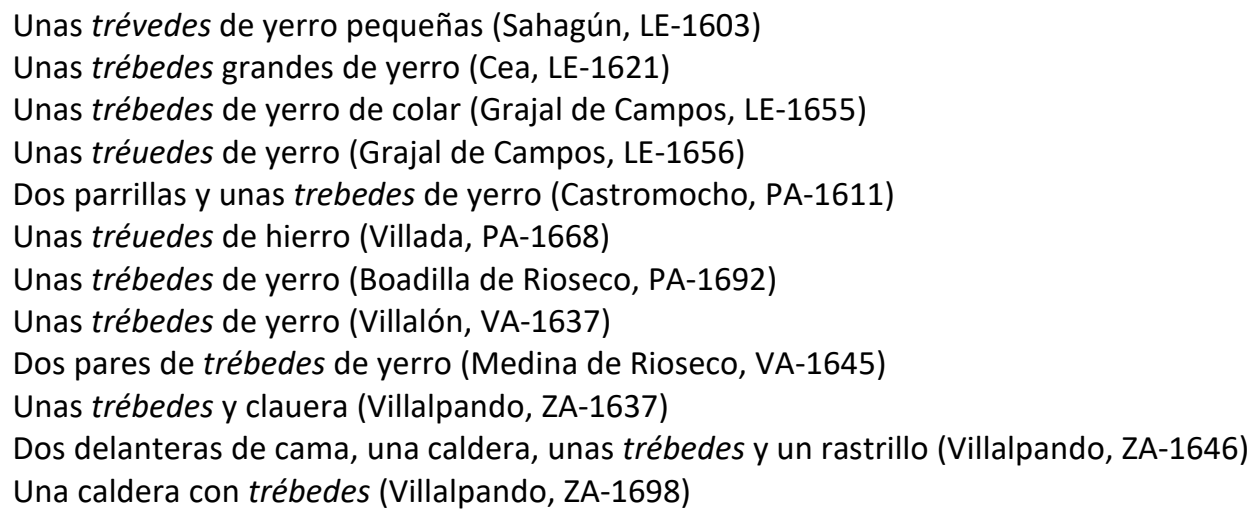


Trébedes siempre se recoge en plural con la acepción que da la Academia. Es un término de uso general en los inventarios del siglo XVII.

Las primeras documentaciones que ofrecen el CORDE y el CDH de esta voz datan del siglo $\mathrm{XV}$, aunque en época anterior -siglos XIII y XIV- registran este término con la forma trebdes.

En el corpus terracampino siempre figura con la forma normativa. Sin embargo, en los textos que conforman el CorLexIn, autores como Morala y Egido han localizado soluciones diferentes a la académica para el grupo romance [b’d] (Morala y Egido, 2018: 405-408).

\subsubsection{Otros útiles de cocina}

\section{ALMIREZ}

Sust. m. 'Mortero de metal, pequeño y portátil que sirve para machacar o moler en él' (DLE). Nebrija y Covarrubias recogen esta voz en sus respectivas obras y la descripción que hacen de la misma se mantiene hasta hoy. Es un término que procede del árabe mihrâs id., de háras 'machacar' (DECH, s. v. almirez).

\footnotetext{
Un almirez pequeño con su mano (Sahagún, LE-1600)

Un almirez con su mano vueno (Cea, LE-1621)

Dos almireçes con sus manos, buenos (Valderas, LE-1647)

Un almirez grande con su mano (Grajal de Campos, LE-1651)

Un almirez con su mano (Castromocho, PA-1611)

Una almirez grande con su mano (Frechilla, PA-1612)

Un almirez con su mano (Autillo de Campos, PA-1642)

Dos almirezes con sus manos (Autillo de Campos, PA-1654)

Una almirez, caxa y mano (Medina de Rioseco, VA-1639)

Un almirez pequeño con su mano (Villalón, VA-1642)

Un almirez con su mano (Medina de Rioseco, VA-1661)

Un almirez con su mano (Cuenca de Campos, VA-1670)

Un almirez con su mano (Villalpando, ZA-1620)

Un almirez pequeño con su mano (Villalobos, ZA-1654)

Un almirez con su mano mediano (Villalpando, ZA-1660)

Un almirez con su mano (Villalpando, ZA-1698)
}

La primera documentación que aparece tanto en el CORDE como en el $C D H$ data de principios del siglo XV.

Es un término muy frecuente en los inventarios del siglo XVII. El CorLexIn nos proporciona un amplio abanico de ocurrencias a lo largo y ancho de la Península, así como algunos casos en Canarias y en documentos americanos. Por regla general, el término mayoritario en los documentos es el normativo almirez. Es una voz de uso general dentro de los inventarios de la Tierra de Campos que figura con la variante normativa de la palabra.

Entre los repertorios dialectales modernos, Le Men registra la variante almidez en su estudio sobre el léxico leonés (Le Men, 2002, s. v. almidez). Gordaliza define esta voz como 'especie de vaso de cobre que se usa en la cocina para aplastar el ajo y el perejil con una pieza también de metal llamada mano', sigue aclarando que 'el almirez es de cobre y el mortero de 
madera'. Además, localiza las formas almidez y almidrez (Gordaliza, 1988: 26). Este tipo de variantes no las hemos localizado en nuestro corpus, aunque es bastante frecuente este cambio de $/ \mathrm{l} / \mathrm{por} / \mathrm{d} /$.

\section{ARTESA [artessa, hartesa, hartessa]}

Sust. f. 'Cajón cuadrilongo, por lo común de madera, que por sus cuatro lados va angostando hacia el fondo y sirve para amasar el pan y para otros usos' (DLE). Aparece en el Vocabulario de Nebrija como 'artesa para amasar el pan', y Covarrubias lo define como 'el tronco de madero cauado en que se amasa el pan' (NTLLE, s. v. artesa, Nebrija, 1495, Covarrubias, 1611). Se trata de un término cuyo origen es incierto, aunque probablemente tenga un origen prerromano, compuesto por el vasco artesia (DECH, s. v. artesa).

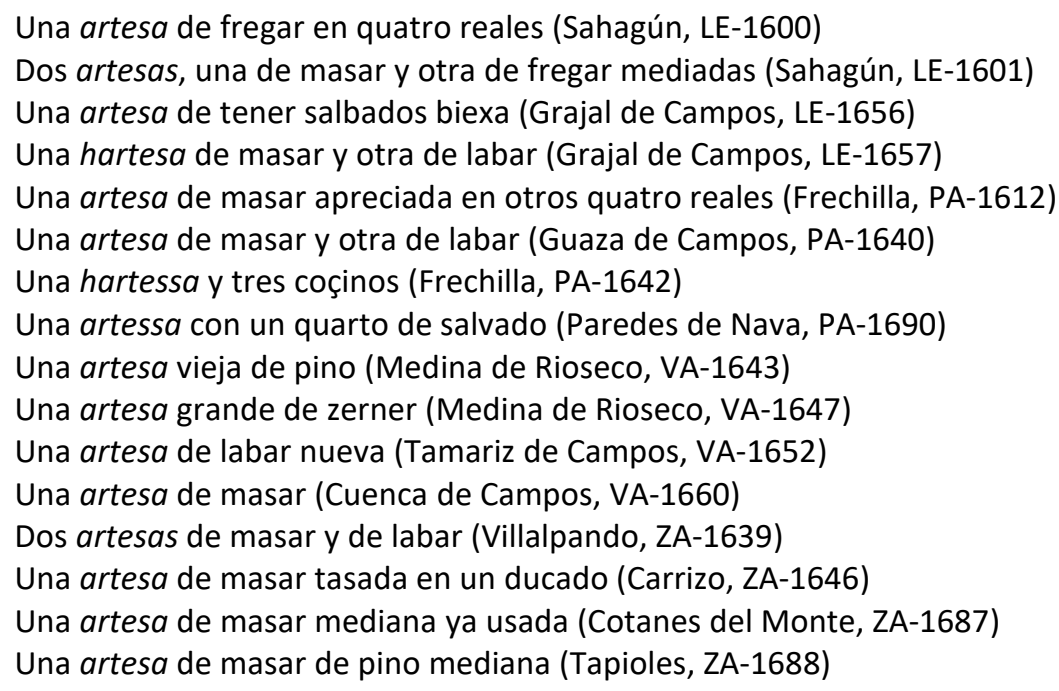

La artesa es uno de los objetos más inventariados en los protocolos del siglo XVII. Además de para amasar el pan, aparece en los documentos con otras funciones, como la de lavar o fregar, o para llenarla de pan, de salvados e incluso de cal. En documentos burgaleses Perdiguero localiza artesa con el significado de 'recipiente para recoger el mosto' o 'recipiente para recoger la carne picada' (Perdiguero, 2012c: 1557).

Desde una perspectiva diacrónica las bases de datos textuales académicas la documentan desde el siglo XIII. Y en el siglo XVII es una voz muy frecuente en los inventarios de bienes como recipiente que se usaba para diferentes fines (CorLexIn).

En ocasiones, para detallar la descripción de artesa, el escribano utiliza o bien el sintagma preposicional "de lavar", "de masar", "de fregar", "de cerner", o con adjetivos formados por derivación con el sufijo deverbal -dera que referencian la función del objeto (Morala, 2018a: 64) como fregadera, lavadera o masadera:

Una artesa fregadera a tres reales (Sahagún, 1600)

Una artesa labadera (Villalpando, ZA-1644)

Una artesa masadera (Villalpando, ZA-1660)

Dos artesas masadera y labadera (Villalpando, ZA-1664) 
En repertorios más modernos se localiza el término en Tierra de Campos como 'recipiente de madera de forma troncopiramidal invertida que se empleaba para amasar el pan' (García Caballero, 1992: 38 en Le Men, 2002, s. v. artesa) y Gordaliza añade que además de para amasar el pan, también se utiliza para 'salar los alimentos, y para lavar a mano en casa' (Gordaliza, 1988: 36).

\title{
ARTESÓN [artessón]
}

Sust. m. 'Recipiente de base redonda o cuadrada que regularmente sirve en las cocinas para fregar' (DLE). Lo registra Autoridades como 'la artésa redonda, que regularmente sirve para fregar' (NTLLE, s. v. artesón, Autoridades, 1726). Término derivado de artesa, origen es incierto, aunque probablemente tenga un origen prerromano, compuesto por el vasco artesia $(D E C H, \mathrm{~s}$. v. artesa).

\author{
Un artesón con un pilón de comer el lechón de madera un real (Sahagún, LE-1600) \\ Un artesón en real y medio (Sahagún, LE-1605) \\ Un artesón de madera (Sahagún, LE-1608) \\ Una artesón redondo (Santa María del Río, LE-1608) \\ Un artesón de madera (Grajal de Campos, LE-1613) \\ Un hartesón de pino pequeño (Grajal de Campos, LE-1655) \\ Una artesa de labar y un artesón nuevo (Castromocho, PA-1602) \\ Un candil y un assador y una sarten bieja y un cazico pequeño y un artesonzillo todo biejo \\ (Boadilla de Rioseco, PA-1641) \\ Un artesón de pino (Autillo de Campos, PA-1653) \\ Un artessón biexo (Paredes de Nava, PA-1690) \\ Un artessón y una banquita en tres reales (Medina de Rioseco, VA-1639) \\ Un herrador y un artessón y tinaxa en quatro reales (Medina de Rioseco, VA-1641) \\ Tres artessones biejos en ocho reales ymedio (Medina de Rioseco, VA-1642) \\ Un artesón (Medina de Rioseco, VA-1644) \\ Dos artesones grandes de las cubas (Medina de Rioseco, VA-1685)
}

Aunque la palabra artesón aparece en los documentos del $C D H$ a finales del siglo XV, con la acepción que presenta en los archivos estudiados, no figura hasta el siglo XVII, en una obra fechada en 1601 donde se registra un artesón para 'salar tocino'.

Esta voz se halla menos documentada que el término artesa, pero sí hay ejemplos a lo largo de la Península y dos focos muy concretos: en zonas limítrofes a la Tierra de Campos en León, Palencia y Zamora; y por otro lado aparecen ejemplos en las provincias de Albacete, Murcia, Jaén y Granada (CorLexIn).

En cuanto al significado, no se especifica en los inventarios; se da por hecho la función del objeto, tan solo se hace referencia a la misma cuando hace referencia a 'recipiente en donde se daba de comer a los puercos'. Así, en Granada nos encontramos con "un artesón grande para marranos" y, dentro ya de la Tierra de Campos, localizamos en Sahagún (León) "un artesón con un pilón de comer el lechón". Lo que sí está claro es que esta palabra referencia un objeto claramente diferente a la artesa, ya que en ocasiones se encuentran inventariados en el mismo asiento, como en el ejemplo de Castromocho.

En cuanto a la forma, estamos ante una forma derivada, en este caso a través del sufijo aumentativo -ón, pero con un sentido propio: se trata de un término lexicalizado, fenómeno 
presente en el siglo XVII en otras parejas de palabras como arquetón, barreñón, botijón, cucharón... Además, en el corpus terracampino encontramos ocurrencias de derivados diminutivos de esta voz, cuya motivación semántica tiene un carácter apreciativo:

Tres artesonillos de madera buenas (Castrillo, LE-1606)

Un artesonzico chiquito (Grajal de Campos, LE-1616)

Un artesonzico pequeño (Villalón, VA-1642)

\section{BARANDA}

Sust. f. los diccionarios no registran la acepción con la que aparece en el corpus terracampino. Término de origen incierto, común al portugués, el castellano, el catalán y la lengua Oc (DECH, s. v. baranda).

Dos barandas (Frechilla, PA-1636)

Un tinaco de tener sal y una baranda (Frechilla, PA-1638)

Tan solo encontramos dos ejemplos en los documentos analizados de la Tierra de Campos, $y$, a pesar de lo poco significativo del contexto en el que figuran estos dos casos, no parece que el significado de esta voz coincida con el que da el diccionario académico. En el CorLexIn es una voz poco frecuente, pues tan solo contamos con algunos ejemplos en Cáceres y Ciudad Real; en estos casos el contexto nos aclara más la función de dicho término, ya que se encuentra al lado de criba, y entre útiles de labranza como azadas o costales, alejándolo del significado de 'barandilla' que le da el DLE. Esta voz se recoge en documentos notariales fechados en el siglo XVIII y pertenecientes a la zona de La Bañeza (Gómez Ferrero, 2015: 165). Además, Morala localiza la voz con la acepción de 'criba' en dos atlas lingüísticos, por un lado, en el ALECMAN, donde aparece en puntos del extremo occidental de Toledo y, por otro lado, en el ALEX, donde registra este término con ese sentido en puntos occidentales de las dos provincias extremeñas (Morala, 2016c: 317). Le Men localiza en este término como 'bastidor de madera que, colocado sobre la masera, sirve para deslizar sobre él los cedazos para cerner la harina' en vocabularios de Astorga (Le Men, 2002, s. v. baranda).

\section{BREGA [vrega]}

Sust. f. no figura en el diccionario académico con el significado con el que aparace en los inventarios terracampinos. Sin embargo, en vocabularios dialectales encontramos esta voz como 'rodillos de madera que se aprietan entre sí y por ellos debe pasar la masa del pan para bregar' (Gordaliza, 1988: 48). Derivado del verbo bregar (DECH, s. v. bregar).

Una brega con su breguil (Valderas, LE-1647)

Una brega de nogal buena (Sahagún, LE-1601)

Una brega de nogal (Grajal de Campos, LE-1656)

una vrega con su vregón (Castromocho, PA-1602)

Otra artesa de masar con sus barillas y brega (Castromocho, PA-1611)

Una brega pequeña con sus baras (Frechilla, PA-1615)

Una brega y bregón de pino (Autillo de Campos, PA-1653)

Una brega de pino de tres tablas y su bregón (Paredes de Nava, PA-1690)

Una artesa de masar con sus barillas una brega y tres zedaços (Medina de Rioseco, VA-1641)

Una artesa de labar nueba y una brega de majar (Tamariz de Campos, VA-1652) 
Una brega con su breguil y cernederas (Cuenca de Campos, VA-1660)

Una brega con su breguil (Cuenca de Campos, VA-1670)

Una brega con su breguil (Villapando, ZA-1632)

Una brega y un breguil (Villalpando, ZA-1644)

Una hartessa de massar y unas barillas y dos piñeras con la brega y su breguil (Villalpando, ZA1652)

Una brega (Cotanes del Monte, ZA-1687)

Con la acepción con la que aparece en el corpus solo la encontramos en la Tierra de Campos, se documenta en todas las provincias que constituyen este territorio. El DLE recoge el verbo bregar como 'amasar de cierta manera el pan' significado que se recoge desde Autoridades 'amasar el pan sobre un tablero o mesa con un palo redondo que está engoznado enla mesa, y sobre él va el panadero sentado dando vuelta a la masa'. Morala ya advierte de la notación dialectal de esta palabra propia de la Tierra de Campos (Morala, 2012f: 316).

Esta lexía se localiza en vocabularios más modernos dedicados al léxico de Tierra de Campos como 'artificio para amasar el pan. Consta de dos rodillos de madera que giran hacia adentro movidos por un manubrio' (García Caballero, 1992: 41). A día de hoy todavía es caracterísco el pan bregado de la zona (Morala, 2012f: 316).

\section{BREGUIL [bregón]}

Sust. $m$. Este término tampoco se localiza en los diccionarios. En estos ejemplos cabe señalar que la brega sería 'la mesa en la que se amasa el pan o herramienta para hacerlo' mientras que breguil designaría l'os cilindros de madera para tal fin' (Morala, 2017b: 272).

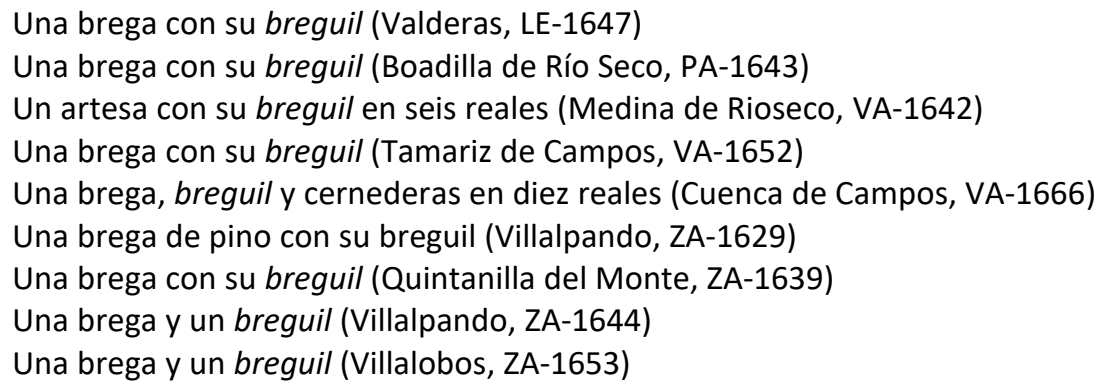

Tampoco dan noticia de esta voz los corpus académicos, tan solo se recoge en el Fichero General, donde la única cédula que aparece referencia 'breguil de la massa' localizado en el Thesaurus Requejo datado de 1729. Esta obra fue llevada a cabo por el jesuita Valeriano Requejo, natural de Cuenca de Campos, conocedor de la lengua de la zona (Fichero General).

En el corpus estudiado figura el término bregón, posiblemente con el mismo sentido que breguil y que muestra una preferencia de uso en los textos palentinos:

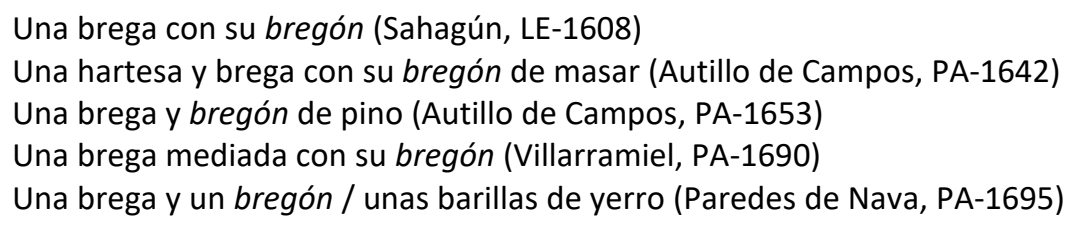




\section{COCINO [cozino, cozinillo]}

No aparece ni en el DLE, ni en el NTLLE. Se trata de un término derivado de cuezo 'artesilla de albañil para amasar yeso', y nombre de otros recipientes, del mismo origen incierto que el cat. cossi 'tina de la colada' (DECH, s. v. cuezo).

Un coçino de labar en quatro reales (Frechilla, PA-1612)

Un coçino de labar grande apreciado en quatro reales (Frechilla, PA-1612)

Un coçino de labar viejo hendido (Frechilla, PA-1612)

Un coçino de pino de labar ropa en quatro reales (Fechilla PA-1612)

Un coçino de pino de labar ropa en quatro reales (Fechilla PA-1612)

Un coçino pequeño biejo de pino en dos reales (Fechilla PA-1613)

Un coçino pequeño biejo de pino en dos reales (Fechilla PA-1613)

Un coçino de labar hendido apreciado en tres reales (Frechilla, PA-1613)

Un coçino de pino pequeño en tres reales (Fechilla PA-1614)

Otro coçino biejo con unas armellas de hierro en dos reales (Fechilla PA-1614)

Un coçino de labar la ropa de pino mediano (Fechilla PA-1615)

Un coçinillo largillo (Frechilla, PA-1636)

Un coçino de pino de labar ropa (Frechilla, PA-1642)

Un cozino de pino mediano con dos harmellas (Frechilla, PA-1675)

Un cozino para lavar la ropa con ocho harmellas en tres reales y medio (Frechilla, PA-1675)

Se trata de un término frecuente en los inventarios de Frechilla, localidad palentina de la Tierra de Campos. Llama la atención el número de veces que aparece esta voz en los textos de esta localidad. Este hecho contrasta con la ausencia de esta palabra en el resto de las localidades de la Tierra de Campos. A pesar de que no ha sido registrado por ninguno de los diccionarios académicos, sí que hay muestras de este término en la documentación, en el CORDE se registra a finales del siglo XV, en el Universal Vocabulario en latín y romance de Alfonso de Palencia, donde se escribe: 'es vasija conque traen la uva o coladero que es coçino' refiriéndose a los enseres de una bodega. Los siguientes ejemplos que nos encontramos son tres casos en documentos de finales del siglo XIX, dos de los cuales hacen referencia a un recipiente donde comen los animales. El CorLexIn registra esta voz en el norte peninsular con diferentes acepciones, entre ellas la de "cocino de estregar paños" (Navarra), significado que suele tener en los documentos terracampinos, "cocino para lavar la ropa". El DECH localiza la voz cocinu, con marca dialectal, en Santander como 'especie de dornajo o artesa', 'tronco del árbol ahuecado para dar de comer a los cerdos'. En repertorios dialectales como el de Gordaliza se presenta como una 'especie de recipiente doméstico, hecho de madera, para ser usado de comedero de animales' (Gordaliza, 1988: 69).

\section{COLADERA}

En las siguientes cuatro entradas estamos ante una serie de palabras derivadas de los sufijos de verbales -dor y -dero, que presentan una relación compleja y que en cierto momento intentan unirse en un derivado único: -dor para el masculino, -dera para el femenino (Pascual y Sánchez, 1993: 693-695; Morales, 1997-1998: 162-165 en Morala, 2012b: 337). El resultado que vemos es una confusión entre estos derivados y también que muy pocas veces podemos establecer una diferencia clara entre las parcelas semánticas que ocupa cada uno de los términos. En Tierra de Campos ocurre con los derivados de colar: encontramos ejemplos de coladera, coladero, colador 
y un único caso de coladora, para los cuales los contextos no son significativos y en ocasiones es difícil saber a qué objeto se refiere en cada caso.

Sust. m. 'Cedazo pequeño para licores' (DLE). Covarrubias lo define como 'cedacillo con que se cuela algun licor para que vaya limpio' y no se registra en ningún diccionario académico hasta el DRAE de 1780, que mantiene la definición dada por Covarrubias. (NTLLE, s. v. coladera, Covarrubias, 1611, DRAE, 1780). Término derivado de colar, del lat. CōLĀRE, derivado de COLUM (DECH, s. v. colar).

Una coladera de açofar (Medina de Rioseco, VA-1685)

Dos piñeras y una coladera (Villalpando, ZA-1600)

Un tostador nuevo, una botija y una jarra, una coladera (Villalpando, ZA-1629)

Una artesa de masar, unas barillas y dos piñeras y una coladera (Villalpando, ZA-1640)

Un medio celemín y una coladera (Villalpando, ZA-1646)

Una hartessa de massar y unas barillas y dos piñeras, con la brega y su breguil, con coladera y arralladera (Villalpando, ZA-1652)

Las primeras documentaciones que registra el $C D H$ de esta palabra datan de la primera mitad del siglo XV: "tinajuelas desculadas / que se llaman coladeras" en textos poéticos fechados entre 1435 y 1445 . Esta base de datos registra 73 concordancias y la restricción diacrónica al siglo XVII solo ofrece media docena de ocurrencias. La mayor presencia de ejemplos se encuentra en documentos americanos del siglo XX.

El CorLexIn ofrece una distribución geográfica general, a los ejemplos recuperados de este corpus habría que sumarles los localizados en Soria, Ávila (Morala, 2012b: 352) y en Huelva (Morala y Egido, 2018: 410).

La voz coladera figura junto a coladero y colador en los inventarios de la Península haciendo referencia a tres objetos diferentes y utilizados de modo aleatorio, incluso en las mismas zonas, así registra colador, coladera o coladero de estopa en Palencia, León, Cáceres y Toledo; en archivos de Ávila y en Valladolid registra colador o coladera de barro; y un tercer grupo, donde se remite a un objeto de madera o metal, en Soria, Ciudad Real y Zamora, utilizando de forma indiferente cada una de las variantes (Morala 2012b: 352).

Estas formas aparecen en repertorios dialectales más actuales y así encontramos coladera en la montaña palentina como 'cesta hecha de mimbre para diversos usos' (Gordaliza, 1988: 70). Le Men, por su parte, localiza la forma coladera en la zona de los Oteros de León, en Asturias, en Toro (Zamora) como 'colador' y en el ámbito del castellano tradicional como 'cesta de mimbre' (Le Men, 2004, s. v. coladera).

\section{COLADERO}

Sust. m. 'Manga, cedazo, paño, cesto o vasija en que se cuela un líquido' (DLE). El término coladero lo recoge Nebrija. Covarrubias le asigna el significado de 'el lugar angosto, por donde se passa con estrechura poco à poco: y si son personas vna à vna'. Sin embargo, en Autoridades figura como 'la manga, banasto, paño, o cedazo por donde se passa y cuela algún liquor para que vaya limpio' (NTLLE, s. v. coladero, Nebrija, 1495, Covarrubias, 1611, Autoridades, 1729). Término derivado de colar, del lat. CōLĀRE, derivado de COLUM (DECH, s. v. colar). 
Un coladero de estopa biejo (Sahagún, LE-1608)

Un coladero destopa nuevo (Riosequillo, LE-1610)

Unos manteles de estopa de torillos y un coladero de estopa (Arenillas, LE-1636)

Un coladero de sacar cera (Castroañe, LE-1637)

Un coladero de ropa nueuo (Grajal de Campos, LE-1658)

Un lenzuelo de estopa y un coladero tambien de estopa y dos almoadas de lienzo (Grajal de Campos, LE-1658)

Un coladero (Castromocho, PA-1614)

Seis çedaços y unas barillas y un coladero (Frechilla, PA-1615)

Un coladero en medio real (Cuenca de Campos, VA-1666)

Un coladero y una bachilla (Villalpando, ZA-1633)

Un coladero y una camisa de muger trayda (Villalpando, ZA-1645)

Vn coladero biexo de estopa (Villalobos, ZA-1654)

Dos coladeros nuebos de estopilla (Villalpando, ZA-1660)

Desde un punto de vista diacrónico, esta lexía se documenta a partir de la segunda mitad del siglo XIII tanto en el $C D H$ como en el CORDE. Pero el término parece entrar en retroceso en el siglo XVII, según la documentación contenida en estas bases de datos.

Cabe destacar que esta variante con el sufijo derivativo masculino -dero es la más frecuente en los textos terracampinos y los ejemplos que figuran en el CorLexIn pertenecen a dicha zona. Morala localiza un ejemplo en Logrosán (Cáceres): "un coladero de estopa" (Morala, 2012b:352). Aunque es difícil saber a qué utensilio se refieren los ejemplos por la información tan escueta que aporta el escribano, la variante coladero presenta una mayor especificación del objeto que se inventaría: tenemos "coladeros de estopa y estopilla" en distintas localidades de León y Zamora, "coladeros de sacar cera" en Castroañe (León) y "un coladero de ropa" en Grajal de Campos (León).

Por otro lado, también encontramos en la zona el témino coladero con naturaleza adjetiva acompañando al término cazo:

Otro caço de açer çera y otro caço coladero grande de cobre (Frechilla, PA-1640)

Trabajos lexicográficos más actuales localizan también la forma coladero, aunque algunas veces con un significado diferente al que presentan los inventarios. Gordaliza, por ejemplo, determina en Palencia esta voz como 'el pozo por donde sube y baja el personal en las minas' (Gordaliza, 1988: 70). Con la acepción de 'colador', Le Men localiza esta voz en vocabularios dialectales de comarcas leonesas como El Bierzo, Murias de Paredes, Babia o Laciana, pero no en Tierra de Campos (Le Men, 2004, s. v. coladero).

\section{COLADOR}

Sust. m. 'coladero (manga en que se cuela un líquido)' (DLE, s. v. colador ${ }^{2}$ ). Nebrija recoge 'colador y coladora de paños' y en la edición de su Vocabulario de 1516 figura 'colador de cirugiano'. Autoridades lo registra como 'el paño ó cedázo por donde se cuela alguna cosa líquida' (NTLLE, s. v. colador, Nebrija, 1495, 1516; Autoridades, 1729). Término derivado de colar, del lat. CōLĀRE, derivado de COLUM (DECH, s. v. colar).

Dos tornos, dos argadillos, cauallete, hordidor, colador y pesso de yerro (Villalpando, ZA-1686) 
Este es el único ejemplo que figura en el corpus objeto de estudio, un único ejemplo situado en la zona más al sur de la Tierra de Campos.

Si consultamos las bases de datos académicas, colador es la forma que más número de concordancias presenta en el $C D H$ y el CORDE en relación con las otras variables (coladera, coladero y coladora). Ambas bases la registran desde mediados del siglo XV, en su mayoría localizada en obras de corte técnico.

Desde un punto de vista diatópico, el CorLexIn ofrece poco más de una decena de casos repartidos sobre todo en la mitad sur de la Península; encontramos casos en Cáceres, Toledo, Cuenca, Ciudad Real y Cádiz. Aunque también aparece una ocurrencia en Santander, y Morala añade más ejemplos de Ávila y Zamora (Morala, 2012b: 352).

\section{COLADORA}

Sust. f. 'Mujer que hace coladas de ropa', aunque el DLE señala que es un término poco usado. Las obras lexicográficas lo recogen desde Nebrija, aunque en las obras académicas se registran desde la edición de 1780 con la misma acepción que se conserva hoy día (NTLLE, s. v. coladora, Nebrija, 1495; DRAE, 1780). Término derivado de colar, del lat. CōLĀRE, derivado de COLUM (DECH, s. v. colar).

Una coladora (Boadilla de Rioseco, PA-1650)

En Tierra de Campos aparecen las cuatro variantes derivadas de colar, si bien hay que decir que la forma coladora aparece en un solo ejemplo en la localidad terracampina de Boadilla de Rioseco (nota 15 en Morala, 2012b: 351).

Esta escasez de casos también se aprecia en bases de datos como el CORDE o el CDH; en este último, figura un único caso documentado en un texto de 1996 de la puertorriqueña Esmeralda Santiago, referenciando "una coladora de café".

El Fichero General presenta en la cédula n.o 27 una ficha del ALEANR, en la lámina 735, donde recoge este término como 'expremijo', o lo que es lo mismo, 'Mesa baja, larga, de tablero con ranuras, cercada de listones y algo inclinada, para que, al hacer queso, escurra el suero y salga por una abertura hecha en la parte más baja' (DLE).

Coladora es una de esas palabras que no han llegado a consolidarse en el acervo léxico del español. A pesar de encontrarse en esta zona los dos pares de términos creados por derivación, este último apenas aparece en la documentación.

\section{DUERNO}

Sust. m. 'Duerna', 'artesa' (DLE, s. v. duerno $\left.{ }^{1}\right)$. La voz duerno aparece por primera vez registrada en la edición del DRAE de 1899 como sinónimo de 'duerna' y con marca diatópica en Asturias hasta el diccionario académico de 1936, donde desaparece la marca dialectal, aunque algunas ediciones académicas vuelvan a señalar la marca diatópica (NTLLE, s. v. duerno, DRAE, 1899, $D R A E$, 1936). Palabra derivada de duerna, 'artesa', del port. dorna 'cuba para pisar la uva', 
'aportadera para llevarla al lagar', y de oc. dǫrna 'jarro', 'olla de barro', de origen incierto (DECH, s. v. duerna).

Un duerno viejo (Castrillo, LE-1606)

Un duerno de roble (Villacalabuey, LE-1614)

Un duerno (Cea, LE-1621)

De los datos facilitados por el CORDE y el CDH se desprende que duerno no es una voz habitual en los textos, a pesar de que la primera ocurrencia que registran data del siglo XIII.

Esta falta de testimonios se puede trasladar a los resultados que ofrece el CorLexIn, donde encontramos la mayoría de las ocurrencias en localidades leonesas relativamente próximas a la zona de estudio y en documentos procedentes de Asturias y Cantabria. En Tierra de Campos se registra solo la forma masculina duerno, que aparece como un término propio de Asturias en los diccionarios académicos. Cabe señalar también que los ejemplos figuran en la zona más occidental del área de estudio, en la zona leonesa, hecho que se corresponde con los datos que aporta el CorLexIn.

No encontramos la forma castellana duerna en los documentos estudiados, pero sí aparecen algunos casos que se ditribuyen en forma de cuña desde Asturias y Cantabria hacia Burgos, pasando por Palenzuela -localidad palentina muy cercana a la provincia burgalesa- y Aguilafuente ya en la provincia de Segovia (CorLexIn). Esta base de datos también registra la forma derivada dornajo en Cantabria, Palencia y Zamora al norte de la Península, y un caso aislado en La Solana (provincia de Ciudad Real). Este término presenta marca diatópica de Cantabria cuando hace referencia al 'pesebre para toda clase de caballerías' (DEL, 2. ac.).

Por un lado, duerno no es un término exclusivo de Asturias, sino que también hay ejemplos en León y Cantabria; por otro, la variante castellana no está generalizada en la Península, pues son pocos los inventarios y los lugares en los que aparece.

En estudios más modernos como el de Gordaliza, podemos observar que sitúa los dos términos en Palencia con el mismo significado, 'artesa o comedero para animales' (Gordaliza, 1988: 93). Por su parte, Le Men recoge la voz duerno en Santander con la acepción de 'artesa pequeña para echar harina, agua y salvado a los terneros o agua y maíz a las gallinas', así como en zonas de León como Villacidayo, Sariegos, Quintanilla de Rueda, Valencia de Don Juan o La Bañeza (Le Men, 2005, s. v. duerno).

\section{EMBUDO [enbudo, envudo]}

Sust. m. 'Instrumento hueco, ancho por arriba y estrecho por abajo, en forma de cono y rematado en un canuto, que sirve para transvasar líquidos' (DLE). Recogido en el Vocabulario de Nebrija. Término procedente del lat. tardío İMBŪTUM íd., abreviación de TRAJECTORIUM IMBUTUM (participio de IMBǓĔRE 'mojar' [en algo], meter [en un líquido]) (DECH, s. v. embudo).

Un enbudo destaño (Sahagún, LE-1608)

Un envudo de madera grande (Cea, LE-1610)

Dos enbudos de madera de enbassar bino (Valderas, LE-1647)

Una escalera andadera y un enbudo y un pozal (Grajal de Campos, LE-1670)

Un enbudo de madera con un aro de yerro en beynte y quatro marauedís (Frechilla, PA-1613) 
Dos embudos de oja de lata pequeños en un real (Fechilla PA-1675)

Un enbudo de envasar de cobre tasado en seis reales (Medina de Rioseco, VA-1644)

Un enbudo y media cántara de cobre (Medina de Rioseco, VA-1648)

Dos poinos y un envudo en tres reales (Cuenca de Campos, VA-1666)

Un enbudo de cobre de el lagar (Medina de Rioseco, VA-1685)

Vn enbudo (Villalobos, ZA-1654)

Un enbudo grande de oja de lata (Villalpando, ZA-1689)

Es una voz común, de uso general que mantiene el significado académico. Se documenta desde el siglo XIII en el $C D H$. Aparece a lo largo de toda la comarca de Tierra de Campos, casi siempre al lado de útiles de la bodega. Se halla repartida por distintos puntos geográficos de la Península Ibérica (CorLexIn) y comparte campo semántico con envasador, término localizado en algunos inventarios de este periodo (Morala 2015a: 1513) y que en nuestro corpus no encontramos.

\section{ESPETERA [espitera]}

Sust. f. 'Tabla con garfios en que se cuelgan carnes, aves y utensilios de cocina' (DLE). Se registra en Autoridades con la acepción que mantiene hoy en día el diccionario académico. Es un término derivado de espeto, el gót. *spitus ( $D E C H$, s. v. espeto).

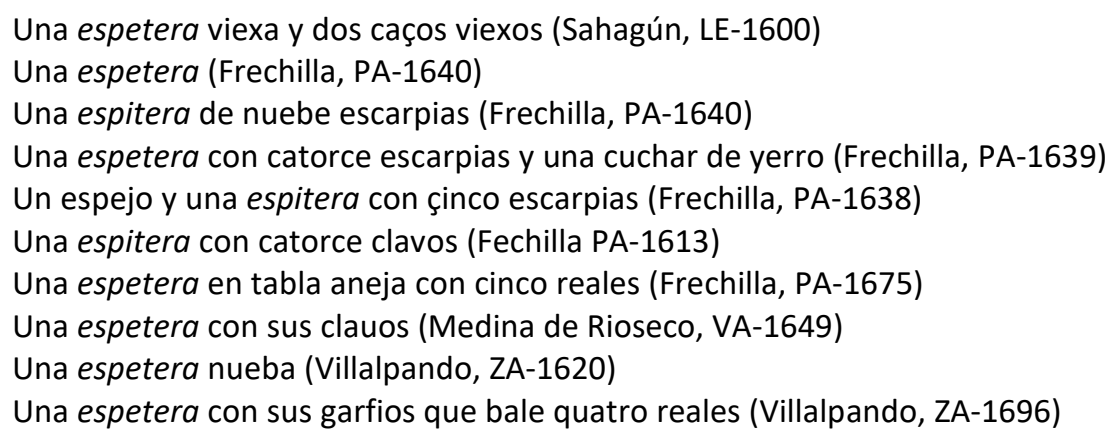

Esta palabra aparece documentada a partir de finales del siglo xV en el $C D H$. Se localiza en Tierra de Campos con la forma académica espetera, pero también con la variante espitera, con el cambio de timbre de la vocal átona tan frecuente en esta época. En la mayoría de los casos, aparece con la acepción académica, puesto que en los textos aparece el número de ganchos del que está compuesto: nuebe escarpias, catorce clavos, con sus garfios..., aunque hay ejemplos en los que el contexto no nos permite confirmarlo. En repertorios más modernos aparece espetera como 'lugar de la cocina donde se cuelgan los cazos, jarros y utensilios' (Gordaliza, 1988: 104), y Le Men localiza el término en Sahagún (León) con la acepción de 'canilla del carral', que no hemos encontrado en los documentos analizados del siglo XVII (Le Men, 2005, s. v. espetera).

\section{MASERA [massera]}

Sust. f. 'Artesa grande que sirve para amasar', 'paño de lienzo con que se abriga la masa para que fermente' (DLE, 1. y 3. a ac.). Masera como 'lienzo para tapar la masa del pan' lo registran diccionarios no académicos como el de Stevens (1706), Bluteau (1721) o Terraros y Pando (1787), la primera vez que aparece la voz en un diccionario académico y con la primera acepción 
descrita más arriba es en el DRAE de 1803 y sin marca diatópica, en la edición de 1884 donde ya aparece con el significado de 'paño' (NTLLE, s. v. masera, DRAE, 1803, DRAE, 1884). Término derivado de masa, del lat. MASSA (DECH, s. v. masa).

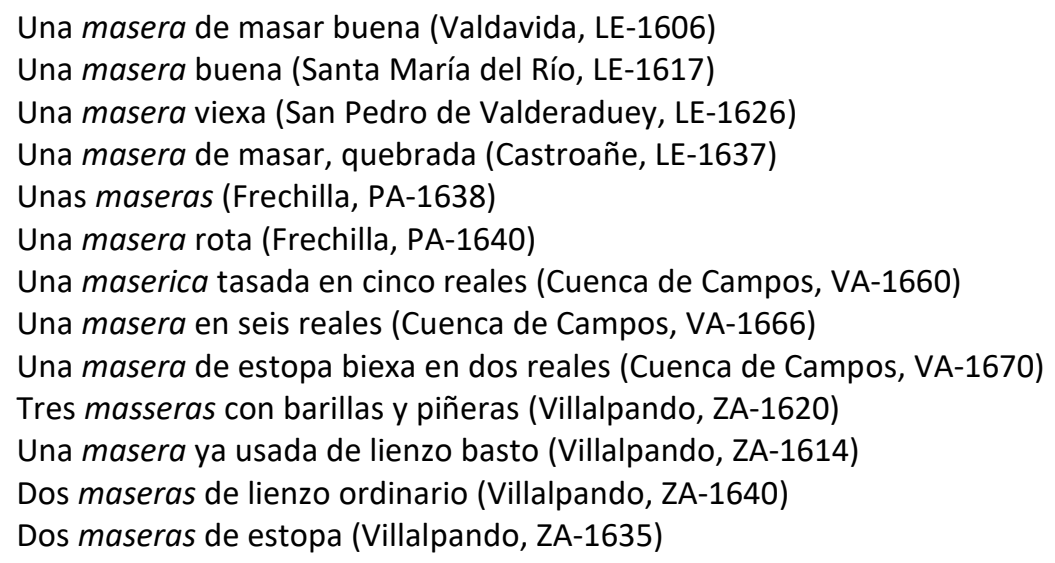

En la Tierra de Campos tenemos noticia de estos dos significados en los inventarios analizados. Tradicionalmente se ha considerado el término masera con la acepción de 'recipiente' como un occidentalismo (Le Men, 2007, s. v. masera). Morala ha señalado la clara distribución geográfica en el norte peninsular de ambas acepciones, comparando documentos notariales del siglo XVII procedentes de Burgos y León, donde el significado de 'recipiente' es el único documentado en la provincia leonesa (Morala, 2010a: 445). Si la búsqueda la ampliamos a documentos de toda la Península, con la acepción de 'paño' aparecen en provincias de Burgos, Palencia, Ávila, Segovia, Soria, Álava, Madrid, Cuenca, Guadalajara, Ciudad Real, Albacete, Córdoba, Jaén o Almería, donde coinciden con "artesas para masar" para hacer alusión al 'recipiente' (Morala, 2012f: 311). Esta voz se utiliza en un ámbito geográfico muy amplio cuando referencia un tipo de paño, ya que a los lugares señalados por Morala, hay que añadir Málaga, Cádiz, Granada, Murcia, Teruel, Toledo, Madrid y La Rioja. Por otro lado, Perdiguero señala otra posible acepción para este término en inventarios burgaleses, la de unidad de medida empleada para telas (Perdiguero, 2012c: 1558), significado que no hemos encontrado en el corpus terracampino.

La Tierra de Campos se encuentra en una zona de transición entre el leonés y el castellano, por lo que, atendiendo a lo que sucede con la distribución de esta palabra cuando se refiere a 'recipiente', vemos que aparece en la zona leonesa de dicha comarca; así encontramos una "masera de masar" en Valdavida o Catroañe, ambas localidades leonesas, pero también localizamos "artesa de masar" en Sahagún o Grajal de Campos -también leonesas-, mientras que la acepción de 'paño' la encontramos registrada en los documentos pertenecientes a los protocolos de Palencia (en los cuales figura "una masera rota" entre manteles y pañuelos), de Valladolid ("una masera de estopa biexa") y de Zamora ("una masera de lienzo").

En la zona de Villalpando, además de "artesa de masar" encontramos la forma derivada de naturaleza adjetiva masadera para acompañar al término artesa:

Dos artesas una masadera y otra de lauar paños (Villalpando, ZA-1633)

Una artesa masadera (Villalpando, ZA-1635)

Una artesa masadera quebrada (Villalobos, ZA-1654) 
Una artesa masadera (Villalpando, ZA-1660)

Dos artesas masadera y lavadera (Villalpando, ZA-1664)

Este término no se halla en las obras lexicográficas que conforman el NTLLE. Apenas hay testimonios en la documentación del castellano que recogen el CORDE y el $C D H$ y los pocos que hay presentan una acepción diferente a la que aquí se encuentra. Esta falta de ocurrencias se da también en el CorLexIn, donde figura "vna masadera de madera andada" en Eslava (Navarra), algo que coincide con la información que ofrece el Fichero General que localiza este término en el ALEANR (Lám. 1455, mapa 1242) como "recipiente donde se prepara el yeso" o "bacía". El resto de los casos del CorLexIn corresponden a la zona zamorana de Tierra de Campos, con la misma naturaleza y el mismo significado. De hecho, también se encuentra un ejemplo de este adjetivo para referirse al 'paño':

Una sabana masadera de estopa de dos piernas (Villalpando, ZA-1600)

Volviendo al término masera, en trabajos lexicográficos más recientes centrados en la zona de Palencia, este término figura como una 'especie de artesa, pero más grande, donde se amasaba antes el pan' (Gordaliza, 1988: 145). Además, en Tierra de Campos aparece manta masera, 'tejido que sirve para tapar el pan' (Celada, 2006: 410 en Le Men, 2007, s. v. masera). Anteriormente ya hemos señalado la presencia de "una sábana masadera de estopa" en Villalpando (Zamora), pero también figuran "dos mantas vanas del pan y una mantilla de lo mismo" en Sahagún (León) para referirse a masera con el significado de 'paño'.

\section{MOLINILLO}

Sust. m. 'Instrumento pequeño para moler', 'palillo cilíndrico con una rueda gruesa y dentada en su extremo inferior, que se hace girar a un lado y otro entre las manos extendidas, para batir el chocolate u otras cosas' (DLE, 1. y 2. a ac.). Término derivado de moler, del lat. MŎLĚRE (DECH, s. v. moler).

Una chocolatera con su molinillo y dos xícaras de Talabera (Villalpando, ZA-1696)

Tan solo encontramos un ejemplo en la zona estudiada. Aparece con la segunda acepción académica en una obra de Francisco de Quevedo en 1628 (CDH). Tampoco es una palabra muy documentada en CorLexIn, donde encontramos ejemplos en documentos de las provincias de Guipúzcoa, La Rioja y Málaga, todos documentos fechados a finales de siglo, como el que aparece en la Tierra de Campos. Parece que estamos ante una palabra de nueva adquisición y que poco a poco se va abriendo hueco en los inventarios. En los protocolos de La Bañeza aparecen más ejemplos de este significado en siglos posteriores -XVIII y XIX- (Gómez Ferrero, 2015: 166).

Hay que destacar que en la zona terracampina aparece la voz molinillo con un significado que no aparece en el DLE. Se trata de un tipo de adorno que llevaban los vestidos:

Unos balones de beynteydoseno pardo con sus molinillos (Arenillas, LE-1636)

Un jubón de mujer de paño negro con molinillos (Frechilla, PA-1636)

Un jubón de estameña con molinillos es fraylego (Frechilla, PA-1639)

Un jubón de paño negro con un molinillo (Frechilla, PA-1640)

Un jubón de gorgueran negro gaurneçido con molinillos negros (Guaza de Campos, PA-1640) 
Veinte y cinco onças de pasamanos negros y molinillos de seda (Medina de Rioseco, VA-1645)

Este significado se documenta en una Carta de dote del Archivo Provincial de Toledo fechada en 1582, también figura en las Pragmáticas relativas a indumentaria española del siglo XVII en $1600(C D H)$. El DRAE recoge este significado a partir de la edición de 1803; así, molinillo se registra como 'guarnicion de que se usaba antiguamente en los vestidos' (NTLLE, s. v. molinillo, DRAE, 1803). Esta acepción es la más extendida en los inventarios de bienes del siglo XVII (CorLexIn). Sin embargo, no aparece en ninguno de los repertorios dialectales consultados. Al ser un término vinculado a la moda, su uso suele ser efímero.

\section{MORTERO}

Sust. m. 'Utensilio de madera, piedra o metal, a manera de vaso, que sirve para machacar en él especias, semillas, drogas, etc.' (DLE). Lo recoge Nebrija y también Covarrubias, que lo define como 'instrumento hueco en que se majan las salsas, y otras cosas'. Autoridades, por su parte, dice que está hecho 'de piedra ù madera' (NTLLE, s. v. mortero, Nebrija 1495, Covarrubias, 1611, Autoridades, 1734). Se trata de una voz procedente del lat. MORTARIUM (DECH, s. v. mortero).

Un mortero nuevo con una mano vieja (Sahagún, LE-1606)

Un mortero de madera (Sahagún, LE-1608)

Un mortero con su mano (Castroañe, LE-1609)

Un mortero con su mano (Cea, LE-1610)

Tres pucheros y un mortero de madera (Frechilla, PA-1615)

Un mortero con su mano (Frechilla, PA-1639)

Un mortero con su mano y una cuchar de yerro y un caldero (Castromocho, PA-1602)

Un mortero de madera en real y medio (Medina de Rioseco, VA-1643)

Un mortero con su mano de madera y dos arcos de yerro (Medina de Rioseco, VA-1647)

Un mortero de piedra con su mano (Medina de Rioseco, VA-1647)

Un tajador y un mortero con media mano (Villalpando, ZA-1620)

Una mesa donde se aze el quesso, dos tinaxas de uarro colorado, prensas, zinchos, zestillas, mortero y otras cosas tocantes a este ministerio (Villalpando, ZA-1696)

La primera documentación de la que disponen el CORDE y el CDH con este signifido pertenece a la Vida de Santo Domingo de Silos, obra de Gonzalo de Berceo fechada en el siglo XIII, más concretamente en el año 1236.

El CorLexIn ofrece una veintena de casos repartidos por todo el ámbito peninsular, con preferencia aparentemente por la zona centro-oriental -Navarra, Huesca, Teruel, Alicante, Murcia, Jaén, Soria, Burgos, Toledo y Ciudad Real-, aunque también documenta algún caso en León y Cádiz. El significado con el que aparece es el de 'utensilio para moler', suele inventariarse junto a su mano y puede ser de distintos materiales (madera, barro, piedra o bronce). La falta de un mayor número de testimonios de esta voz puede deberse al hecho de compartir función con almirez, una voz mucho más frecuente en los inventarios de bienes. Esto se traslada al

corpus terracampino, en el cual, aunque presenta un nutrido número de ejemplos de esta voz, sigue siendo mucho mayor el uso de almirez.

Gordaliza localiza esta palabra como 'almirez de madera' (Gordaliza, 1988: 152), y Le Men localiza esta voz en León, Asturias, Palencia y Burgos (Le Men, 2007, s. v. mortero). 


\section{TAJA [taxa, taxica, taxuela]}

Sust. f. 'Armazón de palos que se pone sobre el baste para llevar sujetas las cargas' o 'tabla de lavar', este último significado con notación diatópica de León y Palencia (DLE, 1. a y 2.a ac.). Autoridades registra este término con su primera acepción y con notación dialectal; señala que es un término de La Rioja hasta la edición de 1899, que desparece. En cuanto al sentido de 'tabla de lavar', no se recoge hasta el DRAE de 1925 como término utilizado en León (NTLLE, s. v. taja, Autoridades, 1739, DRAE, 1899 y DRAE, 1925). Término derivado de tajar, del lat. vulgar TALEARE 'cortar', 'rajar', derivado del lat. TALĚA 'retoño, hijuelo que se trasplanta' (DECH, s. v. tajar).

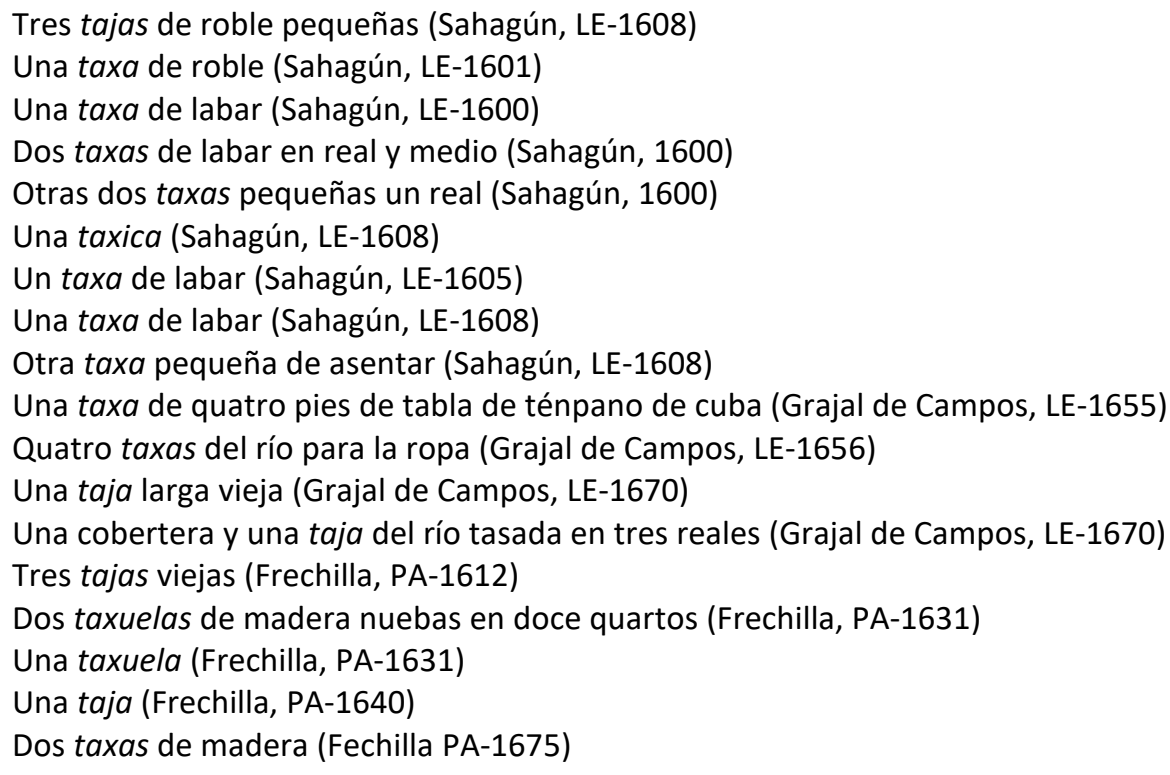

Se trata de un término abundante en los inventarios de bienes analizados de la Tierra de Campos. En cuanto a la acepción con la que aparece, hay una clara referencia a la 'tabla de lavar' especificada en los ejemplos encontrados: "una taxa de labar" o "quatro taxas del río"; en el caso de estas últimas, tenían en la parte de atrás de la taja un trozo de madera o un palo clavado para fijar en la orilla del río. Pero hay otros ejemplos en los que taja no tiene este significado o no se especifica.

Gordaliza señala esta palabra con varias acepciones: además de 'lavadera, normalmente de madera ondulada y a veces con dos patas, que sirve para lavar en el río', también la define como 'pequeño asiento de madera que el diccionario académico registra como tajuelo' (Gordaliza, 1988: 207); este segundo significado podría encajar con el que aparece en la zona estudiada, ya que nos encontramos con "taxa de asentar", "taxa de cuatro pies" o "una taxica" que se encuentra entre mobiliario, en este caso, entre dos mesas. El término taxa figura también en otros inventarios de la época, pero de forma menos frecuente y con significados diferentes: así nos encontramos con "una taxa alta sobredorado" entre diferentes joyas en un inventario de Vizcaya (1638) y también aparece un ejemplo en Cantabria cuya acepción estaría cercana a la de 'asiento de madera' a juzgar por el contexto (CorLexIn). Sin embargo, no encontramos en ninguna otra zona el término taxa referido a 'utensilio que se usa para lavar la ropa'. 
Perdiguero localiza en documentos notariales de Aranda (Burgos) "taxas de sentar" y que define como 'bancos pequeños y bajos que tenían un corte de tabla horizontal, en forma de vírgula, para agarrarla' (Perdiguero, 2012c: 1560).

\section{TAJADERA}

Sust. f. 'Cuchilla, a modo de media luna, con que se taja una cosa; como el queso, el turrón, etc.' (DLE). Palabra registrada desde Autoridades (1739). Término derivado de tajar, del lat. vulgar TALEARE 'cortar', 'rajar', derivado del lat. TALĚA 'retoño, hijuelo que se trasplanta' (DECH, s. v. tajar).

Una tajadera (Villalpando, ZA-1620)

Una tajadera de cortar turrón y una regla y un adelgazador (Villalpando, ZA-1620)

Aparecen dos ejemplos de esta palabra pertenecientes al mismo inventario en Villapando. En el $C D H$ aparecen una docena de ejemplos; en los siglos XIV y XV aparece este término utilizado como adjetivo: "fos tajadera" o "espada tajadera". Como sustantivo, aparece en un documento de Fray Bernardino de Sahagún de 1576 localizado en México como "herramienta que utilizaba el herrero"; con la acepción de 'utensilio de cocina' se documenta en una carta de dote de 1620 donde se inventaría "dos tajaderas de partir queso". Tampoco hay mucha información sobre esta voz en el CorLexIn. Esta escasez de ejemplos puede deberse a que sea el nombre que se da a una herramienta profesional que utilizaban los herreros; de hecho, los pocos ejemplos que encontramos en el $C D H$ pertenecen la mayoría a manuales técnicos.

\section{TAJADERO / TAJADOR [taxadero, taxador]}

Estos dos términos aparecen en el DLE en entradas diferentes, pero con un significado muy próximo, tajadero es sinónimo de 'tajo, pedazo de madera para partir carne' o ya en desuso, 'plato que sirve para trinchar' (DLE). Tajador sería 'tajo pedazo de madera para partir carne'. 'Cuchilla, semejante a un raspador, que se utiliza para cortar materias laminadas blandas, como el cuero, cartón, chapa de plomo, etc.' (DLE, 2. y y 3. a ac.). Tajador aparece registrado por Covarrubias como 'plato redondo de palo, sobre el qual se corta la carne', y en Autoridades aparecen los dos términos con significados muy próximos (NTLLE, s. v. tajadero, tajador, Covarrubias, 1611, Autoridades, 1739). Término derivado de tajar, del lat. vulgar TALEARE 'cortar, rajar', derivado del lat. TALĔA (DECH, s. v. tajar).

Dos taxaderos e una colodra y un plata de madera en tres reales (Sahagún, 1600)

Dos taxadores de madera (Sahagún, LE-1608)

Dos jarros y una jarra blanca biejo y un tajadero de madera bueno (Castroañe, LE-1637)

Un tajador de madera en diez y seis marauedís (Frechilla, PA-1613)

Un taxadero (Grajal de Campos, LE-1613)

Otro taxadero bueno (Grajal de Campos, LE-1613)

Un taxadero y dos paramentos (Castromocho, PA-1602)

Un tajadero con una armella (Frechilla, PA-1639)

Un tajador con armella (Frechilla, PA-1639)

Un marrano de lagar, un taxador de picar carne (Boadilla de Rioseco, PA-1692)

Dos docenas de platos, tres medias fuentes y un taxador de madera, todo en seis reales (Medina de Rioseco, VA-1641) 
Un barreñón grande de perihuela y un tajador y un mortero con media mano tasado todo en dos reales (Villalpando, ZA-1620)

Tres taxadores (Villalpando, ZA-1614)

Un tajador de madera (Villalpando, ZA-1661)

Hay una clara preferencia por el término tajador en la documentación, como puede verse en el $C D H$, así como en otras bases documentales como el CorLexIn, donde encontramos algún ejemplo más de dicha palabra. Al margen de este hecho, tanto tajadero como tajador aparecen en los archivos localizados de la Tierra de Campos, muchas veces utilizadas de forma indistinta, ya que encontramos las dos palabras en un mismo inventario con la misma acepción (como ocurre en el inventario de Frechilla, fechado en 1639, donde aparece "un tajadero con armella" y dos líneas más abajo el escribano registra "otro tajador"); este hecho ya había sido señalado por Morala en documentos de Soria y Segovia (Morala 2012b: 351). En cuanto a la acepción o las acepciones con las que aparece, no siempre están claras, ya que suelen aparecer en los inventarios sin dar muchos detalles de los mismos. Hay alguna excepción como la que aparece en Boadilla de Rioseco, donde figura "un taxador de picar carne". El contexto nos puede ayudar algunas veces a dilucidar el significado: en algunas ocasiones aparecen estos términos junto al sintagma "de madera", lo que hace que lo identifiquemos con 'el plato de madera para picar o trinchar la carne'; sin embargo, en otras ocasiones, junto al tajador o el tajadero aparece un plato de madera, lo que nos hace pensar que en este caso puede estar haciendo referencia a un 'cuchillo para cortar la carne o longanizas'.

\section{TAJO}

Sust. m. 'Pedazo de madera grueso, por lo regular afirmado sobre tres pies, que sirve para partir y picar la carne sobre él'. 'Tajuelo (banco rústico)' (DLE, 5. y 6. a ac.). Recogido Figura en el DRAE desde Autoridades. Es una voz derivada de tajar (DECH, s. v. tajar).

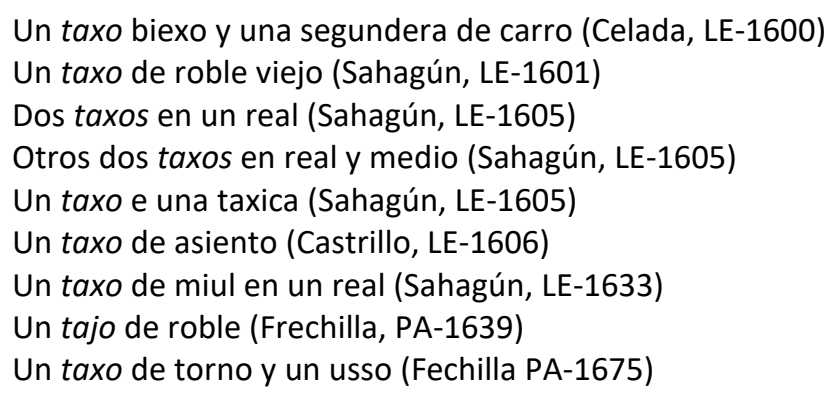

Este término comparte campo semántico con tajador y tajadero. Se documenta a partir del siglo XIV como 'pedazo de madera grueso' $(C D H)$. En los inventarios de bienes de la época aparece con varias acepciones, aunque, como ocurre con las otras dos voces, muchas veces no está claro su significado, ya que ni su descripción ni el contexto son suficientes para saber la acepción con que se utiliza en cada momento. Entre los datos encontrados en el CorLexIn, se localizan algunos ejemplos de esta palabra en localidades de Zamora, Salamanca y Segovia. En la Tierra de Campos nos encontramos con tajo como 'asiento de madera pequeño' en los ejemplos que aparecen en un inventario de Sahagún (1605), donde podría estar haciendo referencia a este significado ya que aparecen junto a escaños, mesas o junto a una taxica; en otros de Salamanca y Segovia, esta voz aparece entre bancos, taburetes y mesas (CorLexIn). 
También es frecuente encontrarla entre aperos de labranza y enseres de cocina, así como haciendo referencia a partes de otras herramientas como el carro o el torno. En repertorios dialectales como el de Gordaliza, esta palabra aparece como 'tabla para cortar la carne o hacer la matanza' o en otras localidades palentinas como Villasarracino aparece como 'tabla para lavar en el río' (Gordaliza, 1988: 207). Le Men localiza más significados de este término en la zona del leonés: lo encuentra como 'asiento bajo de madera', 'tronco de árbol que sirve para picar leña o carne', la 'tabla de lavar' o 'tablones gruesos que se colocan sobre la masa de la uva contenida en la sartén de lagar para actuar como prensa' (Le Men, 2009, s. v. tajo).

\section{TOSTADOR}

Sust. m. 'Instrumento o vasija para tostar algo' (DLE). Esta palabra se encuentra en algunos de los diccionarios preacadémicos fechados en la época correspondiente a este estudio, como Percival, Oudin, Vittori, Minsheu, Franciosini; todos ellos la recogen como un instrumento, muchas veces de hierro, que sirve para tostar. Autoridades registra dos acepciones para este término: por un lado, 'el que tuesta' y, por otro, 'el instrumento, en que se tuesta alguna cosa' (NTLLE, s. v. tostador, Percival, 1591; Oudin, 1607; Vittori, 1609; Minsheu, 1617; Franciosini, 1620, Autoridades, 1739). Término derivado de tostar y este del lat. vulgar, TǑSTARE (DECH, s. v. tostar).

Dos sartenes y un tostador de yerro bueno (Villalpando, ZA-1620)

Un tostador nuevo, una botija y una jarra, una coladera (Villalpando, ZA-1629)

Tanto el CORDE como el $C D H$ dan noticia de esta voz con naturaleza sustantiva a principios del siglo XVII en una obra de teatro datada en México. Estas bases de datos presentan pocos casos en la documentación, con preferencia de uso ya en el siglo Xx. No encontramos casos en ningún inventario de bienes, pues todos los ejemplos pertenecen a obras de corte técnico o literario. Rojo Vega localiza en el inventario de Tomás Álvarez ${ }^{9}$ fechado en 1589 en Valladolid "un tostador de castañas", que coincide con el uso que aparece en alguno de los ejemplos localizados en la documentación del castellano.

Los datos del CorLexIn ofrecen un único ejemplo en la localidad riojana de Lumbreras, a finales de siglo: "vnas tenazas, vna boluedera, vn badil y un tostador". Lo mismo ocurre en los documentos que conforman el corpus terracampino donde figuran dos ocurrencias en documentos de Villalpando, en ambos casos inventariado entre enseres de cocina.

\footnotetext{
${ }^{9}$ Rojo Vega, Anastasio: 1589 Un lector de libros de caballería: el coletero Tomás Álvarez. Consultado en https://investigadoresrb.patrimonionacional.es/node/8010
} 


\subsubsection{Ropa de hogar}

La riqueza material que encontramos a la hora de vestir los hogares del siglo XVII proporciona un nutrido abanico de palabras que afloran en las relaciones de bienes. Resulta interesante la proximidad semántica de los objetos que referencian, por ello, hemos decidido en algunos casos no seguir el orden alfabético, si no ordenarlo por cercanía de significados.

\section{ACERICO [azerico, açerico]}

Sust. m. 'Almohadilla que sirve para clavar en ella alfileres o agujas'. Además, se señala como un término poco usado cuando hace referencia a 'almohada pequeña que se pone sobre las otras grandes de la cama para mayor comodidad' (DLE). Lo registra Covarrubias en su Tesoro como 'almohada pequeña sobre la qual echamos la cabeça para leuantarla un poco mas sobre la almohada'; la edición de Autoridades recoge las dos acepciones que encontramos en el diccionario académico actual, la diferencia es que sigue apareciendo como primera acepción la de "almohada pequeña", que pasará a un segundo lugar en la siguiente edición del diccionario (NTLLE, s. v. acerico, Covarrubias, 1611, Autoridades, 1726 y 1770). Diminutivo de hacero, cast. ant. facero, y éste derivado de FAz 'cara' (DECH, s. v. acerico).

Vn açerico de prender alfileres echo de avxa de seda de colores; y otro más pequeño vsado, exedreçado tanbién de seda de colores (Valderas, LE-1647)

Quatro almuadas, las dos açericos, labradas de seda negra de ruan (Valderas, LE-1647)

Un tafetán verde de una bara y quarto bolsillas de tela fina y un azerico de lo mismo en veinte y ocho reales (Medina de Rioseco, VA-1642)

Un azerico grande (Medina de Rioseco, VA-1660)

Tres almuadas de olanda vordadas de negro, dos azericos de lo mismo (Medina de Rioseco, VA1660)

La acepción más habitual es 'almohada pequeña' y aparece referenciada junto al resto de almohadas que componen la ropa de cama. También documenta el significado de 'almohadilla para clavar alfileres', pero con menor frecuencia en los textos analizados. Desde un punto de vista diacrónico, esta palabra figura en el $C D H$ en un inventario fechado en 1538 :

Dos acericos de Olanda con vn cayriel prieto, baçios, dos rreales... (Escritura de inventario, tasación y partición de los bienes que quedaron por fin y muerte de la señora doña Sancha de Guzmán, 1538)

El uso mayoritario de la palabra la encontramos en el siglo XVII con la acepción de 'almohadilla', sin embargo, a partir de este siglo este significado va dejando paso al de 'almohadilla para clavar alfileres' $(C D H)$.

Esta forma lexicalizada se distribuye por toda la Península y parte de América como se puede observar en el CorLexIn, donde la acepción más repetida es la que hace referencia a la ropa de cama. A las que habría que añadir aquellos casos encontrados en estudios de la época de diferentes autores (Morala, 2012a: 561, Perdiguero, 2014: 152, Morala, 2019b: 388-389).

Poco a poco esta definición va dejando paso en los textos a la de 'almohadilla para clavar alfileres', así en estudios dialectales más actuales como el de Le Men o Gordaliza aparece acerico con el significado de 'mullido especial, a veces con artísticos bordados que servía para clavar alfileres y agujas' (Gordaliza, 1988: 19). 


\section{ALFAMAR}

Sust. m. 'alhamar' ('manta o cobertor encarnado'), el DLE nos señala que estos dos términos -alfamar y alhamar- son voces poco usadas y con marca diatópica. La forma alfamar es un término propio de Salamanca. Aparece recogido en el Vocabulario de Nebrija y también en Covarrubias, pero en la edición de 1770 de Autoridades figura como una palabra anticuada. En el DRAE de 1925 se incluye la marca diatópica del término, se sigue señalando que es una voz antigua y propia de Salamanca (NTLLE, s. v. alfamar, Nebrija, 1495; Covarrubias, 1611; Autoridades, 1770; DRAE, 1925). Término procedente de una forma del árabe magrebí hanbal (DECH, s. v. alhamar).

Un alfamar listado colorado salamanqués tasado en diez y seys reales (Villalpando, ZA-1613) Un alfamar viejo de lana (Villalpando, ZA-1620)

Dos alfamares biejos tassados en real y medio (Villalpando, ZA-1635)

Un alfamar (Villalpando, ZA-1637)

Un alfamar usado (Villalpando, ZA-1644)

Un alfamar biexo (Villalpando, ZA-1645)

La forma alfamar con la acepción académica de 'manta o cobertor' se localiza en la parte zamorana de la Tierra de Campos, la más próxima a Salamanca. En bases de datos como el CDH y el CORDE figura con este significado a partir del siglo XIII y no se documenta más allá de la primera mitad del siglo XVII, salvo en documentos muy posteriores a los que posiblemente llegó por vía culta (Morala 2012e: 92). La variante alhamar es menos frecuente en los textos, de hecho, en la zona de estudio tan solo se han localizado ejemplos de la variante con /-f-/. En cuanto al significado de esta voz, por regla general aparece como 'manta o cobertor', pero en diccionarios no académicos como el de Salvá se añade la acepción antigua de 'alfombra o tapete', este hecho viene referenciado por Morala, que apunta que algunos autores señalan que dicho término puede tener otro significado más amplio que el de ropa de cama y así aporta la opinión de D. Oliver Asín (2004: 183-184) que muestra casos de la documentación medieval leonesa, en los que esta palabra puede tener un doble significado 'pieza de lana con la textura de un tapiz que puede servir de alfombra o de cobertor de cama' (Morala, 2012e: 92). En nuestra zona de estudio siempre aparece junto a los enseres de la casa, no necesariamente entre las ropas de cama, y hay un ejemplo en el que se inventaría junto a manta y cobertor, por lo que el escribano en ese caso diferencia el alfamar de los otros dos textiles. En el CorLexIn esta voz se localiza en la zona centro (en documentos de Salamanca, Ávila y Guadalajara) con la forma alfamar, que es la misma que encontramos en la Tierra de Campos zamorana. Morala confirma otras formas en Ávila -alfamare-y en Zamora -alfamara y alfanbar-:

Por último, hay que hacer referencia a la variante con pérdida de /f/ que representaría alhamar recomendada hoy por la Academia. En este caso, lo que nos encontramos en el corpus de inventarios es la variante alamar. No es extraño en los arabismos con /f-/ precedidos del artículo al- que convivan con las variantes con mantenimiento y con pérdida de /f/. El ejemplo más repetido en el corpus es sin duda el de alfombra y alombra o alhombra. En la voz que aquí nos interesa, es necesario deslindar los casos en los que estamos ante alamar < alfamar 'manta' y ante otro arabismo homógrafo, alamar, con el sentido de 'presilla, adorno que se pone sobre la capa' (Morala, 2012e: 93). 


\section{ALMOHADA [almoada, almuada, almohadilla, halmohada, halmoada]}

Sust. f. 'Funda rellena de un material blando, que sirve para reclinar la cabeza', 'funda de tela en que se mete la almohada para reclinar la cabeza' ( $D L E, 1 . \underline{a}$ y $3 . \underline{a}$ ac.). Este término lo recogen tanto Nebrija como Covarrubias, y en Autoridades aparece como 'funda de lienzo, tela, cuero, ù otra cosa semejante, que llena de pluma, lana, ò algodón sirve para sentarse con blandúra y conveniencia, ò para recostar la cabeza en la cama. Por otro nombre se llama coxín' (NTLLE. s. v. almohada, Nebrija, 1495; Covarrubias, 1611; Autoridades, 1726). También se recoge la variante almuada pero de forma tardía y en contandas ocasiones, el primero en recogerlo es Zerolo en 1895 donde le atribuye su uso popular. La única edición académica que lo recoge es la de 1927 como un americanismo utilizado en Colombia, Ecuador y Guatemala (NTLLE, s. v. almuada, Zerolo, 1895, DRAE, 1927). Este término tiene su origen en el árabe hispánico y magrebí muhádda derivado de hadd 'mejilla' (DECH, s. v. almohada).

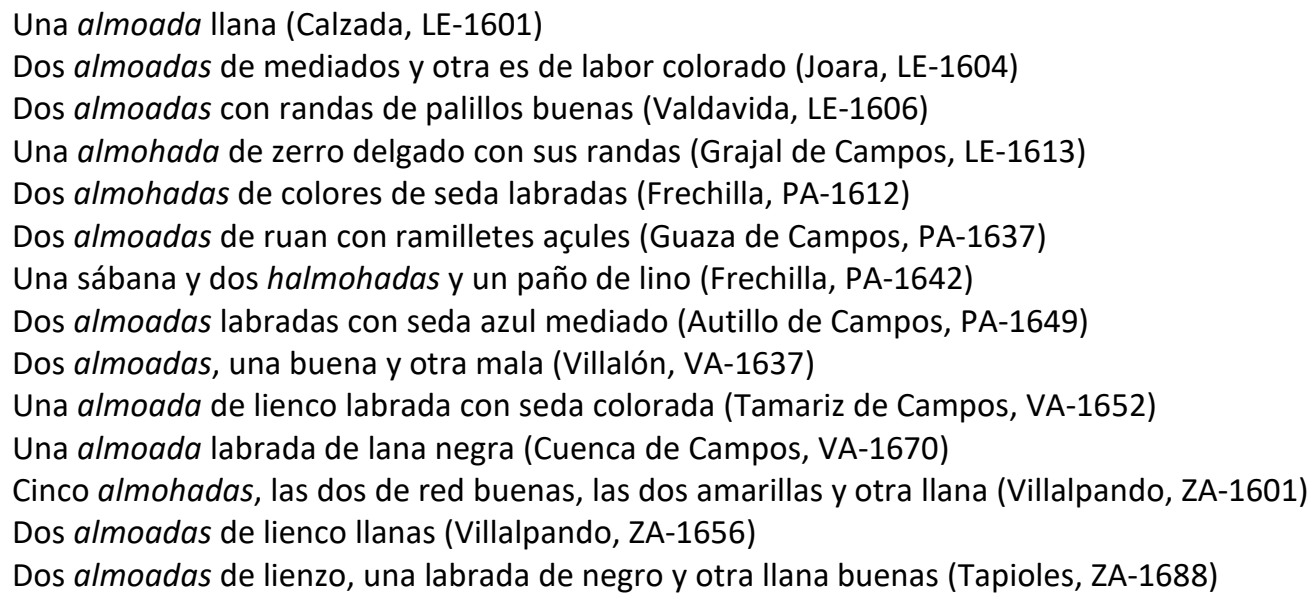

Desde una perspectiva formal, nos encontramos esta palabra con el hiato /oa/. Sin embargo, no es raro encontrarse con la solución diptongada /ua/ en los textos (Morala y Egido, 2010: 428):

Una almuada lavrada de colorado (Sahagún, LE-1615) Seis almuadas de lienço hordinario y quatro delgadas (Grajal de Campos, LE-1658) Una colcha de botonzillos y dos almuadas de lienzo (Valderas, LE-1682) Una almuada de lienzo llena de lana (Paredes de Nava, PA-1690) Tres almuadas de lana labrada de grana y una de red y otra con randas (Castromocho, PA-1614) Una almuada de ruan con desylados y randa en catorçe reales (Cuenca de Campos, VA-1666) Veinte y siete almuadas de lienço de Santiago, Aroca y Asturias (Medina de Rioseco, VA-1685) Una almuada azul, otra amarilla (Quintanilla del Monte, ZA-1639) Una almuada de lienzo delgado labrada de azul y caparrossa (Villalobos, ZA-1654)

Es uno de los arabismos más extendidos en los inventarios de bienes de la época. Como ya hemos señalado se utiliza tanto la variable con hiato almohada, como la variante con diptongo almuada. Cabe señalar que ambas variantes se pueden encontrar en un mismo documento, hecho señalado anteriormente por Pérez Toral en documentos peninsulares, sobre todo en la mitad norte de la Península (2017d: 56). Esto puede deberse a la cercanía a nivel fonético en la lengua oral, donde el cierre de la /o/ es muy frecuente. 
Desde un punto de vista diacrónico, las bases de datos académicas ofrecen un número extenso de concordancias. El CDH localiza el término almohada en el siglo XIV, en el Libro del cavallero Cifar (1300-1305). Tanto el CDH como el CORDE documentan el término diptongado en un documento del siglo XV, fechado en 1487 y titulado Autos y diligencias. La variante almuada presenta un número muy inferior al de almoada y almohada, y tan solo aparece en la documentación de corte jurídico o notarial, rara vez se encuentran casos en la literatura: un único caso en la autobiografía titulada Vida de Miguel de Castro, palentino de nacimiento. El resto de referencias literarias se encuentran en obras hispanomaericanas de finales del siglo XIX y principios del xx. Este hecho delata que la variante almuada era menos apreciada y se la entendía como un vulgarismo (Pérez Toral, 2017d: 58).

Los datos que nos proporciona el CorLexIn nos muestran una palabra de uso general que presenta distintas variantes gráficas, además de las mostradas aquí ${ }^{10}$. Las almohadas se confeccionaban con diferentes materiales, se cubrían con fundas ornamentadas y también tenían diferentes funciones, algo que el escribano trataba de especificar en el inventario (Morala, 2019b: 388):

Dos almoadas de cama buenas (Cea, LE-1610)

Una almuada de lienzo llena de lana (Paredes de Nava, PA-1690)

Media almuada de media bara de ruan tasada en dos reales (Villalpando, ZA-1620)

Dos almuadas de cama con sus randas (Villalpando, ZA-1620)

Quatro almuadas de las andas de Nuestra Señora (Medina de Rioseco, VA-1651)

Seys almuadas de estrado de terziopelo carmesí y damasco usadas que estas las trajo a el matrimonio la difunta (Medina de Rioseco, VA-1660).

Un estrado de terçiopelo y damasco carmessí con doçe almuadas con su galón de seda (Medina de Rioseco, VA-1685)

En cuanto a la morfología derivacional, la única forma diminutiva que encontramos en el corpus terracampino es la terminada en -illa, con los mismos significados que acerico:

Un[a] almoadilla de labrandera (Cea, LE-1610)

Un menester de minbres, con un harte, una almuadilla y unas tijeras (Grajal de Campos, LE-1670)

Una almuadilla para sobre en qué coser o labrar de un dechado viejo (Villalpando, ZA-1620)

Una almoadilla (Villalpando, ZA-1629)

Tanto el $C D H$ como el CORDE documentan esta voz a partir de las Cuentas de Gonzalo de Baeza, tesorero de Isabel la Católica fechadas en 1477 como "vn almohadilla de labor", aunque el significado de 'almohada pequeña para diferentes usos' también se registra en la documentación de estas bases de datos. El CorLexIn presenta menos ocurrencias de esta variante, aunque se encuentra en un ámbito geográfico relativamente amplio dentro de la Península.

${ }^{10}$ Morala y Perdiguero (2019: 186-187) localizan las variantes almoxada, almojada y almujada en el área meridional de la Península, donde en vez de $h$ intervocálica, aparecen las antiguas dorsopalatales $(g, j$ o $x$ ) con sonido velar sordo. Además, la forma almoxada también aparece en inventarios de Canarias (CorLexIn): "quatro almoxadas con puntas de ruan" (Adeje, Tenerife, 1695). 


\section{COJíN [coxín]}

Sust. m. 'Almohadón que sirve para sentarse, arrodillarse o apoyar sobre él cómodamente alguna parte del cuerpo' (DLE). Es un término que aparece registrado en Nebrija y Covarrubias. Autoridades se halla como 'cierto género de almoháda hecha por lo regular de badána ò cuero, llena de lana, pluma ò borra, que comunmente sirve para sentarse en él ò hincarse de rodillas', también aparece como 'otro género diferente de almohada, más ancho de abaxo que de arriba, de cuero, paño ù otra tela, lleno de lana, pluma ò borra, y regularmente colchado, que se pone sobre las sillas, para ir mas acomodadamente acaballo' (NTLLE, s. v. cojín, Nebrija, 1495; Covarrubias, 1611 y Autoridades, 1729). Término derivado del lat. vulgar *coxīnum íd., derivado de cŏXA 'cadera' porque sirve para sentarse encima, probablemente tomado del cat. coixí 'cojín', 'almohada' (DECH, s. v. cojín).

\section{Una silla de vaqueta con el cojín de cordován buena (Grajal de Campos, LE-1658) Dos coxines biejos (Medina de Rioseco, VA-1642) Una maleta y cojín de terçiopelo berde biejos (Medina de Rioseco, VA-1642) Dos sillas viejas de mulas, una maleta y cojín (Medina de Rioseco, VA-1660)}

Formalmente el término cojín presenta la forma académica en la Tierra de Campos. Esta voz se documenta en los textos que configuran el $C D H$ a finales del siglo XIV, a finales del siglo XV aparece en las Cuentas de Gonzalo de Baeza, tesorero de Isabel la Católica fechadas en 1477 donde se localizan dos acepciones dadas por Autoridades:

Dos coxines para la sylla de la mula

Doze coxines, a 60 mrs. cada vno, 6.600 mrs., los quales mando poner en su Camara

Estas dos acepciones se documentan en diferentes puntos de la Península (CorLexIn). Sin embargo, en las ocurrencias localizadas en los documentos americanos se presenta como 'elemento confeccionado para el ornamento o de uso práctico del hogar' que se inventaría junto a mantas, sábanas, alfombras y cortinas, lo mismo que sucede con los documentos canarios.

En Tierra de Campos suele aparecer junto al ajuar de camino -alforjas, sillas de montar o maletas-. Posiblemente para la acepción de 'ropa de cama' se prefiere el término cabezal o acerico presentes también en los inventarios terracampinos.

\section{CABEZAL [cauezal, cabeçal, cabiçal, cabeçalejo]}

Sust. m. 'Almohada', 'cabecero (pieza de la cama)' (DLE, 3. y 4. ac.). Aparece en Nebrija como 'cabeçal o almohada de cabeça', también se halla en el Tesoro de Covarrubias y Autoridades lo registra como 'colchoncillo largo y angosto, hecho de lienzo, y embutido de lana basta, paja ò borra, que por la mayor parte no tiene bastas, del qual usan los Labradores para dormir en los escaños junto à la lumbre', 'se llama también una almohada larga que coge todo el ancho de la ella para reclinar la cabéza' y 'paño pequeño de lienzo, redoblado varias veces, que se pone sobre la sangría para que no salga sangre, y se assegúra atándole con la venda' (NTLLE, s. v. cabezal, Nebrija, 1495; Covarrubias, 1611; Autoridades, 1729). Se trata de una voz derivada de cabeza procedente de CAPัTĬA, forma del lat. vulgar que sustituyó a CAPUT, -ĬTIS (DECH, s. v. cabeza). 
Quatro cabezales de lino viexos (Cea, LE-1610)

Quatro cabezales viexos, los tres de Mayorga y otro de lino y lana (Sahagún, LE-1623)

Un caveçal de colores vueno (Sahagún, LE-1626)

Tres cabezales de undero (Grajal de Campos, LE-1670)

Un cauezal listado de colores apreciado en diez reales (Frechilla, PA-1613)

Otro cauezal de barillas en cinco reales (Frechilla, PA-1613)

Çinco cabeçales de cama con su pluma, los tres de labor entera y dos hordinarios (Guaza de Campos, PA-1639)

Un cauezal ondero con su pluma (Villada, PA-1668)

Dos cabiçales destopa (Villalón, VA-1637)

Dos cavezales de Salamanca viejos bazíos (Medina de Riosceo, VA-1641)

Un caueçal de terliz abarillado traydo (Villalón, VA-1641)

Dos cauezales de terliz con su pluma (Medina de Rioseco, VA-1651)

Un cabezal de puntas nuevo en onze reales (Villalpando, ZA-1600)

Tres cavezales viejos con su pluma (Villalpando, ZA-1620)

Dos cabeçales listados, biexos (Villalobos, ZA-1654)

Un cabezal de lino y lana abarillado (Villalpando, ZA-1661)

En la mayoría de los ejemplos estudiados aparece con la acepción de 'almohada donde se apoya la cabeza o cabecero'. Sin embargo, en algunos casos, aparece referenciado junto a enseres del campo como cocinos, escriños o azadones, en esos casos puede tratarse de una especie de almohada que se ubicaba debajo del yugo para evitar rozaduras en los animales (Gómez Ferrero, 2015: 172). Por lo que vemos en los documentos, solía estar relleno de pluma y también podían ser confeccionados con diferentes telas, desde las más finas a las más groseras (terliz, estopa, lana, lino...). Con el significado de 'almohada' figura desde el siglo XIII hasta bien entrado el siglo XVII, pero a partir de esta época comienza a caer en desuso ( $C D H$, s. v. cabezal).

Respecto a la distribución diatópica que el término ofrece en el siglo XVII, se ve una clara preferencia de uso en la mitad norte de la Península -las provincias castellanoleonesas y norteñas-, con ocurrencias más esporádicas en las provincias de Guadalajara, Cuenca, Toledo, Ciudad Real y Murcia. Tan solo se recoge un ejemplo en los textos procedentes de América -Colombia-con una acepción diferente a las que aparecen en los documentos peninsulares.

La documentación terracampina presenta una extensa nómina de casos entre los que se encuentra la variante cabiçales, debido al cambio de timbre de las vocales átonas, muy frecuente y extendido en esta época (Morala 2012a: 560). En cuanto al significado de esta voz, no es exactamente lo mismo que 'almohada', ya que en muchos inventarios se enumera junto a este término, incluso en el mismo asiento -"un caueçal y una almoada" (Medina de Rioseco, VA1657)-, podría referir una funda o un colchón pequeño (Perdiguero, 2015a: 1575), de hecho, en la localidad vizcaína de Elorrio figura "una funda o cauezal de un colchón", equiparándolo con el primer significado que da Perdiguero.

Formado por derivación aparece el término cabezalejo, que por contexto podemos sospechar que se trataba de una almohada más pequeña y de peor calidad por la confección de la misma:

Un cabeçalejo de listas coloradas biejo y roto (Frechilla, PA-1637)

Un cabeçalejo negro con poca pluma (Frechilla, PA-1638)

Un cabeçalejo blanquillo con trapos de terliz (Frechilla, PA-1639) 
Autoridades registra este diminutivo de cabezal como 'la almohada pequeña, que se pone debaxo de la cabéza', pero este lema no llega hasta las ediciones modernas del diccionario (NTLLE, s. v. cabezalejo, Autoridades, 1729). El resto de bases de datos académicas presentan una nómina de casos reducida de este derivado. El CORDE y el $C D H$ dan testimonio de la misma en documentos del siglo XVI, la primera en un Manual de mujeres en el qual se contienen muchas y diversas reçeutas muy buenas (1525): "poné encima un cabeçalejo como de sangría, e tocaos la cabeça con un paño de manera que tapéis el oído". En uno de los ejemplos equiparan esta palabra con una especie de colchón pequeño: "assi sera necessario poner sobre las vertebras salidas vn colchonzillo o cabeçalejo" en Instituciones para el aprovechamiento y examen de los algebristas de Luis Mercado (1598).

Los datos proporcionados por el CorLexIn muestran dos ocurrencias en textos segovianos, donde cabezalejo se inventaría junto a artesas, tinajas, coyundas o suelas, podría tratarse de una especie de almohadilla empleada para diversos fines. Sin embargo, los pocos ejemplos de la Tierra de Campos se inventarían siempre entre cabezales, estamos ante un diminutivo del término.

No es extraño encontrar este derivado en estudios más recientes como 'pequeño cabezal que se ponía a veces al cuello de las mulas' (Gordaliza, 1988: 52).

\section{TRAVESERO [trauesero]}

Sust. m. 'travesaño' (almohada), 'almohada larga que ocupa toda la cabecera de la cama' (DLE, s. v. travesero, travesaño, 2.a ac.). Este término aparece registrado con esta acepción desde Autoridades (NTLLE, s. v. travesero, Autoridades, 1739). Aunque no hay entrada en el Tesoro de Covarrubias de esta voz, cabe destacar que en la definición de cabezal afirma que 'quando es labrado, y de gente de ciudad, se llama trauesero' (Covarrubias, 1674: 112). Término derivado del verbo verter, del lat. VĚRTĚRE 'girar, hacer girar, dar vuelta', 'derribar', 'cambiar, convertir' (DECH, s. v. travesero).

Un pesso de hierro travessero con una pesa de libra de yerro (Frechilla, PA-1659)

Quatro traveseros de olanda en ochenta reales (Medina de Rioseco, VA-1640)

Un trauesero de cama traído tasado en seis reales (Medina de Rioseco, VA-1644) Un trauesero de lo mismo (lienzo) (Villalpando, ZA-1689)

En el corpus analizado apararecen escasos ejemplos de esta palabra y salvo en uno de los ejemplos que aparece como adjetivo "peso travessero", el resto hace referencia a la 'almohada que atravesaba toda la anchura de la cama' (Ágreda, 2017: 28). En bases de datos como el CDH aparece en inventarios a partir del siglo XIII junto a ropa de cama como cabezales o almadraques. Sin embargo, al igual que pasa con cabezal, esta voz parece perder uso conforme pasa el siglo XVII. En el CorLexIn lo documentamos en zonas de la cornisa cantábrica como Asturias, Cantabria, País Vasco y puntos de Navarra con la forma travesera. Quirós advierte que frente a travesera 0 travesal, está la forma travesero 'almohada', que ha sido considerada como la forma castellana propiamente dicha (Quirós, 2012: 379). En algunos inventarios de Navarra o Teruel aparecen ejemplos como "Dos bufetes de nogal sin yerros, solo hunos palos por trabeseros de abajo", donde el significado es diferente. En la zona de La Bañeza los ejemplos que figuran de esta 
palabra datan de los siglos XVIII y XIX y mantienen la acepción anteriormente vista (Gómez Ferrero, 2015: 220).

En estudios dialectales actuales como el de Gordaliza, travesero es el 'taco grande de madera que se usa, por ejemplo, para atizar el fuego. En su origen es un madero que se coloca al través' (Gordaliza, 1988: 218). Y, en el ámbito del leonés, esta voz posee significados que tienen que ver con los aperos de labranza y que no están presentes en el DLE. Estos se recogen en el Léxico del leonés actual, pero no los encontramos en el corpus estudiado (Le Men, 2011, s. v. travesero).

Es una palabra que aparece de manera esporádica en el corpus, tal vez, por la preferencia que existía por la voz cabezal.

\section{FUNDA [HUNDA, UNDA]}

Sust. f. 'Cubierta o bolsa de cuero, paño, lienzo u otro material con que se envuelve algo para conservarlo y resguardarlo' (DLE). Nebrija recoge esta voz como 'funda de almohada o colchón' y Autoridades además de este significado, registra el de 'aquello sobre que se forma y funda alguna cosa' (NTLLE, s. v. funda, Nebrija, 1495; Autoridades, 1732). Término procedente del lat. tardío FŬNDA 'bolsa', en lat. clásico 'honda' y luego 'red de pescar', de donde 'bolsa' ( $D E C H$, s. v. funda).

Una funda de almuada de olanda con votones de muletillas (Grajal de Campos, LE-1658) Unas fundas y ropilla de vayeta de Sevilla contraecha bueno (Grajal de Campos, LE-1658) Una funda de caveçal (Castromocho, PA-1614)

Un bestido de bayeta de Sebilla, funda y ropilla y ferreruelo (Medina de Rioseco, VA-1640)

Dos pistolas de cavallo con sus fundas (Medina de Rioseco, VA-1642)

Unos estriuos de la vrida viexa dorados en sus fundas (Medina de Rioseco, VA-1644)

Unas fundas y ropilla de bayeta negra y un sonbrero (Medina de Rioseco, VA-1644)

Unas fundas, ropilla y ferreruelo de bayeta de Palençia (Medina de Rioseco, VA-1649)

Un coleto con sus calçones de camuças y fundas de estameña (Medina de Rioseco, VA-1657)

Otro bestido de bayeta de Palenzia capa ropilla y fundas biejo (Medina de Rioseco, VA-1660)

Unos corporales con sus fundas de guadamazil (Villalpando, ZA-1660)

Esta voz es de uso general en la época y suele aparecer con el significado de 'funda de almohada' en la mayoría de los protocolos notariales que constituyen el CorLexIn, de hecho, es un significado que localizamos en los textos de la Península, Canarias y América. Sin embargo, en el corpus estudiado localizamos pocos ejemplos de este -una ocurrencia en un inventario de Grajal de Campos-, funda referencia más la bolsa que sirve para la ropa, las pistolas o las bridas.

Cabe señalar que en esta zona hay una preferencia por la forma hunda o unda con pérdida de la /f-/ (Morala, 2009:15), solución patrimonial que solo se documenta en las zonas leonesa y palentina de la Tierra de Campos.

Una unda blanca viexa con un poco de orégano (Sahagún, LE-1600)

Una unda para echar trigo, de lino e lana, en dos reales (Sahagún, 1601)

Una unda con quatro çelemines de arina (Valderas, LE-1606)

Una vnda viexa con un poco de lana (Sahagún, LE-1608)

Otra vnda de lino e lana con hasta media carga zeuada (Sahagún, LE-1608)

Una hundica con unos papeles (Grajal de Campos, LE-1613)

Una hunda de lino y lana vuena (Cea, LE-1621) 
Otra hunda buena con una fanega de salvados (Cea, LE-1621)

Quatro undas de lino y lana a modo de costal (Grajal de Campos, LE-1656)

Vna vnda de cauezal con su pluma, en doze reales (Boadilla de Rioseco, PA-1650)

Tres cauezales con su pluma el uno de undas y dos de terliz (Boadilla de Rioseco, PA-1659)

Sin embargo, la acepción que presenta esta variante en las ocurrencias pertenecientes a localidades leonesas -los ejemplos de Boadilla de Rioseco coinciden con 'funda de almohada', al igual que el de Cea, fechado en 1621, ya que se encuentra entre ropa de cama- no es equivalente a la normativa funda, sino que hace referencia a una especie de 'saco' o 'costal' que se utilizaría para llenarlo de cereal fundamentalmente. Morala señala que estamos ante una voz antigua, que a pesar de la solución para /ŭ/, se puede considerar como un resultado de carácter patrimonial (Morala, 2014a 14).

No tenemos constancia de esta variante ni en las bases académicas del castellano (CORDE y $C D H)$, ni en las obras lexicográficas que componen el NTLLE. Por otra parte, los resultados que ofrece el CorLexIn se localizan en esta misma zona -aparece un ejemplo en Guadalajara, pero con una acepción que tiene que ver con 'ondas' dado el contexto en el que aparece (Íbidem, nota 14).

Desde la perpectiva de la morfología derivacional, se encuentra la forma undilla, localizada Villamuñío, localidad cercana a Tierra de Campos (CorLexIn) y con el mismo significado:

Vna undilla de echar pan (Villamuñío, LE-1673)

\section{HUNDERO [UNDERO, ONDERO]}

La palabra hundero no se registra en ninguno de los diccionarios que conforman el NTLLE. Tampoco aparece en el $D E C H$, pero parece que se trata de una voz derivada de hunda a través del sufijo -ero, muy productivo en la época.

Tres underos con su pluma en doze reales, los dos de lana e uno de lino (Sahagún, LE-1601) Un hundero de terliz bueno (Sahagún, LE-1601)

Tres terlizes con sus underos llenos de pluma (Sahagún, LE-1601)

Tres cauecales de terliz con sus hunderos (Sahagún, LE-1605)

Dos underos de lino y lana con listas negras y blancas con su pluma nuebos (Grajal de Campos, LE-1655)

Tres cabezales de undero (Grajal de Campos, LE-1670)

Dos cabezales underos biejos con pluma (Grajal de Campos, LE-1671) Tres cauezales, los dos underos de lienzo, el otro de labor entera con su pluma (Villada, PA-1665)

Un cauezal ondero con su pluma (Villada, PA-1668)

Seis caueçales underos con su pluma (Villada, PA-1669)

No tenemos noticias de esta palabra en las obras lexicográficas del NTLLE. Tampoco encontramos ocurrencias en bases como el CORDE o el CDH o en corpus textuales como el CorLexIn. Sin embargo, hay un nutrido número de casos en el corpus terracampino, siempre con un significado que tiene que ver con la ropa de cama, ya que siempre se encuentra inventariado entre sábanas, mantas, cobertores, jergones y, sobre todo, cabezales.

Desde un punto de vista morfológico, esta lexía presenta tanto naturaleza sustantiva como adjetiva. Cuando aparece como adjetivo, siempre modifica a la palabra cabezal, y cuando se trata de un sustantivo, en muchas ocasiones comparte asiento con cabezales y terlices. Podría 
tratarse de una funda sencilla para los cabezales. Como adjetivo también aparece la variante ondero -"un cauezal ondero con su pluma" (Villada, PA-1668)- donde hay una abertura de la vocal /u/ en /o/, cambio más esporádico en la época (Morala, 2012a: 559).

\section{CASCO}

Sust. m. La acepción con la que aparece en los siguientes ejemplos no la encontramos en ninguno de los diccionarios académicos. El $D E C H$ señala el carácter polisémico de esta voz. Es un término derivado de cascar 'romper, quebrantar' (DECH, s. v. casco).

Dos cascos de almuada (Cuenca de Campos, 1666, Valladolid)

Un casco de almoada tassado en quatro Reales (Cuenca de Campos, VA-1668)

dos cascos de lienzo para una almoada (Villalpando, ZA-1637)

El término casco se presenta en la documentación con varias acepciones. Entre la primera que se localiza está la de 'pieza de armadura que cubre la cabeza' y que tenemos noticia desde el Cantar de Mío Cid fechado en 1140 (DECH, s. v. casco y CDH). En el corpus terracampino aún se conserva este significado: "vna cota de malla y un casco de yerro" (Medina de Rioseco, VA1644). En este siglo todavía se inventarían de forma esporádica este tipo de objetos reminiscentes de otras épocas. Sin embargo, el significado que aquí nos ocupa tiene más que ver con la ropa de cama, significado poco documentado, con una exigua nómina de casos tanto en la documentación analizada de Tierra de Campos -tan solo tres ocurrencias-, como en el CorLexIn que presenta un par de casos, uno en la localidad vallisoletana de Navas del Rey (1648) -"vn casco labrado, caparrosado [después de almohada]"-y otro en un inventario de Cuevas de Almazora, provincia de Almería (1649) "tres cascos de almohagadas de ruán labrados con seda colorada y pajiça", al que Perdiguero añade "un casco de almohagada labrado con hilo acejado". Este autor considera que este término, por el contexto en el que aparece, esté designando a la 'funda de la almohada' (Perdiguero, 2015a: 1575). Lo que está claro es que este significado no prosperó en el acervo léxico castellano y que tan solo nos quedan unos pocos ejemplos de este en los inventarios de bienes del siglo áureo.

\section{CERCADURA [zercadura]}

El DLE registra este término como en desuso y lo equipara con cerca. No se corresponde con la acepción a la que hacen referencia los ejemplos encontrados en los documentos analizados. Autoridades define esta voz como 'moldúra, filéte, ù otra labór, con que se labra la madéra, para adornarla, ò ponerla vistósa'. Sin embargo, en la edición de 1780 el término se le señala como antiguo y como 'vallado, tapia, ó muro que se pone alrededor de cualquiera sitio' (NTLLE, s. v. cercadura, Autoridades, 1729; DRAE, 1780). Palabra derivada de cerco, del lat. CǐRCUs 'círculo' (DECH, s. v. cerco).

Unas cercaduras de cama con unas listas negras por el medio con flocadura de hilo amarillo y blanco apreçiadas en diez reales (Fechilla PA-1614)

Una cama de pino con cielo, cabeçales buenos, dos mantas buenas, una sobrecama açul, dos almoadas y unas cercaduras con çinco piernas y çielo de randas con sus flocaduras y una tarimilla (Frechilla, PA-1640)

Una cercadura de cama, tres paramentos y el çielo con sus fluecos (Guaza de Campos, PA-1640)

Vna cercadura de cama de red en quatro pedazos (Autillo de Campos, PA-1654)

Una zercadura de lienzo de red en çinco piezas (Autillo de Campos, PA-1654) 
Este término aparece documentado en la zona palentina de la Tierra de Campos, su presencia es exigua en el corpus estudiado. Lo mismo ocurre en bases de datos como el $C D H$, donde figuran cuatro ejemplos de esta voz datados todos ellos a finales del siglo XVI. No transcienden más ejemplos de esta voz más allá del siglo XVI.

En el CorLexIn tampoco encontramos una mayor presencia de ocurrencias, estas se localizan en inventarios de Almería, Cuenca, Burgos y Palencia, con el mismo significado. Por el contexto en el que aparecen todos estos ejemplos, podemos aventurarnos a pensar que, dada la etimología de la palabra, el objetivo de este textil sería dar la oportunidad de aislar la cama como un sitio más íntimo, como venían haciendo las cortinas, voz preferida en aquella época y de la que se encuentra un mayor número de ejemplos.

\section{CERNADERA}

No hay constacia de este término en diccionarios académicos.

Una cernadera (Paredes de Nava, PA-1689)

En Tierra de Campos solo encontramos este ejemplo en Paredes de Nava, el contexto en el que aparece y la información que se desprende del mismo no es suficiente para aclarar su significado. No hay constancia en bases léxicas como el CORDE y el CDH. Morala localiza además una ocurrencia en Cáceres "dos pares de çernaderas biejas" (Morala, 2012b: 346). Con los datos que nos ofrece el CorLexIn localizamos un ejemplo en Baza (Granada) "vnas cernaderas y una tabla de horno y un tablero" (1660) y otro en Cáceres (1629) "vna artesa de masar con sus çernaderas y mesa y barillas". El Fichero General conserva una única célula referenciando la obra de López de Guereñu Voces alavesas (1958) donde define esta voz como 'instrumento que ayuda a cerner' remitiendo inmediatamente a cernederas y dando como ejemplo un asiento de un inventario de 1753: "dos reales de unas cernaderas". Dato este que muestra la confusión que se da entre ambos vocablos (cernadera y cernedera).

Cernadera sí se registra en algunos corpus léxicos actuales como el de Le Men donde aparece este vocablo como 'recipiente en que se recoge la ceniza o cernada' (Le Men, 2004, s. v. cernadera), también aparece en el Vocabulario del valle del Tera con este mismo significado (Vara y Nuevo, 2008: 259).

\section{CERNADERO [zernadero]}

Sust. m. 'Lienzo que se pone por delante la persona que cierne la harina, para no enharinarse la ropa', 'lugar destinado para cerner la harina' (DLE). Esta voz está recogida por Corvarrubias como 'el paño gruesso que ponen sobre los demas que estan en la colada; en el qual se echa la ceniza y el agua en que ha heruido' (NTLLE, s. v. cernadero, Covarrubias, 1611). Es una voz derivada de cernada, y esta a su vez de *cen(e)rada, derivada del lat. CINIS, -ĔRIS 'ceniza' (DECH, s. v. cernada).

Seis çernaderos de estopa (Medina de Rioseco, VA-1644)

Un cernadero biexo (Medina de Rioseco, VA-1643)

Dos cernaderos en dos reales (Medina de Rioseco, VA-1647)

Un cernadero de estopa en real y medio (Medina de Rioseco, VA-1641)

Seis zernaderos destopa (Medina de Rioseco, VA-1648) 
La voz cernadero aparece documentada en la zona de estudio, pero no de manera generalizada como ocurre con otras voces. Se localizan algunos ejemplos en bases de datos como el CORDE o el $C D H$, donde se documenta a mediados del siglo XVI, más concretamente en un inventario fechado en 1547. Su presencia en estos documentos se limita en el tiempo entre mediados del siglo XVI y primera mitad del siglo XVII y en la mayoría de los casos se trata de usos figurados. Sin embargo, en textos de La Bañeza del siglo XVIII y XIX aparece en los inventarios de bienes como un enser más de la casa (Gómez Ferrero, 2015: 181). En el CorLexln, la voz cernadero se distribuye por la zona central, desde Málaga a La Rioja y compartiendo campo semántico con cernador, aunque la presencia de este último es más escasa. En cuanto al significado, en los documentos analizados no se clarifica mucho ante qué tipo de paño podemos estar y para qué se utilizaba, aparece referenciada junto a sábanas, toallas, servilletas o manteles. La clave de lo que puede ser nos viene dada por dos inventarios en los que sí se especifica para qué sirve dicho paño. Por un lado, tenemos un inventario de Navarrete (La Rioja) donde se escribe los siguiente: "vn çernedero de colar viejo" y otro en Villamayor (Cuenca) donde aparece "una terçia de çernadero que está enbuelta la ropa", este último parace coincidir al dado por Covarrubias en su Tesoro. En corpus léxicos actuales aparece como 'paño para colar cernada o lugar destinado al cernido de la harina' (Gordaliza, 1988: 67). En distintas zonas de León figura como 'lienzo gordo que se pone en el cesto o coladero de la ropa para colar la cernada' (Le Men, 2004, s. v. cernadero).

\section{CERNEDERA [zernedera, çernadera]}

Sust. f. 'Marco de madera del tamaño de la artesa, sobre el cual se ponen uno o dos cedazos para cerner con más facilidad la harina que cae dentro de la artesa' (DLE), se usa mayoritariamente en plural. No se registra en el DRAE hasta la publicación de 1936 con la acepción con la que contamos actualmente (NTLLE, s. v. cernedera, DRAE, 1936). Término derivado del verbo cerner, del latín CĚRNĚRE 'separar' (DECH, s. v. cernedera).

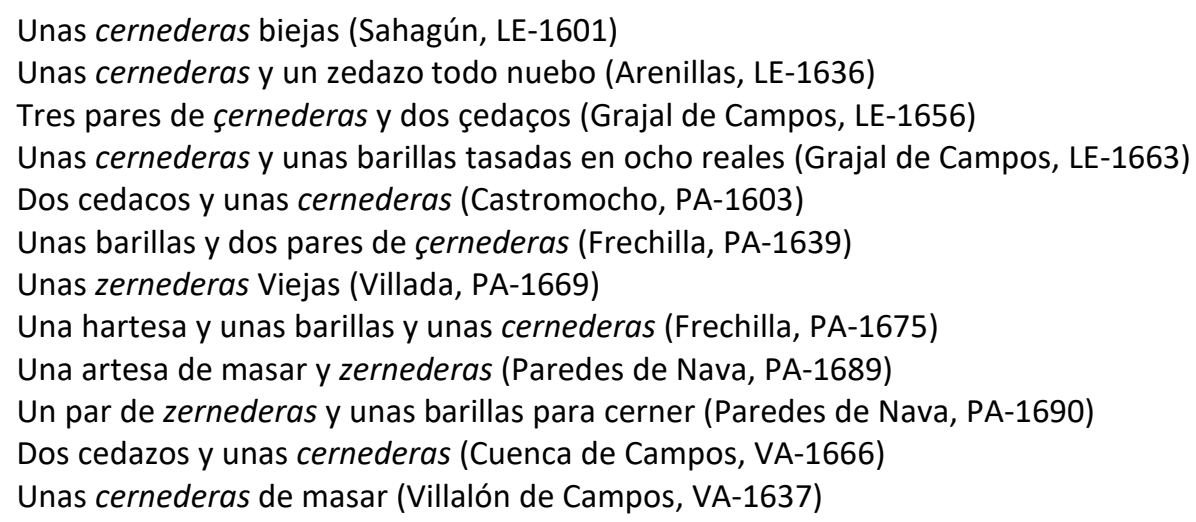

Palabra documentada en los textos analizados con la acepción que da el DLE y que aparece siempre en plural. Apenas tiene presencia en el $C D H$, donde aparecen varios ejemplos, todos ellos recogidos en el siglo xx a través de textos literarios. Esta situación en las bases del castellano contrasta con lo encontrado en la Tierra de Campos, donde se muestran un número importante de ejemplos con la acepción académica. Ocurre lo mismo si realizamos la búsqueda en el CorLexIn, esta voz figura con este significado y siempre en plural. En la zona de Navarra y 
Huesca se localizan cernedores para designar este mismo objeto, y que al igual que cernederas comparte asiento junto a cedazos y artesas. Morala encuentra esta palabra con la variante cernidera, un occidentalismo ubicado en Salamanca y Cáceres y que se utiliza indistintamente en masculino y en femenino (Morala, 2012b: 347). En corpus léxicos actuales como el de Gordaliza registra cernadera como 'dos palos finos y alargados, generalmente de chopo, que se usan para poner encima un cedazo o criba para cribar la harina' (Gordaliza, 1988: 67).

\section{CERNEDERO}

Sust. $m$. 'Lienzo que se pone por delante la persona que cierne la harina, para no enharinarse la ropa', 'lugar destinado para cerner la harina' (DLE). Covarrubias recoge esta voz como 'el lugar donde se cierne, o el paño que se pone delante que cierne por no enharinar el vestido' (NTLLE, s. v. cernedero, Covarrubias, 1611). Término derivado del verbo cerner, del lat. CĔRNĚRE 'separar' (DECH, s. v. cernedero).

Un cernedero de lienço (Castromocho, PA-1614)

Un cernedero nueuo tasado, en dos reales (Medina de Rioseco, VA-1643)

Una servilleta de estopa y un cernedero, una almoada y un regalico (Medina de Rioseco, VA-1643)

Esta voz se halla escasamente documentada en los textos analizados, tal vez por existir otras voces que ocuparan ese campo semántico como mandil o delantal. Se documenta en el CDH en el siglo XVII y haciendo referencia 'al lugar en que se cierne', con esta acepción localiza Morala un único ejemplo en Guijo de Granadilla (Cáceres, 1670) "una mesa redonda que está en el çernidero" (Morala, 2012b: 347), en nuestro corpus solo aparece con la primera acepción que da el DLE. Tampoco encontramos la variante cernidero, que se registra en la edición del DRAE de 1925 con marca diatópica de Salamanca y que Morala localiza en localidades de Salamanca y Cáceres y que aparece con el significado de cernedera (Morala, 2012b: 347). Se trata de una palabra poco documentada tanto en el área de estudio, como en el resto de la Península, donde encontramos ejemplos aislados en Navarra y Álava.

\section{CIELO [çielo, zielo]}

Sust. m. 'Parte superior que cubre algunas cosas' (DLE, 6. a ac.). Nebrija recoge cielo de cama en su Vocabulario y en Autoridades aparece cielo de cama como 'la parte superior de la colgadúra, hecha à medida de lo ancho y largo de la cama, que sirve como de techo para cubrirla, y se pone sobre quatro piláres, ò pendiente (si es Imperial) de quatro cordónes, ò hierros que se asseguran en las vigas del techo de la pieza' (NTLLE, s. v. cielo, Nebrija, 1495; Autoridades, 1726). Término procedente del lat. CAELUM (DECH, s. v. cielo).

Otro zielo de cama de lienzo con bías azules en ocho reales (Sahagún, LE-1600)

Un zielo de cama de lino (Sahagún, LE-1608)

Tres paramentos pintados los dos grandes y uno pequeño y un çielo de cama de guadamaçil biejo (Grajal de Campos, LE-1657)

La parementadura de una cama de red tenida de açul con su çielo, cortinas y rodapies (Grajal de Campos, LE-1658)

Una cercadura de cama, tres paramentos y el çielo con sus fluecos (Guaza de Campos, PA-1640)

Un zielo de cama de lienzo amarillo (Autillo de Campos, PA-1653) 
Una colgadura y çielo de cama de red blanco biejo (Boadilla de Rioseco, PA-1687) Tres cortinas y un cielo de cerraxón con sus flecos de lo mesmo (Paredes de Nava, PA-1689) Un çielo de cama en dos ducados (Medina de Rioseco, VA-1643)

Una cuja de cama de nogal dorada con cortinas couertor y cielo de damasco carmesí y goteras de terciopelo y flocadura y alamares de oro (Medina de Rioseco, VA-1647)

Una cama de paramentos que son tres y el cielo de la cama con red (Cuenca de Campos, VA1660)

Una cama de nogal entera con sus cortinas y rodapie, çielo y cobertor de paño berde (Villapando, ZA-1644)

Un çielo de cama y un paramento biejo (Villalpando, ZA-1620)

Una cama de campo con cortinas de estameña colorada con su cielo y cobertor (Villalpando, ZA1650)

Unos paramentos de cama con su zielo (Villalpando, ZA-1653)

Es un término de uso habitual en los inventarios de bienes, tanto de la zona de estudio como del resto de la Península y algunos países de América. Se trata de una parte de la cama que abarcaba lo ancho y largo del lecho y que cubría, protegía y decoraba la zona superior (Ágreda, 2017: 24).

\section{COBERTOR [couertor, covertor]}

Sust. m. 'colcha', 'manta o cobertura de abrigo para la cama' (DLE, 1. y 2. a ac.). Recogido por Nebrija y Covarrubias en sus respectivos trabajos, este último lo define como 'el paño que cubre la cama'. Autoridades, además de 'cierto género de manta ò cubierta, que se echa en las camas para el abrigo, que ordinariamente suele ser de lana', también aparece como 'lo mismo que cubierta ò tapa' (NTLLE, s. v. cobertor, Nebrija, 1495; Covarrubias, 1611; Autoridades, 1729). Término derivado del verbo cubrir procedente del lat. COOPERIRE (DECH, s. v. cubrir).

Dos covertores, el uno blanco y el otro colorado (Riosequillo, LE-1610)

Un covertor vlanco usado tasado en ducado y medio (Cea, LE-1626)

Un cobertor de cama terçiado con listas negras y blancas demediado (Grajal de Campos, LE-1655)

Dos cobertores colorados, el uno de paño y el otro bueno (Grajal de Campos, LE-1656)

Un covertor colorado (Castromocho, PA-1602)

Un cobertor de paño verde viejo apreçiado en cinco reales (Frechilla, PA-1612)

Un cobertor con listas amarillas y coloradas (Frechilla, PA-1642)

Un cobertor berde de cordellate con flecos de luna paxizos y açules (Paredes de Nava, PA-1690)

Un cobertor azul todo con sus fluecos pajicos (Villalón, VA-1637)

Una cuxa dorada con cortinas, cielo y couertor de damasco carmessí con flocadura de seda en ocho cientos reales (Medina de Rioseco, VA-1647)

Un cobertor berde nuebo de lana (Tamariz de Campos, VA-1652)

Un cobertor de Palencia blanco nuevo en quatro ducados (Cuenca de Campos, VA-1666)

Dos cobertores colorados (Quintanilla del Monte, ZA-1639)

Un paramento y un cobertor (Carrizo, ZA-1646)

Un cobertor de estameña escarmenada (Villalpando, ZA-1688)

Un covertor de estameña verde (Villalpando, ZA-1690)

Se trata de una palabra que aparece con mucha frecuencia en los inventarios de bienes. Documentada desde el siglo XIII, está presente en textos notariales del siglo XVII de la Península y de América. En inventarios de la época áurea figuran algunos cobertores con el significado de 'colcha' (Perdiguero, 2012b:385), y otras veces este término se equipara con el de 'manta frazada': 
Una manta frazada o cobertor nuevo (Villalpando, ZA-1689)

Sin embargo, en lo que respecta a la zona de Campos, manta, colcha o cobertores coincidían en un mismo inventario, por lo que se trataría de un tipo de ropa de cama diferente. Además de para la cama, también se utilizaba para cubrir los animales de tiro y así encontramos:

Un cobertor de bueyes (Villalpando, ZA-1644)

En algunas ocasiones, cobertor se encuentra inventariado entre aperos y objetos de usos doméstico, lejos de las cortinas, las sábanas, las colchas o los jergones. En estudios dialectales actuales localizamos esta voz como 'especie de manta muy delgada, de cuadros negros y verdes (tipo Astudillo) que se coloca sobre la trébede para tumbarse encima y a veces en las camas' y también 'cortina para las ventanas, muchas veces hecha de trozos de tejidos sobrantes y usada también como manta' (Gordaliza, 1988: 69).

Pero estos no serían los significados exclusivos para esta voz, en ocasiones figura inventariada entre gorgueras, sayuelos, jubones o cuerpos que nos hace sospechar que podemos estar ante una prenda de vestir. Con esta acepción se documenta también en la Ribera del Órbigo (León) y algunos autores la definen como una especie de capa o manto, que todavía hoy se reconoce en la zona de Babia como mantillín (Egido, 2010: 105):

Una gorguera guarnezida de oro / otra gorguera de lienzo / un cobertor colorado bueno / un sayuelo de paño pardo (Frechilla, PA-1631) Otro centillo con piedras de boema / un couertor listado / un calçón y mangas de riço / un calçón y ropilla de raso biejo (Paredes de Nava, PA-1680)

Un par de cuerpos nuevos [...] / un jubon de estameña [...] / un covertor colorado (Medina de Rioseco, VA-1643)

Cabe señalar que, en el ejemplo de Frechilla, se documenta otro cobertor que forma parte del ajuar de la cama entre lençuelos, mantas y cabezales.

Otra de las acepciones con las que encontramos este término en el corpus terracampino es el de 'cubierta de libro':

Un libro vita Christi en real y medio / Otro de oraciones y exercicios con cobertor en negro en dos reales (Frechilla, PA-1613)

Le Men la localiza en la zona del leonés y señala que 'si bien hoy en día la gente joven usa la palabra manta, antes se decía cobertor en muchas zonas rurales. Suelen ser mantas de lana. Este arcaísmo se documenta también en Asturias' (Le Men, 2004, s. v. cobertor).

\section{SOBRECAMA}

Sust. f. 'colcha' (DLE). Autoridades define este término como 'la cubierta, que se pone sobre las sábanas, y cobertores, para abrigo, y decencia de la cama' (NTLLE, s. v. sobrecama, Autoridades, 1739). Es una palabra compuesta de sobre, del lat. SŬPER ( $D E C H$, s. v. sobre) y de cama del hispanolatino cama, de origen incierto, quizá prerromano ( $D E C H$, s. v. cama).

Dos sábanas, dos almoadas y dos sobrecamas açules de estameña, la vna nueba y la otra vsada (Valderas, LE-1647)

Un cobertor de Palençia y una sobre cama de estameña usada (Valderas, LE-1682)

Una sobrecama buena blanca y negra (Frechilla, PA-1639)

Una sobrecama açul, dos almoadas y unas cercaduras con çinco piernas (Frechilla, PA-1640) 
Dos sobrecamas (Frechilla, PA-1642)

Una sobrecama de paño de la que se fabrica en esta villa, teñida de azul (Frechilla, PA-1671)

Una cama de blanqueta colorada con dos mantas y una sobrecama colorada (Villalpando, ZA-

1601)

Una sobrecama colorada en dos ducados (Villalpando, ZA-1613)

Una sobrecama y dos mantas (Villalpando, ZA-1614)

Una sobrecama de blanqueta azul con fluecos pajiços y amarillos (Villalpando, ZA-1632)

Las primeras documentaciones de esta palabra que proponen el $C D H$ y el CORDE son de finales del siglo XV, aunque el uso mayoritario se da en el siglo XVII. La constancia de esta voz en textos americanos data del siglo XVI y parece que con un éxito mayor que en los textos peninsulares.

La distribución diatópica de este término en el siglo XVII presenta un ámbito geográfico peninsular amplio. Cabe señalar que su presencia en los textos americanos es ligeramente mayor y nos encontramos ocurrencias en Bolibia, Chile, Colombia, México o Perú.

El corpus terracampino presenta una amplia nómina de casos y contrasta con los ejemplos encontrados en el resto de los documentos por el tipo de telas con el que se confeccionaba. Así en los ejemplos del CorLexIn nos encontramos sobrecamas elaboradas con cotonía labrada, gante, chamelote, tafetán o damasco entre otras telas de cierta calidad, además de llevar adornos como randas, galones o bordados. En Tierra de Campos las sobrecamas son de estameña, blanqueta o paño y sin referencia a ningún tipo de adorno o labor. Seguro que colcha y sobrecama cumplían la misma función de cubrir la cama, sin embargo, en algo se debían de diferenciar, ya que en algunos inventarios los dos términos aparecen juntos.

\section{SOBRELECHO}

No aparece registrado en el DLE con la acepción que presentan los ejemplos recogidos en el corpus estudiado. El término se registra desde Autoridades pero con el significado técnico de 'la superficie inferior de la piedra, que descansa sobre el lecho de la que está debaxo', nada que ver con el encontrado en los inventarios terracampinos (NTLLE, s. v. sobrelecho, Autoridades, 1739). Es una palabra compuesta de sobre, del lat. SŬPER (DECH, s. v. sobre) y de lecho del del lat. LĚCTUs 'cama' (DECH, s. v. lecho).

Un sobrelecho con unos castillos colorados blancos y azules (Fechilla PA-1612)

Un sobrelecho de colores apreciado en catorce reales (Frechilla, PA-1613)

Un sobrelecho demediado con unas pájaras tejidas en ocho reales (Frechilla, PA-1613)

Un sobrelecho negro con listas blancas (Frechilla, PA-1615)

Un sobrelecho (Frechilla, PA-1637)

Se trata de un término con pocos testimonios en la documentación histórica -25 concordancias en el $C D H$ y 19 en el CORDE-, sin embargo, se recoge desde época muy temprana. Las primeras documentaciones datan de la primera mitad del siglo XIII:

Tod aquel que aotro sobrelecho testiguare, siel mantenedor dixiere que lo conpro enla feria, de otor fasta IX dias; passados los IX dias, firmelo segund fuero es dela feria, et sea creydo (Fuero de Zorina de los Canes, 1218-1250)

[...] cubriólo con la manta e con el sobrelecho (Los Milagros de Nuestra Señora de Gonzalo de Berceo, 1246-1252) 
Este término entra pronto en recesión, hasta tal punto que no hay casos de esta voz en ninguno de los textos del siglo XVII que conforman tanto el CDH como el CORDE. Y este hecho se ve reflejado en los inventarios de bienes que configuran el CorLexIn, donde no hay ocurrencias de este vocablo, lo más cercano que encontramos es el sintagma "lecho de cama" que no parece referenciar el mismo objeto:

Vn lecho de cama de cordeles, encordelada, en diez reales (Tamajón, Gu-1643)

El corpus de la Tierra de Campos ofrece una serie de ejemplos de esta voz localizados todos ellos en Frechilla, núcleo textil por excelencia en esa época. Cabe señalar que todas las ocurrencias se fechan en la primera mitad del siglo (1612-1637), hecho que indicaría que estamos ante un término que ya no se usa. En cuanto al significado, parece que no es sinónimo de sobrecama, ya que en alguno de los ejemplos aparece inventariado junto a esta voz, en asientos distanciados entre sí, pero los dos entre ropa de cama. La única diferencia es el precio. Puede que se identifique más con cobertor, ya que en uno de los documentos encontramos una enumeración que equipara los dos términos:

Un cobertor amarillo y blanco con un castillo en el medio biejo apreçiado en quatro reales Otro sobrelecho de tres piernas de costal negro y blanco apreçiado en ocho reales Otro sobrelecho de dos piernas nuevo fraylego apreçiado en ocho reales (Frechilla, PA-1614)

\section{COLCHA}

Sust. f. 'Cobertura de cama que sirve de adorno y abrigo' (DLE). En Nebrija encontramos 'colcha de cama' y Covarrubias lo define como 'cobertura de cama labrada, y pespuntada con embutidos de algodon, que hazen diuersos laços, las comunes son de lienço, otras de olanda fina, y otras de seda' (NTLLE, s. v. colcha, Nebrija, 1495; Covarrubias, 1611). Término procedente del francés antiguo colche 'yacija, lecho', derivado de colchier 'acostar', lat. COLLOCARE (DECH, s. v. colcha).

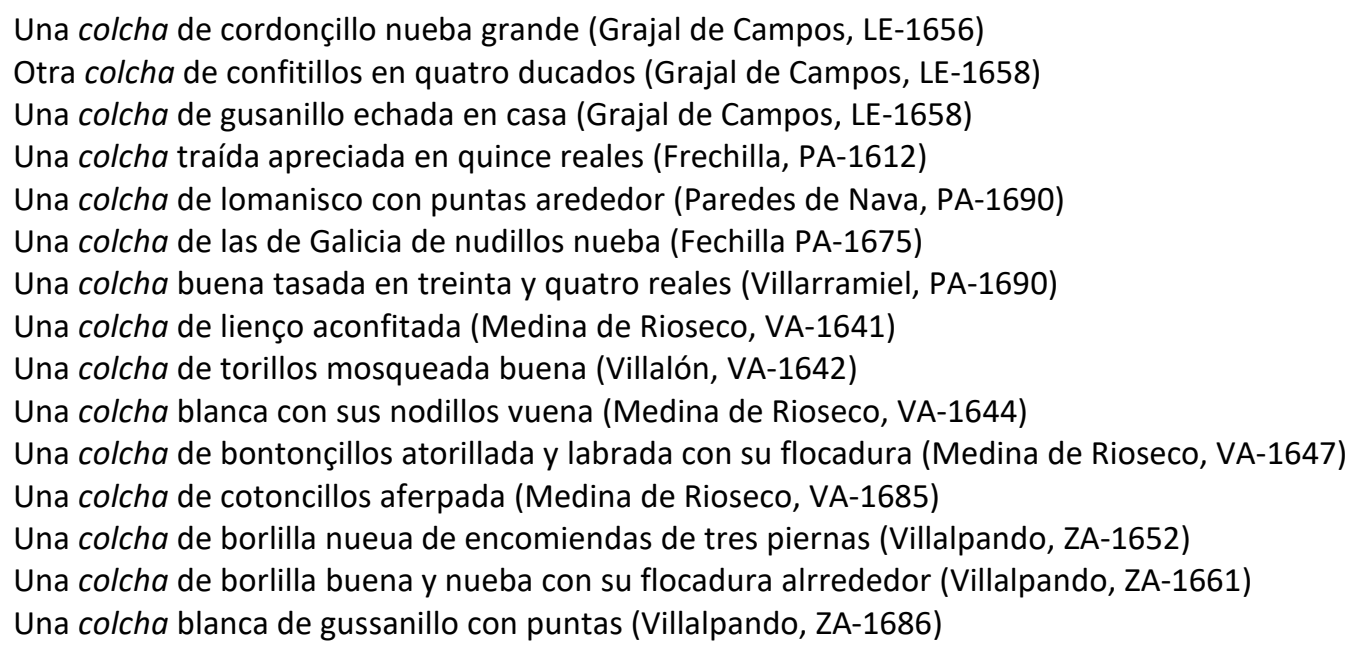

Es una palabra de uso general que forma parte de la ropa de cama. Documentada desde el siglo XIII en el $C D H$ y el CORDE, en el siglo XVII presenta una distribución general en la Península, Canarias y América (CorLexIn). Esta frecuencia en los textos también aparece en la zona terracampina. Estaba confeccionada con diferentes tejidos y se caracterizaban por distintas labores que utilizaban para su decoración -cordoncillos, confitillos, gusanillo torillos... - (Ágreda, 2017: 33). 


\section{COLCHÓN}

Sust. m. 'Pieza rectangular de un material blando o elástico que se coloca sobre la armazón de la cama o sobre otro soporte para tumbarse en ella' (DLE). Aparece en Nebrija junto al término almadraque. Covarrubias afirma que en un primer monteto las camas eran de 'yerbas quebrantadas y torcidas' y que poco a poco fue evolucionando hasta armarse en la cama y rellenarse de pluma o plumón. Autoridades lo define como 'invencion que para la comodidad, mayór reposo y regalo, hallaron los hombres, para usar de ella en las camas, y acostarse blandamente: la qual se compone de dos lienzos, terlices, ù otra tela iguales, proporcionados al tamaño de la cama, entre los quales se mete porcion de lana, pluma ù otra materia: y extendida igualmente y cofinadas después las dos telas, se bastean, y queda el colchón formado' (NTLLE, s. v. colchón, Nebrija, 1495; Covarrubias, 1611; Autoridades, 1729). Término derivado de colcha (DECH, s. v. colcha).

Un colchón lleno viexo (Sahagún, LE-1600)

Vn colchón bueno, con su lana, en tres ducados (Sahagún, LE-1601)

Dos colchones con su lana (Cea, LE-1621)

Vn colchón y vn xergón, dos sábanas, dos almoadas y dos sobrecamas (Valderas, LE-1647)

Quatro colchones de lienço buenos con su lana (Castromocho, PA-1611)

Un colchón de lienzo bueno (Autillo de Campos, PA-1647)

Un colchón vueno con su lana (Boadilla de Rioseco, PA-1692)

Un colchón mediado (Villarramiel, PA-1694)

Un colchón de lienzo traydo (Villalón, PA-1637)

Un colchón viexo (Villalón, VA-1642)

Un colchón con su lana tasado en quatro ducados (Medina de Rioseco, VA-1642)

Un colchón con su lana usado (Tamariz de Campos, VA-1652)

Un colchón de lienzo y lana (Cuenca de Campos, VA-1660)

Un colchón nuevo tasado en cinco ducados (Villalpando, ZA-1613)

Un colchón nuevo (Villalpando, ZA-1631)

Un colchón nuevo de lienzo casero con su lana nuevo (Villalpando, ZA-1654)

Un colchón de lienzo con su lana usado (Villalpando, ZA-1661)

Un colchón de terliz biejo (Villalpando, ZA-1688)

Es una palabra de uso general en la documentación con la forma y acepción académicas. Se documenta en los corpus del castellano en la segunda mitad del siglo XIV, en el Fuero viejo de Castilla fechado en 1356 (CDH y CORDE), adelantando la fecha de primera documentación unos años respecto a la dada por el $D E C H$-Universal vocabulario en latín y en romance de Alfonso de Palencia (1423-1492)-. Los datos que nos ofrece el CorLexIn nos confirman que es una palabra cuyo uso es generalizado en los documentos peninsulares, canarios y americanos. En Tierra de Campos estos colchones se rellenan de lana fundamentalmente.

En los inventarios de bienes terracampinos se localizan sábanas de colchón, haciendo referencia a un tipo de textil que cubría el colchón "para evitar el contacto de la piel con los tejidos de los colchones" (Ágreda, 2017: 30):

Vna sábana del colchón biexa y rota (Valderas, LE-1647)

Dos sauanas viejas de un colchón desvaratado (Grajal de Campos, LE-1658)

Una sabana muy bieja de colchón (Valderas, LE-1682)

Seis sabanas de colchones nuebas de estopa (Medina de Rioseco, VA-1640)

Una sauana de colchón (Medina de Rioseco, VA-1671) 


\section{JERGóN [xergón, gergón, jergona]}

Sust. m. 'Colchón de paja, esparto o hierba y sin bastas' (DLE). Recogido en Autoridades como 'funda gruessa en forma de colchón, que se llena de paja, atocha, ò cortaduras de papél' (NTLLE, s. v. xergón, Autoridades, 1739). Derivado de jerga, de origen incierto (DECH, s. v. jerga).

Un xergón en quatro reales (Sahagún, LE-1600)

Dos gergones buenos en dos ducados anbos (Sahagún, LE-1602)

Un jergón de cama y tres caueçales de terliçes (Grajal de Campos, LE-1658)

Un xergón de çerro nuevo (Grajal de Campos, LE-1655)

Un gergón de estopa (Frechilla, PA-1642)

Un jergón con su paxas (Villada, PA-1665)

Un jergón de estopa (Paredes de Nava, PA-1690)

Un gergón de estopa nuevo (Boadilla de Rioseco, PA-1687)

Una cama de cordeles con su xergón (Medina de Rioseco, VA-1640)

Un jergón biexo de arpilleras (Villlalón, VA-1642)

Un jergón tasado en dos reales (Tamariz de Campos, VA-1651)

Un jergón de estopa nueba (Villalpando, ZA-1620)

Un xergón nuevo de estopa para la cama (Villalpando, ZA-1654)

Tres jergones de estopa, dos buenos y uno uiejo (Villalobos, ZA-1654)

Una cama de madera con xergón, colchon, dos mantas, cobertor de estameña azul (Villalpando, ZA-1698)

Es un término de uso general en la época de estudio. Desde un punto de vista diacrónico, esta voz se recoge por primera vez en el $C D H$ en la Cuentas de Gonzalo de Baeza, tesorero de Isabel la Católica en 1477, finales del siglo Xv:

Vn cama de madera, encaxada, para el prinçipe, e vnas puertas para su aposentamiento e vn aparador, todo de madera, 981 mrs., e vn xergon de lienço pra la dicha cama, 378 mrs., que son todos $1.259 \mathrm{mrs}$.

Desde el punto de vista de la distribución diatópica en el siglo XVII, el CorLexIn ofrece un gran abanico de ocurrencias en los documentos peninsulares, frente a la ausencia en textos canarios y americanos. Muchas veces aparece inventariado con cama de cordeles y pueden estar confeccionados con estopa, arpillera, esparto, de marga, anjeo o cáñamo.

En el corpus terracampino aparece este término en femenino entre costales y zernederas:

Dos jergonas, una grande y otra pequeña (Sahagún, LE-1603)

No hay entradas de esta voz en ningún diccionario académico. Tampoco en bases de datos como el $C D H$ y el CORDE, ni en el CorLexín. Morala y Perdiguero atestiguan en la localidad cacereña de Brozas las siguientes variables cercanas a la encontrada en Tierra de Campos (Morala-Perdiguero, 2019: 184):

Una jergonera [...] otra hergonera vsada (Brozas, Cc-1684)

En los ejemplos de este mismo inventario aparecen almohada y almoxadas, aunque no podemos garantizar que aparezcan en el contexto de ropa de la cama.

En el caso encontrado en Tierra de Campos, el contexto en el que aparece dicha voz no es el de ropa de cama, se inventaría entre costales y zernederas, por lo que podría estar haciendo referencia a un tipo de saco, en vez de a un colchón. 


\section{COLGADURA}

Sust. f. 'Cortinas, cenefas y cielo de la cama que sirven de abrigo y adorno de ella' (DLE, s. v. colgadura de cama). Término recogido por Nebrija y Autoridades, aunque no es hasta la edición del DRAE de 1780 en el que se recoge la locución colgadura de cama (NTLLE, s. v. colgadura, Nebrija, 1495; Autoridades, 1729; DRAE, 1780). Se trata de una palabra derivada de colgar, del lat. CŎLLǑCARE (DECH, s. v. colgar).

Una colgadura de media cama de damasco açul con su cielo y cenefas todo en un pedazo con colgadura de lo mismo más que demediada (Grajal de Campos, LE-1658)

Una colgadura de cordellate haçul de cama con sus flecos de lana amarillos y colorados (Paredes de Nava, PA-1689)

Una colgadura de cama de cordellate verde que se compone de cielo y cinco cortinas y pasamanos de Santa Yssavel (Paredes de Nava, PA-1690)

Una colgadura de cama vlanca con su delantera en quatro pieças (Boadilla de Rioseco, PA-1692)

Colgaduras de jerguilla açul y vlanco y pajiças con cinco piezas y rodapié. (Villalón, VA-1637)

Una cama de nogal con sus balaustres y colgadura de paño colorado con zenefas de seda (Medina de Rioseco, VA-1661)

Una colgadura para la misma cama de jerguilla, çielo, cortinas y couertor y delantera, de color encarnada, con un galonçillo de plata falssa (Medina de Rioseco, VA-1685)

Una colgadura de cama de estameña azul aprensada (Cotanes del Monte, ZA-1687)

Una colgadura de cama de paño verde con fluecos de seda (Villalpando, ZA-1688)

Una colgadura de estameña prensada que son seis cortinas y su zielo con dos zenefas todo ello bordado de zintilla de plata (Villalpando, ZA-1696)

Una colgadura de estameña azul con fluecos (Villalpando, ZA-1697)

En los textos analizados de Tierra de Campos siempre aparece como un complemento o complementos asociados a la cama, tanto si aparece en plural como en singular. Aunque el CDH presenta como primera documentación la obra lexicográfica de Nebrija fechada en 1495, su uso regularizado no se manifiesta hasta casi un siglo más tarde:

$Y$ todas las calles y partes por donde su magestad passó y todo Çocadover estavan entapiçadas y colgadas de muy ricos tapices y colgaduras (Relación y memoria de la entrada en Toledo del rey y la reina de Sebastián de Horozco, 1579).

La presencia mayoritaria de esta voz se da en el siglo XVII, donde se registran las primeras documentaciones en América, aumentado su presencia a finales de este siglo. Los datos que ofrece el CorLexIn corroboran la presencia de colgadura en América y también en Canarias. En la Península parece que hay una preferencia de esta voz zona meridional, aunque esto puede ser mera coincidencia. La colgadura hacía referencia a "las telas que cubren y adornan la cama" (Perdiguero, 2014: 150).

Desde el punto de vista semántico, da la impresión de que estamos ante un nombre colectivo, en ciertos contextos colgadura actúa como tal, ya que esta palabra referencia una serie de telas que adornan y complementan la cama, esto se puede ver en ejemplos como el de Paredes de Nava donde se inventaría una colgadura que se compone de "cielo y cinco cortinas" o el de Boadilla de Rioseco o Villalón donde esta se compone de cuatro y cinco piezas respectivamente. Y lo mismo ocurre con algunos de los ejemplos que muestra el CorLexIn. 


\section{CORTINA}

Sust.f. 'Tela que por lo común cuelga de puertas y ventanas como adorno o para aislar de la luz y de miradas ajenas' (DLE). Voz recogida por Nebrija y Covarrubias. En Autoridades aparece como 'paño grande hecho de texidos de seda, lana, lino ù otro género, con que se cubren y adornan las puertas, ventanas, camas y otras cosas' (NTLLE, s. v. cortina, Nebrija, 1495; Covarrubias, 1611; Autoridades, 1729). Término procedente del lat. tardío CORTīNA ya con el significado de 'tela' y este a su vez derivado del lat. COHORS, -TIS 'recinto' (DECH, s. v. cortina).

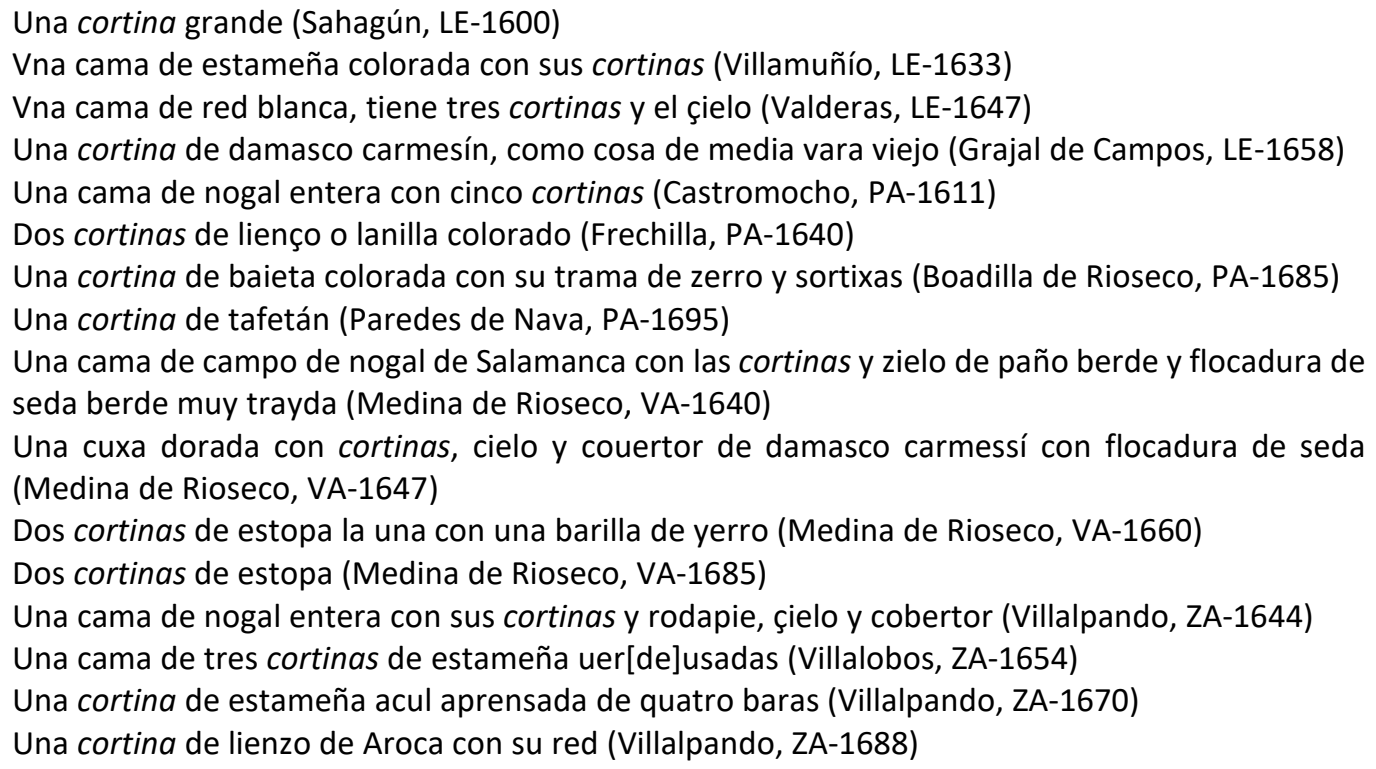

De nuevo estamos ante un término de uso general tanto desde el punto de vista diacrónico, como diatópico. Se documenta en obras literarias del siglo XIII como las compuestas por Berceo o en El libro de Alexandre (CDH). El CorLexIn aporta más de un centenar de items repartidos entre la Península, Canarias y América. Ese uso extenso se ve también en el corpus terracampino, siempre con la acepción textil.

\section{DELANTERA}

Sust. f. 'una prenda de vestir, pieza que forma la parte anterior' o 'parte anterior de algo' (DLE, 4. a y 6. ac.). Covarrubias recoge esta léxía como 'la haz de vna cosa, como delantera de casa, delantera de saya. Delantero y delantera, la cosa que va delante de otra [...]' (NTLLE, s. v. delantera, Covarrubias, 1611). Procedente del adverbio delante del lat. tardío ǏNANTE 'delante, enfrente' (DECH, s. v. delante).

Una delantera de cama en diez reales (Sahagún, LE-1600)

Una cama de paramentos de lienzo con su cielo y quatro paramentos y dos delanteras (Sahagún, LE-1602)

Vna delantera de cama de red biexa (Valderas, LE-1647)

La cama en que murio que es de madera de nogal con sus cordeles, una delantera, un jergón destopa, dos colchones, dos sauanas, una de estopa, y otra destopilla (Valderas, LE-1682)

Una delantera de cama de red (Frechilla, PA-1612)

Dos almoadas y una delantera de cama (Castromocho, PA-1614)

Vna delantera de cama de red, buena (Autillo de Campos, PA-1654)

Una delantera de cama (Villarramiel, PA-1694)

Una delantera de cama de red y lienco vieja (Villalón, VA-1642) 
Una delantera de cama viexa su festón açul (Tamariz de Campos, VA-1652)

Una delantera de cama, de red, en nuebe reales (Becilla de Valderaduey, VA-1654)

Una delantera de lana vieja (Cuenca de Campos, VA-1666)

Vna delantera de red con su lienço tassadaen dos ducados (Villalpando, ZA-1652)

Una delantera de cama biexa (Villalobos, ZA-1654)

Dos colchones y un gergón y una delantera de cama (Villalpando, ZA-1660)

Una almoada con su delantera de red (Tapioles, ZA-1686)

Posiblemente era una pieza de la cama que servía para salvaguardar y decorar la cubierta de la cama y, aunque en menor medida, las almohadas (Ágreda, 2017:34). Este es el significado mayoritario con el que aparece en el corpus terracampino, pero no es el único, también nos encontramos con el de 'prenda de vestir':

Una saya de estameña vuriel nueba con ribete de terciopelo forrada la delantera en olanda azul (Autillo de Campos, PA-1648)

Otra saya de raja açul con delantera (Autillo de Campos, PA-1649)

Una delantera de estameña buriel buena (Villarramiel, PA-1694) entre cuerpos y basquiña

Una ropa de vayeta de Sevilla aforrada en tafetan negro las delanteras (Medina de Rioseco, VA1640)

Una basquiña de paño almendrucado aforrada la delantera en boatí azul y con zinco pasamanos de seda negra (Villalpando, ZA-1620)

Una vasquiña de estameña con su ribete de paño negro y aforrada, la delantera en olandilla negra (Villalobos, ZA-1654)

EI CORDE localiza esta acepción en un inventario de bienes de los moriscos, fechado en 1549; y el CDH unos años más tarde, en Relaciones de 1623 de Andrés Almansa y Mendoza -[...] cortinaje de dos lados y delantera de raso de oro, carmesí de Milán-.

Los datos que nos proporciona el CorLexIn nos muestran un extensa nómina de casos repartidos entre la documentación peninsular, canaria y americana con el significado mayoritario de 'delantera de cama', aunque también presenta significados como el relacionado con la vestimenta -"una ropa, labrada de tafetán [...] y una delantera de lo mismo" (Cañedo, Cantabria-1608)-.

\section{DOSEL}

Sust. m. 'Antepuerta o tapiz' (DLE, 2.a ac.). En Covarrubias aparece como 'la cortina con su cielo, que ponen a los Reyes, y después a los Titulados, y lo mesmo es en el estado Ecclesiastico, entre los Prelados [...]' y en Autoridades hace referencia al 'adorno honorífico y magestuoso, que se compone de uno como cielo de cama puesto en bastidor, con cenefas a la parte de adelante y a los dos lados, y una cortína pendiente en la de atrás que cubre la pared o parage donde se coloca. Hácese de terciopelo, damasco, o otra tela, guarnecido de galones o fluecos, y a veces bordado de oro o sedas. Sirve para poner las Imágenes en los altares, y tambien le usan los Reyes y los Prelados Eclesiásticos en sus sitiales, y los Presidentes de los Consejos, Señores y Titulos le tienen en sus antecámaras' (NTLLE, s. v. dosel, Covarrubias, 1611; Autoridades, 1732). Término procedente del lat. DǒRsum 'espalda' ( $D E C H$, s. v. dosel).

Una echura de un cruçifixo en un dosel de cañamazo vordado de seda y con puntas de plata tasado en çien reales (Medina de Rioseco, VA-1644)

Un dosel pequeño labrado de sedas açules y otros colores (Medina de Rioseco, VA-1645)

Un dosel de vordadillo encarnado (Medina de Rioseco, VA-1660) junto a cortina y cama 
Una cruz con un Santo Xpto pintado y un dosel de damasco (Medina de Rioseco, VA-1671)

Un dosel de rasso de primauera con su reuetillo de oro (Medina de Rioseco, VA-1685)

Un frontal, un dosel y un respaldo que juega con el dosel todo de pintura sobre anxeo y en sus bastidores (Villalpando, ZA-1696)

Desde un punto de vista diacrónico, esta voz se documenta en el CDH y en CORDE desde El Seguro de Tordesillas, fechado en 1439 -"Y el Rey se retrayó a su dossel y se assentó es su silla"con una presencia importante en los textos de las bases académicas del castellano. Sin embargo, el número de casos es significativamente menor en el CorLexIn, donde presenta una distribución geográfica bastante amplia, una veintena de ocurrencias repartidas de norte a sur de la Península y en América, donde el significado más utilizado es el dado por Autoridades y con gran carga religiosa. En Tierra de Campos aparece la voz dosel en inventarios de Medina de Rioseco y Villalpando, y en la mayoría de los ejemplos está en lugares de oración, referenciada junto a crucifijos, frontales y mesa de altar. En esta época parece que era más común utilizar el término paramento o pabellón para referenciar la estructura y adorno que cubre la cama (Ágreda, 2017:21).

\section{FRONTAL}

Sust. m. 'Paramento de sedas, metal u otra materia con que se adorna la parte delantera de la mesa de altar' (DLE, 4. a ac.). Covarrubias recoge este término con un significado igual al que se registra hoy día en el diccionario académico: 'el adorno que se pone en el altar en la frontera que mira hazia el pueblo. Frontaleras las baxas, y adorno a modo de goteras, qeu por lo alto y por los lados guanece el frontal' (NTLLE, s. v. frontal, Covarrubias, 1611). Palabra derivada de frente, del lat. FRŎNS, -TIS (DECH, s. v. frente).

Un frontal y un çielo de ángeles pintado (Medina de Rioseco, VA-1644)

Un frontal de Rasso blanco biejo con sus frontaleras de damasco carmesí y cenefa paxiça (Medina de Rioseco, VA-1651)

Un frontal de brocalete amarillo morado y blanco con sus frontaleras de lo mesmo (Villalpando, ZA-1633)

Un frontal biexo (Villalpando, ZA-1660)

Los primeros testimonios que nos presenta el CORDE datan de finales del siglo XIII, las concordancias se remontan a la relación de bienes que lleva por título Inventario de bienes de la catedral y que pertenece a la documentación de los archivos catedralicios y diocesanos de Salamanca fechados en 1275: "Un frontal de púrpura forrado con dos façaleyas". Por su parte, el $\mathrm{CDH}$ presenta las primeras ocurrencias en documentos fechados en el siglo xiv, aunque no es hasta un siglo más tarde donde se referencia claramente un frontal textil en las Cuentas de Gonzalo de Baeza, tesorero de Isabel la Católica y fechado entre 1477 y 1491: "[...] obligado de mantener la dicha cappiella de vestimentas e de cáliz e de frontales para el altar e de los otros ornamentos".

Si restringimos la búsqueda a las relaciones de bienes de la documentación del siglo xvii, aparecen una treintena de casos repartidos entre la Península, Canarias y América con este significado. Es una palabra de uso general en el ámbito de ajuar litúrgico, ya que todos los ejemplos pertenecen a inventarios de iglesias, oratorios o catedrales. En el corpus terracampino 
existe un uso exiguo de esta voz, no tanto por la falta de testimonios en este momento, sino más bien por tratarse de un textil de un ámbito muy específico, en este caso, el litúrgico.

\section{GOTERA}

Sust. f. 'Cenefa o caída de la tela que cuelga alrededor del dosel, o del cielo de una cama, sirviendo de adorno' (DLE, 7. a ac.). Con este significado lo registra Autoridades que es el que se mantiene en las ediciones más actuales (NTLLE, s. v. gotera, Autoridades, 1734). Término derivado de gota, del lat. GŬTTA (DECH, s. v. gota).

Una cuja de cama de nogal dorada con cortinas, couertor y cielo de damasco carmesí y goteras de terciopelo y flocadura y alamares de oro (Medina de Rioseco, VA-1647)

Las goteras pendían del cielo de la cama u decoraban la unión entre el paramento y las cortinas de la cama (Ágreda, 2017: 24). Estos adornos se inventarían a partir de las Cuentas de Gonzalo de Baeza, tesorero de Isabel la Católica fechadas entre 1477 y 1491; el resto de las concordancias que ofrece el $C D H$ certifican su uso regularizado en documentos de corte notarial mayoritariamente, desde finales del siglo XV hasta mediados del siglo XVII. A partir de esta fecha la presencia de gotera con este significado textil es más esporádica. Muchos de los inventarios en los que aparece este término pertenecen a reyes o infantes como Isabel la Católica, su hijo don Juan o su nieto Felipe II.

Respecto a la distribución diatópica en el siglo XVII que ofrece el CorLexIn, no presenta un patrón de reparto geográfico claro, figura en inventarios de Guipúcoa, Álava, Zaragoza, Guadalajara, Madrid y Toledo, así como en documentos americanos -México y Bolivia-. Esta falta de testimonios viene dada por el hecho de estar ante un elemento que subía el valor económico de la cama, elaborado con ricos materiales.

\section{LENZUELO [linçuelo, lançuelo]}

Sust. m. 'Pieza de lienzo fuerte, del tamaño de la sábana, con un cordón o trenza de pezuelo en cada extremo, que se emplea en las faenas de la trilla para llevar la paja y para otros usos' o 'pañuelo de bolsillo' (DLE). Autoridades recoge esta lexía como diminutivo de lienzo y lo define como 'el pañuelo pequeño, que sirve para limpiarse y otros usos' (NTLLE, s. v. lenzuelo, Autoridades, 1734). Derivado de lienzo, del lat. LǏnTĚUM 'tela de lino' 'lienzo' (DECH, s. v. lienzo).

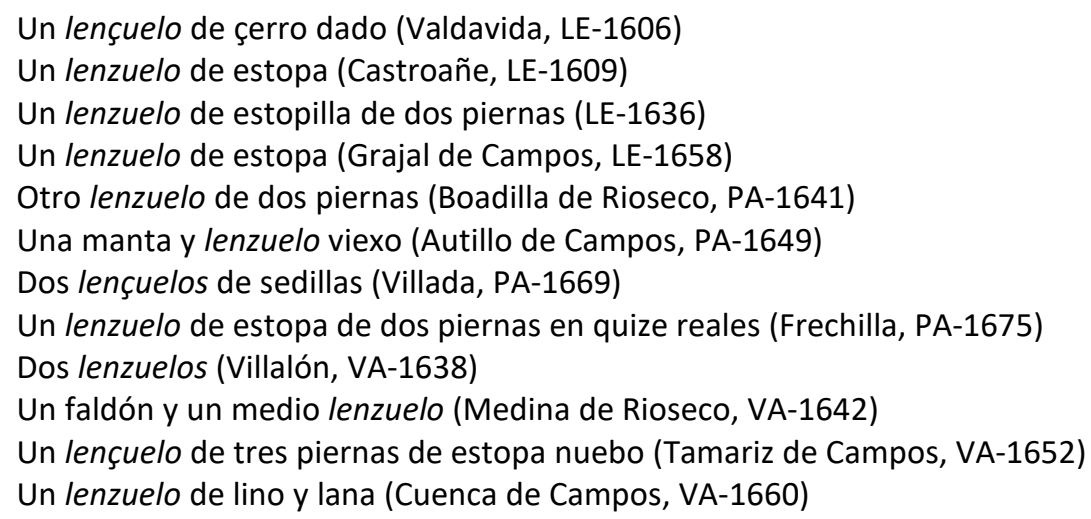


En contraste con otras voces de este campo semántico, lenzuelo no se halla documentado de forma extensa en los textos históricos. EI CORDE recoge este término en la obra medieval Vida de Santa María Egipciaca datada en 1215. A pesar de esta temprana documentación, el mayor número de casos se registran en el siglo XVII y a partir de la segunda mitad de este siglo, casi no hay testimonios de esta palabra en los textos. El CorLexIn presenta un poco más de una veintena de casos distribuidos por la Península, sin un patrón de distribución claro.

Desde un punto de vista formal, en algunas ocasiones presenta la inflexión de la vocal de la sílaba inicial, fenómeno estudiado anteriormente (Morala, 2010a: 440; Morala 2012a: 559; Morala 2016a: 378). En Tierra de Campos figuran las variantes con /i/ y con /a/:

Dos linçuelos biejos rotos trapeados (Frechilla, PA-1613)

Un linçuelo de estopa de tres piernas apreçiado en ocho reales (Frechilla, PA-1616)

Un lançuelo de estopa (Cea, LE-1638)

Un lanzuelo con tres piernas (Villarramiel, PA-1690)

Un lançuelo de tres piernas de cordeles (Villarramiel, PA-1696)

Un lanzuelo de estopa usado (Cuenca de Campos, VA-1660)

Un lançuelo de estopa nuevo en quarenta reales (Cuenca de Campos, VA-1666)

La forma linçuelo se documenta de forma temprana en una obra de corte legal titulada Vidal Mayor y fechada en 1250, pero la presencia en la documentación es escasa (CORDE). Esta variante no viene recogida por ningún diccionario académico, en la única obra lexicográfica en la que aparece es en el Diccionario Enciclopédico de Gaspar y Roig (suplemento 2) en el que presenta notación dialectal de Navarra y se le define como 'cobertor' (NTLLE s. v. linzuelo, Gaspar y Roig Suplemento 2,1855). Sin embargo, el CorLexIn muestra una ditribución de esta voz que ocupa el área oriental de Cantabria, Burgos, La Rioja (Morala 2016a: 378) y Palencia, pero ningún ejemplo en Navarra. Este hecho contrasta con los datos que recoge el Fichero General, que de nuevo muestra ejemplos de esta voz recogidos en el ALEANR, donde figura como 'sábana', 'sábana basta' o 'sábana hecha de lana y algodón usada en invierno' en Teruel, en la lám. 1663 bis, mapa 1411; y en Navarra y Huesca con el significado de 'manta para transportar trigo', en la lám. 97 bis, mapa 86 (Fichero General, cédula n.o 6 y 7).

Además de la variante con /i/, en Tierra de Campos figura lanzuelo en los inventarios palentinos y vallisoletanos, a los que habría que añadir un ejemplo más localizado por Morala en Cea, donde esta alternancia vocal suele producirse con cierta frecuencia en palabras que comienzan con /-an/ y /-en/ y que "parecen sufrir una indefinición en el timbre de la vocal incial" (Morala, 2012a: 559).

En cuanto al significado, la mayor parte de las ocasiones se inventaría entre el ajuar de la cama (sábanas, colchas, colchones, almohadas...). Sin embargo, otras veces aparece junto a los enseres de concina, con una función claramente diferente:

Un lençuelo para una artessa vueno (Riosequillo, LE-1610)

Un lenzuelo de pan vueno (Grajal de Campos, LE-1671)

Un medio lenzuelo (Boadilla de Rioseco, PA-1641)

Este último ejemplo se enumera entre "un candil, un assador, una sarten bieja, un cazico pequeño y un artesonzillo". 


\section{MANTA}

Sust. f. 'Pieza de lana, algodón u otro material, de forma rectangular, que sirve de abrigo en la cama', además aparece la locución 'manta de pared' que lo equipara con tapiz y lo marca como término en desuso (DLE). En Nebrija aparece registrado tanto 'manta de cama' y como 'manta de pared' (NTLLE, s. v. manta, Nebrija, 1495). Término derivado de manto, del lat. tardío MANTUM 'manto corto', que a su vez es de origen incierto; parece haberse extraído del lat. MANTELLUM, que quizá fuese voz antigua en latín (DECH, s. v. manto).

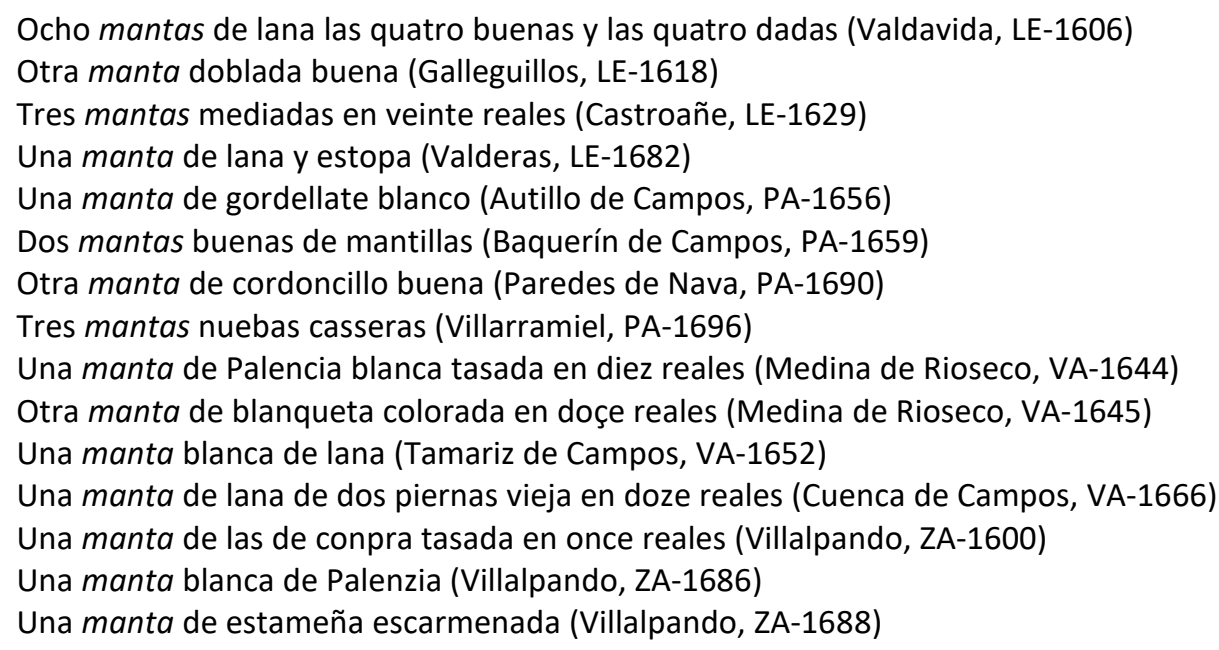

Hay pocas relaciones de bienes en las que no se inventaríe alguna manta, es un término de uso general en todos los textos del castellano. Manta se recoge en la documentación altomedieval, así el $D E C H$ da como primera documentación la segunda mitad del siglo x. Por otra parte, el CORDE recoge este término a partir del siglo XI (1050), en documentos notariales y en el Fuero de Avilés en 1155. El CDH lo registra de forma más tardía en una Carta inventario fechada entre 1218 y 1300 perteneciente a la Colección Diplomática del Monasterio de Carrizo.

Esta lexía presenta una distribución diatópica de carácter general en el CorLexIn. EI escribano detalla con minuciosidad las características de las mantas: el tejido con el que están elaboradas, el estado en el que se encuentra o la función que cumplen entre otras propiedades. Se documenta, por ejemplo, "manta frazada":

Otra manta frazada, casera, en quinze reales (Sahagún, LE-1601)

Vna manta frazada, demediada, tassada en veinte reales (Boadilla de Rioseco, PA-1650)

Una manta frazada de Palenzia buena (Autillo de Campos, PA-1654)

Se llamaba así a las mantas de pelo y en muchas ocasiones, el primer término se eliminaba y se inventaría únicamente como frazada por metonimia, mecanismo muy productivo para la extensión del léxico:

Una frazada blanca trayda en beynte reales (Medina de Rioseco, VA-1640)

Una fraçada blanca (Medina de Rioseco, VA-1641)

Seis fraçadas blancas, a nuebe reales (Medina de Rioseco, VA-1646)

Dos frazadas vuenas tasadas en dos ducados (Villalpando, ZA-1620)

El CorLexIn registra a lo largo de la Península las dos posibilidades, aunque el término frazada en solitario presenta una nómina de casos mayor, aún así, ambas llegan a compartir el 
mismo inventario. Sin embargo, en los casos localizados en la documentación americana -Bolivia, Guatemala, México y Perú-, siempre aparece como frazada. Desde una perspectiva diacrónica, frazada se recoge a partir de la segunda mitad del siglo XV, en el Arancel de precios y salarios de Cuenca, fechado en 1462 en el CDH y en el CORDE. A partir del siglo XVII el término comienza a extenderse con mayor vitalidad en los textos americanos y dejando poco a poco de utilizarse en la Península. En la actualidad, el término frazada sigue utilizándose de forma general en América.

Además de ropa de cama, las mantas cumplían otras funciones que se especificaban en las relaciones de bienes. Encontramos "mantas de pared", que cumplían con usos más decorativos, aunque estos tapices aislaban también del frío:

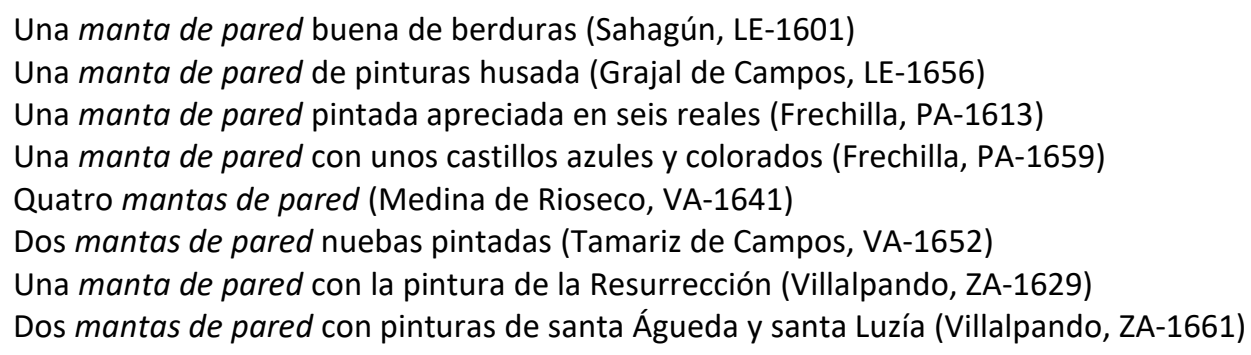

Es más común encontrar en los inventarios de bienes peninsulares paramentos, reposteros, tapices, pero sobre todo "paños", todos ellos "de pared". sin embargo, no se localizan "mantas de pared" en el CorLexIn. Desde un punto de vista diacrónico, tanto el CORDE como el CDH presentan una escasa nómina de ejemplos, casi todas ellas documentadas en el siglo XV. El CDH, por su parte, documenta este sintagma a partir de 1411 en un Testamento: "para ayuda a casamiento dos mantas de pared de la lauor de Valladolid", pero las concordancias no pasan de este siglo, incluyendo el Vocabulario de Nebrija. Tan solo se localiza un ejemplo en una obra de Juan de Pineda fechada en 1589 en ambas bases académicas, donde "manta de pared" se equipara a "paramento": "Ferénico.- Paréceme que os falta poco para hacer a Dios manta de pared o paramento, según le habéis depintado".

Otra acepción con la que figura en nuestro corpus es como accessorio de los animales de carga o tiro o de cabalgaduras:

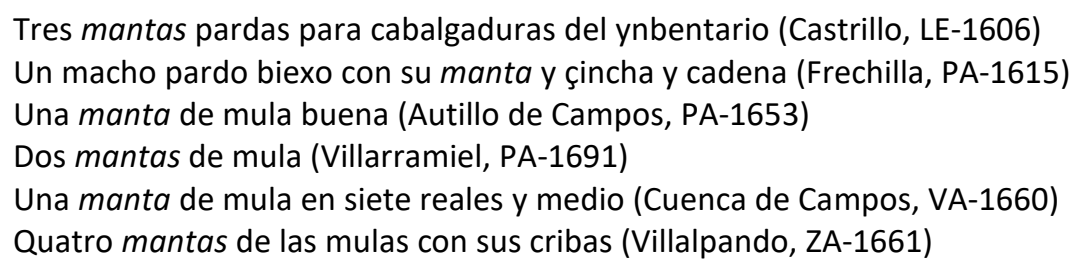

Aunque con menor presencia documental, en la Tierra de Campos leonesa también figuran "mantas de artesa" o relacionadas con la elaboración del pan:

Otra media manta de masar buena (Valdavida, LE-1606) Una manta de artesa y un lenzuelo (Riosequillo, LE-1609) Dos mantas vanas del pan y una mantilla de los mismo (Grajal de Campos, LE-1656) 
Además de diferentes usos, las mantas estaban hechas con distintas telas y tenían diferentes características, nos encontramos con mantas de lana, de lino, de saca, de marga, de sayal, dobladas, sencillas, banas, terciadas, torcidas...

\section{PABELLÓN [PAUELLÓN]}

Sust. m. 'Colgadura plegadiza que cobija y adorna una cama, un trono, un altar, etc.' (DLE, 2. a ac.). En Nebrija y Covarrubias aparece la acepción de 'pavellon de cama' (NTLLE, s. v. pavellón, Nebrija, 1495; Covarrubias, 1611). Término procedente del fr. ant. paveillon 'tienda de campaña' que vino del lat. PAPǏLǏo, -ŌNIS, 'mariposa' (DECH, s. v. pabellón).

Un pauellón de paño azul con sus fluecos de seda nuevo (Villalpando, ZA-1631)

Tan solo recogemos un ejemplo de esta voz en el corpus terracampino. Los datos que nos ofrece el CorLexin nos muestran un escaso número de ocurrencias en la Península repartidas de norte a sur. Sin embargo, en América la palabra goza de mayor vitalidad, con hasta medio centenar de items. Una de las razones por la que este término presenta una escasa nómina de casos en la Península y en el propio corpus terracampino, es la de compartir campo semántico con paramento, de hecho, en algunos documentos se equiparan ámbos términos: "[...] el paramento, o pabellón, de estameña berde [...]" (Zaragoza, 1603).

La primera concordancia que recoge el $C D H$ data de 1256, aunque el manuscrito que registra pertenece a una copia de finales del siglo XIII muy cercana a la original. En concreto, figura en la Primera Partida de Alfonso x, con el significado de 'tienda de campaña':

[...] assí cuemo los pannos bermeios, o el palafre blanco, o la tienda que trahe sobre ssí a que llaman pauellón.

Sin embargo, este significado se traslada a la ropa de cama tanto en la documención del CDH como la del CORDE (Pediguero, 2014a: 150).

La procedencia de esta voz se puede explicar a través de un procedimiento metafórico, ya que se establece una semejanza entre las telas de estas tiendas de campaña agitadas por el viento y las alas de las mariposas, apariencia que pudieron adquirir también los cielos de cama (Ágreda, 2017: 21, 22).

\section{PARAMENTO}

Sust. m. 'Adorno o atavío con que se cubre algo' (DLE). Nebrija ya registra 'paramentos de cama' y que mantiene, entre otras acepciones, Autoridades (NTLLE, s. v. paramento, Nebrija, 1495; Autoridades, 1737). Término derivado de parar, con el significado de 'adorno', tomado del lat. PARAMĔNTUM (DECH, s. v. parar).

Una cama de paramentos (Sahagún, LE-1600)

Quatro piezas de paramentos de cama biexos con bías amarillas (Sahagún, LE-1600)

Una cama de paramentos con çinco pieças (Cea, LE-1626)

Unos paramentos de pared viejos (Cea, LE-1670)

Unos paramentos de pared viejos (Grajal de Campos, LE-1671)

Un paramento de cama pintado (Castromocho, PA-1603)

Un paramento de terliz biejo (Frechilla, PA-1639)

Una cercadura de cama, tres paramentos y el çielo con sus fluecos (Guaza de Campos, PA-1640)

Un paramento grande biexo (Autillo de Campos, PA-1653) 
Un paramento de pared pintado biejo (Villalón, VA-1642)

Quatro paramentos de cama con sus listas coloradas (Medina de Rioseco, VA-1644)

Una cama de paramentos que son tres y el cielo de la cama con red (Cuenca de Campos, VA1660)

Una cama de paramentos [...] un çielo y un paramento de cama (Cuenca de Campos, VA-1666)

Una cama de paramentos de red con tiras de ruan (Villalpando, ZA-1637)

Una cama de paramentos de red de siete pieças y el cielo (Villalpando, ZA-1644)

Quatro paramentos grandes pintados con unos vraços y uno pequeño (Villalobos, ZA-1654)

Dos paramentos viejos (Quintanilla del Monte, ZA-1689)

El CDH documenta el término paramento como 'adorno o complemento que cubre algo' a partir de 1427. Consultado el CorLexIn, la distribución diatópica en el siglo XVII se limita a los documentos peninsulares, distribuidos por buena parte de la geografía española.

En el corpus estudiado, esta lexía hace referencia principalemente a la ropa de la cama. No obstante, nos encontramos con otros significados como el que se acercaría a 'tapiz', así, en los inventarios se contabilizan "paramentos de pinturas" o "paramentos de pared". Cuando estamos ante un paramento de cama suele presentar un sentido colectivo y hacer referencias a varias piezas bajo su propio nombre, como ocurría con colgadura. Lo comentado para los ejemplos peninsulares se hace extensible a la Tierra de Campos.

En los asientos de los inventarios terracampinos, aparece la variante paramentadura, siempre en relación directa con la cama.

Una paramentadura de cama blanca con randas y desylados buena en quatro pieças y el çielo (Grajal de Campos, LE-1656)

No es frecuente en el resto de la documentación, tan solo se documenta una ocurrencia en otra población leonesa con el mismo significado:

Vna paramentadura de cama de lienzo, buena, que son tres piezas y el cielo (Cifuentes de Rueda, León-1648)

Este término formado por derivación y con esa naturaleza colectiva no tuvo éxito y tan solo se conservan ejemplos muy esporádicos.

\section{FRUTERO}

Sust. $\mathrm{m}$. 'Lienzo labrado con que por higiene se cubre la fruta que se pone en la mesa.' ( $D L E$, 4. ac.). Autoridades lo recoge como 'tohalla labrada, con que se cubre la fruta que se pone en la mesa, para que esté limpia, y no se sienten las moscas sobre ella' (NTLLE, s. v. frutero, Autoridades, 1732). Término derivado de fruto, del lat. FRŪCTUS, -US (DECH, s. v. fruto).

Un frutero azul en seys reales (Sahagún, LE-1605)

$\mathrm{Vn}$ frutero de red con sus puntas pequeñas (Valderas, LE-1647)

Un frutero en ocho reales (Grajal de Campos, LE-1658)

Un frutero de red con sus puntas (Castromocho, PA-1611)

Un frutero de red de criba (Castromocho, PA-1611)

Un frutero de red bueno (Villalón, VA-1637)

Un frutero blanco con sus puntas (Medina de Rioseco, VA-1641)

Un frutero de seda con puntas blancas (Medina de Rioseco, VA-1643)

Ocho fruteros de países (Medina de Rioseco, VA-1671)

Un frutero ya usado (Villalpando, ZA-1614)

Un frutero de red de todas colores y plata con puntas de lo mesmo (Villalpando, ZA-1631) 
Un frutero de ylo de pita (Villalpando, ZA-1632)

Un frutero de red con puntas (Villalpando, ZA-1637)

Un frutero de olanda con desilados (Villalpando, ZA-1644)

El término frutero presenta una naturaleza polisémica y aparece con diferentes significados en los textos del castellano. Este término se documenta a partir del siglo XV con el sentido de paño $(C D H)$, aunque también se localizan otros significados como el de recipiente o bodegón (CORDE y $C D H$ ). Con estos significados se recoge en las concordancias que devuelve el CorLexIn, donde se certifica un reparto geográfico general.

En el corpus terracampino, aparece fundamentalmente como 'paño', tan solo hay un ejemplo que nos puede hacer sospechar que estamos ante otro tipo de objeto inventariado, pero el contexto no nos da suficientes pistas como para confirmarlo:

Un frutero pequeño (Frechilla, PA-1639)

En este caso, frutero se encuentra inventariado junto a tajadera, cocino y artesa por lo que podría hacer referencia al recipiente.

En cuanto a la morfología derivativa, aparece el diminutivo fruteruelo en documentos de la localidad palentina de Frechilla donde parece referenciar un tipo de recipiente:

Un fruteruelo pequeño (Frechilla, PA-1639)

Un fruteruelo y una artesa desondonada (Frechilla, PA-1639)

No encontramos referencias de esta voz en la documentación del español, tampoco en las obras lexicográficas académicas. Desde una perspectiva diatópica, además de estos casos terracampinos, localizamos "Dos fruteruelos de vidrio leonado, 20 maravedíes" en la Almoneda de los bienes de la Duquesa de Medinaceli, Doña Maria de Silva, fechada en Medinaceli en 1545 y en Valladolid tres años más tarde (Documentos de interés relacionados con la casa ducal de Medinaceli Tomo I, Tomados del libro Series de los más importantes documentos del Archivo y Biblioteca del Excmo. Sr. Duque de Medinaceli elegidos por su encargo y publicados a sus expensas por A. Paz y Mélia 1. a Serie Histórica. Años 800-1814 (Madrid, 1915). Recopilados y ordenados por Juan Luis Pérez Arribas.

\section{PEINADOR [PEYNADOR]}

Sust. $m$. 'Prenda o lienzo ajustada al cuello con que se protege el vestido de quien se peina o afeita' ( $D L E, 2$. a ac.). Este término lo recogen con esta misma acepción Covarrubias y Autoridades (NTLLE, s. v. peinador, Covarrubias, 1611; Autoridades, 1737). Vocablo derivado de peinar y este del lat. PECTiNaRe ( $D E C H$, s. v. peinar).

Dos peinadores (Paredes de Nava, PA-1695)

Un peynador de lienzo de Aroca con sus puntas (Paredes de Nava, PA-1689)

Un peinador de olanda con puntas (Medina de Rioseco, VA-1642)

Un peinador con randas y puntas, çintas y sobrepaño guarnecido de puntas (Medina de Rioseco, VA-1649)

Un peynador (Villalpando, ZA-1670)

Otro peinador con unas zenefas (Villalpando, ZA-1676)

Un peynador con puntas medianas (Villalpando, ZA-1686)

Un peynador (Villalpando, ZA-1670)

Un peinador de cocha con puntas (Villalpando, ZA-1688) 
El término peinador como 'lienzo o toalla' se halla documentado en los corpus académicos del castellano casi a mediados del siglo XV:

Un peinador de lienzo delgado (Inventario de los bienes de Diego López de Ayala, tercer señor de la Cebolla, 1441)

En la segunda mitad del siglo XVI figura en textos americanos y la mayoría de estas ocurrencias se encuentran en relaciones de bienes hasta el siglo XVII. A partir de aquí, su presencia se hace extensible y casi de forma exclusiva a las obras literarias (CDH y CORDE).

Es una palabra de uso general y que se llega a equiparar con 'paño o toalla' como sucede en uno de los ejemplos de Villalpando, donde el hecho de que se inventaría como "otro peinador", depués de toalla y antes de paño hace equiparar estos términos.

En los protocolos notariales del siglo XVII se localizan ejemplos de esta voz tanto en la Península como en Canarias y América, con la acepción de paños de valor guarnecidos, labrados con encajes, puntas, deshilados y elaborados con diferentes telas que se encuadran dentro de la ropa blanca y el aseo personal.

\section{POYAL [poial, poyalejo]}

Sust. m. 'Paño listado con que se cubren los poyos en algunos lugares' (DLE). Lo recoge Nebrija en su Vocabulario. Covarrubias lo define dentro del lema poyo como paño que 'en las aldeas el recel listado, que se pone sobre el poyo' y que mantiene Autoridades (NTLLE, s. v. poyal, Nebrija, 1495; Covarrubias, 1611; Autoridades, 1737). Término derivado de poyo del lat. PŎDǏM (DECH, s. v. poyo).

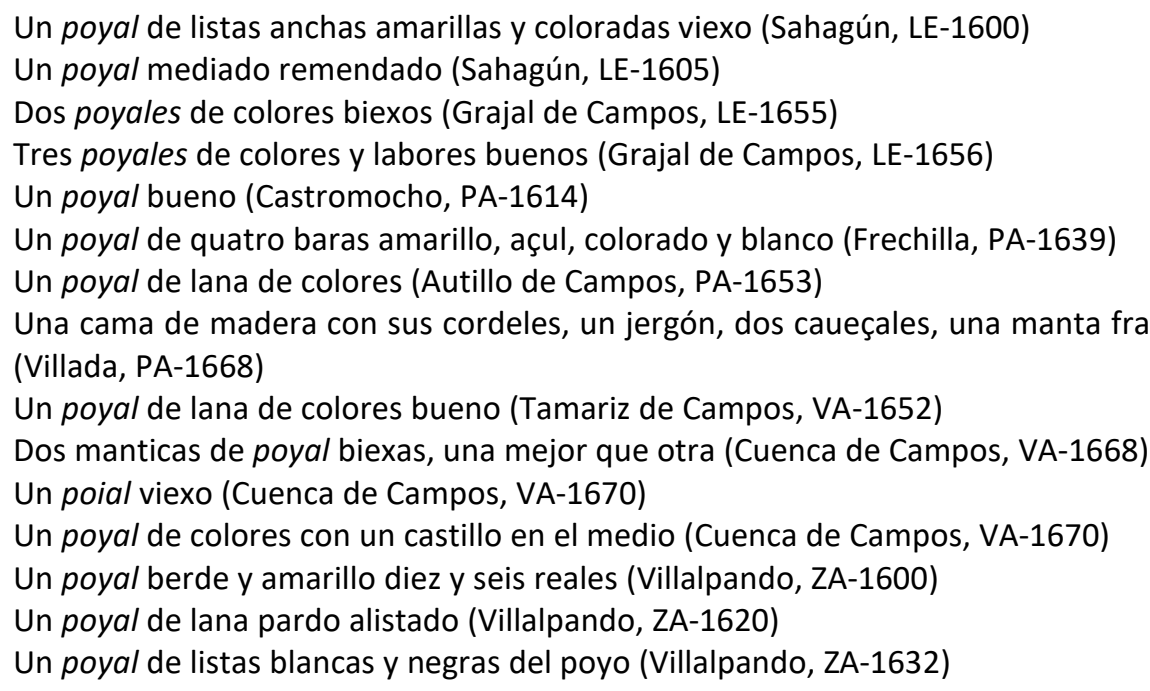

El término poyal se documenta en el $C D H$ y en el CORDE en la segunda mitad del siglo XVI, tan solo se documentan media docena de ocurrencias en los Bienes secuestrados a los moriscos del Reino de Granada con el significado con el que aquí se estudia. Frente a estos escasos testimonios, su presencia en el CorLexIn es relativamente frecuente en la Península. En el corpus terracampino suele inventariarse junto a mantas, sobremesas, cobertores o paramentos, pero también junto a alforjas o escarpetas.

En el corpus estudiado figura por derivación el término poyalejo que prodría referir el diminutivo de poyal, pero el contexto de este inventario no nos permite saberlo con seguridad 
dado que no presenta un orden lógico. Sí que coincide con los elementos adyacentes que suele llevar el poyal-listado, amarillo y negro-:

Un poyalejo bueno listado de amarillo y negro (Frechilla, PA-1632)

\section{TAPETE}

Sust. m. 'Cubierta de hule, paño u otro tejido, que para ornato o resguardo se suele poner en las mesas y otros muebles' (DLE). Covarrubias lo define como 'el alhombra con que se cubre el suelo'. Autoridades especifica un poco más el término y afirma que se trata de una 'alfombra pequeña, y manual, ù cosa parecida à ella'; en la edición académica de 1832, además de alfombra, añade el significado de 'cubierta de mesa, de cofre ó otra cosa', mucho más cercano al actual (NTLLE, s. v. tapete, Covarrubias, 1611; Autoridades, 1739; DRAE, 1832). Esta palabra procede del lat. TAPẼTE (DECH, s. v. tapete).

Un tapete de guadamaçil viejo (Cea, LE-1621)

Un tapete listado de colores berdes y paxizas en beinte y dos reales (Frechilla, PA-1671)

Un tapete de messa (Medina de Rioseco, VA-1647)

Un tapete de la India labrado (Medina de Rioseco, VA-1648)

Un tapete casi nuevo de bufete de la sacristía (Medina de Rioseco, VA-1651)

Un tapete de guadamaçil viejo (Villalón, VA-1642)

Un tapete berde y colorado (Villalpando, ZA-1632)

Esta lexía se documenta de forma muy temprana en los textos. Se puede localizar en la Colección diplomática del monasterio de Sahagún (Mínguez Fernández, 1974):

Et dedistis nobis una saia carmez et uno tapete quod nobis bene complacuit [...]

Facio uos cartula de uno tapete antemano et de una almuzalla et de uno plumazo palio et de alio lanio et de duas sabanas et una muta de manteles leteratos nobos [...]

Por su parte el CORDE recoge esta voz en el Becerro gótico de Cardeña, De Villa-Alvilla en el año 988. Unos siglos más tarde, el $C D H$ da testimonio de este vocablo en la Crónica de Sahagún fechada en 1255:

[...] veniendo el rrei a la dicha villa de San Fagum, fuele fecho gran aparejamiento e mui solepne rresçiuimiento, seyendo ornado el suelo de las calles con tapetes e cobierto por ençima con cortinas de lino e de seda preçiosas [...]

En cuanto a la distribución diatópica en el siglo XVII, el CorLexIn presenta una nómina de casos distribuidos en la Península, Canarias y América -Bolivia, Chile, Guatemala y México-. Su presencia mayoritaria se encuentra en el sur peninsular, especialmente por las provincias andaluzas, aunque esta distribución pueda ser simple casualidad. En la Tierra de Campos figura junto a mesas y bufetes, con una función de protección fundamentalmente, aunque no se descarta el ornato, pero en este corpus no encontramos tapetes con grandes alardes de decoración. Además, hay dos ejemplos donde tapete se inventaría junto a ropa de cama y junto a toallas, en las que la función podría acercarse a su significado original de 'alfombra'.

\section{MANTEL}

Sust. 'Cubierta de lino, algodón u otra materia que se pone en la mesa para comer' (DLE). Nebrija lo recoge en su Vocabulario, Covarrubias, por su parte, lo define como 'el lienço particular con 
que se cubren las mesas para comer [...]' (NTLLE, s. v. mantel, Nebrija, 1495; Covarrubias, 1611). Término procedente del lat. MANTÉLE 'toalla' (DECH, s. v. mantel).

Una tabla de manteles de gusanillo largos de más de cinco varas (Sahagún, LE-1600)

Otros dos pares de manteles de estopa de torillos en ocho reales (antes aparece Primeramente unas tobaxas mediadas de zerro tassadas en ocho reales) (Sahagún, LE-1608)

Unos manteles de estopa de torillos y un coladero de estopa (Arenillas, LE-1636)

Unos manteles de torillos de lienço nuebos (Grajal de Campos, LE-1655)

Uno manteles bastos (Villarramiel, PA-1696)

Una tabla de manteles hordinarios mediado (Autillo de Campos, PA-1649)

Unos manteles de tobaja de gusanillo (Boadilla de Rioseco, PA-1659)

Una tabla de manteles de gusanillo (Villalón, VA-1637)

Quatro tablas de manteles de lienço de gusanillo (Medina de Rioseco, VA-1644)

Una toalla pequeña de manteles con sus puntas (Medina de Rioseco, VA-1657)

Siete varas de manteles en pieza de gusanillo de siete quartas de ancho (Medina de Rioseco, VA1660)

Unos manteles alemaniscos nuebos y buenos (Villalpando, ZA-1631)

Quatro baras y media de manteles (Villalpando, ZA-1637)

Una mesa de manteles finos alemaniscos (Villalpando, ZA-1670)

Una tabla de manteles de gussanillo (Villalpando, ZA-1688)

El término mantel es otra de esas palabras que figuran con mucha frecuencia en las relaciones de bienes. Se documenta desde época temprana en los textos, la encontramos en la Colección diplomática del monasterio de Sahagún en el siglo x "[...] tres lectos inter tapites et gainapes, VI parelios de manteles[...]" (957), o en la Donación al monasterio de San Mamés de Obarenes datado entre 1008 y 1009 en el CORDE: "[...] libros, casulla linea, capas, scamnos, mesas, manteles et carros". El DECH señala como primera documentación el 908 , y apunta que para Alfonso de Palencia mantel era menos vulgar que tovaja (DECH, s. v. mantel). El CorLexIn proporciona una nutrida nómina de casos repartida por el territorio peninsular y americano. En cuanto al significado, Gonzalo Correas en su obra Vocabulario de refrenes y frases proverbiales escribe lo siguiente: "«Tabla», por: la mesa; «tovaxa»: manteles; i se dize «una tabla de manteles» porke sirve a la tabla i mesa" $(C D H)$ y no son pocos los casos en los que ambos términos se equiparan como ocurre en este asiento de un inventario de Frechilla:

Unas tobaxas o manteles alemaniscos buenos (Frechilla, PA-1631)

$Y$ en ocasiones encontramos el sintagma "toalla de manteles":

Una toalla de manteles de Orense en çinco reales (Medina de Rioeco, VA-1644)

Una toalla de manteles con puntas (Medina de Rioseco, VA-1657)

Una toalla pequeña de manteles con sus puntas (Medina de Rioseco, VA-1657)

E incluso:

Unos manteles tobaja de gusanillo (Boadilla de Rioseco, PA-1659)

Algo parecido ocurre con el término colcha en la Tierra de Campos vallisoletana localizamos "colcha de manteles" o "colcha amantelada":

Una colcha de manteles de gusanillo de estopa (Medina de Rioseco, VA-1640)

Una colçha de manteles grande trayda (Medina de Rioseco, VA-1642)

Otra colcha de manteles nueba (Medina de Rioseco, VA-1649)

Una colcha amantelada con sus puntas tasada en seis ducados (Medina de Rioseco, VA-1644)

Otra colcha de manteles de gusanillo (Medina de Rioseco, VA-1645)

Una colcha de manteles con su flocadura (Medina de Rioseco, VA-1660)

Tres colchas de manteles (Medina de Rioseco, VA-1661) 
Posiblemente referencie algún tipo de técnica textil que recordaba a los manteles. No es frecuente en los inventarios de bienes que conforman el CorLexIn donde se localiza un único ejemplo que se acerca a los encontrados en el corpus terracampinos en la localidad madrileña de Torrelaguna: "Otra colcha de lienço de confitillos, labor de manteles, con sus puntas pequeñas a el rededor, vuena". Con la expresión localizada en el corpus terracampino, las encuentra Rojo Vega en algunos inventarios vallisoletanos ${ }^{11}$, lo que implica una expresión exclusiva de la zona.

Es habitual encontrar la voz mantel bajo la expresión "tabla de manteles", aparentemente para designar el mismo lienzo. EI CDH lo registra en el Inventario de los bienes de Diego González de Cuéllar, clérigo fechado en 1580 -"tres tablas de manteles de gusanillo"-y el CORDE dos años más tarde en la Carta de dote de Jerónimo Ruiz, tejedor de lienzos -"una tabla de manteles de gusanillo, en nueve rreales"-. Casi todas las concordancias que figuran en estas bases pertenecen a la documentación notarial. A mediados del siglo XVII los textos reflejan un descenso de uso de este sintagma. El CorLexIn presente una distribución diatópica general en la Península, en Canarias y en América. Las obras lexicográficas académicas registran esta expresión desde Autoridades como 'el paño de lino, que se tiende, y con que se cubre la mesa, para comer' y se mantiene en el resto de las ediciones académicas, donde a partir de la edición de 1936 la señalan en desuso. En ocasiones esta expresión se encuentra junto a la voz mantel en un mismo inventario.

Otra secuencia habitual en los documentos notariales del XVII es la secuencia "mesa de manteles" y que se localiza en un amplio ámbito geográfico peninsular (Pérez Toral, 2015a: 143). Sin embargo, en Tierra de Campos encontramos tras solo tres ocurrencias:

Una mesa de manteles mediada (Paredes de Nava, PA-1690)

Más una mesa de manteles finos alemaniscos (Villalpando, ZA-1670)

Otra messa de manteles de gussanillo usado (Villalpando, ZA-1689) Antes una tabla de manteles

A diferencia de la expresión "tabla de manteles" que quedaba recogida por las obras lexicográficas desde Autoridades, el sintagma "mesa de manteles" no se registra en ninguna de ellas. Las concordancias localizadas tanto en el $C D H$ y el CORDE son poco frecuentes, no llegan a la media docena. Sin embargo, los datos que aporta el CorLexIn muestran la vitalidad de esta secuencia en el siglo XVII (Pérez Toral, 2015a: 143).

Desde una perspectiva formal, nos encontramos con el sufijo diminutivo -ico con una motivación semántica basada probablemente en el tamaño del mantel:

Unos mantelicos buenos (Boadilla de Rioseco, PA-1687)

Dos mantelicos de gusanillo en diez Reales (Cuenca de Campos, VA-1670)

Unos mantelicos pequeños (Cuenca de Campos, VA-1670)

Unos mantelicos biejos de gusanilo en (h)asta dos baras de lienzo casero (Villalpando, ZA-1620)

${ }^{11}$ Rojo Vega localiza tres asientos en inventarios localizados en Valladolid y fechados entre 1659 y 1661 :

"Una sábana rota y una colcha de manteles de lavores" en Testamento e inventario de un cantarero: Matías Entero (1659); "Otra colcha de manteles quatro ducados" Testamento e inventario de Pascual Cocho cerero (1660); "Otra colcha de manteles de gusanillo" en Testamento e inventario de María de Carasa, viuda de Paulo de la Fuente receptor de la audiencia episcopal (1661). Ejemplos recogidos en la web Investigadores de la Real Biblioteca, https://investigadoresrb.patrimonionacional.es/. 


\section{SÁBANA [sáuana, sávana]}

Sust. f. 'Cada una de las dos piezas de lienzo, algodón u otro tejido, de tamaño suficiente para cubrir la cama y colocar el cuerpo entre ambas' (DLE). Lo recoge Nebrija en su Vocabulario como 'savana de lienço' y Covarrubias dice que 'comunmente son dos lienços de dos piernas y media, o tres, entre las quales nos acostamos en la cama' (NTLLE, s. v. sábana, Nebrija, 1495; Covarrubias, 1611). Voz procedente del lat. SABĂNA, plural de SABĂNUM, y este del griego sabañón 'toalla de baño', a su vez de origen semítico ( $D E C H$, s. v. sábana).

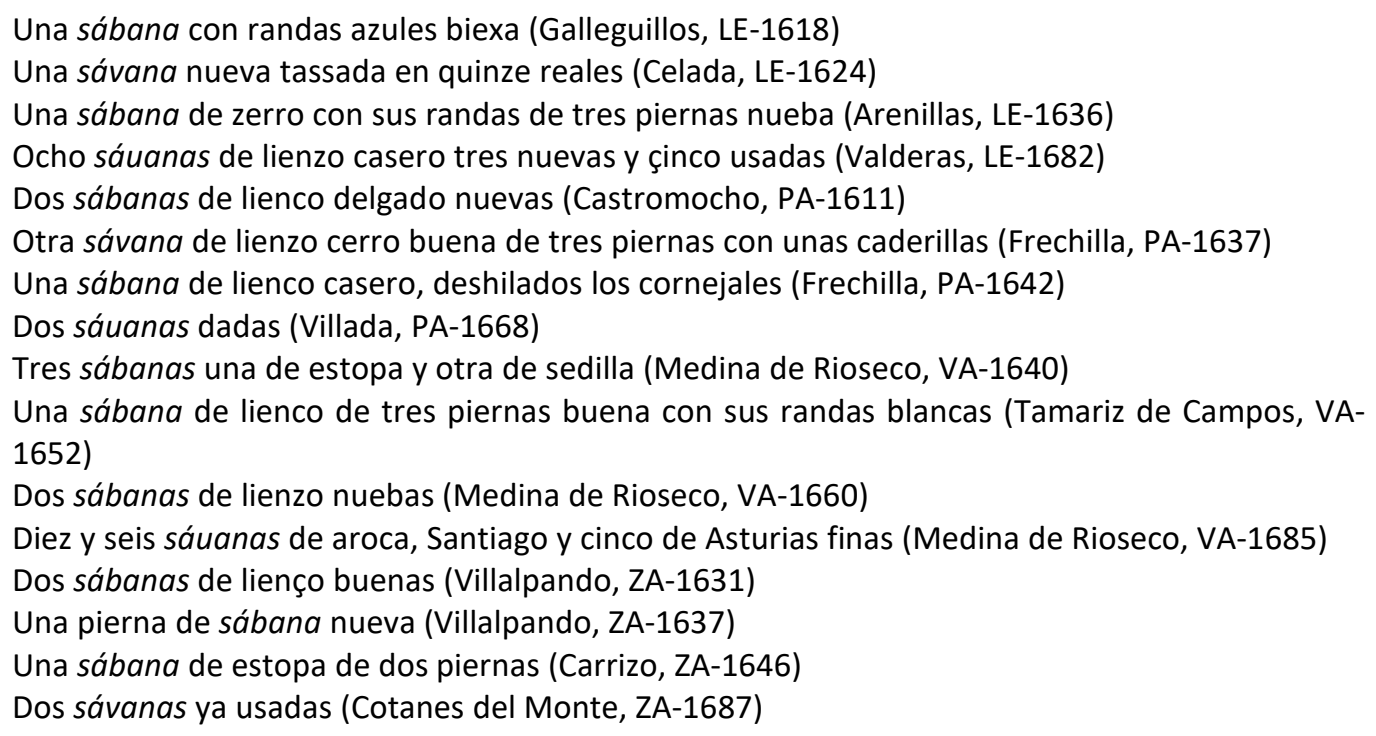

Es un término muy frecuente en las relaciones de bienes, raro es el inventario que no presenta uno o varios casos dentro de la ropa blanca. No obstante, hay que señalar que su significado era mucho más amplio que el actual. Además de la sábana de cama que hoy conocemos, en estos documentos se encuentran distintas funciones y se inventarían junto a otros enseres como mobiliario, utensilios de cocina, prendas de vestir... que le confiere otro tipo de fin al de ajuar de cama. De hecho, en algunas ocasiones se especifica que estamos ante una sábana de cama: "una sabana de cama de tres piernas vuena" (Sahagún, LE-1623).

Además de introducir comodidad, higiene y abrigo en la cama, este lienzo también formaba parte del ajuar de la cama, así encontramos los siguientes ejemplos:

Una sávana que esta puesta por cielo demediada de tres piernas de lienzo (Frechilla, PA-1675)

Una sáuana que sirue de cielo de cama (Medina de Rioseco, VA-1657)

Donde la sábana hace las veces de cielo de la cama. Con una función parecida la encontramos en algunos documentos del CorLexIn, donde aparecen "sábanas colgaderas", "sábanas de paramento" o "para colgar", con cierto paralelismo con los sintagmas encontrados en el corpus terracampinos.

Terreros y Pando registra en su diccionario sábana con que se entierra á los muertos y remite a los términos mortaja y sudario (NTLLE, s. v. sábana, Terreros y Pando, 1788). Con esta función se muestra en alguna de las ocurrencias localizadas en en la documentación de Medina de Rioseco:

Tres savanas delgadas que la una se gastó en la mortaxa (Medina de Rioseco, VA-1639) 
Y lo mismo en algunos puntos de la Península:

Vna sábana de buelto, trayda, en que se amortaxó la difunta (Alaejos, VA-1630)

Vna sáuana de mortuorio de lienzo de la tierra (Hernani, Guipúzcoa, 1641)

Tres sábanas de ataúd con dos cabezales para lo mismo (Alzaga, Guipúzcoa, 1697)

Para este fin, los documentos cántabros presentan la llamada sábana de honra que parece exclusiva de esta región ya que no aparece ni en el CorLexIn, ni en bases textuales como el CORDE o el CDH (Bartolomé y Junquera, 2018: 128-129).

Otro de los significados que presenta esta voz es la de 'lienzo para cubrir el altar' y que ya se documenta en los textos medievales (Ágreda, 2017: 30):

Una mesa del altar con su ara, una sabana ençima de ella con sus puntas (Medina de Rioseco, VA-1644)

Una sáuana de olanda de el altar (Medina de Rioseco, VA-1685)

Otra sáuana de manteles del altar con sus puntas (Medina de Rioseco, VA-1685)

El CorLexIn recoge esta manufactura textil en documentos notariales de Guipúzcoa, Madrid y Zaragoza. Esta escasez de casos es debida a la especificidad del término, es decir, se encuentra en relaciones de bienes pertenecientes a iglesias, y en ocasiones este término se ve sustituido por el de manteles (Huesca, Álava, Guipúcoa, Sevilla, Granada, México y Chile).

Muy común en el corpus terracampino es la sábana que forma parte de los enseres para la elaboración del pan:

Dos sáuanas viejas de estopa y otra vieja de lo mismo de pan (Grajal de Campos, LE-1658) otra manta de lana nueva de pan con su sábana (Castromocho, PA-1611) Una sábana masadera de estopa de dos piernas en ocho reales (Villalpando, ZA-1600) otra sabana de la artesa (Villalpando, ZA-1644) Vna sáuana del pan de dos piernas ussada (Villalobos, ZA-1654) una savana de el pan de estopa viexa de dos piernas y media (Villalpando, ZA-1690)

Este tipo de sábana aparece con cierta frecuencia en los inventarios terracampinos, junto a manta y masera para referenciar el paño que se usa para la elaboración del pan. El CorLexIn tan solo documenta un ejemplo en la localidad cacereña de Brozas (1664): "vna sáuana de el pan vssada". Cabe señalar que existe cierta tendencia de uso en documentos del occidente de la Península, ya que además de este ejemplo, los usos son más frecuentes en el occidente de la Tierra de Campos.

Por otro lado, de manera excepcional, encontramos este significado asignado al diminutivo sabanilla:

Dos sauanillas de pan buenas (Grajal de Campos, LE-1658)

$\mathrm{Y}$, aunque no con el mismo sintagma, el CorLexIn recoge el siguiente ejemplo en Tafalla (Navarra): "Una sabanica destopa para masar, bieja".

Para terminar, en los textos terracampinos encontramos sintagmas como sábana de ropa, sábana de tocados o sábana como tejido para confeccionar determinadas prendas:

Una sáuana de ropa vieja de tres piernas (Grajal de Campos, LE-1658)

Dos sáuanas de ropa buenas (Grajal de Campos, LE-1658)

Una sábana bieja de tocados (Frechilla, PA-1616)

De ylo y hechura de las dos camissas que se le hicieron de las sauanas (Villalpando, ZA-1656), 
Los datos aportados por el CorLexIn relacionados con esta acepción son escasos, aunque aparece "vna sábana de tocados" en Cáceres y "vna tela de sábana de olanda con sus puntas, buena" en Álava.

Desde el punto de vista morfológico, a pesar del escaso número de ejemplos encontrados, alternan los diminutivos terminados en -illa e -ica:

Dos sauanillas de pan buenas (Grajal de Campos, LE-1658)

Dos sabanicas de lienzo biexas de dos piernas (Villalpando, ZA-1660)

\section{SERVILLETA [seruilleta, serbilleta]}

Sust. f. 'Pieza de tela o papel que usa cada comensal para limpiarse los labios y las manos' (DLE). Para Covarrubias 'es el pañiçuelo de mesa en que nos limpiamos las manos, y la boca quando comemos' (NTLLE, s. v. servilleta, Covarrubias, 1611). Término probablemente tomado del francés serviette ( $D E C H$, s. v. siervo).

Dos serbilletas de gusanillo mediadas (Valdavida, LE-1606)

Una servilleta de gusanillo (Cea, LE-1621)

Dos panizuelos de serbilleta nuebos (Grajal de Campos, LE-1655)

Seis baras de serbilletas de estopilla en pieza (Grajal de Campos, LE-1658)

Doce serbilletas de mesa de gusanillo nuebas (Castromocho, PA-1611)

Unos manteles y servilleta (Frechilla, PA-1639)

Dos almoadas y una seruilleta todo viejo (Villada, PA-1669)

Seis baras de serbilletas de gussanillo en tela (Paredes de Nava, PA-1689)

Tres varas de servilletas gruesas tasadas en diez reales (Medina de Rioseco, VA-1644)

Tres servilletas de gusanillo la una fina y las dos bastas (Cuenca de Campos, VA-1666)

Quarenta y çinco seruilletas finas que estrenar (Medina de Rioseco, VA-1685)

Treinta y quatro seruilletas hordinarias por estrenar (Medina de Rioseco, VA-1685)

Quatro seruilletas alimaniscas (Villalpando, ZA-1637)

Cuatro serbilletas de gussanillo nueva en pieza (Villalpando, ZA-1654)

Media dozena de servilletas de gusanillo Nuebas (Villalpando, ZA-1660)

Ocho servilletas de gusanillo ya usadas (Cotanes del Monte, ZA-1687)

Es un término de uso general en las documentaciones que manejamos. El CDH documenta esta palabra en la Valuación hecha en la villa de Bilbao del precio de las mercaderías que venían de fuera del Reino fechada en 1563:

Docena de servilletas de Francia cortadas á seiscientos doce maravedís la docena [...]

Servilletas de Flandes á cincuenta y cinco maravedís el ana [...]

El CorLexIn recoge un nutrido número de items a lo largo y ancho de la Península, también aparecen ocurrencias en Canarias y América. Y lo mismo ocurre en la Tierra de Campos, donde esta voz es frecuente en las relaciones de bienes.

\section{SOBREMESA [sobremesilla]}

Sust. f. 'Tapete que se pone a la mesa por adorno, limpieza o comodidad' (DLE). Autoridades lo recoge como 'la cubierta, que se pone encima de la mesa por decencia, limpieza, y comodidad' (NTLLE, s. v. sobremesa, Autoridades, 1739). Término compuesto, procedente del lat. SŬPER (DECH, s. v. sobre) y de MENSA (DECH, s. v. mesa). 
Una sobremesa salamanquesa nueba tasada en diez reales (Sahagún, LE-1605)

Una sobremesa de lana de blanco y negro (Sahagún, LE-1608)

Una sobremesa de colores nueba (Arenillas, LE-1636)

Tres sobremesas de colores buenas (Grajal de Campos, LE-1656)

Una sobremesa tasada en un real (Mazariegos, PA-1619)

Una sobremesa vieja de colores (Frechilla, PA-1612)

Una sobremesa buena de ofrenda (Guaza de Campos, PA-1637)

Vna sobremesa de lana de colores, mediada, digo nueba (Autillo de Campos, PA-1654)

Una sobremesa de otro bufete de xerguilla desvarillada (Medina de Rioseco, VA-1644)

Una sobremessa (Becilla de Valderaduey, VA-1654)

Una sobremesa de damasco carmesí (Medina de Rioseco, VA-1657)

Una sobremesa de orillos nueva seis reales (Villalpando, ZA-1600)

Dos costales y tres sobremesas viejos (Villalpando, ZA-1614)

Una sobremesa, amarilla y colorada (Villalpando, ZA-1632)

Una sobremesa buena (Villalpando, ZA-1640)

Las primeras documentaciones que propone el $C D H$ para este término datan de principios del siglo XVI, aparece en la Instrucción para el régimen interior de su palacio de Fray Hernando de Talavera (1500): "Que esten linpios e bien cogidos manteles, pañizuelos, toallas, mesas e sobremesas", y veinte años más tarde, en Inventario de bienes (1522): "vn sobremesa de lana e vn alcatifa de bieja lana", ejemplo que también recoge el CORDE. Y un siglo más tarde aparecen los primeros ejemplos en textos americanos. Esta voz presenta ligeras diferencias de significado, podemos encontrarlo como una especie de 'tapete para cubrir bufetes o cofres' en muchas ocasiones, pero también como parte de la cama: "una cama rica de tela de oro amarilla listada con su cobertor y sobremesa de lo mismo y colgaduras y almohadas de estrado vestidos, ropa blanca y otras cosas" (Promesa de dote, 1626). En algunos textos sobremesa se equipara a poyal o bancal:

[...] que el poial es sobremesa / i el que fue arca es baúl [...] (Romances de Luis de Góngora y Argote (1580-1627)

Una sobremesa o vancal listado de blanco y azul ya traydo (Memorial de los bienes de Diego López, 1581)

A partir de la segunda mitad del siglo XVII, este término con el significado textil entra en recesión y su aparición en los documentos se hace más esporádica.

Los datos que ofrece el CorLexIn muestran una voz que goza de gran vitalidad en todo el ámbito geográfico peninsular, también se documentan ocurrencias en inventarios americanos -Bolivia, Chile, México y Perú-.

En cuanto al significado con el que figura en el corpus terracampino coincide con los encontrados en los corpus del castellano. Cabe destacar que sobremesa se inventaría en ocasiones junto a poyal y bancal lo que hace suponer que no hay una equivalencia exacta entre estos términos.

En cuanto a la morfología derivacional, el diminutivo alterna las formas sobremesica y sobremesilla en Tierra de Campos:

una sobremesica viexa y rota (Sahagún, LE-1600)

Un cabeçal biejo y una sobremesilla (Castromocho, PA-1614)

Una sobremesica vieja rota de lana de colores (Villalpando, ZA-1620) 
El significado con el que aparece es el académico y con un valor apreciativo de la palabra, siempre acompañando a mesicas o bufetillos, referenciando un menor tamaño.

Los derivados de este término son poco comunes en la documentación. El CORDE recoge solamente "una sobremesilla de un bufetillo de tafetan açul y la çenefa [sic] de damasco açul y dorado con flecadura, traida" en el Inventario de los bienes del licenciado Domingo Pérez de Rivadeneira, fechado en 1622. Por su parte, el CorLexIn también presenta un único caso de este diminutivo: "vna sobremesilla de paño verde, biexa" en Burgo de Osma (Soria, 1612).

\section{TOALLA [tualla, toalla, taballa, tovaja, touaxa, tobaxa]}

Sust. f. 'Pieza de felpa, algodón u otro material, por lo general rectangular, para secarse el cuerpo', 'tela de rizo usada especialmente para hacer toallas y albornoces de baño', el diccionario académico también recoge un significado ya en desuso, 'cubierta que se tendía en las camas sobre las almohadas'. Además, también recogen las variantes tobaja y toballa que señala como en desuso (DLE). Autoridades recoge toaja o toalla como 'paño de lino, ù lienzo, para limpiarse las manos. Regularmente es de uno, que llaman gusanillo [...]', para toalla también ofrece el significado de 'cubierta, ò telliza, que se tiende en las camas sobre las almohadas para mayor decencia'. En la obra lexicográfica de Rosal se remite al lema tovalla o tobaja y se reconoce esta voz como 'paño de manos' (NTLLE, s. v. toalla, Rosal, 1611; Autoridades, 1739). Es un término procedente del germánico thwahljō. Según Corominas y Pascual, la forma antigua y castiza en castellano fue toaja, mientras que la moderna se tomó del italiano o del catalán (DECH, s. v. toalla).

\footnotetext{
Una toalla de amarillo y blanco tasado todo en cien reales (Sahagún, LE-1605) Tres toallas guarneçidas las dos alimaniscas y la otra de olanda (Grajal de Campos, LE-1658) Una toalla de red blanca labrada aguja con diferentes lauores (Grajal de Campos, LE-1658) Una toalla angosta de gusanillo (Grajal de Campos, LE-1658)

Una toalla de gusanillo labrada (Castromocho, PA-1611) Unas toallas de gusanillo grandes (Guaza de Campos, PA-1640) Una toalla de tafetán açul (Paredes de Nava, PA-1689) Dos toallas de bocadillo con sus puntas ordinaria (Paredes de Nava, PA-1690) Una toalla alimanisca husada (Villalón, VA-1642)

Una toalla de manteles de Orense en çinco reales (Medina de Rioseco, VA-1644)

Una toalla de tafetán pajiço labrada de cañamaço de seda (Medina de Rioseco, VA-1648)

Una toalla de manteles con puntas (Medina de Rioseco, VA-1657)

Una toalla de lienço delgado con puntas (Villalpando, ZA-1637)

Dos toallas con $r$

andas y puntas en quarenta y seis reales (Quintanilla del Monte, ZA-1639)

Una toalla de olanda con randa de cadeneta, ylo de pita, punta y encaje (Villalpando, ZA-1644)

Una toalla de Cambray con puntas de ylo de pita (Villalpando, ZA-1688)
}

Es un término muy frecuente en las relaciones de bienes, las toallas siempre han formado parte del ajuar doméstico y de ahí su presencia en los inventarios. Además de esta forma académica, en el corpus terracampino se alterna con la variante tualla:

Vna tualla de olanda nueba con tiras de red (Valderas, LE-1647)

Dos tuallas de lienzo compuntas, una nueva y otra husada (Valderas, LE-1682)

Dos tuallas la una blanca vordada de oro y la otra labrada de cañamaço sobre tafetán carmesí (Medina de Rioseco, VA-1648) 
Tres tuallas vizcaynas de gusanillo nuebas / Una tualla de raso alistada con galón de plata de cubrir las almuadas de la cama / otra tualla de gusanillo con puntas nueba (Medina de Rioseco, VA-1660)

Una tualla de gasa con su tafettan encarnado / dos tuallas de bretaña guarneçidas con puntas hordinarias (Medina de Rioseco, VA-1685)

El cierre de la vocal /o/ en / $u$ / suele ser frecuente y reflejar, de alguna forma lo que estaba ocurriendo a nivel fonético en la lengua oral en este momento y que ocurría con otras voces - almuada-. El interés de esta variante radica en el hecho de presentar una distribución geográfica localizada en zonas leonesas (Morala y Egido, 2010: 428; Pérez Toral, 2017d: 59-60). La escasa nómina de casos que nos muestra el CorLexIn pertenecen a documentación leonesa. En Tierra de Campos, además de en localidades de León, también aparece en documentos vallisoletanos de la comarca. Otro dato que avala la oralidad del término es el hecho de la escasez de datos en bases textuales como el CORDE y el $C D H$.

La variante más generalizada es la forma académica toalla, presente en la documentación de toda la Península, además de en textos canarios y americanos (CorLexIn). De forma habitual, el escribano explicita con qué telas está elaborada -lienzo, olanda, tafetán...-y, en algunas ocasiones, expone su uso: "de rostro", "de manos", "de cubrir la mesa", "de adereço de bautismo", "para tomar chocolate" "de cama", "de limpiar la casa", "de almohada", "de espejo"... Los ejemplos aportados por el corpus terracampino no entran en tanto detalle, tan solo encontramos "tres tuallas [...] de cubrir las almuadas de la cama".

Una de las variantes con las que aparece esta voz es toballa:

Unas toballas de gusanillo buenas y grandes (Fechilla PA-1613)

Tres toballas de lienzo delgado buenas (Villalpando, ZA-1620)

Una toballa de olanda de red nueba ermana de la que rescivió de dote (Villalpando, ZA-1620)

El DLE recoge esta lexía como forma en desuso y como sinónimo de toalla (DLE). Autoridades ya describe este término como lo mismo que toaja o toalla, y en la edición académica de 1803 tanto tobaja como toballa aparecen como términos antiguos (NTLLE, s. v. toballa, Autoridades, 1739; DRAE, 1803).

De todas las variantes de esta voz, toballa es la menos frecuente en el corpus terracampino. Desde una perspectiva diacrónica, las bases del español registran el término "touallola" como parte de la ropa blanca a partir de finales del siglo XIV. No es hasta la primera mitad del siglo XVI cuanto aparece en los textos "tovalla":

[...] la princesa iva como criada de Fulgencia e llevava una tovalla delante del rostro porque nadie la pudiesse conocer [...] (Libro de Don Claribalte de Gonzalo Fernández de Oviedo, 1519)

Aunque, un siglo más tarde la palabra parece desaparcer de la documentación que conforma el $C D H$ y el CORDE, la última concordancia que registran de esta voz pertenece a una escritura de dote fechada en 1626 . El $C D H$ recoge un único ejemplo de toballa después de esta fecha, en una novela de 1986.

El CorLexIn muestra más de una treintena de items repartidos en documentos peninsulares, aunque también recoge algún ejemplo aislado en Canarias y América -Chile-. En cuanto al reparto geográfico en la Península, parece que hay una clara preferencia de esta lexía en la parte 
oriental, en especial en el norte, ya que el mayor número de casos lo registran localidades de Huesca y Navarra. Esto corresponde con el hecho de que en Tierra de Campos sea la variante menos documentada.

En repertorios léxicos más modernos, toballa se recoge como la forma vulgar de toalla (Gordaliza, 1988: 213).

Por último, localizamos tobaja en el corpus estudiado:

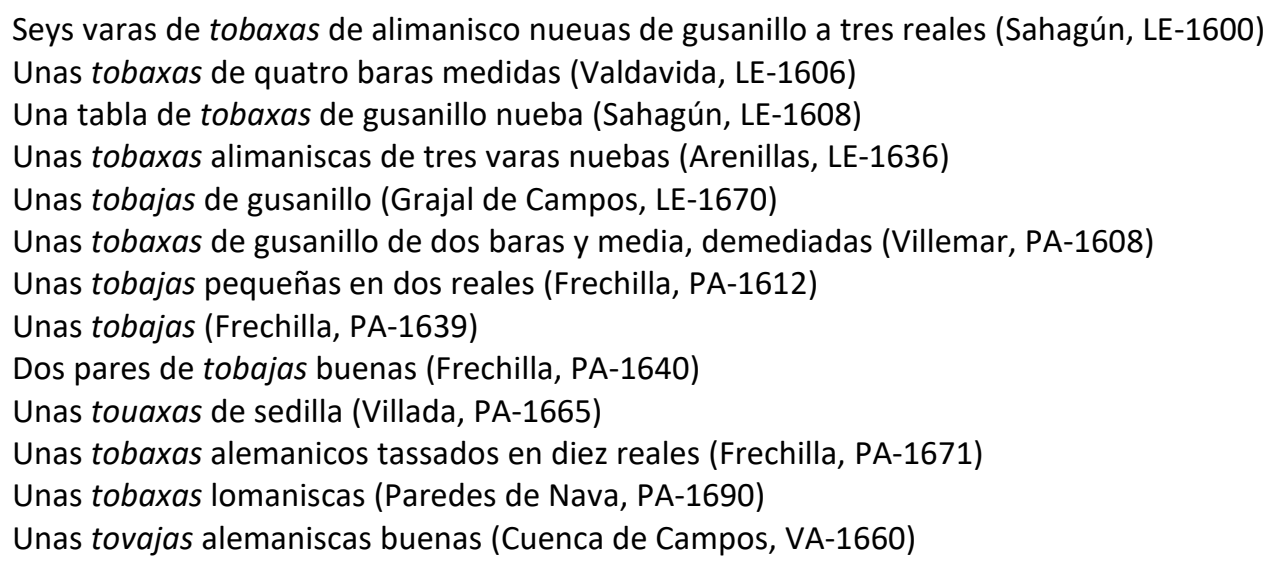

Lo mismo que ocurre con toballa, ocurre con tobaja, el DLE lo recoge como término en desuso que es sinónimo de toalla y, además, usado en Andalucía (DLE). Vittori recoge este lema junto a toalla y toaja; Rosal lo equipara a toballa, advirtiendo que coincide con el italiano y el francés. Autoridades de nuevo lo equipara con el término toaja o toalla, en la edición académica de 1884 tobaja aparece en un lema independiente, aunque sigue manteniendo la marca de término antiguo. En la edición de 1936 añaden la marca diatópica del término que se mantiene hasta la actualidad (NTLLE, s. v. tobaja, Vittori, 1609; Rosal, 1611; Autoridades, 1739; DRAE, 1884; DRAE, 1936).

El CDH y el CORDE dan cuenta de esta variante en el Libro de Alexandre fechado entre 1240 y 1250 , en la primera mitad del siglo XIII, unos siglos antes que toballa y toalla. Como ocurre con la variante toballa, a partir del siglo XVII el uso de tobaja entra en retroceso, acabando por desaparecer de los textos, la última concordancia que ofrecen tanto el CDH como el CORDE se referencia en una carta de dote fechada en 1630.

Desde un punto de vista diatópico y centrándonos en los documentos notariales del siglo XVII, esta voz presenta una distribución peninsular amplia, sin casos en Canarias, ni América. Cabe destacar que los items ofrecidos por el CorLexIn pertenecen principalmente a la primera mitad del siglo, aunque también haya casos que se acercan a los años setenta del siglo. Esta distribución temporal también está presente en los textos terracampinos, donde la mayoría de las concordancias pertenecen a la primera mitad.

Antes de terminar con esta palabra, quisiera señalar que no hemos encontrado la voz toaja en el corpus objeto de estudio, y tampoco en el CorLexIn -en esta época puede que ya no formarse parte del acervo lingüístico-. Sin embargo, la consulta en las bases como el CORDE y el $C D H$ es poco fructífera, tan solo aparece un ejemplo en el CORDE en la Tercera parte de la Historia de San Jerónimo de Fray José de Sigüenza fechada en 1605. El DECH da como primera 
documentación el Libro de Alexandre. Este término lo recogen los diccionarios preacadémicos junto a toalla, a veces, incluso en la misma entrada, también junto a tobaja. Autoridades registra el término de la misma manera, en la misma entrada que toalla y así hasta la edición de 1803, donde aparece por última vez en los diccionarios académicos. La referencia lexicográfica más moderna del NTLLE es la de Zerolo (1895) con la misma defición que le otorgó el DRAE de 1803. Esto nos hace pensar que estamos ante una palabra que fue poco frecuente en los textos y que enseguida entró en retroceso.

\subsubsection{Ornamentación}

\section{ALFOMBRA [alfonbra, alombra, alhonbra, alonbrita]}

Sust. f. 'Tejido de lana o de otras materias, y de varios dibujos y colores, con que se cubre el piso de las habitaciones y escaleras para abrigo y adorno' (DLE). El diccionario académico mantiene la entrada alhombra. Nebrija y Covarrubias recogen el término alhombra en sus respectivas obras como sinónimo de tapete. En Autoridades aparece alfombra como 'tapete o paño grande con que se cubre y adorna el suelo, hecho de una pieza en telar con varias sedas, lana y oro, o cada cosa de por si, de diversos colores y labores' y advierte de que 'muchos escriben esta voz con $h$, diciendo Alhombra' (NTLLE, s. v. alfombra, alhombra, Nebrija, 1495; Covarrubias, 1611; Autoridades, 1726). Término procedente del árabe húmra, íd. (DECH, s. v. alfombra).

Una afonbra tasada en tres ducados (Sahagún, LE-1605)

Otra alfonbra de verde y amarillo (Cea, LE-1621)

Una alombra de colores buena (Grajal de Campos, LE-1658)

Una alfonbra pequeña (Frechilla, PA-1640)

Una alfombra atapiçada (Guaza de Campos, PA-1637)

Una alfonbra amarilla demediada (Boadilla de Rioseco, PA-1643)

Una alfombra de lana de colores (Autillo de Campos, PA-1647)

Una alfombra de dicho bufete usada (Medina de Rioseco, VA-1643)

Una alfonbra de hestrado blanca y negra (Medina de Rioseco, VA-1645)

Una alfonbra con diez ruedas verdes y el canpo colorado (Medina de Rioseco, VA-1647)

Una alfombra de estrado grande afelpada (Medina de Rioseco, VA-1685)

Una alfombra ussada (Villalpando, ZA-1656)

Una alfonbra grande buena (Villalpando, ZA-1686)

Una alfombra muy bieja (Villalpando, ZA-1688)

El término alfombra se documenta en las bases académicas del castellano en las Cuentas de Gonzalo de Baeza, tesorero de Isabel la Católica fechadas en1477, a partir de aquí comienza a mostrarse en los textos de forma esporádica, dado que en la documentación se muestra otra variable del término que parece tener más aceptación en esos años. Esta variable es el término alombra o alhombra y que también está presente en el corpus terracampino:

Una alonbra verde y vuena (Cea, LE-1621)

Vna alonbra mediana dorada y çeniçienta (Valderas, LE-1647)

Una alombra de colores buena (Grajal de Campos, LE-1658)

Una alhonbra pequeña colorada y amarilla (Paredes de Nava, PA-1689)

Una alhonbra con tres randas coloradas y verdes (Paredes de Nava, PA-1690)

Un pedazo de alonbra mui biexa (Medina de Rioseco, VA-1639) 
Una alonbra en dos ducados (Medina de Rioseco, VA-1641)

Otra alonbra pajiça pequeña en beinte reales (Medina de Rioseco, VA-1647)

Una alonbra mediana ya trayda (Medina de Rioseco, VA-1649)

Una alonvra destrado de zinco varas de largo (Medina de Rioseco, VA-1660)

Una alunbra grande (Villalpando, ZA-1601)

Una alhombra buena tasada en seys mil maravedís (Villalpando, ZA-1620)

La variante alombra se documenta con anterioridad, en el Testamento de Pedro I de Castilla datado en 1362 (Fichero General, cédula 2). Poco a poco esta variable va cediendo el paso al término que hoy conocemos, a mediados del siglo XVII el término mayoritario es alfombra, figurando de forma esporádica la variante alhombra. Siguiendo esta tendencia, el CorLexIn presenta una nómina de casos de alfombra notablemente superior al de alombra y sus variantes gráficas.

En esta época "no es extraño en los arabismos con /f-/ precedidos del artículo al- que convivan las variantes con mantenimiento y con pérdida de /f/" (Morala, 2012e: 93), como ocurre en este caso.

En el corpus de Tierra de Campos localizamos la variante alunbra en documentos de Villalpando y que presenta el cierre de la vocal tónica.

Respecto a la morfología derivativa de esta lexía cabe destacar que pocos son los términos derivativos encontrados. El único sufijo diminutivo que figura en el corpus estudiado es -ita con un valor puramente apreciativo:

Una alonbrita muy bieja y un repostero de lana biejo con su barilla de yerro (Medina de Rioseco, VA-1643)

\section{ANTEPUERTA}

Sust. f. 'Repostero o cortina que se pone delante de una puerta para abrigo u ornato' (DLE). Nebrija da cuenta de este término en su Vocabulario. Autoridades recoge el significado que perdura hasta hoy en el diccionario académico (NTLLE, s. v. antepuerta, Nebrija, 1495; Autoridades, 1726). Término compuesto por la preposición procedente del lat. ANTE 'delante de', 'antes de' y del sustantivo puerta procedente del lat. PǑRTA 'portón, puerta grande' ( $D E C H$, s. v. ante y puerta).

Una antepuerta que es una escarpeta viexa (Sahagún, LE-1603)

Una antepuerta de lana biexa (Autillo de Campos, PA-1653)

Una antepuerta de paño azul (Medina de Rioseco, VA-1641)

Una antepuerta bieja (Villalpando, ZA-1620)

Es un término con escasa representación en la documentación terracampina, sin embargo, aparece en todo su ámbito geográfico. Tanto el CORDE como el $C D H$ recogen esta voz a partir de las Cuentas de Gonzalo de Baeza, tesorero de Isabel la Católica datadas en 1477. El cómputo total de concordancias de esta voz no llega a la centena en ninguna de las dos bases y su uso mayoritario se da entre el siglo XVI y la primera mitad del siglo XVII, a partir de aquí su presencia en los textos es prácticamente anecdótica. Respecto a la distribución diatópica del término, el CorLexIn recoge casi una treintena de casos con un patrón de reparto geográfico amplio. 


\section{BANCAL}

Sust. m. 'Tapete o cubierta que se pone sobre el banco para adorno o para cubrir su madera' (DLE, 4. a ac.). El término lo recoge Nebrija en 1495 con un significado muy cercano al que aquí se estudia. Autoridades lo recoge como cuarto significado del lema bancal con la misma acepción que se conserva hoy en día en el diccionario (NTLLE, s. v. bancal, Nebrija, 1495; Autoridades, 1726). Voz derivada del germ. Bank, tomado ya por el latín vulgar de todo el Imperio de Occidente (DECH, s. v. banco).

Un bancal colorado y amarillo (Sahagún, LE-1600)

Un bancal (Villalón, VA-1637)

Tan solo se documentan dos casos de esta voz en el corpus de Tierra de Campos con la acepción de 'tapete o cubierta que se pone sobre el banco'. Con este significado figura en los ejemplos que aporta el CorLexin y que preseta un uso preferente en la zona sur y este de la Península. Con un significado similar o muy cercano aparece la lexía bancaleta, localizada en textos gaditanos (Bastardín, 2012: 53; Morala, 2015d: 169) donde el derivado de bancal se ha lexicalizado.

El CDH propone como primera documentación el Inventario de los bienes muebles dejados por Ramón Torrent fechado en 1325 y certificando su uso mayoritario en el siglo XVI, a partir del siglo XVII, el significado que predomina en los textos es el de 'terreno para el cultivo'.

\section{CARPETA}

Sust. f. 'Cubierta de badana o de tela que se ponía sobre las mesas y arcas para aseo y limpieza' (DLE, 5. a ac.). Las obras lexicográficas académicas recogen esta entrada desde Autoridades con el mismo significado que se mantiene hoy en día, lo único que añade es que '[...] la qual está dada de colór: y también se llama assi la que es de seda ò paño, ù otra qualquiera matéria texida'. En la siguiente edición académica añade el significado de 'especie de cartapacio que se pone en las mesas para escribir sobre él, y guardar papeles' (NTLLE, s. v. carpeta, Autoridades, 1729; $D R A E, 1780)$. Término tomado del fr. carpette y este a su vez del ingl. carpet 'alfombra' y este a su vez del it. antic. carpita 'manta peluda', derivado de carpire, lat. CARPĔRE, en el sentido de cardar la lana (DECH, s. v. carpeta).

\footnotetext{
Una carpeta buena que estaba sobre la dicha mesa buena (Valdavida, LE-1606)

Una carpeta nueva y quatro mantas nuebas (Carvajal, LE-1609)

Tres carpetas buenas (Cea, LE-1610)

Una carpeta de colores vuena (Cea, LE-1621)

Una carpeta de colores mediada en cinco reales (Sahagún, LE-1633)

Una carpeta fina (Castromocho, PA-1611)

Una carpeta bieja de colores amarillo y blanco (Frechilla, PA-1616)

Una carpeta Çamorana (Villada, PA-1668)

Una carpeta de bufete de seda de labores encarnado, paxido y verde (Paredes de Nava, PA-1690)

Una arca de pino bieja sin çerradura y enzima una carpeta vieja (Medina de Rioseco, VA-1641)

Tres carpetas de Salamanca viejas (Medina de Rioseco, VA-1649)

Una carpeta mediada de colores (Tamariz de Campos, VA-1652)

Una carpeta salamanquesa nueba en treçe reales y medio (Cuenca de Campos, VA-1666)
} 
Una carpeta de lana de colores bieja (Villalpando, ZA-1620)

Una carpeta (Quintanilla del monte, ZA-1639)

Vna carpeta alistada (Villalobos, ZA-1654)

Un bufete pequeño con una carpeta de lana (Villalpando, ZA-1686)

Una carpeta zamorana (Villalpando, ZA-1698)

EI CDH recoge media docena de concordancias entre la documentación del siglo XVI y XVII Y muchas de ellas en obras literarias, la primera constacia de esta voz se encuentra en la Obra poética de Baltasar del Alcázar fechada a mediados del siglo XVI. El CORDE presenta un número ligeramente mayor de casos, y en el siglo XVI casi todos pertenecen a relaciones de bienes, a partir del siglo XVII su presencia es más frecuente en las obras literarias. El término lo documenta en primera instacia en la Donación de Juan Francisco locadelo en favor de Doña Andrea de Cervantes de 1568.

Si restringimos la búsqueda a la documentación notarial del CorLexIn, podemos ver la vitalidad de esta voz en el siglo XVII, donde presenta una distribución diatópica amplia, siempre con el significado dado por Autoridades. Lo mismo ocurre en la Tierra de Campos, es un término frecuente en el corpus y que presenta algunos derivados del término. Por un lado, alternan las formas del sufijo diminutivo -ica e -illa:

Otra carpetica (Sahagún, LE-1600)

Una mesa pequeña y una carpetica (Villalpando, ZA-1697)

Una carpetilla que estaba sobre los cordeles de la cama (Castrillo, LE-1606)

Y por otro, encontramos el aumentativo -on, aunque aquí no tenemos claro que tenga un carácter apreciativo, ya que el contexto en el que se encuentra no da muchas pistas sobre el significado, tan solo el material del que está hecho y que podría llevarnos a decir que se trata de una especie de felpudo:

Un carpetón de minbres vueno (Cea, LE-1621)

De carpetón no tenemos noticias en las obras lexicográficas académicas, tampoco en el CorLexIn. Tan solo tenemos tres concordancias entre el $C D H$ y el CORDE, pero en documentos contemporáneos, todos del siglo pasado. El CORDE lo recoge en una obra de 1972 de Max Aub y el significado con el que aparece es el de 'material de escritorio', lo mismo que ocurre con los casos registrados en el $C D H$, una de un artículo del $A B C$ de 1983 y otro de una obra del periodista y escritor argentino Ernesto Ekaizer, en los tres casos mantiene el significado aumentativo.

\section{ESCARPETA [hescarpeta]}

Esta palabra no aparece registrada en ningún diccionario académico. Aparece en el diccionario no académico de Rosal en el que remite a escarpín 'tapiz para los pies' (NTLLE, s. v. escarpeta, Rosal, 1611).

Una escarpeta dada en seis reales salamanquesa (Sahagún, LE-1600)

Una antepuerta que es una escarpeta viexa (Sahagún, LE-1603)

Una hescarpeta de lino y lana (Grajal de Campos, LE-1655)

Dos escarpetas de bufete grandes de colores y lavores (Grajal de Campos, LE-1656)

Dos escarpetas de lana de colores (Grajal de Campos, LE-1656)

Una hescarpeta de colores nueba (Grajal de Campos, LE-1670)

Una escarpeta buena un poco desgajada (Frechilla, PA-1639) 
Un cobertor de cama colorado traydo y una escarpeta (Guaza de Campos, PA-1640)

Una escarpeta buena çamorana (Villada, PA-1665)

Una escarpeta nueva (Villalón, VA-1638)

Tampoco aparece esta voz en bases académicas como el CDH o el CORDE. Se trata de un vulgarismo, tiene el mismo significado que carpeta. En el CorLexIn presenta una escasa nómina de casos repartidos entre La Rioja, Palencia y Burgos, zona norteña que se acerca a Tierra de Campos.

Cejador y Frauca señala en su obra escarpeta y carpeta en una misma entrada, igualando los dos términos y remitiendo a la definición dada por Rosal (1611) 'tapiz para los pies' (Cejador, 1912: 442).

\section{ESTERA}

Sust. f. 'Tejido grueso de esparto, juncos, palma, etc., o formado por varias pleitas cosidas, que sirve para cubrir el suelo de las habitaciones y para otros usos' (DLE). Palabra recogida por Nebrija y Covarrubias con el significado con el que aparece en los textos (NTLLE, s. v. estera, Nebrija, 1495; Covarrubias, 1611). Término procedente del lat. STORĔA, de donde *estuera y luego estera (DECH, s. v. estera).

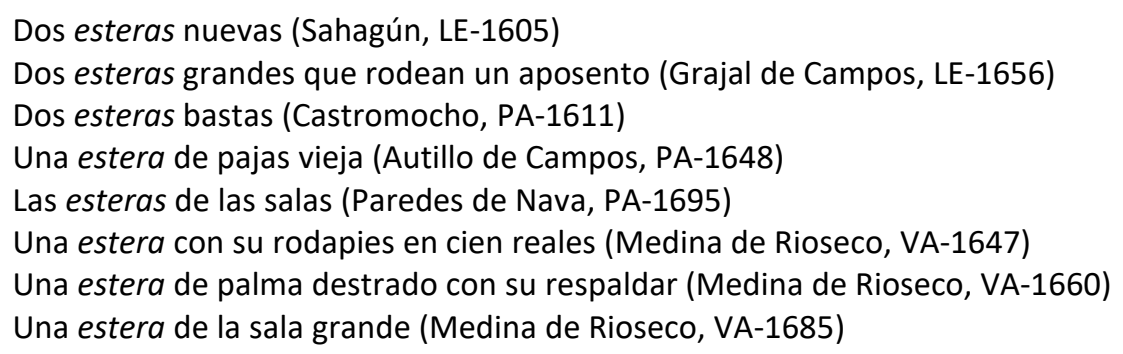

Es un término de uso general que, aunque presenta una distribución diatópica muy amplia -Península, Canarias y algunos casos en textos americanos-, hay una preferencia por este término en las provincias andaluzas que son las que presentan un mayor número de ocurrencias (CorLexIn). En la Tierra de Campos aparece documentada en las relaciones de bienes, aunque es más frecuente encontrar el térmio alfombra y sus variantes poligráficas.

En estudios dialectales actuales se recoge el término con diferentes acepciones, por ejemplo, en zonas de Palencia se define como 'especie de felpudo grande o chupabarros para limpiar los zapatos, que se hacía de paja de respadañas y para limpiarlo se golpeaba' (Gordaliza, 1988: 106). Estera también se localiza en zonas del leonés con el significado de 'tejido de paja para cubrir la colmena y evitar que las abejas piquen al que se acerca a ellas' (Le Men, 2005, s. v. estera).

En nuestro corpus figura la forma esterado, en este caso, como sustantivo, no como participio del verbo esterar. Se localiza en inventarios de bienes de Sahagún:

Dos paños de manos uno roto con su esterado (Sahagún, LE-1605)

un paño de manos labrado de esterado bueno (Sahagún, LE-1601) 
Se trata de un complemento o género textil que acompaña a los paños de manos, pero tampoco podemos dar más detalles. El témino aparece en el Universal vocabulario en latín y romance de Alfonso de Palencia, fechado en 1490, en este caso como participio:

[...] es otrosi stratos lecho fecho enel suelo quasi esterado. enestos tales se acostauan los antiguos.

De la docena de concordancias que presenta el CORDE, solo tres hacen referencia a un sustantivo, y todos fechados a partir de finales del siglo xIX. Tanto en los casos de participio como de sustantivo, siempre tiene que ver con un tipo de tejido grueso con el que se cubre el suelo. Significado que no corresponde totalmente al encontrado en la Tierra de Campos.

Esterado lo registran obras lexicográficas como la de Palet, Oudín, Vittori o Franciosini entre otros vocabularios preacadémicos. También lo registra Autoridades como participio del verbo esterar, algo que se mantiene hasta la edición de 1822, a partir de aquí, no se recoge en el diccionario académico (NTLLE, s. v. estarado, Palet, 1604; Oudin, 1607; Vittori, 1609; Franciosini, 1620; Autoridades, 1732 y DRAE, 1822).

En cuanto a la morfología derivativa, el diminutivo que aparece en la documentación terracampina, poco o nada tiene que ver con el significado que aquí se estudia:

Una pollera de damasco negro con una hesterilla (Grajal de Campos, LE-1658)

Otra pollera de senpiterna encarnada con una esterilla de oro (Grajal de Campos, LE-1658)

Otro guardapies de bayeta encarnada con esterilla de oro (Grajal de Campos, LE-1658)

En este contexto, el diminutivo esterilla designa un tipo de adorno de la pollera o el guardapiés.

\section{BASTIDOR [vastidor, uastidor]}

Sust. m. 'Armazón que sirve para fijar, encajar o soportar algo como un lienzo, una tela, un cristal de una ventana, etc.' (DLE). Covarrubias recoge esta palabra como 'dos perchas con sus hembras en que se embastan las orillas de lo que se ha de bordar, con qué está la tela tirante para poderla bordar, o labrar con aguja'. En Autoridades este vocablo aparece también como 'la armazón hecha de quatro palos, ó listónes de madéra, en quadro, ù prolongados, que sirve para poner y fijar los lienzos para pintar [...]' (NTLLE, s. v. bastidor, Covarrubias, 1611; Autoridades, 1726). Palabra procedente de bastir, del oc. bastir y este del germ. *bastjan 'tejer, trenzar' (DECH, s. v. bastir).

Un quadro pequeño em bastidor, con la echura de Christo Nuestro Bien y San Franzisco (Valderas, LE-1682)

Una echura de Santiago otra de San Andrés todas en bastidor (Frechilla, PA-1640)

Una echura de Santa Clara en vastidor (Villada, PA-1665)

Quatro estanpas en bastidor de diferentes pinturas (Paredes de Nava, PA-1690)

Una tabla en bastidor de Nuestra Señora de la Contenplación (Medina de Rioseco, VA-1657)

Otro [lienzo] en uastidor de San Enofre (Medina de Rioseco, VA-1657)

Otra echura de la birjen del Carmen pequeña en vastidor (Medina de Rioseco, VA-1661)

Cinco damisselas en vastidor mediano (Villalpando, ZA-1686)

Un cuadro pintura de san Joseph en bastidor mediano (Villalpando, ZA-1688)

Una pintura de un cardenal en vastidor (Villalpando, ZA-1688) 
EI $C D H$ documenta esta voz a la segunda mitad del siglo XIII, en la novela que lleva por título La donzella Teodor datada en 1250, aunque las copias que se conservan son de los siglos XV y XVI. EI CORDE localiza esta voz en el Vocabulario eclesiástico de Rodrigo Fernández de Santaella fechado en 1499.

Desde una perspectiva diatópica y atendiendo a los documentos notariales del siglo XVII, esta lexía presenta un número importante de casos en el CorLexın, con una distribución geográfica amplia.

En cuanto al significado que presenta suele ser el de 'armazón para bordar o pintar', tan solo encontramos un caso en Sahagún donde aparece inventariado junto a "vna mesa de quatro pies" (1601).

\section{CUADRO [quadro]}

Sust. m. 'Composición pictórica desarrollada sobre lienzo, madera, papel, etc., generalmente enmarcada.' (DLE, 3. a ac.). Autoridades recoge esta acepción y hasta el DRAE de 1803 mantiene la variante quadro (NTLLE, s. v. cuadro, quadro, Autoridades, 1737; DRAE, 1803). Se trata de un término derivado del lat. QUADRUM (DECH, s. v. cuadro).

Un quadro de pinçel en lienço de la ymaxen de Nuestra Señora con el niño dormido, con su marco dorado (Valderas, LE-1647)

Quatro quadros con sus marcos los dos de la figura de Nuestro Señor y el otro de Nuestra Señora de las Angustias y el otro de san Xerónimo (Grajal de Campos, LE-1658)

Un quadro con la pintura de San Miguel (Autillo de Campos, PA-1653)

Quatro quadros de ymájenes más pequeños (Villada, PA-1665)

Otro cuadro de la magdalena con marco pequeño en ocho reales (Frechilla, PA-1675)

Un quadro de nuestra señora con san Joseph (Villarramiel, PA-1690)

Otro quadro grande de san Juan de Saagún con marco dorado (Medina de Rioseco, VA-1640)

Doce emperadores antiguos con sus cuadros y marcos viexos (Villalón, VA-1642)

Zinco cuadros de Flandes ya usados todos ello con sus marcos (Villalpando, ZA-1629)

Un quadro de un Santo Christo (Villalobos, ZA-1654)

Cuatro cuadros con sus marcos (Villalpando, ZA-1666)

Tres quadros hordinarios con diferentes pinturas (Tapioles, ZA-1688)

Es una palabra de uso general con el significado de 'cuadrado', todo aquello que tiene esta forma. El DECH da como fecha de primera documentación el siglo x. Las primeras concordancias que ofrece el $C D H$ están fechadas en el siglo XIII, aludiendo a un tipo de 'terreno' y que también encontramos en algunos textos asturianos del CorLexIn: "vn quadro que está dentro de la llosa de Mateo de Fuentes en la llosa del Ponteyo, en Granda, que será mediodía del bueys pequeño, en doçe ducados (Sebreño, 1640); "junto a esto de arriba, vn quadro de prado que será el terçio de día de bueys", "vn quadro de heredad que llebaba Juan dela Bara, que será medio día de bueys" (Ribadesella, 1599).

El significado más común en la documentación notarial del CorLexIn y del corpus terracampino es el de 'composición pictórica'. Ocasionalmente referencia al marco que rodea la obra artística, aunque es más frecuente encontrar el término marco:

Vn lienso de la ma-[...]a con su quadro de madera[...] negro (Cuzco, Perú, 1670) 
Vn quadro de madera todo pintado, en él, el Naçimiento, de madera también, andado (Herrera de Pisuerga, PA-1700)

En cuanto a los términos derivados, tan solo localizamos el diminutivo con el sufijo -ico:

Quatro quadricos el uno de un niño Jesus de peregrino y los tres de estampas paganos (Cuenca de Campos, VA-1666)

\section{ESTAMPA [estanpa, estanpica]}

Sust. f. 'Reproducción de un dibujo, pintura, fotografía, etc., trasladada al papel o a otra materia, por medio del tórculo o prensa, desde la lámina de metal o madera en que está grabada, o desde la piedra litográfica en que está dibujada' (DLE). Covarrubias recoge esta voz como 'la escritura, o dibuxo que se imprime, con la inuencion de la imprenta [...]' y Autoridades matiza que este dibujo se elabora mediante 'torno, con molde ò lámina gravada ò abierta à buril' (NTLLE, s. v. estampa, Covarrubias, 1611; Autoridades, 1732). Témino derivado de estampar, procedente del germánico, probablemente del francés estamper, antiguamente 'machacar', 'aplastar', y este del fráncico *stampôn (DECH, s. v. estampar).

Tres estanpas de papel (Cea, LE-1621)

Otra estanpa de la echura de Cristo Nuestro Señor con la cruz a cuestas, pareçe ser de papelón (Valderas, LE-1647)

Vna estanpa de vna Berónica (Valderas, LE-1647)

Una estampa de la pintura de santa Catalina (Grajal de Campos, LE-1670)

Una estampa de papel (Frechilla, PA-1631)

Una estampa de la Resurreçión en su tabla (Guaza de Campos, PA-1640)

Una estampa sin marco, pintura de san Telmo (Paredes de Nava, PA-1690)

Una estampa mediana de las de Valladoli (Villarramiel, PA-1691)

Una cruzitica y dos estampas (Villalón, VA-1637)

Ocho láminas y estanpas pequeñas (Medina de Rioseco, VA-1643)

Tres estampas de ymagenes viejas guarnesçidas en marcos, la una de san Gerónimo, la otra, de santo Antonio y, la otra, de papel (Villalpando, ZA-1620)

Una estampa de Nuestra Señora de las Angustias (Villalpando, PA-1639)

Una estampa de la Concepción (Villalpando, ZA-1653)

Dos estampas de diferentes pinturas en bastidor (Villalpando, ZA-1688)

El DECH da como primera documentación de esta palabra la obra de Garcilaso de la Vega. Las bases de datos académicas adelantan unos años la presencia de esta voz, ya que la localizan en la Égloga de Plácida y Vitoriano de Juan del Encina, fechada en 1513. En el siglo XVII tanto el CORDE como el $C D H$ registran un importante número de concordancias. Esta palabra estaba generalizada en la época. Es un término de uso general.

Si atendemos a la morfología derivacional, tan solo encontramos un ejemplo de diminutivo en el corpus estudiado, donde la motivación es puramente semántica:

Vna estanpica con la pintura de Nuestra Señora y su Hixo (Autillo de Campos, PA-1654)

\section{LÁMINA}

Sust. f. 'figura trasladada al papel u otra materia' (DLE, 4. ac.). Covarrubias recoge el término como 'la plancha de algun metal oro, plata, y los demás' referenciando el molde para hacer 
determinados dibujos o pinturas. Autoridades, además de la acepción dada por Covarrubias, añade 'la pintura hecha sobre plancha de cobre' y 'la pintura fina y de figúras, que se pone en los abanicos' (NTLLE, s. v. lámina, Covarrubias, 1611; Autoridades, 1734). Voz procedente del lat. LAMǏNA 'hoja o plancha de metal' ( $D E C H$, s. v. lámina).

Dos láminas (Villada, PA-1669)

Tres láminas pequeñas con bidrieras de cuarta de alto otras dos láminas sin bidriera (Paredes de Nava, PA-1690)

Una estanpa con unas láminas (Paredes de Nava, PA-1695)

Ocho láminas y estanpas pequeñas (Medina de Rioseco, VA-1643)

Un dosel de cañamaça con sus láminas y un Santo Cristo (Medina de Rioseco, VA-1657)

Dos piezas de vronze pequeñas con sus láminas (Medina de Rioseco, VA-1660)

Dos láminas pequeñas con sus bidrieras y marco negro (Villalpando, ZA-1688)

Una lámina de Roma pequeña (Villalpando, ZA-1688)

Tres láminas enzima de la puerta de la Sacristia pintadas sobre cobre, las dos con marcos negros de peral y la de el medio un marquito dorado (Villalpando, ZA-1696)

Junto a las estampas es muy habitual encontrar inventariadas láminas como se puede obsevar en alguno de los asientos mostrados. Es una palabra de uso general que presenta diferentes significados en los textos, aunque en el corpus estudiado referencia principalmente un dibujo o pintura trasladada al papel u otras materias. El término se registra a partir de la segunda mitad del siglo XIII tanto en el CORDE como en el CDH. Los datos que nos proporciona el CorLexIn presentan un mayor número de items que en el caso de estampa, y un ámbito geográfico de uso más extenso, encontramos esta voz en documentos peninsulares, canarios y americanos. En Tierra de Campos es más habitual el término estampa, aunque lámina también está presente en los documentos.

Como ocurre con cuadro y estampa, la presencia de términos derivados es más bien escasa $\mathrm{y}$, los pocos ejemplos registrados, presentan el sufijo diminutivo -ico/-ica:

Dos laminicas con sus marcos (Valderas, LE-1682)

\section{PAís [payses]}

Sust. m. 'Paisaje (pintura o dibujo)' (DLE, 5.a ac.), el diccionario académico señala esta acepción como poco usada. Esta acepción se recoge desde Autoridades: 'la pintúra en que están pintados, Villas, Lugares, fortalezas, casas de campo y campañas', la edición del DRAE de 1780 agrega 'pintase en lienzos mas anchos que altos, para que comprehendiendo mas horizonte se puedan variar mas los objetos', lo que dota a estos países de una forma reconocible para inventariarlos. La edición manual del 1984 señala el término como poco usado (NTLLE, s. v. país, Autoridades, 1737; DRAE, 1780; Diccionario manual e ilustrado de la lengua española, 1984). Palabra procedente del lat. vulgar PAGENSIS, que pasó al francés como pays, en sentido de 'territorio rural' y después 'comarca' (DECH, s. v. pago).

Dos países en bastidor, el uno de San Juan y el otro de San Mateo, de cinco quartas de alto y una de ancho (Paredes de Nava, PA-1690)

Ocho lienços de payses con figuras de la cassa de Austria pequeños (Medina de Rioseco, VA1644)

Quatro países medianos y onçe países de diferentes pinturas mui pequeños thasado todo en sesenta reales (Medina de Rioseco, VA-1645) 
Un país de verduras (Medina de Rioseco, VA-1647)

Seis payses de berduras y ermitaños (Medina de Rioseco, VA-1649)

Ocho países grandes de diferentes pinturas sin marcos de abarca y quartar (Medina de Rioseco, VA-1671)

Tres payses indiferentes pinturas de ermitaños con sus marcos negros en que entra una de un niño de Nápoles, con su marco negro cada país (Medina de Rioseco, VA-1685)

Dentro de los enseres dedicados a la decoración de paredes están los llamados países, ubicados dentro del campo semántico de los cuadros, las pinturas, los lienzos o las tablas de pintura. Aparecen en la documentación terracampina en inventarios procedentes, principalmente, de la localidad de Medina de Rioseco. Y lejos de representar un paisaje o alguna escena de la historia de algún país, es común encontrarlos en las relaciones de bienes representando santos o reyes, aunque también verduras como ocurre en algunas de las ocurrencias de Tierra de Campos. Desde una perspectiva diatópica, el CorLexIn muestra un ámbito geográfico de uso extenso, repartido entre la Península, Canarias y América. De hecho, el $D E C H$ señala la generalización del término y su popularización en América. Desde 1597 aparece documentado en Góngora (Perdiguero, 2014: 153). El CDH documenta en la Crónica burlesca del emperador Carlos V, obra de Francés de Zúñiga (1525), un ejemplo que menciona "país de lança" referenciando un tipo de ornamentación con algún retrato.

\section{REPOSTERO [ripostero, reposterico]}

Sust. m. 'Paño cuadrado o rectangular, con emblemas heráldicos' ( $D L E$, 4.a ac.). Nebrija recoge esta lexía en su Vocabulario como 'lo que se tiende'; Covarrubias lo define como 'un paño quadrado con las armas del señor que se pone sobre las acemilas [...]. Repostero de plata y repostero de estrado'. Autoridades afirma que, además de ponerlo sobre las cargas de las acémilas, también sirve 'para colgar en las antecámaras' (NTLLE, s. v. repostero, Nebrija, 1495; Covarrubias, 1611; Autoridades, 1737). Término procedente del lat. *REPOSITARIUS derivado de PŌNĚRE (DECH, s. v. poner).

Un repostero biexo de retazos (Joara, LE-1603)

Un repostero de colores biejo (Castroañe, LE-1609)

Un repostero nuevo de lana de colores (San Nicolás del Real Camino, LE-1631)

Un repostero de colorado y amarillo con un escudo en el medio nuebo (Arenillas, LE-1636)

Un cielo de cama y un reposero de pared tasados en diez reales (Mazariegos, PA-1619)

Un repostero traydo amarillo y colorado con un castillo en el medio apreciado (Frechilla, PA-1612)

Un repostero con unas pajarillas (Frechilla, PA-1640)

Un repostero con armas de un león en medio (Paredes de Nava, PA-1690)

Dos reposteros biejos de Salamanca (Medina de Rioseco, VA-1649)

Dos reposteros de colores (Medina de Rioseco, VA-1661)

Un repostero con un escudo que tiene el sol y la luna (Cuenca de Campos, VA-1666)

Un repostero de poial con unos escudos tasado en treinta reales (Cuenca de Campos, VA-1670)

Un repostero de lana y pelotes en onçe reales (Villalpando, ZA-1600)

Un repostero y una alfonbra (Villalpando, ZA-1650)

Dos reposteros viexos (Cotanes del Monte, ZA-1687)

Otro repostero en otra cozina (Villalpando, ZA-1697)

Repostero, con el significado de 'en los palacios de los antiguos reyes y señores, encargado del orden y custodia de los objetos pertenecientes a un ramo de servicio, como el de cama, de 
estrado, etc.' ( $D L E, 2$. a ac.), se documenta de forma temprana, la documentación medieval da buena cuenta de ello y así lo encontramos desde el siglo XI en el CORDE.

Con la acepción que nos ocupa en este estudio, el CDH y el CORDE localizan en la Crónica de Juan II de Castilla, fechada en 1406 el siguiente ejemplo: "e como yban las más de las azémilas con reposteros colorados", donde el significado se acerca más a un elemento textil. En la Historia General y natural de las Indias de Gonzalo Fernández de Oviedo fechada en 1535, repostero aparece como un elemento de tapicería, más próximo a los ejemplos localizados en Tierra de Campos:

[...] mandó a los indios que le hiciesen cierta tapicería e reposteros, con sus armas, de oro e plata e lanas tan finísimas como seda [...]

Se certifica su uso regularizado hasta el siglo XVII, a partir de este su presencia en la documentación decrece considerablemente.

Restringiendo la búsqueda a la documentación notarial del siglo XVII, el CorLexIn nos ofrece medio centenar de ocurrencias repartidas entre documentos peninsulares y americanos. El uso está generalizado en la Tierra de Campos y el significado que suele presentar es el aquí estudiado.

Desde una perpectiva formal, se documenta de forma excepcional la variante con cambio de timbre con el cierre de la vocal /e/ en /i/ (Morala, 2012a: 562):

Un ripostero nuevo (Cea, LE-1621)

En cuanto a la morfología derivacional, la única forma que aparece para el diminutivo es el sufijo -ico que además de una motivación semántica de tamaño, parece redundar también en la calidad del objeto inventariado:

Un reposterico viexo (Sahagún, LE-1600)

Otra manta biexa y un reposterico listado muy biexo (Valderas, LE-1647)

Un reposterico viejo roto de lana de colores de modo de tapiz (Villalpando, ZA-1620)

\section{TAPIZ [tapizillo]}

Sust. m. 'Paño grande, tejido con lana o seda, y algunas veces con oro y plata, en el que se copian cuadros y sirve de paramento' (DLE). Covarrubias remite a la entrada tapar, vocablo del que también derivan palabras como tapete, muy próximo al tapiz. Autoridades amplía de manera significativa la definición 'texido fabricado de lana, seda, y algunas veces de hilo de oro, en que se figura un passo de historia, ù monteria, el qual se hace, poniendo el dibuxo debaxo, y labrando por él las imágenes, ò figuras con los adornos, colores, y matices correspondientes' (NTLLE, s. v. tapiz, Covarrubias, 1611; Autoridades, 1739). Término procendente del fr. ant. tapiz, 'tapiz', 'tapete', 'alfombra', y este del griego bizantino tapíti, diminutivo del griego tápes, -ētos (DECH, s. v. tapiz).

Tres paños de pared, el uno tapiz y el tapiz en quatro ducados y los otros en ducado y medio (Sahagún, LE-1602)

Un tapiz de pared no se tasa por lo mismo (Cea, LE-1626)

Un tapiz grande (Frechilla, PA-1640)

Otro tapiz de lana listado (Frechilla, PA-1640) 
Un tapiz con las armas de un león (Frechilla, PA-1639)

Dos tapiçes de diferentes figuras grandes buenos (Paredes de Nava, PA-1690)

Quatro tapiçes, dos grandes y uno de berduras y otro de figuras y los dos pequeños de figuras

(Castromocho, PA-1611)

Tres tapices de figuras y verduras diferentes (Medina de Rioseco, VA-1649)

Seis tapices hordinarios de la Victoria de Salomón (Medina de Rioseco, VA-1644)

Un tapiz biejo con un león en medio de cobres encorados (Villalpando, ZA-1601)

Dos tapizes buenos de boscaje de lana fina y labores tassados ambos en zien ducados con dos Quatro tapiçes uiejos o resposte[ros] (Villalobos, ZA-1654)

Dos tapizes en la alcoba (Villalpando, ZA-1697)

Desde una perspectiva diacrónica, tapiz se documenta en las bases textuales del español a partir de la Sevillana medicina de Juan de Aviñón, fechada en1381:

[...] encortinen la casa con mucho paño y peñas y tapices \& camas de cocedras de pluma [...]

Sin embargo, la presencia de este vocablo no se generaliza en los textos hasta unos siglos después. A partir del siglo XVI comienzan a documentarse de forma tímida las primeras concordancias en textos americanos, y será a partir de la segunda mitad del siglo XIX cuando se refleje un uso mayoritario de esta lexía.

En el CorLexIn se localizan otros vocablos y sintagmas que podrían sustituir esta voz como "paño de pared", "repostero" o el propio "tapete" como señala el DECH. En cuanto a la distribución geográfica, presenta una preferencia de uso en la mitad norte de la Península.

En el corpus terracampino, aparecen "tapices de boscaje", el término boscaje lo reconoce el $D L E$ como 'cuadro o tapiz que representa un paisaje poblado de árboles, matorrales y animales'. Este sintagma aparece también en documentos de Madrid y Toledo junto a tapices y paños:

Tres paños françesesde boscaje y vn alombra grande (Toledo, 1616)

Otros seis paños de tapiçes de lana, que son de boscaxe (Madrid, 1649)

Çinco tapiçes que son de boscaxe, que son ya traídos (Madrid, 1649)

Desde una perspectiva formal, no es habitual encotrar derivados de este término, en Tierra de Campos localizamos un único ejemplo de diminutivo en -illo:

Dos tapizes buenos de boscaje de lana fina y labores tassados ambos en zien ducados con dos almuadas de tapizillo mismo (Villalpando, ZA-1620)

\subsubsection{Iluminación}

\section{HACHERO [achero]}

Sust. m. 'Candelero o blandón que sirve para poner el hacha de cera' (DLE). Covarrubias registra esta palabra en su Tesoro como 'el candelero donde se pone el hacha' (NTLLE, s. v. hachero, Covarrubias, 1611). Término derivado de hacha 'antorcha' que procede de una alteración del lat. FACŬLA 'antorcha pequeña' (DECH, s. v. hacha I).

Dos acheros blancos con sus arandelas (Medina de Rioseco, VA-1651) 
El ejemplo localizado en el corpus terracampino pertenece al inventario de una iglesia de Medina de Rioseco (Valladolid). No es un término frecuente en los documentos estudiados, algo también apreciable en el resto de documentación notarial que configura el CorLexIn.

En trabajos dialectales más actuales se mantiene esta voz como 'artefacto de madera en que se colocan las velas y blandones para alumbrar a los difuntos de cada familia' en zonas del leonés como Murias de Paredes, Riaño, Valencia de Don Juan y Tierra de Campos (Le Men, 2007, s. v. hachero). Asimismo, en Palencia encontramos hachero como especie de 'estanterías con dos tablas agujereadas al efecto, para colocar en ellas las hachas de las sepulturas' (Gordaliza, 1988: 121).

\section{ARAÑA}

Sust. f. 'Lámpara de techo con varios brazos, de los que cuelgan piezas de cristal, sueltas o enlazadas, de diversas formas' (DLE, 4. a ac.). Autoridades define araña como 'espécie de lámpara fabricada de metál, de madera, vidro, ò crystál, en que se ponen muchas luces. Díxose aráña por la semejanza y figúra que tiene con la aráña quando está extendida' (NTLLE, s. v. araña, Autoridades, 1726). Término procedente del lat. aranĕa 'telaraña', 'araña' (DECH, s. v. araña).

Dos arañas de plata pequeñas, quebrada la una (Medina de Rioseco, VA-1651)

Tan solo encontramos un ejemplo en Tierra de Campos, araña, que aparece inventariada junto a candelero, pero no podemos asegurar que su significado se pueda identificar con el de lámpara, podría referenciar un objeto de decoración. No contamos con ningún ejemplo en el CorLexIn. Aunque cabe señalar que Autoridades ya registra este término con la acepción de 'lámpara en que se ponen muchas luces'.

\section{BUJíA [buxía, vuxía]}

Sust. f. 'vela (pieza de cera para alumbrar)', 'palmatoria (candelero bajo)', este último significado en desuso ( $D L E, 1$. a y 4 . a ac.). Terreros registra por primera vez esta palabra en 1786 como 'vela pequeña de cera blanca' y 'se suele tomar por el mismo candelero en que está'. El primer diccionario académico que lo recoge es el DRAE de 1837 con las acepciones vistas (NTLLE, s. v. bujía, Terreros y Pando, 1786; DRAE, 1837). Es un término procedente del ár. vulg. buğîia, ár.clás. buğâya, nombre de la ciudad africana de Bujía, de donde se traía la cera (DECH, s. v. bujía).

Dos bujías de latón nuevas (Valderas, LE-1682)

Seis bujías de latón buenas (Valderas, LE-1682)

Una bujía de latón digo de azófar (Villada, PA-1668)

Quatro buxías (Paredes de Nava, PA-1690)

Dos buxías la una ochabada y la otra quadrada (Boadilla de Rioseco, PA-1692)

Dos bujías (Medina de Rioseco, VA-1657)

Otros candeleros vuxías (Medina de Rioseco, VA-1671)

Un candelero buxía nuebo (Tamariz de Campos, VA-1652)

Dos candeleros bujías (Medina de Rioseco, VA-1661)

Seis bujías de açófar ochauadas (Medina de Rioseco, VA-1685),

Una buxía y un candelero (Tapioles, ZA-1688)

Tres buxías (Villalpando, ZA-1689)

Dos buxías de metal (Villalpando, ZA-1696) 
Bujía se registra de forma tardía en los textos. El CORDE y el $C D H$ presentan las primeras documentaciones de esta voz en Romances, obra de Góngora datada en 1580. Los datos que ofrece el CorLexIn no presentan un patrón de reparto claro, un poco más de una veintena de ocurrencias repartidas en diferentes puntos de la Península, sin casos en Canarias o América. El número de casos fechados en la segunda mitad del siglo es significativamente mayor que los que se documentan principios de siglo. Por todo ello, parece tratarse de un vocablo de nueva adquisición que poco a poco va incrementando su presencia en los textos. Lo mismo ocurre con los ejemplos localizados en la Tierra de Campos, donde todos los ejemplos pertenecen a la mitad del siglo XVII. Por regla general encontramos bujía inventariada junto al material del que está hecha -latón, metal o azófar-, en este caso, bujía referencia el objeto donde se coloca la vela. Pero también encontramos bujía con una naturaleza adjetiva, al lado de candelero, posiblemente para definir el tipo de vela o cera del que se disponía -candeleros bujías (Medina de Rioseco)- y que se repite en otras provincias como Vizcaya, Guipúzcoa, Soria o Badajoz (CorLexIn).

\section{CALDERUELA [caldiruela]}

Sust. f. palabra en desuso que referencia una 'vasija en que los cazadores nocturnos llevaban la luz para encandilar y deslumbrar a las perdices, que huyendo de ella caían en la red' (DLE). Autoridades recoge el significado que se ha mantenido a lo largo de las ediciones académicas y advierte que 'Covarrubias la llama Calderilla, pero que segun el uso de los cazadores se dice Calderuéla'. Término derivado de caldo, del antiguo adjetivo caldo 'caliente' y éste del lat. CALǏDUS íd. (DECH, s. v. caldo).

Una caldiruela de cobre pequeña en un real (Fechilla, PA-1612)

A pesar de su presencia en las obras lexicográficas, la falta de testimonios en la documentación del castellano es evidente. Los datos que nos ofrecen tanto el CORDE como el $\mathrm{CDH}$ muestran un escaso número de concordancias, todas ellas datadas entre los siglos XV y XVII y no llegando a la veintena de ejemplos. La primera documentación que encontramos al respecto en el $C D H$ data de 1462, en el Arancel de precios y salarios de Cuenca, donde figura "una calderuela pequeña para pastores [...]", en referencia a un instrumento que sirve para iluminar a los pastores. Sin embargo, en el Libro de acuerdos del Concejo Madrileño fechado en 1464 , se mantiene el significado académico, como instrumento que servía para deslumbrar a las perdices $u$ otras aves por la noche y cazarlas:

Este día, mandaron los dichos corregidor e rregidores que todos los que anduuieren a caça con bueytres o bueytrón o rredes tiraderas con dos leguas en derredor, o calderuela, que pierdan los aparejos e paguen seisçientos maravedís de pena por cada vez [...]

Hay documentos donde calderuela tiene un significado que no aparece en el diccionario académico y que está más próximo al de recipiente que forma parte de la vajilla. Por ejemplo, en las Cuentas de Gonzalo de Baeza, tesorero de Isabel la Católica (1477), figura el término calderuela junto a los de escudillas, salsera o copas: "vna calderuela de plata de copela blanca, para tener agua, con su asa labrada de unas rrocas [...]" o "vna calderuela de plata para beuer agua $[\ldots] "$. 
Todos los casos pertenecientes a documentos del siglo XVII se localizan en obras literarias como La Celestina u obras técnicas como el Arte de Ballestería y Montería (1644).

La falta de ejemplos en documentos notariales se trasvasa al CorLexIn, donde no aparecen ocurrencias de esta voz. La zona terracampina ofrece un único caso de esta lexía, que formalmente presenta un cambio de timbre en la vocal átona por la inestabilidad fónica provocada por la presencia de la [w] en el diptongo de la sílaba tónica (Morala, 2012a: 560). El contexto en el que figura este término no proporciona datos suficientes para saber exactamente su significado, ya que se encuentra entre un plato de peltre y un candelero.

\section{CANDELERO}

Sust. m. 'Utensilio que sirve para mantener derecha la vela o candela, y consiste en un cilindro hueco unido a un pie por una barreta o columnilla', 'velón' (DEL, 1. a y 2. ac.). Nebrija y Covarrubias recogen esta voz como 'el asiento en que se pone la candela' (NTLLE, s. v. candelero, Nebrija, 1495; Covarrubias, 1611). Es un término derivado de candela, del lat. CANDÉLA 'vela de luz', derivado de CANDĒRE 'arder' ( $D E C H$, s. v. candela).

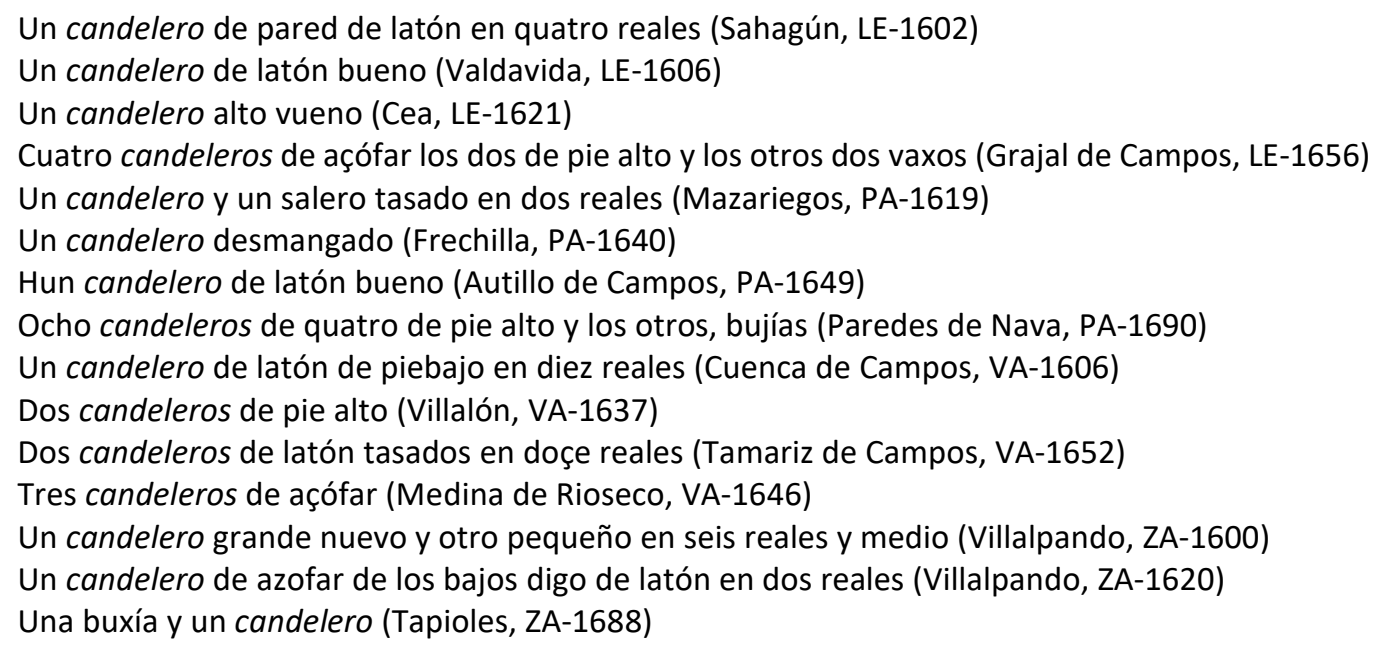

Desde una perspectiva diacrónica, del CDH documenta esta voz en La fazienda de Ultra Mar fechado en el 1200. Si restringimos la búsqueda a los inventarios del siglo XVII, observamos que se trata de un término con una distribución diatópica de carácter general. Por esto, es frecuente en la documentación de Tierra de Campos. El corpus terracampino presenta la variante candilero fruto de la disimilación de la /e/ átona que se cierra en /i/ (Morala, 2012a: 562):

Un candilero de latón vueno (Sahagún, LE-1615)

\section{CANDIL [candilete]}

Sust. m. 'Utensilio para alumbrar, dotado de un recipiente de aceite y torcida y una varilla con gancho para colgarlo' (DLE). Se recoge de forma temprana en las obras lexicográficas, Nebrija lo incluye en su Vocabulario, Covarrubias ya incluye la definición que ha perdurado hasta hoy sin cambios significativos. Autoridades, aunque mantiene el mismo significado, amplia la definición: 'especie de velón con una asa arriba para poderle colgar, el qual tiene sus mecheros par poner 
torcidas, y echarle el azéite: Los hai de várias echúras, y los usan mucho en las casas de trato para darlas luz de noche, y poder vender cada uno de sus géneros' (NTLLE, s. v. candil, Nebrija, 1495; Covarrubias, 1611; Autoridades, 1729). Término procedente del ar. qandîl, 'lámpara' del lat. CANDĒLA 'vela' (DECH, s. v. vela).

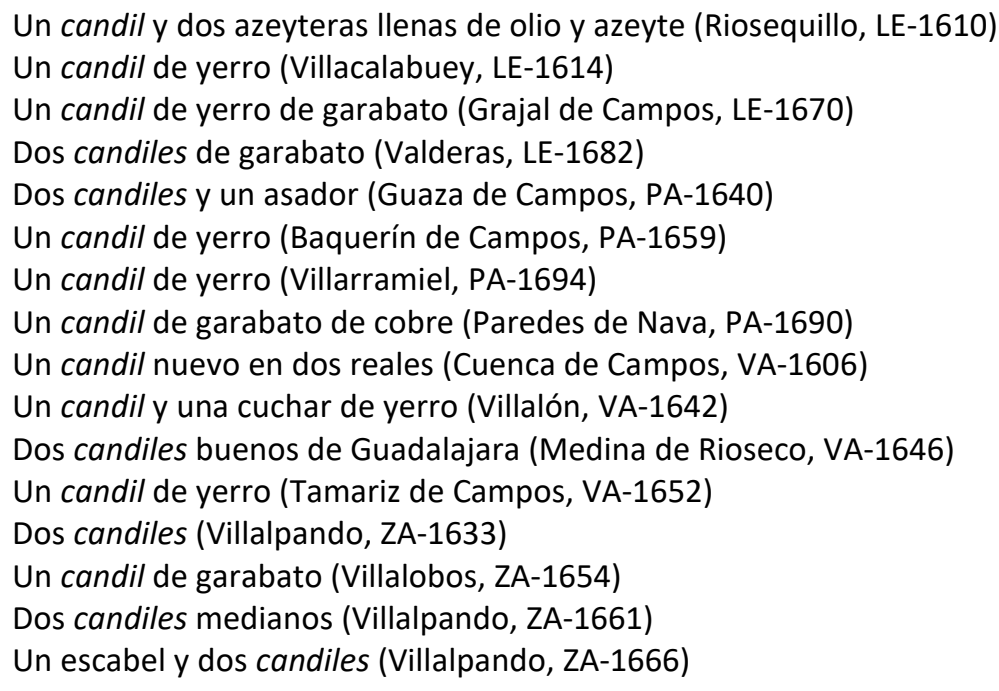

Esta voz la recoge el CORDE y el $C D H$ a mediados del siglo XIV, en la obra Sumas de la historia troyana de Leomarte fechada en 1350. La palabra presenta una distribución diatópica de carácter general en la Península, según los datos que nos ofrece el CorLexIn. Su presencia en los textos canarios y americanos es más esporádica.

Formado por derivación figura el término candiletes, con el sufijo -ete, posiblemente con motivación apreciativa:

Dos candiletes de garabato (Medina de Rioseco, VA-1657)

\section{CIRIO}

Sust. m. 'Vela de cera, larga y gruesa' (DEL). Covarrubias registra este término como 'candela cerea, candela de cera gruessa, y redonda, y de vn pavilo, segun el vso. Cirial, el candelero donde se pone el cirio' (NTLLE, s. v. cirio, Covarubias, 1611). Palabra procedente del término latino CĒRĔUs 'de cera', 'cirio', derivado del lat. CĒRĔUs 'de cera' (DECH, s. v. cirio).

Veinte y seis piezas de cirios gruesos grandes y pequeños (Medina de Rioseco, VA-1651) Veinte y tres cirios de a bara de largo (Medina de Rioseco, VA-1651)

Aunque Covarrubias registra esta palabra, no solo como un tipo de vela determinado, sino también como el candelero que lo sustenta -esto también ocurría con la voz bujía-, en el corpus estudiado tan solo lo encontramos como 'un tipo de vela'. En el CorLexIn presenta una escasa nómina repartida por de forma esporádica, pero abarcando un territorio amplio. En Tierra de Campos solo encontramos un par de ejemplos en un mismo inventario vallisoletano donde se enumera la relación de bienes de una iglesia. Por regla general, esta voz suele encontrarse en pertenencias sacras de iglesias, capillas o de gente pudiente. Tal vez esta especificidad del término haga que figueren menos ocurrencias en la documentación notarial, ya que este se 
documenta de forma temprana en los textos que configuran los corpus del castellano -el $C D H$ documenta esta voz en 1223-.

\section{LÁMPARA [lánpara]}

Sust. f. 'Utensilio o aparato que, colgado o sostenido sobre un pie, sirve de soporte a una o varias luces artificiales', 'utensilio para dar luz, que consta de uno o varios mecheros con un depósito para la materia combustible, cuando es líquida, o de una boquilla en que se quema un gas' (DLE). Nebrija recoge esta voz en su obra lexicográfica, por su parte Covarrubias le da el significado de 'vidro hondo lleno de azeite dentro del qual arde vna mecha trauada en vna redecilla que llaman mechero' (NTLLE, s. v. lámpara, Nebrija, 1495; Covarrubias, 1611). Término procedente del lat. LAMPĂDA, acusativo de LAMPAS, -ADIS 'antorcha' (DECH, s. v. lámpara).

Una lámpara de latón (Medina de Rioseco, VA-1651)

Otra lánpara grande de plata (Medina de Rioseco, VA-1651)

Una lámpara de el oratorio de açofar (Medina de Rioseco, VA-1685)

Las primeras documentaciones de esta voz aparecen en el siglo XIII con las variantes lámpara y lámpada que se alternan en los textos hasta mediados del siglo XIV, fecha en la que lámpada comienza a aparecer de manera más esporádica. Esta frecuencia del término en la documentación en los corpus académicos contrasta con lo que encontramos en el CorLexIn, donde apenas aparecen ejemplos de lámpara en la Península -en Álava y Jaén-. Las ocurrencias son más frecuentes en los textos americanos donde se localiza esta lexía en Bolivia, Chile y Guatemala. El corpus terracampino ofrece un escaso abanico de casos, todos ellos procedentes de la localidad vallisoletana de Medina de Rioseco y siempre con un uso eclesiástico, que propició la difusión del término ( $D E C H$, s. v. lámpara).

En el campo morfológico nos encontramos con el sufijo diminutivo -illa en un ejemplo con el significado que aquí barajamos:

Una lamparilla de vidrio (Frechilla, PA-1675)

El término lamparilla lexicalizado referencia un tipo de tela que se ha estudiado en el apartado correspondiente al apartado 7.3 dedicado al Textil.

\section{LINTERNA}

Sust. f. 'Farol portátil con una sola cara de vidrio y un asa en la opuesta' (DLE). Autoridades describe perfectamente este objeto en su definición: 'instrumento formado de planchas ó láminas de hierro, hoja de lata ú otra materia, con una ó mas ventanillas, en que se ponen vidros ú hojas transparentes de madera del áire, y en la parte superior tien una cubierta como de chiminéa, y encerrada en ella la luz sale el humo por arriba, y alumbra al que camina de noche. Hacense de diferentes figúras, ya redondas a modo de torrecilla, o ya cuadradas' (NTLLE, s. v. linterna, Autoridades, 1734). Palabra tomada del lat. LANTĚRNA, con /-i-/ por influjo de interna (por estar la luz, en las linternas, encerrada) (DECH, s. v. linterna). 


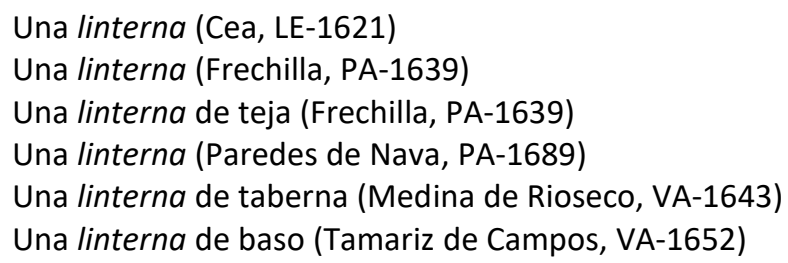

El $C D H$ señala como primera documentación de esta palabra la variante lenterna, -con alteración del timbre de la vocal átona- en La fazienda de Ultramar de Almerich fechada en el inicio del siglo XIII. Para la variante procedente del latín lanterna hay que esperar a la segunda mitad de este siglo, concretamente a 1260 en una obra religiosa. Linterna no aparece hasta la primera mitad del siglo $\mathrm{XV}$, a partir de esta fecha comienza a ser habitual en los textos en detrimento de las variantes lenterna y lanterna, más esporádicas en la documentación a partir de entonces. Los datos recabados en el CorLexIn nos presentan una distribución geográfica amplia. El corpus terracampino presenta media docena de casos de esta voz con la acepción académica, tan solo hay un caso en Paredes de Nava donde podríamos tener ciertas dudas, ya que aparece inventariado entre lienzos, pero el contexto no nos permite asegurarlo, ya que el contexto no nos da la información suficiente. En relaciones de bienes vallisoletas encontramos "linterna de taberna" y "linterna de baso", posiblemente haga referencia a la forma, la función o el material del que está hecho.

\section{MECHERO}

Sust. $m$. 'En el candil o velón, cañutillo donde se pone la mecha para alumbrar o para encender lumbre', 'cañón de los candeleros, en donde se coloca la vela' (DEL, 2. y 3.a ac.). En Nebrija aparece como 'mechero de candil', Covarrubias registra el término como 'el cañutillo del candil en que se inxiere la mecha, y en la lámpara el que se sustenta sobre unos corchuelos' (NTLLE, s. v. mechero, Nebrija, 1495; Covarrubias, 1611). Término derivado de mecha, común con el portugués, y probablemente tomada del fr. meche en fecha antigua ( $D E C H$, s. v. mecha).

Un belón de tres mecheros (Villalpando, ZA-1696)

La documentación revisada de Tierra de Campos nos ofrece un único ejemplo de esta voz con el significado académico. La consulta en el CorLexIn presenta un término de uso general tanto en la Península como en América.

\section{VELA [bela]}

Sust. f. 'Pieza generalmente cilíndrica o prismática y de cera o parafina, con un pabilo en su eje y que se utiliza para alumbrar' (DLE, 8. a ac.). Las obras lexicográficas del NTLLE recogen el término desde Nebrija. Covarrubias en primera instancia la define como 'la candela que arde, quasi vegela, a vigilando, porque nos da luz de noche para vela y no dormirnos. Esta es, o de cera, o de sebo. Los Antiguos gastauan aceyte, y su luz se llamaua lucerna a luce [...]', en Autoridades, con este significado, figura en la séptima entrada (NTLLE, s. v. vela, Nebrija, 1495; Covarrubias, 1611; Autoridades, 1739). Palabra derivada de velar 'estar sin dormir', del lat. VĬĞLARE (DECH, s. v. velar). 
Una vela de zera de un quarterón (Riosequillo, LE-1610)

Nueve belas de sevo, ochenta y cinco maravedís (Fechilla PA-1675)

Dos belas con sus espadillas (Medina de Rioseco, VA-1649)

Tres libras de belas de sebo (Cuenca de Campos, VA-1668)

Seis doçenas de belas de sebo (Villalpando, ZA-1661)

Una bela (Villalpando, ZA-1670)

Es un término de uso general. Se documenta de forma temprana, a partir del siglo XIII en bases textuales académicas como el $C D H$ y el CORDE. En el siglo XVII esta voz presenta un uso general en los inventarios. Esta vela podía ser de cera o de sebo según lo que se ve en los ejemplos del corpus estudiado.

\section{VELADOR [belador, veladorcillo, beladorzico]}

Sust. m. 'Candelero, regularmente de madera' (DEL, 4.a ac.). Derivado de velar, del lat. vॉ̆ĞLĀRE $(D E C H$, s. v. velar). Entre otros significados, Autoridades recoge esta acepción que se mantiene casi igual hasta la edición actual (NTLLE, s. v. velador, Autoridades, 1739). Término derivado de velar, del lat. VĬĞLARE $(D E C H$, s. v. velar).

Una espada biexa y un velador de yerro en real e medio (Sahagún, 1600)

Un belador de madera (Sahagún, LE-1603)

Dos beladores de madera (Valderas, LE-1647)

Un velador de seis pies (Grajal de Campos, LE-1658)

Un belador de nogal pequeño (Paredes de Nava, PA-1690)

Un belador de pino de pie y la tabla de enzima de nogal biejo (Medina de Rioseco, VA-1640)

Un belador de açofar (Medina de Rioseco, VA-1644)

Un velador de pino (Medina de Rioseco, VA-1641)

Un belador de nogal bueno (Villalpando, ZA-1620)

Vn belador de nogal (Villalobos, ZA-1654)

El $C D H$ registra velador como 'el que vela' en el siglo XIII, con el sufijo deverbal -dor procente del sufijo activo -tore del latín. A finales de este mismo siglo, aparecen en los textos "veladores de madera" en sentido figurado. El CorLexIn recoge esta palabra como objeto inventariable generalizado en la Península. Los veladores que se localizan en Tierra de Campos suelen ser "de madera" (nogal, pino), aunque se encuentra alguno de "açófar".

El diccionario académico incorpora a partir de la edición de 1817 la acepción de 'mesita en que se coloca la luz para alumbrarse las personas que trabajan de noche'.

Desde un punto de vista morfológico, aparece el diminutivo bajo dos sufijos diferentes, pero con un mismo significado:

Un veladorcillo de nogal (Paredes de Nava, PA-1690)

Un beladorzico de nogal cuadrado (Medina de Rioseco, VA-1640)

Un belardocillo de nogal en que estauan el escritorio y arquilla (Villalpando, ZA-1629)

En el CorLexIn encontramos una ocurrencia en Villamuñío, localidad muy cercana a nuetra zona de estudio que ofrece información sobre la función de este objeto:

Vn veladorçico para poner candeleros, de madera. (Villamuñío, LE-1633) 


\section{VELÓN [belón]}

Sust. f. 'lámpara de metal para aceite común compuesta de un vaso con uno o varios picos o mecheros, y de un eje en que puede girar, subir y bajar, terminado por arriba en un asa y por abajo en un pie, por lo general de forma de platillo' (DLE, 2. a ac.). Ni Nebrija, ni Covarrubias dan cuenta de este término en sus respectivas obras. Es Autoridades quien recoge el término como 'instrumento para las luces de azeite. Es un vaso en figura redonda (que llaman cebolla) con una, dos, ò mas narices, que llaman mecheros, colocado en una vara, ù espiga con su pie. Hacense de diversos metales, y en varias formas, ù figuras. Llamóse assi, porque se vela à su luz', definición que se ha mantenido sin cambios significativos hasta la edición actual (NTLLE, s. v. velón, Autoridades, 1739). Lexía derivada de velar, del lat. v̆̌̆L̆LĀRE (DECH, s. v. velar).

Un belón grande de candeleros con tres caños (Paredes de Nava, PA-1690)

Un belón de açofar, diez ducados (Medina de Rioseco, VA-1645)

Un belón de açófar de quatro luces (Medina de Rioseco, VA-1640)

Un belón de dos mechas (Medina de Rioseco, VA-1671)

Un belón mediano sin pantalla (Cotanes del Monte, ZA-1687)

Un belón de tres mecheros (Villalpando, ZA-1696)

Como aumentativo de vela figura en una obra de Cristóbal de Villalón fechada en 1553: "[...] ençima una pirámide llena de velones y hachas de çera blanca [...]" y en 1608 en una Carta de pago: "dos candeleros de azofar e un velon, en cinco ducados". El uso mayoritario del término se registra a partir del siglo XIX en el CORDE y el $C D H$, lo que nos hace pensar que en el siglo XVII era una palabra que comenzaba a afianzarse en el acervo léxico. El CorLexIn presenta una preferencia del término en la zona meridional de la Península y Canarias. El corpus terracampino documenta media docena de casos repartidas por las provincias de Palencia, Valladolid y Zamora. 


\subsection{MOBILIARIO Y ACCESORIOS}

\section{ALACENA [alazena, alaçena, lacena, lazena]}

Sust. f. 'Armario, generalmente empotrado, con puertas y estantes, donde se guardan diversos objetos' (DLE). Covarrubias recoge alhacena como 'ventana cerrada cauada en la pared con sus puertas para guardar dentro vidros e vasos, confituras, y otros regalos', también posee entrada para este término con la grafía alacena 'vale en Arabigo ventana atacada en la pared, y en Cordoua la llaman por esta razón taca'. La edición de 1726 de Autoridades recoge el término alhazena con el mismo significado, aunque añade que '[...] se hacen alhazénas protátiles todas de madera, como escaparates ò almarios'; en la siguiente edición, el lema que figura para esta voz es alacena (NTLLE, s. v. alhacena, Covarrubias, 1611; Autoridades, 1726, 1770). Término procedente del ár. ḩazâna 'armario', 'aparador', 'librería', de la misma raíz que la palabra almacén (DECH, s. v. alacena)

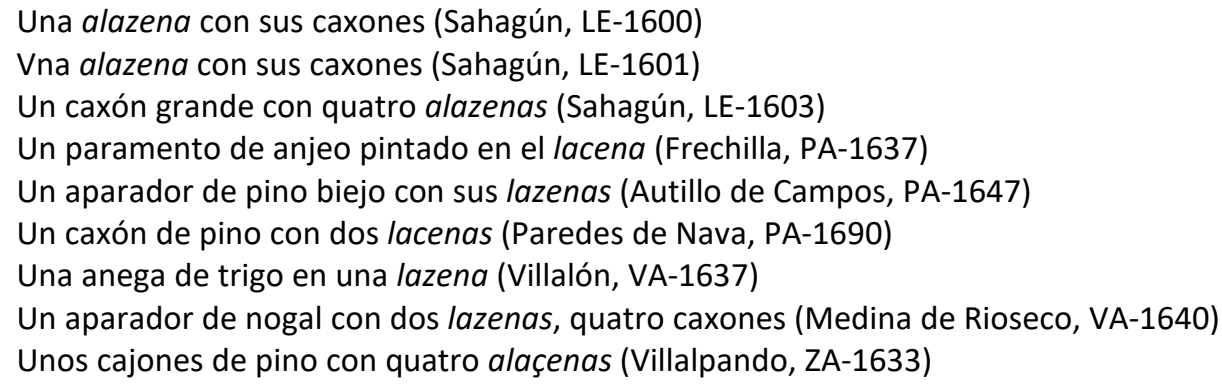

Desde un punto de vista diacrónico, el $C D H$ nos muestra diferentes variantes de este término, así bajo la forma alfazena aparece en La facienda de Ultra Mar, obra fechada en el siglo XIII. Con la forma alhazena figura a partir del siglo XV en la Biblia Alba con el significado de 'ventana o celda'. Alacena la documentan tanto el CORDE como el CDH en el siglo XVI, en las Epístolas familiares de Fray Antonio de Guevara, fechadas en 1521. Por las aportaciones de estos corpus, el término alacena en el siglo XVII tiene un uso consolidado.

El CorLexIn presenta una distribución diatópica general. En Tierra de Campos se recogen una decena de casos que además de hacer referencia a un tipo de armario, también figura como parte de un mueble mayor. Este corpus presenta una vacilación de uso entre las formas alacena y lacena con aféresis de la $a$. No encontramos casos de esta variante con este significado en las bases académicas como el CORDE y el $C D H$. Tampoco hay ocurrencias en el CorLexIn. Algo que contrasta con el corpus objeto de estudio, ya que la mitad de los ejemplos encontrados figuran con esta aféresis inicial.

Cabe destacar que lacena se recoge en las obras lexicográficas académicas de forma tardía, a partir de la edición de 1925.

En trabajos lexicográficos más modernos sí que figura esta variable. Le Men documenta el uso de lacena en Galicia, Asturias, Navarra, León, Palencia, Zamora, Salamanca, Jaén, Andalucía 
y Canarias (Le men, 2002, s. v. alacena). Gordaliza señala que esta aféresis inicial es un fenómeno fonético habitual que sufren muchas otras palabras (Gordaliza, 1988: 133).

\section{APARADOR}

Sust. m. 'Mueble donde se guarda o contiene lo necesario para el servicio de la mesa' (DLE). Nebrija recoge el término en su Vocabulario como un tipo de armario para guardar vasos y también vestidos. Para Covarrubias es la 'credencia, o mesa donde estan las vagillas para el seruicio, y las mesmas pieças de oro y plata se llaman todas juntas aparador'. Autoridades mantiene la definición de Covarrubias y añade que 'llámase también así el que se pone en las Iglesias para el servicio del altar', aunque también recuerda las definiciones dadas por Nebrija (NTLLE, s. v. aparador, Nebrija, 1495; Covarrubias, 1611; Autoridades, 1726). Término derivado de parar, del lat. PARARE 'preparar', 'disponer' (DECH, s. v. parar).

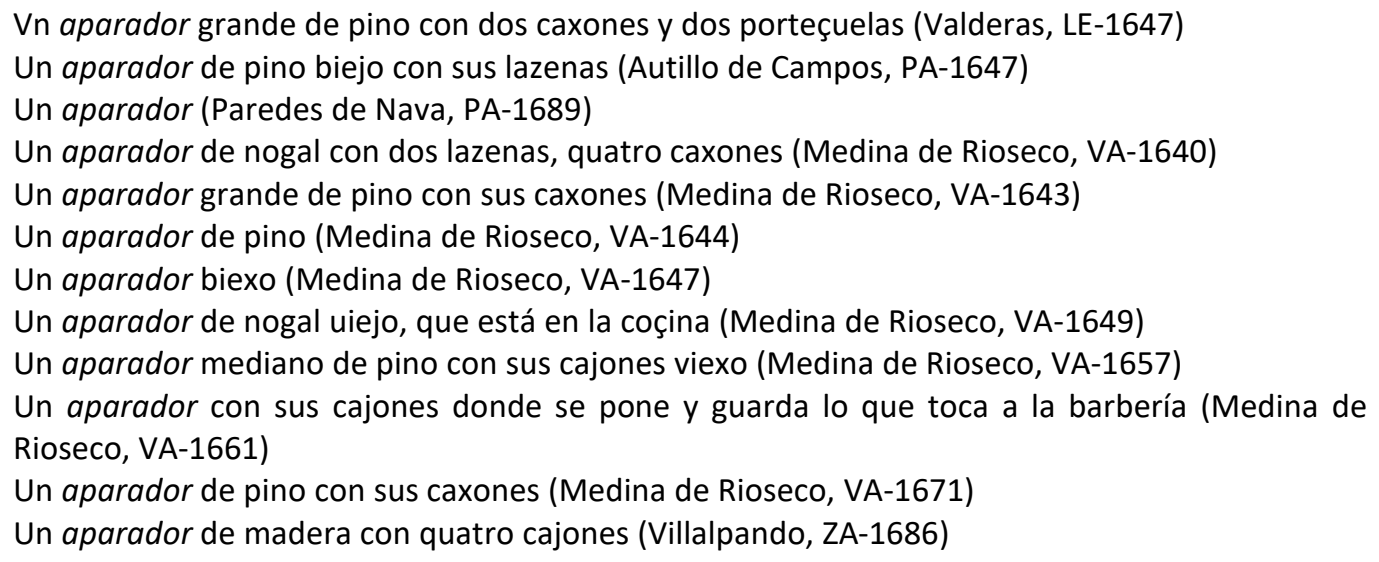

Esta palabra figura en los corpus del castellano pasada la primera mitad del siglo XV. Este término referencia un tipo de armario que tenía diferentes funciones y así lo refleja la documentación, donde podemos encontrar aparadores para guardar vestidos, paños, la plata, la vajilla e incluso alimentos.

Respecto a su presencia en los documentos notariales del siglo XVII, el CorLexIn facilita un número representativo de casos repartido por un amplio ámbito geográfico. Este uso generalizado se refleja también en la Tierra de Campos. Formalmente estamos ante un término formado por derivación, por el prefijo a y el sufijo -dor, fórmula muy utilizada en esta época para la formación de nuevas palabras.

\section{ARCA [harca]}

Sust. f. 'Caja, comúnmente de madera sin forrar y con tapa llana que aseguran varios goznes o bisagras por uno de los lados, y uno o más candados o cerraduras por el opuesto' (DLE). Aparece registrada en los repertorios lexicográficos desde Nebrija. Covarrubias define esta voz como 'la caxa grande con cerradura' (NTLLE, s. v. arca, Nebrija, 1495; Covarrubias, 1611). Término procedente del lat. ARCA (DECH, s. v. arca).

Una arca de nogal pequeña (Celada, LE-1600)

Una arca de pino nueba con cerradura y llave (Galleguillos, LE-1618) 
Una harca de pandilla bieja (Villadiego, LE-1627)

Una arca de nogal buena con su çerradura y llaue, cantoneras y aldabones (Arenillas, LE-1636)

Una harca de pino vieja del pan, con su cerradura y llaue (Grajal de Campos, LE-1658)

Dos harcas de espadilla biejas apreçiadas en tres reales (Frechilla, PA-1614)

Una arca de aya biexa de tener pan [...] con llave (Mazariegos, PA-1619)

Otro harca de pino pequeño con llave cerradura en doce reales (Frechilla, PA-1671)

Una arca de castaño mediada con cerradura y llaue (Villarramiel, PA-1696)

Una arca de nogal vuena (Villalón, VA-1637)

Una arca en que se hecha la limosna con tres zerraduras (Medina de Rioseco, VA-1651)

Otra arca biexa de quatro pies grande de pino (Tamariz de Campos, VA-1652)

Una arca de pino con llave y cerradura (Cuenca de Campos, VA-1666)

Una arca de nogal con su zerradura y llabe sin aber dentro della cosa alguna (Villalpando, ZA1660)

Una arca de pino con zeradura y llave y en ella nada (Villalpando, ZA-1690)

Una arca con su zerradura y llaue donde está la ropa blanca (Villalpando, ZA-1696)

Este término es común en toda la documentación, notarial o no. En el $C D H$ y el CORDE figura en el Cantar de Mío Cid en el año 1140 con la acepción que aquí encontramos. Así mismo, en los inventarios de bienes del siglo XVII documentan esta lexía a lo largo y ancho de toda la Península y Canarias, aunque su presencia es menor en los documentos procedentes de América (CorLexIn). Se trata pues de un elemento básico del mobiliario que comparte campo léxico con baúles, cofres y arcaces. Habitualmente el escribano suele especificar de qué material está hecho -pino, pandilla, nogal, haya o castaño- $y$, en algunas ocasiones también nos aclara su función: "para tener el pan", "en la que se echa la limosna", "donde está la ropa blanca" o bien pone en el documento lo que hay dentro de ella. Estas arcas también presentan accesorios como cantoneras, aldabas y aldabones, pies o barrotes entre otros.

Formalmente aparecen dos diminutivos - arquita y arquilla-presentes en los inventarios de la Tierra de Campos:

Una harquilla de nogal en diez y ocho reales (Grajal de Campos, LE-1658)

Una arquilla pequeña con zerradura y llaue (Villada, PA-1669)

Una arquilla pequeña de nogal (Paredes de Nava, PA-1690)

Una arquilla pequeña (Villalón, VA-1637)

Una arquilla quadrada de nogal biexa (Medina de Rioseco, VA-1647)

Un arquita de nogal pequeña (Medina de Rioseco, VA-1661)

Una arquita pequeña de pino para el pan (Villalpando, ZA-1652)

Una arquita pequeña de nogal con su zerradura y llaue (Villapando, ZA-1688)

Un arquita pequeña de bender bino con çerradura y llabe (Villalpando, ZA-1689)

Una arquilla pequeña bareteada y en ella un capillo de espumilla (Villalpando, ZA-1690)

En estos ejemplos, ambas variantes parecen hacer referencia al tamaño menor del arca. Los determinantes que acompañan a la forma genérica arca y a los derivados arquita y arquilla, vacilan entre las formas de masculino y femenino. Llama la atención que el diminutivo vaya acompañado en la mayoría de las ocasiones del adjetivo pequeño, lo que podría reflejar el grado de lexicalización de la forma derivada ya que el escribano necesita justificar de alguna manera el valor económico (Perdiguero, 2015a: 1568-1569). 


\section{ARCAZ [harcaz, arquezico, arcazico, harcaçes, harcadejo, arcaçexo, harcaçeses]}

Autoridades recoge este término como 'el arca grande. Es como aumentativo de arca', en la siguiente edición se señala que corresponde al aumentativo de arca y añade que es 'lo mismo que arcón, que es como hoy se dice', también añade como acepción que se le da en Aragón al 'escaño ò andas en que llevan à los difuntos à enterrar' (NTLLE, s. v. arcaz, Autoridades, 1726 y 1770). Término derivado de arca, del lat. ARCA (DECH, s. v. arca).

Una arcazico de pino pequeño (Sahagún, LE-1600)

Dos arcaces viexos (Sahagún, LE-1600)

Otro arcaz de nogal sin cerradura tasado en seis reales (Sahagún, LE-1605)

Un arcaz de pino (Sahagún, LE-1601)

Un arquezico sin zerradura (Sahagún, LE-1608)

Un arcazico de pino (Sahagún, LE-1608)

Un arcacico quebrado sin tapadero (Castroañe, LE-1637)

Un arcaz de pino uiexo (Villemar, PA-1608)

Un arcaz de castaño bueno con su llaue y cerradura apreçiado en doçe reales (Frechilla, PA-1612)

Un arcaz de nogal con tapador de pino (Frechilla, PA-1612)

Un harcaz de pino biejo con llaue (Frechilla, PA-1642)

Tres harcaçes uno nuevo y dos biejos (Frechilla, PA-1642)

Dos harcaçeses, uno nuevo sin llabe, ni çerradura y el otro biejo con cerradura y sin llabe de pino (Fechilla PA-1613)

Desde una perspectiva diacrónica, el CORDE y el $C D H$ registran el uso mayoritario de esta voz en las primeras décadas del siglo XVII. Como primera documentación, el CORDE recoge el término en un inventario navarro fechado en 1329. A partir del siglo XVII, tan solo se documenta algún caso esporádico en obras literarias del siglo xx.

Por los datos que aporta el CorLexIn podemos decir que estamos ante una voz de carácter general. En cuanto al significado de este término parece coincidir con el dado por Autoridades, ya que en muchas ocasiones le acompaña el adjetivo grande.

En Tierra de Campos aparece este término -a veces con / $\mathrm{h}-/$ - con la acepción descrita anteriormente y con variantes derivadas como los diminutivos arcacico o arquezico, esta última con cierre de la vocal átona, y que solo encontramos en esta zona. Además de la variante académica arcaces para formar el plural, nos encontramos con arcaceses, donde parece que el escribano acumula dos desinencias para expresar plural.

En la zona palentina de la Tierra de Campos se localiza el siguiente término, que tampoco localizamos en el CorLexIn, ni en la documentación de las bases de datos académicas.

Un arcaçexo con çerradura (Guaza de Campos, PA-1639)

Un arcadejo de pino más pequeño con llave y cerradura (Frechilla, PA-1631)

\section{ARQUETA}

Sust. f. 'Arca o caja pequeña, hecha con materiales nobles, en la que se guardan reliquias, tesoros u otros objetos de valor' (DLE, 2.a ac.). Nebrija registra arqueta como 'arca pequeña'. Autoridades mantiene este significado y lo equipara a la voz arquita (NTLLE, s. v. arqueta, Nebrija, 1495; Autoridades, 1726). Término derivado de arca, del lat. ARCA (DECH, s. v. arca). 
Una arqueta forrada en baqueta de Moscouia con su çerradura y llaue (Medina de Rioseco, VA1645)

Dos arquetas de nogal, una de vender bino (Villalpando, ZA-1644)

Una arqueta mediana para el pan con cerradura y llave (Villalpando, ZA-1654)

Una arqueta pequeña con zerradura y llaue (Villalpando, ZA-1686)

Quatro reales en una arqueta de nogal pequeña, zerradura y llaue (Villalpando, ZA-1688)

Una arqueta vaxa de madera sin zerradura ni llave (Villalpando, ZA-1689)

Solo aparece un ejemplo en el CorLexIn que coincide con el de Medina de Rioseco del corpus estudiado, esto puede deberse a que comparte campo semántico con todos los diminutivos de arca. En el $C D H$ se documenta desde el siglo XIII y en estos primeros años hay vacilación de género "el arqueta", "la arqueta", posiblemente por la sílaba inicial, como ocurre con el término del que deriva, arca. En el siglo XVI hay mucha presencia de este término con esta acepción, pero en el siglo XVII solo cinco casos, parece que arqueta entra en desuso con este significado. En Tierra de Campos se localiza en Villalpando y en menor medida en Medina de Rioseco.

\section{ARQUETÓN}

Sust. m. Autoridades lo recoge como 'aumentativo de arca. El arca grande, que se hace para guardar ropa, dinero y otras cosas'; en la siguiente edición se recoge como aumentativo de arqueta (NTLLE, s. v. arquetón, Autoridades, 1726, 1770). Voz derivada de arca, del lat. ARCA $(D E C H$, s. v. arca).

Dos arquetones biejos (Paredes de Nava, PA-1689)

Un arquetón (Medina de Rioseco, VA-1647)

Un arquetón biexo de pino (Medina de Rioseco, VA-1648)

Un arquetón de pandilla en ocho reales (Villalpando, ZA-1606)

Es un término poco documentado en el CORDE y el $C D H$ y la mayoría de los ejemplos pertenecen al siglo XVII. Tan solo se localiza una ocurrencia en el CorLexIn en Alaejos (Valladolid). Los ejemplos que nos proporcionan los inventarios de la Tierra de Campos no dan la información suficiente como para saber si estaban destinados a un fin determinado o es simplemente una arqueta de un tamaño mayor.

\section{ARQUIMESA [arcamesa, arcamessa, harcamesa]}

El DLE recoge la forma arquimesa para 'mueble con tablero de mesa y varios compartimentos o cajones'. Autoridades lo describe como 'papeléra al modo de los caxones ò escritorios de las Secretarías, que caída, ò baxada la tapa forma una mesa capáz de comer en ella', además señala que se trata de una voz 'usada en Aragón', la notación geográfica se mantiene hasta el DRAE de 1869 (NTLLE, s. v. arquimesa, Autoridades, 1726; DRAE, 1864). Palabra compuesta.

Una arcamesa de pino (Sahagún, LE-1601)

Una arcamesa de pino grande con su zerradura y llabe (Sahagún, LE-1601)

Una arcamesa de aya nueva (Santa María del Río, LE-1617)

Una harcamesa de pino faltosa de un pie, sin cerradura y llabe (Grajal de Campos, LE-1655)

Una arcamessa de pino vieja (Grajal de Campos, LE-1671)

Una arcamesa con su llaue y cerradura (Frechilla, PA-1612)

Un arcamesa de pino con su caxón mediada (Autillo de Campos, PA-1647)

Una arcamessa de pino con su cerradura y llave (Paredes de Nava, PA-1689) 
Una arcamesa vieja sin llave ni cerradura en ocho reales (Cuenca de Campos, VA-1666)

Una arcamesa con llabe y zerradura (Villalpando, ZA-1644)

En Tierra de Campos se localiza la forma arcamesa en los inventarios de bienes para hacer referencia a un mueble que posiblemente se corresponda con la acepción que da Autoridades para arquimesa.

El uso de la variante arcamesa es escasa en la documentación histórica del español. Si se restringe la búsqueda a los archivos notariales del siglo XVII, el CorLexIn presenta una escasa nómina de casos del resultado arcamesa. A los casos señalados en esta base académica -Ávila, Palencia y Soria- debemos añadir los localizados en inventarios burgaleses (Perdiguero, 2012c: 1558), Valladolid ${ }^{12}$, Álava (Perez Toral, 2015a: 144, nota 6), Cantabria (Morala, 2018b: 220), y los encontrados en la Tierra de Campos, donde este término es frecuente. A pesar de la notación diatópica que señala Autoridades, parece que su uso se extendería a la mitad norte de la Península como lo demuestran los ejemplos localizados. La variante académica arquimesa es menos frecuente en la documentación en general.

\section{AZUFRADOR [açufrador]}

Sust. m. 'Aparato con que se azufraban las vides atacadas por el oídio', 'enjugador (camilla para secar la ropa)' (DLE, 2. y y 3.- ac.). Aparece en Autoridades como 'instrumento de madéra hecho de unas tablas pequeñas angostas à manéra de costillas en figúra de una jáula grande algo alta, sobre el qual se tiende la ropa blanca, para que se enxugue, por lo que tambien se llama enxugadór. Y porque se suele en él sahumar la ropa con azufre, para que se ponga blanca, se dixo azufradór'. En Terreros y Pando este término tiene que ver con las manufacturas de lanas y lo define como 'una estufa pequeña, bien cerrada, para que se blanquée la lana con el humo de azufre, que se quema para este efecto' y señala que en España para este fin utilizan el tendedero común o las varas. En la edición de 1884 del diccionario académico figura una nueva acepción para este término 'instrumento ó aparato con que se azufran las vides atacadas del oídium' (NTLLE, s. v. azufrador, Autoridades, 1726, Terreros y Pando, 1786, DRAE, 1884). Es una voz derivada de azufre, del lat. SŬLPHŬR (DECH, s. v. azufre).

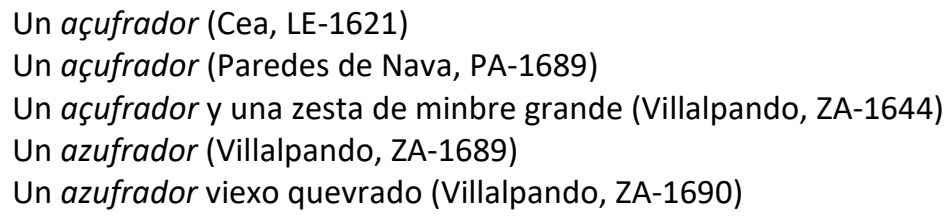

Este término se documenta a principios del siglo XVI en bases de datos como el CORDE y el $C D H$, pero su presencia es escasa en estas fuentes. Esto contrasta con los ejemplos que encontramos en el CorLexIn donde se localiza esta voz en diferentes puntos de la Península. En Tierra de Campos se localizan unas cuantas ocurrencias de este término, aunque la información

\footnotetext{
12 Rojo Vega localiza ocurrencias de esta lexía en los protocolos vallisoletanos, en su mayoría fechadas en el siglo XVI. Estos textos se pueden consultar en la página web Investigadores de la Real Biblioteca, https://investigadoresrb.patrimonionacional.es/.
} 
que ofrecen los textos no es muy esclarecedora sobre el significado de la misma. Morala, por su parte, amplía el abanico de ocurrencias a zonas de La Rioja, Segovia, Guadalajara, Palencia y Valladolid, lo que muestra que era un término más común de lo que a priori puede parecer en aquella época, $y$, además, localiza ejemplos donde se pone de manifiesto la función de dicho objeto: "un azufrador para secar balonas" o "un brasero para secar ropa con su azofrador" (Morala, 2015a: 1507). En la zona de estudio aparece la forma azufrador o açufrador.

\section{BANCA [vanca, uanca, banquilla]}

Sust. f. 'Asiento de madera, sin respaldo y a modo de mesa baja' o 'cajón donde se colocaban las lavanderas para lavar la ropa' (DLE, 1. a y 7. a ac.). Covarrubias recoge este vocablo como 'el asiento de palo sin espaldar para sentarse'. Autoridades recoge los dos significados del DLE (NTLLE, s. v. banca, Covarrubias, 1611; Autoridades, 1726). Es un término derivado de banco, procedente del germ. bank (DECH, s. v. banco).

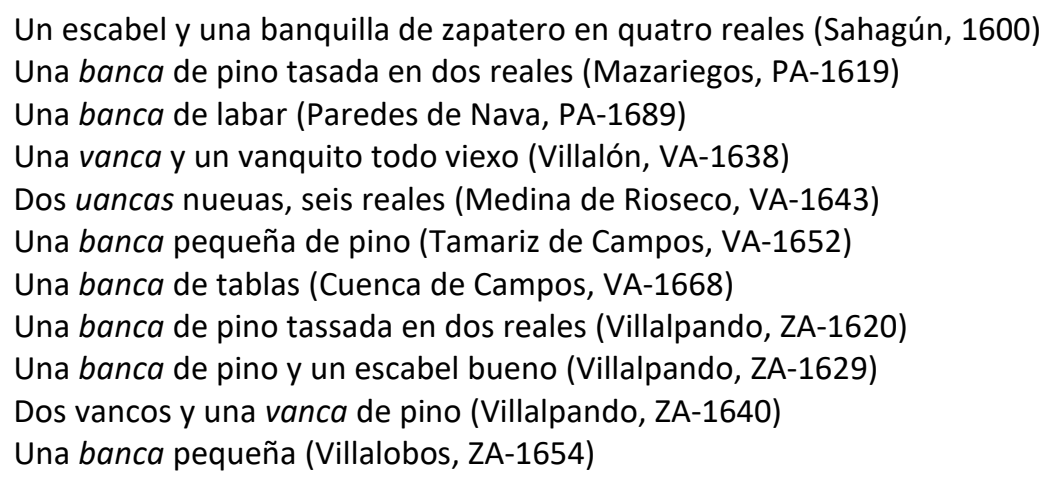

El $C D H$ y el CORDE documentan esta voz a principios del siglo $\mathrm{xV}$, aunque no es muy frecuente en los textos del siglo XVII. Sin embargo, en los protocolos de este siglo, este término presenta un uso generalizado, aunque hay que señalar que no tiene tanta presencia como el masculino banco. En el corpus de Tierra de Campos, el contexto no es lo suficientemente claro como para saber exactamente a qué se refiere el escribano, tan solo en el ejemplo de Paredes de Nava nos aclara que servía para lavar. En el resto de los ejemplos se hace mención al material con el que estaba hecha -de pino la mayoría de las veces- y el tamaño. Se encuentra referenciada junto a bancos, banquitos o escabeles, lo que denota que guarda alguna diferencia con estos.

Repertorios léxicos más actuales recogen esta palabra como 'cajón o tabla de lavar en el río. También banco, banquilla, lavadera, redondel, rodillero, taja, tajo' (Gordaliza, 1988: 41) o como 'asiento pequeño sin respaldo, con un agujero en el centro para poder cogerla más fácilmente introduciendo un dedo por el agujero. También se llama banqueta' en la localidad terracampina de Villada (Casas 1989: 526).

Formalmente podemos encontrar en los inventarios los diminutivos de este término con dos variantes banquilla y banquita, esta última más escasa en los textos de Tierra de Campos:

Vn escabel y una banquilla de zapatero, en quatro reales (Sahagún, LE-1601)

Una banquilla redonda de tres pies viexa (Sahagún, LE-1624)

Vna banquita biexa (Valderas, LE-1647) 
Una banquita de labar paños (Valderas, LE-1682)

Un artessón y una banquita en tres reales (Medina de Rioseco, VA-1639)

Una artesa de pino y dos banquillas (Medina de Rioseco, VA-1642)

Una silla y una banquilla en cinco reales (Medina de Rioseco, VA-1643)

Una banquilla de quatro pies de nogal biexo (Tamariz de Campos, VA-1652)

Una banquilla de tablas en quatro reales (Cuenca de Campos, VA-1666)

Dos banquillas de pino nuevas (Villalpando, ZA-1654)

Dos banquillas de nogal (Villalobos, ZA-1654)

Como ocurre con el término genérico, en ocasiones no tenemos muchos datos para saber cuál es la diferencia con otras lexías de este campo como banquillo, banco, escabel... junto con las que aparecen referenciadas. En otras ocasiones el contexto nos da información para saber cuál era su uso -para uso del zapatero, para lavar paños-, a qué objeto acompañaban -artesón y artesa- o qué accesorios tenían -pies-.

En el Vocabulario Palentino figura como sinónimo de una de las acepciones de banca 'cajón de madera donde apoyan las rodillas las mujeres que van a lavar al río' (Gordaliza, 1988: 41).

\section{BANCO [vanco, uanco]}

Sust. m. 'Asiento con respaldo o sin él, en que pueden sentarse varias personas', 'madero grueso escuadrado que se coloca horizontalmente sobre cuatro pies y sirve como de mesa para muchas labores de los cerrajeros, herradores y otros artesanos' (DLE, 1. - y 2.a ac.). Palabra recogida por Nebrija y Covarrubias. Es un término procedente del germ. bank (DECH, s. v. banco).

Vn banco de matar puercos (Valderas, LE-1647)

Dos bancos largos llanos el uno tabla de nogal y el otro de pino (Grajal de Campos, LE-1656)

Otro tres vancos de colar (Grajal de Campos, LE-1656)

Otro banco rasso dado (Grajal de Campos, LE-1671)

Un banco de pino con sus clauos (Frechilla, PA-1642)

Un banco largo de pino de respaldar (Guaza de Campos, PA-1640)

Un vanco de respaldo de pino con sus clavos (Boadilla de Rioseco, PA-1692)

Un banco rasso de pino (Boadilla de Rioseco, PA-1692)

Un banco de matar (Villada, PA-1665)

Un banco raso con tirantes de yerro de nogal (Villalpando, ZA-1632)

Un banco de alamo de respaldo mediano (Villalpando, ZA-1661)

Un banco de respaldo de nogal grande (Villapando, ZA-1688)

Otro vanco grande de matar (Villalpando, ZA-1697)

Dos vancos grandes, uno de carretero y otro de cubero (Villalpando, ZA-1696)

Dos uancos de pino nuebos de respaldo y los pies de alamo con su clabazón de caueza redonda limados (Villalpando, ZA-1696)

Es un término documentado en el $C D H$ desde el Libro de Alexandre que data del siglo XIII hasta la actualidad. La forma mayoritaria en la documentación de Tierra de Campos es la académica, aunque aparecen algunos ejemplos, los menos, con /v-/ y /u-/, vacilación gráfica muy habitual en esta época. Esta palabra presenta algunos significados que no recoge el DLE, como puede ser la de "banco de matar", hallados en la documentación de Villalpando y Valderas y que designa el banco que se utiliza para sacrificar a los cerdos, y que también localizamos en documentos del CorLexIn como, por ejemplo, en Montefrío, provincia de Granada, lo que en otros inventarios se convierten en "mesas de matar lechones" como en la localidad cacereña de Albalá. También encontramos "banco de colar" en Grajal de Campos, o bancos destinados a un 
fin específico como ocurre con los "bancos de carretero y de cubero" en Villalpando, en otros lugares se pueden encontrar también bancos de carpintero, herrador, alfarero, alpargateros o herreros (Morala, 2019b: 390). Los tipos de bancos que encontramos pueden ser rasos o de respaldo o respaldar.

Como ocurría con banca, también figuran los diminutivos banquito y banquillo en los documentos de la Tierra de Campos:

Un banquillo de dos pies en un real (Sahagún, 1600)

Un banquillo biejo (Sahagún, LE-1603)

Un banco y un banquillo y un badil (Castromocho, PA-1611)

Un banquillo tasado en dos reales (Mazariegos, PA-1619)

Un tablero de tundir con sus banquillos (Frechilla, PA-1675)

Un banquito de pino (Medina de Rioseco, VA-1646)

Dos banquillos de peynar (Medina de Rioseco, VA-1666)

Dos sillicas de pino y un banquito y una banca viexa (Villalpando, ZA-1629)

Dos banquitos pequeños (Villalpando, ZA-1689)

En el caso de banquillo, con el paso del tiempo pierde su naturaleza derivada para adquirir otros significados donde no hay relación apreciativa, como puede ser el 'banquillo de los acusados' o el 'banquillo de los jugadores reservas' (Perdiguero, 2015a: 1568).

\section{BAÚL [vahúl, vaúl, uaúl]}

Sust. m. 'Especie de arca, cubierta por lo común de piel, tela u otra materia y con una tapa frecuentemente convexa, que suele servir para guardar ropas' (DLE). Autoridades lo identifica como 'cofre redondo, menos por la parte inferiór, que es llana, y hace asiento como el de la arca' (NTLLE, s. v. baúl, Autoridades, 1726). Término procedente del fr. antiguo bahur de origen incierto, quizá onomatopéyico ( $D E C H$, s. v. baúl).

Un baúl cesteño bueno (Castroañe, LE-1629)

Dos baúles nuebos tasados en çien reales (Grajal de Campos, LE-1658)

Un vahúl viejo con zerradura sin llabe tasada en veinte riales (Grajal de Campos, LE-1670)

Un baúl negro clabeteado con su zerradura y llave (Valderas, LE-1682)

Un baúl encorado negro, claveteado con su cerradura y llave (Paredes de Nava, PA-1689)

Un baúl aforrado en badana negra (Medina de Rioseco, VA-1640)

Dos vaules encorados atachonados aforrados en olandilla verde con trençaderas blancas (Villalón, VA-1642)

Un cofre uaúl con çerradura y llaue tassado en tres ducados (Medina de Rioseco, VA-1644)

Un baúl de madera con cuero tachonado para guardar el recado de la dicha missa (Medina de Rioseco, VA-1644)

Seis baúles encorados con sus çerraduras y llaues (Medina de Rioseco, VA-1646)

Un baúl de vadana en treinta y tres reales (Medina de Rioseco, VA-1647)

Un baúl de camino (Medina de Rioseco, VA-1649)

Un baúl negro con clauaçón dorada (Villalpando, ZA-1666)

Este término es menos frecuente en los inventarios de Tierra de Campos que arca, aun así, aparece nutridamente documentado en Tierra de Campos. Esto se puede extender al resto de inventarios de la Península, Canarias y América, de hecho, el término baúl es más frecuente en los textos americanos que arca (CorLexIn). 
Encontramos en el corpus un "baúl cesteño", respecto a este apelativo, Morala señala que el sufijo de origen latino -eño crea adjetivos a partir de sustantivos con "el sentido de semejanza, material, pertenencia o procedencia" y localiza un par de ocurrencias en dos localidades leonesas, Cifuentes de Rueda y Sahagún referido a dos barriles (Morala, 2017a: 141, 144). Dicho esto, parece que se trate de un baúl realizado o forrado de mimbre, material con el que se hacían los cestos. Además, al término baúl suelen acompañarle adjetivos como encorado -cubrir de cuero- y tachonado o atachonado, clavado el cuero con tachuelas. En el último ejemplo de Medina de Rioseco se documenta un "baúl de camino", posiblemente para el transporte del equipaje en los viajes, puede que con unas características peculiares para proteger la mercancía de los golpes y de las inclemencias del tiempo.

\section{BRIZO [briço, breço]}

No aparece en el $D L E$, aunque sí el verbo brizar 'acunar, cunear', sin embargo, sí figura la variante brezo 'cuna (cama pequeña para niños)' (DLE, brezo ${ }^{2}$ ). Covarrubias recoge la voz brizo como 'la cuna en que mecen al niño, para que se duerma'. En la edición de 1770 de Autoridades esta palabra se considera antigua (NTLLE, s. v. brizo, Covarrubias, 1611; Autoridades, 1770). Corominas y Pascual advierten de su origen incierto, seguramente céltico y además señalan que se trata de un vocablo leonés ( $D E C H$, s. v. brizo).

Vn briço de niños, en quatro reales (Sahagún, LE-1601)

Un briço en quatro reales (Sahagún, LE-1602)

Un breço de niño en tres reales (Frechilla, PA-1613)

Dos brizos en ocho reales (Medina de Rioseco, VA-1645)

Un briço de el niño (Medina de Rioseco, VA-1685)

Según Corominas y Pascual se documenta a partir de la primera mitad del siglo XVI, siempre en obras literarias y eruditas, no en inventarios, aun así, su presencia en la documentación es escasa, el $C D H$ y el CORDE presentan pocas concordancias y con un significado diferente, el único ejemplo que se acerca al significado es el perteneciente a una obra de Fray Alonso de Cabrera donde aparece el siguiente ejemplo: "[...] el pesebre suple la falta de cuna y brizo [...]" (1598).

Desde una perspectiva diatópica, el CorLexIn no muestra más datos de esta voz que los hallados en el corpus terracampino, aunque sí que encontramos la variante bricio en la localidad zamorana de Figueruela (1685) -"un bricio en dos reales"-, y que todavía hoy se conserva en algunas localidades de Zamora (Le Men, 2002, s. v. brizo). En la zona de estudio hay una preferencia del término brizo frente a cuna, más frecuente en las relaciones de bienes del siglo áureo.

Desde un punto de vista formal, nos encontramos con la variante brezo con cambio de timbre en la vocal tónica.

Esta palabra se halla presente en estudios dialectales más modernos del leonés. Aparecen formas con diptongo exclusivamente en León -briezo-, y en el noreste de León alternan las formas trubieco o tribieco con briezo o brezo (Le Men, 2002, s. v. brizo). Con una variante muy parecida a las primeras aparece en textos terracampinos del siglo XVII:

Dos bieldos y un trebiezo y dos aspas todo en dos reales (Sahagún, LE-1601) 
Tres çedazos y el candelero biexo y un trebiezo (Sahagún, LE-1606)

Sin embargo, el significado no parece ser el mismo, en estos ejemplos el contexto indica que estamos ante un apero agrícola.

\section{BUFETE [vufete, bufetillo, vofete]}

Sust. f. 'Mesa de escribir con cajones' (DLE). Autoridades lo describe como 'mesa grande, ò à lo menos mediana y portatil, que regularmente se hace de madéra, ò piedra, mas ò menos preciosa, y consta de una tabla, ù otra matéria. Sirve para estudiar, para escribir, para comer, para otros muchos y diversos usos' (NTLLE, s. v. bufete, Autoridades, 1726). Es un término procedente del fr. ant. bufet 'especie de mesa' de origen incierto (DECH, s. v. bufete).

Un bufete de nogal vueno (Cea, LE-1621)

Un bufete de nogal grande de quatro pies (Grajal de Campos, LE-1658)

Un bufete de nogal con los pies de lo mismo (Valderas, LE-1682)

Un bufete de nogal grande con su cajón (Valderas, LE-1682)

Un vofete de nogal con sus dos cajones (Castromocho, PA-1611)

Un bufete de nogal con unas varillas de hierro (Frechilla, PA-1642)

Un bufete de nogal grande (Paredes de Nava, PA-1690)

Un bufete de castaño (Boadilla de Rioseco, PA-1692)

Un bufete con sus caxones y llave (Medina de Rioseco, VA-1639)

Un bufete de nogal con barras de yerro (Medina de Rioseco, VA-1640)

Un bufete de granadillo con barras de yerro (Medina de Rioseco, VA-1646)

Un vufete de pino de tres tablas con sus yerros a los pies en diez y seis reales (Cuenca de Campos, VA-1666)

Un bufete de nogal mediano (Villalpando, ZA-1629)

Un bufete de pino con su cajón y llabe (Quintanilla del Monte, ZA-1639)

Un bufete de nogal con sus barrotes de una pieza (Villalpando, ZA-1654)

Un bufete de nogal grande (Cotanes del Monte, ZA-1687)

Este término es habitual en los inventarios de la época, por lo que en Tierra de Campos aparece con bastante asiduidad. El bufete era una mesa que podía tener varias funciones en la casa, como apunta Autoridades. El contexto en el que figura no nos permite aventurar con seguridad cuál era su fin, pero parece por algunas descripciones que, además de ser una mesa para escribir o guardar documentos, servía de adorno, ya que suele estar hecha con materiales nobles, además suele llevar pies, cajones y barrotes o varillas de hierro.

Formalmente encontramos la variante vofete, con cierre de la vocal átona.

El diminutivo bufetillo lo recoge Autoridades como 'el que sirve para tocador de las mugéres, ò para adorno de los estrados' (NTLLE, s. v. bufetillo, Autoridades, 1726), acepción con la que coinciden los ejemplos encontrados en la Tierra de Campos:

Vn bufetillo pequeño de taraçea con su caxoncito (Valderas, LE-1647)

Un bufetillo de nogal sin pies (Autillo de Campos, PA-1649)

Un banco y un bufetillo (Boadilla de Rioseco, PA-1658)

Un bufetillo pequeño con su caxón, con su cerradura y llave (Paredes de Nava, PA-1689)

Unos bufetillos de estrado (Paredes de Nava, PA-1689)

Un bufetico pequeño con su cajón de lo mismo [nogal] (Medina de Rioseco, VA-1643)

Un bufetillo de nogal con sus caxones (Medina de Rioseco, VA-1645)

Un bufetillo de ébano y marfil con su contador de lo mismo (Medina de Rioseco, VA-1649) 
Existe una clara preferencia por el diminutivo en -illo en el corpus terracampino, algo extensible al resto de documentos notariales de la época. La forma derivativa con -ico presenta un uso más restringido, tan solo localizamos un caso en el corpus estudiado. De hecho, mientras el término bufetillo lo recogen algunos de los diccionarios académicos, la variante en -ico no figura en ninguna obra lexicográfica (Perdiguero, 2015a: 1571).

\section{CAMA}

Sust. f. 'Mueble destinado a que las personas se acuesten en él, compuesto de un armazón, generalmente con patas, sobre la que se colocan un somier o tabla, un colchón, almohada y diversas ropas' (DLE). Este término lo recogen Nebrija, Covarrubias y Autoridades, en este último diccionario advierte que 'se hace de varias maneras, como de piláres labrados, de bancos y unas tablas encima, de cordéles enredados en un bastidór de madera... y todas son levantadas del suelo, por cáusa de la humedad' (NTLLE, s. v. cama, Autoridades, 1729). Es un término procedente del hispanolatino cama 'yacija, lecho en el suelo', de origen incierto, quizá prerromano (DECH, s. v. cama).

\footnotetext{
Una cama de paramentos blancos raxados buenos (Sahagún, LE-1600)

Una cama encaxada en quatro reales (Sahagún, 1600)

Una cama de paramentos, estera de lienzo zinco ducados (Sahagún, 1600)

Una cama de campo y dos arcas grandes de pino (Sahagún, LE-1605)

Una cama de cordeles (Grajal de Campos, LE-1613)

Una cama de cordeles usada y los cordeles nuebos (Arenillas, LE-1636)

Una cama llana con sus cordeles digo sin ellos (Grajal de Campos, LE-1655)

Dos camas de medio campo con sus cordeles (Grajal de Campos, LE-1656)

Una cama de nogal de medio campo con sus cordeles y un jergón (Grajal de Campos, LE-1658)

Una cama rasa (Valderas, LE-1682)

Una cama de cordeles con sus cordeles apreciada en cinco reales (Frechilla, PA-1612)

Una cama encajada de pino vieja (Frechilla, PA-1612)

Una cama andadera de roble con sogas por cordeles en quatro reales (Fechilla PA-1612)

La cama cotidiana con su jergón quatro cabezales con su pluma, dos mantas buenas y un cobertor (Guaza de Campos, PA-1637)

Una cama de nogal de medio campo con sus cordeles (Paredes de Nava, PA-1690)

Una cama rasa con sus cordeles y en ella un gergón de arpilleras (Boadilla de Rioseco, PA-1690)

Una cama montañesa con sus cordeles (Villarramiel, PA-1690)

Una cama montañesa con sus cordeles (Villarramiel, PA-1694)

Una cama entera de campo de nogal en çiento y sesenta reales (Medina de Rioseco, VA-1645)

Otra cama de madera de pino de medio campo de las de la montaña (Medina de Rioseco, VA1657)

Una cama entera de Brasil con sus bronzes dorados (Medina de Rioseco, VA-1660)

Una cama de paño açul con cuxa de nogal todo ussado (Medina de Rioseco, VA-1671)

Una cama colgada y dorada de Valladolid (Medina de Rioseco, VA-1685)

Una cama de blanqueta colorada con dos mantas y una sobrecama colorada (Villalpando, ZA-1601)

Dos camas de castaño de medio campo con sus cordeles (Villalpando, ZA-1660)

Una cama de estameña verde con su zielo con canas y rodapies (Villalpando, ZA-1686)

Una cama de pino alta con sus cordeles y en ella un xergom viexo y una manta casera ya usada (Villalpando, ZA-1690)
}

Raro es el inventario de bienes que no cuenta con una o varias camas en su haber, desde la cama que se lleva de dote al matrimonio, hasta el lecho donde ha muerto el difunto. Es un término de uso cotidiano, muy documentado en bases de datos como el CORDE o el CDH desde 
el siglo XII. En el corpus estudiado aparecen muchas camas y de muchos tipos, una de ellas es la llamada "cama de campo" que Autoridades describe como la cama 'que era mui capaz, y extendida' y que se documenta en textos históricos desde finales de la Edad Media hasta mediados del siglo XVII (CORDE), frente a esta se localiza también la cama "de medio campo" que era más pequeña. Aparece con bastante frecuencia la "cama de cordeles" formada por un bastidor de madera con unas cuerdas a modo de somier que sostienen el colchón (Gómez Ferrero, 2015: 213). El CORDE documenta este tipo de cama en el siglo XVI y XVII. Otro tipo de cama es la llamada "cama encajada", menos frecuente en el corpus que las anteriores, posiblemente porque estaba ya en desuso. En el CorLexIn aparecen ejemplos aislados, sobre todo en Segovia y las pocas ocurrencias que localizamos en el CORDE son de los siglos XV y XVI. En la localidad palentina de Villarramiel encontramos una "cama montañesa", que hacían los montañeses en la provincia de Cantabria. La voz cama suele aparecer junto a modificadores adjetivos, así encontramos camas rasas, llanas, cotidianas o andaderas, además de decir el tipo de madera con el que están fabricadas -pino, nogal o roble entre otros-.

En otras ocasiones, el término cama está asociado directamente con la ropa de cama como "cama de paramentos" haciendo referencia al conjunto de cortinajes que aíslan el lecho del resto de la estancia; o también "camas de blanqueta" o "camas de estameña".

\section{CAPERO}

Sust. m. 'Cuelgacapas' ('Mueble para colgar la capa y otras prendas de vestir') (DEL, 2.a ac.). Con esta acepción no se registra en los diccionarios académicos hasta la edición de 1899. Anteriormente, Domínguez, en el Suplemento, y Gaspar y Roig recogen este significado, ambos en 1853 (NTLLE, s. v. capero, Suplemento Domínguez, 1853; Gaspar y Roig, 1853; DRAE, 1899). Término derivado de capa procedente del lat. tardío CAPPA 'capucho' (DECH, s. v. capa).

Un capero blanco (Frechilla, PA-1640)

Un capero (Villalpando, ZA-1666)

En Tierra de Campos este es un término poco documentado, tan solo encontramos dos ocurrencias, el contexto no nos ofrece datos suficientes como para saber exactamente el tipo de mobiliario que era. La documentación histórica muestra muy pocos casos de este término con la acepción de mueble para colgar las capas $(C D H)$ y esta ausencia de ejemplos se extiende a los inventarios del siglo XVII (CorLexIn).

Sin embargo, capero aparece registrado en algunos estudios léxicos actuales, Le Men localiza este término como 'antigua percha de madera formada por dos tablas gruesas clavadas en escuadra y unos fuertes ganchos de listón' en zonas leonesas como Murias de Paredes y Astorga (Le Men, 2004, s. v. capero). También está presente en tierras palentinas como 'perchero o ganchos para colgar la ropa, especialmente los abrigos o capas antiguamente' (Gordaliza, 1988: 59). En ambos estudios, esta voz se tilda de antigua. 


\section{COFRE [cofrecito, cofreçico, cofrecillo]}

Sust. m. 'Caja resistente de metal o madera con tapa y cerradura para guardar objetos de valor', 'baúl (especie de arca)' (DLE, 1. y 2. ac.). Nebrija y Covarrubias lo registran en sus respectivas obras, equiparándolo al término arca. Autoridades lo describe como 'cierto género de arca ò baúl de hechúra tumbada, aforrado por fuera en pellejos de caballo ú de otro animal, y por de dentro en lienzo, ù otra cosa semejante que sirve para guardar todo género de ropas' (NTLLE, s. v. cofre, Nebrija, 1495; Covarrubias, 1611; Autoridades, 1729). Es un término procedente del francés coffre íd., y este del lat. cŭPHINNUs 'cesta', tomado a su vez del griego kóфıvoৎ (DECH, s. v. cofre).

Dos cofres de taraçea en ocho reales (Sahagún, LE-1602)

Un cofre encorado y varreado con cerradura y llave (Cea, LE-1626)

Vn cofre tunbado grande aforrado en vn pellejo roxo y guarneçido de oja de lata (Valderas, LE1647)

Un cofre encorado con zerradura y llaue que estaua en la sala (Grajal de Campos, LE-1658)

Un cofre biexo forrado en piel de caballo (Autillo de Campos, PA-1647)

Un cofre encorado sin zerradura (Villada, PA-1669)

Un cofre mediano encorado claveteado y con su cerradura y llave (Paredes de Nava, PA-1690)

Un cofre varreteado y en él zinco pieças de colgadura vlanca (Boadilla de Rioseco, PA-1692)

Otro cofre viexo aforrado en pellejo de cavallo (Medina de Rioseco, VA-1640)

Un cofre biexo (Villalón, VA-1642)

Un cofre encorado de blanco tassado en veinte reales (Medina de Rioseco, VA-1644)

Un cofre encorado viexo con cerradura y llaue (Medina de Rioseco, VA-1657)

Un cofre barreado de coçina (Villalpando, ZA-1633)

Vn cofre bueno, nuevo, negro, con clauaçón dorada (Villalpando, ZA-1652)

Un cofre encorado roxo con su zerradura y llave (Cotanes del Monte, ZA-1687)

Dos cofres medianos negros tachonados con tachuelas bronzeadas (Villalpando, ZA-1689)

Es una voz presente en los inventarios de bienes de la Tierra de Campos y de uso general en la época. El CDH lo documenta a partir del siglo XIV en los textos. En esta época convive con los términos arca y baúl, aunque el uso que le da en los textos se acerca más a baúl, en uno de los ejemplos localizados en Valderas nos encontramos con "otro cofre baúl negro tachonado de latón con su çerradura y llabe", tal vez por la cercanía entre uno y otro. Formalmente este término presenta en los inventarios diferentes formas del diminutivo del término genérico -cofrecito, cofrecico y cofrecillo- con el significado de cofre pequeño.

Un cofrezico pequeño de pino (Grajal de Campos, LE-1613)

Un cofreçico pequeño encorado con çerradura y llabe (Grajal de Campos, LE-1656)

Un cofrecito muy pequeño con zerradura y llave (Valderas, LE-1682)

Un cofrecillo de pino pequeño en cinquenta marauedís (Frechilla, PA-1613)

Un cofrecillo aforrado y barreteado (Frechilla, PA-1675)

Un cofrecillo de concha (Paredes de Nava, PA-1695)

Un cofreçico pequeño varreteado (Medina de Rioseco, VA-1648)

Un cofrecito pequeño con su llaue y cerradura (Villalobos, ZA-1654)

\section{CONTADOR [contadorcito, contadorcillo]}

Sust. m. 'Especie de escritorio o papelera, con varias gavetas, sin puertas ni adornos de remates' (DEL, 7. a ac.). Término recogido tanto por Nebrija como por Covarrubias en su Tesoro donde, entre otras acepciones, recoge la de 'cierta forma de escritorio de gauetas, donde se ponen los 
papeles'. También hace referencia a esta acepción Autoridades donde lo reconoce como 'cierto género de Escritório, con seis o ocho gavetas, sin puertecillas ni adornos de remates o corredores, que son hechos para guardar papeles' (NTLLE, s. v. contador, Nebrija, 1495; Covarrubias, 1611, Autoridades, 1729). Término derivado de contar, del lat. CŏMPŬTARE 'calcular' (DECH, s. v. contar).

Un contador de nogal con quatro caxones y en ellos unas tenaças de yerro, martillo y diferentes clavos (Paredes de Nava, PA-1690)

Un contador de pino (Villada, PA-1669)

Una mesa contador de aya (Villada, PA-1669)

Dos escritorillos pequeños y un contadorcillo de nogal enbutido de taraçea (Medina de Rioseco, VA-1644)

Un contador bajo de évano y marfil con su bufete de lo mismo, con ocho cajonzicos digo navetas (Medina de Rioseco, VA-1647)

Un contadorcito con su bufete de nogal (Medina de Rioseco, VA-1685)

Un contador de nogal y un bufete (Villalpando, ZA-1651)

El término contador es habitual localizarlo en los inventarios junto a tasador y partidor, que referencian oficios que estaban muy relacionados con la actividad notarial. Pero el contador al que hacemos referencia es un tipo de mueble, muy cercano al escritorio donde se guardaban los papeles. Perdiguero afirma que este tipo de mobiliario hacía referencia a 'un mueble o tabla con pies para archivar los papeles, metidos en cajas' (Perdiguero, 2014: 153). Aunque contador se documenta tanto en la Península como en América, es un término que aparece de forma aislada y sobre todo en inventarios del sur de la Península -Córdoba, Granada, Málaga y Sevilla-. Estaba fabricado con maderas y materiales nobles como el nogal, el ébano o el marfil. En Tierra de Campos contamos también con el diminutivo contadorcito, que hacía referencia a un contador de menor tamaño.

\section{COPERO}

Sust. m. 'mueble que se usa para contener las copas en que se sirven licores', 'sitio donde se guardan o ponen las copas' ( $D L E, 4$. y 6 . a ac.). No se recoge con la acepción de mueble hasta la edición del DRAE de 1869 (NTLLE, s. v. copero, DRAE, 1869). Voz derivada de copa, del lat. CŬPPA (DECH, s. v. copa).

Un copero de madera (Valderas, LE-1682)

Un copero biexo en seis reales (Medina de Rioseco, VA-1645)

Un copero de pino (Medina de Rioseco, VA-1659)

Un copero en dos reales y medio (Villalpando, ZA-1600)

Un copero de pino en quatro reales (Villalpando, ZA-1600)

Un copero viexo (Villalpando, ZA-1686)

Un copero con talauera que son tres platos, seis escudillas, una dozena de platos de los finos la metad, una aljafana y un salero (Villalpando, ZA-1688)

Un copero pequeño con dos altos (Villalpando, ZA-1689)

El término copero aparece en la Tierra de Campos en Valderas, Medina de Rioseco y, sobre todo, Villalpando. No se halla documentado con la acepción que tiene en estos inventarios en bases de datos textuales como el $C D H$ o el CORDE. En las ocurrencias encontradas parece estar haciendo referencia a un tipo de vasar hecho de madera, donde se guardaban los platos, las escudillas y los saleros. No es una voz muy documentada en la época, aunque hay algunos casos, 
casi todos enmarcados en la actual comunidad de Castilla y León. Este mueble se inventaría en protocolos procedentes de Soria, Segovia, Ávila, Salamanca, Valladolid y la zona que nos ocupa, además de algún ejemplo aislado en Cáceres y Cuenca. A estos casos habría que sumar los encontrados en la zona de La Bañeza (León) (Gómez Ferrero, 2015: 196).

\section{CUJA [cuxa]}

Sust. f. 'Armadura de la cama', el DLE lo señala como término en desuso. Rosal registra esta palabra en su diccionario como 'la cama de madera' y Autoridades como el 'lecho o armadúra de la cama' (NTLLE, s. v. cuxa, Rosal, 1611; Autoridades, 1729). Probablemente galicismo tomado de couche 'lecho' (DECH, s. v. cuja).

Una cuja (Valderas, LE-1682)

Otra cuja de cama en la misma forma treinta reales (Medina de Rioseco, VA-1649)

Una cuxa de madera de nogal biexa (Medina de Rioseco, VA-1640)

Dos cuxas de nogal en cien reales (Medina de Rioseco, VA-1645)

Una cuja de nogal entorchada en blanco, cortinas, cielo y couertor de paño azul con flocadura de seda en ochocientos reales (Medina de Rioseco, VA-1647)

Una cuja de cama de nogal dorada con cortinas, couertor y cielo de damasco carmesí y goteras de terciopelo y flocadura y alamares de oro (Medina de Rioseco, VA-1647)

Una cama de paño açul con cuxa de nogal todo ussado (Medina de Rioseco, VA-1671)

Corominas y Pascual documentan esta voz con la acepción de 'lecho' en el Guzmán de Alfarache de 1604, este galicismo penetra en el castellano de forma tardía y por la zona norte de la Península (Morala, 2012f: 302). El CDH atestigua este significado a partir de mediados del siglo XVI. La documentación notarial del siglo XVII que conforma el CorLexIn muestra un uso restringido a determinadas zonas del norte peninsular -Vizcaya, Guipúzcoa, Cantabria (Bartolomé-Junquera, 2018: 121-122), Burgos, Logroño-. Mientras que su uso en América parece estar más generalizado a la vez que presenta un significado más genérico del término -Bolivia, Chile, Panamá y Perú-, a los que habría que añadir Uruguay (Egido, 2012: 1302-1303). El corpus terracampino ofrece unos cuantos ejemplos casos concentrados, principalmente, en la localidad vallisoletana de Medina de Rioseco.

\section{CUNA}

Sust. f. 'Cama pequeña para niños, con bordes altos o barandillas laterales, a veces dispuesta para poderla mecer' (DLE). Nebrija recoge 'cuna de niño' en su Vocabulario. Entre los diccionarios no académicos, Rosal señala 'que otros llaman Bríço' (NTLLE, s. v. cuna, Nebrija, 1495; Rosal, 1611). Término procedente del lat. CŪNA (DECH, s. v. cuna).

Una cuna de niños (Valderas, LE-1682)

Tan solo localizamos un ejemplo en los inventarios terracampinos, aunque está claro por el contexto que la acepción que manifiesta es la dada por el diccionario académico. El CorLexln pone de manifiesto un uso más extendido que brizo, aunque la nómina de casos sigue siendo pequeña. En esta base, se localizan poco más de una docena de ocurrencias concentradas en su mayor parte en la zona oriental de la Península. En la documentación notarial de Tierra de Campos hay una preferencia de uso del término brizo frente a cuna. 


\section{ENTREMIJO}

El DLE señala este término con marca diatópica de Salamanca y remite a expremijo 'mesa baja, larga, de tablero con ranuras, cercada de listones y algo inclinada, para que, al hacer queso, escurra el suero y salga por una abertura hecha en la parte más baja' (DLE). Entremijo lo registra el $D R A E$ de 1791 y advierte de que se trata de un vocablo antiguo y remite a entremiso, término también antiguo que define como 'banco largo con listones de madera por todos los lados, donde los que tienen cabaña, forman y hacen los quesos' (DRAE, 1791). En la edición de 1925 la entrada entremijo con notación diatópica de Salamanca remite al término expremijo-lo mismo hace con estremiso- (NTLLE, s. v. entremijo, DRAE, 1791; DRAE, 1925). Término derivado de meter, del lat. MİTTĔRE (DECH, s. v. meter).

Un real de un entremijo (Paredes de Nava, PA-1690)

Tan solo localizamos un ejemplo en el corpus estudiado con la forma entremijo. Esta variante también la localizamos en un inventario de Sevilla, donde el contexto nos identifica mejor el referente "dos entremijos en que se hacen los quesos" (CorLexIn).

Esta palabra presenta mucha variabilidad gráfica, no en nuestro corpus, ya que solo contamos con una ocurrencia, pero sí en los encontrados en el CorLexln donde aparecen también las formas estremijo, localizada en La Rioja y Palencia, o entremiso en Villacabiel, provincia de León. Esta última forma la recoge Le Men con diferentes acepciones, en Astorga y La Rioja como 'círculo de piedra que tiene forma de fregadero poco profundo y con un canalín para que salga el agua de la colada', y en Salamanca y Burgos con la acepción que aquí hemos dado (Le Men, 2005, s. v. entremiso). Lo que demuestra que esta voz no es exclusiva de Salamanca.

La forma académica expremijo se localiza en los inventarios de la época de estudio en Cáceres y Toledo (CorLexIn). Lo recoge Autoridades en su edición de 1732 como 'artésa grande y larga, la qual se ponen las encellas para hacer los quesos, la qual tiene en uno de los lados una canál para que salga el suero del requesón ò leche cuajada que se exprime al tiempo de formar el queso' (NTTLE, s. v. expremijo, Autoridades, 1732).

\section{ESCABEL [escauel, escavel, escabelico, escavelillo]}

Sust. $m$. 'Tarima pequeña que se pone delante de la silla para que descansen los pies de quien está sentado', 'asiento pequeño hecho de tablas, sin respaldo' (DEL, 1. ․ y 2. a ac.). Covarrubias lo recoge con la forma escabelo como 'asiento pequeño de madera', y Autoridades añade que sirve 'para poner los pies' (NTLLE, s. v. escabelo, Covarrubias, 1611; Autoridades, 1732). La variante escabel se registra a partir del siglo XVII en diccionarios no académicos, Terreros y Pando lo equipara a banquillo y en el DRAE de 1791 aparece con las acepciones académicas vistas anteriormente (NTLLE, s. v. escabel, Terreros y Pando, 1786; DRAE, 1791). Término procedente del lat. SCABĔLLUM (DECH, s. v. escabel).

Dos silletas de pino de respaldo y un escavelillo de pino (Grajal de Campos, LE-1658)

Un escabelico pequeño bueno (Grajal de Campos, LE-1671)

Un escabel raso tasado en seis reales (Grajal de Campos, LE-1670) 
Un banco de pino y un escavel biejos (Castromocho, PA-1614)

Un banco de pino biejo, otro banco de respaldo, un escabel (Frechilla, PA-1639)

Cinco escabeles, los tres de texo y dos de nogal (Paredes de Nava, PA-1690)

Tres escaveles dos de nogal y uno de pino (Villalón, VA-1637)

Tres escabeles de nogal, dos grandes y uno pequeño (Medina de Rioseco, VA-1639)

Un escabelico de pino en cuatro reales y una banca en tres reales (Medina de Rioseco, VA-1644)

Tres escaueles de nogal altos (Medina de Rioseco, VA-1671)

Un escauel de nogal (Villalpando, ZA-1639)

Un escabelico de nogal y en él un escriptorico pequeño de quatro naveticas (Villalpando, ZA1690)

Este término lo encontramos documentado bajo la forma escabello desde finales del siglo XIII con la primera acepción que da la Academia, escabel no aparece hasta mediados del siglo XVI. Su presencia se extiende hasta el siglo XVII, pero apenas hay documentación en el XVIII. Sin embargo, parece que en el siglo XIX vuelve a resurgir el término de la mano de los textos literarios del romanticismo y realismo decimonónico ( $C D H$, s. v. escabel). Es un término de uso general, que aparece en el corpus estudiado con el significado académico, podia se de diferenes maderas como pino, tejo o roble. En cuanto a la morfología derivacional, presenta las formas de diminutivo escabelillo y escabelico.

\section{ESCAÑo [esqaño]}

Sust. m. 'Banco con respaldo en el que pueden sentarse tres o más personas' (DLE). Nebrija y Covarrubias lo recogen es sus respectivas obras, este último lo define como 'cierto género de banco ancho con espaldar', Autoridades añade que en él se pueden sentar 'tres, quatro, cinco ù mas personas' (NTLLE. s. v. escaño, Covarrubias, 1611; Autoridades, 1732). Término derivado del latín SCAMNUm 'escambel', 'banco' (DECH, s. v. escaño).

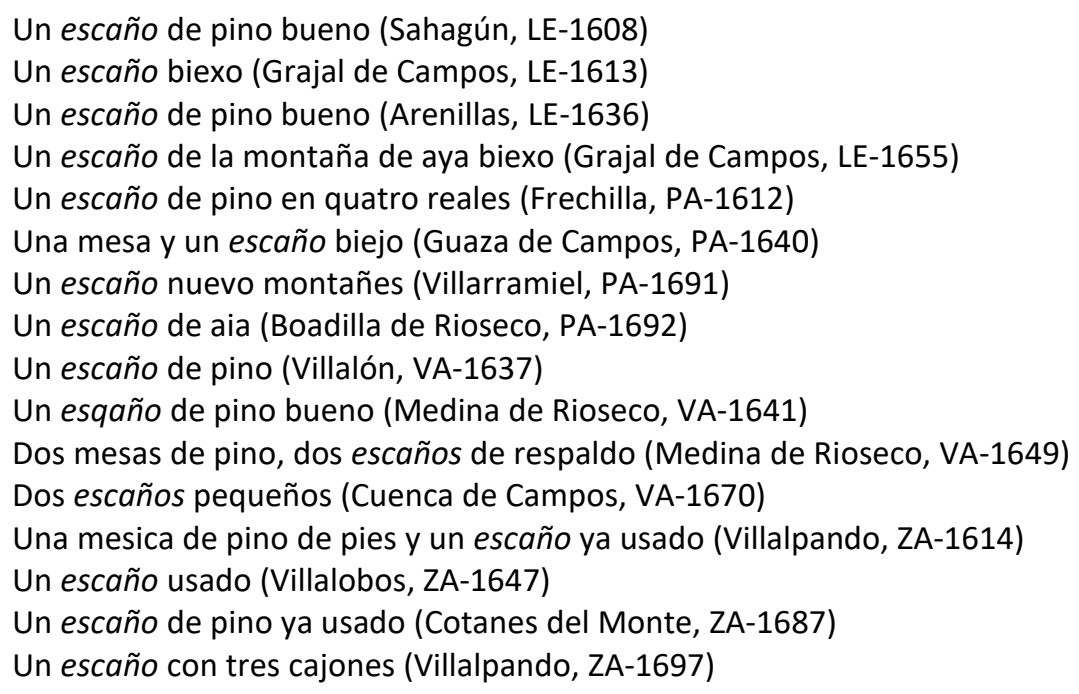

Es un término de uso general, muy presente en la documentación del castellano. El DECH señala que el término scanno se halla de forma temprana en la documentación leonesa del siglo $\mathrm{X}$, también a finales de ese mismo siglo, del XI y el XII figura en la Colección diplomática del Monasterio de Sahagún con esta variante. EI CDH y el CORDE localizan la voz escaño en el Mío Cid. Los datos que nos aporta el CorLexIn muestran un uso extenso de esta voz en el siglo XVII. Habitualmente el escribano señala el tipo de madera con el que está hecho -mayoritariamente 
de pino o pinariego en documentos burgaleses, aunque también los hay de roble, álamo, nogal o haya-, si tienen cajones o si tienen respaldo:

Un escaño de pino de respaldo viejo (Grajal de Campos, LE-1658)

Otro escaño de pino de respaldo ya ussado (Medina de Rioseco, LE-1661)

Un escaño de respaldo de pino (Medina de Rioseco, VA-1671)

Un escaño biexo de respaldo de pino (Villalpando, ZA-1660)

Un escaño de pino de respaldo (Villapando, ZA-1688)

Un escaño de pino y respaldo ussado (Villalpando, ZA-1698)

En repertorios léxicos actuales encontramos este término como 'banco antiguo de madera, con respaldo, que suele estar en la cocina' afirma que también se llama escañil al escaño pequeño, pero en nuestro corpus no hemos encontrado ningún ejemplo (Gordaliza 1988: 99).

\section{ESCAPARATE}

Sust. m. 'vitrina (mueble)' (DLE). Este término lo recoge Autoridades como 'Alhaja hecha a manera de alhacena o almário, con sus puertas y andenes dentro, para guardar buxerías, barros finos y otras cosas delicadas, de que usan mucho las mugeres en sus salas de estrado para guardar sus dixes' (NTLLE, s. v. escaparate, Autoridades, 1732). Término procedente del neer. antic. schaprade 'armario' (DECH, s. v. escaparate).

Un escaparate de pino grande con sus çelusías y laçenas (Medina de Rioseco, VA-1685)

Tan solo hemos encontrado un ejemplo de este término en la zona de estudio. Se documenta a partir de la segunda mitad del siglo XVI en el $C D H$. Aunque no es un término muy abundante en los inventarios, está presente en la Península y América (CorLexIn). Es un mueble de lujo donde se exhibían objetos de adorno y devoción, de hecho, en un ejemplo localizado en Panamá se dice lo siguiente: "un escaparate de madera, biejo, que adorna la sala", este mueble se utilizaba principalmente para exhibir adornos y objetos de devoción. El único ejemplo encontrado pertenece a la documentación notarial de Medina de Rioseco, localidad de mayor actividad económica que otras localidades pertenecientes a esta comarca.

\section{ESCRIBANÍA [escriuanía]}

Sust. f. 'escritorio (mueble para guardar papeles)', 'recado de escribir, generalmente compuesto de tintero, salvadera y otras piezas, y colocado en un pie o platillo' ( $D L E$, 4. a y 5. a ac.). Autoridades registra esta voz con los significados recogidos anteriormente (NTLLE, s. v. escribanía, Autoridades, 1732). Término derivado de escribir, procedente del bajo lat. SCRĪBA, ĀNIS (DECH, s. v. escribir).

Una escribanía en real y medio (Frechilla, PA-1613)

Un escriptorio de tortuga grande con su escriuanía encima guarnecida de bronce y un bufete sobre esta con uarrotes de yerro (Medina de Rioseco, VA-1647)

Dos escriuanías de concha con sus bufeticos de nogal (Medina de Rioseco, VA-1685)

Dos escribanías que valen, la una siete ducados aforrada en raso morado con tres llaves y la otra de nogal (Villalpando, ZA-1620)

Como en el caso de escaparate, escribanía no es habitual en los inventarios de la Tierra de Campos, aparecen contados ejemplos y siempre en documentos pertenecientes a localidades 
con mayor actividad económica. Desde una perspectiva formal, esta voz presenta la forma académica, con la vacilación gráfica habitual en la época entre la /b/, / / y /u/. En cuanto al significado, el contexto que nos encontramos en Tierra de Campos no aporta demasiados datos, en ellos no aparecen tinteros, ni salvaderas por lo que se puede deducir que haga referencia a una especie de arquita o caja donde se metían diferentes objetos, y así las encontramos "guarnecidas de bronce", "de concha", "aforradas de raso" o "de nogal" y "con llaves". Autoridades también define este término como 'el caxón, escritório o papelera donde se guardan los papeles'.

\section{ESCRITORIO [escriptorio, eschritorio, escritorillo, escritorico]}

Sust. m. 'Mueble cerrado, con divisiones en su parte interior para guardar papeles y, a veces, con un tablero sobre el cual se escribe', 'mueble de madera, comúnmente con embutidos de marfil, concha u otros adornos de taracea, $\mathrm{y}$ con gavetas o cajones pequeños para guardar joyas' (DLE, 1. a y 3. a ac.). Covarrubias recoge el término como el 'cajón donde estan los papeles y escrituras, y tambien sinifica la estancia, o aposento del escriuano, a donde escriue y despacha', también registra escritorillo que lo equipara a contador. Autoridades lo define como 'caxón hecho de madéra con distintos apartadijos y divisiones, para guardar papéles y escritúras, que también se llama papelera' (NTLLE, s. v. escritorio, Covarrubias, 1611; Autoridades, 1732). Es un término derivado de escribir, del lat. SCRĪBĔRE (DECH, s. v. escribir)

Vn escriptorio con sus caxones (Villamuñío, LE-1633)

Un escritorio de nogal en çien reales (Grajal de Campos, LE-1658)

Un escriptorio de pino con cerradura y llaue (Grajal de Campos, LE-1658)

Un escritorio de nogal grabado (Frechilla, PA-1640)

Un eschritorio con su cerradura y llave de nogal con sus caxones (Paredes de Nava, PA-1690)

Un escriptorio de nogal con diez y siete nobetas y su zerradura y llave con diferentes papeles (Paredes de Nava, PA-1689)

Un escriptorio de nogal con sus pies (Villalón, VA-1642)

Un escritorio de nogal pequeño con su pie de lo mismo (Medina de Rioseco, VA-1646)

Un escriptorio de nogal de Salamanca con sus pies traído en quinientos y treinta reales (Medina de Rioseco, VA-1649)

Dos escritorios grandes de concha fábrica de real con sus corredores de bronce y bufetes de nogal con varrotes de yerro (Medina de Rioseco, VA-1685)

Un escriptorio de Flandes y con labores entalladas (Villalpando, ZA-1620)

Los escritorios no solo se utilizaban para escribir o guardar papeles, sino que como ocurre con otros objetos del mobiliario, también servían de adorno, así se cubrían de materiales de lujo como la concha de tortuga, el ébano o el marfil.

El CorLexIn presenta una distribución geográfica general tanto en la Península como en Canarias y América, es un término totalmente afianzado en el acervo léxico del castellano en el siglo áureo.

Desde una perspectiva formal presenta variantes gráficas muy habituales en la época -escriptorio o eschritorio-.

En esta zona, los diminutivos alternan entre los sufijos -ico e -illo, posiblemente haciendo referencia al menor tamaño del escritorio. 
Un escritorico con tres cajones (Valderas, LE-1682)

Un escritorillo (Paredes de Nava, PA-1689)

Un escavelico de nogal y en él un escriptorico pequeño de quatro naveticas (Villalpando, ZA-1690)

\section{ESTRADO [hestrado, estradillo, estradico]}

Sust. m. 'Tarima cubierta con alfombra, sobre la cual se pone el trono real o la mesa presidencial en actos solemnes', 'conjunto de muebles que servía para adornar el lugar o pieza en que las señoras recibían las visitas, y se componía de alfombra o tapete, almohadas y taburetes o sillas' (DLE, 2. a y 5. ac.). Covarrubias recoge este término como 'la tarima cubierta de alhombras, que se pone para asistir los Reyes a los actos publicos, sobre las cuales ponen sus sillas y tronos [...]' y también 'el lugar donde las señoras se asientan sobre cogines, y reciben las visitas' (NTLLE, s. v. estrado, Covarrubias, 1611). Término procedente del lat. STRATUM (DECH, s. v. estrado).

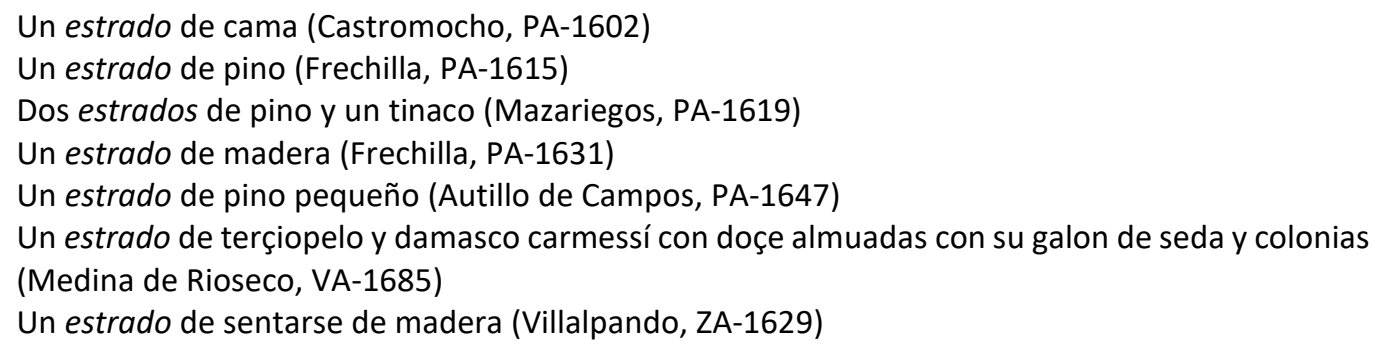

El término estrado se suele inventariar de forma indirecta, ya que son muchos los ejemplos de esta palabra formando parte del sintagma "de estrado", así la mayor parte de los items recuperados en el CorLexIn aparecen de esta manera: "cabeceros de estrado", "alfombra de estrado", "almohadas de estrado" o "bufetillo de estrado". La nómica de casos en los que estrado figura como objeto inventariado se reduce en más de la mitad y con especial presencia en los textos americanos -Bolivia, Chile, Guatemala y México-. El corpus terracampino ofrece una nutrida nómina de este término con la acepción académica, aunque también documenta algunos casos formando parte de un sintagma preposicional:

Unos bufetillos de estrado (Paredes de Nava, PA-1695)

Un bufete de estrado enbutido de hébano y marfil (Medina de Rioseco, VA-1645)

Una alfonbra de hestrado blanca y negra (Medina de Rioseco, VA-1646)

Desde un punto de vista formal, podemos señalar la presencia del diminutivo en el corpus estudiado, donde alternan -illo e -ico que, a priori, presentan una motivación apreciativa. Aunque cabe destacar que, en algunos ejemplos de la documentación notarial del siglo XVII, estradillo pueda referenciar una especie de 'taburete o tajuela' (Perdiguero, 2015a: 1567):

Un estradillo de pino en quatro Reales (Frechilla, PA-1613)

Quatro cabeueçales y un estradillo (Frechilla, PA-1640)

Un medio estradico de una tabla pequeña (Villalpando, ZA-1620)

\section{GAVETA [gaueta]}

Sust. f. 'Cajón corredizo que hay en los escritorios y sirve para guardar lo que se quiere tener a mano' (DLE). Covarrubias lo recoge como 'el caxoncito del escritorio'; Autoridades es más explícito y dice que es una 'especie de caxa corrediza, y sin tapa, que hai en los escritorios, 
armários y papeleras, y sirve para guardar lo que se quiere tener en orden y à la mano' (NTLLE, s. v. gaveta, Covarrubias, 1611; Autoridades, 1734). Es una alteración del lat. GABĂTA 'escudilla', 'gamella' (DECH, s. v. gaveta).

Un escritorio de nogal viejo con sus gauetas (Villalpando, ZA-1698)

Gaveta aparece en la documentación a partir de la segunda mitad del siglo XVI pero con un significado diferente al que aquí estudiamos, en estas primeras concordancias del CDH referencia un recipiente de cocina, muy parecido a la escudilla. Con el significado de 'cajón' lo registran tanto el CORDE como el CDH a partir de los Inventarios Reales. Bienes muebles que pertenecieron a Felipe II, fechados en 1600.

El CorLexIn ofrece una distribución diatópica, aunque un alto porcentaje de los ejemplos se localizan en las provincias andaluzas. Por el contrario, en Tierra de Campos este término aparece muy poco documentado, en esta zona se prefiere el término naveta.

\section{MACETA [mazeta]}

Sust. f. 'Pie de plata u otro metal, o de madera pintada, donde se ponen ramilletes de flores artificiales para adorno de altares o de otros sitios' (DLE, s. v. maceta ${ }^{2}, 2$. a ac.). Término derivado de maza, del lat. vulgar * MATTĚA (DECH, s. v. maza).

Dos ramilletes de seda con sus mazetas pintadas (Villalpando, ZA-1696)

Diacrónicamente, el $C D H$ y el CORDE recogen este término a finales del siglo $\mathrm{xv}$, en el Universal vocabulario en latín y en romance de Alfonso de Palencia fechado en 1490 y donde escribe 'que es vasija de agua'. El CorLexIn reúne casi una decena de casos en los cuales esta palabra presenta diferentes acepciones. Como 'recipiente' figura en inventarios de Jaén y con la forma macetón, en textos granadinos, pero con una acepción más cercana a la de tinaja (Junquera-Morala, 2019: 206). Como recipiente también figura también en los documentos terracampinos, aunque en este caso hace referencia a un elemento decorativo ubicado en el inventario de una iglesia.

\section{MOSTRADOR}

Sust. $m$. 'Mesa o tablero que hay en las tiendas para presentar los géneros' (DLE, 2. a ac.). Este significado es recogido desde Autoridades (NTLLE, s. v. mostrador, Autoridades, 1734). Término derivado de mostrar, del lat. MONSTRARE 'mostrar, indicar, advertir' (DECH, s. v. mostrar).

Un mostrador de pino con sus cajones y llaves (Medina de Rioseco, VA-1660)

Un mostrador de nogal con sus cajones y en cada uno su llave (Medina de Rioseco, VA-1685)

En el $C D H$ aparece con esta acepción académica desde mediados del siglo XVI en una novela de Cristóbal de Villalón:

"[...] y de allí me fue a casa de un mercader y demandéle me diesse un poco de paño de que me vestir, y él luego me lo puso en el mostrador [...]"

Sin embargo, los casos que encontramos de este término, no se ajustan exactamente al académico, ya que estos mostradores cuentan en ambos casos con cajones y llaves. Este término 
no es muy frecuente en la documentación de la zona, tampoco en los inventarios de la época, donde la mayoría de los ejemplos pertenecen a localidades grandes-Córdoba, Madrid, Sevilla o Zaragoza-, y casi todos forman parte de una carta de dote (CorLexIn).

Estamos ante un tipo de mueble al que tenían acceso las familias más adineradas, en él, como ocurría con el escaparate, exhibían las piezas y adornos más valiosos, para que fueran admirados por quien entraba en la casa.

A finales del siglo XVII se localiza un mostrador en el inventario de una joven noble de Nueva España donde el mostrador se presenta como una especie de "tablas apiladas, siempre en disminución, cubiertas con ricas telas de importación, sobre las que colocaban para su exhibición las mejores piezas de orfebrería y los cristales de Venecia que había logrado atesorar la familia" y que se denomina pirámide-mostrador (Curiel, 2000: 72). En el corpus terracampino localizamos el término pirámide, pero el contexto no da la información suficiente como para ratificar su función y significado:

Dos pirámides de madera doradas tassados en seis reales (Medina de Rioseco, VA-1644)

Un pie redondo de lo mesmo [plomo] para asentar algún pirámile (Villalpando, ZA-1633)

\section{NAVETA / -O [naueta, nabeta]}

Sust. f. 'Gaveta de escritorio', término en desuso (DLE). Además de como vaso o caja para administrar el incienso en la Iglesia, Autoridades define esta palabra como sinónimo de gaveta pero no se indica que sea una palabra en desuso (NTLLE, s. v. naveta, Autoridades, 1734). Es un término derivado de nave, del lat. NAVIS (DECH, s. v. nave).

En otra naveta se alló un rosario de palo de la India engaçado de oro, (Valderas, LE-1647)

Un escriptorio de nogal con çerradura y llave con sus caxones y navetas (Grajal de Campos, LE1656)

Un escriptorio de nogal con sus navetas (Villada, PA-1669)

Un escriptorio de nogal con diez y siete nabetas y su zerradura y llave con diferentes papeles (Paredes de Nava, PA-1689)

Se abrió uno de los escritorios ynventariados con quinze navetas (Medina de Rioseco, VA-1660) Un contador bajo de évano y marfil con su bufete de lo mismo, con ocho cajonzicos digo nabetas (Medina de Rioseco, VA-1647)

Una naueta de dicho escriptorio (Medina de Rioseco, VA-1647)

Un bufete de nogal con dos nabetas (Medina de Rioseco, VA-1640)

Se trata de un término polisémico que encontramos en la documentación histórica del español a partir del siglo XIV -en la Gran Conquista de Ultramar, 1300-, con el significado de 'nave pequeña' $(D E C H)$, en el siglo xv los testimonios que aparecen suelen hacer referencia también al 'recipiente para contener incienso' y con el significado de 'cajón de escritorio' no aparece hasta el siglo XVII, que, al igual que su homólogo gaveta, se registra en el Inventario de bienes de Felipe ॥ (CORDE y CDH). En el corpus terracampino presenta una importante nómina de casos con este último significado únicamente, aunque también figura como 'cajón de bufete'. El escribano lo diferencia del cajón ordinario, puesto que en uno de los ejemplos de Medina de Rioseco rectifica su asiento: "ocho cajonzicos digo nabetas". La presencia de este término en el CorLexIn se reduce a un par de ejemplos que cubren los dos significados: el aquí recogido y el de 'vaso o recipiente para el incieso'. 


\section{ORATORIO}

Sust. m. 'Sitio de algunas casas particulares, donde por privilegio se celebra el santo sacrificio de la misa' (DLE, 2.a ac.). Covarrubias lo define como 'el lugar dedeuocion, dedicado para hazer oracion a Dios' (NTLLE, s. v. oratorio, Covarrubias, 1611). Término derivado de orar, del lat. ŌRĀRE 'hablar', 'hacer un discurso', 'rogar, solicitar' (DECH, s. v. orar).

Un oratorio, veinte reales (Sahagún, LE-1605)

En el oratorio una tabla de nuestra señora de la Piedad con su marco estofado y dorado (Medina de Rioseco, VA-1644)

En el oratorio que está a lo último de la dicha galería una mesa de pino que seruía de altar con sus puertica donde se metían los (h)ornamentos en el cajón que tiene (Villalpando, ZA-1633)

En el siglo XVII, las familias más pudientes solían tener una sala que hacía las veces de oratorio. De este tipo de oratorios tenemos varios ejemplos en Medina de Rioseco y Villalpando. Sin embargo, la ocurrencia encontrada en Sahagún no hace referencia a una estancia, sino que estemos ante otro tipo de objeto, y es que el oratorio podía pasar de ocupar una sala entera a ser una especie de hornacina con elementos litúrgicos donde practicar la oración. El oratorio, aunque en contadas ocasiones, puede encontrarse como un tipo de mueble de puertas que contenía el altar, con elementos litúrgicos y de devoción y así lo podemos ver en un ejemplo localizado en México DF (1622) (CorLexIn):

Vn oratorio con su reja grande de tres caras y media, con puertas y balaustres de madera dorada; y seis mançanas grandes doradas con su remate; y çerradura y llaue.

\section{RAMILLETERO [ramiletero]}

Sust. m. 'Florero (vaso para flores) (DLE, 2.a ac.). Autoridades lo registra como 'especie de adorno que se pone en los altáres, formado de una macéta ò pié, y encima diversas flores de mano, que imitan un ramilléte. Hacense tambien de hojas mui sutiles de plata, lata y otros metáles' (NTLLE, s. v. ramilletero, Autoridades, 1737). Palabra derivada de ramo, del lat. RAMUS 'rama' (DECH, s. v. ramo).

Dos ramiletes de flores de mano en dos ramilleteros de madera plateados (Medina de Rioseco, VA-1644)

Quatro ramilleteros para flores dos de uidrio labrado y dos de Talauera que son dos xarras (Villalpando, ZA-1696)

Tanto el CORDE como el $C D H$ documentan este término en el inventario de bienes muebles que pertenecieron a Felipe II fechado en 1600, pero a partir del siglo XVIII entra en claro retroceso. El CorLexIn no ofrece ningún resultado de búsqueda de esta voz. Las dos ocurrencias localizadas en Tierra de Campos pertenecen a inventarios de bienes de dos capillas, una en Medina de Rioseco y otra en Villalpando, por lo que aquí ramilletero referencia el significado dado por Autoridades. No obstante, esta voz también designaba un tipo de florero que muchas veces se fabricaba con metales nobles como el oro o seminobles como la plata, lo que le dotaba de cierto valor. Desde el punto de vista formal presenta el sufijo -ero, muy productivo en esta época. 


\section{SALVADERA [saluadera, salbadera]}

Sust. f. 'Vaso, por lo común cerrado y con agujeros en la parte superior, en que se tenía la arenilla para enjugar lo escrito recientemente' $(D L E)$. El primer testimonio lexicográfico de esta voz lo recoge Percival en su diccionario español, inglés y latín fechado en 1591. Autoridades le da la definición que se ha mantenido hasta la actualidad sin cambios significativos (NTLLE, s. v. salvadera, Percival, 1591; Autoridades, 1739). Es una palabra derivada de salvado por el empleo de esta materia para enjugar lo escrito recientemente, derivado a su vez de salvo, del lat. SALVUS (DECH, s. v. salvo).

Una salvadera biexa del ynbentario (Castrillo, LE-1606)

Un tintero de pluma y un salbadera de ojadelata (Frechilla, PA-1642)

Una salvadera de querno (Boadilla de Rioseco, PA-1687)

Vn tintero y salbadera, thasado todo en quatro reales (Medina de Rioseco, VA-1645)

Unas escribanías y una saluadera y nauaxa de cortar plumas (Villalpando, ZA-1696)

La primera documentación que señalan el CORDE y el CDH para esta palabra data del año 1580 , localizada en un inventario de bienes de un clérigo, pero no es hasta el siglo XVII donde presenta un uso más extenso. En general no es un término muy documentado, dada la especificidad de este, aunque en los corpus del castellano se localizan ocurrencias a lo largo de todos los siglos. Esta escasez de datos también está presente en el CorLexIn, que a pesar de no llegar a la decena de items, el ámbito geográfico de uso es amplio. El término salvadera presenta una distribución diatópica de carácter general en la misma.

\section{SILLÓN}

Sust. m. 'Silla de brazos, mayor y más cómoda que la ordinaria.' o 'silla de montar construida de modo que una mujer pueda ir sentada en ella como en una silla común.' (DLE). Se registra en Autoridades con estas dos acepciones que conservamos en la actualidad, con la peculiaridad de que señala sillón como nombre que 'en Andalucía dan à las sillas comunes, que sirven en las salas' (NTLLE, s. v. sillón, Autoridades, 1739). En Diccionarios no académicos anteriores al de Autoridades relacionan este término con una 'silla grande de cavallo que sirve para una muger' (Sobrino, 1705). En el Diccionario académico de 1783 siguen manteniendo el carácter diatópico de la palabra sillón cuando se refiere a una silla grande, además de la segunda acepción. En la edición de 1843 desaparece la marca diatópica pasando a ser el aumentativo de silla y el de silla para el caballo. No es hasta la edición de 1914 en la que aparece la definición de sillón tal y como la conocemos hoy en día para la primera acepción. (NTLLE, s. v. sillón).

Seis sillones viejos (Villalpando, ZA-1633)

Otro sillón viexo (Villalpando, ZA-1633)

El CORDE no recoge este término hasta mediados del siglo XVI, fecha bastante tardía. En la documentación terracampina localizamos este término en un inventario de Villalpando, el contexto no es lo suficientemente claro como para saber de forma categórica ante qué significado estamos pues se enumera junto a un "relox" pero también al lado de un "maletón" y unas "angarilla", correspondientes al ajuar de camino en el que estaría la 'silla para montar las mujeres'. El CorLexln presenta un nutrido número de ocurrencias en la Península con ambos 
significados, y donde muestra una preferencia del aumentativo de silla en la zona meridional, aunque no podemos confirmarlo de manera absoluta, ya que hay ejemplos, que, por falta de un contexto claro, no podemos hacer afirmaciones tan tajantes. Esto explicaría esa marca diatópica que asigna Autoridades al término.

\section{SITIAL (taburete)}

Sust. m. 'Taburete, especialmente el que se solía poner en el estrado de las señoras', término en desuso (DEL, 2. a ac.). Autoridades lo registra como 'un taburetillo raso, como de una vara de largo, y media de ancho, con que adornan el estrado de las señoras, y sirven de assiento', en la edición del DRAE de 1899 no aparece esta acepción hasta la edición de 1925 donde la recupera, pero ya con la marca de palabra en desuso (NTLLE, s. v. sitial, Autoridades, 1739; DRAE, 1899, $D R A E, 1925)$. Término derivado de sitio y probablemente tomado del cat. setial o sitial (DECH, s. v. sitio).

Quatro reales de unos sitiales (Paredes de Nava, PA-1689)

Además del significado señalado anteriormente, el sitial también podía referenciar 'asiento de ceremonia, especialmente el que usan en actos solemnes ciertas personas constituidas en dignidad' (DLE), lo que podría explicar la falta de testimonios en la documentación notarial del momento. En el corpus terracampino, se recoge un único caso de sitial en Paredes de Nava, en el que el contexto no da detalles sobre su función o material del que está elaborado. Este documento tampoco presenta un orden lógico a través de campos léxicos, como ocurre en otras ocasiones. El CorLexIn muestra dos únicos casos de esta voz en documentos de la Ciudad de México (1622).

Desde una perspectiva diacrónica, el número de concordancias es mayor en los corpus del castellano. La primera noticia que dan el $C D H$ y el CORDE de esta voz es en la Cuentas de Gonzalo de Baeza, tesorero de Isabel la Católica, fechadas en 1477, y se presenta con naturaleza adjetiva: "se hizo vn paño sitial bordado" y también como sustantivo "una capa e setial e almohada de terçiopelo negro, e otras cosas para hornamentos".

\section{TABURETE [tavurete, tauurete, tabulete, taurete]}

Sust. m. 'Asiento sin brazos ni respaldo, para una persona', 'silla con el respaldo muy estrecho, guarnecida de vaqueta, terciopelo, etc. ( $D L E, 1$. a y 2. a ac.). La primera obra lexicográfica que recoge la voz taburete es el diccionario de Palet fechado en 1604. Autoridades lo recoge como 'especie de asiento como una silla, con la diferencia de que es raso, y sin brazos, y el respaldo para reclinarse mas estrecho. Guarnecese de baqueta, terciopelo, tafetan, y otras telas, clavadas à la madera', además señala que hay quien utiliza la variante taurete (NTLLE, s. v. taburete, Palet, 1604; Autoridades, 1739). Término procedente del francés tabouret, derivado del francés antiguo tabour 'tambor' por comparación de forma (DECH, s. v. tambor).

Un taburete de badana vsado (Valderas, LE-1647)

Dos sillas ordinarias y un taburete (Castromocho, PA-1611)

Dos taburetes de badana negro (Paredes de Nava, PA-1689) 
Quatro tavuretes altos (Paredes de Nava, PA-1690)

Treinta y dos reales de quatro taburetes altos (Paredes de Nava, PA-1689)

Un tauurete de madera (Boadilla de Rioseco, PA-1692)

Tres taburetes de baqueta de moscobia colorados son de badana con clauaçón dorada (Medina de Rioseco, VA-1640)

Ocho tavuretes, los quatro de nogal y los otros de pino (Medina de Rioseco, VA-1646)

Dos tauuretes de baqueta (Medina de Rioseco, VA-1649)

Un tavurete y una banca de madera en dos reales (Cuenca de Campos, VA-1666)

Dos taburetes altos (Villalpando, ZA-1644)

Un taburete de pie alto (Villalpando, ZA-1651)

Dos taburetes (Villalobos, ZA-1654)

Un tauurete de madera, otro de badana (Villalpando, ZA-1689)

El $C D H$ y el CORDE documentan varios ejemplos de esta voz a finales del siglo XVI. Por su parte, el CorLexIn presenta una distribución diatópica de carácter general, encontramos una extensa nómina de casos repartidos entre documentos notariales de la Península, Canarias y América. Lo que indica que en esta época la palabra ya formaba parte del acervo léxico del castellano. Esta situación se puede extrapolar a la zona terracampina, donde el uso de este término es frecuente. Además de la forma académica, también localizamos otras variantes, una de ellas es aquella que presenta la vacilación consonántica entre /r/ y /l/:

Un tabulete de quero demediado (Guaza de Campos, PA-1637)

Esta variante no es frecuente en los textos, el CorLexIn localiza un caso en la localidad conquense de Villamayor de Santiago (1638): "Un tabulete de pino, en dos reales". Otro item se localiza en Ciudad Rodrigo, provincia de Salamanca, en un inventario fechado en 1675: "dos tabuletes de nogal, biexos" (Pediguero, 2016: 138).

Otra variante que se halla en los documentos terracampinos y que es más frecuente es taurete, con síncopa de la consonante intervocálica:

Dos tauretes con respaldos de vaqueta (Grajal de Campos, LE-1656)

Quatro tauretes, a cinco reales (Medina de Rioseco, VA-1649)

Quinze tauretes de baqueta con clabazón dorado usados (Medina de Rioseco, VA-1660)

Zinco tauretes, los tres altos y dos vajos (Medina de Rioseco, VA-1661)

Quatro tauretes (Medina de Rioseco, VA-1661)

Morala y Egido localizan esta variante en La Rioja y León, y de forma más tardía en Uruguay (1769) (Morala y Egido, 2010: 433). El CORDE y el CDH muestran un único caso de esta variante ya entrado el siglo xx, en Matalaché, obra del escritor y poeta peruano López Albújar. Esta escasez de ejemplos contrasta con lo registrado en las obras lexicográficas, el primero en recoger esta variante es Franciosini (1620) y Autoridades da cuenta también de la misma como hemos visto anteriormente. Las ediciones académicas mantienen esta voz hasta la edición de 1803 (NTLLE, s. v. taurete, Franciosini, 1620; Autoridades, 1639; DRAE, 1803).

Desde el punto de vista de la morfología derivacional, el diminutivo alterna entre las formas de diminutivo en -illo, -ico e -ito:

Vn taburetillo baxo de badana con su respaldo biexo (Valderas, LE-1647)

Otros dos tabureticos de nogal muy viexos con las vadanas echos pedaços (Medina de Rioseco, VA-1644)

Dos tauureticos pequeños (Villalpando, ZA-1689)

Un taburetito con una encomienda / Otro taburetito (Villalpando, ZA-1666) 


\section{TARIMA [tarimilla]}

Sust. f. 'Zona del pavimento o entablado, superior en altura al resto' (DLE). Este término lo recoge Covarrubias como 'el estrado que acostumbran poner a los Reyes y Pricipes de madera, el qual cubren con paños de seda, o brocado, y sobre el la silla y sitial. También llaman estrado en el quese asientan las damas, cubierto de tapetes, y cogines, o almohadas' (NTLLE, s. v. tarima, Covarrubias, 1611). Del árabe tarîma, también târima 'estrado, tarima' (DECH, s. v. tarima).

Una tarima (Cea, LE-1621)

Una tarima de seis tablas (Grajal de Campos, LE-1658)

Una tarima buena (Grajal de Campos, LE-1670)

Una tarima (Villada, PA-1665)

Dos tarimas de pino en diez y seis reales (Medina de Rioseco, VA-1649)

Dos telares de tejer trançaderas nuebos con su tarima y escaño (Medina de Rioseco, VA-1657) Una tarima (Villalpando, ZA-1667)

Una tarima para los pies (Villalpando, ZA-1696)

Desde un punto de vista diacrónico, el $\mathrm{CDH}$ da cuenta de este término a partir del siglo XVI, El CorLexIn presenta un uso generalizado del término. En cuanto al significado que presenta en nuestro corpus, en principio suele coincidir con el dado por Covarruvias, aunque existen casos donde parece que tiene que ver con los accesorios que tienen relación con el lecho, algunos casos se disponen entre el ajuar de la cama (colchones, mantas, jergones, camas, etc.).

Desde un punto de vista más formal, los derivados de este término no son muy usuales en la documentación en general. En Tierra de Campos se localiza un único caso de diminutivo con el sufijo -illo:

Una cama de pino con cielo, cabeçales buenos, dos mantas buenas, una sobrecama açul, dos almoadas y unas cercaduras con çinco piernas y çielo de randas con sus flocaduras y una tarimilla (Frechilla, PA-1640)

\section{TINTERO}

Sust. m. 'Recipiente en que se pone la tinta de escribir' (DLE). Recogido por Nebrija y Covarrubias que lo define como 'el vaso donde tenemos la tinta' (NTLLE, s. v. tintero, Nebrija, 1495; Covarrubias, 1611). Término derivado de teñir, del lat. TĩNGĚRE 'mojar, empapar' (DECH, s. v. teñir).

Un tintero (Cea, LE-1610)

Un tintero de pluma y un salbadero de ojadelata (Frechilla, PA-1642)

Un tintero de latón (Medina de Rioseco, VA-1643)

Vn tintero y salbadera, thasado todo en quatro reales (Medina de Rioseco, VA-1645)

A pesar de la falta de testimonios, estamos ante una palabra de uso general. En Tierra de Campos no llega a la media docena de ocurrencias repartidas entre localidades de León, Palencia y Valladolid. Esta falta de casos puede deberse al fin del objeto inventariado, ahora la acción de escribir es algo cotidiano para un número importante de personas, pero en aquel entonces estaba reservado a unos pocos. 


\section{TOCADOR}

Sust. m. 'Mueble, por lo común en forma de mesa, con espejo y otros utensilios, para el peinado y aseo de una persona', 'caja o estuche para guardar alhajas, objetos de tocado o de costura, etc.' o 'paño que servía para cubrirse y adornarse la cabeza' (DLE, 1.ㄹ, 3. a y 4. a ac.). Autoridades en su segunda acepción lo define como 'el paño, con que se rodéa la cabeza, y cubre en forma de gorro', también lo registra como 'una caxa de madera exquisita con algunos embutidos de concha, ù marfil, ó plata, y en ella divisiones para guardar los adornos, y buxerías del tocado de las mugeres. Suele tener un espejo, para estarse mirando quando se peinan', pero no incluye la primera acepción que contempla el DLE, esta no se incluye hasta la edición de 1832 (NTLLE, s. v. tocador, Autoridades, 1739; DRAE, 1832). Término derivado de toca, voz antigua del cast., port. (touca) y vasco (taika) (DECH, s. v. toca).

Diez tocadores, digo beatillas (Sahagún, LE-1601)

Quince reales de un tocador con espejo (Paredes de Nava, PA-1689)

Un tocador de nogal con sus caxones (Medina de Rioseco, VA-1643)

Un arquilla tocador de nogal (Medina de Rioseco, VA-1660)

Con la 4. a acepción que propone el DLE solo encontramos una ocurrencia en Sahagún. En la zona existe una preferencia por otros vocablos como toca, tocado o beatilla. Algo que contrasta con los resultados de las búsquedas en la documentación general. El término con el significado relacionado con el mobiliario se recoge de forma tardía. En un primer momento figura como adjetivo, así lo hace en el inventario de Felipe II fechado en 1600: "bufete tocador", sin embargo, unos años más tarde aparece con naturaleza sustantiva en la Relación de capitulaciones de los marqueses de Toral y boda del Condestable de Castilla (1624): "[...] bufetes grandes de marfil, y euano, el tocador, de la señora Duquesa con el mismo adereço que el estrado de retiro". Cabe señalar que su presencia en los textos sigue siendo esporádica y, a menudo, se equipara con otros enseres como el escritorio: "[...] di con un escritorio o tocador de plata" en la obra Varia fortuna del soldado Píndalo fechada en 1626. Hay que esperar al siglo XVIII para apreciar un uso mayoritario de este significado.

Desde una perspectiva diatópica, el CorLexIn también recoge más casos del significado 'tocado'. Independientemente de cuál sea la acepción más documentada, esta base presenta casos con el significado que aquí nos ocupa tanto en la Península -Córdoba, Cáceres y Madrid-, Canarias-Tenerife-y América-México-.

\section{VASAR [basar, bassar, basal]}

Sust. m. 'Estante de fábrica u otra materia que, especialmente en las cocinas y despensas, sirve para poner la vajilla' (DLE). Covarrubias recoge vasar y vasera como 'el lugar donde se ponen los platos y las escudillas de barro [...]. La acepción ofrecida por Autoridades es la que conservamos hoy día (NTLLE, s. v. vasar, Covarrubias, 1611; Autoridades, 1739). Es un Término derivado de vaso, del lat. VAS, -IS 'vasija', vulgarmente VASUM (DECH, s. v. vaso).

Un basar de madera (Grajal de Campos, LE-1613)

Un vasar de madera (Grajal de Campos, LE-1658)

Un bassar nuevo de pino (Medina de Rioseco, VA-1640) 
Un basal de pino con sus yerros (Medina de Rioseco, VA-1647)

Un vasar de pino (Medina de Rioseco, VA-1648)

Un bassar de madera (Medina de Rioseco, VA-1657)

Un basar de tener platos en quatro reales (Cuenca de Campos, VA-1666)

El CORDE documenta vasar en el Becerro de las visitaciones de casas y heredades fechado en 1303: "una casa en que está un destajado que es cozina con I vasar de dos vigas colgadas e dos traviessas luengas". El vasar también está presente en los documentos terracampinos con una discreta nómina de casos. Dicho esto, en la zona también se recoge la variante vasal en un documento vallisoletano, este intercambio entre los fonemas líquidos es común en esta área. También es frecuente en las áreas que pertenecieron al Reino de León, por ejemplo, Gómez Ferrero (2015: 196-197) localiza esta variante como única en documentos de La Bañeza en los siglos XVIII y XIX.

Desde una perspectiva más formal, encontramos la forma derivada del diminutivo con la terminación -ico:

Un basarico de madera (Medina de Rioseco, VA-1639)

Aunque el contexto no da mucha información, parece que la motivación del diminutivo es puramente apreciativa. Rojo Vega localiza más casos de este diminutivo en documentos procedentes también de la documentación de Valladolid ${ }^{13}$.

En trabajos contemporáneos, este término sigue estando presente como 'poyo o estantería para poner la vajilla de una casa. Normalmente está en la cocina o despensa' (Gordaliza, 1988: 226), también como 'repisa para colocar platos, vasos y la vajilla en general' (García Caballero, 1992: 97). Le Men lo documenta en el ámbito del leonés, donde recoge la variante vasal en diferentes comarcas leonesas. Esta variante también se presenta en zonas ajenas a León: en Asturias, Zamora, Santander, La Rioja, Álava (Le Men, 2014, s. v. vasar).

Para cerrar esta lexía, cabe hacer referencia a una variante que Covarrubias identifica con vasar, pero que también presenta otros significados, es el caso de vasera:

Dos zestillas viexas pequeñas y una vasera con una redoma (Sahagún, LE-1608)

Autoridades, por su parte, añade un significado más a esta voz, el de 'caxa, ó funda, en que se guarda, ó con que se defienden los vasos'. Acepción que creemos que es la que tiene en este ejemplo recogido en el corpus terracampino.

Los datos que nos aporta el CorLexIn muestran un número exiguo de concordancias repartidas entre León, Ávila y Toledo. Acorde con la escasez de datos en el corpus estudiado.

\footnotetext{
${ }^{13}$ Rojo Vega localiza esta forma derivada en la documentación notarial vallisoletana que se puede consultar en https://investigadoresrb.patrimonionacional.es/
} 


\subsection{APEROS Y LABORES AGRÍCOLAS}

\subsubsection{Del arado}

\section{ARADO}

Sust. m. 'Instrumento de agricultura que, movido por fuerza animal o mecánica, sirve para labrar la tierra abriendo surcos en ella $(D L E)$. Es una voz recogida en el Vocabulario de Nebrija y en el Tesoro de Covarrubias donde lo define como 'el instrumento con que rompemos la tierra, para limpiarla delas malas yeruas, y disponerla para sembrar el trigo y las demas semillas' (NTLLE, s. v. arado, Covarrubias, 1611). Es un término derivado de arar, del lat. ARARE (DECH, s. v. arar).

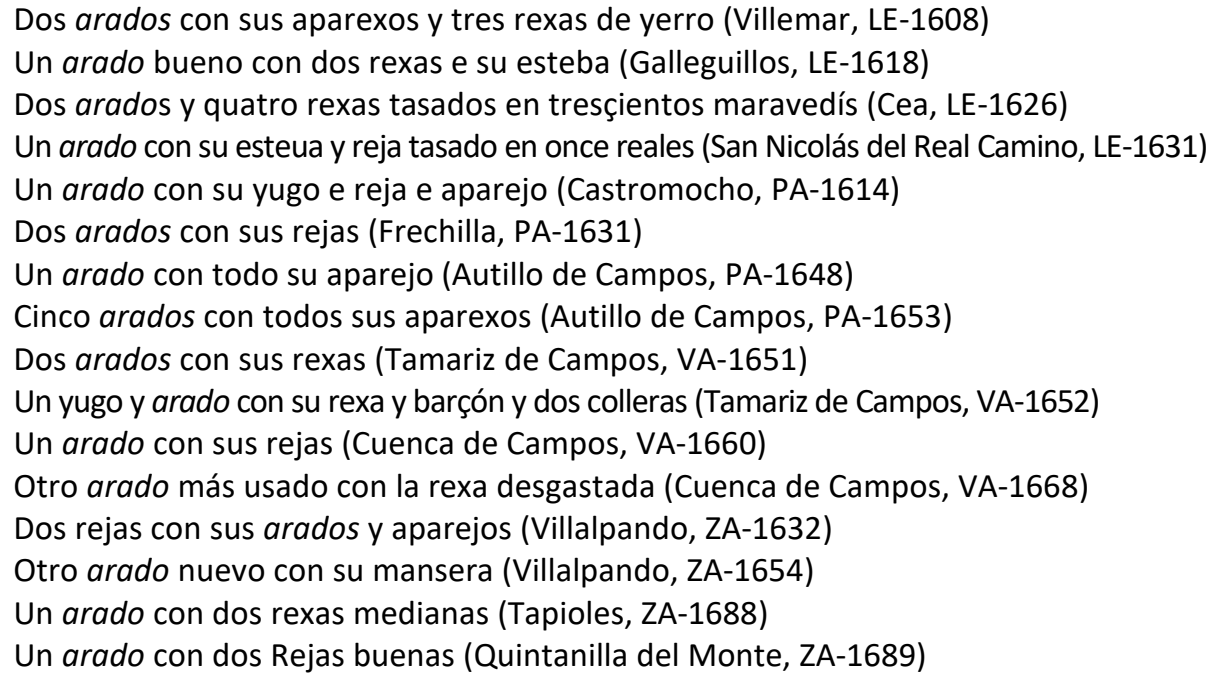

El uso de este término está generalizado en la documentación del siglo XVII. Se recoge en los corpus del castellano de forma temprana con la forma aradro, el CORDE lo documenta en el Fuero de Soria (1196) y el CDH en el Fuero de Zorita de los Canes unos años más tarde, ya entrado el siglo XIII (1218). También hacen eco de esta voz algunos textos altomedievales como la Colección Diplomática del Monasterio de Sahagún: "e dos aradros, de que seamos nos pagados" (1243) o "IIII aradros, con V reyas" (1245).

En Tierra de Campos se inventarían los arados junto a sus rejas, barzones, colleras, yugos, manseras y demás aparejos de labranza. Por otro lado, este término aparece modificado por el adjetivo golpejo, del que no tenemos noticias ni en las obras lexicográficas, ni en la documentación académica:

Dos arados golpejos con una reja, más dos cornales y dos melenas (Villalpando, ZA-1685)

El asiento en el que se halla no da mucha información sobre a qué se refiere con la denominación golpejos. Debemos recordar que vulpeja es 'zorra' en latín, con esta base se crean algunos topónimos como Golpejar derivado del VULPES latino. Por otro lado, el término zorra es equivalente a raposa, $y$ ' hace referencia 'cuña que se mete en el arado entre la reja y el dental' en León (Le Men, 2014, s. v. raposo). Posiblemente golpejos haga referencia a un tipo de arado concreto. 


\section{CAMBA [cama, canva, canba]}

Sust. f. 'cama', 'en el arado, pieza encorvada de madera o de hierro, en la cual encajan por la parte inferior delantera el dental y la reja, y por detrás la esteva; por el otro extremo está afianzada en el timón' y con marca dialectal de Asturias, Cantabria y Salamanca 'pina (pieza curva de la rueda de un carro)' ( $D L E$, s. v. camba 1 1. a y 2. a ac.). Camba se registra en la edición académica de 1817 como 'cualquiera de las barretas del freno, a que están asidas las riendas' y sin notación dialectal, en la edición del DRAE de 1884 señala esta voz como propia de Asturias y Santander cuando tiene el significado de 'pina' y en 1925 añade este uso en Salamanca (NTLLE, s. v. camba, DRAE, 1817; DRAE, 1884; DRAE, 1925). Término procedente del céltico *cambos 'curvo' (DECH, s. v. cama I).

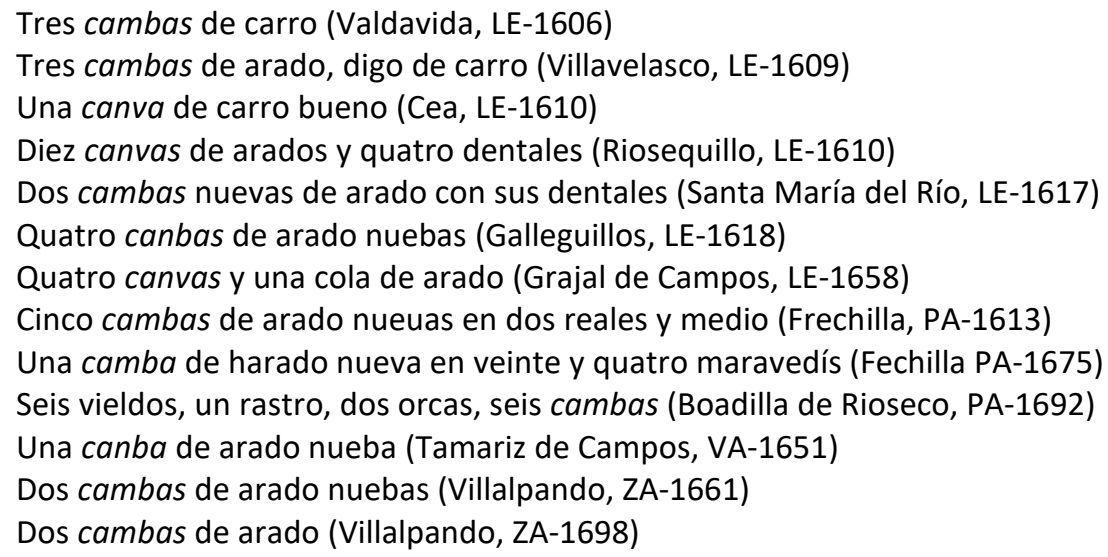

Camba figura en nuestro corpus con dos acepciones diferentes, como 'parte curva del tiradero del arado en la que se insertan la reja y el dental' -que es la más frecuente- y como 'cada una de las piezas curvas de madera de la rueda del carro'. Lo interesante de esta palabra es el mantenimiento de grupo consonántico latino /-mb-/ en posición intervocálica, solución propia del leonés, en vez de la solución castellana cama, de la que tan solo localizamos una ocurrencia:

Una cama de arado (Frechilla, PA-1640)

La frecuencia con la que aparece camba en el corpus terracampino contrasta con la escasa nómina de casos que presentan el CORDE y el CDH. El CorLexIn no ofrece datos de esta voz. Sí se localizan un par de ejemplos en La Bañeza, uno en un documento de 1644 y otro de un siglo más tarde (Gómez Ferrero, 2015: 231), a los que habría que añadir los localizados en la localidad zamorana de Tábara (Morala, 2017c: 352).

Morala, utilizando como fuente el Atlas Lingüístico de Castilla y León ( $A L C y L$ ), realiza un estudio sobre la diversidad dialectal del castellano norteño, donde señala que camba ocupa zonas donde lo esperable es el resultado castellano cama-como toda la provincia de Palencia, la mayor parte de la de Burgos y la parte vallisoletana del norte del Duero, la franja oriental de León y una aún más estrecha en Zamora y puntos dispersos en Soria, Segovia y Salamanca(Morala, 2002b: 959-960). 
En la zona de León aparece en los textos encambadura, un derivado del término camba que no aparece registrado en el $D L E$ y que hace referencia al 'conjunto de las cambas puestas a la vez' y que Le Men recoge en la zona de Riaño (Le Men, 2004, s. v. encambadura):

Quatro encanvaduras de carros nuevas (Riosequillo, LE-1610)

\section{CAMBIZO [canbiçio, cambiço, camizo, camiço, camiçio]}

Sust. m. 'Timón del trillo' ( $D L E)$, además señala que se utiliza en Extremadura, León, Salamanca y Zamora. La voz cambizo la recoge por primera vez el DRAE de 1925 como término utilizado en Salamanca (NTLLE, s. v. cambizo, DRAE, 1925). Término procedente del céltico *cambos 'curvo' (DECH, s. v. cama II).

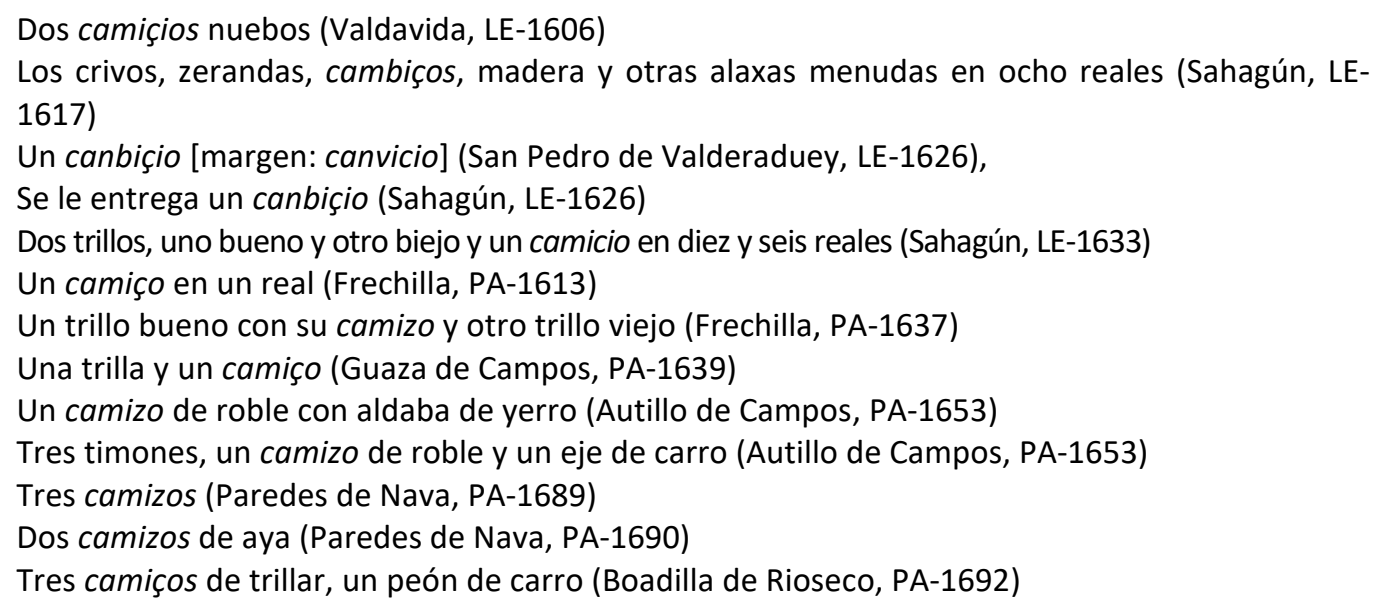

El término cambizo o camizo aparece poco documentado en bases de datos como el CORDE o el $C D H$, este último documenta la voz camizo en el Fuero de Alcalá en 1235 y casi diez años más tarde lo recoge la documentación perteneciente al Monasterio de Sahagún: "[...] dos trilos con sos camiços; [...]" (1243), "[...] dos trillos, con sos camizos; [...]" (1245). Por otra parte, no hay constancia del registro de esta voz en los diccionarios académicos hasta la edición de 1925, donde reconocen la forma cambizo, localizada con marca diatópica. Esta voz mantiene el grupo /-mb-/ intervocálico, rasgo propio del leonés y que se ubica en Extremadura, León, Salamanca y Zamora. Morala señala que la variante cambizo no es frecuente en la documentación notarial del siglo XVII, aun así, localiza un par de ejemplos en el norte de Cáceres y el área más oriental del leonés, con la /i/ epentética también frecuente en zonas de León (Morala 2012c: 317). Esto coincide con lo que nos encontramos en la zona de estudio, donde la variante cambizo se localiza en la parte leonesa de la Tierra de Campos, también con la /i/ epentética que convive de vez en cuando con la forma castellana camicio. En el resto de la Tierra de Campos la voz que se prefiere en los textos es el resultado patrimonial camizo.

Los datos que nos presenta el CorLexIn muestran una preferencia por la variante castellana camizo, también localizada con la variante con /i/ epentética camicio, lo que lleva a afirmar a Morala que se trata de una voz relativamente extendida en esta época (Morala, 2012f: 317-318). En el CorLexIn encontramos ocurrencias en inventarios de Cantabria, Palencia, Burgos, Segovia y Guadalajara, donde el contexto en el que aparece es el mismo y con la misma acepción que da el DLE para cambizo (Morala, 2012f: 318). 
La voz cambicio -con conservación del grupo consonántico /-mb-/ y epéntesis de la yod-se localiza en repertorios léxicos más actuales de León, Zamora, suroeste de Salamanca y Montaña palentina; cambizo se registra en Zamora, Santander y en la zona norte de Extremadura (Le Men, 2004 , s. v. cambicio). Por su parte, Gordaliza registra el término como 'madero o vara que sirve para enganchar la trilladera al yugo de las vacas' (Gordaliza, 1988: 55). Tanto cambizo como cambicio también se usan en la zona este de la provincia de Zamora (Álvarez Tejedor, 1989: 93).

\section{CAMBÓN}

Sust. $m$. 'Trozo de la rueda de la carreta, que sirve de sostén a las cambas y en el medio del cual penetra el eje', lo señala como un término rural utilizado en Asturias (DLE). El primer diccionario académico que recoge este término es el DRAE de 1925 con la misma acepción y marca diatópica. Se trata de un término derivado de camba -del céltico *cambos 'curvo'-, que Corminas y Pacual identifican como asturiano occidental con el significado de 'timón o lanza' (DECH, s. v. cambón).

Dos cambones de carro (Valderas, 1655)

Dos ruedas de carro con su yerro, cambones, ojales y demás aparejos (Villalpando, ZA-1661)

Este término apenas figura documentado en la Tierra de Campos, tan solo se han localizado dos ejemplos, ambos con la acepción académica. En bases léxicas textuales como el $C D H$, esta palabra aparece documentada de forma tardía, bien entrado el siglo XX, en un solo documento, en una obra de Caro Baroja sobre Tecnología popular española fechado en 1969 y con una acepción distinta a la académica. Tampoco se localiza en los inventarios del CorLexIn, por lo que cabe sospechar su carácter dialectal ya referido en los diccionarios académicos. Sin embargo, parece que la zona de presencia de este término en el siglo XVII se amplía a la Tierra de Campos. Formalmente en esta zona también se localiza la variante castellana camón en Frechilla:

Un labador de camones de carreta (Frechilla, PA-1612)

En estudios léxicos actuales, Gordaliza registra la voz cambón como 'trozos curvos de madera donde van los radios y el eje de la rueda del carro' y señala que más al norte se llama cambizo. En el estudio que hace Le Men del léxico leonés, esta palabra figura con diferentes acepciones: 'cada uno de los pedazos de madera, curvos, que unidos forman la rueda del carro, cubiertos luego por la llanta de hierro' o 'palo curvado que une el trillo al yugo', con la primera acepción se documenta en el este y noroeste de la provincia de León y con la segunda en la Ribera del Órbigo y La Cepeda, mientras que en otras comarcas suelen utilizar otras voces, como la de cambicio (Le Men, 2004, s. v. cambón).

\section{CAÑIZO [cañicio]}

Sust. m. 'Timón del trillo' (DLE, 3. a ac.). Con el significado que recogemos en Tierra de Campos no se recoge hasta una edición académica de 1925, con otras acepciones aparece desde Autoridades (NTLLE, s. v. cañizo, DRAE, 1925). Esta palabra deriva de caña, del lat. CANNA (DECH, s. v. caña). 
Dos cañizos biejos (Autillo de Campos, PA-1649)

Dos colleras, un yugo, un arado y un cañicio y dos rexas (Villada, PA-1665)

Un trillo mediado con su cañiçio (Villarramiel, PA-1696)

Cañizo se documenta a partir del siglo $\mathrm{xV}$ en el $C D H$, figura en los textos con la primera acepción que le otorga el DLE. Observando la información que nos ofrece el CorLexIn, este término aparece esporádicamente: "vn cañizo par trillar de salzes" en Herrara de Valdecañas (PA-1700), y un par de ejemplos junto a horcas en Ávila y Guadalajara. En la Tierra de Campos nos ocurre algo parecido, contamos con tres ejemplos, el caso de Villarramiel (PA-1696) muy clara la referencia a 'timón del trillo', en los otros dos casos, aunque aparece junto a aperos de labranza, tal vez su cometido sea otro. Formalmente, al igual que cambicio y camicio, también se da la epéntesis de /i/ cañiçio. Morala localiza esta voz en documentos de la Península de esta época, aunque señala que es menos frecuente (Morala, 2017a: 148).

Desde una perspectiva más formal, este derivado de caña presenta el sufijo -izo, especializado habitualmente en crear adjetivos, pero que en este caso ha dado lugar a un sustantivo.

Entre los repertorios dialectales modernos, como el de Gordaliza, se registra la forma cañicio -con /i/ epentética- como 'cada una de las piezas que forman la circunferencia de la rueda del carro' señala que se utiliza sobre todo en la zona Norte. Otra acepción que señala es la de 'palo que arrastra el trillo que en otros sitios se llama cambicio (Gordaliza, 1988:55).

\section{CLAVIJA [clabixa, clabija, clauixa, clabixares]}

Sust. f. 'Trozo cilíndrico o ligeramente cónico de madera, metal u otra materia apropiada, que se encaja en un taladro hecho al efecto en una pieza sólida' (DLE). Covarrubias recoge esta voz como 'los clauillos de hierro, o madera, en que estan tirantes las cuerdas, la quales suben, o se abaxan por ellas' (NTLLE, s. v. clavija, Covarrubias, 1611). Término derivado del lat. CLAVICǓLA 'llavecita', semicultismo de llave procedente del lat. CLAVIS (DECH, s. v. Ilave).

\footnotetext{
Una çestica con yerro viexo, clabos y un punzón y una clabixa del arado (Villacalabuey, LE-1614)

Tres clabixas de arado (Galleguillos, LE-1618)

Vna vrega con su clauixa de yerro (Villalobos, ZA-1654)

Un yugo de carro con su trasga, sobijuelo y clabija (Villalpando, ZA-1660)

Dos arcos de yerro con sus usillos y puercas y clauixas que tienen veinte y nuebe piezas que son para las cubas y valen ziento y zinquenta reales (Villalpando, ZA-1696)
}

Este término aparece en la zona más occidental de la Tierra de Campos referenciando uno de los elementos que configuran el arado o el trillo. Se documenta de forma temprana en el Fuero de Cáceres, en 1234 con la forma clauilla. La variante clavija se halla en documentos de corte literario fechados un siglo más tarde. En la documentación se utiliza en diferentes ámbitos léxicos y parece que la presencia de esta voz aumenta a partir de finales del siglo XIX (CDH y CORDE). Aunque está presente en los inventarios del siglo XVII, su presencia es más bien escasa. En el CorLexIn se localizan dos ocurrencias, una en Cuenca, donde no guarda relación con el arado, ya que es una parte de la cama, y el ejemplo de Villalobos (Zamora), donde forma parte de una brega. Estamos ante una palabra polisémica que se empleaba para denominar ciertas piezas de aperos, muebles u otros enseres. 
En algunas zonas de León esta palabra aparece como 'palo resistente de madera o hierro de unos veinte centímetros que, al introducirse en los agujeros de la lanza del carro, trillo u otros aperos de labranza, sirve de punto de apoyo a las fuerzas que arrastran tales objetos' (Le Men, s. v. clavija, 2004). En la zona de Palencia se conoce como 'el hierro que une el cambón del trillo al yugo' (Gordaliza, 1988: 69).

Muy próxima a esta palabra, el corpus terracampino nos ofrece el siguiente ejemplo:

Un taladro grueso y otro taladro de cabixares de yerro buenos (Santa María del Río, LE-1617).

Entendemos que la forma que más se acerca a la norma es la de clavijal que tampoco tiene entrada en el $D L E$, ni en ninguno de los diccionarios académicos. En su defecto aparece clavijero como 'parte del timón del arado en la cual están los agujeros para poner la clavija' (DLE, 3.a ac.). La ocurrencia localizada en la Tierra de Campos presenta la variante *cabijar.

Esta variante se localiza en estudios léxicos más actuales en la zona este de Zamora y también en Aragón (Álvarez Tejedor, 1989: 210-211)

\section{COLA}

Sust. f. 'Punta o extremo posterior de algo, por oposición a cabeza o principio' (DLE, 7. a ac.). Término procedente del lat. vulgar CŌDA 'rabo' (lat. CAUDA), el origen de la -l-castellana es incierto, pero en todo caso se trata de una variante muy antigua, que reaparece en el sur de Italia, y tal vez ya existente en lat. vulgar ( $D E C H$, s. v. cola I).

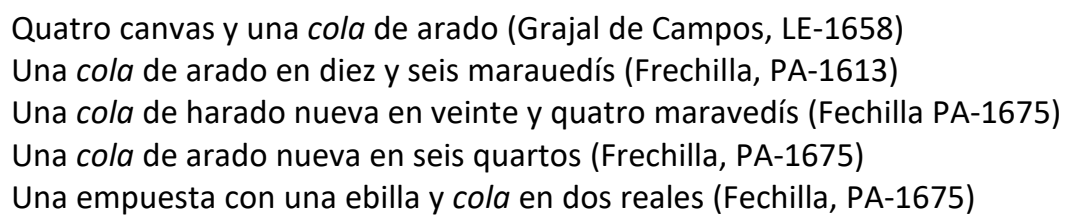

Esta voz aparece en la Tierra de Campos como parte del arado. Con esta acepción no lo encontramos ni en corpus léxicos como el CORDE, ni tampoco en el CorLexIn. Sí se halla en repertorios léxicos, como en el de Gordaliza, en el que cola hace referencia a una 'pieza del arado romano que se une al ventril' (Gordaliza, 1988: 70). En la zona noreste de León figura como 'tronco alargado que sirve para desmenuzar la tierra' y en Valencia de Don Juan es 'el rabo de la reja del arado que sobresale por detrás de la camba' (Le Men, 2004, s. v. cola).

\section{DENTAL}

Sust. m. 'Palo donde se encaja la reja del arado' (DRAE, s. v. dental ${ }^{1}$ ). Término recogido por Nebrija y también por Covarrubias con la acepción que aparece ahora en el DLE. Se trata de un derivado de diente, del latín DENS, DĔNTIS, íd. (DECH, s. v. diente).

Dos arados con sus dentales (Cea, LE-1610)

Diez canvas de arados y quatro dentales (Riosequillo, LE-1610)

Dos cambas nuevas de arado con sus dentales (Santa María del Río, LE-1617)

Otras tres canbas de arado e un dental nuebas (Galleguillos, LE-1618)

Un dental de vn ex (Castroañe, LE-1637)

Un dental (Castromocho, PA-1614) 
Dos dentales y una camba de aya (Fechilla PA-1615)

Un dental de haya nuevo en beinte y cuatro maravedís (Fechilla PA-1675)

Dos dentales, una cama de arado (Villarramiel, PA-1690)

Un dental de ancina por labrar (Tamariz de Campos, VA-1651)

Dos dentales de arado (Villalpando, ZA-1698)

Término frecuente en los inventarios analizados. A pesar de no presentar muchos ejemplos en el CorLexIn, el ámbito geográfico representado es amplio, por lo que estaríamos ante una palabra de uso general en la Península.

Esta lexía sigue estando vigente en estudios dialectales más actuales. Le Men señala la presencia de esta voz en vocabularios dialectales de muchas provincias: León, Asturias, Andalucía, Zamora... (Le Men, 2005, s. v. dental). En Palencia se recoge como 'pieza más inferior donde se encaja la reja y se sujetan la camba y la esteva' (Gordaliza, 1988: 90). Álvarez Tejedor (1989: 213) también da cuenta de esta palabra en la zona este de Zamora.

\section{IMPUESTA [empuesta, enpuesta]}

Este término no aparece en el $D L E$, ni en ningún diccionario académico con el significado con el que aparece en los documentos analizados de la Tierra de Campos. Lo encontramos en estudios dialectales recientes como el realizado por Le Men sobre el léxico leonés donde esta voz da cuenta de la 'parte media del tiradero del arado' (Le Men, 2007, s. v. impuesta).

Una empuesta de arado en dos reales (Frechilla, PA-1613)

Dos empuestas de arado (Frechilla, PA-1640)

Una enpuesta de arado (Autillo de Campos, PA-1649)

Una impuesta de arado nueba (Boadilla de Rioseco, PA-1692)

Una empuesta de arado (Frechilla, PA-1631)

Dos rexas y dos empuestas con sus ebillas (Fechilla PA-1612)

Una impuesta viexa sin rexas (Frechilla, PA-1637)

Una empuesta con una ebilla y cola de doze reales (Frechilla, PA-1675)

Tres enpuestas de álamo nuebas (7682-05-Villalpando, ZA-1661)

Impuesta se inventaría en los inventarios terracampinos como una parte del arado. Sin embargo, encontramos una ausencia de casos en los textos que conforman el CorLexIn. Tenemos que consultar estudios dialectales más recientes para tener noticias de esta voz. Le Men la documenta como 'parte media del tiradero del arado', aunque dependiendo de la zona donde se localice este término, el significado cambia ligeramente. De esta manera, aparece como 'timón del arado' en la zona de Toro (Zamora), en Tierra de Campos también aparece con esta acepción, en Palencia como 'la parte del timón del arado unida a la cama', en la Bureba (Burgos) como 'tronco o eje longitudinal de la vertedera' (Le Men, 2007, s. v. impuesta). Álvarez Tejedor localiza este término como 'mástil de madera que une el trillo al yugo' (Álvarez Tejedor, 1989: 210). Formalmente en Tierra de Campos nos encontramos con las variantes impuesta y empuesta, Álvarez Tejedor, además, halla en su zona de estudio la forma ampuesta.

\section{ESTEVA [esteba, esteua]}

Sust. f. 'Pieza corva y trasera del arado, sobre la cual lleva la mano quien ara, para dirigir la reja y apretarla contra la tierra' (DLE). Término recogido por Nebrija y Covarrubias con la misma 
acepción que conserva hoy el DLE (NTLLE, s. v. esteva, Nebrija, 1495; Covarrubias, 1611). Procedente del lat. vulgar *STËVA que parece ser variante dialectal, umbro-sabélica, del lat. STITVA, íd. (DECH, s. v. esteva).

\author{
Un arado con su rexa y esteba biexa (Celada, LE-1600) \\ Un arado con su esteua y reja (San Nicolás del Real Camino, LE-1631) \\ Un arado bueno con dos rexas e su esteba (Galleguillos, LE-1618) \\ Una esteba de arado (Villadiego, LE-1627) \\ Un arado compuesto de su reja y esteba en onçe reales (Frechilla, PA-1613) \\ Una esteva (Castromocho, PA-1614) \\ Tres arados, el uno nuevo con su rexa y aparexo y otros dos demediados con sus rexas y estevas \\ (Frechilla, PA-1615) \\ Un harado con su reja y esteva (Frechilla, PA-1637) \\ Una esteba de arado nuevo (Frechilla, PA-1639) \\ Un arado con su rexa y esteva y cuatro ebillas (Frechilla, PA-1675)
}

Esteva se encuentra ampliamente documentada en los inventarios de Tierra de Campos. Este término está presente en algunos textos desde el siglo XIII con la acepción académica $(C D H)$. Sin embargo, en los inventarios del siglo XVII su escasa presencia se limita a Guadalajara, Albacete y Navarra (CorLexIn). En la comarca de Tierra de Campos está presente en los inventarios pertenecientes a los partidos judiciales de Frechilla (Palencia) y Sahagún (León).

En época más moderna, se localiza como 'manceras del arado romano, de forma curva, por donde se le agarraba y dirigía' en Palencia (Gordaliza, 1988: 106). Esta voz figura en la zona este de León, aunque no es el término más usual para designar esta parte del arado (Le Men, 2005, s. v. esteva).

\title{
MANCERA [manjera]
}

Sust. f. 'Esteva de arado' (DLE). Covarrubias lo define como 'aquella parte del arado sobre la qual lleua el labrador la mano, y arrima el pecho para ahondar el surco' (NTLLE, s. v. mancera, Covarrubias, 1611). Podría ser un lat. vulgar *MANICIARIA, derivado de un *MANICIA, que se hallaría en Cerdeña, o más bien *MANUCIARIA, derivado de MANUCIUM, pero es más probable que resulte de un cambio de prefijo de manicella, 'manecilla, manija' (DECH, s. v. mano).

Otro arado nuevo con su manjera (Villalpando, ZA-1654)

Tan solo encontramos un ejemplo en la Tierra de Campos y con la variante manjera.

Mancera figura en los documentos como sinónimo de esteva en un texto de 1549, aunque la presencia de esta voz es esporádica $(C D H)$. En el CorLexIn tan solo localizamos una ocurrencia de este término en Navahermosa (Toledo) con la acepción y forma académica. Esta escasez de ejemplos también se traslada a la Tierra de Campos, donde encontramos un único ejemplo con la variante manjera en Villalpando (Zamora) donde hace referencia a una parte del arado, parece que en esta zona había preferencia por otros términos.

Esta palabra se localiza con diferentes variantes en zonas de León, entre ellas la de manjera, variante muy extendida por el dominio leonés. En cuanto al significado, en muchas localidades hay una "confusión de denominación entre el nombre de la esteva y el de una de sus partes, mientras que en otras se distingue entre la parte final o empuñadura y el resto de la esteva" (Le 
Men, 2007, s. v. macera). Con la variante localizada en este estudio, también se halla en época más cercana en la zona este de Zamora (Álvarez Tejedor, 1989: 214). En Palencia se mantiene el término académico mancera y referencia 'cada brazo de madera con que se empuña el arado' es una parte del arado diferente a la esteva en esta definición (Gordaliza, 1988: 143).

\section{REJA [rexa, arrejada]}

Sust. f. 'Instrumento de hierro, que es parte del arado y sirve para romper y revolver la tierra' (DLE). Nebrija registra en su Vocabulario 'reja de hierro para arar' y Autoridades hace una descripción detallada del término 'instrumento de hierro para romper la tierra, de media vara de largo, y de gruesso de mas de dos dedos por la parte superior que hace lomo, y menos à dos lados, que están en forma de vertiente. Tiene figura triangulár, y su cabo del mismo largór, quadrado, y gruesso de dos dedos, que sirve para assentar en la cama del arado' (NTLLE, s. v. reja, Nebrija, 1495; Autoridades, 1737). Es un término procedente del lat. RĒGŬLA 'barra de metal o de madera' (DECH, s. v. reja).

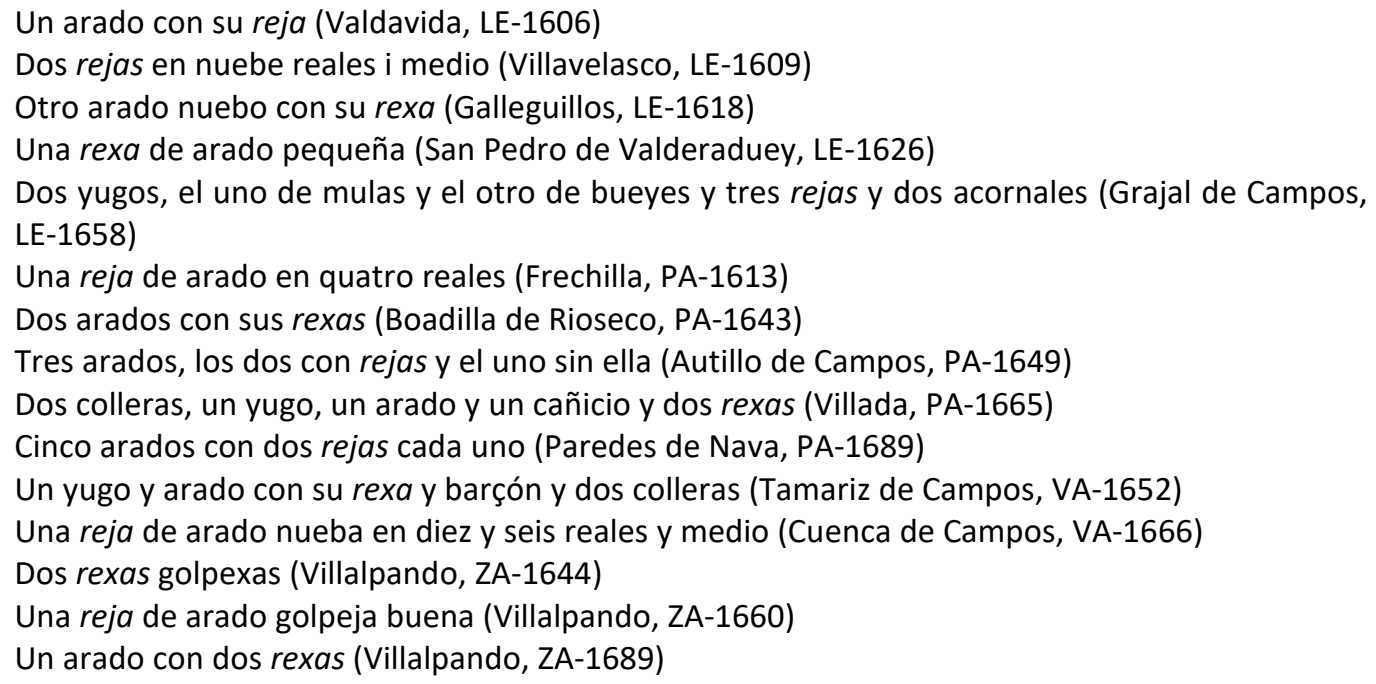

Es un término muy presente en los inventarios de la Tierra de Campos y también en los del resto de la Península (CorLexIn). Corominas y Pascual localizan relia en un documento burgalés fechado en el 974. Parece que todos los ejemplos localizados en el corpus terracampino hacen referencia a la acepción dada por el $D L E$, tan solo se hallan un par de ejemplos donde se especifica un tipo de reja llamada golpeja, apelativo ya comentado anteriormente.

En estudios dialectales actuales reja figura en zonas del leonés en donde el término se usa en plural con la acepción de 'piezas de madera con las que se ensamblan y hacen más resistentes las piezas de las ruedas del carro' (Le Men, 2012, s. v. reja). Por su parte, Gordaliza habla de 'parte del arado que rompe la tierra. En el arado romano es de forma piramidal, afilada, y antes de hacerla metálica, se usaron maderas muy duras' (Gordaliza, 1988: 192).

Derivado de reja, figura el término arrejada, formado por parasíntesis, pero en esta ocasión, en vez de dar lugar a un adjetivo, forma un sustantivo:

Dos arrejadas y un ocexo de yerro (Autillo de Campos, PA-1653) 
El diccionario académico recoge esta voz como sinónimo de aguijada (vara del arado), que según el DLE es la 'vara larga con un hierro de forma de paleta o de áncora en uno de sus extremos, en la que se apoyan los labradores cuando aran, y con la cual separan la tierra que se pega a la reja del arado'. Nebrija lo recoge como 'arrejada para limpiar la reja' y Autoridades como 'el hierro que tiene la aguijáda por la parte inferiór à manéra de una paléta para limpiar la reja quando está embarrada y llena de tierra' (NTLLE. s. v. arrejada, Nebrija, 1495; Autoridades, 1726).

La presencia de este término en bases académicas como el CORDE y el CDH es escasa, aunque cabe señalar que el CORDE la documenta de forma temprana: " [...] e den el açadon bueno e nueuo por diez mr., e den la arrejada por dos mr." (Cortes de Toro, 1369), y todavía conservan casos de esta voz en textos literarios de finales del siglo Xx como se puede observar en el $C D H$. En cuanto a los datos aportados por el CorLexIn, a pesar de no ser muy frecuente, presenta ejemplos en Segovia, Toledo, Badajoz o Sevilla.

\section{TIMÓN}

Sust. $m$. 'Palo derecho que sale de la cama del arado y al que se fija el tiro' (DLE, 4. a ac.). Nebrija y Covarrubias recogen el 'timón de carro o arado' y Autoridades habla de 'instrumento que gobierna el movimiento de algunas máquinas'. En diccionarios no académicos como el de Terreros y Pando entre otros, da como acepción de timón 'en el arado aquella especie de lanza que vá á dar á los animales que aran [...]; esta pieza entra en otra que se llama mediana, que es un palo combo, que entra en el yugo' (NTLLE, s. v. timón, Nebrija; 1495, Autoridades, 1739; Terreros y Pando, 1788). Es un término procedente del lat. TĒMO, -ŌNIS 'timón de carro o de arado', aunque casi todas las formas romances suponen una variante mal explicada *TīMO, -ōNIS, que debe ser antigua y probablemente existente en lat. vulgar (DECH, s. v. timón).

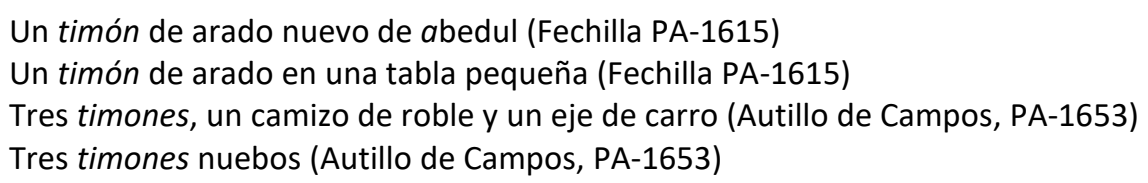

Se trata de un término documentado en el $C D H$ desde el siglo XIII con esta acepción. En el CorLexIn aparecen ejemplos sin un patrón de reparto geográfico claro -Tenerife, Palencia, Ciudad Real, Valladolid, Granada, Toledo y Burgos-. Además, se registran dos casos en Colombia que hacen referencia al timón de un barco, no al significado que encontramos en los textos de Tierra de Campos.

Le Men encuentra en León este término con el significado de 'palo que une el trillo al yugo', acepción que no recoge el DLE; o 'lanza o pértiga del carro' (Le Men, 2011, s. v. timón).

\section{TIRADERO}

Este término no aparece en el DLE con el significado que presenta en los inventarios de Tierra de Campos. Sí se encuentra en estudios dialectales actuales. Así, Le Men localiza esta voz como 
'palo grueso enganchado a una cadena y, esta, a la yunta que arrastra al trillo' (Le Men, 2012, s. v. tiradero). Es una palabra derivada de tirar, de origen incierto ( $D E C H$, s. v. tirar).

Dos tiraderos de trillo con sus yerros (Villalpando, ZA-1661)

Dos tiraderos con sus yerros (Villalpando, ZA-1698)

Tan solo encontramos dos ocurrencias en los textos analizados de Tierra de Campos. En bases de datos textuales como el $C D H$, se documenta de forma tardía, ya en el siglo xx y en un tratado de agricultura en el que se puede leer "timón en Castilla y tiradero en León", donde se señala la marca diatópica de este término. En el CorLexIn no encontramos ejemplos de esta palabra, tal vez por ese carácter dialectal que hemos mencionado anteriormente. Otros autores que han encontrado esta voz en inventarios del siglo XVII, son Gómez Ferrero en La Bañeza (2015: 229) y Morala en Zamora (2018a: 86-87).

\subsubsection{Del carro}

\section{ANGARILLAS}

Sust. f. pl. 'Cada una de las bolsas de las angarillas (armazón para transportar cualquier tipo de carga)', 'armazón de cuatro palos clavados en cuadro, de los cuales penden unas como bolsas grandes de redes de esparto, cáñamo u otra materia flexible, que sirve para transportar en cabalgaduras cosas delicadas, como vidrios, loza, etc.' (DLE, 2. a y 6. a ac.). Este término no es recogido por la Academia hasta la edición de 1927, siempre remitiendo a la forma en plural para esta acepción (NTLLE, s. v. angarillas, DRAE, 1927). Voz procedente de *ANGARIELLAE, diminutivo del lat. ANGARIAE 'prestaciones de trasporte, trasporte obligado en caballería o en carro', 'la silla de caballo empleada para este efecto'. De angarillas o anguerillas por metátesis salió la variante arganillas, de donde se extrajo un seudo-primitivo árganas o árguenas (DECH, s. v. angarillas).

Un carro bueno con sus pies de angarillas y su yugo y sobeo (Fechilla PA-1615)

Las angarillas de carro y bribiones todo en ocho reales (Cuenca de Campos, VA-1668)

Dos angarillas de mugeres uiejas (Villalpando, ZA-1633)

Al igual que en el $D L E$, este término presenta diferentes significados en Tierra de Campos, por un lado, designaría claramente a una parte del carro y, por otro, haría referencia a un instrumento que sirve para que las mujeres puedan ir más cómodas sobre las cabalgaduras y no se caigan. Es una voz con una presencia escasa en los inventarios, aun así, se localizan muestras de esta voz en América y se puede ver su naturaleza polisémica. Las ocurrencias que localizamos en Tierra de Campos siempre se presentan en plural, sin embargo, en inventarios de Burgos y Toledo se encuentra este vocablo en singular, con acepciones diferentes en ambos casos:

Vna angarilla de sacar pan, tres reales (Navahermosa, TO-1638)

Vna angarilla y dos escaleras de vancos, y vn banco de haçer arados, todo viexo, en quatro reales (San Millán de Juarros, BU-1642)

Esta voz aparece en estudios dialectales actuales, como 'mesa para matar el cerdo', esta acepción se encuentra principalmente en la montaña palentina, y como 'especie de armazón hecho de cuatro palos y unas redes que sirven para transportar cosas delicadas. También se 
llamaban así a unos brazos que se empleaban para traer las nías o mieses (Gordaliza, 1988: 29). Por su parte, Le Men señala la gran difusión que tiene esta voz y la variedad de acepciones que presenta, que justifica por la similitud en los objetos que designa (Le Men, 2002, s. v. angarilla).

\section{CARRETA}

Sust. f. 'Carro largo, estrecho y más bajo que el ordinario, cuyo plano se prolonga en una lanza en que se sujeta el yugo. Comúnmente tiene solo dos ruedas, sin herrar'. 'Carro cerrado por los lados, que no tiene las ruedas herradas, sino calzadas con pinas de madera' (DLE, 1. a y $2 . \underline{a}$ ac.). Término recogido desde Nebrija, en la segunda acepción que recoge Autoridades y que coincide con el $D L E$, señala que es como se llama a este tipo de carros 'en el Réino de Tolédo'. Se trata de una palabra derivada de carro, del latín CARRUS ( $D E C H$, s. v. carro).

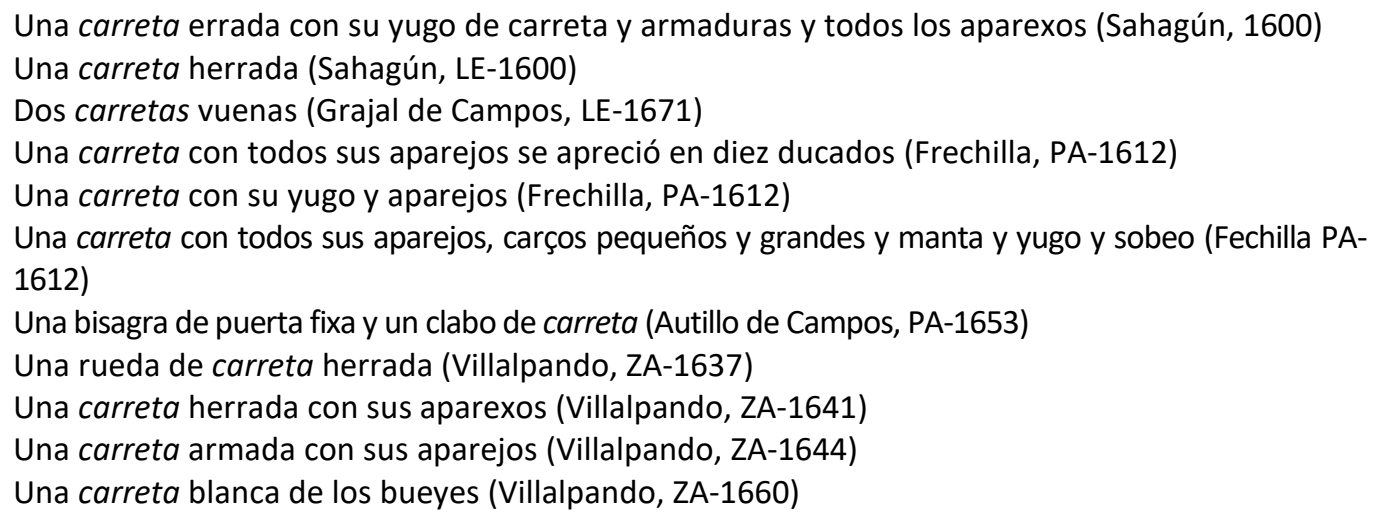

Es una palabra que se documenta desde el siglo XIII en el $C D H$. En los inventarios del siglo XVII de la Tierra de Campos este término está ampliamente documentado, señalando en muchas ocasiones que se trata de una 'carreta herrada', algo que no se corresponde con la definición que da el DLE. Es una voz de uso general.

\section{CARRETILLA}

Sust. f. 'Carro pequeño de mano, generalmente de una sola rueda, con un cajón para poner la carga y, en la parte posterior, dos varas para dirigirlo y dos pies en que descansa, utilizado en las obras para trasladar tierra, arena y otros materiales' (DLE). Autoridades lo registra como diminutivo de carreta 'la que es pequéña y de menor tamaño que la regular y común. En Andalucía y otras partes donde las carretas son mui anchas y grandes, llaman Carretillas a las que son mas pequéñas y recogidas' o también como 'cierto instrumento de madera de tres piés con ruedas en ellos, que se hace para poner delante a los niños: al qual se agarran por un palo que tiene atravesado, y estribando en él caminan seguros, con el qual se enséñan a andar'; en el diccionario no académico aparece como 'un carro de una rueda sola, y sirve para acarreár piedra', acepción que añade la siguiente edición académica (NTLLE, s. v. carretilla, Autoridades, 1729; Terreros y Pando, 1786). Término derivado de carro, del lat. CARRUS (DECH, s. v. carro).

Una carretilla en dos reales (Sahagún, 1600)

Una carretilla (Cea, LE-1610)

Una carretilla de labar lana (Frechilla, PA-1612) 
Una carretilla quebrada (Frechilla, PA-1615)

Una taja de carretilla (Frechilla, PA-1637)

Una carretilla de madera en quatro reales (Frechilla, PA-1675)

Pocos son los ejemplos que aparecen de este vocablo en los documentos del siglo XVII en bases de datos como el CORDE o el $C D H$, la mayoría de la documentación pertenece a los siglos XVIII, XIX y XX. En Tierra de Campos aparecen unos cuantos ejemplos de esta palabra, la gran mayoría en Frechilla, donde carretilla se referencia junto a libras de estambre, potros de peynar, peynes o cardas, y una de las carretillas sirve para "labar lana", con lo que este término se relaciona con la manufactura textil, muy extendida en la zona en aquella época. Sin embargo, en los inventarios pertenecientes a la zona leonesa de Tierra de Campos, carretilla aparece inventariada junto con otros enseres como escaleras, rastrillos o artesas de masar y sin ninguna otra información que especifique una función concreta. Aunque, a priori, se trata de un término común, cabe destacar que en esta época no es tan habitual en los textos y que los ejemplos que nos proporciona el CorLexIn se encuentran en documentos leoneses.

\section{CARRO}

Sust. m. 'Carruaje de dos ruedas, con lanza o varas para enganchar el tiro, y cuya armazón consiste en un bastidor con listones o cuerdas para sostener la carga, y varales o tablas en los costados, y a veces en los frentes, para sujetarla' (DLE). Voz procedente del lat. CARRUS (DECH, s. v. carro).

Un carro con sus ruedas raçonable (Valdavida, LE-1606)

Un carro bueno (Cea, LE-1610)

Un carro con dos pares de ruedas, berbiones y armaduras bueno (Sahagún, LE-1633)

Un carro herrado con su yugo y sobeo (Guaza de Campos, PA-1637)

Otro carro de buejes con su yugo y aparexos (Boadilla de Rioseco, PA-1643)

Un carro de mulas herrado con su yugo i sobeo (Autillo de Campos, PA-1653)

Un carro blanco con su yugo (Villarramiel, PA-1694)

Un carro montañez con ruedas çerradas (Villarramiel, PA-1696)

Un carro errado de mulas biexo con su yugo bueno (Paredes de Nava, PA-1690)

Un carro de madera (Cuenca de Campos, VA-1666)

Un carro chillón con su yugo y sobeo tassado todo en treynta y seis reales (Cuenca de Campos, VA-1668)

Un carro herrado con su soga de yugo y demás aparejos (Villalpando, ZA-1661)

Un carro chirrión nuevo (Villalpando, ZA-1685)

Un carro de calzas todo blanco (Villalpando, ZA-1685)

Un carro blanco (Tapioles, ZA-1688)

Un carro chirrión viexo (Villalpando, ZA-1686)

Un carro montañés con sus armaduras (Villalpando, ZA-1690)

El carro destinado a las labores del campo fue una herramienta imprescindible para la vida rural española. La tipología de este vehículo es de lo más variada dependiendo de su forma y la utilidad que se le daba. Estamos ante un término uso general y muy presente en los inventarios de bienes. En los textos nos encontramos con carros herrados, de calzas, blancos, chillones, chirriones o montañeses. A las ruedas de los carros de montaña se les denominaba blancas, porque no disponían de radios, sino que eran totalmente macizas, de ahí muy probablemente surgiera la denominación "carros blancos", en cambio los carros "chillones o chirriones", probablemente fuera por el ruido característico de sus ruedas al girar (Alcalde, 2002: 58). 
Autoridades recoge el sustantivo chirrión referenciando al 'carro en forma de caxa, de dos ruedas y pértigo mui fuerte, con mucho herrage, y abundancia de volandéras, por lo qual hace un chirrío áspero, récio, è inaguantable, de donde vino à llamarse Chirrión. Es acomodado para llevar aréna, tierra, basúra y otras cosas'. En Villalpando, localidad donde se documenta, siempre aparece como adjetivo.

El término carro figura como medida de capacidad en los inventarios de la época:

Diez carros de paxa a quatro reales el carro (Sahagún, 1600)

Beynte carros de estiércol en el corral (Grajal de Campos, LE-1616)

Un carro de leña (Cea, LE-1621)

Como cosa de dos carros de leña (Castroañe, LE-1637)

Seis carros de paja de trigo y zeuada (Valderas, LE-1682)

Tres carros y medio de paja bueno y malo (Frechilla, PA-1640)

Treinta o quarenta carros de canto labrado (Frechilla, PA-1640)

Seis carros de paxa (Paredes de Nava, PA-1690)

Dos carros de estiércol seco (Castromocho, PA-1614)

Medio carro de carbón de brezo (Medina de Rioseco, VA-1651)

Treinta carros de paxa (Tamariz de Campos, VA-1652)

Dos carros de paxa que abía en el paxar (Cuenca de Campos, VA-1668)

Diez carros de paja (Villalpando, ZA-1631)

Tres carros de paja en unas casas de la susodicha (Villalpando, ZA-1661)

Dos carros de manojos (Villalpando, ZA-1690)

\section{COCHE}

Sust. m. 'Carruaje de cuatro ruedas de tracción animal, con una caja, dentro de la cual hay asiento para dos o más personas' (DLE, 2. a ac.). Covarrubias lo registra como 'carro cubierto y adornado, de cuatro ruedas, que le tiran cauallos, o mulas'. Autoridades mantiene la definición de Covarrubias y añade que 'está cerrado por los lados con vidros ò vaquétas, y sostenido sobre quatro pilares con correones de vaquéta, para que el movimiento sea más acomodado' (NTLLE, s. v. coche, Covarrubias, 1611; Autoridades, 1729). Resulta incierto su origen, no se sabe si procede del húngaro o del checo ( $D E C H$, s. v. coche).

Dos coches, el uno que trajo el Conde Lemss De Nápoles que se llama coche Úngaro y está desarmado y hecho pedaços, y el otro es un carro largo que el Conde Lemss trajo de Flandes que se le dio el gouernador de Unquerque y éste está tan maltratado que no es de ningún prouecho (Villalpando, ZA-1633)

Encontramos documentada esta voz en textos del siglo XVI, en obras literarias de Lope de Rueda (CORDE) o en el Cancionero de Sebastián de Horozco (CDH). En el CorLexIn vemos algunos ejemplos, todos ellos pertenecientes a inventarios de personas que ocupaban un estatus social alto, tanto de la nobleza como del clero, así nos encontramos "vn coche encarnado con seis cortinas de damasco claveteado y su enzerado berde, y seis cortinas de baieta encarnada y enzerado blanco en zinco mil reales" (Córdoba, 1687). En el ejemplo que recuperamos del inventario zamorano, no tenemos información sobre qué materiales y adornos llevaban debido al mal estado en el que se encuentra, aunque sí sabemos que pertenecía al Condestable de Castilla, perteneciente a una clase social alta y privilegiada. Los dos vehículos son de importación, uno traído por el mismo Condestable de Nápoles, el coche úngaro y el otro que fue un regalo del gobernador de Unquerque, en Flandes (Miguel Borge, 2016: 352). 


\section{COSTANA}

Sust. f. En León, Palencia y Zamora 'adral'. 'Cada uno de los zarzos o tablas que se ponen en los costados del carro para que no se caiga lo que va en él' ( $D L E$, 3. a ac.). La academia no incluye la voz costana hasta la edición de 1925 y en ella este término ya aparece con marca diatópica, como un término utilizado en León (NTLLE, s. v. costana, DRAE 1925). Se trata de una voz derivada de cuesta 'espalda' del lat. Cŏsta 'costilla', 'costado, lado' (DECH, s. v. cuesta).

Dos costanas buenas (Castrillo, LE-1606)

Dos costanas buenas (Sahagún, LE-1608)

Dos costanas buenas (Grajal de Campos, LE-1671)

Dos costanas buenas en cinco reales (Cuenca de Campos, VA-1666)

Dos pares de costanas nuebas (Villalpando, ZA-1661)

Dos costanas nuebas del carro (Villalpando, ZA-1685)

Dos costanas ya usadas (Villalpando, ZA-1690)

Un carro blanco con sus costanas (Villalpando, ZA-1696)

Dos costanas buenas (Castrillo, LE-1606)

Dos costanas buenas (Sahagún, LE-1608)

Dos costanas buenas (Grajal de Campos, LE-1671)

Dos costanas buenas en cinco reales (Cuenca de Campos, VA-1666)

Dos pares de costanas nuebas (Villalpando, ZA-1661)

Dos costanas nuebas del carro (Villalpando, ZA-1685)

Dos costanas ya usadas (Villalpando, ZA-1690)

Un carro blanco con sus costanas (Villalpando, ZA-1696)

Esta voz aparece en Tierra de Campos con la acepción académica de 'tablas que se ponen en los costados del carro' y en los ejemplos encontrados siempre aparecen en plural. Apenas encontramos ejemplos de esta acepción en la documentación del $C D H$ y el CORDE. En los inventarios del siglo XVII aparecen ejemplos en León y Zamora (CorLexIn). Parece que este término presenta una clara marca diatópica que comprende también la Tierra de Campos donde esta voz está ampliamente documentada con la acepción anteriormente expuesta. A pesar de su presencia, esta voz comparte campo léxico con zarzo, que aparece en la zona de Frechilla (Palencia). En repertorios léxicos actuales, Gordaliza señala dos acepciones para este término, como 'calle en cuesta' y con la acepción que tenemos en los textos de la zona terracampina 'costados laterales del carro' señalando que en León también se llaman adrales (Gordaliza, 1988: 76). En el área del leonés 'estos laterales se añaden por dentro del carro para el acarreo de estiércol u otros materiales menudos. [...] Están hechos con un tejido de mimbres o con tablas solamente'. Hay que señalar que los carros podían aumentar la carga tanto por la zona lateral, como por delante y por detrás, en muchas ocasiones los nombres que reciben estos apósitos del carro cambian dependiendo de qué zona sea la que se aumente, por regla general las costanas aumentan el tamaño del carro por la parte lateral. Aunque la falta de contexto no nos permite saber exactamente este dato. En León se localizan usos de costanas para utilizar delante y detrás del carro (Le Men, 2004, s. v. costana). 


\section{SOJADO [soxado]}

Sust. m. 'suelo del carro', palabra derivada del lat. sŏLum 'suelo' (DECH, s. v. sojado). No se registra en ninguna de las obras lexicográficas académicas.

Un sojado de carreta apreçiado en quinze reales (Frechilla, PA-1613)

Un carro con todo su aparejo, sojado y yugo (Frechilla, PA-1631)

Un eje viejo, un sojado biexo (Frechilla, PA-1639)

Otro soxado biexo de carro (Boadilla de Rioseco, PA-1643)

Una rueda buena y otra biexa sin erraxe y un soxado (Villalpando, ZA-1613)

Un carro herrado con su sojado, yugo y demás aparejos (Villalpando, ZA-1661)

El término sojado, con las variantes gráficas atribuidas al sonido velar sordo $/ x /$, es el que se halla en el corpus terracampino para referenciar el suelo del carro o la carreta. Se trata de un término poco frecuente en documentación histórica. Las pocas concordancias que nos devuelve el CORDE y el CDH datan esté término en el Becerro de visitaciones de casas y heredades de la catedral de Ávila (1303). En el CorLexIn no figuran ejemplos de esta palabra. Rojo Vega localiza ocurrencias de esta voz en documentos fechados entre finales del siglo XVI y principios del XVII en poblaciones vallisoletanas -Alaejos, Villanueva de Duero y Valladolid- ${ }^{14}$.

Donde sí encontramos ejemplos de esta lexía es en estudios dialectales actuales en los que aparecen diferentes variantes para hacer referencia al suelo del carro. La variante sojado se localiza en Cantabria y Salamanca (Le Men, 2005, s. v. desojado). Mientras que en la propia zona terracampina se utiliza deshojado para referenciar la 'carga de un carro hasta la altura en que terminan las barandillas' (García Bermejo, 1946: 479 en Le Men, 2005). En la zona este de Zamora se utiliza sojao, con caída de la /-d-/ intervocálica y también deshojado (Álvarez Tejedor, 1989: 221, 227).

\section{TENTEMOZO [TENTEMOÇOS]}

Sust. m. 'Palo que cuelga del pértigo del carro, que, puesto de punta contra el suelo, impide que aquel caiga hacia adelante' ( $D L E, 2 . \underline{a}$ ac.). Aunque Autoridades registra esta palabra en su edición de 1739, no es hasta la edición de 1899 cuando se recoge la acepción con la que aparece en los inventarios (NTLLE, s. v. tentemozo, Autoridades, 1739; DRAE, 1899). Palabra compuesta del verbo tener y el sustantivo mozo.

Quatro tentemoços y un yugo carral apreciados en dos reales (Frechilla, PA-1613)

Tan solo se ha localizado un ejemplo en la zona de estudio. Los ejemplos de este término compuesto son muy escasos en bases de datos textuales como el $C D H$. Tampoco se localizan ejemplos en el CorLexIn. Sin embargo, sí localizamos este término en estudios dialectales más actuales. Así, Gordaliza localiza este vocablo en Palencia como 'palos que cuelgan de las varas

\footnotetext{
${ }^{14}$ Rojo Vega localiza el siguiente ejemplo:

Testamento de Carlos de Abaunza (1576) en Villanueva de Duero: "unas ruedas y un sojado de un chirrión". https://investigadoresrb.patrimonionacional.es/node/5747 [recuperado diciembre de 2020].
} 
del carro y le sujetan evitando que se caiga hacia delante' y como 'palo que servía para apretar los colmos de paja de centeno, usados luego para techar las casas' (Gordaliza, 1988: 210).

\section{TRINCHERA}

Sust. f. 'Cada una de las piezas curvas que en la carreta sujetan el eje al tablero' (DLE, 4. a ac.), lo marca además como término utilizado en León. Esta distinción diatópica se introduce en la edición del DRAE de 1925 (NTLLE, s. v. trinchera). Término derivado de tranzar 'cortar, tronchar', de origen incierto (DECH, s. v. tranzar).

Una media trinchera de carro (Tamariz de Campos, VA-1651)

Tan solo encontramos un ejemplo en la zona terracampina y es el propio contexto el que nos aclara que se trata de una parte del carro. La escasez de ejemplos en la zona de estudio y los inventarios de la época hace que no podamos dar mucha más información sobre esta voz.

\section{VENTRIL [bentril]}

Sust. m. 'León. Vara del carro de bueyes a la cual se unce el ganado'. 'Pal. Correa que pasa por debajo del vientre de las mulas y se une al yugo' ( $D L E$, 2. y 3.a ac.), con marca diatópica. Esta voz la registra Terreros con dos acepciones: ventril es la 'correa que se pone en lugar de cincha en la guarniciones de las caballerías, y ventriles, en plural, 'llaman en el molino de aceite à las tablas menores que las que en él se llaman trabas, y que tienen el mismo servicio'; y con una acepción muy parecida a esta última, la recoge el DRAE de 1837 'pieza de madera que sirve para equilibrar el movimiento de la viga en los molinos de aceite', en ambos diccionarios sin notación dialectal; es en la edición de 1925 cuando aparecen registradas las acepciones que se identifican como utilizadas en León y Palencia (NTLLE, s. v. ventril, Terreros y Pando, 1788; DRAE, 1837; $D R A E, 1925)$. Término derivado de vientre, del lat. VĚNTER, TRIS (DECH, s. v. vientre).

Dos vueltas, dos bentriles, tres cabezadas con sus cadenas (Villalpado, ZA-1661)

Tan solo encontramos un ejemplo en Tierra de Campos y por el contexto en el que se encuentra, forma parte de los aparejos del carro o del arado, ya que está entre "dos trasgas" y "dos arados". Bases textuales como el CORDE y el CDH presentan pocas concordancias. Esta escasez de ocurrencias en la documentación histórica se traslada a la de los inventarios de bienes del siglo XVII, donde no encontramos ejemplos (CorLexIn).

Sí aparece en estudios léxicos más recientes como el de Gordaliza que lo recoge como 'pieza del arado romano, situada en el centro del mismo, que se une a la camba y a la cola', además de las acepciones dadas para León y Palencia en el DLE (Gordaliza, 1988: 226). En el estudio del habla de Villada aparece ventril como 'correa que pasaba por debajo de la mula en el carro' (Casas, 1989:538) y Álvarez Tejedor afirma que esta palabra se usa en Palencia, pero también en Huesca -Hu. 601-y en Teruel -Te. 306- (ALEANR, I.129) (Álvarez Tejedor, 1989: 235). 


\section{VERBIÓN [berbión, brebión, bribión]}

Esta palabra no figura en los diccionarios académicos, aunque sí es de uso frecuente en el leonés y designa 'cada uno de los maderos perpendiculares a la vara del carro que limitan la caja del carro por delante y por detrás. Llevan agujeros en los extremos en que se introducen las pernillas o palos verticales de la armadura del carro', 'cada uno de los taladros rectangulares de los maderos donde entran las armaduras' (Le Men, 2012, s. v. verbión).

Un brebión de carro de álamo (Galleguillos, LE-1618)

Se entrega un carro con dos pares de ruedas, berbiones y armaduras (Sahagún, LE-1633)

Un berbión, pedaço de eje de aya (Frechilla, PA-1640)

Dos latillas, una açoleta, un bocado de freno y un berbión (Frechilla, PA-1640)

Se tasó las angarillas de carro y bribiones todo en ocho reales (Cuenca de Campos, VA-1668)

Es una palabra que no aparece en bases de datos académicas como el CORDE o el CDH. Las ocurrencias que aparecen en el CorLexIn pertenecen a inventarios de localidades leonesas -Solanilla, Villacalbiel, y Villacelama-, muy cercanas a la zona de estudio. A Estos ejemplos habría que sumar aquellos localizados en relaciones de bienes de La Bañeza, también en León (Gómez Ferrero, 2015: 238). Por lo que la presencia de este término se limita a la zona noroccidental de la Península. En Tierra de Campos esta voz aparece tanto en singular como en plural, aunque es más habitual encontrarlo en plural en los inventarios. Formalmente encontramos la metátesis de la / $\mathrm{r}$ / en brebión y bribiones, este último ejemplo con cierre de la vocal palatal, un cambio de timbre muy habitual en esta época del que ya hemos hablado anteriormente.

Álvarez Tejedor localiza aimón, mejor dicho, aimones -casi siempre aparece en plural-, utilizado en Zamora en vez de verbión. Se trata de 'cada uno de los potentes maderos de la escalera del carro sobre los que descansan los tableros laterales' (Álvarez Tejedor, 1989: 221). Gordaliza también registra aimón en el Vocabulario Palentino con varias acepciones 'anilla de madera o de cuero que sujeta el timón del arado al yugo', 'pescante del carro', dos vigas laterales de unos dos metros de largo en el carro tirado por caballerías. Solían ser de olmo' (Gordaliza, 1988: 23). Del término aimón no hemos localizado ningún caso.

\section{VOLANDERA [bolandera]}

Sust. f. 'Rodaja de hierro que se coloca como suplemento en los extremos del eje del carro para sujetar las ruedas' (DLE, 5.a ac.). Esta voz la recoge la edición académica de 1803 como 'cualquiera de las tablillas que se ponen en la superficie de la rueda de la azuda, ú otro artificio semejante [...]' y que tiene que ver con la rueda de molino, (NTLLE, s. v. volandera, DRAE, 1803). Palabra derivada de volar, del lat. VŏLARE íd. (DECH, s. v. volar).

Un peto de yerro biejo con una bolandera (Frechilla, PA-1640)

El CorLexIn localiza esta voz en Palencia, en la localidad de Herrera de Valdecañas. La única ocurrencia que se localiza en la Tierra de Campos se ubica en Frechilla, localidad también palentina y que por el contexto podemos decir que hace referencia a la pieza del carro, y que se encuentra junto a "una trauiesa de carro de yerro". Morala aumenta el número de ocurrencias 
y de localizaciones, ya que encuentra este término en inventarios de El Espinar (Segovia) -"un bux de carreta y [...] çinco bolanderas de yerro"- y diferentes localidades de Cáceres -"unas volanderas de carreta"- (Morala, 2014a: 20-21).

Entre los repertorios modernos, se registra la forma volandera en el vocabulario de Gordaliza, donde mantiene esta misma acepción de 'especie de palomilla o arandela en el extremo del eje de la rueda del carro que sirve para sujetarla' (Gordaliza, 1988: 228).

\section{ZARZO [çarzo, zarço, çarço, çarçe]}

Sust. m. 'Tejido de varas, cañas, mimbres o juncos, que forma una superficie plana' (DLE). Palabra derivada de zarza, antiguamente saça, voz peculiar al cast. y el port., de origen incierto, seguramente prerromano (DECH, s. v. zarzo).

Un çarzo, un real (Sahagún, LE-1601)

Quatro zarzos de binbres vuenos (Santa María del Río, LE-1617)

Un zarço pajariego (Frechilla, PA-1612)

Una carreta con todos sus aparejos, çarços pequeños y grandes (frechilla, PA-1612)

Dos zarços viejos en cinquenta marauedís (Frechilla, PA-1613)

Un çarço de barear y unas tablas (Frechilla, PA-1615)

Un çarço biexo de harcar de cañas (Frechilla, PA-1616)

Dos çarçes pajariegos (Frechilla, PA-1639)

Dos zarzos nuebos (Autillo de Campos, PA-1653)

Un zarzo de cañas para harcar en dos reales (Frechilla, PA-1675)

Un zarzo de lanas para harcar en dos reales (Frechilla, PA-1675)

Dos zarços para meter paxa en ocho reales (Frechilla, PA-1675)

Dos pares de çarzos (Paredes de Nava, PA-1689)

Los çarços que se allaron abajo (Villalón, VA-1642)

Tres çarços biexos (Villalón, VA-1642)

Es un término ampliamente documentado en la Tierra de Campos, donde nos encontramos zarzos "de barear", "de harcar" o "de meter paja", estos últimos también llamados pajariegos, con el sufijo -iego, poco productiva en castellano, pero que tiene una presencia significativa en el norte de España, preferentemente en la franja occidental (Morala, 2017a: 137).

Gordaliza localiza esta voz como 'trama hecha de varas de avellano que forma la armadura del carro de vacas', también como 'tejido de mimbres que sirve de tapa a la hoya del semillero y lo protege del frío. Se llama también zarceto (Saldaña)' o las 'tapias de corrales hechas con bardas (albardilla)' (Gordaliza, 1988: 234). En el este de la provincia de Zamora, se localiza este término como 'un tinglado de cuatro listones de madera que prolongaban hacia arriba las pernillas de la caja del carro, unidos entre sí en su parte superior por otros horizontales de los que colgaban cuatro grandes redes' (Álvarez Tejedor, 1989: 83). En León también suele utilizarse bajo la forma sardo (Le Mén, 2014, s. v. sardo). 


\subsubsection{Del yugo y del uncir}

\section{BARZÓN [barçón, varzón, varçón]}

Sust. m. 'Anillo de hierro, madera o cuero por donde pasa el timón del arado en el yugo' como término especializado de agricultura ( $D L E, 3$. a ac.). Lo recoge Autoridades como un término agrícola y con marca diatópica en Aragón y otras partes y lo define como 'el anillo, ù sortija de hierro, ù de palo por donde passa el timón del arado en el yugo' pero en la siguiente edición, esta voz para a significar 'paseo ocioso' usado en algunas partes de Andalucía y Extremadura, en el edición de 1803 volvemos a encontrar la primera acepción que le dio Autoridades en un primer momento y sin ninguna indicación geográfica de uso (NTLLE, s. v. barzón, Autoridades, 1726; Autoridades, 1770; DRAE, 1803). Palabra procedente de *brazón, derivado de brazo (DECH, s. v. barzo).

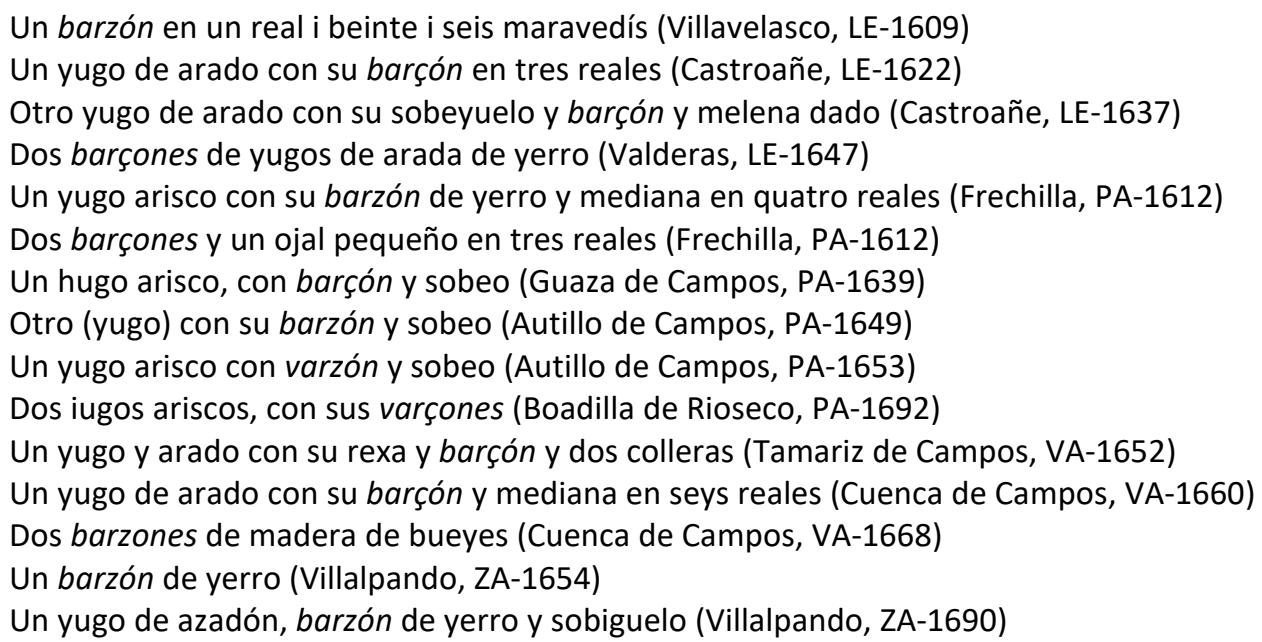

Es un término con una presencia frecuente en los inventarios de la Tierra de Campos y con la acepción académica. En bases de datos textuales como el $C D H$ se documenta en el Fuero de Alcalá junto a otros aparejos agrícolas, en el año 1235, a pesar de aparecer en fechas tempranas, no hay muchos ejemplos del mismo. En los inventarios de bienes de la época, aparecen distintos ejemplos sobre todo en la zona norte de la Península en localidades de Palencia, León, Burgos, Segovia, Zaragoza, y alguno disperso por textos de Guadalajara y Jaén. Es significativo que las localidades leonesas donde aparece este término pertenecen a la Tierra de Campos, y las de Palencia o pertenecen o están muy próximas. Sin embargo, en estudios de corte diacrónico como el de Gómez Ferrero sobre La Bañeza, o más actuales como el de Le Men, esta voz no aparece (Gómez Ferrero, 2015; Le Men, 2002) .

Gordaliza lo recoge en su vocabulario Palentino como 'anillo del yugo por donde se engancha el timón del arado romano de madera. En general anillo (cuero o madera) que ajusta la rueda al eje' (Gordaliza, 1988: 43). Álvarez Tejedor también localiza esta voz en el Este de Zamora y lo equipara a trasga o argolla (Álvarez Tejedor, 1989: 207). 


\section{CORNAL [acornal]}

Sust. m. f. 'coyunda', 'correa o soga con que se uncen los bueyes' (DLE). La Academia no incorpora este término hasta la edición de 1780, hasta ese momento no aparece en ningún otro diccionario. Esta voz procede del lat. CORNU (DECH, s. v. cornal).

Dos acornales biejas (Galleguillos, LE-1618)

Un yugo con melenas y acornales (San Nicolás del Real Camino, LE-1631)

Una cornal bieja (Castroañe, LE-1637)

Un yugo con sus acornales y sobejuelo (Grajal de Campos, LE-1658)

Dos yugos y tres rejas y dos acornales (Grajal de Campos, LE-1658)

Dos yugos ariscos con sus cornales y melenas (Boadilla de Rioseco, PA-1643)

Un ugo, melenas y acornales para unçir los vueyes para arar y trillar (Villarramiel, PA-1696)

Un yugo de carro con sus cornales en diez reales (Cuenca de Campos, VA-1666)

Un yugo de arar con sus acornales tassado en ocho reales (Cuenca de Campos, VA-1668)

Dos yugos con dos cornales biexas y una soga (Villalpando, ZA-1632)

Es una voz muy presente en el corpus estudiado, suele aparecer en plural y femenino, aunque encontramos algún caso en singular. Formalmente, presenta en algunos casos epéntesis de la /a/ y podemos encontrar en los inventarios acornales. El CDH documenta esta palabra en un inventario perteneciente a la Colección diplomática del Monasterio de Carrizo en San Pedro del Páramo y datado en el siglo XIII, donde aparece con otros aperos agrícolas. El resto de la documentación donde se encuentra este término pertenece a obras de Julio Caro Baroja, ya en el siglo xx y donde señala que se dice cornal de Asturias. Aunque en el DLE no se señala marca dialectal, la documentación que analizamos parece decir todo lo contrario. En el CorLexIn solamente aparece esta palabra en la zona noroccidental (Asturias, León, Palencia y Zamora). En tierra de Campos este término se documenta en toda la comarca, incluida la zona vallisoletana, que ampliaría ligeramente la presencia de esta lexía.

Gordaliza recoge cornal con tres acepciones diferentes, aunque muy próximas: 'normalmente en plural, especie de yugo que se coloca sobre la cornamenta de los bueyes y se sujeta con correas, 'esas mismas correas que sujetan el yugo a la cornamenta' y 'se dice por cornejal: esquinazo, rincón'. Registra acornales que usado en plural tiene el significado de 'tiras de cuero para uncir las vacas al yugo' y que se localizaría su uso en Valdavia y zona norte de Palencia y que compartiría campo semántico con cornal y sobeo (Gordaliza, 1988: 74).

Le Men señala que se usan por regla general en plural y femenino ya que se trata de 'dos correas largas, hechas de cuero, que van sujetando el yugo a los cuernos de la pareja' y también señala la preferencia de uso en la zona noroccidental (Le Men, 2004, s. v. cornal).

\section{COYUNDA [coyunta, conyuntal]}

Sust. f. 'Correa fuerte y ancha, o soga de cáñamo, con que se uncen los bueyes' (DLE). Nebrija en la edición de 1516 recoge 'coyunda de yugo', y Autoridades lo define como 'la correa con que se atan los bueyes al yugo' (NTLLE, s. v. conyunda, Nebrija, 1516; Autoridades, 1729). Término procedente de *CONJǓNGǓLA, derivado de CONJUNGERE, y este de JUNGERE (DECH, s. v. uncir).

Dos yugos de carro y uno de arado y ese arado con sus coyuntas (Sahagún, LE-1633)

Un yugo de arado con su coyuntal (Villemar, PA-1608) 
Dos esquilones con sus coyundas tassados en diez reales (Cuenca de Campos, VA-1666)

Además de no tener mucha presencia en los textos analizados de la Tierra de Campos, esta lexía presenta distintas variantes en la zona: la forma académica coyunda, pero también coyunta y conyuntal para hacer referencia a la correa con la que se uncen los bueyes o las vacas, parece que en este territorio había una preferencia por el término cornales. Como en ese caso, figura en los textos en plural. En los inventarios que conforman el CorLexIn, coyunda es la variante que más aparece (Zona occidental y centro peninsular), menos presencia tiene conyunta, del cual solo se localiza un ejemplo en Cáceres. Aparece también la variante yunta, más presente en el sur de la Península y América.

Le Men localiza coyunta y afirma que la /-t-/ "se debe, tal vez, al influjo de yunta" (Le Men, 2004 , s. v. coyunta). Por otro lado, Gordaliza registra coyunda en Palencia como 'correas o sogas para llevar atados y emparejados dos animales, principalmente vacas' (Gordaliza, 1988: 77).

\section{MELENA}

Sust. f. 'Almohadilla o piel que se pone a los bueyes bajo el yugo' (DLE, 5.a ac.). Ya aparece con esta acepción en el Vocabulario de Nebrija (NTLLE, s. v. Melena). Esta voz tiene un origen dudoso, aunque ciertamente no latino, quizá viene del árabe melîna 'ablandada', participio pasivo del verbo lân 'ser blando', 'ablandar' (DECH, s. v. melena).

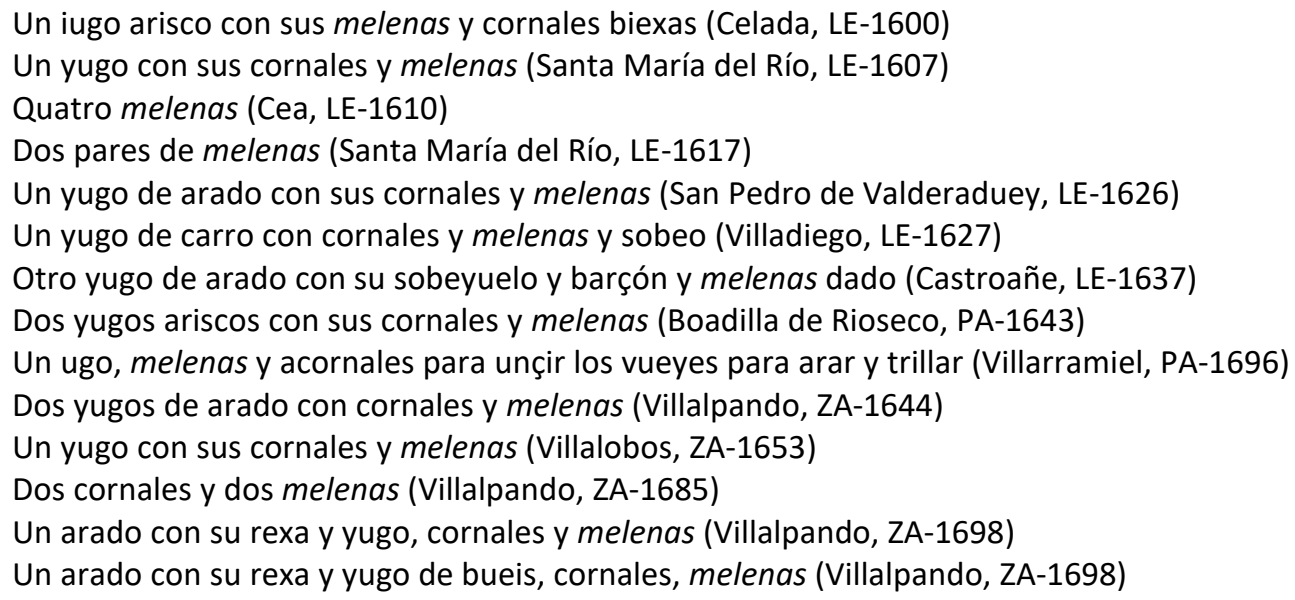

Se trata de un término muy corriente en los textos de la Tierra de Campos, en la mayoría de las ocasiones aparece en plural y referenciado junto a yugo y cornales. Se documenta en el siglo XIII en el Fuero General De Navarra según los datos que nos ofrece el CDH con la acepción académica. A pesar de que el DLE no da ninguna notación diatópica al término, si observamos los datos que nos ofrece el CorLexIn, encontramos una preferencia de uso en la zona occidental de la Península (Cantabria, León, Palencia, Zamora, Cáceres). En cuanto al significado, tanto en Tierra de Campos como en el resto de ocurrencias aparecen con la acepción académica.

En estudios más recientes sobre léxico dialectal, Gordaliza localiza el uso de esta lexía como 'almohadilla y también piel que se pone bajo el yugo y encima de la cabeza de las vacas' tal y como se describe en el DLE (Gordaliza, 1988: 148). Mientras Le Men sí que encuentra más acepciones al margen de la académica, así localiza este término como 'cubierta de piel que se 
coloca encima de la mullida' y al 'fleco que se pone delante de la mullida para evitar que las moscas molesten al animal en la cara' (Le Men, 2007, s. v. melena).

\section{PÉRTIGO}

Sust. m. 'Lanza del carro' (DLE). Se recoge en Autoridades con esta acepción. Término derivado de pértiga, foma semiculta del lat. PĔRTİGA (DECH, s. v. pértiga).

Un pértigo de carro viexo (Villacalabuey, LE-1614)

Un pértigo de carro (Grajal de Campos, LE-1658)

Corominas y Pascual señalan que la voz pértigo está muy viva en Aragón. A finales del siglo XVI aparece en un tratado de artillería donde aparece pértigo como sinónimo de timón o limón del carro (CDH, Plática manual de artillería de Luis Collado). En el CorLexIn se recogen dos casos de pértigo, en Mahamud y San Millán de Juarros, ambas poblaciones pertenecientes a la provincia de Burgos. Asimismo, Perdiguero documenta la variante piértigo en inventarios burgaleses del siglo XVII con la acepción académica (Perdiguero, 2013: 237). En Tierra de Campos su presencia no es muy cuantiosa, tan solo se localizan dos ocurrencias, ambas en la zona leonesa de la comarca, parece que en esta zona prefieren el término timón.

Le Men localiza este término en los límites del leonés, pero el significado de esta lexía varía con respecto al $D L E$, así, encuentra pértigo como 'mayal, instrumento compuesto de dos palos, con el cual se desgrana la mies', 'mazo de mayal' o 'instrumento utilizado para extraer agua del pozo' y que se reparten por el oeste de León, Asturias y Zamora (Le Men, 2009, s. v. pértigo).

\section{SOBEO [soveo, soueo, sobeyo]}

Sust. m. 'Correa fuerte con que se ata al yugo la lanza del carro o el timón del arado' (DLE). La recoge Autoridades como 'látigo que se afianza el arado con el yugo. Es voz de Andalucía, y otras partes', Terreros y Pando no le pone marca dialectal y lo equipara con coyunda. En la edición académica de 1817 se elimina la marca diatópica de Andalucía y se cambia por la construcción indefinida "en algunas partes" hasta que en la edición de 1832 se elimina cualquier notación dialectal (NTLLE, s. v. sobeo, Autoridades, 1739; Terreros y Pando, 1788; DRAE, 1817 y DRAE, 1832). Término procedente tal vez de un lat. vulgar *sŬBĬĞUM (DECH, s. v. sobeo).

Un sobeo de carro bueno (Galleguillos, LE-1618)

Dos cornales y un sobeyo biejo (Cea, LE-1625)

Un sobeo biejo y malo (Castroañe, LE-1637)

Un soveo bueno (Grajal de Campos, LE-1658)

Un sobeo de carreta en quatro reales (Frechilla, PA-1613)

Un carro con yugo y sobeo y unos careos biejos (Frechilla, PA-1640?)

Un carro de mulas herrado con yugo y sobeo (Autillo, PA-1644)

Un yugo arisco con barçón y sobeo (Boadilla de Rioseco, PA-1655)

Un gario, un soueo de carro, quatro orcas viexas (Boadilla de Rioseco, PA-1692)

Un sobeo de bueyes (Villalpando, ZA-1644)

Un sobeo nuebo del carro (Villalpando, ZA-1685)

Un sobeo de carro (Tapioles, ZA-1688) 
Palabra muy documentada en la zona de estudio. El CDH lo documenta ya en el siglo XVII, en un documento de 1635. La mayoría de los ejemplos que encontramos en el CorLexIn se ubica en una zona que comprendería las provincias de León, Palencia, Zamora, Segovia y Cáceres principalmente, aunque también aparecen dos ejemplos aislados en Jaén, todos ellos con la acepción académica, lo que nos hace recordar la marca diatópica dada por Autoridades.

Formalmente esta palabra presenta de forma más esporádica la variante sobeyo ${ }^{15}$ que el CorLexIn localiza en Zamora y Cantabria. En Tierra de Campos encontramos los siguientes ejemplos:

Un yugo de arada con sus melenas y un sobeyo (Valdavida, LE-1606)

Dos cornales y un sobeyo bueno (Santa María del Río, LE-1617)

Dos cornales y un sobeyo biejo (Cea, LE-1625)

La presencia de esta variante ya fue señalada por Morala que señala que "la forma simple se documenta ocasionalmente como sobeyo, aunque generalmente aparece como sobeo, con la /y/ elidida" (Morala, 2017c: 355).

Sobeo se documenta en estudios dialectales más actuales como 'correa de guarnicionería que sujeta la bolera al animal o con la que se ata al yugo la lanza del carro o del arado', también se localiza el variante subeo en Palencia (Gordaliza, 1988: 203).

\section{SOBEYUELO [sobigüelo, sobejuelo, sobijuelo]}

Sust. m. 'especie de sobeo pequeño para unir el arado con el yugo' (Morala, 2017c: 354). No aparece registrado por el $D L E$, ni por ningún diccionario académico.

Un yugo de arado con su bardón e sobeyuelo (Galleguillos, LE-1618)

Un yugo con sus acornales y sobejuelo (Grajal de Campos, LE-1658)

Dos dozenas de sobejuelo de cuero (Medina de Rioseco, VA-1649)

Un sobigüelo para el yugo de arada (Villalpando, ZA-1652)

Seis sobigüelos para yugos de arado (Villalpando, ZA-1661)

Otro yugo de yeguas con su barzón y sobigüelo (Tapioles, ZA-1688)

Un yugo con su subigüelo, barzón de yerro y dos cornales nuebas (Quintanilla del Monte, ZA1689)

Un yugo de carro con su trasga, sobijuelo y clabija (Villalpando, ZA-1660)

Se trata de una voz frecuente en Tierra de Campos y que aparece como diminutivo de sobeo, aunque el contexto y los datos que podemos obtener no son suficientes como para saber si había alguna diferencia de tamaño o realmente es lo mismo que sobeo. Las ocurrencias encontradas en el CorLexIn se hallan ubicadas dentro de la Tierra de Campos. Aparecen diferentes formas que Morala lo atribuye a una ultracorrección del propio escribano, señala que el hecho de que "esta voz no sea usual en castellano, le permite al notario dudar de la /y/ que

15 "[...] en el área del leones, preferentemente en las zonas montañosas lindantes con Asturias, el hiato /eo/ puede resolverse también con la introducción de una consonante antihiática /y/. Aunque esta consonante podría incluso analizarse como la pervivencia de la antigua palatal cuya pérdida da lugar al hiato, la aparición frecuente de las formas $\sin / \mathrm{y} /$ (sobeo), mucho más frecuentes, apunta sin embargo a que ha sido reintroducida posteriormente" (Morala y Egido, 2010: 425-426). 
le parece lo suficientemente vulgar como para tratar de convertirla en -j- en la escritura, mostrándonos con esta ultracorrección que las soluciones dialectales en /y/ eran aún tan frecuentes como para ser bien reconocibles y, en consecuencia, ser objeto de enmienda a la hora de escribir" (Morala, 2017c: 355).

\section{TRASGA}

Sust. f. 'pértigo de la carreta de bueyes', además señala el término como propio de Galicia, León y Zamora (DLE). No se registra hasta la edición académica de 1925 , donde ya presenta marca diatópica de León, en la siguiente edición, la del DRAE de 1927 aparece una nueva acepción propia de Zamora 'pieza de madera con que se sujeta el timón al arado' (NTLLE, s. v. trasga, $D R A E, 1925 ; D R A E$, 1927). Probablemente procedente de un lat. vulgar *TRANSICA, derivado de TRANSJICĔRE 'hacer pasar (por alguna parte)' porque el timón se introduce en la trasca (DECH, s. v. trasca).

Un yugo de carro con su trasga, sobijuelo y clabija (Villalpando, ZA-1660)

Dos trasgas, una de yerro y otra de madera (Villalpando, ZA-1661)

Es un término poco documentado en los inventarios analizados, tan solo aparecen un par de ejemplos en la zona zamorana de Tierra de Campos, ya que en esta zona parece haber una preferencia por el término barzón. Sin embargo, en Zamora es más normal encontrar trasga para referirse al 'barzón del yugo'. Parece tener la misma acepción académica y por el contexto podemos ver que bien podían ser de yerro o de madera, seguro que también de cuero. Aunque no encontramos ejemplos en el CorLexIn de este vocablo, Gómez Ferrero sí recoge diferentes ejemplos en la zona de La Bañeza (Gómez Ferrero, 2015: 242-243), así como Morala en Zamora (Morala, 2017c: 354-355, 368-369). Parece que se trata de una palabra con marca dialectal en el occidente de León y Zamora, tal y como registra el DLE.

\section{YUGO [iugo, ugo, vgo, hugo]}

Sust. m. 'Instrumento de madera al cual, formando yunta, se uncen por el cuello las mulas, o por la cabeza o el cuello, los bueyes, y en el que va sujeta la lanza o pértigo del carro, el timón del arado, etc.' (DLE). Nebrija recoge 'ugo para uñir'. Autoridades registra la definición que ha perdurado hasta nuestros días sin cambios significativos (NTLLE, s. v. yugo, Nebrija, 1495; Autoridades, 1739). Término procedente del lat. JŬGUM (DECH, s. v. yugo).

Un iugo arisco con sus melenas y cornales biexas (Celada, LE-1600)

Un yugo de arado con su coyuntal (Villemar, 1608)

Un yugo de arado con su bardón e sobeyuelo (Galleguillos, LE-1618)

Un yugo con sus acornales y sobejuelo (Grajal de Campos, LE-1658)

Un yugo arisco con su barzón de yerro y mediana en quatro reales (Frechilla, PA-1612)

Dos yugos carrales viejos apreciados en dos reales (Frechilla, PA-1613)

Un carro errado de mulas biexo con su yugo bueno (Paredes de Nava, PA-1690)

Dos iugos ariscos, con sus varçones (Boadilla de Rioseco, PA-1692)

Un yugo de bueyes serrano (Tamariz de Campos, VA-1651)

Un yugo con su barçón (Cuenca de Campos, VA-1651)

Un yugo de arado con su barçón y mediana en seys reales (Cuenca de Campos, VA-1660)

Un yugo de arar con sus acornales tassado en ocho reales (Cuenca de Campos, VA-1668) 
Un yugo biexo (Villalpando, ZA-1637)

Un carro chirrión con yugo, sobeo y cornales (Villalpando, ZA-1686)

Un yugo con su subiguelo, barzón de yerro y dos cornales (Quintanilla del Monte, ZA-1689)

Un carro errado con su yugo a medio usar (Villalpando, ZA-1690)

El término yugo es de uso general en la Tierra de Campos. Es la variable que aparece en las fuentes históricas, el término menos marcado que resulta interesante cuando es esta la única variable que se documenta en una zona determinada, sin dejarse guiar por el registro general o culto (Morala, 2016d: 145). La Tierra de Campos es una zona donde la variante más habitual es yugo, o su variante gráfica iugo, solo alterna con la caída de la yod inicial ugo en la zona palentina.

Un hugo de arado y dos hugos de de carro buenos (Santa María del Río, LE-1617)

Un carro de mulas errado con su vgo andado, otro carro de mulas errado con su vgo biexo dos vgos ariscos con sus barçones de yerro (Paredes de Nava, PA-1690)

Un carro errado de mulas biexo con su yugo bueno, dos arados con dos rexas de a diez libras cada una un vgo arisco con sus barçón y mediana (Paredes de Nava, PA-1690)

Tres vgos ariscos (Paredes de Nava, PA-1689)

Un ugo de arada con su braçon y un ugo de carro (Villarramiel, PA-1691)

Dos ugos ariscos (Villarramiel, PA-1690)

Un ugo, melenas y acornales para unçir los vueyes para arar y trillar (Villarramiel, PA-1696)

Un hugo arisco, con barçón y sobeo (Guaza de Campos, PA-1639)

Hun carro herrado con hugo y sobeo (Autillo de Campos, PA-1649) también yugo

Respecto a esta variante, no es muy frecuente en los textos, apenas tenemos ejemplos en bases académicas como el CORDE, CDH o el CorLexIn. Sí encontramos alguna referencia a esta forma en estudios dialectales que se recogen en el Fichero General como su uso en la localidad leonesa de Oseja de Sajambre (cédula n.o 3, n. 5 y n. 1), o en Tierra de Campos (cédula n.으 8). En la zona leonesa de Riaño, zona a la que pertenecen la localidad mencionada anteriormente, comparte uso junto a Ilugo. También se encuentran casos en Palencia (Le Men, 2014 , s. v. yugo). Otra zona donde se localiza ugo aparece en el extremo occidental de Cantabria según los datos que aporta el ALECant (Morala, 2016d: 132, nota 3).

\subsubsection{Arreos y aparejos de caballería}

\section{ALBARDA [alvarda, aluarda, albardilla]}

Sust. f. 'Pieza principal del aparejo de las caballerías de carga, que se compone de dos a manera de almohadas rellenas, generalmente de paja, y unidas por la parte que cae sobre el lomo del animal' (DLE). Nebrija registra esta lexía como 'albarda de bestia', 'albarda de asno' y 'albarda de mulo', Covarrubias por su parte la define como 'la cobertura y el fuste de la bestia de carga, para que con ella no se mate, o maltrate' y Autoridades como 'el aparejo que ponen à las bestias de carga, para que puedan comodamente llevarla, y sin lastimarse el lomo' (NTLLE, s. v. albarda, Nebrija, 1495; Covarrubias, 1611 y Autoridades, 1726). Término procedente del ár. al-barda'a (DECH, s. v. albarda). 
Una albarda con su cincho en quatro reales (Sahagún, 1600)

Vna jumenta con su albarda (Sahagún, LE-1608)

Una aluarda con sus estriuos (Grajal de Campos, LE-1658)

Una alvarda nueua aforrada en vadana (Grajal de Campos, LE-1656)

Dos albardas buenas apreciadas en tresçientos marauedís (Frechilla, PA-1612)

Un cesto y una alvarda bieja (Castromocho, PA-1614)

Una albarda de pollino (Frechilla, PA-1640)

Una alvarda demediada (Autillo de Campos, PA-1647)

Una albarda muy bieja (Cuenca de Campos, VA-1666)

Vna albarda biexa con su çincha (Villalobos, ZA-1654)

Dos albardas de pollina con sus cinchas jinetas nuebas (Villalpando, ZA-1661)

Dos burras, madre yxa, con su albarda (Villalpando, ZA-1666)

Una albarda (Villalpando, ZA-1685)

Es un término muy común en los inventarios de la Tierra de Campos, que presenta el resultado y acepción académicos. Esta palabra se documenta de forma temprana en los corpus del español, el CORDE, por su parte, da noticias de esta voz desde el Fuero de Uclés, fechado en 1179 , mientras que la primera documentación que presenta el $C D H$ data del siglo XIII, en el Fuero de Cáceres en 1234. En la documentación de América se presenta de forma más tardía, los primeros testimonios datan de finales del siglo XVI y en el XVII figuran de forma ocasional.

Desde una perspectiva diacrónica, el CorLexIn presenta poco más de una treintena de ocurrencias distribuidas en un amplio ámbito geográfico peninsular, sin embargo, no se han localizado casos en documentos americanos. Se trata de una palabra de uso general en la Península.

Si atendemos a la morfología derivacional de la palabra, tan solo encontramos el diminutivo en -illa y que parece tener una motivación semántica de carácter apreciativo:

Una albardilla pequeña y una çincha (Fechilla PA-1616)

En trabajos dialectales modernos como el de Gordaliza se recoge de nuevo como el 'aparejo que se pone sobre el lomo de las caballerías, hecho de piel de burro o de vaca y relleno interiormente de paja', pero también presenta un sentido figurado y así en Palencia y León esta voz da cuenta del 'vestido o prenda mal hecha'. Registra el diminutivo albardilla como 'albarda más pequeña, hecha de badana' como en el corpus estudiado, pero también como 'pequeño tejadillo de barro y paja o ramas para defensa de muros o tapias' sobre todo en la zona sur de Palencia (Gordaliza, 1988: 24).

Por otro lado, Álvarez Tejedor señala que la silla o montura es la utilizada para los caballos mientras que el aparejo y la albarda se utilizan para la monta y la carga de los asnos. (Álvarez Tejedor, 1989: 238).

\section{ALBARDÓN [alvardón, albardonillo, alvardonçillo]}

Sust. m. 'Aparejo más hueco y alto que la albarda, el cual se pone a las caballerías para montar en ellas' (DLE). Lo registra Nebrija tanto para mulo como para caballo y Autoridades lo equipara con albarda, solo que afirma que es 'mas hueco y alto que la albarda. Formase con fuste y barras para mayor fortaleza y seguridad, de que no se siente sobre el lomo del animal à quien se pone, 
porque no le mate [...]' (NTLLE, s. v. albardón, Nebrija, 1495; Autoridades, 1726). Término derivado de albarda, del del ár. al-barda'a (DECH, s. v. albarda).

Un albardón con sus estribos de yerro aforrado con badana negro (Paredes de Nava, PA-1690)

Un albardón nuevo (Fechilla PA-1675)

Un alvardón de baqueta biexo en veinte reales (Fechilla PA-1675)

Un albardón bueno (Frechilla, PA-1676)

Un rozín con su albardón y aparejos (Medina de Rioseco, VA-1660)

Un albardón con su cincha ya usado (Villalpando, ZA-1660)

Un albardón (Villalpando, ZA-1698)

En general, tiene menos presencia tanto en el $C D H$-que lo documenta desde el siglo XIIIcomo en el CorLexin y en la zona de estudio, aun así, se trata de una palabra de uso general, que presenta la forma y acepción académica.

Formalmente podemos decir que el término presenta una lexicalización del aumentativo, haciendo referencia a un tipo de albarda concreto, que presenta entrada en las obras lexicográficas académicas y, desde un punto de vista morfológico, muestra términos formados por derivación, como es el caso de diminutivos:

Un alvardonçillo (Cea, LE-1621)

Un albardonillo viejo (Frechilla, PA-1631)

También se halla en estudios actuales como el de Gordaliza como 'albarda grande para montar' (Gordaliza, 1988: 24).

\section{ALFORJA [ALFORXA, ALFORGAS]}

Sust. f. 'Especie de talega abierta por el centro y cerrada por sus extremos, los cuales forman dos bolsas grandes y ordinariamente cuadradas, donde, repartiendo el peso para mayor comodidad, se guardan algunas cosas que han de llevarse de una parte a otra' (DLE). Lo registra Nebrija y Autoridades ya advierte de que se usa 'regularmente en número plural' (NTLLE, s. v. alforja, Nebrija, 1516; Autoridades, 1726). Es una voz procedente del ár. hurŷ (DECH, s. v. alforja).

\footnotetext{
Una silla de cabalgadura con unas alforxas con çinchas (Castrillo, LE-1606) Unas alforxas demediadas (Sahagún, LE-1608)

Quatro costales y unas alforxas todo nuevo (Arenillas, LE-1636)

Unas alforjas de lana buenas (Grajal de Campos, LE-1658)

Dos pares de alforxas y dos costales (Frechilla, PA-1642)

Dos pares de alforjas mediadas mediado (Autillo de Campos, PA-1649)

Dos pares de alforxas las unas grandes y las otras pequeñas (Villada, PA-1665)

Unas alfroxas (Paredes de Nava, PA-1695)

Unas alforxas biexas (Medina de Rioseco, VA-1641)

Un par de alforxas con sus listas (Tamariz de Campos, VA-1652)

Unas alforxas de lana en catorce reales (Cuenca de Campos, VA-1666)

Unas alforxas biexas tassadas en seis Reales (Cuenca de Campos, VA-1668)

Unas alforgas nuebas tasadas en ocho reales (Villalpando, ZA-1613)

Unas alforxas rojas (Villalpando, ZA-1686)

Unas alforxas negras (Villalpando, ZA-1696)

Unas alforjas casseras (Villalpando, ZA-1698)
} 
Las alforjas es otra de esas palabras que está muy presente en las relaciones de bienes terracampinas. Desde un punto de vista diacrónico, tanto el $C D H$ como el CORDE documentan esta voz a partir del siglo XV, en el Libro de las Paradojas (1437) donde aparece en singular, aunque es más común encontrarla en plural, suelen inventariarse por pares.

El CorLexIn presenta una nómina importante de casos repartidos por la Península, con una preferencia de uso en la mitad norte, aunque pueda que sea fruto de la casualidad. En los textos americanos tan solo figura un ejemplo en Panamá a finales de siglo (1681).

Formalmente, en Tierra de Campos aparece la variante alforga, algo normal en la época, ya que "la equivalencia entre las grafías / $\mathrm{g} / \mathrm{y} / \mathrm{j} / \mathrm{o} / \mathrm{x} /$ en algunas palabras donde la fonética de la época lo permite (encage, encaje o encaxe) lleva a que, en algunos casos, aparezca también ese trasvase gráfico en otros contextos en los que /g/, de un lado, $y$, de otro, /j/o / $\mathrm{x} /$ tienen lecturas diferentes, algo que ocurre también con la voz jarra, que la podemos encontrar como xarra pero tambíen como garra" (Morala, 2014c: 288, nota 9). Las formas derivadas no son muy frecuentes en el corpus terracampino, a pesar de ello, el sufijo del diminutivo alterna entre -uela e -illa:

Unas alforxuelas de camino vuenas (Cea, LE-1621)

Unas alforxillas de lana azul y paxiza (Medina de Rioseco, VA-1640)

\section{ALMOHAZA [almoaça, almoaçe]}

Sust. f. 'Instrumento, usado para limpiar las caballerías, que se compone de una chapa de hierro con cuatro o cinco serrezuelas de dientes menudos y romos, y de un mango de madera o un asa' $(D L E)$. Covarrubias lo recoge como 'una rascadera de hierro, dentada con tres, o quatro ordenes con que estriegan los cavallos, y las demás bestias, y los rascan, sacandoles el polvo, y caspa de la piel y alisando el pelo' (NTLLE, s. v. almohaza, Covarrubias, 1611). Es un término procedente del hispanoárabe mahássa (ár. mihássa), derivado de hass 'quemar', 'almohazar' (DECH, s. v. almohaza).

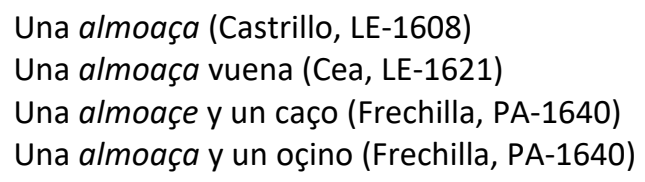

Aparece en el libro de Buen Amor del Arcipreste de Hita en 1330, se documenta durante los siguientes siglos, hasta que a mediados del siglo XVII entra en desuso y tan solo quedan algunos ejemplos del siglo XIX y Xx en obras de equitación o literarias españolas y americanas $(C D H)$. Estamos entonces ante una voz que está en desuso y esto se puede observar también en el CorLexIn donde los ejemplos son escasos y todos fechados en la primera mitad de siglo, salvo un ejemplo de 1680 documentado en Panamá: "vna almoaza de hierro". En la documenación terracampina figura la forma almoaçe, con /-e/ final, posiblemente por disimilación de la /a/.

En trabajos dialectales más actuales se recoge en la zona de Palencia, aunque Gordaliza señala que no es la más utilizada y que 'se dice más corrientemente hormaza. También arrascadera, rasqueta' (Gordaliza, 1988: 26). Términos que no hemos encontrado en el corpus seleccionado. 


\section{CARGUILLA Vid. medidas}

\section{ARREO}

Sust. m. pl. 'Guarniciones o jaeces de las caballerías de montar o de tiro' ( $D L E$, 2. a ac.). Autoridades registra esta voz con esta misma acepción, y en la siguiente edición incluye para la misma su propio lema en plural (NTLLE, s. v. arreo, Autoridades, 1726, 1770). Palabra derivada de arrear, del lat. vulgar *arredare, 'proveer', derivado del gótico *rêths, 'consejo', 'previsión', 'provisión' (DECH, s. v. arrear).

Los arreos de la labranza que es un yugo de bueyes, quatro rejas y cornales y sobeo (Villalpando, ZA-1685)

Un yugo con sus arreos (Villalpando, ZA-1689)

Se trata de una voz poco documentada en la Tierra de Campos, tan solo se han localizado dos ocurrencias en inventarios de Villalpando (Zamora) y las dos a finales del siglo XVII y siempre en plural. En estos dos casos, arreos, hace referencia a los complementos del yugo, y que habitualmente en los textos vemos como aperos, aparejos, aderezos... términos que se prefieren en esta zona.

En el CorLexIn, localizamos un par de ejemplos también en Zamora: "todos los arreos de la lagar" y "un lagar con todos sus arreos", también a finales del siglo. En La Bañeza aparece este término con la misma acepción que en los ejemplos localizados, aunque en documentos del siglo XIX (Gómez Ferrero, 2015: 245). El resto de los casos que aparecen pertenecen a inventarios de América donde el significado de este término tiene que ver con 'adherentes o cosas menudas que pertenecen a otra principal o se usan con ella' (DLE, 3.a ac.). Tan solo encontramos un par de casos en singular localizados en el País Vasco y que hacen referencia a los bienes del inventario "memoria de arreo" (Bilbao, 1638). Esta acepción también está presente en un documento titulado Traducción de la Corónica de Aragón de fray Gauberto Frabricio de Vagad, fechada en 1499 y donde se puede leer "Y otras muchas frutas secas llenas de ropa, de atauios, de arreos de casa [...]" $(C D H)$.

\section{BADAL}

Sust. m. 'acial' ('Instrumento con que se oprime un labio, la parte superior del hocico, o una oreja de las bestias, para que estén quietas mientras las hierran, curan o esquilan') (DLE). Covarrubias lo recoge como 'el que echan a las bestias de carga quando caminan, para que no se abaxen a pazer [...]); en la edición de Autoridades de 1770 agrega la acepción de 'lo mismo que acial' (NTLLE, s. v. badal, Covarrubias, 1611; Autoridades, 1770). Término procedente del cat. badall 'acial', derivado de badar 'abrir (la boca)' y este del lat. vulgar *BATARE (DECH, s. v. badal).

Un yerro que llaman badal (Valderas, LE-1682)

Es el único ejemplo localizado en Tierra de Campos. Tan solo aparece un ejemplo de esta lexía en el $C D H$, en un documento datado en 1499 "Y los diez cavalleros ataron las manos a Oliveros [...] y le ataron los pies por debaxo; y le puesieron un badal en la boca [...]", parece que se trata de un instrumento para poner en la boca, sea de animal o de hombre. En el caso 
localizado en Valderas, este objeto se encuentra referenciado junto a útiles de cirugía - algalia, lanzetas, sajador, libros de zirujía...- por lo que, tal vez, este yerro puede hacer referencia a uno de los utensilios utilizado por los cirujanos en aquella época. En el CorLexlin no encontramos ejemplos de este vocablo, sin embargo, en un inventario sobre "las cosas que hay en el oficio de cirugía del monasterio" fechado en 1501 y perteneciente al Monasterio de Guadalupe (Cáceres), aparece entre sus pertenencias "un badal" (Arana y Amurrio, 1987: 11). Por lo que pone en el asiento, el escribano no parece conocer el término "que llaman badal" y se fía del declarante. Parece que la escasez de datos de este término se debe a ser un objeto especializado, que, a pesar de figurar en el $D L E$, no tiene mucha presencia en la documentación. Tampoco aparece en los estudios léxicos más actuales.

\section{BOCADO}

Sust. m. 'Parte del freno que entra en la boca de la caballería' ( $D L E, 6$. a ac.). Aunque el término lo registran tanto Nebrija como Covarrubias, con el significado que aquí se estudia figura desde Autoridades 'parte del freno que entra en la boca de la caballería, por la cual se rige y gobierna' (NTLLE, s. v. bocado). Derivado de boca, del lat. BŭcCA 'mejilla' (DECH, s. v. boca).

Un bocado de coscojos (Cea, LE-1621)

Un bocado con sus cauezas y riendas (Valderas, LE-1682)

Un bocado de freno (Frechilla, PA-1640)

Un bocado con sus riendas (Autillo de Campos, PA-1653)

El vocablo bocado es habitual en los textos que conforman los corpus del $C D H$ y el CORDE, lo que es más difícil es encontrar ejemplos con este significado. Juan de Luna, escritor y profesor del siglo áureo, menciona este término en una obra de 1619 , donde recoge las instrucciones para preparar la montura y recuerda que hay que "poner freno y bocado" (Abad, 2012: 49, nota 44). Con esta acepción también figura en inventarios pertenecientes al partido judicial de La Bañeza, eso sí, en los siglos siguientes (Gómez Ferrero, 2015: 246).

De los ejemplos recogidos en el CorLexIn, ninguno de ellos referencia el objeto inventariado en los ejemplos de Tierra de Campos. El bocado, en estos casos, es un adorno que se pone en las piezas de plata.

En trabajos más actuales como el Vocabulario palentino de Gordaliza aparece esta voz como 'pieza de metal sujeta a la brida que entra en la boca de las caballerías' (Gordaliza, 1988: 45).

\section{BOZO [boço]}

Sust. m. 'Parte exterior de la boca', 'cabestro o cuerda que se echa a las caballerías sobre la boca, y dando un nudo por debajo de ella, forma un cabezón con solo un cabo o rienda' ( $D L E$, 2. y 3.a ac.). De un antiguo derivado del lat. BūcCA 'mejilla, boca' (DECH, s. v. bozo).

Un burro negro con boço blanco de dos años (Galleguillos, LE-1618)

Tres boços de machos (Frechilla, PA-1639)

Un macho de labrar negro con el boço descubierto cerrado (Boadilla de Rioseco, PA-1692)

Tres dozenas de bozos de estopa (Medina de Rioseco, VA-1649) 
Se documentan cuatro ejemplos localizados en los textos analizados de la Tierra de Campos, con dos acepciones diferentes. Por un lado, bozo como 'una parte de los aparejos de caballería' $y$, por otro, como 'parte exterior de la boca del animal'. Aunque presenta la forma académica, los ejemplos son escasos en esta zona, esta falta de ocurrencias se observa también en el CorLexIn.

Gordaliza recoge esta palabra como 'pieza de cuero que va debajo de la cabezada y también especie de cabestro para las caballerías' (Gordaliza, 1988: 48). Esta palabra con la acepción de 'bozal' figura en distintas comarcas leonesas, además de en Asturias, Andalucía, Navarra y Aragón (Le Men, 2002, s. v. bozo).

\section{CABESTRO [cavestro]}

Sust. m. 'Ronzal que se ata a la cabeza o al cuello de la caballería para llevarla o asegurarla' (DLE, 2.- ac.). Covarrubias lo recoge como 'el ramal, o soga de cañamo con que se ata la bestia' (NTLLE, s. v. cabestro, Covarrubias, 1611). Término procedente del lat. CAPǏsTRUM (DECH, s. v. cabestro).

Dos cavestros uno de estopa y otro de sedas negro (Riosequillo, LE-1610)

Dos sueltas y dos cabestros de serdas (Frechilla, PA-1675)

Nuebe dozenas de cabestros de caballos (Medina de Rioseco, VA-1649)

Dozena y media de cabestros de real (Medina de Rioseco, VA-1649)

Cabestros de mula (Medina de Rioseco, VA-1649)

Esta voz figura en la Tierra de Campos con el significado que le da el diccionario académico y comparte campo semántico con bozo y cabezada. Esta voz aparece documentada también en el CorLexIn, aunque con una acepción diferente, la encontramos en León, Palencia y Guadalajara como un tipo de azuela. En zonas de León se presenta este término como 'argolla de hierro que sujeta la pala de la azuela de este nombre al mango' (Le Men, 2004, s. v. cabestro). Y Gordaliza lo localiza con el significado que tenemos en los documentos analizados y coincidiendo con el académico 'cabezada o ramal para conducir una caballería' (Gordaliza, 1988: 51).

\section{CABEZADA [cabeçada, caveçada, cauezada]}

Sust. f. 'correaje que ciñe y sujeta la cabeza de una caballería, al que está unido el ramal' (DLE, 7.a ac.). Este término lo registra Autoridades con diferentes acepciones entre las que están 'guarnición que se pone à la mula ó caballo en la cabéza apra afianzarla al pesebre ó sacarla à beber, la qual suele ser de vaqueta, con una argolla de hierro, de la qual se ata una cuerda, cn que se assegura para que no se suelte' y también 'la guarnición del bocado, que se pone à los caballos con que se afianza el freno' (NTLLE, s. v. cabezada, Autoridades, 1729). Término derivado de cabeza procedente de CAPITTǏ, forma del latín vulgar que sustituyó a CAPUT, -ITTIS (DECH, s. v. cabeza).

Dos cabezadas blancas y una zincha (Autillo de Campos, PA-1647) Una cabezada y riendas de baqueta (Autillo de Campos, PA-1647) Una cabeçada de cadena viexa (Autillo de Campos, PA-1653) Dos dozenas de cauezadas de reata anchas (Medina de Rioseco, VA-1649) Una cabeçada pequeña de cáñamo (Tamariz de Campos, VA-1651) Una caveçada y una çincha en real y medio (Cuenca de Campos, VA-1660) 
Tres cadenas de yerro para las mulas con una caueçada (Villalpando, ZA-1652)

Este término aparece con la acepción académica de 'correaje que se pone en las caballerías' en los casos documentados en la Tierra de Campos. En estudios léxicos actuales Gordaliza localiza en Palencia esta voz como 'correaje que se pone en las cabezas de las caballerías que también sirve para sujetar el freno. De él cuelgan los mosqueros o tapaojos' (Gordaliza, 1988: 52), tal y como lo encontramos los documentos analizados. Con la acepción de 'objeto hecho de varias correas que se pone en la cabeza a las caballerías y mediante el cual se las gobierna' figura en muchas zonas de León, pero en alguna de sus comarcas se prefiere el término cabezal, al igual que La Rioja y Aragón (Le Men, 2004, s. v. cabezada).

\section{CANAL}

Sust. m. o f. 'camellón ${ }^{21}$ ('artesa cuadrilonga para abrevar el ganado vacuno') (DLE). La edición del DRAE de 1780 recoge el significado de 'lo mismo que camellon por bebedero' (NTLLE, s. v. canal, DRAE, 1780). Término procedente del latín CANNALIS (DECH, s. v. canal).

Quatro canales de obejas (Frechilla, PA-1612)

Una canal de ganado (Villarramiel, PA-1690)

Un canal de comer ganado de roble en seis reales (Cuenca de Campos, VA-1660)

En Tierra de Campos nos encontramos con esta palabra con la acepción de 'comedero o bebedero de ganado', este significado se documenta en el $C D H$ desde el siglo XIII. Localizamos una ocurrencia en un inventario de Segovia, donde encontramos "vna canal para dar sal al ganado" (CorLexIn). Esta acepción no es muy frecuente en la documentación, tal vez por tener que compartir este campo léxico con otras lexías como comedero o bebedero.

Hay otros contextos en los que se documenta inventariada junto a otro tipo de utensilios agrícolas que hace pensar que estamos ante otro tipo de objeto. Así nos encontramos con:

Çinco orcas de palo, tres bieldos, dos garios, quatro canales (Frechilla, PA-1639)

Una pala de orno de yerro, otra canal, un coçino endido (Frechilla, PA-1639)

Una canal de haya en dos reales y medio (Frechilla, PA-1675)

Dos canales (Paredes de Nava, PA-1695)

Esta acepción no la encontramos en el $D L E$, parece tratarse de un tipo de recipiente para labores cotidianas al aparecer junto a garios, coçinos, hachas... Esta acepción se localiza en inventarios de Segovia "dos canales" junto a conyundas, barrenas y asadores o "un canal de tres braçadas" en La Rioja y en Cádiz donde aparece "quatro canastas de colar y quatro canales blancos". En estudios más recientes, Gordaliza localiza en Carrión de los Condes (Palencia) esta voz como 'una cuba pequeña para el vino' (Gordaliza, 1988: 56).

Para dar cuenta del valor polisémico de esta palabra, encontramos esta voz como referente a una de las piezas que componen de un telar.

Dos telares con sus castillos, canales e ynjulios (Grajal de Campos, LE-1657)

Este significado se localiza en zonas de León como 'pieza del telar de lino' (Le Men, 2004, s. v. canal). 


\section{CINCHA [çincha, zincha]}

Sust. f. 'Faja de cáñamo, lana, cerda, cuero o esparto, con que se asegura la silla o albarda sobre la cabalgadura, ciñéndola ya por detrás de los codillos o ya por debajo de la barriga y apretándola con una o más hebillas' (DLE). Del lat. CĬNGŬLA, derivado de cincho del lat. CǏnGŬLUM 'cinturón' (DECH, s. v. cincho).

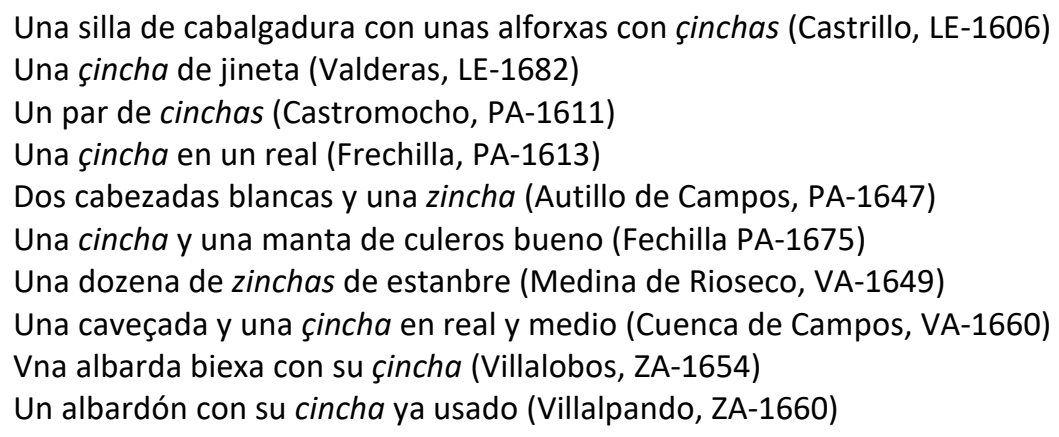

Se trata de una palabra de uso general y que aparece con la acepción académica. Término documentado desde el Mío Cid, pero también en inventarios a partir del siglo xv con la acepción académica $(C D H)$. Los datos que nos proporciona el CorLexIn, sitúan el uso de esta palabra en el centro y norte de la Península principalmente. También se recoge en estudios actuales como el de Gordaliza donde registra esta voz como 'correa de la barriga de las caballerías y en general cualquier correa tipo cinturón' (Gordaliza, 1988: 68). Figura en el estudio del leonés que hace Le Men (Le Men, 2004).

\section{CINCHO}

Sust. m. 'Pleita de esparto que forma el contorno de la encella', 'cincha' (DLE, 5.a y 8. a ac.). Nebrija recoge el término con varias acepciones, entre ellas la de 'cincho para espremir queso' (NTLLE, s. v. cincho, Nebrija, 1495). Término procedente del lat. CĭNGŬLUM 'cinturón' (DECH, s. v. cincho).

Una albarda con su cincho en quatro reales (Sahagún, 1600)

Un cincho y tres ancillas (Cuenca de Campos, VA-1666)

Un cincho de azer quesso en un real (Cuenca de Campos, VA-1668)

La primera ocurrencia que aparece en Sahagún tiene la misma acepción que cincha 'faja de cáñamo, lana, cerda, cuero o esparto, con que se asegura la silla o albarda sobre la cabalgadura, ciñéndola ya por detrás de los codillos o ya por debajo de la barriga y apretándola con una o más hebillas' (DLE). Sin embargo, los dos casos localizados en Cuenca de Campos (Valladolid) hacen referencia a una especie de 'faja de esparto que sirve para sacar el suero al queso', dado el contexto, ya que uno de ellos se explicita en el propio asiento qué función tiene cincho y, en el otro, aparece con el término ancillas, variante del académico encenlla y que Gordaliza localiza en Palencia con la forma encilla con el significado de 'pequeña vasija de barro, para hacer el queso'.

En la documentación de la época son esporádicos los casos de cincho, para la primera acepción se prefiere la forma en femenino (Morala, 2014a: 19). 
En estudios recientes también se localiza este término con diferentes acepciones. Gordaliza recoge esta voz en Palencia con varias acepciones: 'cualquier correa, especialmente la que rodea la barriga de las caballerías', 'aro que rodea la cuba' o 'trenza de esparto que rodea la encilla' (Gordaliza, 1988: 68), esta última acepción se localiza en León, Zamora, Extremadura, Palencia, Valladolid o Toledo (Le Men, 2004, s. v. cincha).

\section{coscojo}

Sust. m. pl. 'Piezas de hierro, a modo de cuentas, que, ensartadas en unos alambres eslabonados y asidos por los extremos al bocado de los frenos de la brida, forman con la salivera los sabores' ( $D L E, 2$. a ac.). Este término no se recoge en el diccionario académico hasta la edición de 1780 , con la acepción que aquí encontramos (NTLLE, s. v. coscojo, DRAE, 1780). Es un término procedente del lat. cŬscŬLIUM 'coscoja', que en latín parece ser de origen hispánico (DECH, s. v. coscojo).

Un bocado de coscojos (Cea, LE-1621)

Es un término muy poco documentado en general. En la Tierra de Campos aparece con el significado académico.

\section{ESTRIBO [estriuos]}

Sust. m. 'Pieza de metal, madera o cuero, que pende de la ación y en la que el jinete apoya el pie' (DLE). Término de origen incierto, quizá germánico ( $D E C H$, s. v. estribo).

Una aluarda con sus estriuos (Grajal de Campos, LE-1658)

Unos estribos (Frechilla, PA-1639)

Unos estribos de ierro (Paredes de Nava, PA-1689)

Un albardón con sus estribos de yerro aforrado de badana negro (Paredes de Nava, PA-1690)

Unos estriuos de la vrida viexa dorados en sus fundas (Medina de Rioseco, VA-1644)

Un vanco llano de nogal con estriuos de yerro (Villalpando, ZA-1643)

Un bufete de nogal con sus estribos de yerro (Villalpando, ZA-1660)

Unos estribos de yerro (Villalpando, ZA-1670)

Estribo aparece en los inventarios de bienes de la Tierra de Campos con la forma y la acepción académica, tan solo presenta las variaciones gráficas típicas de esta época entre /b/ y /u/. Sin embargo, localizamos dos ejemplos en la zona de Villalpando en la que esta voz aparece con una acepción diferente y que no encontramos en los diccionarios académicos, así encontramos un banco y un bufete con "estribos de yerro", posiblemente el significado que aquí ocupa es muy parecido al de barrotes o varillas que aparecen en algunas ocasiones en el mobiliario, bien para decorar, bien para dar estabilidad o apoyar los pies, con lo que el uso estaría más cercano al original.

\section{FRENO}

Sust. m. 'Instrumento de hierro que se compone de bocado, camas y barbada, y sirve para sujetar y gobernar las caballerías' (DLE, 2. ac.). Recogido por Nebrija y también por Covarrubias como 'el vocado de yerro, que pone en la voca al cauallo o mula o bestia cauallar, para regirle o 
gouernarle' (NTLLE, s. v. freno, Nebrija, 1495; Covarrubias, 1611). Del lat. FRĒNUM 'freno, bocado' (DECH, s. v. freno).

Dos frenos biexos del inventario (Castrillo, LE-1606)

Una huna yegua y una silla y freno (Castromocho, PA-1603)

Un freno con cordeles de cáñamo apreciado en dos reales (Frechilla, PA-1613)

Dos frenos de hierro (Frechilla, PA-1615)

Un freno con riendas de cáñamo en cinco reales (Frechilla, PA-1675)

Dos sillas con frenos y demás adreços biexas (Medina de Rioseco, VA-1642)

Una mula ensillada con su freno y todos los demás adreços y cojín y maleta (Medina de Rioseco, VA-1657)

Un freno de yegua con sus riendas de cordel en seis reales (Cuenca de Campos, VA-1666)

Un caballo ruçio con su manta tocado y freno (Villalpando, ZA-1631)

Un freno caballar *jitano con sus correas nuebas (Villalpando, ZA-1661)

Es un término de uso general en la época, siempre relacionado con los arreos de las caballerías. Aparece bastante bien referenciado en los textos, siempre junto a riendas, sillas, correas... y además el escribano suele inventariarlo junto con el animal que lleva la cabalgadura -mula, yegua, caballo-, incluso en ocasiones discierne el tipo de freno "de riendas" o "de cordeles". Junto al sintagma "de caballo" aparece el adjetivo caballar.

\section{GRUPERA [gurupera]}

Sust. f. 'Almohadilla que se pone detrás del borrén trasero en las sillas de montar, sobre los lomos de la caballería, para colocar encima la maleta u otros efectos que ha de llevar a la grupa', 'baticola' ('Correa sujeta al fuste trasero de la silla o albardilla, que termina en una especie de ojal, donde entra el maslo de la cola, y sirve para evitar que la montura se corra hacia adelante') (DLE). Autoridades recoge este término como 'la corréa con que de la parte de atrás se afianza la silla en la cola del caballo ù otra bestia, para que no pueda passarse adelante. Algunos llaman Gurupera', sin embargo, en la edición académica de 1869 la acepción de la Academia cambia por la que registra como primera acepción hoy en día el $D L E$, para en la siguiente edición incorporar las dos acepciones (NTLLE, s. v. grupera, Autoridades, 1734; DRAE, 1869; DRAE, 1884). Término derivado del fr. croupière, derivado de croupe (DECH, s. v. grupo).

Una gurupera vuena (Cea, LE-1621)

Un adreço de cauallo de orilla de la brida con guruperas françesas, çinchas y otras caueçadas tasado en sesenta y seis reales (Medina de Rioseco, VA-1644)

Es un término poco frecuente en los protocolos de la Tierra de Campos y siempre hallado con la forma gurupera. La ocurrencia que localizamos en Medina de Rioseco se corresponde con la acepción de 'almohadilla' dada por el $D L E$, ya que el contexto facilita su interpretación; el ejemplo de Cea (León) no es tan generoso, el contexto no aclara su significado.

\section{JÁQUIMA [xáquima]}

Sust. f. 'Cabezada de cordel, que suple por el cabestro, para atar las bestias y llevarlas' (DLE). Es una voz recogida por Nebrija como 'xaquima de la bestia' y se mantiene la grafía con / $\mathrm{x}$ / hasta la edición del DRAE de 1803, la forma jaquima con /j/ lo registra el DRAE de 1817 como sinónimo 
de cabestro (NTLLE, s. v. jáquima, Nebrija, 1495; DRAE, 1817). Término procedente del ar. šakîma 'cabestro, jáquima' (DECH, s. v. jáquima).

Una xáquima de mulas (Cea, LE-1610)

Tres dozenas de jáquimas blancas de cáñamo (Medina de Rioseco, VA-1649)

Dozena y media de jáquimas labradas de lana (Medina de Rioseco, VA-1649)

En los inventarios de la época parece que se prefiere la voz cabestro en la Península, ya que las únicas ocurrencias que se localizan de jáquima en el CorLexIn aparecen en documentos americanos. Esta escasez de términos se da también en la zona terracampina, ya que solo localizamos tres ejemplos de esta voz. Estamos ante un término que se documenta sobre todo en los siglos XVI y XVII por la información que ofrece el $C D H$, aun así, no es muy frecuente en los textos, aparece tanto en la Península como en América. Tampoco tenemos noticias de este vocablo en trabajos léxicos actuales consultados.

\section{RIENDA}

Sust. f. 'Cada una de las dos correas, cintas o cuerdas que, unidas por uno de sus extremos a las camas del freno, lleva asidas por el otro quien gobierna la caballería' (DLE). Nebrija recoge este término como 'rienda de freno' y Covarrubias como 'las correas que asen las cambas del freno' (NTLLE, s. v. rienda, Nebrija, 1495; Covarrubias, 1611). Término procedente del lat. vulgar * RĔTITNA, derivado de RETĩNĒRE (DECH, s. v. retener).

Un bocado con sus cauezas y riendas (Valderas, LE-1682)

Un bufete de nogal con riendas de yerro (Boadilla de Rioseco, PA-1643)

Una cabezada y riendas de baqueta (Autillo de Campos, PA-1647)

Un bocado con sus riendas (Autillo de Campos, PA-1653)

Un freno con riendas de cáñamo en cinco reales (Frechilla, PA-1675)

Un freno de yegua con sus riendas de cordel en seis reales (Cuenca de Campos, VA-1666)

Este término se encuentra documentado en las bases del castellano de forma temprana, la primera documentación que presentan tanto el CORDE como el CDH se halla en el Mio Cid (1140) y su presencia se dilata hasta hoy día. Según esta información estamos ante una palabra de uso general. Sin embargo, cabe destacar que este dato contrasta con lo encontrado en la búsqueda en documentos notariales del siglo XVII. El CorLexIn tan solo nos devuelve una decena de ocurrencias repartidas en un amplio ámbito geográfico -en la Península figura en provincias norteñas como Álava y León, pasando después por Ávila, Toledo y llegando a Sevilla-, incluyendo las colonias americanas -Bolivia, Chile y Trinidad y Tobago-. Esta situación se traslada a estudios de zonas más específicas como la que nos ocupa, donde se localizan media docena de casos solamente. Lo mismo ocurre con otros estudios, como el realizado por Gómez Ferrero (2015: 249) en La Bañeza, donde tan solo reporta un ejemplo en documentos del siglo XVII. A pesar de estos datos, estamos ante una palabra de uso general tanto en la zona de estudio como en el resto de zonas.

Desde un punto de vista formal, cabe destacar que siempre se encuentra inventariada en plural, solo de forma esporádica la encontramos en singular en relaciones de bienes. 


\subsubsection{Otros aparejos de animales}

\section{CARRANCA}

Sust. f. 'Carlanca ('collar de puntas de hierro')' (DLE, s. v. carranca ${ }^{1}$ ). Autoridades recoge el término carlanca, que define como 'collar ancho con puntas de hierro puestas hácia fuera, para armar el pescuezo de los mastínes contra las mordedúras de los lobos, el qual suele hacerse de hierro, o cuero mui fuerte', no es hasta la edición académica de 1803 donde se registra la variante carranca ya como un término antiguo y equivalente a carlanca (NTLLE, s. v. carranca y carlanca, Autoridades, 1729; DRAE, 1803). Término de origen incierto, quizá del lat. tardío CARCANNUM 'collar', cambiado por metátesis en *CARCANCU (DECH, s. v. carlanca o carranca).

Unas carrancas de perro (Cea, LE-1621)

En los inventarios terracampinos solo se ha localizado un caso con la forma carranca, frente a carlanca, término un poco más frecuente en los textos de bases de datos léxicas como el $C D H$. Son muy escasos los ejemplos de esta voz en los inventarios de bienes de la época, Gómez Ferrero encuentra otro ejemplo en la zona de La Bañeza en esta época con la variante carranca. Esto contrasta con la presencia del término en algunos repertorios léxicos actuales que estudian la zona objeto de estudio o localidades próximas a la mismas, así Gordaliza recoge los términos carlanca, carlanga y carranca con la acepción de 'collar de grandes púas de hierro que los pastores coloncan a sus mastines cuando deben luchar contra el lobo' (Gordaliza, 1988: 61, 62). Esta lexía aún sigue viva en la vida rural y la forma más frecuente es carrancas, en plural, como el ejemplo localizado en la Tierra de Campos o La Bañeza. Este término se extendería por León, Zamora, Palencia o Asturias (Le Men, 2004, s. v. carranca)

\section{CEBADERA [çebadera, zevadera]}

Sust. f. 'Morral o manta que sirve de pesebre para dar cebada al ganado en el campo' (DLE). Autoridades recoge este término como 'manta con quatro cordéles en las puntas, que llevan los Galetéros pa atarla a la galéra, y dar el pienso al ganado' (NTLLE, s. v. cebadera, Autoridades, 1729). Palabra derivada de cebo, del lat. Cॉ̈вus 'alimento, manjar' (DECH, s. v. cebo).

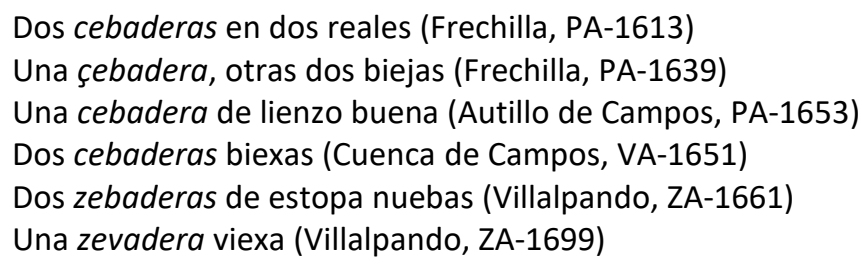

Cebadera, con la acepción académica que aquí barajamos, se documenta desde finales del siglo XV, con una presencia escasa en la documentación histórica $(C D H)$ y notarial (CorLexIn). Esto contrasta con lo que ocurre en Tierra de Campos, donde esta voz es de uso frecuente y encontramos cebaderas "de lienzo" y "de estopa". Gordaliza recoge esta palabra como 'saco que se les cuelga al cuello a las caballerías para que coman mientras descansan' (Gordaliza, 1988: 
65). Le Men también la recoge, pero con otra acepción 'hueco que en el pajar sirve para echar hierba al pesebre', este significado no lo encontramos en los inventarios estudiados.

\section{COLLAR}

Sust. m. 'Aro, por lo común de cuero, que se ciñe al cuello de los animales domésticos para adorno, sujeción o defensa' (DLE). Tanto Nebrija como Covarrubias registran el término definiéndolo como 'cadena de oro o collar' y como adorno o complemento de los trajes. Autoridades añade que es el que se hace 'de vaquéta u otro cuero, u de hoja de lata, para poner a los animales, y de hierro para poner por castigo à algun malhechór, ò esclavo fugitivo' (NTLLE, s. v. collar, Nebrija, 1495; Covarrubias, 1611; Autoridades, 1729). Término derivado de cuello, del lat. COLLARE (DECH, s. v. cuello).

Un collar de madera de bacas (Valdavida, LE-1606)

Un collar de buey (Cea, LE-1610)

Tres collares con sus esquilones (Grajal de Campo, LE-1658)

Un esquilón con su collar y tarugo (Autillo de Campos, PA-1653)

Un collar de yerro de galgos (Boadilla de Rioseco, PA-1687)

Tres dozenas de collares de lana labrada (Medina de Rioseco, VA-1649)

Diez y siete cencerras con sus collares (Cuenca de Campos, VA-1666)

En Tierra de Campos se localizan media docena de ocurrencias referenciadas junto a esquilones, tarugos, cencerras o señalando a quién pertenecen -vacas, bueyes o galgos-. Si echamos un vistazo al resto de la Península, el CorLexIn registra poco más de una veintena de casos, aunque solo cuatro se corresponden con el significado encontrado en el corpus terracampino, sin un patrón de reparto geográfico claro -Segovia, Toledo, Teruel y Jaén-. Es más frecuente encontrarlo con la acepción de joya o adorno que se pone al cuello, y pese a no llegar a la veintena de ejemplos, se utiliza en un ámbito geográfico amplio -Asturias, Guipúzcoa, León, Zamora, Cuenca, Toledo, Badajoz, Albacete, Jaén, Murcia y Almería-. El resto de las ocurrencias aparecen con el significado de adorno o joya que se pone en el cuello.

Con un significado similar o próximo al encontrado en la documentación de Tierra de Campos figura en estudios léxicos más modernos. En Palencia se recoge como el 'aro sobre el cuello de las caballerías, con borlas y campanillas' (Gordaliza, 1988: 71). En la zona Este de la Zamora también se localiza con esta acepción (Álvarez Tejedor, 1989: 235). Le Men cambia un poco este significado y referencia una 'pieza de madera en forma de herradura, donde se introduce el cuello de la res para atarla al pesebre' que se halla en localidades leonesas como Murias de Paredes, León o Astorga, pero también en Asturias, Cantabria, Andalucía (Le Men, 2004 , s. v. cuello).

\section{COLLERA}

Sust. f. 'Collar de cuero o lona, relleno de borra o paja, que se pone al cuello a las caballerías o a los bueyes para que no les haga daño el horcate' (DLE). Esta voz la recoge Casas en su Vocabulario en 1570, y seguirá apareciendo en alguno de los diccionarios preacadémicos como collera de bestia. Autoridades incluye este término con un significado al que conservamos hoy 
día (NTLLE, s. v. collera, Casas, 1570; Autoridades, 1729). Palabra derivada de cuello, del lat. cŏLLUM (DECH, s. v. cuello).

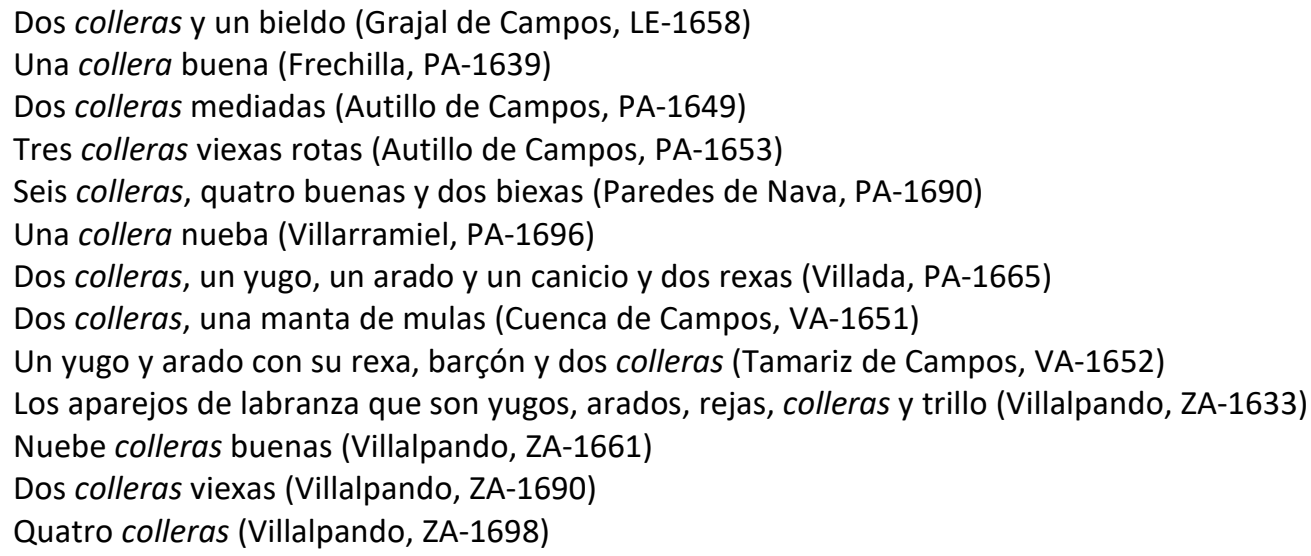

Desde una perspectiva diacrónica, los corpus del castellano documentan esta voz a partir del siglo XIII con diferentes acepciones. Aunque su presencia es mayor a partir del siglo XVI, incluso en documentos americanos, las obras en las que se documenta son de corte técnico o literario. Collera con el significado que aquí nos ocupa figura de manera esporádica en la documentación académica ( $C D H$ y CORDE).

La búsqueda realizada en el CorLexIn devuelve un único ejemplo localizado en la localidad salmantina de La Alberca que parece referenciar más una medida que un apero agrícola, ya que se encuentra inventariada entre "fanegas de trigo", "quarentales de lino" y "haces de heno":

Nueve quarentales de lino machado, a seis rales cada quarental, digo a siete rales, montan sesenta y tres rales. Más, quinze colleras de paja, a tres rales cada collera, quarenta y zinco rales. Más, ochenta azes de eno.

Sin embargo, el corpus terracampino presenta una extensa nómina de casos. Collera es un término de uso general en Tierra de Campos y, aunque el contexto no da muchas pistas de su naturaleza, podríamos aventurarnos a pensar que estamos ante una especie de collar que servía de protección a las bestias de tiro para que no se lastimaran.

La búsqueda en trabajos dialectales más modernos tiene mayor éxito. Se localiza como 'especie de collar de guarnicionería, relleno de paja que se pone encima del sudadero y forma parte de los arreos de las caballerías. Según la forma se llamaba collera catalana, collera de pico, etc.' en Palencia (Gordaliza, 1988: 71). En concreto en Villada, localidad que entra dentro de este estudio, aún se recuerda este término como 'soporte de cuero que se pone en el cuello de las mulas para poder enganchar los aperos de arrastre' (Casas, 1989: 529). En el este de Zamora también se diferencian dos tipos de collera, una para tiro y otra para el yugo (Álvarez Tejedor, 1989: 235). Le Men documenta esta voz en territorio leonés como 'collar de madera en forma de herradura que se pone a las vacas para atarlas al pesebre', además del dado por la Academia (Le Men, 2004, s. v. collera). 


\section{COMEDERO [comedera]}

Sust. m. 'Vasija o cajón donde se echa la comida a las aves y otros animales' (DLE, 3.a ac.). Con esta acepción se recoge comedero desde Autoridades (NTLLE, s. v. comedero, Autoridades, 1729). Palabra derivada de comer, del lat. COMĔDĔRE (DECH, s. v. comer).

Una taona, de págaros con su comedero y ueuedero (Grajal de Campos, LE-1658)

Un comedero viexo de esparto (Autillo de Campos, PA-1653)

Cuatro comederas a cuatro reales cada una (Medina de Rioseco, VA-1649)

A pesar de ser un término poco documentado, se hallan tanto la variante masculina comedero como la femenina comedera, esta última mucho menos frecuente en los textos. Desde un punto de vista diacrónico, con naturaleza adjetiva, tanto el CORDE como el CDH certifican el uso de forma temprana, sin embargo, como sustantivo se documenta a partir de finales del siglo XVI y en su forma masculina:

[...] se les pueda poner heno en el Invierno, y se alimpien a menudo jaula, comedero, bevedero, y palillos [...] (Agricultura de los jardines de Gregorio de los Ríos, 1592)

Si restringimos la búsqueda al siglo XVII, el $C D H$ no llega a la decena de concordancias de las que solo dos hacen referencia al significado aquí estudiado:

A este pájaro unas veces le echa de comer en el comedero que tiene dentro de su propia jaula [...] (Apuntes sueltos en torno a la reforma de San Juan Bautista de la Concepción, 1609)

Dos bebederos blancos bedriados y un comedero y unas tablas de palomar, en beinte rreales (Inventario de los bienes de Isabel Bautista, 1629, Archivo provincial de Toledo)

Por otra parte, en inventarios del siglo XVII, se localizan ejemplos de comedero en documentos toledanos, donde se especifica si son de madera o de palo (Vázquez Balonga, 2015: 167), materiales diferentes al esparto encontrado en la Tierra de Campos. Anterior a esta fecha, Rojo Vega ${ }^{16}$ localiza este término en el Inventario de una pastelera fechado en 1579: "un comedero de gallinas".

El femenino comedera con este significado no lo encontramos en la documentación de las bases académicas. Algo parecido ocurre cuando se consulta el CorLexIn donde no hallamos resultados. Comedera se localiza en documentos del siglo XVIII y XIX en la zona de La Bañeza (Gómez Ferrero, 2015: 250). Resultan interesantes los datos que nos ofrece el corpus terracampino, ya que alternan las dos opciones, tanto el masculino, como el femenino.

En trabajos dialectales más recientes la presencia de este término es más extensa. Se localiza comedera en zonas leonesas con acepciones similares o cercanas en La Vecilla, Riaño, Valencia de Don Juan y Astorga. También aparece en Asturias, Andalucía, Canarias, Galicia y Aragón (Le Men, 2004, s. v. comedera).

${ }^{16}$ Rojo Vega:

Inventario de una pastelera (1579) en Valladolid.

https://investigadoresrb.patrimonionacional.es/node/5908 [consultado noviembre 2020] 


\subsubsection{Utensilios de labranza}

\section{AZADA [açada, haçada, hazada]}

Sust. f. 'Instrumento que consiste en una lámina o pala cuadrangular de hierro, ordinariamente de 20 a $25 \mathrm{~cm}$ de lado, cortante uno de estos y provisto el opuesto de un anillo donde encaja y se sujeta el astil o mango, formando con la pala un ángulo un tanto agudo. Sirve para cavar tierras roturadas o blandas, remover el estiércol, amasar la cal para mortero, etc.' (DLE). Término recogido tanto por Nebrija como por Covarrubias con la grafía ç. Covarrubias la registra junto con azaçadón. En Autoridades presenta en solitario el lema azada que define como 'instrumento bien conocido para mover y cavar la tierra, à modo de azadón pequeño, con la diferencia de que el hierro es plano, y no tiene punta, y el hastíl es de media vara poco más' (NTLLE, s. v. azada / açada, Nebrija, 1495; Covarrubias, 1611; Autoridades, 1726). Término procedente del lat. vulgar *ASCIATA 'herramienta provista de un ascia'. (DECH, s. v. azada).

Una açada ancha bieja (Valdavida, LE-1606)

Vna açada pequeña biexa (Valderas, LE-1647)

Un uso pequeño de azada (Villarramiel, PA-1694)

Una haçada (Paredes de Nava, PA-1695)

Una azada de dicho oficio [curtidor] (Villalón, VA-1637)

Tres haçadones y una hazada (Quintanilla del Monte, ZA-1639)

Una artesa de lavar, unas escaleras, un marrón y una açada (Villalpando, ZA-1646)

Una azada bieja (Villalpando, ZA-1685)

Una azada (Villalpando, ZA-1688)

Es un término de uso general en los textos, aunque no es el objeto más inventariado dentro de los utensilios de labranza. Se recoge desde muy temprano en la documentación, como fecha, Corominas y Pascual señalan el 978 (DECH, s. v. azada), mientras que los corpus del castellano la recogen siglos más tarde en el Fuero de Madrid, fechado entre 1141 y 1235 (CDH y CORDE). También encontramos ejemplos de esta lexía en documentación medieval como la colección diplomática del Monasterio de Sahagún: "IIII fozes podaderas; IIII arreyadas; dos / azadas; II payares xenos de paya menuda" (1245).

Desde una perspectiva diatópica, el CorLexIn muestra casi medio centenar de casos repartidos por la Península con especial incidencia en la meseta norte, y en concreto en La Rioja y León. También presenta casos en documentos canarios. Es un instrumento imprescindible para las tareas agrícolas junto al azadón, apero que es más frecuente en los textos terracampinos que azada, aunque esta se halla presente también en toda la Tierra de Campos.

\section{AZADÓN [azadonillo]}

Sust. m. 'Instrumento que se distingue de la azada en que la pala, cuadrangular, es algo curva y más larga que ancha, y que sirve para rozar y romper tierras duras, cortar raíces delgadas y otros usos análogos', el DLE también lo considera como sinónimo de azada (DLE). Nebrija recoge azadón 'para roçar, de pala y peto y de muchos dientes', lo que muestra la versatilidad de esta 
herramienta agrícola (NTLLE, s. v. açadón, Nebrija, 1495). Palabra derivada de azada, por lo que procede del lat. vulgar *ASCIATA (DECH, s. v. azada).

Un açadón de peto y otro de las rexas (Sahagún, LE-1600)

Un açadón angosto (Valdavida, LE-1606)

Un azadón de matas (Santa María del Río, LE-1617)

Un açadón de yerro bueno (Galleguillos, LE-1618)

Un haçadón llano bueno apreçiado en çinco reales (Frechilla, PA-1612)

Vn azadón de yerro con su astil, mediado (Autillo de Campos, PA-1654)

Un azadón de picos cinco reales / otro azadón de hierro llano nuebo (Frechilla, PA-1675)

Un açadón de monte (Paredes de Nava, PA-1690)

Un azadón viejo quebrado (Villalón, VA-1642)

Un açadón alto y otro baxo (Tamariz de Campos, VA-1651)

Un azadón alto biejo (Medina de Rioseco, VA-1651)

Otro azadón tasado en ocho reales (Cuenca de Campos, VA-1670)

Tres haçadones y una haçada (Quintanilla del Monte, ZA-1639)

Vn açadón de rayo (Villalobos, ZA-1654)

Un açadón de pico (Villalpando, ZA-1667)

Un azadón y un picarro (Villalpando, ZA-1689)

La presencia de este vocablo en el corpus terracampino es mayor que el de azada, mientras que esta aparece en los inventarios sin mayor especificación, con azadón encontramos una variada relación de tipos ("de peto", "de rejas", "de picos", "alto", "bajo", "ancho", "angosto"...) y también con diferentes funciones ("de matas", "de monte", "de labrar", "de labrar lentexas", "de viñas"...). Desde un punto de vista diacrónico, el CORDE da cuenta del término en fecha temprana, en el Calila e Dimna cuya traducción está fechada en 1251: "Et sepas qu' el açadón corta el árbol et nasçe".

Si restringimos la búsqueda a los documentos notariales del siglo XVII, vemos que el CorLexIn presenta un número mayor de ocurrencias al de azada, casi setenta ocurrencias repartidas por distintos puntos de la Península, también con especial presencia en la meseta norte, además de ejemplos en textos americanos -Bolivia y Panamá-.

Desde la perspectiva morfológica, la lexicalización del aumentativo se hace más patente cuando nos encontramos formas derivadas con el sufijo diminutivo -illo en la localidad palentina de Frechilla:

Un azadonillo de peto (Frechilla, PA-1631)

\section{BIELDA [bienda, vienda]}

Sust. f. 'Bieldo de seis o siete puntas o dientes y dos palos atravesados, con los que forman como una rejilla' (DLE). Las obras lexicográficas académicas recogen esta voz desde Autoridades con un significado similar al que mantiene la Academia en la actualidad, aunque también especifica que sirve para 'recoger la paja, y cargarla en los carros, y para encerrarla en los pajares', información que se mantiene hasta la edición del 2001 (NTLLE, s. v. bielda, Autoridades, 1726; $D R A E$, 2001). Término derivado de beldar, aunque Corominas y Pascual señalan que pudo resultar de la forma bieldar, verbos cuyo origen se encuentra en el término latino VENTILARE (DECH, s. v. beldar). 
Una bienda piñera y ralladera (Villalpando, ZA-1637)

Tres biendas y tres biendos y quatro tornaderas (Villalobos, ZA-1653).

Biendos y dos biendas y demás cosas (Villalpando, ZA-1666)

Quatro viendas y un rastro todo usado (Villalpando, ZA-1686)

Dos viendas (Tapioles, ZA-1688)

Dos palas, dos viendos, una bienda, dos rastros, tres tornaderas (Quintanilla del Monte, ZA-1689)

Dos viendas (Villalpando, ZA-1690)

EI CORDE apenas presenta casos de esta voz en la documentación que lo conforma y los dos únicos casos pertenecen a obras enmarcadas en el siglo XX. El $C D H$, por su parte, recoge un documento a finales del siglo XVIII donde aparece este término:

formar las horcas, tan útiles como las bieldas para menear la parva, recoger y cargar la paja, y otros usos del campo (Observaciones sobre la historia natural, geográfica, agricultura, población y frutos del reyno de Valencia, II de José Antonio Cavanilles, 1797)

Los datos ofrecidos por el CorLexIn presentan una exigua nómina de casos repartidos entre las provincias de Palencia, Burgos, León y Zamora. La variante académica bielda se halla localizada en los textos palentinos y burgaleses, mientras que la variante bienda está presente en los documentos de León y Zamora.

Cabe señalar que los ejemplos terracampinos de esta voz siempre aparecen con la variante con / $\mathrm{n} /$ en vez de con / //, y solo los localizamos en la documentación zamorana de la Tierra de Campos, algo que coincide con lo señalado por Morala que la encuentra en inventarios de León y Zamora (Morala, 2012f: 323).

El término bielda y su variante bienda se localizan en trabajos léxicos más modernos. Es una voz de uso general al sur del dominio leonés, y en Andalucía. Su género gramatical constituye un significado cuantificador, mientras que bielda referencia una herramienta grande, bieldo designa un objeto de menor tamaño (Le men, 2002, s. v. bielda). La forma bienda se sigue manteniendo en zonas de Zamora, así lo confirma el estudio lingüístico realizado en la zona Este de la provincia (Álvarez Tejedor, 1989: 121).

\section{BIELDO [vieldo, biendo, viendo]}

Sust. m. 'Instrumento para aventar compuesto de un palo largo, de otro de unos $30 \mathrm{~cm}$ de longitud que lo atraviesa en uno de sus extremos, y de otros cuatro o más fijos en este en forma de dientes', también lo registra como 'bielda' (DLE). Nebrija recoge 'bieldo para aventar' que es lo mismo que beldar. Covarrubias mantiene este significado y Autoridades especifica mucho más esta información 'instrumento de Labradóres hecho de un palo como de escóba, y clavado al remáte, ò metido en la punta por un agujero, otro del tamaño de una tercia, y mas gruesso, del qual salen otros quatro como dientes de péines, delgados, y puntiagúdos, con el qual sepáran la paja del grano, y la avientan para que quede límpio' (NTLLE, s. v. bieldo, Nebrija, 1495; Covarrubias, 1611; Autoridades, 1726). Esta palabra derivada del verbo beldar, del lat. VENTILARE (DECH, s. v. beldar).

Dos bieldos y un trebiezo y dos aspas todo en dos reales (Sahagún, LE-1600)

Una pala, un gario, dos horcas y un vieldo, todo de madera (Celada, LE-1624)

Dos horcas y un bieldo y un gario en tres reales (Castroañe, LE-1629)

Un bieldo (Grajal de Campos, LE-1670) 
Dos bieldos (Frechilla, PA-1640)

Trastos de verano como son rastros, vieldos, orcas y garios (Autillo de Campos, PA-1647)

Dos orcas y dos bieldos y dos garios (Paredes de Nava, PA-1690)

Dos bieldos, dos rastros, un trillo biexo (Villarramiel, PA-1691)

De orcas, palas, bieldos, varas de abellano, ruecas, y otras cosas de este jénero (Medina de Rioseco, VA-1646)

Quatro palas, dos vieldos, dos rastros y dos orcas (Medina de Rioseco, VA-1660)

Quatro rastros, quatro bieldos, quatro orcas, tres garios y dos orcas biexas de cargar (Cuenca de Campos, VA-1668)

Dos rastros biexos y un viendo (Villalpando, ZA-1632)

Quatro rastros, quatro tornaderas y quatro biendos (Villalpando, ZA-1661)

Dos viendos (Tapioles, ZA-1688)

Zinco viendos usados (Villalpando, ZA-1686)

Dos viendos (Villalpando, ZA-1690)

Bieldo lo registramos en la zona de Tierra de Campos con la variante académica y la forma biendo, alternando en ambos casos la grafía b/v habitual en la época. Tal y como pasaba con bielda, bieldo también presenta la variante biendo con $/ \mathrm{n} /$ como resultado en los textos zamoranos pertenecientes a la Tierra de Campos $^{17}$, reservando el resultado académico para el resto de provincias. Pero esta variabilidad de las formas de esta voz no es exclusiva de la zona de estudio, sino que se extiende a otras zonas de la Península. En los inventarios de La Bañeza (León) se recoge la forma bildo para referenciar este apero (Gómez Ferrero, 2015: 258); Morala, en esta misma época, localiza liendro y liendra en Cáceres además de biendro o bierno; en Segovia y Ávila bielgo, forma a la que habría de añadir documentos gaditanos que la recogen según los datos del CorLexIn; en Burgos y Toledo localiza las formas bienlo y bienla; en documentos del Norte de Guadalajara y Soria figura la variante bielo (Morala, 2012f: 321-326).

En la documentación histórica que conforman el $C D H$, localiza esta voz a partir del Fuero de Cáceres ( 1290) y con la forma bienlo: "cosa emprestada, aradro, bienlo, forca e tales cosas ". Dos siglos más tarde lo recoge Alfonso de Palencia con la forma académica en su Universal Vocabulario (1490). A pesar de que aparece en los textos de forma temprana, no es una voz muy frecuente en los corpus del castellano.

En repertorios dialectales modernos sigue apareciendo este término. En el Vocabulario Palentino se registra el término académico bieldo (Gordaliza, 1988: 44). En la zona este de Zamora se localizan las formas bieldo, biendo y briendo (Álvarez Tejedor, 1989: 99). Las variantes más usadas en León son bildo y biendo (Le Men, 2002, s. v. bieldo).

\section{CEDAZO [zedazo, zedaço, cedaço, sedaço]}

Sust. m. 'Instrumento compuesto de un aro y de una tela, por lo común de cerdas, más o menos clara, que cierra la parte inferior. Sirve para separar las partes sutiles de las gruesas de algunas cosas, como la harina, el suero, etc.' (DLE). Covarrubias lo registra como 'harnero de tela delgada, con que se cierne la harina [...]' (NTLLE, s. v. cedazo, Covarrubias, 1611). Abreviación

\footnotetext{
${ }^{17}$ Morala localiza la variante biendo en la provincia zamorana (Morala, 2017c: 369)
} 
del lat. vulgar CRIBRUM SETACĚUM 'criba hecha de cerdas', derivado del lat. SAETA 'cerda, crin' (DECH, s. v. cedazo).

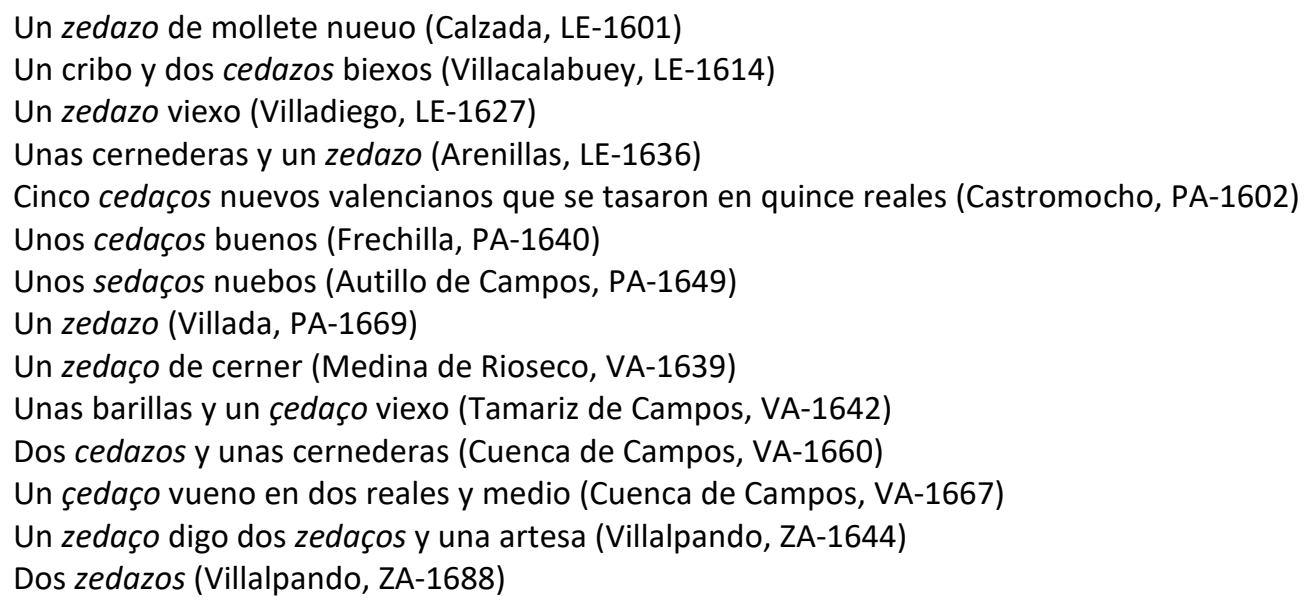

Dentro de los instrumentos para cribar, es frecuente hallar en las relaciones de bienes los cedazos. Este término referencia un tipo de criba muy fina que se utiliza para limpiar las impurezas de la harina. El uso de esta voz es frecuente en los inventarios terracampinos, a pesar de compartir campo semántico con piñera, opción preferida en los textos zamoranos de la zona. En cuanto a la distribución diatópica en la Península presenta un ámbito geográfico amplio -zonas peninsulares que abarcan del norte al sur, Canarias y un caso en documentos panameños-, lo que daría cuenta de que estamos ante un término de uso general. Debemos señalar la variedad poligráfica del término, a pesar de que el cambio de /s-/ inicial se da en la Edad Media, en las zonas de seseo de la Península, Canarias y América se mantiene (Morala, 2016c: 312), además de la alternancia de grafías como la z, c, ç y de manera más excepcional s, ya que como hemos dicho antes se suele mantener en las zonas de seseo. Sin embargo, cabe destacar que en la documentación terracampina figura un caso, donde la trascripción original sería ssedaço, que posiblemente viniera dado por la confusión entre sibilantes que aún mantiene algún vestigio en esta época.

Desde la perspectiva de la morfología derivacional, encontramos en documentos leoneses de la Tierra de Campos el diminutivo cedacilla:

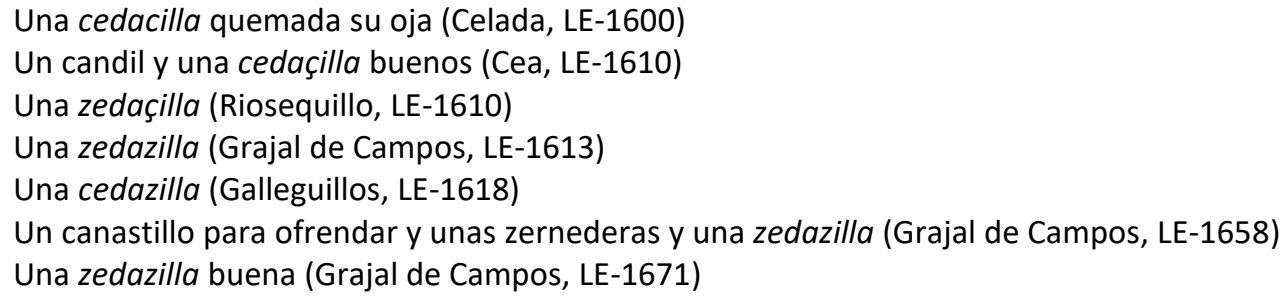

En este caso el término adopta el género femenino y, por el contexto en el que suele aparecer, no referencia un diminutivo al uso de cedazo, sino más bien un diminutivo lexicalizado que Morala también localiza en Zamora, Burgos y Salamanca donde estos dos términos aparecen en el mismo asiento, lo que indica que no referencian el mismo objeto (Morala, 2016c: 313). En el corpus estudiado, cedacilla figura inventariada junto a candiles, jarras, cántaros, 
platos u ollas y pucheros, lo que también sería indicio de estar ante otro tipo de enser, más relacionado con los utensilios domésticos.

En trabajos recientes se sigue recogiendo esta voz, por ejemplo, Gordaliza registra cedazo como 'criba fina de tela, para la harina y otros usos. Se usaba mucho en los molinos para cerner', pero también recoge la variante ceazo o ciazo, forma vulgar que se utiliza en la mitad norte y también en León. Algo que confirma el estudio realizado por Le Men que recoge el término en León, pero también en Asturias, Zamora, Salamanca, Extremadura, Andalucía, Soria, Toledo, Cuenca, Albacete, Murcia, Navarra y La Rioja. Con esta forma no figura en el corpus estudiado.

\section{ZARANDA [ceranda, zeranda, çeranda, çaranda]}

Sust. f. 'criba' (DLE). Nebrija y Covarrubias recogen esta palabra con la ç inicial, este último la define como 'criba agugerada para limpiar el trigo, echandolo en alto, y meneandolo de vna parte a otra, para que salga el poluo y la paja'. Autoridades ya lo registra con z (NTLLE, s. v. çaranda / zaranda, Nebrija, 1495; Covarrubias, 1611; Autoridades, 1739). Probablemente se trata de una onomatopeya tsándara que expresaría el sonido rítmico de la criba y el grano al zarandearlos (DECH, s. v. zaranda).

Un cribo y una ceranda (Sahagún, LE-1601)

Un escriño y una ceranda tres reales (Castromudarra, LE-1606)

Una zeranda tasada en un real (Celada, LE-1624)

Una ceranda y dos criuos viejos (Castroañe, LE-1629)

Dos escriños y dos cerandas (Castromocho, PA-1602)

Una zeranda buena (Autillo de Campos, PA-1647)

Una ceranda mediada (Autillo de Campos, PA-1653)

Una çeranda (Villarramiel, PA-1696)

Un cribo y una ceranda y un escriño, todo ello en quatro reales (Villalpando, ZA-1600)

Una ceranda de trigo buena (Villalpando, ZA-1632)

Un criuo y una ceranda (Villalpando, ZA-1652)

Dos cerandas para paja (Villalpando, ZA-1661)

Un cribo y una zeranda nuebos (Villalpando, ZA-1670)

Dos zerandas nuebas (Tapioles, ZA-1688)

Una zeranda y una piñera (Quintanilla del Monte, ZA-1689)

Un cribo y una zeranda biejos (Villalpando, ZA-1690)

En los documentos recogidos en la Tierra de Campos figura preferentemente la variante ceranda con /e/, frente a la académica zaranda, de la que solo localizamos tres ocurrencias:

Dos çarandas, dos cribos tasado en quatro reales (Grajal de Campos, LE-1656)

Una zaranda y un criuo (Villalpando, ZA-1688)

Un criuo y una zaranda viexos (Villalpando, ZA-1689)

Esta situación puede extrapolarse al corpus que conforma el CorLexIn, donde apenas encuentra un par de ejemplos repartidos entre inventarios de Huesca y Zamora, a los que habría que sumar los localizados por Morala en Soria, Albacete y Cuenca en documentos inéditos 
pertenecientes a inventarios de bienes del siglo XVII (Morala, 2016c: 319). De manera esporádica también aparece en documentos vallisoletanos ${ }^{18}$.

Por su parte, ceranda presenta una docena de items distribuidos por el occidente de la Península coincidiendo con el área de las hablas leonesas, por las provincias de León, Zamora y Cáceres, señalado ya por Corominas y Pascual (DECH, s. v. zaranda). Área a la que habría que añadir la zona palentina de Tierra de Campos y otras zonas occidentales como El Cerrato, señalado por Morala (2016c: 320) y Valladolid.

En relaciones de bienes de la zona de La Bañeza también se localiza la variante ceranda que, un siglo más tarde, alterna con la forma Zelanda, que presenta confusión entre la / $\mathrm{r} /$ y la / $/$, (Gómez Ferrero, 2015: 261).

En cuanto al significado, por regla general, se equipara con el término criba. Sin embargo, de manera esporádica aparecen documentos donde las dos voces -criba y ceranda- figuran inventariadas, incluso en el mismo asiento:

Una zeranda e una criba (Calzada, LE-1601)

Vna criua biexa, vna ceranda uiexa (Autillo de Campos, PA-1654)

Este hecho hace que nos planteemos que, a pesar de tener una acepción muy cercana, ambos términos tengan alguna característica que les haga objetos diferentes (Morala, 2016c: 320).

Desde una perspectiva diacrónica, se presenta el patrón contrario, Tanto el $C D H$ como el CORDE documentan la voz académica zaranda a partir del siglo $\mathrm{xV}$ y presentan un uso mayoritario del término en la primera mitad siglo XVII. Los casos en los que este término aparece en relaciones de bienes son testimoniales, tan solo se muestran dos inventarios en el siglo XVII, el resto de ejemplos se localizan en obras de corte literario o técnico, de ahí la preferencia del resultado académico.

En trabajos dialectales actuales se localiza ceranda en las zonas leonesas de Murias de Paredes, La Vecilla, Riaño, León, Sahagún, La Bañeza y Astorga. También se localiza en Zamora, Galicia o Canarias (Le Men, 2004, s. v. ceranda).

Desde un punto de vista formal, en la zona encontramos el derivado aumentativo zarandón, del que no tenemos noticias en ninguno de los diccionarios académicos, ni en los corpus académicos.

Un zarandón (Villalpando, ZA-1689)

Zarandón lo documenta el Diccionario General de la Lengua Asturiana (DGLA) como 'ceranda grande' o 'ceranda de agujeros grandes' y recoge la variante cerandón. Esta última figura en documentos de los siglos XVIII y XIX pertenecientes al partido judicial leonés de La

\footnotetext{
18 Rojo Vega, Anastasio:

Inventario y biblioteca del licenciado Luis Núñez de Sagarra, abogado, 1596: "una zaranda". Consultado en diciembre de 2020 en: https://investigadoresrb.patrimonionacional.es/node/8401.
} 
Bañeza (Gómez Ferrero, 2015: 262). En estudios más modernos se localiza en localidades leonesas como Villacidayo, Valencia de Don Juan y Astorga (Le Men, 2004, s. v. cerandón).

\section{CRIBA [criva, criua]}

Sust. f. 'Utensilio consistente en un aro con una malla u otro material agujereado fijados en él, y que sirve para cribar' (DLE). Se registra en Autoridades como 'lo mismo que Cribo ò Harnero: y solo se diferencia en que tiene los agujéros mayóres, y sirve para limpiar y acribar la paja, y otras cosas' (NTLLE, s. v. criba, Autoridades, 1729). Término derivado de cribo, del lat. CRĪBRŪM, los dos únicos romances que tienen la forma femenina criba es el cast. y el port. (DECH. s. v. cribo).

Dos cribas buenas (Sahagún, LE-1600)

Una zeranda e una criba (Calzada, LE-1606)

Una criba buena (Villadiego, LE-1627)

Dos crivas, una biexa y la otra mediana (Castroañe, LE-1629)

Un harnero y una criba en dos reales (Frechilla, PA-1613)

Tres cedaços y una criba de pino (Castromocho, PA-1614)

Una criba buena (Frechilla, PA-1640)

El arnero, dos cribas y un panadero (Frechilla, PA-1639)

Una criua (Villalón, VA-1637)

Una criva de acribar trigo en un real (Cuenca de Campos, VA-1660)

Criba es un término de uso general en los documentos de la Tierra de Campos y esta frecuencia de uso puede aplicarse a prácticamente el resto de la Península. Aunque Autoridades lo equipara a cribo y harnero, el hecho de que en los inventarios aparezca junto a esas dos lexías, significa que en algo debía variar su significado. Morala señala que la forma criba es más frecuente y está más extendida por la Península que su masculino cribo (Morala, 2016c: 310). Lo que sí está claro es que debían de diferenciarse en algo, puesto que hay inventarios donde aparecen los dos términos en el mismo asiento, algo que ocurre en documentos de otros lugares (Morala, 2016c: 310), lo que indica que estamos ante palabras no sinónimas:

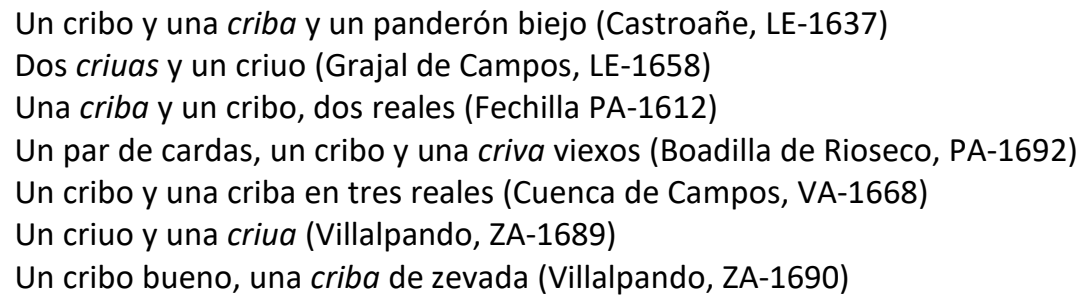

Gordaliza recoge criba como 'cualquier aparato para limpiar el grano y especialmente un aro con cuero agujereado para cribar legumbres' y a continuación recoge la voz cribo y señala que es 'más fino' que la criba (Gordaliza, 1988: 77). Álvarez Tejedor también localiza esta voz en la zona este de Zamora y afirma que en la mayoría de los pueblos diferencian entre cribas y harneros (Álvarez Tejedor, 1989: 102). Le Men utiliza la misma entrada para recoger criba y cribo, aunque señala que este último es de menor tamaño (Le Men, 2004). Tal vez habría diferencia de tamaño en cuanto a la envergadura del objeto, o bien en los agujeros que la conforman, o puede que el material del que están hechos. 


\section{CRIBO [crivo, criuo]}

Sust. m. y f. 'Cuero ordenadamente agujereado y fijo en un aro de madera, que sirve para cribar. También se fabrica de plancha metálica con agujeros, o con red de malla de alambre' (DLE). Autoridades recoge este término como 'especie de instrumento, que se forma de un cerco ò aro de madéra delgada con el suelo de cuero crudo de caballo ù de otro animal, todo agujereado, el qual sirve ordinariamente de limpiar el trigo y otras semillas'. Sin embargo, en el DRAE de 1780, ya se le da el mismo significado que a criba (NTLLE, s. v. cribo, Autoridades, 1729; DRAE, 1780). Del lat. CRĪBUM (DECH, s. v. cribo).

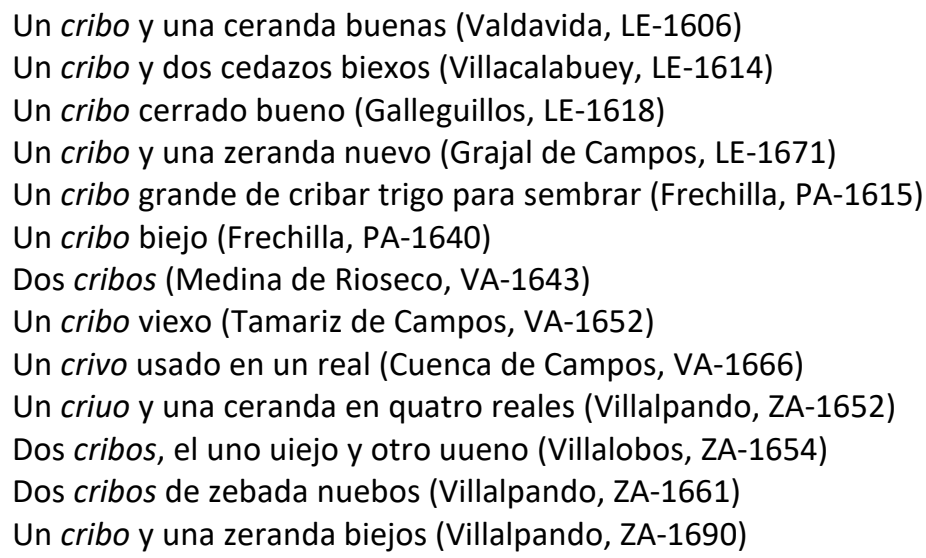

A finales del siglo XIII aparece documentado la forma criviello en la General Estoria de Alfonso $x$, fechada en 1275 . Con la forma que la conocemos actualmente -cribo- la recogen tanto el CORDE como el CDH en 1283, unos años más tarde en el Acuerdo con el concejo en Luquin. EI CDH muestra un total de 62 concordancias de cribo, frente a las 214 de criba, lo que demuestra que cribo es menos frecuente en los textos del castellano.

En cuanto a las áreas de uso, el CorLexIn ofrece trece items distribuidos en las provincias de Burgos, Palencia, León y Zamora a las que habría que añadir las de Cantabria, Asturias y Salamanca (Morala, 2016c: 310) y la Tierra de Campos vallisoletana, siempre en provincias norteñas. En el corpus recogido en Tierra de Campos se contabilizan más ejemplos de cribo, además suele aparece junto a criba, pero también al lado de cerandas y cedazos.

\section{HARNERO [arnero]}

Sust. m. 'Especie de criba' (DLE). Esta voz se recoge desde Nebrija. Covarrubias la define como 'quasi harinero: aunque este nombre se ha estendido a sinificar las criuas con que limpian el trigo, la ceuada, y la paja. Bien se vee que tomò el nombre de la harina; pero este ya le perdio, porque se le dieron al cedaço [...]'. Por su parte, Autoridades lo equipara con cribo (NTLLE, s. v. harnero, Nebrija, 1495; Covarrubias, 1611; Autoridades, 1734). Término derivado de harina, del lat. FARĪNA, esta forma procede de la síncopa de harinero (DECH, s. v. harina).

Un arnero (Castrillo, LE-1606)

Un harnero y una criba en dos reales (Frechilla, PA-1613)

Dos arneros tasados en real y medio (Mazariegos, PA-1619)

El arnero, dos cribas y un panadero (Frechilla, PA-1639)

Una zincha de arnero pequeña (Autillo de Campos, PA-1653) 
Tanto el CORDE como el $C D H$ recogen este término en el Libro del Buen Amor del Arcipreste de Hita con mantenimiento de la f- inicial-farnero-, obra fechada en el siglo XIV. Con pérdida de la f- inicial se documenta en el Cancionero castellano y catalán de París (1430). A finales del siglo XVI figura en textos americanos, por ejemplo, en Elegías de varones ilustres de Indias de Juan de Castellanos se localiza el siguiente ejemplo: "hay cedazo, harnero, y hay zaranda" (Colombia, 1589). Esta lexía presenta mayor frecuencia de uso en la documentación americana a partir de mediados del siglo XVII, aunque hay que puntualizar que la mayor parte de las obras en las que aparece son de corte literario.

Si restringimos la búsqueda a los archivos notariales del siglo áureo, nos encontramos con un uso generalizado en las dos mesetas, Extremadura y Andalucía -en estas dos zonas se documentan también las formas con aspiración: jarnero o garnero-. La presencia del vocablo en documentos terracampinos es menor que otras voces con un significado similar. Harnero figura de forma excepcional en zonas de León y Aragón, hecho que se ve reflejado en el corpus estudiado (Morala, 2016c: 313).

En Palencia, en estudios lexicográficos más modernos, se localiza este término como 'especie de criba que se usaba para cribar el trigo y dar así una limpieza a la semilla, separando granos de otras plantas, tierra, etc. Estaba hecha de piel. Y lo señala como una palabra propia de El Cerrato, comarca palentina' (Gordaliza, 1988: 33-34). Es una palabra que se encuentra vigente hoy en día en el ámbito rural castellano (Perdiguero, 2012b: 388).

\section{PANDERO [panderón]}

Con la acepción con la que aquí figura pandero no la encontramos en el $D L E$, ni en ninguno de los diccionarios académicos. En un par de inventarios aragoneses fechados en el siglo XIV figura esta lexía figura entre cribas o cedazos, donde podría referenciar 'una especie de cesto o canasta para harina y trigo' (DECH, s. v. pandero). Aunque, Corominas acaba señalando que pude que se trate de una ultracorrección por panero, panera por esa tendencia a reducir /nd/ a /n/ en aragonés.

Un cribo y una criba y un panderón biejo (Castroañe, LE-1637)

Unas barillas de pino de çerner y un pandero (Frechilla, PA-1614)

El corpus terracampino ofrece un par de casos, siempre con género masculino. El significado que presenta coincide con el de un tipo específico de criba, dado el contexto en el que se inventaría. Los testimonios que ofrece el CorLexIn suman una docena de casos repartidos entre la zona del castellano oriental -La Rioja, Soria y Guadalajara- a la que habría que sumar algunos casos en Burgos, Segovia y Ávila (Morala, 2016c: 315-316). A estas zonas habría que sumarles los encontrados de forma esporádica en la Tierra de Campos, zona limítrofe entre los dos romances.

En el campo morfológico cabe destacar la presencia del aumentativo panderón, basado posiblemente en una motivación semántica de tamaño, dado el contexto en el que se encuentra, entre un cribo y una criba. 


\section{PEÑERA [piñera]}

El DLE define este término como 'cedazo fino' y le otorga la notación dialectal de Asturias. Las obras lexicográficas académicas registran esta entrada de forma tardía, no es hasta la edición de 1884 que se introduce entre sus lemas tal y como se conserva hoy en día (NTLLE, s. v. peñera, $D R A E, 1884)$. Término de procedencia leonesa con el significado de 'cedazo' con origen incierto (DECH, s. v. peñera).

Dos piñeras y unas barillas de çerner y una pala de horno (Valderas, LE-1647)

Dos piñeras y una coladera (Villalpando, ZA-1600)

Tres masseras con barillas y piñeras (Villalpando, ZA-1620)

Una piñera buena en quatro reales (Villalpando, ZA-1629)

Quatro piñeras biexas y unas barillas (Villalpando, ZA-1632)

Una artesa de masar, unas barillas y dos piñeras y una coladera (Villalpando, ZA-1640)

Una hartessa de massar y unas barillas y dos piñeras, con la brega y su breguil, con coladera y arralladera (Villalpando, ZA-1652)

Unas barillas, dos piñeras (Tapioles, ZA-1688)

Una zeranda y una piñera (Quintanilla del Monte, ZA-1689)

En la zona zamorana de la Tierra de Campos es habitual la forma piñera, con cambio de timbre de la vocal átona. Tan solo localizamos un ejemplo en la localidad leonesa de Valderas. Parece que en zonas de León, Palencia y Valladolid era más habitual el uso de cedazo. De forma frecuente se inventarían junto a varillas -'bastidor rectangular en que se mueven los cedazos para cerner' (DLE, 6. ac.) -.

El CorLexIn ofrece media docena de ejemplos repartidos entre Asturias, León y Zamora, lugares en los que se prefiere este término a cedazo, aunque, este último aparezca de forma ocasional (Morala, 2016c: 320-321). Como vemos en estos resultados, esta voz no solo era propia de Asturias, como señala la Academia, sino que está presente en textos de León y Zamora. Hecho que se mantiene en estudios actuales donde se certifica su presencia en León, Zamora y también Salamanca (Le Men, 2009, s. v. peñera). En cuanto a la forma académica peñera, tan solo se documenta en Asturias y norte de León, en el resto de documentos se prefiera la variante con /i/ (Morala, 2016c: 320-321).

\section{ESCOBETA}

Sust. f. 'Escobilla de cerdas o alambre' (DLE, 2.a ac.). El primer registro académico se hace en el DRAE de 1791 como 'lo mismo que escobilla para limpiar' (NTLLE, s. v. escobeta, DRAE, 1791). Término derivado de la palabra escoba y esta a su vez procedente de del latín ScōPA íd., primitivamente SCŌPAE 'briznas' (DECH, s. v. escoba).

Una escobeta (Castromocho, PA-1614)

Una escobeta limpiadera de cerdos negra en tres reales (Frechilla, PA-1675)

Este término se documenta a mediados del siglo XVI en el $C D H$ y en el CORDE, pero su presencia en la documentación no es muy extensa, y no encontramos esta palabra más allá del siglo XVII en la Península. Parece que la lengua se decantó por el uso de escobilla, término que tiene más presencia en la documentación. Sin embargo, esta palabra se localiza en los 
documentos en México a partir de finales del siglo XIX hasta la actualidad con el significado de instrumento utilizado para la limpieza.

Encontramos dos ejemplos de este término en los documentos consultados de Tierra de Campos, uno de ellos detalla que este instrumento se utiliza para limpiar a los cerdos, el otro ejemplo no especifica su uso. En el CorLexIn aparece otra ocurrencia en la localidad Villamuñío, pero con la finalidad de limpiar vestidos: "vna escobeta de limpiar vestidos" (Villamuñío, LE1633).

\section{ESCOBILLA [escouilla, escubilla]}

Sust. f. 'Cepillo para limpiar', 'escoba pequeña formada de cerdas o de alambre que se usa para limpiar' (DLE, 1. a y 2. a ac.). Término recogido por Nebrija como 'escobilla de limaduras' y Covarrubias añade 'limpiadera con que se limpian los vestidos, comúnmente cerdas de jauali' y Autoridades lo equipara con la voz cepillo (NTLLE, s. v. escobilla, Nebrija, 1495; Covarrubias, 1611; Autoridades, 1732). Término derivado de la palabra escoba y esta a su vez procedente de del lat. SCŌPA íd., primitivamente SCŌPAE 'briznas' (DECH, s. v. escoba).

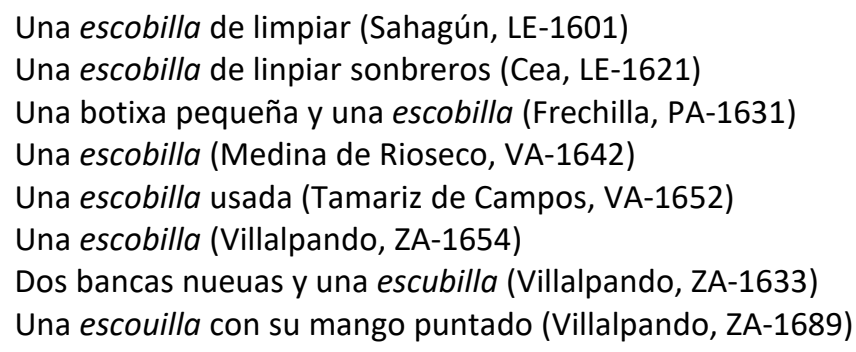

Se documenta en el $C D H$ a finales del siglo xv en las Cuentas de Gonzalo de Baeza, y en los textos encontramos este término con las acepciones académicas. En los protocolos del siglo XVII, esta palabra se localiza con la acepción de 'herramienta de limpieza', pudiendo ser para limpiar la ropa, la cabeza y otros enseres, también la encontramos como sinónimo de cepillo para cepillar al caballo. En Tierra de Campos se utiliza con las acepciones dadas por la academia. Formalmente, presenta la variante escubilla, con cambio del timbre de la vocal átona.

En compendios dialectales contemporáneos como el de Le Men o Gordaliza se recoge como 'planta compuesta que florece en Mayo, muy corriente en sitios incultos y linderas', de esta planta se elaboran las escobas y las escobillas (Gordaliza, 1988: 101, Le Men, 2005, s. v. escobilla).

\section{DALLE}

Sust. m. el DLE nos remite a guadaña 'instrumento para segar a ras de tierra, constituido por una cuchilla alargada, curva y puntiaguda, sujeta a un mango largo que se maneja con las dos manos' (DLE). Covarrubias recoge esta palabra como 'arma enastada, y el hierro es vna cuchilla taxante, de ambos cortes, ancha al principio, y terminase en vna punta muy aguda, con la qual hiere'. Autoridades añade que 'regularmente sirve para cortar la hierba' y en la edición del DRAE de 1884 remiten al término guadaña (NTLLE. s. v. dalle, Covarrubias, 1611; Autoridades, 1732; 
$D R A E, 1884)$. Lexía tomada del cat. dall o de oc. dalh 'guadaña', 'cuchilla fijada en la punta de un palo', procedentes del lat. tardío DACǓLUM, de origen desconocido (DECH, s. v. dalle).

Un dalle bueno (Galleguillos, LE-1618)

Palabra poco frecuente en el corpus terracampino, tan solo se documenta una ocurrencia en la localidad leonesa de Galleguillos, inventariado junto a aperos de labranza como arados y rejas. Estos datos nos constatan que es una voz poco habitual en la zona.

Las primeras apariciones en las bases académicas se remontan a 1490, en el Universal Vocabulario de Alfonso de Palencia donde se recoge como un tipo de arma, significado que se encuentra en otros documentos como en la Historia General de Indias de A. Herrera fechada en 1601: "mataron los mexicanos vn cauallo con vn dalle hecho de vna espada".

El CorLexIn apenas recoge resultados de esta palabra, encontramos "vna dalla con sus martillos" (Tordelrábano, GU-1613). Con terminación en -a, el DLE identifica esta voz con 'guadaña' en zonas de Aragón y Navarra. De dalle encontramos casos esporádicos en documentos de Burgos "un dalle con sus martillos, piedras y colodras viexas" (Perdiguero, 2013: 238) y también en algunos textos vallisoletanos rescatados por Rojo Vega ${ }^{19}$.

En repertorios dialectales más modernos figura como "instrumento para segar hierba. Es más ancho que la guadaña. Sus partes son manillas (donde se agarra), estil (el mango), virola (para sujetar la hoja). Cantearse es mellarse el dalle" (Gordaliza, 1988: 88). Es una voz poco usada en León, sin embargo, es frecuente en otras provincias como Asturias, Andalucía, Santander, Palencia, Burgos, La Rioja, Cuenca, Navarra o Aragón (Le Men, 2005, s. v. dalle). Los datos que aportan los atlas lingüísticos reflejan un uso de dalla general en Aragón, el oriente de Soria, Cuenca, Albacete y Guadalajara por lo que debemos considerar que estamos ante un orientalismo (Morala, 2020: 100). Aunque cabe destacar la presencia de dalle en casi todo el territorio cántabro (ALECant), lo que daría cuenta de una expansión tardía del vocablo (Ibidem).

\section{GUADAÑA [aguadaña]}

Sust. f. 'Instrumento para segar a ras de tierra, constituido por una cuchilla alargada, curva y puntiaguda, sujeta a un mango largo que se maneja con las dos manos' (DLE). Nebrija da cuenta de esta palabra en su Vocabulario. Covarrubias lo define como 'cuchilla falcada, que puesta en vn astil largo siegan con ella la yerua, y el heno que se ha de encerrar para dar comer a los bueyes y a las bestias el inuierno despues de seca'. Autoridades presenta una definición más técnica, aunque sin cambios significativos con respecto a Covarrubias (NTLLE, s. v. guadaña, Nebrija,

\footnotetext{
${ }^{19}$ Rojo Vega. Consultado en diciembre de 2020:

Testamento e inventario de Pierres de Chauz, fiel ejecutor (Medina del Campo, VA-1577) "un dalle" https://investigadoresrb.patrimonionacional.es/node/5813

Testamento, inventario y blioteca de Antonio Romero, chantre (Traspinedo, VA-1577) "un dalle" https://investigadoresrb.patrimonionacional.es/node/5815 Inventario de Diego Mudarra, regidor de Valladolid (1610) "un dalle con tres ganchos" https://investigadoresrb.patrimonionacional.es/node/9095
} 
1495; Covarrubias, 1611; Autoridades, 1734). Término procedente de la raíz germánica waith-, probablemente como derivado (romance o germánico) del gótico *waithô, 'prado, pastizal' (DECH, s. v. guadaña).

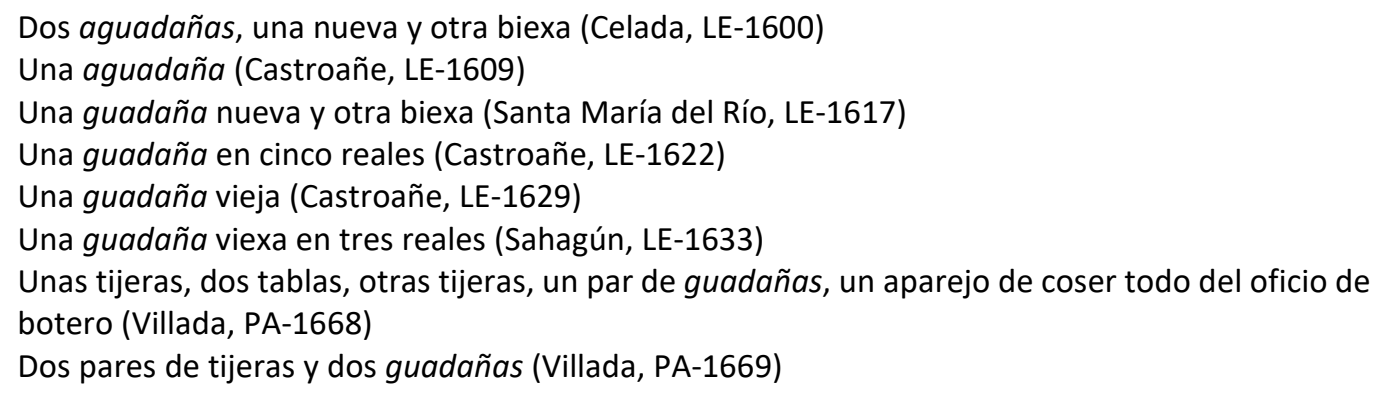

Según las documentaciones que la palabra posee en el corpus terracampino, estamos ante un término más productivo que dalle. En la comarca de Tierra de Campos alternan las formas guadaña con aguadaña, con adición de la vocal a- protética, fruto de la confusión con el artículo femenino (Morala, 2020: 99). Esta segunda forma la recoge desde temprano los diccionarios como el de Percival (1591), Palet (1604) o Vittori (1609) entre otros. También la recoge Autoridades, aunque señala que es voz anticuada y envía directamente la referencia a guadaña (NTLLE, s. v. aguadaña, Persival, 1591; Palet, 1604; Vittori, 1609; Autoridades, 1724).

Si restringimos la búsqueda a los inventarios del siglo XVII, encontramos el término en documentos de Jaén (1648), una referencia toponímica en Burgos (1655), León, Zamora o Madrid, donde se documenta en masculino. También figuran algunos asientos en documentos zamoranos cercanos a la Tierra de Campos -"vna guadaña con su martillo y vigornia; vn martillo y vna cincha (Tábara, ZA-1690) -. Figuran ejemplos de guadaña y aguadaña para referenciar útiles de pesca en textos cántabros (Bartolomé y Junquera, 2018: 114-115).

\section{HOCINO [oçino, ozino]}

Sust. m. 'Instrumento corvo de hierro acerado, con mango, que se usa para cortar leña' ( $D L E$, s. v. hocino ${ }^{1}$ ). Nebrija registra 'hocino para segar'; Covarrubias referencia con esta palabra un tipo de terreno. Por su parte, Autoridades recoge las dos acepciones, especificando más su significado: "instrumento deque se usa para cortar leña: el cual es de hierro acerado, de hechura curva, de media vara de largo y quatro dedos de ancho, con un mango o empuñadura para obra con él" (NTLLE, s. v. hocino, Nebrija, 1495; Covarrubias, 1611; Autoridades, 1734). Término derivado de hoz I 'instrumento para segar', del lat. FALX, -CIS (DECH, s. v. hoz I).

Una almoaça y un oçino (Frechilla, PA-1640)

Una zestica y un oçino de bendimiar (Baquerín de Campos, PA-1658)

Dos ozinos biexos en cinquenta y un maravedís (Fechilla PA-1675)

EI CORDE registra este término desde las Cortes de Toro fechadas en 1369 donde figura "el hozino para segar yerba por dos mr. e medio". El número de concordancias no es muy frecuente en las bases académicas. En cuanto al significado con el que aparece en los documentos es el de 'herramienta de corte' que en ocasiones se le equipara con podadera -"dejase las gavillas, y el hocino ó podadera olvidada en el árbol" (Siglo de Oro en las selvas de Erífile de Bernardo de 
Se prefiere este término en la zona leonesa de Tierra de Campos, frente a hocino, más visible en los textos palentinos. Es un término que, a pesar de estar recogido por la Academia, no figura en la documentación que configura el CORDE y el $C D H$. Esta situación se puede extrapolar a lo que ocurre en los inventarios de bienes del siglo XVII, la única ocurrencia que encontramos en el CorLexIn pertenece a la localidad leonesa de Castroañe, perteneciente a este estudio. Esto nos hace sospechar que estamos ante un localismo, propia de esta zona terracampina. Encontramos alguna referencia a este vocablo en el Fichero General, en la cédula número 3, donde se referencia esta lexía en el Libro de la montería del Rey D. Alfonso XI, fechado en el siglo XIV, aunque cuenta con añadidos del siglo XVI. Sin embargo, el significado que presenta no tiene nada que ver con el que aquí estudiamos, se trata de un topónimo que tiene que ver con accidentes geográficos, de hecho, este término se recoge en Voces alavesas, donde oncejo hace referencia a un 'puerto en la subida de un monte' (López de Guereñu, 1998: 210). En la cédula número 6 se registra honcejo como 'podón o podadera corva que usan en las viñas' recogido por V. García de Diego en el volumen 15 de la Revista de Filología Española, donde no se especifica ningún otro dato. No encontramos esta palabra recogida en estudios léxicos más recientes.

Cabe señalar que, dentro de la zona de estudio, nos encontramos con la variante ocexo en documentos de Autillo de Campos (Palencia). La forma hocejo figura en estudios lexicográficos más recientes, así Gordaliza (1988: 125) recoge en su Vocabulario este término como 'cuchillo más pequeño que la hoceja usado, por ejemplo, para cortar racimos en la vendimia o cosas pequeñas' y señala que a este instrumento el diccionario académico le da el nombre de honcejo. Le Men, por su parte, señala el uso de esta voz en Riaño, Prioro, Tierra de la Reina o Villacidayo. Fuera de León, figura en Santander y Álava (Le Men, 2009, s. v. focín).

\section{MACHADO [machada]}

Sust. m. 'Hacha para cortar madera' sin notación dialectal (DLE). Este término se encuentra recogido en los diccionarios académicos desde Autoridades, donde se le atribuye notación dialectal de Galicia que mantiene hasta la edición de 1791 inclusive (NTLLE, s. v. machado, Autoridades, 1734; DRAE, 1803). Término derivado de macho II, 'mazo grande para forjar hierro', 'especie de yunque', de origen incierto (DECH, s. v. macho ॥).

Un machado con su estil (Valderas, LE-1647)

Una machada grande (Villalón, VA-1642)

Una podadera y una machada biexa (Villalpando, ZA-1632)

No son muchos los ejemplos localizados en el corpus terracampino, en la localidad leonesa de Valderas figura el término académico machado, en masculino, sin embargo, en localidades de Valladolid y Zamora se halla el término con género femenino entre rallos y podaderas, por lo que entendemos que ambos términos forman parte del mismo campo semántico. La primera noticia que dan las bases académicas de esta voz se remonta a una Carta de inventario perteneciente a la Colección Diplomática del Monasterio de Carrizo, fechada en 1218. Unos años más tarde también lo documentan en un testamento perteneciente a documentos de la Catedral de León y fechado en 1316 ( $C D H$ y CORDE). Las escasas concordancias en la documentación diacrónica nos indican que no estamos ante un término de uso general. Morala advierte que la 
única forma de constatar la presencia de este término en el pasado es consultando documentos pertenecientes al Reino de León (Morala, 2004b: 1025), hecho que se verifica al ver los resultados de la búsqueda de machado en el CorLexIn. Esta voz se localiza fundamentalmente en inventarios de León y Zamora (Morala, 2020: 93) y en trabajos lexicográficos modernos se localiza machado "desde León a Extremadura" (Morala, 2017c: 371), Le Men documenta en distintos trabajos dialectales la voz machado y la variante machao, además de en León, en Asturias, Zamora, Salamanca, Extremadura, Galicia y Portugal (Le Men, 2007, s. v. machado).

\section{PETO}

Sust. m. 'parte opuesta a la pala y en el otro lado del ojo, afilada o sin afilar, que tienen algunas herramientas, como el hacha, la podadera y el azadón' (DLE, 5. a ac.). Los diccionarios académicos recogen este significado de forma tardía, es en la edición de 1803 donde introducen esta acepción: 'entre los jardineros un cabo que tiene la podadera por la parte opuesta, el qual es en figura de formon con el qual cortan, y podan las ramas de los árboles à golpe' (NTLLE, s. v. peto, $D R A E, 1803)$. Término procedente del italiano petto y de la variante onomatopéyica pet-, el portugués peto 'pico carpintero' y peta 'hacha pequeña' (DECH, s. v. pecho y picar).

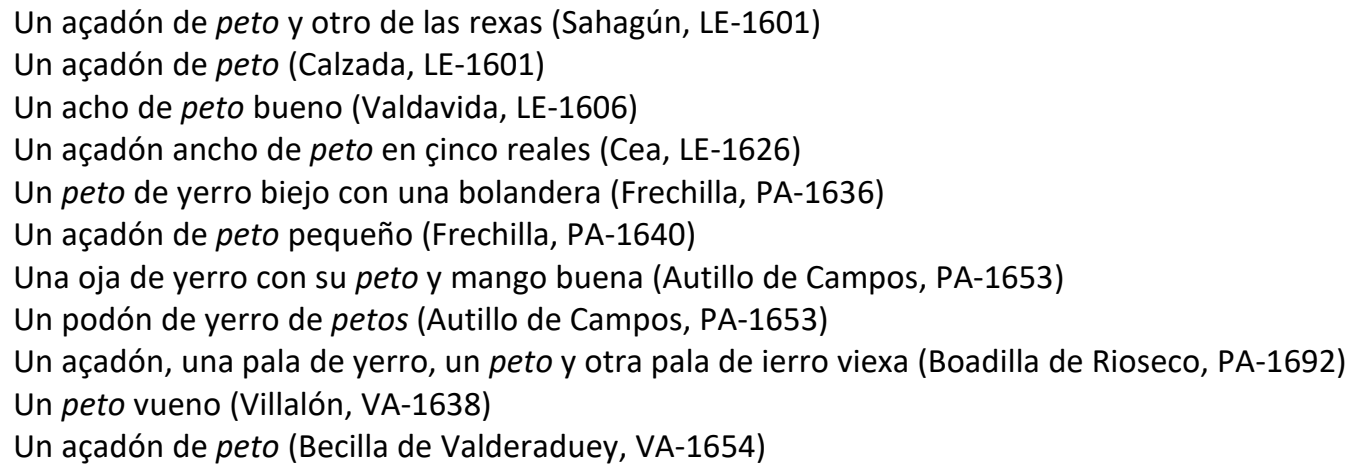

En la mayoría de las ocasiones este término se referencia en el sintagma preposicional "de peto" para especificar azadones, azuelas o hachas entre otras herramientas. Son menos los asientos donde peto se inventaría en solitario, no obstante, en el corpus terracampino contamos con tres ocurrencias de este tipo.

Restringiendo la búsqueda a los protocolos notariales del siglo XVII, el CorLexIn nos ofrece más de una veintena de casos de este vocablo, de forma mayoritaria como parte de las azuelas, hachas y azadones. Es más extraño encontrar el término aislado, como ocurre en Tierra de Campos, en este caso referenciando una herramienta agrícola, por el contexto en el que se inventaría.

En estudios más actuales, además de como parte de algunas herramientas, también figura con entidad propia. En Riaño peto figura como 'azuela alargada que servía para hacer ruedas de carro', en La Bañeza, como 'especie de azadón sin pala especial para sacar el barro de los barreros', y el femenino peta para referenciar una 'azada de un solo diente, de forma rectangular' en El Bierzo (Le Men, 2009, s. v. peto). 


\section{PODADERA}

Sust. f. 'Herramienta acerada, con corte curvo y mango de madera o hierro, que se usa para podar' (DLE). Podadera aparece ya recogido en el Vocabulario y se mantiene su significado sin cambios significativos desde Autoridades (NTLLE, s. v. podadera, Nebrija, 1495). Es una palabra derivada de podar, del lat. PǓTARE, propiamente 'limpiar' (DECH, s. v. podar).

Dos podaderas y dos martillos y un azadón ancho y un hacho y unas trébedes (Sahagún, LE-1601)

Dos podaderas demediadas (Sahagún, LE-1608)

Una podadera (Grajal de Campos, LE-1656)

Una podadera viexa y algunos clavos de yerro biejos (Valderas, LE-1659)

Una podadera en seis reales (Frechilla, PA-1612)

Una podadera nueua (Frechilla, PA-1612)

Una podadera vieja en real y medio (Frechilla, PA-1613)

Una podadera de hierro buena en seis reales (Frechilla, PA-1675)

Una podadera viexa (Villalón, VA-1642)

Una podadera en tres reales (Medina de Rioseco, VA-1661)

Una podadera vieja en quatro reales (Cuenca de Campos, VA-1666)

Una podadera viexa en çinco reales (Cuenca de Campos, VA-1670)

Dos podones, una acha y una podadera (Villalpando, ZA-1644)

Un piquete y una podadera (Villalpando, ZA-1661)

Una podadera viexa (Villalpando, ZA-1686)

Una podadera (Villalpando, ZA-1698)

Podadera aparece de forma temprana en la documentación, en la Colección Diplomática del Monasterio de Sahagún figura en un documento donde se relata un conflicto acaecido entre el sacristán de Sahagún y el merino del Rey en Cea, fechado en 1182:

In nomine Domini nostri Ihesu Christi. Certum sit omnibus atque comprobatum quod rixa magna facta fuit inter Guillel/mum, Sancti Facundi sacristam, et Martinum de Castro, maiorinum regis de Ceya, super unam capam et unam podaderam /3 quam idem maiorinus abstulit lohanni Comiti, uassallo Sancti Felicis, qui succidebat uimina in soto Sancti Felicis.

En esta colección, años más tarde, aparecen fozes podaderas (1245), proveniente del lat. FALX PUTATŌRIA (DECH, s. v. podar), para más adelante podadera pasa a tener naturaleza sustantiva en documentos fechados a finales de este mismo siglo: "Qui aduxier foces o podaderas a uender, I dinero".

En los ejemplos seleccionados en Tierra de Campos presentan siempre naturaleza sustantiva, y se inventaría sin que el escribano dé mucha información descriptiva de esta herramienta. Es una voz de uso general en todas las zonas y épocas, por lo que podadera es una lexía frecuente en las relaciones de bienes.

En vocabularios actuales se recoge esta palabra en El Bierzo, Valencia de Don Juan y Astorga. Fuera del territorio leonés, encuentra ocurrencias en Asturias, Zamora, Galicia, se trata de una 'herramienta semejante a un hacha. Tiene un corte curvo y el mango de madera o de hierro. Se distinguen dos partes: laparte de delante: cocote, ganguilla o ganga y la de detrás, con la que se puede cortar' (Le Men, 2009, s. v. podadera). Álvarez Tejedor localiza esta lexía como instrumento para podar, junto a podinche, podona y puderín (1989: 160). 


\section{PODEJO [podexo]}

El término que aquí nos ocupa no se localiza en ninguno de los diccionarios académicos ni preacadémicos. En el corpus estudiado, el uso de esta voz se localiza en documentos leoneses y, más específicamente, en los pertenecientes a Sahagún, por lo que hace pensar que estamos ante un localismo.

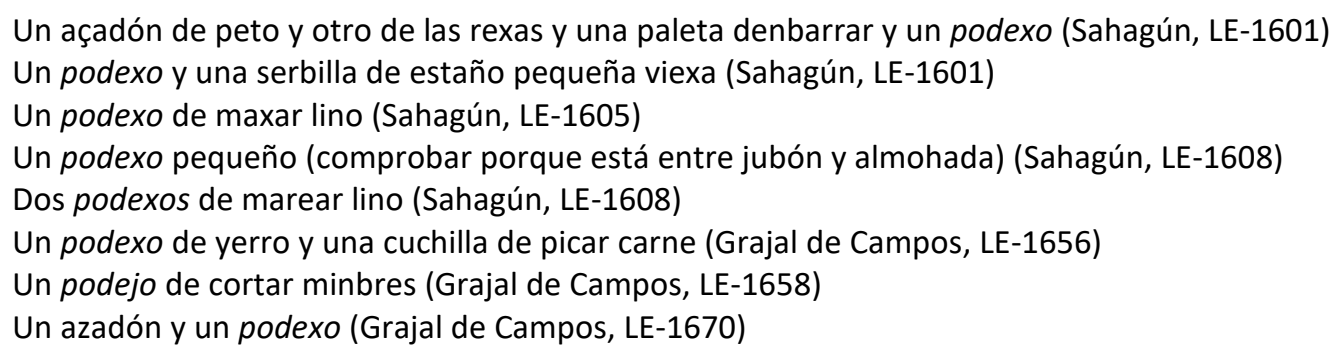

No se hallan referencias documentales en el CDH o en el CORDE. Sin embargo, sí se localizan ejemplos de esta voz en el CorLexIn, todos ellos ubicados en la localidad de Sahagún (León), dentro de la Comarca de Tierra de Campos. Parece que este término designaba un tipo de herramienta agrícola que se utilizaba bien para cortar, bien para majar y marear el lino, por las pistas que nos ofrecen las ocurrencias encontradas.

En repertorios más modernos como el de Le Men encontramos la forma podeja para referirse al 'instrumento de hierro con un mango de madera parecido a la hoz y que sirve para podar' en la localidad leonesa de Quintanilla de Rueda (Le Men, 2009, s. v. podeja).

\section{PODÓN [podonil]}

Sust. m. 'Podadera grande y fuerte usada para podar y rozar' o 'herramienta para podar, con mango a modo de martillo y una boca en forma de hacha y la otra en forma de cuchillo' (DLE). Autoridades lo define como 'instrumento corvo de acéro, que sirve para podar cosas fuertes' (NTLLE, s. v. podón, Autoridades, 1737). Término derivado de podar, del lat. PǓTARE 'limpiar', 'podar'(DECH, s. v. podar).

Un podón (Autillo de Campos, PA-1653)

Un podón de yerro de petos (Autillo de Campos, PA-1653)

Un podón biexo (Medina de Rioseco, VA-1641)

Dos podones, una acha y una podadera (Villalpando, ZA-1644)

Un podón (Villalpando, ZA-1689)

Dos podones para cortar la mimbre y podar arboles (Villalpando, ZA-16969)

Lo interesante de esta palabra es la distribución que presenta en Tierra de Campos. Si en la entrada anterior, podejo solo aparecía en tierras de Sahagún, ahora es podón el que se halla en documentos terracampinos sin presencia en este partido judicial, donde parece, a la vista de los datos, que prefieren el término podejo.

A pesar de hallarse registrado en los diccionarios académicos desde Autoridades, podón es una de esas voces que cuentan con una escasa documentación (Perdiguero, 2016: 143). El CDH devuelve apenas una veintena de concordancias, donde se tiene noticia del término a partir de la segunda mitad del siglo XIV. Cabe destacar que, a pesar de la escasa nómina de casos, el 
término presenta un largo recorrido, encontramos este término en tierras americanas, en obras de corte literario o histórico donde se referencia un arma cortante, defensiva -Colombia (1589) y Ecuador (1641 y 1684)-. El CorLexIn presenta un importante número de ocurrencias y una distribución geográfica relativamente amplia (Morala, 2020: 82).

Desde el punto de vista de la morfología derivacional, se documenta el término con el sufijo $-i l$ :

Un podonil de yerro con peto (Autillo de Campos, PA-1653)

Procedente del sufijo latino -īLIS da lugar a adjetivos procedentes de sustantivos en la mayoría de las ocasiones (Pharies, 2002: 324,325). El uso de este sufijo para la formación de palabras es frecuente en esta época y alterna con otros términos (Morala, 2017b: 279).

Podón sigue apareciendo en algunos estudios léxicos modernos. En Palencia referencia una pequeña herramienta que llevaban los pastores para cortar algo de leña y poder hacer fuego (Gordaliza, 1688: 181). Se ha recogido en localidades leonesas de El Bierzo, Murias de Paredes, Riaño, La Bañeza y Astorga, pero también en Asturias, Zamora, Extremadura, Andalucía, Canarias, Galicia o La Rioja, en algunas de ellas se recoge el femenino con un significado idéntico o muy cercano al masculino (Le Men, 2009, s. v. podón). En la zona más occidental de la Tierra de Campos se recoge el término podín como 'herramienta en forma de hoz, aunque menos curva, empleada para podar' (García Caballero, 1992: 83).

\section{PURRIDERA}

El DLE recoge el verbo apurrir como verbo transitivo propio de Asturias y Cantabria que significa 'alargar (alcanzar algo y darlo a alguién)', es el término más cercano a la palabra que aquí analizamos. El verbo purrir lo recoge Rosal en el siglo XVII con esta misma acepción, pero no es hasta la edición académica de 1970 donde se recoge este término con notación dialectal de Burgos y Valladolid. La forma apurrir se recoge en los diccionarios desde Autoridades como término propio de Burgos (NTTLE, s. v. purrir, Rosal, 1611; DRAE, 1970; s. v. apurrir, Autoridades, 1770). Término derivado del verbo apurrir 'alargar, alcanzar, acercar (algo) al que está apartado', del lat. PORRIGGĔRE y propio de Asturias y Santander (DECH, s. v. apurrir).

Dos purrideras de yerro (Villalpando, ZA-1644)

Una purridera (Villalpando, ZA-1686)

Una purridera de yerro (Villalpando, ZA-1688)

Una purridera de yerro (Villalpando, ZA-1696)

Tres purrideras de yerro (Villalpando, ZA-1698)

En localidades palentinas como Frechilla y Paredes de Nava figura el sintagma "horca de purrir":

dos orcas de purrir miesses en un real (Frechilla, PA-1675)

dos orcas de yerro de purrir (Paredes de Nava, PA-1690)

Purridera no aparece en la documentación que conforma el $C D H$ y el CORDE. Si restringimos la búsqueda al CorLexIn el resultado es el mismo. Sin embargo, el Fichero General da cuenta de dos ejemplos de esta lexía localizados en Palencia y Zamora (Morala, 2018a: 81). Donde encontramos más información de esta palabra es en repertorios dialectales más actuales, Le 
Men localiza apurridera y purridera en localidades leonesas pertenecientes a la Maragatería, Cepeda, La Bañeza, Comarca de Oteros y Tierra de Campos. Además de Zamora, Palencia y Valladolid (Le Men, 2002, s. v. apurridera). En la zona occidental de la Tierra de Campos se documenta esta voz como horca, 'útil con pinchos de hierro y mango de madera muy propio para faenas agrícolas tales como la de cargar estiercol o mieses en los carros de mucha altura' (García Caballero, 1992: 84).

\section{TORNADERA}

Sust. f. 'Horca de dos puntas usada para revolver la parva en las labores de la trilla' (DLE). Esta lexía no se recoge en diccionarios académicos hasta la edición de 1852 que la define como 'especie de bieldo de dos puntas que se usa en Castilla para las labores de la siega', definición se se cambia en la edición de 1899 por 'horca de dos puntas que se usa para dar vuelta à las parvas en las labores de la trilla' (NTLLE, s. v. tornadera, DRAE, 1852; DRAE, 1899). Es un término derivado de torno, del lat. TORNUS y este del griego tópvos ( $D E C H$, s. v. torno).

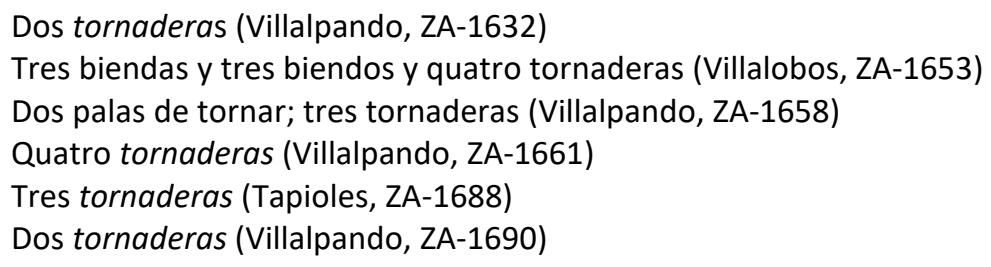

Estamos ante un término poco frecuente en bases académicas como el $C D H$ y el CORDE. En el CorLexIn la única ocurrencia localizada pertenece a la localidad zamorana de Muga de Alba, acorde con las encontradas en el corpus terracampino, pertenecientes a la documentación notarial de Villapando (Zamora). Con un significado más cercano a los cubiertos de cocina aparece en un inventario de bienes vallisoletano "una tornadera de huevos" ${ }^{12}$. Volviendo a la acepción que aquí aparece, como sintagma correlativo a tornaderas figura "pala de tornar" en Zamora, Palencia (Morala, 2018a: 87-88), además de en Valladolid:

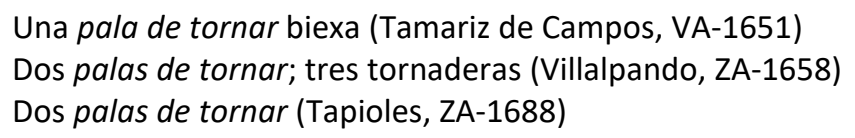

En trabajos dialectales más modernos se mantiene esta lexía, cuyo uso se extendería principalmente por León -Sahagún, Valencia de Don Juan, La Bañeza y Astorga-, Zamora, áreas palentinas y la Tierra de Campos vallisoletana (Le Men, 2012, s. v. tornadera). En Palencia además de la variante académica, se recoge tornedera (Gordaliza, 1988: 214).

\footnotetext{
${ }^{21}$ Rojo Vega:

Inventario y libros de un clérigo: Antonio Zaranga, 1577. Consultado en

https://investigadoresrb.patrimonionacional.es/node/8349.
} 


\section{ZOLETA [çoleta, çuleta, açoleta, zoletón, çoletón]}

Este término lo recogen los diccionarios académicos de forma muy tardía, es en la edición de 1970 cuando se registra, también en las ediciones de 1984, 1985, 1989 y 1992. En todas ellas se define como diminutivo de zuela o azuela. Sin embargo, en trabajos dialectales se halla como 'especie de azada de tamaño reducido que se usa para quitar las malas hierbas o cosas parecidas' (Gordaliza, 1988: 39), en este Vocabulario palentino también se localiza la variante azoleta con epéntesis de la $a$.

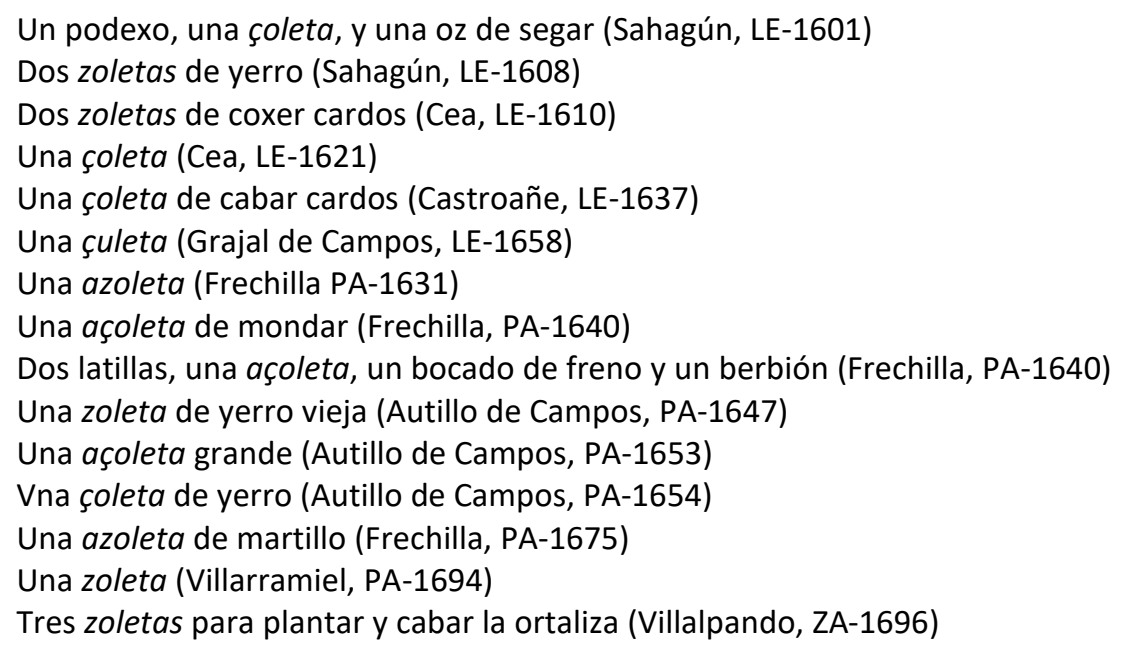

Con este significado es como lo encontramos en las relaciones de bienes de Tierra de Campos, con un nutrido número de ocurrencias con el significado de 'azada pequeña empleada para labores de cava o escardado en fincas tales como huertos y jardines' (García Caballero, 1992: 100). En los documentos terracampinos se inventarían zoletas o azoletas "para plantar y cabar la hortaliza", "de mondar" o "de cabar o coxer cardos".

No hay noticias de este término en las bases del castellano, ni el $C D H$, ni el CORDE lo documentan. Además de en nuestra zona de estudio, este término también se documenta en Andalucía -Cádiz, Sevilla o Málaga-y "la franja norte de ascendencia leonesa" (Morala, 2015d: 150).

En el campo morfológico advertimos la presencia de la forma derivativa de aumentativo en -on:

Dos azadones y un zoletón (Villada, PA-1665)

Un çoletón de yerro en tres reales (Cuenca de Campos, VA-1667)

Dos çoletones de yerro tassados en seis reales (Cuenca de Campos, VA-1668)

Un çoletón y un açadón de hierro (Cuenca de Campos, VA-1670)

Un zoletón grande (Villalpando, ZA-1696) 


\subsubsection{Recipientes agrícolas}

\section{BACHILLA [vachilla]}

No aparece registrada por ninguno de los diccionaros académicos. Minsheu recoge este término, pero con una acepción muy distinta a la que aparece en el corpus analizado. Esta voz se registra en el Fichero General de la RAE, donde las cédulas que referencian bachilla proceden de vocabularios o glosarios zamoranos de finales del siglo XIX y el siglo XX. Entre otras definiciones encontramos la de 'especie de canasta de mimbre, de forma circular y de como un metro de diámetro'.

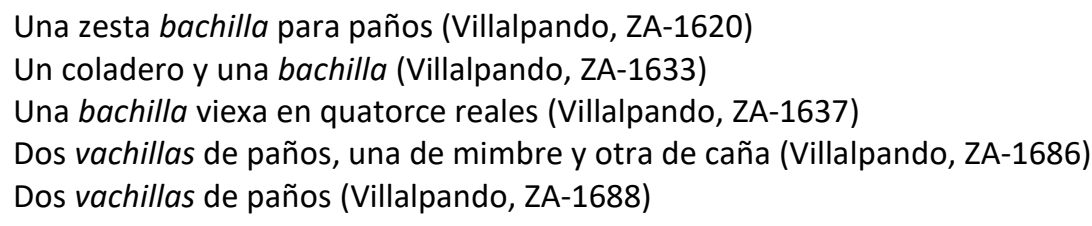

En las ocurrencias localizadas en Tierra de Campos parece tratarse de un tipo de cesta de mimbre o caña que se utilizaba para llevar paños. Formalmente aparece en los textos como sustantivo principalmente, aunque encontramos casos en los que se documenta como adjetivo "una zesta bachilla para paños". Todos los ejemplos pertenecen al área zamorana de Tierra de Campos, algo que no sorprende si tenemos en cuenta que estamos ante un término específico de Zamora (Morala, 2017c: 373).

\section{BANASTA [vanasta]}

Sust. f. 'Cesto grande formado de mimbres o listas de madera delgadas y entretejidas' (DLE). Autoridades recoge este término como 'cesta grande que se hace de mimbres ò costillas de madéra delgada y encadenada, que sirve para poner dentro alguna cosa, y transportarla á otra parte en cargas, ó acuestas. Es su figúra prolongada, y del tamaño á proporción de lo que se ha de llevar en ella' (NTLLE, s. v. banasta, Autoridades, 1726). Término cuyo origen es el mismo que el de canasta, y este de canastillo del lat. CANISTĚLLUM, derivado de CANISTRUM, cruzado con el galo benna 'cesto de mimbre' (DECH, s. v. banasta).

Siete banastas y dos esportillas (Medina de Rioseco, VA-1644)

Treynta y cuatro vanastas y zinco escriños (Medina de Rioseco, VA-1646)

Son dos los ejemplos recogidos en Tierra de Campos en el corpus analizado. El contexto en el que aparecen no aporta la suficiente información como para saber cuál era la función de este tipo de recipiente. Hay otras voces como canasta o cesta que se localizan con más frecuencia en los textos. El CorLexIn presenta también un número inferior de ocurrencias con respecto a otros vocablos, aun así, se localizan ejemplos en Zamora, Guadalajara, Cuenca, Badajoz y también se registra la variante banastra en Canarias.

En repertorios actuales, Le Men recoge la acepción de 'canasta, cesta para recoger huevos, uvas, etc.' para la Tierra de Campos (Le Men, 2002, s. v. banasta). 


\section{BANASTO}

Sust. $\mathrm{m}$. 'Cesto grande formado de mimbres o listas de madera delgadas y entretejidas' (DLE). El banasto 'a diferencia de la banasta es 'de figura levantada á manéra de cubo' (NTLLE, s. v. banasto, Autoridades, 1726). Término derivado de banasta, del mismo origen que canasta y este de canastillo del lat. CANISTĚLLUM, derivado de CANISTRUM, cruzado con el galo benna 'cesto de mimbre' (DECH, s. v. banasta).

Un zesto banasto de los de costillas con una poca lana bieja (Villalpando, ZA-1620)

Diacrónicamente banasto se documenta en desde finales del siglo XIV ("hun banasto de tener escudiellas" en un inventario aragonés fechado en 1380 en el Fichero General de la RAE), hasta mediados del siglo XVII, donde la palabra parece entrar en retroceso según lo que se observa en el $C D H$. En el CorLexIn se documentan un caso en Alburquerque (Badajoz) y otro en La Solana (Ciudad Real).

En Tierra de Campos, banasto se documenta formalmente como adjetivo, así encontramos un "zesto banasto".

\section{CANASTA}

Sust. f. 'Cesto de mimbres, ancho de boca, que suele tener dos asas' (DLE). Esta palabra la registra Nebrija en su Vocabulario en 1495 con varias acepciones, entre ellas la equipara con cuévano. Covarrubias dice que'en las canastas de mimbres se hazen las coladas, y con ellas se vendimia la vba, y se lleuan las meriendas al campo, y se suele sacar a vender el pan, y la verdura, y aun suelen pescar con ellas, donde ay abundancia de pezes, y los sacan, como dizen a canastas' (NTLLE, s. v. canasta, Nebrija, 1495; Covarrubias, 1611). Término derivado de canastillo, del lat. CANISTĔLLUM, diminutivo de CANǏstRUM ( $D E C H$, s. v. canastillo).

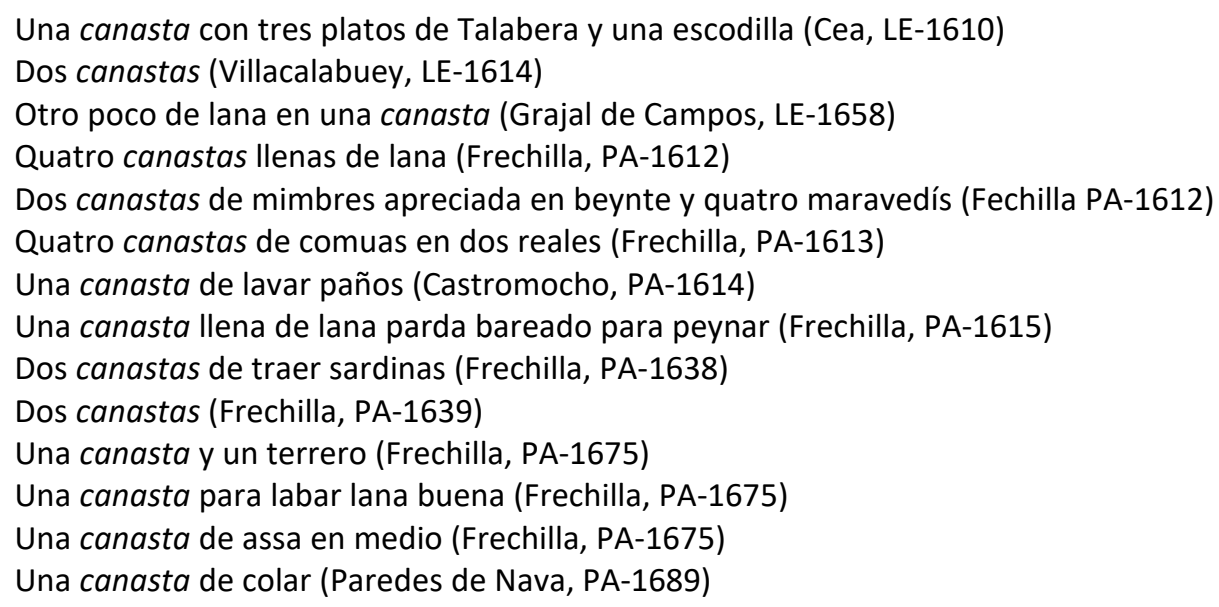

Esta voz es de uso general, con carácter polisémico, ya que este tipo de cesta se utilizaba para diferentes menesteres, como señala Covarrubias en su Tesoro. El CorLexIn registra un mayor número de ocurrencias en la zona meridional de la Península, aunque también recupera ejemplos de otros puntos del Centro y Norte. Además de en documentos peninsulares, también aparece algún ejemplo en América. 
Se localiza en Tierra de Campos con la variante académica, no encontramos casos de canastra. Además, aparecen las formas del diminutivo en -illa e -ica:

Una canastica con una maçorca de ylo (Grajal de Campos, LE-1670)

Una canastilla de mimbres viexa (Frechilla, PA-1631)

Una canastilla con un poco de yerro biejo (Frechilla, PA-1640)

$Y$ tan solo documentamos un caso de esta palabra en género masculino:

Un canasto con dos assas en dos reales (Frechilla, PA-1675)

En Tierra de Campos esta voz refiere un cesto más pequeño que el canasto (Le Men, 2004, s. v. canasta). Por su parte, Casas registra canasta como 'el cunacho de mimbre. También se llama terrero' en su estudio del habla de Villada (Casas, 1989: 527).

\section{CANASTILLO [canestillo]}

Sust. m. 'Canasta en forma de bandeja' (DLE). Término registrado por Nebrija. Autoridades matiza 'llámase assi los que se hacen mui baxos y extendidos, que sirven de azafátes: y por lo regular hacia la circunferéncia, se echan los mimbres mui apartados, formando como un enrejado. En estos se pone de ordinario lo que se quiere tener separado, y sin ajár' (NTLLE, s. v. canastillo, Autoridades, 1729). Término procedente del lat. CANISTĚLLUM, diminutivo de CANǏsTRUM (DECH, s. v. canastillo).

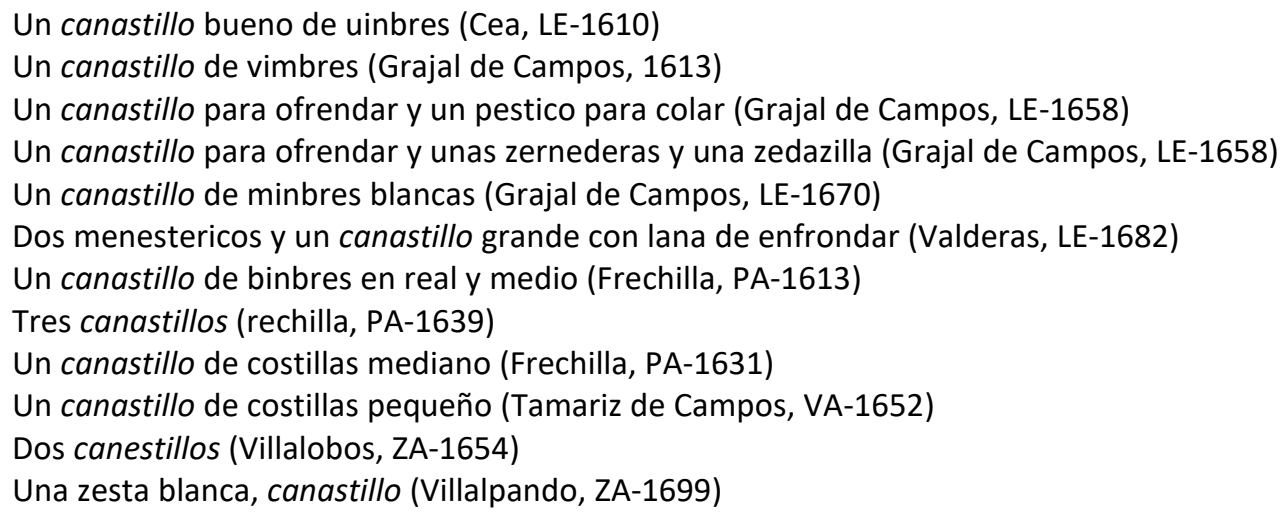

Al igual que en el caso de canasta, esta palabra polisémica es de uso general en la documentación. En el CorLexIn se documenta con mayor frecuencia en la mitad norte de la Península, en contraposición a lo que ocurre con canasta. En la Tierra de Campos también aparece la variante canestillo en la localidad zamorana de Villalobos. En este caso estamos ante la variación del timbre de la vocal átona /a e/, vacilación menos extendida por lo general en la documentación y restringida geográficamente (Morala, 2016a: 377).

\section{CÁNTARO [Vid. Medidas]}

Sust. m. 'Vasija grande de barro o metal, angosta de boca, ancha por la barriga y estrecha por el pie y por lo común con una o dos asas', 'medida de vino, de diferente cabida según las varias regiones de España' (DLE, 1. a y 2.a ac.). Nebrija recoge esta palabra con la acepción de 'recipiente'. Covarrubias afirma lo siguiente de ella: 'quando sirue para vino, comunmente en 
Castilla le llamamos cantara. Quando sirue para agua, le llamamos cantaro: tiene sola vna asa' (NTLLE, s. v. cántaro, Nebrija, 1495; Covarrubias, 1611). Término procedente del lat. CANTHARǓs 'especie de copa grande, de dos asas' (DECH, s. v. cántaro).

Tres cántaros de barro de agua (Sahagún, LE-1603)

Un cántaro de agua (Castrillo, LE-1606)

Tres cántaros de barro e una cantarilla (Galleguillos, LE-1618)

Quatro cántaros de uarro (Valderas, LE-1682)

Quatro cántaros (Frechilla, PA-1640)

Tres cántaros de teja (Castromocho, PA-1614)

Dos cántaros de cobre (Castromocho, PA-1611)

Dos cántaros colorados de tener agua (Villalón, VA-1642)

Cuatro cántaros de cobre a treinta reales cada uno (Medina de Rioseco, VA-1649)

Un cántaro de barro pequeño (Tamariz de Campos, VA-1652)

Tres tejas y dos cántaros (Villalpando, ZA-1620)

Dos cántaros grandes con sus tapadores (Villalpando, ZA-1629)

Vn cántaro de bero (Villalobos, ZA-1654)

Es un término general que aparece en los textos con dos acepciones. En la documentación del CorLexIn encontramos esta voz como 'un tipo de vasija' que por lo general es de barro, pero que también se fabrica con teja, cobre e incluso cuero y que tiene diferentes matices semánticos dependiendo de la zona. Covarrubias ya advertía de que esta voz referenciaba la vasija para contener agua, y así lo documentamos en la zona de estudio -los asientos de Sahagún, (LE1603), Castrillo, (LE-1606) o Villalón, (VA-1642) -, y con esta misma acepción se localiza el diminutivo cantarico:

Dos cantaricos nuevos para agua con sus tapaderas (Sahagún, LE-1606)

Pero los cántaros no siempre sirven para contener líquidos o simplemente agua, encontramos ejemplos como el de Zamora:

Un cántaro lleno de sal (Villalobos, ZA-1654)

Además, aparece como recipiente que posiblemente se utilizaba para medir el vino y trasvasarlo de un recipiente a otro.

Un cántaro de barro medidero (Fechilla PA-1675)

Al igual que ocurre con otros términos, cántaro no solo hace referencia al recipiente, sino que también designa un tipo de medida de capacidad para líquidos:

Ciento y treynta cántaros de vino (Fechilla, PA-1612)

Beinte quatro cántaros de bino en un tonel (Frechilla, PA-1639)

Un pellejuelo de medio cántaro (Autillo de Campos, PA-1653)

Un pozal que haze nuebe cántaros (Frechilla, PA-1675)

Un tonel de sesenta cantaros (Villarramiel, PA-1694)

Unos cuebanos de quatro cántaros (Villalpando, ZA-1685)

El cántaro como medida de capacidad en esta zona equivalía a 16 litros, este valor puede variar dependiendo de la zona, como ocurre con otras medidas en este periodo. 


\section{CARGUETÓN}

Este término no aparece en el $D L E$, ni tampoco en los diccionarios académicos o preacadémicos.

Un carguetón de binbres en dos reales (Sahagún, 1600)

Un carguetón de ropa nueuo (Sahagún, LE-1608)

Unos carguetones de llevar obra (Villalón, VA-1637)

No se documenta ninguna ocurrencia de este vocablo en ninguna de las bases consultadas $-C D H, C O R D E$, CorLexIn, Fichero general-. Sin embargo, en Tierra de Campos se localizan varios ejemplos repartidos por localidades leonesas y vallisoletanas de la zona. Por el contexto se puede saber que se trata de un recipiente de mimbre que sirve para trasladar diferentes enseres u objetos. La única referencia textual que se ha localizado de esta lexía pertenece a un libro novelado de costumbres campesinas dedicada a la Tierra de Campos, escrita por Eugenio Merino, Rector del Seminario de Valderas y fechada en 1930, en la que en un momento dado aparecen "unos carguetones de cepas" (Merino, 1930: 205).

\section{CARGUILLA}

Esta voz la recoge el DRAE de 1780 como diminutivo de carga y la mantiene hasta la edición de 1869. Sin embargo, en el ejemplo localizado en Tierra de Campos, carguilla hace referencia a un 'armazón de madera o de mimbre, que se coloca sobre las caballerías, para llevar cántaros de agua o cualquier tipo de forraje para el ganado', término derivado de cargar (Le Men, 2004, s. v. carguilla).

Quatro carguillas de traer agua (Grajal de Campos, LE-1658)

EI CORDE documenta varios ejemplos de este término en diferentes obras a partir del siglo $\mathrm{XVI}$, siempre en singular y referenciada como una especie de 'mochila':

[...] con alguna carguilla a cuestas (Apologética historia sumeria, de Fray Bartolomé de las Casas, 1527-1550)

[...] mandó que cada uno aparejase su carguilla de alhajas (Historia de las Indias, Fray Bartolomé de las Casas, 1527-1561)

[...] cada uno llevó una carguilla de ciruelas a vender (Historia verdadera de la conquista de la Nueva España, Bernal Díaz del Castillo, 1568-1575)

[...] chiquitos con sus cordelillos que parecen juguetes en que les atan alguna carguilla liviana conforme a sus corpezuelos (Historia eclesiástica indiana de Fray Jerónimo Mendieta, 1604).

Sin embargo, el ejemplo localizado en Tierra de Campos aparece en plural y señala un tipo de objeto con una función específica, la de transportar el agua. Significado que encontramos en repertorios dialectales más modernos como el dedicado al vocabulario de Paredes de Nava donde carguilla hace referencia a unos 'cestos de mimbre para llevar los cántaros de agua o vino sobre un animal. Es muy frecuente en plural' (Helguera y Náguera, 1990: 524). En el estudio de Casas sobre el habla de Villada lo define como 'soporte de mimbre de cuatro huecos y un espacio en medio para colocar sobre el lomo de las caballerías y servía para transportar cuatro cántaros y también uva para comer' (Casas, 1989: 528). En ambos estudios se recoge el término en plural. Gordaliza también da cuenta del término y advierte que habitualmente se utiliza en plural y lo define como 'especie de alforjas con que se cargaba el burro. Eran cuatro cestos de mimbre unidos entre sí'. En este último caso parece que comparte campo semántico con aguaderas. 


\section{ESPORTILLA}

Sust. f. dim. de espuerta 'especie de cesta de esparto, palma u otra materia, con dos asas, que sirve para llevar, de una parte a otra, escombros, tierra u otras cosas semejantes (DLE). Término derivado de espuerta, del lat. SPǑRTA íd. (DECH, s. v. espuerta).

Siete banastas y dos esportillas (Medina de Rioseco, VA-1644)

Tres anchos de hacer quesso con sus esportillas (Cuenca de Campos, VA-1660)

Consultado el $C D H$ y el CORDE, esportilla se documenta a partir del siglo XIII con la acepción de 'mochila' para transportar diferentes objetos. Durante el siglo XVII amplía geográficamente su alcance y se localiza en documentos de América. Sin embargo, todas las obras en las que aparece pertenecen a la literatura, no a inventarios. En el CorLexIn se localizan una docena de casos repartidos por diversos puntos de la Península, de Palencia a Granada y de Ávila a Sevilla. En los textos de Tierra de Campos tan solo aparecen dos ocurrencias, las dos en localidades vallisoletanas, en el primer caso con la acepción académica y en el caso de Cuenca de Campos se inventaría junto a útiles para elaborar queso.

\section{CHORRA}

No se encuentra en el DLE con la acepción que aparece en la ocurrenca localizada en Tierra de Campos, tampoco en el resto de obras lexicográficas (NTLLE, s. v. chorra). Es un término derivado de chorro, onomatopeya de la caída del agua, la acepción originaria parece haber sido 'agua que salta en cascada o torrente', y es voz común al castellano con el portugués, el vasco y el gascón (DECH, s. v. chorro).

Una chorra de minbres nueba sin pegar en quatro reales (Cuenca de Campos, VA-1666)

Entre las unidades de capacidad es habitual su creación a partir de un proceso de derivación dando lugar a nuevos términos por sufijación, así Julià enumera una serie de términos entre los que se encuentra chorrada (Julià, 2008: 708). Término por otro lado que se considera tradicional a pesar de no estar considerado por el DLE. Si tenemos en cuenta este proceso, posiblemente, chorrada derivaría de un término *chorra que referenciaría un recipiente como ocurre con carretada, calderada, cucharada o borricada.

\section{ESCRIÑA [hescriña, eschriña, escriñuela]}

La forma femenina escriña no se recoge en ningún diccionario académico. Sin embargo, varios estudios dialectales registran esta voz como 'recipiente hecho de paja trenzada que sirve para echar harina y salvado al ganado o para llevar el grano cuando se está sembrando' (Le Men, 2005, s. v. escriña).

Una escriña grande en dos reales (Sahagún, 1600)

Una escriña pequeña vieja en un real (Frechilla, PA-1613)

Una hescriña de paja (Autillo de Campos, PA-1649)

Una eschriña (Paredes de Nava, PA-1695)

Una escriña biexa (Frechilla, PA-1631)

Un escriño pequeño, una escriña, una cesta para paños y otra para carne (Villalpando, ZA-1654)

Dos escriñas de pagar, la una llena de arina y otra mediada (Villalpando, ZA-1690) 
Dos escriñas grandes del pajar (Villalpando, ZA-1688)

Una escriña de paxas (Villalpando, ZA-1697)

Tampoco hay ejemplos de esta palabra en el CDH o el CORDE. Sin embargo, en los inventarios de bienes que conforman el CorLexIn se documentan una serie de ejemplos de este término repartidos geográficamente por el norte de la Península entre localidades de Burgos, Palencia, León y Zamora, además de un caso en Cantabria. Este reparto geográfico coincide con los casos localizados en la Tierra de Campos, donde escriña está presente con la acepción de 'recipiente de paja'.

En estudios dialectales modernos, escriña se localiza en Tierra de Campos como 'cesto más grande que el escriño' (Gordaliza, 1988: 101), y también en León, Zamora, Segovia o Burgos con acepciones muy similares (Le Men, 2005, s. v. escriña).

Desde una perspectiva morfológica, se documenta el diminutivo escriñuela, posiblemente con valor de diminutivo en los documentos terracampinos. Es un derivado que no se documenta en diccionarios académicos, ni en bases de datos como el $C D H$, ni en el CorLexIn, pero que en la zona de Campos sí está presente:

Una escriñuela con un poco de sal biexo (Galleguillos, LE-1618)

Tres cedazos viejos; y una escriñuela (Grajal de Campos, LE-1671)

Dos escriños y una escriñuela (Villada, PA-1665)

\section{ESCRIÑO}

Sust. m. y f. 'Cesta o canasta fabricada de paja, cosida con mimbres o cáñamo, que se usa para recoger el salvado y las granzas de los granos, o para dar de comer a los bueyes cuando van de camino' (DLE). Nebrija recoge dos tipos de escriño, uno 'como arca' y otro 'pequeño' (NTLLE, s. v. escriño, Nebrija, 1495). Término procedente del lat. SCRĪNǏUM 'arca pequeña para libros y papeles', 'biblioteca', 'cajita de tocador' (DECH, s. v. escriño). Es de uso general en el corpus analizado.

Tres escriños biexos con pluma (Valdavida, LE-1606)

Dos escriños buenos de cebar bueis (Villacalabuey, LE-1614)

Seis escriños buenos (Sahagún, LE-1608)

Tres escriños de pajas y minbres (Grajal de Campos, LE-1658)

Un escriño y una artesa de labar en dos reales (Mazariegos, PA-1619)

Dos escriños buenos de tres reales (Frechilla, PA-1612)

Dos escriños nuevos de los buenos (Paredes de Nava, PA-1690)

Un escriño viexo (Boadilla de Rioseco, PA-1692)

Unas trévedes viejas y pequeñas y un escriño biejo (Medina de Rioseco, VA-1642)

Un escriño biejo (Villalón, VA-1642)

Un escriño viexo lleno de lana negra (Tamariz de Campos, VA-1651)

Un escriño grande y tres pequeños (Cuenca de Campos, VA-1668)

Dos escriños pequeños el uno nuevo y otro biejo (Villalpando, ZA-1620)

Dos escriños, el uno bueno y el otro más viejo (Villalpando, ZA-1629)

Dos escriños (Quintanilla del Monte, ZA-1689)

Tres escriños y un panero con su asa de yerro (Villalpando, ZA-1696)

Escriño es una palabra de uso general, que en el siglo XVII está presente en los inventarios de la mitad Norte de la Península. La función de este tipo de recipiente agrícola puede variar 
según las zonas, y en la misma Tierra de Campos, los escriños pueden utilizarse para diferentes menesteres, entre los que se encuentra 'cesta para dar de comer a los bueyes', función que también localiza Gómez Ferrero en la zona de La Bañeza en un inventario del siglo XVIII (Gómez Ferrero, 2015: 288).

Este término también está presente en repertorios léxicos más modernos como el de Gordaliza que recoge diferentes funciones para este tipo de recipiente 'que se usaba entre otras cosas para guardar los panes de una cocedura y evitar que su pusieran duros. También se usaba para dar de comer los bueyes o recoger los salvados, etc. A veces se metía en él una colmena' (Gordaliza, 1988: 101). Todavía hoy se localiza esta voz en Tierra de Campos, donde referencia una 'cesta grande de paja, cosida con mimbre o cáñamo, que sirve para echar harina, salvado o trigo' -Sahagún-y también un 'cesto hecho con pajas de centeno torcidas y cosidas con mimbres finas' (Le Men, 2005, s. v. escriño).

\section{HERRADA [errada, herradón]}

Sust. f. 'Cubo de madera, con grandes aros de hierro o de latón, y más ancho por la boca que por la base' (DLE). Nebrija registra 'herrada para sacar agua' y 'herrada o tarro para ordeñar'. Covarrubias recoge esta voz como 'cierto género de cubo, con que se sacan agua de los poços, y aunque es de palo se dixo assi, por los cercos que tiene de hierro'. Autoridades matiza que es 'mas baxo que el cubo [...]. Tiene dos asos y una asa de hierro, por lo qual se llamó Herráda' (NTLLE, s. v. herrada, Nebrija, 1495; Covarrubias, 1611; Autoridades, 1734). Término derivado de hierro, del lat. FĔRRUM (DECH, s. v. hierro).

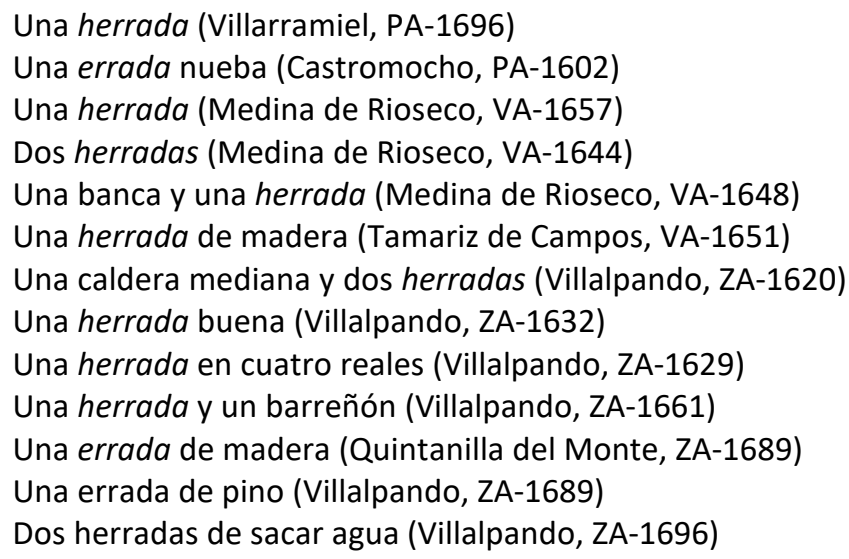

Herrada con la acepción de 'recipiente' se documenta en textos de corte literario y técnico desde mediados del siglo XV -la forma con mantenimiento de /f-/ ferrata se documenta en el siglo XIII en inventarios de bienes leoneses- $(C D H)$. En estos textos, herrada referencia un 'cubo para contener líquidos' fundamentalmente. No obstante, también figura como 'olla' para hervir agua: "[...] manojos, y seys puerros: hieruan en vna herrada de agua" en un libro de medicina fechado en 1600.

Los inventarios del siglo XVII presentan una distribución geográfica amplia. Las ocurrencias se localizan con preferencia en las provincias norteñas-Asturias, Cantabria, País Vasco y algunas provincias de Castilla y León- principalmente, aunque también se documentan algunos casos en 
Madrid o Cáceres. Con la forma ferrada solo se documenta en Asturias junto con la solución castellana. La distribución de esta palabra se amplía al consultar los inventarios de Tierras de Campos, donde figura con la variante académica, con o $\sin h$, y con la misma acepción.

Al significado de 'cubo o caldero' hay que añadirle el de medida de capacidad para líquidos, que se documenta en el corpus terracampino:

Una caldera que haze dos erradas de agua (Calzada, LE-1601)

Una caldera grande que ará quatro herradas de agua (Villalpando, ZA-1676)

El DECH presenta esta lexía con la forma ferrada con el significado de 'medida de vino' en un documento de 1135. Sin embargo, con esta acepción no lo encontramos en los documentos que conforman el $C D H$. Si restringimos la búsqueda a los documentos que conforman el CorLexIn, rescatamos dos inventarios pertenecientes a localidades leonesas limítrofes a la Tierra de Campos en las que aparece este sentido:

Una caldera de hasta tres herradas de agua (Santas Martas, LE-1625)

Una caldera que ará cuatro herradas (Villacabiel, LE-1647)

Entre los repertorios dialectales modernos se registra la forma herrada en Palencia, como 'cubo para el agua. Si es de madera tiene forma de tronco de cono, con aros de hierro alrededor, aunque es más corriente la de metal' (Gordaliza, 1988: 123). Álvarez Tejedor localiza el término herrada en el este de Zamora como 'instrumento para trasegar' donde comparte campo semántico con otras voces como caldero, cántaro, colambre o jarrón entre otros (Álvarez Tejedor, 1989: 182). No solo se documenta en zona leonesa, sino que se puede observar su uso a lo largo de toda la Península con diferentes matices de significado, pero con la acepción de medida de capacidad solo la encontramos en Tierra de Campos (Le Men, 2005, s. v. ferrada).

\section{HERRADÓN}

No aparece en los diccionarios académicos, ni en ninguna de las obras lexicográficas que configuran el NTLLE, salvo en dos ocasiones que hacen mención a una localidad denominada con dicho nombre -Domínguez, 1853 y Rodríguez Navas, 1918-.

Un herradón grande en que se ordenia que bale ocho reales (Villalpando, ZA-1696)

Según el contexto en el que aparece este término hace referencia a un tipo de recipiente destinado al ordeño del ganado.

Localizamos esta voz en estudios dialectales como el de Le Men, donde herradón se utiliza en poblaciones vallisoletanas como Barcial de la Loma donde hace referencia a la 'vasija de metal en la cual se ordeña' (Panizo, 1985: 141, en Le Men 2005, s. v. ferrada), o en Cuéllar, provincia de Segovia 'vasija grande de barro o metal en la que se echa la leche acabada de ordeñar' (Torre, 1951: 158 en Le Men 2005, s. v. ferrada). Gordaliza también localiza esta palabra en localidades de Palencia como 'pieza de cerámica utilizada para ordeñar, llamada también colodra' o en la localidad terracampina de Frómista como 'garrafa grande de hierro galvanizado que se usa para recoger la leche' (Gordaliza, 1988: 123). 


\section{MENESTER}

Sust. m. 'Instrumentos o cosas necesarias para los oficios u otros usos' (DLE, 4. a ac.). Este término procede del lat. MǏNǏsTĚRIUMm 'servicio', 'empleo', 'oficio', derivado de MINISTER, TRI, 'servidor', 'oficial' (DECH, s. v. menester).

Quatro zestos y un menester y una zesta de abellano todo en quatro reales e medio (Sahagún, 1600) Un menester nueuo (Calzada, LE-1601)

Dos menesteres, uno grande y otro pequeño viejos (Sahagún, LE-1608)

Un menester de minbres roto (Grajal de Campos, 1613)

Un menester de minbres, con un harte, una almuadilla y unas tijeras (Grajal de Campos, LE-1670)

Un menester mediano de colar (Valderas, LE-1682)

Dos menesteres de vimbres blancas pequeños en un real (Frechilla, PA-1612)

Dos menesteres de binbres en dos reales (Frechilla, PA-1613)

Una cesta de mimbres y pajas, un menester biejo, dos escriños (Frechilla, PA-1639)

Un menester (Frechilla, PA-1640)

Un menester de mimbres (Fechilla PA-1675)

Un menester de mimbres (Cuenca de Campos, VA-1660)

Medina dozena de platos y media de servillicas de tabla con su menester en que están (Villalpando, ZA1614)

Un menester (Villalpando, ZA-1688)

Este término no se documenta en corpus léxicos como el CORDE con la acepción que aparece en la documentación de la Tierra de Campos. Se trata de 'una cestilla en que se guardan los útiles de costura' (Le Men, 2007, s. v. menester). En la documentación de este estudio hay presencia del término en todas las provincias que la configuran. Sin embargo, es clara la mayor presencia de esta lexía en textos leoneses y palentinos de la Tierra de Campos. Esto coincide con los datos que aporta el CorLexIn, en el que los escasos datos que ofrece pertenecen a León y Palencia.

Le Men documenta esta palabra en León, Asturias y Zamora, y también en la Tierra de Campos donde menester es un 'cesto de mimbre blanca de dos asas, de unos 0,50 metros de diámetro y 0,25 de alto, aproximadamente, muy usado para la ropa' (Domínguez, 2001: 46 en Le Men, 2007).

Desde un punto de vista formal, cabe destacar la presencia de las formas menesteo y menesteros en documentos vallisoletanos, forma que puede justificarse por analogía a otras voces de uso cotidiano como el panadero o terrero entre otros términos.

Un menesteo (Villalón, VA-1637)

Otros dos menesteros, uno de mimbres y otro de pajas y una cesta (Cuenca de Campos, VA-1660)

Por otro lado, se documenta la forma derivada con el sufijo diminutivo -ico:

Tres menestericos blancos en tres reales (Sahagún, LE-1600)

Un menesterico de minbres pequeño (Castroañe, LE-1637)

Dos menestericos y un canastillo grande con lana de enfrondar (Valderas, LE-1682)

Un menesterico pequeño de mimbres blancos (Villalpando, ZA-1620)

Del contexto en el que aparece este derivado extraemos información que nos permite reconocer un tipo de cesta de mimbre de pequeño tamaño, con lo que el valor del sufijo sería claramente apreciativo. Desde un punto de vista formal, localizamos el término con naturaleza adjetiva en algunos asientos: 
Una zestica menesterico de mimbres blancos (Villalpando, ZA-1620)

\section{PANADERO}

Sust. $\mathrm{m}$. 'Persona que tiene por oficio hacer o vender pan' (DLE). Covarrubias lo define como 'el que massa y cueze el pan, y lo vende' (NTLLE, s. v. panadero, Covarrubias, 1611). Se trata de una voz derivada del lat. PANIS ( $D E C H$, s. v. pan).

Ochenta reales de dos cargas de trigo que le dio en pan estando en Villagarcía Gaspar Alonso, panadero vecino de Pozuelo (Villalpando, ZA-1656)

Se trata de una palabra de uso general en el siglo XVII para referirse a dicho oficio. También aparece documentado con este significado en el CORDE y los ejemplos que nos ofrece el CorLexIn, aunque son escasos, hacen referencia a dicho oficio. Sin embargo, en los inventarios palentinos de la Tierra de Campos aparece:

Un panadero de vimbres en dos reales (Frechilla, PA-1612)

Un panadero en un real (Frechilla, PA-1613)

Un panadero biejo (Fechilla PA-1613)

Un panadero (Frechilla, PA-1639)

Dos panaderos de mimbres (Frechilla, PA-1631)

Un panadero de minbres biexas (Frechilla, PA-1631)

Un panadero de minbres en veinte y cuatro maravedís (Fechilla PA-1675)

En este caso, el término panadero no se corresponde con las acepciones que aparecen en el $D L E$, el CORDE o el CorLexIn. Tampoco aparece en los repertorios dialectales consultados. Este término hace referencia a una especie de cesta de mimbre que podía utilizarse para contener el pan. Esta palabra está localizada en una zona muy concreta de la Tierra de Campos, está dentro del partido judicial de Frechilla. En otras zonas de este mismo territorio utilizan otro tipo de voces para referirse al contenedor del pan: panero, arca, cofre, artesa o tablero.

\section{PANERA}

Sust. f. 'Troje o cámara donde se guardan los cereales, el pan o la harina', 'cesta grande sin asa, generalmente de esparto, que sirve para transportar pan' (DLE). Nebrija lo registra en su Vocabulario. Derivado de del lat. PANIS (DECH, s. v. pan).

Otros maderos en otra panera (Cea, LE-1621)

Una pila de tablas de rodeles de paneras buenas (Valdavida, LE-1606)

Dos silos llenos de trigo en la panera (Boadilla de Rioseco, PA-1643)

Doze cargas de trigo en una panera (Medina de Rioseco, VA-1660)

Cuatro cargas de cebada en la panera (Villalpando, ZA-1661)

Una almirez con su mano en la panera (Villalpando, ZA-1686)

Es un término poco documentado en la muestra recogida de la Tierra de Campos. En este caso, la panera es una 'habitación de la casa o de la cuadra destinada a guardar en ella la cosecha de cereales' (Le Men, 2009, s. v. panera). En la zona este de Zamora, también se recoge esta acepción, además de compartimentos en los que se divide dicha habitación para separar el grano (Álvarez Tejedor, 1989: 119-120). 


\section{PANERO}

Sust. $\mathrm{m}$. 'Canasta redonda que sirve en las tahonas para echar el pan que se va sacando del horno' (DLE). Lo introduce por primera vez la academia en la edición de 1884. Término derivado del lat. PANIS (DECH, s. v. pan).

Un panero con su asa de yerro (Villalobos, ZA-1630)

Quatro escriños y un panero (Villalpando, ZA-1661)

Un panero con su assa de yerrro (Villalpando, ZA-1685)

Un panero (Villalpando, ZA-1686)

Tres escriños y un panero con su asa de yerro que valen quinze reales (Villalpando, ZA-1696)

Panero se localiza en la documentación zamorana de nuestros corpus. La documentación es escasa en los repertorios léxicos. Desde una perspectiva diacrónica, el CORDE atestigua un ejemplo de esta voz con el significado que aquí se estudia en el inventario de bienes del doctor Sancho de Mendoza en el que se inventaría "un panero grande de roble" (1630). Los datos que proporciona el CorLexIn nos remite a un ejemplo en la localidad terracampina de Villalobos (Zamora).

La consulta en el Fichero General da mayores resultados, algunos extraídos de los datos que ofrecen algunos atlas lingüísticos, como el de Andalucía, donde se recoge esta voz con estos dos significados. Por un lado, se presenta como 'capachos del lagar' (1961, ALEA, lám. 211 mapa 210,) -cédula n.o 15-y, por otro, como 'vasija para lavar la ropa' (1964, ALEA, lám. 712, mapa 788, [Ca301]) -cédula n.o 36-. También la registra en el ALEANAR como 'vasija honda, de mimbre o caña y con dos asas pequeñas' (1980, ALEANAR lám. 1048, mapa 860, [Hu 201]) -cédula n.o 32-.

\section{QUILMA}

Sust. f. 'Costal de tela gruesa' (DLE). Autoridades recoge esta palabra como término que se 'usa en las Montañas de Burgos'. En la edición del DRAE de 1803 desaparece la marca diatópica (NTLLE, s. v. quilma). Se trata de una voz emparentada con el árabe qírba 'odre', pero este vocablo en África era anterior a la invasión árabe, es probable que en España también fuese anterior a la conquista musulmana ( $D E C H$, s. v. quilma).

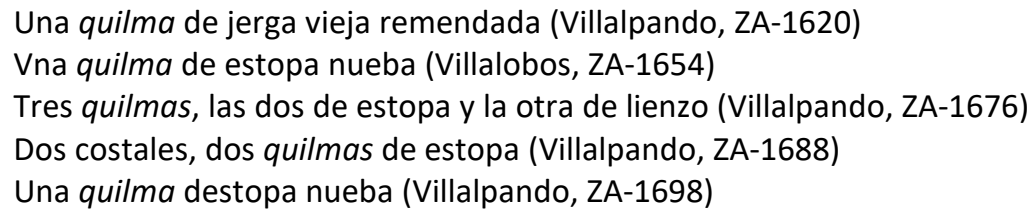

Esta lexía aparece de forma temprana en la documentación del castellano, figura en obras del siglo XIII como en Berceo o el Libro de Alexandre (1240), lo que implicaría a priori un uso generalizado del término, pero nada más lejos de la realidad. A pesar de su pronta presencia en los textos, tanto el CORDE como el $C D H$ presentan pocas concordancias. Hernán Núñez afirma en sus Refranes o proverbios en romance (1549) que "quilma es costal", una afirmación genérica que, cuando la recoge Correas en su Vocabulario de refranes y frases proverbiales menos de un siglo después (1627) afirma que quilma "es «kostal» en el rreino de León, i antiguo, i 
ordinariamente de lino", donde, además de la notación diatópica, señala que se trata de una voz antigua.

Si restringimos la búsqueda a los documentos notariales del siglo XVII, los resultados indican que es una voz con una distribución geográfica muy definida, tan solo aparecen ejemplos en documentos de León y Zamora (CorLexIn). Además, en algunos inventarios leoneses, esta palabra figura diferenciada de costal, lo que indica que costal y quilma no son voces sinónimas en sentido estricto y posiblemente referencien objetos ligeramente distintos (Morala, 2012f: 310). Siguiendo esta distribución del término, Gómez Ferrero (2015: 296-297) localiza un nutrido número de ejemplos en documentos pertenecientes a La Bañeza en el siglo XVII, XVIII y XIX. En el corpus estudiado hay una clara preferencia de este término en la zona zamorana de la Tierra de Campos, coincidiendo con los datos que proporciona el CorLexIn.

Le Men sigue localizando quilma hoy en el dominio del leonés, señala su uso en Asturias, Cantabria, León, Zamora, Salamanca, además de en Galicia (Le Men, 2009, s. v. quilma).

\section{TALEGA}

Sust. f. 'Saco o bolsa anchos y cortos, de lienzo basto u otra tela, que sirven para llevar o guardar las cosas' (DLE). Figura en el Vocabulario de Nebrija como 'saco'. Covarrubias lo define como 'costal pequeño acomodado en la milicia, para lleuar el soldado alguna vitualla [...]', mientras que Autoridades lo recoge con un significado más general: 'saco o bolsa ancha, y corta de lienzo, estopa, ù otra tela, que sirve para llevar dentro las cosas de una parte à otra' (NTLLE, s. v. talega, Nebrija, 1495; Covarrubias, 1611; Autoridades, 1739). Palabra derivada del árabe taclîqa 'saco, bolsa, zurrón' (DECH, s. v. talega).

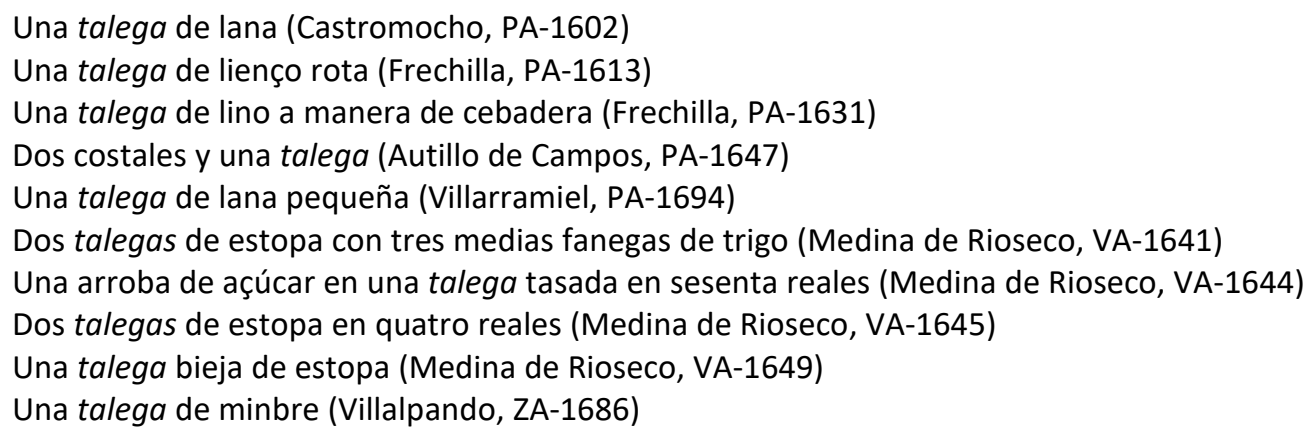

Desde la perspectiva diacrónica que nos ofrecen el CORDE y el $C D H$, se desprende que el uso de esta voz se documenta de forma temprana, a partir del Fuero de Madrid, fechado en 1141 y La fazienda de Ultra Mar de Almerich (1200). A partir del siglo XVI comienza a figurar en textos procedentes de América.

Los datos que nos ofrece el CorLexIn muestran la naturaleza polisémica de esta lexía, sobre todo en la función que desempeña en las diferentes relaciones de bienes: para guardar el cereal, también los condimentos como la sal, el azúcar o la harina; se inventarían talegas donde se mete la ropa y también monedas. En Tierra de Campos encontramos una decena de ejemplos distribuidos por casi todo el territorio estudiado, en la muestra recogida no encontramos casos en la zona leonesa. En cuanto al significado, en estas relaciones de bienes encontramos dos tipos 
de talega principalmente, la que está elaborada con lana, lino o estopa y aquella que es de mimbre que posiblemente tuvieran una función más agrícola. De hecho, talega en la Tierra de Campos se recoge en trabajos lexicográficos que la definen como 'cesto de mimbre usado para recoger las uvas en la vendimia y para otros menesteres' (García Caballero, 1992: 91). Acepción que recoge Le Men (2014) en comarcas leonesas como los Oteros, Valdevimbre y Tierra de Campos, por lo que la ausencia de esta voz en los inventarios del siglo XVII sea fruto de la casualidad.

Desde el punto de vista formal, esta palabra presenta formas derivadas de diminutivo alternando las terminaciones -illa e -ita, siendo más frecuente la primera:

Una taleguilla con ocho reales y diez y ocho maravedís (Frechilla, PA-1615)

Una taleguilla con canpeche y alumbre (Frechilla, PA-1638)

Una taleguilla de estopa en medio real (Medina de Rioseco, VA-1641)

Un cobrecico en que está una taleguilla con zinco reales de a ocho de plata (Medina de Rioseco, VA-1642)

Dos taleguitas de estopa rotas en un real y un quartillo (Villalpando, ZA-1620)

En este caso, hay que añadirle el significado de monedero que aparece en los textos americanos con la forma académica.

\section{TALEGO}

Sust. m. 'Saco largo y estrecho, de lienzo basto o de lona, que sirve para guardar o llevar algo' $(D L E)$. Las obras lexicográficas académicas registran esta entrada desde Autoridades con una definición similar a la que se mantiene hoy día: 'saco o lienzo basto, y ordinario de figura angosta, y larga, que sirve para guardar alguna cosa, ò llevarla de una parte á otra' (NTLLE, s. v. talego, Autoridades, 1739). Término derivado de talega.

En un talego de anxeo ciento y treinta reales (Valderas, Le-1647)

Un talego de estopa (Valderas, LE-1682)

Un talego de lienzo basto en real y medio (Frechilla, PA-1675)

En otro talego que se alló en el dicho escritorio (Medina de Rioseco, VA-1640)

Un talego con unos papeles (Medina de Rioseco, VA-1641)

Quarenta talegos de estopa bazíos (Medina de Rioseco, VA-1660)

Ocho talegos de estopa (Medina de Rioseco, VA-1671)

En la documentación recogida de la Tierra de Campos se recoge poco más de media docena de ocurrencias de este término. En cuanto al significado con el que aparece no está del todo claro en algunos de los ejemplos. El primer ejemplo de Valderas está claro que estamos ante una bolsa donde se guarda dinero, al igual que en dos de los ejemplos de Medina de Rioseco, donde se guarda en un talego una serie de papeles o está en un escritorio, lo que nos hace pensar que no estamos ante un enser agrícola. Otra cosa que dejan clara es que se trata de una especie de bolsa, dado el material con el que están confeccionados: anjeo, estopa o lienzo basto, no encontramos ningún talego elaborado con mimbre. En esta misma línea se presentan las ocurrencias que nos muestra el CorLexIn, donde la gran mayoría de ellas referencian una bolsa para meter monedas. En cuanto a la distribución geográfica, casi todos los ejemplos se notifican en la mitad norte peninsular, 
aunque se encuentra un caso aislado en Almería. Con este significado se localiza también en inventarios de Valladolid ${ }^{22}$ donde son pocos los casos en los que se utiliza para otros menesteres como llevar clavo, azúcar, perdigones o zapatos, lo que sí está claro que es un uso más personal que agrícola.

En la documentación de La Bañeza aparecen ejemplos de esta voz que se ajustan mejor a la definición que da la Academia, aunque tenemos que señalar que estos ejemplos son recogidos en siglos posteriores -Coomonte de la Vega (1722) y Destriana (1843)- (Gómez Ferrero, 2015: 292).

En trabajos léxicos más modernos encontramos el significado de 'cesto' para esta voz. En zonas de León como el Bierzo se recoge como 'cesto grande usado para transportar uvas y patatas', acepción que también se presenta en la zona de Oteros o Astorga a los que hay que unirle algunos pueblos de la provincia de Zamora limítrofes con León (Le Men, 2014, s. v. talego; Álvarez Tejedor, 1989: 172). Sin embargo, los casos localizados en plena Tierra de Campos se recoge el uso de esta voz como 'recipiente de tela gruesa en forma de bolsa; realmente es un saco pequeño para llevar en la mano. Puede ser de cuero' (Casas, 1989: 536), mucho más cercano al académico.

\section{FARDEL}

Sust. m. 'Saco o talega que llevan regularmente los pobres, pastores y caminantes, para las cosas comestibles u otras de su uso', 'fardo' (DLE, 1. a y 2. a ac.). Lo recoge Covarrubias con el significado de 'saco o talega, donde se mete alguna cosa, y se aprieta, que va como embutida, como las sacas de lana, que se lleuan de España para Italia'. Sin embargo, Autoridades presenta la definición que mantenemos hoy en día (NTLLE, s. v. fardel, Covarrubias, 1611; Autoridades, 1732). Término de origen incierto, probablemente tomado del francés donde fardel 'fardo' y farde, íd. son muy antiguos y de etimología dudosa. Es posible que el francés antiguo fardel resulte de una metátesis *FARCITELLUM (DECH, s. v. fardo).

Un fardel de lino chiquito (Castroañe, LE-1609)

El CORDE documenta esta voz a partir de la General Estoria de Alfonso x fechada en el año 1280, finales del siglo XIII. Alfonso de Palencia incluye este término en su Universal Vocabulario donde se equipara a 'zurrón de pastor', también alerta de que se trata de una palabra vulgar junto a troxel, término este último que encontramos en Tierra de Campos como troja. Por las concordancias que recoge esta base de datos podemos apreciar cierto retroceso de esta lexía a partir del siglo XVII. El CorLexIn documenta dos casos repartidos entre localidades de León y Zamora. También aparece en algunos documentos cántabros (Bartolomé y Junquera, 2018:

\footnotetext{
${ }^{22}$ Rojo Vega localiza un gran número de ejemplos de talego en la documentación vallisoletana, en su gran mayoría hace referencia a la bolsa que guarda el dinero: "un talego de echar dinero" (Testamento e inventario de posadera: María Solís, 1627). Estos inventarios se pueden consultar en: https://investigadoresrb.patrimonionacional.es/.
} 
129). Lo mismo ocurre en el corpus terracampino donde se localiza un único ejemplo de esta voz.

Estos datos contrastan con lo encontrado en estudios léxicos más modernos, donde se localiza fardel en zonas de Palencia como 'especie de saquillo para llevar comida, propio de pastores o caminantes. Cierra con una cinta corredera en la boca' también documenta el término en femenino fardela como morral o mandil para recoger espigas, llevar comida, etc. $Y$ señala que también se dice así en bable' (Gordaliza, 1988:58). Se localiza en Villada, localidad de la Tierra de Campos palentina, donde se usa como 'saco pequeño de tela' (Casas, 1989: 530), Le Men, en Sahagún como 'saquito propio para hacer recados' (Le Men, 2005, s. v. fardel) y de forma más general como 'especie de talego que se cierra por su boca con un cordel, apto para llevar la comida al campo' (García Caballero, 1992: 58). Estos trabajos también recogen fardela, aunque en nuestro estudio de la documentación áurea no se ha encontrado ninguno.

\section{TERRERO}

En el DLE este término aparece como un adjetivo y, por el contexto en el que aparece en los inventarios, el que más se ajustaría sería el de adj. 'Dicho de una cesta de mimbres o de una espuerta: que se emplea para llevar tierra de un punto a otro' (DLE, 4. ac.). Con el significado de 'cestas de mimbres ó espuertas que se emplean para llevar tierra de un punto a otro' lo recoge la edición académica de 1869 , sin notación dialectal (NTLLE, s. v. terrero, DRAE, 1869). Es un término derivado de tierra, procedente del lat. TĚRRA ( $D E C H$, s. v. tierra).

Tres terreros buenos de minbres (Grajal de Campos, LE-1613)

Dos terreros biexos (Villacalabuey, LE-1614)

Tres cuébanos biexos con sus terreros en dos reales (Sahagún, 1600)

Tres terreros en real y medio (Sahagún, LE-1605)

Tres terreros de llevar la ropa en seis reales (Grajal de Campos, LE-1656)

Treynta çestos de mendimiar y doçe terreros (Grajal de Campos, LE-1656)

Quatro terreros de mendimiar (Grajal de Campos, LE-1658)

Dos terreros de minbres (Grajal de Campos, LE-1671)

Un terrero grande de ropa (Grajal de Campos, LE-1671)

Un terrero bueno de mimbres (Fechilla PA-1616)

Un puchero grande y un terrero en que está (Frechilla, PA-1639)

Catorçe cestos y dos terreros (Frechilla, PA-1640)

Una canasta y un terrero (Frechilla, PA-1675)

Dos terreros demediados (Frechilla, PA-1676)

Un terrero medeano de minbres (Villalón, VA-1642)

Tres cargas de cestos y dos terreros (Cuenca de Campos, VA-1660)

Terrero aparece con naturaleza sustantiva en el corpus terracampino para referenciar una especie de cesto que por la forma o el tamaño recibía este nombre, ya que podía utilizarse para distintos menesteres, como era vendimiar o llevar la ropa. Con este significado no es frecuente en la documentación de bases de datos como el $C D H$ y el CORDE. De los pocos casos localizados en el CorLexIn ninguno presenta esta acepción. Rojo Vega halla "dos terreros de minbres" en un 
inventario vallisoletano ${ }^{23}$. Este mismo autor localiza en un inventario inédito perteneciente a la localidad terracampina de Arenillas de Valderaduey "terreros de colar", "terreros de mynbles" o "terreros de bendimyar" constatando la productividad de la palabra en la zona de estudio. De esto se desprende que el uso de terrero como un tipo de cesto muestra una distribución geográfica con un patrón de uso claro, lo encontramos en la meseta norte con especial incidencia en las provincias de León, Valladolid y Palencia.

En León se localiza con el significado de 'cesto de mimbre de castaño con dos asas para acarrear tierra' en El Bierzo, en la Cabrera se localiza con la variante leonesa terreiro. Además de en León, lo encontramos en Soria como 'saco de cáñamo para acarrear patatas' y en La Rioja como 'especie de media cesta de mimbre para el campo y albañilería' (Le Men, 2014, s. v. terrero). Casas (1989: 527) recoge terrero en la localidad terracampina de Villada como 'cunacho de mimbre, pero solían ser algo más altos aunque mucho menos que los cestos de vendimiar'.

\section{TIÑóN}

Sust. m. Este término no aparece en el DLE. Tampoco tenemos noticias en la documentación histórica o las obras lexicográficas.

Un tiñón de pajas y minbres que ará asta dos cargas de trigo (Grajal de Campos, LE-1658)

Un tiñón grande a modo de escriño de pajas y binbres que hará dos cargas de trigo (Grajal de Campos, LE-1656)

Estas ocurrencias muestran que estamos ante un recipiente agrícola realizado en mimbre y pajas, muy parecida al escriño cuya función era la de contener cereal. El CorLexIn documenta un caso en Burgos, donde parece tener una acepción similar a la encontrada, "un tinón de cauida de ocho fanegas". Al margen de estos casos, no encontramos nada más sobre esta lexía. Sin embargo, si atendemos a la morfología de la palabra, parece que estamos ante una forma derivada con el sufijo aumentativo -on, lo que supondría una forma simple de la que no tenemos noticia. Por otro lado, Morala y Egido localizan las formas tuña y toña para referenciar un recipiente que sirve para almacenar cereal y que presentan similitudes tanto formales como funcionales con tiñón. Estos autores atestiguan que son voces que aparecen desde hace mucho en el dominio asturleonés, y que, en la actualidad, por lo menos en León, la forma toña estaría en retroceso (Morala y Egido, 2018). Morala también localiza la variante tuña en documentos notariales pertenecientes a localidades de la comarca de Aliste, en el occidente de Zamora (Morala, 2017c: 369).

En trabajos más actuales como el de Le Men todavía se localizan las formas tuña, toña en el occidente de Asturias, noroeste de León y occidente de Zamora como 'arcón o depósito de madera para guardar el grano' (Le Men, 2012, s. v. toña), pero no hemos encontrado referencias a tiñón.

\footnotetext{
${ }^{23}$ Rojo Vega:

Testamento e inventario de Isabel del Campo, mujer del licenciado Juan Santos, fiscal de su Majestad (Valladolid, 1577):
} 


\section{TROJA [troxa]}

Sust. f. ant. 'Alforja, talega o mochila' (DLE, 2.a ac.). La recoge la edición del DRAE de 1817 con la acepción actual o y también como sinónimo de trox (NTLLE, s. v. troja, DRAE, 1817). El término trox ya es recogido por Covarrubias 'es lo mesmo que el granero do se recoge el trigo, o ceuada [...]' (NTLLE, s. v. trox, Covarrubias, 1611). De origen incierto, derivado de trojar (DECH, s. v. trojar).

Una troxa pequeña de minbre tassada en seis reales (Cuenca de Campos, VA-1668)

Una troxa de paxas bieja en seis reales (Cuenca de Campos, VA-1670)

Un troja de agujeras (Cuenca de Campos, VA-1660)

Una troja en quatro reales (Villalpando, ZA-1688)

Dos trojas de pajas (Quintanilla del Monte, ZA-1689)

En este corpus parece tratarse de un 'recipiente panzudo de paja trenzada para guardar grano y harina' (Le Men, 2012, s. v. troja), igualmente aparece en zonas de Palencia como 'recipiente, a veces de paja, para guardar el grano' (Gordaliza, 1988, 220). El DLE la recoge como voz en desuso en sus dos acepciones, la de 'alforja, talega o mochila' y la de sinónimo de troj utilizado en ciertos países hispanoamericanos. Troj es una de esas voces peculiares del castellano que, pese a no ser muy frecuente, se utilizó en un ámbito geográfico relativamente amplio.

Troxa se documenta en época temprana, en las Actas de las Cortes de Alcalá de Henares en 1252 en las que referencia una especie de alforjas para llevar algún tipo de carga (CDH y CORDE). Sin embargo, parece que no haya resistido el paso del tiempo y la consulta en el CorLexIn solo aporta una ocurrencia en Adeje (Tenerife) con el significado de 'arca', más que como recipiente o bolsa para llevar grano. Rojo Vega localiza el siguiente ejemplo: "en una troja cuarenta y cinco cargas y una fanega de trigo" en un inventario fechado en 1574 en la localidad leonesa de Matadeón de los Oteros y que coincide con la función que se da a este objeto en esta zona ${ }^{24}$. Aunque las voces troj / troje presentan un número ligeramente mayor en la documentación que la variante terracampina, tampoco podemos afirmar que son términos de uso frecuente.

${ }^{24}$ Rojo Vega, A.: Testamento e inventario de Antonio Vázquez de Acuña, señor de Matadión (1574) en Matadeón de los Oteros (León). https://investigadoresrb.patrimonionacional.es/node/8947. 


\subsubsection{Bodega}

\section{ALQUITARA}

Sust. f. 'alambique, utensilio para destilar' (DLE). Nebrija recoge 'alambique ó alquitara'. Autoridades equipara de nuevo los dos términos, aunque precisa que alquitara es 'la que está hecha de plomo, ù de otra materia, y tiene la cazuéla de cobre' (NTLLE, s. v. alquitara, Nebrija, 1495; Autoridades, 1726). Término procedente del árabe qațtâra y este de qáțra 'gota', qátțar 'destilar' (DECH, s. v. alquitara)

Una alquitara de cobre (Paredes de Nava, PA-1689)

Un caldero de cobre y una alquitara de lo mismo en sesenta reales (Medina de Rioseco, VA-1646) Una alquitara de cobre (Medina de Rioseco, VA-1648) Una alquitara de cobre (Medina de Rioseco, VA-1660)

Estamos ante una palabra de uso general, que dada su especificidad no encuentra un uso tan frecuente en los documentos consultados como otras voces estudiadas.

La primera documentación que nos presenta el $C D H$ data de 1429 , en un tratado de medicina. El CORDE la documenta pasada la segunda mitad del siglo XV, en el Arancel de precios y salarios de Cuenca fechado en 1462: "una alquitara de tres lybras de plomo con el suelo de arambre, sesenta e tres mrs". A partir de esta fecha se certifica su uso regularizado hasta finales del siglo XVII, donde la palabra entra en un claro retroceso.

El CorLexIn devuelve tan solo una docena de ocurrencias distribuidas por una amplia zona geográfica en la Península -en las provincias andaluzas de Almería, Málaga y Sevilla, Toledo, Valladolid y Álava-, Canarias -Tenerife-y América -Chile, también se localiza en un inventario mexicano fechado en 1695 (Curiel, 2000: 100)-.

Lo que ocurre en estas bases académicas se puede trasvasar a la Tierra de Campos, donde no llega a la media docena de casos localizados en la localidad vallisoletana de Medina de Rioseco y la palentina Paredes de Nava.

\section{BOTA [botilla]}

Sust. f. ' Cuero pequeño empegado por su parte interior y cosido por sus bordes, que remata en un cuello con brocal de cuerno, madera u otro material, destinado especialmente a contener vino' o 'cuba para guardar líquidos' (DRAE, 1. a y 2. a ac.). Lo registra Nebrija y Covarrubias dice que 'en castellano llamamos bota a la que los demas llaman borracha, que es cuerezito pequeño con la mitad de costura, y vn brocal en el cuello' y Autoridades añade que 'se llama tambien el barril, cubéta, o pipa de madéra con arcos, en que se lleva en las embarcaciones el vino, agua, azéite [...]' (NTLLE, s. v. bota). Término procedente del lat. tardío BŬTTIS 'odre' cuyo origen último se desconoce (DECH, s. v. bota).

Una bota viexa (Cea, LE-1621)

Una bota pequeña de echar bino (Valderas, LE-1682) 
Una bota biexa con su broçal (Autillo de Campos, PA-1653)

Una bota con una costura, un boçal (Autillo de Campos, PA-1653)

Una botilla de asta un açumbre (Fechilla PA-1615)

Los casos encontrados de bota en Tierra de Campos se documentan con la primera acepción que da el DLE. Los datos recogidos en corpus como el CORDE, el CDH y el CorLexIn nos presentan una palabra de uso general y en la mayoría de las ocasiones con este significado. Como 'cuba para guardar líquidos', aunque con menor número de casos, el CorLexln presenta una preferencia de este significado en la zona catalano-aragonesa (Junquera y Álvarez García, 2020: 86).

\section{CARRAL [carrala, carralexo, carralexa, carraleja, carralica, carralón]}

Sust. m. 'Barril o tonel a propósito para acarrear vino' (DLE). Autoridades recoge el término como femenino y lo define como 'barril o tonel para transportar el vino en carros, de donde tomó el nombre', además de destacar el uso que de este recipiente se hacía en Castilla, para llevar el vino a las montañas (NTLLE, s. v. carral, Autoridades, 1729). Término derivado de carro, del lat. CARRUS, de origen galo ( $D E C H$, s. v. carro).

Dos carrales, la una de doze cántaras y la otra de diez y seis (Sahagún, LE-1601)

Quatro carrales que arán a treynta cántaras de vino cada una (Cea, LE-1610)

En la cueba, una carral de bino de nuebe cántaras (Galleguillos, LE-1618)

Dos carrales, una de diez cántaras y otra de quatro (Grajal de Campos, LE-1670)

Una carral vieja que hará diez cántaros (Frechilla, PA-1642)

Una carral de ocho cántaras de bino nuebo digo de bino anexo (Boadilla de Rioseco, PA-1643)

Una carral de cavidad de diez cántaras (Boadilla de Rioseco, PA-1692)

Una carral que ará doçe cántaras poco más o menos (Villarramiel, PA-1696)

Dos carrales pequeñas y una grande que ará veinte y quatro cántaras (Villalón, VA-1638)

En la cueba, tres carrales, la una muy pequeña (Medina de Rioseco, VA-1640)

Dos carrales pequeñas en beynte reales (Medinad de Rioseco, VA-1661)

Tres carralones y una carral (Villalpando, ZA-1686)

Una carral (Cotanes del Monte, ZA-1687)

Una cueba con una cuba y una carral (Villalpando, ZA-1698)

Es un término de uso general en la Tierra de Campos. Corominas y Pascual encuentran carral como 'barril para acarrear vino' en el año 1295, en la Crónica General (DECH, s. v. carro). Aunque ya había aparecido en un inventario medieval del monasterio de Carrizo del año 1268 (MoralaLe Men, 1996 en Le Men, 2004, s. v. carral). Se pueden localizar más ocurrencias de esta voz en textos medievales pertenecientes a la Catedral de León o a los monasterios de Vega, Otero de Dueñas, Gradefes o Vega (Junquera y Álvarez García, 2020: 90).

Aparece en el DLE con género masculino, algo que no se corresponde con la zona de estudio, ya que, en la mayor parte de los inventarios, el género que prevalece es el femenino, tal es así que en la zona de Zamora presenta la variante carrala, que añade una - $a$ analógica por esa preferencia de género (Le Men, 2004, s. v. carral):

Una carrala grande montañesa con tres arcos de yerro (Villalpando, ZA-1696)

Dos carralas pequeñas (Villalpando, ZA-1696)

En la Tierra de Campos palentina y el Cerrato la carral es una 'cuba de menos de veinte cántaros que abunda mucho en las bodegas y que se usó también para el transporte del vino' 
(Gordaliza, 1988: 63). Álvarez Tejedor señala que 'el área de la forma carral se extiende por las tierras del Norte del Duero. Quizás ello sea debido a que esas tierras eran suministradas de vino procedente de más al sur. Por el contrario, al sur del río Duero las formas cubeta, cubeto y tonel aparecen repartidas de forma desigual' (Álvarez Tejedor, 1989: 193). En cuanto a la acepción, en la mayoría de las ocasiones parece afín a la primera definición que nos ofrece el DLE. Sin embargo, encontramos tres ejemplos donde carral se utiliza para llevar otro tipo de productos, como son los salvados, el centeno o la sal:

Un poçal y una carral para salvados en dicho aposento (Grajal de Campos, LE-1656)

Una carral uieja para tener çenteno vaçía (Grajal de Campos, LE-1658)

Una carral salinexa viexa (Villalpando, ZA-1698)

En el CorLexIn solo se encuentra carral en zonas de León y Palencia, por lo que parece que es una palabra que, a pesar de no llevar marca diatópica en el $D L E$, es utilizada en una zona muy concreta.

Desde un punto de vista formal, aparecen variantes derivadas de diminutivo y aumentativo. Por un lado, se recoge la voz carraleja para hacer referencia a una carral más pequeña, que presenta tanto la forma femenina como la masculina. Es menos frecuente el diminutivo en -ica:

Nueue carralexas y una tina (Sahagún, LE-1600)

Una carralexa sin bino tasada en seis reales (Sahagún, LE-1605)

Un carralexo sin ténpano (Castrillo, LE-1606)

Una carralica de cinco cántaras (Cea, LE-1621)

Una carraleja (Castromocho, PA-1614)

Otro derivado habitual en el corpus terracampino es carralón:

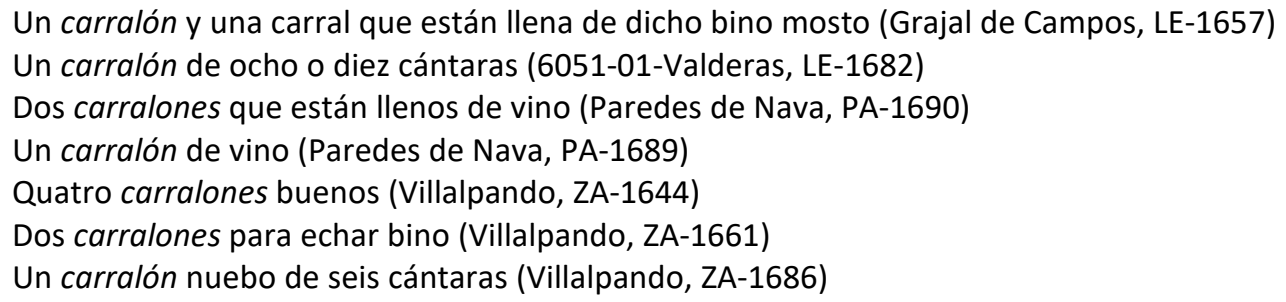

Este vocablo no se recoge en ninguna de las obras lexicográficas académicas. Pero desde un punto de vista diacrónico se localiza en la Documentación medieval de la iglesia Catedral de León, fechada en 1419 y donde figura "un carralón que faze sesenta cántaras" (CDH y CORDE). En algunos estudios dialectales más recientes, como el que hace Fernández González sobre el habla de Oseja de Sajambre recoge esta voz como 'barril para el vino que era más pequeño que la carral' (Fichero General, cédula 1). Estos datos sugieren que estamos ante un occidentalismo léxico cuyo uso era limitado.

\section{CUBA [cuva, quba]}

Sust. f. 'Recipiente de madera, o también modernamente de chapa metálica, que sirve para contener agua, vino, aceite u otros líquidos, y está compuesto de duelas unidas y aseguradas con aros de hierro, madera, etc., y cerradas con tablas por los extremos' (DLE). Nebrija recoge 'cuba para el vino'. Covarrubias define este término como 'el vaso hecho de costillas de madera delgada, que se ciñe con aros y cercos, y comunmente se hazen las cubas, para echar en ellas el 
vino' definición que no ofrece cambios significativos en Autoridades (NTLLE, s. v. cuba, Nebrija, 1495; Covarrubias, 1611). Término procedente del lat. CŪPA (DECH, s. v. cuba).

Onze cubas las dos de a ziento y zinquenta cantaras (Sahagún, LE-1608)

Una cuba de cien cántaras poco más o menos con sus poynos (Sahagún, LE-1601)

Una cuba de vino tinto (Valderas, LE-1659)

Una cuba de bino de diez palmos de vodega (Grajal de Campos, LE-1671)

Una cuba de tener vino de hasta ciento y treynta cántaros (Frechilla, PA-1612)

El bino de la cuba de canto (Frechilla, PA-1639)

Dos cuvas de vino (Paredes de Nava, PA-1690)

En la bodega, dos qubas, la una de nuebe palmos y la otra de diez (Boadilla de Rioseco, PA-1687)

Una cuba de vino (Villalón, VA-1638)

Dos cubas y tres silos (Medina de Rioseco, VA-1642)

Quinientas cántaras de vino en quatro cubas (Medina de Rioseco, VA-1649)

Dos cubas de bino (Medina de Rioseco, VA-1660)

Una cuba de bino de cien cántaras (Villalpando, ZA-1650)

Una cuba nueua de ocho palmos (Villalpando, ZA-1689)

Una cuba nueba de ocho palmos (Villalpando, ZA-1690)

Una cueba con una cuba y una carral (Villalpando, ZA-1698)

Es una palabra de uso general en toda la zona de estudio. Aparece con la acepción que da el $D L E$ para este término. Sin embargo, en el siglo XVII, parece haber una preferencia en la zona centro y norte de la Península (CorLexIn).

\section{CUBETO [cuveto]}

Sust. m. 'Vasija de madera, más pequeña que la cubeta' (DRAE). En Autoridades aparece como 'vaso de madera, más pequeño que la cubéta, que sirve para transportar géneros, y viene á ser lo mismo que barril ' (NTLLE, s. v. cubeto, Autoridades, 1729). Es un término derivado de cuba, procedente del lat. CŪPA (DECH, s. v. cuba).

Vn cubeto de heechar bino (Valderas, LE-1647)

Dos cubetos de tener escaueche dos reales (Frechilla, PA-1612)

Un cubeto de tener escabeche (Castromocho, PA-1614)

Un cuveto de asta un quarto de sal (Frechilla PA-1615)

Dos cubetos de escabeche en diez quartos (Villalpando, ZA-1629)

Nebrija equipara cubeto con una 'cuba pequeña'. En la zona de Tierra de Campos, el cubeto se usa para transportar el escabeche y otros productos como la sal. Este término aparece documentado en el siglo XVII en la parte noroccidental de la Península, casi todos los casos se utilizan para transportar vino, salvo pequeñas excepciones (CorLexIn).

En estudios más recientes como el Vocabulario Palentino, este término hace referencia a la 'carral pequeña para el vino' (Gordaliza, 1988: 79). Álvarez Tejedor recoge en la zona este de Zamora el uso de cubeto como un tipo de tonel, más pequeño que la cubeta para recoger el vino (Álvarez Tejedor, 1989: 193-196). En León, además de la acepción de cuba pequeña para el vino, también servía para guardar vinagre (Le Men, 2004, s. v. cubeto). 


\section{CUÉVANO [cuébano, québano, cobanillo]}

Sust. m. 'Cesto grande y hondo, poco más ancho de arriba que de abajo, tejido de mimbres, usado especialmente para llevar la uva en el tiempo de la vendimia' (DLE). Aparece en el Vocabulario de Nebrija, pero no lo recoge la Academia hasta el DRAE de 1780 (NTLLE, s. v. cuévano). Palabra procedente del lat. cŏPHĪNUs 'cesto hono', 'cuévano' ( $D E C H$, s. v. cuévano).

Tres cuébanos biexos con sus terreros en dos reales (Sahagún, LE-1600)

Diez y nueve cuebanos de huba (Villemar, LE-1608)

Ocho cuévanos buenos (Cea, LE-1610)

Vnos cuébanos de llevar fruta (Valderas, LE-1647)

Zinco cuebanos de binbres de bendimiar (Grajal de Campos, LE-1658)

La lana que está en dos cuévanos y un terrero (Grajal de Campos, LE-1658)

Quatro cestos cuébanos en dos reales (Frechilla, PA-1613)

Un cuébano lleno de pluma (Fechilla, PA-1613)

Hasta nuebe listas de lana menudas fraylego en un cuébano (Frechilla, PA-1616)

Un cuébano de carbón apreçiado en dos reales (Frechilla, PA-1616)

Seis cuévanos mediados (Frechilla, PA-1638)

Siete cargas de cuébanos (Boadilla de Rioseco, PA-1643)

Unos cuébanos (Villalpando, ZA-1644)

Unos cuébanos de quatro cántaros (Villalpando, ZA-1685)

Es un término bastante común en la zona de estudio. Está poco documentado en la documentación histórica. Sin embargo, sí está presente en diferentes repertorios dialectales. En algunas zonas de León se trata de 'un cesto grande y hondo, trenzado con mimbres gruesos, que servían para transportar la uva en tiempo de vendimia desde las cepas al carro y en éste al lagar' (Le Men, 2004, s. v. cuévano). En la zona este de Zamora, cuévano se ajusta a la definición que da el DLE (Álvarez Tejedor, 1989: 172). Y en Palencia esta voz equivale a 'cesto pequeño que se llevaba a la espalda, al que también se llamaba covanillo', y también se le llamaba así al 'cesto grande para las vendimias, muy hondo, para transportar la uva' (Gordaliza, 1988: 80). En la comarca de Tierra de Campos, esta voz no solo se utilizaba para hacer referencia al cesto grande y hondo para llevar la uva en época de vendimia, sino que podía servir para llevar otro tipo de productos tan dispares como puede ser fruta, lana, pluma o carbón.

Desde un punto de vista formal, figura el diminutivo con la desinencia -illo y con monoptongación del diptongo:

Onze quebanos y un cobanillo de minbres (Sahagún, LE-1608)

El $D L E$ recoge este término con género femenino -covanilla- para referenciar el diminutivo de cuévano.

\section{ODRE}

Sust. m. 'Cuero, generalmente de cabra, que, cosido y empegado por todas partes menos por la correspondiente al cuello del animal, sirve para contener líquidos, como vino o aceite' (DLE). Nebrija lo recoge junto con cuero, como contenedores de vino. Siguiendo esta línea, Covarrubias lo define como 'el cuero en que se trasiega el mosto'. La definición de Autoridades especifica que este cuero es 'de cabra ù otro animál, que cosido por todas partes, y dexandole arriba una 
boca, sirve para echar en él, vino, azéite y otros licores' (NTLLE, s. v. odre, Nebrija, 1495; Covarrubias, 1611; Autoridades, 1737). Palabra que viene del lat. ŬTER, ǓTRIS (DECH, s. v. odre).

Un odre bueno (Villacalabuey, LE-1614)

Aunque se trata de un término de uso general, en el corpus terracampino no es un término frecuente, tan solo localizamos un único ejemplo de esta voz. Esta escasez de ejemplos puede deberse a la preferencia en la zona por el término pellejo. Desde una perspectiva diacrónica, esta voz se documenta desde el siglo XIII en bases textuales como el CORDE y el $C D H$. Sin embargo, su presencia en el CorLexIn es escasa, solo localizamos una ocurrencia en un documento de Bolivia, fechado a principios del siglo xVIII y cuya función es la de llevar miel. El ejemplo rescatado de la documentación terracampina presenta género masculino, pero puede admitir la concordancia en femenino (Junquera y Álvarez García, 2020: 98-99).

\section{PELLEJO [pellexo, pillexo, pellexa, pellejuelo, pellexuelo]}

Sus. m. 'Piel de animal, especialmente cuando está separada del cuerpo' u 'odre' ( $D L E, 1$. y 4 . a ac.). Covarrubias en su Tesoro señala que en algunos sitios 'suelen llamar pellejos a los cueros de vino', dentro del lema pelleja. Autoridades lo dispone en su propia entrada como 'el cuero ò piel del animal' y también como cuero adobado y dispuesto para conducir cosas líquidas' (NTLLE, s. v. pellejo, Covarrubias, 1611; Autoridades, 1737). Voz derivada de piel, del lat. PĔLLIS (DECH, s. v. piel).

Un pellexo de cordero (Cea, LE-1610)

Dos pellexos (Grajal de Campos, LE-1616)

Una ropa de chamelote aforrada en pellejos (Cea, LE-1621)

Vn cofre tunbado grande aforrado en vn pellejo roxo y guarneçido de oja de lata (Valderas, LE-1647)

Vn manguillo de pellexo de fuina o marta (Valderas, LE-1647)

Dos pellejos de tener aceyte apreciados en tres reales (Frechilla, PA-1613)

Un pellexo de osso (Frechilla, PA-1631)

Tres pellexos de cabrito (Frechilla, PA-1631)

Un pellexo de tener bino viexo (Autillo de Campos, PA-1653)

Un pellejo de carnero (Villarramiel, PA-1690)

Otro cofre viexo aforrado en pellejo de cavallo (Medina de Rioseco, VA-1640)

Un pellejo para vino (Medina de Rioseco, VA-1641)

Un pillexo de castrón en cinco reales (Cuenca de Campos, VA-1660)

Dos pellejos de echar bino (Villalpando, ZA-1644)

Un pellejo de tener bino (Villalpando, ZA-1644)

Pellejo se presenta en Tierra de Campos con las acepciones que nos da la Academia, como 'piel de animal' y como 'odre' para contener vino u otros líquidos. Término común que, en nuestro corpus, suele presentar la vacilación de la vocal átona, la /e/ cierra en /i/ -pillejo-. Con mucha menor presencia también localizamos el término femenino pelleja:

Tres pellexas grandes curadas con lana (Frechilla, PA-1675)

Tanto Nebrija como Covarrubias hacen referencia a la 'piel del animal'. Mientras, Autoridades indica que se trata 'especialmente de la piel de las ovejas ù carneros' (NTLLE, s. v. pelleja, Nebrija, 1495; Covarrubias, 1611; Autoridades, 1737). 
Desde un punto de vista formal, encontramos el sufijo diminutivo -uelo para esta voz:

Un pellejuelo de dos cántaros (Frechilla, PA-1639)

Un pellejuelo de cotear (Frechilla, PA-1639)

Un pellexuelo de medio cántaro (Autillo de Campos, PA-1653)

\section{PoíNO [poýno]}

Sus. $m$. 'Codal que sirve de encaje y sustenta las cubas en las bodegas' (DLE). No se registra hasta la edición del DRAE de 1803 con la misma definición que se mantiene hoy en día (NTLLE, s. v. poíno). Es una palabra derivada de poyo, del lat. PŏDĭum 'repisa' (DECH, s. v. poyo).

Una cuba de cien cántaras poco más o menos con sus poýnos (Sahagún, LE-1601)

Ocho poýnos de carrales (Sahagún, LE-1601)

Una cuba de cien cántaras poco más o menos con sus poýnos (Sahagún, LE-1601)

Tres cubas y quatro carrales con sus poínos, todo bazío y sin vino (Grajal de Campos, LE-1670)

Los poínos de canto del tonel (Frechilla, PA-1639)

Otros dos poínos de canto de una carral (Frechilla, PA-1639)

Los poínos de quatro carrales de madera (Frechilla, PA-1639)

Doçe maderuelos que sirben de poýnos a las carrales (Frechilla, PA-1639)

Dos poínos y un envudo en tres reales (Cuenca de Campos, VA-1666)

Este número de ocurrencias contrasta con la búsqueda en las bases textuales académicas, tanto el CORDE como el $C D H$ no registran casos de la palabra con este significado. El CorLexIn da cuenta de un único caso en la población leonesa de Villacabiel. Gómez Ferrero localiza un par de ejemplos en su estudio léxico de La Bañeza (León) en documentos áureos (Gómez Ferrero, 2015: 302). En época actual, Le Men amplía el ámbito geográfico de esta voz con la acepción que aquí contemplamos en localidades leonesas como Valencia de Don Juan, en Benavente (Zamora), en la Ribera Norte de Salamanca, Las Hurdes en Extremadura y la Tierra de Campos leonesa y palentina (Le Men, 2004, s. v. poíno). Este reparto geográfico sería indicio de estar ante un occidentalismo.

Desde una perspectiva formal, estamos ante un diminutivo lexicalizado que conserva la forma plena -ino (Morala, 2009: 11). Esta palabra ha perdido la palatal /y/ de poyino por asimilación, al estar en contacto con una vocal también palatal (Morala, 2010a: 448).

\section{POZAL [poçal, poçaleta, pozaleta]}

Sust. m. 'Cubo o zaque con que se saca el agua del pozo', 'brocal del pozo', 'vasija empotrada en tierra para recoger líquidos' $(D L E)$. Se trata de un término derivado de pozo, del lat. PǓTĚUS (DECH, s. v. pozo).

Un pozal de mediado (Sahagún, LE-1603)

Un pozal bueno (Cea, LE-16110)

Un poçal y una carral para salvados (Grajal de Campos, LE-1656)

Una escalera andadera y un enbudo y un pozal (Grajal de Campos, LE-1670)

Un poçal, dos artesones vueno y pequeño y otro grande (Grajal de Campos, LE-1671)

Un pozal (Valderas, LE-1682)

Otro tonel serrado por medio echo del dos poçales o tinacos (Frechilla, PA-1631)

Un poçal de roble bueno (Autillo de Campos, PA-1647)

Un poçal de tener bino mediado (Autillo de Campos, PA-1649) 
Un pozal que haze nuebe cántaros sin vino (Frechilla, PA-1675)

Un pozal (Paredes de Nava, PA-1695)

Una artesa de masar y un pozal, (Cuenca de Campos, VA-1651)

Un poçal de tonel en tres reales (Cuenca de Campos, VA-1666)

Vn poçal con tres arcos de yerro (Villalobos, ZA-1654)

Dos poçales de tener bino, el un grande y otro mediano (Villalpando, ZA-1661)

En la cueba, dos pozales, el uno con arcos de yerro (Villalpando, ZA-1696)

La acepción con la que aparece con mayor frecuencia en los inventarios de Tierra de Campos es de vasija que se utilizaba para contener vino, en los casos en los que no se especifica su función, aparecen junto a otro tipo de recipientes utilizados en la bodega. Este significado se contempla en textos medievales pertenecientes al Monasterio de Sahagún desde finales del siglo XIII:

Et prior de Piasca, singulis annis in festum Sancti Andree, det / XXti panes et IIIlor pozales de uino et unum tocinum pauperibus [...] (Monasterio de Sahagún, 1190).

II quartarios de /12 trictici et II pozales de bono uino et uno tocino [...] (Monasterio de Sahagún, 1209).

$\mathrm{VI}$ quarteros de pan, / tres de trigo e tres de centeno, pora los pobres e tres pozales de buen uinu. (Monasterio de Sahagún, 1229)

En León este término se utiliza para designar a la 'vasija de madera de forma cilíndrica que sirve para recibir el vino de la cuba en la operación de envase' (Le Men, 2009, s. v. pozal). En Zamora se recoge como 'recipiente de madera en el que se efectúa el pisado de la uva' (Álvarez Tejedor, 1989: 175) y en Tierra de Campos se suele referir también a la 'cuba partida por la mitad que se tiene en las bodegas para recoger el vino que se cae al trasegarlo' (Gordaliza, 1988: 183), de esta última acepción encontramos un ejemplo claro en un documento de Frechilla donde pozal se equipara a tinaco, y otro de Cuenca de Campo:

Otro tonel serrado por medio echo de dos poçales o tinacos (Frechilla, PA-1631)

Un poçal de tonel en tres reales (Cuenca de Campos, VA-1666)

La consulta de esta voz en el CorLexIn nos facilita una serie de concordancias distribuidas principalmente por la meseta norte -Léon, Palencia, Zamora y Zaragoza-, sin olvidar un caso en Murcia.

En cuanto a la morfología derivacional que presenta el término, cabe señalar que encontramos formas con el sufijo derivativo -eta:

Una pozaleta de una pieça con dos arcos de hierro apreciada en seis reales (Frechilla, PA-1612)

Una poçaleta de tener sal (Fechilla PA-1616)

Una pozaleta de madera (Frechilla, PA-1631)

Dos poçaletas biejas y dos tablas (Frechilla, PA-1640)

Una poçaleta de mimbres pezgada (Autillo de Campos, PA-1653)

Una poçaleta de mimbres (Autillo de Campos, PA-1653)

Una pozaleta de madera echa de un pedazo con dos arcos de hierro (Frechilla, PA-1675)

Esta voz no aparece en ninguno de los diccionarios académicos y por lo que nos cuenta el contexto en el que se asientan, parece tener otras funciones, a parte de contener vino o mosto. En el listado que hemos recogido del corpus terracampino tenemos una pozaleta para tener sal, $y$, además de con madera, también se elaboran con mimbre. Esto hace que tenga diferentes funciones. 
Si queremos encontrar información sobre esta palabra debemos recurrir a estudios léxicos más modernos. Como hemos dicho anteriormente, estamos ante una palabra polisémica. Mientras en León referencia un 'balde de fregar', en Aragón se utiliza como 'caldero de albañil' o 'pozal pequeño' (Le Men, 2009, s. v. pozaleta). en la localidad leonesa de Calzada del Coto, perteneciente a la Tierra de Campos, localizan este término como 'recipiente donde se deposita el mosto o el vino antes de llevarse a la bodega' (Hernández Alonso, N., 2000: 75).

\section{TONEL [tunel]}

Sust. m. 'Cuba grande' (DLE). Lo registra Covarrubias como 'cubeta pequeña o barril'. Autoridades especifica un poco más el término 'cubeta, o candiota, en que se echa el vino, ú otro liquór, para llevarle de una parte a otra [...]', esta definición se mantendrá hasta la edición académica de 1925, diccionario que asigna a la palabra el significado con el que hoy se recoge de 'cuba grande' (NTLLE, s. v. tonel, Covarrubias, 1611; Autoridades, 1739; DRAE, 1925). Término tomado del fr. ant. tonel, diminutivo de tonne 'tonel grande', y éste del lat. tardío TǔnNA íd., de origen celta tunna 'piel', de donde 'odre' y después 'cuba' (DECH, s. v. tonel).

\footnotetext{
Dos toneles de a quarenta cántaros cada uno poco más o menos (Frechilla, PA-1612) Un tunel (Fechilla PA-1612)

Un tonel baçío que ará treynta y quatro cántaras (Frechilla, PA-1631)

Un tonel lleno de bino que ará treinta y siete cántaros poco más o menos (Frechilla, PA-1639)

Un tonel y una carral de quatro cántaras y una tina en el patio de las cas una pila de canto grande (Guaza de Campos, PA-1640)

Un tunel que ará como diez y ocho cántaros (Villarramiel, PA-1690)

Un tonel de sesenta cántaros (Villarramiel, PA-1694)

Una podadera bieja, una pala de orno, tres toneles y un carralón (Cuenca de Campos, VA-1651)

Un poçal de tonel en tres reales (Cuenca de Campos, VA-1666)

Unas cassas de morada con su queba, dos qubas, quatro toneles, su lagar con biga y piedra (Cuenca de Campos, VA-1668)
}

Tonel es una palabra de uso general que designa un tipo de cuba más pequeña que esta y con capacidades diferentes. Desde un punto de vista formal, el corpus estudiado presenta la forma tunel, con cambio de timbre de la vocal átona. En la mayoría de los casos, tonel referencia un tipo de contenedor de vino principalmente. No obstante, se localiza un ejemplo en Villalpando donde aparece con un significado diferente al académico, este nos recuerda al uso que se hacía de cubeto en otros documentos, donde el tamaño debe ser menor, ya que se utilizaba para guardar escabeche:

Un tonel de escabeche (Villalpando, ZA-1690)

En trabajos más actuales se sigue encontrando esta voz, simplemente ha cambiado la capacidad del recipiente. Lo encontramos como 'depósito de madera para el vino, guardado en el interior de las bodegas, de más de ochenta cántaros' (Gordaliza, 1988: 213). 


\subsection{HERRAMIENTAS PROFESIONALES}

Este apartado se articula a través de una serie de términos que referencian herramientas profesionales. Debemos tener en cuenta la singularidad de este tipo de términos, puesto que la consecuencia inmediata va a ser la falta de ocurrencias en el CORDE, el $C D H$ y, especialmente, el CorLexIn.

Al igual que hemos visto en los apartados anteriores, las herramientas profesionales también están presentes en los inventarios de bienes de la época. Para describirlas, el escribano no duda en indicar distintas características tales como forma, material, estuche, funda o caja donde se guardan, accesorios que la acompañan...

De cara al desarrollo de este apartado, las herramientas se han agrupado en función de la profesión en las que se utilizan. De las distintas encontradas, solo se presentan aquellas en las que la profesión queda representada por un número mínimo de términos. Estas herramientas son las que usan los barberos -en aquella época hacían las veces de cirujanos y dentistas-, albañiles, carpinteros, herreros, tejedores y zapateros.

\subsubsection{Barberos}

\section{ALGALIA}

Sust. f. Med. desus. 'Especie de tienta algo encorvada, hueca, abierta por una punta y agujereada por uno o por dos lados del otro extremo, usada para las operaciones de la vejiga, para la dilatación de la uretra y especialmente para dar curso y salida a la orina' (DLE, s. v. algalia ${ }^{2}$. Autoridades recoge esta acepción propia del ámbito quirúrgico en su edición de 1726 (NTLLE, s. v. algalia, Autoridades, 1726). Este término con la acepción de 'sonda para la vejiga', procede del griego medieval 'herramienta' (DECH, s. v. algalia ॥).

Una algalia de plata (Valderas, LE-1682)

La presencia de esta voz relativa al ámbito médico es escasa en el corpus analizado. Tan solo se ha localizado un ejemplo en un inventario de Valderas (León). Algo parecido ocurre cuando consultamos el CorLexIn, donde localizamos un ejemplo en Vergara (Guipúzcoa) con este significado.

Desde una perspectiva diacrónica, con el significado, figura con la variante argalia en la traducción de un Tratado de cirugía de Cauliaco, fechada en 1493. La variante algalia aparece en los corpus del castellano en Secretos, obra de Pedro Arias de Benavides, del año 1566:

hize hazer vn hierrezillo / de plata, de gordor de vn algalia / maçiço, con vna punta algo / vota y vna bombilla de plata. 
Muchas de las concordancias que figuran en estas bases de datos presentan el significado de 'sustancia untuosa, de consistencia de miel, blanca, que luego pardea, de olor fuerte y sabor acre. Se saca de la bolsa que cerca del ano tiene el gato de algalia y se emplea en perfumería' (DLE, s. v. algalia $)^{1}$, con presencia en los textos desde el siglo XIII. Sin embargo, no es así en la zona terracampina, ni el CorLexIn, donde las escasas ocurrencias encontradas referencian la herramienta quirúrgica.

\section{BOTADOR}

Sust. m. 'Instrumento de hierro en forma de escoplo, dividido en dos dientes o puntas, usado por los dentistas' (DEL, 6. a ac.). Covarrubias recoge esta voz como 'cierto hierro para echar fuera los clavos, que no se pueden sacar con tenezas' (NTLLE, s. v. botador, Covarrubias, 1611). Término derivado de botar, y este a su vez tomado, por vía del gascón ant. botar, del fr. ant. boter 'golpear, empujar, poner' (fr. med. bouter), y este del fráncico *BŌTAN 'empujar, golpear' (DECH, s. v. botar).

Un estuche del ofiçio de zirujía y en el siete lanzetas, un apostemero, un sajador, un berduguillo, una tienta, unas tijeras, una espadilla de plata, una lima, unas pinzas, una buja, um botador, dos cañones, un de aujas y otro de polvos (Valderas, LE-1682)

Esta palabra se presenta documentada a finales del siglo XVI en el tratado fechado en 1570 y escrito por Francisco Martínez de Castrillo sobre la boca en el que se puede leer "estos dentecillos se han de sacar con un botador" $(C D H)$. Sin embargo, no es la única acepción que presenta esta voz, ya que también está presente la que le asigna Covarrubias. Los textos muestran su uso tanto en documentos de la Península como en los de América con los dos significados.

Respecto a los datos que nos ofrece la documentación notarial del siglo XVII, el CorLexIn facilita pocos casos del término - dos en la Península (en la localidad cordobesa de Cabra y en Cortes, provincia de Navarra) y uno en América, en Santiago de Chile)-. En los tres casos, referencia una herramienta que tiene que ver más con el oficio de carpintero, dado el contexto en el que encuentra, ya que, en los tres casos, botador, se encuentra entre barrenas, bigornias, martillos, azuelas...

Por su parte, Morala amplía el número de ocurrencias de esta lexía ubicadas en el norte de la Península -Hacinas (Burgos), Vadillo (Soria) y El Espinar (Segovia)- cuya acepción se acerca más a la de 'instrumento de hierro, a modo de cincel sin afilar, para arrancar los clavos que no se pueden sacar con las tenazas' y que aparece con la marca de carpintería (Morala, 2015a: 1507). También se registra en inventarios del siglo XVII en localidades próximas a Sala de los Infantes (Burgos) como 'herramienta utilizada para sacar clavos' por el contexto en el que aparece, junto a escoplos y barrenas (Perdiguero, 2013: 238-239).

El único ejemplo que se ha localizado en los documentos estudiados de la Tierra de Campos pertenece al inventario de un barbero que en esta época era además cirujano y dentista. Con 
esta acepción quirúrgica solo lo encontramos en testamentos e inventarios de barberos cirujanos vallisoletanos ${ }^{25}$

\section{LANCETA [lanzeta]}

Sust. f. Med. 'Instrumento provisto de una hoja de acero de corte muy delgado por ambos lados y punta agudísima, que sirve para sangrar abriendo una cisura en la vena y para abrir tumores y otras cosas' (DLE). Esta voz la recoge Nebrija como 'lanceta de sangrador' y Covarrubias la define como 'scalpellus, la punta con que el barbero abre la vena para sangrar' (NTLLE, s. v. lanceta, Nebrija, 1495; Covarrubias, 1611). Es una voz derivada de lanza del lat. LANCĔA (DECH, s. v. lanza).

Un estuche del ofiçio de zirujía y en él siete lanzetas, un apostemero, un sajador, un berduguillo, una tienta, unas tijeras, una espadilla de plata, una lima, unas pinzas, una abuja, um botador, dos cañones, un de aujas y otro de polvos (Valderas, LE-1682)

Frente a las escasas documentaciones que la voz lanceta posee en el corpus terracampino y en los documentos notariales que conforman el CorLexIn, su presencia es relativamente frecuente en las bases de datos del castellano-CORDE y $C D H$ - que dan testimonio de esta a partir del siglo XIII, en la gran mayoría de los ejemplos en obras de corte técnico y literario.

Desde un punto de vista morfológico, presenta el morfema derivativo -eta, sufijo de sustantivos principalmente y de gran productividad en castellano (Pharies, 2002: 240).

\section{PINZAS [despinzas, despinças]}

Sust. f. 'Instrumento, generalmente compuesto de dos piezas, cuyos extremos se aproximan para hacer presión sobre algo y sujetarlo', 'pliegue que se cose en la tela para darle una forma determinada' o en plural 'Instrumento a manera de tenaza pequeña, que sirve para coger o sujetar algo' (DLE, 1. a , 3. a y 5. a ac.). Covarrubias recoge el término en plural con el significado de 'las tenazuelas con que se despinça, es instrumento de cirujanos, dizense à pungendo. Despinzar, despinçadera la muger, que saca los nudillos del paño quando acaba de salir del telar' (NTLLE, s. v. pinzas, Covarrubias, 1611). Término tomado del fr. pinces 'tenazas', 'pinzas', derivado de pincer 'coger con tenazas', 'pellizcar' (DECH, s. v. pinzas).

Un estuche del ofiçio de zirujía y en el siete lanzetas, un apostemero, un sajador, un berduguillo, una tienta, unas tijeras, una espadilla de plata, una lima, unas pinzas, unabuja, um botador, dos cañones, un de aujas y otro de polvos (Valderas, LE-1682)

Una basquiña de estameña pardo aforrada el ruedo con olandilla azul que la mandó las pinzas a Juana Aparicio tassada en setenta reales (Frechilla, 1675)

\footnotetext{
${ }^{25}$ Rojo Vega localiza este término en documentación notarial vallisoletana y perteneciente a profesionales de la salud: "otro gatillo y un botador", Testamento e inventario de un fabricante de instrumental quirúrgico: Alonso Carrasco; "un botador", Inventario de un barbero cirujano: Andrés de Mijangos, 1596; "un botador y una palatilla y un escarnador", Inventario y libros de un barbero-cirujano: Andrés Maldonado, 1599; "Un policán y gatillo y botador", Inventario quirúrgico del hernista y urólogo Diego de Zama, 1624; "un botador y un descarnador en cinco reales", Testamento e inventario de Rodrigo Álvarez Vélez cirujano y batidor de cataratas, 1646. Consultado en diciembre de 2020 en la web Investigadores de la Real Biblioteca <https://investigadoresrb.patrimonionacional.es/>.
} 
Diacrónicamente este término se documenta en el CDH y en el CORDE a partir de finales del siglo XIV con sentido figurado, ya que forma parte de la obra literaria de Juan Fernández de Heredia, Gran crónica de España (1385): "encara pelar con pinças de /que fue / muchas uezes escarnido". Los ejemplos que aparecen en estas bases de datos pertenecen, sobre todo, a obras o tratados de corte técnico. Es un término poco frecuente en el CorLexIn, tan solo documenta un caso en un inventario s de Cuzco (Perú).

El corpus terracampino registra este término de forma esporádica, los dos ejemplos encontrados hacen referencia a campos semánticos distintos. Por un lado, estarían las pinzas del barbero-cirujano y por otro, un término perteneciente al mundo textil. En referencia a este último significado, cabe señalar que encontramos otra variante derivada con el prefijo des-:

quatro despinças en real y medio (Frechilla, PA-1613)

Zinco despinças (Frechilla, PA-1615)

quatro despinzas de hierro en quatro reales (Frechilla, PA-1675)

Las obras lexicográficas académicas registran esta palabra a partir de la edición de 1791 donde se define como 'instrumento para despinzar los paños: lo mismo que pinzas' y que mantiene hasta hoy. Su carácter singular hace que no esté presente en bases de datos como el CORDE o el $C D H$, así como en el CorLexIn. Estamos ante un tecnicismo del ámbito textil y que en el corpus estudiado se localiza en los inventarios de Frechilla, famosa en la época por su industria textil.

\section{VENTOSA [bentosa]}

Sust. f. 'Vaso o campana, comúnmente de vidrio, que se aplica sobre una parte cualquiera de los tegumentos, enrareciendo el aire en su interior al quemar una cerilla, una estopa, etc.' (DLE, 5. a ac.). Covarrubias define este término como 'vaso hueco y ventrudo, y angosto de boca, y assi sepudo dezir ventosa [...]'. Autoridades entre otras acepciones mantiene la de 'Instrumento de Cirugia, que es un vaso por lo regular de vidrio, augosto de boca, y ancho de barriga, que calentandole con estopas encendidas, se aplica à algunas partes del cuerpo, para atraher con violencia los humores à lo exterior, y suelen sajar algunas veces aquella parte, y entonces las llaman Ventosas sajadas: y quando no se hace esta operacion, las llaman Ventosas secas' (NTLLE, s. v. ventosa, Covarrubias, 1611; Autoridades, 1739). Término derivado de viento, y este procedente del lat. VĔNTUS (DECH, s. v. viento).

Una çesta con beinte y ocho bentosas grandes y dozena y media de bentosas de niños (Valderas, LE-1682)

El CORDE y el CDH dan amplio testimonio de esta lexía a partir del Fuero de Cáceres fechado en 1234.

En la documentación estudiada de Tierra de Campos, tan solo aparecen los dos ejemplos localizados en un inventario de Valderas (León), con forma y significado académico. Es un instrumento utilizado en 'Cirugia' como señala Autoridades. 


\section{VERDUGUILLO [berduguillo]}

Sust. m. 'Arma blanca, como, por ejemplo, una navaja o un puñal' (DLE, 3. a ac.). Esta palabra la recoge la edición de 1780 del DRAE con la acepción de 'navaja angosta de barbero' (NTLLE, s. v. verduguillo, $D R A E, 1780)$. Término derivado de verdugo que en arag. significa 'hoz de acero' (DECH, s. v. verdugo).

Un estuche del ofiçio de zirujía y en el siete lanzetas, un apostemero, un sajador, un verduguillo y una tienta (Valderas, LE-1682)

Una raspa y un berduguillo del oficio [zapatero] (Medina de Rioseco, VA-1649)

Se localizan dos ocurrencias con acepciones diferentes en Tierra de Campos, una coincidente con la dada por el DRAE de 1780 y la otra tiene que ver más bien con una navaja o cuchillo que utilizaban los zapateros.

El $C D H$ y el CORDE solo registran dos ejemplos de esta voz en el siglo XVII, en el inventario de los Bienes muebles que pertenecieron a Felipe II fechado en 1600, con la acepción de un 'tipo de tejido o tela que servía para confeccionar adornos'. Esta escasez de ocurrencias se traslada también al CorLexIn donde se localiza un caso en Oviedo (1634) "una raspadera y berduguillo" que aparece referenciado junto a otras herramientas propias del oficio de zapatero -ormas, entresuelas, cuero de suela, chaplones... - .

\subsubsection{Albañiles}

\section{AMACAL [amecal]}

Este término no aparece registrado en las obras lexicográficas que configuran el NTLLE. El término referencia un molde de madera con el que se hacen los adobes.

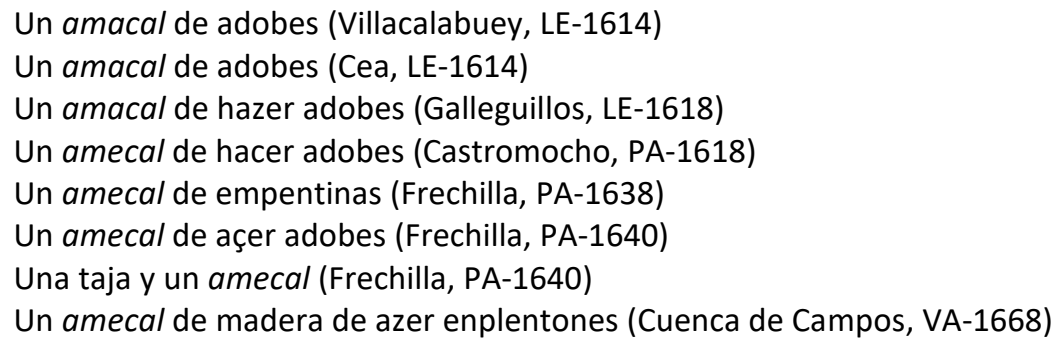

A pesar de la poca o nula presencia de este término en los diccionarios y en las bases de datos académicas, en la Tierra de Campos aparece de manera frecuente y con dos variantes: amacal y amecal, esta segunda con el cambio de timbre en la vocal átona tan frecuente en esta época. En el CorLexIn aparece un ejemplo con la variante amacal en Carrión de los Condes, localidad palentina muy próxima a la Tierra de Campos.

En estudios más recientes encontramos las formas amacal, amecal y macal con la aféresis de la /a/ inicial como por ejemplo en el Vocabulario palentino de Godaliza como 'molde para hacer adobes' (Gordaliza, 1988: 28). Le Men localiza este término en vocabularios del sur de 
León con la forma macal (Le Men, 2007: 512). En Paredes de Nava se registra esta voz como muy frecuente en esta localidad (Helguera y Nágera, 1990: 503).

No es extraño que este instrumento esté presente en los inventarios de la Tierra de Campos ya que la construcción con adobes ha sido habitual hasta hace muy poco en la misma. El amacal o amecal estaba formado por cuatro tablas perimetrales y una central para ir haciendo los adobes de dos en dos.

\section{EMBARRADERA [enbarradera, envarradera]}

No aparece en el $D L E$, ni en ninguno de los diccionarios académicos y preacadémicos. Es una palabra derivada del verbo embarrar, y este a su vez del sustantivo barro 'arcilla' (DECH, s. v. barro ॥).

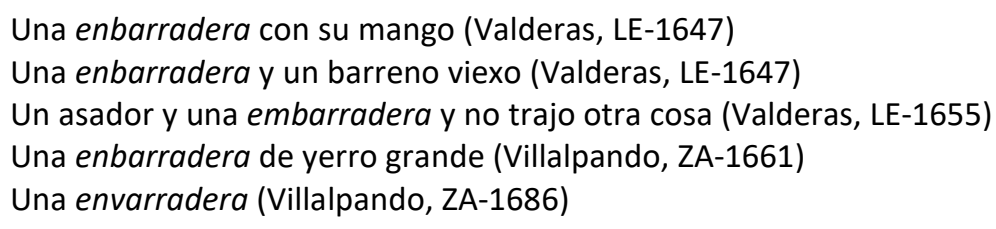

No hay constancia de esta voz en los textos que conforman el CDH ni el CORDE. Los ejemplos que aparecen en los inventarios de bienes del siglo XVII se localizan en la Tierra de Campos, como Valderas (León) y Villalpando (Zamora), coincidiendo con la parte más occidental de la zona de estudio. Lo interesante de esta lexía es su distribución geográfica que nos permite determinar que estamos ante un término propio de esta zona. En el CorLexIn no figura ni embarradera, ni embarrador, pero sí 'paleta de embarrar' en localidades como Candelera (Ávila, 1648) o Mansilla Mayor (Léon, 1637). Morala localiza este mismo sintagma en Casarejos (Soria, 1648) o también 'plana de lucir' en Santa María la Real de Nieva (Segovia, 1652) (Morala, 2018a: 74). Su forma en masculino embarrador sí que aparece el $C D H$ desde el siglo XVI, aunque el mayor número de ejemplos se documentan en el siglo XVII con la acepción de 'el que embarra'.

Embarrar en el DLE es 'untar y cubrir con barro y en Ávila, Extremadura, Salamanca y Zamora también significa enjalbegar las paredes o, lo que es lo mismo, blanquear las paredes con cal, yeso o tierra blanca'.

\section{TRULLADERA}

La palabra trulladera no figura recogida en el $D L E$, aunque sí aparece el verbo del que deriva, trullar que presenta marca diatópica como término utilizado en Palencia y con el significado de 'enlucir con barro una pared' o 'manchar, embadurnar' (DLE).

Una trulladera y una plana (Castromocho, PA-1614)

Una trulladera biexa (Frechilla, PA-1675)

En Tierra de Campos se localizan dos ocurrencias de este término. Esta lexía no aparece en bases de datos como el CORDE o el $C D H$, y tampoco en los inventarios de bienes del siglo XVII. Morala señala que este derivado tendrá el mismo significado que trulla y que sería sinónimo de 
Ilana o embarradera (Morala, 2018a: 90), términos que también se localizan en la zona de estudio.

\section{TRULLA}

Sust. f. 'llana ${ }^{1}$ ('herramienta compuesta de una plancha de hierro o acero y una manija o un asa, que usan los albañiles para extender y allanar el yeso o la argamasa')' (DLE, s. v. trulla ${ }^{2}$ ). Autoridades recoge la palabra trulla que equipara con 'llana de albañil' (NTLLE, s. v. trulla, Autoridades, 1739). Es una voz que proviene del lat. TRULLA (DECH, s. v. trulla ॥).

Una trulla de embarrar (Boadilla de Rioseco, PA-1692)

Con la acepción que presentan los textos estudiados, no hay muchos ejemplos en el $C D H$, aunque, como señala Morala, figura en el Universal Vocabulario de Alfonso de Palencia de 1490 (Morala, 2018a: 90). La presencia tan excepcional de trulla en el corpus terracampino viene dada por el uso de otros términos con un significado muy cercano o parecido como embarradera o Ilana, incluso algunos de ellos derivados de esta misma palabra como es el caso de trulladera.

\section{LLANA}

Sust. f. 'Herramienta compuesta de una plancha de hierro o acero y una manija o un asa, que usan los albañiles para extender y allanar el yeso o la argamasa' (DLE). Lo mismo que ocurre con el término plana, Autoridades referencia la voz latina TRULLA y describe esta palabra con la definición que mantenemos hoy en día (NTLLE, s. v. Ilana, Autoridades, 1734). Voz derivada de llano, del lat. PLANUS (DECH, s. v. Ilano).

Vna llana de henbarrar (Valderas, LE-1647)

Un artesón de pino con llanas (Autillo de Campos, PA-1653)

Un varrilete de yerro, una Ilana, dos azuelas viejas (Medina de Rioseco, VA-1641)

La voz llana designa una especie de paleta para distribuir, entre otros materiales, la arcilla con paja del embarrado que cubría la pared exterior de las casas, una vez colocados los adobes. Por lo tanto, estamos ante un término técnico propio de los albañiles y como pasa en otras ocasiones, la distribución de esta lexía en documentación histórica del castellano es exigua.

Los documentos notariales que conforman el CorLexIn presentan el término llano y llana, con naturaleza adjetiva y con el significado de 'sencillo, sin ornamento alguno'. Sin embargo, no hay presencia de la herramienta de albañilería en los textos, dada su especificidad. Sí se ha localizado una ocurrencia en un documento vallisoletano recogido por Rojo Vega ${ }^{26}$ :

Dos escarpias garabatos, una llana y un martillo (Testamento, inventario y biblioteca de Gregorio Tovar del Consejo de Órdenes, Valladolid, 1636)

26 https://investigadoresrb.patrimonionacional.es/, ejemplo tomado de la web Investigadores de la Real Biblioteca, recogido por Rojo Vega. [consultado, agosto, 2020] 


\section{PLANA}

Sust. f. 'llana ${ }^{1}$ ('herramienta compuesta de una plancha de hierro o acero y una manija o un asa, que usan los albañiles para extender y allanar el yeso o la argamasa')' (DLE, s. v. plana ${ }^{1}$ ) Covarrubias registra esta palabra con dos acepciones que encontramos en los textos de Tierra de Campos, como 'instrumento del murador o del albañil, por allanar con ella la cal, y el yeso' y referencia el término latino TRULLA. Además, plana era también 'la escritura de vna haz de la hoja del papel'; Autoridades por su parte equipara este término con llana y afirma que se conserva esta voz en el Reino de Murcia, pero que regularmente se usa llana (NTLLE, s. v. plana, Covarrubias, 1611; Autoridades, 1737). Voz derivada de Ilano, del lat. PLANUS. Corominas y Pascual también señala la marca diatópica de esta palabra, como usada en Murcia (DECH, s. v. Ilano).

Una trulladera y una plana (Castromocho, PA-1614)

En los textos estudiados aparece una ocurrencia de este término junto a trulladera, otro de los términos que parecen tener el mismo significado. Cabe destacar que este ejemplo está inventariado en el mismo asiento, por lo que parece que se trata de dos objetos diferentes, tal vez con una función muy similar, pero diferente al fin y al cabo. En el CorLexIn encontramos muy pocos ejemplos, dos ubicados en la Península y con una acepción diferente a la recogida por los diccionarios - parece tratarse de una herramienta utilizada por los cuberos-; y otro ejemplo en Panamá con la acepción con la que encontramos en los documentos de la Tierra de Campos "vna juntera, dos planas de madera, vn cepillo [...]" (Los Santos, 1611). Pese a la marca diatópica de Autoridades o el $D E C H$, no encontramos ejemplos de este término en Murcia.

\section{MACHóN [maçhones]}

Sust. m. 'Madero de escuadría de cinco metros de largo' (DEL). Este término lo define Autoridades como 'voz de la Architectúra. Pilár sin labór, que sostiene por alguna parte principal la fábrica' (NTLLE, s. v. machón, Autoridades, 1734). Palabra derivada de macho con el significado de 'hacha grande de cortar' o 'viga escuadrada' en Zamora (DECH, s. v. macho II).

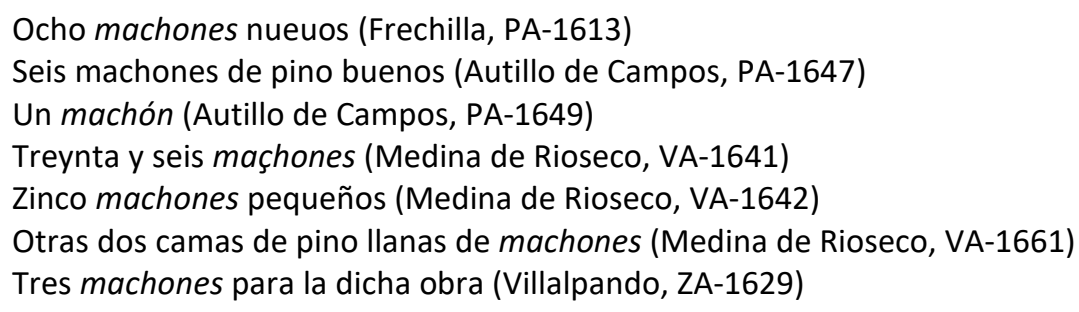

El término machón figura en documentos ya entrado el siglo XVII, más en concreto aparece en una obra toledana que habla del arreglo de unas casas en $1663(C D H)$. En el CorLexIn no encontramos ninguna ocurrencia, aunque esto no quiere decir que no fuera una palabra común. Se trata tan solo de un término técnico o reservado al mundo de la arquitectura y por ello no constan muchos ejemplos en la documentación en general. En cambio, en la Tierra de Campos se localizan unos cuantos casos repartidos entre las diferentes provincias que recorren esta zona. En estudios dialectales más recientes, la palabra machón se recoge como 'cada tablero 
grande que se coloca sobre los tablones que cubren la uva del lagar. Sobre ellos se construye el castillo' (Gordaliza, 1988: 141).

\section{PIQUETA}

Sust. f. 'zapapico' y 'herramienta de albañilería, con mango de madera y dos bocas opuestas, una plana como de martillo, y otra aguzada como de pico' (DLE). Esta palabra se recoge en Autoridades con las mismas acepciones que conservamos hoy en día, como herramienta de albañil y también de labradores (NTLLE, s. v. piqueta, Autoridades, 1737). Término derivado de picar (DECH, s. v. picar).

Tres piquetas de ganado (Villacalabuey, LE-1614)

Una bigornia de hacer ojales y una piqueta de peña (Frechilla, PA-1614)

Otra piqueta y una caja de taça (Frechilla, PA-1640)

Una piqueta (Frechilla, PA-1637)

Un açadón y una piqueta (Frechilla, PA-1639)

Una piqueta buena de hierro (Fechilla PA-1675)

Una piqueta tasose en quatro reales (Villalpando, ZA-1689)

Una piqueta de yerro (Villalpando, ZA-1698)

Diacrónicamente piqueta se documenta en bases de datos como el $C D H$ en la segunda mitad del siglo XVI con un par de ejemplos y lo mismo ocurre en el XVII y XVIII. Es en el siglo XIX cuando esta palabra comienza a tener más presencia en los textos. La escasez de datos en el siglo XVII se extrapola a lo que se observa en el CorLexIn donde se localiza un ejemplo en la segunda mitad de siglo, en La Rioja, como apero del campo: "Más de herramientas del campo, cinco piquetas y tres achas" (Pedroso, LR-1676). El corpus terracampino presenta unas cuantas ocurrencias de este término, que, por el contexto en el que aparecen, ofrecen diferentes acepciones. Piqueta se documenta con el significado académico cuando aparece entre bigornias, toberas o yunques, también se localiza como un apero de labranza y así está entre azadas y azadones. Por último, el primer ejemplo proveniente de Villacalabuey (León) habla de "piquetas de ganado", por lo que la acepción que aquí tiene difiere de las dos anteriores. Le Men localiza este término en el noreste de León como 'cencerro pequeño' y que se extiende a otros lugares de la Península como Salamanca o Extremadura y que se ajustaría al significado que presenta el ejemplo de Villacalabuey en el corpus objeto de estudio (Le Men, 2009, s. v. piqueta). En este sentido, aparece el diminutivo piquetico, que se encuentra inventariado después de un cencerro y que podría tener este último significado:

Dos piquetiços pequeños (Tamariz de Campos, VA-1651)

\section{PLOMADA}

Sust. f. 'Instrumento compuesto por una pesa cilíndrica o cónica de metal que se sujeta al extremo de una cuerda para que esta, tensada por la fuerza de la gravedad, señale la línea vertical' (DLE). Nebrija recoge esta voz como 'plomada de reglar' y Autoridades la define como 'cierta pesa de plomo, que atada à una cuerda sirve a los Maestros de obras y otros Artífices, para reconocer la igualdad de una paréd ù otra obra' (NTLLE, s. v. plomada, Nebrija, 1495; Autoridades, 1737). Es un término derivado de plomo, del lat. PLǓMBUM (DECH, s. v. plomo). 
Una plomada, tres zepillos (Medina de Rioseco, VA-1641)

Una plomada en quatro reales (Medina de Rioseco, VA-1661)

Una escoda de cantero, un zinzel, plomada, nivel y un conpás (Villalpando, ZA-1696)

El $C D H$ y el CORDE recogen esta palabra polisémica desde el siglo XIII, pero es a partir del siglo XV cuando aparece este significado, tanto en el CORDE como en el CDH. Plomada presenta un número reducido de ocurrencias en Tierra de Campos que presenta el significado académico. El CorLexIn recoge un único caso en la localidad abulense de Cebreros: "vn esparabel con su plomada, en tres ducados". Rojo Vega encuentra varios ejemplos de esta voz en inventarios vallisoletanos pertenecientes a arquitectos, maestros de ingenios de jardines, albañiles, pintores o maestros de obras ${ }^{27}$. En los documentos de Tierra de Campos presenta una escasa nómina de casos con el significado académico.

\subsubsection{Carpinteros}

\section{AZUELA [açuela, çuela]}

Sust. f. 'Herramienta de carpintero que sirve para desbastar, compuesta de una plancha de hierro acerada y cortante, de diez a doce centímetros de anchura, y un mango corto de madera que forma recodo' (DLE). Se trata de una palabra procedente del hispanolatino ASCIOLA, diminutivo del lat. ASCIA 'azuela', 'hacha' (DECH, s. v. azuela).

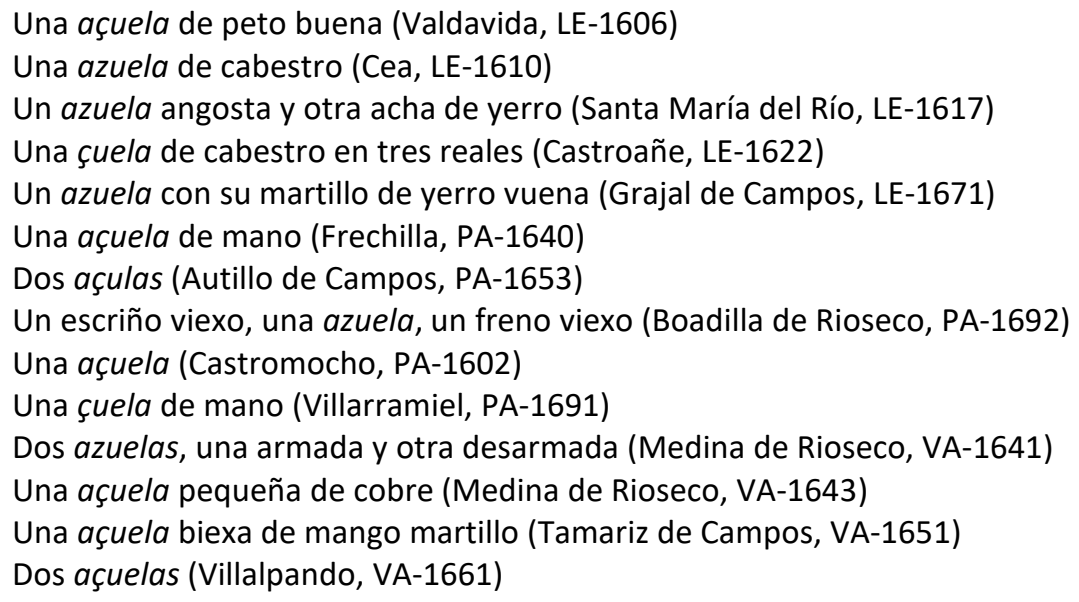

27 Estos ejemplos han sido tomados de la web Investigadores de la Real Biblioteca https://investigadoresrb.patrimonionacional.es/, recogidos por Rojo Vega:

"Una plomada" (Inventario de un gallinero y arquitecto: Alonso Rodríguez, Valladolid, 1584)

"Dos piquetillas biexas, dos plomadas viejas Y una plomada nueba" (Testamento e inventario de Antonio Salvador, maestro de obras y carpintero, Valladolid, 1607).

"Una plomada de bronçe pequeña" (Inventario de Juan de la Cuesta, arquitecto y vecino de Penagos, Valladolid, 1624).

"Una azuela y una palanca de yerro de catorze libras y una plomada en ziento y zinquenta reales" (Inventario de un albañil: Tomás de Palacios, Valladolid, 1671). 
Una azuela y martillo (Villalpando, VA-1685)

Una azuela de cabresto (Villalpando, ZA-1686)

Una azuela de martillo (Villalpando, ZA-1690)

Este término aparece a lo largo de toda la Tierra de Campos donde se aprecian diferentes tipos: " de peto", "de cabestro", "de mano", "de martillo". Es un término de uso general que aparece abundantemente documentada en bases de datos como el CORDE y el CDH desde el Fuero de Cáceres fechado entre 1234 y 1275.

En el área de estudio nos encontramos con dos variantes, la normativa azuela que aparece en el $D L E$, cuyo uso es habitual en la zona, pero también nos encontramos con la forma zuela, con aféresis de la /a-/. En los textos, este término aparece, en ocasiones, con la acepción del $D L E$, es decir, como instrumento para rebajar la madera, pero otras veces, parece que su uso no es solamente el de trabajar la madera, sino que es una herramienta destinada a quehaceres agrícolas, ya que inventaría entre útiles propios de la labranza.

Actualmente localizamos el término azuela en Palencia donde 'se llama así a una azoleta. Era una pequeña azada, parecida al azadón, con una cuchilla larga y estrecha y mango alto para escardar el trigo o la cebada' (Gordaliza, 1988: 39). En el este de Zamora se conserva la voz zuela y azuela como instrumento para limpiar las tierras de malas hierbas de los campos en primavera (Álvarez Tejedor, 1989: 66).

En el siglo XVII su uso está generalizado y con las dos acepciones que encontramos en nuestra zona de estudio, de hecho, en Bercial de Zapardiel, en Ávila aparece "una azuela de labranza" (CorLexIn).

\section{BARRENO [varreno]}

Sust. m. 'Barrena, especialmente la de tamaño grande' y barrena lo define como 'Instrumento de acero con una rosca en espiral en su punta y provisto generalmente de un mango en el otro extremo, que sirve para taladrar madera, metal, piedra u otro cuerpo duro' (DLE). Es en la edición de Autoridades de 1770 en la que se incluye la acepción que lo equipara con el término barrena 'comunmente se usa la terminación masculina para significar los que son de mayor tamaño' (NTLLE, s. v. barreno, Autoridades, 1770). Término derivado de barrena, del hispanoárabe barrîna, y éste del lat. vERUĪNA 'jabalina' (DECH, s. v. barrena).

Un punzón y un barreno (Cea, LE-1621)

Ocho barrenos grandes y pequeños del oficio de carpintero (Valderas, LE-1647)

Una enbarradera y un barreno viexo (Valderas, LE-1647)

Tres barrenos, dos conpases (Castromocho, PA-1614)

Un barçón y un barreno (Frechilla, PA-1640)

Un barreno (Guaza de Campos, PA-1642)

Un varreno grande (Boadilla de Rioseco, PA-1692)

Quatro barrenos de amedios trabaderos (Medina de Rioseco, VA-1661)

Un barreno grande de orejones (Villalpando, ZA-1661)

Es un término documentado en la literatura a partir del siglo XVI en el $C D H$. En los protocolos notariales del siglo XVII se localizan media docena de ejemplos repartidos por diversos puntos de la Península como Vitoria (Álava), Sos del Rey Católico (Zaragoza), Santurde (La Rioja), 
Villacelama (León) y Alburquerque (Badajoz), y puntos de las Islas Canarias (Tenerife) y América (Santiago de Chile), aunque la voz más frecuente en los inventarios es barrena, hecho que contrasta con la Tierra de Campos, donde se prefiere el término masculino frente al femenino barrena, del que no se han encontrado ejemplos en los textos analizados.

\section{BARRILETE [varrilete]}

Sust. m. 'Instrumento grueso de hierro y con forma de un siete, que usan los carpinteros y otros artesanos para asegurar sobre el banco los materiales que labran' (DLE). Lo recoge Autoridades con la acepción actual en su edición de 1770, en ediciones anteriores lo registra como un término náutico (NTLLE, s. v. barrilete). Es una palabra derivada de barril y esta a su vez de barrica, tomado del gasc. barrique, procedente de una base *barrīca, de origen incierto (DECH, s. v. barril)

Una prensa y un barrilete (Paredes de Nava, PA-1690)

Un varrilete de yerro (Medina de Rioseco, VA-1641)

El corpus terracampino presenta un número exiguo de ocurrencias. Por el contexto en el que se presentan, no parece que hagan referencia al mismo instrumento. En el documento vallisoletano, barrilete aparece con la misma acepción que ofrece el $D L E$, ya que estamos ante el inventario de un carpintero. Sin embargo, en el que se localiza en Palencia, se trata del diminutivo de barril, término que tiene más que ver con un recipiente para contener vino u otro líquido. Aparece documentado en el CORDE, donde tan solo un documento de este siglo hace referencia al término con la acepción de herramienta de carpintero. Tampoco se han encontrado ejemplos en repertorios léxicos, ni en el CorLexIn.

\section{CANALADOR [canelador]}

Sust. m. el término más parecido que recoge el DLE es acanalador que define como 'instrumento para abrir en los cercos y peinazos de puertas y ventanas ciertas canales en que entran y quedan asegurados los tableros'. Con el lema canalador aparece en los diccionarios académicos hasta la edición de 1992, así la edición de Autoridades de 1729 recoge esta voz como 'instrumento à modo de cepillo, de que usan los ensambladores, con el hierro al canto, y su rosca para ensancharle ò encogerle, del qual se sirven para formar canales en la madera, de cuya voz se formó', aunque en la edición de la academia de 1780 ya aparece este término como voz antigua, prefiriendo la forma acanalador (NTLLE, s. v. canalador, Autoridades, 1729; DRAE, 1780).

Un canelador biejo (Medina de Rioseco, VA-1661)

En la Tierra de Campos encontramos un ejemplo con la forma canelador, con cambio de timbre en la vocal átona. Esta misma variante se registra en algunos diccionarios no académicos como el de Terreros y Pando donde aparece como 'especie de cepillo, que usan los carpinteros para acepillár la madera, y formar canales en ella' o en los diccionarios de Gaspar y Roig y Rodríguez Navas (NTLLE, s. v. canelador, Terreros y Pando, 1786; Gaspar y Roig (1853); Rodríguez Navas, 1918). Se trata pues de una herramienta profesional utilizada por los carpinteros y que no es muy frecuente en los inventarios de esta época dada la especificidad de estos términos, 
hecho que se puede apreciar en el resultado de la búqueda en el CorLexIn que devuelve un único ejemplo localizado en un inventario de Álava (Vitoria, 1638) con la forma académica (Morala, 2015a: 1508), sin cambio de timbre en la vocal átona.

\section{CEPILLO [çepillo, zepillo]}

Sust. m. 'Instrumento hecho de cerdas distribuidas en una armazón, que sirve para distintos usos de limpieza', 'instrumento de carpintería formado por un prisma cuadrangular de madera dura, que lleva embutido, en una abertura transversal y sujeto por una cuña, un hierro acerado con filo, el cual sobresale un poco de la cara que ha de ludir con la medra cuya superficie se quiere alisar' (DLE, 1. a y 2. a ac.). Voz registrada desde el Vocabulario de Nebrija y con las acepciones que encontramos en el corpus analizado. Término derivado de cepo, del lat. CĭpPUS ( $D E C H$, s. v. серо).

Dos cepillos de linpiar sonbreros, biexos (Valderas, LE-1647)

Vn çepillo; más otros dos çepillos, todos guarneçidos (Valderas, LE-1647)

Un zepillo en dos reales (Medina de Rioseco, VA-1661)

Zinco zepillos biejos en real y medio todos (Medina de Rioseco, VA-1661)

Un cepillo (Villalón, VA-1637)

Una plomada, tres zepillos (Medina de Rioseco, VA-1641)

Un cepillo grande y otro pequeño en tres reales y medio (Cuenca de Campos, VA-1666)

Un cepillo de limpiar (Villalpando, ZA-1660)

Otro cepillo juntera (Villalpando, ZA-1661)

Esta voz está presente a lo largo del corpus estudiado, con dos acepciones diferentes, por un lado, hace referencia a un instrumento utilizado por los carpinteros para rebajar la madera, ya que aparece con otras herramientas propias de este oficio; y por otro, como cepillo de limpiar la ropa y, sobre todo, los sombreros.

\section{ESCOFINA}

Sust. f. 'Herramienta a modo de lima, de dientes gruesos y triangulares, muy usada para desbastar' (DLE). Nebrija recoge este término como 'escofina para limar madera' y Covarrubias amplía la definición: 'lima grande de dientones gruessos: desta vsan los entalladores' (NTLLE, s. v. escofina, Nebrija, 1495; Covarrubias, 1611). Voz procedente del lat. vulgar *scoffīnA forma dial. itálica del lat. scoBînA (DECH, s. v. escofina).

Una escofina en dos reales (Medina de Rioseco, VA-1661)

Desde un punto de vista diacrónico, escofina está presente tanto en el CORDE como en el $C D H$ en un inventario de bienes fechado en 1322. A pesar de esta temprana aparición, el número de concordancias es escaso, posiblemente por tratarse de un término técnico, como ocurre con otras lexías. Esta falta de ocurrencias también se nota en el CorLexIn donde hay un par de ejemplos en el sur de la Península, en Badajoz y Jaén, también con esta acepción. Lo mismo ocurre en la Tierra de Campos, donde el único ejemplo encontrado se ubica en Medina de Rioseco (Valladolid). 


\section{ESCOPLO [hescoplo]}

Sust. m. 'Herramienta de hierro acerado, con mango de madera, de unos $30 \mathrm{~cm}$ de largo, sección de uno a tres centímetros en cuadro, y boca formada por un bisel', término específico de la carpintería (DLE). Recogido desde Nebrija con la misma acepción que recogen los diccionarios actuales. Término procedente del antiguo escoplo, y este del lat. SCALPRUM 'escoplo', 'buril', 'podadera', 'escalpelo', derivado de SCALPĚRE 'rascar', 'grabar, esculpir'. Escopro se alteró en escoplo por influecia ultracorrecta leonesa, que convierte comúnmente el grupo /pl/ en /pr/ (DECH, s. v. escoplo).

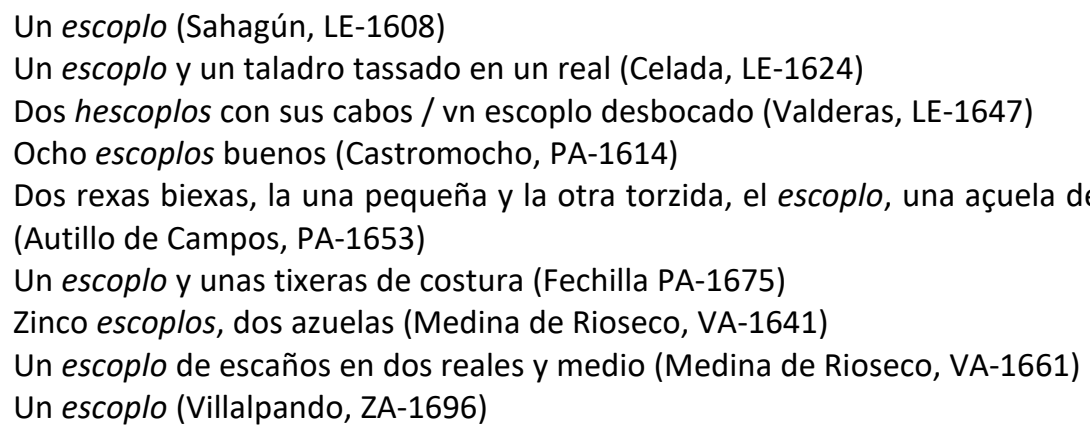

Morala y Le Men localizan la forma escopro en un documento medieval de Carrizo (León) en un inventario fechado en 1268 en el que se puede leer "una azuela y un escopro" (Morala-Le Men, 1996 en Le Men, 2005, s. v. escoplo). El CDH documenta esta palabra en el siglo XIII bajo la forma escopro. La variante estándar se documenta unos años más tarde en el Libro de los caballos (1275).

El CorLexIn presenta poco más de una veintena de ocurrencias entre documentos peninsulares y americanos de Colombia y Panamá, sin un patrón geográfico de reparto claro. En el siglo XVII la variante de uso generalizado es escoplo, lo mismo que sucede en el corpus de estudio, no hay ocurrencias de escopro. Es un término de uso general que hace referencia a una herramienta utilizada en carpintería.

\section{GARLOPA}

Sust. f. Carp. 'Cepillo largo y con puño, que sirve para igualar las superficies de la madera ya cepillada, especialmente en las junturas de las tablas.' (DLE). Término recogido por algunos diccionarios preacadémicos del siglo XVII y XVIII, al igual que Autoridades que lo registra como un término propio de los carpinteros (NTTLE, s. v. garlopa, Autoridades, 1732). De oc. garlopo, fem., y este del fr. dial. warlope íd., que a su vez resulta de un cruce de las denominaciones que este instrumento tiene en los dialectos flamencos: voorlooper, propte. 'precursor' y weerlucht, propte. 'relámpago'. Explicables ambas porque la garlopa precede a la labor del cepillo, como el relámpago al trueno (DECH, s. v. garlopa).

Una garlopa bieja en real y medio (Medina de Rioseco, VA-1661)

Una garlopa grande en ocho reales (Medina de Rioseco, VA-1661)

Este término se documenta de forma tardía en bases de datos como el $C D H$, aparecen muy pocos ejemplos fechados antes del siglo XX, el primero, localizado en el siglo XVII data de 1652 y 
procede de Colombia. En el CorLexIn se localizan tan solo dos ocurrencias, una muy cerca de la zona de estudio, en Solanilla (León, 1662) y la otra en Vitoria (Álava, 1638). Esta ausencia de ejemplos puede ser debido a dos motivos; uno, que, al tratarse de una herramienta especializada, no es habitual en los inventarios de bienes, y dos, puede que comparta campo semántico muy próximo al de juntera o cepillo.

\section{GUBIA}

Sust. f. 'Formón de mediacaña, delgado, que usan los carpinteros y otros artífices para labrar las superficies curvas' (DLE). La variante guvia se registra en el Suplemento al Tesoro de Covarrubias como 'una forma de escoplo acanalado con que los entalladores forman las que llaman medias canas. Diçen ser nombre muy antiguo y dél se dixo Aguviar por torçer y Aguviado lo que está torçido y enarcado' (CDH, s. v. guvia). Autoridades recoge esta voz en la edición de 1734 con la acepción y grafía que conservamos hoy en día, aunque anteriormente es recogida por diccionarios no académicos con las variantes gráficas con / v/ y con / $\mathrm{u} /$ como el de Casas en 1570, Oudin en 1607 o Rosal en 1611 como 'herramienta de carpintero' (NTLLE, s. v. gubia/guvia/guuia Casas, 1570; Oudin, 1607; Rosal, 1611; Autoridades, 1734). Término procedente del lat. tardío GǓLB̆A íd., de origen céltico, emparentado con el irl. ant. gulba 'pico de ave' (DECH, s. v. gubia).

Una gubia en dos reales (Medina de Rioseco, VA-1661)

Al tratarse de un término específico de una profesión, en este caso, la de carpintero, su presencia en los textos es menor, aunque es una palabra de uso general que hace referencia a una herramienta especializada. En el $C D H$ se registra esta palabra en textos a partir del siglo XVI con el significado académico. Esta escasez de ocurrencias también se observa en los documentos notariales $Y$ el CorLexIn presenta tres ocurrencias repartidas por el norte de la Península (Navarra, Álava y Burgos), junto a la localizada en Medina de Rioseco (Valladolid) en el corpus objeto de estudio.

\section{GUILLAME}

Sust. m. 'Cepillo estrecho que usan los carpinteros y ensambladores para hacer los rebajos y todo lo que no se puede cepillar con la garlopa ni con otros cepillos' (DLE). Este término lo recoge Terreros y Pando a finales del siglo XVIII y el diccionario académico a partir de sus ediciones del siglo XIX con la misma acepción que conservamos hoy en día (NTLLE, s. v. guillame, Terreros y Pando, 1787; DRAE, 1803). Es una palabra procedente del francés guillaume íd., del nombre propio de persona Guillaume, inventor de este cepillo ( $D E C H$, s. v. guillame).

Un guillame en quatro reales (Medina de Rioseco, VA-1661)

Es un galicismo que referencia un término propio del oficio de carpintero y que las obras lexicográficas recogen de manera tardía. Las bases históricas del castellano contemplan de forma exigua la variante guillamen con esta acepción en obras de corte técnico y ya entrado el siglo xx. El DECH da como primera documentación para esta palabra el diccionario de Terreros y Pando (1787). 
Esta falta de testimonios se traslada también a los documentos notariales del siglo XVII. Rojo Vega ${ }^{28}$ localiza un único caso entre los inventarios vallisoletanos que adelanta en más de un siglo la fecha dada por el $D E C H$ como primera documentación:

Tres gubias, un guillame, diez herramientas de moldear y tres junteras (Inventario de un ebanista y alquilador de tafetanes: Juan Pardo, Valladolid, 1669)

Y la ocurrencia localizada en el corpus terracampino adelanta en unos años el ejemplo anterior.

\section{JUNTERA}

Sust. f. 'Garlopa para alisar el canto de las tablas' (DLE, 2.a ac.). Este término aparece en Nebrija como 'juntera de carpintero' y Autoridades lo registra como 'Instrumento de Carpinteria, que tiene el corte por un lado solo, y sirve para pulir y acoplar las juntas de las tablas o maderos' (NTLLE, s. v. juntera, Nebrija, 1495; Autoridades, 1734). Término derivado procedente de JŪNCTŪRA, común a todo el romance de Occidente ( $D E C H$, s. v. junto).

Una juntera y dos espellas (Castromocho, PA-1614)

Una zesta de costillas y en ella una juntera (Medina de Rioseco, VA-1641)

Otro cepillo juntera (Villalpando, ZA-1661)

Como ocurre con otros términos técnicos, la presencia en los textos de juntera es más bien escasa. Desde un punto de vista diacrónico, el CORDE recoge esta palabra en el Arte cisoria, obra de Enrique de Villena, fechada en el año 1423 donde se puede leer "nos non podién debastar, fallaron açuela, plana e juntera que lo fiziesen". Esta base de datos documenta media docena de concordancias que van desde la primera mitad del siglo XV hasta finales del siglo XVII.

Los datos aportados por el CorLexIn presentan pocos ejemplos repartidos entre localidades leonesas (Gradefes y Solanilla) y Domingo García en Segovia, además de un ejemplo en Los Santos (Panamá), siempre con el mismo significado académico. A estos ejemplos hay que sumar las localizados en el corpus terracampino, tres casos en localidades de Palencia, Valladolid y Zamora. Cabe señalar que, desde un punto de vista formal, estamos ante un término derivado a partir de un sustantivo femenino (Perdiguero, 2012b: 386). Por otro lado, en los textos de Tierra de Campos se presenta con naturaleza adjetiva: "cepillo juntera" que junto con el sustantivo referencian la juntera de los otros asientos.

\section{TALADRO}

Sust. m. 'Herramienta aguda o cortante con que se agujerea la madera u otra cosa', 'agujero practicado con un taladro' (DLE). Este término lo recoge Nebrija en su Vocabulario y Covarrubias lo define en su Tesoro como 'la barrena con que agujereamos el madero, para que con más facilidad el clauo prenda en el' y Autoridades añade el significado de 'agujero angosto hecho con

\footnotetext{
${ }^{28}$ https://investigadoresrb.patrimonionacional.es/, ejemplo tomado de la web Investigadores de la Real Biblioteca, recogido por Rojo Vega.
} 
el taladro, ò barrena' (NTLLE, s. v. taladro, Nebrija, 1495; Covarrubias, 1611; Autoridades, 1739). Palabra procedente del lat. tardío TARATRUM íd., voz de origen céltico ( $D E C H$, s. v. taladro).

Dos açuelas de peto y seis taladros (Valdavida, LE-1606)

Un taladro pequeño (Sahagún, LE-1608)

Un yerro de melar, un taladro (Cea, LE-1610)

Un taladro (Villacalabuey, LE-1614)

Un taladro grueso y otro taladro de cabixares de yerro buenos (Santa María del Río, LE-1617)

Dos taladros pequeños (Santa María del Río, LE-1617)

Un escoplo y un taladro tassado en un real (Celada, LE-1624)

Una azuela quebrada y dos taladros (Castroañe, LE-1629)

Un martillo de yerro y dos taladros y una paletilla de yerro en medio ducado (Sahagún, LE-1633)

Esta voz se documenta tanto en el CDH como en el CORDE desde finales del siglo XIII. Respecto a la distribución diatópica que presenta el CorLexIn, no está muy claro el reparto geográfico, aunque de la docena de ocurrencias que aparecen la mayor parte pertenecen a la mitad norte de la Península donde se localizan ocurrencias en textos cántabros -Arroyuelos-, zamoranos -Mahíde y Muga de Alba-, palentinos -Otero de Guardo y Valderrabano de Valdavia- o leoneses -Mansilla Mayor, Sahagún, Santas Martas y Cordiñanes, en Valdeón (Morala, 2018a: 77)- a los que habría que sumar algunos casos en la zona de La Bañeza, estos documentados en el siglo XVIII (Gómez Ferrero, 2015: 109, 311). También se localizan ejemplos en documentos de Teruel y Jaén (CorLexIn). En la documentación estudiada figuran unos cuantos casos, todos ellos de la zona leonesa terracampina.

\subsubsection{Herreros}

\section{BIGORNIA}

Sust. f. 'Yunque con dos puntas opuestas' (DRAE). Covarrubias lo registra como 'vn instrumento, del que vsan los que labran hierro, en que aprietan la pieça que han de labrar, y les sirue como de mano' (NTLLE, s. v. bigornia, Covarrubias, 1611). Es una palabra procedente del lat. vulgar *B̆CǑRNIA, variante del adjetivo BICORNIS 'de dos cuernos' (DECH, s. v. bigornia).

Un añunque y una bigornia de hacer ojales (Frechilla, PA-1614)

Una bigornia en zinco reales (Medina de Rioseco, VA-1661)

Un yunque y una bigornia grande (Villalpando, ZA-1620)

Una bigornia de yerro buena (Villalpando, ZA-1633)

Al ser un instrumento especializado, aparece de manera aislada en los documentos estudiados. Lo mismo ocurre con el CORDE y en el $C D H$ donde se documenta desde el sigio XVI en textos procedentes de Ámerica, y a partir del siglo XVII también de la Península. Este uso esporádico de la voz se traslada al CorLexIn que da testimonio de media docena de ocurrencias repartidas entre Badajoz, Córdoba, Jaén y Perú.

Este instrumento podía ser utilizado tanto por herreros, como por zapateros. En la Tierra de Campos del siglo XVII, la birgonia no era un sinónimo de yunque, ya que aparecen juntos en 
el mismo asiento, lo que nos hace pensar que podrían ser instrumentos similares y existiese una diferencia de tamaño entre ellos.

En estudios más recientes, referencia al 'yunque que usa el herrador, para preparar y aplastar las herraduras de las caballerías. También el zapatero. Es de tres brazos' en zonas de Palencia (Gordaliza, 1988: 44); en poblaciones del este de Zamora esta voz designa 'el yunque para afilar la guadaña' (Álvarez Tejedor, 1989: 238).

\section{CLAVERA [clauera, clabera]}

Sust. f. 'Agujero o molde en que se forman las cabezas de los clavos' (DLE). Autoridades recoge esta palabra como 'el pedazo de tierra que naturalmente lleva y produce claveles sencillos o clavellinas sin cultivo', sin embargo esta acepción ya no aparece en el DRAE de 1780 donde esta voz figura como 'la turquesa, ó molde en que forjan los herreros las cabezas de los clavos', así como 'el agujero de la herradura por donde se introduce el clavo para asegurarla al casco', acepción esta última que sufre pequeñas variaciones a lo largo de los años. Estas dos últimas acepciones son las que mantiene la Academia hasta nuestros días (NTLLE, s. v. clavera, Autoridades, 1729; DRAE, 1780). Sin embargo, algunos de los diccionarios no académicos como el de Salvá, Gaspar y Roig o el Suplemento de Domínguez registran una acepción diferente y que es la que nos encontramos en los documentos analizados 'tabla en que hay varios clavos para colgar de ellos algunas cosas' (NTLLE, s. v. clavera, Salvá, 1846; Gaspar y Roig, 1853; Domínguez, 1869). Palabra derivada de clavo, y esta a su vez del lat. CLAVUS (DECH, s. v. clavo).

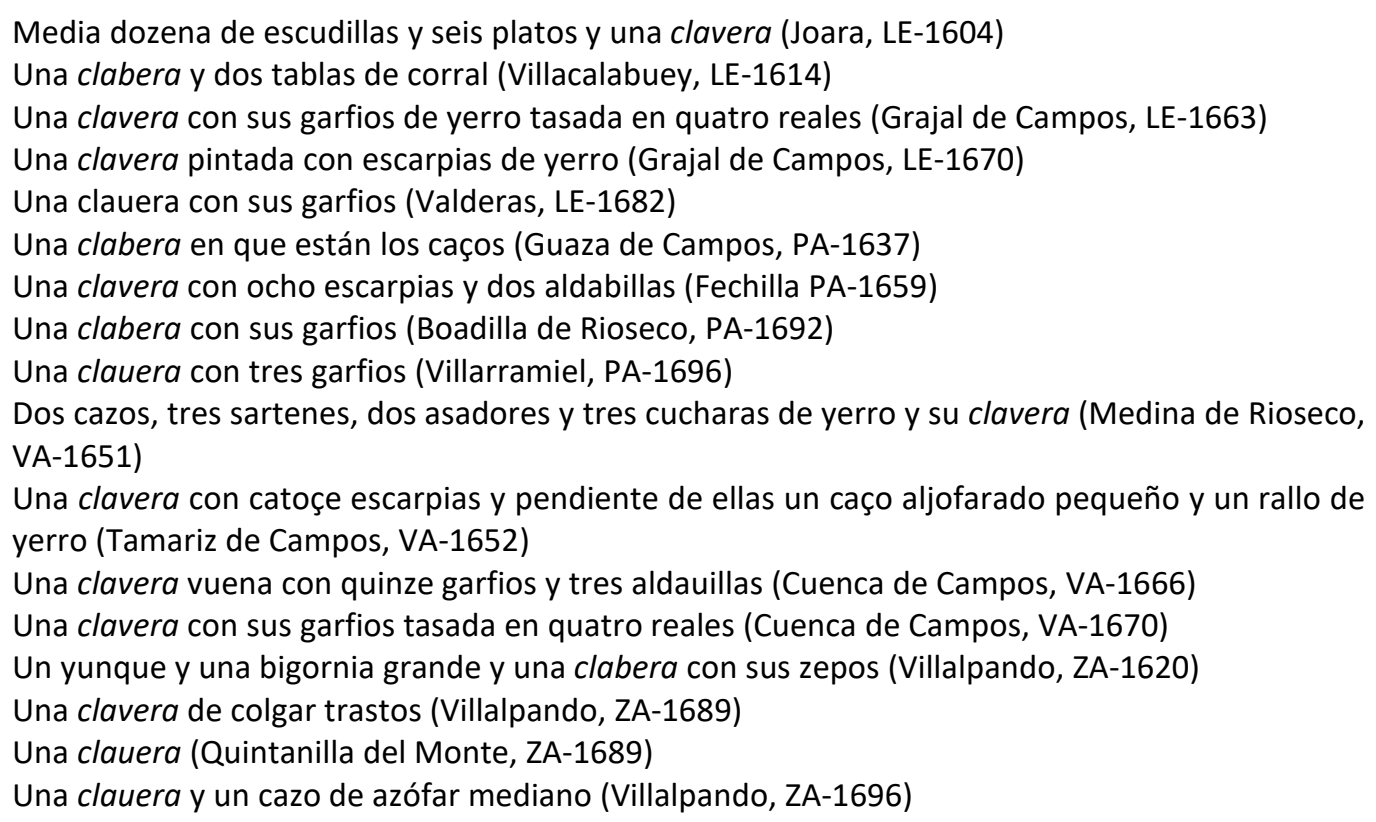

Clavera es un término localizado en los textos de la Tierra de Campos con la acepción no académica de 'tabla en que hay varios clavos para colgar de ellos algunas cosas' y que comparte campo semántico con espetera. En el CorLexIn aparecen algunos ejemplos que hacen referencia a diferentes acepciones, por un lado, las ocurrencias localizadas en Tenerife y Potosí referencian una especie de 'molde de clavos de carreta', mientras que el resto de ejemplos localizados en la base léxica pertenecen a la zona terracampina o zonas muy próximas. Dado el contexto en el 
que aparece este término, su significado tiene que ver con la tabla con escarpias o clavos que servía para colgar utensilios de cocina como cazuelas, cazos, asadores, badiles... (Castroañe, Valderas, Villalobos o Villamuñío). En esta misma zona se localiza la variante con la confusión de /l/ y /r/ (Morala, 2009: 15):

Dos craberas, la una buena y la otra bieja (Cea, LE-1625)

En repertorios dialectales más actuales, figura en el acervo léxico de la localidad terracampina de Villada, este término se recoge como el 'soporte de madera con ganchos para colgar los cacharros de cocina' (Casas, 1989: 529). Además de esta acepción, en zonas de Palencia también se recoge como 'molde que se usaba para hacer clavos' (Gordaliza, 1988: 69). Esta voz está presente en el sureste de León (Le Men, 2004, s. v. clavera).

\section{CLAVO [clauo, clabo]}

Sust. m. 'Pieza metálica, larga y delgada, con cabeza y punta, que sirve para introducirla en alguna parte, o para asegurar una cosa a otra' (DLE). Su carácter polisémico lo recoge Nebrija en su Vocabulario. También presenta diferentes acepciones en Covarrubias y Autoridades. Término procedente del lat. CLAVUS (DECH, s. v. clavo).

Cantidad de clavos [de] yerro que valdría tres reales (Riosequillo, LE-1602)

Como dos libras de clauos (Sahagún, LE-1608)

Una cestica biexa con unos clabos y un punzón y una clabixa de arado (Cea, LE-1614)

Un punzón, una lima e dos clavos (Galleguillos, LE-1618)

$\mathrm{Vn}$ caxonçico de madera lleno de clabos y otros yerros biexos (Valderas, LE-1647)

Algunos clavos de yerro biejos (Valderas, LE-1659)

Unas tenaças de yerro, martillo y diferentes clavos (Paredes de Nava, PA-1690)

Una cesta con sus clabos y yerro biexo que seran asta dos libras (Tamariz de Campos, VA-1651)

Çinquenta juelas, y seis libras de clabos (Villalpando, ZA-1629)

Unas tenazas de sacar clabos (Villalpando, ZA-1696)

Es una palabra de uso general que presenta diferentes significados en los textos.

El CDH recoge esta voz de forma temprana, en el Poema de Mío Cid (1140) con una de sus acepciones, como adorno: "los guadamecís vermejos e los clavos bien dorados", aunque también figuran otros de sus significados en la extensa documentación que presenta de esta palabra. Si restringimos la búsqueda a la documentación notarial del siglo XVII, el CorLexIn nos ofrece un nutrido número de ocurrencias repartidas entre la Península, Canarias y América, también con esa naturaleza polisémica.

El clavo es un elemento más de la vida cotidiana cuyo uso recorre varios campos semánticos. En nuestro corpus, no solo lo encontramos como una pieza fundamental en diferentes oficios, e incluso como elemento común en aperos y herramientas agrícolas y domésticas -"un clabo de carreta bueno" (Autillo de Campos, PA-1653); "un oxal de carro y dos clauos" (Boadilla de Rioseco, PA-1692); "una clauera con cinco clauos " (Frechilla, PA-1613); "una espetera con sus clauos" (Medina de Rioseco, VA-1649)-, sino también como elemento decorativo de muebles:

Cinco sillas de baqueta colorado las quatro y la otra de terçiopelo encarnado, con sus clabos dorados todas cinco (Paredes de Nava, PA-1690) 
Otro vanco de respaldo de pino con sus clavos (Boadilla de Rioseco, PA-1692)

Un vanco de respaldar de pino con clavos dorados (Medina de Rioseco, VA-1643)

Siete sillas de nogal con sus queros de vaqueta negra y clavos de latón a lo antiguo (Medina de Rioseco, VA-1644)

Un cofre negro con clauos de latón (Medina de Rioseco, VA-1648)

Un taburete pequeño con clavos dorados (Villalpando, ZA-1644)

$\mathrm{O}$ como un adorno personal, inventariado entre joyas u objetos de un alto valor pecuniario:

Unas barillas de plata con seis clabos y un par de chapines (Medina de Rioseco, VA-1651)

De forma habitual suele ser el contexto, o una especificación en el asiento quienes aclaren ante qué tipo de clavo estamos (Morala, 2019b: 391).

\section{ESPETÓN}

Sust. m. 'Hierro largo y delgado; p. ej., un asador o un estoque' (DLE). Este significado lo recoge Autoridades (NTLLE, s. v. espetón, Autoridades, 1732). Es una palabra derivada de la voz espeto ant., 'asador', del gót. *spittus (DECH, s. v. espeto).

Una fragua con sus aparejos que son tres pares de tenazas y sus espetón y tajadera y dos machos y dos martillos y una tobera y un yunque y una bigornia grande y una clabera con sus zepos (Villalpando, ZA-1620)

La primera documentación que aparece de esta voz en el CDH y en el CORDE data del siglo XVII, para ser más exactos, se localiza en un documento datado unos años más tarde que el localizado en el corpus terracampino y con el significado que en este se recoge:

Quiébrense, pues, los mayores, y aun después de esta prevención es necessario, de quando en quando, antes de echar el metal, que con un espetón de hierro, entrándolo dos o tres veces de alto a baxo por las brasas, se haga que se junten, y si huviere alguna concavidad, se llene. (Arte de los metales, de Álvaro Alonso Barba, 1640).

En el CorLexIn no aparecen ejemplos de esta palabra, sí aparece espeto en documentos de Asturias, junto a candiles, cazuelas o cazos. El DLE equipara esta voz a espetón, además Autoridades consideraba espeto como un término propio de Galicia.

En estudios más modernos aparece con la acepción de 'el hierro o gancho de la cocina. También cualquier pincho fuerte' (Gordaliza, 1988: 104).

\section{FRAGUA}

Sust. f. 'Fogón en que se caldean los metales para forjarlos, avivando el fuego mediante una corriente horizontal de aire producida por un fuelle o por otro aparato análogo' (DLE). Covarrubias registra esta voz y Autoridades lo recoge como 'la hornaza en que el herrero y otros artífices, que trabajan en metales, tienen la lumbre para beneficiarlos' (NTLLE, s. v. fragua, Covarrubias, 1611; Autoridades, 1732). Es un término derivado de *fravga, ${ }^{*}$ frabica, procedente del lat. FABRĭCA 'arte del herrero', 'fragua' (DECH, s. v. fragua).

Un fragua con todos sus aparexos (Joara, LE-1606)

Una fragua con sus aparejos que son tres pares de tenazas y sus espetón y tajadera y dos machos y dos martillos y una tobera y un yunque y una bigornia grande y una clabera con sus zepos (Villalpando, ZA-1620) 
El corpus terracampino presenta dos ocurrencias referenciando una 'herrería' o 'lugar donde se ubica la fragua', una en Joara y otra en Villalpando. Documentado en el CDH desde finales del siglo XI principios del XII. En los ejemplos encontrados en el CorLexIn se presenta como una herrería solo en protocolos de América. En España figura como topónimo o el apellido Fraguas. A pesar de su poca presencia en los protocolos, se trata de una palabra de uso general a lo largo y ancho de la Península.

\section{MARTILLO}

Sust. m. 'Herramienta de percusión compuesta de una cabeza, por lo común de hierro, y un mango, generalmente de madera' (DLE). Aparece en el Vocabulario de Nebrija y Covarrubias lo define como 'instrumento fabril de que usan los herreros y carpinteros, y todos los que labran metales' y Autoridades especifica más sus usos (NTLLE, s. v. martillo, Nebrija, 1495; Covarrubias, 1611; Autoridades, 1734). Término procedente del lat. vulgar MARTĔLLUS, diminutivo del lat. MARTŬLUS (DECH, s. v. martillo).

Un martillo de mano (Sahagún, LE-1608)

Una azuela de martillo (Grajal de Campos, LE-1616)

Un martillo de rexas en real y medio (Castroañe, LE-1622)

Un martillo de yerro y dos taladros y una paletilla de yerro (Sahagún, LE-1633)

Vn martillo de horexas bueno (Valderas, LE-1647)

Una acha de partir leña, un martillo, un eje biejo (Frechilla, PA-1639)

Un martillo de orejas (Frechilla, PA-1639)

Un martillo de orejas sin mango (Frechilla, PA-1638)

Un martillo de yerro y orexas pequeño (Autillo de Campos, PA-1653)

Un martillo sin barrena y un mazo (Medina de Rioseco, VA-1641)

Una açuela de martillo (Tamariz de Campos, VA-1652)

Un martillo de orejas en tres reales (Cuenca de Campos, VA-1660)

Una fragua con sus aparejos que son tres pares de tenazas y su espetón y tajadera y dos machos y dos martillos y una tobera y un yunque y una bigornia grande y una clavera con sus cepos (Villalpando, ZA-1620)

Una azuela y martillo (Villalpando, ZA-1685)

Un martillo mediano (Villalpando, ZA-1689

Una azuela de martillo (Villalpando, ZA-1690)

Esta lexía está presente en el $C D H$ y el CORDE desde el siglo XIII, en un primer momento aparece bajo la forma martiello que así se encuentra en El libro de Alexandre (1240) o Berceo (1246), hasta la General Estoria (1280) de Alfonso x, donde figura la actual martillo.

Es un término de uso general en el siglo XVII, los datos que ofrece el CorLexIn presentan una distribución geográfica muy amplia en el territorio peninsular y también en América -Bolivia, Chile, Panamá y Perú-. Es muy habitual en los inventarios de la Tierra de Campos, entre los mismos podemos distinguir diferentes tipos y acepciones: "martillo de orejas" que es el que se utiliza en carpintería ya que las orejas permiten quitar los clavos, según Autoridades; tanto la "azuela de mano" como la "azuela de martillo" son herramientas de carpintería y es bastante habitual encontrarlas en los documentos de esta época. El martillo también forma parte de los aparejos de la herrería pues permite moldear el hierro. 


\section{PUJAVANTE [puxabante]}

Sust. m. 'Instrumento que usan los herradores para cortar el casco a los animales de carga' (DLE). Autoridades describe este instrumento 'de hierro acerado, que se compone de una plancha quadrada, de quatro o cinco dedos de largo con corte por la parte de adelante, y por los dos lados está un poco vuelto hácia arriba, y tiene por la parte posterior un mango largo con que se maneja. [...]' (NTLLE, s. v. pujavante, Autoridades, 1737). Término derivado del cat. botavant íd. 'pujavante', compuesto de botar 'empujar' y avant 'adelante', en cast. pujavante 'herramienta para herrar el caballo' (DECH, s. v. botar).

Una puxabante de hierro del ynbentario (Castrillo, LE-1606)

El $D E C H$ da como primera documentación para esta voz 1580, aunque el $C D H$ adelanta la fecha al Cancionero de Baena (1406), principios del siglo XV, donde se utiliza en un contexto literario. Su presencia en los textos es escasa, aunque de ámbito geográfico extenso, ya que se documentan concordancias de esta palabra en América.

Pese a no ser muy frecuente en el CorLexIn, se utiliza en un ámbito geográfico amplio: Badajoz y Toledo en la Península, Adeje en Tenerife y Los Santos en Panamá. A los que habría que sumar los localizados por Rojo Vega en la documentación vallisoletana ${ }^{29}$ de finales del siglo XVI, el encontrado en la Tierra de Campos y el localizado en La Bañeza con este mismo significado, pero en el siglo XIX (Gómez Ferrero, 2015: 314).

En la actualidad esta voz está presente en repertorios léxicos palentinos, especialmente localizada en la Tierra de Campos (Gordaliza, 1988: 184), en la localidad terracampina de Villada, se registra como 'cuchilla para rebajar los cascos del ganado de tiro' (Casas, 1989: 535). Y Le Men localiza en estudiales dialectales este término, además de en tierras terracampinas, en el Bierzo, Murias de Paredes, Riaño o Valencia de Don Juan, y fuera del territorio leonés en Asturias, Zamora, Galicia, Navarra o Aragón entre otras zonas (Le Men, 2009, s. v. pujavante).

TENAZA [Vid. útiles de la lumbre]

\section{SUFRIDERA}

Sut. f. 'Pieza de hierro, con un agujero o cavidad en medio, que los herreros ponen debajo de la que quieren penetrar con el punzón, para que este no se melle contra la bigornia' (DLE). Sufridero/a se recoge como adjetivo desde Nebrija, no es hasta la edición académica de 1803 donde se recoge este término como un sustantivo que 'entre los herreros es cierta pieza de

29 Estos ejemplos han sido tomados de la web Investigadores de la Real Biblioteca https://investigadoresrb.patrimonionacional.es/, recogidos por Rojo Vega:

"Un martillo y un puxabante de herrador y unas tenaças" (Inventario de Juan López de Calatayud, regidor de Valladolid, Valladolid, 1584)

"Unas tenazas con su pujabante y martillo" (Inventario de Don García Rodríguez de Montalvo, Medina del Campo, 1593)

"Un puxabante de yerro biexo" (Inventario de Francisco López, tratante de fruta, Valladolid, 1598) 
hierro que ponen debaxo de la que quieren penetrar con el punzón, para que éste no se melle contra la vigornia, y dé lugar a separarse la pepita ó pedazo de hierro que saca el punzon' (NTLLE, s. v. sufridera, DRAE, 1803). Término derivado del verbo sufrir, del lat. SŬFFĔRRE 'soportar', 'tolerar', 'aguantar' (DECH, s. v. sufrir).

Tres pilas, una grande y dos pequeños, dos sufrideras (Frechilla, PA-1614)

Es una palabra muy poco documentada, no solo en la Tierra de Campos sino en el resto de la documentación. Tanto en el CDH como en el CORDE recogen esta voz con la acepción que aquí se estudia en dos obras de corte técnico, una de finales del siglo XIX y otra del XX, el resto de las concordancias, pertenecientes a siglos anteriores $-\mathrm{XV}$ y XVI-, dan testimonio del adjetivo. En el Fichero general de la RAE aparece una nota de sufridera como 'herramienta de herreros' en una Relación de Artillería de 1738, además de en diccionarios técnicos fechados con posterioridad.

El término sufridera es poco frecuente en los inventarios de bienes del siglo XVII, el CorLexIn tan solo recoge tres ítems en un inventario de bienes de Alcalá la Real, provincia de Jaén con la variante zufridera o çufridera, al que habría que sumarle un ejemplo localizado en la localidad zamorana de Benavente (Morala, 2018a: 86) y el de Tierra de Campos. Estamos ante un tecnicismo, lo que justifica la falta de testimonios en otros documentos.

\section{TOBERA}

Sust. f. 'Tubo troncocónico por donde se inyecta aire, agua o combustible en dispositivos o instalaciones como fraguas, altos hornos, motores o turbinas' (DLE). Lo recoge Autoridades como un término de plateros y lo define como 'el agujerillo, que tiene la forja, ù hornillo, por donde entra el cañon del fuelle' (NTLLE, s. v. tobera, Autoridades, 1739). Término derivado de tubo, tomado del lat. TǓBUs 'caño', 'conducto' (DECH, s. v. tubo).

Una fragua con sus aparejos que son tres pares de tenazas y sus espetón y tajadera y dos machos y dos martillos y una tobera y un yunque y una bigornia grande y una clabera con sus zepos (Villalpando, ZA-1620)

En Tierra de Campos localizamos este término en la localidad zamorana de Villalpando, es el único caso del corpus objeto de estudio. Esta escasez de ejemplos se extrapola a otros corpus y bases de datos. Con la acepción académica se registra en la Relación del coste que tuvo la Armada de Magallanes fechada en 1519: "[...] unos barquines grandes y yunques y tobera que vino de Vizcaya [...]" ( $C D H)$. Los únicos ejemplos que localizamos en el CorLexIn pertenecen al Inventario y arriendo de la farga de Bielsa a Gilberto Cubero, en Bielsa (Huesca, 1656), en un documento donde el vocabulario es muy específico del oficio del herrero.

\section{YUNQUE}

Sust. m. 'Prisma de hierro acerado, de sección cuadrada, a veces con punta en uno de los lados, encajado en un tajo de madera fuerte, y a propósito para trabajar en él a martillo los metales' $(D L E)$. En los diccionarios también se registra la forma ayunque como el 'instrumento en que labran los Herreros el hierro' aunque Autoridades aclara que yunque se utiliza más (NTLLE, s. v. 
yunque / ayunque, Autoridades, 1726). Este término sufre la metátesis del antiguo íncue, procedente, con probabilidad, de un lat. vg. *ĩNCǓDE, que sustituyó el clásico INCUS, -ŪDIS, íd. (DECH, s. v. yunque).

Un añunque y una bigornia de hacer ojales (Frechilla, PA-1614) Un yunque y una bigornia grande (Villalpando, ZA-1620) Un yunque de yerro y un punçón (Villalpando, ZA-1660)

Yunque se documenta desde el siglo XV con género femenino hasta bien entrado el siglo XVI, a partir de esta fecha figura la variante ayunque con género masculino. Esta vacilación entre los géneros es constante hasta la segunda mitad del siglo XVII, a partir de ese momento hay una clara elección por el género masculino ( $C D H$ y CORDE). Corominas y Pascual advierten de este hecho y consideran que en el momento que comienza a aparecer la forma "aglutinada" ayunque se tiende a cambiar de género extendiéndose a la forma yunque. Además, señalan que posiblemente sea el tipógrafo el responsable de la introducción de esta variante más moderna y que, muy probablemente, estuviese presente en la lengua oral de la época y de ahí el trasvase a los textos (DECH, s. v. yunque).

El $C D H$ registra ayunque en la Historia general y natural de las Indias de Gonzalo Fernández de Oviedo fechado en 1535, el mayor número de ejemplos se localizan en el siglo XVI y XVII, no encontrando ninguno después del siglo XIX.

Los datos que ofrece el CorLexIn presenta una escasa nómina de casos de ambas palabras, localizamos yunque en documentos de Badajoz, Jaén y Lima (Perú), siempre inventariados con género masculino. Ayunque tan solo presenta una ocurrencia en un inventario de Jaén, al que habría que sumarle la variante palatalizada añunque, presente en los documentos terracampinos.

\subsubsection{Tejedores}

\section{ESPADADERO}

No está registrado en el $D L E$, ni en ningún otro diccionario académico. Sí aparece en diccionarios a partir del siglo XIX como el de Salvá que lo registra como 'tablilla sostenida por un pie, sobre la cual se espada el lino' (NTLLE, s. v. espadadero, Salvá, 1846). Es un término derivado de espadar 'macerar y quebrantar con la espadilla el lino o el cáñamo para sacarle tamo y poderlo hilar', por lo que espadadero será 'el instrumento que sirve para espadar el lino' (Morala, 2018a: 76).

Un vanco de mehul y otro de tavla y dos espadaderos (Riosequillo, LE-1610)

Un banco de roble, un espadadero, tres horcas de madera (Cea, LE-1610)

Un espadadero con su espadilla (Grajal de Campos, LE-1616)

Tres espadaderos (Sahagún, LE-1626)

El espadadero es un término que no aparece registrado en los diccionarios académicos y tampoco en la documentación que conforma el $C D H$ y el CORDE. En el CorLexIn se localiza un único ejemplo en una localidad limítrofe con la zona de estudio: 
Vn costal viejo y un espadadero con su espadilla (Mansilla la Mayor, LE-1637)

A esta ocurrencia habría que añadir las localizadas en Tierra de Campos que pertenecen a la zona leonesa de la misma -Sahagún, Cea, Riosequillo, Grajal de Campos-, por lo que parece que estamos ante un término con marca diatópica de León. Además, a esta zona hay que sumarles las encontradas por Morala en Villamol y Valdavida localidades pertenecientes al partido judicial de Sahagún; y las de León y Fresno de la Vega (Morala, 2018a: 76).

En estudios más recientes se localiza en el Fichero general de la RAE este término como 'tabla sobre la que se maja el lino con la espadiella', recogido por Fernández Gónzalez en el Habla de Oseja de Sajambre (1959: 266). En el Vocabulario Palentino se recoge la voz espadadera como 'instrumento para espadar, machacar y limpiar el lino', pero recuerda que en León se denomina espadadero (Gordaliza, 1988: 103). Espadadero como 'instrumento para espadar lino consistente en una tabla con púas de hierro muy juntas' se registra en el noreste de León (Le Men, 2005, s. v. espadadero).

\section{ESPADADOR}

La acepción de espadador como 'instrumento de espadar' no se registra en las obras lexicográficas, se le recoge desde Autoridades con su significado activo como 'el que macéra y quebranta el lino y cáñamo, y le saca el tamo con la espadilla' (NTLLE, s. v. espadador, Autoridades, 1732).

Tres espadicas y un espadador (Medina de Rioseco, VA-1649)

Dos ruedas con sus crucetas, banco, un espadador y espadillas del oficio de cabestrero (Medina de Rioseco, VA-1661)

Si espadadero figuraba en los textos leoneses de Tierra de Campos para referenciar el instrumento que servía para espadar el lino, para este mismo significado aparece espadador en textos vallisoletanos de este mismo corpus.

Como ocurre con muchos de los términos estudiados en este apartado, su presencia en las bases de datos del castellano es muy escasa, tanto el CORDE como el CDH reúnen un par de concordancias extraídas de documentos del siglo XVII y dentro del sintagma "caballete de espadador".

Cabe destacar que, aunque de forma esporádica, esta acepción sí aparece en alguno de los inventarios que conforman el CorLexIn:

Una romana de pesar cáñamo, y un espadador y dos espadillas (Huelva, 1609)

Al que habría que unir el localizado por Morala (2018a: 76) en Soria y otro más en la localidad madrileña de Carabaña (Vázquez Balonga, 2015: 174):

Un rastrillo con su espadador y cubador y caxa y dos espadillas (Soria, 1646)

Un espadador de espadar cáñamo mediado (Grabaña, M-1631)

La búsqueda en el Fichero General de la RAE recoge este término en Huesca, obtenida del ALEANR en la lámina 322a y los mapas 206 y 400, donde en el primer mapa se presenta como sinónimo de 'espadilla' y en el segundo como 'trípode al que se ata el lino que se espada' (Fichero General, cédula n.운). 


\section{ESPADILLA}

Sust. f. 'Instrumento de madera, a modo de machete, que se usa para espadar' (DLE). Término derivado de espada (DECH, s. v. espada).

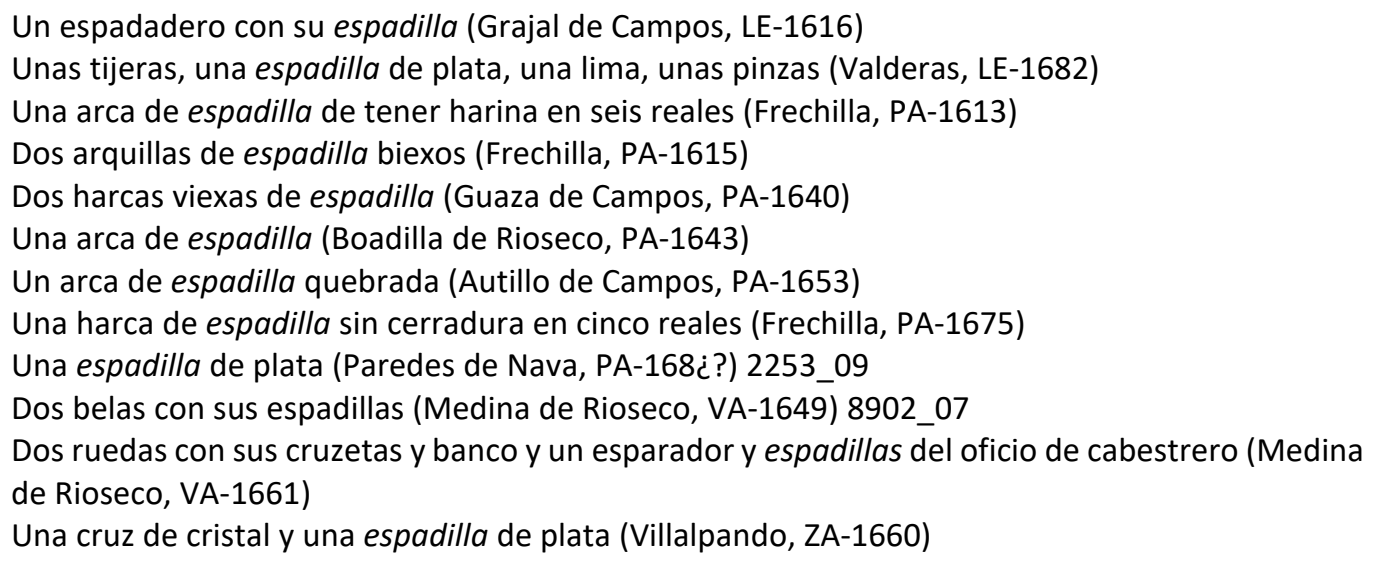

Este término polisémico aparece en los inventarios de bienes con varias acepciones: el diminutivo de espada: "una cruz de cristal y una espadilla de plata", como diminutivo lexicalizado que hace referencia a un instrumento o herramienta utilizada en el hilado junto con el espadadero "un espadadero con su espadilla" y también como material para fabricar arcas, acepción que no contempla el diccionario académico y que aparece en varias ocasiones en el corpus de Tierra de Campos "una arca de espadilla de tener harina".

Se documenta en el $C D H$ desde finales del siglo $\mathrm{XV}$, con las acepciones que aparecen en el diccionario académico. A partir del siglo XVII comienzan a registrarse ejemplos en documentos americanos.

En el CorLexIn, esta voz con la acepción de 'instrumento de espadar' se localiza en el occidente peninsular, más en concreto, en Madroñera (Cáceres) y Mansilla (Léon). En estudios actuales, espadilla con esta acepción figura en los estudios de Gordaliza y Le Men.

En cuanto a la acepción que hace referencia a un tipo de material o de técnica de fabricación del arca, en el CorLexIn figura un ejemplo en Herrera de Pisuerga (Palencia) donde se documenta "una arca de espadilla". Sin embargo, en Tierra de Campos aparecen unas cuantas ocurrencias de este tipo de arcas. Perdiguero localiza también este uso en un inventario de Melgar de Fernamental (Burgos): "arca de espadillas" en plural, pero que se asemeja a los encontrados en la zona palentina de Tierra de Campos (Perdiguero, 2015a: 1566).

\section{LANZADERA [lançadera]}

Sust. f. 'Pieza cerámica en forma de barco, con una canilla dentro, que usan los tejedores para tramar' (DLE). Lo recoge Nebrija como 'lançadera de tejedor' y Covarrubias lo define como 'el rayo de texedor, dentro del qual va el cañutillo de la trama, o la canilla'. Autoridades lo registra con la grafía /z/ y define esta palabra como 'instrumento de texedóres, hecho de madéra en forma de barquillo con dos espolónes, dentro del qual va el cañutillo ó canilla en que está la trama para texer' (NTLLE, s. v. lanzadera, Nebrija, 1495; Covarrubias, 1611; Autoridades, 1734). Término derivado de lanza del latín LANCĚA (DECH, s. v. lanza). 
Dos templenes y dos lançaderas y lo demás del dicho ofiçio (Grajal de Campos, LE-1657)

Dos lanzaderas (Medina de Rioseco, VA-1639)

Dos lançaderas (Medina de Rioseco, VA-1649)

Un temple de yerro y cuatro lançaderas y un peso con su pesa (Villanpando, ZA-1626)

Es una palabra documentada desde el siglo XIII en el $C D H$ que hace referencia al instrumento que utilizaban los tejedores para confeccionar sus telas. No figura de manera habitual en el CorLexIn dado el uso exclusivo del mismo. En Tierra de Campos, lugar privilegiado de la industria textil, aparecen unos cuantos ejemplos de este término con la forma académica.

\section{MAZA [maça]}

Sust. f. 'Instrumento de madera dura, parecido a la maza antigua de combate, que sirve para machacar el esparto y el lino, y para otros usos' (DLE, 2. a ac.). Nebrija recoge en su Vocabulario 'maça para majar lino' y Covarrubias también registra esta acepción (NTLLE, s. v. maza, Nebrija, 1495; Covarrubias, 1611). Palabra procedente del lat. vg. *MATTĔA, que parece ser derivado retrógrado del lat. MATEOLA íd. (DECH, s. v. maza).

Una maza de maxar lino (Sahagún, LE-1608)

Una taxa de maça (Frechilla, PA-1616)

Una maça de carro, la mayor (Frechilla, PA-1636)

Corominas y Pascual señalan que se trata de una lexía de uso general en todas las épocas y común en los romances de Occidente ( $D E C H, \mathrm{~s}$. v. maza). Los primeros testimonios de esta voz se recogen a partir de la segunda mitad del siglo XI con la acepción de arma defensiva en el CORDE.

El corpus terracampino presenta una escasa nómina de ocurrencias. El ejemplo de Sahagún se recoge con el sentido de herramienta para majar el lino. Sin embargo, los otros dos ejemplos de Frechilla presentan otros significados, uno de ellos referencia una parte del carro, significado que también localiza el CorLexIn en un inventario de Herrera de Valdecañas (Palencia, 1700).

\section{MAZO [maço]}

Sust. m. 'Martillo grande, generalmente de madera', 'conjunto abundante de papeles $u$ otras cosas atadas o unidas formando grupo' (DLE, 1. a y 3 . ac.). Término derivado de maza, del lat. vulgar * MATTĔA, que parece ser derivado regresivo del lat. MATEOLA (DECH, s. v. maza).

Un martillo sin barrena y un mazo (Medina de Rioseco, VA-1641)

Un mazo de apoyar y otro de mano en quatro reales (Medina de Rioseco, VA-1661)

En el $C D H$ localiza entre otras concordancias "maços de batán" que, aunque utilizado de forma figurativa, referencian claramente el instrumento profesional del ámbito textil. Este significado se recoge en algunos vocabularios más actuales donde mazo se describe como 'cada uno de los martillos que, empujados por los llevadores, golpean el paño en las pisas, instalaciones hidráulicas para abatanar los tejidos' (Gordaliza, 1988: 147). Pero también es una herramienta utilizada para otros fines profesionales. 
Es un término de uso general y de carácter polisémico, donde además de herramienta profesional tiene el significado de apero agrícola:

Tres garios, tres rastros, quatro bieldos, dos orcas y dos mazos de machucar (Frechilla, PA-1675)

Con la acepción de 'apero de labranza' se localiza un siglo más tarde en documentos notariales de La Bañeza (Gómez Ferrero, 2015: 313). Con este significado se sigue recogiendo en estudios sobre el léxico leonés como 'instrumento agrícola consistente en un tablón de unos $50 \mathrm{~cm}$. de largo, 20 de ancho y 12 de altura; en el centro lleva un agujero para insertar el mango; se utiliza para machacar los garbanzos y el lino' (Le Men, 2007, s. v. mazo).

Relacionado con el mundo de los tejidos, tenemos los siguientes ejemplos donde el significado tiene que ver con la forma de contabilizar determinados complementos textiles:

Dos libras de trançadoras de belduque he ylo açul y de caparrosa con cerdones y sus maços de nebenas anchos podaços començados y aguxetas coloradas finas y de yladillo (Mazariegos, PA1619)

Maços de orillas (Medina de Rioseco, VA-1644)

Ochenta y cinco maços de vartolones (Medina de Rioseco, VA-1645)

Un maço de perlas con nuebe ylos (Medina de Rioseco, VA-1647)

Un maço de aljófar con ueinte y un ylos (Medina de Rioseco, VA-1685)

Ejemplos de mazo como 'conjunto de cosas atadas o unidas formando grupo' (DEL, 3. a ac.)

\section{PLANCHA}

Sust. f. 'Pieza plana de poco grosor, generalmente de metal' o 'utensilio de forma triangular, con base metálica lisa y pulida y un asa en la parte superior, que se calienta normalmente con energía eléctrica y sirve para planchar' ( $D L E, 1$. a y 2. a ac.). Covarrubias recoge esta palabra con el significado de 'lámina de metal ancha y delgada, quasi plana' y Autoridades añade una nueva acepción: 'cierto instrumento hecho de una plancha de hierro, de una quarta de largo y un dedo de gruesso, con una manija ó asta del mismo hierro, por la parte superior para manejarla, y por la parte inferior está acerda y mui lisa è igual. Sirve para aplanchar todo género de ropa blanca. Hácense de diversas figuras y hechúras, unas puntiagudas y otras romas' (NTLLE, s. v. plancha, Covarrubias, 1611; Autoridades, 1737). Voz procedente del fr. planche y este del lat. PALANCA, 'rodillo', 'garrote' (DECH, s. v. palanca).

Una plancha de abrir fuentes (Valderas, LE-1682)

Una mesa de pino con una plancha de cobre de engomar sombreros (Medina de Rioseco, VA1639)

El término plancha se documenta en el $C D H$ y en el CORDE desde el siglo XV. El CorLexIn presenta una lexía polisémica repartida por un ámbito geográfico general. En Tierra de Campos se localizan dos casos de esta voz con dos acepciones diferentes; la ocurrencia ubicada en Valderas hace referencia a una especie de tapa que servía a modo de cobertor de las fuentes, con este mismo significado localizamos el inventario de Isabel María Morquedo y Sandoval en el que se incluyen "dos planchas de plata pequeñas para fuentes" (Puerta Rosell, 1994: pág. 151 del Apéndice documental) y Gómez Ferrero (2015), en inventarios de La Bañeza señala "una fuente de Talavera planchada", aunque un par de siglos más tarde, pero que puede tener que ver con esta acepción. El otro significado que presenta en el corpus terracampoino es del de 
instrumento que sirve para engomar sombreros, significado que también se localiza en documentos americanos el CorLexIn.

\subsubsection{Zapateros}

\section{LEZNA [lesna]}

Sust. f. 'Instrumento que se compone de un hierro con punta muy fina y un mango de madera, que usan los zapateros y otros artesanos para agujerear, coser y pespuntar' (DLE). La forma académica se recoge a mediados del siglo XIX, en la edición del DRAE de 1852. La forma que recoge Nebrija y Covarrubias es la de alesna que este último define como 'la aguja con que el çapatero passa la suela del çapato, y el cuero, antes de los cabos de cáñamo encerotados con que cose' y en Autoridades se señala la preferencia por el uso de lesna '[...] modernamente se dice lesna'. En el DRAE de 1852 la forma alesna se señala como antigua y se remite a lesna e introdurce como lema la forma lezna como sinónimo de lesna (NTLLE, s. v. lesna, Nebrija, 1495; Covarrubias, 1611; Autoridades, 1726; DRAE, 1852). Palabra procedente del germano occidental *alisna $(D E C H$, s. v. lezna).

Una piedra de amolar i quatro lesnas, las tres con sus manguillos y la otra sin él (Tamariz de Campos, VA-1651)

Diez lesnas (Medina de Rioseco, VA-1657)

Otras seis lesnas (Medina de Rioseco, VA-1657)

El $C D H$ localiza las tres variantes del término -alesna, lezna y lesna- en los textos que lo configuran. La variante alesna se documenta a partir del siglo XIV, aunque enseguida entra en retroceso y apenas se documentan ejemplos en el siglo XVII. La forma lezna se localiza en el Libro de Palladio de Ferrer fechado en 1380 y parece que esta es la forma que va a tener continuidad en el tiempo. Por su parte, lesna se documenta más tarde, en la Valuación hecha en Burgos del precio de las mercaderías que venían de fuera del Reino donde aparecen "lesnas de zapateros a seis reales la gruessa" fechado en 1563 , se trata de una palabra cuya presencia en los textos va a ser limitada, ya que apenas aparece en los documentos del siglo XVII del CDH.

A pesar de ser una palabra poco documentada en general, se puede apreciar la preferencia de la forma lesna en los inventarios del CorLexin y en los de Tierra de Campos donde la única variante que se documenta es esta misma. En repertorios léxicos más actuales, Le Men localiza la forma lesna para Tierra de Campos (Le Men, 2007, s. v. lesna) y Gordaliza señala que se utiliza lesna y lezna como 'herramienta de zapatero y guarnicionero' (Gordaliza, 1988: 136).

\section{TRANCHETE}

Sust. m. 'Cuchilla de zapatero' (DLE). Este término lo recoge Covarrubias como 'instrumento mecanico de que usa el çapatero para cortar el cuero y las suelas' (NTLLE, s. v. tranchete, Covarrubias, 1611). Término derivado de tranzar 'cortar, tronchar' de origen incierto (DECH, $\mathrm{s}$. v. tranzar). 
Dos tranchetes con sus manguillos (Villada, PA-1669)

Unas tixeras y un tranchete buenos (Frechilla, PA-1675)

Dos tranchetes (Medina de Rioseco, VA-1657)

Tranchete con la acepción de 'herramienta de zapatero' se documenta a mediados del siglo XVI, pero las ocurrencias de esta palabra son más bien escasas en el $C D H$ y en el CORDE. Esta escasez de ejemplos también se da en el CorLexIn donde se localiza un ejemplo en Carrión de los Condes (Palencia, 1652): "vn tranchete y una xarra vidriada". En Tierra de Campos se documentan tres ocurrencias, pero el contexto no da los suficientes datos para saber de qué tipo de herramienta se trata, ya que de forma habitual las herramientas profesionales suelen ir juntas en los inventarios, pero en este caso, tranchete se encuentra entre jarros o cabezales, lo que hace sospechar que el uso sea otro. Del mismo modo, tranchete aparece en otros estudios más recientes sobre léxico, así Casas recoge tranchete en la localidad terracampina de Villada como 'navaja curva para vendimiar' (Casas, 1989: 537), por su parte Gordaliza recoge varias acepciones para este instrumento en su Vocabulario Palentino, además de la documentada por Casas, añade la de 'especie de hoz corta y gruesa, usada para cortar maleza' que localiza en Saldaña y Guardo y 'cuchillo ancho usado para partir carne' en Fuentes de Nava (Gordaliza, 1988: 218).

\section{SIERRA}

Sust. f. 'Herramienta para cortar madera, piedra u otros objetos duros, que generalmente consiste en una hoja de acero dentada sujeta a una empuñadura, bastidor o armazón' (DLE). Nebrija recoge 'sierra para aserrar de hierro' y 'sierra pequeña' mientras que Covarrubias la define como 'instrumento para diuidir madera, la qual gasta con sus agudos dientes' (NTLLE, s. v. sierra, Nebrija, 1495; Covarrubias, 1611). Término procedente del lat. SĔRRA 'sierra de aserrar' (DECH, s. v. sierra).

\footnotetext{
Una sierra de yerro (Santa María del Río, LE-1617)

Vna sierra pequeña (Valderas, LE-1647)

Una sierra (Grajal de Campos, LE-1670)

Una sierra (Frechilla, PA-1612)

Cinco sierras grandes y pequeñas (Castromocho, PA-1614)

Una sierra pequeña de seis reales (Fechilla PA-1675)

Una oja de sierra pequeña de media bara (Frechilla, PA-1675)

Una sierra de vara (Medina de Rioseco, VA-1641)

Una sierra biexa en ocho reales (Cuenca de Campos, VA-1670)

Una sierra mediana (Villalpando, ZA-1661)
}

Es un término de uso general en todas las épocas ( $D E C H$, s. v. sierra). Diacrónicamente la voz sierra con el significado de herramienta la recoge el $C D H$ a partir de La fazienda de Ultra Mar de Almerich: "Manasses fizo serrar a Ysayas con sierra de fust" (1200).

Los datos que nos proporciona el CorLexIn de este significado ofrecen una distribución diatópica de carácter general que incluye tanto la Península como Canarias y América. A pesar de no ser de los términos más documentados en el corpus terracampino, ofrece un nutrido número de ejemplos repartidos por toda el área de estudio. 


\subsection{MEDIDAS}

\subsubsection{Unidades}

El campo semántico de las medidas es de gran interés lexicológico, ya que en este siglo todavía estaba muy lejos la entrada en vigor de un sistema métrico unitario, general en todo un territorio. En el siglo XVII existía un complejo sistema de medidas que presentaban diferentes orígenes y diferencias geográficas (Morala, 2016b:559), y que, a pesar de los intentos de las diferentes pragmáticas, nunca llegó a homogeneizarse. En este apartado hemos clasificado los términos bajo los epígrafes de medidas de capacidad para áridos, para líquidos, medidas de peso, de longitud, de superficie, medidas formadas por partitivos y utensilios de medir.

\subsubsection{Medidas de capacidad para áridos}

Las medidas de capacidad para áridos -que en la documentación aparecen principalmente, bien para expresar medidas de cereales, lino o legumbres, bien registrando junto a otros enseres el propio recipiente con el que se efectúa la medición-tienen la peculiaridad de que, en la mayor parte de las ocasiones, cuentan con un doble valor. Salvo uno o dos casos, las medidas de capacidad de áridos sirven también como medidas de superficie. Este proceso, que es mucho más raro a la inversa, se basa en el hecho de que la extensión de terreno que se considera adecuada para sembrar el contenido de una determinada medida de grano acaba por tomar como referencia el criterio de la medida de capacidad aplicándolo a la superficie (Morala, 2016b: 570).

\section{BORRICADA [borrecada]}

El término borricada aparece en el diccionario académico, pero no con la acepción métrica que encontramos en los documentos.

Una borrecada de trigo (Castromocho, PA-1602)

Esta voz no figura en las bases de datos académicas como el $C D H$ y el CORDE con esta acepción.

Esta falta de testimonios se extiende también al CorLexIn, donde tan solo figura un único caso localizado en la localidad leonesa de Santas Martas, muy próxima a la zona de estudio y con este mismo significado, 'medida para áridos':

Tres costales, los dos de carro y el otro de borricada, usados (Santas Martas, LE-1625)

En Tierra de Campos, donde solo aparece una ocurrencia, también se observa el carácter singular de la palabra. Formalmente, este caso presenta un cambio de timbre en la vocal átona: borrecada. 
Parece que existían algunas medidas que se formaban a partir de los nombres de animales como podían ser: borricos (burraxos), borrego o borrega (Castaño, 2015: 295). Algo parecido puede que ocurra con el término que analizamos aquí.

Le Men, recoge el termino burricada con la acepción de 'carga que lleva o puede llevar un burro' en vocabularios del occidente de León y de Asturias (Le Men, 2002, s. v. burricada).

Esta última acepción nos anima a pensar que, en este caso, el sufijo -ada tiene el valor de indicar cantidad que puede ser transportada por.

\section{CARGA}

Sust. f. 'Unidad de medida de algunos productos forestales, como leñas, carbones, frutos, etc.' o 'cierta cantidad de granos que en unas partes es de cuatro fanegas y en otras de tres' (DLE, 10. y 11. a ac.). Covarrubias lo define como 'el peso que lleua sobre si la bestia, o el hombre [...]'. Autoridades registra entre otras acepciones la de 'cierta porción de granos, que en Castilla son quatro fanegas' (NTLLE, s. v. carga: Covarrubias, 1611; Autoridades, 1729). Procedente del lat. vulgar CARRICARE, íd., derivado de CARRUS 'carro', voz latina de origen céltico (DECH, s. v. carga).

Quatro cargas de lentexas (Sahagún, LE-1600)

Diez y seis cargas y media de tierras (Valdavida, LE-1606)

Quatro cargas de centeno a treinta y dos reales carga (Grajal de Campos, LE-1656)

Vna tierra a Rastrapaxas, término de esta billa, que açe vna carga de tierra de sembradura (Valderas, LE-1682)

Tres cargas de cebada (Frechilla, PA-1612)

Dos cargas de trigo apreciadas a cinquenta y dos reales la carga (Frechilla, PA-1612)

Una carga de arina de trigo (Frechilla, PA-1642)

Dos cargas de cuébanos y dos canastas de saçar lana (Frechilla, PA-1642)

Seis cargas de zestos (Autillo de Campos, PA-1654)

Dos cargas de zestos de bendimiar (Paredes de Nava, PA-1689)

Dos cargas de cestos buenos de Villalón (Fechilla PA-1675)

Dos cargas de zestos de bindimiar (Villalón, VA-1642)

Once cargas de cebada que tienen las dichas cassas (Medina de Rioseco, VA-1647)

Seis cargas de trigo (Cuenca de Campos, VA-1660)

Tres cargas de cestos tasadas en nuebe reales (Cuenca de Campos, VA-1666)

Otras dos cargas de barbecho en quarenta reales (Carrizo, ZA-1646)

Onçe cargas de zestos uiejos (Villalobos, ZA-1654)

Quatro cargas de zenteno (Villalpando, ZA-1686)

Seis cargas de trigo en una panera (Cotanes del Monte, ZA-1687)

Esta medida de capacidad es muy frecuente en los inventarios de bienes terracampinos. En ellos aparece como medida de capacidad de áridos como el trigo, la cebada y el centeno, pero también para la cal, el carbón y otros productos. Morala señala que esta voz se halla presente sobre todo en los documentos de la meseta norte, cuenca del Ebro o la cordillera cantábrica, mientras que es menos frecuente en la mitad sur de la Península, aunque localiza ocurrencias de esta voz en Cáceres, Toledo, Albacete o Murcia (Morala, 2016b: 561).

La carga también se utiliza como medida de superficie en Tierra de Campos, principalmente en documentos leoneses y zamoranos de la zona, lo que confirma lo señalado por Morala en estudios anteriores: ubica una mayor concentración de ocurrencias en el área occidental -León, Zamora, con algún punto aledaño en Palencia- (Morala, 2016b: 561). Se suele presentar bajo 
los sintagmas carga de tierra, carga de tierra de senbradura, carga de senbradura (Pérez Toral, 2015b: 84) o carga de barbecho, como el ejemplo de Carrizo (Zamora).

Por otro lado, se inventarían "cargas de cestos", cuyos ejemplos se concentran en la zona de estudio y que en apariencia tienen que ver con la recogida de la uva, donde carga hace referencia a los cestos que solían llevar las bestias para sacar la uva del majuelo. En el CorLexIn también se localizan usos aislados de este sintagma en Cebreros (Ávila), Domingo García (Segovia) y Montánchez (Cáceres).

Carga todavía se registra en estudios léxicos como el de Gordaliza (1988), Álvarez Tejedor (1989) o Le Men (2004).

\section{CARRETADA}

Sust. f. 'Carga que lleva una carreta o un carro' (DLE). Esta voz la registran algunos de los diccionarios preacadémicos, y aparece en Autoridades con el mismo significado que hoy en día (NTLLE, s. v. carretada; Autoridades, 1729). Es un término derivado de carro, del lat. CARRUS (DECH, s. v. carro).

Un prado en el término de Renedo que aze dos carretadas de yerba linda con prado de Francisco de Portilla rectoral de Billaçanco (Valdavida, LE-1606)

Una carretada de yerba de la almoneda en beinte y ocho reales (Sahagún, LE-1627)

Castaño referencia este término con la acepción de medida en el Fuero de Villaviciencio, fechado en torno al 1090 (Castaño, 2015: 159):

De karretacatada [por cada carretada] de sal dé una eminda et una travessa (Muñoz y Romero, T., Colección de fueros municipales, 1847: 175)

En los datos facilitados por el CORDE y el $C D H$ se observa que tuvo un uso mayoritario a partir del siglo XV, aunque el $C D H$ lo documenta desde el siglo XIII y, a partir de finales del siglo $X V I$, también en documentos americanos. En los ejemplos localizados, este término se utiliza para medir piedras, tablas, aljófar, leña, madera, tierra, paja, etc.

Desde un punto de vista diatópico, el CorLexIn nos ofrece una docena de ejemplos procedentes de diferentes puntos de la Península -Zaragoza, Ávila, Segovia, Cuenca, Jaén, Sevilla y Málaga-que presentan el mismo significado -carretadas de paja, abono, carbón o leña -. Lagüens localiza este término como parte del sintagma 'carretadas de leña' en documentos aragoneses entre 1592 y 1755 (Lagüens, 2012).

En los textos terracampinos se han localizado dos ejemplos de esta voz, cuyo significado difiere entre sí. En el caso de Sahagún, se trata de una medida de capacidad: mide la cantidad de hierba que se entrega. Sin embargo, la ocurrencia de Valdavida hace referencia a la superficie del prado que se inventaría. El transvase entre las medidas de capacidad a las de superficie es común en todas las épocas.

Le Men señala que con la acepción de 'medida de capacidad' se mantiene en el ámbito rural de Castilla y León (Le Men, 2004, s. v. carretada). Por su parte, Castaño advierte que la carretada es una medida muy versátil e indica que, usándose para las uvas, en Cádiz esta medida es 
equivalente a 480 litros, mientras que en Gerona hace 499. En México carretada es una medida para la cal equivalente a 220 arrobas (Castaño, 2015: 307).

\section{CARRO [Vid. Aperos agrícolas]}

\section{CELEMÍN [çelemín, zelemín]}

Sust. m. 'Medida de capacidad para áridos, que tiene cuatro cuartillos y equivale en Castilla a 4,625 I aproximadamente' ( $D L E)$. Covarrubias lo registra como 'medida de las cosas áridas, como trigo, ceuada, garuanços', en Autoridades aparece como 'medida de los granos, semillas y otras cosas que hace la duodecima parte de una fanega, y se divíde en quatro quartillos' (NTLLE, s. v. celemín: Covarrubias, 1611; Autoridades, 1729). Es una voz derivada del árabe hispánico ७emēnî, plural de ৩umnîya 'vaso de barro, cantarillo', cambiado en *cemenín y *cenemín, pasó luego a celemín por disimilación (DECH, s. v. celemín).

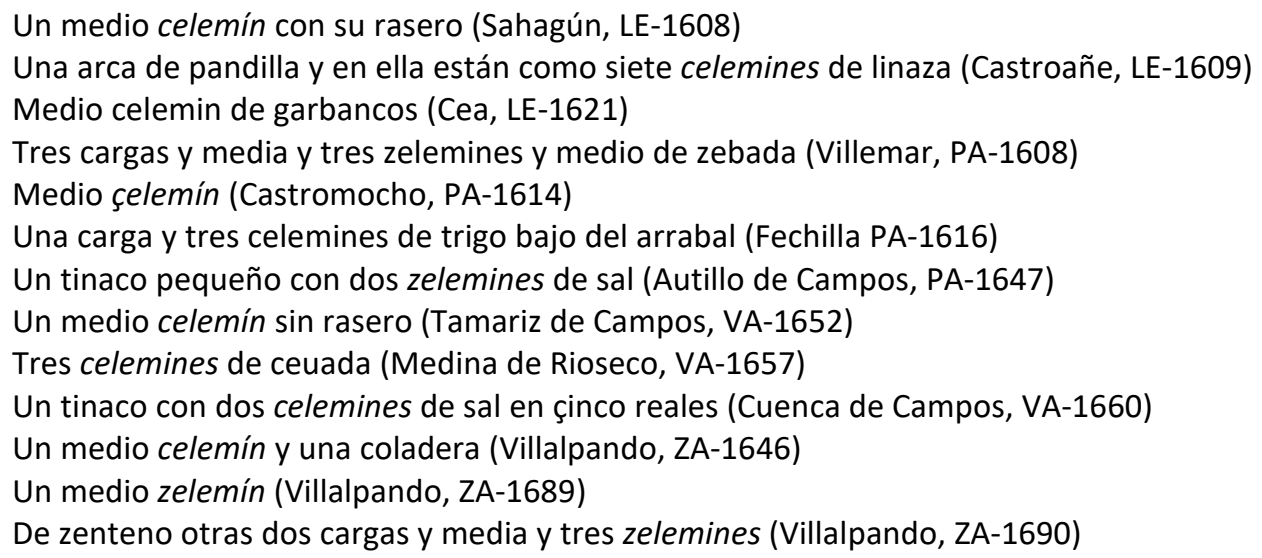

Es un término común para expresar una unidad de medida que se documenta en toda la zona de Tierra de Campos. Como sucede con otros términos, celemín aparece como medida de capacidad: "tres celemines y medio de zebada", y como recipiente en el que se mide: "Un medio celemín con su rasero", siempre como "medio celemín", tal y como ocurre con fanega. Está presente en los inventarios de toda la Península como medida fraccionaria de fanega, carga o hemina. Morala también documenta celemín como medida de superficie; sin embargo, de los documentos estudiados en Tierra de Campos, ninguno presenta este uso (Morala, 2016b: 562).

Además de como medida de capacidad, estudios léxicos como el de Le Men (2004, s. v. carga) o Gordaliza (1988: 61) recogen este término también como medida de superficie.

\section{FANEGA [anega]}

Sust. f. 'Medida de capacidad para áridos que, según el marco de Castilla, tiene 12 celemines y equivale a 55,5 I. pero es muy variable según las diversas regiones de España' (DLE). Covarrubias recoge esta voz como 'medida con que se mide el trigo, y la ceuada, y las demas semillas: las nuezes, las habas secas, castañas, bellotas, y otros frutos y legumbres, y la sal, y la media hanega se llama en muchas partes de Castilla' y señala los téminos fanegada o hanegada de tierra para referirse a 'que tiene de sembradura vna hanega'. Por su parte, Autoridades lo registra como 
'medida de granos y otras semillas que contiene doce celemínes, y es la quarta parte de lo que en Castilla llaman una carga de trigo, porque cabiendo en ella cerca de quatro arrobas de trigo, puede llevar un macho quatro fanégas' (NTLLE, s. v. fanega; Covarrubias, 1611; Autoridades, 1732). Término procedente del árabe faníqa 'saco grande, costal', 'fanega, medida de capacidad equivalente al contenido de un saco' (DECH, s. v. fanega).

Una anega de linaza en quinze reales (Sahagún, LE-1600)

Otra tierra al pozuelo que ará fanega y media (Calzada, LE-1601)

Tres fanegas y media de linaça sembradas (Valdavida, LE-1606)

Una media fanega con su rasero y varras de yerro buena (Grajal de Campos, LE-1656)

Una fanega de trigo (Frechilla, PA-1639)

Dos fanegas y media de trigo (Villarramiel, PA-1694)

Una media fanega buena sin rasero (Autillo de Campos, PA-1653)

Tres fanegas de zebada (Boadilla de Rioseco, PA-1692)

Una media anega con su rasero (Medina de Rioseco, VA-1643)

Dos anegas de avellana (Medina de Rioseco, VA-1646)

Anega y media de garvanços (Medina de Rioseco, VA-1646)

Una media fanega con su rasero buena (Villalón, VA-1637)

Otro costal con asta una anega de arina (Villalpando, ZA-1637)

Una fanega de çebada (Carrizo, ZA-1646)

Una anega de trigo tasada en doze reales y medio (Carrizo, ZA-1646)

Trece fanegas de trigo que llebó de simiente (Villalpando, ZA-1670)

Es un término presente tanto en la documentación de la Tierra de Campos como en el resto de los inventarios de la época. Voz muy común, aunque con valores diferentes dependiendo de su ubicación. Por regla general hace referencia a una medida de capacidad de áridos, aunque también encontramos referencias a superficie y al instrumento que sirve para medir. En este caso, figura bajo el sintagma media fanega. Al igual que indica Morala, la variante con /f-/ es la más frecuente tanto en la documentación objeto de estudio como en la incluida en el CorLexIn. La otra variante que localizamos en los textos terracampinos es anega, que en algunas ocasiones figura junto a fanega en un mismo inventario, como ocurre en el inventario de Carrizo (Zamora); algo que es frecuente en los documentos de la época (Morala, 2016b: 560).

En estudios sobre léxico más actuales se sigue recogiendo este término; así, en Palencia la fanega es 'medida de superficie equivalente a 64,395 áreas o 576 estadales', pero también se utiliza como 'medida de capacidad para áridos equivalente a dos cuartos o $42 \mathrm{~kg}$ ' (Gordaliza, 1988: 108). Le Men también localiza este término en toda el área del leonés, donde fanega se utiliza como medida de áridos y también de superficie (Le Men, 2005, s. v. fanega). Álvarez Tejedor (1989: 114-115) recoge el término en Zamora como 'medida de grano'.

\section{HEMINA [emina]}

Sust. f. 'Medida antigua para líquidos, equivalente a medio sextario', 'en la provincia de León, medida de capacidad para frutos, equivalente a algo más de 18 I'; 'en la provincia de León, medida agraria para la tierra de secano, que tiene 110 pies de lado y equivale a 939 centiáreas y $410 \mathrm{~m}^{2}$; 'en la provincia de León, medida para las tierras de regadío, que tiene 90 pies de lado y equivale a $628,88 \mathrm{~m}^{21}$ (DLE, 1. . 3. , 4. a y 5. a). Aparece en Nebrija como medida pero sin "h". Autoridades la registra como una medida utilizada por los romanos que 'servía tanto para las 
cosas líquidas como para los granos, la qual era la mitad de un sextário', aunque también registra el uso que se le daba en Castilla como 'cierta medida de granos que tiene la tercera parte de una fanega' (NTLLE, s. v. hemina; Nebrija, 1495; Autoridades, 1734). El equivalente griego de semies * $\eta \mu \iota$ que entra en la composición de varias palabras entre las que se encuentra hemina (DECH, s. v. semi-).

Otra tierra a los Billares, que ansimismo es suya y açe treçe eminas de senbradura (Valderas, LE1647)

Un costal con una emina de çenteno (Valderas, LE-1682)

Una emina de medir trigo tasada en dos reales (Mazariegos, PA-1619)

Dos eminas pequeñas (Frechilla, PA-1640)

Quatro cargas de trigo menos una emina (Cuenca de Campos, VA-1651)

Una emina de madera con su rasero tassada en veynte reales (Cuenca de Campos, VA-1668)

Cuatro eminas de trigo (Cuenca de Campos, VA-1670)

Ocho eminas de çenteno (Villalobos, ZA-1654)

La hemina es una medida de origen romano que se localiza en la Tierra de Campos con tres acepciones diferentes, como ocurre con las medidas estudiadas anteriormente. Se encuentra en los textos como 'medida de capacidad para áridos' (trigo, centeno o cebada) y el DLE marca este significado como propio de León. Lo mismo ocurre con otra de las acepciones de esta voz, como 'medida de superficie'. Así se documenta en León, Zamora y Valladolid (Pérez Toral, 2015b: 85). $Y$, por último, hace referencia al 'recipiente en el que se mide': "una emina de madera con su rasero".

Este carácter dialectal de hemina se puede observar también en los textos que conforman el $C D H$, donde esta medida se localiza en documentos pertenecientes al Reino de Léon: una Carta de relación de bienes perteneciente al Monasterio de Carrizo (León) y fechada en 1218 figura como medida de capacidad de áridos ("eminas de zeuada"); en los Fueros que el abad de Sahagún y otros señores dieron a Villavicencio (1221) donde se documentan "eminas de trigo"; en los Documentos de la Catedral de León, Apeo y desplazamiento de tierras en Documentos del Monasterio de Santa Clara de Villalobos o la Colección diplomática de Santo Toribio de Liébana. En la documentación medieval se amplía la zona donde se localiza este término que está presente en parte del antiguo Reino de León (Morala 2007: 423-425).

Esta distribución que se observa en los documentos del $\mathrm{CDH}$ se extrapola a los textos que conforman el CorLexIn, donde las ocurrencias se localizan sobre todo en León y en algunos puntos de Cantabria, Valladolid y Zamora. A estas zonas habría que sumarles el occidente de Asturias, occidente de Valladolid y Zamora (Morala, 2017c: 360); este recorrido incluye toda la Tierra de Campos, comprendida la zona palentina.

Repertorios léxicos actuales como el de Le Men o Gordaliza también recogen esta voz en la Tierra de Campos y otros puntos de León, Palencia, Valladolid, Zamora, además de algunos puntos de Asturias. 


\subsubsection{Medidas de capacidad para líquidos}

\section{AZUMBRE [azunbre, açumbre]}

Sust. m. o f. 'Medida de capacidad para líquidos que equivale a unos dos litros' (DLE). Es un término recogido por Nebrija y que Autoridades define como 'cierta medída de las cosas líquidas, como agua, vino, vinagre, ò leche, que es la octava parte de una arróba: promiscuamente se llama azumbre la medida, y lo que se contiene en ella [...]' (NTLLE, s. v. azumbre; Nebrija, 1495; Autoridades, 1726). Término procedente del ár. țmn 'octava parte' (DECH, s. v. azumbre).

Dos calderas buenas que la una hará una cántara y la otra, tres açumbres (Celada, LE-1600)

Dos xarros de azunbre cada uno (Santa María del Río, LE-1617)

Treynta cántaros de vino que se vendió a diez y ocho marauedíes azumbre (Frechilla, PA-1612)

Una botilla de hasta un açumbre (Frechilla, PA-1615)

Otro botijón, un puchero, tres botijas de a tres azumbres cada una (Frechilla, PA-1639)

Tres botijas de a tres açumbres (Frechilla, PA-1639)

Otro jarro de una azumbre (Frechilla, PA-1675)

Una botixa de tres azumbres (Frechilla, PA-1675)

Otra olla bidriada con tres açumbres de manteca de lechón (Frechilla, PA-1675)

Una açumbre de manteca (Villarramiel, PA-1692)

Una olla que tiene como cosa de una azumbre de manteca de puerco (Boadilla de Rioseco, PA1692)

Media azumbre de manteca (Cuenca de Campos, VA-1668)

Dos açumbres y media de manteca (Villalpando, ZA-1629)

En Tierra de Campos designa la capacidad que tienen los recipientes que contienen vino -"jarro de un açumbre", "botixa de tres azumbres", "dos jarros de azumbre cada uno"-, habitualmente en los documentos terracampinos hay preferencia por el término cántara para medir los líquidos y en especial el vino. Azumbre también se utiliza para medir otros productos como la manteca.

Morala ya advierte de que la distribución de esta voz es bastante irregular (Morala, 2016b: $572)$.

\section{CÁNTARA}

Sust. f. 'Cántaro' o 'medida de capacidad para líquidos, equivalente en Castilla a 16,13 I, y de cabida distinta en otras regiones' (DLE). Esta medida la recoge Autoridades como medida de capacidad propia de Castilla: 'espécie de medida que se usa en Castilla para el vino, y viene à ser lo mismo que arróba' Sin embargo, en la edición del DRAE de 1780 aparece como lema principal el de sinónimo de 'vasija o cántaro para contener líquidos', aunque sigue manteniendo la marca diatópica de la medida de capacidad (NTLLE, s. v. cántara, Autoridades, 1729; DRAE, 1780). Término derivado de cántaro, del lat. CANTHARǓs 'especie de copa grande, de dos asas' (DECH, s. v. cántaro).

Dos calderas buenas que la una hará una cántara y la otra, tres açumbres (Celada, LE-1600) Una carral buena de asta biente y seis cántaras (Santa María del Río, LE-1617) 
Una carralica de cinco cántaras (Cea, LE-1621)

Un carralón de ocho o diez cántaras (Valderas, LE-1682)

Un tonel y una carral de quatro cántaras y una tina (Guaza de Campos, PA-1640)

Dos toneles de a treinta y dos cántaras cada uno llenos de vino (Autillo de Campos, PA-1653)

Quarenta cántaras de mosto (Villada, PA-1665)

Un tunel que hará treinta y quatro cántaras (Villarramiel, PA-1690)

Una carral de cabidad de diez cántaras (Boadilla de Rioseco, PA-1692)

Dos carrales pequeñas y una grande que ará veinte y quatro cántaras (Villalón, VA-1638)

Zinco tinajas grandes y pequeñas de varro de diez y siete cántaras de vinagre (Medina de Rioseco, VA-1646)

Quinientas cántaras de vino en quatro cubas (Medina de Rioseco, VA-1649)

Una cuba de bino de cien cántaras (Villalpando, ZA-1650)

Una quba de vino tinto de ochenta cántaras (Villalobos, ZA-1654)

Sesenta cántaras de vino tinto (Villalapando, ZA-1661)

Un carralón nuebo de seis cántaras (Villalpando, ZA-1686)

Cántara se encuentra ampliamente documentado en los inventarios de la Tierra de Campos con las dos acepciones que ofrece el diccionario académico para esta palabra.

Con la acepción de 'medida de capacidad para líquidos', cántara se registra en el CDH desde el siglo XIII. Las ocurrencias que aparecen de este significado en el CorLexIn se documentan sobre todo en el Norte de la Península. Este significado se presenta en documentos de la mitad norte de la Península (Morala, 2016b: 568).

Otra acepción con la que se documenta cántara es como 'recipiente', que además de en las zonas mencionadas anteriormente, se localizan ejemplos en localidades más septentrionales como en Ciudad Real o Córdoba. En la Tierra de Campos encontramos las siguientes ocurrencias:

Dos cántaras de varro, el uno desasado (Sahagún, LE-1608)

Dos cántaras y una votixa de varro viexos (Cea, LE-1621)

Una media cántara de uarro (Valderas, LE-1682)

Una cántara y un jarro que está en el bassar y una cazuela de barro (Frechilla, PA-1675)

Una media cántara y un enbudo de cobre (Medina de Rioseco, VA-1640)

Una media cántara de covre (Medina de Rioseco, VA-1660)

Vna media cántara desondada con vn zelemín de sal (Villalobos, ZA-1654)

Además de cántara como recipiente, principalmente de barro, encontramos la media cántara, que recuerda a la media fanega y al medio celemín localizados en la zona de estudio.

Este vocablo se localiza en repertorios dialectales más modernos. Gordaliza señala que se trata de una 'medida antigua de capacidad que equivalía a ocho azumbres y 16,113 litros. Hoy se usa especialmente para el vino con el valor aproximado de 16 litros, cabida del garrafón normal' (Gordaliza, 1988: 57). Le Men registra este término en diferentes zonas del leonés como La Vecilla, Riaño, Valencia de Don Juan o La Bañeza (Le Men, 2004, s. v. cántara).

CÁNTARO [Vid. Recipientes agrícolas] 


\subsubsection{Medidas de peso}

\section{ARROBA [arroua, arrova]}

Sust. f. 'Peso equivalente a 11,502 kg', 'Medida de líquidos que varía de peso según las medidas y los mismos líquidos' (DLE, 1. y 4. a ac.). En el Tesoro de Covarrubias aparece como 'peso de venticinco libras', mientras que Autoridades añade la acepción de 'medida para cosas líquidas, que en algunas partes se llama cántara, ò cántaro, y contiene regularmente ocho azumbres' (NTLLE, s. v. arroba; Covarrubias, 1611; Autoridades, 1726). Término que designa el 'peso equivalente a la 4. a parte de un quintal', de rúba', pronunciación vulgar del árabe rub ${ }^{\varsigma}$ 'cuarta parte' (DECH, s. v. arroba).

Una arroba de lana en bellón (Sahagún, LE-1606)

Dos tocinos que pesarán tres arrobas (Cea, LE-1621)

Un lechón de matança que pesará diez arrobas (Grajal de Campos, LE-1656)

Una $\operatorname{ar}(r) o b a$ de lana ylada y de por ylar blanco y negro (Grajal de Campos, LE-1671)

Dos arrobas de lana negra lavada (Frechilla, PA-1612)

Dos toçinos que pesarán quatro arrobas (Frechilla, PA-1640)

Otra tinaxa con un quarto de arrova de aceite (Frechilla, PA-1675)

Un zerdo que pesará diez arrobas (Paredes de Nava, PA-1689)

Tres arrobas de queso (Villarramiel, PA-1690)

Dos arrobas de lana en xugo (Villarramiel, PA-1691)

Tres arrobas de ygos (Medina de Rioseco, VA-1646)

Una romana de tres arrobas (Medina de Rioseco, VA-1646)

Quatro arrobas de queso añejo (Medina de Rioseco, VA-1646)

Zien arrobas de cáñamo (Medina de Rioseco, VA-1649)

Noventa y dos arrouas de lana negra en xugo (Villalpando, ZA-1629)

Tres arrobas de cal entre biba y muerta a dicho precio (Villalpando, ZA-1629)

Un marrano çebado bueno de siete arrobas (Villalpando, ZA-1660)

Dos arrobas de tocino (Villalpando, ZA-1698)

En el siglo XVII, esta era una de las medidas más extendidas en España y de sus colonias de ultramar. En Tierra de Campos se documenta fundamentalmente con el primer significado académico, como medida de peso - de tejidos como la lana, de alimentos como el tocino, el queso o los higos, de animales criados para alimento como el cerdo.

Con la acepción de 'medida de capacidad para líquidos' aparece de forma menos regular y utilizada solamente para el aceite, en ningún caso para vino:

Asta seis arrobas de aceyte en una tinaja (Frechilla, PA-1638)

Cuatro ollas grandes vidriadas y la una aze tres arrobas de aceyte (Medina de Rioseco, VA-1648)

Dos ollas bidriadas con dos arrovas de azeyte (Medina de Rioseco, VA-1660)

Gómez Ferrero tampoco encuentra ejemplos de este término con esta acepción en el estudio léxico de La Bañeza (Gómez Ferrero, 2015: 321). Morala señala que la arroba como medida de capacidad para líquidos es más frecuente en la mitad sur de España -desde Ávila a Málaga, desde Cáceres a Alicante o desde Cuenca a Cádiz- (Morala, 2016b: 568-569). 


\section{LIBRA [livra, liura]}

Sust. f. 'Peso antiguo de Castilla dividido en 16 onzas y equivalente a 460g. En Aragón, Baleares, Cataluña y Valencia tenía 12 onzas, 17 en las Provincias Vascongadas y 20 en Galicia, y además las onzas eran desiguales según los pueblos' (DLE, 5. a ac.). Término recogido por Nebrija y Covarrubias como 'medida de peso' y como 'moneda' (NTLLE, s. v. libra, Nebrija, 1495; Covarrubias, 1611). Palabra procedente del lat. LīBRA 'libra de peso', 'balanza' (DECH, s. v. libra).

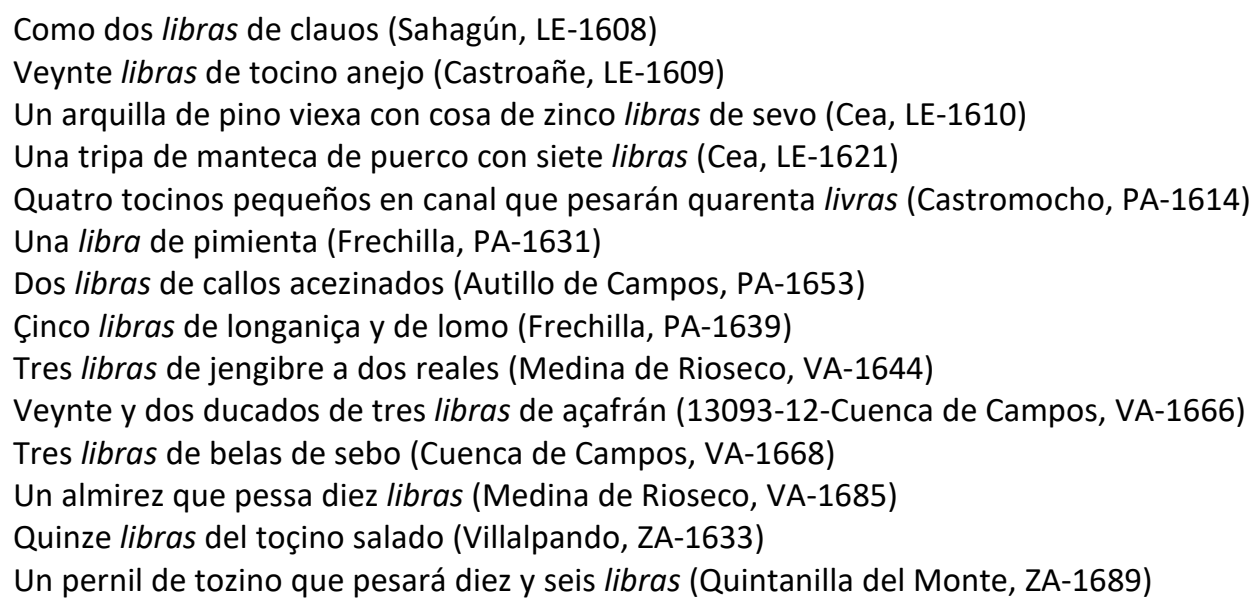

Este vocablo se encuentra ampliamente documentado en la zona de estudio, al igual que en el resto de documentación consultada (CorLexIn, $C D H, C O R D E$ ).

Es una palabra de uso generalizado en el siglo XVII, con distintas acepciones y con valores también diferentes dependiendo de la zona. Castaño localiza este término en la Documentación de la catedral de León en el año 916 (Castaño, 2015: 260):

Pro unacuiqu sollemnia, XII libras de cera [...] et pro diem Sanctam Pasce libra una piperis (Del Ser, Q.: Documentación de la catedral de León (siglos IX-X), 1981, p. 62).

La primera documentación que figura en el $C D H$ es del Fuero de Madrid, documento de mitad del siglo XIII que es una copia y cuyo original es de 1141.

En Tierra de Campos figura como medida de peso para alimentos como tocino, manteca, jengibre, azafrán o pimienta, pero también para otro tipo de sustancias y objetos como cera, lana o clavos entre otros.

Además, la libra representa una de las medidas por excelencia en el campo textil en esta zona:

Veynte libras de zerro ylado en obillos y dos madexas (Sahagún, LE-1601)

Una libra de griñones en diez reales (Sahagún, LE-1602)

Diez y seis libras de lana labada negra apreçiadas en diez y seis reales (Frechilla, PA-1612)

Dos paños de tocar y seis libras de serbilletas y dos baras de estopa (Grajal de Campos, LE-1658)

Seis libras de orillas sin teñir (Frechilla, PA-1639)

Cinco libras de tramas (Frechilla, PA-1642)

Siete libras de lana basta yladas al torno para alforjas (Guaza de Campos, PA-1640)

Una libra de lana ylada basta (Villarramiel, PA-1690)

Treynta libras de lino en madejas y obillos (Medina de Rioseco, VA-1644)

Ocho libras de ylaza de estopa (Medina de Rioseco, VA-1661)

Tres libras de estopa ylada (Villalpando, ZA-1688) 
Otra acepción que acompaña este término es la de peso que configuraba las balanzas en aquella época:

Un peso de balanças con una pesa de quarterón y otra de media libra y otra pesa de una libra (Grajal de Campos, LE-1655)

Un peso de valanças con sus libras y media de pesas de yerro (Grajal de Campos, LE-1658)

Un pesso de Valanças con dos liuras i media de yerro (Boadilla de Rioseco, PA-1692)

Un peso de garabatos con una pesa de una libra (Villarramiel, PA-1696)

Un pesso de yerro grande nuevo con una pesa de dos libras de yero (Villalpando, ZA-1661)

\section{ONZA [onça, honza, honça]}

Sust. f. 'Cada una de las 16 partes en que se divide la libra, equivalente a 28,75 g' (DLE). Nebrija recoge la voz onça como 'duodecima parte de libra' y Covarrubias mantiene la grafía, pero aclara que 'en Castellano repartimos la libra en deziseis onças, aunque los antiguos la repartian en doze, y oy dia es la libra de mas o menos onças' (NTLLE, s. v. onça, Nebrija, 1495; Covarrubias, 1611). Término procedente del lat. ǓNČ̃A 'duodécima parte de la libra y de otras medidas' (DECH, s. v. onza).

Unos sartales de corales con dos anus dei de plata que pesaron quatro onzas (Grajal de Campos, LE-1671)

Un sartal de corales gruesos de ocho onças (Frechilla, PA-1613)

Seis libras menos dos onças en siete pieças de pesar (Frechilla, PA-1640)

Dos barquillos de plata medianos con sus pies que pessan doce onças (Paredes de Nava, PA-1690)

Una sarta de plata que pessó quarenta y tres honças (Medina de Rioseco, VA-1640)

Onças de molinillos finos de seda (Medina de Rioseco, VA-1644)

Quarenta y oçho botones de oro que pesaron dos onças (Medina de Rioseco, VA-1645)

Un pesso de garavatos con libra y dos honzas (Medina de Rioseco, VA-1649)

Quatro cucharas y un barquillo de plata que todo pesó ocho honzas (Medina de Rioseco, VA1649)

Un brassero de plata que pessó diez y ocho honças y media (Medina de Rioseco, VA-1657)

Unas manillas de aljofar que pessan dos onças y media (Medina de Rioseco, VA-1685)

Un onça de seda gruesa y delgada (Villalpando, ZA-1670)

Un pimentero de plata y tres bassos de fratiquera que pesan nuebe onzas (Villalpando, ZA-1696)

La onza es una de las medidas más extendidas en los textos del siglo XVII. Los ítems recuperados del CorLexIn se distribuyen por un extenso ámbito que comprende la Península, Canarias y América. En cuanto al significado, tanto en la Tierra de Campos como en los documentos que conforman el CorLexIn, de forma habitual suele utilizarse como medida de peso de la plata, el oro o el aljófar; así, nos encontramos con "braseros, cucharas, vasos, pimenteros, barquillos,..." cuyo peso se expresaba en onzas. Aunque este no era el único uso que se le daba a esta medida, pues en onzas también se pesaban los adornos y pasamanería de los vestidos (botones, hilo, molinillos, pasamanes, puntas, seda). Otro de los significados que también figura en los inventarios de bienes es el de 'peso de balanza' ("Un pesso de garavatos con libra y dos honzas").

Desde una perspectiva diacrónica, onza figura en la documentación que conforma el $C D H$ a partir del Fuero de Zorita de los Canes (1218-1250):

La libra dela carne deue seer de quarenta et ocho onças (Fuero de Zorita de los Canes, 1218-1250) 
En la documentación que nos ofrecen tanto el $C D H$ como el CORDE aparece la onza para pesar carne, pimienta, azúcar o manteca, y para medir vino, agua, zumo o aceite, entre otros. Castaño afirma que la onza ha llegado hasta nuestros días para medir especias fundamentalmente como el incienso, el azafrán, la pimienta... (Castaño, 2015: 261). Sin embargo, en los documentos que nos encontramos en la Tierra de Campos, el azafrán se pesa en libras y el aceite en arrobas o medias arrobas. Por su parte, el CorLexIn tan solo presenta tres casos en los que onza aparece junto a azafrán, cera y aceite:

Una onza de aceite (Potosí, Bolivia, 1609)

Cuatro onzas de azafrán (Zarabes, SO-1638)

Vna acha de cera de quatro libras y una onza (S-1650)

Esta medida también se usa para calcular el peso de los ingredientes utilizados para elaborar medicinas; la onza forma parte de los pesos utilizados en la misma para pesar jarabe, llantén o polvos (Perdiguero, 2019: 153).

En estudios dialectales más actuales se recoge como medida antigua medida de peso equivalente a un sexto de libra o 28 gramos y también como antigua medida de capacidad para el aceite (Gordaliza, 1988:161).

\subsubsection{Medidas de longitud}

\section{ANA}

Sust. f. 'Antigua medida de longitud, generalmente para tejidos, equivalente a $1 \mathrm{~m}$ aproximadamente' (DLE, s. v. ana ${ }^{1}$ ). Nebrija registra el término alna como 'medida de paño'. Covarrubias afirma que alna es voz valenciana y recoge ana como 'cierta medida con que miden las tapicerías, menor que la vara comun' (NTLLE, s. v. ana, Nebrija, 1495; Covarrubias, 1611). Término procedente del gót. álina 'codo (medida)' (DECH, s. v. ana I).

Seis tapizes de figuras que tubieron ziento y onze anas a nueve reales el ana (Medina de Rioseco, VA-1640)

Tres frangotes de navales finos con cinquenta y quatro pieças con treçientas y [tachado: veinte] diez y siete anas que reducida y aneadas a ciento y quarenta son quatroçientos y [tachado: ocho] quarenta y quatro varas castellanas (Medina de Rioseco, VA-1645)

Quatro tapiçes de figuras grandes con cinquenta y seis anas, a diez reales cada una (Medina de Rioseco, VA-1649)

Se localiza este término en inventarios pertenecientes a Medina de Rioseco, localidad vallisoletana de la Tierra de Campos famosa por la manufactura y comercio textil. Estamos ante un vocablo poco frecuente en los textos.

La primera documentación que nos presenta el CORDE corresponde a las Cuentas de Gonzalo de Baeza, tesorero de Isabel la Católicas y publicadas entre 1477 y 1491 :

Entresuelo de rras, de 25 anas, que vendió para la cámara de sus Altezas

Las concordancias se repiten hasta finales del siglo XVI en textos notariales como dotes, inventarios, particiones, etc. para referenciar la longitud de tapices, paños con hagiografías o 
historias de personajes literarios, antepuertas, etc. A partir del siglo XVII la palabra entra en un claro retroceso. El motivo puede ser la preferencia de la llamada vara castellana, que era una medida equivalente utilizada en Toledo; incluso en el Manual de contadores de Juan Pérez Moya fechado en 1589 se recomienda convertir las anas en varas:

Artículo primero: convertir o hazer de anas varas.

Parece que este término no tuvo éxito en el castellano peninsular; sin embargo, los datos que nos ofrece el CorLexIn apuntan a una mayor presencia en la documentación americana -México, Perú, Chile- con la misma acepción académica.

En cuanto a la etimología de esta voz, Castaño señala que los romanos utilizaban la palabra ulna para designar el antebrazo, por lo que no resulta raro encontrar ana o alna como medidas de longitud para denominar el codo. Así sucede en algunos países europeos y también en Cataluña y Valencia (Castaño, 2015: 134).

La variante alna de la que habla el mismo autor la recoge el CORDE en una obra titulada Tratado de plantar o enjerir árboles o de conservar el vino fechado entre 1385 y 1407: "E a largueza de vna alna o de vn palmo"; en 1495 la registra Nebrija en su Vocabulario españollatino, pero de modo meramente testimonial, ya que la presencia en la documentación de esta base es muy escasa. Algo que ocurre tanto en el CorLexIn como en la zona de estudio donde no se han registrado casos en sus correspondientes corpus.

\section{PALMO}

Sust. m. 'Distancia que va desde el extremo del pulgar hasta el del meñique, estando la mano extendida y abierta', 'medida de longitud de unos $20 \mathrm{~cm}$, que equivalía a la cuarta parte de una vara y estaba dividida en doce partes iguales o dedos' ( $D L E$, 1. a y 2.a ac.). Término derivado de palma, procedente del lat. PALMA 'palma de la mano' (DECH, s. v. palma).

Cuba pequeña llena de bino nuebo de la cosecha deste dicho año de siete palmos (Grajal de Campos, LE-1657)

Una cuba de bino de diez palmos de vodega (Grajal de Campos, LE-1671)

Un basto de ocho palmos lleno de uino tinto de la cosecha de este año (Valderas, LE-1682)

Vna quba de bino blanco, la primera a mano izquierda de diez palmos (Villalobos, ZA-1654)

Un basto de cuba de siete palmos (Villalpando, ZA-1661)

Una cueba con dos vastos de cuba ya usados la una de ocho palmos y la otra de nueve (Cotanes del Monte, ZA-1687)

Una cuba nueba de ocho palmos (Villalpando, ZA-1690)

En Tierra de Campos se localiza esta palabra con una acepción diferente a la que da el DEL: aparece como medida de líquidos y, más concretamente, para medir el vino; siempre aparece referenciada junto a cubas y bastos llenos de vino. En el CorLexIn encontramos palmo como medida de longitud en diferentes puntos de España, Canarias y colonias de ultramar. Con la acepción que figura en la documentación terracampina encontramos un ejemplo en un inventario perteneciente a la localidad palentina de Herrera de Valdecañas, localidad próxima a la zona de estudio:

Vna cuba de doze palmos nueba, sin juntar (Herrera de Valdecañas, PA-1700) 


\section{PIE}

Sust. m. 'Medida de longitud usada en muchos países, aunque con varia dimensión' ( $D L E, 15$. a ac.). Nebrija recoge este término como 'medida comun'. Autoridades lo define como 'especie de medida mui usada en las mas partes; pero desigual en unas, respecto de otras' entendiendo que la medida es diferente dependiendo del lugar en el que se usa (NTLLE, s. v. pie, Nebrija, 1495; Autoridades, 1737). Término derivado de PĒS, PĚDIS, íd. (DECH, s. v. pie).

Dos vigas de a diez y ocho pies nueuas (Frechilla, PA-1612)

Un poste de roble bueno grande de asta doçe pies (Frechilla, PA-1614)

Diez y ocho vigas de a veynte y dos pies diez y ocho quartones (Medina de Rioseco, VA-1641)

Otras seys tablas de a seys pies y media bara y dos dedos de ancho (Medina de Rioseco, VA-1661)

Es voz de uso general en la época que en los inventarios de bienes de la Tierra de Campos figura con diferentes acepciones, entre ellas la de medida, principalmente para designar la longitud de vigas, postes o tablas, como se observa en las ocurrencias anteriores. El pie como objeto y como medida procede del pie romano, lo que hace que pronto forme parte del acervo léxico de todos los romances (Castaño, 2015: 140-142). Como medida es uno de los submúltiplos de la vara, y, como en la mayoría de las medidas de esta época, su valor variaba dependiendo de las zonas. En los inventarios del siglo XVII lo encontramos asimismo como medida de longitud, pero también de superficie para medir tierras plantadas de olivos, castaños, nísperos, tamarindos, naranjos, etc., en documentos peninsulares y americanos (CorLexIn).

Es un término de uso general en la época que en los inventarios de bienes de la Tierra de Campos también aparece con un significado general como 'base o parte en que se apoya algo' (DLE, 3. a ac.):

Unos pies de mesa (Castroañe, LE-1609)

Una mesa larga de quatro pies buena (Galleguillos, LE-1618)

Tres argadillos los dos con pies y aguxa de yerro (Grajal de Campos, LE-1656)

Una mesica pequeña de quatro pies (Valderas, LE-1659)

Una vanca de quatro pies (Castromocho, PA-1614)

Una messa de pino de quatro pies demediada (Frechilla, PA-1642)

Dos barquillos de plata medianos con sus pies que pessan doce onças (Paredes de Nava, PA-1690)

Un banco de respaldo de castaño con tres pies (Boadilla de Rioseco, PA-1692)

Una mesica de pino serrana de tres pies (Villalón, VA-1642)

Una arca de nogal mediana con sus pies tassada en treinta reales (Medina de Rioseco, VA-1644)

Dos vanquillos de quatro pies en dos reales (Cuenca de Campos, VA-1666)

Una arca sin pies (Carrizo, ZA-1646)

Vna arca de quatro pies, biexa (Villalobos, ZA-1654)

Dos pies de argadillo (Villalpando, ZA-1690)

Y como 'parte análoga al pie humano en los animales' (DLE, 2. ac.):

Ocho pies de puerco (Castromocho, PA-1614)

Siete pies de puerco (Frechilla, PA-1639)

Quatro toçinos medianos con las cabezas y pies de los marranos (Villalpando, ZA-1660) 


\section{PIERNA}

Sust. f. 'Cosa que unida con otras formas o compone un todo. Pierna de sábana' (DLE, 5. a ac.). Esta misma acepción la recoge Autoridades en su edición de 1737 (NTLLE, s. v. pierna, Autoridades, 1737). Término procedente del lat. PĔRNA 'muslo y pierna juntos, en un animal', 'muslo del cerdo', 'zanca en el hombre' (DECH, s. v. pierna).

Una pierna de manta de lino y lana mytad blanco y mitad pigazo (Sahagún, LE-1608)

Una sábana de tres piernas de cerro buena (Santa María del Río, LE-1617)

Una sábana de lienzo de tres piernas (Grajal de Campos, LE-1670)

Una media pierna de sáuana (Valderas, LE-1682)

Una sávana de lienco de quatro piernas (Castromocho, PA-1614)

Una manta de gordellate blanca con dos piernas (Autillo de Campos, PA-1653)

Un lenzuelo de estopa de dos piernas en quinze reales (Frechilla, PA-1675)

Una sábana con tres piernas mediada (Villarramiel, PA-1691)

Una manta blanca y una sáuana bieja de dos piernas (Medina de Rioseco, VA-1641)

Dos sábanas de lienco de a tres piernas nuevas (Tamariz de Campos, VA-1651)

Una sávana de lienco basto de seis piernas nueva (Cuenca de Campos, VA-1666)

Otra manta de lino y lana de dos piernas y media (Cuenca de Campos, VA-1670)

Vna sáuana del pan de dos piernas ussada (Villalpando, ZA-1654)

Sus sávanas de lienzo de a tres piernas ya usadas (Cotanes del Monte, ZA-1687)

Dos sávanas de lienzo de tres piernas buenas (Tapioles, ZA-1688)

Una manta cassera de dos piernas (Villalpando, ZA-1698)

Esta medida equivalía aproximadamente a 2,5 metros (González Mena, 1994: 72) y el nombre está relacionado con la forma de confeccionarse. Los telares solían ser demasiado estrechos, por lo que era necesario coser varias piezas entre sí; a cada una de estas piezas se la denominó pierna.

El corpus terracampino presenta el sintagma "de x piernas" para especificar el tamaño, sobre todo, de las sábanas, pero también de las mantas y los lenzuelos. Los datos que nos ofrece el CorLexIn amplían este uso a paramentos, cortinas, pabellones, colchas, doseles, sobrecamas, colgaduras y paños. Presenta un uso extendido por toda la Península.

Bases de datos académicas como el CORDE y el $C D H$ ofrecen un número más reducido de uso de la palabra con este significado métrico. La primera documentación que aparece en el CORDE es en un inventario de bienes fechado en 1466 (Castaño, 2015: 155): "quatro lençuelos e un par de sávanas de a dos piernas de lino". Como medida de longitud aparece en el $C D H$ unos años antes, pero no para referirse a sábanas o ropa de cama, sino a una "crux de tres piernas" en la Traducción y glosas de la Biblia de Alba, datada entre 1422 y 1433 . Cabe decir que esta acepción figura fundamentalmente en documentos de corte notarial como inventarios, secuestros de bienes, particiones o dotes y ajuares.

\section{SESMA}

De las definiciones que el DLE da al término sesma, ninguna coincide con la encontrada en la zona de estudio. Covarrubias recoge esta palabra como 'la sexta parte de vna vara', acepción que encontramos en el corpus terracampino. Las obras lexicográficas académicas registran esta entrada desde Autoridades que mantiene este significado 'la sexta parte de qualquier cosa. 
Tómase regularmente por la de la vara'. Este significado se mantendrá hasta la edición de 1884 (NTLLE, s. v. sesma, Covarrubias, 1611; Autoridades, 1739; DRAE, 1884). Término derivado de seis, del lat. SĔX (DECH, s. v. seis).

Una sesma de terciopelo negro en catorce reales (Frechilla, PA-1675) Una sexma ${ }^{30}$ de terciopelo negro en catorce reales (Frechilla, PA-1675)

Quatro varas y sesma de riço pardo (Medina de Rioseco, VA-1645)

Esta voz no es de uso frecuente en los textos terracampinos, pues solo se localizan dos ocurrencias, ambas en localidades referentes del desarrollo textil en la época -Frechilla y Medina de Rioseco. Los ejemplos localizados en Tierra de Campos mantienen la acepción dada por Covarrubias.

Tampoco es una palabra frecuente en los textos que conforman el CorLexIn, donde apenas se localiza media docena de casos repartidos entre Tudela (Navarra) y Zaragoza en la Península, y Panamá y Santiago de Chile (Chile) en la documentación americana. En todos los casos con la medida textil que hemos documentado.

Desde una perspectiva diacrónica, esta lexía figura en los textos desde el siglo XIII, pero no exclusivamente con la acepción estudiada; de hecho, las primeras concordancias que aparecen tanto en el CORDE como en el $C D H$ referencian una medida de superficie:

[...] en fondo de Fogedo en una tierra la sesma e del otra sesma la quinta; en el prado de Sol Ladrero la sesma e de la otra sesma la quinta, costaneros filios de álvar Biejo; al Duruelo en dos prados la sesma e del otra sesma la quinta" (CORDE. Carta de venta. Documentos del Archivo Histórico Nacional, 1210).

[...] este corral ye ena uila que dizen Sancta Maria, so essa misma campana, \& ye bien determinado: de la primera parte uos mismo conprador, de la .iia. parte dona Eluira; esta sesma deste corral vendemos con sus entradas \& con suas yxidas" (CDH. Carta de venta. Documenación del Monasterio de Carrizo, 1247).

Con este significado no se registra en los diccionarios académicos hasta la edición de 1803: 'división de territorio' (NTLLE, s. v. sesma, DRAE, 1803).

Como medida en el ámbito textil se presenta en Cuentas de Gonzalo de Baeza, tesorero de Isabel la Católica datado entre 1477 y 1491: "dos varas e vna sesma de damasco negro"

Su uso es bastante regular hasta el siglo XVII, cuando la palabra entra en retroceso y prácticamente deja de usarse. En los diccionarios académicos dejan de registrar la acepción de medida a partir de la edición de 1889.

\section{VARA [bara, uara]}

Sust. f. 'Palo largo y delgado'. 'Medida de longitud que se usaba en distintas regiones de España con valores diferentes, que oscilaban entre 768 y 912 mm.', 'barra de madera o metal, que tiene

\footnotetext{
${ }^{30}$ Este ejemplo pertenece a la almoneda correspondiente al inventario anterior, en este caso hay un cambio de grafía (sesma frente a sexma), pero pertenece al mismo objeto inventariado.
} 
la longitud de una vara y sirve para medir' ( $D L E$, 3. , 6. 6 y 7.a ac.). El valor polisémico de vara se corrobora tanto en Nebrija como en Covarrubias. Voz procedente del lat. VARA 'travesaño en forma de puente' (DECH, s. v. vara).

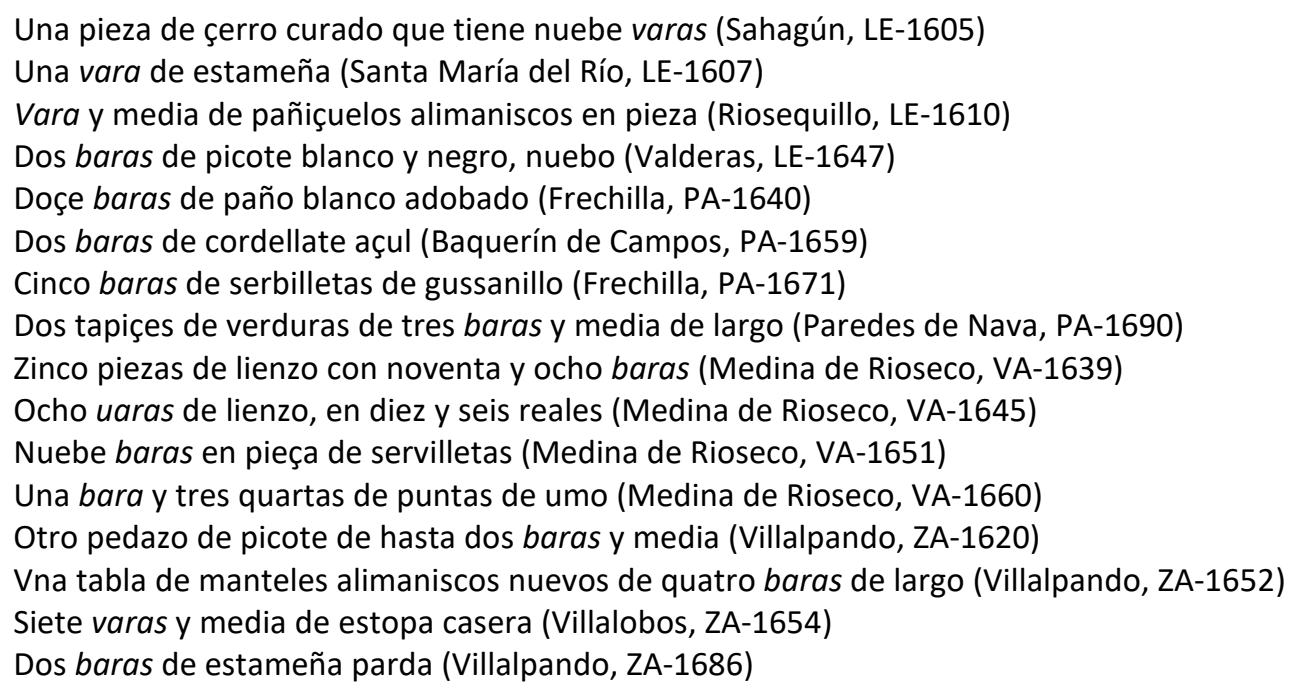

Esta palabra de múltiples significados es habitual en los inventarios de bienes de Tierra de Campos y del resto de documentación que conforma en el CorLexIn que se extiende por toda la Península, Canarias y América. La acepción más utilizada en tales textos es la de 'medida de longitud de telas'. Aunque también aparecen otras acepciones: así, en los documentos terracampinos encontramos:

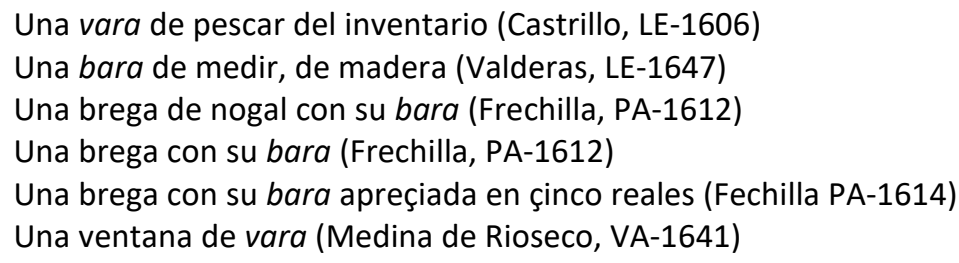

Formado por derivación se localiza en el corpus terracampino el verbo varear, procedente de documentos de la localidad palentina de Frechilla, muy conocida por sus manufacturas textiles. Para este verbo, entre otros significados figuran los de 'dar golpes con la vara o palo', 'medir con la vara' o 'vender por varas':

Una tabla de barear en un real (Frechilla, PA-1613)

Una tabla de varear lana (Frechilla, PA-1615)

Un carço de barear y unas tablas en noventa y quatro maravedís (Frechilla, PA-1615)

Una tabla par barear lana (Frechilla, PA-1616)

Un tablón para varear (Frechilla, PA-1631)

Una puerta de barear vieja (Frechilla, PA-1638) 


\subsubsection{Medidas de superficie}

\section{JERA [YERA]}

Sust. f. El DLE registra esta palabra con marca dialectal; cuando significa 'yugada', es término propio de Extremadura, mientras que en Salamanca significa 'obrada, jornal' y en Zamora 'ocupación, quehacer' (DLE, s. v. jera ${ }^{1}$ ). Cuando buscamos la variante yera-solución encontrada en Tierra de Campos- en el diccionario académico, nos remite a hiera, como un término en desuso con la acepción de 'jornal o trabajo que se hace en un día'. Terreros y Pando recoge jera como 'tierra que dejan en seco los esteros', sin marca diatópica. Sin embargo, años más tarde, en la edición académica de 1817, esta palabra se registra como propia de Extremadura y con la acepción de 'tierra que puede labrar en un día un par de bueyes' (NTLLE, s. v. jera, Terreros y Pando, 1787; DRAE, 1817). Jera es voz leonesa procedente del lat. DIARIA, 'ración o comida diaria', 'salario, jornal', derivado de DIES 'día' (DECH, s. v. jera).

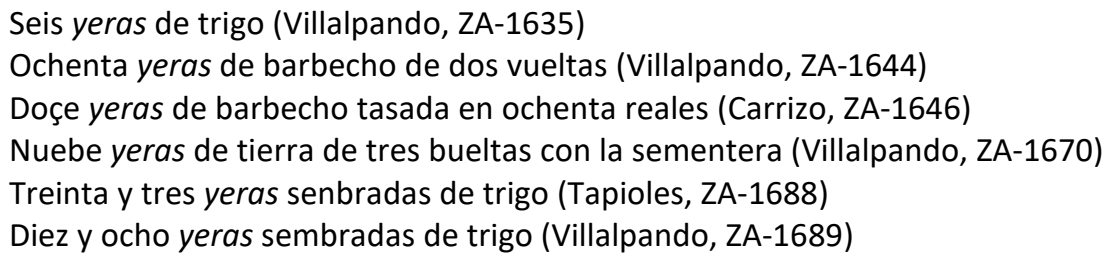

La voz yera se localiza en el territorio zamorano de Tierra de Campos con la acepción de medida de superficie y que hace referencia a la 'cantidad de tierra que es capaz de arar una pareja de bueyes en un día', compartiendo significado con yguada-salvo que este se extiende por otras zonas terracampinas.

Diacrónicamente, encontramos la solución patrimonial leonesa yera en dos colecciones diplomáticas medievales localizadas en el CORDE; en la Documentación Diplomática de León, en textos fechados en 1329 podemos encontrar ejemplos como "Item del otro cabo dessa misma carrera vnna yera de tierra" u "otra tierra en que ha media yera tras el palonbar", donde este término aparece como medida de superficie claramente. En diferente zona, enmarcada en la Tierra de Campos zamorana, encontramos en la Documentación de Santa Clara de Villalobos en diferentes fechas casos de este término: "en Bustiello otra tierra, en que ha una yera" o "una yera de tierra en Poços" fechados en 1356 y 1376 respectivamente. Unos años antes, en 1307 se localiza este término también en documentación leonesa: "Otra tierra carrera trauiessa en que a dos yeras, fronteras tierra que fue de García Cano e tierra que fue de Françisco Cano" (Martín Fuentes, J. A., Colección documental del archivo de la Catedral de León, XI, 1995, 2.780, P. 121 en Castaño, 2015: 223). En el siglo xvii, Morala esta voz en inventarios de localidades pertenecientes al partido judicial de Villalpando (Morala, 2017c: 362).

En repertorios dialectales más actuales se localiza yera en la zona este de la provincia de Zamora con la acepción encontrada en este estudio, como 'medida de superficie' semejante a la fanega y a una porción de cultivo en llano (Álvarez Tejedor, 1989: 48, 62). 


\section{YUGADA [YGUADAS]}

Sust. f. 'Espacio de tierra de labor que puede arar una yunta en un día' (DLE). En Tierra de Campos la variante que se documenta es yguada, registrada por Rosal como 'iguada de tierra, es corrupto de yugada [...]' (NTLLE, s. v. iguada, Rosal, 1611). El término académico yugada deriva de yugo, del lat. JǓGUM íd. (DECH, s. v. yugo).

Diez yguadas de barbecho los siete a dos bueltas y los tres a una buelta (Villarramiel, PA-1696) Aradura de una yguada de tierra (Villarramiel, PA-1696)

Las araduras de dos yguadas de tierra a tres bueltas (Villarramiel, PA-1696)

Asta doze yguadas senvradas de trigo (Cotanes del Monte, ZA-1687)

Asta quinze yguadas que quedaron de dho difunto suyas propias (Cotanes del Monte, ZA-1687)

La yugada es una medida de superficie que hace referencia a la 'tierra que era capaz de labrar en un día una yunta de bueyes'. Con la forma académica yugada se documenta en bases de datos como el $C D H$ desde el siglo XIII, al igual que la variante yubada que el DLE marca como aragonesismo. Sin embargo, Perdiguero localiza esta variante en textos sorianos del siglo XVII (Perdiguero, 2012a: 335). Y estos datos se corroboran consultando el CorLexIn, donde se localizan once documentos repartidos entre localidades de Soria y Zaragoza -Zábares y Maluenda respectivamente-con esta solución. La variante yugada aparece en textos de Vitoria y La Rioja en esta base de datos. Pérez Toral localiza la voz yugada, jubada y yubada como medida de superficie en la zona Norte y oriente peninsular -Asturias, Vitoria, La Rioja, Soria, Zaragoza, Castellón y Valencia- (Pérez Toral, 2015b: 91-93).

La variante que documentan los textos de Tierra de Campos es yguada, forma que presenta metátesis entre / $\mathrm{u}$ / y la /g/. Desde una perspectiva diacrónica, el CORDE y el CDH documentan esta voz con el significado metrológico a partir del siglo XV en textos de Ávila y Álava. Por su parte, el CorLexIn no presenta ocurrencias de esta variable en su base de datos. Tanto yguada como iguada aparecen en documentos notariales de Valladolid y provincia, incluida la zona terracampina (Rojo Vega):

[...] las dos tierras de nuebe iguadas a la horca y la otra a los martires de dos yguadas y media las tasaban y tasaron a seis mil y trezientos mrs cada yguada (Testamento, inventario y biblioteca del licenciado Diego Cifuentes, abogado, Villalón de Campos, 1577) ${ }^{31}$.

\subsubsection{Medidas de capacidad formadas sobre partitivos}

\section{CATORZAL}

El DLE registra esta palabra como adjetivo 'Dicho de una pieza de madera de hilo: De catorce pies de longitud y escuadría de ocho pulgadas de tabla por seis de canto'. Sin embargo, señala

\footnotetext{
${ }^{31}$ Rojo Vega, Anastasio: Testamento, inventario y biblioteca del licenciado Diego de Cifuentes, abogado, Villalón de Campos, 1577. Consulta realizada en diciembre de 2020 en:

https://investigadoresrb.patrimonionacional.es/node/5799.
} 
que es más común su uso en sustantivo masculino. La primera edición académica que recoge este término es la de 1884 y también como adjetivo (NTLLE, s. v. catorzal, DRAE, 1884). Es un término compuesto de cuatro y de diez, del lat. QUATTUǑRDĔCIM (DECH, s. v. cuatro).

Cinco catorzales, digo seis de pino nueuos (Frechilla, PA-1612)

Este término es muy poco frecuente en la zona de estudio, tan solo se ha localizado una ocurrencia en la localidad palentina de Frechilla. Esta escasez de datos se puede extrapolar al resto de documentos: en el $C D H$ y el CORDE se localiza un caso en Documentos de teatro en Burgos en un artículo titulado "Condiciones expuestas por Andrés de Ribas, para las reparaciones en la casa de Comedia", fechado en 1732:

Y han de ser de grueso de catorzal doble o quartón benturero

En el CorLexIn los ejemplos también son escasos, tan solo un documento en Herrera de Valdecañas (Palencia), fechado en 1700:

Dos catorzales pequeños (Herrera de Valdecañas, PA-1700)

Los ejemplos aportados tanto por el $C D H$ como por el CorLexIn son posteriores al recogido en La Tierra de Campos.

En estudios más recientes, localizamos a través del Fichero general de la RAE la definición que hace Velasco Sanz en un artículo dedicado al léxico de los pinares de Cuéllar y publicado en 1981, donde define este término como 'las vigas de sujeción de un tejado, fabricadas con los cuerpos del pino, de aquí que metafóricamente se conozca como 'catorzal' al pino del que se pueda hacer una de estas vigas. El llamado catorzal es un pino de veinte o veinticinco centímetros de diámetro, es decir, más delgado de lo normal' y advierte de que se usa siempre como sustantivo.

\section{CUARTA [quarta]}

Sust f. 'Palmo' ('medida de longitud de unos $20 \mathrm{~cm}$, que equivalía a la cuarta parte de una vara y estaba dividida en doce partes iguales o dedos' $D L E$, 2. a ac.) (DLE, 22. a ac.). Con la acepción de medida lo recoge la edición de 1817 del $D R A E$ 'una parte de cuatro en que se divide cualquier cosa. Regularmente se entiende por la cuarta parte de una vara en la medida, y de una onza en el peso' (NTLLE, s. v. cuarta, DRAE, 1817). Derivado de cuarto, del lat. QUARTUS (DECH, s. v. cuarto).

Dos quartas de lino (Sahagún, LE-1601)

Media quarta de fustán en beinte i quatro maravedies (Villavelasco, LE-1609)

Una pieza de çerro que tubo seis baras menos una quarta (Villacalabuey, LE-1614)

Quatro baras y una quarta de estameña (Grajal de Campos, LE-1658)

Tres varas menos una cuarta de paño pardo fino (Frechilla, PA-1631)

Dos paramentos pequeños como de tres quartas de largo cada uno (Villada, PA-1668)

Unos manteles de gusanillo de una bara y una quarta en seis reales (Frechilla, PA-1671)

Una mantilla de baeta berde de tres quartas (Frechilla, PA-1675)

Otro paño frailengo con treinta y dos baras y tres quartas de marvete (Medina de Rioseco, VA1642)

Siete varas de manteles en pieza de gusanillo de siete quartas de ancho (Medina de Rioseco, VA1660) 
Una bara y tres quartas de puntas de umo (Medina de Rioseco, VA-1660)

Quatro baras y una quarta de serbilletas de estopa de gusanillo (Villalpando, ZA-1620)

Una quarta de estopa para el cuello de la capa (Villalpando, ZA-1656)

Otra zestica con cossa de dos quartas de tela angosta (Villalpando, ZA-1690)

Es un término común en la documentación áurea con un valor fragmentario que se utiliza en diversos campos. En el corpus terracampino figura como medida de longitud para tejidos o ajuar doméstico, como se puede observar en los ejemplos anteriores.

Sin embargo, también es habitual encontrarla para indicar la superficie de viñas o majuelos:

Una viña adonde decen a la Pedraza que ará vna quarta (Joara, LE-1604)

Un majuelo a do diçen las Quemadas de Baldefuentes que açe diez y siete quartas (Valderas, LE1647)

Una biñuela a las terçias que hace media quarta lindero Toribio Rodríguez (Mazariegos, PA-1619)

Vna viña que ay, y tiene, en término desta villa a Rubalejos, que haze quatro quartas (Boadilla de Rioseco, PA-1650)

Siete quartas de biña (Boadilla de Rioseco, PA-1689)

Un majuelo que açe una quarta (Villarramiel, PA-1690)

Tres quartas de viña al pago de San Martín (Cuenca de Campos, VA-1606)

Una biña maxuelo quel dicho difunto quedó en los términos de esta villa al pago de Taragudillo que hace cinco quartas poco más o menos (Cuenca de Campos, VA-1668)

Una viña de veinte quartas (Villalpando, ZA-1631)

Un majuelo de quatro quartas (Villalpando, ZA-1637)

Una uiña a Lagunilla, camino de Fuentes, que ace veinte quartas (Villalobos, ZA-1654)

Una viña al zaguazal que aze siete quartas (Villalpando, ZA-1686)

Un maxuelo de diez quartas (Villalpando, ZA-1686)

Tres quartas de viña (Cotanes del Monte, ZA-1687)

Otra viña a los maxuelos de tres quartas (Tapioles, ZA-1688)

También se recogen ejemplos de tierras de labor, aunque de manera más restringida:

Las araduras de diez quartas de tierra a tres bueltas y la simiente de trigo para senbrarlos (Villarramiel, PA-1696)

Una tierra a Santa Marta que linda con tierra de herederos de Francisco Guerrero y camino de concejo que açe siete quartas (Villalobos, ZA-1654)

Otro de los contextos en los que figura este partitivo es el de las láminas, imágenes o cuadros para identificar sus dimensiones:

Tres hechuras de la virgen, de la Conzepcion la una y otra de san Jerónimo y otra del san Francisco y un Sto Xpto de a bara y cuarta con sus marcos (Medina de Rioseco, VA-1642)

Tres láminas pequeñas con bidrieras de cuarta de alto (Paredes de Nava, PA-1690)

Un quadro de San Joseph y el niño con su marco dorado de cinco quartas de alto (Paredes de Nava, PA-1690)

Un marco de un ecceomo con su marco dorado de tres quartas (Paredes de Nava, PA-1690)

Veinte y tres ymájenes y quadros de santos y personas doctas de tres quartas de largo en lienço con sus marcos dorados y negros (Villalpando, ZA-1633)

Como medida para áridos, aunque de manera menos frecuente, aparece en la documentación de Tierra de Campos:

Cinco quartas de trigo digo diez quartos de trigo (Frechilla, PA-1642)

Tres cargas y siete cuartas de zavada (Frechilla, PA-1659)

Diez quartas de trigo (Villalpando, ZA-1634) 
Con este significado es más habitual encontrar el término cuarto, y se puede ver en el primer ejemplo, donde el escribano rectifica la medida.

De manera mucho más esporádica, casi anecdótica, encontramos esta medida utilizada para describir el tamaño de animales, en nuestro caso una mula:

Una mula de labra color castaño, de siete quartas, de edad de doce años (Paredes de Nava, PA1690)

\section{CUARTAL [quartal]}

Sust. $m$. 'Duodécima parte de la cuartera, que se divide en cuatro picotines' (DLE, 2. a ac.). Nebrija reconoce esta voz como medida y Autoridades recoge la forma quartal como 'medida de las cosas secas, que es la quarta parte de la fanéga de Aragón', esta marca diatópica de medida utilizada en Aragón la mantiene hasta la edición de 1992 (NTLLE, s. v. cuartal, Nebrija, 1495; Autoridades, 1737, DRAE, 1992). Es un término derivado de cuarto, del lat. QUARTUS (DECH, s. v. cuarto).

Un quartal con su rasero (Villalpando, ZA-1620)

Un quartal (Villalpando, ZA-1639)

Un quartal de medir trigo y dos tableros del pan (Villalpando, ZA-1644)

Doçe quartales de yesso (Villalpando, ZA-1629)

Un cuartal con su rasero barreteado de yerro y potado (Villalpando, ZA-1661)

Dos quartales de garbanzos (Villalpando, ZA-1661)

Cuartal se localiza en los textos zamoranos de la Tierra de Campos, y aparece con dos acepciones principalmente, por un lado, como medida de capacidad de áridos y, por otro, como recipiente que los contiene. La forma gráfica más común es quarta.

Autoridades señala esta palabra con marca diatópica de Aragón, sin embargo, cuando consultamos el CorLexIn aparecen ejemplos de otras zonas como Navarra, País Vasco o Asturias y algún punto de Segovia y Burgos. Este término aparece casi de forma exclusiva en los inventarios de la zona Norte de la Península. Además, autores como Morala, Egido o Perdiguero localizan ejemplos en León, Zamora y Burgos, ampliando la zona en la que se localiza esta palabra con las acepciones de la Tierra de Campos (Morala y Egido, 2018: 404; Morala, 2017c: 361 y Perdiguero, 2013: 237):

Tres toñas grandes de paxas y en ellas se alló dentro de la vna cosa de vn quartal de salbados / Más se alló en vn escriño biexo vn quartal de linaça (Brimeda, LE-1648)

Dos quartales de linaza (Abejera, ZA-1689)

Vn quartal con su raso (Tábara, ZA-1690)

Siete quartales de lana ylado negro y otros dos quartales y medio de lana negro por ylar (Salas de los Infantes, BU-1680)

Además, en Zamora, Morala localiza ejemplos donde se ha producido el transvase de esta medida de capacidad de áridos hacia medidas de superficie (Morala, 2017c: 361):

Otra tierra [...] hace un quartal en sembradura (Ferreras de Arriba, ZA-1690)

Una tierra: hará un quartal (Pozuelo de Tábara, ZA-1690)

Este término se localiza en textos desde el siglo XIII con las formas quartal y quoartal, variante esta última que se recoge en los inventarios del siglo XVII en localidades del País Vasco 
y Navarra. En las primeras ocurrencias recogidas por el $C D H$ se puede observar la localización de este término en Aragón, Navarra y País vasco, ya que suele aparecer en documentos como el Fuero general de Navarra (1250-1300), los Documentos de la Colección Diplomática de Irache (1283) o el Fuero de Teruel, entre otros.

En repertorios léxicos más recientes, cuartal se localiza en León con varias acepciones entre las que se encuentran 'medida de capacidad para áridos y de superficie para tierras de sembradura', 'recipiente de madera, especie de cajón con un asa pequeña en uno de los lados, que sirve para medir los áridos' o 'saco que da la media del trigo', pero que no se localizan en Tierra de Campos (Le Men, 2004, s. v. cuartal). Álvarez Tejedor ubica cuartal en tierras zamoranas, en la localidad terracampina de Villalobos, pero también en Villafáfila o San Martín de Valderaduey (Álvarez Tejedor, 1989: 114).

\section{CUARTERÓN [quarterón]}

Sust. m. 'Cuarta parte de una libra'. 'Postigo, puerta pequeña de algunas ventanas' (DLE, s. v. cuerterón ${ }^{2}$ 2. a y 3.a ac.). Autoridades registra esta palabra con la variante gráfica quarterón y las acepciones que mantiene el DLE (NTLLE, s. v. quarterón, Autoridades, 1737). Derivado de cuarto, del lat. QUARTUS (DECH, s. v. cuarto).

\footnotetext{
Un peso de balanzas con un pesa de a libra y otra de quarterón (Sahagún, LE-1601) Una vela de zera de un quarterón (Riosequillo, LE-1610)

Diez y seis madejas de zerro coçidas de a libra y quarterón cada una (Cea, LE-1621)

Una pesa de dos libras, una libra y un quarterón de yerro (Grajal de Campos, LE-1670)

Un peso de yerro con tres libras menos quarterón de yerro (Castromocho, PA-1602)

Un quarterón de cáñamo en catorce maravedís (Fechilla PA-1615)

Quarterón y medio de corales buenos con sartal de christal (Guaza de Campos, PA-1639)

Un pesso de garfios con dos libras menos un quarterón de pessar hierro (Frechilla, PA-1675)

Seis libras y un quarterón de açabaches colorados y dorados (Medina de Rioseco, VA-1645)

Treze madejas de a libra y quarterón de sedilla (Medina de Rioseco, VA-1661)

Un peso de garabatos con tres libras menos un quarterón (Cuenca de Campos, VA-1670)

Seys libras y un quarterón de ylado de estopa que fueron ocho madejas (Villalpando, ZA-1620)

Una cestica con cossa de un quarterón de lana azulada, ylada (Villalpando, ZA-1689)
}

Cuarterón se localiza en el corpus de la Tierra de Campos con dos acepciones principalmente; por un lado, con la primera acepción que da el DLE para esta palabra y que se utiliza principalmente para medir tejidos -lana, sedilla, hilado, galones o seda- y joyas -azabaches, corales-. Por otro lado, este término hace referencia a una de las pesas que forman los pesos de las balanzas.

En el CorLexIn no hay un patrón claro de distribución para esta voz, pues encontramos ejemplos que se localizan desde Canarias a Cantabria y País Vasco, pasando por Jaén, Ciudad Real, Badajoz, Guadalajara, Segovia, Palencia o León.

Le Men localiza esta palabra en Tierra de Campos como 'cuarta parte de la libra, equivalente a unos 115 g.', pero también como 'contraventana o postigo de madera', significado que aún está vigente en algunas de las localidades que conforman este territorio; sin embargo, en los documentos recogidos no encontramos esa acepción (Le Men, 2004, s. v. cuarterón). Gordaliza 
recoge la acepción de 'contraventanas' o 'puerta más pequeña en un portón' (Gordaliza, 1988: 77).

\section{CUARTILLO [quartillo]}

Sust. m. 'Medida de capacidad para áridos, cuarta parte de un celemín, equivalente a $1156 \mathrm{ml}$ aproximadamente', 'medida de líquidos, cuarta parte de una azumbre, equivalente a $504 \mathrm{ml}$.' o 'cuarta parte de un real' ( $D L E, 1$. a, $2 . \underline{\text { a }}$ y 3. a ac.). Estas tres acepciones ya vienen recogidas en Autoridades. Es un término derivado de cuarto, del lat. QUARTUS (DECH, s. v. cuarto).

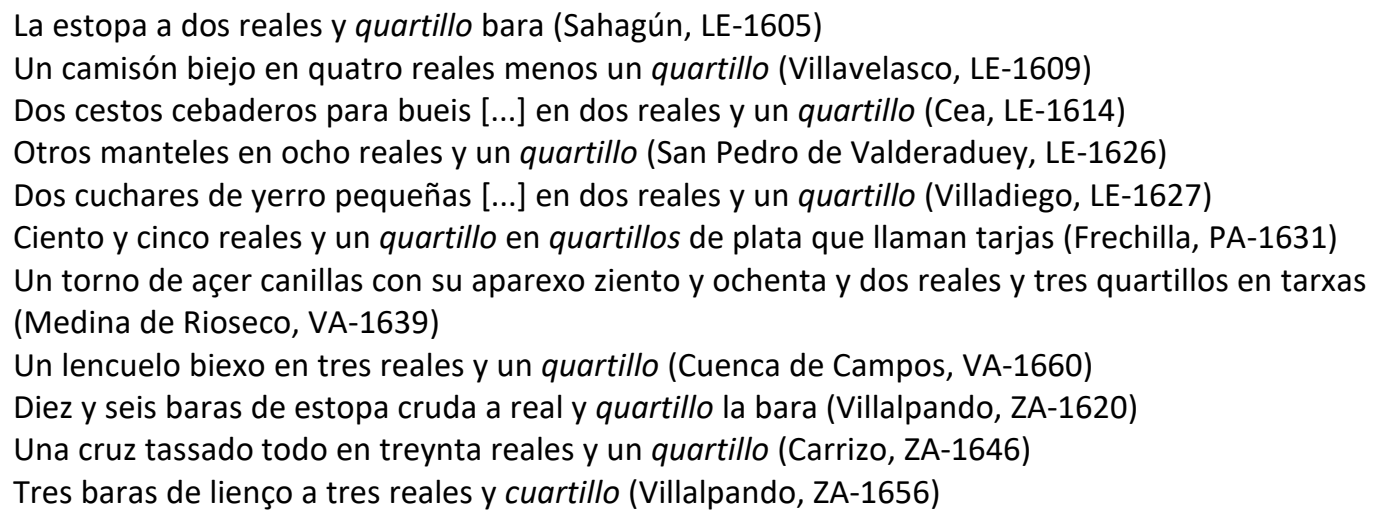

En la Tierra de Campos el término cuartillo aparece preferentemente con la acepción de 'cuarta parte de un real' y así se puede observar en los ejemplos obtenidos del corpus estudiado.

No se localizan ocurrencias de esta voz como medida de capacidad para líquidos en los documentos seleccionados para este corpus, aunque sí se encuentran algunos ejemplos como medida de capacidad para áridos:

Un tinaco con tres quartillos de sal (Castroañe, LE-1637)

Hasta tres cuartillos de manteca de puerco (Frechilla, PA-1638)

Una puchera bidriada que tiene tres quartillos de miel (Frechilla, PA-1675)

Esta palabra hace referencia a otro par de acepciones que no registra el DLE. Por un lado, aparece como un tipo de recipiente, algo que ocurre con otros términos referidos al campo semántico de las medidas:

Un quartillo de madera y una media fanega (Grajal de Campos, LE-1658)

Una messa de pino y un quartillo (Frechilla, PA-1615)

Un quartillo, una messa de pino de quatro pies (Frechilla, PA-1631)

Por otro lado, también aparece como medida de telas y tejidos:

Un quartillo de paño de estambre urdido (Frechilla, PA-1613)

Un quartillo pardo hurdido regalado tassado en veynte reales (Frechilla, PA-1675)

Dos quartillos de lino (Medina de Rioseco, VA-1641)

El término cuartilla es poco frecuente en los documentos de Tierra de Campos, ya que ninguno de los ejemplos localizados hace referencia a medida de capacidad:

Otro libro yntitulado Marabillas de Roma de media quartilla (Paredes de Nava, PA-1690)

Una serbilleta alimanisca en un real y tres cuartillas (Medina de Rioseco, VA-1642) 


\section{CUARTóN [quartón]}

Sust. m. 'Cada uno de los maderos que resultan de aserrar longitudinalmente en cruz una pieza enteriza' (DEL). Autoridades define esta palabra como 'madéro gruesso, que sirve para fábricas y otras cosas: y tiene diez y seis pies de largo, nueve dedos de tabla y siete de canto'; Terreros y Pando añade la acepción de 'medida de vino, y vinagre de Barcelona' que el DRAE de 1817 incluye (NTLLE, s. v. Autoridades, 1737, Terreros y Pando, 1786). Palabra derivada de cuarto, del lat. QUARTUS (DECH, s. v. cuarto).

Diez catorçales de pino nuevos y un quartón (Frechilla, PA-1659)

Diez y ocho vigas de a veynte y dos pies diez y ocho quartones (Medina de Rioseco, VA-1641)

Un madero de pino quartón (Medina de Rioseco, VA-1641)

Nuebe quartones anchos (Villalpando, ZA-1661)

En la Tierra de Campos solo encontramos este término con la primera acepción que le da la academia a esta palabra. En el CorLexIn se documenta mayoritariamente en la zona meridional de la Península -Almería, Córdoba, Granada-; también se halla algún ejemplo en Toledo y Guadalajara.

Morala localiza este término con la acepción de medida en el área del Ebro (Morala, 2016b: 556), zona próxima a la marca diatópica que señalaba Terreros y Pando para esta palabra.

\section{OCHAVA [ochaua]}

Sust. f. 'Octava parte de un todo' (DLE, 6. a ac.). Covarrubias recoge ochava como 'la octava parte de una onça' en el peso' y Autoridades añade también 'la octava parte de la vara' (NTLLE, s. v. ochava, Covarrubias, 1611; Autoridades, 1737). Término derivado de ocho, del lat. Ǒcto íd. (DECH, s. v. ocho).

Vna bara menos ochaua de dublión negro angosto (Medina de Rioseco, VA-1645)

Vna bara menos vna ochaua de sarga negra (Medina de Rioseco, VA-1645)

Dos varas y una ochaua de tafetán doble pardo y açul (Medina de Rioseco, VA-1645)

Este término no es frecuente en los documentos seleccionados de la Tierra de Campos: tan solo encontramos ocurrencias en un inventario de una tienda de ropa de Medina de Rioseco con la acepción de 'medida de longitud' en el campo textil.

Ochava como 'medida de granos igual a media fanega' se señala como propia de Zamora en el $D E C H$. Y en el CorLexIn se documenta en la Tierra de Alba en Zamora, pero también como medida superficie o como recipiente (Morala, 2016b: 578). A pesar de ser una zona muy próxima a la de estudio, no se han encontrado casos de la misma. Gordaliza localiza ochavilla como 'medida de capacidad para el grano que se utilizaba antiguamente' en su estudio sobre el léxico palentino (Gordaliza, 1988: 161).

Tampoco hay casos de esta palabra como medida de peso, 'la octava parte de una onza' que aparece en diferentes puntos de la Península como Álava, Vizcaya o Cáceres, además de encontrarse en documentos americanos. 


\section{QUINZAL [quinçal]}

Sust. m. 'Madero en rollo de quince pies de largo' con marca diatópica de Valladolid (DLE). La primera definición lexicográfica es bastante tardía, pues la registra la edición académica de 1884 con la misma definición y marca dialectal que se conserva hoy (NTLLE, s. v. quinzal, DRAE, 1884). Palabra compuesta procedente del lat. QUīNDĚCIM íd. compuesto con DECEM 'diez' (DECH, s. v. cinco).

Doce quinçales de pino redondos (Frechilla, PA-1676)

Treynta quinçales (Villarramiel, PA-1691)

Doce quinçales (quinzales en el margen) (Villalpando, ZA-1661)

Quatro quinzales (Villalpando, ZA-1688)

Este término aparece en cuatro documentos de la Tierra de Campos, con la acepción dada por la Academia. Además de la tardía incorporación al diccionario académico, tampoco se localizan datos de esta voz en la documentación del $C D H$ o el CORDE, ni en los documentos que conforman el CorLexIn. A pesar de la marca dialectal que le atribuye la Academia, la realidad es que los ejemplos proceden de la zona palentina y zamorana de la Tierra de Campos, aunque esto no resulta significativo, ya que puede ser producto de la casualidad en la selección de los inventarios. Sin embargo, en el Fichero general de la Academia, además de varias referencias lexicográficas de quinzal, encontramos dos cédulas que recogen sendos estudios en los que se localiza el término. En primer lugar, un estudio realizado por Albert Klemm y que habla de La cultura popular de Ávila donde amplía la zona de uso de esta voz, y sostiene que "tanto cuartón como quinzal encubren una antigua medida de madera"; dicho estudio se publicó en 1962, aunque los datos fueron recogidos en 1932. La otra ficha hace referencia a la publicación de Sánchez López en 1966 sobre el vocabulario de Medina del Campo, donde afirma que esta palabra había sufrido una ampliación de su significado y así, además del valor general, se aplicaría también a 'los palos que sirven de armazón a los chopos de los pastores, a los árboles jóvenes, de quince meses, incluso a los delgados palos donde se curan los chorizos'.

\section{SESÉN [sessenes]}

El DLE define esta palabra como 'moneda de Aragón que equivalía a seis maravedís burgaleses', y no consta otra referencia lexicográfica en diccionarios académicos. Es un término derivado de seis, del lat. SĔX íd. (DECH, s. v. seis). Pero en Tierra de Campos nos encontramos con las siguientes ocurrencias que no coinciden con la acepción académica:

Treynta y cinco sesenes de tabla (Frechilla, PA-1612)

Diez sesenes de tablas (Frechilla, PA-1613)

Sesenta sesenes de tabla de chilla de pino nueba (Autillo de Campos, PA-1647)

Tres tablas de sesén (Boadilla de Rioseco, PA-1692)

Doze tablas de sessenes algo largas (Medina de Rioseco, VA-1641)

Treinta sessenes de Frechilla (Medina de Rioseco, VA-1641)

Diacrónicamente este significado lo encontramos en varios documentos localizados en las bases de datos del CDH y el CORDE. Por un lado, en los Documentos para la Historia del Arte del Archivo de Santo Domingo de la Calzada, fechados entre los años 1493 y 1564, aparecen ejemplos como "Más doze sesenes de chilla a quarenta y çinco dxl"; por otro, en la 
Documentación del Teatro de Burgos (1700-1752) se hallan algunos textos que hacen referencia a reparaciones que se han llevado a cabo en el mismo, incluyendo asientos como "más dos sesenes de tabla de chilla para cerrar un buxero [...]", "más se gastaron en toda dicha casa, 15 sesenes de tabla de chilla, para los suelos y aforros de algunas puertas". En ambos casos el término sesén se relaciona directamente con la "tabla de chilla".

En un estudio sobre el léxico de la construcción en archivos notariales de la ciudad de Burgos, fechados entre los años 1525 y 1609, se localiza el término sesén en archivos de compra venta de madera (Ibáñez Pérez y Vallejo Arroniz, 1978: 224-225).

Parece que sesén designa un tipo de medida de madera, preferentemente referido a la "tabla de chilla", un tipo de madera más fina, y el término sesén haría referencia al conjunto de seis tablas. Es una voz muy específica, un tecnicismo que se localiza sobre todo en Burgos y zonas limítrofes como ocurre con la Tierra de Campos.

\section{TERCIA [terçia, terzia]}

Sust. f. 'Tercera parte de una vara' (DLE, ac. 27. a). Término derivado de tres, del lat. TRĒS (DECH, s. v. tres).

Una terzia de estameña blanco (Grajal de Campos, LE-1613)

Una terçia de chillón colorado tassado en siete reales (Castroañe, LE-1622)

Una terçia de estopa nuevo (Villada, PA-1665)

Tres baras y tercia de tirela de riuetillo negra (Medina de Rioseco, VA-1645)

Veinte y cinco baras y tercia de lama lisa fina de Seuilla (Medina de Rioseco, VA-1645)

Bara y tercia de raso (Villalpando, ZA-1670)

Tercia se localiza en Tierra de Campos con la acepción académica de 'tercera parte de la vara' como medida de longitud y no se localizan otros significados.

\subsubsection{Otros}

\section{COPO}

Sust. m. 'Mechón o porción de cáñamo, lana, lino, algodón u otra materia que está en disposición de hilarse' (DLE, s. v. copo', 3. a ac.). Nebrija recoge 'copo de lino o lana'. Covarrubias lo define como 'cierto mechon, o pegujon de lino, o de lana, o de algodon, que se hila puesto en la rueca' (NTLLE, s. v. copo, Nebrija, 1495; Covarrubias, 1611). Término derivado de copar, del fr. couper 'cortar' (DECH, s. v. copar).

Un cribo con dos copos de lana blanca (Valdavida, LE-1606)

Quatro copos peynados fraylegos (Frechilla, PA-1631)

Es el único ejemplo documentado en la Tierra de Campos que coincide con la acepción académica. A pesar de la falta de ejemplos, se trata de una palabra de uso general, con la forma y acepción académica. En este mismo siglo, Gómez Ferrero localiza "nuebe copos de lino maxado" en la zona de La Bañeza (Gómez Ferrero, 2015: 353). 
Este vocablo todavía pervive en repertorios dialectales más modernos como el realizado por Gordaliza, que lo recoge en La Vadavia -zona palentina cercana a Tierra de Campos-como 'conjunto de fibras de lino para escardar o hilar' (Gordaliza, 1988: 72). Esta palabra también se registra en Astorga (León) y en Zamora (Le Men, 2004, s. v. copo).

\section{GRUESA}

Sust. f. 'Número de doce docenas, especialmente de cosas menudas' (DLE, 10.a ac.). Autoridades recoge el término con la misma acepción, pero con la grafía gruessa (NTLLE, s. v. gruesa, Autoridades, 1734). Término derivado del lat. GRŏssus 'grueso', 'abultado, de mucho espesor' (DECH, s. v. gruesa).

De yladillo una gruesa (Mazariegos, PA-1619)

Media gruesa de cordones de lana y una gruesa de agujetas (Medina de Rioseco, VA-1644)

Una gruesa de sortijas de piedras falsas (Medina de Rioseco, VA-1644)

Treinta y tres gruesas de chauascas de color y negras (Medina de Rioseco, VA-1645)

Onçe gruesas de cordones (Medina de Rioseco, VA-1645)

Una gruesa de botones (Villalpando, ZA-1670)

El $C D H$ documenta este sustantivo en el Arancel de precios y salarios de Cuenca fechado en 1462, donde se registra "una gruesa de cucharas pyntadas de foja de peral".

En el CorLexIn se localizan ejemplos de este sustantivo, sin un patrón de reparto claro, en documentos de Tudela (Navarra), Atienza (Guadalajara), Teruel, Huelva, Sevilla o Canarias -en donde se registra la variante grueza-. El uso de esta voz se extiende a las colonias del otro lado del Atlántico; gruesa, gruessa y grueza son las formas que conviven en documentos de dichas colonias.

En Tierra de Campos se localiza gruesa con la acepción académica referida a botones, agujetas, cordones o yladillo, aunque en otros documentos se pueden encontrar otros productos inventariados por gruesas como tablas, alfileres y puntas (Castaño, 2015: 44).

\section{MADEJA [madexa, madejita]}

Sust. f. 'Hilo recogido sobre un torno o aspadera, para que luego se pueda devanar fácilmente' (DLE). Covarrubias lo define como 'el hilo haspado que queda en circulo para deuanarse y pulirse' (NTLLE, s. v. madexa, Covarrubias, 1611). Término procedente del lat. MATAXA 'hilo', 'seda cruda', que en todas las lenguas romances ha tomado el mismo sentido que en castellano ( $D E C H, \mathrm{~s}$. v. madeja).

Una madexa de estopa de a dos libras (Santa María del Río, LE-1617)

Dos madejas por curar de zerro (Cea, LE-1621)

Tres madejas de estopa y tres de zerro (Grajal de Campos, LE-1670)

Diez y ocho madejas de ilo basto, tres madejitas de ylo fino (Valderas, LE-1682)

Una libra colorada para muestras en madexa (Frechilla, PA-1637)

Una madeja de seda negro (Autillo de Campos, PA-1653)

Una madexa de lino y otra de estopa (Boadilla de Rioseco, PA-1692)

Treynta libras de lino en madejas y obillos (Medina de Rioseco, VA-1644)

Treze madejas de a libra y quarterón de sedilla (Medina de Rioseco, VA-1661)

Ocho madejas de lino crudo (Villalpando, ZA-1620)

Una madeja de ylo de León (Villalobos, ZA-1654) 
Es una palabra de uso general tanto en la zona de estudio como el resto de la documentación. Hay una alternancia gráfica entre $x y j$, al igual que en el resto de los inventarios que conforman el CorLexIn. En la zona de estudio aparece la forma diminutiva madejita, con valor apreciativo.

\section{MANADA}

Sust. f. 'Porción de hierba, trigo, lino, etc., que se puede coger de una vez con la mano' ( $D L E$, 3.a ac.). Covarrubias, además de 'el hato de ganado', la define como 'aquello que se puede coger con la mano' refiriéndose a 'puñado de hierbas' (NTLLE, s. v. manada, Covarrubias, 1611). Término derivado de mano, del lat. MANUS (DECH, s. v. mano).

Dos manadas de orégano (Autillo de Campos, PA-1653)

Tres manadas de lino (Paredes de Nava, PA-1689)

Manada, con la acepción que aquí ocupa lugar, se documenta en el $C D H$ desde el siglo XIII: "manadas de lino" - La facienda de Ultra Mar, 1200-, "una manada de esparto" -Libro de Palladio, 1380-1385- o "una manada de figos pasas" -Compendio de medicina de Gómez de Salamanca, 1453-; también se halla en documentos americanos: "arrancavan una manada de heno" -Historia general de las cosas de Nueva España de Fray Bernardino de Sahagún, 1576. Sin embargo, a partir de la segunda mitad del siglo XVI su presencia en los textos es menor. Esta falta de ocurrencias se ve reflejada en los inventarios de bienes que conforman el CorLexIn, donde apenas se encuentran ejemplos, salvo los localizados en Tierra de Campos. Posiblemente esta palabra de uso general no tenga presencia en los inventarios dada la rigurosidad de lo inventariado, y manada no deja de tener un valor relativo ('cantidad que cabe en una mano').

Entre los repertorios dialectales modernos se localiza en amplias zonas de Léon, incluida la Tierra de Campos como 'cantidad de cosas que entran en una mano', además de 'conjunto de animales' (Le Men, 2007, s. v. manada). Con este mismo significado también se documenta en la zona Este de Zamora (Álvarez Tejedor, 1989: 75). Gordaliza localiza el término manadón en Tierra de Campos como aumentativo de manada que hace referencia al 'montón de matas de lentejas o garbanzos, etc. que las arrancadoras cogían con la mano' (Gordaliza, 1988: 143).

\section{MANOJO [manoxo]}

Sust. m. 'Haz pequeño de cosas que se puede coger con la mano' (DLE). Nebrija equipara el término a manada. Covarrubias lo define como 'el hazecito que se puede ceñir con la mano' (NTLLE, s. v. manojo, Nebrija, 1495; Covarrubias, 1611). Término procedente del lat. vulgar MANŬCŬLUS, alteración del lat. MANIPULUS, -UPULUS, 'puñado' (DECH, s. v. mano).

Quatro zientos manoxos (Sahagún, LE-1608)

Asta quatro doçenas de manojos (Frechilla, PA-1616)

Ay en el ordeñadero asta tresçientos manojos (Frechilla, PA-1639)

Trescientos manoxos (Villarramiel, PA-1691)

Doscientos manoxos (Paredes de Nava, PA-1695)

Una tenada de manoxos de leña (Medina de Rioseco, VA-1651)

Mill y quinientos manojos (Medina de Rioseco, VA-1660)

Cien manojos en dosçientos maravedís (Cuenca de Campos, VA-1666) 
Hasta tres cargas de manojos (Villalpando, ZA-1620)

Quatroçientos manoxos (Villalobos, ZA-1654)

Dos carros de manojos (Villalpando, ZA-1690)

Esta palabra aparece relativamente pronto en la lexicografía histórica, como se ha podido comprobar anteriormente. De esta aparición temprana dan cuenta otras bases como el $C D H$ y el CORDE, donde manojo se documenta desde el siglo XIII y ofrecen una amplia nómina de ejemplos del término.

En los ejemplos que proporciona el CorLexIn, la acepción que más se documenta es la de 'haz pequeño de cosas que se puede coger con la mano', y este significado lo encontramos en documentos de Liébana (Cantabria), Tolosa (Guipúzcoa), Navarrete (La Rioja), Tudela (Navarra), Villalba Baja (Teruel), localidades pertenecientes casi todas al centro norte de la Península, junto con las ocurrencias encontradas en Canarias y en algunos documentos americanos en los cuales manojo se referencia junto a llaves, cordones, plumas, esparto, lino, cáñamo o tabaco.

Sin embargo, en Tierra de Campos manojo tiene un significado más restringido; el hecho de que el escribano inventaríe "cuatro docenas de manojos" sin mayor especificación hace suponer que el término se va a identificar con un objeto concreto. Le Men señala que en León esta voz ha concretado su significado "ya que no designa un haz de cualquier cosa sino de mies u, ocasionalmente de sarmientos" (Le Men, 2007, s. v. manojo). En la zona de estudio, el manojo se refiere a los 'sarmientos entrelazados' que se utilizaban para quemar y preparar fuego; tan solo encontramos un ejemplo en el que se especifica "una tenada de manojos de leña" en la localidad vallisoletana de Medina de Rioseco, y también tiene que ver con el fuego. En el CorLexIn se localizan dos ocurrencias donde comparte este significado; Carrión de los Condes (Palencia), muy próxima a la Tierra de Campos y en Tanos (Cantabria) donde en un asiento aparecen "quatro manojos" sin ninguna especificación.

Entre los repertorios actuales de la zona, Gordaliza recoge esta voz con el significado de 'haz de sarmientos muy usado para quemar en las chimeneas de las bodegas en Tierra de Campos' (Gordaliza, 1988: 143); y en el estudio sobre el habla de Villada, manojo referencia los 'palos de la poda de la viña, preparados en un haz o mostela, para facilitar su manejo para quemarlos. Se usaban y usan mucho para la gloria'. (Casas, 1989: 541).

\section{MAÑIZO [mañiço]}

El término mañizo se recoge de forma tardía en la edición académica de 1927 con marca diatópica de León y Salamanca y con el significado de 'manojo'; se mantiene en el DRAE hasta la edición de 1989 (NTLLE, s. v. mañizo, DRAE, 1927). En el estudio que Le Men hace del léxico leonés, localiza mañizo en Tierra de Campos como 'haz, atado de mieses o de lino' (Le Men, 2007, s. v. mañiza).

Seis mañizos seis reales (Joara, LE-1606)

Dos mañizos en caña de lino (Cea, LE-1610)

Sesenta mañiços de lino en caña buenos (Riosequillo, LE-1610)

Diez mañizos de lino en caña (Santa María del Río, LE-1617)

Ocho mañiços de lino a tres reales (San Pedro de Valderaduey, LE-1626)

Trece mañas y un mañiço majado de lino (Castroañe, LE-1637) 
No hay testimonio de esta voz ni en el CORDE ni el CDH. En el CorLexIn las ocurrencias que aparecen pertenecen a la zona de estudio, donde se recoge la variante masculina y con la acepción de 'atado o haz de lino', siempre en documentos pertenecientes al partido judicial de Sahagún (León). En documentos notariales de La Bañeza se localiza esta voz en los siglos XVII, XVIII y XIX, con esta misma acepción (Gómez Ferrero, 2015: 375-376). En esta área de estudio parece que los fejes de la zona centro-meridional del leonés pasan a ser "manizos de lino" e, incluso, se da la solución castellana para el conjunto de los mismos, hacina - "una acina de lino en la era" (Cea, LE-1638) - (Morala, 2009: 15).

Con menos frecuencia que en el corpus estudiado figura el término maña ("Trece mañas y un mañiço majado de lino"), que el DLE define como 'manojo pequeño, de lino, cáñamo, esparto, etc.' y que también figura en otros inventarios, aunque de manera esporádica. El CorLexIn nos ofrece los siguientes ejemplos:

Tres mañas de lino por majar (Mansilla Mayor, LE-1637)

Veynte hazes de lino de a diez mañas cada haz con su gárgola (Rupelo, BU-1680)

Quarenta mañas de lino (Narila, GR-1697)

Este término mañizo se documenta en estudios dialectales más recientes que enmarcan la zona noroccidental de la Península y donde la palabra aún perdura; mañizo, hallado en Tierra de Campos, también se localiza en diferentes zonas leonesas -Astorga, Ancares, Lomba, Prioro, Valencia de Don Juan, La Bañeza, Valdería, Cabrera, Cepeda-, pero también en Zamora -Sanabria-y Extremadura -Las Hurdes-(Le Men, 2007, s. v. mañiza).

\section{MAZORCA [maçorca]}

Sust. f. 'Porción de lino o lana ya hilada y recogida en el huso' (DLE). Nebrija recoge esta palabra como sinónimo de husada -'porción de lino, lana o estambre que, ya hilada, cabe en el huso'- (DLE). Covarrubias dice que es 'el hilo que la muger va sacando del copo, y reboluiendo en el uso' (NTLLE, s. v. mazorca, Nebrija, 1495; Covarrubias, 1611). Es una palabra de origen incierto (DECH, s. v. mazorca).

Un cesto con tres maçorcas de lana blanca (Valdavida, LE-1606)

Una canastica con una maçorca de ylo (Grajal de Campos, LE-1670)

A pesar de documentarse relativamente pronto en obras lexicográficas, no es un término frecuente en los inventarios. Esto mismo ocurre con otras voces como copo o manada, aun siendo una palabra de uso general y que presenta una forma y acepción académica.

En Tierra de Campos no encontramos las variantes amazorga o mazorga que Le Men localiza en localidades de esta comarca (Le Men, 2007, s. v. mazorca).

\section{OVILLO [OBILLO, UBILLO]}

Sust. $\mathrm{m}$. 'Bola o lío que se forma devanando hilo de lino, algodón, seda, lana, etc.' (DLE). Nebrija recoge esta voz como 'ovillo de hilado'. Por su parte, Covarrubias lo define como 'el hilo deuanado y cogido en forma oual' (NTLLE, s. v. ovillo, Nebrija, 1495; Covarrubias, 1611). Término procedente del antiguo luviello. Este procede del lat. GLOBELLUM, diminutivo de GLOBUS 'bola', 
'amontonamiento', 'grupo de gente' (que en lat. vulgar se confundió con GLomus 'ovillo', 'bola') (DECH, s. v. ovillo).

Veynte libras de zerro ylado en obillos y dos madexas todo en setenta reales (Sahagún, LE-1601) Un obillo de lana blanca (Cea, LE-1610)

Doze libras de lana negra con obillos (Grajal de Campos, LE-1616)

Tres obillos de hilado de cerro (Santa María del Río, LE-1617)

Dos ovillos de lana blanco (Cea, LE-1621)

Quatro ovillos de lana negra (Castroañe, LE-1637)

Una piña de ubillos de zerro (Grajal de Campos, LE-1658)

Beinte y nueve obillos de lana blanca delgada (Valderas, LE-1682)

Siete obillos de estopa ylada (Medina de Rioseco, VA-1670)

Una casillera de obillos en quatro reales (Cuenca de Campos, VA-1670)

Dos obillos de ylo azul y una madeja (Villalpando, ZA-1637)

Es un término de uso general con la acepción académica. Se documenta en el $C D H$ y en el CORDE en la General Estoria de Alfonso X tanto con la forma diptongada ouiello como la académica ouillo en 1275.

Respecto a la distribución diatópica, el CorLexIn presenta una distribución de carácter general en la Península, y también en algunos documentos americanos -El Salvador, Perú, Colombia y Chile-.

En los documentos de Tierra de Campos, además de la forma académica ovillo u obillo, localizamos ubillo, con cierre de la vocal /o/ en / $\mathrm{u} /$ debido al cambio de timbre de las vocales átonas (Morala, 2012a: 557).

\subsubsection{Utensilios de medir}

CÁNTARA [Vid. Medidas de capacidad para líquidos]

\section{BALANZA [balança, valança, valanza]}

Sust. f. 'Aparato que sirve para pesar' (DLE). Covarrubias afirma que '[...] entre otras maneras de pesos tenemos vna de dos platos diferentes en fiel y en equilibrio; en el vno se echa lo que se ha de pesar, y en el otro las pesas [...]'. Autoridades por su parte, además de los 'vasos ò platos cóncavos que penden de los extremos de los brazos del peso', también indica que se 'toma alguna vez por todo el peso compuesto de las dos balanzas' (NTLLE, s. v. balança y balanza, Covarrubias, 1611; Autoridades, 1726). Término procedente del lat. vulg. BĬLANCIA (DECH, s. v. balanza).

Unas balanças (Frechilla, PA-1638)

Unas balanças de cobre (Frechilla, PA-1639)

Dos valanzas de peso de cobre tasadas en ocho reales (Cuenca de Campos, VA-1670)

Una balança de madera para pesar el pan (Villalpando, ZA-1633)

Una balanza grande de yerro (Villalpando, ZA-1686)

El $C D H$ y el CORDE dan testimonio del uso de este término desde el siglo XIII hasta nuestros días. EI CDH presenta como primera fecha documentada el 1200: 
[...] pesar, fo pesado en las balanças e fue fallado menguado (La fazienda de Ultra Mar de Almerich, 1200)

Desde un punto de vista diatópico y restringiendo la búsqueda al siglo XVII, el CorLexIn ofrece una nómina de casos importante. Aunque debemos hacer una pequeña aclaración, y es que el término balanza suele aparecer en los documentos de la Península dentro del sintagma "pesos de balanzas", mientras que en los documentos de Canarias y América suele documentarse con el término genérico en textos de finales de siglo: "unas balansas de latón" (Adeje, Tenerife, 1695); "unas balanzas" (Garachico, Tenerife, 1695); "unas balansas pequeñas" (Santiago de Chile, Chile, 1689), "unas balanzas grandes" (Cuzco, Perú, 1691); "unas balanzas con sus pesas" (La Plata, Bolivia, 1704).

Lo mismo ocurre en la Tierra de Campos; la nómina de casos que presenta de esta voz de manera genérica es poco frecuente y no llega a la media docena de casos. Sin embargo, el sintagma "peso de balanzas" aparece con mayor frecuencia:

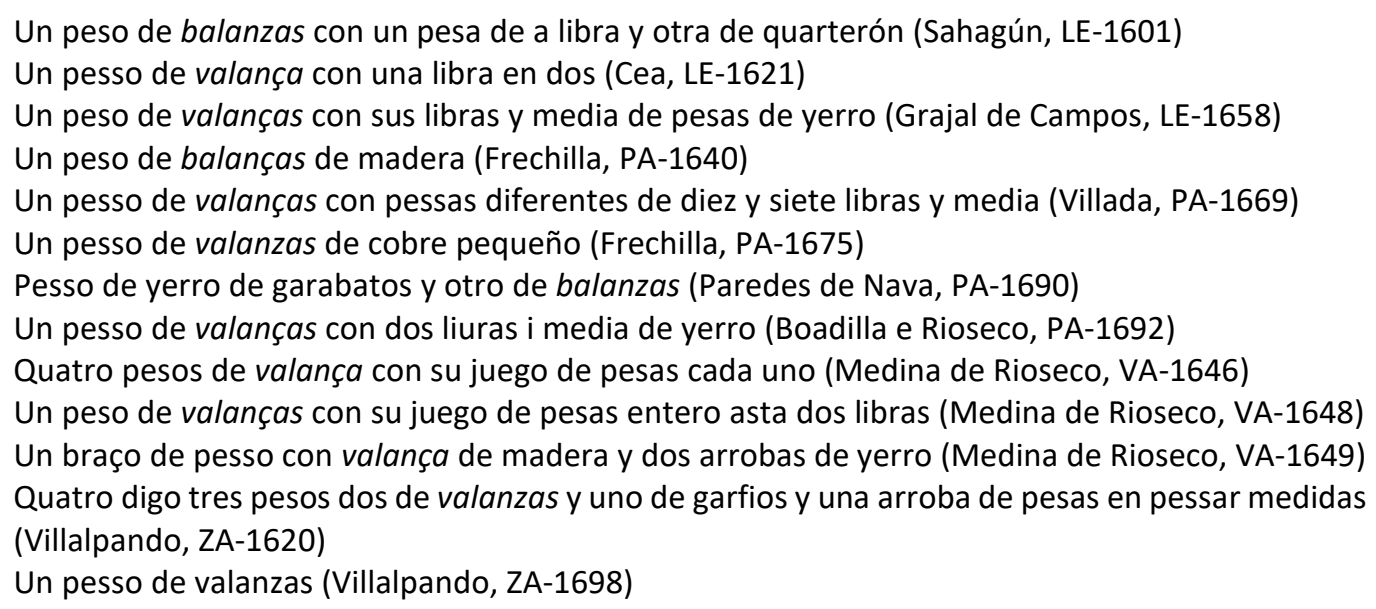

\section{LIBRADOR [LIVRADOR]}

Sust. m. 'Cogedor, generalmente de hojalata, con que en las tiendas ponen en el peso las mercancías secas para librearlas' ( $D L E, 3$. a ac.). Con esta acepción aparece en Autoridades, que lo define un instrumento utilizado en confiterías y otras tiendas, 'de cobre ó hierro, de una tercia de largo, y seis dedos de ancho, con un borde alto todo alrededor, menos por la parte angosta: el qual se va ensangostando y estrechando hacia la boca, y sirve para sacar y librear los potáges y otros géneros secos, de donde parece tomó el nombre' (NTLLE, s. v. librador, Autoridades, 1734). Es un término procedente de librar 'despachar' (Morala, 2015a: 1515) y no de librear 'distribuir por libras' como señalaba Autoridades; y librar deriva de libre, descendiente semiculto de lat. LīBER, -A, -UM (DECH, s. v. librar).

Un livrador de covre (Medina de Rioseco, VA-1646)

Un librador de covre (Medina de Rioseco, VA-1660)

Esta voz con la acepción que aquí presentamos es más bien escasa en los corpus del castellano. El CORDE documenta esta lexía en una carta de dote fechada en 1620 donde aparece "una pala y un librador de en quattro rreales y medio" procedente de documentación toledana. Por otro lado, ambas bases de datos ( $C D H$ y CORDE) registran varias ocurrencias en el inventario 
de Isabel Bautista, fechado en 1629 y procedente también de la documentación toledana (Morala, 2015a: 1515). Este uso exiguo del término se manifiesta también en los datos aportados por el CorLexIn, donde tan solo se registra un caso en un documento de Alfaro (La Rioja), hacia mediados de siglo (1646). A estos ejemplos debemos añadir el par encontrado en el corpus terracampino, ambos casos localizados en la localidad vallisoletana de Medina de Rioseco.

\section{PESA [pessa, pesilla]}

Sust. f. 'Pieza metálica que se utiliza como término de comparación para determinar el peso de un cuerpo' (DLE). Esta voz la recoge Covarrubias en plural como 'todo aquel peso que se opone a la cosa que pesamos, desde adarmes y onças hasta arrobas y quintales'. Por su parte, Autoridades la registra en singular y la define como 'pieza de determinado peso, que sirve para poner en equilibrio aquello de que se intenta saber el peso. Tiene varios nombres: como quintál, arróba, libra, onza, etc.' (NTLLE, s. v. pesa, Covarrubias, 1611; Autoridades, 1737). Voz procedente del lat. PENSUM 'peso de lana que debe hilarse' y vulgarmente 'peso' en general (DECH, s. v. pesar).

Un peso de balanzas con dos pessas de a media libra (Sahagún, LE-1600)

Un peso de balanças con una pesa de quarterón y otra de media libra y otra pesa de una libra (Grajal de Campos, LE-1655)

Un peso de valanças con sus libras y media de pesas de yerro (Grajal de Campos, LE-1658)

Una pesa de dos libras, una libra y un quarterón de yerro (Grajal de Campos, LE-1670)

Una brega y una pesa de masar (Castromocho, PA-1603)

Un pesso de valancas con pessas diferentes de diez y siete libras y media (Villada, PA-1669)

Una pessa de hierro de media arrova en cinco canastas de lavar lana (Frechilla, PA-1675)

Cinco pesas de yerro que acen siete libras (Paredes de Nava, PA-1690)

Dos pessos de balanças con sus pesas (Medina de Rioseco, VA-1644)

Quatro pesos de valança con su juego de pesas cada uno (Medina de Rioseco, VA-1646)

Un peso de valanças con su juego de pesas entero asta dos libras (Medina de Rioseco, VA-1648)

Dos arrobas de pesas de yerro (Medina de Rioseco, VA-1660)

Tres pesos, dos de valanzas y uno de garfios y una arroba de pesas (Villalpando, ZA-1620)

Un pesso con pesas (Villalpando, ZA-1646)

Dos pessas de a dos liuras (Villalobos, ZA-1654)

Un pesso de yerro grande nuevo con una pesa de dos libras de yerro (Villalpando, ZA-1661)

Es un término de uso general, que se documenta en las bases de datos como el CORDE y el CDH desde el siglo XIII, concretamente en el Fuero de Alcalá, en 1223 (Castaño, 2015: 279).

Los datos que aporta el CorLexIn presentan un uso frecuente en la Península, no tanto en los documentos americanos, donde se localiza poco más de una docena de casos y ninguno en los textos canarios que conforman esta base de datos. Esto se debe a que el término pesa representa el hiperónimo de libras, arrobas, onzas, etc. En la localidad toledana de Navahermosa figura un ejemplo donde este término aparece más como una medida que como un instrumento de pesar: "Vna pesa de lino de quatro o cinco libras". En el corpus terracampino mantiene un uso general con la acepción de 'instrumento para pesar'.

No son frecuentes los derivados morfológicos de esta palabra en la documentación. En Tierra de Campos tan solo se localiza un caso con el morfema derivativo de diminutivo -illa: 
Un peso de hierro con sus garauatos tiene una libra, tres pesillas y media libra y otra libra y dos pesas menudas (Frechilla, PA-1631)

Algo que ocurre también en los documentos del resto de la Península, donde también encontramos otro ejemplo con el sufijo derivativo -ita:

vna pesita de estaño (Eslava, NA-1631)

\section{PESO [pesso]}

Sust. m. 'Peso que se necesita para equilibrar en la balanza un cuerpo determinado', ' Balanza u otro utensilio para pesar' (DLE, 5. a y 10. a ac.). Nebrija ya recoge el 'peso para balança'; Covarrubias lo define como 'instrumento con que se pesan las cosas. Ay muchas diferencias de pesos' (NTLLE, s. v. peso, Nebrija, 1495; Covarrubias, 1611). Voz derivada del lat. PENSUM 'peso de lana que debe hilarse' y vulgarmente 'peso' en general ( $D E C H$, s. v. pesar).

Un peso de garabatos (Valdavida, LE-1606)

Un pesso de valança con una libra (Cea, LE-1621)

Un peso de balanças con una pesa de quarterón (Grajal de Campos, LE-1655)

Un peso de garabatos con quatro pesas de cuatro libras y cuarterón (Grajal de Campos, LE-1656)

Un peso de yerro con tres libras menos quarterón de yerro (Castromocho, PA-1602)

Un peso de trauesía con una pesa de hierro en diez reales (Frechilla, PA-1613)

Un pesso pequeño de balanças con pesas y su aderezo (Mazariegos, PA-1619)

Un pesso de valanças con pessas diferentes de diez y siete libras y media (Villada, PA-1669)

Un peso de valanças con su juego de pesas entero asta dos libras (Medina de Rioseco, VA-1648)

Un pesso con sus balanzas (Medina de Rioseco, VA-1660)

Un pesso de valança de cobre con seis libras y un cuarterón (Medina de Rioseco, VA-1666)

Un peso de garabatos con tres libras menos un quarterón (Cuenca de Campos, VA-1670)

Tres pesos, dos de valanzas y uno de garfios y una arroba de pesas (Villalpando, ZA-1620)

Un peso con su pesa (Villalpando, ZA-1629)

Un peso con sus dos libras y media libra más (Villalpando, ZA-1632)

Unos pessos de garabatos (Villalpando, ZA-1644)

Peso es un término de uso común que suele tener más de un significado, aunque en el corpus estudiado solamente encontramos el de 'instrumento para pesar'. Esta voz está presente desde los orígenes del español ( $D E C H$, s. v. peso). Tanto el CORDE como el CDH lo documentan desde muy temprano en los textos. Los datos que se obtienen de la búsqueda en el CorLexIn atestiguan la presencia de dicha lexía los textos tanto de la Península como de las colonias de ultramar, con diferentes significados. La documentación de Tierra de Campos ofrece un abanico de concordancias mayor que el de su análogo femenino pesa. En el contexto que encontramos esta palabra, se referencia el instrumento sin especificar cuál es -balanza o romana- (Castaño, 2015: 270).

Desde un punto de vista de la morfología derivacional, son pocos los casos de sufijos diminutivos de este término, acorde también con pesa. Tan solo encontramos un ejemplo en el corpus estudiado con el morfema derivativo -ico:

Un pesico biexo de garabatos sin pesas (Sahagún, LE-1606)

Los casos aumentan ligeramente al consultar el CorLexIn, siempre en documentos peninsulares y con las desinencias -ito, -illo e -ico: 
Vna gaueta con su pesito y sus pesas (Sevilla, 1650)

Vn pessillo de garauatos con dos pessas de hierro de a libra (Navahermosa, Toledo, 1638)

Vn pesico muy pequeño, tres reales (La Solana, Ciudad Real, 1655)

Vn pesico pequeño para pesar seda (Albacete, 1642)

\section{ROMANA}

Sust. f. 'Instrumento que sirve para pesar, compuesto de una palanca de brazos muy desiguales, con el fiel sobre el punto de apoyo. El cuerpo que se ha de pesar se coloca en el extremo del brazo menor, y se equilibra con un pilón o peso constante que se hace correr sobre el brazo mayor, donde se halla trazada la escala de los pesos' (DLE). Covarrubias recoge esta voz de la que afirma que '[...] vulgarmente sinifica vn genero de peso ingenioso [...]' (NTLLE, s. v. romana, Covarrubias, 1611). Es un término de origen incierto que bien podría ser abreviación de 'balanza romana' (DECH, s. v. romana).

Una romana de hierro pequeña en ocho reales (Fechilla PA-1675)

Una romana en quarenta reales (Medina de Rioseco, VA-1649)

Una romana de tres arrobas (Medina de Rioseco, VA-1646)

Una romana (Medina de Rioseco, VA-1660)

Una romana de yerro (Villalpando, ZA-1633)

Una romana de yerro (Villalpando, ZA-1656)

Una romana de yerro buena (Cotanes del Monte, ZA-1687)

La primera documentación de esta palabra se remonta a finales del siglo XIV, en un inventario aragonés ( $D E C H$, s. v. romana). Otras bases de datos del castellano como el $C D H$ localizan esta voz unos años más tarde en documentos también zaragozanos:

[...] la primera torre enta la part del mercado et en cada una de las ditas casas haya un peso e romana con sus tornos cuerdas e otras cosas necesarias pora pesar todos los panes que seran leuados a moler [...] (Modificaciones y corroboraciones de las Ordenanzas de Zaragoza por el rey don Alonso V, con las confirmaciones del rey don Juan II (1429-1458))

El CorLexln ofrece algo más de una treintena de ocurrencias repartidas entre los documentos peninsulares y americanos. En cuanto a los ejemplos de la Península, ofrece una nómina de casos ligeramente mayor en la zona oriental -Guipúzcoa, Navarra, Huesca, Zaragoza, La Rioja, Guadalajara, Cuenca, Albacete, Alicante, Murcia, Almería y Granada-, aunque también hay ocurrencias en Asturias, Madrid, Huelva y Sevilla, además de la comarca de Tierra de Campos, que atestigua casi una decena de casos.

Este término de uso general todavía se registra en estudios léxicos más actuales como el de Gordaliza, quien la recoge como 'instrumento usado todavía para pesar'. Sus piezas son: pilón, lanza, gancho, fiel, cadenas y platillo' (1988: 196). 


\subsection{ANIMALES}

\subsubsection{Ganado vacuno}

\section{AÑEJO [añexo]}

Adj. 'Dicho de una cosa: Que tiene uno o más años' (DLE). Nebrija recoge en su Vocabulario 'añejo de muchos años' y 'añejo de mucho tiempo' y Covarrubias lo define como 'lo que pasa de vno, o mas años, como el vino, o el queso' (NTLLE, s. v. añejo, Nebrija, 1495; Covarrubias, 1611). Término derivado de año, del lat. ANNǏcǔLus 'que tiene un año' (DECH, s. v. año).

Seis carneros añexos (Villacalabuey, Le-1639)

Diez marones añejos de quatro y seis dientes (Villalpando, ZA-1632).

Seis pauos nuevos y dos añexos (Villalpando, ZA-1686)

Dos maranos añejos estos no an de entrar en Partixa (Villalpando, ZA-1688)

El término añejo es de naturaleza adjetival con el significado que da el DLE a esta voz 'dicho de una cosa: Que tiene uno o más años'. El resultado castellano de ANNǐcŭLus -añejo-, se ve desplazado por la forma añojo (Morala, 2010c: 260). En el corpus estudiado encontramos añejo siempre junto al sustantivo que califica (marones, pavos o marranos), en ningún caso aparece como sustantivo.

En cuanto al adjetivo añejo, fue un adjetivo que se aplicó primero al vino, al queso y viandas análogas cuando tenían un año o más $(D E C H$, s. v. año). Este adjetivo aparece en Tierra de Campos junto a los alimentos que forman parte de los inventarios:

Veynte libras de tocino añejo (Castroañe, LE-1609)

Seis libras de toçino añejo (Frechilla, PA-1639)

Treinta cargas de trigo añejo en dos montones (Frechilla, PA-1640)

Una cuba de bino añexo de ducientas cántaras (Boadilla de Rioseco, PA-1643)

Diez y seis cargas de trigo añexo (Autillo de Campos, PA-1649)

Diez libras de tozino añejo (Boadilla de Rioseco, Pa-1650)

Cinco cargas de trigo añexo en quinientos y cinquenta reales (Frechilla, PA-1675)

Tres arrovas de tozino añexo tassada cada libra a diez y ocho quartos suma (Frechilla, PA-1675)

Un tocino añexo que pesó cinquenta y dos libras (Villalpando, ZA-1629)

Tres cántaras de vino añejo (Villalpando, ZA-1635)

\section{AÑOJO /A [añoxo, añoxillas]}

Sust. m. y f. 'Becerro o cordero de un año cumplido' (DLE). Aparece en Nebrija como 'becerro de un año', definición que mantiene Covarrubias y Autoridades (NTLLE, s. v. añojo, Nebrija, 1495). Término derivado de año, del lat. ANNǐcǔLus 'que tiene un año' (DECH, s. v. año).

Un añojo quebradizo de un año (Castroañe, LE-1609)

Un xato añoxo pardillo (Cea, LE-1625)

Otras dos añoxillas oscas de un año y ban a dos (Valdavida, LE-1606)

Un añojo de dos años poco más (Cea, LE-1637).

Un añojo de dos años (Cea, LE-1637) 
Añojo se presenta en la mayoría de las ocasiones como sustantivo en el corpus estudiado y hace referencia al 'becerro de uno o dos años de edad'. La naturaleza adjetiva es menos frecuente, aunque figura un "jato añoxo" en la localidad terracampina de Cea (León).

Añojo siempre se presenta en los documentos referido al ganado vacuno, y lo mismo ocurre con las escasas ocurrencias del CorLexIn, el término figura junto a vacas o becerros, tan solo hay un caso en el que añojo se utiliza como adjetivo en un inventario en Huelva (1611) donde aparece "un becerro añojo". De manera habitual se trata de un animal que ronda entre uno y dos años y se suelen inventariar junto a la vaca de la que ha nacido (Morala, 2014d: 121).

\section{BUEY [buei, bueis, bueies, buejes, vueys]}

Sust. m. 'macho vacuno castrado' (DLE). Nebrija recoge esta lexía como 'vaca o novillo' dependiendo de la edad del animal. Autoridades lo define como 'el toro castrado, animál util y provechoso para labrar la tierra y otros exercicios' (NTLLE, s. v. buey, Nebrija, 1516; Autoridades, 1726). Es una voz procedente del lat. BŌs, BŏvIS (DECH, s. v. buey).

Dos bueyes, uno osco de hedad de quatro años para zinco y el otro color blanco de hedad de tres años e ba a quatro (Calzada, LE-1601)

Tres bueyes de labranza de a ocho o nuebe años de color ruzio y dos amarillos (Sahagún, LE-1608) Un buey negro de hedad de cinco años (Castroañe, LE-1609)

Dos bueyes labradores (Grajal de Campos, LE-1616)

Otro buei pardo de quatro años (Santa María del Río, LE-1617)

Dos bueis, el uno color hosco y el otro bermejo (Castroañe, LE-1622)

Dos vueys de hedad de seis años (Cea, LE-1626)

Un buey color amarillo de labor de hedad de ocho años (Villemar, PA-1608)

Zinco buejes de labranza, los dos negros, otro ruçio, otro roxo, otro fosco (Boadilla de Rioseco, PA-1643)

Una baca y un buey de labrança (Villarramiel, PA-1696)

Dos bueyes de labranza en setenta ducados (Medina de Rioseco, VA-1649)

Dos bueyes, el uno blanco y el otro roxo (Cuenca de Campos, VA-1668)

Un buey biexo amarillo (Villalpando, ZA-1632)

Un buey grande de zinco años (Villalpando, ZA-1676)

Siete bueyes para el abasto de la carnezería en pie (Villalpando, ZA-1686)

Un par de bueies negros (Villalpando, ZA-1689)

Un buey negro de edad de seis años (Villalpando, ZA-1690)

Es un término de uso habitual en los inventarios de bienes estudiados, pero también en el resto de la Península y América. En Tierra de Campos suele aprecer con la forma académica buey, aunque, de manera esporádica, también se observa algún caso con /v/. Más variedad presentan las vocales de final de palabra, donde podemos encontrar, tanto la forma que presenta el DLE, como buei para singular, y bueis -que se documenta en la zona leonesa de la Tierra de Campos-, bueies o buejes para plural, en este último caso entendiendo que la grafía $j$ se corresponde con un sonido vocálico.

Normalmente los textos especifican el color, la edad y su función. Para señalar la edad, los años suelen ir precedidos por la preposición de y, en algunas ocasiones, por de $a$, como ocurre en el ejemplo de Sahagún y que recuerdan a las localizadas por Morala en León, Valladolid y Burgos (Morala, 2014d: 119), y por Pérez Toral en inventarios de Asturias (Pérez Toral, 2016: 2627). Se trata de una locución donde se aproxima a la edad del animal, sea vacuno o no, como lo 
demuestran otros ejemplos recogidos en este corpus y en el CorLexIn y que también dan cuenta de ellos estos autores:

Dos mulas castañas de a treinta meses (Autillo de Campos, PA-1654).

Tres mulas de a quinze meses (Autillo de Campos, PA-1654)

Aunque lo más habitual es encontrar solo la preposición de o la locución de edad de o de tiempo de para hacer referencia a la edad del animal.

\section{BECERRO [uecerro]}

Sust. m. 'Cría de la vaca hasta que cumple uno o dos años o poco más' (DLE). Esta lexía la recoge Aurotidades como 'el buey ò vaca que apénas tiene un año' y además advierte que también se le conoce por otros nombres 'añójo y ternéra' (NTLLE, s. v. becerro, Autoridades, 1726). Es un término de origen ibér., probablemente del hispanolat. IBEX, -ǏCIS 'rebeco' (DECH, s. v. becerro).

Seis uecerros, quatro machos y dos embras (Medina de Rioseco, VA-1649)

Del corpus estudiado de la Tierra de Campos, tan solo aparece un ejemplo de esta voz, síntoma de que en esta zona se prefiere otro tipo de términos para designar estos animales como puede ser nobillo o jato. Sin embargo, este término se encuentra ampliamente documentado en el resto de la Península (CorLexIn).

\section{JATO / A [xato, xata]}

Sust. m. y f. 'Becerro o ternero' (DLE). Autoridades lo registra con la grafía xato y con marca diatópica 'lo mismo que becerro. Es voz usada en Galicia, se pronuncia la $x$ suavemente'. La edición del DRAE de 1803 recoge la forma jato, ta y elimina la notación diatópica, ambas formas estarán presentes en los diccionarios académicos hasta la edición de 1869, donde xato desaparece y también su marca geográfica (NTLLE, s. v. xato, Autoridades, 1739; DRAE, 1869; s. v. jato, DRAE, 1803). Término de origen incierto (DECH, s. v. choto).

Un xatico de leche (Valdavida, LE-1606)

Tres bacas paridas, las dos con dos jatos y una nobilla preñada de más años (Valdavida, LE-1606) Una baca parida con un jato (Valdavida, LE-1606)

Dos jatas hijas de las mismas bacas, las quales dicen son de amedias (Santa María del Río, LE1607)

Otra jata color amarilla de hedad de un año (Castroañe, LE-1609)

Una jata en quarenta reales (Villavelasco, LE-1609)

Un xato y una xata de dos años (Grajal de Campos, LE-1616)

Un xato de un año y otro en dos, color uermexo (Santa María del Río, LE-1617)

Un xato añoxo pardillo (Cea, LE-1625)

Una vaca color amarilla de hedad de seis annos con una $x a t a$, su hija al pie (Sahagún, LE-1626)

Una vaca hosca con una jata de leche (Castroañe, LE-1629)

Una jata, color bermeja, de edad vn año (Castroañe, LE-1637)

Un jato de un año, color bermejo, otro jato color bermejo que va a dos años (Cea, LE-1638)

Un xato de un año color castaño (Tapioles, ZA-1688)

Una jata de leche (Villalpando, ZA-1689)

Una jata de un año (Quintanilla del Monte, ZA-1689)

Un jato color rojo (Quintanilla del Monte, ZA-1689)

Un xato, dos gallinas, dos marranos medianos de cría (Villalpando, ZA-1699) 
Se trata de un término poco documentado y de forma tardía en los textos del $C D H$. En diccionarios académicos como el de Rosal dice que así 'llaman en León al ternerillo o bezerrico: de lacteo que en latín quiere decir leche' (NTLLE, s. v. jato, Rosal, 1611), hay que recordar que los primeros diccionarios académicos sitúan el lema xato en Galicia y en el diccionario no académico de Gaspar y Roig (1855) se localiza esta voz también en Santander (Pérez Toral, 2015b: 97). Al consultar los inventarios del CorLexIn, se puede observar cómo este término se localiza únicamente en Asturias, León y Cantabria principalmente, con algunas incursiones ocasionales a las zonas limítrofes de Zamora y Palencia. Las ocurrencias localizadas en Tierra de Campos coinciden con esta distribución a la que señala esta base de datos, así encontramos jato y xatos en zonas leonesas y zamoranas de la Tierra de Campos.

En cuanto al alcance de este término varía en los textos, Morala hace un estudio detallado de este término que en Asturias cuenta con significados que van desde el 'ternero recién nacido' al 'becerro o novillo' y que en masculino puede llegar a referirse al 'toro semental' (Morala, 2010c: 259). Le Men señala que esta forma está muy viva en León, se trata de un occidentalismo con el significado de 'ternero' pero también hace referencia a un animal mayor (Le Men, 2007, s. v. jato).

\section{NOVILLO/A [nobillo, nobilla]}

Sust. $m$. y f. 'Res vacuna de dos o tres años, en especial cuando no está domada' (DLE). Nebrija recoge el término novillo como 'buei nuevo' y novilla como 'vaca nueva', Covarrubias va un poco más allá y escribe 'el bezerro que aun no ha sido sugetado al yugo [...] Dixose nouillo por ser nueuo, como ternero por ser tierno' (NTLLE, s. v. novillo, Nebrija, 1495; Covarrubias, 1611). Término derivado de nuevo, del lat. NŏvUs,-A,-UM (DECH, s. v. nuevo).

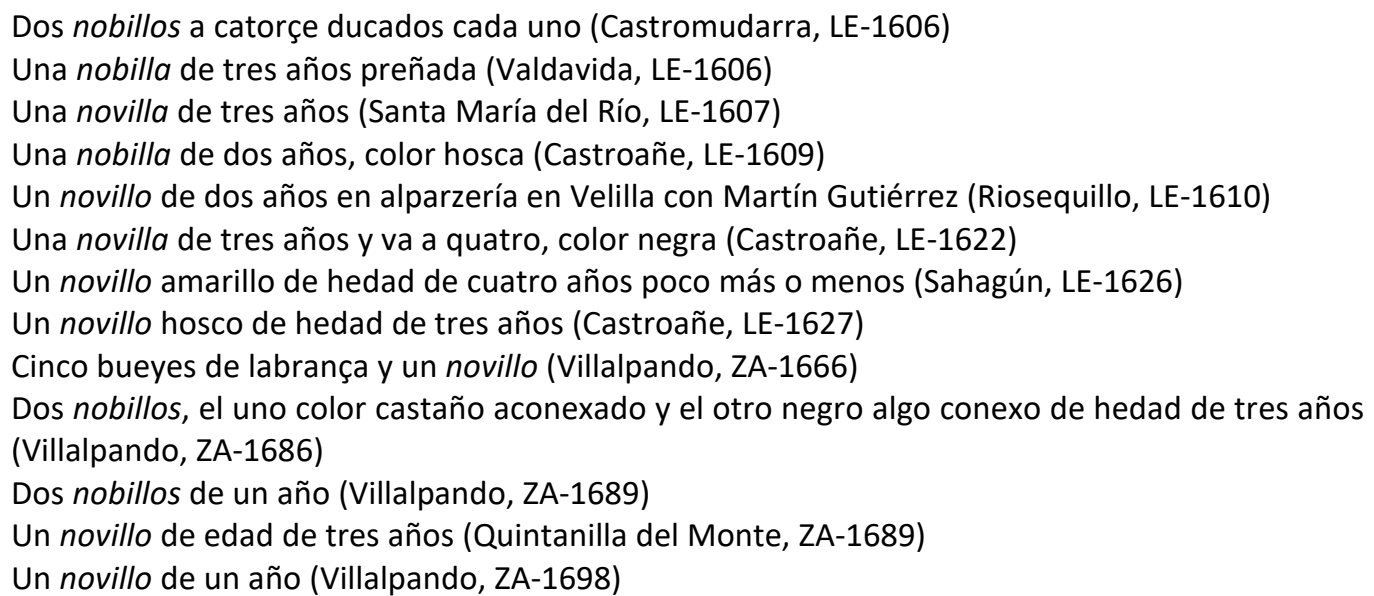

Esta palabra se localiza en los textos de la Tierra de Campos con la forma académica. Hace referencia a la 'res joven' y que en el caso de la zona estudiada no pasaría de los tres o cuatro años, aunque en inventarios de otros puntos peninsulares señalan que pueden llegar hasta los cinco años (Valle de Guriezo, Cantabria, 1667). Aparece documentado tanto en el CORDE como el $C D H$ a partir del siglo xIII y mantiene su presencia hasta nuestros días. En inventarios del siglo XVII registran esta palabra a lo largo de toda la Península, Canarias y también en América (México, El Salvador o Guatemala). En cuanto al alcance del término, parece que hace referencia 
a 'la res vacuna que es joven'. Pérez Toral hace un estudio sobre el léxico de la ganadería en Asturias en este siglo y este término aparece como 'res vacuna a partir de quince o dieciocho meses, cuando ya sirve para la monta, y hasta los cinco años', también advierte de que esta voz figura en la zona central y oriental de Asturias (Pérez Toral, 2015b: 103). Gómez Ferrero, por su parte, localiza ejemplos en el siglo XVIII de novillo en los que su margen de edad va desde los dos a los seis años (Gómez Ferrero, 2015: 381). En Tierra de Campos, el contexto no siempre está claro en cuanto al significado, en el caso de novilla parece que se trata de una res que no ha parido, aunque puede estar preñada, pero no aparece junto a crías.

Tres bacas paridas, las dos con dos jatos y una nobilla preñada de más años (Valdavida, LE-1606) Más una nobilla de tres años preñada (Valdavida, LE-1606)

En el caso de novillo, tan solo contamos con la edad, que en zona terracampina que iría hasta los cuatro años. Sin embargo, en un inventario de Sevilla, aparece el siguiente ejemplo "bueyes de lauor y novillos" (Sevilla, 1700), lo que nos llevaría a la definición dada por Covarrubias.

En estudios léxicos actuales el término novillo hace referencia a 'res vacuna mayor que el choto y menor que el buey o toro' y cuando se trata de novilla 'res vacuna de más de dos años y que no ha parido todavía por primera vez' y en el caso de novillo también 'toro semental' (Le Men, 2007, s. v. novillo).

\section{TERNERO/A}

Sust. m. y f. 'Cría de la vaca' (DLE). Nebrija registra la palabra como 'hijo o hija de la vaca', y Covarrubias lo describe como 'el bezerrillo hijo de la vaca, por quanto entonces su carne, es tierna y sabrosa, especialmente si esta criado con sola la leche de la madre' (NTLLE, s. v. ternero, Nebrija, 1495; Covarrubias, 1611). Término derivado de tierno, del lat. TĚNER, -ĚRA, -ĔRUM (DECH, s. v. tierno).

Una baca con su ternera al pie (Villalpando, ZA-1632)

Una vaca con una ternera negra (Villalpando, ZA-1698)

Una vaca con una ternera negra (Villalpando, ZA-1698)

Tan solo se han localizado estos tres ejemplos en Tierra de Campos, con la acepción de 'res vacuna de corta edad'. Se documenta en el $C D H$ desde el siglo XIII y, a partir del siglo XVII también en documentos de América, hasta hoy. Sin embargo, en la zona de estudio, esta voz es escasa, en los textos aparece de manera más extensa el término jato o jata para hacer referencia a la cría de la vaca. Esta escasez de ocurrencias es aplicable al resto de la Península, donde solo encontramos cuatro ejemplos repartidos en Zamora -los ejemplos localizados en nuestro corpus pertenecen a la Tierra de Campos zamorana-, Liébana (Cantabria) y Zaragoza y un ejemplo en Santiago de Chile (Chile). Sin embargo, Gómez Ferrero localiza unos cuantos ejemplos en este siglo en la zona de La Bañeza, donde parece que este vocablo era más habitual (Gómez Ferrero, 2015: 382). 


\title{
VACA [baca]
}

Sust. f. 'Hembra del toro' (DLE). Esta lexía la registra Nebrija en su Vocabulario junto a buey, y Covarrubias la define como 'la hembra en el ganado vacuno' (NTLLE, s. v. vaca, Nebrija, 1495; Covarrubias, 1611). Término procedente del lat. vACCA (DECH, s. v. vaca).

Tres bacas paridas, las dos con dos jatos (Valdavida, LE-1606) Dos bacas, la una hosca y la otra negra (Santa María del Río, LE-1607) Una baca color rucia de hedad de cinco años (Castroañe, LE-1609) Una baca bieja, otra de quatro años (Carvajal, LE-1609)

Dos vacas, la una de ocho años y la otra de tres y va a quatro (Riosequillo, LE-1610) Dos bacas color amarilla, la una biexa y la otra de hedad de ocho años (Cea, LE-1625) Una vaca preñada de quatro años color bermexa (Cea, LE-1626) Una baca y un buey de labrança (Villarramiel, PA-1696) Una baca con su ternera al pie (Villalpando, ZA-1632) Una vaca zerril que va a tres años tassada en catorze ducados (Carrizo, ZA-1646) Una vaca mansa tasada en diez y siete ducados (Carrizo, ZA-1646) Dos bacas, la una de color roxo y la otra negra (Tapioles, ZA-1688) Dos vacas grandes de labranza (Villalpando, ZA-1689) Una vaca de quatro años color castaña (Quintanilla del Monte, ZA-1689)

Es una voz de uso general en los inventarios de la Península y América (CorLexIn), también en la documentación histórica del CORDE y el CDH. En Tierra de Campos está localizada, sobre todo en inventarios de León y Zamora, como el resto del ganado vacuno,tal vez en otras zonas era más habitual trabajar con mulas o bueyes que con vacas de labranza. En las ocurrencias terracampinas, esta lexía referencia a 'hembra del ganado vacuno' de una edad de tres años en adelante, antes son novillas o jatas. Sin embargo, no en todos los lugares es así, en la documentación asturiana este término figura en ocasiones como genérico para referirse tanto a la hembra que ya ha parido como a la que es novilla (Pérez Toral, 2015b: 89, nota 5).

Sí aparecen ejemplos en las zonas palentina y vallisoletana de este vocablo, pero, en otros términos, bien como 'piel de vaca' para fabricar calzado o como 'alimento':

\author{
Hasta diez libras de zezina de baca (Frechilla, PA-1631) \\ Çinco uñas de baca (Frechilla, PA-1639) \\ Quatro uñas de baca acezinadas (Autillo de Campos, PA-1653) \\ Ocho libras y media de cecina de baca (Frechilla, PA-1675) \\ Unos çapatos de baca viexos (Frechilla, PA-1631) \\ Un coleto de baca biejo (Boadilla de Rioseco, PA-1687) \\ Un lomo de baca para suelas encerado (Medina de Rioseco, VA-1657) \\ Más unos çapatos de baca tasado en ocho reales (Cuenca de Campos, VA-1668)
}

\subsubsection{Ganado Equino}

\section{BESTIA [vestia]}

Sust. f. 'Animal doméstico de carga; p. ej., el caballo, la mula, etc.' (DLE, 2. a ac.). Covarrubias afirma que en la lengua castellana 'ordinariamente se toma por los animales de quatro pies 
corpulentos, de los quales vnos son domesticos, como el asno, el mulo o el cauallo' (NTLLE, s. v. bestia, Covarrubias, 1611). Término tomado del lat. BËSTǏA (DECH, s. v. bestia).

Una vestia y una borriquilla (Celada, LE-1624)

Una bestia (Castromocho, PA-1611)

Una vestia asnal parda de seis años (Castromocho, PA-1614)

Otra vestia negra ya vieja (Castromocho, PA-1614)

El término bestia aparece documentado de forma frecuente en los documentos históricos que conforman el $C D H$ desde le Mío Cid a nuestros días. Sin embargo, no es tan habitual en los inventarios de bienes, donde tan solo encontramos esta voz para referirse a los animales de carga en San Cristóbal de la Laguna (Tenerife), donde se documentan "quatro bestias asnales". El resto de los ejemplos que se citan en los inventarios, hacen referencia a instumentos destinados a uncir o marcar a las bestias, Morala $(2016 \mathrm{~d}$ : 141, 145) encuentra los siguientes ejemplos:

Dos pares de yubos, digo un yubo con su barzón, y mediana de bestias, ... otro yubo de buey y vestia ... otro yubo de vueyes (La Perera, SO-1705)

Un yubo de bestias (Tordelrábano, GU-1613)

Una trilla y un yugo de bestias (Candeleda, ÁV-1645)

Utilizando esta voz con un significado genérico, no como ocurría en el ejemplo de Tenerife, donde se especificaba el tipo de bestia, en este caso asnal. Otra cosa bien distinta es lo que ocurre en América donde encontramos ejemplos de esta palabra en Colombia, Panamá o Guatemala, casi siempre con el adjetivo mular al lado.

Doçe bestias mulares y cauallares (Guatemala, Guatemala, 1623)

Beynte y seys bestias mulares, mansas y cerradas (La Palma, Panamá, 1611)

Siete reses y dos bestias mulares (Santa Cruz, Colombia, 1691)

En Tierra de Campos, aparecen algunos ejemplos en los que el escribano sabe qué es exactamente una bestia, ya que solo se especifica en un caso, donde aparece una bestia asnal, pero no localizamos en ningún inventario el término asno.

\section{BURRO / A [burrico/a, borrico/a, borriquilla]}

Sust. m. y f. 'Asno' (DLE). Autoridades registra esta palabra como 'el asno, el pollino, el jumento' (NTLLE, s. v. burro, Autoridades, 1726). Término derivado de borrico, regresivo de la pronunciación vulgar burrico, y este del lat. tardío BŬRRICUS 'caballo pequeño' (DECH, s. v, borrico).

Un burro pardo de tres años en ocho ducados (Sahagún, LE-1600)

Una burra alvilla nueba (Castromudarra, LE-1606)

Un burro color ruzio de tres años bueno (Sahagún, LE-1608)

Un burro negro con el boço blanco de dos años (Galleguillos, LE-1618)

Un burro ruçio de edad de tres años (Frechilla, PA-1612)

Un burro collor blanco, manco de un ojo, de hedad de seis años (Frechilla, PA-1637)

Un burro ruçio nuevo de dos años (Guaza de Campos, PA-1639)

Un burro negro de sobreaño (Villalpando, ZA-1644)

Una burra parda que se tasó en tres mil maravedís (Villalpando, ZA-1613)

Otra burra çerril de un año nueba (Villalpando, ZA-1632)

Una burra castaña hoscura que ba a quatro años (Villalpando, ZA-1652) 
Dos burras, madre e yxa con su albarda (Villalpando, ZA-1666)

Una burra color negro con su pollino al pie (Villalpando, ZA-1686)

Es un término de uso general, presente en los inventarios de la época, tanto en Tierra de Campos como en el resto de la Península, aunque hay una especial preferencia por este término en el centro sur de la misma (Badajoz, Huelva, Málaga, Almería, Murcia o Ciudad Real). También hay ocurrencias en la documentación de Canarias y América (Colombia, El Salvador, Guatemala, México, Panamá o Perú). Suelen coexistir en los textos junto a pollino/a y jumento/a. No ocurre lo mismo con asno, aunque como hemos visto en ejemplos anteriormente, sí aparece la locución "bestia asnal". Este término suele venir referenciando la edad (sobreaño, de seis, de edad de tres años, nueva, vieja...), el color del animal (pardo, alvilla, ruçio, negro, blanco...) o el estado (çerril, manco de un ojo...).

En el corpus terracampino figuran las formas borrico, borrica o burrica, que referencia una burra o un burro más joven, o también a la propia cría de la burra:

Una burrica de tres años color ruçia tasada en doze ducados (Sahagún, LE-1605)

Una borrica nueva (Castroañe, LE-1637)

Una burra con su borrico al pie (Villalpando, ZA-1632)

Una burra negra con su borrica al pie (Villalobos, ZA-1654)

Esta diferencia de edad no está tan clara en otros inventarios peninsulares, donde solo se inventarían borricos y borricas, también con esa preferencia geográfica de la meseta sur (Córdoba, Granada, Sevilla, Jaén, Cuenca, Toledo o La Rioja). El término borrico se documenta con anterioridad a burro en las bases del Castellano como el $C D H$ y también en obras lexicográficas como la de Nebrija y Covarrubias (NTLLE, s. v. borrico, Nebrija, 1495; Covarrubias, 1611).

Desde un punto de vista formal, la documentación de Tierra de Campos presenta la palabra derivada borriquilla, que hace referencia a la cría:

Una vestia y una borriquilla (Celada, LE-1624).

El diminutivo es poco frecuente en la documentación notarial, además de este ejemplo, tan solo se localiza otro caso en documentos canarios con el sufijo -ito:

Sien burros y sinco burriquitos (Adeje, TF-1695)

\section{JUMENTO /A [xumenta, jumentilla]}

Sust. m. y f. 'asno (animal)' (DLE). Autoridades lo recoge como 'en su riguroso significado, es toda béstia de carga: y en el comun modo de hablar se entiende el Asno' (NTLLE, s. v. jumento, Autoridades, 1734). Término tomado del lat. JŪMĔNTUM 'bestia de carga', en castellano especializado por eufemismo como nombre del asno ( $D E C H$, s. v. jumento).

Un jumento de hedad de cinco años (Santa María del Río, LE-1607)

Una jumenta con su albarda, la jumenta ruçia castaña (Sahagún, LE-1608)

Una jumenta de un año pequeña, color blanca (Castroañe, LE-1609)

Una xumenta (Grajal de Campos, LE-1616)

Una jumenta de nuebe años (Santa María del Río, LE-1617)

Una jumentilla de dos años (Santa María del Río, LE-1617)

Dos jumentas madre e yxa ruzias (Cea, LE-1621) 
Un jumento pardo de edad de quatro años (Frechilla, PA-1612)

Una jumenta color negra, cerrada de hedad (Autillo de Campos, PA-1648)

Huna jumenta ruçia çerrada de hedad (Autillo de Campos, PA-1649)

Dos jumentas, una negra y otra ruçia, con cría, con sus aparexos (Medina de Rioseco, VA-1641)

Aparece en la Tierra de Campos con la forma y el significado académico, es una palabra de uso general y presente en los inventarios. Se documenta en el $C D H$ desde el siglo XIII (1268), más concretamente en un testamento perteneciente a la Documentación de la Catedral de León y referenciada junto al ganado. Pero no será hasta mediados del siglo XVI cuando esta palabra aparezca de manera más genaralizada en los documentos históricos, así en el Manual de escribientes de Antonio de Torquemada, fechado en 1552 se dice lo siguiente: "Así solíamos dezir vna bestia, y de poco acá dezimos jumento", a finales de este mismo siglo tambien figura la palabra en textos de América. Esta abundancia de ejemplos se mantiene en el siglo XVII y es usado por autores como Cervantes, Quevedo, Tirso de Molina o Lope de Vega entre otros. A partir del siglo XVIII su presencia en la documentación de esta base se hace más esporádica.

No ocurre lo mismo en los inventarios del siglo XVII, los datos que nos ofrece el CorLexIn muestran ocurrencias sin un reparto claro en la Península, aunque el número de casos es ligeramente mayor en la mitad norte de la misma. También se documentan ejemplos en Canarias y, en menor medida, en América, donde se localiza un ejemplo en Cuzco (Perú).

En Tierra de Campos se presenta con la forma y la acepción académica y, tal vez por la elección del corpus, predomina más la forma femenina jumenta, que la masculina, de la que solo localizamos un ejemplo. Esta voz compartía campo semántico con burro/a, borrico/a y pollino/a ligeramente superiores en número de casos, tanto en el corpus estudiado, como en el CorLexIn.

En cuanto a la morfología derivacional encontramos el diminutivo jumentilla en un único asiento, en la que solo se nos dice la edad que tiene (dos años), por lo que aquí el sufijo tendría un carácter apreciativo propio de su naturaleza. Este hecho se aprecia mejor en un ejemplo de la localidad leonesa de Santas Martas, zona limítrofe con la Tierra de Campos, donde jumentilla hace referencia directa a la cría de la jumenta: "una jumenta con una jumentilla al pie" (Morala, 2010c: 276).

\section{MACHO}

Sust. m. 'Mulo ('hijo de caballo y burra o de asno y yegua, casi siempre estéril') (DLE). Covarrubias lo registra en su Tesoro como 'animal quadrupede, hijo de cauallo y burra, y de asno y yegua: $y$ a la hembra desta especie llamamos mula' (NTLLE, s. v. macho, Covarrubias, 1611). Probablemente tomado del port. macho íd., antiguamente muacho, derivado de muo (hoy $m u$ ), que viene del lat. MūLus (DECH, s. v. macho ${ }^{3}$ ).

Dos machos, el uno de color castaño de edad de quatro años y el otro de edad de cinco años color castaño (Frechilla, PA-1612)

Un macho rojo cerrado apreçiado en doçe mil marauedís (Frechilla, PA-1612)

Dos machos de labrar, un macho de sobreaño (Frechilla, PA-1631)

Otro macho de color pardo y el bozo castaño de harar de un par de años (Frechilla, PA-1637)

Un macho pardo que hace agora çinco años (Frechilla, PA-1640) 
Otros cuatro machos de dos añales y dos de leche (Frechilla, PA-1640)

Un macho pardo zerrado (Autillo de Campos, PA-1653)

Vn macho de leche color roxo (Autillo de Campos, PA-1654)

Un macho de labra capón color castaño claro (Paredes de Nava, PA-1690)

Un macho çerril color pardo (Paredes de Nava, PA-1690)

Un macho de labor color castaño (Paredes de Nava, PA-1690)

Un macho castaño grande (Medina de Rioseco, VA-1642)

Un macho color pardo claro (Medina de Rioseco, VA-1643)

Un macho color negro en pelo que va a seys años (Medina de Rioseco, VA-1660)

Un macho pardo capón de quatro años que ba cinco (Vallalpando, ZA-16529

Un macho pardo, moyno de hedad de nuebe años (Villalpando, ZA-1661)

Un macho de labranza capón de zinco años, castaño oscuro (Villalpando, ZA-1690)

Macho no solo hace referencia al género de los animales, sino que también al 'mulo', así lo localizamos en el corpus terracampino. Hay una preferencia generalizada por esta voz, frente a mulo, del que no aparece ningún ejemplo. Esta ausencia se refleja también en el resto de la Península donde apenas hay ejemplos del masculino de mula, tan solo se localizan un par de ejemplos en Guadalajara (Atiena y Tordelrábano), y uno en La Alberca (Salamanca), Sevilla y Soria (Zárabes). Macho se extiende en más puntos peninsulares y también de América. El DECH documenta esta palabra en un ejemplo aislado de Juan de Mena en 1456, y a partir del siglo XVII lo emplea Góngora (1605), también Cervantes en la segunda parte del Quijote (1615) o Covarrubias (1611), además de en inventarios, sin embargo señala su ausencia en otras fuentes anteriores donde sí aparece el término mulo-Percivale (1591)- (DECH, s.v. macho $\left.{ }^{3}\right)$. Algunos autores reafirman que gracias a la influencia del portugués esta voz llegó al castellano con este significado y de ahí su presencia en los textos a partir del siglo XVII (Marcos Álvarez, 1987: 891 en Gómez Ferrero, 2015: 384).

Además de la acepción de 'género' y de 'mulo', esta palabra ofrece otros significados dentro del corpus, como un 'tipo de martillo que sirve para diferentes usos', 'mazo de hierro que usa el herrero' al que el $D E C H$ le otorga un origen incierto, probablemente variante mozárabe del mazo (DECH, s.v. macho $\left.{ }^{2}\right)$.

Un macho para machacar lino (Castroañe, LE-1609)

Otro macho de yerro (Villalpando, ZA-1620)

Un macho de herrero y dos pinas de ender que balen doze reales (Villalpando, ZA-1696)

En estos casos el escribano opta por especificar el término y que no haya confusiones, así especifica el uso o el material de que está hecho, algo que ocurre con otros términos similares como burro, potro o caballo (Morala, 2019b: 395).

EI DLE recoge la acepción de 'mazo grande que hay en las herrerías para forjar el hierro' y que encontramos en el un inventario de Villalpando. Los otros dos casos hacen alusión a un tipo de herramienta que, en uno de los casos, sabemos que sirve para "machacar lino". En el estudio del léxico leonés, Le Men señala que, aunque el DLE recoge este término sin notación dialectal, tan solo se documenta en algunas provincias -León, Asturias, Zamora, Salamanca y Extremadura- (Le Men, 2007, s.v. macho ${ }^{2}$ ). 


\section{MULO/A}

Sust. $\mathrm{m}$. y f. 'Hijo de caballo y burra o de asno y yegua, casi siempre estéril' (DLE). Término recogido por Nebrija 'mula de asno' y 'mulo de asno' (NTLLE, s. v. mulo/a, Nebrija, 1495). Del lat. MŪLA (DECH, s. v. mulo).

Tres mulas de labranza, dos de color roxo y una negra (Sahagún, LE-1600)

Una mula castaña en treyta y quatro ducados (Riosequillo, LE-1610)

Una mula de leche en once ducados (San Nicolás del Real Camino, LE-1631)

Un cesto de la mula color castaña que la difunta auia bendido (Villemar, PA-1608)

Una mula color castaña de edad de cinco años (Frechilla, PA-1612)

Otra mula color parda de labranza zerrada (Autillo de Campos, PA-1649)

Una mula de labra color torda de edad de onçe años (Paredes de Nava, PA-1690)

Otra mula calçada de labra cerrada (Boadilla de Rioseco, PA-1692)

Una mula rucia, en mill reales (Medina de Rioseco, VA-1649)

Una mula color castaña de hedad de quinçe meses (Tamariz de Campos, VA-1652)

Una mula rucia cerrada tasada en doce mil maravedís (Villalpando, ZA-1613)

Una mula color castaña ya civada (Villalpando, ZA-1639)

Una mula tordilla que ba para quatro años (Villalpando, ZA-1632)

Una mula de tres años morena de labranza (Villalpando, ZA-1690)

Es un término que siempre aparece en género femenino en la comarca de Tierra de Campos. La forma masculina es poco habitual en los listados de bienes semovientes, de hecho, de los datos que nos ofrece el CorLexIn, se han localizado apenas media docena de ocurrencias -Zárabes (Soria), La Alberca (Salamanca), Atienza y Tordelrábano (Guadalajara) en la Península, a las que habría que añadir un caso en Santiago de Guatemala (Guatemala).

Sin embargo, Mula se utiliza de forma habitual en los inventarios del siglo XVII, tanto en la Península, como en Canarias y América. Ya hemos visto anteriormente que el masculino no es muy frecuente en este tipo de textos, tampoco en América, donde sí aparece el sintagma "bestias mulares" en algunas ocasiones para referirse a dichos animales.

\section{MULETO / A}

Sust. f. y m. 'Mulo pequeño, de poca edad o cerril' (DLE). Recogido por Nebrija y también en Autoridades donde registra dos entradas, una para el femenino y otra para el masculino (NTLLE, s. v. muleto, Nebrija, 1495; Autoridades, 1734). Término derivado del lat. MūLUS (DECH, s. v. muleto).

Tres muletas negras de treinta meses a quarenta ducados cada una (Sahagún, LE-1600)

Otro muleto de un año (Frechilla, PA-1631)

Una muleta çerril color castaño (Paredes de Nava, PA-1690)

Otra muleta de un año (Paredes de Nava, PA-1690)

Es un término poco documentado en la Tierra de Campos, con el primero de los significados que le otorga el diccionario académico. El CorLexIn presenta poco más de media docena de casos repartidos entre el centro y sur de la Península, repartidos entre localidades de Ávila, Cáceres, Ciudad, Real, Albacete, Granada y Almería. A estos ejemplos podemos añadir otros dos, uno en Montefrío (Granada) y otro en Cartagena de Indias (Colombia) donde esta palabra tiene una 
acepción diferente a la que aquí encontramos, hace referencia a un objeto que podría servir de apoyo:

Dos muletas pequeñas, una de ébano (Montefrío, GR-1661)

Vn gato y un pie de cabras de yerro y una muleta (Cartagena de Indias, Colombia-1689)

Los pocos ejemplos que aparecen con el significado que aquí nos ocupa suelen ir acompañados del adjetivo cerril, para indicar que no están domados, también suele especificarse su edad y color.

\title{
POLLINO/A
}

Sust. m. y f. 'Asno joven'. 'Asno' (DLE). Este término lo recoge Nebrija en su Vocabulario como 'hijo de asna', Covarrubias como 'el borrico nueuo' y en Autoridades como 'el asno nuevo y cerríl; pero oy regularmente se entiende como qualquier borríco' (NTLLE, s. v. pollino, Nebrija, 1495, Covarrubias, 1611 y Autoridades, 1737). Palabra derivada de PǓLLUs 'cría de un animal cualquiera' (DECH, s. v. pollo).

\author{
Una pollina color parda cerrada (Grajal de Campos, LE-1657) \\ Una pollina negra de hedad de tres años (Valderas, LE-1659) \\ Un pollino negro y pardo que ba a dos años (Grajal de Campos, LE-1670) \\ Una pollina parda con su cría al pie (Grajal de Campos, LE-1670) \\ Una pollina parda (Valderas, LE-1682) \\ Un pollino pardo çerrado de ocho años (Frechilla, PA-1640) \\ Una pollina parda zerrada (Autillo de Campos, PA-1649) \\ Una pollina color negra con su chría color tordillo (Paredes de Nava, PA-1690) \\ Un pollino de tres años (Villarramiel, PA-1694) \\ Una pollina (Medina de Rioseco, VA-1643) \\ Una pollina de edad de seys años (Cuenca de Campos, VA-1651) \\ Otra pollina nueba de dos años tassada en doçe ducados (Cuenca de Campos, VA-1668) \\ Una pollina que se bendió en diez ducados (Cuenca de Campos, VA-1670) \\ Una pollina semental con un pollino al pie, zerrada (Vallalpando, ZA-1661) \\ Una pollina de quatro años morena, otra pollina atera de tres años (Villalpando, ZA-1676) \\ Un pollino mediano pardo de edad de seis años (Villalpando, ZA-1688) \\ Una pollina color tordillo de treinta meses (Villalpando, ZA-1690)
}

Pollino/a comparten campo semántico con otras lexías como burro/a, jumento/a. Morala señala que la elección de un término u otro responde a razones de corte estilístico (Morala, 2010c: 276). Como en otras ocasiones, este término se documenta en los textos desde el siglo XIII (CDH). También aparecen de forma generosa en los inventarios de la Península (CorLexIn). Se localiza en toda la Tierra de Campos con la forma académica y dando cuenta de la edad, el color...

En un inventario de Villalpando, aparece "una pollina atera", este adjetivo el DLE lo recoge como hatero, ra 'dicho de una caballería: Que sirve para llevar la hatería de los pastores', y en un inventario de esta misma localidad vuelve a aparecer, pero esta vez sustantivado "cinco cabras y una atera", tal vez se trata de la pollina que lleva los bártulos del pastor, el contexto tampoco nos da más datos, pero sí que aparece otro ejemplo en Villalpando donde se sustantiva este adjetivo y aparece "una hatera ruçia". 
Otro adjetivo que llama la atención en estos ejemplos es el de semental referido al femenino pollina, que también se localiza en Villalpando, tal vez fuese una pollina que se utilizara para la cría:

Una pollina semental con un pollino (Villalpando, ZA-1661)

Dos pollinas sementales (Villalpando, ZA-1696)

Cabe mencionar el uso del adjetivo lechaça para referirse y precisar la edad, en este caso estamos ante una cría que se alimenta de leche todavía:

Una pollina viexa, otra lechaça (Villarramiel, PA-1694)

Una pollina color parda de edad de quatro años con una cría al pie lechaça (Villarramiel, PA-1696)

Este mismo adjetivo lo localiza Morala en un inventario de Posada de Valdeón, fechado en 1647 "un potro castaño claro de dos años y ba a tres, con potro del mismo color, dos potros lechaços", con la misma acepción que encontramos en Tierra de Campos (Morala, 2010c: 276).

\section{POTRO/A}

Sust. m. y f. 'Caballo desde que nace hasta que muda los dientes de leche, que, generalmente, es a los cuatro años y medio de edad', 'armazón de madera que sirve para sujetar a los caballos cuando se resisten a dejarse herrar o curar' (DLE, 1. a y 2. a ac.). Nebrija registra 'potro de dos años' y 'potro de tres años'. Covarrubias, además de 'cauallo nueuo', registra el significado de 'cierto instrumento de madera para dar tormento'; Autoridades afirma que el caballo, para llamarse potro, no debe pasar de los quatro años; recoge la otra acepción dada en el Tesoro y, además, añade la 2. acepción que registra el DLE (NTLLE, s. v. potro, Nebrija, 1495; Covarrubias, 1611; Autoridades, 1737). Término de origen incierto (DECH, s. v. potro).

Una potra de quatro años con un potro castaño de un año frontino (Castrillo, LE-1606)

Una potra de dos años castaña (Cea, LE-1610)

Una potra color negra, calçada, de hedad de tres años (Cea, LE-1626)

Una potra de tres años color castaño (Autillo de Campos, PA-1653)

Un potro ruçio que se uendió en trescientos reales (Villada, PA-1665)

Un potro de un año (Villarramiel, PA-1690)

Otra potra de bientre color castaño con una potra de leche al pie (Paredes de Nava, PA-1690)

Un potro con una estrella blanca en la frente (Medina de Rioseco, VA-1642)

Una yegua con un potro de año y medio (Medina de Rioseco, VA-1649)

Una potra de un año (Cuenca de Campos, VA-1651)

Una potra de cinco años con un potro al pie (Cuenca de Campos, VA-1651)

Una potra roxa de tres años (Quintanilla del Monte, ZA-1639)

Una potra roja de hedad de tres años poco más o menos preñada (Villalpando, ZA-1661)

Una yegua de diez a doze años con una potra al pie (Villalpando, ZA-1689)

Una potra color castaño de sobreaño (Villalpando, ZA-1690)

Aparece tanto en su forma en masculino como en femenino, aunque parece que el alcance en cuanto a edad difiere entre géneros. Por un lado, encontramos potro que, en los ejemplos que localizamos, no pasaría de los tres años, sin embargo, sí nos encontramos potras que llegan a los cinco años. También hay diferencia entre ambos géneros si se observa la documentación histórica, ambos aparecen en los textos a partir del siglo XIII, pero, mientras que potro aparece en gran cantidad de textos, potra se documenta de forma más esporádica $(C D H)$. Este desequilibrio entre las formas de masculino y femenino también se traslada a los inventarios del 
siglo XVII, donde encontramos potro al lo largo de toda la Península y también en las islas Canarias y en diversos puntos de Amércia, parece ser un término general para referirse a la cría de la yegua. Con el femenino potra no ocurre lo mismo, apenas hay ejemplos en los inventarios, se reducen a varios casos en la zona Norte de la Península, así tenemos ocurrencias en Asturias, León y Huesca y otro ejempo en Bercial de Zapardiel (Ávila) donde comparte campo con potranca, término este último que está más extendido por el resto de la Península y que parece ser el generalizado en los inventarios de la época ya que cubre la misma extensión de uso que potro. Sin embargo, no ocurre lo mismo con los textos del corpus estudiado, en Tierra de Campos se prefiere el femenino potra frente a potranca, que no aparece documentada en esta zona.

Pero este término aparece con otras acepciones en esta zona, que contrasta con el CorLexIn donde tan solo encontramos un ejemplo Carbajales del Alba (Zamora), al que Morala añade dos más también en localidades zamoranas (Morala, 2019b: 395), donde aparece "un potro para zera". En Tierra de Campos encontramos varios casos de "potro o potra para peynar":

Una potrilla de peynar (Frechilla, 1615)

Un potro de madera para peynar (Frechilla, 1616)

Una potra para peynar y una carbonera (Frechilla, 1659)

Una potra de peynar (Frechilla, PA-1671)

Un potro de madera para peynar (Frechilla, PA-1675)

Un potro de madera de peinar lana (Villarramiel, PA-1694)

Cabe señalar que todos estos ejemplos se localizan en Frechilla, zona textil por excelencia en aquella época y que este tipo de instrumentos entraría dentro de las herramientas especializadas para el oficio. Además de estos 'potros de peinar lana', también aparece otro con la segunda acepción que le daba Covarrubias:

Un potro de dar tormento (Villalpando, ZA-1660)

En este caso estamos ante un documento que es 'entrega de los presos y prisiones', un contexto muy específico en el que no cabe duda a lo que se refiere.

\section{YEGUA}

Sust. f. 'Hembra del caballo' (DLE). Lo registra Autoridades en 1739 con esta misma acepción (NTLLE, s. v. yegua, Autoridades, 1739). Término del lat. ĔQUA, femenino de EQUUS 'caballo' (DECH, s. v. yegua).

Una yegua color castaña, de zinco años en treynta ducados (Sahagún, LE-1600)

Una yegua color castaña, no se saue la edad, con un macho (Cea, LE-1607)

Una yegua castaña de tiempo de ocho años poco más o menos (Santa María del Río, LE-1617)

Una yegua de color roja cerrada (Autillo de Campos, PA-1649)

Una yegua morena zerrada (Autillo de Campos, PA-1653)

Una yegua blanca de cinco años, con el macho al pie (Paredes de Nava, PA-1689)

Una yegua de vientre color roxa (Paredes de Nava, PA-1690)

Otra yegua de vientre color castaño, con una potra de leche al pie (Paredes de Nava, PA-1690)

Una yegua ruçia çerrada (Boadilla de Rioseco, PA-1692)

Otra yegua roxo de seis a siete años (Boadilla de Rioseco, PA-1692)

Otra yegua morena cerrada (Boadilla de Rioseco, PA-1692)

Una yegua pequeña con su cola en veinte y quatro ducados (Medina de Rioseco, VA-1649)

Una yegua y un macho al pie (Villalpando, ZA-1639) 
Otra yegua preñada del contrario, pequeña de hedad de cinco años tasada, digo color roja frontina calçada de todos los quatro piés (Villalpando, ZA-1661)

Dos yeguas viexas, la una de color alazán (Tapioles, ZA-1688)

Es una palabra de uso general y que aparece con frecuencia tanto en los documentos del $C D H$ y el CORDE, como en los inventarios del siglo XVII que recoge el CorLexIn. Suele ir referenciada junto a la edad, el color y aquellas características que la identifican.

\subsubsection{Ganado Porcino}

\section{CEBÓN [zebón]}

Sust. m. y f. 'Cerdo (mamífero)' (DLE, 2.a ac.). Autoridades lo recoge como 'el puerco cebado, para que su carne esté tierna y deliciosa al gusto. Tambien se llaman asi los animales, que se ceban con cuidado para el mismo fin' (NTLLE, s. v. cebón, Autoridades, 1729). Término derivado de cebo, del lat. Cі̆Bus 'alimento, manjar' ( $D E C H$, s. v. cebo).

Dos zebones (Villalpando, ZA-1629)

Tan solo localizamos este ejemplo en el corpus analizado. Se encuentra referenciado junto a una yegua blanca, pero sin más datos no podemos dilucidar a qué acepción se refiere. EI CDH lo documenta a partir de mediados del siglo xv, en el Cancionero de obras de burlas provocantes a risa de 1445-1519 donde aparece como adjetivo "puerco cebón"; es en el siglo XVI donde aparece sustantivado para hacer referencia al 'cerdo que se engorda', aún así su presencia no es muy frecuente. Lo mismo ocurre con los inventarios de bienes del siglo XVII, de los textos que configuran el CorLexIn, tan solo se ha localizado en un inventario de Navahermosa (Toledo) "vn cebón y una lechoncilla".

\section{CERDO /A [çerdo, zerdo]}

Sust. m.y f. 'Mamífero artiodáctilo del grupo de los suidos, de cuerpo grueso, cabeza y orejas grandes, hocico estrecho y patas cortas, que se cría especialmente para aprovechar su cuerpo en la alimentación humana' (DLE). Lo recoge Autoridades como 'lo mismo que cochino ò marrano. Llámese tambien assi, porque este animál en lugár de pelo está cubiero de cerdas cortas' (NTLLE, s. v. cerdo, Autoridades, 1729). Es un término derivado de cerda 'cada uno de los pelos duros y gruesos de ciertos animales, como el caballo y el cerdo', procedente del lat. vulgar CĬRRA 'vellón', 'mechón de pelos' ( $D E C H$, s. v. cerda).

Un zerdo que pesará diez arrobas (Paredes de Nava, PA-1689)

Un çerdo de tres arrobas poco más o menos (Villarramiel, PA-1696)

Tres zerdos grandes, dos marranas parideras y quatro cerdos pequeños (Villalpando, ZA-1698)

En la documentación estudiada nos encontramos escasos ejemplos de este término y siempre en género masculino para referirse al animal porcino, para el femenino se prefiere la voz marrana, así parece atestiguarlo el asiento de Villalpando (Zamora). En el DECH se afirma que cerdo surge como una formación eufemística de fecha muy posterior a la de cerda, cuando 
puerco y sus sucedáneos marrano y cochino se hicieron de mal tono (DECH, s.v. cerda). La voz cerdo aparece en el siglo XVIII en la documentación del CDH. Al consultar el CorLexIn no encontramos ejemplos de la palabra cerdo, tan solo encontramos dos ocurrencias de cerda en Puentedura y San Pedro de la Villa, provincia de Burgos. Lo que sí localizamos es la locución "ganado de cerda o cabezas de cerda", que no solo aparece en la Península, sino también en América. Dada la escasez del término en el corpus de estudio, y en la documentación de la época, parece que cerdo era una palabra de reciente adquisición en el siglo XVII.

\section{LECHÓN / A [lichones, lechoncitos, lechonicas]}

Sust. m. y f. 'Cochinillo que todavía mama', 'Cerdo macho de cualquier tiempo' (DLE, 1. a y 3.a ac.). Nebrija recoge lechón como cría del cerdo que se alimenta de leche, pero también el que es mayor y de la misma forma lo registra Covarrubias (NTLLE, s. v. lechón, Nebrija, 1495; Covarrubias, 1611). Se trata de un término derivado de leche, del lat. LAC, LACTIS (DECH, s. v. leche).

Un lechón que se cría de presente, tres ducados (Sahagún, LE-1600)

Un lechón y una lechona en nouenta reales (Sahagún, LE-1602)

Un lechoncito mamón (Castroañe, LE-1628)

Una lechona con siete lenchoncitos (Castroañe, LE-1629)

Un lechón de matança que pesará diez arrobas (Grajal de Campos, LE-1656)

Una lechona tasada en tres ducados (Sahagún, LE-1605)

Un lechón cebado bueno (Guaza de Campos, PA-1637)

Dos lechones blancos de cría (Castromocho, PA-1614)

Un lechón pequeño (Medina de Rioseco, VA-1641)

Dos lechones, henbra y macho (Medina de Rioseco, VA-1639)

Doce lechones nuebos (Tamariz de Campos, VA-1652)

Quatro lechones grandes, buenos, tasados en ducientos reales (Villalpando, ZA-1613)

Un lechón, más otra lechona, ambos grandes para la matança (Villalpando, ZA-1632)

Dos lichones (Villalpando, ZA-1634)

Dos lechonas con once lechonicas mamantonas (Villalpando, ZA-1639)

Una lechona zebada tasada en ocho ducados (Carrizo, ZA-1646)

Una lechona de cría de más de un año y medio (Villalpando, ZA-1664)

Tanto el CORDE como el CDH documentan esta palabra por primera vez en una Carta de relación de bienes perteneciente a la documentación del Monasterio de Carrizo fechada en en 1218. Sin embargo, el $D E C H$ adelanta la misma hasta el año 1099, en la documentación de Toro: "una porca cum suos lectones", con el primer significado dado por el DLE (DECH, s. v. leche).

Si limitamos la búsqueda al siglo XVII, el uso parece generalizado en toda la Península, salvo en las provincias andaluzas, donde su presencia es menor. No se documentan casos en documentos canarios ni americanos (CorLexIn).

En tierra de Campos figura con las acepciones académicas, hace referencia tanto a los animales de cría, como al lechón grande. Es la lexía más utilizada para dar cuenta del ganado porcino. Formalmente, aunque de forma esporádica, aparece lichón con cierre de la /e/, un cambio de timbre de la vocal átona común en esta época y que Morala localiza en la localidad terracampina de Cea -"una lichona"-, en Zuares del Páramo (Léon) -"un lichón pequeño"- y 
Villamañán (León) -"un lichón pequeño"- (Morala, 2012a: 562; Morala, 2010c: 275), a los que habría que sumarles el localizado en Villalpando (Zamora) -"dos lichones".

En el área de estudio figuran las formas derivadas de diminutivo lechoncitos y lechonicas cuya motivación semántica está basada en la edad del animal, en ambos casos referencian las crías de las lechonas. Estos diminutivos presentan un exiguo abanico de casos, tanto en la zona de estudio como en los inventarios que conforman el CorLexIn, donde las ocurrencias los sufijos alternan entre lechonica (Muga de Alba, Zamora), lechoncilla (Navahermosa, Toledo), lechonçitos (San Pedro de la Villa, Burgos) y lechonçilla (Valdesogo de Arriba, León), a los que habría que añadir, además de los localizados en Tierra de Campos, habría que añadir "quatro lechoncitos pequeños" en documentos pertenecientes a Soto de Valdeón y "una llechona con dos lechonçitos pequeños" en Cordiñanes, ambas localidades leonesas (Morala, 2010c: 275).

\section{MARRANO /A}

Sust. m. y f. 'Cerdo (mamífero)' (DLE, s. v. marrano ${ }^{1}$ ). Para Nebrija esa palabra hacer referencia al 'cochino de un año' (NTLLE, s. v. marrano, Nebrija, 1495). Marrano en el sentido de 'cerdo' probablemente fue tomada del árabe máhram 'cosa prohibida' (DECH, s. v. marrano).

Un marrano pequeño para criar (Grajal de Campos, LE-1670)

Dos marranos medianos de cría (Grajal de Campos, LE-1670)

Dos marranos, uno grande y otro mediano (Valderas, LE-1682)

Un marrano (Villarramiel, PA-1691)

Un marrano mediano (Medina de Rioseco, VA-1657)

Un marrano en seis ducados (Medina de Rioseco, VA-1661)

Un marrano mediano tassado en doçe ducacos (Cuenca de Campos, VA-1668)

Una marrana de cría (Villalpando, ZA-1685)

Un marrano blanco de zeva (Cotanes del Monte, ZA-1687)

Una marrana con dos marranos pequeños (Villalpando, ZA-1689)

Una marrana (Quintanilla del Monte, ZA-1689)

Quatro marranos, los dos medianos y la una grande y otro más pequeño (Villalpando, ZA-1690)

Es la voz más utilizada para designar el 'cerdo' después de lechón, aunque se documenta a lo largo de toda la Tierra de Campos, hay un mayor número de casos en Zamora. La nómina de ocurrencias en la Península es significativamente menor que las de lechón, aunque en este caso sí aparecen ejemplos del término en América (CorLexIn). En la zona de estudio esta voz suele aparecer junto al sintagma "de ceba", "de cría" o "para criar".

Por otro lado, cabe destacar que esta palabra aparece con otra acepción en el corpus estudiado y que no hemos encontrado en otros inventarios:

Un marrano de lagar, un taxador de picar carne (Boadilla de Rioseco, PA-1692)

El contexto solo nos aclara el ámbito léxico que ocupa, pero tampoco da más información sobre la función del mismo. El DLE prensenta otra entrada para el término marrano, donde hace referencia a 'pieza fuerte de madera, colocada sobre el tablero de las prensas de torre de los molinos de aceite, que sirve para igualar la presión' ( $D L E$, s. v. marrano ${ }^{2}, 3$. a ac.), pero no hace referencia al 'madero de lagar' que aparece en los inventarios. Le Men localiza esta acepción en León, Asturias, Palencia, Burgos o Galicia. 


\section{PUERCO}

Sust. m. y f. 'Cerdo (mamífero)' (DLE). Nebrija registra tanto puerco como puerca. Autoridades hace una descripción del animal y afirma que 'se ceba y engorda para que sirva de mantenimiento [...] su carne es mui util y sabrosa' (NTLLE, s. v. puerco, Nebrija, 1495; Autoridades, 1737). Término procedente del lat. PǑRCUs. Fue de uso general en la Edad Media, y a partir del siglo XVII se sustituye por cerdo, debido del uso metafórico de este término como 'muy sucio' (DECH, s. v. puerco).

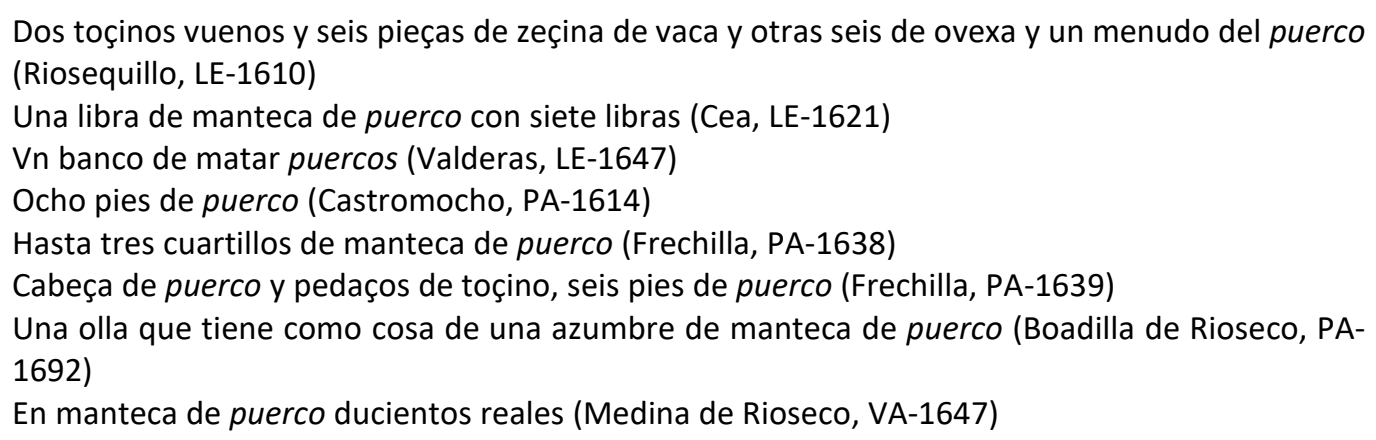

En los inventarios analizados de la Tierra de Campos, puerco hace referencia al cerdo ya sacrificado y despiezado principalmente. Nos encontramos con menudos, pies, manteca o cabeza de puerco. Lo mismo ocurre en algunos puntos de la Península, donde puerco tiene un claro significado de alimento -Valladolid, León, Ávila, Navarra y Jaén-.

No obstante, uno de los ejemplos localizados en el corpus terracampino podría hacer referencia al animal vivo: "Un puerco pequeño" (Castromocho, PA-1614), aunque la información del asiento y el contexto en el que se encuentra no nos permite asegurarlo con rotundidad. Con el significado de animal porcino figura casi una docena de ocurrencias en algunos de los inventarios que conforman el CorLexIn, tanto en la Península como en América.

\subsubsection{Ganado caprino}

\section{ENGÜEDA}

Este término no aparece en el DLE. 'Hembra que tiene un año, que ha dado a luz por primera vez' (Le Men, 2005, s. v. engüeda).

Quatro cabras y dos cabritas engüedas (Valdavida, LE-1606)

Ocho cabras, quatro añexas y dos angüedas y dos cabritas de este año (Valdavida, LE-1606)

Una angüeda (Castroañe, LE-1609)

Es un término escasamente documentado, formalmente aparacen dos variantes, engüeda y angüeda, con variación vocálica de la sílaba inical que suele encontrarse en la zona suroriental del leonés (Morala, 2009: 15). Morala localiza otros dos casos en esta misma zona, en la notaría de Cea "una cabra con un cabrito, tres machorras, dos angüedas" y "Honze cabras, quatro angüedas" (Villacalabuey, LE-1639) (Morala, 2010c: 273). Pascual señala que esta voz se documenta principalmente en femenino, algo que coincide con los ejemplos localizados en 
Tierra de Campos (Pascual, 2009:175-177). También localiza estas dos formas y en femenino Le Men en vocabularios dialectales de la Maragatería y en algunos puntos de Cantabria (Le Men, 2005, s.v. engüeda).

\section{CABRA [cabrito, cabrita]}

Sust. y adj. f. y m. 'Mamífero rumiante doméstico, como de un metro de altura, muy ágil para saltar y subir por lugares escarpados, con pelo corto, áspero y a menudo rojizo, cuernos vueltos hacia atrás, un mechón de pelos largos colgante de la mandíbula inferior y cola muy corta', 'hembra de la cabra, algo más pequeña que el macho y a veces sin cuernos' (DLE, 1. a y 2.a ac.). Tanto cabra como cabrito lo recoge Nebrija y Covarrubias (NTLLE, s. v. cabra, Nebrija, 1495; Covarrubias, 1611). Es un término procedente del lat. CAPRA (DECH, s. v. cabra).

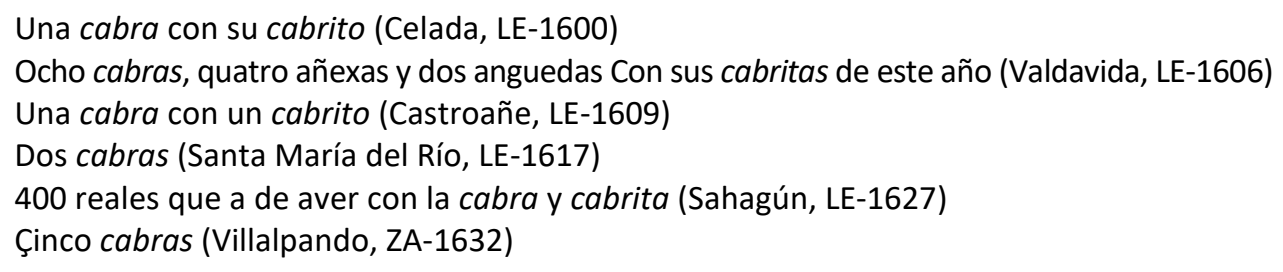

Cabra, cabrito y cabrita son voces ampliamente documentadas en los textos. En la Tierra de Campos hay ejemplos de este tipo de ganado, aunque no es el que más presencia tiene en los inventarios de la zona.

Destacan un par de ejemplos donde aparece cabritilla con una acepción muy diferente a la de 'animal caprino', por un lado, se documenta un tipo de tela o piel para elaborar ropajes y que tiene que ver con el ámbito textil, y por otro estamos ante el adorno de la rodadura de un manteo. En cuanto a la forma, aparece la forma diminutiva cabritilla y en uno de los casos con el cambio de timbre de la vocal átona muy frecuente en esta época y del que hemos hablado anteriormente cabretilla.

Un xubon de cabritilla guarnecido (Frechilla, PA-1631)

Un manteo de paño acul forrado la rodadura con cabretillas (Villalpando, ZA-1664)

\section{CHIVARRO/A}

Sust. $m$. y f. 'Chivo desde uno a los dos años de su edad' (DLE). Este término lo recoge por primera vez el DRAE de 1936 como 'el chivo o chiva desde uno a los dos años de su edad' y sin notación dialectal (NTLLE, s. v. chivarro, DRAE, 1936). Término derivado de chivo 'cría de la cabra' (DECH, s. v. chivo).

Una cabra con su cabrita y una chivarra (Castoañe, LE-1628)

Morala localiza este ejemplo en plena Tierra de Campos con la acepción que le otorga el $D L E$. Se trata de una voz muy escasa en la documentación, tanto en el CDH como en el CORDE. En el CorLexIn localizamos un ejemplo en Villamuñío, localidad cercana a nuestra zona de estudio:

Dos chibarras y una cabra (Villamuñío, LE-1633) 
Como señala Morala, lo fundamental de este ejemplo es la datación que aporta, ya que se trata de un término que apenas aparece en la documentación y la Academia no lo registra hasta su edición de 1936, por lo que estas dos ocurrencias adelantan la datación de este término en los textos (Morala, 2010c: 274). En repertorios léxicos actuales esta palabra figura en localidades leonesas como Villacidayo y San Feliz de Torío (León), Las Hurdes (Extremadura), y algunas zonas de La Rioja (Le Men, 2004, s. v. chivarro).

\subsubsection{Ganado ovino}

\section{BORREGO/A [vorrega]}

Sust. m. 'cordero de uno o dos años' (DLE). Es una voz registrada por Nebrija y Covarrubias. Voz puede que derivada de borra, por la lana tierna de que está cubierto ( $D E C H$, s. v. borrego).

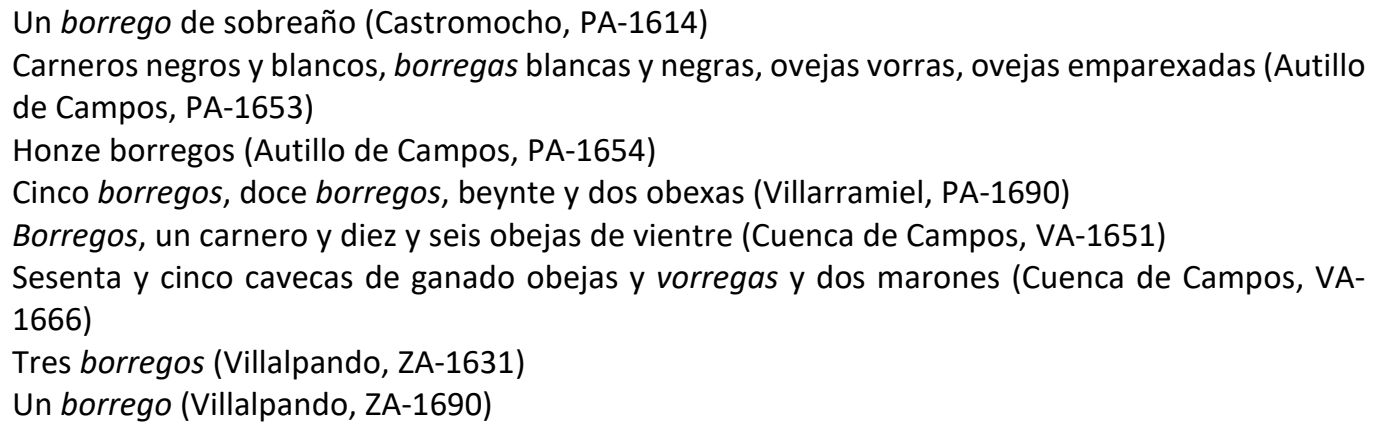

Se documenta en los textos desde el siglo XIV y está presente en ellos, bien haciendo referencia al animal o también con la segunda acepción del $D L E$ 'persona que se somete gregaria o dócilmente a la voluntad ajena' $(C D H)$.

Los datos que ofrece el CorLexIn presetan una docena de ocurrencias repartidas entre diferentes localidades peninsulares, con preferencia de la franja noroccidental, aunque también encontramos casos en La Rioja, Guadalajara y Alicante. Siempre presenta el significado académico de 'cordero', en la Península. En Tierra de Campos parecen preferir el término borro, borra.

\section{BORRO/A [vorro/a, borrilla]}

Sust. m. y f. 'Cordero que pasa de un año y no llega a dos' (DLE). Lo registra Autoridades como sinónimo de 'borrego'. Es un término que no aparece en los diccionarios con notación geográfica. Derivado regresivo de borrego, y este a su vez de borra 'lana grosera' ( $D E C H, \mathrm{~s} . \mathrm{v}$. borrego).

Diez obexas y borras sin corderos (Valdavida, LE-1606)

Catorçe obejas con sus corderos, quatro borras que ban a parir (Valdavida, LE-1606)

Seis borras (Santa María del Río, LE-1617)

Doze ovexas de lana, las ocho paridas y las quatro borras, las paridas tassadas a diez reales cada una y las vorras a siete reales me suman ciento ocho reales (Celada, LE-1624) 
Quinçe ovejas y vorras (Sahagún, LE-1626)

Tres vorros que se tasaron a diez y ocho reales cada uno (Castromocho, PA-1602)

Beinte i çinco borros con el marón (Frechilla, PA-1639)

Doce borras con diez crías a beinte reales (Frechilla, PA-1639)

Quatro borras (Boadilla de Rioseco, PA-1643)

Carneros negros y blancos; borregas blancas y negras; obejas vorras; obejas emparexadas (Autillo de Campos, PA-1653)

Quarenta y cinco borros que van a carneros (Paredes de Nava, PA-1689)

Veinte borrillas (Paredes de Nava, PA-1690)

Doce borrillas (Paredes de Nava, PA-1690)

Ocho borros (Paredes de Nava, PA-1690)

Treinta obexas de vientre, ocho borros, siete borras (Paredes de Nava, PA-1690)

Treinta y nuebe vorras y machorras (Villalpando, ZA-1698)

Esta lexía se documenta a lo largo y ancho de toda la Tierra de Campos, tanto en masculino como en femenino. También aparece el diminutivo borrilla, este lexicalizado ya que puede que haya alguna diferencia con repecto a la forma borro/a (Morala, 2010c: 270). En bases de datos léxicas como el $C D H$ o el CORDE esta palabra aparece desde el siglo XIII. Sin embargo, los datos que nos ofrecen los inventarios del siglo XVII muestran una presencia esporádica en los textos y centrados en las zonas pertenecientes a las provincias de Palencia y Burgos principalmente, aunque aparece un ejemplo en Segovia (CorLexIn). En Tierra de Campos esta palabra es de uso habitual en los inventarios de bienes para hacer referencia al ganado ovino, en concreto 'al carnero u oveja de uno o dos años', aunque el contexto en el que aparecen el término es más general, se localizan ejemplos de "borras con diez crías", pero también "ovejas paridas y borras" o "borras que van a parir"; en el caso del masculino tenemos "borros que van a carnero", pero Morala localiza un ejemplo en Villacalabuey donde aparecen "cinquenta y ocho borros para la capadura", es decir, para producir carne (Morala, 2010c: 270). Formalmente figura el diminutivo femenino borrilla, posiblemente lexicalizado, y que añade algún matiz al término genérico (ibidem). Formalmente también aparece en ocasiones como adjetivo en los textos, así nos encontramos con:

Carneros negros y blancos; borregas blancas y negras; obejas vorras; obejas emparexadas (Autillo de Campos, PA-1653)

Esta lexía figura en estudios dialectales actuales, así se localiza el término borro y borra en León -Murias de Paredes, La Vecilla, Riaño o Valencia de Don Juan-, pero también en Palencia, Valladolid, Salamanca, Extremadura, La Rioja o Andalucía (Le Men, 2002, s. v. borro).

A lo largo del corpus aparece el término borra con la acepción académica de 'pelo de cabra de que se rellenan las pelotas, cojines y otras cosas' ( $D L E$, 4. a ac.), y así en la localidad de Frechilla nos encontramos:

Una almohada de çerro con su borra y lana con randas de hilo en tres reales (Frechilla, PA-1616)

Es el único ejemplo localizado en Tierra de Campos, pero esta voz se halla muy presente en el CorLexIn en distintos puntos de la Península y se documenta con anterioridad a la acepción vista anteriormente. 


\section{CARNERO}

Sust. m. 'Macho de la oveja, que alcanza de 70 a $80 \mathrm{~cm}$ de altura hasta la cruz, con frente convexa, cuernos huecos, angulosos, arrugados transversalmente y arrollados en espiral, y lana espesa, blanca, negra o rojiza. U. a veces para referirse a la especie' (DLE). Nebrija recoge varias acepciones para este término entre las que está la de 'carnero para casta', 'carnero cojudo' y 'carnero para comer' (NTLLE, s. v. carnero, Nebrija, 1495). Es una voz derivada de carne (DECH, s. v. carne).

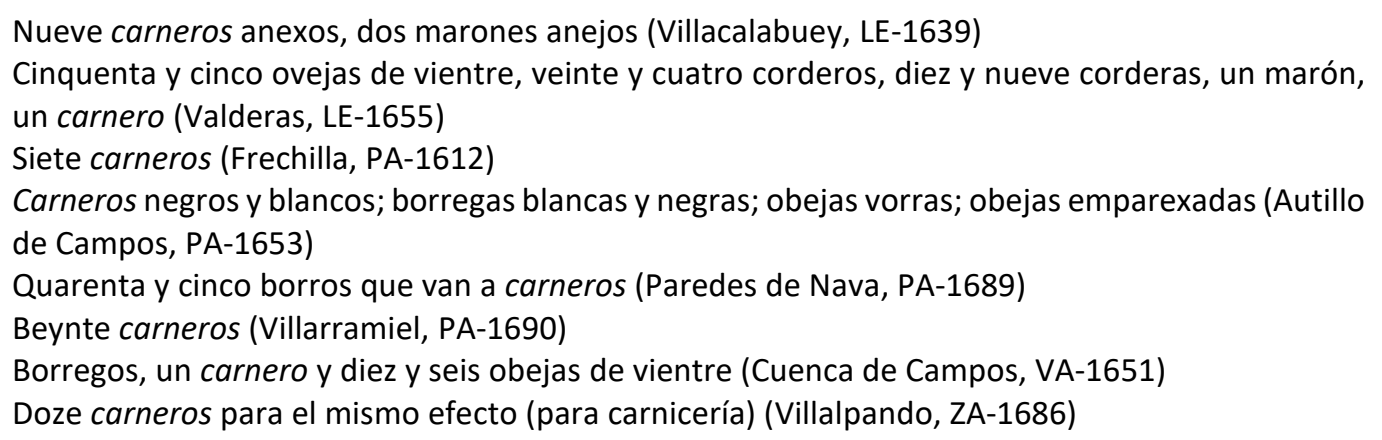

Este término, documentado desde el siglo XII en el $C D H$, presenta matices en su significado. Nebrija registra la palabra con diferentes acepciones $y$, dentro de la designación al animal, también resalta diferentes matices, podría ser tanto el 'macho de la oveja, que se cría para obtener de él carne' o bien como 'marueco' -'carnero padre' (DLE)- (DECH, s.v. carnero). En Tierra de Campos este término parece hacer referencia al mamífero ovino que se cría para la obtención de su carne, y así nos encontramos "borros que van a carneros" o "doze carneros para la carnicería". Parece que en los textos analizados prefieren otro término para el macho que se utiliza para semental, marón.

\section{MACHORRA [machona]}

Sut. f. 'Hembra estéril' (DLE, 3.a ac.). Este término lo registra Nebrija en su Vocabulario. Autoridades recoge esta palabra con género femenino como 'la oveja estéril: y por extensión se llama assí la mugér ù otro qualquier animál del sexo femenino que no pare' (NTLLE, s. v. machorra, Nebrija, 1495; Autoridades, 1734). Término derivado de macho y que significa 'oveja estéril' (DECH, s. v. macho I).

\footnotetext{
beinte y una obexas de bientre y dos machorras y seis baçías y dos borros (Cea, LE-1625) Ciento cinquenta y seis obejas de vientre con sus corderos, más otras cinquentas y dos obejas machonas con su lana, yten setenta y una vaçía con su lana (Villalpando, ZA-1644)

Treinta y nuebe Vorras y machorras (Villalpando, ZA-1698)

Sesenta y nuebe ovejas enparejadas, más treinta y nuebe vorras y machorras (Villalpando, ZA1698)
}

Encontramos cuatro ejemplos en Tierra de Campos de este término, siempre referenciando a la 'oveja estéril'. El CorLexIn localiza un par de ejemplos: uno en San Millán de Juarros (Burgos), junto a ganado ovino y en Villamuñío (Léon), localidad muy próxima a la Tierra de Campos, y que presenta el siguiente ejemplo:

Setenta y ocho baçías y machorra (Villamuñío, LE-1633) 
Tanto en este ejemplo como en el de Villalpando y Cea, el término machorra comparte asiento en el inventario con 'oveja vacía', por lo que debe haber alguna diferencia en el significado entre ambas, parece que, en algunos inventarios, vacías se identifican con aquellas hembras que no están preñadas, mientras que machorra haría referencia a aquella que no puede quedarse preñada (Morala, 2010c: 270).

\section{MARÓN}

Sust. m. 'Carnero padre' ( $D L E$, s.v. marón ${ }^{2}$ ). Este término se recoge en el diccionario no académico de Rosal con el significado de 'carnero', el primer diccionario académico que registra esta palabra es la edición de 1925, donde le dan a marón el significado de morueco -' carnero padre o que ha servido para la propagación'- (NTLLE, s. v. marón, Rosal, 1611; DRAE, 1925). Término procedente de marueco que es empleado en Álava, Salamanca, el Bierzo, Astorga, etc. (DECH, s. v. morueco).

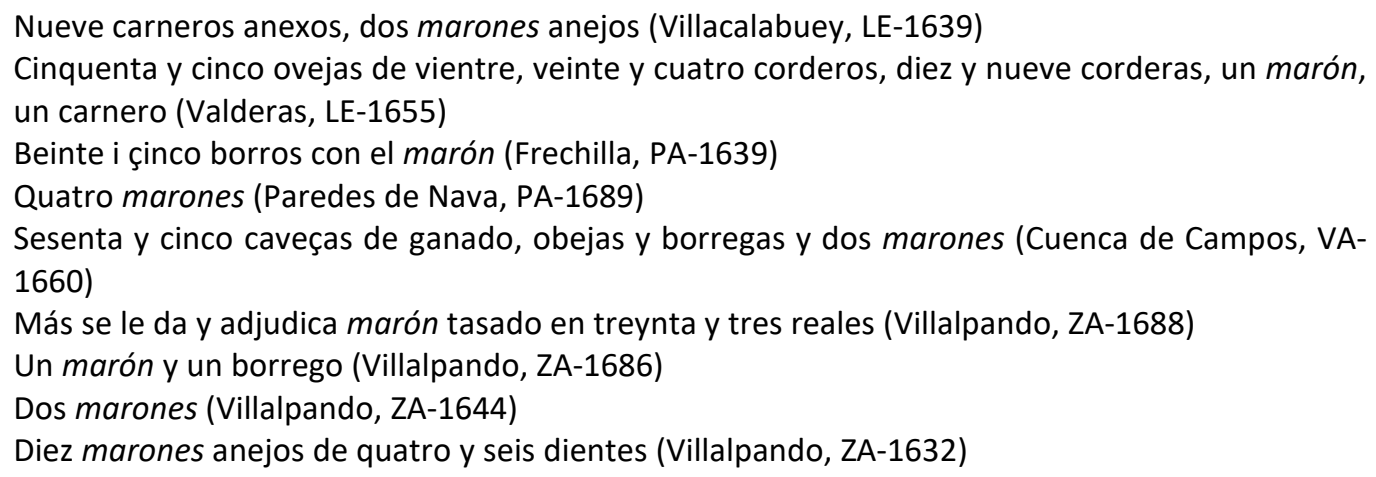

No solo es un término que registra de forma tardía la lexicografía académica, sino que en el $C D H$ y en el CORDE esta voz se localiza en contadas ocasiones. Los escasos ejemplos que recoge el CorLexIn se distribuyen por la zona noroccidental de la Península, en concreto en las provincias de Zamora, León -Carbajales del Alba y Villamuñío, localidades muy próximas a Tierra de Campos-. Sin embargo, en Tierra de Campos esta lexía es habitual en los inventarios, y aparece en más ocasiones que carnero o marueco, voz esta última de la que no hemos localizado ningún ejemplo.

Morala, además de localizar ocurrencias en la zona en el siglo XVII, señala que es una voz que aún tiene vigencia en la actualidad, consulta el $A L C y L$ (mapa 503) que refleja el uso de marón en las tres provincias leonesas, mientras que en las castellanas predomina marueco (Morala, 2010c: 270).

\section{OVEJA}

Sust. f. 'Mamífero rumiante de tamaño mediano, que posee lana y carne muy apreciadas, cuyo macho presenta cuernos arrollados en espiral y de cuya hembra se obtiene leche con la que se elaboran quesos' $(D L E)$. Se registra en la lexicografía desde Nebrija. Término procedente del lat. tardío ovǐcŭLA, diminutivo de ovIs 'oveja' (DECH, s. v. oveja). 
Catorçe obejas con sus corderos (Valdavida, LE-1606)

Ocho ouexas buenas (Sahagún, LE-1608)

Una docena de obexas con sus corderos (Sahagún, LE-1605)

Catorze obexas de bientre (Santa María del Río, LE-1617)

Doze ovexas de lana, las ocho paridas y las cuatro borras (Celada, LE-1624)

Beynte y dos ovexas de vientre nuebas (Cea, LE-1625)

Treynta ovejas de vientre (Frechilla, PA-1612)

Seis obexas madriçes (Villarramiel, PA-1694)

Doce obexas madriçes (Villarramiel, PA-1696)

Treynta y dos obejas de bientre y dos corderos machos (Guaza de Campos, PA-1640)

Treinta obexas de vientre (Paredes de Nava, PA-1690)

Veinte obejas (Medina de Rioseco, VA-1643)

Doce obexas tasada cada una a diez y ocho reales (Tamariz de Campos, VA-1652)

Ziento y veinte obejas, zinquenta corderas, tres borregos (Villalpando, ZA-1631)

Cien obexas de vientre tresquiladas (Villalpando, ZA-1640)

Ciento cinquenta y seis obejas de vientre con sus corderos, más otras cinquentas y dos obejas machonas con su lana, yten setenta y una vaçía con su lana (Villalpando, ZA-1644)

Sesenta y nuebe ovejas enparejadas, más treinta y nuebe vorras y machorras (Villalpando, ZA1698)

Se trata de una voz presente en los inventarios de la zona estudiada y también en el resto de documentación presente en el CorLexIn. Muy presente en los textos que constituyen el CORDE y el $C D H$. El escribano especifica qué características tiene el grupo de ovejas haciendo mención sobre todo a su capacidad reproductiva, así aparecen ovejas de vientre, aquellas destinadas a la cría, en Villarramiel se localiza el adjetivo madriçes, que aprece registrado en el $D L E$ como un sustantivo en desuso que significa 'matriz', por lo que el sentido que recogen estos ejemplos tiene que ver con la capacidad de criar de la oveja. Otras especificaciones que aparecen con el término oveja es el de vacía y también machorra que ya se han comentado anteriormente.

\subsubsection{Aves}

\section{ÁNADE}

Sust. m. y f. 'pato' (DLE). Este término lo recogen Nebrija y Covarrubias. Autoridades lo describe como 'ave amphíbia bien conocida, que habita en tierra, y mas frequentemente en el agua, algo menor que el Ganso, y muy semejante a él en colór, pies, cuello y pico. Es ambiguo, que igualmente se dice del macho y de la hembra' (NTLLE, s. v. ánade, Nebrija, 1495; Covarrubias, 1611; Autoridades, 1726). Término procedente del lat. ANAS, ANĂTIS 'pato' (DECH, s. v. ánade).

Seis ánades, quatro hembras y dos machos (Fechilla PA-1613)

Dos capones, dos pollas y un pollo y dos ánades en veynte reales (Frechilla, PA-1675)

Los términos que identifican animales de corral no son muy frecuentes en los inventarios de bienes, quizás por el escaso valor pecuniario de los mismos (Morala, 2010c: 276). En este caso, tan solo hemos encontrado dos ejemplos en Tierra de Campos. Se documenta a partir del siglo XIII en el $C D H$ con la acepción académica. En el caso de las ocurrencias localizadas en los 
inventarios de Frechilla se trata de un animal de corral y que formaba parte de las posesiones que se inventarían.

\section{ÁNSAR [ansare, ansarones]}

Sust. m. 'Ganso' (DLE). Al igual que ánade, es una voz recogida tando por Nebrija como por Covarrubias. Autoridades defiene esta palabra como 'ave doméstica mui semejante al cysne, aunque algo menór, de colór pardo: lo mismo que Ganso, ò Pato' (NTLLE, s. v. ánsar, Nebrija, 1495; Covarrubias, 1611; Autoridades, 1726). 'ganso, especialmente salvaje', procedente del lat. vulgar ANSAR, ANSĂRIS (DECH, s. v. ansar).

Dos ansares y un ganso (Celada, LE-1600)

Una ansare con quatro ansarones (Valdavida, LE-1606)

Una ansar con siete ansarones (Castroañe, LE-1609)

Dos ansares digo una (Castroañe, LE-1609)

Una ánsare con diez huebos (Castroañe, 1628)

Desde un punto de vista diacrónico, esta voz se documenta en el CDH desde el siglo XIII, concretamente en una carta de relación de bienes perteneciente a la Colección Diplomática del Monasterio de Carrizo, fechada en el siglo XIII. Su presencia en los textos es más o menos regular hasta el siglo XVI y primera mitad del XVII, a partir de aquí, el término comienza a caer en desuso.

En el CorLexIn no se localizan ejemplos en los documentos que lo conforman, tal vez sea por lo apuntado por Morala y es que este tipo de animales no solía ser inventariado por su escaso valor, y lo mismo ocurre con otras aves de corral (Morala, 2010c: 276).

Formalmente, esta voz mantiene de manera bastante generalizada la /-e/ y provoca que existan ciertas dudas sobre el género del animal inventariado (Morala, 2010c: 277):

Dos ansares digo una (Castroañe, LE-1609)

Un ánsare [...] dos ánsares (Cea, LE-1625)

Desde un punto de vista morfológico, este corpus presenta la forma derivativa ansarón, recogido en la Academia como 'ansarino o pollo de ánsar' (DLE). De nuevo, desde una perspectiva histórica, aunque con un número significativamente menor de casos, este derivado se documenta de manera temprana en la Colección Diplomática del Monasterio de Carrizo en una carta de otorgamiento fechada en 1294 , finales del siglo XIII y como ocurre con la voz general ánsar, el uso mayoritario se da en el siglo XVI, frente a las escasas concordancias de siglos posteriores $(C D H)$. Respecto al uso en el siglo XVII, el CorLexIn no facilita ningún dato al respecto tampoco.

\section{CAPÓN}

Sust. m. 'Pollo que se castra cuando es pequeño, y se ceba para comerlo' ( $D L E$, 2.a ac.). El término se registra en Nebrija como 'ave castrada', también aparece en Covarrubias como perteneciente al verbo capar. Autoridades lo registra como 'el que es castrado. Lo que se entiende assi de los hombres, como de los animales; si bien entre estos con especialidad del gallo' (NTLLE, s. v. 
capón, Nebrija, 1495; Covarrubias, 1611; Autoridades, 1729). Término procedente del lat. vulgar *CAPPO, -ŌNIS (DECH, s. v. capón).

Diez y siete gallinas y pollas, una paua, un capón y un pollo (Valderas, LE-1682)

Quatro gallinas y un gallo y dos capones (Frechilla, PA-1639)

Dos capones, dos pollas y dos ánades tasado todo en veinte reales (Frechilla, PA-1675)

Dos gallinas y un gallo, tres capones (Villarramiel, PA-1694)

En Tierra de Campos encontramos capón como sustantivo, referido al 'pollo castrado' y con la forma académica. Sin embargo, capón también aparece en el corpus estudiado como adjetivo, con la acepción de 'castrado', en el caso de la Tierra de Campos siempre aparece acompañando a macho.

Otro macho çerrado capón pardo (Frechilla, PA-1639)

Un macho de labra capón color castaño claro (Paredes de Nava, PA-1690)

Un macho pardo capón de quatro años que ba cinco (Villalpando, ZA-1652)

Un macho de labranza capón de zinco años castaño oscuro (Villalpando, ZA-1690)

Con estas dos acepciones también aparece en el CorLexIn, donde el adjetivo también aparece junto a caballo, borrico o pollino (CorLexIn).

\section{GALLO / GALLINA}

Sust. f. 'Ave doméstica del orden de las galliformes, con cresta roja y carnosa, pico corto, grueso y arqueado, de plumaje abundante, lustroso y a menudo con visos irisados, cuyo macho tiene tarsos fuertes armados de espolones, y cuya hembra es de menor tamaño y tiene la cresta más pequeña' (DLE). Gallina deriva del término gallo, y este del lat. GALLUS ( $D E C H$, s. v. gallo).

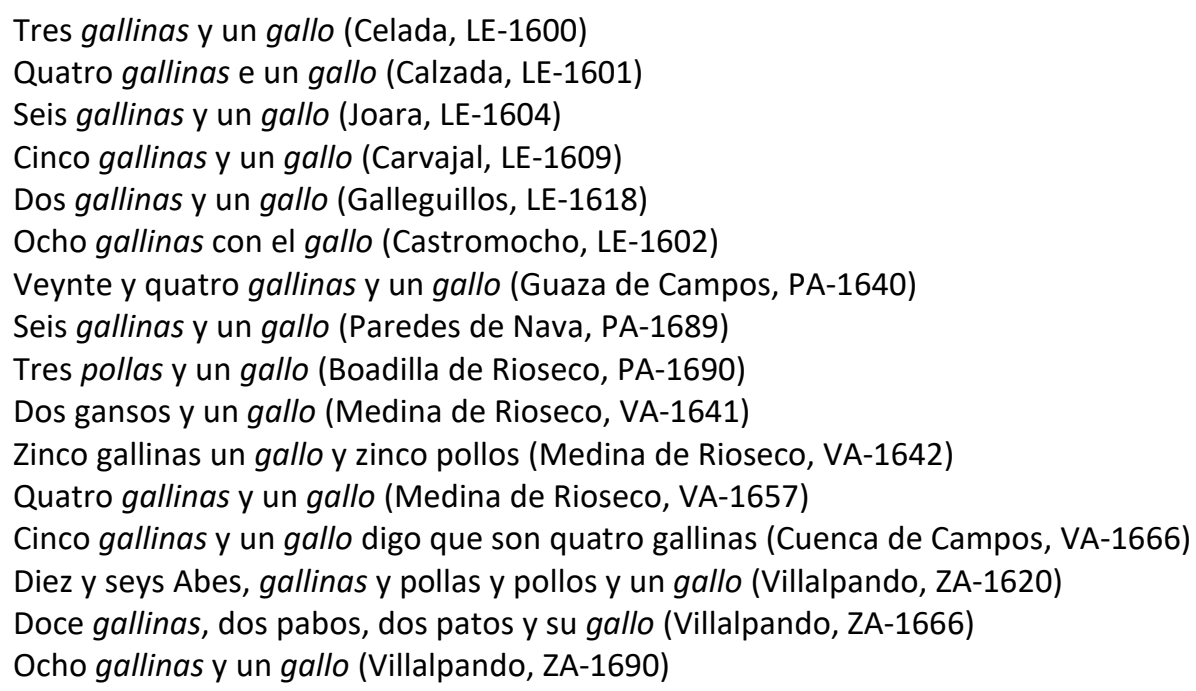

Son dos voces de uso general y que aparecen en su forma y acepción académica en la zona analizada. Tan solo tenemos un ejemplo en un inventario de Villalpando, en el que nos encontramos con una acepción no recogida en el $D L E$, y que aparece referenciada con utensilios de la lumbre.

Un gallo de yerro, más dos braseros de mano de cobre (Villalpando, ZA-1686)

Un gallo de yerro donde se asa (Villalpando, ZA-1696) 
De los inventarios que constituyen el CorLexIn tampoco hemos encontrado ejemplos de esta acepción. En algunos repertorios dialectales de León se localiza la variante gayo para referenciar la punta de la horca, término que presenta un significado más cercano al que aquí se referencia (Le Men, 2007, s. v. gajo).

\section{GANSO}

Sust. m. y f. 'Ave palmípeda migratoria del orden de las anseriformes, semejante al pato, pero de mayor tamaño, con plumaje básicamente gris, y pico y patas de color naranja, rosa o amarillo, según la especie, que vive en herbazales cercanos al agua en Europa, Asia y Norteamérica, y de la cual existen varias especies, algunas de ellas domésticas, como la oca, que se cría por su carne y por su hígado' (DLE). Nebrija lo recoge como equivalente de ánsar y Covarrubias advierte de que es 'aue conocida. Ay gansos domesticos, y gansos campesinos, y brauos'. Autoridades dice que en España lo llamamos también 'Ansar, Pato o Ganso' (NTLLE, s. v. ganso, Nebrija 1495; Covarrubias, 1611; Autoridades, 1734). Es un término procedente del gót. * gans (DECH, s. v. ganso).

Dos ansares y un ganso (Celada, LE-1600)

Una gallina con quatro pollos y un ganso (Villarramiel, PA-1696)

Dos gansos y un gallo (Medina de Rioseco, VA-1641)

Como ocurre con este tipo de animales, los ejemplos no son muy abundantes en la documentación terracampina, lo mismo ocurre en el CorLexIn. En las ocurrencias localizadas aparece siempre en masculino, sin embargo, Morala encuenta en esta zona ejemplos en femenino "una gansa" (Villacalabuey, LE-1639) y "una ganssa vuena" (Santa María del Río, LE1629) (Morala, 2010c: 276).

\section{LAVANCO/A}

Sust. m. 'Pato salvaje' (DLE). Recoge este término Covarrubias como 'especie de anade, que comunmente anda en las lagunas, y por çabullirse en el agua de ordinario y lauarse en ella tomó este nombre' (NTLLE, s. v. lavanco, Covarrubias, 1611). Es una alteración del antiguo navanco por disimilación, por lo que se trata de un derivado de nava 'lugar pantanoso en despoblado', por ser los que más frecuentan los patos bravíos, que hallen de los ríos y parajes acuosos habitados (DECH, s. v. lavanco).

Tres labancas y un labanco (Villalpando, ZA-1661)

Este término se localiza entre capones, ánades y ansarones en el Libro de buen amor del Arcipreste de Hita en el siglo XIV $(C D H)$. Sin embargo, en el CorLexIn no encontramos ningún ejemplo en los inventarios. En Tierra de Campos solo encontramos dos ejemplos, uno en masculino y otro en femenino. En repertorios léxicos actuales lo localizamos en el Vocabulario Palentino de Gordaliza donde lo registra como 'especie de pato silvestre muy común en nuestros ríos' (Gordaliza, 1988: 135). 


\section{PALOMA}

Sust. f. 'Ave domesticada que provino de la paloma silvestre y de la que hay muchas variedades o castas, que se diferencian principalmente por el tamaño o el color' (DLE). Término procedente del lat. vulgar PALǓMBA, del lat. PALUMBES, 'paloma torcaz' (DECH, s. v. paloma).

Quatro pares de palomas (Castromocho, PA-1611)

Quatro pares de palomas (Medina de Rioseco, VA-1641)

Seis pares de palomas mansas (Villalpando, ZA-1661)

Como ocurre con otras aves de corral, su presencia en el corpus es muy escasa, tan solo se han localizado dos ejemplos en Tierra de Campos. Esta escasez de ocurrencias también se da en el CorLexIn. En el corpus estudiado aparecen palomas mansas, adjetivo que se localiza también en uno de los ejemplos de La Solana (Ciudad Real), en cambio el ejemplo de Sevilla habla de palomas brauías. La muestra de que las palomas eran animales que ocupaban un puesto en la vida y la economía familiar de la época es que, en algunas casas, había un palomar para criar estos animales y que en algunas ocasiones aparecen inventariados en los textos, así encontramos palomares en documentos de Cea y Sahagún.

Además, el término paloma aparece con una acepción muy diferente a la del animal, que tampoco encontramos recogida en ningún diccionario, si bien es cierto que el $D L E$ recoge la voz palomilla para referenciar la 'parte anterior de la grupa de las caballerías' o 'punta que sobresale en el remate de algunas albardas' que podría acercarse a lo encontrado en el siguiente asiento:

Dos palomas de plomo (Villalpando, ZA-1633)

Claramente nos encontramos con otro significado, posiblemente una herramienta de artillería fabricada con plomo por el lugar que ocupa en el inventario.

\section{PATO}

Sust. m. y f. ' Ave palmípeda acuática, con el pico aplanado y patas cortas, con dedos unidos entre sí por una membrana, de la cual existen varias especies, algunas de ellas domésticas' (DLE). Covarrubias lo recoge como sinónimo de 'ganso y ansaron' (NTLLE, s. v. pato, Covarrubias, 1611). Voz común a varios idiomas de familias diversas. De la misma onomatopeya que ha dado pata, por alusión al andar pesado de este animal (DECH, s. v. pato).

Diez y seys abes, gallinas y pollas y pollos y un gallo, más dos patos (Villalpando, ZA-1620)

Tres patos, las dos embras y echadas y un macho (Villalpando, ZA-1661)

Doce gallinas, dos pabos, dos patos y su gallo (Villapando, ZA-1666)

Se trata de una voz muy poco inventariada en los protocolos de la época, hecho que se confirma en la zona de estudio donde tan solo se localizan tres ejemplos, todos ellos en género masculino.

\section{PAVO/A [pabo, pauo, paua]}

Sust. $m$ y f. 'Ave del orden de las galliformes, oriunda de América, más grande que la gallina, cuello largo y sin plumas, del que cuelgan, al igual que de la cabeza, unas carnosidades rojas' 
(DLE). Nebrija recoge 'pavo, pava o pavón' y Covarrubias afirma que 'por otro nombre se llama gallo de las Indias' (NTLLE, s. v. pavo, Nebrija, 1495; Covarrubias, 1611). Término procedente del lat. PAVUS 'pavo real' (DECH, s. v. pavo).

Diez y siete gallinas y pollas, una paua, un capón y un pollo (Valderas, LE-1682)

Seis pauos nuevos y dos anexos (Villalpando, ZA-1686)

Doce gallinas, dos pabos, dos patos y su gallo (Villapando, ZA-1666)

Una paua (Villalpando, ZA-1698)

Es una palabra de uso generalizado y que en el corpus estudiado aparece con el significado que le da la Academia.

\section{POLLO/A}

Sust. m. 'Cría que nace del huevo de un ave y en especial la de la gallina', sust f. 'Gallina nueva, medianamente crecida, que no pone huevos o que hace poco tiempo que ha empezado a ponerlos' (DLE, s. v. pollo y polla). Polla deriva del término pollo, del lat. PǓLLUS ( $D E C H$, s. v. pollo).

Dos gallinas y quatro pollas (Grajal de Campos, LE-1616)

Diez y siete gallinas y pollas, una paua, un capón y un pollo (Valderas, LE-1682)

Un gallo y ocho pollas y gallinas (Villada, PA-1669)

Dos capones, dos pollas y un pollo y dos ánades en veynte reales (Frechilla, PA-1675)

Tres pollas y un gallo (Boadilla de Rioseco, PA-1690)

Sies pollas pequeñas y un gallo (Medina de Rioseco, VA-1651)

Nuebe pollas y un pollo (Cuenca de Campos, VA-1666)

Tres gallinas negras y dos pollas grandes y dos medianas y dos pollos en veynte y seis reales (Cuenca de Campos, VA-1666)

Diez y seys abes, gallinas y pollas y pollos y un gallo (Villalpando, ZA-1620)

Ocho pollas medianas, un pollo, tres pollas pequeñas (Villalpando, ZA-1637)

Diez y ocho pollos y pollas medianos y pequeños (Villalpando, ZA-1689)

Es un término de uso cotidiano que aparece en la Tierra de Campos con el significado que da el diccionario académico.

\subsubsection{Otros}

AÑAL

Adj. desus. 'anual', 'dicho de un cordero, de un becerro o de un macho cabrío: que tiene un año cumplido' y con esta última acepción también se utiliza como sustantivo ( $D L E, 1$. y 2. a ac.). Este término lo recoge Nebrija como 'cosa de año', sin embargo, Covarrubias lo registra como 'la ofrenda que se pone sobre la sepultura del difunto el primer año desde su entierro, hasta su cabo de año', no es hasta la edición de Autoridades de 1770 cuando se registra esta voz como 'cordero, becerro, ò macho cabrío que tiene un año cumplido' (NTLLE, s. v. añal, Nebrija, 1495; Covarrubias, 1611 y Autoridades, 1770). Étimo derivado de año, del lat. ANNUS (DECH, s. v. año)

Otros cuatro machos de dos añales y dos de leche (Frechilla, PA-1640) 
Tan solo se encuentra un ejemplo del término añal en Tierra de Campos. Esta escasez se puede hacer extensible al resto de la Península. La poca frecuencia de esta voz con la acepción referida al ganado la señala también Morala, que documenta tan solo un caso en Soria que hace referencia al ganado porcino, grupo que, como bien señala este autor, no está comprendido entre los que cita el DLE "un lechón cojudo, añal" (Morala, 2014d: 118). Si observamos la documentación del $C D H$ podemos observar cómo aparece annal referido a puercos en documentos del siglo XIII, pero también aynal junto a bestia, cordero, cabrito... de hecho a finales de este siglo, en la General Estoria de Alfonso X se puede leer "E cataredes que aya el cordero estas tres cosas, que sea manso e añal e sin manziella [...]". En el siglo XIV siguen apareciendo casos de añal junto a corderos, becerros, cabritos, ovejas o bestias. Sin embargo, en el siglo XV esta palabra entra en retroceso y apenas se utiliza ya en el siglo XVI. Estaríamos pues ante un arcaísmo, que aparece de forma muy esporádica en los documentos del siglo XVII.

\section{SOBREAÑO}

Este término no aparece registrado en el $D L E$, en ninguno de los diccionarios académicos. La edición del DRAE de 1803 registra el adjetivo sobreñal para referirse a un animal de 'poco más de un año'. Por su parte, la edición de 1925 registra la variante sobreño con notación dialectal de Salamanca aplicada preferentemente al ganado vacuno. Con estos datos, Morala establece que sería lógico pensar que la forma académica se debiera interpretar como un compuesto de añal (Morala, 2014d: 118):

En la zona de estudio no aparecen las formas académicas, sino que, de los escasos ejemplos localizados en Tierra de Campos, todos ellos registran la forma sobreaño.

Un borrego de sobreaño (Castromocho, PA-1614)

Un macho de sobreaño (Frechilla, PA-1631)

Vna burra con dos crías, vna de sobreaño (Villalobos, ZA-1654) 


\subsection{DENOMINACIONES GEOGRÁFICAS}

\section{ÁGREDA}

Sust. f. 'Localidad soriana'. Esta ciudad era un centro manufacturero donde se elaboraban paños de menor calidad y dirigidos a un consumidor con recursos más bajos (Asenjo, 1991: 3).

Una mantilla de paño de Ágreda pardo de cubrir (Grajal de Campos, LE-1655)

Un vestido, calzon, ropilla y ferreruelo de paño de Ágreda azeytunado (Medina de Rioseco, VA1646)

Paños de Ágreda (Medina de Rioseco, VA-1647)

Una ropilla de paño de Ágreda diezyocheno tasada en quatro ducados (Carrizo, ZA-1646)

El paño de Ágreda, aunque conocido y de gran tradición en la manufactura de paños y lana (Morala, 2010b: 387-388), no tiene gran presencia en la documentación, ni en el CDH, ni en el CorLexIn encontramos ejemplos de este tipo de paños. En Tierra de Campos encontramos ocurrencias de este tipo de paños, aunque no es un tipo de tejido que se caracterice por su presencia en los inventarios.

\section{ANJEO [angeo, anxeo]}

Sust. m. 'Especie de lienzo basto' y que es poco usado. De Angeu, nombre provenzal del Ducado de Anjou, en Francia, de donde procede (DLE). Este término lo recoge Covarrubias afirma que 'es vna tela de estopa o lino basto que se trae de Francia, o de Flandes [...]' y Autoridades señala su origen de la provincia de Anjou en Francia (NTLLE, s. v. angeo, Covarrubias, 1611; Autoridades, 1726). Término procedente de la forma occitana del fr. Anjou, región de donde procedía el anjeo (DECH, s. v. anjeo).

Una sábana de anjeo de dos piernas buena (Sahagún, LE-1624)

Un jergón de anxeo (Castromocho, PA-1620)

Un jergón de anjeo (Villada, PA-1665)

Un jergón de angeo bueno (Medina de Rioseco, VA-1649)

Unas cortinas de anjeo con su zenefa, barilla y tres yerros que la sustentan (Medina de Rioseco, VA-1651)

Un paramento de angeo (Villalpando, ZA-1697)

Este término como tejido se localiza en la Instrucción a los padres de la Orden de San Jerónimo, fechado en 1517 y documentado en Puerto Rico:

"Yten, que en la cacona que a cada yndio se oviere de dar sea prinçipal mente doss camisas: la vna de angeo para trabajar, y otra de lienço más delgado para las fiestas"

En España es en un texto de Fray Bartolomé de la casa fechado diez años más tarde con esta misma acepción y también para hacer mención al tipo de tela con el que se confeccioan una camisa $(C D H)$. Como ocurre con otros términos, parece que esta voz aparece de forma frecuente en los textos del siglo XVI y XVII, pero a partir de aquí entra en desuso y su presencia en bases de datos como el CORDE o el CDH se hace más ocasional (Morala, 2010b: 389). 
En el siglo XVI este tipo de tejido formaba parte del comercio entre España y Francia y se utilizaba principalmente para confeccionar prendas interiores como camisas, cuellos o gorgueras (DHTT, s. v. anjeo). En el siglo XVII, los ejemplos recogidos en el CorLexIn recorren la Península de Norte a Sur y reflejan una ampliación en el uso de este tipo de tejido, así también es utilizado también para la confección de ropa del hogar como sábanas, jergones, cortinas, colchones... e incluso se utiliza como forro (Pérez Toral, 2017a: 198). Este uso se extiende también en la Tierra de Campos donde se utiliza principalmente para la confección de ropa del hogar y que formalmente presenta la vacilación entre las grafías $/ g /, / j / y / x /$, muy frecuente en esta época.

\section{ARAGÓN}

Sust. m. 'región del interior ubicada en el nordeste de España'.

Una pollera de cordellate de Aragón (Medina de Rioseco, VA-1648)

En el corpus analizado encontramos este ejemplo en Medina de Rioseco, hace referencia a la procedencia del cordellate con el que está confeccionada la pollera. No es la única ocurrencia que aparece en inventarios, así en el CorLexIn localizamos un par de casos en Madrid, donde también aparece "cordellate de Aragón" para el uso en ropa del hogar como sobremesas y cortinas y en Alicante se localiza un "cubertor de Cordellate de Aragón amusco". Pero además aparece como denominación de origen para la estameña: "una basquiña destameña de Aragón, colchada" (Cuenca, 1631), y para otro tipo de enseres como las escudillas: "unas escudillas de Aragón" (Tafalla, 1640).

\section{ASTUDILLO}

Sust. 'Nombre de una localidad de la provincia de Palencia, es una zona de transición entre la Tierra de Campos y el Cerrato'.

Un trillo nuebo de Astudillo (Villalpando, ZA-1690)

La presencia en los textos de esta denominación de origen es escasa en el siglo XVII, así parece que el desarrollo industrial de esta localidad tuvo lugar entre los siglos XVIII y XIX, ya que sí que aparece este término en inventarios de bienes posteriores. Lo constata los ejemplos encontrados en la zona de La Bañeza, todos ellos del siglo XIX y que confirma la industria textil emergente en aquel entonces, se inventarían mantillas, manteos, chupas o capas confeccionadas con paño de Astudillo (Gómez Ferrero, 2015: 451). Sin embargo, el ejemplo que encontramos en el corpus de la Tierra de Campos no referencia ningún tejido confeccionado en esta localidad, sino que se trata de un trillo fabricado en la misma y datado a finales del siglo XVII. Parece que además de la industria textil, Astudillo contaba con la fabricación, al menos, de trillos. Esto parece confirmarse en algunos protocolos, por ejemplo, en el año 1771 un carretero se compromete a llevar y vender cuarenta y cinco trillos fabricados en Astudillo (Hernández García, 2004: 100, nota 206). 


\section{BRETAÑA}

Sust. f. 'Lienzo fino fabricado en la región francesa de Bretaña' (DLE). Nebrija recoge este término como 'región de Francia'. Sin embargo Covarrubias lo reconoce como 'cierta tela de lino dicha assi porque se trae de Bretaña' (NTLLE, s. v. bretaña, Nebrija, 1495; Covarrubias, 1611).

Diez y siete libras de bretaña [...] diez y siete pieças de bretañas (Medina de Rioseco, VA-1645)

Dos tuallas de Bretaña guarneçidas con puntas hordinarias (Medina de Rioseco, VA-1685)

Esta es una muestra más de la importancia textil francesa en la época y ese comercio hispanofracés que existía. En la Tierra de Campos encontramos dos ocurrencias, una como tejido en pieza y, otra, para confeccionar toallas, ambos ejemplos localizados en Medina de Rioseco (Valladolid). Los ejemplos que aparecen en el CorLexIn se localizan sobre todo en el sur de la Península y América, aunque también contamos con casos esporádicos en la meseta Norte, además de los localizados en Tierra de Campos. Se utilizaba para la fabricación de ropa de cama como sábanas, almohadas o toallas, pero también para confeccionar ropa interior como camisas, enaguas, almillas, y en el caso de Burgos y algún inventario de Bolivia también se localiza para hacer rebozos - una especie de toca-, mangas, jubones, albas, amitos..., se trataba de una tela que tenía mucha versatilidad y es que las manufacturas textiles de Bretaña estaban especializadas en el lino (Morala, 2010b: 391).

\section{CALABRIA}

Sust. f. 'Nombre de una región del Sur de Italia'

Una ropa gurbión de Italia acauellado con dos pasamanos de Calabria aforrada en tafetán berde (Villalpando, ZA-1631)

En el corpus estudiado solo encontramos un ejemplo de esta procedencia. Morala (2010b: 391) localiza otro ejemplo en Tierra de Campos en un inventario de una familia pudiente:

Diez y siete madexitas de seda encarnada de Calabria [...], doce madexitas de seda dorada, también de Calabria (Valderas, LE-1647)

Esta escasez de ocurrencias también se da en el CorLexIn, donde todos los ejemplos que localizamos pertenecen a inventarios americanos de Colombia y Chile. Esto puede ser consecuencia de la política proteccionista en relación con la seda, así en las ordenanzas castellanas de 1540-1553 se prohibe expresamente la improtación de seda de Nápoles y Calabria (Morala, 2010b: 391). A pesar de esto, el comercio de esta seda, aunque en menor medida, se venía dando por la presencia de mercaderes sederos en la Península que compraban seda en el sur de Italia, especialmente la de Calabria (Miralles, 2003: 501), posiblemente reservada a aquellos bolsillos que puedieran pagarla. Además de los ejemplos recogidos en Tierra de Campos, se localiza "una petrinilla de damasco con su pasamanos de Calabria" en La Bañeza en 1641 (Gómez Ferrero, 2015: 452). 


\section{CAMBRAY [cambrai, canbray, cambraies]}

Sust. m. 'Especie de lienzo blanco y sutil' (DLE). Aparece en los diccionarios preacadémicos de Vittori y Rosal, este último lo define como 'suerte de lienzo de la ciudad dos se labra en Flandes'. Autoridades da información sobre qué tipo de ropas se confecciona con este lienzo 'cierta tela de lienzo mui delgada y fina, que sirve para hacer sobrepellices, pañuelos, corbatas, puños y otras cosas. Dixose assi por haver venido de la Ciudad de Cambray, donde por lo regular se fabrica' (NTLLE, s. v. Cambray, Rosal, 1611; Autoridades, 1729). Del nombre de Cambray, ciudad del norte de Francia, donde se fabricaba (DECH, s. v. Cambray).

Ocho pieças de Canbraies a nouenta y dos reales (Medina de Rioseco, VA-1645)

Seis lienços de narizes dos de Canbray y el otro de olanda (Medina de Rioseco, VA-1648)

Tres varas de Cambray (Medina de Rioseco, VA-1660)

Un mantillo de Cambrai con puntas de vmo (Medina de Rioseco, VA-1660)

Unas manguillas de Canbray (Medina de Rioseco, VA-1660)

Un pañuelo de Cambray de vara con sus encajes (Villalpando, ZA-1686)

Una toalla de Cambray con puntas de ylo de pita (Villalpando, ZA-1688)

Esta procedencia aparece documentada desde el siglo XIII en el $C D H$ y este tipo de lienzo sigue presente en los inventarios de bienes del siglo XVII, tanto en la Península como en América (CorLexIn).

En cuanto a la forma que presenta, existe una alternancia de las terminaciones -ay, -ai, común en otras palabras como buey o estoy y presentes también en este tipo de documentos. Por otro lado, también aparece la neutralización de la $/ \mathrm{n} /$ y la $/ \mathrm{m} /$ en esta posición, así encontramos en algunas ocurrencias canbray (Morala, 2010b: 392).

\section{CHINA}

Sust. f. Autoridades registra esta palabra como 'qualquiera pieza de loza fina, que viene del Réino de la China' (NTLLE, s. v. china, Autoridades, 1729).

Otros platillos chinos, dos porcelanas chinas (Paredes de Nava, PA-1680)

Quatro reales de una bandeja de la China (Paredes de Nava, PA-1689)

Una volsa de rasillo de la China de colores aforrado de tafetán (Medina de Rioseco, VA-1644)

Una media fuente y un plato de Talauera de la China (Villalpando, ZA-1689)

El DLE ya no registra este significado entre sus acepciones, pero sí está presente en las ediciones anteriores. En Tierra de Campos encontramos platillos, porcelanas, bandejas, fuentes y platos de China, haciendo mención a un tipo tipo de loza o porcelana fina que provenía de Oriente. Cabe destacar que a principios del siglo XVII se crearon en Europa compañías mercantiles de Indias, por lo que el comercio se inundó de productos orientales, cuya influencia llegó también a las propias creaciones europeas por el afán de imitar dichas cerámicas (Ramiro, 2015: 90), solo así se puede entender ejemplos como el de Villalpando "media fuente y un plato de Talauera de la China". A esto hay que sumarle ese espíritu coleccionista de objetos exóticos que surge en esta época por parte de las clases más adineradas. También encontramos ocurrencias en la Península, en las Islas Canarias y en América (CorLexIn). Además de la acepción de porcelana, encontramos en el corpus de la Tierra de Campos un ejemplo de tejido procedente de este lugar "rasillo de la China". Esta acepción no es extraña en los inventarios de la época, en 
el CorLexIn encontramos de Norte a Sur de la Península ejemplos de tafetanes, sedas, rasos, teciopelos... todos ellos de la China. Pero si hay un lugar donde este intercambio comercial tiene una mayor presencia en los textos, es en América donde figuran de forma frecuente ocurrencias de tejidos procedentes de Oriente, parece que había un tráfico comercial con las colonias de la Nueva España.

\section{COLONIA (vid. complementos de cabeza y tocado/otros)}

\section{CONTRAY [contrai, contrae, contrahe]}

Sust. 'Especie de paño fino' (DLE). Autoridades lo registra como una especie de paño muy fino 'que se usaba en lo antiguo' (NTLLE, s. v. Contray, Autoridades, 1729). Nombre que daban los españoles a la ciudad de Courtray en Flandes, donde se fabricaban estas telas (DECH, s. v. Contray).

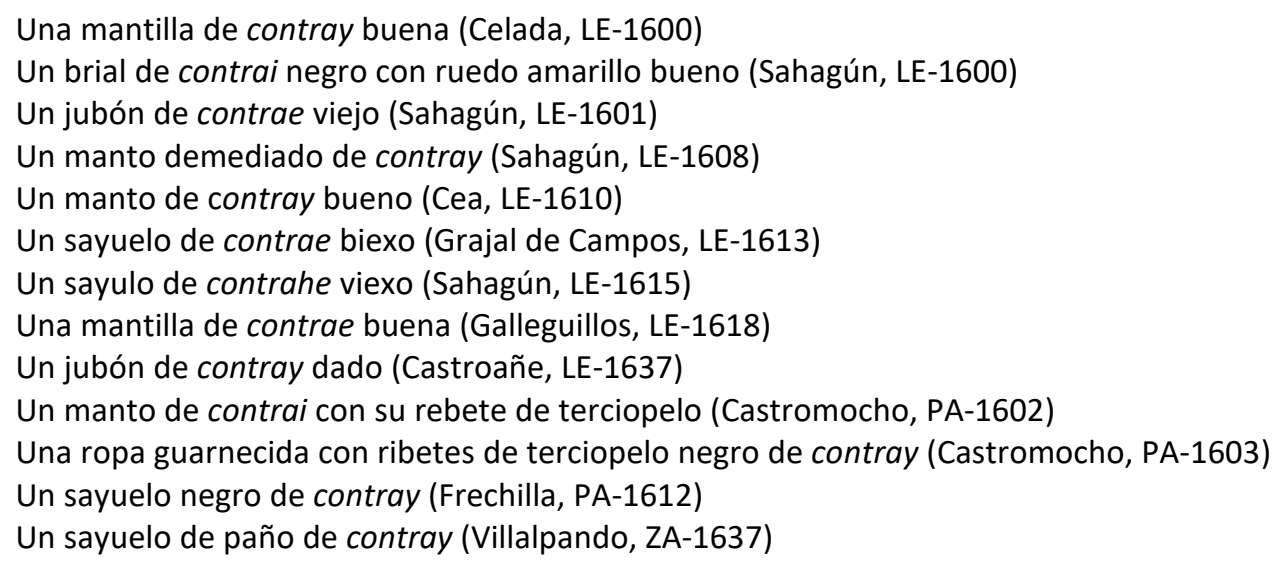

EI CDH documenta este término con la acepción de tejido desde el siglo XIV, en el siglo XV aparece en las Cuentas de Gonzalo de Baeza, tesorero de Isabel la Católica, entre otros documentos, pero en el siglo XVI su presencia va disminuyendo y en el siglo XVII apenas tenemos una docena de casos en esta base académica, puede que esta sea una señal de que el término entra en retroceso. En los inventarios que conforman el CorLexIn hay como una veintena de ejemplos repartidos por la zona castellano leonesa sobre todo -León, Palencia, Zamora, Ávila y Soria-, además de algún caso en Cáceres, La Rioja y Navarra. A pesar de estas localizaciones, no tiene la presencia que otros tejidos de la época (CorLexIn). Esto contrasta con la Tierra de Campos donde la presencia de este término es constante. Algo que se repite en este mismo siglo y un siglo más tarde en la zona leonesa de La Bañeza (Gómez Ferrero, 2015: 453). Fomalmente esta voz vacila en los textos en su terminación entre/-ay/y/-ai/, como ocurre en cambray y que hemos visto anteriormente. Además, encontramos la forma contrae o contrahe que obedece a una hipercorrección del propio escribano del diptongo /ai/ como ae y que aparece en otros casos como cambray (Pérez Toral, 2017d: 66). 


\section{CÓRDOBA}

Sust. f. 'ciudad y municipio español de Andalucía'.

Ocho libras de ilo açul de Córdoua (Medina de Risoseco, VA-1645)

Otra ropilla sin mangas de picote de Córdoba aforrada en tafetán (Valderas, LE-1647)

Es una de las procedencias menos representada en el corpus estudiado, tan solo encontramos un par de ejemplos en la Tierra de Campos. A pesar de esta escasez de ejemplos, Morala señala que tuvo que ser conocida en la época pues figura de esta manera en una obra coetánea de Lope de Vega en el CORDE (Morala, 2010b: 393). Las manufacturas textiles procedentes de Córdaba están presentes en los inventarios del CorLexIn, tanto en la Península como en América, lo que ratifica lo dicho por Morala. Parece que el tejido más famoso de esta localidad era el picote, presente en muchos de los documentos, aunque también encontramos el hilo, la seda, la bayeta, la trama o el listón.

\section{DAMASCO [adamascado]}

Sust. m. 'Tela fuerte de seda o lana y con dibujos formados con el tejido' (DLE). Autoridades lo registra como 'tela de seda entre tafetán y raso, labrado siempre con dibuxo. Haile doble y simple, y de distintos colóres. Es tela noble, y la usan las Señoras, y Caballeros para vestidos y colgaduras' (NTLLE, s. v. damasco, Autoridades, 1732). Del nombre de la ciudad de Damasco, gran centro de intercambio comercial entre el Occidente y el Oriente, región desde donde se importaron estos productos (DECH, s. v. damasco).

Un calzón y ropilla de hombre, de damasco, viexo (Valderas, LE-1647)

Unos cuerpos de damasco negro con guarnición de plata falsa buenos (Grajal de Campos, LE1657)

Una colgadura de media cama de damasco açul con su cielo y cenefas (Grajal de Campos, LE1658)

Una vasquiña con sus cuerpos de damasco pardo (Castromocho, LE-1611)

Un faldellín de damasco colorado ussado guarnecido con passamanos de Santa Ysauel (Autillo de Campos, PA-1648)

Unas mangas de damasco colorado mediado (Autillo de Campos, PA-1649)

Unos cuerpos de damasco azul con riuete de terziopelo berde y galón de oro (Villada, PA-1669)

Un jubón de damasco negro nuebo en zien reales (Medina de Rioseco, VA-1640)

Sesenta baras de damasco blanco de Toledo (Medina de Rioseco, VA-1645)

Una pollera de damasco de lana con galón de plata de puntas (Medina de Rioseco, VA-1648)

Zinco almoadas de terciopelo y damasco carmesí muy traídas y rotas (Medina de Rioseco, VA1649)

Un guardapiés encarnado de damasco traydo aforrado en lo mismo (Media de Rioseco, VA-1660) Unos cuerpos de damasco berde (Villalpando, ZA-1620)

Un bestido, ropa, basquiña y jubón de damasco negro (Villalpando, ZA-1644)

Un jubón de labradora con su garapiña y cuerpos de damasco berde con guarnición de oro (Villalpando, ZA-1670)

El damasco es un 'tipo de tela de alta calidad con una sola urdimbre y una sola trama, formadas por hilos del mismo grosor, color y calidad, y con dibujo entretejido' (DHTT, s.v. damasco). Este término es de uso general desde finales de la etapa medieval (Morala, 2010b: 395) y su presencia en los inventarios de esta época es constante tanto en la Península como en América (CorLexIn). Esta tela aparece en los inventarios de bienes de Tierra de Campos como la 
materia prima para confeccionar vestimentas y ropa del hogar. En general, es un término muy presente en los inventarios de la época, que es bastante rica y utilizada para la elaboración de distintas prendas como cuerpos, jubones, basquiñas, calzones, ropillas...; pero también colgaduras o almohadas.

En la documentación analizada aparece el diminutivo lexicalizado damasquillo que ya ha sido analizado en el apartado de tejidos, y además el adjetivo derivado adamascado para identificar 'telas parecidas al damasco' (DLE):

Otra colcha blanca de lienzo adamascado con sus puntas, vsada (Valderas, 1647)

Diez tablas de manteles nuebas de gusanillo y adamascado (Medina de Rioseco, VA-1645)

Quarenta y ocho serbilletas adamascadas (Medina de Rioseco, VA-1645)

Dos dozenas y media de cintas de Santa Ysauel adamascadas (Medina de Rioseco, VA-1645)

Lo recoge Autoridades como 'el texido, ù otra cosa que está hecho en forma de damasco, ó lo paréce' (NTLLE, s. v. adamascado, Autoridades, 1726). Se documenta en el CDH a partir de finales del siglo XVI, pero su presencia es escasa en estos siglos, el número de ejemplos asciende en el siglo $\mathrm{xx}(C D H)$. A pesar de las ocurrencias aisladas que se localizan en los inventarios de bienes del siglo XVII, los ejemplos se documentan tanto en la Península como en América con la acepción académica. Este adjetivo designa el tejido que intenta imitar el damasco y que se suele utilizar para confeccionar manteles y servilletas (CorLexIn). En nuestro corpus aparecen varios casos, en su mayoría ubicados en la zona vallisoletana de la Tierra de Campos, y el último de ellos pertenece al inventario de una tienda de ropa.

\section{FRANCIA [Françia]}

Sust. f. Nebrija la define como 'región de Europa', pero Covarrubias se extiende más en su definición y la define como 'reyno opulentissimo y abundante de todo, campos fertiles, ciudades muy populosas, mucha nobleza y muy antigua, gente belicosa, ingeniosa en las artes mecanicas, y en las liberales, florentissima en letras [...]' (NTLLE, s. v. Francia, Nebrija, 1495; Covarrubias, 1611).

Un jubón y escapulario de estameña de Françia noguerada (Valderas, LE-1647)

Un ábito de estameña de Françia (Grajal de Campos, LE-1658)

Pasamanos de Francia (Medina de Rioseco, VA-1644)

Doce pieças de vonbasíes de Francia, colores y negros (Medina de Rioseco, VA-1645)

Siete pieças fustanes de Francia de diferentes colores [...]. Sessenta y siete varas de fustanes de Francia de colores en seis pedaços (Medina de Rioseco, VA-1645)

Ciento y cinquenta y cinco gruesas de votones de cerdas, pequeños, de Francia (Medina de Rioseco, VA-1645)

Treinta y ocho libras de ylo azul morado de Francia (Medina de Rioseco, VA-1645)

Este término designa de forma genérica la estameña, el bombasí, el fustán o el hilo entre otros tejidos procedentes del país vecino. En el copus estudiado, salvo los tres primeros ejemplos, el resto proceden de un inventario de una tienda de ropa en Medina de Rioseco, por lo que resulta normal localizar nombres de muchos tejidos de distintas procedencias y que, en ocasiones, apenas aparecen en el resto de los inventarios. En los dos primeros ejemplosValderas y Grajal de Campos - hacen referencia a un tipo de estameña, ya referenciada por Morala junto a otro ejemplo de Mora (Toledo) donde parece que se trata de una estameña 
oscura (Morala, 2010b: 396). Esta denominación se extiende además de a la estameña a otros tejidos, además de los localizados y mencionados en Tierra de Campos, aparece picote de Francia en Tudela (Navarra), seda verde y negra de Francia en Vergara (Guipúzcoa) o lama de Francia en Sevilla, entre otros. A veces los escribanos no tienen clara la denominación de origen y podemos encontrarnos con esta duda en el propio inventario, como ocurre en Tolosa (Guipúzcoa) donde se localiza el siguiente ejemplo:

Yten, se alló otro pedaço de lienço de Flandes, o de Francia

También aparece esta procedencia en protocolos de América, pero en los ejemplos que nos hemos encontrado es para aclarar el país de procedencia del tejido inventariado, así nos encontramos ocurrencias en Chile y Bolivia en las que aparece "lienço de Cambray de Francia" o "un pañuelo de Cambray de Francia" respectivamente.

También figura el correspondiente gentilicio de este término para identificar un tipo de sillas presentes en los inventarios analizados de la Tierra de Campos:

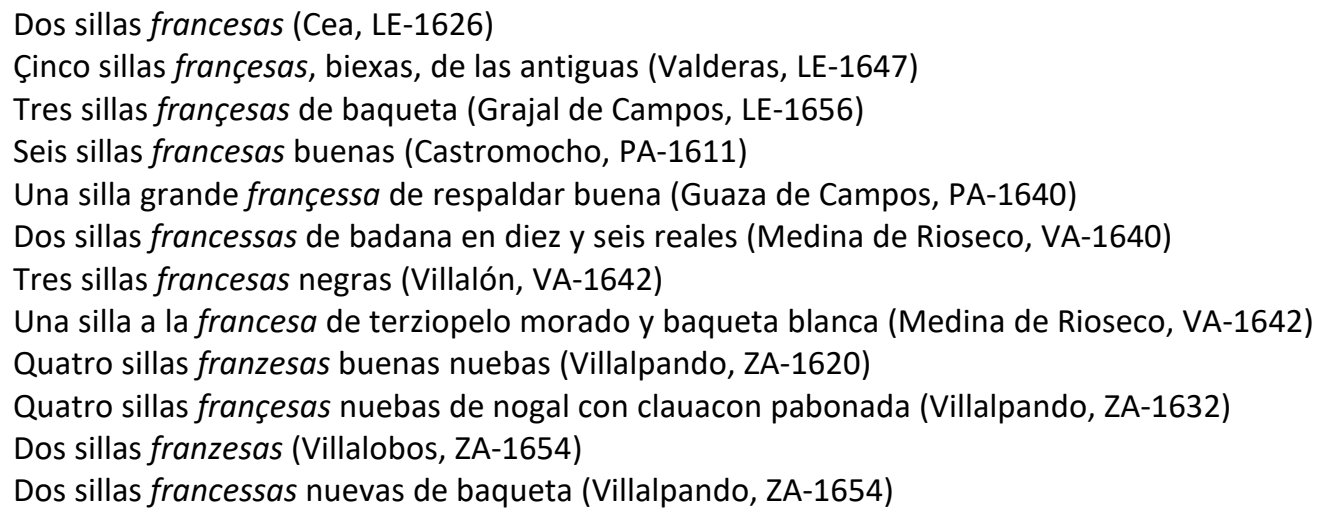

Aparecen algunos ejemplos en el CORDE de finales del siglo XVI y primera mitad del siglo XVII, en donde llama la atención lo documentado en las Ordenanzas de la ciudad de Logroño, fechadas en el año 1607 y que predisponen lo siguiente:

\footnotetext{
"Yten hordenaron y mandaron que las sillas françesas que en esta çiudad se hiçieren por los offiçiales della o binieran de ffuera a benderse sean de nogal o pomal o çereço y que lleuen dos quixeras encoladas y que los barretes de abaxo y las caueças por parte de atrás lleuen cada dos clauixas. Y que la silla que no lo llebare como dicho es no se pueda dar ni dé por buena. Y al offiçial que no lo hiçiere así tenga de pena mill maravedís y la silla o sillas perdidas"
}

Estas ordenanzas nos informan de que en ocasiones esta voz no está determinando una procedencia, sino más bien un tipo de mobiliario concreto que se elaboraba en cualquier ciudad con unas características dadas (Morala, 2014b: 256). Cabe señalar que son pocos los ejemplos que pasan de las primeras décadas del siglo XVII, parece que los vestidos y las telas no eran lo único codicionado a las modas del momento, algunas modas llegaban también al ajuar doméstico a las modas imperantes en cada momento (Morala, 2010b: 397).

Del gentilicio también aparece en el corpus estudiado el siguiente ejemplo:

Un bestido a la francessa con alamares de oro (Medina de Rioseco, VA-1642)

En aquella época España dejaba de ser el referente de moda para pasar el testigo a Francia, y en este siglo ya se comienza a ver ese gusto por la moda venida de la corte francesa. 


\section{FRECHILLA}

Sust. 'Nombre de una localidad de la provincia de Palencia'.

Una mantilla de pardo de Frechilla nueva (Sahagún, LE-1608)

Quatro baras de paño pardo de Frechilla (Castroañe, LE-1622)

Quatro baras de paño Frechilla bueno (Grajal de Campos, LE-1656)

Una capa parda buena de paño de Frechilla con unos capillos (Frechilla, PA-1613)

Una saya parda buena de paño de Frechilla con un ruedo açul (Frechilla, PA-1613)

Un jubon de paño pardo de Frechilla ya traydo apreçiado en quatro rreales (Frechilla, PA-1615)

Otra saya fraylega biexa de paño de Frechilla con ruedo amarillo con tres ribetes apreçiada en diez reales (Frechilla, PA-1615)

Una mantilla parda de paño de Frechilla buena (Frechilla, PA-1615)

Unos balones biexos de Frechilla (Cuenca de Campos, VA-1668)

Una capa de paño de Frechilla buena (Cuenca de Campos, VA-1666)

Es un término muy presente en la Tierra de Campos, algo que no es de extrañar dada la tradición manufacturera de esta localidad. La frecuencia con la que aparece en el corpus terracampino contrasta con los pocos casos que devuelve el CorLexIn en León y Asturias, posiblemente por el comercio de proximidad que hacía que no fuera conocido más allá de límites. Egido localiza varios ejemplos de esta procedencia en inventarios leoneses -"mantillas y sayuelo de Frechilla"- (Egido, 2014: 88-89). Parece que los paños de esta localidad eran muy apreciados en tierras leonesas hasta bien entrado el siglo XVIII (Gómez Ferrero, 2015: 455).

\section{GRANADA}

Sust. 'Ciudad y municipio español de Andalucía'

Una anguarona de raso de mujer negro aforada en tafetán de Granada (Paredes de Nava, PA1690)

Una loba de una saya aforada en tafetán de Granada (Paredes de Nava, PA-1690)

Un manto de tafetán de Granada (Boadilla de Rioseco, PA-1690)

Setenta y seis baras y una quarta de damasco carmesí de Granada (Medina de Rioseco, VA-1645)

Catorce baras y tercia de tafetán doble carmesí de Granada (Medina de Rioseco, VA-1645)

Tres baras de tafetán negro de Granada y mangas (Villalpando, ZA-1670)

A priori los ejemplos localizados en Tierra de Campos referencian la procedencia del tejido con el que se elabora las prendas inventariadas, así destaca sobre todo el "tafetán de Granada". Además de en la Península, El CorLexIn documenta este sintagma en América con la misma acepción, encontramos con tafetanes y damascos de Granada en México, Guatemala, Bolivia y Chile. Tal vez, no estamos ante una denominación de origen, sino ante un tipo de tejido.

Por su parte, Morala localiza esta procedencia en unas piezas de adorno ubicadas en un inventario de Valderas, en Tierra de Campos (Morala, 2010b: 397):

Dos pieças de çintillas angostas de nácar de las de Granada encarnadas (Valderas, LE-1647) 


\title{
HOLANDA [olanda, olandilla]
}

Sust. f. 'Lienzo muy fino de que se hacen camisas, sábanas y otras cosas' (DLE). Este término lo recoge Autoridades como 'tela de lienzo mui fina de que se hacen camisas para la gente principal y rica' (NTLLE, s. v. holanda, Autoridades, 1734). Procedente del nombre de Holanda, de donde se traía (DECH, s. v. holanda).

\author{
Una bara de olanda nueua en diez reales (Sahagún, 1600) \\ Una pelliz de olanda viexa (Cea, LE-1621) \\ Vna tualla de olanda nueba con tiras de red (Valderas, LE-1647) \\ Una funda de almuada de olanda con votones de muletilla (Grajal de Campos, LE-1658) \\ Un paño de manos de olanda con sus puntas bueno (Castromocho, PA-1603) \\ Un capillo de niño de olanda deshilado de red (Frechilla, PA-1613) \\ Cinco almuadas de olanda (Paredes de Nava, PA-1680) \\ Una pelliz de olanda con pespuntes y rrandas (Villalón, VA-1642) \\ Dos armadores de olanda acuchillados (Medina de Rioseco, VA-1642) \\ Un paño de olanda con red (Cuenca de Campos, VA-1666) \\ Un jubon de olanda en beynte rreales (Villalpando, ZA-1600) \\ Una toalla de olanda buena labrada de ylo amarillo con puntas (Villalpando, ZA-1654) \\ Una colcha de dos olandas con algodón (Villalpando, ZA-1686)
}

La holanda es un tejido de uso frecuente en el corpus terracampino, algo extensible al resto de inventarios de la Península y de América (CorLexIn) referenciando el mismo tipo de tejido de lienzo fino, por lo general de lino con el que se confeccionan sábanas, toallas, paños de manos, camisas, peinadores y, en general, prendas delicadas. EI CDH localiza este término en las Cuentas de Gonzalo de Baeza, tesorero de Isabel la Católica a finales del siglo XV, a lo largo del xvı y la primera mitad del XVII encontramos el término en inventarios, cartas de dote, reparticiones de bienes... pero a partir de esta fecha entra en retroceso. Como ocurre con otros términos relacionados con el mundo textil, su presencia en la documentación es pasajera. Formalmente esta voz aparece en Tierra de de Campos sin /h-/, algo que es extensible también al resto de documentos (Morala, 2010b: 398-399).

En el corpus estudiados aparece olandilla, también sin /h-/, un término derivado de holanda que se registra en los diccionarios académicos como 'lienzo teñido y prensado, usado generalmente para forros de vestidos' (DLE).

Una vasquiña de estameña plateada aforrada en olandilla morada (Grajal de Campos, LE-1656) Un guardapies de damasco açul forrado en olandilla, con seis guarniçiones de Santa Ysabel y una de galones de plata (Grajal de Campos, LE-1658)

Una basquiña y anguarina de olandilla [...] otro jubon de olandilla (Valderas, LE-1682)

Otra basquiña de estameña parda forrada en olandilla y con ribete de terçiopelo negro (Guaza de Campos, PA-1640)

Dos varas de olandilla nuevo (PA-Autillo de Campos, 1647)

Unos cuerpos de estameña azul y una saia destameña parda con su olandilla (Villada, PA-1665)

Dos vaúles encorados atachonados aforrados en olandilla verde con trençaderas blancas (Villalón, VA-1642)

Una saya destameña aforrada en olandilla morada (Medina de Rioseco, VA-1646)

Una basquiña de estameña buriel y rueda de olandilla y ribete de paño (Cuenca de Campos, VA1668)

Una uasquiña de olandilla y de estameña fina con olandilla morada (Villalpando, ZA-1631)

Una basquiña de raja acanelada aforrada en olandilla azul (Villalpando, ZA-1643) 
Una basquiña de estameña açul prensada aforrada en olandilla del mismo color y con su ribete de terzio pelo verde (Villalpando, ZA-1661)

Su presencia en la documentación es más escasa, aparece en inventarios de bienes que van desde finales del siglo XVI a mediados del XVII en España, también se registran algunos ejemplos en América en siglos posteriores, pero de forma aislada $(C D H)$. Como ocurre con la forma genérica, su uso es puntual en una época. La documentación de esta lexía es menor que la de holanda, pero está presente en los inventarios de la Península, Canarias y América con la acepción académica, haciendo referencia a un tipo de tejido que servía sobre todo para confeccionar forros, tanto de prendas de vestir como de cofres o baúles. Además solía ser de colores muy vivos y vistosos -olandilla azul, leonada, amarilla, morada, colorada- (Morala, 2010b: 398-399).

\section{INDIA [Yndias]}

Sust. f. 'País situado en el sur de Asia'.

Una vandejilla pequeña de la India (Grajal de Campos, LE-1658)

Un tapete de la India labrado (Medina de Rioseco, VA-1648)

Un guebo de las Yndias quebrado (Medina de Rioseco, VA-1651)

Un plato de porcelana de la Yndia China como Talabera açul (Valderas, 1647)

Un rosario de palo de la India engaçado de oro, (Valderas, 1647)

Esta referencia toponímica tiene una interpretación dudosa en los documentos, ya que existían las Indias de Oriente y las indias de Occidente y en muchas ocasiones no sabemos a cuál de ellas se refiere (Morala, 2010b: 399-400). Esta falta de referencia exacta se ve también en los inventarios del CorLexIn. Formalmente esta palabra aparece tanto en singular "de India o Yndia" y en plural "de las Indias o Yndias". Tal vez lo que más pueda decantarnos por una u otra opción sea el tipo de material inventariado, por ejemplo, la porcelana o la seda solía venir de China, mientras que otros productos como el coco -como recipiente-, o la caña venía de América.

\section{INGLATERRA [Ingalaterra, Yngalaterra]}

Sust. 'una de las naciones constituyentes del Reino Unido'.

Dos pares de medias de Yngalaterra (Medina de Rioseco, VA-1661)

Además de este ejemplo localizado en la zona vallisoletana de Tierra de Campos encontramos unos cuantos casos más en un inventario de bienes de una tienda de ropa, donde no solo encontramos media de Inglaterra, sino anascotes, damasquillos o bombasíes de Inglaterra:

Trece pares de medias encarnadas de Inglaterra (Medina de Rioseco, VA-1645)

Dos pieças de anascotes negros de Ingalaterra (Medina de Rioseco, VA-1645)

Çinquenta baras y media de damasquillos angostos de Ingalaterra de colores (Medina de Rioseco, VA-1645)

Quarenta y una pieças de vonvasíes de Ingalaterra de colores (Medina de Rioseco, VA-1645)

Tres docenas de medias encarnadas de Ingalaterra de tornai (Medina de Rioseco, VA-1645)

Cinco piecas de damasquillos de lana de Ingalaterra de colores (Medina de Rioseco, VA-1645) 
Formalmente hay vacilación gráfica en la vocal inicial / $/$ o $/ \mathrm{Y} /$, además en la mayoría de los casos nos encontramos con la variante Ingalaterra, con una vocal epentética que también se localiza en otros inventarios de la Península y Canarias.

\section{LONDRES}

Entre las acepciones que da Nebrija a este étimo está el de 'paño de allí' (NTLLE, s. v. londres, Nebrija, 1495).

Una saya de Londres azules, ruedo amarillo buena (Sahagún, LE-1601)

Una capa de Londres en casa de Juan (Sahagún, LE-1601)

Un brial de Londres vueno (Riosequillo, LE-1610)

Una saya de Londres azules bueno con su ruedo amarillo (Sahagún, LE-1613)

Una pollera azul de paño de Londres con honze guarniziones (Medina de Rioseco, VA-1646)

En el CORDE se localizan paños de Londres desde finales del siglo XV, pero los ejemplos en la documentación no son muy abundantes $y$, además, este paño tan apreciado no pasa de inventariarse de principios del siglo XVII. En los inventarios del siglo XVII se localizan ocurrencias aisladas en la Península y América (CorLexIn). Formalemente parece que este término no se identifica con la ciudad de procedencia, sino más bien con el tejido, de tal forma que el término es considerado como un sustantivo plural por los escribanos haciéndole concordar con el adjetivo cuando lo acompaña "Londres azules".

\section{MAYORGA}

Sust. 'municipio de la provincia de Valladolid, en Castilla y León'.

Quatro cabezales viexos, los tres de Mayorga y otro de lino y lana (Sahagún, LE-1623)

Dos cabeçales de los de Mayorga, buenos (Valderas, LE-1647)

Quatro cabezales, el uno de lana de colores de los de Mayorga bueno con su pluma (Grajal de Campos, LE-1663)

Dos cabezales biexos de Mayorga sin pluma (Tamariz de Campos, VA-1651

Un cabezal de Mayorga con su pluma (Cuenca de Campos, VA-1668)

Quatro cabezales de Mayorga buenos (Villalpando, ZA-1629)

Un cauezal de Mayorga (Villalpando, ZA-1635)

Parece que en Tierra de Campos son muy conocidos los cabezales de Mayorga en el siglo XVII, también en algunas localidades leonesas muy próximas o dentro de esta zona -Cifuentes de Rueda (León)- (CorLexIn). Sin embargo, esta referencia toponímica no la hallamos en la documentación del CORDE y tampoco transciende más allá de la zona estudiada. Morala señala que, a pesar de su uso reducido, la expresión es conocida por el escribano perfectamente (Morala, 2010b: 402)

\section{OVIEDO [Obiedo, Ubiedo]}

Sust. 'ciudad y municipio español localizada en Asturias'.

Otras dos beatillas de Obiedo ... otras dos tocas de Obiedo (Sahagún, LE-1601)

Yten, dos tocados de Ubiedo buenos (Sahagún, LE-1608)

Una beatilla fina nueua de Obiedo (Frechilla, PA-1612) 
Otro tocado beatilla de Ubiedo nuebo (Frechilla, PA-1631)

Una beatilla de Ubiedo (Frechilla, PA-1639)

Un tocado de Obiedo (Guaza de Campos, PA-1639)

Una beatilla de las de Obiedo fina biexa (Frechilla, PA-1675)

Veatilla de Oviedo (Medina de Rioseco, VA-1644)

En la Tierra de Campos localizamos unos cuantos ejemplos de beatillas, tocas y tocados referenciados como "de Oviedo". Sin embargo, no encontramos ejemplos en el CORDE de esta referencia toponímica y apenas hay un ejemplo en la documentación del CorLexIn en Santas Martas, localidad muy próxima a nuestra zona de estudio. Parece que se trataba de un tipo de complementos que los escribanos y tasadores identificaban perfectamente. Formalmente suelen alternar las grafías /b/, / / y / u/ en los documentos y también nos encontramos con el cierre de la vocal inicial en $/ \mathrm{u} /$.

\section{PALENCIA [Palençia, Palenzia]}

Sust. 'ciudad y municipio español localizada en la Comunidad Autónoma de Castilla y León'

Vn cobertor de Palençia blanco apolillado (Valderas, LE-1647)

Una manta frazada de Palenzia buena (Autillo de Campos, PA-1654)

Una manta de Palençia bieja (Boadilla de Rioseco, PA-1687)

Un guardapies de bayeta de Palencia colorado (Boadilla de Rioseco, PA-1689)

Un cobertor de Palencia blanco nuevo en quatro ducados (Cuenca de Campos, PA-1666)

Unas enaguas, son de Baeta de Palenzia mediadas (Villarramiel, PA-1696)

Otro manteo de veyntedosseno negro usado aforrado parte de él en bayeta de Palencia (Villalón, VA-1642)

Ciento y treinta varas de vaieta cavellada de Palençia (Medina de Rioseco, VA-1645)

Dos mantas de Palençia traydas (Medina de Rioseco, VA-1649)

Un covertor vlanco de Palenzia de dos rajas (Mediana de Rioseco, VA-1660)

Un ferreruelo y sotanilla de bayeta de Palençia bueno con botones de seda (Villalpando, ZA-1629)

Un juvón de bayeta de Palençia (Villalpando, ZA-1630)

Un couertor blanco de Palenzia (Villalobos, ZA-1654)

Una manta blanca de Palenzia (Villalpando, ZA-1686)

Parece que en esta época las referencias a las mantas palentinas son frecuentes en Tierra de Campos, territorio cercano a esta importante industria textil, sobre todo, en lana y bayeta. Pero esta presencia se extiende al resto de la Península, parece que las mantas, frazadas y cobertores de Palencia tienen fama. No pasa lo mismo con la bayeta, de la que encontramos un número más escaso de ejemplos, no tenía tanta calidad como la de Sevilla o eso se intuye del siguiente ejemplo localizado por Morala (2010b: 404):

Una capa larga y su sotana de baeta de Sebilla porque me encomiende a Dios, digo a entranbas a dos, que a de ser la baeta de Palencia y no más (León, 1643)

\section{PERERUELA [Perigüela, pirigüela]}

Sust. f. municipio y localidad de Zamora, perteneciente a la Comunidad Autónoma de Castilla y León'.

Una olla de Pereruela grande vuena (Grajal de Campos, LE-1671)

Cinco ollas de perigüela las dos grandes (Villalpando, ZA-1661)

Un uarreñón de perigüela con una mela de ganado (Villalpando, ZA-1688) 
Una tinaja de perigüela (Villalpando, ZA-1689)

Un barreñón de pirigüela mediano (Villalpando, ZA-1690)

Una olla mediana de perigüela (Villalpando, ZA-1689)

Las variantes que aparecen de este término en el corpus analizado son dispares y algunas se alejan del aceptado hoy en día pereruela, que no se encuentra documentada en los textos del $C D H$ hasta finales del siglo XIX. Nos encontramos variantes como la de periguela que además cierra la vocal palatal /e/ en /i/ y en ocasiones nos encontramos con la forma piriguela con el doble cierre de las dos /e/, variantes que se mantendrán en los textos en siglos posteriores, como lo demuestran las ocurrencias localizadas en La Bañeza (Gómez Ferrero, 2015: 459).

\section{PERPIÑ́N}

Debemos tener presente que en estos momentos Perpiñán es una ciudad de la corona española, pero que con la firma de la Paz de los Pirineos en 1659 pasa junto con el resto del Rosellón a formar parte de la corona francesa (Morala, 2010b: 405)

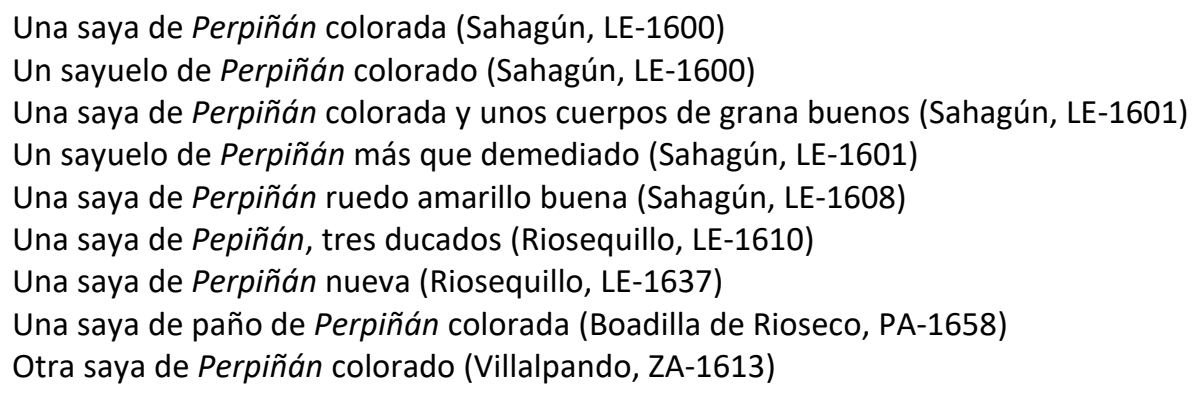

En Tierra de Campos documentamos esta procedencia sobre todo para sayas y sayuelos. Morala advierte de que esta expresión no es muy habitual, algo que constatan las consultas a bases de datos léxicas o al CorLexIn. Es cierto que hay cierto acopio de ejemplos en la zona de estudio, pero ninguno de ellos sobrepasa la fecha de la firma de la Paz de los Pirineos.

\section{PORTUGAL}

Sust. 'País del sur de Europa'.

Cincuenta y una madexitas de ylo de Portugal de coser (Valderas, LE-1647)

Un manto de tafetán negro bueno hasta una bara de brocadillo de Portugal (Frechilla, PA-1671) Otro gergón de lienzo de Portugal de tres piernas de ancho (Frechilla, PA-1675) Ylo de Portugal (Medina de Rioseco, VA-1644)

No son muchas las referencias toponímicas de Portugal, no solo en Tierra de Campos, sino que se hace extensible al resto de la Península donde las ocurrencias no llegan a la media docena, aunque se localizan en la Península, Canarias y América (CorLexIn). A pesar de que las relaciones comerciales con Portugal debían ser habituales en esta época, las referencias explícitas a Portugal y al gentilicio son más bien escasas (Morala, 2010b: 406). En nuestros corpues siempre aparece haciendo referencia al campo téxtil -hilo, tafetán o lienzo -. 


\section{RUAN [roan]}

Sust. m. 'Tela de algodón estampada en colores que se fabrica en Ruan, ciudad de Francia' (DLE). Es un término que recoge Autoridades con la acepción señalada. El DECH documenta esta voz en 1385 (DECH, s. v. ruan)

Una toca de ruan buena (Santa María del Río, LE-1617)

Una toca de ruan nueva (San Nicolás del Real Camino, LE-1631)

Un paño de manos de ruan desilado bueno (Arenillas, LE-1636)

Quatro almuadas, las dos açericos, labradas de seda negra de ruan (Valderas, LE-1647)

Una camissa de ruan vuena (Castromocho, PA-1603)

Un pedaçillo de ruan en rreal y medio (Frechilla, PA-1613)

Una sabana de ruan viexa tasada en quatro reales (Mazariegos, PA-1619)

Dos almoadas, la una de ruan y la otra de lino(Autillo de Campos, PA-1649)

Una toalla de ruan labrada con bordados y desylados y con puntas (Medina de Rioseco, VA-1640)

Ocho albas las zinco de lienço y las tres de roan con puntas (Medina de Rioseco, VA-1651)

Un pañico de ruan con desylados en quatro reales (Cuenca de Campos, VA-1666)

Otra almoada de roan con desilados llena de lana (Cuenca de Campos, VA-1668)

Dos almuadas de ruan con sus regalicos labradas de pinos negros (Villalapando, ZA-1620)

Una alba y un amito de ruan (Villalpando, ZA-1633)

Ocho almoadas de lienzo roan (Vilalpando, ZA-1637)

Un paño de manos de ruan labrado de seda colorada (Villalpando, ZA-1643)

Esta referencia toponímica se documenta en el $C D H$ dese el siglo $\mathrm{xV}$, y a mediados de este mismo siglo esta voz la documenta en textos americanos. Sin embargo, a partir del siglo XVII, su presencia experimenta un retroceso y apenas figura en esta base datos con esta acepción. Esto ya ha sido señalado por autores como Puche Lorenzo o Castañeda Ordoñez (Morala, 2010b: 407). Este tipo de tejido de algodón era utilizado sobre todo para confeccionar ropa blanca, aunque también prendas como tocas, albas, camisas...

Es un término de uso general en los inventarios de la época de la Península, Canarias y América (CorLexIn), y por lo tanto, los ruanes están presentes también en los inventarios de la Tierra de Campos. Formalmente presenta la forma roán por hipercorrección, fenómeno que ya vimos en el término contray, explicable por el hecho de la transformación del hiato /oa/ en el diptongo/ua/ en registros coloquiales o no cuidados (Morala, 2010b: 407). 



\section{CONCLUSIONES}

Como conclusiones generales de esta tesis cabe señalar que hemos recopilado una muestra significativa de documentos notariales que nos han servido de fuente de información para articular el presente estudio. Hemos preseleccionado, seleccionado y transcrito más de 500 documentos, que nos ha permitido configurar un corpus lo suficientemente representativo de la zona.

Para organizar las palabras, hemos clasificado el léxico por categorías apoyándonos en las propuestas de autores como Quirós (2011), Carriazo (2012) o Gómez Ferrero (2015). Las categorías raíces que se presentan en el cuerpo de la tesis son: indumentaria y arreglo personal, objetos religiosos y de devoción, textil, ajuar doméstico, mobiliario y accesorios, aperos agrícolas, herramientas profesionales, medidas, animales y denominaciones geográficas, todos ellas con sus subcategorías.

La metodología llevada a cabo para realizar esta tesis se ha basado en el estudio directo de inventarios de bienes y nos ha permitido conocer el léxico de Tierra de Campos y compararlo con el de otros ámbitos geográficos gracias al CorLexIn.

Durante el periodo de redacción de la presente tesis, algunos documentos de esta zona se han incorporado al Corpus Léxico de Inventarios (CorLexIn).

Como conclusiones más específicas de este estudio, hemos situado el contexto histórico de la Tierra de Campos que nos permite entender la inestabilidad que sufrieron las fronteras entre el Reino de León y el Reino de Castilla y cómo fronteras de otra naturaleza dieron cierta estabilidad a la zona. Una de las hipótesis que se barajan para justificar ciertas características filológicas comunes a esta zona es atender a las demarcaciones eclesiásticas que dotaron de una mayor estabilidad a la comarca y que permanecieron estables hasta mediados del siglo xx (Morala, 2011a: 104). Esta zona es de gran interés filológico pues representa la confluencia entre las isoglosas del leonés y del castellano. Esta franja territorial actuaría como bisagra entre ambos romances.

Las particularidades dialectales del romance que figura en los textos terracampinos del siglo XVII es coincidente con el castellano norteño de la época. A pesar de ello, debemos tener en cuenta que esta zona presenta una serie de características que la diferencian del resto a lo largo de la historia y queda documentado como vimos en diferentes textos. A continuación, vamos a ir desgranando una serie de rasgos que nos han llamado la atención y que podrían contribuir a identificar el romance terracampino en el siglo XVII.

Antes de nada, debemos poner de relieve la naturaleza de los textos con los que trabajamos, las relaciones de bienes contenidas en documentos notariales. Una tipología textual que, a pesar de seguir una norma culta a la hora de ser redactados, cuenta con pequeñas incursiones de la lengua oral, bien por parte del propio escribano que duda y corrige en ocasiones lo que no debe, 
bien por influencia del entorno en el que está. Dicho de otro modo, debemos estar atentos a aquellos detalles que no encajen con lo esperado; lo que nos cuentan puede ser clave para la interpretación de ciertos fenómenos lingüísticos.

\subsection{EL LÉXICO ENCONTRADO}

Comenzaremos hablando del léxico que figura en los textos, que mantiene características propias del leonés y que podemos tildar de occidentalismos. Pero, también de soluciones patrimoniales del castellano, cuando la norma prefiere otras. Veremos que el influjo se produce en ambas direcciones, a veces se prefiere la solución leonesa, pero otras veces la que pervive y se adentra a los límites es la castellana.

Uno de esos términos representativos de esta zona es camba, que presenta el mantenimiento del grupo consonántico /-mb-/ en posición intervocálica propia del leonés y, solo esporádicamente, se localiza el resultado castellano cama. Lo mismo ocurre con algunos de sus derivados como cambón o encambadura, término que no se registra en los diccionarios y que tampoco encontramos en la documentación histórica, pero sí en estudios dialectales leoneses (Le Men, 2004). Sin embargo, lo reseñable es que para designar el 'timón del trillo', la forma más utilizada es la solución castellana camizo frente a cambizo del que solo tenemos noticia en los inventarios leoneses de Tierra de Campos y que comparten espacio con camizo o camicio. Por otro lado, ceranda es la solución leonesa que se prefiere en la Tierra de Campos, la voz castellana zaranda es menos frecuente en el corpus y se localizada en Grajal de Campos y Villalpando, la franja más occidental del ámbito terracampino. Este hecho demuestra que ambas isoglosas, del castellano y del leonés, se entremezclan.

Otro término que presenta dos soluciones para un único objeto es abarcas, variante académica recogida en Frechilla, frente a albarcas propia de diferentes zonas leonesas y localizada en Cea.

En ocasiones, el término normativo se identifica con el occidentalismo como ocurre con el término funda. Sin embargo, no es extraño encontrar en estos inventarios la solución patrimonial hunda, que también presenta el derivado hundero, términos exclusivos de la Tierra de Campos. Caso parecido es el de herreruelo, aunque en este caso, se prefiere la forma académica y no la patrimonial.

Otro término con fuerte arraigo en la zona es el término cornal o acornal, con una preferencia de uso en la zona noroccidental de la Península. Gran parte de estos occidentalismos tienen que ver con los aperos y recipientes agrícolas como impuesta, manjera, trasga, piñera, machado, purridera, costana, carral o poíno. Mención especial requiere el término trinchero recogido de forma tardía en los diccionarios y poco documentado Esta voz con notación dialectal de León se recoge en vocabularios en El Bierzo, Murias de Paredes y Astorga (Le Men, 2014, s. v. trinchera). Lo mismo ocurre con ventril, palabra propia de León y muy poco documentada en los archivos notariales y que, aunque de forma esporádica, localizamos en la Tierra de Campos. 
Honcejo figura en la Tierra de Campos y más concretamente en la zona leonesa frente a otras voces como hocejo que, además de en Tierra de Campos, se extiende por zonas de León, Palencia y Cantabria (Morala, 2020: 81-82). Otra herramienta de corte propia de esta zona es podejo, término localizado en Sahagún y del que no se encuentra otra referencia que el actual podeja en el valle del Esla, seguramente con un significado muy similar (Le Men, 2009).

En cuanto a los recipientes agrícolas, recogemos palabras como bachilla propia de Zampora, chorra de la que no tenemos noticias en otros documentos o tiñón, que podría ser un derivado de los términos tuña y toña registrados en el dominio asturleonés (Morala y Egido, 2018). Estos términos se hallan desarrollados en el estudio léxico.

Los animales domésticos forman otro de los campos que suelen ser muy productivos en cuanto a léxico se refiere. En esta zona encontramos voces como jato/a que está muy documentado en el corpus. Propio de la zona noroccidental es marón, término vigente en la actualidad y localizado en las tres provincias leonesas (Morala, 2010c: 270). La voz engüeda se recoge en Valdavida y Catroañe, siempre en género femenino (Pascual, 2009: 175-177) y es variante de igüedo propia de la Maragatería (Le Men, 2005). Aunque no se trata de un occidentalismo -hay casos de esta voz en La Rioja-, debemos mencionar el término chivarra documentado en Castroañe, voz que no se registra en los diccionarios hasta la edición de 1936 y del que apenas hay documentación (Morala,2010c: 274).

Resulta más complicado encontrar rasgos dialectales en el campo textil. Habitualmente son campos semánticos muy marcados por las modas y que suelen presentar un uso general. No obstante, encontramos algunos complementos del vestir como sobarbio en Calzada, Grajal de Campos y Sahagún y que es propio de la zona de Astorga (Egido, 2010: 98; 2014: 78-79). Ceñidero es una de esas voces propias de los documentos pertenecientes a la frontera del leonés oriental (Morala, 2012b: 337, 346). En el campo de los textiles destaca el término estameñica, propio de la documentación leonesa y que en fechas posteriores también se localiza en Asturias.

Además de hunda y hundero, este corpus presenta palabras cuyo uso es prácticamente exclusivo de esta zona. Una de esas palabras representativa de la zona es brega y sus derivados -breguil y bregón-, con la acepción 'artificio para amasar el pan' (García Caballero, 1992: 41).

Otro campo léxico que presenta diferentes términos propios de la zona es el de la albañilería donde se documenta amacal, que es el molde de madera para hacer adobes. Por otro lado, hay distintas voces para designar la herramienta para 'enlucir las paredes' y así encontramos trulladera o embarradera propias de la Tierra de Campos junto a trulla y llana.

Dentro de los cubiertos encontramos la palabra compuesta tornahuevos que presenta variedad poligráfica: tornahuebos, torna huebos, tornahuebo, tornagüebos, tornagüevos y que recogen las localidades terracampinas de Palencia y Valladolid. Por regla general para designar este objeto se suele utilizar sintagmas del tipo "paleta de volver huevos".

Muchas de estas palabras no se documentan en los diccionarios académicos, precisamente por esa singularidad que presentan y que algunas de ellas ya hemos señalado. Sin embargo, otras no se registran porque se trata de tecnicismos que no han recogido los diccionarios dada 
su especificidad o bien porque la forma adquirida no llegó a cuajar en la lengua, es lo que pasa con chillón, dublión, fajadero, cernadera, jergona, paramentadura o brocalete.

En otras ocasiones, lo que no recoge el diccionario es la acepción con la que aparecen estas voces, como, por ejemplo, papal "tejido", tramoya "tejido", colodro "recipiente", tinaco "bañera", carbonera "recipiente", caza [como enser de cocina que tenía que ver con el fuego], baranda "cedazo", estufa "para calentar la cama" o cercadura "cortina".

\subsection{FENÓMENOS QUE AFECTAN AL VOCALISMO}

El corpus terracampino presenta la alternancia de timbre en las vocales átonas, lo que demostraría que este fenómeno estaría vigente aún esta época, al menos en el registro oral (Morala, 2012a: 556). Las vacilaciones se dan entre pares vocálicos. El cierre de /o/ en /u/ y la abertura de / $\mathrm{u} /$ en /o/ es habitual en estos textos, en su mayoría provocado porque la vocal tónica es una /i/, lo que produce la inestabilidad del timbre de las vocales velares (Ibidem, 2012a: 557). En los inventarios encontramos estufilla y estofilla, escudilla y escodilla, obillo y ubillo o garrobilla y garrubilla. Los otros contextos en los que se produce el cambio son menos frecuentes en el corpus, por ejemplo, cuando la sílaba tonica es una /u/, genera también cierta inestabilidad, que en el corpus analizado presenta un ejemplo común a todas las zonas: sepultura / sepoltura. Lo mismo ocurre con los casos de presencia de la yod en la sílaba tónica. Al igual que el caso anterior es frecuente en otras zonas y no resultan significativos: doçientos / duçientos (Ibidem, 2012a: 557-558). No hay casos de cambio cuando la sílaba está alejada de la vocal tónica. Sin embargo, encontramos otros contextos en los que se da esta variación como por ejemplo tunel por tonel y alumbra por alombra, en ambos casos el contacto es con nasal.

Figura en el corpus estudiado la vacilación entre las vocales abiertas /a/ y /e/. Al igual que en el par anterior, el timbre de la /a/ y de la /e/ se ven afectados cuando la palabra cuenta con una /i/ en la sílaba tónica, así encontramos cornelina por cornalina o arquecico por arcacico. Otro de los contextos en el que aparece es en voces que empiezan con /en-/ y /an-/ como es el caso de lenzuelo y lanzuelo, pero también linzuelo, es decir, en este ejemplo puede presentar tanto abertura como cierre de la vocal. Algo parecido ocurre cuando va trabada con /-s/, es el caso de anascote, que presenta las variantes anescote y aniscote. En otras ocasiones es un proceso de disimilación el que da lugar al cambio de timbre en este par de vocales. Son los casos de arrecada por arracada, bernagal por bernegal o amecal por amacal. El fenómeno de asimilación se ve en guadamacil por guadamecil, documentado igualmente en otras zonas (Ibidem, 2012a: 559) o alamanisco por alemanisco.

La alternancia entre el par de /i/y/e/ es el más productivo del corpus, no por su regularidad, sino por el número de palabras que se ven afectadas. Son distintos los contextos en los que se da este cambio, por ejemplo, cuando la sílaba tónica recae en el diptongo /ué/ (Ibidem, 2012a: 560), la palabra sobeyuelo la encontramos en algunos inventarios con el cierre de la átona sobiyuelo, y lo mismo que grigüescos o pirigüela. También aparece el fenómeno de la 
disimilación como es el caso de feligrana por filigrana, felipichín por filipichín o espitera por espetera.

De manera general estas soluciones suelen alternar en los documentos con la forma normativa $-\mathrm{y}$ suelen darse de manera esporádica- a pesar del gran número de casos encontrados. Solo hay un caso en el que aparece únicamente la forma con el cambio del timbre que piñera por peñera, de esta última no se localiza ninguna ocurrencia.

\begin{tabular}{|c|c|c|}
\hline \multicolumn{3}{|c|}{ Vacilación del timbre de las vocales átonas } \\
\hline /o/ - /u/ & $\mid a /-/ e /$ & /e/-/i/ \\
\hline estufilla / estofilla & arracada / arrecada & faldellín / faldillín \\
\hline garrobilla / garrubilla & cornalina / cornelina & mantellina / mantillina \\
\hline escudilla / escodilla & bernegal / bernagal & centillo / cintillo \\
\hline obillo / ubillo & arcacico / arquecico & sobeyuelo / sobigüelo / sobijuelo \\
\hline cuchillo / cochillo & amacal / amecal & alemanisco / alimanisco \\
\hline tonel / tunel & astil/estil & verbión o brevión / bribión \\
\hline toalla / tualla & anascote / anescote / aniscote & bebedero / bibedero \\
\hline alombra / alumbra & lenzuelo / lanzuelo & lenzuelo / linzuelo \\
\hline bufete / bofete & guadamacil / guadamecil & gregüescos / grigüescos \\
\hline undero / ondero & alemanisco / alamanisco & perigüela / pirigüela \\
\hline sepultura / sepultura & canastillo / canestillo & jirón / jerón \\
\hline doçientos / duçientos & enguada / angüeda & espetera / espitera \\
\hline nudillo / nodillo & & cabezal / cabizal \\
\hline \multirow[t]{9}{*}{ ruan / roán } & & repostero / ripostero \\
\hline & & calderuela / caldiruela \\
\hline & & candelero / candilero \\
\hline & & brizo / brezo \\
\hline & & ceñidor / ciñidor \\
\hline & & ceñidero / ciñidero \\
\hline & & filigrana / feligrana \\
\hline & & filipechín / felipichín \\
\hline & & lechona / lichona \\
\hline
\end{tabular}

Tabla 8.1. Vacilación del timbre de las vocales átonas.

La epéntesis de /a/ es frecuente en la Tierra de Campos. Lo encontramos en acornales, arralladera, apelliz, azoleta, aguadaña, añunque [yunque] o amacal -en los vocabularios dialectales figura como macal-. Sería una muestra más de la oralidad de la época que de alguna forma queda reflejada en los textos notariales. El hecho de que el escribano elimine esta /a-/ inicial de palabras, indica que era considerado como vulgar y por ello, en ocasiones aplica la ultracorrección:

En la cocina una lacena de pino (Paredes de Nava, PA-1689)

Dos tablas de manteles lemaniscos de Flandes (Medina de Rioseco, VA-1642)

Quarenta y siete baras de cotonías blancas felpadas (Medina de Rioseco, VA-1645)

Aunque este fenómeno aparece de forma muy esporádica, localizamos casos en los que se añade una vocal al final de la lexía frente a la variante normativa como ocurre con ansare y rede: 
Una ansare con quatro ansarones (Valdavida, LE-1606)

Una rede de ylo (Autillo de Campos, PA-1653)

Por otro lado, en Tierra de Campos aparecen diferentes fenómenos que propician la formación de diptongos e hiatos. Es el caso de la epéntesis de la /i/, fenómeno presente en esta zona y que es común a todos los romances hispánicos, aunque con especial presencia en el romance de la zona leonesa (Morala y Gancedo, 2009: 83). Se forman diptongos en sobarbio, cambicio, cañicio.

En otras ocasiones la formación del diptongo o el hiato viene dada por la caída de una consonante intervocálica. Es lo que pasa en casos como taurete [taburete] y trincheo [trinchero] o auxeta [aguxeta] en Medina de Rioseco y Grajal de Campos. El caso de baeta [bayeta], es frecuente en los textos leoneses y muy documentada en todo el corpus terracampino excepto en las localidades pertenecientes a Valladolid.

Hay una preferencia por la forma patrimonial flueco en el corpus terracampino, aunque también figura la normativa fleco, pero con menor extensión.

Se documenta la epéntesis de vocal para apoyar la dicción de la palabra, son los casos de gurupera [grupera], ingalaterra [Inglaterra], y como algo esporádico guiriñon [griñón]. Fenómenos como este pueden ser muestra de la oralidad de la época.

\subsection{FENÓMENOS QUE AFECTAN AL CONSONANTISMO}

Son pocos los ejemplos donde se mantiene la /f-/ en Tierra de Campos. De hecho, si quitamos el resultado normativo ferreruelo, tan solo localizamos un único caso del adjetivo fosco "otro fosco [buey]" en un inventario de Boadilla de Rioseco, la zona más oriental terracampina. La /f-/ desaparece en Tierra de Campos y se sustituye por una h que muy posiblemente fuera meramente gráfica, sin ningún tipo de aspiración. De hecho, en Tierra de Campos se ve como prefieren términos como hunda o hundero frente al normativo funda.

El único caso de consevación del grupo consonántico -mb- es camba y sus derivados, en el resto de soluciones se mantiene la reducción de las consonantes como en el caso de paloma.

La confusión entre las consonantes líquidas / / y / $/$ / se da en posición implosiva como en el caso del término alcorcí que presenta gran variedad gráfica. En Sahagún y Valdavida se da el cambio entre la / $\mathrm{r} /$ implosiva y la $/ \mathrm{n} /$, además de añadir una /// deshaciendo el diptongo final alconçiles. La variante arcoçiles y arcoçíes con $/ r$ / se documenta en Frechilla. Vasar suele mantener la variante académica, sin embargo, se recoge un ejemplo de basal en Medina de Rioseco. Y aunque no está en el estudio léxico de esta tesis, también localizamos arcabuz y alcabuz. El único ejemplo que encontramos en el corpus que afecta a grupos consonánticos es el de prata frente a plata, aunque su uso es minoritario. En posición en interior de palabra, encontramos la neutralización en tabulete en Guaza de Campos.

Esta zona presenta una confusión de la bilabiales al inicio de palabra como ocurre con los términos pañal y bañal, en este caso son las anotaciones que hace el escribano en el margen lo 
que aclara la confusión. Otros casos son balandrán / malandrán o mimbre / bimbre. También se documenta la pérdida de /g-/ y / $/$ - / encontramos en los textos usanillo y ugo. Estos dos términos resultan interesantes por ser indicadores de la oralidad del momento. Mientras que el término ugo se documenta de manera frecuente, de usanillo solo encontramos un caso en Grajal de Campos. El término yugo pertenece a la parcela de los aperos agrícolas, fuente de localismos y para el que es más complicado encontrar una palabra con la que sustituirla. Sin embargo, el término gusanillo pertenece al ámbito textil, mucho más reconocible y con menos palabras dialectales.

La vacilación con las consonantes iniciales también se da entre el sonido /g/ y / k/, en Tierra de Campos documentamos el término camuza con el sonido velar sordo, frente a gamuza, y lo mismo ocurre en el caso de cubilete, aunque de este par sí documentamos la forma gubilete en Boadilla de Rioseco.

En posición intervocálica figura la pérdida de la palatal procedente de los grupos /dj, gj y j/, es el caso de baeta o joel, aunque comparten asientos con las variantes sin pérdida.

En cuanto a la solución del grupo consonántico / $/$ 'l/ por regla general mantiene la solución castellana /x/: espejo, cerrojo o botija.

\subsection{INCORPORACIÓN Y CREACIÓN DE NUEVAS PALABRAS}

El procedimiento más utilizado para la creación de nuevos términos es la derivación. Entre los resultados fruto de la prefijación encontramos amacal, antojo, antepuerta, trasfuego, revolvedera, sobrecama, sobrelecho, sobremesa, sobreaño, sobretodo, sobrepelliz. Curioso resulta el término entremijo, localizado en Paredes de Nava, cuya solución se crea por analogía con los compuestos formados por la preposición entre-. Lo mismo ocurre con el término entremuzes recogido en Celada -"quatro zelemines de entremuzes"-, donde se refiere a los altramuces.

Mucho más productivo es el proceso de sufijación donde destaca el vocabulario creado a través del sufijo diminutivo terminado en -illo/a y que da lugar a nuevos términos, muchos de ellos relacionados con el mundo textil estopilla, beatilla, beatilla, espumilla y otros campos semánticos como zarcillos, arillo, morillo o parrilla. Otros sufijos como -ito, -ico, -uelo o -ino tienen menos productividad, aun así, se recogen ejemplos de algunas lexicalizaciones: manguito, acerico, sayuela, cornalina o botines. También entran en juego los aumentativos a la hora de crear nuevas palabras, de forma general con el sufijo -ón, aunque también aparece -azo u -ote: faldón, cañamazo, pipote.

Es preciso señalar la confusión que presentan las palabras que se forman a través de los sufijos derivativos -dor / -dero procedentes del latín y que entran a formar parte del acervo lingüístico perdiendo en parte la diferencia semántica entre ellos. Esta confluencia se ve en claramente en las soluciones colador, coladora, coladero y coladera, todos ellos presentes en el 
corpus terracampino y lo mismo ocurre con aguadero, aguadera y aguador; tajadera, tajadero y tajador o tapadera, tapadero o tapador. Al margen de la confusión semántica debemos tener en cuenta la productividad de estos sufijos, sobre todo el par-dor,-dera (podadera, cebadera, tranzadera, azufrador, arador (Paredes de Nava) o librador entre otros).

Otro sufijo presente en los textos es -ero/-a con diferentes sentidos semánticos. No obstante, el más frecuente es el que aporta un significado locativo: tartera, trinchero, chocolatera o terrero.

El sufijo -il también se encuentra documentado en el corpus terracampino en palabras de sobra conocidas como barril, guadamacil, mandil o pernil. Sin embargo, en otras ocasiones las palabras en las que aparece son más propias del lugar al que pertenecen los protocolos. Nos encontramos con el termino derivado podonil en Autillo de Campos, derivado de podón y que posiblemente referencie una herramienta de corte. Por su parte, breguil está extendido en toda la Tierra de Campos y es derivado de brega, ambos términos propios de esta zona y que tienen que ver con el amasado del pan. El sufijo -il es muy productivo en la época tanto para crear adjetivos, aunque también sustantivos.

Aunque el mecanismo de la parasíntesis está reservado sobre todo a la creación de adjetivos (acanelado, achapinada o acoletada), en nuestro corpus encontramos arrejada, derivado de reja, en Autillo de Campos y de camba figura encanvaduras en Riosequillo.

El fenómeno de la composición nos aporta términos como guardabajos, guardapiés, tapapiés, pasamanos, rodapiés, tentemozo, guardainfante o guardapolvo donde los elementos de composición son verbo más sustantivo; mientras, papahigo, arcamesa [arquimesa] o escusabaraja combinan dos sustantivos.

El procedimiento de la metáfora es también habitual en la creación de palabras, en muchos casos la asociación está clara, como es el caso de aquellos términos que nos recuerdan a elementos de la naturaleza como avellana, calabaza, almendrillas o caracol. En otras ocasiones esa asociación se ha perdido en parte. Son los casos de beatilla, morillo, pabellón o gusanillo.

Habituales son también los nombres de lugares de procedencia de un objeto que dan origen a nuevos vocablos como damasco, holanda, colonia o bujía donde es fácil saber el origen, con otras voces es más complicado establecer la relación como en el caso de anascote. También los nombres o títulos nobiliarios de personas pueden dar lugar a una nueva palabra es el caso de cariñana o guillame.

Los préstamos también son habituales en el corpus. Hay que señalar que el número más elevado de estos corresponde al árabe. Los términos procedentes de Francia ocupan el segundo lugar en nuestro corpus, la gran mayoría referenciando textiles. También figuran términos procedentes del italiano, alemán, neerlandés, portugués, catalán, vasco y palabras amerindias. 


\begin{tabular}{|l|l|}
\hline \multicolumn{1}{|c|}{$\begin{array}{l}\text { Préstamos } \\
\text { Del francés }\end{array}$} & $\begin{array}{l}\text { Polainas, casaca, jaquetilla, botón, bota, broche, cornalina, bofetán, } \\
\text { camelote, espolín, lama, pasamanos, colcha, pabellón, carpeta, cobre, } \\
\text { taburete }\end{array}$ \\
\hline Del neerlandés & $\begin{array}{l}\text { Valón, valona, flamenquilla } \\
\text { Roquete, bonete, gandalla, cantimplora, perol, escalfeta, pujavante }\end{array}$ \\
\hline Del catalán & Corpiño, basquiña, ropa, abanico, bandeja, filigrana, brocado \\
\hline Del portugués & Coleto, chinelas, escarpines, medalla, catalufa, brocatel, tabi, tercianela \\
\hline Del italiano & Falda, guante, blanqueta, bancal, bastidor, banco \\
\hline Del alemán & Enaguas, chocolatera, jícara, pita \\
\hline Americanismos & zamarro \\
\hline Del vasco & $\begin{array}{l}\text { Gabán, jubón, zaragüelles, albanega, abalorio, alforza, alcorcí, algodón, } \\
\text { albornoz, aceitera, albornía, alcuza, aljáfana, almofía, azafate, jarra, taza, } \\
\text { almirez, almohada, candil, alacena, jáquima. }\end{array}$ \\
\hline Del árabe &
\end{tabular}

Tabla 8.2. Préstamos.

Por otro lado, encontramos voces que se encuentran en retroceso y que apenas aparecen uno o dos ejemplos en el corpus, es el caso de dalle, quilma, garbín, papahigo, tranzaderas, sobrelecho, casco [de almohada], jáquima, purificador o forqueta. Muchos de los términos pertenecen al ámbito de la moda, en otras ocasiones la palabra no se afianza en la lengua como es el caso de forqueta y sus homólogas forcheta y forchina frente a tenedor. Y por el contrario también registra voces de nueva incorporación como son culero, monillo, cornelina, bombasí, chocolatera, fiambrera, garapiñera, molinillo, bujía o cartera.

\subsection{ASPECTOS MORFOSINTÁCTICOS}

El neutro de materia es uno de los fenómenos más reconocidos, aunque no exclusivo, de la Tierra de Campos, a través del cual, el hablante distingue entre sustantivos contables y no contables. Destaca el uso de neutros de materia con nombres de telas y efectos textiles (Morala, 2015c: 317):

Quatro baras de cotonia abarillado nuebo (Sahagún, LE-1600)

Una almoada labrada de seda colorado (Sahagún, LE-1600)

Una escriñuela con un poco de sal biexo (Galleguillos, LE-1618)

Dos reboçiños de vayeta negro de Segouia (Grajal de Campos, LE-1656)

Otra beatilla delgado en ocho reales (Castromudarra, LE-1606)

Dos halmohadas una de ruan con randas de hilo blanco y otra de çerro con randas de lana blanco (Frechilla, PA-1615)

Una saya de estameña pardo con ruedo amarillo (Frechilla, PA-1642)

Quatro docenas de botones de seda negro (Autillo de Campos, PA-1653)

Una almoada labrada con seda colorado (Autillo de Campos, PA-1654)

Siete arrovas de lana blanco (Frechilla, PA-1676) 
Un angurina de estameña nueba forrada en baeta colorado (Villarramiel, PA-1690)

Una capa de vaieta negro de la sierra (Boadilla de Rioseco, PA-1692)

Una anguarina de muger de estameña negro (Boadilla de Rioseco, PA-1692)

El neutro de materia se documenta en los inventarios pertenecientes a la Tierra de Campos leonesa y Palentina. En Valladolid se recupera algún caso aislado en Cuenca de Campos (Ibidem, 2015c: 321).

Otro de los rasgos que caracterizan esta zona en la actualidad es el cambio en la desinencia verbal de la 3. - personal del pretérito perfecto simple y que alternan con la forma estándar. Algo que hemos localizado en un inventario de Cea donde se escribe lo siguiente:

Çinco caveçales de lana con su pluma que no se tasan por ser de los que vinon de Burgos (Cea, LE-1626)

Debemos poner de relieve la importancia que tienen los documentos notariales para el estudio de la historia de la lengua. Un estudio que pretenda acercarse lo más posible a la lengua real de la época, porque a pesar de seguir una rígida normativa a la hora de redactarlos, el escribano puede dejar su impronta y salirse del guion para sorpresa del investigador filológico. Como hemos visto en nuestro corpus, la oralidad figura en estos textos de manera, a veces imperceptible, pero nos puede dar la información suficiente como para describir nuestro objeto de estudio.

Por otro lado, es necesario destacar el valor incalculable que poseen corpus como el CorLexIn que nos permite cotejar nuestros datos con el resto de documentación notarial, tanto con protocolos de la Península, como de Canarias y de América. Lo que nos permite tener una visión muy amplia de cualquier término que queramos estudiar. 


\subsection{FUTURAS LÍNEAS DE INVESTIGACIÓN}

El hecho de disponer de un corpus terracampino de 585 documentos nos permitirá incluir otros campos léxicos que no están presentes en esta tesis ampliando de esa manera el resultado de la investigación. Por ejemplo, se podrá incluir el campo semántico de los materiales (alquimia, peltre, azófar, vaqueta, campeche, mehúl) o el de las armas (arcabuz, escopeta, carabina o pistola).

Por otro lado, sería interesante el estudio de los adjetivos que configuran el corpus. Dada la puntillosidad del escribano a la hora de describir el objeto, estos textos ofrecen una riqueza léxica que recae en muchas ocasiones sobre los adjetivos que lo definen refiriéndose a la forma, el color o el tiempo (acabellado, acanelado, achapinada, açoletada, adovado, almendrucado, arenosso, atacada, estofado, razonable, tornasolado, trapeado, ynbultada...).

Otro estudio interesante sería ver qué voces se han mantenido y cuáles han desaparecido para siempre, aunque estén recogidas en el diccionario. La despoblación rural es una realidad que no solo se lleva a las personas, sino que también se lleva las palabras. 

BIBLIOGRAFÍA 



\section{BIBLIOGRAFÍA}

ABAD ZARDoyA, Carmen (2012) "Por tierra y mar. El ajuar del camino como proyección del espacio doméstico" Res Mobilis: Revista internacional de investigación en mobiliario y objetos decorativos, vol 1, no 1, pp. 42-58.

ÁGREDA PINO, Ana María (2011) "La indumentaria religiosa". Emblemata: Revista aragonesa de emblemática, Institución "Fernando el Católico". № 17, Zaragoza. pp. 107-128.

ÁGREDA PINO, Ana María (2017): "Vestir el lecho. Una introducción al ajuar textil de la cama en la España de los siglos XV y XVI". Res Mobilis, Revista internacional de investigación en mobiliario y objetos decorativos, vol. 6, n.o 7. pp. 20-41.

Alarcos LloRACH, Emilio (1986): Fonología Española. Biblioteca Románica Hispánica. Editorial Gredos. Madrid.

ALCALDE CRESPO, GONZALO (2002): Viejos oficios relacionados con la agricultura y la ganadería. ASAJA, Ediciones Cálamo, Palencia.

AlfaU de Solalinde, Jesusa (1969): "Nomenclatura de los tejidos españoles del siglo XIII", Anejos del Boletín de la Real Academia Española, no 19. Real Academia Española, (RAE), Madrid.

ALMEDA MolinA, Elena (2013): "La tradición en el léxico de la indumentaria: análisis comparativo del Tesoro de Covarrubias y el Diccionario de Autoridades" en Revista de Estudios Filológicos, n. 25, julio 2013. Universidad de Murcia. Murcia. Disponible en: https://www.um.es/tonosdigital/znum25/secciones/estudios-04-lexico indumentaria.htm [Consultado por última vez en diciembre de 2020].

ALONSO, DÁmASO (1962). La fragmentación fonética peninsular, Suplemento de la Enciclopedia Lingüística Hispánica, Consejo Superior de Investigaciones Científicas, (CSIC), Madrid.

Alvar EzQuerra, Manuel (1995): La formación de palabras en español. Arco Libros, Madrid.

Alvar EzQuerra, Manuel (1999) Atlas Lingüístico de Castilla y León. (ALCyL). Consejería de Educación y Cultura. Junta de Castilla y León. Valladolid.

ÁLVAREZ TEJEDOR, Antonio (1989): Estudio lingüístico del léxico rural de la zona este de la provincia de Zamora, Universidad de Salamanca, Salamanca.

ANDUEZA UnANUA, Pilar (2009) "Joyas, alhajas y tapices de una dama aragonesa en el siglo xviii: la condesa de Contamina y San Clemente", Artigrama: Revista del Departamento de Historia del Arte de la Universidad de Zaragoza, n. 24. Universidad de Zaragoza. Zaragoza. pp. 373-389.

ARANA Y AMURRIO, José. Ignacio. (1987): "Práctica y enseñanza médicas en el Guadalupe bajomedieval". Medicina \& historia. Revista de estudios históricos de las ciencias médicas. $\mathrm{n}$. o 18. Centro de Documentación de Historia de la Medicina de J. Uriach. Barcelona. pp. 6-28. 
ARANDA HUete, Amelia María (2000) "Aspectos tipológicos de la joyería femenina española durante el reinado de Felipe V". Anales de Historia del Arte, vol. 10. Universidad Complutense. . pp. 215-246.

ArbetetA, Letizia (1988): La joyería española de Felipe II a Alfonso XIII en los museos estatales. Editorial Nerea. Madrid.

ARIzA Viguera, Manuel (1992): Manual de Fonología Histórica del Español, Editorial Sintesis, Madrid

ASENJo GonZÁlEZ, María (1991): "Transformación de la manufactura de paños en Castilla. Las Ordenanzas Generales de 1500", Historia. Instituciones. Documentos, n.o 18. pp. 1-38.

BARRIO MoYA, José Luis (1999): "El hidalgo mallorquín don Agustín de Anglés Rullan, aposentador de Carlos II en la Real Casa de Borgoña (1691)". Bolletí de la Societat Arqueològica Lul-liana: Revista d'estudis històrics, n.o 55, pp. 373-380.

BarRoso CASTRO, José y SÁNCHEZ de Bustos, Joaquín (1993): "Propuestas de transcripción para textos del XV y Siglos de Oro". Estado actual de los estudios sobre el Siglo de Oro: actas del II Congreso Internacional de Hispanistas del Siglo de Oro, celebrado en 1990. Volumen n.o 1. Universidad de Salamanca. Salamanca. pp. 161-178.

BARTOlomé, L. y JUNQUeRA, A (2018): "Cosas de montañeses (y II): sustantividad y léxico", Altamira. Revista del Centro de Estudios Montañeses, LXXXIX, 97-135.

BASTARDín CANDóN, Teresa (2012): "Léxico de los Siglos de Oro en documentos notariales: las particiones de bienes del Archivo Histórico Provincial de Cádiz" en Revista Quadernos del Instituto de Historia de la Lengua, n. 7, Cilengua, San Millán de la Cogolla. pp. 31-59.

BejARANo RuBio, Amparo (1996): "Los escribanos públicos en Castilla: El condado de Ledesma en el siglo XVI". Miscelánea Medieval Murciana, vol. 19-20, Universidad de Murcia. Murcia. pp. 926.

BeLLIDO BLANCO, Antonio (2006): "Aproximación al patrimonio industrial de la Tierra de Campos palentina", Publicaciones de la Institución Tello Téllez de Meneses (PITTM), n. 77, Diputación de Palencia, Palencia. pp. 263-293.

Bernis Madrazo, Carmen. (1979): Trajes y modas en la España de los Reyes Católicos, tomo II: Los hombres, Instituto Diego Velázquez, Consejo Superior de Investigaciones Científicas (CSIC), Madrid.

BeRnIS MAdRAZO, Carmen. (2001): El traje y los tipos sociales en El Quijote. El Viso. Madrid.

BoniALIAN, Mariano. (2014): "Tejidos y cerámica de China en la gobernación de Tucumán y Buenos Aires, siglo XVIII. Apuntes sobre su circulación y consumo". Anuario de Estudios Americanos, n.o 71, 2, Sevilla, julio-diciembre. pp. 631-660. 
Bustillo Merino, Victoria Eugenia (2000): "Ajuar doméstico y patrimonio mueble: estructura, función y evolución del hogar en las villas vizcaínas de los siglos XVII y XVIII. Un modelo para Elorrio" en Ondare. Cuadernos de Artes Plásticas y Monumentales, n.o 19, pp. 581-587.

CABallero Morante, Armando (1999): Alaejos a la antigua usanza. Diputación de Valladolid. Valladolid.

CANO AGUILAR, Rafael (2008): "Cambios en la fonología del español durante los siglos XVI y XVII". Historia de la lengua española. Rafael Cano Aguilar (Coord.), 3.a impresión, editorial Ariel, Barcelona. pp. 826-657.

CARRERA DE LA Red, María Fátima (1988): Toponimia de los valles del Cea, Valderaduey y Sequillo. Institución Fray Bernardino de Sahagún. León.

CARRIAZO RUIZ, José Ramón (2012): "Categorización, clasificación y repertorización onomosiológica del vocabulario doméstico de los inventarios de bienes de San Millán", Cuadernos del Instituto de Historia de la Lengua, no 12. pp. 125-141.

CASADO LOBATO, María Concepción (1991) La indumentaria tradicional en las comarcas leonesas. Diputación de León. León.

CASADO LOBATO, M.a Concepción (1996) "La joyería popular leonesa". Revista de Dialectología y tradiciones populares. Vol. 51, n. $\mathrm{2}$ 2, Consejo Superior de Investigaciones Científicas, (CSIC), pp. 237-249.

CASAS CARNICERO, Ángel (1989). "El habla en una localidad de Tierra de Campos: Villada". Publicaciones de la Institución Tello Téllez de Meneses, pp. 519-542.

CDH (2013-). Corpus del Nuevo diccionario histórico del español (CDH) [en línea] de la Real academia española (RAE). Disponible en: http://web.frl.es/DH/org/ [Consultado por última vez en diciembre de 2020].

COLÓN DOMÉNECH, Germà. (1967). "Elementos constitutivos: catalanismos". Enciclopedia Lingüística Hispánica. Consejo Superior de Investigaciones Científicas, (CSIC), Madrid, 193-238.

CONGOSTO MARTín, Yolanda (2002): Aportación a la historia lingüística de las hablas andaluzas (siglo XVII), Secretariado de Publicaciones de la Universidad de Sevilla, Sevilla.

CoterA, Gustavo (1999): La indumentaria tradicional en Aliste. Ed. Instituto de Estudios Zamoranos "Florián Do Campo"/ Caja España, Zamora.

CORDE. Banco de datos [en línea] del Corpus diacrónico del español (CORDE) de la Real Academia Española (RAE). Disponible en: http://www.rae.es [Consultado por última vez en diciembre de 2020].

CORLEXIN. Corpus Léxico de Inventarios (CorLexIn) [en línea] realizado por el grupo de investigación que dirige el Dr. Morala Rodríguez de la Universidad de León. Creado en marzo de 2013 y actualizado periódicamente. Disponible en: http://corlexin.unileon.es/ [Consultado por última vez en diciembre de 2020]. 
COROMINAS, Joan y PASCUAL, José Antonio (2012): Diccionario Crítico Etimológico Castellano e Hispánico, Ed. En cd-rom (DECH), Ed. Gredos, Madrid.

CURIEL MÉNDEZ, Gustavo (2000): "El efímero caudal de una joven noble. Inventario y aprecio de los bienes de la Marquesa Doña Teresa Francisca María de Guadalupe Retes Paz Vera (Ciudad de México, 1695)", Anales del Museo de América, n.ㅇ 8. pp. 65-101.

De La Granja Alonso, Manuel (2003): "La decadencia castellana en el final del siglo XVII a través de una villa terracampina: Villafáfila" Estudios humanísticos. Historia, №. 2, Universidad de León. pp. 37-60.

DLE. Banco de datos [en línea] del Diccionario de lengua española (DLE) de la Real Academia Española (RAE). Disponible en: https://dle.rae.es/ [Consultado por última vez en diciembre de 2020].

EGIDO FERNÁNDEZ, M.a Cristina (2010): "Léxico de indumentaria femenina y joyas en relaciones de bienes de la Maragatería, Cepeda y Astorga, León (S. XVII)", en Ana Ma Cano (ed.) Homenaxe al profesor Xosé Lluis García Arias, Lletres Asturianes, anexu 1, tomo I, Academia de la Llingua Asturiana. Oviedo. pp. 95-116.

EGIDO FernánDEZ, M.a Cristina (2014): "Léxico de la indumentaria en relaciones de bienes leonesas del siglo XVII", en Ma Pilar Garcés Gómez (ed.), Léxico, historia y diccionarios, Anexos Revista de Lexicografía, no 30, Universidade da Coruña, A Coruña, pp. 77-94.

EGIDO FERNÁNDEZ, M.a Cristina (2015): "Léxico de la indumentaria en relaciones de bienes leonesas del siglo XVII", en M. a Pilar Garcés Gómez (ed.), Léxico, historia y diccionarios, Anexos Revista de Lexicografía, no 30, Universidade da Coruña, A Coruña. pp. 77-94.

EgIDO FERNÁNDEZ, M.a Cristina (2016a): "América vs. España: contrastes gramaticales y léxicos en documentación del siglo XVII", en Marta Fernández Alcalde, Elena Leal Abad y Álvaro S. Octavio de Toledo y Huerta (eds.), En la estela del Quijote. Cambio lingüístico, norma y tradiciones discursivas en el siglo XVII, Peter Lang Edition, Frankfurt am Main, pp. 189-213.

EGIDO FERnÁndeZ, M. a Cristina (2016b): "Joyas femeninas: un aporte sobre léxico del español colonial americano", Anuario de Letras. Lingüística y Filología, Vol. 4, Núm. 2, pp. 99-151.

EGIDO FERNÁndeZ, M.a Cristina (2018): "Léxico cotidiano en la América colonial: vestimenta femenina y joyas que la adornan", en M.a L. Arnal, R. M.a Castañer, J. M.a Enguita, V. Lagüens y M. a A. Martín (eds.), Actas del X Congreso Internacional de Historia de la Lengua Española, tomo 2, Institución «Fernando el Católico» / Diputación Provincial de Zaragoza, Zaragoza, pp. 19291948.

ENGUITA UTRILLA, José María y ARNAL PURROY, María Luisa (1994): "Particularidades lingüísticas en textos notariales zaragozanos de finales del siglo XVII", Archivo de filología aragonesa, Vol. 50, 1994, Institución Fernando el Católico. Zaragoza. pp. 43-64.

ENĂCHESCU, Mihai (2019): "Pérdida y reemplazo de arabismos en español: enfermedades y afecciones de la medicina medieval", Colindancias: Revista de la Red de Hispanistas de Europa central, pp. 187-200. 
ESTERAS Martín, Cristina (2004): "Sobre bernegales mexicanos del siglo XVII" en Estudios de Platería: San Eloy. Coord. por Jesús Rivas Carmona, Universidad de Murcia, Murcia, págs. 147164.

FERNÁNDE GUTIERRI, Gausón. (2007): El Traje asturiano o traje del país, El paxellu asturianu o traxel'l país. Editorial: Caja De Ahorros De Asturias.

FernándeZ FlóReZ, José Antonio (1984). "El Becerro de presentaciones", Cod. 13 del ACL. Un parroquial leonés de los siglos XIII-XV. Centro de Estudios e Investigación "San Isidoro" (C.S.I.C.). Archivo Histórico Diocesano. Caja de Ahorros y Monte de Piedad. León.

FERNÁNDEZ GonZÁLEZ, Ángel R. (1959). El habla y la cultura popular de Oseja de Sajambre. Instituto de Estudios Asturianos, Oviedo, 1959.

FERNÁNDEZ ORDóÑEZ, Inés (2011): La lengua de Castilla y la formación del español. Real Academia Española (RAE). Madrid.

FERNÁNDEZ PÉREZ, Adolfo, (1991): "La constitución de la sociedá familiar entre xaldos ya vaqueiros nel concechu de Navia a traviés de los contratos familiares" (1775-1874)", Cultures, vol. 1, Academia de la Llingua Asturiana. Oviedo. pp. 101-131.

García Caballero, Abundio (1992): Localismos. Colección Nueva Castilla 17. Castilla Ediciones. Valladolid.

GIL ARRANDO, María Consuelo (1986): "Contribución al estudio lingüístico del español del siglo XVII" Cauce: Revista Internacional de Filología, Comunicación y sus Didácticas, n.ㅇ 9, Universidad de Sevilla. pp. 39-60.

Girón AlCONCHEL, José Luis (2008): "Cambios gramaticales en los Siglos de Oro". Historia de la lengua española. Rafael Cano Aguilar (Coord.), 3.a impresión, editorial Ariel, Barcelona. pp. 859893.

Gómez FerRero, María Cristina (2015): Estudio del léxico en los protocolos notariales del Partido Judicial de La Bañeza (ss. XVII-XIX), Tesis doctoral dirigida por J.R. Morala y leída en la Universidad de León el 16 de febrero de 2015.

GÓMEZ ORTíN, Francisco (2012): "Miscelánea dialectológica", Tonos digital: Revista electrónica de estudios filológicos, n.․․ 23.

GonzÁlez MenA, M. Ángeles (1994): Colección textil de la Universidad Complutense de Madrid, vol. 1.

GoRdalizA, F. Roberto. (1988): Vocabulario Palentino. Ed. Caja de Ahorros de Palencia. 1. a Edición, Palencia.

Helguera Castro, María Ángeles y Nágera Salas, Paz (1990): "Una cala en el vocabulario hondo de Tierra de Campos", Publicaciones de la Institución Tello Téllez de Meneses (PITTM), n.o 61. pp. 499-540. 
Hernández Alonso, Néstor (2000): Calzada del Coto. Historia, lengua y toponimia. León.

HeRnández García, Ricardo (2004): La industria textil rural en Castilla: Astudillo, 1750-1936. Alicante, Biblioteca Virtual Miguel de Cervantes. Edición digital a partir del texto original de la tesis doctoral.

JULIA LUNA, Luna (2008): "El léxico de la metrología en la lexicografía académica de los siglos XVIII y XIX : las unidades de capacidad tradicionales", El diccionario como puente entre las lenguas y culturas del mundo : Actas del II Congreso Internacional de Lexicografía Hispánica, coord. por Dolores Azorín Fernández, Belén Alvarado Ortega, Jaume Climent de Benito, M. Isabel Guardiola i Savall, Ruth M. Lavale Ortiz, Carmen Marimón Llorca, José Joaquín Martínez Egido, Xose A. Padilla García, Herminia Provencio Garrigós, Isabel Santamaría-Pérez, Larissa Timofeeva Timofeev, Elena Toro Lillo, Editores: Biblioteca Virtual Miguel de Cervantes, pp. 706-714.

JUNQUera MARTínez, A. y MORALA RodríGUez, J. R. (2019): "Léxico de origen italiano en documentos notariales del Siglo de Oro", en Florencio del Barrio de la Rosa (ed.), Lexicalización, léxico y lexicografía en la historia del español, Colección VenPalabras. Estudios de lexicologia espanola, 2, Edizioni Ca' Foscari, Venezia, pp. 187-233.

Junquera MARTínez, A. y Álvarez García, E. (2020): "De botas, toneles y candiotas: léxico del vino del siglo XVII", en Miguel Ibáñez Rodríguez (ed.), Enotradulengua. Vino, lengua y traducción, Peter Lang Edition, Frankfurt am Main, pp. 83-108.

LAGÜENS, Vicente (2012): "Notas léxicas sobre documentos municipales aragoneses" en Revista Quadernos del Instituto de Historia de la Lengua, n.o 7, Cilengua, San Millán de la Cogolla. pp. 257-295.

LAgUna ÁlvareZ, Asunción (2017): "Adjetivos parasintéticos documentados en Inventarios de Bienes del siglo XVIII", en Jesús Pena Seijas, ed., Procesos morfológicos. Zonas de interferencia, Anexos de Verba, 76, Universidad de Santiago de Compostela, Servicio de Publicaciones de la Universidad, pp. 223-231.

LAPESA, Rafael (1985): Estudios de historia lingüística española, Paraninfo, Madrid.

LAPESA, Rafael (2008): Historia de la lengua española; prólogo de Ramón Menéndez Pidal, Editorial Gredos, Madrid.

LASMARÍAS PONZ (2007): "Vestido para viajar 1600-1650". Revista de historia Jerónimo Zurita, n.o 80-81 (2005-2006), Institución Fernando el Católico. Zaragoza. pp. 203-226.

LASMARÍAS PONZ (2009): "El traje popular en el siglo XVII". Revista Ars longa cuadernos de arte, n.o 18, Cilengua, Universitat de València: Departament d'Història de l'Art. Valencia. pp. 133-142.

Leguizamón, MARTINIANo (1896): Recuedos de la tierra;Editor: Félix Lajouane, Buenos Aires. Argentina.

LE MeN LOYER, Janick (2002-2014): Léxico del Leonés actual, tomos I-VI, Centro de Estudios e Investigación "San Isidoro", León. 
LIARTE ALCAINA, Maria Rosa (2010): "La industria de la seda en España durante la Edad Moderna", Revista de Claseshistoria, n. 1, pp. 1-15.

LILLO REDONET, Fernando. (2012): "El Códice Calixtino: un tesoro medieval para el aula de latín en bachillerato y universidad". Thamyris, nova series: Revista de Didáctica de Cultura Clásica, Griego y Latín, n. 3. Universidad de Málaga. Málaga. pp. 137-147.

López de Guereñu GalarRAGA, Gerardo (1998): Voces alavesas, Ayuntamiento de Vitoria, Bilbao. López Vallejo, Ángeles (2008): Historia del léxico militar en el español áureo: la conquista de granada, el conflicto hispano-italiano y las guerras de flandes, Tesis doctoral, Departamento de Lengua Española, Universidad de Granada, Granada.

MAdOz, Pascual (1845). Diccionario Geográfico, estadístico e histórico de España y de sus posesiones de ultramar. Tomo 2. Ed. Pascual Madoz. Madrid.

MARCos ÁlvaREZ, Fernando (1987): "La capa de los animales de carga y tiro en Badajoz durante el S. XVII. Notas léxicas" en M. Ariza, A. Salvador y A. Viudas (eds.) en Actas del I Congreso Internacional de Historia de la Lengua, Cáceres. pp. 889-897.

Martínez MelÉndez, Ma del Carmen (1989): Los nombres de tejidos en castellano medieval. Universidad de Granada. Publicaciones de la cátedra de historia de la lengua española. Granada. MARTínez MeLÉNDEZ, Ma del Carmen (1995): Estudio de los nombres de oficios artesanales en castellano medieval, Granada.

MARTínez SHAW, Carlos (2008): "La España moderna (1474-1700)". Historia de la lengua española, Rafael Cano Aguilar (Coord.), 3. impresión, editorial Ariel, Barcelona. pp. 659-680.

Mendoza García, Eva María (2005): "Los escribanos reales de Málaga en el siglo XVII". Baética: Estudios de arte, geografía e historia, n. 27, Universidad de Málaga. Málaga. pp. 405-422.

MenÉNDEZ PIDAL, Ramón (1906): "El Dialecto Leonés". Revista de Archivos, Bibliotecas y Museos Año X. Números 2 y 3. Febrero-Marzo. Cuerpo Facultativo de Archiveros, Bibliotecarios y Anticuarios. Madrid.

Merino, Eugenio (1930): Tierra de Campos. Novela de costumbres campesinas para fomentar el progreso agrícola, sin menos cabo de las costumbres cristianas. Tomo 2. Editorial poliglota. Barcelona.

Miguel Borge, Marta (2016): "Inventario de bienes de la fortaleza de Villalpando en 1633. Estudio del léxico del lujo", Anuario del Instituto de Estudios Zamoranos Florián de Ocampo, no 31, pp. 335-357.

Miguel Borge, Marta (2018): "Entre delantales y mandiles en la Tierra de Campos del siglo XVII", Estudios panhispánicos: lingüística teórica y aplicada. Universidad de León, León, pp. 81-94.

Miralles Martínez, Pedro (2003): "Familias genovesas afincadas en Murcia vinculadas al comercio sedero", Los extranjeros en la España moderna, eds. M.B. Villar García, P. Pezzi Cristóbal. Málaga. pp. 493-503. 
Mínguez FeRnÁndeZ, José María (1976): "Colección diplomática del Monasterio de Sahagún (siglos IX y X)" en Fuentes y Estudios de Historia leonesa, núm. 17, León 1976.

MORALA RodríGUEZ, José R. (2002a): "Originales y copias. El proceso de castellanización en el área leonesa", en Actas del V Congreso Internacional de Historia de la Lengua Española, Tomo I, Ed. Gredos, Madrid, pp. 1335-1345.

Morala RodríGUEZ, José R. (2002b): "De la complejidad interna del castellano en Castilla (y León)" en C. Saralegui, M Casado (Eds.), Pulchre, bene, recte. Estudios en homenaje al Prof. Fernando González Ollé, Eunsa, Pamplona, pp. 955-969.

Morala RodríGuez, José R. (2004a): "Del leonés al castellano" (Capítulo 21) en Rafael Cano (coord.), Historia de la lengua española, Ariel, pp. 555-569.

Morala RodríGuez, José R. (2004b): "Documentación leonesa y léxico hispánico", Escritos dedicados a José María Fernández Catón, Centro de Estudios e Investigación "San Isidoro", León, pp. 1019-1039.

MORALA RodríGUeZ, José R. (2006): "Leonés y castellano en Zamora. De la Edad Media a nuestros días", Anuario del Instituto de Estudios Zamoranos "Florián de Ocampo" Zamora. pp. 347-365.

MORALA RodríGUeZ, José Ramón (2007): "Léxico de la vida cotidiana. El trabajo en el campo", en Orígenes de las lenguas romances en el Reino de León. Siglos IX-XII, León, Centro de Estudios e Investigación "San Isidoro", vol. I. pp. 377-444.

MoRALA RodRIGUEZ, José .R. (2008a), "Leonés y castellano a finales de la Edad Media" en J. Elvira, I. Fernández-Ordóñez, et al. (eds.) Lenguas, reinos y dialectos en la Edad Media ibérica: la construcción de la identidad: homenaje a Juan Ramón Lodares. Madrid / Frankfurt, Iberoamericana / Vervuert, pp. 129-148.

MoRAla RodRíGuez, José R. (2009): "El proceso de castellanización al sur de la Cordillera Cantábrica en el siglo XVII", Lletres Asturianes, Oviedo, 101. pp. 7-22.

Morala Rodríguez, José R. (2010a): "Inventarios de bienes y lexicografía histórica", en A. M.a Medina Guerra y M.C. Ayala Castro (ed. y coord.). Los diccionarios a través de la historia. Universidad de Málaga, Málaga. pp. 433-454.

Morala RodríGuez, José R. (2010b): "Léxico con denominaciones de origen en inventarios del Siglo de Oro", en Rosa Rabadán, Trinidad Guzmán y Marisa Fernández (eds.), Lengua, traducción, recepción. En honor de Julio César Santoyo //Language, Translation, Reception. To Honor Julio César Santoyo, vol. I, Universidad de León, León. pp. 385-417.

Morala Rodríguez, José R. (2010c): "Notas de lexicografía histórica leonesa: léxico de la ganadería" en Ana M. a Cano (ed.). Homenaxe al profesor Xosé Lluis García Arias, Lletres Asturianes, anexu 1, tomo I, Academia de la Llingua Asturiana. Oviedo. pp. 257-277.

MORALA ROdRíGUEZ, José R. (2011) "La frontera histórica entre el asturleonés y el castellano" en Ramón de Andrés Díaz (Coordinador), Lengua, Ciencia y fronteras. Anexos de Revista de Filoloxía Asturiana. Trabe. Universidad de Oviedo. Oviedo. pp. 89-119. 
MORALA ROdRíGUEZ, José R. (2012a): "Alternancias en el vocalismo átono en textos notariales del siglo XVII" en E. Montero Cartelle (ed.) Actas del VIII Congreso Internacional de Historia de la Lengua Española, Santiago de Compostela, tomo I. pp. 555-564.

MoRALA RodRíGUEZ, José R. (2012b): "Datos sobre interferencias entre los sufijos - dor y -dero en un corpus del Siglo de Oro" en Mar Campos Souto, Ramón Mariño, José Ignacio Pérez Pascual, Antonio Rifón (Eds.), "Assí como es de suso dicho": Estudios de morfología y léxico en homenaje a Jesús Pena, Cilengua. San Millán de la Cogolla. pp. 337-354.

Morala RodríGuez, José R. (2012c): "Léxico e inventarios de bienes en los siglos de oro", en G. Clavería, M. Freixas, M. Prat y J. Torruella (eds.), Historia del léxico: perspectivas de investigación, Iberoamericana. Madrid-Frankfurt. pp. 199-218.

Morala Rodríguez, José R. (2012d): "El proyecto CorLexIn" en Dolores Corbella, Josefa Dorta, Alejandro Fajardo Aguirre, Laura Izquierdo, Javier Medina López y Antonia Nelsi Torres (eds.), Lexicografía hispánica del siglo XXI: nuevos proyectos y perspectivas. Homenaje al profesor Cristóbal Corrales Zumbado, Arco /Libros. Madrid. pp. 421-439.

Morala Rodríguez, José R. (2012e): "Arabismos en textos del siglo XVII escasamente documentados" en Revista de investigación lingüística $\mathrm{n}$. - 5, Universidad de Murcia, Murcia. pp. 77-102.

MoRAla Rodríguez, José R. (2012f): "Relaciones de bienes y geografía lingüística del siglo XVII" en Revista Quadernos del Instituto de Historia de la Lengua n. 7 , Cilengua, San Millán de la Cogolla. pp. 297-328.

MoRAla RodRíGuez, José R. (2014a): “El CorLexIn un corpus para el estudio del léxico histórico y dialectal del siglo de oro" Scrimptum digital, 3. pp. 5-28.

MORALA ROdRíGUez, José R. (2014b): "La explotación interdisciplinar del Corpus Léxico de Inventarios (CorLexIn)", en Joaquín García Nistal (coord), Imagen y documento: Materiales para conocer y construir una historia cultural, Ediciones el Forastero. León. pp. 249-264.

MoRALA Rodríguez, José R (2014c): "La expresión de la calidad en el léxico de los inventarios del Siglo de Oro", en M.a Pilar Garcés Gómez (ed.), Léxico, historia y diccionarios, Anexos Revista de Lexicografía, n.o 30, Universidade da Coruña, A Coruña, pp. 283-298.

MoRALA RODRíGUEZ, José R. (2014d): "Léxico ganadero formado sobre denominaciones relativas al tiempo", en Maria Bargalló Escrivà, María Pilar Garcés Gómez y Cecilio Garriga Escribano (ed.), "Llaneza». Estudios dedicados al profesor Juan Gutiérrez Cuadrado, Anexos de Revista de Lexicografía, n.o 23, Universidade da Coruña. A Coruña. pp. 117-129.

Morala Rodríguez, José R. (2015a): "Derivados en -dor en la documentación del Siglo de Oro. Voces escasamente documentadas", en José María García Martín (dir), Francisco Javier de Cos Ruiz y Mariano Franco Figueroa (coord), Actas del IX Congreso Internacional de Historia de la Lengua Española. Iberoamericana-Vervuert, Madrid, Tomo II, pp.1503-1519.

MoRALA ROdRíGUEZ, José R. (2015b): "Norma y variación en el romance de la documentación leonesa del siglo XIII", en R. Mariño Paz y X. Varela Barreiro (eds), Lingüística histórica e edición 
de textos galegos medievais, Verba, Anexo no 73, Universidade de Santiago de Compostela, Santiago, pp. 29-53.

MORALA RodRíGUEZ, José R. (2015c): "Datos para la historia del neutro de materia en castellano", Revista de Filología Española, Tomo 95, fascículo n. 2o, julio-diciembre, Consejo Superior de Investigaciones Científicas, (CSIC), pp. 307-337.

MORALA ROdRíGUEZ, José R. (2015d): "Los inventarios de bienes y el léxico del siglo XVII en el AHP de Cádiz", en T. Bastardín y M.a M. Barrientos (eds.), Lengua y cultura en el Archivo Histórico Provincial de Cádiz, Universidad de Cádiz, Cádiz, pp. 147-174.

Morala RodrígueZ, José R. (2016a) "Fuentes manuscritas del siglo XVII e Historia de la Lengua", en Marta Fernández Alcalde, Elena Leal Abad y Álvaro S. Octavio de Toledo y Huerta (eds.), En la estela del Quijote. Cambio lingüístico, norma y tradiciones discursivas en el siglo XVII, Peter Lang Edition, Frankfurt am Main, pp. 373-388.

Morala Rodríguez, José R. (2016b) "Léxico de las medidas de capacidad en el siglo XVII", en M. Quirós, J. R. Carriazo, E. Falque y M. Sánchez (eds.), Etimología e historia en el léxico del español, Iberoamericana-Vervuert, Madrid, pp. 559-579.

MoRAla Rodríguez, José R. (2016c) "Léxico histórico: sobre cribas, cedazos y harneros", en Araceli López Serena, Antonio Narbona Jiménez, Santiago del Rey Quesada (dirs.), El español a través del tiempo. Estudios ofrecidos a Rafael Cano Aguilar, Editorial Universidad de Sevilla. Sevilla. pp. 309-324.

MoRALA RodRíGUEZ, José R. (2016d) “Lexicografía dialectal histórica y evolución etimológica: el caso de yugo", Revista de Historia de la Lengua Española, no 11, pp. 131-153.

MORALA RodRíGUEZ, José R. (2017a): "Voces derivadas en documentación notarial del siglo XVII", Cuadernos del Instituto de Historia de la Lengua, no 10. pp. 135-163.

Morala RodríGueZ, José R. (2017b) "Algunos derivados en -il en un corpus del siglo XVII", en Florencio del Barrio de la Rosa (ed.), Palabras Vocabulario Léxico. La lexicología aplicada a la didáctica y a la diacronía, Edizioni Ca' Foscari, Venezia. pp. 267-281.

MORALA RODRÍGUEZ, José R. (2017c) “Lengua y vida cotidiana en la provincia de Zamora en el siglo XVII", Anuario del Instituto de Estudios Zamoranos Florián de Ocampo, no 32, Zamora, pp. 347374.

Morala RodríGuez, José R (2018a): “Derivados en -dero en documentación del Siglo de Oro. Voces escasamente documentadas", en María Pilar Garcés Gómez (ed.), Perspectivas teóricas y metodológicas en la elaboración de un diccionario histórico. (Lingüística Iberoamericana, no 71), Iberoamericana-Vervuert, Madrid-Frankfurt am Main, pp. 63-94.

MORALA ROdRÍGUez, José R (2018b): "Variación diatópica y etimología en léxico del Siglo de Oro", en Ma L. Arnal, R. Ma Castañer, J. Ma Enguita, V. Lagüens y Ma A. Martín (eds.), Actas del X Congreso Internacional de Historia de la Lengua Española, Institución «Fernando el Católico» / Diputación Provincial de Zaragoza, Zaragoza, T. I, pp. 215-238. 
MORALA RODRÍGUEZ, José R (2019a): ““Norma leonesa y norma castellana en textos notariales de Ios siglos XVI-XVII", en Viorica Codita (ed) y J. P. Sánchez Méndez y E. Bustos Gisbert (coords.), La configuración histórica de las normas del castellano. Tirant Humanidades, Valencia, pp. 193225.

MORALA RODRÍGUEZ, José R (2019b): “Fórmulas para la desambiguación léxica en documentación del Siglo de Oro", en M.a del Carmen Cazorla Vivas, M.a Ángeles García Aranda y M.a Pilar Nuño Álvarez (eds.), Lo que hablan las palabras. Estudios de lexicología, lexicografía y gramática en honor de Manuel Alvar Ezquerra, Axac, Lugo, pp. 387-401.

MORALA RodRíGUEZ, José R (2020):"Léxico agrícola en el siglo XVII: herramientas de corte" Revista de Investigación Lingüística, no 23. Universidad de Murcia, Murcia. pp. 77-103.

Morala Rodríguez, José R. y EGIDO FERNÁNDEZ, M.a Cristina (2010): “Variantes formales en hiatos y diptongos en textos medievales del s. XVII" en R. M. a Castañar y V. Lagüens García (eds.). De moneda nunca usada. Estudios dedicados a J. M.a Enguita Utrilla. Institución Fernando el Católico, Zaragoza. pp. 423-435.

Morala Rodríguez, José R. y EGIDO FERNÁNDEZ, Mạ Cristina (2018): “El proyecto Corlexin y la variación diatópica en el léxico del Siglo de Oro", en Corbella Diaz, Dolores; Fajardo Aguirre, Alejandro; Langenbacher-Liebgott, Jutta, (eds.) Historia del léxico español y Humanidades digitales. (Colección: Studia Romanica et Linguistica, 53), Peter Lang, Berlin, pp. 397-417.

Morala Rodríguez, José R. y Gancedo Fernández, Emilio (2009): El habla de León. Biblioteca leonesa de tradiciones, Edilesa, León.

Morala Rodríguez, José R y Perdiguero Villarreal, Hemógenes (2019): "La isoglosa de la aspiración de /f/ en el siglo XVII", en Mónica del Castillo Lluch \& Elena Diez del Corral Areta (eds.), Reescribiendo la historia de la lengua española a partir de la edición de documentos, Peter Lang, Berna, pp. 175-199.

NDHE (2013-). Nuevo diccionario histórico del español (NDHE) [en línea] de la Real academia española (RAE). Disponible en: http://web.frl.es/DH/org/ [Consultado por última vez en diciembre de 2020].

NTLLE. Nuevo tesoro lexicográfico de la lengua española (NTLLE) [en línea] de la Real academia española (RAE). Disponible en: http://ntlle.rae.es/ntlle/SrvltGUILoginNtlle [Consultado por última vez en diciembre de 2020].

Oliva HeRreR, Hipólito Rafael. (2000-2001): “La industria textil en Tierra de Campos a fines de la Edad Media". Studia historica. Historia medieval, n. 18-19. Ediciones Universidad de Salamanca. Salamanca. pp. 225-251.

ORTIZ CRUZ, Demelsa (2013): "Estudio léxico del inventario realizado a la muerte de la duquesa de Híjar D. a Mariana Pignatelli y Aragón (1681)". Res Diachronicae, vol. 11, Asociación de Jóvenes Investigadores de Historiografía e Historia de la Lengua Española (AJIHLE) . pp. 72-83.

PASCUAL ROdRíGuez, José Antonio (1988): "Notas sobre las confusiones medievales de las sibilantes". LEA: Lingüística española actual, Vol. 10, №. 1, Arco libros. Pp.125-131. 
PASCUAL RodríGueZ, José Antonio (2009): "Más allá de la ley fonética: Sobre la evolución de las vocales átonas iniciales y de la sj en castellano", en Fernando Sánchez Miret (ed.): Romanística sin complejos. Homenaje a Carmen Pensado. Berna: Peter Lang. pp. 185-218.

PASTOR BLANCO, José María (2004): Tesoro léxico de las hablas riojanas. Universidad de La Rioja. Logroño.

PenSAdo, José LUIS (1999): Estudios asturianos, Academia de la Llingua Asturina, Oviedo.

Perdiguero Villarreal, Hermógenes (2012a): "Variación léxica en protocolos notariales de Castilla en el siglo XVII" en Revista Quadernos del Instituto de Historia de la Lengua, no7, Cilengua, San Millán de la Cogolla. pp. 333-345.

Perdiguero VillarReal, Hermógenes (2012b): “Palabras en -ero/-era en protocolos notariales de Castilla”, en Mar Campos Souto, Ramón Mariño, José Ignacio Pérez Pascual, Antonio Rifón (Eds.), "Assí como es de suso dicho»: Estudios de morfología y léxico en homenaje a Jesús Pena, Cilengua, San Millán de la Cogolla. pp. 381-392.

Perdiguero Villarreal, Hermógenes (2012c): "Léxico de aperos y enseres en protocolos notariales de Burgos en el S. XVII" en Emilio Montero Cartelle (ed.), Actas del VIII Congreso Internacional de Historia de la Lengua, Santiago de Compostela, Meubook. pp. 1551-1562.

Perdiguero VillarReal, Hermógenes (2013): “Aspectos léxicos en inventarios burgaleses del siglo XVII", Cuadernos del Instituto Historia de la Lengua, no 8. pp. 229-240.

Perdiguero Villarreal, Hermógenes (2014): "Tratamiento lexicográfico de vocablos de una almoneda de 1654", en Maria Bargalló Escrivà, María Pilar Garcés Gómez y Cecilio Garriga Escribano (ed.), «Llaneza». Estudios dedicados al profesor Juan Gutiérrez Cuadrado, Anexos de Revista de Lexicografía, no 23, Universidade da Coruña. A Coruña. pp. 145-154.

Perdiguero Villarreal, Hermógenes (2015a). "Léxico de bienes domésticos en documentos notariales del siglo XVII: sustantivos con sufijos diminutivos y variación diatópica" Actas del IX Congreso Internacional de Historia de la Lengua Española (Cádiz, 2012). Iberoamericana: Vervuert. pp. 1565-1578.

Perdiguero Villarreal, Hermógenes (2015b) "Bienes en la recámara: léxico de guarniciones y otros útiles en un inventario burgalés de 1639". en Mạ Pilar Garcés Gómez (ed.), Léxico, historia y diccionarios, Anexos Revista de Lexicografía, no 30, Universidade da Coruña. A Coruña., pp. 299-308.

Perdiguero Villarreal, Hermógenes (2016) "Peculiaridades léxicas en un inventario mirobrigense de 1632", Scriptum Digital, Vol. 5 (2016), pp. 135-145.

Perdiguero Villarreal, Hermógenes (2017) "Voces de elementos y útiles de las herrerías guipuzcoanas en documentos del siglo XVII", Cuadernos del Instituto de Historia de la Lengua, no 10 (2017), pp. 165-181.

Perdiguero Villarreal, Hermógenes (2019) “Voces de medicinas en un inventario de bienes del siglo XVII", en Julia Sanmartín Sáez y Mercedes Quilis Merín (eds.), Retos y avances en 
lexicografía: los diccionarios del español en el eje de la variación lingüística. Normas, anejo 10 , València, pp. 151-158.

PÉReZ TORAL, Marta. (2014): "Huellas de lo oral en documentos notariales turolenses del Siglo de Oro", Archivo de Filología Aragonesa, 70, pp. 145-168.

PÉREZ TORAL, Marta. (2015a): "Las expresiones mesa de manteles y cama de ropa en el siglo XVII: ¿ropa de hogar o mobiliario?”, Anuario de Letras. Lingüística y Filología, vol. III,1. Universidad de Oviedo. Oviedo. pp. 131-167.

PÉREZ TORAL, Marta. (2015b): "Léxico tradicional para la superficie agraria en inventarios del siglo XVII", Revista de Historia de la Lengua Española, 10, pp. 77-103.

PÉRez TORAL, Marta (2016), Precisiones semánticas referidas al léxico de la ganadería en inventarios asturianos del Siglo de Oro, Real Instituto de Estudios Asturianos, Oviedo.

PÉrez TORAL, Marta. (2017a): "Tejidos y textiles en la vida cotidiana del siglo XVII", Revista de Investigación Lingüística, № 20, pp. 195-219.

PÉrez TORAL, Marta (2017b): "A vueltas con el léxico textil inventariado en el Siglo de Oro", Anadiss, numéro hors-série / mai, In Honorem Doctor Honoris Causa Johannes Kabatek, Editura Universitatii "Stefan cel Mare" din Suceava, pp. 89-108.

PÉREZ TORAL, Marta (2017c): "El léxico de tejidos en inventarios notariales del siglo XVII", Revista de Lexicografía, no. 23, Universidade da Coruña. A Coruña. pp. 157-184.

PÉREZ TORAL, Marta (2017d): “¿Escribo como hablo?: variaciones gráficas en el vocalismo tónico en documentos del XVII", Revista Española de Lingüística, no 47/2, pp. 49-69.

PHARIES, David(2002) Diccionario etimológico de los sufijos españoles (y de otros elementos finales). Editorial Gredos. Madrid.

PORRES MARIJUÁN, María Rosario (1996): "Protocolos notariales e investigación. Introducción" en Aproximación metodológica a los protocolos notariales de Álava (Edad Moderna). Coord. por María Rosario Porres Marijuán, Universidad del País Vasco/Euskal Herriko Unibertsitatea, Servicio de Publicaciones, pp. 11-22.

PoundS, Norman J. G. (1999): La vida cotidiana: Historia de la cultura material. Editorial Crítica. Barcelona.

PuCHe LoRenzo, Miguel A. (2012): "Léxico de la vida cotidiana en la Murcia áurea" en Revista Quadernos del Instituto de Historia de la Lengua, no7, Cilengua. San Millán de la Cogolla. pp. 343-359.

Puerta RoselL, M. Fernanda (1994): Platería madrileña. Colecciones de la segunda mitad del siglo XVII. Tomo III (Apéndice Documental). Tesis doctoral. Universidad Complutense de Madrid.

Quirós García, Mariano (2011): “Léxico e inventarios de bienes en el Bilbao del Siglo de Oro” en Oihenart, no. 26, Donostia-San Sebastián. pp. 423-453. 
Quirós GarcíA, Mariano (2012): “El léxico de la ropa blanca en inventarios bilbaínos del Siglo de Oro" en Revista Quadernos del Instituto de Historia de la Lengua no7, Cilengua. San Millán de la Cogolla. pp. 361-392.

RAMíreZ LUENGO, José Luis (2005): "Variación gramatical y tipos textuales: el diminutivo en la época de Don Quijote". Ámbitos: revista de estudios de ciencias sociales y humanidades, n.o 13. pp. 29-34.

RAMIRo Reglero, Elisa (2015) "La porcelana del siglo XVIII. El nacimiento de un nuevo arte", Geconservación, n.o 8, Grupo Español GE-IIC. Madrid. pp. 89-97.

REAL ACADEMIA ESPAÑolA: Fichero general de la lengua Española: Versión en línea Disponible en: http://web.frl.es.

Renedo Prieto, Eugenio (2007). Vocabulario de Frómista (Palencia).

Rodríguez Molina, José; Martínez Plaza, Manuel y Cuevas Mata, Juan (1986): "Precios y Salarios en Jaén en 1627. Pragmática de Felipe IV", Chronica nova: Revista de historia moderna de la Universidad de Granada, n. 15, pp. 365-448.

Rojo VegA, Anastasio: Web Investigadores de la Real Biblioteca. Patrimonio Nacional. Consultada en https://investigadoresrb.patrimonionacional.es/. [Consultado por última vez en diciembre de 2020].

SÁnChez AlBornoz, Claudio (1959): "Tradición y Derecho visigodos en León y Castilla", en Cuadernos de Historia de España, 29-30. Buenos Aires. pp. 243-265.

SÁnCHEZ-PRIETO BORJA, Pedro (2012): "Desarrollo y explotación del "Corpus de Documentos Españoles Anteriores a 1700" (CODEA)". Scriptum digitalrevista de corpus diacrònics i edició digital en llengües iberoromàniques, $\mathrm{n}$. ․ 1. Universitat Autònoma de Barcelona. Barcelona. pp. 5-35.

SESEÑA LA FUeNTE, Natacha (2009): El vicio del barro. Ediciones El Viso, Madrid.

TERREROS Y PANDO, Esteban de (1987): Diccionario castellano con las voces de ciencias y artes. Ed. Facsímil, Arco Libros.

URDIALES, José Millán (1966). El habla de Villacidayo. Anexo del Boletín de la Real Academia (BRAE). Real Academia Española. Madrid.

VACA LORENZO, Ángel (1992): "La Tierra de Campos y sus bases ecológicas en el siglo XIV. Studia Historica. Historia Medieval, v. 10, Ediciones Universidad de Salamanca, Salamanca. pp. 149186.

Vara Gallego, Clemente y Nuevo Cuervo, Carlos (2008-2009): "Vocabulario del valle del Terra" (I), Brigecio: revista de estudios de Benavente y sus tierras, n. 18-19, Centro de Estudios Benaventanos "Ledo del Pozo", pp. 239-267.

VÁzquez BALONGA, Delfina (2015): Léxico en la documentación de Toledo y Madrid en los siglos XVI-XVII. Tesis doctoral. Universidad de Alcalá. 
VERDONK, Robert (2008): "Cambios en el léxico del español durante la época de los Austrias". Historia de la lengua española. Rafael Cano Aguilar (Coord.), 3.a impresión, editorial Ariel, Barcelona. pp. 895-916.

VILLAAMIL Y CASTRO, José (1907): Pasatiempos eruditos. Colección de artículos en su mayoría sobre el mobiliario Litúrgico de las iglesias gallegas, en la Edad Media, Madrid.

VIVANCOS MULERO, María Esther (2013): La lengua del repoblador. Estudio histórico-lingüístico y tipología documental en el oriente del Reino de Granada. La Tierra de Vera (siglos XVI-XVII, Tesis doctoral. Universidad de Granada. Granada.

YUN CASALILLA, Bartolomé (1987): Sobre la transición al capitalismo en Castilla. Economía y sociedad en Tierra de Campos (1500-1830). Consejería de Educación y Cultura. Junta de Castilla y León.

ZAMORA VICENTE, Alonso (1974): Dialectología española, Gredos, Madrid. 

ANEXOS 



\section{ANEXO 1 FUENTES DOCUMENTALES}

\section{Fuentes documentales}

Todos los documentos pertenecen a los Archivos Históricos Provinciales de León, Palencia, Valladolid y Zamora. La relación de los mismos que se detalla a continuación está agrupada por partidos judiciales. Dentro de cada partido judicial se organizan los documentos de acuerdo al lugar en el que se encuentra la notaría a la que pertenece el propietario del inventario, testamento, partija, etc., el año, la caja, la signatura y el número de folio en el que se encuentra. En algunos no es posible ya que debido al deterioro del documento no se aprecia este dato. Finalmente se señala en la mayoría de los casos el tipo de documento sobre el que se ha trabajado (inventario, carta de dote, etc.).

A continuación, se presenta el listado de los 585 documentos localizados. Su distribución por provincias es la siguiente:

- 87 documentos de León,

- 208 de Palencia,

- 165 de Valladolid y

- 125 de Zamora. 



\section{A1.1. ARCHIVO HISTÓRICO PROVINCIAL DE LEÓN Partido Judicial Sahagún (León)}

P. N. Miguel Alonso Sanjuán. Castrillo, 1606. Caja 4139, sig. 105, fol. 1-3. (Inventario de bienes). P. N. Miguel Alonso Sanjuán. Sahagún, 1606. Caja 4139, sig. 105, fol. 68-72 recto (Obligación).

P. N. Miguel Alonso Sanjuán. Castrillo, año 1606. Caja 4139, sig. 105, fol. 88 vuelto -115 recto. (Entrega de bienes).

P.N. Miguel Alonso. Valdavida, año 1606. Caja 4140, sig. 120, fol. 8-18 recto. (Inventario de bienes).

P.N. Miguel Alonso. Valdavida, año 1606. Caja 4140, sig. 120, fol. 39-40 recto. (Inventario de bienes).

P.N. Miguel Alonso. Castromudarra, año 1606. Caja 4140, sig. 120, fol. 55-56 recto (Inventario de bienes).

P.N. Miguel Alonso. Valdavida, año 1606. Caja 4140, sig. 120, fol. 67-68 recto (Inventario de bienes).

P.N. Miguel Alonso. Celada, año 1607. Caja 4140, sig. 123, fol. 7-8 recto (Inventario de bienes).

P.N. Miguel Alonso. Santa María del Río, 1607. Caja 4140, sig. 125, fol. 2-8 (Inventario de bienes).

P.N. Miguel Alonso Sanjuán. Castroañe, 1609. Caja 4141, sig. 135, fol. 2-9 (Inventario de bienes). P.N. Miguel Alonso Sanjuán. Riosequillo, 1609. Caja 4141, sig. 137, fol. 137-143 recto (inventario de bienes).

P.N. Miguel Alonso Sanjuán. Carvajal, 1609. Caja 4141, sig. 137, fol. 60. (Inventario de Bienes).

P.N. Miguel Alonso Sanjuán. Riosequillo, 1609. Caja 4141, sig. 137, fol. 67 (Inventario de bienes).

P.N. Miguel Alonso Sanjuán. Riosequillo, 1609. Caja 4141, sig. 137, fol. 81 recto (Inventario de bienes).

P.N. Miguel Alonso Sanjuán. Cea, 1609. Caja 4141, sig. 137, fol. 144-156 recto (Inventario de bienes).

P.N. Miguel Alonso Sanjuán. Villacalabuey, 1614, Caja 4142, sig. 147, fol. 6 (Inventario de bienes). P.N. Miguel Alonso Sanjuán. Cea, 1614, Caja 4142, sig. 147, fol. 7 (Memoria de bienes).

P.N. Miguel Alonso Sanjuán. Sahagún, 1614, Caja 4142, sig. 148, fol. 6 (Inventario de bienes).

P.N. Miguel Alonso Sanjuán. Villavelasco, 1614, Caja 4142, sig. 148, fol. 116-117 recto (Almoneda).

P.N. Miguel Alonso Sanjuán. Sahagún, 1615. Caja 4142, sig. 149, fol. 33 vuelto -34 (Inventario de bienes).

P.N. Miguel Alonso Sanjuán. Sahagún, 1615. Caja 4142, sig. 149, fol. 35-36 (Entrega de bienes muebles).

P.N. Miguel Alonso Sanjuán. Sahagún, 1615. Caja 4142, sig. 151, fol. 16 recto (Memoria de bienes).

P.N. Miguel Alonso Sanjuán. Grajal de Campos, 1616. Caja 4142, sig. 153, fol. 3-5 recto (Inventario de bienes).

P.N. Miguel Alonso Sanjuán. Santa María del Río, 1617. Caja 4143, sin signatura, fol. 1-5 recto (Partija). 
P.N. Miguel Alonso Sanjuán. ¿Sahagún?, 1617?. Caja 4143, sig. 155, fol. 5-10 (Tasación de bienes muebles e inmuebles).

P.N. Miguel Alonso Sanjuán. Cea, 1621. Caja 4144, sig. 169, fol. 3-14 recto (Inventario de bienes). P.N. Miguel Alonso Sanjuán. Castroañe, 1625?. Caja 4144, sig. 155, fol. 55-57 (Inventario de bienes).

P.N. Miguel Alonso Sanjuán. Sahagún?, 1623. Caja 4145, sig. 180, fol. 3 (Inventario de bienes). P.N. Miguel Alonso Sanjuán. Sahagún?, 1624. Caja 4145, sig. 183, s.f. (Inventario de bienes). P.N. Miguel Alonso Sanjuán. Celada, 1624. Caja 4145, sig. 184, s.f. (Inventario de bienes). P.N. Miguel Alonso Sanjuán. Sahagún?, 1626. Caja 4145, sig. 187, s.f. (Inventario de bienes). P.N. Miguel Alonso Sanjuán. Sahagún?, 1626. Caja 4145, sig. 187, s.f. (entrega de bienes). P.N. Miguel Alonso Sanjuan. San Pedro de Valderaduey, 1626. Caja 4145, sig. 187, s.f. (almoneda).

P.N. Miguel Alonso Sanjuán. Sahagún?, 1626. Caja 4145, sig. 188, fol. 131-133 (tasación).

P.N. Miguel Alonso Sanjuán. Cea, 1626. Caja 4145, sig. 188, fol. 137-142 (Inventario de bienes). P.N. Miguel Alonso Sanjuán. Cea, 1627. Caja 4146, sig. 191, fol. 1-6 recto (Inventario de bienes). P.N. Miguel Alonso Sanjuán. Villadiego, 1627. Caja 4146, sig. 190, fol. 3-6 recto (almoneda). P.N. Miguel Alonso Sanjuán. Sahagún?, 1627. Caja 4146, sig. 190, fol. 17-18 (entrega de bienes). P.N. Miguel Alonso Sanjuán. Cea, 1627. Caja 4146, sig. 190, fol. 19 (Inventario de bienes). P.N. Miguel Alonso Sanjuán. Castroañe, 1629. Caja 4146, sig. 192, fol. 204-215 recto (Almoneda de bienes).

P.N. Miguel Alonso Sanjuán. San Nicolás del Camino Francés, 1631. Caja 4146, sig. 196, fol. 3942 (Inventario de bienes).

P.N. Miguel Alonso Sanjuán. Joara, 1632. Caja 4146, sig. 196, fol. 19-20 (Inventario de bienes). P.N. Miguel Alonso Sanjuán. Sahagún?, 1633. Caja 4146, sig. 197, fol. 34-35 recto (Memorial de bienes).

P.N. Miguel Alonso Sanjuán. Sahagún?, 1633. Caja 4146, sig. 197, fol. 223-232 (Relación de bienes).

P.N. Juan Fernández. Sahagún?, 1601. Caja 4147, sig. 199, fol. 9-10 (Inventario de bienes). P.N. Juan Fernández. Sahagún?, 1601. Caja 4147, sig. 199, fol. 50-52 (Inventario de bienes). P.N. Juan Fernández. Sahagún?, 1601. Caja 4147, sig. 199, fol. 73-74 (Inventario de bienes). P.N. Juan Fernández. Sahagún?, 1601. Caja 4147, sig. 199, fol. 104-106 (Inventario de bienes). P.N. Juan Fernández. Sahagún?, 1608. Caja 4147, sig. 200, fol. 214-219 (Inventario de bienes). P.N. Juan Fernández. Villemar, 1608. Caja 4147, sig. 200, fol. 228-231 (Inventario de bienes). P.N. Juan Fernández. Sahagún?, 1608. Caja 4147, sig. 200, fol. 279-284 (Inventario de bienes). P.N. Juan Fernández. Grajal de Campos, 1613. Caja 4147, sig. 201, fol. 34-36 (Inventario de bienes).

P.N. Juan Fernández. Grajal de Campos, 1613. Caja 4147, sig. 201, fol. 104-107 (Inventario de bienes).

P.N. Andrés de Prado. Sahagún, 1600. Caja 4148, sig. 208, fol. 393-394 (Inventario de bienes). P.N. Andrés de Prado. Sahagún, 1600. Caja 4148, sig. 208, fol. $70-78$ (Inventario de bienes). P.N. Andrés de Prado. Sahagún, 1600. Caja 4148, sig. 208, fol. 80-87 recto (Inventario de bienes). 
P.N. Andrés de Prado. Sahagún, 1600. Caja 4148, sig. 208, fol. 105-108 recto (Inventario de bienes).

P.N. Andrés de Prado. Sahagún, 1600. Caja 4148, sig. 208, fol. 109-114 (Inventario de bienes).

P.N. Andrés de Prado. Sahagún, 1601. Caja 4148, sig. 210, fol. 431 (Inventario de bienes).

P.N. Andrés de Prado. Calzada, 1601. Caja 4148, sig. 210, fol. 437-439 (Inventario de bienes).

P.N. Juan Fernández. Sahagún?, 1613. Caja 4148, sig. 202, fol. 255-256 (Inventario de bienes).

P.N. Juan Fernández. Arenillas, 1636. Caja 4148, sig. 203, fol. 7-13 recto (Carta de inventario).

P.N. Andrés de Prado. Sahagún, 1602. Caja 4149, sig. 212, fol. 237 vuelto-239 recto (Inventario de bienes).

P.N. Andrés de Prado. Sahagún, 1604. Caja 4150, sin signatura, fol. 435-437 recto (Inventario de bienes).

P.N. Andrés de Prado. Sahagún, 1605. Caja 4151, libro 1, fol. 210-211 (Inventario de bienes).

P.N. Andrés de Prado. Sahagún, 1605. Caja 4151, libro 1, fol. 414-418 recto (Inventario de bienes).

P.N. Andrés de Prado. Sahagún, 1605. Caja 4151, libro 1, fol. 419-421 (Inventario de bienes).

P.N. Andrés de Prado. Sahagún, 1605. Caja 4151, libro 1, fol. 466-468 (Inventario de bienes).

P.N. Andrés de Prado. Sahagún, 1605. Caja 4151, libro 1, fol. 539-540 (Inventario de bienes).

P.N. Andrés de Prado. Sahagún, 1605. Caja 4152, sin signatura, fol. 444-447 recto (Inventario de bienes).

P.N. Andrés de Prado. Sahagún, 1608. Caja 4152, sin signatura, fol. 439-443 recto (Inventario de bienes).

P.N. Manuel Almansa. Galleguillos, 1618. Caja 4221, sig. 600, fol. 4-6 (Inventario de bienes).

P.N. Manuel Almansa. Sahagún?, 1618. Caja 4221, sig. 600, fol. 17 (Inventario de bienes).

P.N. Dámaso Baeza. Grajal de Campos, 1655. Caja 4239, sin signatura, fol. 174-177 (Inventario de bienes).

P.N. Dámaso Baeza. Grajal de Campos, 1656. Caja 4239, sin signatura, fol. 123-136 (Inventario de bienes).

P.N. Dámaso Baeza. Grajal de Campos, 1657. Caja 4239, sin signatura, fol. 152 (Inventario de bienes).

P.N. Dámaso Baeza. Grajal de Campos, 1657. Caja 4239, sin signatura, fol. 217-220 (Inventario de bienes).

P.N. Dámaso Baeza. Grajal de Campos, 1657. Caja 4239, sin signatura, fol. 221-230 (Inventario de bienes).

P.N. Dámaso Baeza. Grajal de Campos, 1658. Caja 4239, sig. 686, fol. 143-144 (Inventario de bienes).

P.N. Dámaso Baeza. Grajal de Campos, 1658. Caja 4239, sin signatura, fol. 37 (Inventario de bienes).

P.N. Dámaso Baeza. Grajal de Campos, 1658. Caja 4239, sin signatura, fol. 38 (Inventario de bienes). 
P.N. Francisco Baeza. Grajal de Campos, 1670. Caja 4260, sig. 825, fol. 7-10 recto (Inventario de bienes).

P.N. Francisco Baeza. Grajal de Campos, 1670. Caja 4260, sig. 825, fol. 27-32 (Inventario de bienes).

P.N. Francisco Baeza. Grajal de Campos, 1670. Caja 4260, sig. 825, fol. 33-36 (Inventario de bienes).

P.N. Francisco Baeza. Grajal de Campos, 1670. Caja 4260, sig. 825, fol. 37-42 (Inventario de bienes).

P.N. Francisco Herrero. Valderas, 1660. Caja 5155, sig. 690, fol. 43-44 (Inventario de bienes).

P.N. Alonso de Escobar. Valderas, 1682. Caja 6051, sig. 2312, fol. 458-462 recto (Inventario de bienes). 


\section{A1.2. ARCHIVO HISTÓRICO PROVINCIAL DE PALENCIA Partido Judicial de Frechilla (Palencia)}

P. N. Juan de Abastas. Frechilla, 1619. Libro 1619, sig. 2106, fol. 143-144, (Inventario de bienes).

P. N. Juan de Abastas. Mazariegos, 1619. Libro 2529, sig. 2106, sin foliar, (Inventario de bienes).

P. N. Miguel Abero. Frechilla, 1612. Libro 2538, sig. 2112, fol. 95 vuelto-96 (Inventario de bienes). P. N. Miguel Abero. Frechilla, 1612. Libro 2538, sig. 2112, fol. 117-123 (Inventario de bienes). P. N. Miguel Abero. Frechilla, 1612. Libro 2538, sig. 2112, fol. 124-127 (Inventario de bienes). P. N. Miguel Abero. Frechilla, 1612. Libro 2538, sig. 2112, fol. 142-145 recto (Cuerpo de hacienda).

P. N. Miguel Abero. Frechilla, 1612. Libro 2538, sig. 2112, fol. 251-252 (Inventario de bienes).

P. N. Miguel Abero. Frechilla, 1613. Libro 2538, sig. 2112, fol. 328-329 (Inventario de bienes).

P. N. Miguel Abero. Frechilla, 1613. Libro 2538, sig. 2112, fol. 330-331 recto (Inventario de bienes).

P. N. Miguel Abero. Frechilla, 1613. Libro 2538, sig. 2112, fol. 331 vuelto-332 (continua del inventario anterior).

P. N. Miguel Abero. Frechilla, 1613. Libro 2538, sig. 2112, fol. 334 vuelto-339 recto (continua del inventario anterior).

P. N. Miguel Abero. Frechilla, 1613. Libro 2538, sig. 2112, fol. 348 vuelto-350 (cuerpo de bienes).

P. N. Miguel Abero. Frechilla, 1635. Libro: 1637, sig. 2125, fol. 1-2, (Partija).

P. N. Miguel Abero. Frechilla, 1637. Libro: 1637, sig. 2125, fol. 5-7 recto, (Inventario de bienes).

P. N. Miguel Abero. Frechilla, 1637. Libro: 1637, sig. 2125, fol. 9-11, (Almoneda).

P. N. Miguel Abero. Frechilla, 1638. Libro: 2410, sig. 2125, fol. 100-101, (Inventario de bienes).

P. N. Miguel Abero. Frechilla, 1639. Libro: 1639, sig. 2125, fol. 20 vuelto - 24 recto, (Inventario de bienes).

P. N. Miguel Abero. Frechilla, 1639. Libro: 1639, sig. 2125, fol. 25 vuelto - 27 recto, (Inventario de bienes).

P. N. Miguel Abero. Frechilla, 1639. Libro: 1639, sig. 2125, fol. 27, (Inventario de bienes).

P. N. Miguel Abero. Frechilla, 1639. Libro: 1639, sig. 2125, fol. 30, (Cuerpo de bienes).

P. N. Miguel Abero. Frechilla, 1639. Libro: 1639, sig. 2125, fol. 79, (Inventario de bienes).

P. N. Miguel Abero. Frechilla, 1639. Libro: 1639, sig. 2125, fol. 115-120 recto, (Bienes materiales).

P. N. Miguel Abero. Frechilla, 1639. Libro: 1639, sig. 2125, fol. 124-126, (Deudas).

P. N. Miguel Abero. Frechilla, 1636-1640 (aparecen las dos fechas). Libro 1: 2556, sig. 2125, sin foliar, (Partija que aparece suelta entre el libro 2556).

P. N. Miguel Abero. Frechilla, 1640. Libro: 1640, sig. 2125, fol. 26-32, (Inventario de bienes y fianza).

P. N. Miguel Abero. Frechilla, 1640. Libro: 1640, sig. 2125, fol. 105-109, (Cuerpo de bienes).

P. N. Miguel Abero. Frechilla, 1642. Libro 1: 2556, sig. 2125, fol. 24-25 recto (Inventario de bienes). 
P. N. Miguel Abero. Frechilla, 1642. Libro 1: 2556, sig. 2125, fol. 86-88 (Inventario de bienes). P. N. Miguel Abero. Frechilla, 1642. Libro 1: 2556, sig. 2125, fol. 98 vuelto-101 (Inventario de bienes).

P. N. Francisco Andrés. Villarramiel, 1694. Libro: -, sig. 2183, fol. 1-2 (Almoneda).

P. N. Francisco Andrés. Villarramiel, 1694. Libro: -, sig. 2183, fol. 73-74 (Inventario de bienes).

P. N. Francisco Andrés. Villarramiel, 1694. Libro: -, sig. 2183, fol. 75 (Inventario de bienes).

P. N. Francisco Andrés. Villarramiel, 1694. Libro: -, sig. 2183, fol. 76 (Inventario de bienes).

P. N. Francisco Andrés. Villarramiel, 1696. Libro: -, sig. 2184, fol. 62 (Inventario de bienes).

P. N. Francisco Andrés. Villarramiel, 1696. Libro: -, sig. 2184, fol. 63 (Inventario de bienes).

P. N. Francisco Andrés. Villarramiel, 1696. Libro: -, sig. 2184, fol. 64-65 recto (Inventario de bienes).

P. N. Francisco Andrés. Villarramiel, 1696. Libro: -, sig. 2184, fol. 66-67 (Inventario de bienes).

P. N. Francisco Andrés. Villarramiel, 1696. Libro: -, sig. 2184, fol. 68 (Inventario de bienes).

P. N. Francisco Andrés. Villarramiel, 1696. Libro: -, sig. 2184, fol. 69 (Inventario de bienes).

P. N. Alonso Andrés. Guaza de Campos, 1637. Libro: 2652, sig. 2201, fol. 26 (Inventario de bienes).

P. N. Alonso Andrés. Guaza de Campos, 1637. Libro: 2652, sig. 2201, fol. 32-33 recto (Inventario de bienes).

P. N. Alonso Andrés. Guaza de Campos, 1637. Libro: 2652, sig. 2201, fol. 99 (Inventario de bienes).

P. N. Alonso Andrés. Guaza de Campos, 1637. Libro: 2652, sig. 2201, fol. 89 (Inventario de bienes).

P. N. Alonso Andrés. Guaza de Campos, 1637. Libro: 2652, sig. 2201, fol. 91-92 recto (Inventario de bienes).

P. N. Alonso Andrés. Guaza de Campos, 1637. Libro: 2652, sig. 2201, fol. 93-94 recto (Inventario de bienes).

P. N. Alonso Andrés. Guaza de Campos, 1639. Libro: 2653, sig. 2201, fol. 72 (Inventario de bienes).

P. N. Alonso Andrés. Guaza de Campos, 1639. Libro: 2653, sig. 2201, fol. 83-84 recto (Inventario de bienes).

P. N. Alonso Andrés. Guaza de Campos, 1639. Libro: 2653, sig. 2201, fol. 87 (Inventario de bienes).

P. N. Alonso Andrés. Guaza de Campos, 1640. Libro: 2654, sig. 2201, fol. 67-69 recto (Inventario de bienes).

P. N. Alonso Andrés. Guaza de Campos, 1640. Libro: 2654, sig. 2201, fol. 80-81 (Inventario de bienes).

P. N. Alonso Andrés. Guaza de Campos, 1642. Libro: 2655, sig. 2201, fol. 116 (Inventario de bienes).

P. N. Alonso Andrés Guerra. Autillo de Campos, 1649. Libro: Libro 1, sig. 2209, fol. sin foliar (Inventario de bienes). 
P. N. Alonso Andrés Guerra. Autillo de Campos, 1650. Libro: Libro 1, sig. 2209, fol. sin foliar (Carta de pago).

P. N. Alonso Andrés Guerra. Autillo de Campos, 1651. Libro: Libro 2, sig. 2209, fol. 3-4 recto (Inventario de bienes).

P. N. Alonso Andrés Guerra. Autillo de Campos, 1649. Libro: Libro 2, sig. 2209, fol. sin foliar (Inventario de bienes).

P. N. Alonso Andrés Guerra. Autillo de Campos, 1649. Libro: Libro 2, sig. 2209, fol. sin foliar (Tasación y carta de pago).

P. N. Alonso Andrés Guerra. Autillo de Campos, 1653. Libro: Libro 3, sig. 2209, fol. 4-9 recto (Inventario de bienes).

P. N. Alonso Andrés Guerra. Autillo de Campos, 1653. Libro: Libro 3, sig. 2209, fol. 9 (Inventario de bienes).

P. N. Alonso Andrés Guerra. Autillo de Campos, 1653. Libro: Libro 3, sig. 2209, fol. 60-68 (Inventario de bienes y almoneda).

P. N. Alonso Andrés Guerra. Autillo de Campos, 1646. Libro: Libro 4, sig. 2209, fol. 5 vuelto-8 (Inventario de bienes).

P. N. Alonso Andrés Guerra. Autillo de Campos, 1647. Libro: Libro 4, sig. 2209, fol. sin foliar (Inventario de bienes).

P. N. Alonso Andrés Guerra. Autillo de Campos, 1649. Libro: Libro 4, sig. 2209, fol. sin foliar (Tasación de bienes).

P. N. Alonso Andrés Guerra. Autillo de Campos, 1649. Libro: Libro 4, sig. 2209, fol. sin foliar (Inventario de bienes).

P. N. Alonso Andrés Guerra. Autillo de Campos, 1648. Libro: Libro 4, sig. 2209, fol. sin foliar (Inventario de bienes).

P. N. Alonso Andrés Guerra. Autillo de Campos, 1642. Libro: Libro 4, sig. 2209, fol. sin foliar (Inventario de bienes).

P. N. Alonso Andrés Guerra. Autillo de Campos, 1647. Libro: Libro 4, sig. 2209, fol. sin foliar (Tasación de bienes).

P. N. José Antonio Avilés. Paredes de Nava, 1690. Legajo: 2728, sig. 2253, fol. 23-28 recto (Inventario de bienes).

P. N. José Antonio Avilés. Paredes de Nava, 1690. Legajo: 2728, sig. 2253, fol. 45-54 recto (Inventario de bienes).

P. N. José Antonio Avilés. Paredes de Nava, 1690. Legajo: 2728, sig. 2253, fol. 130-131 recto (Memoria de bienes).

P. N. José Antonio Avilés. Paredes de Nava, 1690. Legajo: 2728, sig. 2253, fol. 160-163 (Inventario de bienes).

P. N. José Antonio Avilés. Paredes de Nava, 1689. Libro: -, sig. 2253, fol. $64-72$ (Inventario de bienes).

P. N. José Antonio Avilés. Paredes de Nava, 1689. Libro: -, sig. 2253, fol. 104-105 (Inventario de bienes).

P. N. José Antonio Avilés. Paredes de Nava, 1695. Libro: -, sig. 2253, fol. 103-106 (Cuentas y particiones de bienes). 
P. N. José Antonio Avilés. Paredes de Nava, 1695. Libro: -, sig. 2253, fol. 155-162 (Parte de un documentos donde se registran bienes para pagar deudas).

P. N. Alonso Bachiller. Boadilla de Rioseco, 1689. Libro: -, sig. 2261, fol. 19-20 (Inventario de bienes).

P. N. Alonso Bachiller. Boadilla de Rioseco, 1689. Libro: -, sig. 2261, fol. 32 (Inventario de bienes). P. N. Alonso Bachiller. Boadilla de Rioseco, 1690. Libro: -, sig. 2261, fol. 101 (Inventario de bienes).

P. N. Alonso Bachiller. Boadilla de Rioseco, 1692. Libro: -, sig. 2261, fol. 144-149 (Inventario de bienes).

P. N. Alonso Bachiller. Boadilla de Rioseco, 1687. Legajo: 2738, sig. 2261, fol. 58-60 recto (Inventario de bienes).

P. N. Juan Bárcena. Castromocho, 1602. Libro: 1, sig. 2286, fol. 83-85 (Inventario de bienes).

P. N. Juan Bárcena. Castromocho, 1602. Libro: 1, sig. 2286, fol. 86-87 (Almoneda).

P. N. Juan Bárcena. Castromocho, 1602. Libro: 1, sig. 2286, fol. 204-206 (Casamiento).

P. N. Juan Bárcena. Castromocho, 1602. Libro: 1, sig. 2286, fol. 257-260 recto (Inventario de bienes).

P. N. Juan Bárcena. Castromocho, 1602. Libro: 1, sig. 2286, fol. 261-262 recto (Casamiento).

P. N. Juan Bárcena. Castromocho, 1602. Libro: 1, sig. 2286, fol. 264-265 (Inventario de bienes).

P. N. Juan Bárcena. Castromocho, 1602. Libro: 1, sig. 2286, fol. 268-269 recto (Almoneda).

P. N. Juan Bárcena. Castromocho, 1603. Libro: 2, sig. 2286, fol. 25-26 (Casamiento).

P. N. Juan Bárcena. Castromocho, 1603. Libro: 2, sig. 2286, fol. 27-29 (Casamiento).

P. N. Juan Bárcena. Castromocho, 1603. Libro: 2, sig. 2286, fol. 95-96 (Inventario de bienes).

P. N. Juan Bárcena. Castromocho, 1603. Libro: 2, sig. 2286, fol. 131-132 (Inventario de bienes).

P. N. Juan Bárcena. Castromocho, 1603. Libro: 2, sig. 2286, fol. 140-141 (Inventario de bienes).

P. N. Juan Bárcena. Castromocho, 1603. Libro: 2, sig. 2286, fol. 218-220 recto (Inventario de bienes).

P. N. Juan Bárcena. Castromocho, 1614. Libro: 2, sig. 2286, fol. 219-222 recto (Inventario de bienes).

P. N. Juan Bárcena. Castromocho, 1614. Libro: 2, sig. 2286, fol. 226-227 recto (Inventario de bienes).

P. N. Juan Bárcena. Castromocho, 1614. Libro: 2, sig. 2286, fol. 232-234 (Inventario de bienes).

P. N. Juan Bárcena. Castromocho, 1614. Libro: 2, sig. 2286, fol. 330-331 (Inventario de bienes).

P. N. Juan Bárcena. Castromocho, 1614. Libro: 2, sig. 2286, fol. 332-333 (Almoneda).

P. N. Juan Bárcena. Castromocho, 1614. Libro: 2, sig. 2286, fol. 342-343 (Inventario de bienes).

P. N. Juan Bárcena. Castromocho, 1614. Libro: 2, sig. 2286, fol. 352-353 recto (Inventario de bienes).

P. N. Juan Bárcena. Castromocho, 1611. Libro: 1, sig. 2290, fol. sin foliar (Inventario de bienes).

P. N. Juan Bárcena. Castromocho, 1611. Libro: 1, sig. 2290, fol. sin foliar (Memoria de inventarios).

P. N. Juan Bárcena. Castromocho, 1611. Libro: 1, sig. 2290, fol. sin foliar (Almoneda). 
P. N. Juan Bárcena. Castromocho, 1611. Libro: 2, sig. 2290, fol. sin foliar ( ).

P. N. Juan Bárcena. Castromocho, 1611. Libro: 2, sig. 2290, fol. sin foliar (Inventario de bienes).

P. N. Juan Bárcena. Castromocho, 1611. Libro: 2, sig. 2290, fol. sin foliar (Inventario de bienes).

P. N. Juan Bárcena. Castromocho, 1611. Libro: 2, sig. 2290, fol. sin foliar (Dote).

P. N. Juan Bárcena. Castromocho, 1611. Libro: 5, sig. 2290, fol. $92-93$ (Inventario de bienes).

P. N. Juan Bárcena. Castromocho, 1611. Libro: 5, sig. 2290, fol. 123-128 recto (Inventario de bienes).

P. N. Juan Bárcena. Castromocho, 1611. Libro: 5, sig. 2290, fol. 158-160 (Memoria de heredades).

P. N. Juan Bárcena. Castromocho, 1612. Libro: 6, sig. 2290, fol. 12-15 (Tasación de bienes).

P. N. Juan Bárcena. Castromocho, 1612. Libro: 6, sig. 2290, fol. 43-44 recto (Inventario de bienes).

P. N. Juan Bárcena. Castromocho, 1612. Libro: 6, sig. 2290, fol. 64-68 recto (Almoneda).

P. N. Juan Bárcena. Castromocho, 1612. Libro: 6, sig. 2290, fol. 214-215 recto (Inventario de bienes).

P. N. Juan Bárcena. Castromocho, 1612. Libro: 6, sig. 2290, fol. 238-239 (Almoneda).

P. N. Juan Bárcena. Castromocho, 1612. Libro: 6, sig. 2290, fol. 249 (Inventario de bienes).

P. N. Juan Bárcena. Castromocho, 1612. Libro: 6, sig. 2290, fol. 250-251 (Almoneda).

P. N. Juan Bárcena. Castromocho, 1612. Libro: 6, sig. 2290, fol. 352-353 (Inventario de bienes).

P. N. Juan Bárcena. Castromocho, 1612. Libro: 6, sig. 2290, fol. 358-359 (Almoneda).

P. N. Juan Bárcena. Castromocho, 1620. Libro: 2, sig. 2293, fol. 86-87 (Inventario de bienes).

P. N. Juan Bárcena. Castromocho, 1620. Libro: 2, sig. 2293, fol. 106-107 (Casamineto).

P. N. Juan Bárcena. Castromocho, 1603. Libro: 2, sig. 2293, fol. 155-156 (Carta de pago).

P. N. Juan Bárcena. Castromocho, 1619. Libro: 3, sig. 2293, fol. 40-41 (Recibo de dote).

P. N. Juan Bárcena. Castromocho, 1619. Libro: 3, sig. 2293, fol. 86-87 (Inventario de bienes).

P. N. Juan Bárcena. Castromocho, 1619. Libro: 3, sig. 2293, fol. 98 (Memoria de bienes).

P. N. Juan Bárcena. Castromocho, 1619. Libro: 3, sig. 2293, fol. 99-101 recto (Inventario de bienes).

P. N. Juan Bárcena. Castromocho, 1619. Libro: 3, sig. 2293, fol. 209-210 recto (Recibo de dote).

P. N. Juan Bárcena. Castromocho, 1619. Libro: 3, sig. 2293, fol. 215-216 (Recibo de dote).

P. N. Juan Bárcena. Castromocho, 1619. Libro: 3, sig. 2293, fol. 217-218 ( ).

P. N. Juan Bárcena. Castromocho, 1619. Libro: 3, sig. 2293, fol. 243-246 recto (Recibo de dote).

P. N. Juan Bárcena. Castromocho, 1619. Libro: 3, sig. 2293, fol. 262-264 recto (Inventario de bienes).

P. N. Juan Bárcena. Castromocho, 1619. Libro: 3, sig. 2293, fol. 310-311 (Recibo de dote).

P. N. Juan Bárcena. Castromocho, 1618. Libro: 3, sig. 2293, fol. 315-318 (Inventario de bienes).

P. N. Juan Bárcena. Castromocho, 1618. Libro: 3, sig. 2293, fol. 319-323 (Almoneda).

P. N. Juan Bárcena. Castromocho, 1618. Libro: 3, sig. 2293, fol. 325-326 recto (Memoria de bienes).

P. N. Juan Bárcena. Castromocho, 1618. Libro: 4, sig. 2293, fol. 125-126 (Inventario de bienes).

P. N. Juan Bárcena. Castromocho, 1618. Libro: 4, sig. 2293, fol. 148-151 (Casamiento).

P. N. Juan Bárcena. Castromocho, 1618. Libro: 4, sig. 2293, fol. 199 (Inventario de bienes).

P. N. Juan Bárcena. Castromocho, 1618. Libro: 4, sig. 2293, fol. 204-208 (Inventario de bienes). 
P. N. Juan Bárcena. Castromocho, 1618. Libro: 4, sig. 2293, fol. 209-212 (Almoneda).

P. N. Juan Bárcena. Castromocho, 1618. Libro: 4, sig. 2293, fol. 223-226 (Inventario de bienes).

P. N. Alonso Blanco. Boadilla de Rioseco, 1641. Libro: -, sig. 2311, fol. $89-91$ (Inventario de bienes).

P. N. Alonso Blanco. Boadilla de Rioseco, 1641. Libro: -, sig. 2311, fol. 104-108 (Inventarios de bienes).

P. N. Alonso Blanco. Boadilla de Rioseco, 1643. Libro: 2, sig. 2311, fol. 10 (Inventario de bienes). P. N. Alonso Blanco. Boadilla de Rioseco, 1643. Libro: 2, sig. 2311, fol. 146-147 recto (Inventario de bienes).

P. N. Alonso Blanco. Boadilla de Rioseco, 1658-59. Libro: 2846, sig. 2315, fol. 39 (Inventario de bienes).

P. N. Alonso Blanco. Boadilla de Rioseco, 1659. Libro: 2847, sig. 2315, fol. 189-190 (Inventario de bienes).

P. N. Alonso Blanco. Boadilla de Rioseco, 1659. Libro: 2847, sig. 2315, fol. 217-218 (Inventario de bienes).

P. N. Pablo Calonge. Frechilla, 1631. Libro: 3117, sig. 2500, fol. 251-253 recto (Inventario de bienes).

P. N. Pablo Calonge. Frechilla, 1631. Libro: 3117, sig. 2500, fol. 245-246 recto (Almoneda).

P. N. Pablo Calonge. Frechilla, 1631. Libro: 3117, sig. 2500, fol. 215-219 (Inventario de bienes).

P. N. Pablo Calonge. Frechilla, 1631. Libro: 3117, sig. 2500, fol. 169 (Inventario de bienes).

P. N. Pablo Calonge. Frechilla, 1631. Libro: 584, sig. 2500, fol. 279 (Inventario de bienes).

P. N. Pablo Calonge. Frechilla, 1631. Libro: 584, sig. 2500, fol. 126-129 (Inventario de bienes).

P. N. Pablo Calonge. Frechilla, 1631. Libro: 584, sig. 2500, fol. 11-17 (Inventario de bienes).

P. N. Juan Calvo Escobar. Baquerín de Campos, 1655. Libro: -, sig. 2515, fol. sin foliar (Inventario de bienes).

P. N. Juan Calvo Escobar. Baquerín de Campos, 1660. Libro: -, sig. 2515, fol. sin foliar (Inventario de bienes).

P. N. Francisco Crespo. Villada, 1665. Libro: - , sig. 2659, fol. 347-348 recto (Carta de pago de bienes).

P. N. Francisco Crespo. Villada, 1665. Libro: - , sig. 2659, fol. 356-357 recto (Carta de pago de bienes).

P. N. Francisco Crespo. Villada, 1665. Libro: - , sig. 2659, fol. 359 (Carta de pago de bienes).

P. N. Francisco Crespo. Villada, 1665. Libro: - , sig. 2659, fol. 360 (Carta de pago de bienes).

P. N. Francisco Crespo. Villada, 1665. Libro: - , sig. 2659, fol. 439-440 (Inventario de bienes).

P. N. Francisco Crespo. Villada, 1665. Libro: - , sig. 2659, fol. 474-475 (Inventario de bienes).

P. N. Francisco Crespo. Villada, 1668. Libro: - , sig. 2662, fol. 175-176 recto (Inventario de bienes y tasación).

P. N. Francisco Crespo. Villada, 1668. Libro: - , sig. 2662, fol. 205-206 recto (Inventario de bienes y tasación).

P. N. Francisco Crespo. Villada, 1669. Libro: - , sig. 2662, fol. 325-328 (Inventario de bienes). 
P. N. Francisco Crespo. Villada, 1669. Libro: - , sig. 2662, fol. 336 (Inventario de bienes).

P. N. Francisco Crespo. Villada, 1669. Libro: - , sig. 2662, fol. 372-373 (Inventario de bienes).

P. N. Francisco Crespo. Villada, 1669. Libro: - , sig. 2662, fol. 391-393 recto (Inventario de bienes).

P. N. Francisco Crespo. Villada, 1669. Libro: - , sig. 2662, fol. 399-400 recto (Inventario de bienes y tasación).

P. N. Francisco Crespo. Villada, 1669. Libro: - , sig. 2662, fol. 403-405 recto (Inventario de bienes y tasación).

P. N. Francisco Ejado. Frechilla, 1612. Libro: 3439, sig. 2756, fol. 88 vuelto- 99 (Inventario de bienes y tasación).

P. N. Francisco Ejado. Frechilla, 1613. Libro: 3440, sig. 2756, fol. 100-102 (Inventarios de bienes).

P. N. Francisco Ejado. Frechilla, 1613. Libro: 3440, sig. 2756, fol. 163 (Carta de pago).

P. N. Francisco Ejado. Frechilla, 1613. Libro: 3440, sig. 2756, fol. 191 vuelta-193 (Inventario de bienes).

P. N. Francisco Ejado. Frechilla, 1613. Libro: 3440, sig. 2756, fol. 195-197 (Almoneda).

P. N. Francisco Ejado. Frechilla, 1614. Libro: 3441, sig. 2756, fol. 23 vuelta-29 recto (Inventario de bienes).

P. N. Francisco Ejado. Frechilla, 1614. Libro: 3441, sig. 2756, fol. 71 (Inventario de bienes).

P. N. Francisco Ejado. Frechilla, 1614. Libro: 3441, sig. 2756, fol. 141-142 (Inventario de bienes).

P. N. Francisco Ejado. Frechilla, 1614. Libro: 3441, sig. 2756, fol. 238-250 recto (Tasaciones y cuerpo de hacienda).

P. N. Francisco Ejado. Frechilla, 1615. Libro: 3442, sig. 2756, fol. 48-51 (Inventario de bienes).

P. N. Francisco Ejado. Frechilla, 1615. Libro: 3442, sig. 2756, fol. 61 vuelta (Testamento).

P. N. Francisco Ejado. Frechilla, 1615. Libro: 3442, sig. 2756, fol. 63-67 recto (Inventario de bienes).

P. N. Francisco Ejado. Frechilla, 1615. Libro: 3442, sig. 2756, fol. 70-77 (Almoneda).

P. N. Francisco Ejado. Frechilla, 1615. Libro: 3442, sig. 2756, fol. 102-103 (Inventario de bienes).

P. N. Francisco Ejado. Frechilla, 1615. Libro: 3442, sig. 2756, fol. 104-106 recto (Inventario de bienes).

P. N. Francisco Ejado. Frechilla, 1616. Libro: 3442, sig. 2756, fol. 109 vuelta-111 recto (Inventario de bienes).

P. N. Francisco Ejado. Frechilla, 1616. Libro: 3443, sig. 2756, fol. 112-115 recto (Inventario de bienes).

P. N. Francisco Ejado. Frechilla, 1616. Libro: 3443, sig. 2756, fol. 149-152 (Inventario de bienes).

P. N. Francisco Ejado. Frechilla, 1616. Libro: 3443, sig. 2756, fol. 164-165 (Inventario de bienes).

P. N. Francisco Ejado. Frechilla, 1616. Libro: 3443 , sig. 2756, fol. $185-186$ recto (Carta de pago).

P. N. Francisco Ejado. Frechilla, 1616. Libro: 3443, sig. 2756, fol. 189-192 (Bienes raíces y muebles).

P. N. Francisco Ejado. Frechilla, 1616. Libro: 3443, sig. 2756, fol. 193-195 (Inventario de bienes raíces y muebles).

P. N. Francisco Ejado. Frechilla, 1638. Libro: 3461, sig. 2767, sin foliar (Inventario de bienes).

P. N. Francisco Ejado. Frechilla, 1637. Libro: libro suelto, sig. 2767, fol. 83-84 (Inventario de bienes). 
P. N. Francisco Ejado. Frechilla, 1637. Libro: libro suelto, sig. 2767, fol. 89-92 (Inventario de bienes).

P. N. Francisco Ejado. Frechilla, 1637. Libro: libro suelto, sig. 2767, fol. 103 (Inventario de bienes).

P. N. Francisco Ejado. Frechilla, 1675. Libro: 3462, sig. 2768, fol. 120 vuelto-123 recto (Inventario de bienes).

P. N. Francisco Ejado. Frechilla, 1675. Libro: 3462, sig. 2768, fol. 278-280 (Inventario de bienes).

P. N. Francisco Ejado. Frechilla, 1675. Libro: 3462, sig. 2768, fol. - (Inventario de bienes).

P. N. Francisco Ejado. Frechilla, 1675. Libro: 3463, sig. 2768, fol. 17-27 (Tasación de bienes).

P. N. Francisco Ejado. Frechilla, 1675. Libro: 3463, sig. 2768, fol. 28 vuelto-38 (Tasación de bienes).

P. N. Francisco Ejado. Frechilla, 1671. Libro: 3463, sig. 2768, fol. 268-273 (Inventario de bienes).

P. N. Francisco Ejado. Frechilla, 1676. Libro: 3464, sig. 2768, fol. 268-270 (Inventario de bienes).

P. N. Francisco Andrés. Villarramiel, 1690. Libro: - , sig. 13332, fol. 94-95 recto (Inventario de bienes).

P. N. Francisco Andrés. Villarramiel, 1690. Libro: - , sig. 13332, fol. 96-97 recto (Inventario de bienes).

P. N. Francisco Andrés. Villarramiel, 1690. Libro: - , sig. 13332, fol. $98-99$ (Inventario de bienes).

P. N. Francisco Andrés. Villarramiel, 1690. Libro: - , sig. 13332, fol. 100 (Inventario de bienes).

P. N. Francisco Andrés. Villarramiel, 1691. Libro: - , sig. 13332, fol. 105-106 (Inventario de bienes). 


\section{A1.3. ARCHIVO HISTÓRICO PROVINCIAL DE VALLADOLID Partido Judicial Medina del Rioseco (Valladolid)}

P. N. Martín Díez. Medina del Rioseco, 1639. Libro: - , sig. 8856, fol. 121 (Carta de dote).

P. N. Martín Díez. Medina del Rioseco, 1639. Libro: - , sig. 8856, fol. 196 (Inventario de bienes).

P. N. Martín Díez. Medina del Rioseco, 1639. Libro: - , sig. 8856, fol. 227-228 recto (Inventario de bienes).

P. N. Martín Díez. Medina del Rioseco, 1639. Libro: - , sig. 8856, fol. 354-355 (Carta de pago).

P. N. Martín Díez. Medina del Rioseco, 1640. Libro: - , sig. 8856, fol. 471 (Inventario de bienes).

P. N. Martín Díez. Medina del Rioseco, 1640. Libro: - , sig. 8856, fol. 472-475 (Inventario de bienes).

P. N. Martín Díez. Medina del Rioseco, 1640. Libro: - , sig. 8856, fol. 526-529 (Carta de pago).

P. N. Martín Díez. Medina del Rioseco, 1639. Libro: - , sig. 8856, fol. 592-594 (Inventario de bienes).

P. N. Martín Díez. Medina del Rioseco, 1640. Libro: - , sig. 8856, fol. 632-635 (Carta de pago).

P. N. Martín Díez. Medina del Rioseco, 1640. Libro: - , sig. 8856, fol. 648 (Inventario de bienes).

P. N. Martín Díez. Medina del Rioseco, 1640. Libro: - , sig. 8856, fol. 649 (Inventario de bienes).

P. N. Martín Díez. Medina del Rioseco, 1640. Libro: - , sig. 8856, fol. 652-654 (Tasación de bienes).

P. N. Martín Díez. Medina del Rioseco, 1641. Libro: - , sig. 8857, fol. 75 vuelto-77 recto (Carta de pago y recibo de bienes).

P. N. Martín Díez. Medina del Rioseco, 1641. Libro: - , sig. 8857, fol. 301-303 (Inventario de bienes).

P. N. Martín Díez. Medina del Rioseco, 1641. Libro: - , sig. 8857, fol. 308-310 recto (Tasación de bienes).

P. N. Martín Díez. Medina del Rioseco, 1642. Libro: - , sig. 8857, fol. 727-728 (Carta de pago).

P. N. Martín Díez. Medina del Rioseco, 1642. Libro: - , sig. 8857, fol. 738-740 recto ( ).

P. N. Martín Díez. Medina del Rioseco, 1644. Libro: 1 libro, sig. 8858, fol. 466-467 (Inventario de bienes).

P. N. Martín Díez. Medina del Rioseco, 1644. Libro: 1 libro, sig. 8858, fol. 523-525 recto (Carta de pago de dote).

P. N. Martín Díez. Medina del Rioseco, 1644. Libro: 1 libro, sig. 8858, fol. 631-632 (Inventario de bienes).

P. N. Martín Díez. Medina del Rioseco, 1645. Libro: 1 libro, sig. 8859, fol. 26-27 (Inventario de bienes).

P. N. Martín Díez. Medina del Rioseco, 1645. Libro: 1 libro, sig. 8859, fol. 744 vuelto-747 (Carta de pago).

P. N. Martín Díez. Medina del Rioseco, 1646. Libro: 1 libro, sig. 8859, fol. 1047 (Inventario de bienes).

P. N. Martín Díez. Medina del Rioseco, 1646. Libro: 1 libro, sig. 8859, fol. 1209 (Carta de pago).

P. N. Martín Díez. Medina del Rioseco, 1647. Libro: 1 libro, sig. 8860, sin foliar (Carta de pago).

P. N. Martín Díez. Medina del Rioseco, 1647. Libro: 1 libro, sig. 8861, sin foliar (Inventario de bienes). 
P. N. Martín Díez. Medina del Rioseco, 1647. Libro: 1 libro, sig. 8861, sin foliar (Inventario de bienes).

P. N. Martín Díez. Medina del Rioseco, 1647. Libro: 1 libro, sig. 8861, sin foliar (Inventario de bienes).

P. N. Martín Díez. Medina del Rioseco, 1647. Libro: 1 libro, sig. 8861, fol. 484-485 recto (Poder). P. N. Martín Díez. Medina del Rioseco, 1650. Libro: 1 libro, sig. 8862, fol. 112 (Carta de pago).

P. N. Pedro de Sandoval. Medina del Rioseco, 1642. Libro: 1 libro, sig. 8876, fol. 124-125 (Carta de pago).

P. N. Pedro de Sandoval. Medina del Rioseco, 1642. Libro: 1 libro, sig. 8876, fol. 189 vuelto-192 (Inventario de bienes).

P. N. Pedro de Sandoval. Medina del Rioseco, 1642. Libro: 1 libro, sig. 8876, fol. 196-197 (Almoneda).

P. N. Pedro de Sandoval. Medina del Rioseco, 1642. Libro: 1 libro, sig. 8876, fol. 345-346 (Carta de pago).

P. N. Pedro de Sandoval. Medina del Rioseco, 1642. Libro: 1 libro, sig. 8876, fol. 423 vuelto- 424 (Documento sobre telas).

P. N. Pedro de Sandoval. Medina del Rioseco, 1639. Libro: 1 libro, sig. 8876, fol. 199-200 (Inventario de bienes).

P. N. Pedro de Sandoval. Medina del Rioseco, 1639. Libro: 1 libro, sig. 8876, fol. 215-217 (Carta de dote).

P. N. Pedro de Sandoval. Medina del Rioseco, 1639. Libro: 1 libro, sig. 8876, fol. 266-267 (Inventario de bienes).

P. N. Pedro de Sandoval. Medina del Rioseco, 1639. Libro: 1 libro, sig. 8876, fol. 312-316 (Inventario de bienes).

P. N. Pedro de Sandoval. Medina del Rioseco, 1639. Libro: 1 libro, sig. 8876, fol. 538-539 recto (Carta de pago de dote).

P. N. Pedro de Sandoval. Medina del Rioseco, 1639. Libro: 1 libro, sig. 8876, fol. 586 vuelto-588 recto (Tasación).

P. N. Pedro de Sandoval. Medina del Rioseco, 1644. Libro: 1 libro, sig. 8877, fol. 232-233 (Carta de pago).

P. N. Pedro de Sandoval. Medina del Rioseco, 1644. Libro: 1 libro, sig. 8877, fol. 366-367 (Carta de pago de dote).

P. N. Pedro de Sandoval. Medina del Rioseco, 1644. Libro: 1 libro, sig. 8877, fol. 441 vuelto-445 recto (Inventario de bienes).

P. N. Pedro de Sandoval. Medina del Rioseco, 1644. Libro: 1 libro, sig. 8877, fol. 457-462 (Tasación de bienes muebles).

P. N. Pedro de Sandoval. Medina del Rioseco, 1644. Libro: 1 libro, sig. 8877, fol. 552-556 (Inventario de bienes).

P. N. Pedro de Sandoval. Medina del Rioseco, 1644. Libro: 1 libro, sig. 8877, fol. 759-763 (Inventario de bienes).

P. N. Pedro de Sandoval. Medina del Rioseco, 1644. Libro: 1 libro, sig. 8877, fol. 787-792 recto (Inventario de bienes). 
P. N. Pedro de Sandoval. Medina del Rioseco, 1644. Libro: 1 libro, sig. 8877, fol. 902 vuelto-903 (Tasación de bienes muebles).

P. N. Pedro de Sandoval. Medina del Rioseco, 1645. Libro: 1 libro, sig. 8878, fol. 170-171 (Capitulaciones matrimoniales).

P. N. Pedro de Sandoval. Medina del Rioseco, 1645. Libro: 1 libro, sig. 8878, fol. 492-493 (Tasación de bienes muebles).

P. N. Pedro de Sandoval. Medina del Rioseco, 1645. Libro: 1 libro, sig. 8878, fol. 503 (Tasación).

P. N. Pedro de Sandoval. Medina del Rioseco, 1645. Libro: 1 libro, sig. 8878, fol. 504-505 (Tasación).

P. N. Pedro de Sandoval. Medina del Rioseco, 1645. Libro: 1 libro, sig. 8878, fol. 675 vuelto-679 (Inventario de bienes).

P. N. Pedro de Sandoval. Medina del Rioseco, 1645. Libro: 1 libro, sig. 8878, fol. 775-786 (Inventario de bienes).

P. N. Pedro de Sandoval. Medina del Rioseco, 1645. Libro: 1 libro, sig. 8878, fol. 797 vuelto-804 recto (Tasación de bienes muebles).

P. N. Pedro de Sandoval. Medina del Rioseco, 1646. Libro: 1 libro, sig. 8879, fol. 227-228 recto (Inventario de bienes).

P. N. Pedro de Sandoval. Medina del Rioseco, 1646. Libro: 1 libro, sig. 8879, fol. 307-310 recto (Carta de pago de dote).

P. N. Pedro de Sandoval. Medina del Rioseco, 1646. Libro: 1 libro, sig. 8879, fol. 415-416 recto (Inventario de bienes).

P. N. Pedro de Sandoval. Medina del Rioseco, 1646. Libro: 1 libro, sig. 8879, fol. 492-493 recto (Carta de pago de dote).

P. N. Pedro de Sandoval. Medina del Rioseco, 1647. Libro: 1 libro, sig. 8879, fol. 699 vuelto-709 recto (Inventario de bienes).

P. N. Pedro de Sandoval. Medina del Rioseco, 1647. Libro: 1 libro, sig. 8879, fol. 911-913 recto (Memorial de gastos).

P. N. Pedro de Sandoval. Medina del Rioseco, 1647. Libro: 1 libro, sig. 8879, fol. 1215 vuelto1216 recto (Tasación).

P. N. Pedro de Sandoval. Medina del Rioseco, 1648. Libro: 1 libro, sig. 8880, fol. 65-68 (Dote).

P. N. Pedro de Sandoval. Medina del Rioseco, 1648. Libro: 1 libro, sig. 8880, fol. 278-279 (Inventario de bienes).

P. N. Pedro de Sandoval. Medina del Rioseco, 1648. Libro: 1 libro, sig. 8880, fol. 291-295 (Dote).

P. N. Pedro de Sandoval. Medina del Rioseco, 1648. Libro: 1 libro, sig. 8880, fol. 728 vuelto-733 recto (Inventario de bienes).

P. N. Pedro de Sandoval. Medina del Rioseco, 1648. Libro: 1 libro, sig. 8880, fol. 733 recto-737 vuelto (Inventario de bienes).

P. N. Pedro de Sandoval. Medina del Rioseco, 1648. Libro: 1 libro, sig. 8880, fol. 737 vuelto-740 (Inventario de bienes).

P. N. Pedro de Sandoval. Medina del Rioseco, 1648. Libro: 1 libro, sig. 8880, fol. 757 vuelto-766 (Inventario de telas).

P. N. Pedro de Sandoval. Medina del Rioseco, 1648. Libro: 1 libro, sig. 8880, fol. 933-957 (Inventarios de bienes). 
P. N. Pedro de Sandoval. Medina del Rioseco, 1648. Libro: 1 libro, sig. 8880, fol. 958-968 recto (Inventario de bienes).

P. N. Pedro de Sandoval. Medina del Rioseco, 1648. Libro: 1 libro, sig. 8880, fol. 1001-1005 (Almoneda).

P. N. Pedro de Sandoval. Medina del Rioseco, 1648. Libro: 1 libro, sig. 8880, fol. 1130 vuelto 1137 recto (Inventario de bienes).

P. N. Pedro de Sandoval. Medina del Rioseco, 1657. Libro: 1 libro, sig. 8887, fol. 222 vuelto-224 recto (Inventario de bienes).

P. N. Pedro de Sandoval. Medina del Rioseco, 1657. Libro: 1 libro, sig. 8887, fol. 290-292 (Almoneda).

P. N. Pedro de Sandoval. Medina del Rioseco, 1657. Libro: 1 libro, sig. 8887, fol. 432-433 (Carta de dote).

P. N. Pedro de Sandoval. Medina del Rioseco, 1657. Libro: 1 libro, sig. 8887, fol. 726-731 (Inventario de bienes).

P. N. Pedro de Sandoval. Medina del Rioseco, 1657. Libro: 1 libro, sig. 8887, fol. 732-735 recto (Carta de pago).

P. N. Pedro de Sandoval. Medina del Rioseco, 1657. Libro: 1 libro, sig. 8887, fol. 738-740 (Tasación).

P. N. Pedro de Sandoval. Medina del Rioseco, 1671. Libro: 1 libro, sig. 8899, fol. 390-403 (Inventario de bienes).

P. N. Pedro de Sandoval. Medina del Rioseco, 1672. Libro: 1 libro, sig. 8899, fol. 404-410 (Almoneda).

P. N. Pedro de Sandoval. Medina del Rioseco, 1673. Libro: 1 libro, sig. 8899, fol. 415-422 (Cuenta de bienes y hacienda).

P. N. A. Ruiz. Medina del Rioseco, 1640. Libro: 1 libro, sig. 8900, fol. irregular (Tasación de bienes).

P. N. A.Ruiz. Medina del Rioseco, 1641. Libro: 1 libro, sig. 8900, fol. irregular: 29-31 (Carta de pago de dote y arras).

P. N. A. Ruiz. Medina del Rioseco, 1642. Libro: 1 libro, sig. 8901, fol. 170-171 (Carta de pago de dote).

P. N. A. Ruiz. Medina del Rioseco, 1642. Libro: 1 libro, sig. 8901, fol. 227-228 (Carta de dote).

P. N. A. Ruiz. Medina del Rioseco, 1642. Libro: 1 libro, sig. 8901, fol. 285-286 (Carta de dote).

P. N. A. Ruiz. Medina del Rioseco, 1643. Libro: 1 libro, sig. 8901, fol. 424-425(Carta de pago).

P. N. A. Ruiz. Medina del Rioseco, 1641. Libro: 1 libro, sig. 8901, fol. 439-442 recto (Inventario de bienes).

P. N. A. Ruiz. Medina del Rioseco, 1642. Libro: 1 libro, sig. 8901, fol. 459-65 (Tasación de bienes). P. N. A. Ruiz. Medina del Rioseco, 1644. Libro: 1 libro, sig. 8901, fol. 564-565 (Carta de pago de dote).

P. N. A. Ruiz. Medina del Rioseco, 1644. Libro: 1 libro, sig. 8901, fol. 631-634 (Carta de pago de dote).

P. N. A. Ruiz. Medina del Rioseco, 1645. Libro: 1 libro, sig. 8901, fol. 775-776 (Carta de pago de dote). 
P. N. A. Ruiz. Medina del Rioseco, 1645. Libro: 1 libro, sig. 8901, fol. 799-800 recto (Inventario de bienes).

P. N. A. Ruiz. Medina del Rioseco, 1646. Libro: 1 libro, sig. 8901, fol. 879-882 (Inventario de bienes).

P. N. A. Ruiz. Medina del Rioseco, 1646. Libro: 1 libro, sig. 8901, fol. 883-884 (Carta de pago de dote).

P. N. A. Ruiz. Medina del Rioseco, 1646. Libro: 1 libro, sig. 8901, fol. 946-947 recto (Inventario de bienes).

P. N. A. Ruiz. Medina del Rioseco, 1647. Libro: 1 libro, sig. 8902, fol. 243-244 (Carta de pago de dote).

P. N. A. Ruiz. Medina del Rioseco, 1648. Libro: 1 libro, sig. 8902, fol. 312-313 (Carta de pago de dote).

P. N. A. Ruiz. Medina del Rioseco, 1648. Libro: 1 libro, sig. 8902, fol. 334-335 (Carta de pago de dote).

P. N. A. Ruiz. Medina del Rioseco, 1648. Libro: 1 libro, sig. 8902, fol. 387-388 (Inventario de bienes).

P. N. A. Ruiz. Medina del Rioseco, 1648. Libro: 1 libro, sig. 8902, fol. 487-488 (Carta de pago de dote).

P. N. A. Ruiz. Medina del Rioseco, 1648. Libro: 1 libro, sig. 8902, fol. 521-522 (Carta de pago de dote).

P. N. A. Ruiz. Medina del Rioseco, 1649. Libro: 1 libro, sig. 8902, fol. 611-614 (Inventario de bienes).

P. N. A. Ruiz. Medina del Rioseco, 1649. Libro: 1 libro, sig. 8902, fol. 681-683 recto (Inventario de bienes).

P. N. A. Ruiz. Medina del Rioseco, 1649. Libro: 1 libro, sig. 8902, fol. 769-770 (Inventario de bienes).

P. N. A. Ruiz. Medina del Rioseco, 1649. Libro: 1 libro, sig. 8902, fol. 771-772 recto (Carta de pago de dote).

P. N. A. Ruiz. Medina del Rioseco, 1649. Libro: 1 libro, sig. 8902, fol. $782-783$ (Carta de pago de dote).

P. N. A. Ruiz. Medina del Rioseco, 1651. Libro: 1 libro, sig. 8903, fol. 298-299 recto (Carta de pago de dote).

P. N. A. Ruiz. Medina del Rioseco, 1651. Libro: 1 libro, sig. 8903, fol. 27-28 (Carta de pago de dote).

P. N. A. Ruiz. Medina del Rioseco, 1651. Libro: 1 libro, sig. 8903, fol. 238-240 (Entrega de bienes).

P. N. A. Ruiz. Medina del Rioseco, 1651. Libro: 1 libro, sig. 8903, fol. 244 vuelto-245 recto (Inventario de bienes).

P. N. A. Ruiz. Medina del Rioseco, 1651. Libro: 1 libro, sig. 8903, fol. 248-249 recto (Tasación de bienes muebles).

P. N. Antonio Ruiz. Medina del Rioseco, 1659. Libro: 1 libro, sig. 8907, fol. 50-51 (Carta de dote). P. N. Antonio Ruiz. Medina del Rioseco, 1660 Libro: 1 libro, sig. 8907, fol. 108-111 recto (Inventario de bienes). 
P. N. Antonio Ruiz. Medina del Rioseco, 1660. Libro: 1 libro, sig. 8907, fol. 127-128 (Carta de dote).

P. N. Antonio Ruiz. Medina del Rioseco, 1660. Libro: 1 libro, sig. 8907, fol. 279 vuelto-280 recto (Inventario de bienes).

P. N. Antonio Ruiz. Medina del Rioseco, 1660. Libro: 1 libro, sig. 8907, fol. 281 vuelto-287 recto (Inventario de bienes).

P. N. Antonio Ruiz. Medina del Rioseco, 1660. Libro: 1 libro, sig. 8907, fol. 292-308 recto (Tasación de bienes).

P. N. Antonio Ruiz. Medina del Rioseco, 1661. Libro: 1 libro, sig. 8907, fol. 401-402 (Carta de dote).

P. N. Antonio Ruiz. Medina del Rioseco, 1661. Libro: 1 libro, sig. 8907, fol. 535-538 (Carta de pago).

P. N. Antonio Ruiz. Medina del Rioseco, 1661. Libro: 1 libro, sig. 8907, fol. 563-565 (Inventario de bienes).

P. N. Antonio Ruiz. Medina del Rioseco, 1661. Libro: 1 libro, sig. 8907, fol. 581-585 (Inventario de bienes).

P. N. Juan Martín Villanueva. Medina del Rioseco, 1685. Libro: 1 libro, sig. 9151, fol. 697-706 (Tasación de bienes).

P. N. Francisco Muñiz. Tamariz de Campos, 1651. Libro: 1 libro, sig. 9588, fol. 20-21 recto (Inventario de bienes).

P. N. Francisco Muñiz. Tamariz de Campos, 1652. Libro: 1 libro, sig. 9588, fol. 183-189 (Cargo).

P. N. Francisco Muñiz. Tamariz de Campos, 1652. Libro: 1 libro, sig. 9588, fol. 221-224 (Inventario de bienes).

P. N. Francisco Muñiz. Tamariz de Campos, 1652. Libro: 1 libro, sig. 9588, fol. 315-319 recto (Carta de pago).

P. N. Francisco Breznes. Villalón de Campos, 1637. Libro: 1 libro, sig. 12212, fol. 24-30 (Inventario de bienes).

P. N. Francisco Breznes. Villalón de Campos, 1637. Libro: 1 libro, sig. 12212, fol. $85-86$ (Inventario de bienes).

P. N. Francisco Breznes. Villalón de Campos, 1637. Libro: 1 libro, sig. 12212, fol. 91 (Inventario de bienes).

P. N. Francisco Breznes. Villalón de Campos, 1637. Libro: 1 libro, sig. 12212, fol. 117-118 (Inventario de bienes).

P. N. Francisco Breznes. Villalón de Campos, 1637. Libro: 1 libro, sig. 12212, fol. 8-10 (segunda numeración del mismo libro) (Inventario de bienes).

P. N. Francisco Breznes. Villalón de Campos, 1639. Libro: 1 libro, sig. 12212, fol. 60 (Inventario de bienes).

P. N. Francisco Breznes. Villalón de Campos, 1642. Libro: 1 libro, sig. 12212, fol. $26-30$ (Inventario de bienes). 
P. N. Francisco Breznes. Villalón de Campos, 1642. Libro: 1 libro, sig. 12212, fol. 31-32 (Almoneda).

P. N. Francisco Breznes. Villalón de Campos, 1642. Libro: 1 libro, sig. 12212, fol. 87 (Almoneda).

P. N. Bernardino Paniagua. Cuenca de Campos, 1660. Libro: $1^{\text {er }}$ hato de documentos, sig. 13093 , sin foliar (Inventario de bienes).

P. N. Bernardino Paniagua. Cuenca de Campos, 1660. Libro: 20 hato de documentos, sig. 13093, sin foliar (Inventario de bienes).

P. N. Bernardino Paniagua. Cuenca de Campos, 1660. Libro: 20 hato de documentos, sig. 13093, sin foliar (Inventario de bienes).

P. N. Bernardino Paniagua. Cuenca de Campos, 1660. Libro: 2ㅇ hato de documentos, sig. 13093, sin foliar (Almoneda).

P. N. Bernardino Paniagua. Cuenca de Campos, 1660. Libro: 20 hato de documentos, sig. 13093, sin foliar (Inventario de bienes).

P. N. Bernardino Paniagua. Cuenca de Campos, 1660. Libro: 20 hato de documentos, sig. 13093, sin foliar (Documento de compromiso).

P. N. Bernardino Paniagua. Cuenca de Campos, 1660. Libro: 20 hato de documentos, sig. 13093, sin foliar (Partición de bienes).

P. N. Bernardino Paniagua. Cuenca de Campos, 1667. Libro: $3^{\text {er }}$ hato de documentos, sig. 13093 , sin foliar (Cuerpo de bienes).

P. N. Bernardino Paniagua. Cuenca de Campos, 1666. Libro: 60 hato de documentos, sig. 13093, sin foliar (Cuerpo y tasación de bienes).

P. N. Bernardino Paniagua. Cuenca de Campos, 1666. Libro: 60 hato de documentos, sig. 13093, sin foliar (Inventario de bienes).

P. N. Bernardino Paniagua. Cuenca de Campos, 1666. Libro: 60 hato de documentos, sig. 13093, sin foliar (Inventario de bienes).

P. N. Bernardino Paniagua. Cuenca de Campos, 1666. Libro: 6o hato de documentos, sig. 13093, sin foliar (Inventario de bienes).

P. N. Bernardino Paniagua. Cuenca de Campos, 1666. Libro: 60 hato de documentos, sig. 13093, sin foliar (Inventario de bienes).

P. N. Bernardino Paniagua. Cuenca de Campos, 1666. Libro: 60 hato de documentos, sig. 13093, sin foliar (Inventario de bienes).

P. N. Bernardino Paniagua. Cuenca de Campos, 1668. Libro: 80 hato de documentos, sig. 13093, sin foliar (Cuerpo de bienes).

P. N. Bernardino Paniagua. Cuenca de Campos, 1670. Libro: 10 hato de documentos, sig. 13093, sin foliar (Inventario de bienes).

P. N. Bernardino Paniagua. Cuenca de Campos, 1668. Libro: 10ㅇ hato de documentos, sig. 13093, sin foliar (Cuerpo de bienes).

P. N. Bernardino Paniagua. Cuenca de Campos, 1670. Libro: hojas sueltas, sig. 13093, sin foliar (Inventario de bienes).

P. N. Bernardino Paniagua. Cuenca de Campos, 1670. Libro: hojas sueltas, sig. 13093, sin foliar (Cuerpo de bienes). 
P. N. Bernardino Paniagua. Cuenca de Campos, 1670. Libro: hojas sueltas, sig. 13093, sin foliar (Inventario de bienes).

P. N. Bernardino Paniagua. Cuenca de Campos, 1671. Libro: hojas sueltas, sig. 13093, sin foliar (Tasación de bienes).

P. N. Bernardino Paniagua. Cuenca de Campos, 1671. Libro: hojas sueltas, sig. 13093, sin foliar (Cuenta de bienes).

P. N. Bernardino Paniagua. Cuenca de Campos, 1672. Libro: hojas sueltas, sig. 13093, sin foliar (Inventario de bienes).

P. N. Bernardino Paniagua. Cuenca de Campos, 1672. Libro: hojas sueltas, sig. 13093, sin foliar (Inventario de bienes).

P. N. Bernardino Paniagua. Cuenca de Campos, 1673. Libro: hojas sueltas, sig. 13093, sin foliar (Inventario de bienes).

P. N. Bernardino Paniagua. Cuenca de Campos, 1673. Libro: hojas sueltas, sig. 13093, sin foliar (Partición de bienes). 


\section{A1.4. ARCHIVO HISTÓRICO PROVINCIAL DE ZAMORA Partido Judicial de Villalpando (Zamora)}

P. N. Pedro de Llamas. Villalpando, 1613. Libro: - , sig. 7366, fol. 380-382 recto (Inventario de bienes).

P. N. Pedro de Llamas. Villalpando, 1620. Libro: - , sig. 7369, fol. 430-431 (Inventario de bienes).

P. N. Pedro de Llamas. Villalpando, 1620. Libro: - , sig. 7369, fol. 430-431 (Inventario de bienes).

P. N. García de León. Villalpando, 1600. Libro: - , sig. 7405, sin foliar (Carta de pago de dote).

P. N. García de León. Villalpando, 1600. Libro: - , sig. 7405, sin foliar (Carta de pago de dote).

P. N. García de León. Villalpando, 1600. Libro: - , sig. 7405, sin foliar (Carta de pago de dote).

P. N. García de León. Villalpando, 1601. Libro: - , sig. 7406, 186-188 recto (Inventario de bienes).

P. N. García de León. Villalpando, 1620. Libro: - , sig. 7417, 68-87 recto (Carta de dote e inventario de bienes).

P. N. García de León. Villalpando, 1620. Libro: - , sig. 7417, 134-138 (Inventario de bienes y almoneda).

P. N. García de León. Villalpando, 1620. Libro: - , sig. 7417, 205 vuelta-208 recto (Carta de pago y recibo de dote).

P. N. García de León. Villalpando, 1620. Libro: - , sig. 7417, 243-246 (Inventario de bienes).

P. N. García de León. Villalpando, 1620. Libro: - , sig. 7417, 259-261 recto (Almoneda).

P. N. Centeno. Villalpando, 1614-16. Libro: - , sig. 7465, 67-68 (Inventario de bienes).

P. N. Centeno. Villalpando, 1614-16. Libro: - , sig. 7465, 83-88 (Inventario de bienes-memoria de tierras).

P. N. Salgado. Villalpando, 1638. Libro: - , sig. 7528, 103-111 (Cuentas).

P. N. Calvo. Villalpando, 1629. Libro: - , sig. 7532, 203-208 recto (Inventario de bienes).

P. N. Calvo. Villalpando, 1632. Libro: - , sig. 7534, 391-393 recto (Inventario de bienes).

P. N. Calvo. Villalpando, 1634-1635. Libro: 2, sig. 7536, 206-209 recto (Inventario de bienes).

P. N. Calvo. Villalpando, 1634-1635. Libro: 2, sig. 7536, 217-218 (Inventario de bienes).

P. N. Calvo. Villalpando, 1634-1635. Libro: 1, sig. 7536, 282-283 (Carta de pago de dote).

P. N. Calvo. Villalpando, 1636-1638. Libro: 2, sig. 7537, 180-181 recto (Carta de pago de dote).

P. N. Calvo. Villalpando, 1636-1638. Libro: 2, sig. 7537, 248-249 (División de hacienda).

P. N. Calvo. Villalpando, 1636-1638. Libro: 2, sig. 7537, 256-257 recto (Almoneda).

P. N. Calvo. Villalpando, 1636-1638. Libro: 2, sig. 7537, 259-261 recto (Inventario de bienes).

P. N. Calvo. Villalpando, 1636-1638. Libro: 2, sig. 7537, 311-313 (Inventario de bienes).

P. N. Calvo. Villalpando, 1636-1638. Libro: 2, sig. 7537, 334-335 (Inventario de bienes).

P. N. Calvo. Villalpando, 1639-1640. Libro: 1, sig. 7538, 82-83 (Carta de pago de dote).

P. N. Calvo. Villalpando, 1639-1640. Libro: 1, sig. 7538, 105-106 (Carta de pago de dote).

P. N. Calvo. Villalpando, 1639-1640. Libro: 2, sig. 7538, 147-148 (Carta de pago de dote).

P. N. Calvo. Villalpando, 1641-1642. Libro: 1, sig. 7539, 55-56 (Donación). 
P. N. Calvo. Villalpando, 1643-1644. Libro: 2, sig. 7540, 2-3 (Arrendamiento).

P. N. Calvo. Villalpando, 1643-1644. Libro: 2, sig. 7540, 236-243 (Inventario de bienes).

P. N. Calvo. Villalpando, 1643-1644. Libro: 2, sig. 7540, 327-331 (Inventario de bienes).

P. N. Calvo. Villalpando, 1645-1646. Libro: - , sig. 7541, 119-121 (Inventario de bienes).

P. N. Calvo. Villalpando, 1645-1646. Libro: 2, sig. 7541, 35-36 recto (Inventario de bienes).

P. N. Calvo. Villalpando, 1645-1646. Libro: 2, sig. 7541, 45-47 (Inventario de bienes).

P. N. Calvo. Villalpando, 1647-1648. Libro: 2, sig. 7542, 45-46 recto (Carta de pago de dote).

P. N. Calvo. Villalpando, 1649-1651. Libro: 1, sig. 7543, 49-52 (Promesa de dote).

P. N. Calvo. Villalpando, 1649-1651. Libro: 2, sig. 7543, sin foliar (Inventario de bienes).

P. N. Calvo. Villalpando, 1652-1653. Libro: 1, sig. 7544, 240-245 (Arrendamiento de bienes).

P. N. Calvo. Villalpando, 1652-1653. Libro: 2, sig. 7544, 206-207 (Declaración de bienes).

P. N. Calvo. Villalpando, 1654-1655. Libro: 2, sig. 7545, 123-124 (Carta de pago de dote).

P. N. Calvo. Villalpando, 1654-1655. Libro: 2, sig. 7545, 125-128 (Inventario de bienes).

P. N. Calvo. Villalpando, 1660/1670/1672/1673. Libro: - , sig. 7548, 246-248 (Inventario de bienes).

P. N. Calvo. Villalpando, 1660/1670/1672/1673. Libro: - , sig. 7548, 13-15 (2a numeración) (Carta de dote).

P. N. Calvo. Villalpando, 1664-1666. Libro: - , sig. 7550, 77-78 (1a numeración) (Carta de pago).

P. N. Calvo. Villalpando, 1664-1666. Libro: - , sig. 7550, 79-80 (1 a numeración) (Carta de dote).

P. N. Calvo. Villalpando, 1664-1666. Libro: - , sig. 7550, 20-22 (3a numeración) (Carta de pago).

P. N. Calvo. Villalpando, 1664-1666. Libro: - , sig. 7550, 35-37 (3a numeración) (Cargos).

P. N. Calvo. Villalpando, 1664-1666. Libro: - , sig. 7550, 86-87 recto (3a numeración) (Inventario de bienes).

P. N. Calvo. Villalpando, 1664-1666. Libro: - , sig. 7550, 88-89 recto (3a numeración) (Almoneda). P. N. Calvo. Villalpando, 1667-1669. Libro: - , sig. 7551, 55-57 (3a numeración) (Memoria de bienes).

P. N. Hernando Gutiérrez. Villalpando, 1629. Libro: 2, sig. 7589, 1-2, (Inventario de bienes).

P. N. Hernando Gutiérrez. Villalpando, 1629. Libro: 2, sig. 7589, 7-10, (Inventario de bienes).

P. N. Hernando Gutiérrez. Villalpando, 1629. Libro: 2, sig. 7589, 250-251 recto, (cuenta y razón de los materiales).

P. N. Hernando Gutiérrez. Villalpando, 1630. Libro: 3, sig. 7589, 160-161, (Carta de pago).

P. N. Hernando Gutiérrez. Villalpando, 1631. Libro: 1, sig. 7590, 29-31, (Dote).

P. N. Hernando Gutiérrez. Villalpando, 1631. Libro: 1, sig. 7590, 220 vuelto-223, (Carta de pago).

P. N. Hernando Gutiérrez. Villalpando, 1631. Libro: 1, sig. 7590, 226-229, (Dos cartas de pago).

P. N. Hernando Gutiérrez. Villalpando, 1631. Libro: 1, sig. 7590, 237-241 recto, (Carta de pago).

P. N. Hernando Gutiérrez. Villalpando, 1632. Libro: 2, sig. 7590, 187-192, (cuenta).

P. N. Hernando Gutiérrez. Villalpando, 1632. Libro: 2, sig. 7590, 298 vuelto - 302, (Carta de pago de dote).

P. N. Hernando Gutiérrez. Villalpando, 1633. Libro: - , sig. 7591, 27-30, (Inventario de bienes).

P. N. Hernando Gutiérrez. Villalpando, 1633. Libro: - , sig. 7591, 233-236, (Carta de pago de dote). P. N. Hernando Gutiérrez. Villalpando, 1635. Libro: 1, sig. 7593, 175-177, (Carta de pago de dote). 
P. N. Hernando Gutiérrez. Villalpando, 1637. Libro: 1, sig. 7594, 113-116, (Carta de pago de dote y recibo de dote).

P. N. Hernando Gutiérrez. Villalpando, 1643. Libro: - , sig. 7596, 244-245, (Recibo de dote).

P. N. Hernando Gutiérrez. Villalpando, 1644. Libro: - , sig. 7597, 126-127, (Carta de pago de dote y recibo de dote).

P. N. Hernando Gutiérrez. Villalpando, 1656. Libro: 2, sig. 7602, 68-69 recto, (Carta de pago).

P. N. Hernando Gutiérrez. Villalpando, 1656. Libro: 2, sig. 7602, 70-71, (Carta de pago).

P. N. Hernando Gutiérrez. Villalpando, 1656. Libro: 2, sig. 7602, 196, (Entrega de la cama de ropa).

P. N. Hernando Gutiérrez. Villalpando, 1656. Libro: 2, sig. 7602, 197, (Recibo de la plata y otras cosas).

P. N. González. Villalpando, 1635. Libro: - , sig. 7621, 14-16, (Inventario de bienes).

P. N. González. Villalpando, 1635. Libro: - , sig. 7621, 46-49 recto, (Inventario de bienes).

P. N. Gutiérrez. Villalpando, 1660. Libro: 2, sig. 7682, 12-14, (Inventario de bienes).

P. N. Gutiérrez. Villalpando, 1660. Libro: 2, sig. 7682, 21, (Almoneda).

P. N. Gutiérrez. Villalpando, 1660. Libro: 2, sig. 7682, 22-23, (Almoneda).

P. N. Gutiérrez. Villalpando, 1660. Libro: 2, sig. 7682, 110-111 recto, (Entrega de los presos).

P. N. Gutiérrez. Villalpando, 1661. Libro: 3, sig. 7682, 45-55 recto, (Declaración de bienes).

P. N. Gutiérrez. Villalpando, 1670. Libro: 3, sig. 7682, 155-158, (Carta de pago de dote).

P. N. Calvo. Villalpando, 1673-1674/1674-1679/1686/1689/1695/1699. Libro: 1, sig. 7715, 2425, (Inventario de bienes).

P. N. Calvo. Villalpando, 1673-1674/1674-1679/1686/1689/1695/1699. Libro: 1, sig. 7715, 5354, (Inventario de bienes).

P. N. Calvo. Villalpando, 1673-1674/1674-1679/1686/1689/1695/1699. Libro: 1, sig. 7715, 6-10 recto (57-59 doble numeración), (Testamento + inventario de bienes).

P. N. de Ureña. Villalpando, 1679. Libro: - , sig. 7723, sin foliar, (Inventario de bienes).

P. N. de Ureña. Villalpando, 1687. Libro: 2, sig. 7724, 13-124, (Cuenta).

P. N. de Ureña. Villalpando, 1689-1698. Libro: - , sig. 7726, sin foliar, (Documento adjunto al protocolo, sin datos y cosido boca abajo, (Inventario de bienes).

P. N. Ainse. Villalpando, 1686-1689. Libro: 1, sig. 7728, 15-17, (Inventario de bienes).

P. N. Ainse. Villalpando, 1686-1689. Libro: 1, sig. 7728, 27-28, (Inventario de bienes).

P. N. Ainse. Villalpando, 1686-1689. Libro: 1, sig. 7728, 33-34 recto, (Inventario de bienes).

P. N. Ainse. Villalpando, 1686-1689. Libro: 1, sig. 7728, 56-57, (Inventario de bienes).

P. N. Ainse. Villalpando, 1686-1689. Libro: 1, sig. 7728, 76-77, (Inventario de bienes).

P. N. Ainse. Villalpando, 1686-1689. Libro: 1, sig. 7728, 55-56 (2a numeración), (Inventario de bienes).

P. N. Ainse. Villalpando, 1686-1689. Libro: 1, sig. 7728, 63-64 (2a numeración), (Inventario de bienes). 
P. N. Ainse. Villalpando, 1690-1693. Libro: 1 (de dos), sig. 7729, 48-49 recto, (Inventario de bienes).

P. N. Ainse. Villalpando, 1690-1693. Libro: 1 (de dos), sig. 7729, 137 vuelto- 139, (Inventario de bienes).

P. N. González Espino. Villalpando, 1686-1690. Libro: 1, sig. 7730, 85- 86 recto, (Inventario de bienes).

P. N. González Espino. Villalpando, 1686-1690. Libro: 1, sig. 7730, 125-128, (Inventario de bienes).

P. N. González Espino. Villalpando, 1686-1690. Libro: 2, sig. 7730, 44-49 recto, (Inventario de bienes).

P. N. González Espino. Villalpando, 1686-1690. Libro: 2, sig. 7730, 52-62, (Cuerpo y deudas de bienes).

P. N. González Espino. Villalpando, 1686-1690. Libro: 2, sig. 7730, 65-66, (Inventario de bienes). P. N. González Espino. Villalpando, 1686-1690. Libro: 2, sig. 7730, 67-68 recto, (Inventario de bienes).

P. N. González Espino. Villalpando, 1686-1690. Libro: 2, sig. 7730, 69-70 recto, (Inventario de bienes).

P. N. González Espino. Villalpando, 1686-1690. Libro: 2, sig. 7730, 71-72 recto, (Inventario de bienes).

P. N. González Espino. Villalpando, 1686-1690. Libro: 3, sig. 7730, 3-5, (Inventario de bienes).

P. N. González Espino. Villalpando, 1686-1690. Libro: 3, sig. 7730, 42-45, (Inventario de bienes).

P. N. González Espino. Villalpando, 1686-1690. Libro: 3, sig. 7730, 47-48, (Inventario de bienes).

P. N. González Espino. Villalpando, 1686-1690. Libro: 3, sig. 7730, 51-54 recto, (Inventario de bienes).

P. N. González Espino. Villalpando, 1686-1690. Libro: 3, sig. 7730, 54 vuelto - 56 recto, (Inventario de bienes).

P. N. González Espino. Villalpando, 1686-1690. Libro: 3, sig. 7730, 56 vuelto - 59 recto, (Inventario de bienes).

P. N. González Espino. Villal pando, 1686-1690. Libro: 3, sig. 7730, 59 vuelto - 60 recto, (Carta de pago).

P. N. González Espino. Villalpando, 1686-1690. Libro: 3, sig. 7730, 90, (Inventario de bienes).

P. N. González Espino. Villalpando, 1686-1690. Libro: 3, sig. 7730, 155-158 recto, (Inventario de bienes).

P. N. González Espino. Villalpando, 1686-1690. Libro: 3, sig. 7730, 159-161, (Inventario de bienes).

P. N. González Espino. Villalpando, 1686-1690. Libro: 4, sig. 7730, 150-152, (Inventario de bienes).

P. N. González Espino. Villalpando, 1686-1690. Libro: 4, sig. 7730, 154-156, (Inventario de bienes).

P. N. González Espino. Villalpando, 1686-1690. Libro: 4, sig. 7730, 157-160, (Inventario de bienes).

P. N. González Espino. Villalpando, 1697. Libro: 1, sig. 7734, 57-58 recto, (Inventario de bienes). 
P. N. González Espino. Villalpando, 1697. Libro: 1, sig. 7734, 178, (Inventario de bienes).

P. N. González Espino. Villalpando, 1698. Libro: 2, sig. 7734, 57-58, (Inventario de bienes).

P. N. González Espino. Villalpando, 1698. Libro: 2, sig. 7734, 164 recto, (Inventario de bienes justo después de un testamento).

P. N. González Espino. Villalpando, 1698. Libro: 2, sig. 7734, 201-203 recto, (Inventario de bienes).

P. N. González Espino. Villalpando, 1698. Libro: 2, sig. 7734, 204-207 recto, (Cuerpo de hacienda).

P. N. González Espino. Villalpando, 1698. Libro: 2, sig. 7734, 209-210, (Hijuela).

P. N. González Espino. Villalpando, 1698. Libro: 2, sig. 7734, 211-214 recto, (Prosigue de la anterior hijuela (pago)).

P. N. González Espino. Villalpando, 1696. Libro: 2, sig. 7734, 333-342, (Inventario de bienes). 

ANEXO 2. MUESTRA DE INVENTARIOS 



\section{Ejemplo n. 1: Inventario de bienes de Joseph de Baamonde}

Tipo de documento: Inventario

Notario: Antonio de Escobar

Localidad: Valderas

Fecha: 1682

Signatura: 2312

Caja: 6051

Folios: $458 r-462 r$

(Fol. 458 r.) En la villa de Valderas a dos días del mes de nobiembre de / mill y seisçientos y ochenta y dos años, el [...] Domingo [...]/ alcalde hordinario en ella, por ante mí el escriuano dicho = se ha/ dado notiçia que Joseph de Baamonde [...], vecino de esta dicha/ uilla, a muerto y passado de esta pressente vida, dejando yjos/ menores de los dos matrimonios, y algunos bienes, que an de auer/ dicho yjos y herederos = y para que no se oculten y cada uno aya/ y lleue la parte que les tocare = mando açer $y$ que se aga ynben- $/$ tario de dichos bienes muebles y raízes, que hubiere dejado/ y pareçe erencia del dicho Joseph de Baamonde, a que mandó/ assista yo el escriuano y por este su auto así lo prouego y no lo [...]/ por [...] y en fe de ello lo firmé, ante mí Antonio de Escobar/ en la dicha uilla de Ualderas el dicho día, mes y año, y yo el dicho escribano/ doy fe que en compañía de dicho señor alcalde, fui a las cassas/ de la morada de dicho Joseph Baamonde, donde bi muerto/ de cuerpo naturalmente en su cama según parezía, y para/ que conste de mandado de su [...], lo doy así por fe, y lo firmo/ siendo testigos Gaspar de Uillalpando, y Joseph de España/ vecinos de dicha uilla, Antonio de Escobar Primeramente, la cama en que murió que es de madera de / nogal con sus cordeles, una delantera, un jergón de estopa, dos/ dos colchones, dos sáuanas, una de estopa, y otra de estopilla/ [...]

(Fol. 458 v.) Un cobertor de Palençia y una sobre cama de estameña usada/ Vna colcha de botonzillos, y dos almuadas de lienzo/ Vn quadro en tabla con la echura del niño san Juan con su/ marco negro y dorado/ Otro quadro mayor con su marco de la echura de san Yldefonso/ Otro quadro del mismo tamaño con el mismo marco con la/ efigie de Christo nuestro bien con la cruz a cuestas/ Vn quadro pequeño en bastidor, con la efigie de Christo nuestro/ bien y San Franzisco/ Otro quadro más pequeño con la echura de a Berónica/ Otro quadro en tabla que no se conozen sus pintura/ Dos laminicas con sus marcos/ Vna cruz con un cruçificado en pintura/ Vn bufete de nogal con los pies de lo mismo/ Una cama rasa/ 


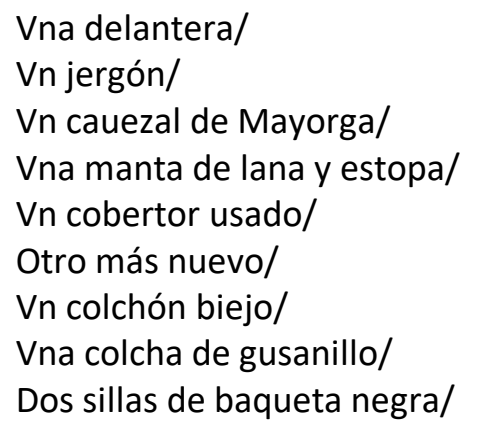

Vn baúl negro clabeteado con su zerradura y llave, y en él o ocho sauanas de lienzo casero/ tres nuevas y çinco usadas/ quatro almuadas de lienzo/ dos nuevas y dos usadas/ quinze serbilletas de gusanillo nueuas y ussadas/ Vna tabla de manteles de gusanillo delgado buena/ otra tabla de manteles de alimanisco

(Fol. 459 r.) Dos tablas de manteles de gussanillo grueso nueuas/ otras dos tablas de manteles de gusanillo grueso ussadas/ Dos tuallas de lienzo compuntas, una nueva y otra husada/ Vna sauana de lienzo ussada desecha/

Dos bujías de latón nuevas/

Diez y ocho madejas de ilo basto/

Tres madejitas de ylo fino/

Vn talego de estopa/

Vnos guantes de hombre/

Dos madejas de ilo mediano/

Vn pergamino con papeles/

que todo se bolbió a dicho baúl y se zerró con llaue/ otro baúl del mismo jénero abriosse y allosse en él lo siguiente/ beinte y nueve obillos de lana blanca delgada/

Vn fajero de lana/

otro fajero de ilo/

Vn obillo de ylo blanco/

Vna camissa de lienzo de hombre/

Dos paños de manos de lienzo basto ussados/

otro obillo de ylo gruesso/

Vna media pierna de sáuana/

Vna camissa de muger bieja/

otra camissa de muger buena/

Vna mantilla de grana blanca/

Vnas calzetas de ylo gruesso/

Vn cubridor con sus puntas/

Vna sábana muy bieja de colchón/

Vna almillica de niño de gusanillo/

Vna camisica bieja de una niña/

Vnas manguillas de lienzo biejas/

que se bolbió todo a dicho baúl y se zerro con llave

Vna banquita baja 
(Fol. 459 v.) Vn baul grande roxo con zerradura y llave abriose y allose/ en el lo siguiente/

Calzón, ropilla y ferreruelo de bayeta de zienfilos/

Vnos calzones y anguarina de paño de Segobia usado/

Vnos calzones y capa de paño de las Nauas/

Vn guardapié de estameña açul bordado/

otro guardapié de la misma estameña/

Vna basquiña y anguarina de olandilla/

Dos almillas de sempiterna encarnado/

otra basquiña de olanda/

Vnas manguillas de tafetán amusco/

otro jubón de olandilla/

Vn guardapié de rasillas azules con tres garapiñas/

Vna basquiña de estameña amusca/

Vn manguito negro/

Dos tocas con sus puntas, una nueva y otra ussada/

Vna mantilla de bayeta blanca/

Vn sombrero forrado biejo con su colonia/

Vna balona con sus puntas

bolbiosse a dicho baúl y se zerró con llave/

Dos candiles de garabato/

Dos morillos de yerro altos/

Vn escalfador de cobre/

Vna arca de pino con zerradura y llave en que solo avía pan cozido/

Vn copero de madera/

Vna sáuana de estopa/

Vn carralón de ocho o diez cántaras/

Vn bufete de nogal grande con su cajón/

Vna muela con su asiento/

Vn banco de bedul de carro/

Vn banco raso de pino/

(Fol. 460 r.) otro banco de álamo de respaldo/

quatro cántaros de uarro/

Vna clauera con sus garfios/

Vna tinaja zamorana pequeña/

Vnas aguaderas

Vna cuchara de olla y una cobertera/

Vn pozal/

Diez ysiete cargas y media de zestos buenos/

Diez y siete gallinas y pollas, una paua, un capón y un pollo/

Dos marranos, uno grande y otro mediano/

Vna pollina parda que está en depósito de las que se quitaron

a las jitana

y por ser oy dicho día tarde, sumad resto en dicho inventario/

no con protesta de proseguirle en los demás bienes, y no como/

por no sauer y en fie de ello lo firmo = Antonio de Escobar/

en la dicha uilla a quatro días del dicho mes de nobiembre/

del dicho año, sumad de dicho señor alcalde, estando en /

las cassas de la morada de dicho difunto prosiguió el yn-/ 
bentario en la manera siguiente/

[...]

[prosigue el inventario]

Vna cama carretera/

Vn jergón

Vna manta de lana y estopa bieja/

otras dos mantas de lana muy biejas/

Vn cauezal de terliz biejo/

Vn costal tambien biejo/

Vn cobertor de Palençia usado/

Vna sáuana de estopa bieja/

Vnas barillas de zerner/

Vna banquita de labar paños/

Siete tablas de álamo y pino/

Dos hojas de paja con çinco fanegas de arina de trigo/

otra hoja más pequeña/

(Fol. 460 v.) Vn menester mediano de colar/

Vna cuna de niños/

Dos escriños buenos/

Vn barril grande acarralado/

Vna olla de bender bino y un ollón/

Vna media cántara de uarro/

Vn bocado con sus cauezas y riendas/

quatro zedazos buenos/

otros quatro zedazos biejos/

Vna artesa mediana bieja/

Vn almirez con su mano/

Vna caldera de cobre mediana/

Otra caldera de cobre pequeña/

Siete camissas de muger/

zinco camissas de hombre/

Diez camissas del niño nueuas/

Dos camissas de las niñas

quatro pares de calçonzillos/

quatro pares de calzetas de ilo/

Dos pares de escarpines/

tres tablas de manteles pequeños de gusanillo/

Vna delantera de cama/

Dos paños de afeitar/

Vna sáuana del pan/

Vn escriño/

Dos menestericos y un canastillo grande con lana de enfrondar/

tres bellones de lana suzia/

seis bujías de latón buenas/

Vn jubón de sempiterna acauellada viejo

otro jubón de estameña cassera azul con mangas de sen-/

Piterna negra/

(Fol. 461 r.) Vna ropilla de paño de Segobia vieja/

Vna çesta con beinte y ocho bentosas grandes/ 
Dozena y media de bentosas de niños/

$\mathrm{Vn}$ costal con una emina de çenteno/

Dos sartenes medianas/

Vn cazo de azófar mediano/

otros dos más pequeños y otro más pequeño/

Vn cazo mediano de cobre/

Vn asador mediano/

Vna baçía de azofar/

Dos baçías de Talabera/

Vna caja de barbería con seis nabajas, dos tigeras, un espe-

jo, Vna piedra de afilar y un peine/

Vn escritorico con tres cajones/

Vna cuja/

Vna bota pequeña de echar bino/

Dos libras de lino en manadas/

Vna çincha jineta/

Vna fuente entrefina y una escudilla fina/

Vn yerro de mula/

Vn yerro que llaman badal/

Vn yerro postemero/

dos gatillos/

Vna algalia de plata/

otro yerro de sedal/

Vna plancha de abrir fuentes/

Dos cuerpos de libros grandes del arte de zirujía/

Siete cuerpos de libros más pequeños del mismo ofiçio/

Seis carros de paja de trigo y zeuada/

Vn estuche del ofiçio de zirujía y en el siete lanzetas/

$\mathrm{Vn}$ apostemero, un sajador, un berduguillo, una tienta/

(Fol. 461 v.) Vnas tijeras, una espadilla de plata, una lima, unas pin-/

zas, $V n$ abuja, um botador, dos cañones, un de aujas y otro/

de polbos/

Vn cofrecito muy pequeño con zerradura y llave y en él/

Dos anillos de oro, el uno con siete piedras y el otro con/

quatro/

Vn basito de plata/

Vna cucharita de plata de niños/

Vnas tijeras de latón/

Dos cucharas de plata/

en un apossento alto se alló un montón de zeuada, que a-/

biendose medido, pareçieron ser tres cargas y media/

En el mismo apossento se alló un montón de trigo que se/

midió y pareçió aver tres cargas y tres fanegas/

en dicho apossento se alló otro montón de trigo que se midió/

y pareçieron ser dos cargas/

en una artesa se alló un poco de zenteno que se midió/

y pareçió ser media carga/

en un silo del portal de dichas casas, se alló otro pedazo/

de trigo de dicho difunto, que suma d ocho sacas y media/

y pareçió aber en él catorze cargas/ 
assimismo, puso por ymbentario una tabla labrada/ y dorada en partes que tiene dos puertezillas con que se/ zierra, pintada, en ella la pasión de Christo nuestro bien/ también pusso por ymbentario un basto de ocho pal-/ mos lleno de uino tinto de la cosecha de este año que está/ en la bodega de Francisco Peláez y uno y otro son bienes/ de dicho difunto y açe çiento y diez cántaros/ assimismo puso por ymbentario un biña que dicho/ difunto en término de esta uilla, y pago que llaman/ carreborrero que açe beinte y quatro quartas y doze çepas/ [Bienes raíces]

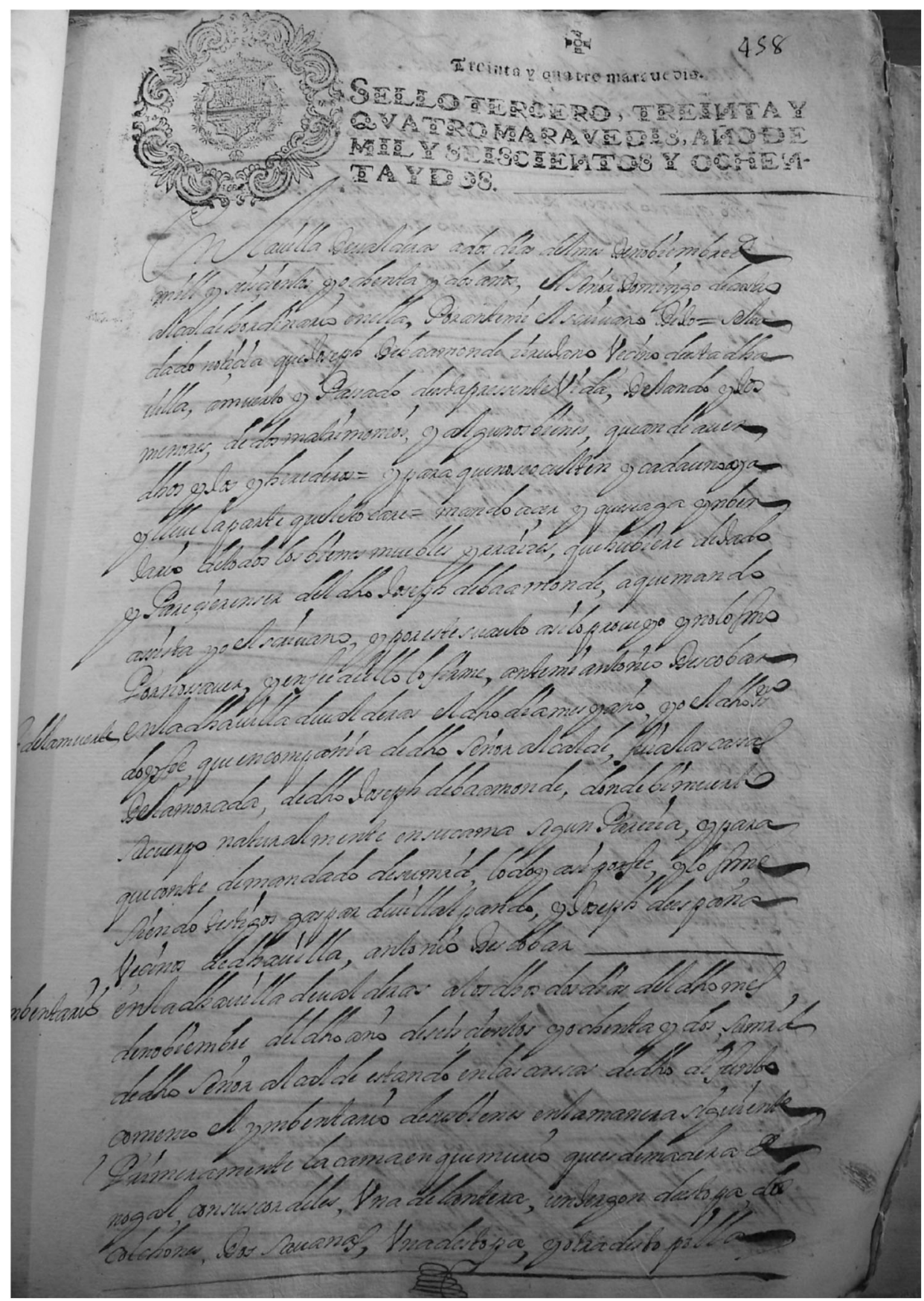




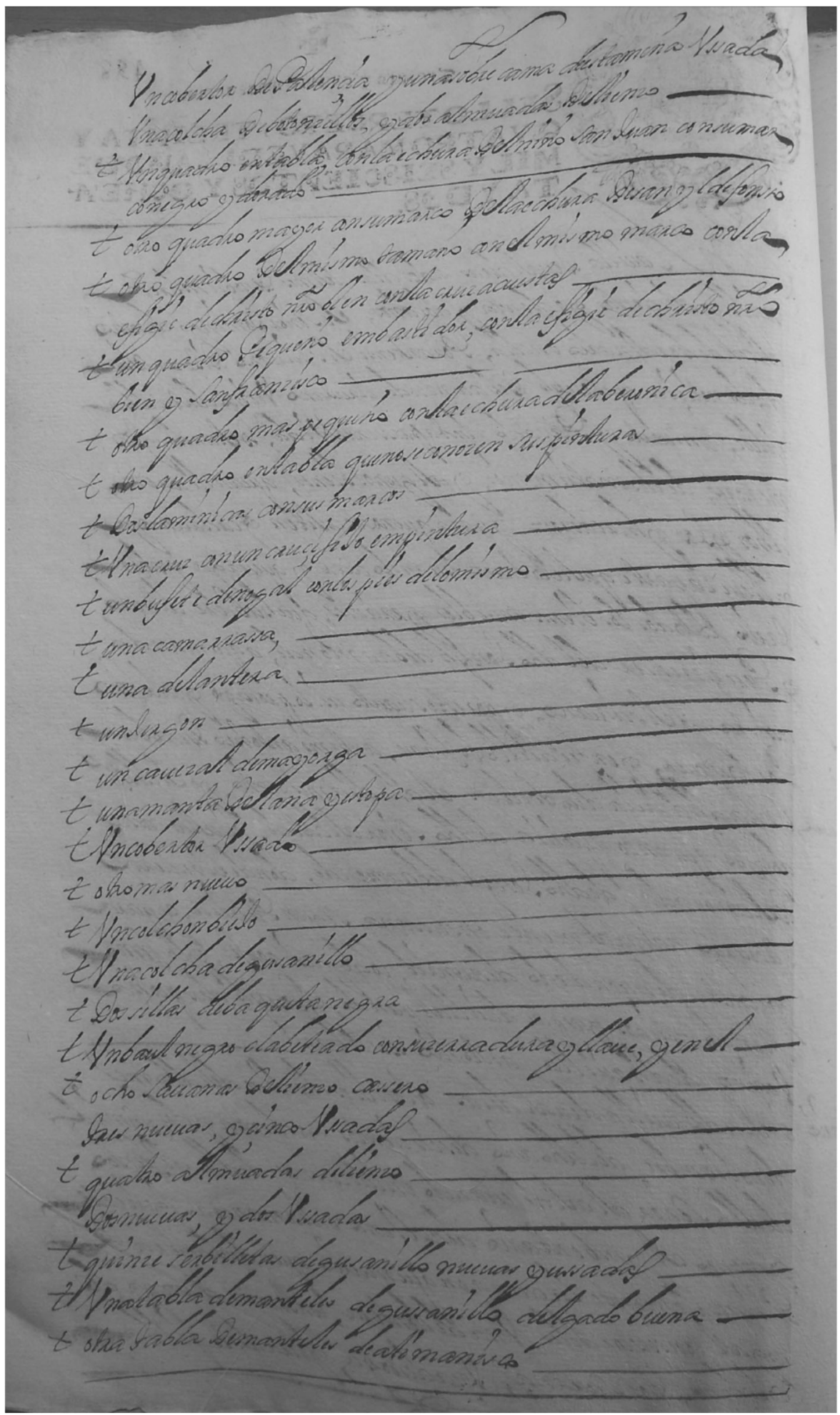




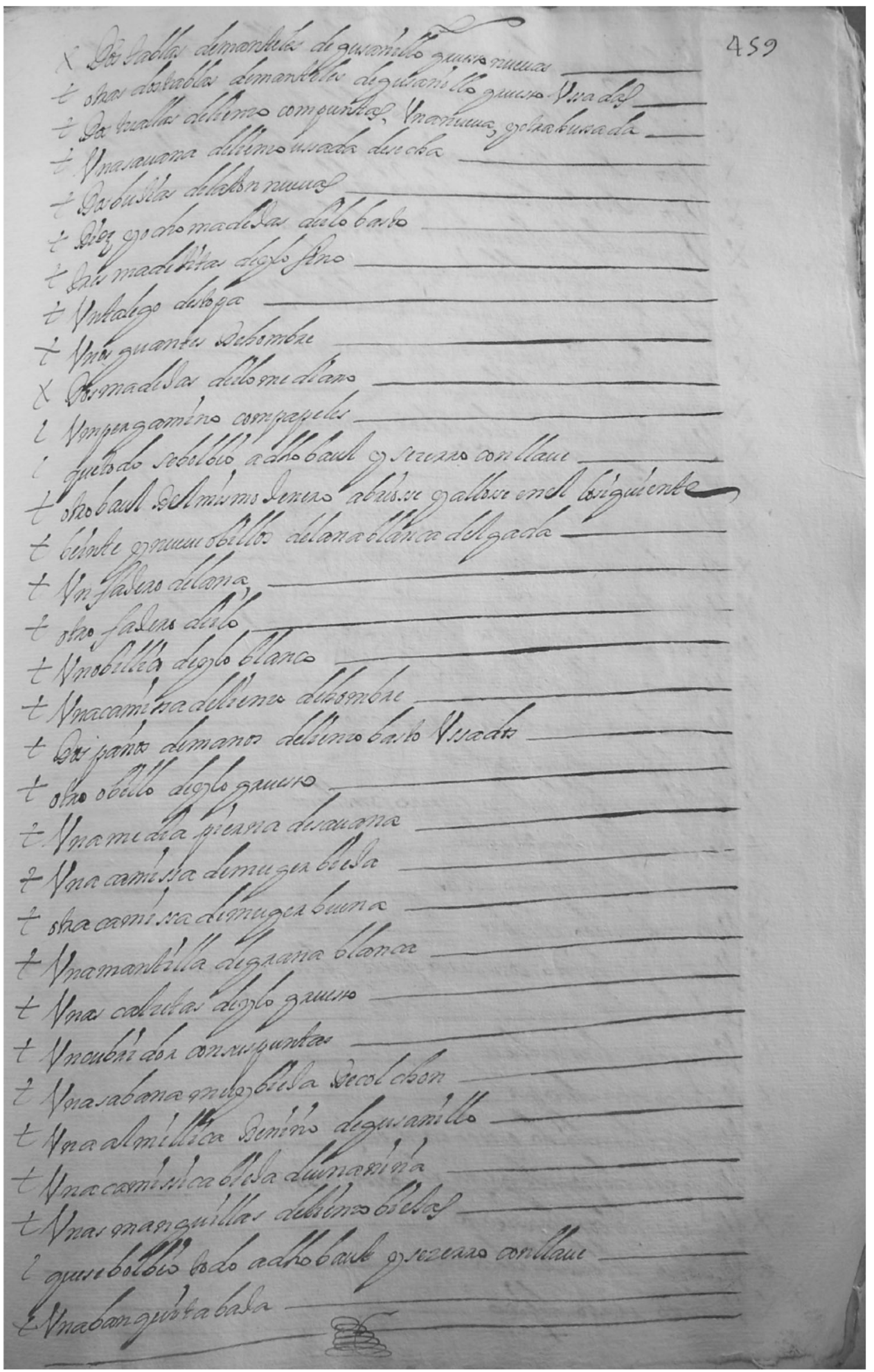




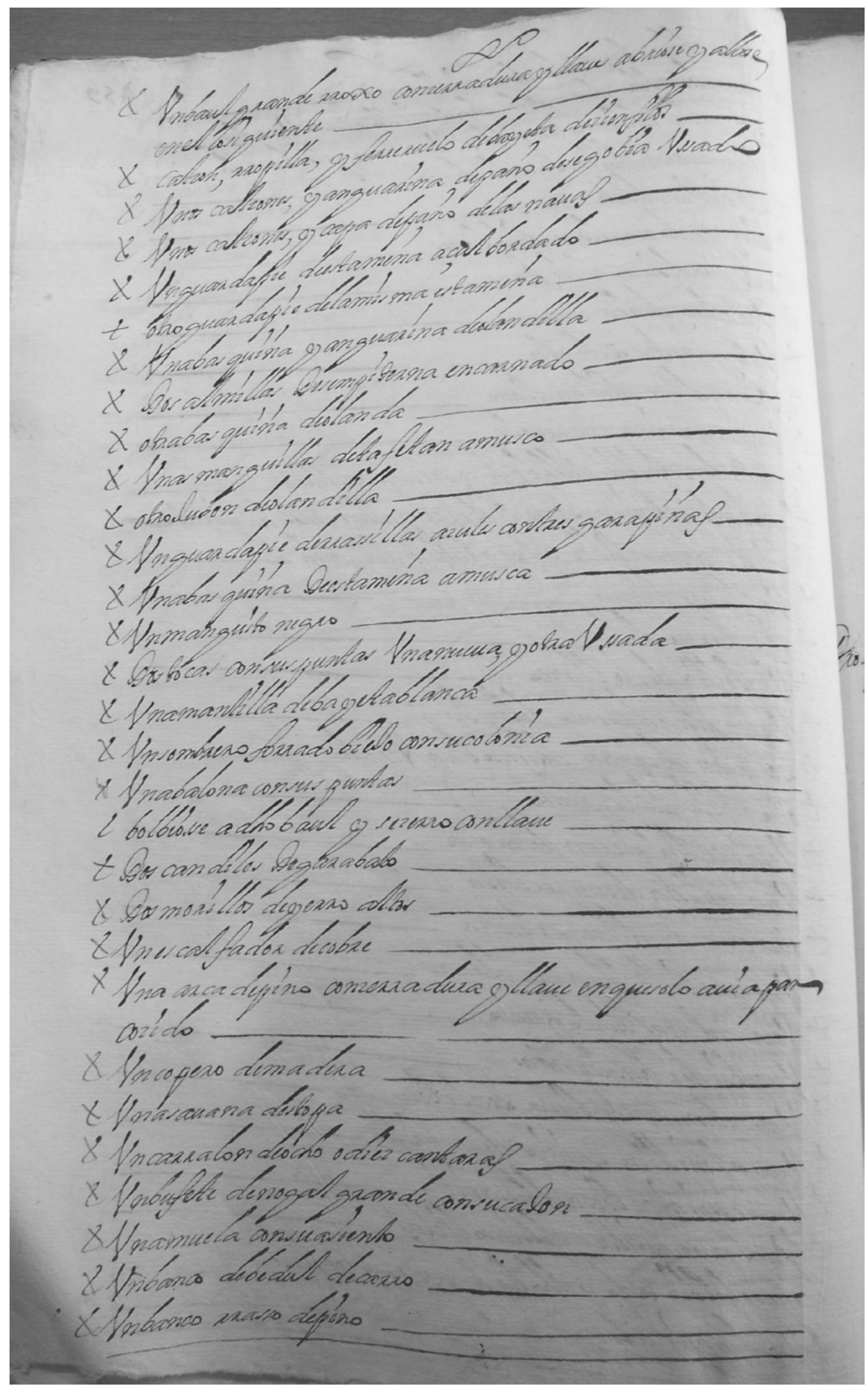




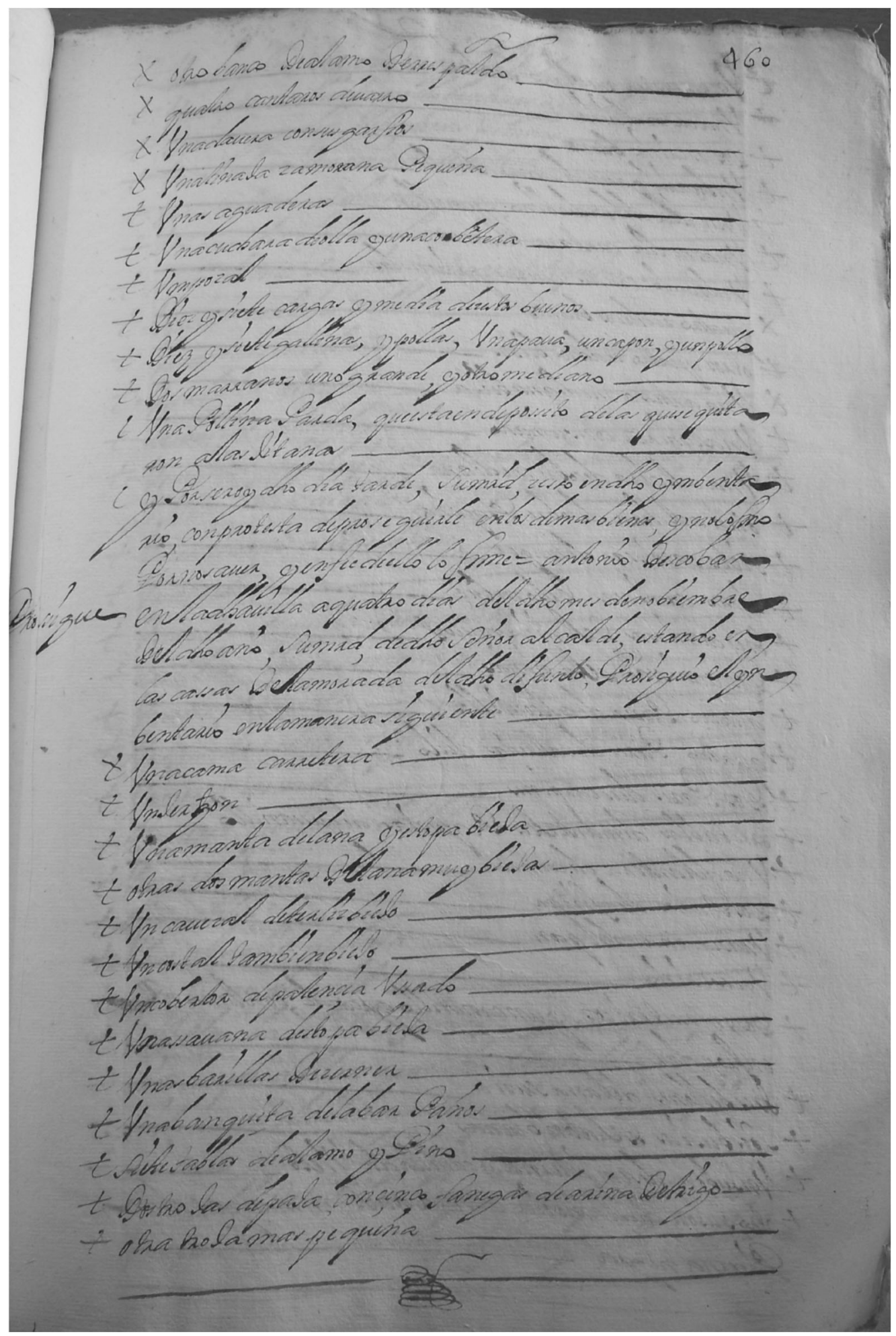




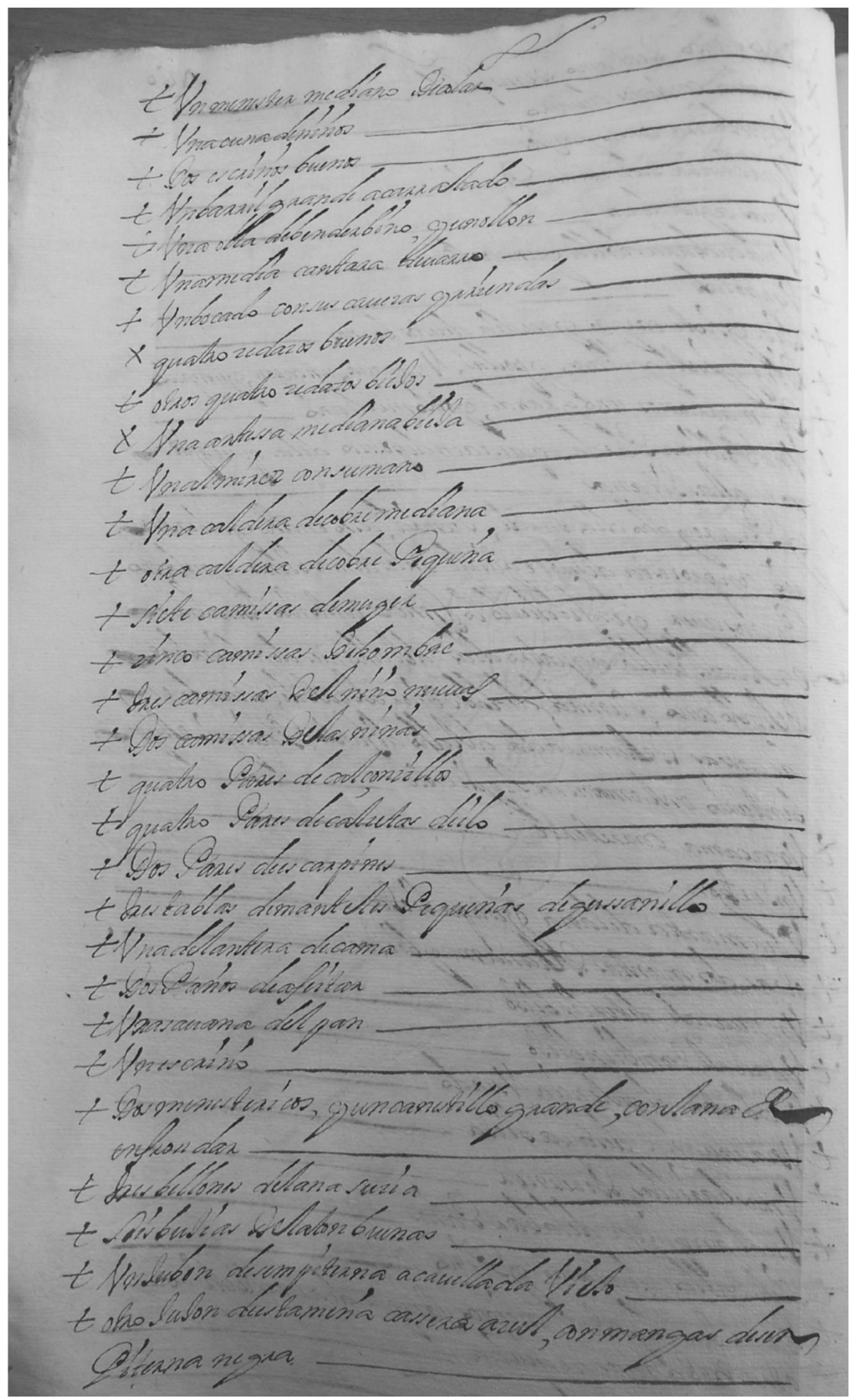




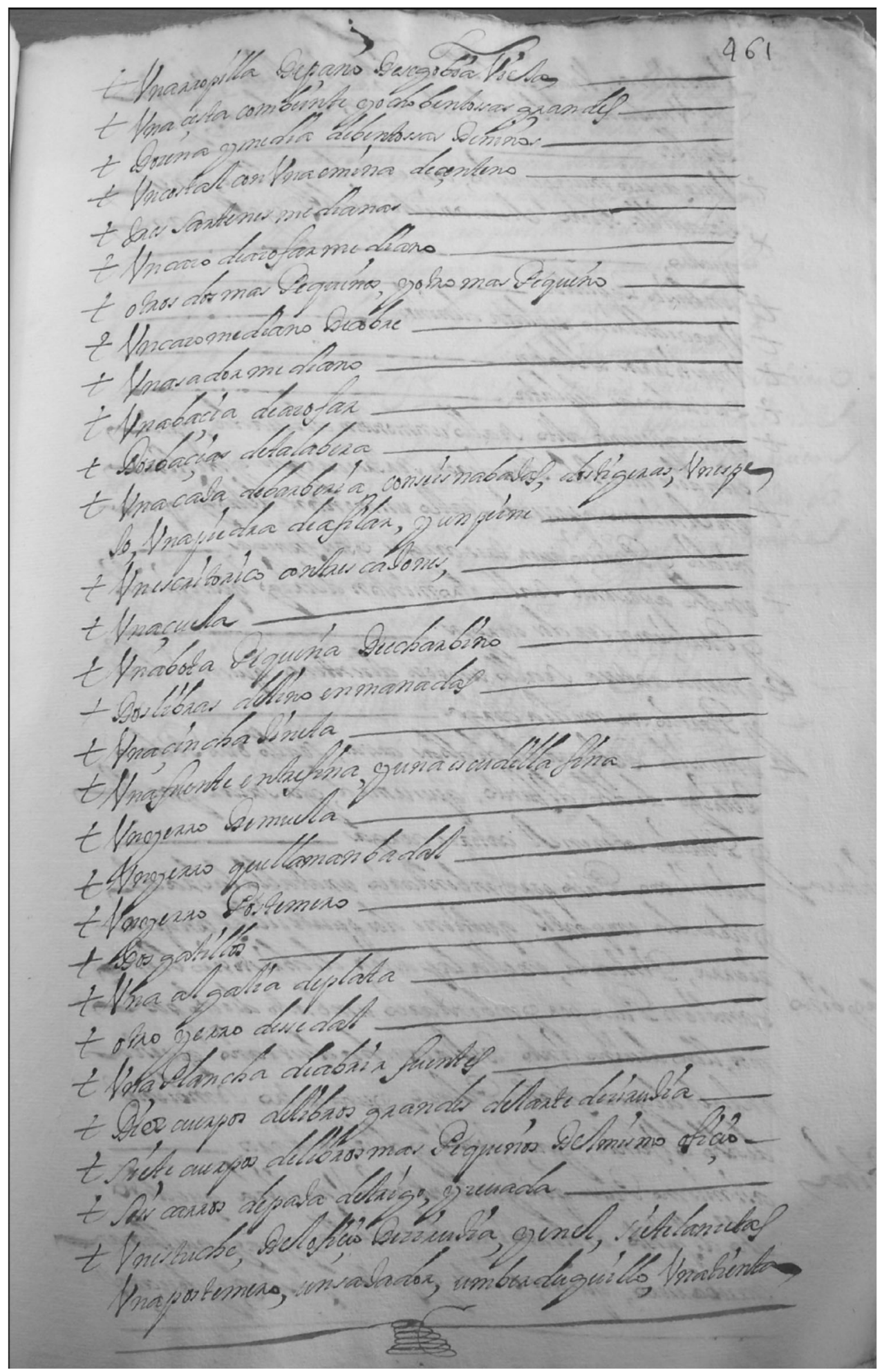




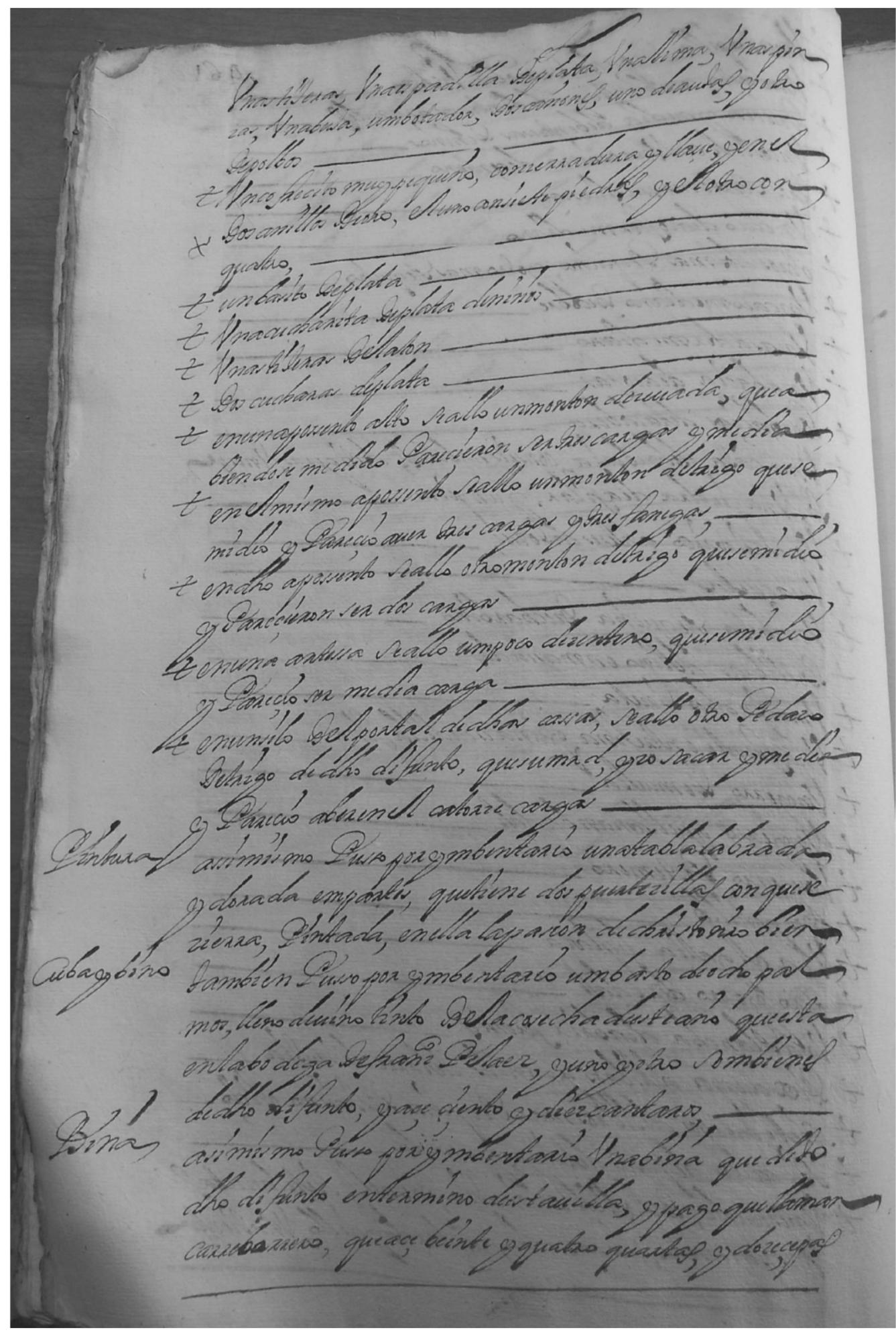




\section{Ejemplo n.o 2: Inventario de los bienes de Matías García}

Tipo de documento: Inventario

Notario: Francisco Andrés

Localidad: Villarramiel (Palencia)

Fecha: 1690

Signatura: 13332

Folios: 94 r. -95 r.

Ynbentario de los bienes que se allaron/

en las casas de Matías García difunto/

(Fol. 94 r.) En la villa de villarramiel a diez y seis dias del mes de abril de mil/

y seiscientos y nobenta años sumo de Tomás Martín alcalde hor-/

dinario en esta dicha villa dijo que por quanto tiene noticia que Matias/

Garçía Martín vezino que fue en esta dicha villa es muerto y murio en/

la villa de castroponçe y porque dejó hijos menores ynábiles de

poder administrar sus bienes y para que en todo entre ellos y los acree-/

dores que ubiere aya la quenta que *a continuación biene, mandó se aga ynbentario/

jurídico de todos los bienes muebles y rayces que se conocieren ser su- $/$

yos, poniéndolos en depósito en persona abonada y no lo firmo sumo/

por no saber de querpo el escribano doy fe y firme/

Ante mí/

Francisco Andrés/

Y cuyo yncontinente sumo fue a las casas de la morada de dicho/

difunto y preguntando a Matías y Alonso García, hijos del dicho difunto/

por su madre respondieron que estaba en Castroponçe a [...] a su padre/

que abía muerto allí y sumo por ante mí el escribano y testigos hiço ynben-/

tario de los bienes siguientes/

Primeramente, quatro medios tozinos = dos ollas de manteca $=$ una an $-/$

gurina de estameña nueba forrada en baeta colorado = una capa de lo/

mesmo nueba $=$ unos balones de lo mesmo forrados en lienço nuebos =/

un sombrero mediado $=$ un reboçino con galones = una mantilla de $/$

estameña = una basquiña de estameña con rodadura = un manto de/

paño negro medidado = unan sábana con tres piernas buena = un lançu /

elo basto = unos manteles de por curar nuebos = una almoada con/

ramos azules buena = unos cuerpos de grana buenos con guarniciones/

de dos géneros = una mantilla de enpañar mediado = una mantilla/

de estameña de mezcla mediada = un manteo azul con rodadura colora-/

$\mathrm{da}=$ un capillo de niño con puntas bastas = una libra de lana ylada bas-/

ta $=$ un paño de ofrenda mediado = una beatilla mediada $=/$

(Fol. 94 v.) onçe piezas de çecina de baca = una delantera de cama con rede /

una almoada buena labrada = un lanzuelo con tres piernas/

media carga de arina = una tina bieja = un tunel que ara como diez/

y ocho cántaros = una media fanega bieja = otra media fanega/

buena con su rasero = un tunel que hará treinta y quatro cántaras/

otro tunel que ará beinte y seis cántaras = un arca de roble gran-/

de nueba con su cerradura y llabe = otra arca de pino pequeña con/

su çerradura y llabe = otra arca más pequeña con çerradu-/ 
ra y llabe $=$ tres çeraços mediados $=$ una brega mediada con su $/$ bregón = una artesa de masar mediada = otra artesa de labar =/ un par de peines de plinar lana buenos = otro par de peines mediados/ dos ugos ariscos $=$ dos arados con sus rejas y todo lo necesario $=$ dos $/$ colleras = un cazo herrado bueno = dos mallas $=$ un par de costanas $/$ un tillo bueno = otro trillo biejo = una mesa de pino pequeña con / su cajón $=$ dos fruteros $=$ un garrote $=$ dos escriños $=$ dos costales $/$ dos pares de alforjas $=$ un cofrezillo pequeño $=$ dos tableros de açer $/$ queso = un espejo biejo = un cuchillo $=$ una cesta de asa $=$ diez/ y seis gallinas y dos gallos = dos herradas mediadas = una cal $-/$ dera bieja $=$ dos candiles de yerro $=$ un badil para la lumbre $=$ tres ca $-/$ nales de ganado = un banco con dos pies = otro banco con quatro/ pies = un banco de respaldo = una escalera con diez banços $/$ un baral de pino $=$ çinco quinçales $=$ dos artesones $=$ un par de $/$ çestos = una mesa bieja = dos tablones buenos = una clabera con $/$ garfios $=$ tres oçes buenas $=$ seis ollas $=$ dos cántaros $=$ çinco $/$ botijones = una mula de labrança color castaña de edad çerrada / una yegua de labrança morena çerrada = un macho çerril de dos años/ un potro de un año = un pollino de carga pardo de seis años = quatro/ jarros $=$ un salero de Talabera $=$ dos cargas y media de trigo $=$ una $/$ botija de tener aceite $=$ tres escodillas de Talabera basto $=$ un plato/ de lo mesmo = una fuente de barro = un almirez con su mano / una sarten mediada = un cazo bueno = una cama con un jer $-/$

(Fol. 95 r.) gón = dos cabezales mediados = una manta mediada = un cober $-/$ tor medidado =un zielo de cama mediado $=$ cinco $*$ sarrodeos biejos $=/$ siete pinturas, tres medianas y quatro pequeñas $=$ una echura de/ un Santo Cristo = una escarpeta medidada = una zerradura $\sin /$ llabe $=$ una podadera $=$ dos azadones mediados $=$ una çoleta $/$ mediada $=$ un aparejo de mula mediado $=$ dos dentales $=$ una $/$ cama de arado = quarenta y dos pellejos enteros de obejas y car-/ neros y quatro pedaços = tres arrobas de lana *sayón labado/ tres arrobas y media de lana en jugo = beinte y siete libras y media de lana/ peinada = nobenta y çinco reales que se allaron en Castroponçe don-/ de murió el difunto como *con esto de testimonio del cura Geró-/ nimo Ribera y Guerra = más sesenta reales de un doblón que dio Francisco/ López Carlon a María Plaça, muger del difunto el día que fue por él / más quarenta y dos reales que quedó debiendo el dicho Francisco López/ que todo son çiento y nobenta y siete reales = para todo lo qual fue- $/$ ron testigos Pedro Martín Sánchez, Juo Martín Arnillos y Pedro García a-/ Asensio, bezinos de esta dicha villa y en fe de ello lo firman... 


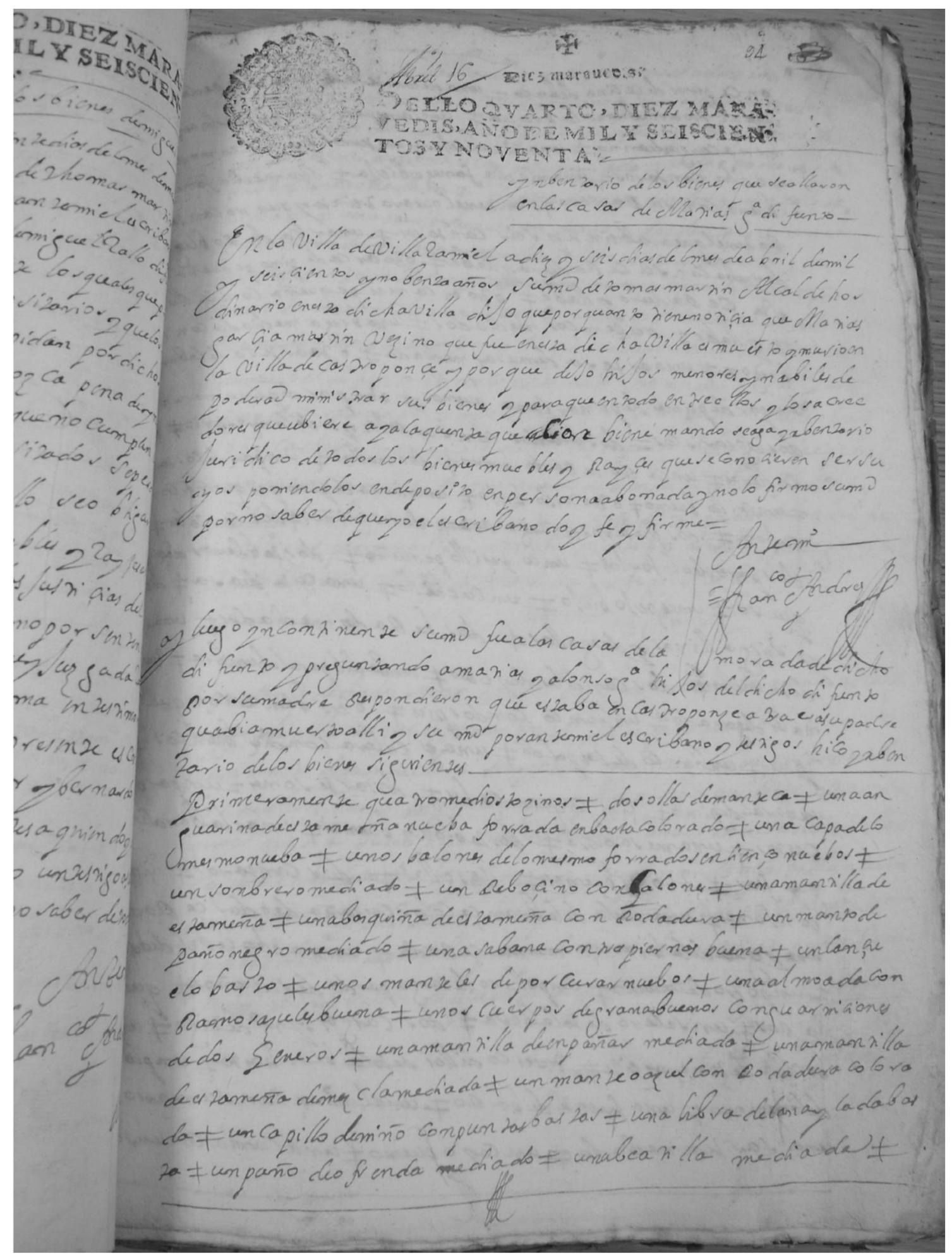




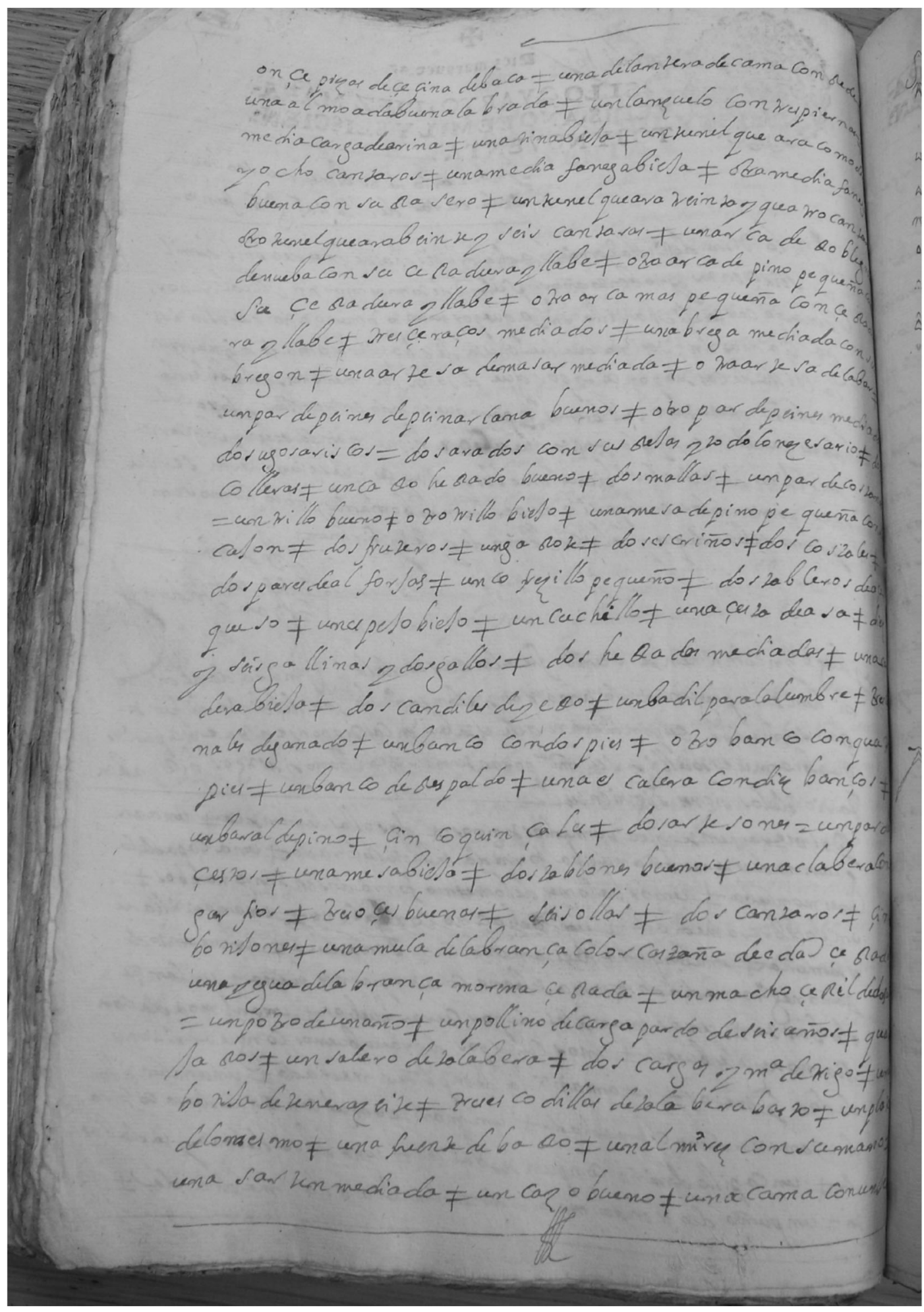




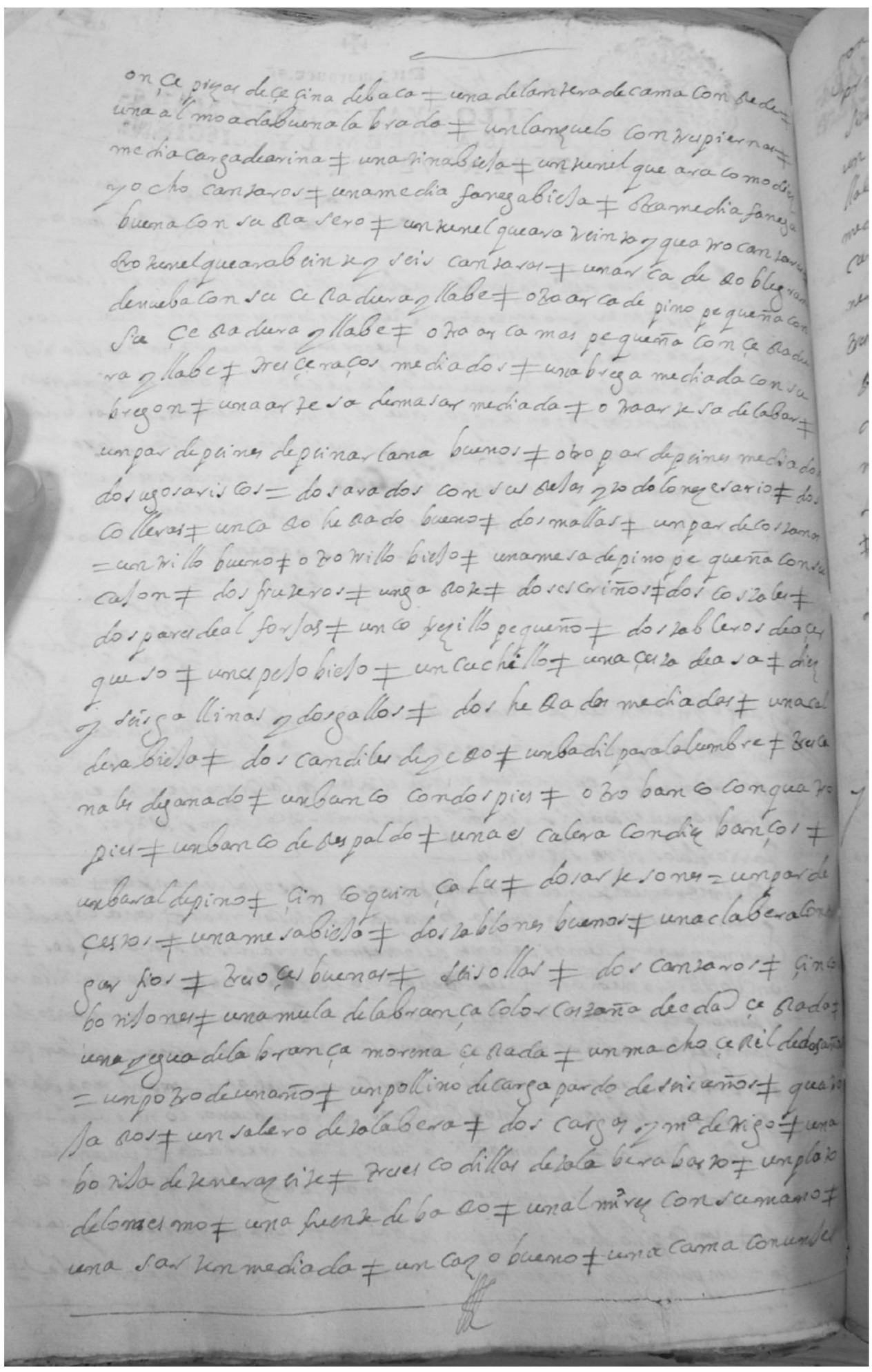




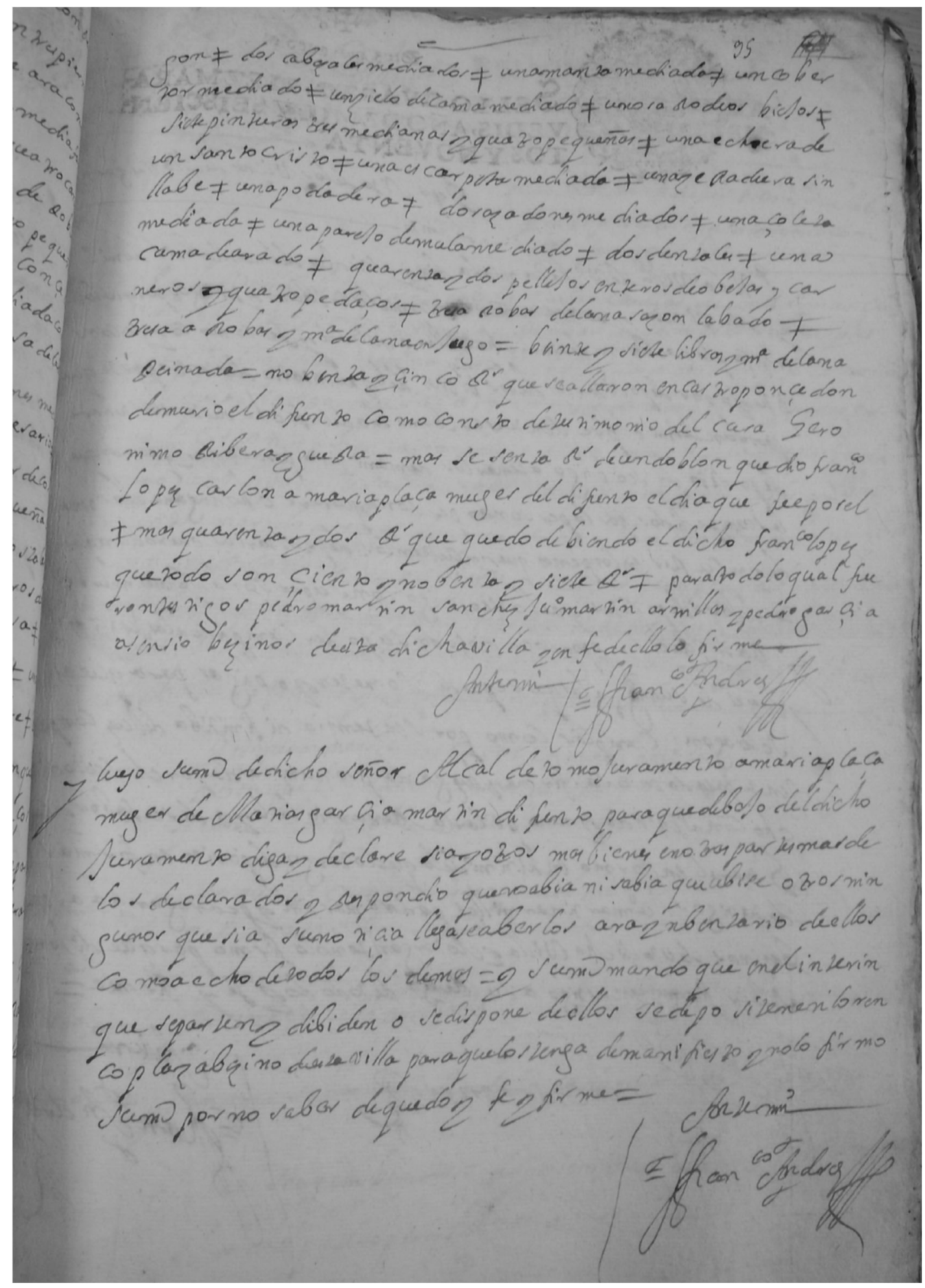




\section{Ejemplo n.o 3: Inventario de los bienes del doctor Baltasar de León Coronel}

Tipo de documento: Inventario

Notario: Martín Díez

Localidad: Medina de Rioseco (Palencia)

Fecha: 1640

Signatura: 8856

Libro: 1

Folios: $472 r-475 r$ (transcrito hasta el $474 \mathrm{v}$ )

(Fol. 472 r) En la ziudad de Medina de Riosseco a diez/ y nuebe días del mes de henero de mill y seis/ zientos y quarenta años en cumplimiento del/ auto de [...] y comisión dada a mí en presente [...]/ estando en las casas donde murió el dicho doctor Baltasar/ de León Coronel médico bezino de esta dicha ciudad/ y abiendosseme echo franca la dicha cassa y estando/ pressentes doña María de Léon Coronel yxa del dicho/ dotor y doña Antonia Díaz de Miranda, *buida del/ dicho dotor y el lizenziado Francisco de Coronel y doña/ Francisca de León Coronel *buida yxos del dicho dotor León/ y Antonio Díaz de Miranda su testamentario/ pusse por ynbentario los siguiente:

Primeramente en el aposento questá en la ssala prinzipal/ donde murió el dicho difunto se alló quatro reposteros de armás/ más una cama de campo de nogal de salamanca con/ las cortinas y zielo de paño aberde y flocadura de seda berde/ muy trayda/ más dos alonbras traydas/ más un escabel de nogal grande/ más un belador de pino de pie y la tabla de enzima de nogal biejo/ más en otro apossento más adentro se alló una arca de nogal/ que se abrió y en ella se alló lo siguiente= siete cuchares de plata/ una xara de plata grande= dorada toda en su caxa = dos/ tazas doradas de plata la una en su caxa = un salero de plata/ dorado de tres piezas $=$ un bernegal de plata dorado $=$ otro bernegal de plata blanca balaustreado = otra xara más pequeña de plata blanca = más un salero, azucarero y pimentero de/ plata blanca=dos platos de plata grandes= que llaman ga $-/$ Ilineros= otra cuchar de plata pequeña de guebos= una salbilla/ de plata $=$ más un plato de plata $=$ más dos candeleros de/ plata grandes/ más en otro apossento se alló los siguiente:/ dos reposteros de armás muy biejos/ una cama de campo de nogal muy bieja con sus cortinas y zielo/ de paño azul y la flocadura de seda dorada todo biejo y apolillado/ 
más una cama de cordeles con su xergón, dos colchones, dos sá-/

banas de lienzo, dos mantas blancas traydas y un cobertor/

azul de Palenzia, dos almoadas Ilanas de lienzo delgado/

más otra cama de campo de nogal que tenía lo siguiente: una cama de cor-/

del con su xergón, un colchón, dos sábanas de lienzo la una y otra, de/

sedilla, dos mantas una nueba y otra trayda, un cobertor/

(Fol. 472 v) de paño azul nuebo, una almoada de lienzo/

labrada con ylo azul/

más una silla negra con el respaldo de baqueta y asiento/

de lo mismo bieja/

un bufete de nogal pequeño con garrotes de yerro/

más quatro lienzos de los quatro dotores con sus marcos dorados [...]

más otro lienzo pequeño de Nuestra Señora con su marco dorado biejo/

más otro lienzo de San Roque pequeño con su marco biejo/

otro lienzo de Nuestra Señora más grande con su marco dorado biejo/

más una echura de un Niño Jesús de bulto con su peana dorado/

y una diadema de plata/

más dos ymáxenes de nuestra señora pequeñas de bulto/

más otro Niño Xesus pequeño metido en sus andas y bestido de [...]/

dos láminas de Nuestra Señora pequeñas, la una con marco dorado y la otra/

con marco de hébano/

más un Sto Xrispto de pinzel en una cruz con su zielo de tafetán/

dos relicarios de anus guarnezidos con plata *escan-/

chada/

más una cruz de reliquias/

dos láminas pequeñas de bronze/

una adorazión de los reyes/

más otra de la Madalena/

otra lámina pequeña redonda de un salbador de alabastro con su marco de madera dorado/

otra lámina pequeña de Nuestra Señora de la Piadad con [...]/

una cruz de santo Toribio grande/

más quatro tablas pequeñas con sus marcos negros muy/

biexas/

más un ezeomo de pinzel mediano con su marco negro/

más un santo Cristo pequeño de bronze/

en una cruz de reliquias y la cruz tiene un brazo quebrado/

más un espejo con el zerco dorado/

otras dos tablicas sin marcos biejas/

más en otro apossentto más adentro quatro tapizes /

de figuras buenos/

más un cuadro grande de Nuestra Señora con el niño/

enzima de la cruz con marco dorado/

más otro quadro grande de san *Juan de Saagun con marco dorado/

más otro quadro grande de Nuestra Señora del populo con marco dorado/

(Fol. 473 r) más otro quadro de Nuestra Señora y San Joseph y el/

niño y san Joan con marco negro y echas unas labores de/

paxizo y blanco/

más otro quadro de un ezeomo con marco negro y *echas/

unas labores de blanco y paxizo/ 
más otro quatro de Nuestra Señora y los ánxeles con/

marco dorado/

más otro cuadro de Nuestra Señora y san Joseph y el niño/

dormido/

más otro quadro en bastidor de san Joan/

más una echura de un santo Xpto de broze: en su/

caxa con puertas/

un banco de nogal con garrotes de yerro/

una messa de pino bieja/

una media cama de campo de pino pequeña y en/

ella un xergón dos colchones, dos sábanas de sedilla tray-/

das, una manta trayda, un cobertor de paño azul/

con flocadura de seda muy traydo, una almoada de/

lienzo llano rota/

más otra cama de cordel y en ella estava lo siguiente:/

un jergón biejo y un colchón y una sábana de lienzo/

trayda y una manta blanca y otra parda y un cober-/

tor colorado, todo muy traydo/

una cruz de reliquias/

una pila de agua bendita/

una arca de nogal que se abrió y en ella lo siguiente:/

una lámina de Nuestra Señora de la piedad con marco de ébano/

otra lámina de Nuestra Señora con marco colorado/

otra lámina de san Antonio con marco negro/

más una colcha de olanda con puntas trayda

más otra colcha de olanda nueba

más una pieza de manteles de gusanillo que tiene nue-/

be baras delgados/

más una pieza de estopa que tiene ocho baras/

más otras tres baras de estopa/

más otra pieza de pañizuelos delgados de gusanillo que tiene/

ocho baras y media/

más otra pieza de pañizuelos delgados de gusanillo de diez baras/

(Fol. 473 v) más una colcha de manteles de gusanillo de estopa/

más otra colcha de lienzo de borlillas muy trayda/

un baúl aforrado en badana negra/

y en otro baúl estaba lo siguiente: una pieza de man-/

teles delgados de gussanillo que tenía ocho baras/

más una tabla de manteles de gusanillo delgados que tiene

zinco baras/

más otra tabla de manteles de gussanillo que tiene/

zinco baras/

más una toalla de ruan labrada con bordados y desylados/

y con puntas/

más otra toalla de manteles de gussanillo delgada labrada/

con bordados y puntas de ylo de pita/

más otra toalla de gussanillo delgada bordada con quadros/

de cadeneta con ylo azijado y puntas de ylo blanco/

más otra tabla de manteles reales con puntas pequeñas/

más una delantera de cama labrada con ylo azijado y puntas/ 
más onze serbilletas de gusanillo delgadas y tres gordas/

más quatro almoadas de olanda con randas/

más dos almoadas de lienzo de aroca con pespuntes/

más otras dos almoadas de olanda con pespuntes/

más quatro almoadas de olanda con pespunte digo de/

lienzo las dos delgadas y las dos gruesas/

más otras dos almoadas de ruan con baynica/

más otras quatro almoadas de lienzo de aroca las dos con/

confitillos y las otras dos por azer/

más dos paños delgados de gussanillo, uno llano y otro con/

desylado/

más dos almoadas de olanda labradas con ylo de pita biejas/

más tres sábanas, una de estopa y otra de sedilla/

más dos sábanas, una de lienzo de aroca y otra de casero delgado/

más quatro sábanas de olanda/

más tres sábanas de lienzo cassero delgado/

más dos almoadas de lienzo muy delgadas y bordadas/

con ylo azixado/

más seis serbilletas de gusanillo delgadas con puntas/

más una toalla pequeña bordada con ylo azixado/

más ocho tafetanes azules y paxizos/

más otra arca de nogal que se abrió y en ella lo siguiente:/

quatro sábanas de estopa y una de sedilla traydas/

más tres sábanas de lienzo gordicas, la una muy trayda/

más tres paños de manos, de gussanillo los dos y el otro de lienzo/

traydos/

más diez serbilletas de gussanillo delgadas traydas/

más tres tablas de manteles de gussanillo delgadas traydas/

más siete almoadas de lienzo delgadas labradas de *ylo azul traydas/

más quatro delanteras de cama las tres labradas con ylo azixado y las otra dada/

(Fol. 474 r) más otro cofre viexo aforrado en pellejo de cavallo y en él esta lo siguiente:/ una ropa de bayeta muy trayda/

una saya de tafetán pardo/

un xubón de picote traydo/

un bestido de estameña buriel, basquiña, jubón y escapulario/

un jubón de tafetán doble acuchillado/

una basquiña de tafetán negro con diez y ocho guaniziones/

una ropa capona de damásco muy trayda/

ocho baras de tafetán doble en pieza/

una saya de damasco azul con randas de oro fino muy trayda/

más se alló all subir de la escalera una arca de nogal/

grande y en ella lo siguiente:/

dos almoadas de terciopelo carmesí traydas con los ondones de damásco/

quatro piezas de lienzo gordico crudo que tiene todas zinquenta/

baras/

más otra pieza de estopa que tiene treynta baras/

más otra pieza de lienzo delgado del ancho de los panizuelos/

que tiene treynta baras/

más se alló en una despenssa una manta blanca/

más un cobertor de Palencia traydo/ 
más dos cantinploras de cobre biejas/

más una serbilla de estaño bieja/

dos delanteras de cama, una berde y otra azul de paño/

más en otro apessento, una arca de pino bieja que no tiene nada/

más en un corredor estaua lo siguiente: un cazo de azófar biejo grande/

más otros dos cazos medianos de azófar biejos/

más otro de cobre mediano/

una sartén grande de yerro bieja/

más otras dos pequeñas traydas/

una cazuela de cobre grande/

un perol de azófar muy biejo/

una calderica pequeña y una aguamanil de cobre muy traydos/

unas trebedes y una espumadera de la olla de yerro biejas/

una calentador de cobre y el tapador de azófar/

una cobertera de yerro grande/

una cuchar de yerro de la olla/

dos asadores, el uno de tres gaxos/

dos calderos de cobre muy biejos/

una cuchilla y un acha de partir leña y un azadón/

una caldera grande de cobre/

otra más pequeña bieja/

un almirez de azófar con su mano/

tres cántaros de cobre/

una media cantara y un enbudo de cobre/

un cazo muy biejo de azófar que no sirbe/

un arco de yerro con treze piezas con la palanca/

(Fol. 474 v) más se alló en el aposento del orno, una brega y una/

artessa grande y unas barillas y zinco zedazos/

más una pala de yerro del orno y un cabezal biejo/

una cama de cordeles bieja/

dos candeleros de azófar y un rallo de yerro/

más en la despenssa del comedor, bajo dos sábanas de lienzo muy [...],/

nuebe madexas de lino/

más en la sala de abajo un aparador de nogal con dos lazenas qua-/

tro caxones/

una arca de pino bieja/

un brassero de yerro biejo mediano/

más en el *patin, un cazo de sacar agua/

más tres cargas de trigo en una tina de madera/

más en otra despensilla, media cama de campo bieja de nogal, zinco colchas/

más una tina de pajar bieja/

una colcha de lienzo de borlilla muy bieja/

más en la cueba tres carrales, la una muy pequeña/

en el estudio del dicho dotor los libros siguientes: treszientos y ochenta y/

tres libros diferentes y pequeños bien encuadernados/

más diez cajones en que están los dichos libros/

más un tablero de pino grande de dos tablas sobre elqual están/

dos caxones de libros más a los pies de pino sobre que están los cajones/

más una silla negra de baqueta muy bieja/

más un zensso de zincomill duszientos y zinquenta a *razo[...]/ 
uno sobre Ysabel de Cartaxena biuda bezina de esta ciudad que passó/ a Manuel de Billazento en beyinte de mayo de mill y seiscientos y treynta y tres/ [sigue con los bienes raíces]

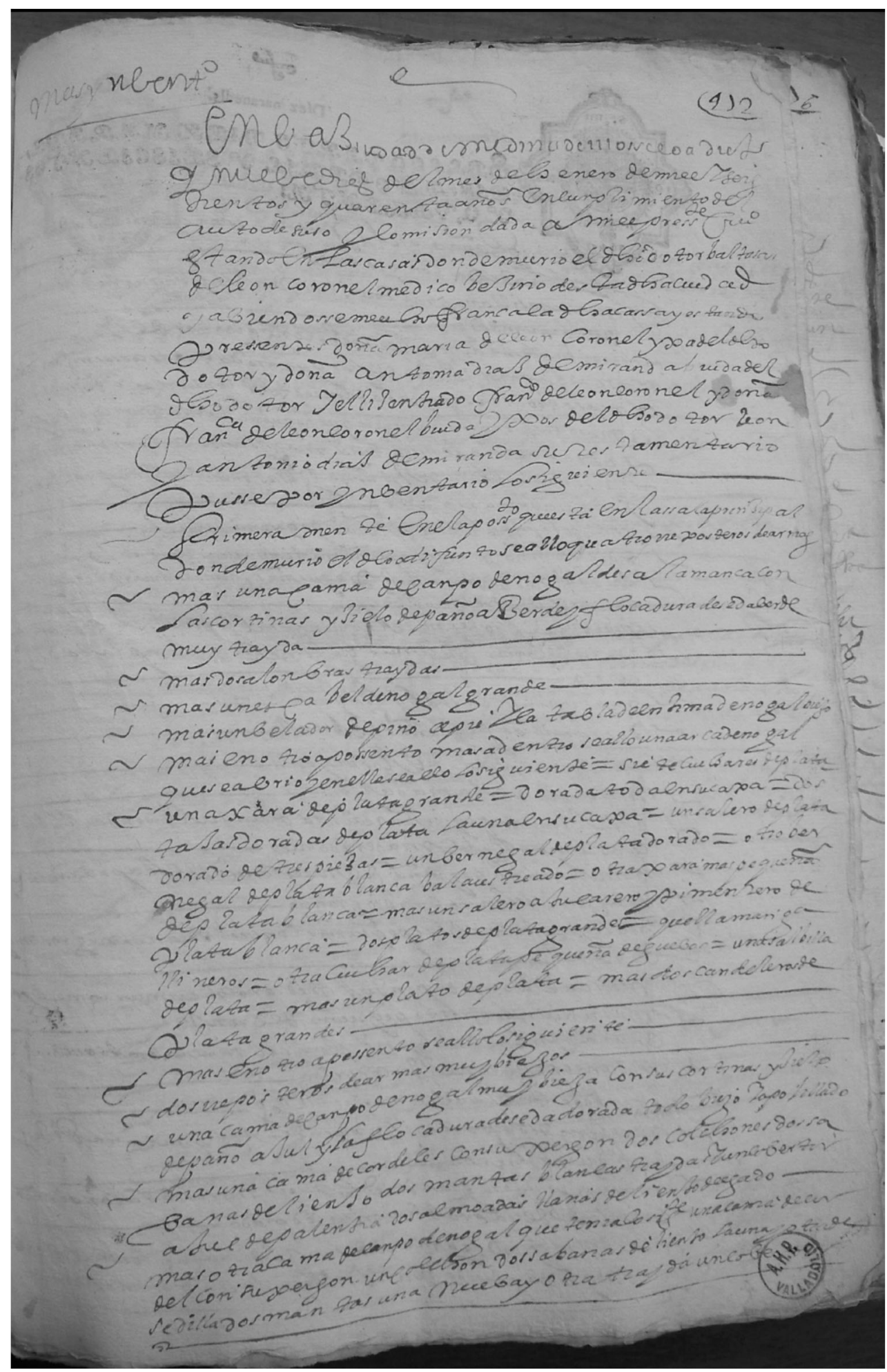




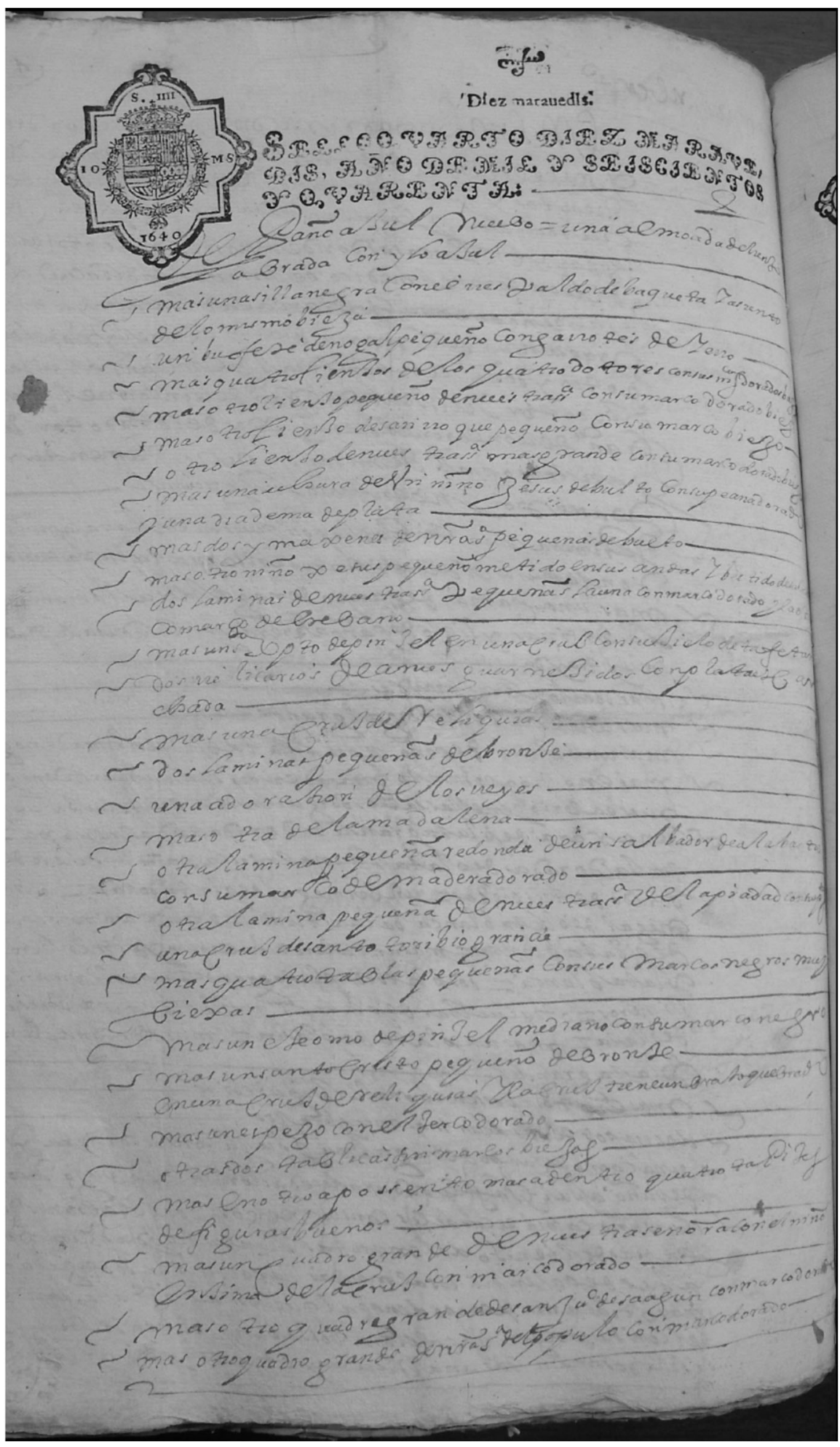




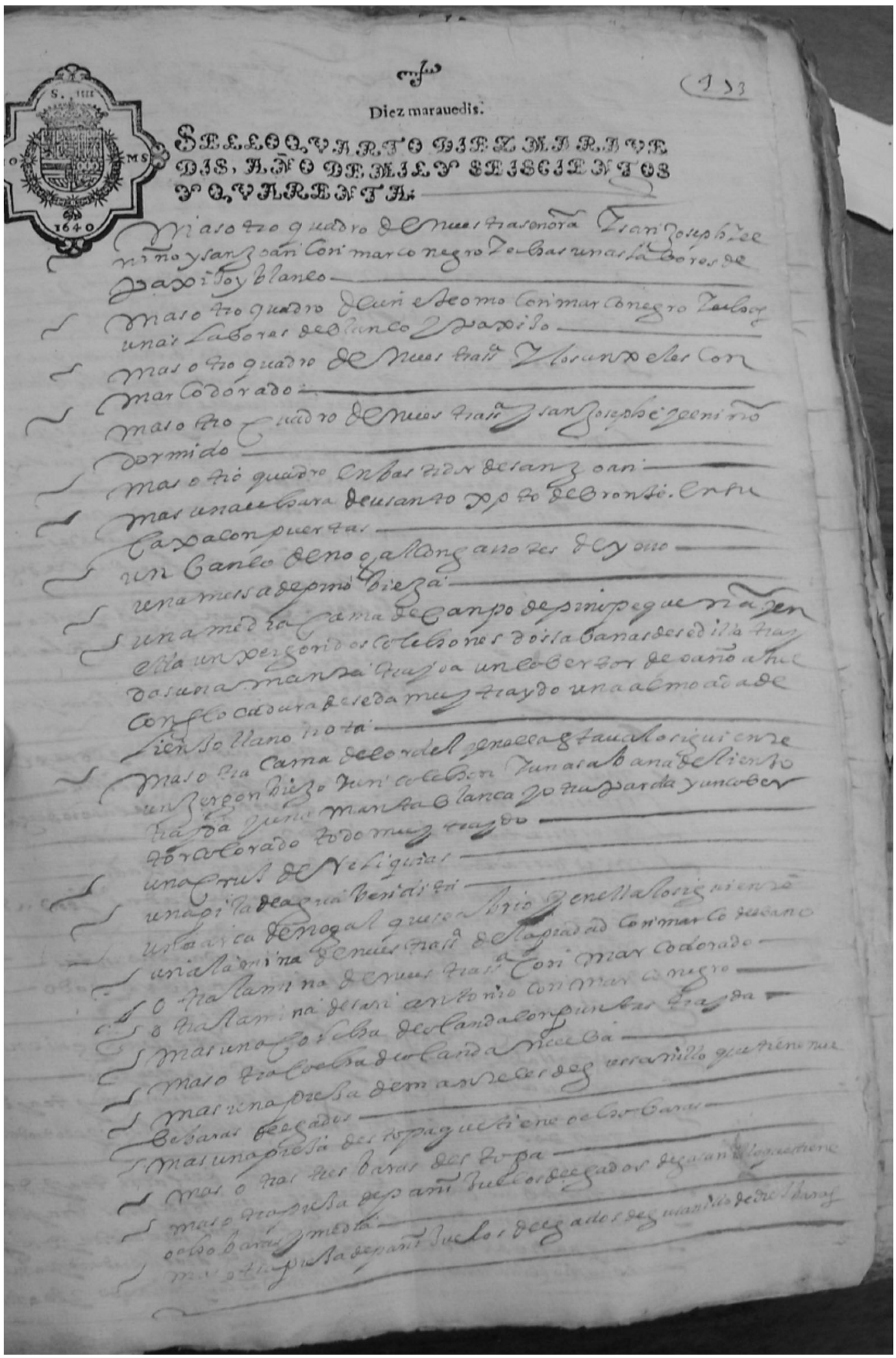




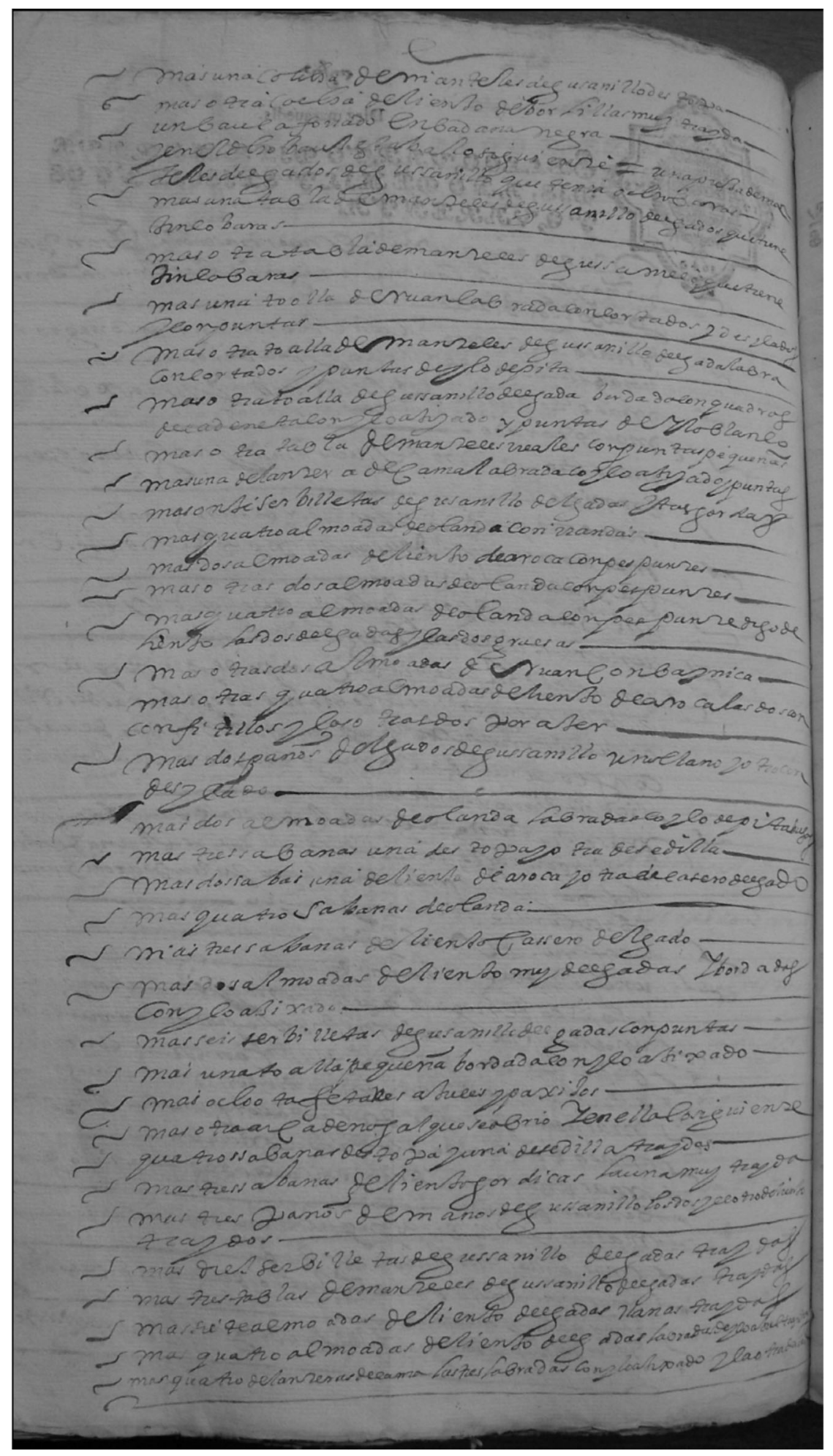




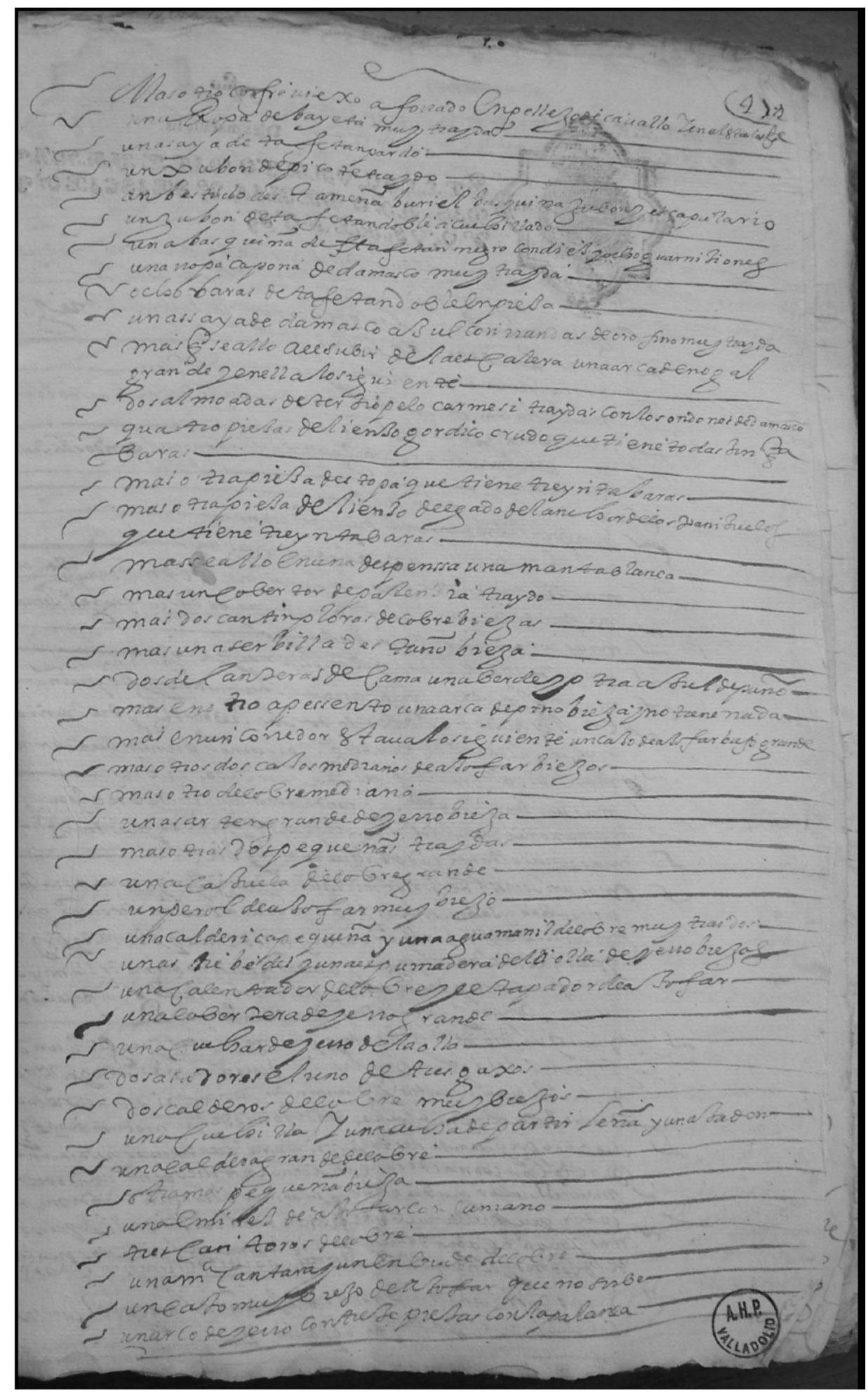




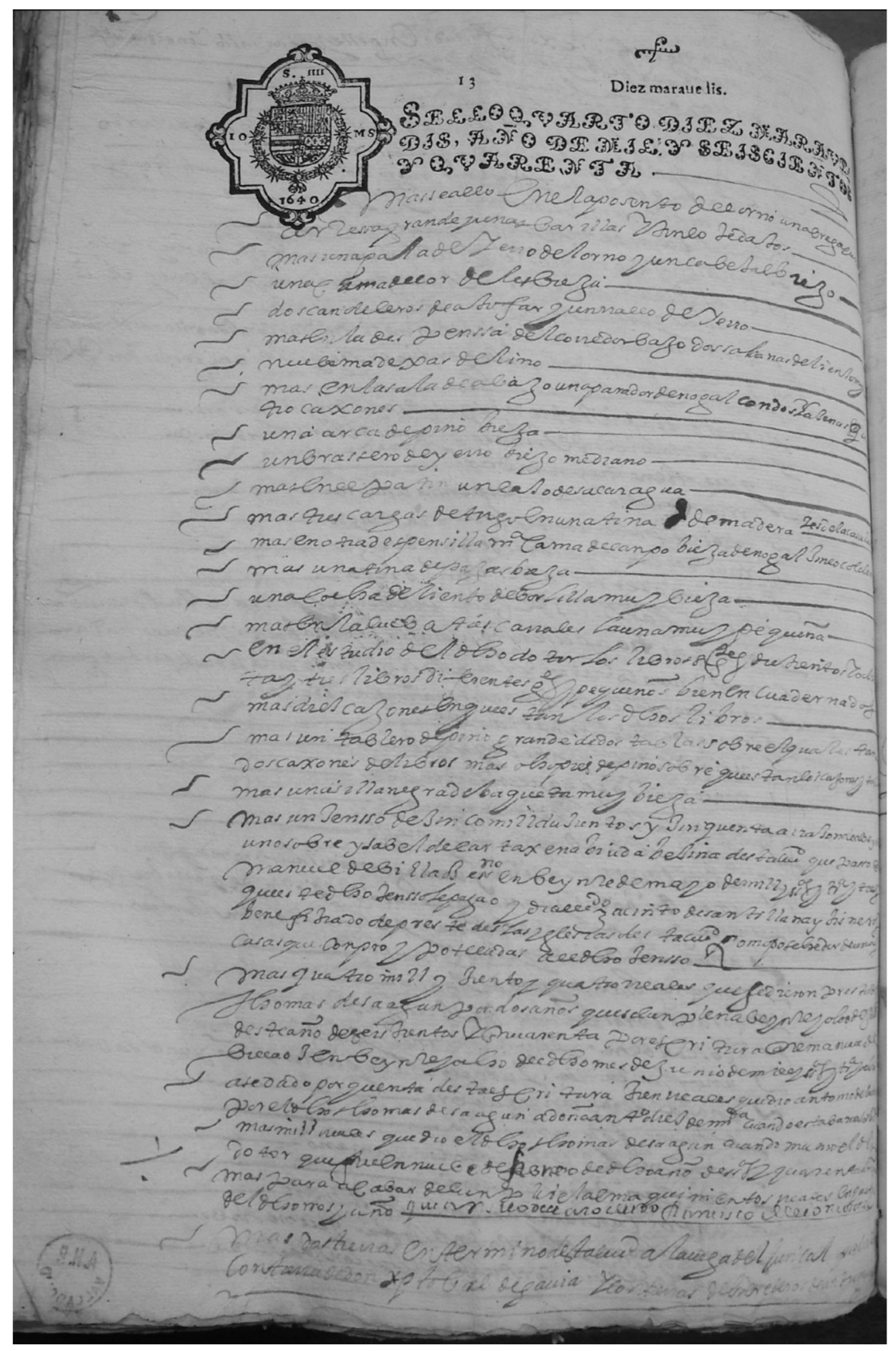




\section{Ejemplo n.o 4: Inventario de los bienes que llevó Luisa Gata al matrimonio con Alonso Martínez}

Tipo de documento: Inventario

Notario: Pedro Llanas

Localidad: Quintanilla del Monte (Villalpando)

Fecha: 1613

Signatura: 7366

Folios: $380 r-382 r$

(Fol 380 r) Ynbentario de lo que llebó Luisa

Gata a poder de Alonso Martínez

Ynbentario de los bienes muebles de Luysa Gata vecina del lugar de *Quintanilla del/

Monte que llebó con Alonso Martínez, vecino del dicho lugar y fueron tasados por/

Julio Rodríguez Sastre y Francisco Redonde y Julio Rodríguez qura de santo Tomé/

Y la de Rodrigo Aguado y la de [...] y Ana Ernández y que fue fecho/

a ocho dias del mes de julio de mill y seyscientos y trece años que/

fueron tasados en la manera siguiente:/

Primeramente una saya de papal tasada en be- $/$

ynti ocho reales/

Yten, otra saya de perpiñán colorado tasada/

en beynte y seys reales/

Yten, otra saya berde en quatro ducados dos que balen

mil y trecientas y noventa y seys maravedís/

Yten, se taso una mantilla de grana colorada en/

tres ducados/

Yten, un fuereruelo negro sin rico en cinco duca-/

dos/

Yten, otro fereruelo negro con su rico tasose en cin-/

quenta reales/

Yten, un mandil de Raxa berde garnecido con tercio-/

pelo negro en beyntiquatro reales/

Yten, un jubón de raso negro tasado en sesenta/

reales/

Yten, un colchón nuevo tasado en cinco ducados/

Yten, una manta blanca nueba tasada en beyn-/

ticuatro reales/

Yten, otra manta nueba fraçada listas coradas ta-/

sada en quarenta reales/

Yten, otra manta ermana de la mesma tasada/

en quarenta reales/

(Fol. 380 v) Yten, una sobrecama colorada tasada en dos du-/

cados/

Yten, una manta blanca de dos piernas tasada en/

beynte reales/

Yten, otra manta de lo mesmo un poco más tray-/ 
da tasada en diez y seys reales/

Yten, otra manta de Palencia buena de listas co-/

loradas tasada en diez y ocho reales/

Yten, otra manta de un remiendo fraçada tasa-/

da en doce reales/

Yten, otra manta de dos piernas casera tasa-/

da en dos ducados/

Yten, otra manta casera ya trayda tasada en/

ocho cientos maravedís/

Yten, otra manta tasada en nuebe reales/

Yten, otra manta tasada en once reales/

Yten, un alfamar listado colorado salamanqués/

tasado en diez y seys reales/

Yten, otro cobertor colorado ya biexo tasado en/

ocho reales/

Yten, quatro cabecales tasados en sesenta re-/

ales/

Yten, dos sábanas de lienço delgado buenas ta-/

sadas en ochenta reales/

Yten, otra sábana buena tasada en tres ducados/

Yten, otra sábana buena tasada en tres ducados/

Yten, otra sábana tasada en diez y ocho re-/

ales/

Yten, otra sábana buena tasada en treynta/

reales/

Yten, otra sábana buena tasada en lo mesmo/

Yten, otra sábana trayda tasada en diez y/

ocho reales/

(Fol. 381 r) Yten, otras dos sábanas de lienço gruesas tasadas/

en treynta reales/

Yten, una tabla de manteles de quatro baras de/

largo tasados en ocho reales/

Yten, otros manteles de seys baras de largo tasa-/

dos en doce reales/

Yten, otros manteles más [...] tasados en se-/

ys reales/

Yten, otros manteles de torillos tasados en cinco re-/

ales/

Yten, ocho pañiçuelos, quatro alimaniscos y/

los quatro de gusanillo tasados en diez y seys/

reales/

Yten, almuadas buenas açules y amarillas y/

blancas tasadas en cinquenta reales/

Yten, otra almuada de randa amarilla y/

blanca tasada en diez y ocho reales/

Yten, otras dos almuadas la una tasada en/

ocho Reales y la otra en quatro reales/

Yten, otras dos almoadas una blanca y otra co-/

lorada tasadas en quatro reales/

Yten, un paño de canastillo sobrered tasado en/ 
diez y seys reales

Yten, otro paño de canastillo bueno con sus puntas/

y cortado, labrado tasado en quatro ducados/

Yten, un frutero de ylo tasado en quatro rea-/

Les/

Yten, un paramento de lana blanca y negra/

tasado en doce reales/

(Fol. 381 v) Yten, una manta de parred, pintura de la conbersi-/

ón de san Pablo tasada en treynta reales/

Yten, otra manta de pared de Nuestra Señora del/

Rosario tasada en ocho reales/

Yten, unas alforgas nuebas tasadas en ocho re-/

ales/

Yten, una arca pequeña con su cerradura tasa-/

da en ocho reales/

Yten, otra arca de pino de pie alto tasada en/

ocho reales/

Yten, otro cofre de nogal bueno con su cerradura/

tasado en beynte reales/

Yten, otra arca de pino tasada en ocho reales/

Yten, un artesa de masar buena tasada en di-/

ez reales/

Yten, una brega con su breguil tasada en ocho/

reales/

Yten, dos camas de cordel tasados en ocho re-/

ales

Yten, otra cama encaxada tasada en quatro/

reales/

Yten, una mesa de pino larga tasada en seys/

reales/

Yten, dos bancas y un escaño tasado en ocho/

reales/

Yten, unas trébedes de yerro tasadas en tres/

Reales/

Yten, dos caços tasados en seys reales al-/

çofarados/

Yten, un almirez tasado en seys reales/

(Fol. 382 r) Yten, dos candeleros tasados en quatro reales/

Yten, una caldera buena tasada en un ducado/

Yten, una rueda buena y otra biexa sin erraxe/

y un soxado tasado todo en nobenta reales/

yten, una echura de un Cristo y otras ymáxi-/

nes, tasado todo en tres ducados/

Yten, una mula rucia cerrada tasada en do-/

ce mil marabedís/

Yten, una burra parda que se taso en tres mil ma-/

rabedís/

Yten, quatro lechones grandes buenos tasados en/

ducientos reales/ 


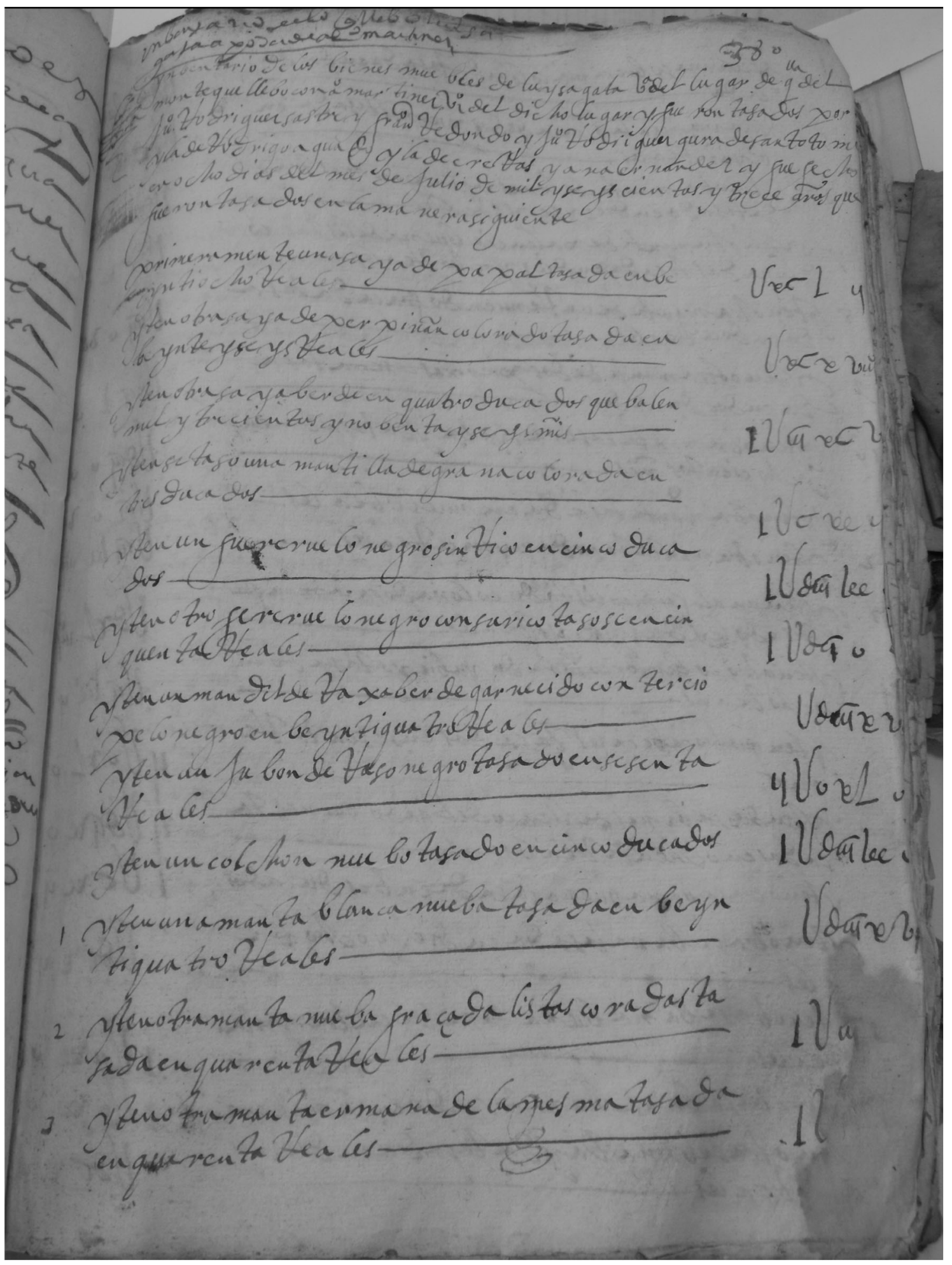




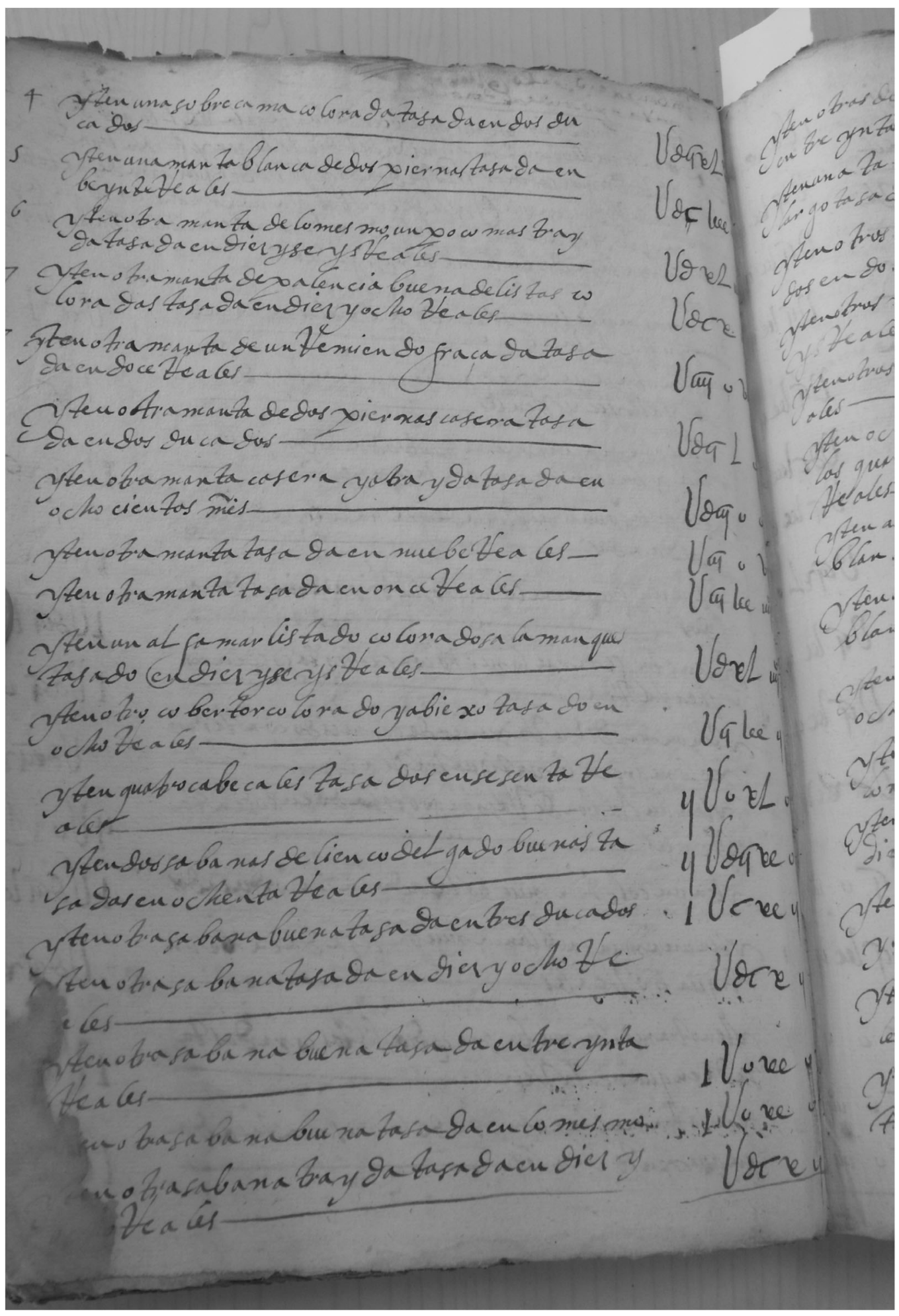




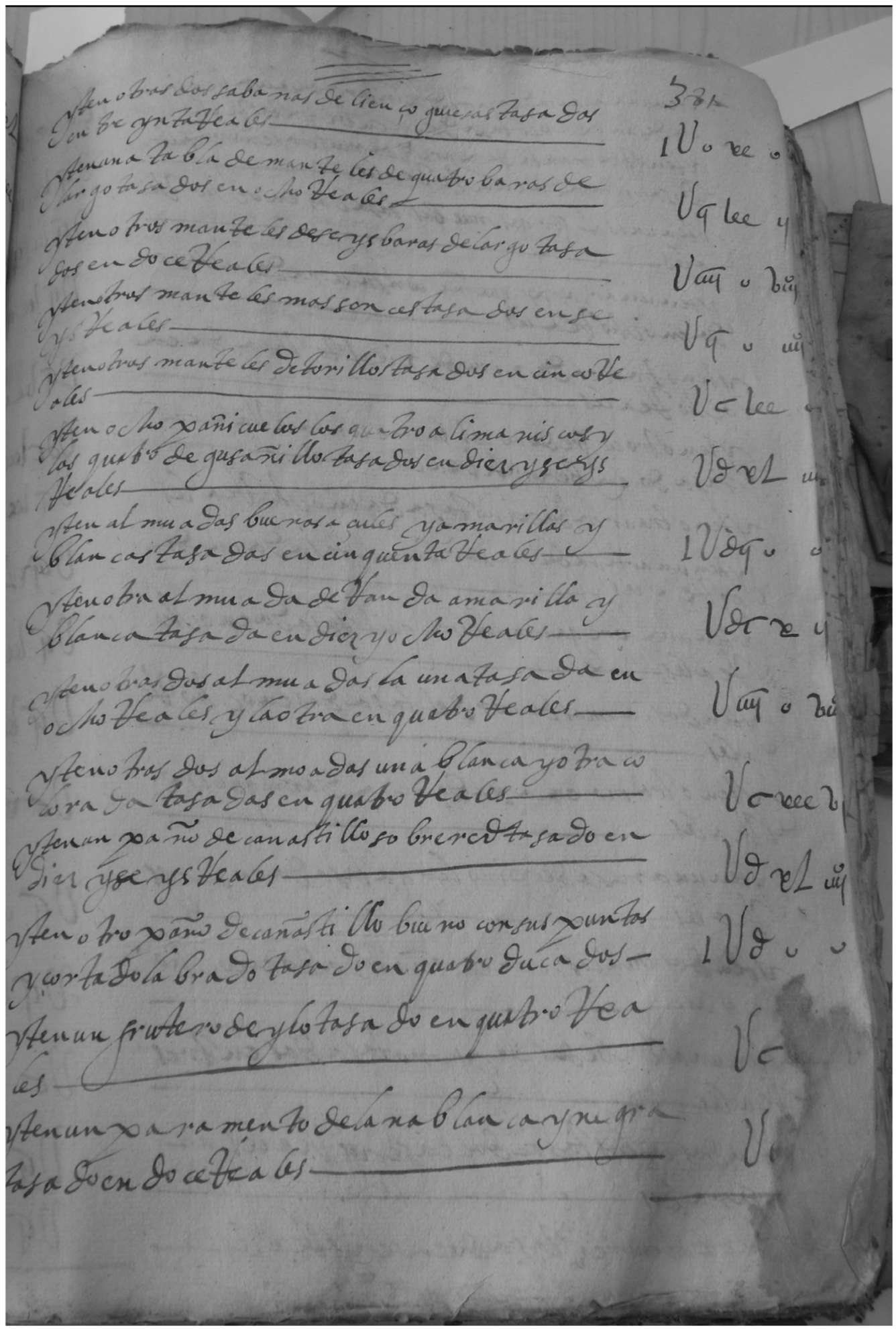




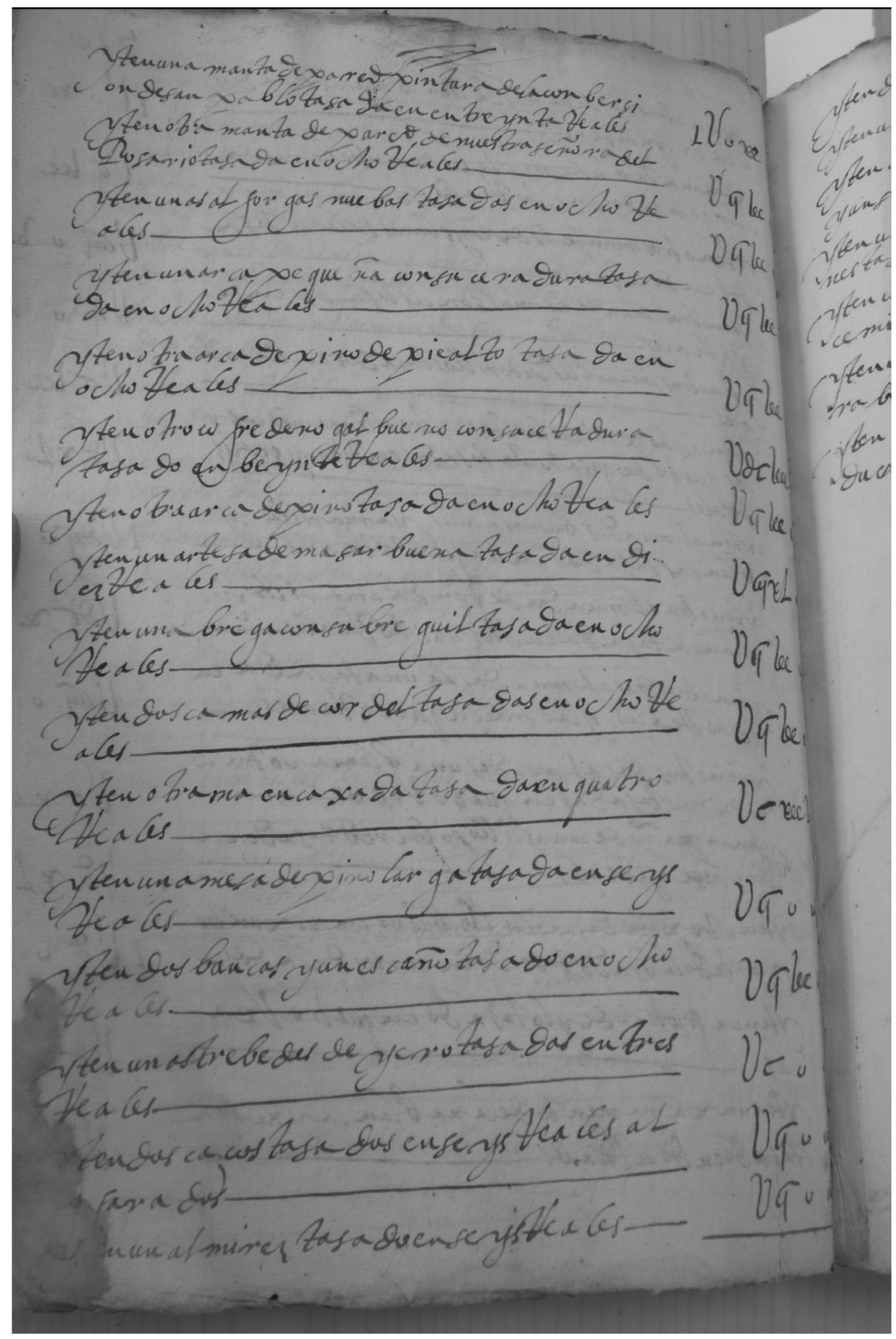




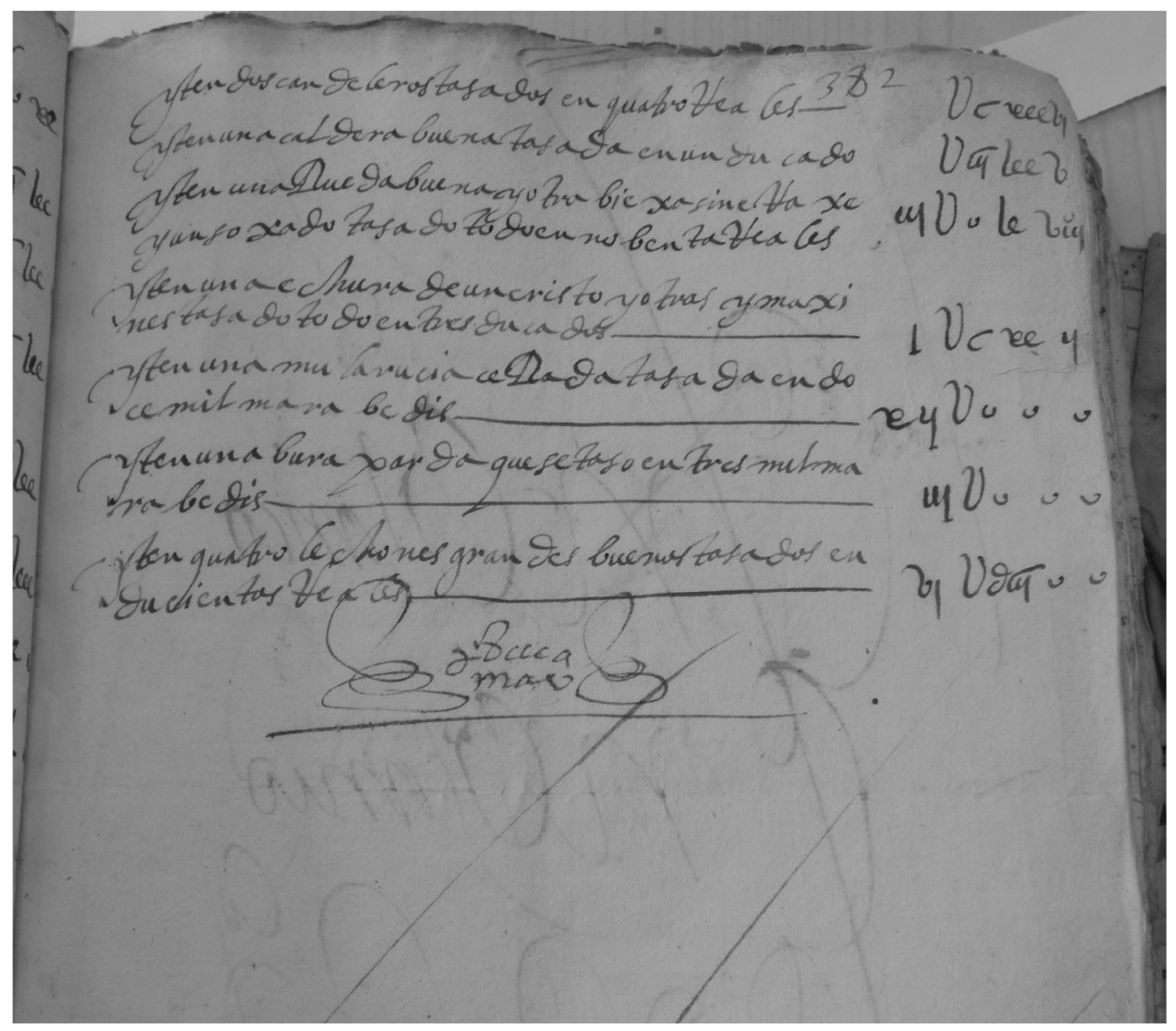


ANEXO 3 GLOSARIO DE TÉRMINOS 

Palabra

Abalorio Página

Abanico

111

Abarca [albarcas]

111

Aceitera [aceytera, azeitera, azeytera) .....249

Acerico [azerico, açerico] cama .................. 340

Afelpada [felpada] ............................... 237

Agnusdéi [anus dey, anus deys, agnus dey, agnus dei, anusdej, anusdei] ................. 170

Ágreda.

617

Aguamanil 276

Agujetas [aguxeta, auxeta, agugeta] ......... 112

Ahogadero [aogadero] ............................. 143

Alacena [alazena, alaçena, lacena, lazena] .401

Alamar

112

Alba [alva, alua] ..................................... 163

Albanega [aluanega] .................................93

Albarda [alvarda, aluarda, albardilla].........456

Albardón [albardón, albardonillo, albardonçillo].

Albornía [alvornia] 249

Albornoz 186

Alcorci [alconcil, alcorçil, arcoçil, arcocil, arcoçi, arcorciles, harcoçí] .................... 144

Alcorques.............................................. 135

Alcuza ................................................. 250

Alfamar................................................ 345

Alfombra [alfonbra, alombra, alhonbra, alonbrita].... 381

Alforja [alforxa, alforgas]........................ 458

Alforza [alforça] ................................. 113

Algalia.................................................. 521

Algodón ................................................. 179

Aljáfana [alxafana] .................................. 250

Almática ............................................ 163

Almendrillas........................................... 144

Almilla [almillica] ..................................... 71

Almirez .............................................. 322

Almofía.................................................. 251

Almohada [almoada, almuada, almohadilla, halmohada]..................... 341

Almohaza [almoaça, almoaçe] .................. 459

Alquitara................................................. 511

Amacal [amecal] .................................... 525

Amantelado.......................................... 238

Amito [admito, amicto] ............................ 164

Ana .................................................... 562

Ánade ................................................. 610

Anafaya [anafaia] .................................. 221
Palabra

Página

Anascote [anescote, aniscote] ..................187

Angarillas ...............................................441

Anguarina [enguarina, anguarona, unguarina, ongarina] ............................61

Anillo ..................................................... 145

Anjeo [angeo, anxeo] ............................617

Ánsar [ansare, ansarones] ......................611

Anteojo [antojos] .................................. 114

Antepuerta ..........................................382

Añal ...................................................615

Añejo [anexo] ........................................587

Añinos................................................ 188

Añojo /a [añoxo, añoxillas].......................587

Aparador..............................................402

Apretador ........................................... 145

Arado.................................................. 431

Aragón....................................................618

Araña .................................................. 393

Arca [harca] ........................................402

Arcaz [harcaz, arquezico, arcazico, harcaçes, harcadejo, arcaçexo, harcaçeses] ...................................404

Arillo.................................................... 146

Armador ................................................ 71

Arpillera................................................ 212

Arqueta.................................................404

Arquetón .............................................405

Arquimesa [arcamesa, arcamessa,

harcamesa] ......................................405

Arracada [arrecadas] ...........................147

Arreo ...................................................... 460

Arroba [arroua, arrova] ............................559

Artesa [artessa, hartesa, hartessa] .............323

Artesón [artessón] ...................................324

Asador [assador] ................................... 310

Astudillo .................................................618

Avantal [abantal, avental, auental, abental] ..........................................640

Avellana [abellana]................................. 148

Azada [açada, haçada, hazada] .................472

Azadón (azadonillo) .................................442

Azafate [açafate] .................................. 251

Azucarero [açucarero]............................ 280

Azuela [açuela, çuela] ............................ 531

Azufrador [açufrador] ............................ 406

Azumbre [azunbre, açumbre]................. 557

Babadero [babadero, bauador] ................ 93

Babador [bauador] ................................ 94 


\begin{tabular}{|c|c|}
\hline Palabra & Palabra \\
\hline 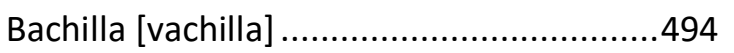 & Borrego/a [vorrega] \\
\hline 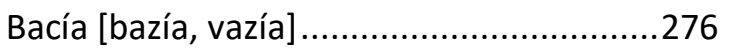 & 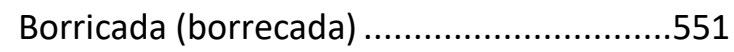 \\
\hline Bacina [vacinica] $\ldots$ & Borro/a [vorro/a, borrilla] .........................606 \\
\hline & Bota/as [botilla] .............................. 136 y 517 \\
\hline Báculo [váculo] ...........................................171 & Botador \\
\hline 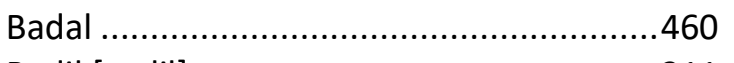 & Botija [botixa, votija, votixa, botixilla] .......257 \\
\hline Badil [vadil] .............................................. & 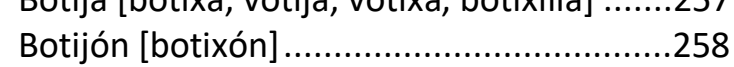 \\
\hline 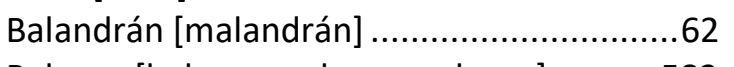 & Botines [votín] ..... \\
\hline Balanza [balança, valança, valanza] ............582 & 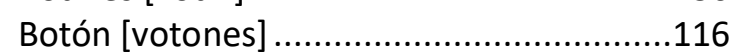 \\
\hline 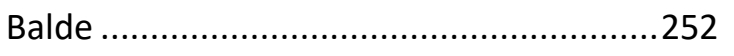 & 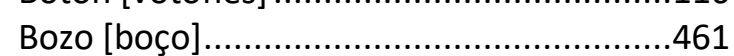 \\
\hline Banasta [vanasta] ....................................494 & 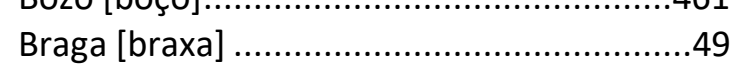 \\
\hline 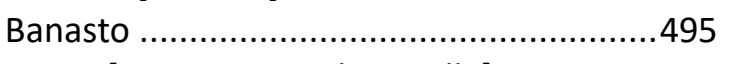 & Brasero [brassero, vrasero] \\
\hline Banca [vanca, uanca, banquilla] .................407 & 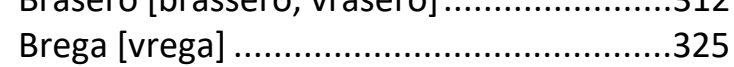 \\
\hline Bancal............................................................ & 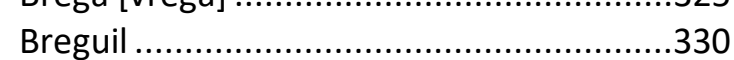 \\
\hline Banco [vanco, uanco] ......................................... & 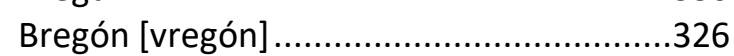 \\
\hline Banda [vanda, bandilla] ...........................114 & 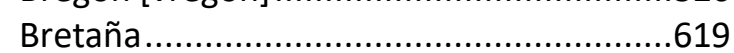 \\
\hline 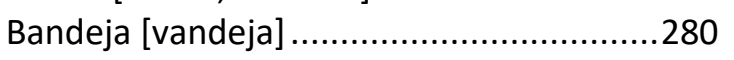 & 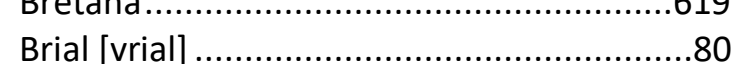 \\
\hline Bañado & Brizo [briço, breço] \\
\hline 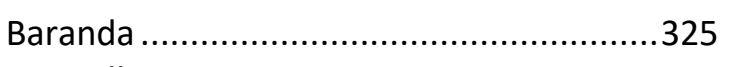 & 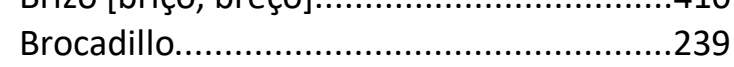 \\
\hline 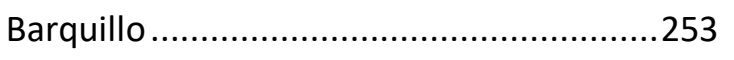 & 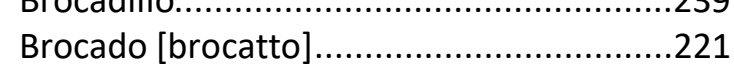 \\
\hline Barragán [varragán] ...................................189 & 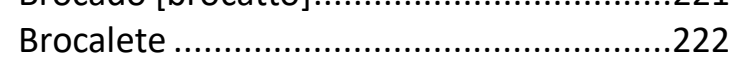 \\
\hline 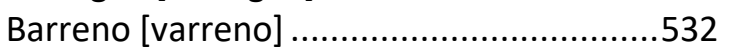 & Brocatel \\
\hline Barreño [barreña, varreño, vareño] ...........254 & Brocatel \\
\hline Barreñón [varreñón, uarreñón] ..................255 & Búcaro \\
\hline 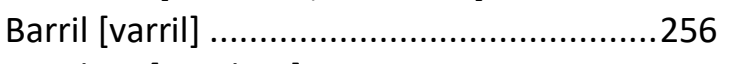 & Buey [buei, bueis, bueies, buejes, vueys] ...588 \\
\hline Barrilete [varrilete] …..............................532 & Bufete [vufete, bufetillo, vofete] ..............411 \\
\hline Barzón [barçón, varzón, varçón] ..................450 & Bujía [buxía, vuxía] ............................... \\
\hline Basquiña [uasquiña, vasquiña] .....................79 & \\
\hline Bastidor [vastidor, uastidor] .........................386 & Burro/a[burrico/a,borrico/aborriquilla]......593 \\
\hline Baúl [vahúl, vaúl, uaúl].................................409 & Cabecito [cabeçito] .................................... \\
\hline Bayeta [vayeta, uayeta, baieta, vaieta, & 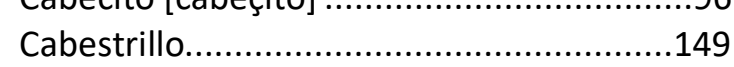 \\
\hline baeta, vaeta]........................................189 & Cabestro [cavestro] .......................................... \\
\hline 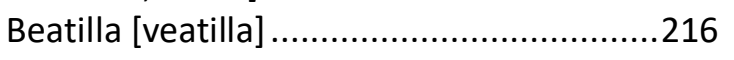 & Cabezada [cabeçada, caveçada, cauezada] 462 \\
\hline 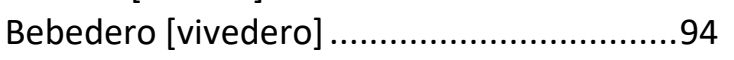 & Cabezal [cauezal, cabeçal, cabiçal, \\
\hline 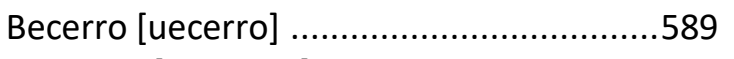 & 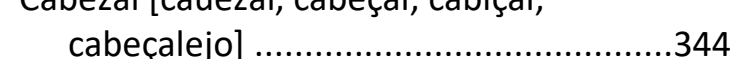 \\
\hline 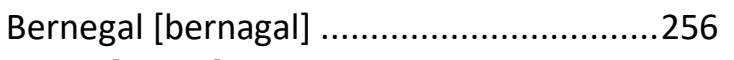 & Cabezón [caueçón, caveçón, cauezón, \\
\hline 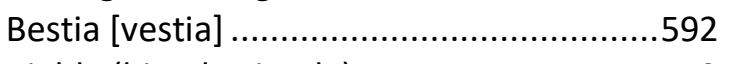 & 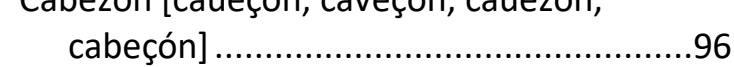 \\
\hline Bielda (bienda,vienda) ..............................473 & Cabra [cabrito, cabrita] \\
\hline Bieldo [vieldo, biendo, viendo]...................474 & 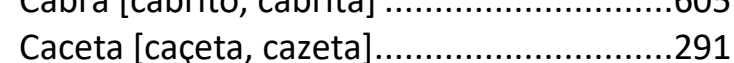 \\
\hline 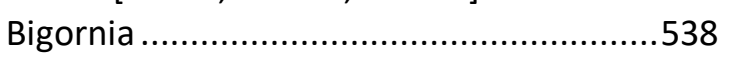 & 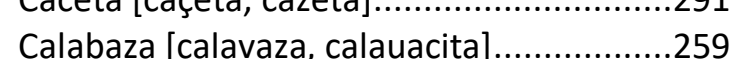 \\
\hline 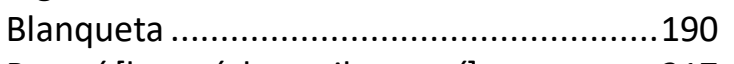 & 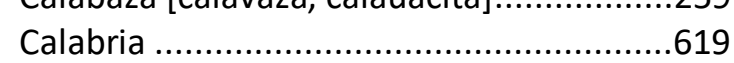 \\
\hline Bocací [bocazí, bocaçil, vocaçí] ...................217 & 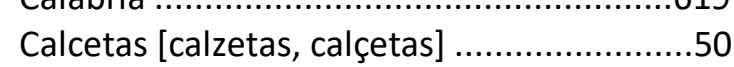 \\
\hline 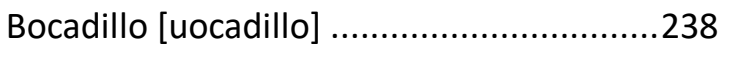 & 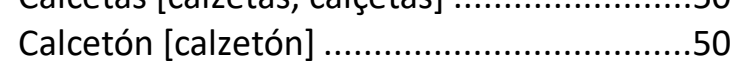 \\
\hline Bocado & 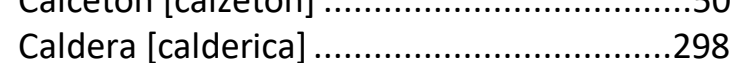 \\
\hline 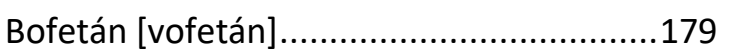 & 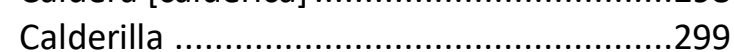 \\
\hline Bombasí [bonbasí, vonvasí, uonvasí] ..........180 & 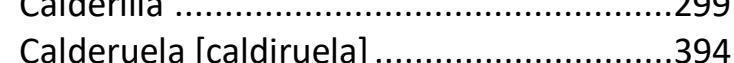 \\
\hline Bonete [vonete] ................................. 95 y 257 & Calentador [calenttador].. \\
\hline Borceguís [borçeguíhes, borzeguíes] ..........135 & \\
\hline 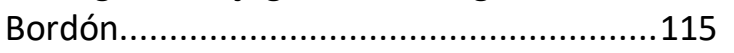 & \\
\hline
\end{tabular}




\section{Palabra}

Calza [calças]

Calzón [calçón]

Calzoncillos [canzonzillos]

Cama

Camba [cama, canva, canba].

Cambizo [canbiçio, cambiço, camizo, camiço, camiçio]

Cambón

.434

Cambray [cambrai, canbray, cambraies] ...620

Camella.

Camelote [chamelote, chamalote] ............192

Camisa.................................................. 53

Camisón [camysón] .................................54

Canal ..................................................4 463

Canalador [canelador]...........................533

Canasta...............................................495

Canastillo [canestillo]............................496

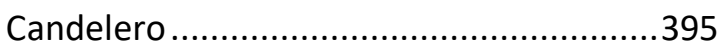

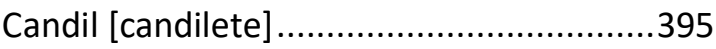

Cántara..................................... 557y 582

Cántaro...................................... 496 y 558

Cantimplora [cantinplora] .........................260

Cañamazo [cañamaço] ...........................213

Cáñamo ............................................214

Cañizo [cañicio]...................................434

Capa ................................................63

Caparrosa ..........................................239

Capero..............................................413

Caperuza..............................................97

Capillo ..................................................97

Capón ..................................................611

Capote..................................................6 63

Capotillo ..............................................64

Caracol ...................................................260

Carbonera.............................................313

Carga .................................................. 552

Carguetón...........................................498

Carguilla ..............................................498

Cariñana [cariñaña]...............................98

Carnero..............................................608

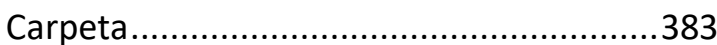

Carral [carrala, carralexo, carralexa, carraleja, carralica, carralón] ..............513

Carranca ...........................................468

Carreta ...........................................442

Carretada............................................555

Carretilla.............................................442

Carro ........................................ 443 y 554

Cartera ...............................................116
Palabra Página

Casaca ................................................. 65

Cascabelero ........................................ 149

Casco ................................................. 349

Casulla ............................................... 165

Catalufa ........................................... 193

Catorzal ............................................ 569

Caza [caça] ................................... 181 y 314

Cazo [caço, caçito, cacico, cazico] ............. 300

Cazoleta [caçoleta, caçueletas]................ 301

Cazuela [caçuela, cazuelica] .................... 301

Cazuelo [caçuelo] ................................... 302

Cebadera [çebadera, zevadera] ............... 468

Cebón [zebón]..................................... 601

Cedazo [zedazo, zedaço, cedaço, sedaço]. 475

Celemín [çelemín, zelemín] ..................... 554

Ceñidor [zeñidor, ciñidor, çiñidor, zeñidero, ziñidero] ............................ 117

Cepillo [çepillo, zepillo] .......................... 533

Cercadura [zercadura]............................ 349

Cerdo /a [çerdo, zerdo] ......................... 601

Cernadera .......................................... 350

Cernadero [zernadero]............................ 350

Cernedera [zernedera, çernadera] .......... 351

Cernedero......................................... 352

Chapines........................................... 137

Chillón ................................................ 193

China ................................................. 620

Chinelas [chiñelas] ............................. 138

Chivarro/a......................................... 605

Chocolatera ..................................... 261

Chorra............................................... 499

Cielo [çielo, zielo] ................................ 352

Cilicio [siliçio] .................................... 165

Cincha [çincha, zincha] ........................ 464

Cincho............................................... 464

Cíngulo [zíngulo, çíngulo] ...................... 166

Cintillo [centillo].................................. 150

Cintura............................................ 118

Cirio ................................................ 396

Clavera [clauera, clabera]...................... 528

Clavija [clabixa, clabija, clauixa, clabuxo] .. 435

Clavijal [cabixar]............................... 436

Clavo [clauo, clabo] .............................. 539

Cobertera [couertera, covertera] ............ 303

Cobertor [couertor, covertor] ................ 353

Cobre........................................... 460

Coche............................................ 444

Cocino [cozino, cozinillo] ......................... 327

Coco ............................................... 261 


\begin{tabular}{|c|c|}
\hline Palabra & Palabra \\
\hline Cofia & 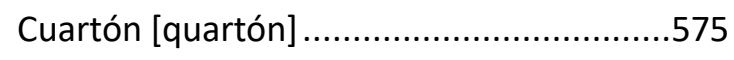 \\
\hline Cofre [cofrecito, cofreçico, cofrecillo] .......414 & Cuba [cuva, guba] \\
\hline 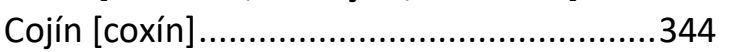 & 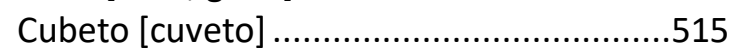 \\
\hline 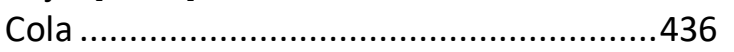 & Cubilete [qubilete, gubilete].....................263 \\
\hline Coladera & 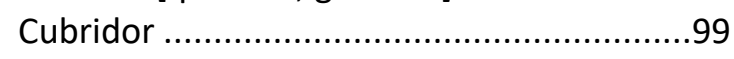 \\
\hline 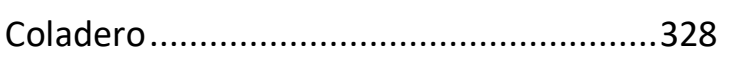 & Cuchara [cuchar, quchar, cucharita] ..........289 \\
\hline 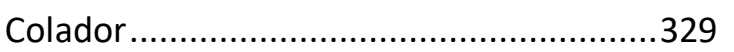 & 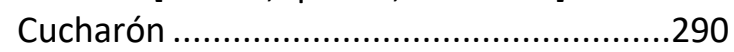 \\
\hline Coladora & Cuchilla \\
\hline 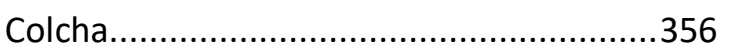 & 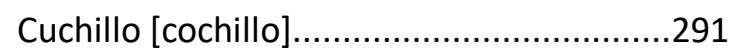 \\
\hline 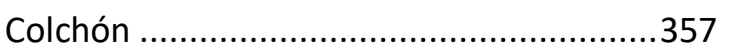 & 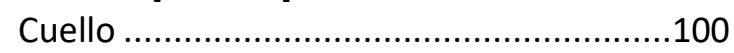 \\
\hline 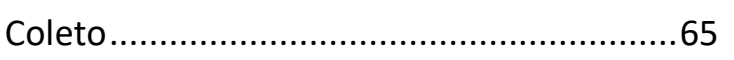 & 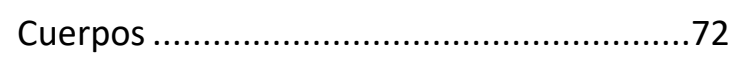 \\
\hline 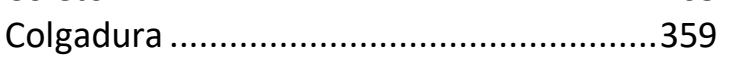 & Cuévano [cuébano, quebano, cobanillo] ...516 \\
\hline 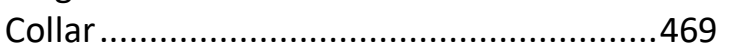 & 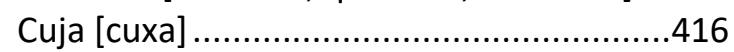 \\
\hline 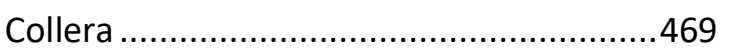 & Culero................... \\
\hline 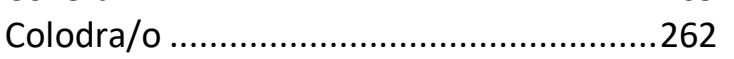 & 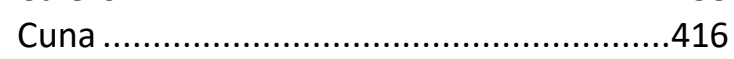 \\
\hline Colonia .............................................. 119 y 621 & 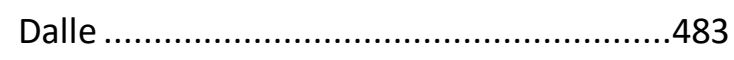 \\
\hline 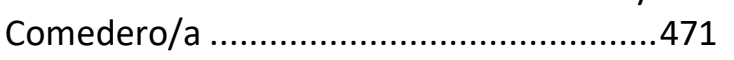 & Damasco [adamascado] .................... 195 y 622 \\
\hline Contador [contadorcito, contadorcillo] .....414 & 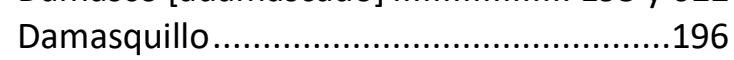 \\
\hline 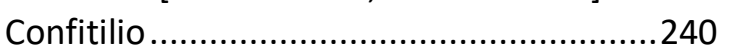 & Delantal [debantal, devantal, avantal].......120 \\
\hline Contray [contrai, contrae, contrahe] .........621 & 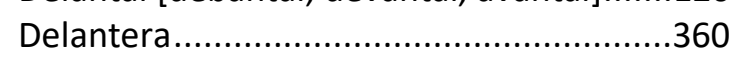 \\
\hline Сора & 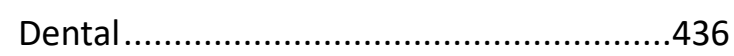 \\
\hline 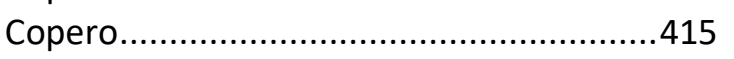 & 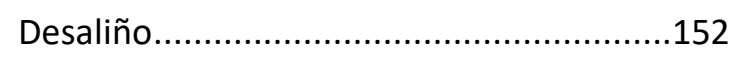 \\
\hline 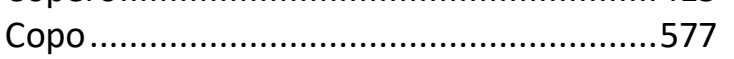 & 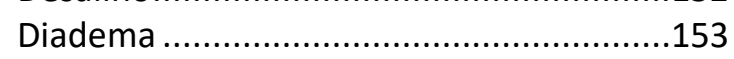 \\
\hline 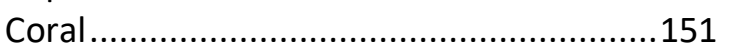 & 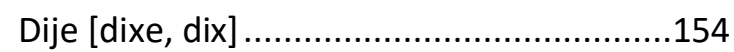 \\
\hline Corchera & 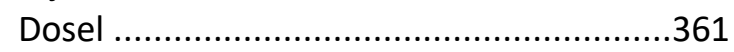 \\
\hline 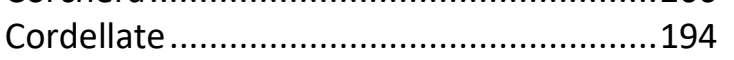 & 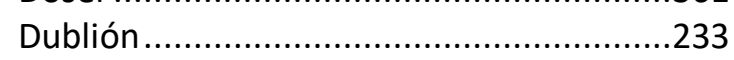 \\
\hline Córdoba....................................................... & 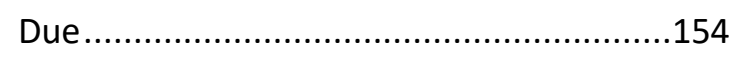 \\
\hline 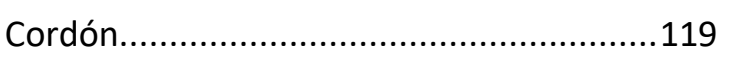 & 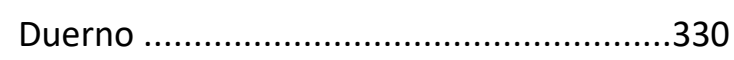 \\
\hline 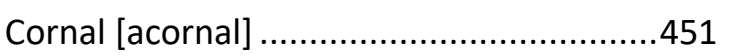 & Embarradera [enbarradera, envarradera] .526 \\
\hline 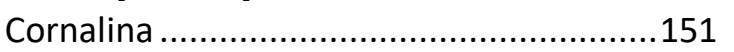 & Embudo [enbudo, envudo] ........................331 \\
\hline 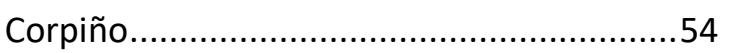 & 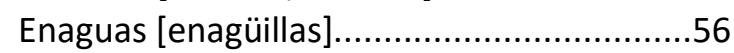 \\
\hline 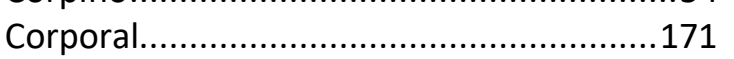 & 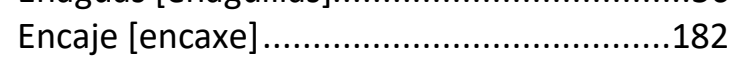 \\
\hline 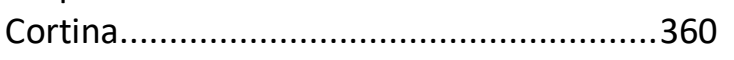 & Encomienda [encomenda] ........................173 \\
\hline 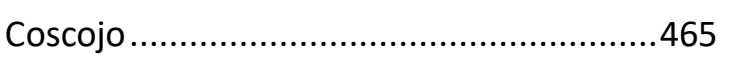 & 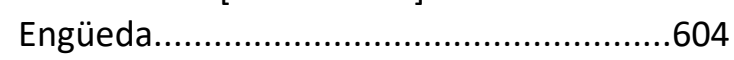 \\
\hline 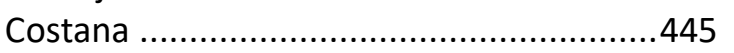 & 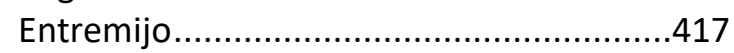 \\
\hline 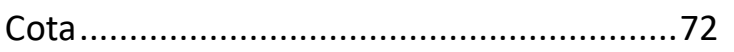 & Escabel [escauel, escavel, escabelico, \\
\hline 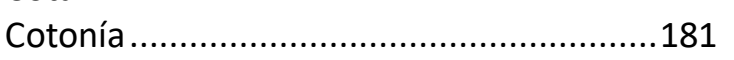 & 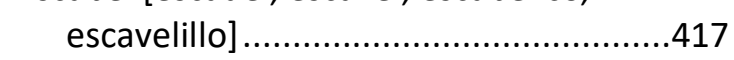 \\
\hline Coyunda [coyunta, conyuntal] ..................451 & 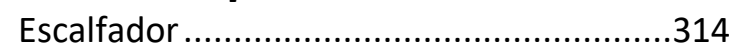 \\
\hline 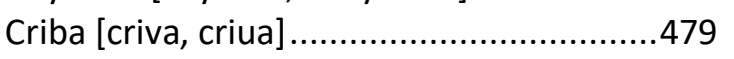 & 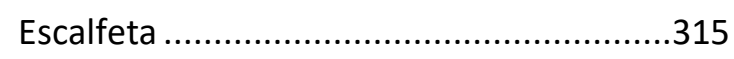 \\
\hline 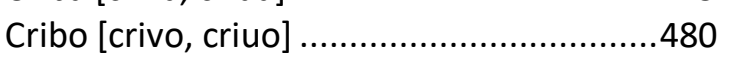 & 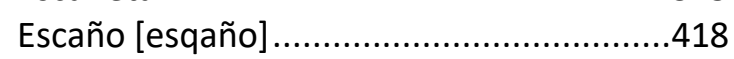 \\
\hline Crucifijo [cruçifijo, crucifixo, cruzifixo].......172 & Escaparate ............................................ \\
\hline Cruz [cruzeticas, cruziticas] .........................172 & 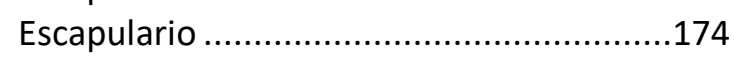 \\
\hline 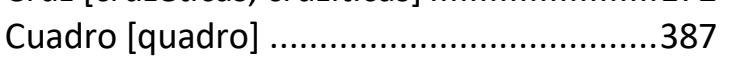 & Escarlata [escarlatta]...............................197 \\
\hline 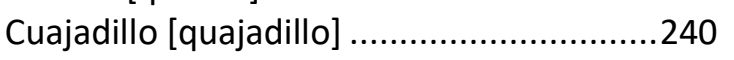 & 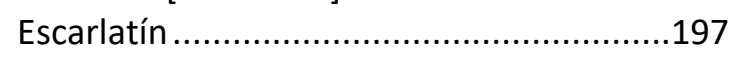 \\
\hline 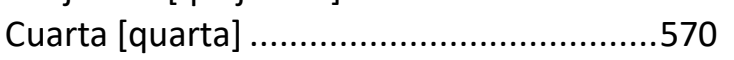 & Escarpeta [hescarpeta] ..................................384 \\
\hline 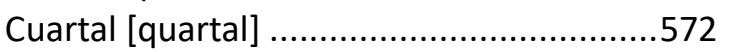 & 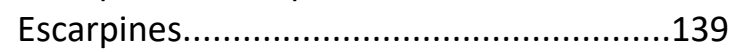 \\
\hline 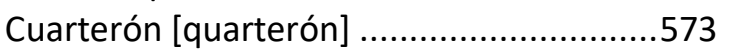 & 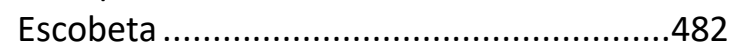 \\
\hline 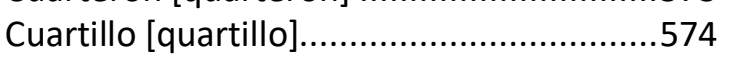 & Escobilla [escouilla, escubilla]......................483 \\
\hline
\end{tabular}




\begin{tabular}{|c|c|}
\hline Palabra & Palabra \\
\hline 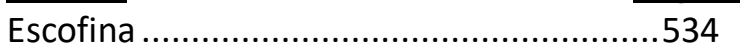 & 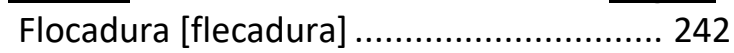 \\
\hline 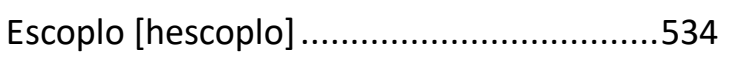 & Forqueta [forcheta, forchina] ..................... 292 \\
\hline Escribanía [escriuanía] ................................... & 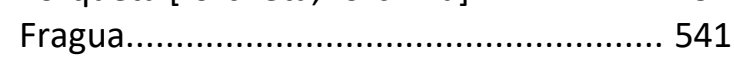 \\
\hline Escriña [hescriña, eschriña, escriñuela] .....499 & Frailego / a [fraylego, frailengo, fraylengo]..... \\
\hline 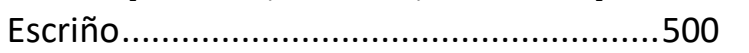 & 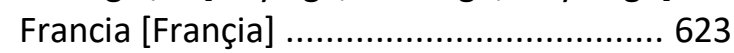 \\
\hline Escritorio [escriptorio, eschritorio, & 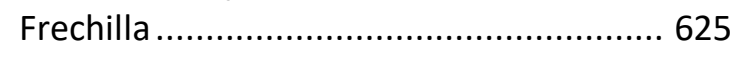 \\
\hline escritorillo, escritorico] .........................420 & Freno \\
\hline Escudilla [escodilla, escodillón] ..................281 & 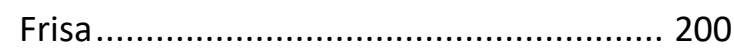 \\
\hline 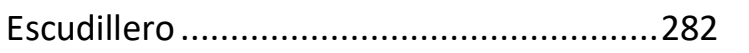 & 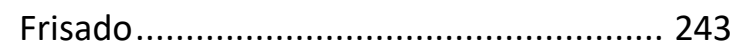 \\
\hline Escusabaraja [escusabaraxa]......................264 & 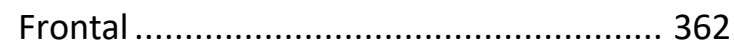 \\
\hline 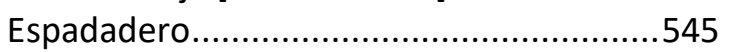 & 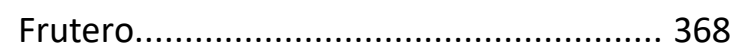 \\
\hline 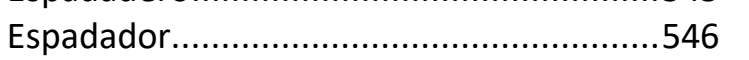 & 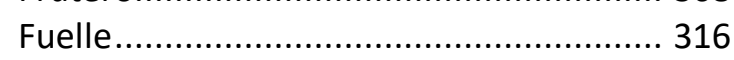 \\
\hline 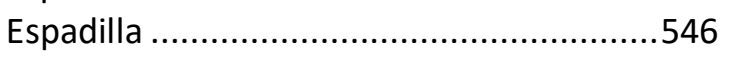 & Funda [hunda, unda] ................................. 347 \\
\hline Esparragón [hesparragón]...........................223 & 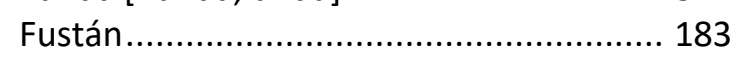 \\
\hline 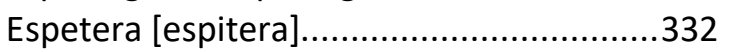 & 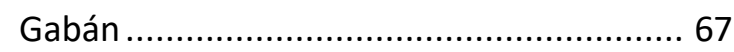 \\
\hline 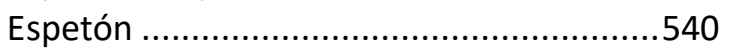 & 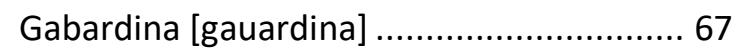 \\
\hline 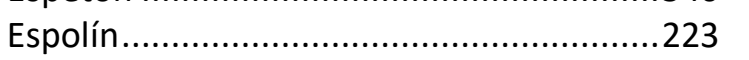 & 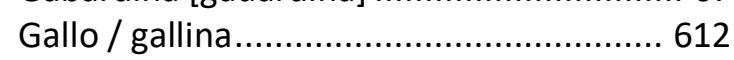 \\
\hline 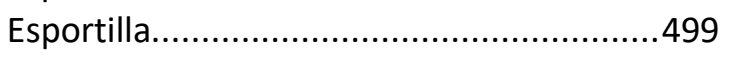 & 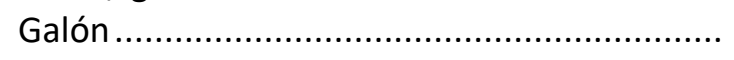 \\
\hline 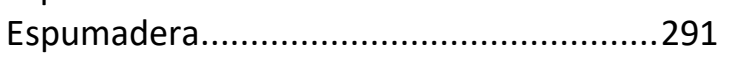 & Gamuza [camuza, camuça]......................... 201 \\
\hline Espumilla ........................................224 & 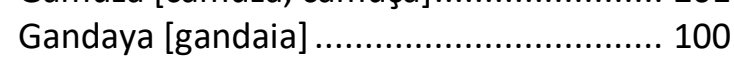 \\
\hline 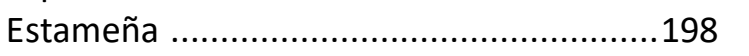 & 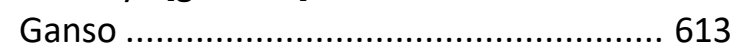 \\
\hline 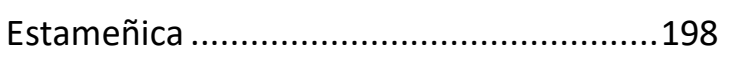 & Garapiña \\
\hline Estampa [estanpa, estanpica] ......... 175 y 388 & 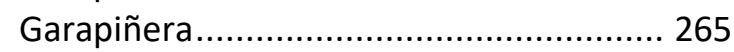 \\
\hline 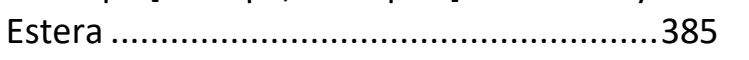 & 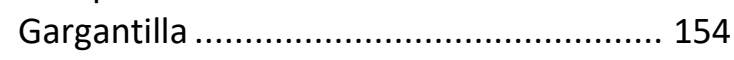 \\
\hline 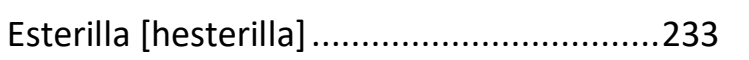 & 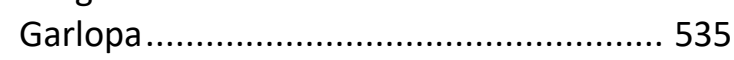 \\
\hline Esteva [esteba, esteua] ..............................437 & 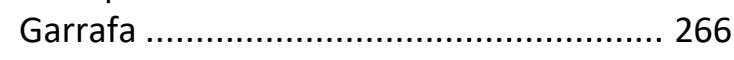 \\
\hline 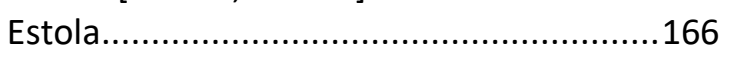 & Garrobilla [garrubilla].................................. 234 \\
\hline 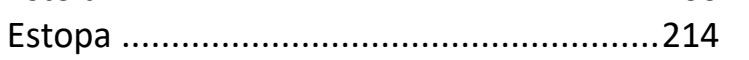 & 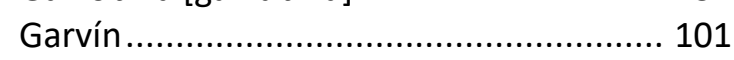 \\
\hline 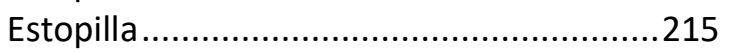 & 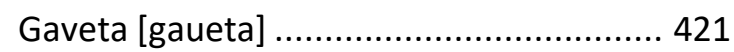 \\
\hline Estrado [estradillo, estradico] ....................421 & Gola \\
\hline 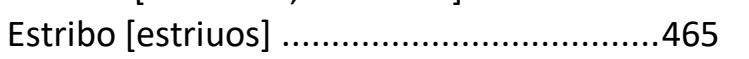 & 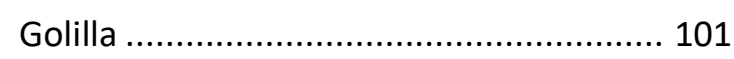 \\
\hline Estufa & Gorgorán [gorguerán, gorgerán] ............... 225 \\
\hline Estufilla (estofilla) ..............................66 y 316 & 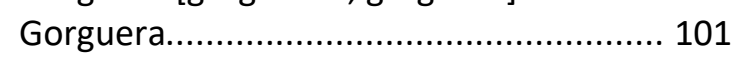 \\
\hline 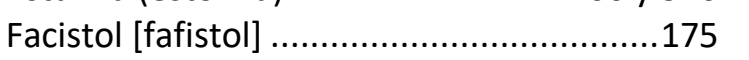 & 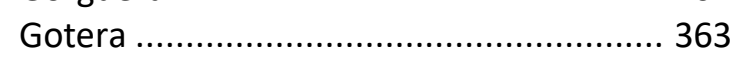 \\
\hline Faja [faxa] ..................................................... & Grana \\
\hline $\begin{array}{l}\text { Fajadero [faxadero, fajaderillo, } \\
\quad \text { fajaderuelo] ......................................124 }\end{array}$ & $\begin{array}{l}\text { Granada ................................................. } 625 \\
\text { Gregüescos [grigüescos, greguiescos, }\end{array}$ \\
\hline 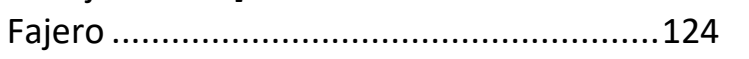 & gregescos, grigescos]................................ 82 \\
\hline 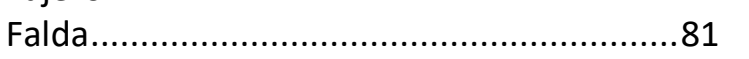 & 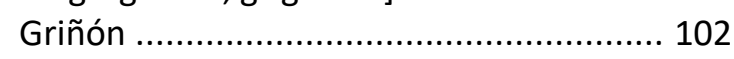 \\
\hline 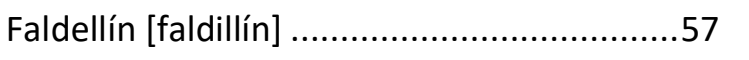 & Gruesa \\
\hline 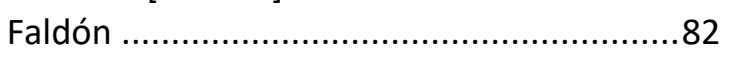 & 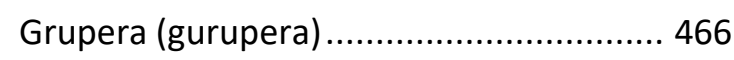 \\
\hline 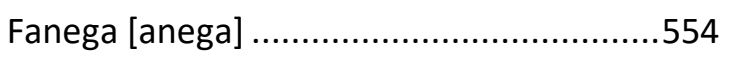 & Guadamecil [guadamaçil, guadamazil, \\
\hline Fardel & guadamací, aguamazil]..................... \\
\hline 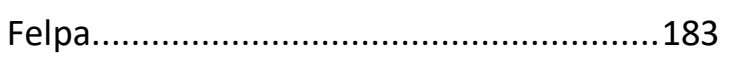 & 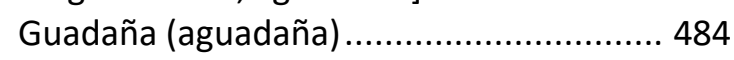 \\
\hline Ferreruelo [herreruelo]................................ & 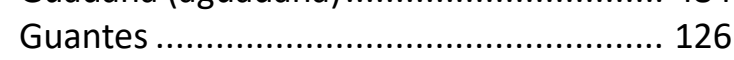 \\
\hline 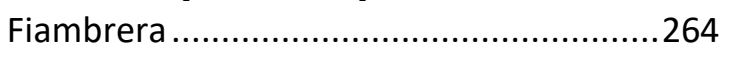 & Guardabajos [guardavajos] ......................... 83 \\
\hline 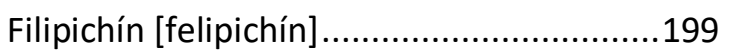 & 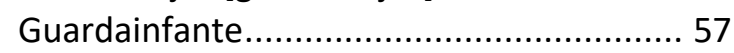 \\
\hline 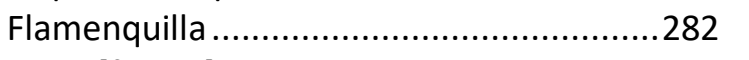 & Guardapiés [guardapié, guardapiesses ........ 83 \\
\hline Fleco [flueco] ................................................... & 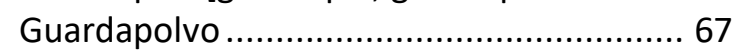 \\
\hline
\end{tabular}




\begin{tabular}{|c|c|}
\hline Palabra & Palabra \\
\hline 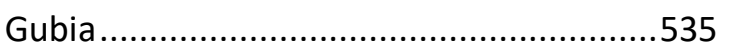 & Lechón/a [lichones, lechoncitos, \\
\hline 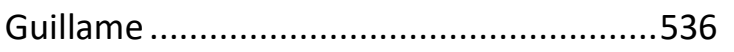 & 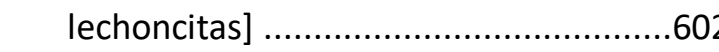 \\
\hline 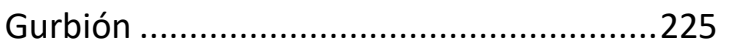 & Lentejuela.................. \\
\hline 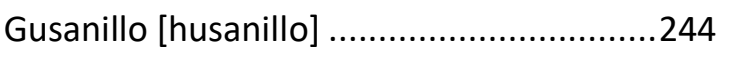 & 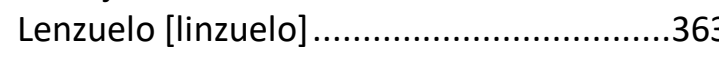 \\
\hline 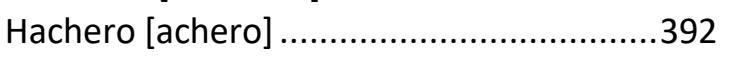 & Lezna [lesna] ............................................ \\
\hline Harnero (arnero)......................................480 & Libra [livra, liura] ......................................560 \\
\hline Hatero/a & Librador [livrador] ................................ \\
\hline 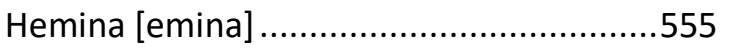 & 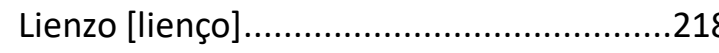 \\
\hline Herbaje [heruaje]................................................ & 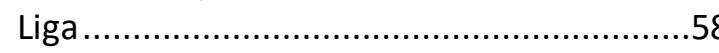 \\
\hline Herrada [errada, herradón] ........................501 & Lígnum crucis [lynum cruçis] ....................17€ \\
\hline 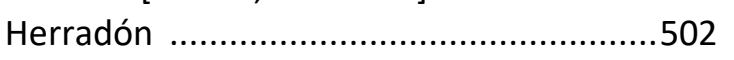 & 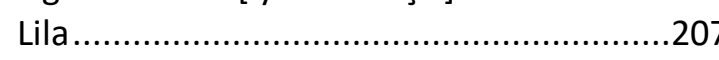 \\
\hline 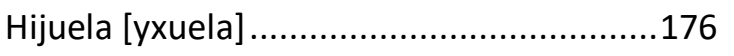 & 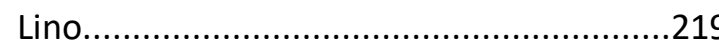 \\
\hline 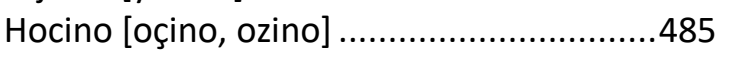 & 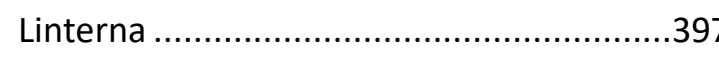 \\
\hline Holanda [olanda, olandilla] .........................625 & Llana \\
\hline Honcejo [honcexo, honçexo, onzexo, & Llar [llares] ................................................ \\
\hline onçexo, ocexo] & 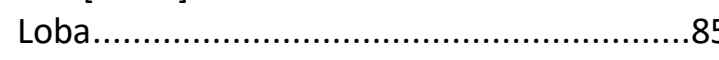 \\
\hline Humo [umo, vmo] & 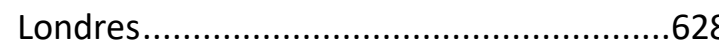 \\
\hline Hundero [undero, ondero] .............................. & Luto \\
\hline Impuesta [empuesta, enpuesta].................437 & 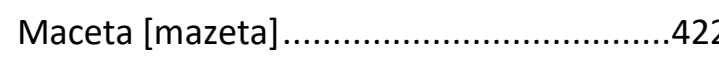 \\
\hline 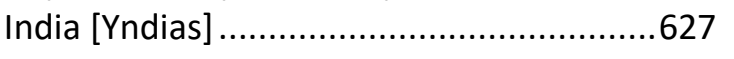 & Machado [machada] ...................................487 \\
\hline Inglaterra [Ingalaterra, Yngalaterra] ..........627 & Macho …….............................................. \\
\hline 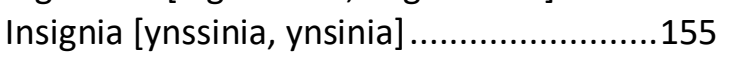 & 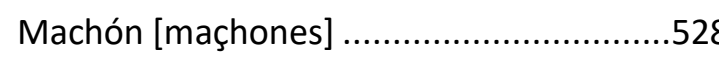 \\
\hline 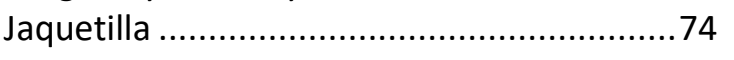 & Machorra [machona] ................................608 \\
\hline 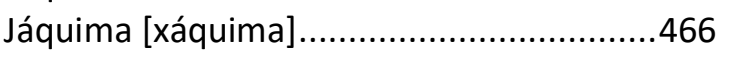 & Madeja [madexa, madejita] .......................578 \\
\hline Jarra [xarra, garra, jarrica] .................................. & 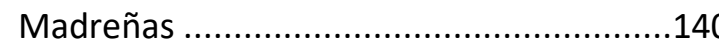 \\
\hline Jarro [xarro, garro] .............................................. & 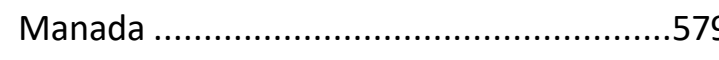 \\
\hline 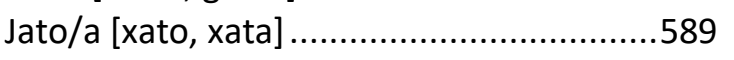 & Mancera [mangera] f.................................. \\
\hline 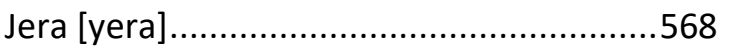 & 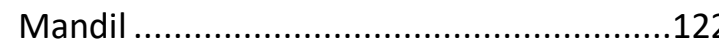 \\
\hline Jerga [gerga, xerga] & Mangas [manguillas, manguitas] ................12 \\
\hline Jergón [xergón, gergón] …...........................358 & Manguito [mangito] ....................................... \\
\hline Jerguilla [gerguilla, xerguilla]......................204 & Manilla \\
\hline 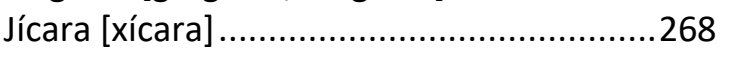 & 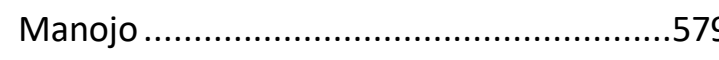 \\
\hline 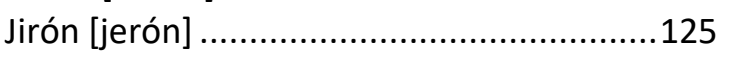 & Manta \\
\hline 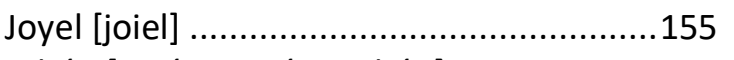 & 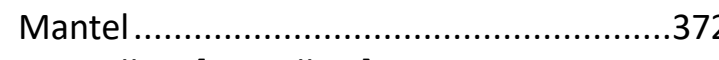 \\
\hline Jubón [juvón, xugón, gubón] ..........................74 & Mantellina [mantillina]................................ \\
\hline Jumento /a [xumenta, jumentilla] ..............594 & Manteo [mantheo] \\
\hline 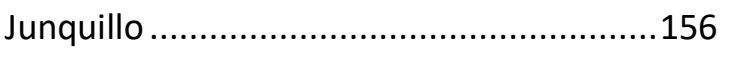 & Mantilla .................................................10 \\
\hline 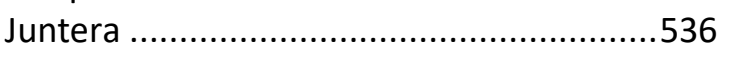 & 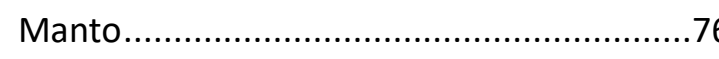 \\
\hline 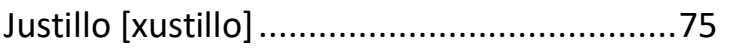 & Mañizo [mañiço] .......................................... \\
\hline 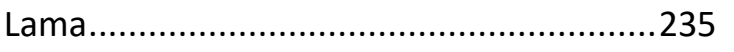 & 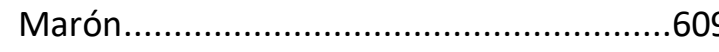 \\
\hline 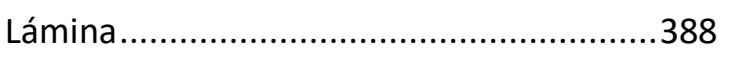 & Marrano/a .................................................. \\
\hline 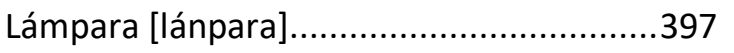 & 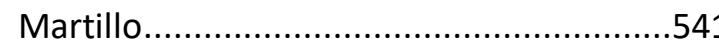 \\
\hline 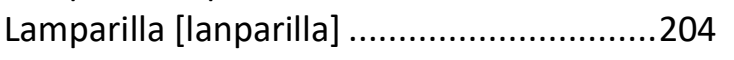 & Masera [massera] …..................................... \\
\hline 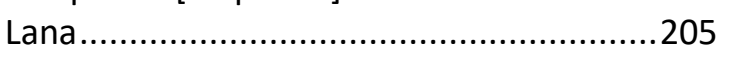 & 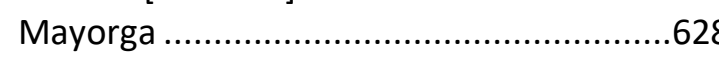 \\
\hline Lanceta [lanzeta] .......................................523 & Maza [maça] …........................................548 \\
\hline Lanilla & Mazo [maço] .......................................... 548 \\
\hline 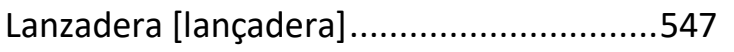 & Mazorca [maçorca] \\
\hline 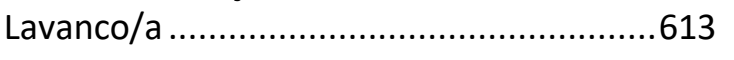 & Mechero \\
\hline
\end{tabular}




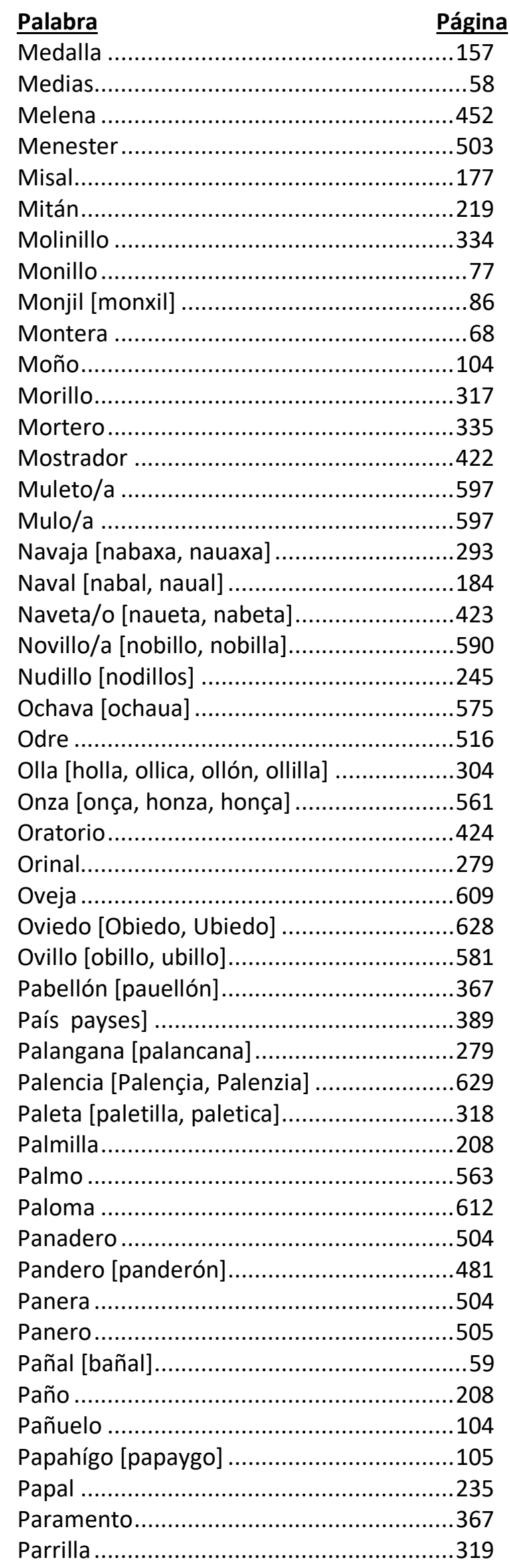

\section{Palabra}

Pasamanos [passamanos]

Pato

Pavo/a [pabo, pauo, paua]

Pechero

Peinador [peynador]

Pellejo [pellexo, pillexo, pellexa, pellejuelo, pellexuelo]

Pelliz

Pelliza

Pelo de camello.

209

Peltre

Pendiente .......................................... 158

Peñera [piñera] .................................. 482

Perendengue ...................................... 158

Pereruela [Periguela, Piriguela] ............... 629

Perol .................................................. 305

Perpiñán .......................................... 630

Pértigo ............................................. 453

Pesa (pessa, pesilla) .............................. 584

Peso (pesso) ...................................... 585

Pestaña............................................ 128

Peto ................................................... 488

Picote ........................................... 227

Pie ................................................. 564

Pierna ............................................. 565

Pimentero......................................... 283

Pinchete.................................................

Pinzas [despinzas, despinças] ................. 523

Piñuela............................................. 228

Pipote ........................................... 268

Piqueta .............................................. 529

Pirámide [piramile] .............................. 423

Pita ................................................. 236

Plana............................................... 528

Plancha ............................................ 549

Plato [platillo] ................................... 283

Plomada............................................. 530

Podadera .............................................. 489

Podejo [podexo].................................. 490

Podón [podonil] ..................................... 490

Poíno [poýno] ...................................... 518

Polainas [polaynas] ............................... 59

Pollera ............................................. 87

Pollino/a ............................................. 598

Pollo/a............................................... 615

Pomo .................................................. 269

Portugal ............................................. 630

Potro/a ............................................. 599

Poyal [poial] ................................... 370 


\begin{tabular}{|c|c|}
\hline Palabra & Palabra \\
\hline Pozal [poçal, poçaleta, pozaleta] .................518 & Sesma \\
\hline Pretina [petrina, pretinilla, petrenilla, & 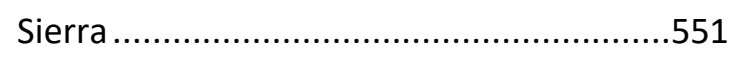 \\
\hline 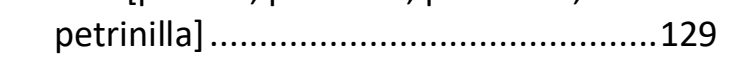 & 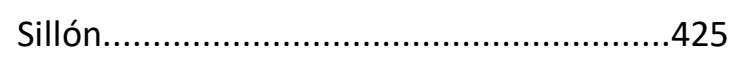 \\
\hline 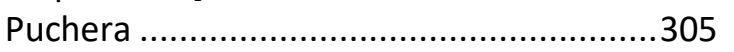 & 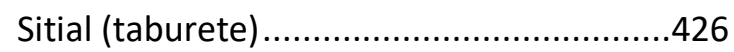 \\
\hline 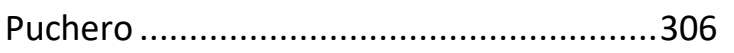 & 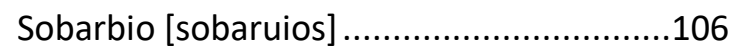 \\
\hline 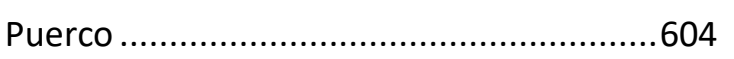 & Sobeo [soveo, soueo, sobeyo] ...................453 \\
\hline Pujavante [puxabante] ...............................542 & Sobeyuelo [sobigüelo, sobejuelo, \\
\hline Puño & 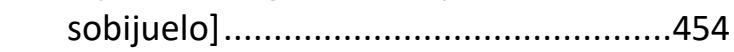 \\
\hline 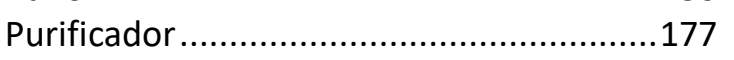 & 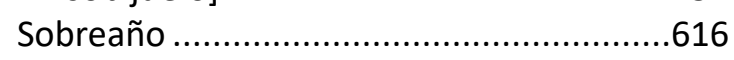 \\
\hline Purridera & 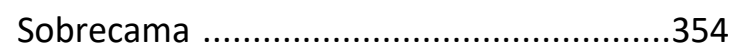 \\
\hline 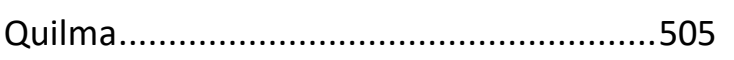 & 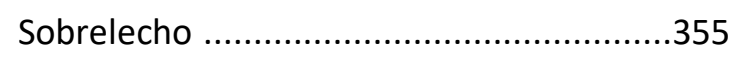 \\
\hline Quinzal [quinçal] .......................................576 & Sobremesa [sobremesilla]...........................376 \\
\hline Raja [raxa] ..................................................... & 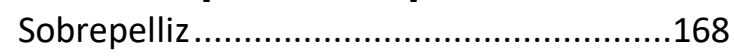 \\
\hline 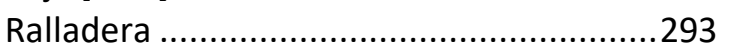 & Sobretodo \\
\hline Rallo & 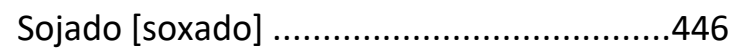 \\
\hline Ramilletero [ramiletero] ...........................424 & Sombrero [sonbrero] …...........................107 \\
\hline 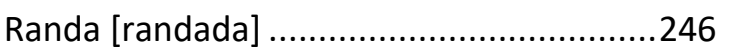 & 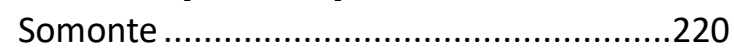 \\
\hline Rebociño [rebociño, revoziño, rebocillo, & 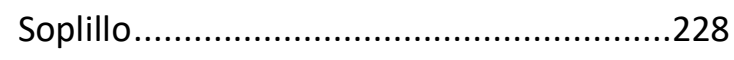 \\
\hline 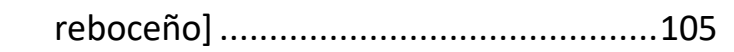 & Sortija [sortixa] \\
\hline 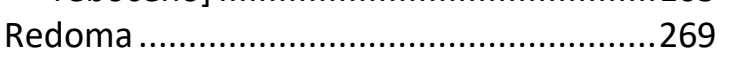 & 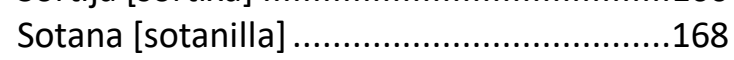 \\
\hline 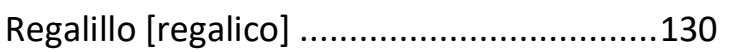 & 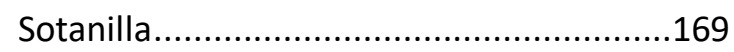 \\
\hline 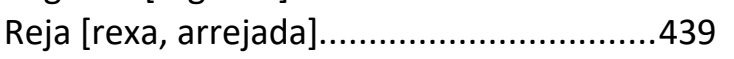 & Sufridera \\
\hline 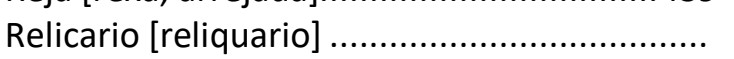 & 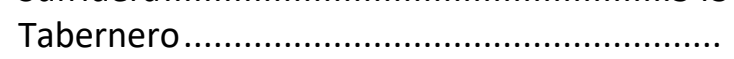 \\
\hline Repostero (ripostero, reposterico) .............390 & Tabí \\
\hline 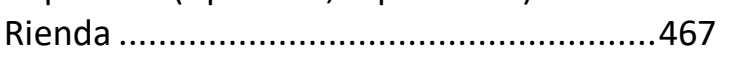 & Taburete [tavurete, tauurete,tabulete, \\
\hline Romana & 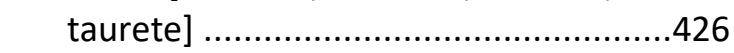 \\
\hline Ropa & 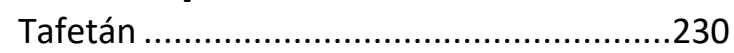 \\
\hline 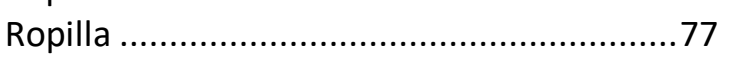 & Taja [taxa, taxica, taxuela]...........................336 \\
\hline 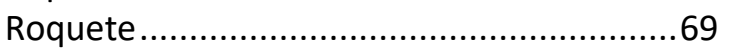 & 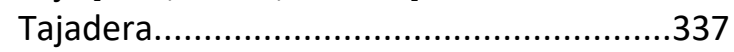 \\
\hline Ruan [roan] ................................................... & Tajadero / tajador [taxadero, taxador] ......337 \\
\hline 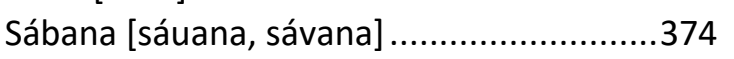 & 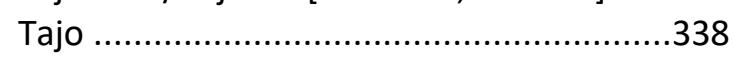 \\
\hline 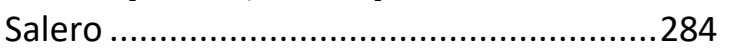 & 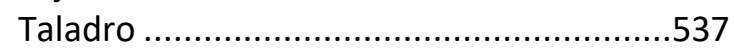 \\
\hline Salvader (saluadera, salbadera).................425 & Talega [taleguilla]........................................ \\
\hline Salvilla [salbilla, saluilla, salba] ...................285 & 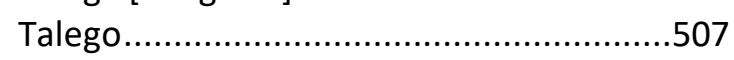 \\
\hline 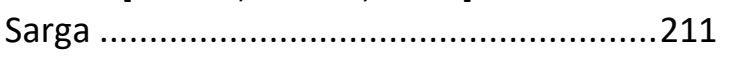 & 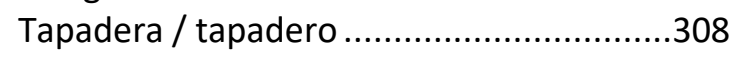 \\
\hline 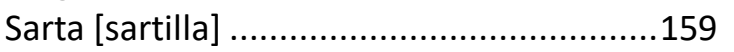 & 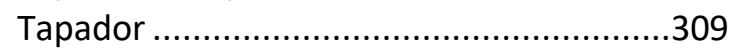 \\
\hline 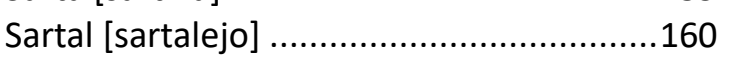 & 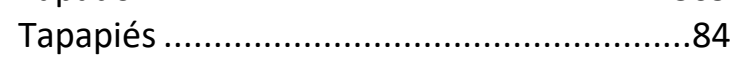 \\
\hline 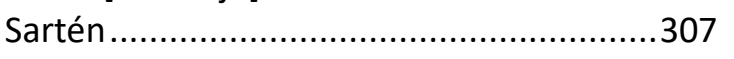 & 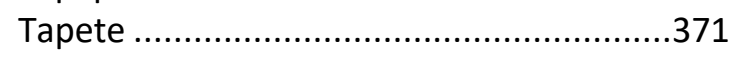 \\
\hline 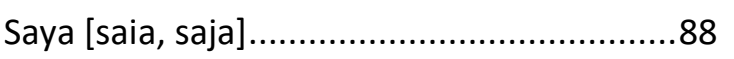 & 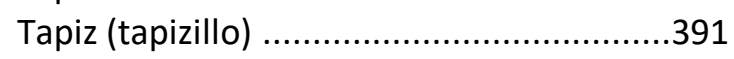 \\
\hline 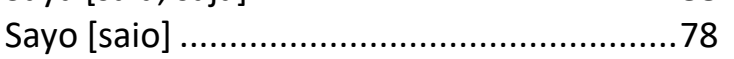 & 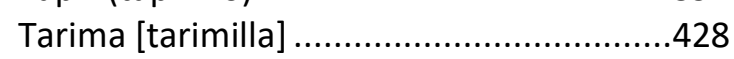 \\
\hline Sayuela & 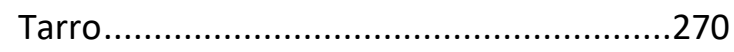 \\
\hline 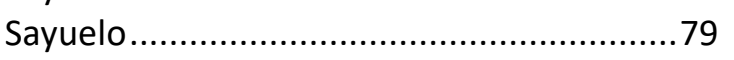 & Tartera \\
\hline 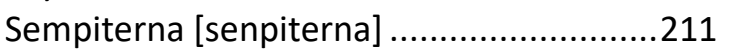 & Taza [taça] \\
\hline 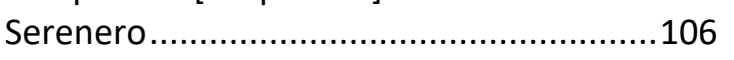 & 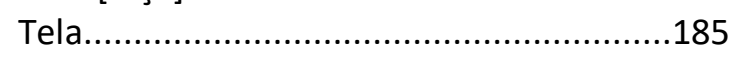 \\
\hline Servidor [seruidor, serbidor] ......................270 & Tembladera [tenbladera, tenpladera] ........271 \\
\hline Servilla [seruilla, serbilla] ..................................... & 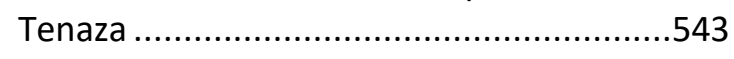 \\
\hline 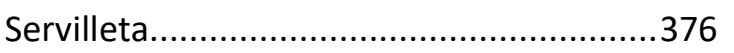 & 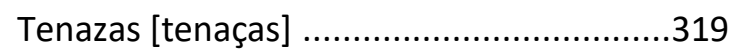 \\
\hline 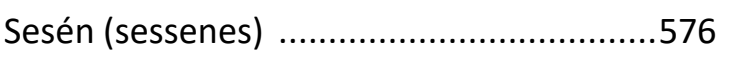 & 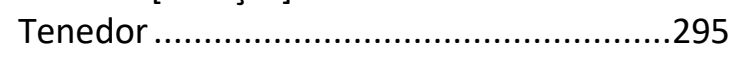 \\
\hline
\end{tabular}




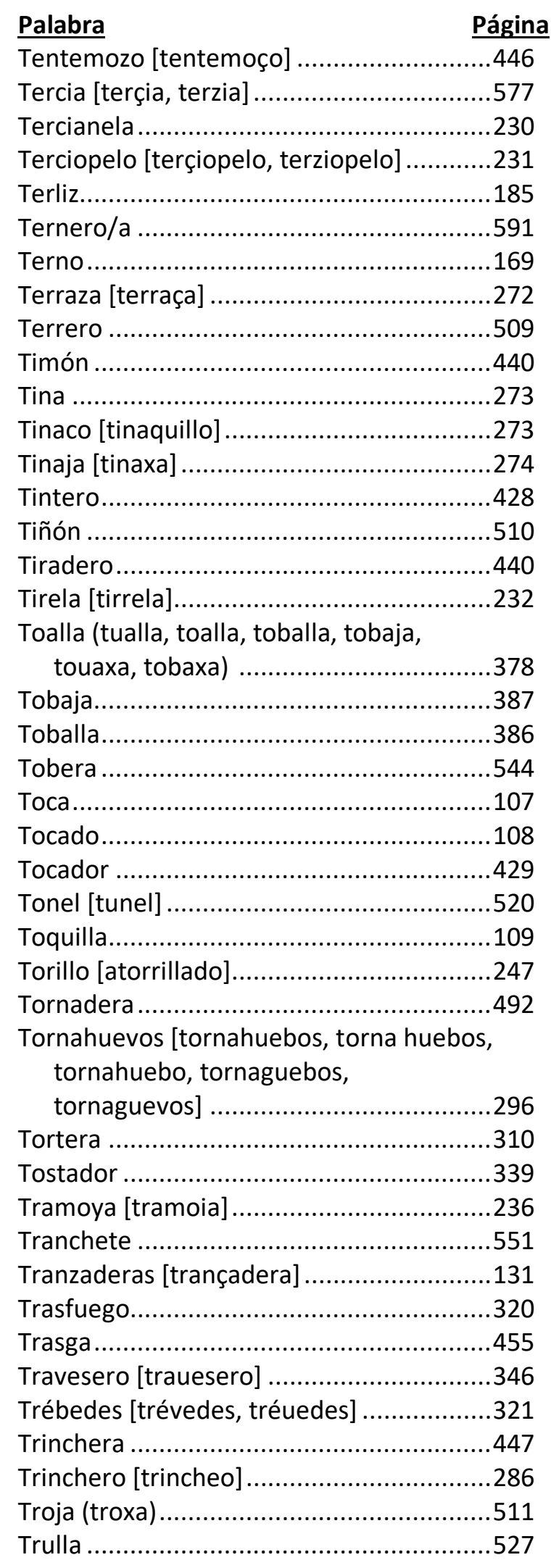

\section{Palabra}

Trulladera (trulludera)

Página

Túnica 527

Vaca [baca] 60

Valón [balón] 592

Valona [balona] .. 89

Vaquero [baquero]... 109

Vara (bara, uara) 90

Vasar [basar, bassar, basal]. 566

Vasera. 429

Vaso [basso, baso, basito] .. 429 y 430

Vela [bela]. 275

Velador [belador, veladorcillo, beladorzico].... 398

Velo [belo] 399

Velón [belón] ............................................ 400

Ventosa [bentosa] ....................................... 524

Ventril [bentril] ........................................... 447

Verbión [berbión, brebión, bribión]............ 448

Verduguillo [berduguillo] .......................... 525

Vestido [bestido, uestido] .......................... 91

Vinagrera [binagrera] ............................... 287

Vinajera [vinaxera, binaxera].................... 287

Volandera [bolandera] ............................. 448

Volante ..................................................... 110

Volvedor / volvedera [boluedor, bolbedera, rebolbedera] ...................... 297

Vuelta [uuelta, buelta] ............................. 132

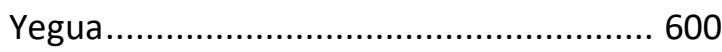

Yera.....

Yugada [yguadas] ..................................... 569

Yugo [iugo, ugo, hugo, yuego] ................... 455

Yunque [añunque] .................................... 544

Zamarro.................................................... 70

Zapatilla [çapatilla].................................. 140

Zapato [çapato]....................................... 141

Zaragüelles [çarafueles, çarafuelles, zarafueles, zarafuelles]......................... 92

Zaranda [ceranda, zeranda, ceranda,

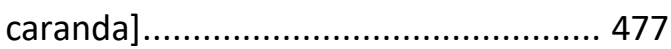

Zarcillo [çarçillo]....................................... 161

Zarzo [çarzo, zarço, çarço, çarçe] .............. 449

Zoleta [çoleta, çuleta, açoleta, zoletón, çoletón] 493

Zoletón [çoletón]

Zuecos [çueco] 142 
